PhD Dissertation

Emilija Apostolova Chalovska

Directors:

Prof. D-r Francisco Juan Vidal

Universidad Politécnica de Valencia

Prof. D-r Elizabeta Kasapova

University "Ss. Cyril and Methodius", Skopje

\title{
THE XIX CENTURY BASILICAS IN MACEDONIA: ORIGIN, TYPOLOGY AND INFLUENCES
}

UNIVERSITAT

POLITÉCNICA DE VALĖNCIA
Arquitectura, Edificación, Urbanismo y Paisaje Escuela Técnica Superior de Arquitectura Universidad Politécnica de Valencia 



\title{
THE XIX CENTURY BASILICAS IN MACEDONIA: ORIGIN, TYPOLOGY AND INFLUENCES
}

\section{Emilija Apostolova Chalovska}

\author{
Directors: \\ Prof. D-r Francisco Juan Vidal (Universidad Politécnica de Valencia) \\ Prof. D-r Elizabeta Kasapova (University "Ss. Cyril and Methodius" - Skopje)
}

Valencia, July 2021 


\section{ACKNOWLEDGEMENTS}

Many persons and institutions have generously contributed towards the realization and completion of this doctoral thesis.

Firstly, I am forever indebted to my mentors, prof. d-r Francisco Juan Vidal of the Polytechnic University of Valencia (Spain) and prof. $d$-r Elizabeta Kasapova of the University "Ss. Cyril and Methodius" in Skopje (Macedonia). It is thanks to their wisdom, guidance, heartfelt encouragement and ongoing support that the long and exhaustive research for this thesis could be undertaken with the necessary motivation, dedication and drive.

In addition, I would like to exert my most sincere gratitude to the employees of the Institute for Protection of Built Heritage, History of Art and Architecture at the Faculty of Architecture, University "Ss. Cyril and Methodius" in Skopje (Macedonia) for the selfless contribution in the digitalization of existing technical documentation acquired through different sources, as well as the abundant technical and photo documentation kept within the Institute's archive which was generously made available for the purpose of this doctoral research. Also, I wish to thank the employees of the Institute of folklore "Marko Cepenkov", University "Ss. Cyril and Methodius" in Skopje (Macedonia) for their support and assistance in the location and digital processing of rare photographs belonging to their archive, as well as various bibliography kept in their library.

Furthermore, I would like to thank Darko Nikolovski from the National Conservation Center in Skopje and Zoran Altiparmakov from the Institute for Protection of Monuments of Culture and Museum - Bitola for their generous contribution in the search for existing documentation within their respective institutions' archives, as well as their personal photo documentation and literature. Also, the invaluable technical assistance provided by Slavica Georgieva and Martin Simjanovski constitutes a significant and much appreciated contribution.

Lastly, none of this would have been possible without the constant support, love and encouragement of my family.

To all of the above, and anyone else that has contributed in any way, I am forever grateful.

Thank you. 
iv | 


\title{
ABREVIATIONS
}

\author{
UCaM \\ University "Ss. Cyril and Methodius" \\ FA \\ Faculty of Architecture \\ IPBHHAA \\ Institute for Protection of Built Heritage, History of Architecture and Art \\ IPMCM \\ Institute for Protection of Monuments of Culture and Museum \\ $\mathrm{DPCH}$ \\ Directorate for Protection of Cultural Heritage \\ NCC \\ National Conservation Centre \\ MOC-OA \\ Macedonian Othodox Church - Ohrid Archbishopric
}




\section{CONTENTS}

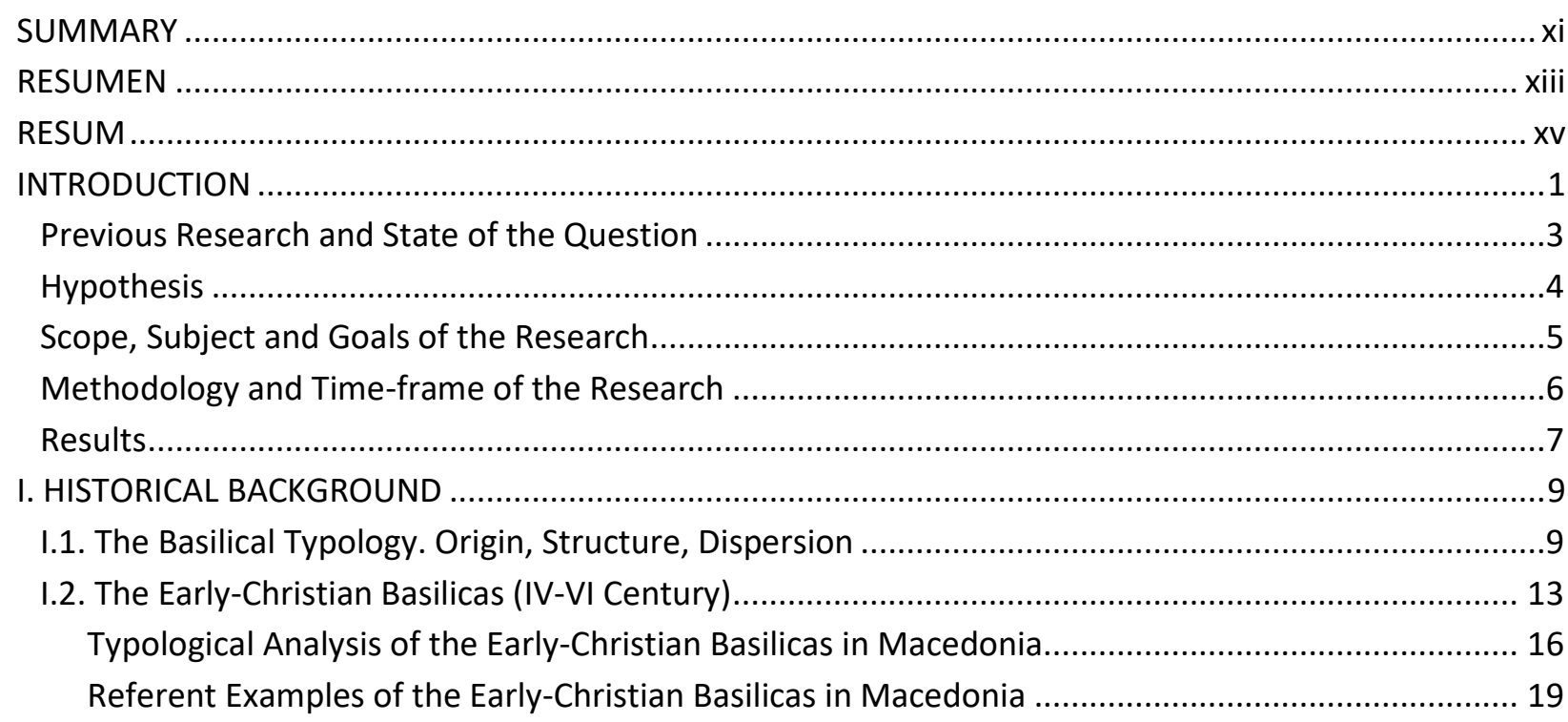

I.3. The Ecclesiastical Typologies in the Following Centuries (VII-IX Century)....................................... 24

I.4 The Resurrection of the Basilica as Royal Ecclesiastical Architecture of Samuel's Kingdom and the

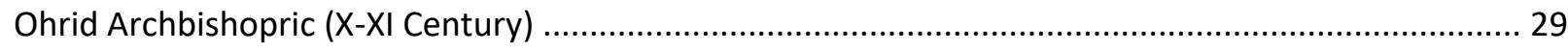

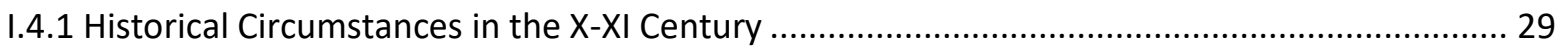

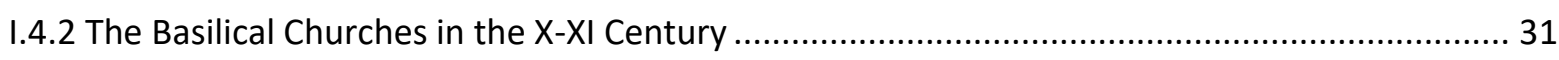

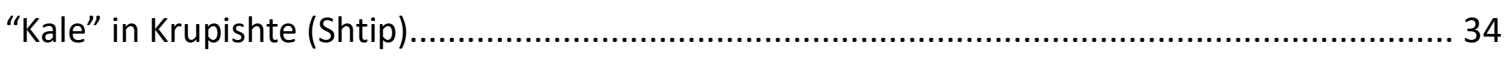

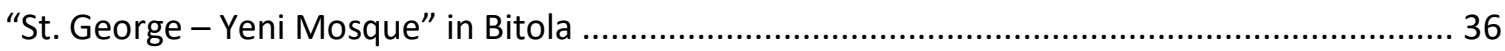

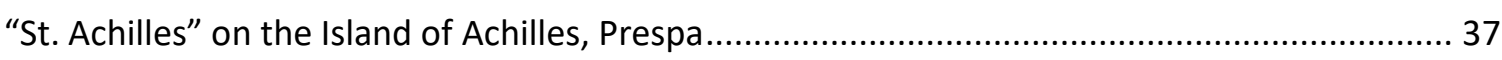

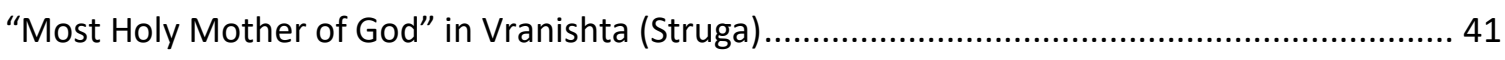

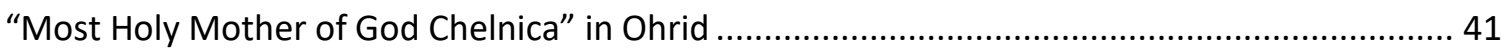

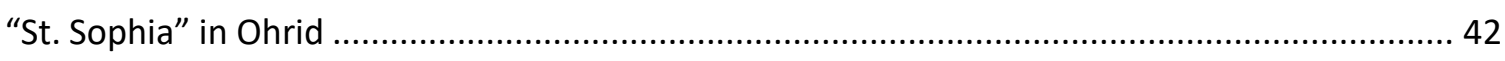

"Dormition of the Most Holy Mother of God" in Velushina (Bitola) ........................................... 48

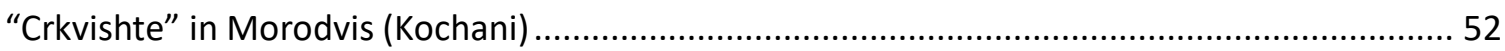

I.4.3 The Basilical Typologies in the Period between XI-XIV Century ............................................... 54

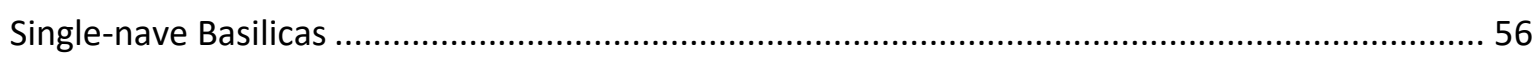

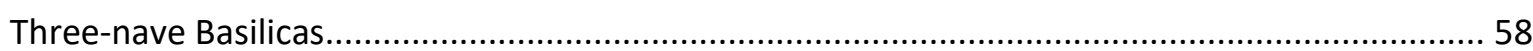

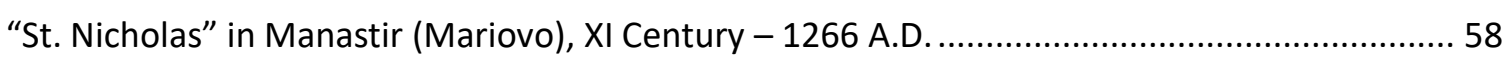

"St. George" in Staro Nagorichane (Kumanovo), XI Century - 1312/1313 A.D. ............................. 60

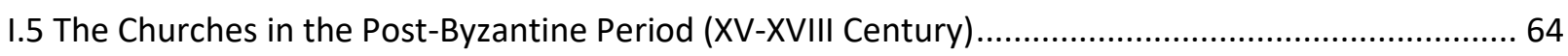

I.5.1 Post-Byzantine Antecedents of the XIX Century Revival Single-nave Basilicas .......................... 67

I.5.2 Post-Byzantine Antecedents of the XIX Century Revival Three-nave Basilicas .......................... 70

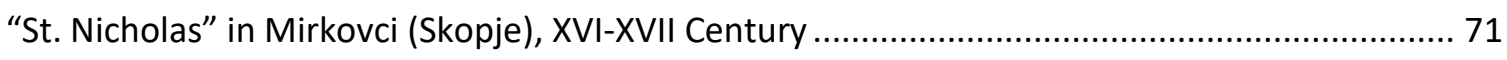

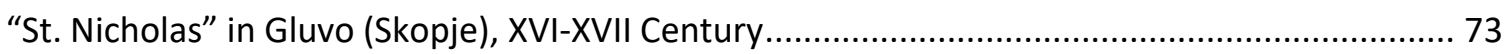




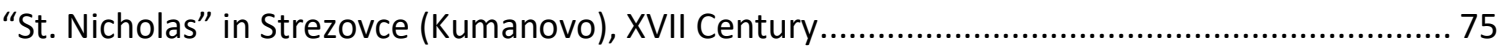

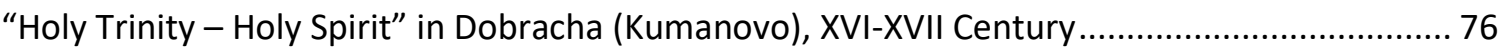

"St. George" in Mlado Nagorichane (Kumanovo), XVI-XVII Century............................................. 77

"Nativity of the Most Holy Mother of God" in Tepavci (Bitola), XVIII Century ............................... 78

II. THE SOCIAL “RENAISSANCE” OF THE XIX CENTURY AND THE PROSPERITY OF THE RELIGIOUS

ARCHITECTURE

II.1 Historical, Social, and Economic Circumstances in Macedonia in the XIX century......................... 83

II.2 Origin and Influences of the Revival Religious Architecture........................................................ 89

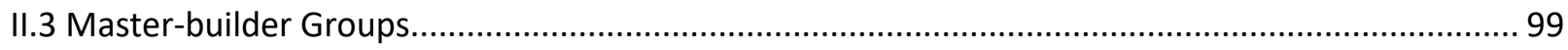

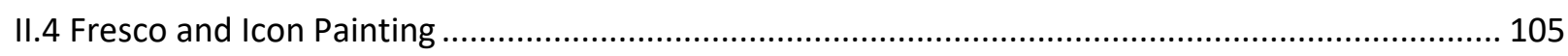

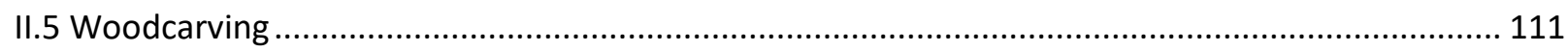

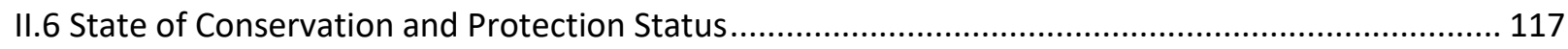

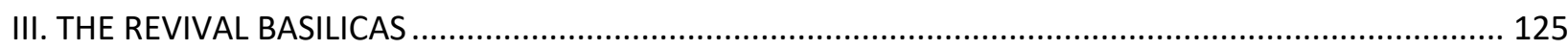

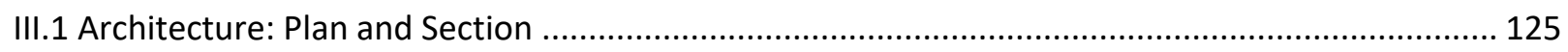

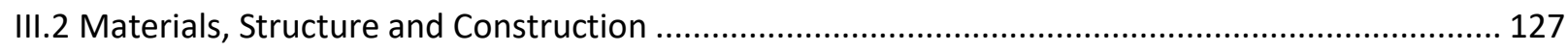

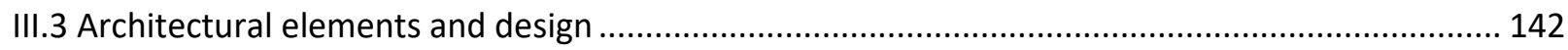

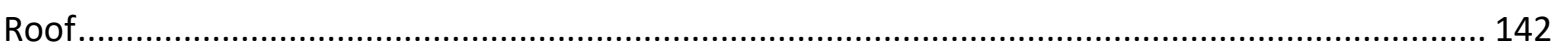

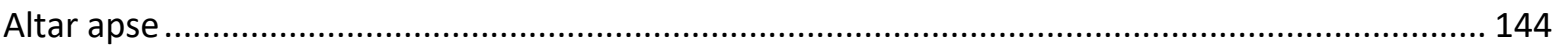

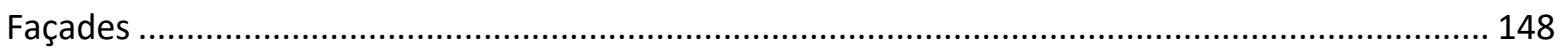

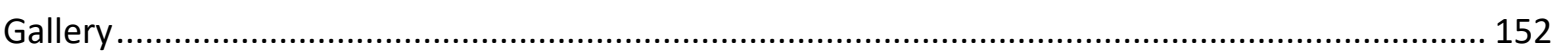

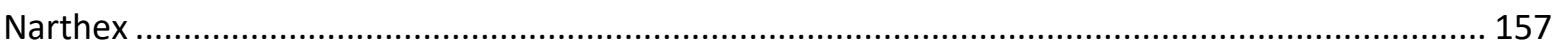

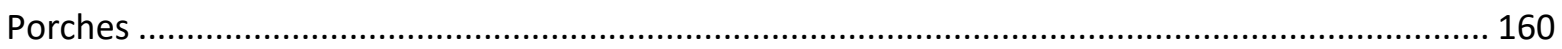

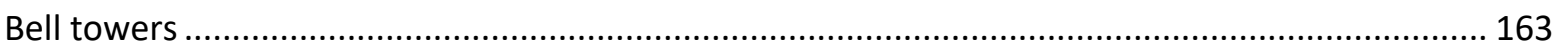

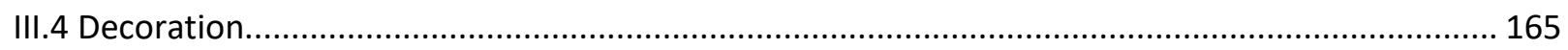

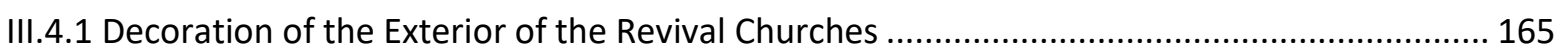

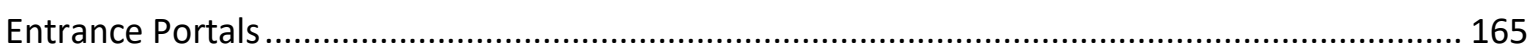

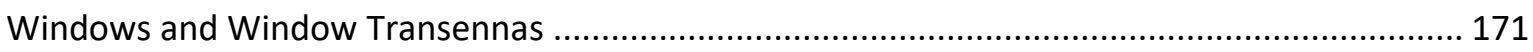

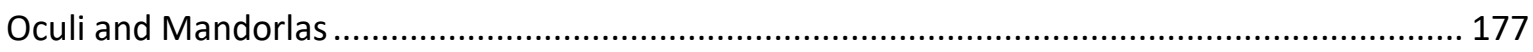

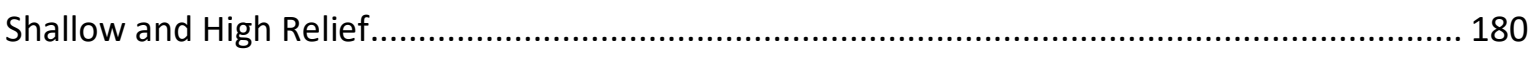

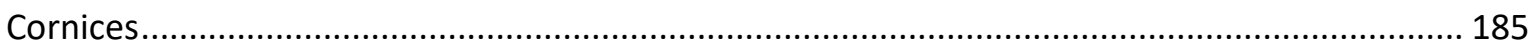

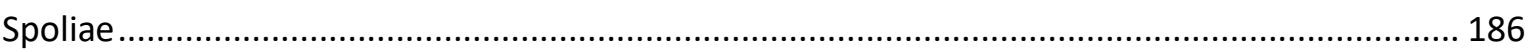

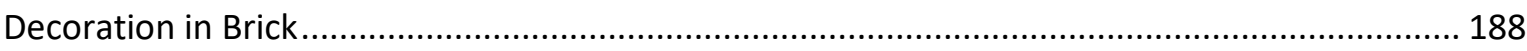

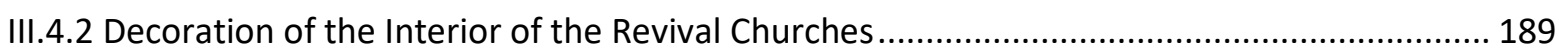

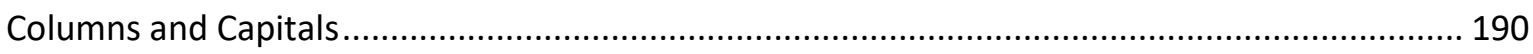

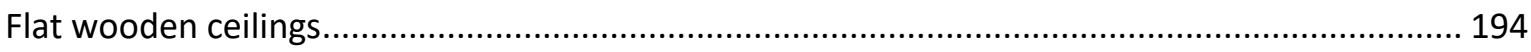

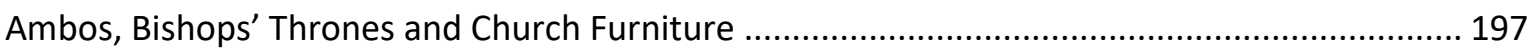

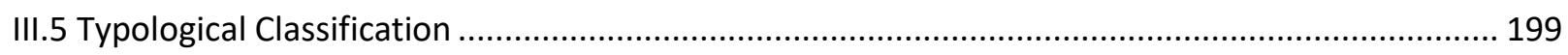

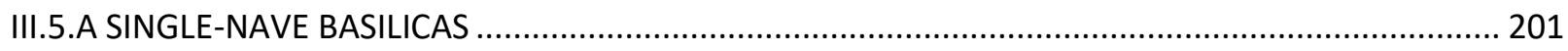

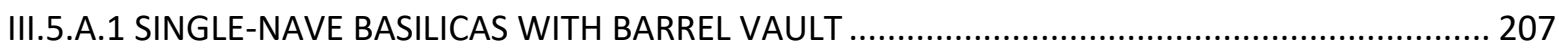

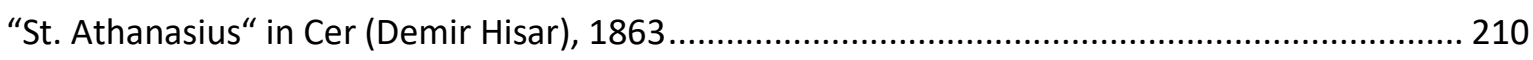

"St. Savior - Ascension of Christ" in Rashtak (Skopje), 1861 ...................................................... 214

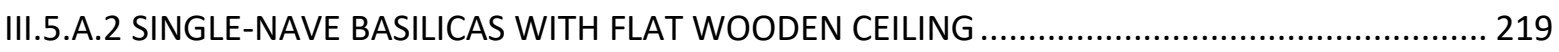

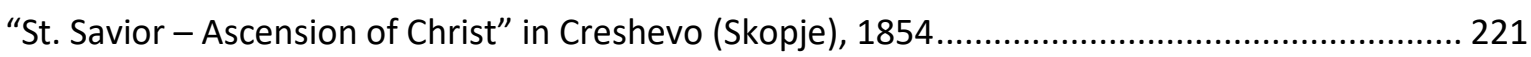

III.5.A.3 SINGLE-NAVE BASILICAS WITH LATERAL PILASTERS CONNECTED WITH ARCHES, COVERED

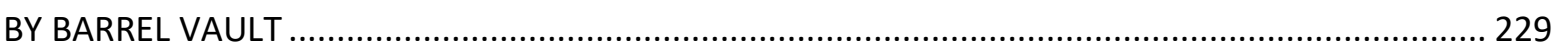

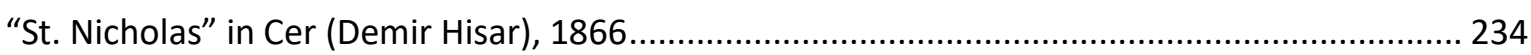


III.5.A.4 SINGLE-NAVE BASILICAS WITH A THREE-NAVE DISPOSITION OF THE

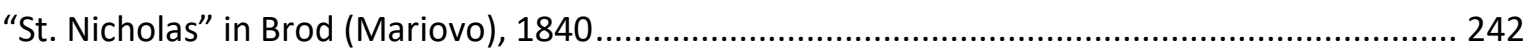

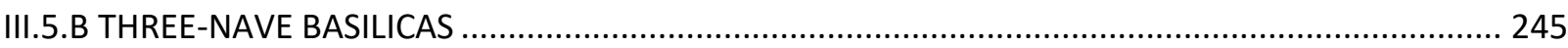

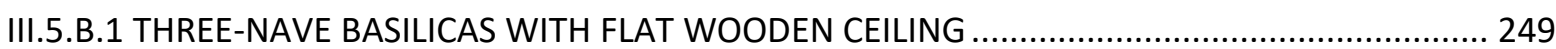

Three-nave basilicas with flat wooden ceiling in all three naves ............................................... 250

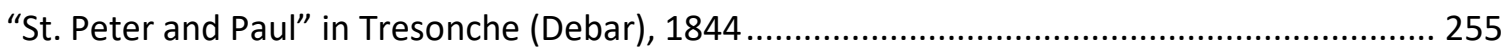

Three-nave basilicas with flat wooden ceiling combined with vaulted segments ........................ 261

"St. Savior - Ascension of Christ" in Kozhle (Skopje), 1847 ....................................................... 263

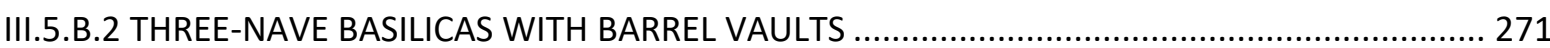

Three-nave basilicas with barrel vault in the central nave and flat wooden ceiling in the lateral

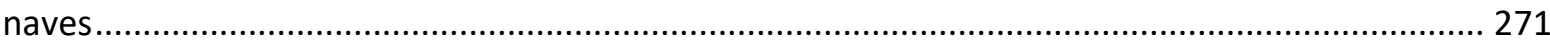

"St. Cosmas and Damian - the Great Holy Healers" in Ohrid, 1842 …................................... 272

Three-nave basilicas with barrel vaults in all three naves .............................................................. 279

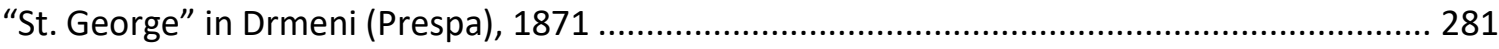

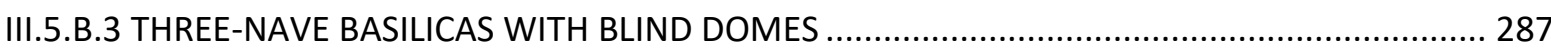

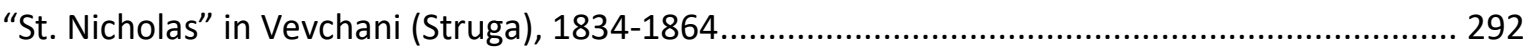

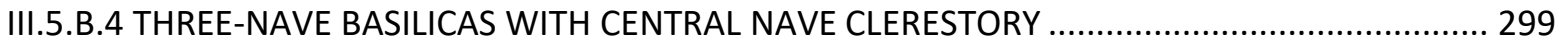

"St. Savior - Ascension of Christ" in Drachevo (Skopje), 1848/1849 ............................................. 300

III.5.B.5 THREE-NAVE BASILICAS WITH ONE OR MORE DOMES SUPPORTED ON

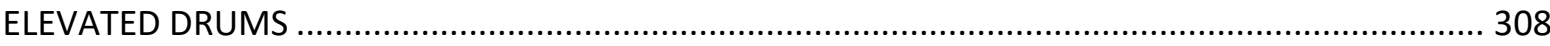

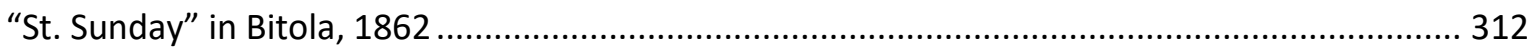

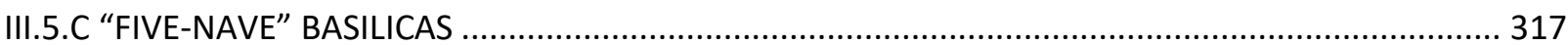

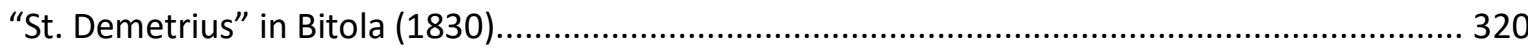

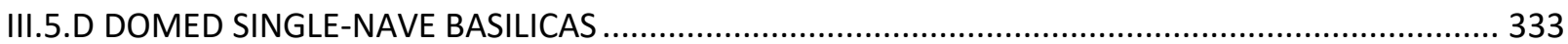

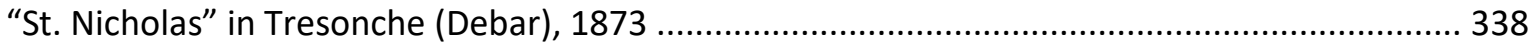

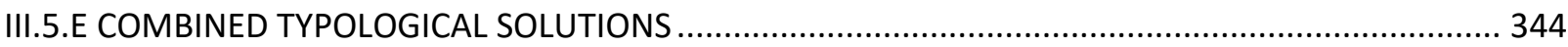

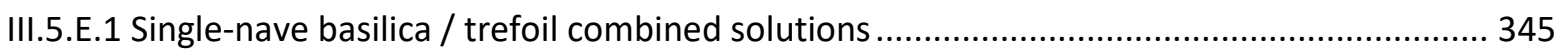

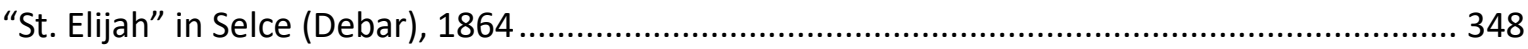

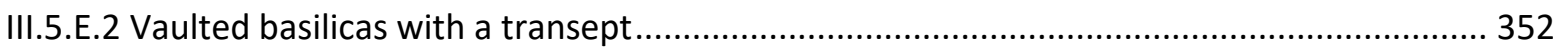

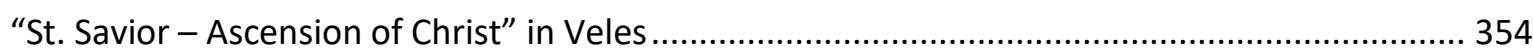

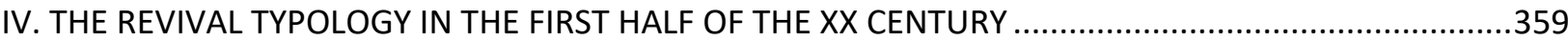

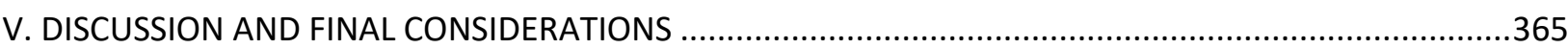

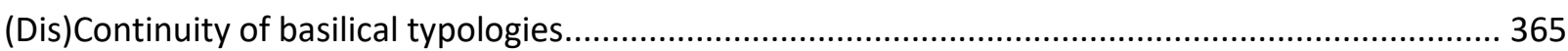

Regional characteristics and representation of individual typological solutions ................................. 370

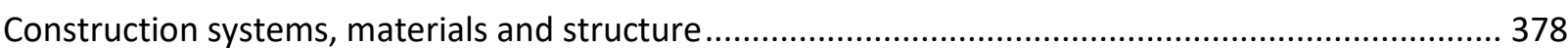

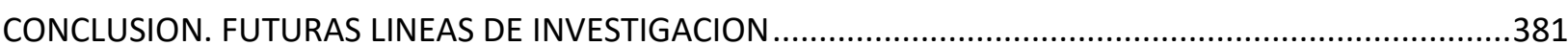

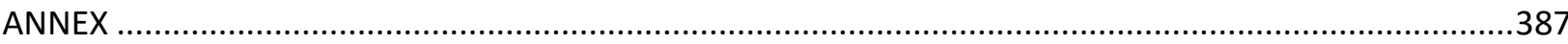

Chronological Overview of the XIX Century Churches in Macedonia................................................. 387

Churches from the First Half of the XX Century with Revival Typology ............................................... 397

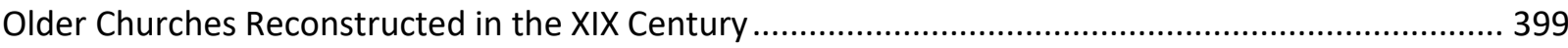

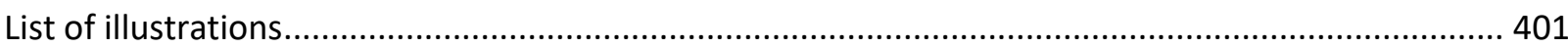

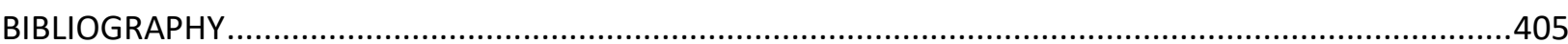




\section{SUMMARY}

The fundamental social and economic transformation of the XIX century "Revival" allowed for a truly astonishing number of hundreds of reconstructed or newly-built churches throughout Macedonia. Based on their architectural typology, they comprise a specific architectural "school", established and developed in the XIX century. Extracting its basic forms and patterns from the layers of the Byzantine millennial tradition, paired with stylistic elements from the renaissance, baroque, rococo, Levantine baroque and classicist movement acquired through the intensified contacts of the Macedonian masterbuilders with the contemporary Western and Central European architecture, this unique "Revival" architecture created its own recognizable vocabulary equally legible in the case of the monumental urban cathedrals as well as the modest village churches built with far less available means.

Several basic broad categories emerged within this architectural school: single-nave, three-nave and five-nave basilicas, domed single-nave basilicas and combined typological solutions, predominant in different regions of Macedonia, characteristic for its urban centers as opposed to the monastic communities or rural settlements. Furthermore, these basic manifestations of the basilica encompassed a rich variety of specific sub-typologies derived from their upper construction: a variety of multiple diverse combinations of architrave and coffered ceilings, barrel, groined and boat vaults, blind domes and fully manifested domes elevated upon drums, protruding through the monumental gabled roof covering the entire naos, with the rare exception of the basilica with a central nave clerestory.

In addition to their similar architectural composition, the Revival churches also regularly incorporate a meticulous decorative repertoire: stone reliefs, especially within the context of the entrance portals; an exceptionally abundant interior decoration - a tall two or three-tier wood carved iconostasis, adorned with multiple icons and intricate church furnishing set against a background of fresco-painted surfaces, all derived from the diverse contemporary currents within the canonic ancient Byzantine and post-Byzantine artistic traditions.

Key words: XIX century Revival, typology, single-nave basilicas, three-nave basilicas, architrave ceiling, vaults, domes, blind domes 
xii | 


\section{RESUMEN}

La profunda transformación social y económica del movimiento conocido como "Renacimiento del siglo XIX" permitió la construcción o renovación de un número verdaderamente asombroso de cientos de iglesias en toda Macedonia. Basándose en su tipología arquitectónica, éstas conforman una "escuela" arquitectónica específica que se estableció y desarrolló en el siglo XIX. Extrayendo sus formas y patrones básicos de la tradición milenaria bizantina, combinados con elementos estilísticos del movimiento renacentista, barroco, rococó, barroco levantino y clasicista adquiridos a través de la intensificación del contacto de los maestros constructores macedonios con la arquitectura contemporánea de Europa Central y Occidental, esta arquitectura única creó su propio vocabulario reconocible, igualmente legible en el caso de las catedrales urbanas monumentales, así como en las modestas iglesias de aldea construidas con medios mucho menos disponibles.

Varias categorías generales básicas surgieron dentro de esta escuela de arquitectura: basílicas de una, tres y cinco naves, basílicas con cúpula y soluciones tipológicas combinadas, predominantes en diferentes regiones de Macedonia, características de sus centros urbanos en contraposición a las comunidades monásticas o asentamientos rurales. Además, estas manifestaciones de la basílica abarcaron una diversa variedad de sub-tipologías específicas derivadas de su construcción superior: múltiples combinaciones de techos artesonados, bóvedas de cañón, de arista y de barco, cúpulas ciegas o elevadas sobre tambores que sobresalen a través de las predominantes cubiertas a dos aguas.

Además de su similar composición arquitectónica, las iglesias "renacentistas" del siglo XIX también incorporan regularmente un meticuloso repertorio decorativo: relieves de piedra, especialmente en el contexto de los portales de entrada; una decoración interior excepcionalmente abundante: iconostasios altos de dos o tres niveles tallados en madera, adornados con múltiples íconos y mobiliarios intrincados sobre un fondo de superficies pintadas al fresco, todo derivado de las diversas corrientes contemporáneas dentro de la antigua canónica tradición artística bizantina y post-bizantina.

Palabras clave: "Renacimiento del siglo XIX", tipología, basílicas de una nave, basílicas de tres naves, techo de arquitrabe, bóvedas, cúpulas, cúpulas ciegas. 
xiv | 


\section{RESUM}

La profunda transformació social i econòmica del moviment conegut com a "Renaixement del segle XIX" va permetre la construcció o renovació d'un nombre veritablement sorprenent de centenars d'esglésies a tota Macedònia. Basant-se en la seua tipologia arquitectònica, aquestes conformen una "escola" arquitectònica específica que es va establir i es va desenvolupar al segle XIX. Extraient les seues formes i patrons bàsics de la tradició mil-lenària bizantina, combinats amb elements estilístics del moviment renaixentista, barroc, rococó, barroc llevantí i classicista adquirits a través de la intensificació del contacte dels mestres constructors macedonis amb l'arquitectura contemporània d'Europa Central i Occidental, aquesta arquitectura única va crear el seu propi vocabulari reconeixible, igualment llegible en el cas de les catedrals urbanes monumentals, així com en les modestes esglésies d'aldees construïdes amb mitjans molt menys disponibles.

Diverses categories generals bàsiques van sorgir dins d'aquesta escola d'arquitectura: basíliques d'una, tres i cinc naus, basíliques amb cúpula i solucions tipològiques combinades, predominants en diferents regions de Macedònia, característiques dels seus centres urbans en contraposició a les comunitats monàstiques o assentaments rurals. A més, aquestes manifestacions de la basílica van abastar una diversa varietat de subtipologies específiques derivades de la seua construcció superior: múltiples combinacions de sostres artesonats, voltes de canó, d'aresta i de vaixell, cúpules cegues o elevades sobre tambors que sobresurten a través de les predominants cobertes a dues aigües.

A més de la seua similar composició arquitectònica, les esglésies "renaixentistes" també incorporen regularment un meticulós repertori decoratiu: relleus de pedra, especialment en el context dels portals d'entrada; decoració interior excepcionalment abundant: iconòstasis alts de dos o tres nivells tallats en fusta, adornats amb múltiples icones i mobiliaris intricats sobre un fons de superfícies pintades a la fresca, tot derivat de les diversos corrents contemporanis dins de l'antiga canònica tradició artística bizantina i postbizantina.

Paraules clau: "Renaixement del segle XIX", tipologia, basíliques d'una nau, basíliques de tres naus, sostre d'arquitrau, voltes, cúpules, cúpules cegues. 



\section{INTRODUCTION}

Macedonia, conditioned by its geographical location in the heart of the Balkan Peninsula, on the main land communication connecting the eastern Mediterranean with Central Europe and stretching further to the West, has represented since prehistoric times a cross-road where various civilizations met and often collided. Each of these civilizations "built on top of the ruins of the previous one it destroyed, or completed or transformed in its own way, using the old foundations of the demolished buildings and their building material, as well as all previously achieved benefits in architecture and art imposing, however, its own style and message" (Алексова, 2003: 7). That way, architecture in Macedonia, as did the other art categories, developed slowly and gradually, soaking in ideas, concepts, influences, techniques and skills from all civilizations and cultures that passed through the region, or inhabited it permanently melting into the existing cultural layers. A combination of the aesthetic and the utilitarian, architecture represents a reflection of the society and its social, economic and political circumstances. As a result of the current occurrences, it is defined by contemporaneity; on the other hand, it is based on a millennial building tradition. Simultaneously, architecture is conditioned by a multitude of defining factors: local climate, available building materials, established construction techniques and skills and previous experiences. All of these factors influence the appearance of regional specifics in both sacral and profane construction whose diversity contributes towards the establishment of local architectural styles - local architectural schools - characteristic for a certain region, whose typological evolution is usually slow and occurs naturally.

Yet, there are crucial periods in the history of any society when the intensity of development and significance transcends natural evolution: a Revival of the society and its social and cultural manifestations. A Revival implies radical transformation of all social circumstances, a phenomenon to which architecture could not be an exception. In Macedonia and the broader region, such evolution leaps directly connected to the social-political circumstances have happened on several occasions. The first one appeared on the transition from the antique to the medieval, with the establishment of Christianity as the official state religion of Rome's heir - Byzantium, setting the foundations of the basic type of Christian cult building which will be upgraded and changed throughout the following centuries, adjusting to the contemporary course in art and architecture. Later, such period of social (and thus also architectural) Revival is Samuel's independent kingdom in the X-XI century which, albeit short-lived, will establish its own architectural vocabulary intrinsic to its monumental religious architecture aiming to convey a mainly political message and meaning. Then, after several turbulent centuries marked by the occupation of Macedonia's territories by different medieval states, the society will be drastically transformed as the result of the Ottoman occupation towards the end of the XIV century and the consequent establishment of a firm Islamic feudal autocratic empire in the Balkans, stretching until the XIX century. Following the same model, quantum leaps in architecture and its social expression occurred also along the following, XX century: at first during the transition from a feudal to a capitalist society, when the so called eclectic style 
was formed on the Balkans and in Macedonia under the influence of western-European academism which, with certain transformations, was predominant towards the end of the XIX and the beginning of the XX century, especially for the design of public buildings (Намичев и Намичева, 2013: 80); then with the dominance of the modern movement and the international purist and structural style, especially in the post-war period; later with the brutalist architecture which will define the post-modern reconstruction in the decades following the devastating 1963 Skopje earthquake; leading to today, when we witness a new quantum leap in architecture, followed by a questionable return to an eclectic historicist architectural syntax as a means towards the (re)shaping of national identity.

As far as Macedonia is concerned, probably the most emblematic, most specific period of cultural and social renaissance is the XIX century, a crucial point in history when the process of "genealogy of nations" reaches its peak throughout Europe (Tamm, 2008: 503). The same process will come to shape the Balkans, where the Ottoman Empire gradually loses its remaining European territories and several independent new states are founded. Although Macedonia will formally remain a part of the Empire until the Balkan Wars, it will also undergo the same important social, economic and cultural transformation known as the XIX century Revival. This crucial, intensive social development will inevitably result in an urban renaissance, not only regarding the increasingly more common renewal and construction of religious architecture in both urban and rural settlements, but also regarding the mass construction of residential architecture followed by an evolution of the regional, autochthonous architectural expression. Namely, the local architectural "schools" will reach their developmental peak precisely in the second half of the XIX century, and regionalism in the broader Balkan architectural tradition will lead to the definition of so called national architecture as one of the defining phenomena of cultural memory and identity within the community.

What does the term "cultural memory" encompass? Cultural memory helps us understand the formation of national identity and the role of representations and references from the past in this process; that is to say it represents a continuous process of shaping identity by the reconstruction of the past. In fact, precisely during the XIX century architects and formal architectural schools in Europe and the USA, in a specific atmosphere of glorification of certain heroic episodes from the past, the rise of nationalism and the aim to establish a unique national identity, will find themselves encouraged to incorporate historical references into their work, to extract comparative analogies with older, ancient examples in order to establish a recognizable national style in architecture (Roth, 1999: 457). In fact, throughout history man's tendency to look back on the glorious epochs of the past in search for inspiration in decisive moments for the society has been confirmed many times. In addition to analogies with vernacular or monumental architecture from the past on a more local level, this process will be promoted with an intense academic interest in the ancient history, the rise of archaeology and the new scientific treatment of archaeological ruins, a phenomenon defined by L. M. Roth as "nostalgic eclecticism" (Ibid). Surely, in such an atmosphere, a logical question arose among architects: which style should be adopted? As a response to this dilemma, many neo-styles will emerge, develop and disperse in various part of Europe: neo-classicism, neo-gothic, neo-baroque etc. Nevertheless, the literal re-utilization of already established architectural forms and patterns has its limitations. As a result, the nostalgic will soon be replaced by a "creative eclecticism" which implies a relatively free, creative and often "idiosyncratic application of historic references" (Ibid: 467-468).

The XIX century Revival basilicas in Macedonia represent a remarkable example of precisely this process of eclectic creativity, looking back on an old and predominantly abandoned architectural form inspired by the most important historic periods regarding Christianity in Macedonia, a process characteristic for periods of social renaissance. Starting from the archaic basilical typology as their base, the XIX century churches share a variety of stylistic features which allows for the definition of a regional 
architectural expression, an easily recognizable architectural language. On the other hand, the remarkable typological diversity of the upper construction within the relatively simple geometrical volume of the basilica speaks of the diverse local and foreign, imported influences which this architecture soaked in and digested, as well as of the importance of the personal and spiritual role of its main protagonists: the master-builders, stone masons, wood-carvers and fresco-painters, who within the compilatory process of re-interpretation of these often stylistically divergent currents will leave their own personal, author's mark. Precisely this unique Revival religious architecture, its origin, the influences which shaped it and its rich typological diversity comprise the main subject of interest of this doctoral dissertation.

\section{Previous Research and State of the Question}

The typology of the monumental religious architecture of the XIX century represents a complex subject whose research, besides architecture, incorporates many other relevant scientific disciplines: history, geography, sociology, history of art and architecture, archeology, theology, aesthetics, linguistics, etc. As stated by the renowned theorist and architecture critic John Ruskin (1819-1900), in order to study architecture of the past, we must "absorb the history and literature of that period and place, the record of its acts and thoughts, before we can understand fully what message the architecture conveys. Architecture, then, is like written history and literature-a record of the people who produced it-and it can be "read" in a comparable way. Architecture is a nonverbal form of communication, a mute record of the culture that produced it" (Roth, 1999: 3). Of course, when addressing the Revival basilicas, as representatives of an old, archaic typological model renewed in the XIX century as the result of specific social conditions, we must look back to the emergence of the basilica in the region, its development, (dis)continuity and influences in the early-Christian, Byzantine and post-Byzantine periods.

The rich cultural heritage of Macedonia enters the focus of world-famous researchers by the end of the XIX century. While limited archeological research will sporadically be undertaken in the first decades of the XX century and between the two world wars, it will intensify in the post-war period when systematic archeological campaigns will be conducted, followed by publication of the obtained results. Among many scholars who have dedicated their research to the Roman and early-Christian period in Macedonia and the Balkans, and thus to the appearance of civil and early-Christian basilicas, it is essential to mention Elica Maneva, Blaga Aleksova, Vera Bitrakova-Grozdanova, Lenche Jovanova, Tome Janakievski, Fanica Veljanovska, Viktor Lilchic-Adams, Vlado Malenko, Carolyn Snively, Zvonko Beldedovski, Gordana Cvetkovic-Tomashevic, Milorad Medic, Milka Chanak-Medic, Ivan Mikulchic, etc. Furthermore, there exists a significant bibliography referent to Byzantium: monographic editions dedicated to its monumental architecture and fresco-painting, papers dedicated to the religious architecture in distinct regions, provinces of the Empire, towns, monuments or specific periods of its long existence. Among the former, it is of necessity to mention the research of several eminent byzantologists, including Gabriel Millet, Karl Krumbacher, André Grabar, Pavel Nikolayevich Milyukov, Fyodor Ivanovich Uspensky, Nikodim Pavlovich Kondakov, Georgije Ostrogorski, Viktor Nikitich Lazarev, David Talbot Rice, etc. As for studies dedicated to the byzantine heritage in Macedonia, the work of Boris Chipan, Cvetan Grozdanov, Vojislav Korac, Marica Shuput, Dimche Koco, Djurdje Boshkovic, Radivoje Ljubinkovic, Petar Miljkovic-Pepek, Svetozar Radojchic, Vojislav Djuric, Goce Angelichin-Zhura, Kiril Trajkovski stands out, as does the work of some scholars from the younger generation, such as Elizabeta Kasapova, Elizabeta Dimitrova, Sasho Korunovski, etc.

As opposed to byzantine architecture and medieval monumental architecture in general, which has traditionally captured the focus of attention of many distinguished scholars, the religious architecture of 
the XIX century has been the subject of less scientific studies, and has unfortunately been considered as less significant. An exception is the life-work of Andreja Damjanov and Gjorgji Novakov-Djongar, as architects of the biggest town cathedral churches which, as true master-pieces of the Revival architectural school, have been researched, well documented, published and legally protected as monuments of culture. The remaining hundreds of Revival churches, located in Macedonia's villages and throughout the Balkans, have so far only sporadically been addressed in scientific publications, and no effort has been initiated towards their systematic study not only as individual objects, but as representatives of local and regional schools which developed and flourished within the broader frame of the XIX century Revival's building spree. An analysis of their specific combined structural systems is also lacking, as well as of their weaknesses and usual pathologies, which will be of greatest importance for their urgently needed restoration. Among the scholars who have conducted research on the XIX century monumental architecture, the most prominent contribution is the work by Krum Tomovski, Jasmina HadzievaAleksievska and Elizabeta Kasapova, whose contribution is also relevant in the study of the period's vernacular architecture and ornament, also studied by Radomir Volinjec, Sotir Tomovski, Slavko Brezovski, Dushan Grabrijan, Boris Chipan, Petar Namichev, Aneta Svetieva, etc. Select works by these authors have been listed in the chapter dedicated to the consulted bibliography.

Furthermore, one must not overlook that the largest portion of available literature regarding the XIX century Revival art and architecture is in fact dedicated to its icons, fresco-paintings and wood-carved iconostasis and furnishings, as opposed to the Revival architecture itself which has been over-shadowed by the accompanying decorative arts despite the fact that they undoubtedly constitute a union. In that context, many distinguished scholars have contributed towards the study of the renowned and well established Revival icon and fresco-painters, as well as the epoch's most eminent wood-carving ateliers. Among others, of essential importance is the contribution of Asen Vasiliev, Dimitar Kjornakov, Cvetan Grozdanov, Kosta Balabanov, Antonie Nikolovski, Zoe Lichenoska, Emil ALeksiev, Viktorija PopovskaKorobar, Julija Trichkovska, Mirjana Mashnic, Darko Nikolovski, Robert Mihajlovski, Sasho Cvetkovski, etc.

This dissertation, therefore, while contributing to the study of the overall Christian architectural production of the XIX century, aims above all to shed a light on the architectural typology of the XIX century Revival, its origin, connections and influences, as well as to provide a review of the construction techniques, methods and skills, the applied materials, the shape and model of various architectural elements and parts comprising the temples. In addition, bearing in mind the premise of indivisibility of architecture from the applied arts during the Revival, the dissertation also addresses the decorative arts used in the churches' interior i.e. icons, frescoes and wood-carved relieves aiming to attract the attention of the expert and general public towards this specific heritage which, unfortunately, is yet to receive the institutional treatment it deserves. The lack of scientific bibliography and critical analysis of the XIX century religious architecture, justifiably defined as a lack of essential knowledge, valuing and protection of this heritage, represents an additional motivation for the undertaking of this doctoral dissertation.

\section{Hypothesis}

The monumental Christian architecture of the XIX century and its basilical typology represent a case of a "resurrection" of an ancient and predominantly abandoned architectural typology inspired by the most important historic periods for Christianity in Macedonia, as a process characteristic for epochs of social Revival. 


\section{Scope, Subject and Goals of the Research}

The temporal and spatial scope of the research represent the basic premises upon which it is based. In temporal terms, the focus of the research is placed on three distinctive and defined historic periods:

- the XIX century Revival, when the specific church architecture and art arose, developed and spread throughout Macedonia and the Balkans;

- the middle-byzantine period, specifically the X-XI century, when a "provincial" archaic basilical church typology was nurtured in Macedonia, influenced by the specific historic constellation marked by the rise and fall of Samuel's independent State and Church - the Ohrid Patriarchate/Archbishopric;

- the early-Christian period, mainly the IV-VI century, when Christianity was established in the region as the official state religion, allowing for the first types of dedicated ecclesiastic typological solutions.

Beside these three basic historic periods, the doctoral dissertation also addresses the remaining inter-periods when basilicas were built, as well as their persistence to this day despite the technical and technological benefits of contemporary architecture.

The spatial scope of the research, on the other hand, proves more challenging to define with precision. This is due to the fact that in the abovementioned specific periods in time, Macedonia's geographical and ethnic territory, partially or entirely, was part of different states whose boundaries often shifted; from an independent state on many occasions it was converted into a province of great and powerful empires; whereas today, as an independent sovereign country, it only embraces a small part of its recent former territory. Although it might seem logical (in the context of the dominant line of research, which is the Revival sacral architecture) for this doctoral thesis to focus on Macedonia's territory in the XIX century, whose integrity within the Ottoman Empire was preserved up until the Bucharest Peace Treaty of 1913, yet this spatial scope has proven to be problematic. Namely, 2/3 of this once ethnically and linguistically unified region is today part of the neighboring countries of Bulgaria, Greece, and a smaller territory in Albania. Researching the Revival churches located currently within foreign territory is unfortunately out of the temporal and financial reach of this doctoral dissertation. Furthermore, as will be discussed in more detail, the Macedonian Revival master-builders worked with great intensity outside their homeland, throughout the Balkans, the Near East and even further, which additionally complicates the identification and deciphering of the origin and spread of the specific architectural language they used. As a result of these aggravating circumstances, the spatial scope of the doctoral thesis is mainly limited to today's political territory of the Republic of North Macedonia, additionally including individual churches built outside its current state frontiers which are considered necessary in order to clarify certain aspects regarding the hypothesis and the goals of the research.

The subject of the research is the entire monumental ecclesiastic architecture of the XIX century which can be classified as belonging to a basilical typology. In order to ensure visibility of their significant quantity, a catalogue of the Revival basilicas identified throughout the research has been included in the doctoral dissertation (see Annex), accompanied by known dates of their building, fresco-painting or consecration. From this catalogue, individual case-study churches have been chosen, as referent examples of the various distinctive typological solutions, for which a full drawing and photo documentation has been elaborated and which will be analyzed in detail in the chapter dedicated to their typological classification (Chapter III.5). In order to study the phenomenon of re-utilization of the basilica, part of the research subject are also the middle-Byzantine (X-XI century) basilicas, their ideal prototype: the earlyChristian basilicas (IV-VI century), as well as all basilical churches built in the meantime, with a special emphasis on several three-nave basilicas from the post-Byzantine period, which were erected in the specific conditions imposed by the Ottoman occupation.

In conclusion, among the main goals of this doctoral dissertation stand out: 
- To identify the origin and influence of the monumental sacral architecture from the XIX century Revival, whose dominant typology is the basilica;

- To confirm its potential connection with the Court basilical architecture of Samuel's kingdom (X$\mathrm{XI}$ century) and its significance;

- To identify the influence of the basilica prototype: the early-Christian basilicas (IV-VI century).

\section{Methodology and Time-frame of the Research}

Many sources have been consulted for the purposes of this doctoral research, which can be divided into two broader categories: primary and secondary sources. The primary sources comprise of constructed (built) and written sources. All basilical ecclesiastic buildings (dating from the early-Christian, middle-Byzantine, late-Byzantine, post-Byzantine as well as the Revival periods), which exist and still function today, have been altered or partially reconstructed or have been preserved as archeological remains, are considered as built sources. As written primary sources, abundant graphic documentation, drawings, sketches, photographs and plans have been consulted, located in the archives of various institutions, notably the Institute for Protection of Built Heritage, History of Architecture and Art within the Faculty of Architecture, University "Ss. Cyril and Methodius" - Skopje; ${ }^{1}$ the Institute of folklore "Marko Cepenkov", University "Ss. Cyril and Methodius" - Skopje; the National Conservation Center - Skopje; the Institute for Protection of Monuments of Culture and Museum - Bitola; the Institute for Protection of Monuments of Culture and Museum - Ohrid, etc. Unfortunately, as was already mentioned, the Revival's sacral architecture has not received sufficient scientific and institutional valorization, thus many of the Revival basilicas, especially the ones which have not been granted legal protection status are still lacking documentation or expert evaluation of their current state of preservation. In that context, the preparatory work for this doctoral dissertation comprised, to a large extent, of the extensive field-work necessary for obtaining relevant documentation.

The secondary sources category comprises all available published and unpublished documents, scientific and popular publications, papers, periodicals and bibliography on the subject. All consulted bibliographical references are listed alphabetically in a dedicated chapter at the end of the thesis, in two sub-categories, according to the alphabet of the publication (Cyrillic or Latin).

Regarding the methodological conceptual approach, the research for this doctoral thesis was based predominantly on compilation, description and comparison. The first methodological phase was comprised of recognition, ordering and cataloging of the available documentation found in various archives, historic sources and scientific literature. Therefore, the description of the monuments bears a significant part of the conceptual load. Within this descriptive approach of each individual reference model (case-study), an effort was made to include several defining categories, such as the geographicalhistorical context and the motifs and influences which contributed towards the chosen architectural typology. Based on such classification of the available material on all reference Revival basilicas, the second part of the research was dedicated to a comparative analysis of the multiple typological solutions

\footnotetext{
${ }^{1}$ The archive of the Institute for Protection of Built Heritage, History of Architecture and Art, Faculty of Architecture, University "Ss. Cyril and Methodius" - Skopje, guards a remarkably extensive drawing and photo documentation of a multitude of examples from Macedonia's architectural heritage including urban and rural residential architecture, monumental early-Christian and medieval architecture, examples from the Islamic built heritage up to representative examples of the modernist and post-modern architecture. As a result of the dedication and commitment of the Institute's employees, with the participation of several external collaborators including the author of this doctoral thesis, throughout the last decade a significant increase has been achieved in the quantity of documented Revival basilicas, which has so far accumulated 22 fully documented churches. In that sense, the author would like to, once more, sincerely thank the Institute for the support, help and selfless collaboration without which the elaboration of this doctoral dissertation would have been significantly more difficult, if not completely impossible.
} 
of the XIX century, as well as a comparison with their post-Byzantine, Byzantine and early-Christian antecedents, so that both their determined similarities as well as their evident differences contribute towards results confirming the defined hypothesis and, ultimately, towards achieving the goals set for this doctoral thesis.

The basic methodological instruments used are, therefore, the chronological and historical method, the cross analysis and comparative analysis. Regarding the used tools, essential to the methodological concept of this doctoral thesis is the graphic representation. The drawing as an elementary form of the architectural syntax is accompanied by photographs made by the author, or older, archival photographs. Therefore, in order to obtain a precise and accurate documentation, for the greater part of the represented examples the principle of direct measurement by hand was applied, especially for those churches which have not been documented ever before or, when available, an existing drawing documentation was meticulously reviewed, updated and expanded; in both cases imposing thorough and laborious field-work as a necessary, inevitable step. In terms of the applied digital tools, in the next phase the technical documentation was processed in the software program AutoCAD, whereas Adobe Photoshop and Illustrator were used for the maps, photographs and graphic illustrations. The software program Microsoft Word was used for processing of the textual part of the doctoral thesis; whereas all tables, charts and statistical analysis of data was completed using Microsoft Excel.

Regarding the proposed time-frame, the research was organized in three basic phases:

1. Identification and localization

a. Identification of bibliographical references and state of previous research (secondary sources)

b. Identification of available documentation, photographs, plans, videos (written primary sources)

c. Localization of existing monuments (built primary sources)

2. Research and elaboration

a. Revision, processing and analysis of bibliographical references (secondary sources)

b. Digitalization and classification (written primary sources)

c. Field-work - visit to referent built monuments. Detection of the applied typological model, chronology of construction, modifications, materials, construction techniques, decoration etc. (built primary sources)

d. Analysis of gathered information

\section{Writing}

a. Writing using a text-processing software

b. Preliminary revision and corrections

c. Graphic layout.

\section{Results}

The expected results can be classified within two groups:

Primary result: to confirm or reject the previously established hypothesis.

Secondary results:

- to expand the existing knowledge of the XIX century monumental religious architecture in Macedonia;

- to elaborate drawing and photo documentation which will enrich the existing documentation for this built heritage, facilitating future research, analysis and comparative studies;

- to contribute towards the valorization, protection and revitalization of this category of monuments, awarding it the attention it deserves. 
8 THEXIX CENTURY BASILICAS IN MACEDONIA: ORIGIN, TYPOLOGY AND INFLUENCES 


\section{HISTORICAL BACKGROUND}

\section{I.1. The Basilical Typology. Origin, Structure, Dispersion}

The basilica is one of the most versatile, archetypical architectural forms, present in the monumental religious and profane architecture to this day. The origin of the basilical typology can be retraced deep into the past, in the architecture of the ancient civilizations, from which Christianity adopted it, adjusted it to its complex ritual and dispersed it throughout its vast sphere of influence or, in other words, throughout the entire then known world.

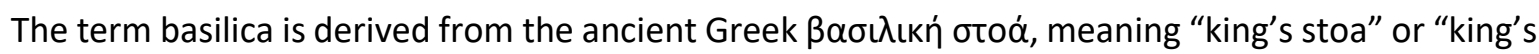
hall" (Бошковић, 1967: 10). During the antique period, the term applied to any large, covered hall, regardless of whether it was used for residential purposes (as was the case of the monarchs' palaces which regularly incorporated an audience hall), as a commercial space, public building (court-house, city council) or a religious structure (oratorio, temple). Its architectural typology is a mix of Hellenistic and Oriental elements. The influence of the eastern-Mediterranean civilizations was present in the region since the expansion of Alexander the Great's state in the IV century B.C., mixed with the predominant Hellenistic culture. In the cosmopolitan spirit of his short-lived reign, an orientation towards the East will prevail in the centuries to come, reflected in the religious art and architecture. ${ }^{2}$ Precisely the mixture of diverse elements constituting his Empire, which will continue despite its rapid territorial disintegration, in the long haul prepared a fertile ground for the development of the upcoming ethnically diverse, composite empires - Rome and later Byzantium - based to a large extent on the Hellenistic and eastern cultures, while also representing a base for the swift expansion and establishment of Christianity (Hoddinott, 1963: 4-5). As far as dominant architectural models and typologies are concerned, it was Alexander's heirs who adopted a proto-basilical form for their audience halls (basically comprised of a tall elongated nave, flanked by colonnades), inspired by the Egyptian hypostyle halls and the Persian mithreum. ${ }^{3}$ Additionally, from the residential architecture of the eastern Mediterranean they borrowed the concept of a closed patio - atrium, surrounded by open porticoes. On the northern edge of the Iranian Plateau, appeared a

\footnotetext{
${ }^{2}$ Namely, influence from older cults is evident in the identification of Alexander the Great as a Sun-God: the Egyptian cult towards the god-pharaoh and towards Osiris; the Hittite's duality comprised of the god Teshub and the sun-goddess Hebat; the Persian cult towards the sun deity Mithra, whose equivalent in the Hellenistic patreon is Apollo. Later on, the same principle will be adopted by the Roman emperors, beginning with Nero (54-68), Caracalla (211-217), Severus (222-235), Constantius II (337-361), Constans (337-350), Valens (364-378) and Honorius (395-423) (Hoddinott, 1963: 9). Their representation as solar deities followed by a respective iconography in different media (coins, reliefs, sculpture, frescoes etc.) will echo in the early-Christian shaping of the cult and its symbolic representations.

${ }^{3}$ Naturally, the temple typologies of these eastern civilizations were imported through warship. The temples dedicated to Mithra - so called mithreums - have an essentially basilical disposition. One such example is the mithreum in Dura Europus, on the banks of the Euphrates, built in 168-170.
} 
tripartite residential structure called an ivan, where the three halls (the central of which, where the local ruler held his ceremonial audiences, was usually broader than the lateral ones), were connected by a continuous open portico on their shorter side (fig. I.1A). The Sassanid palaces of the VI century further developed this earlier prototype (Hoddinott, 1963: 10-11). ${ }^{4}$ A similar concept can be found in Syria, ${ }^{5}$ where the tripartite sanctuaries already demonstrate a distinguished basilical typology, including an apse in the central nave, carved into the massive eastern wall and flanked by rectangular lateral chambers (fig. I.1B). Lastly, the influence from the Jewish temples and synagogues must not be overlooked.
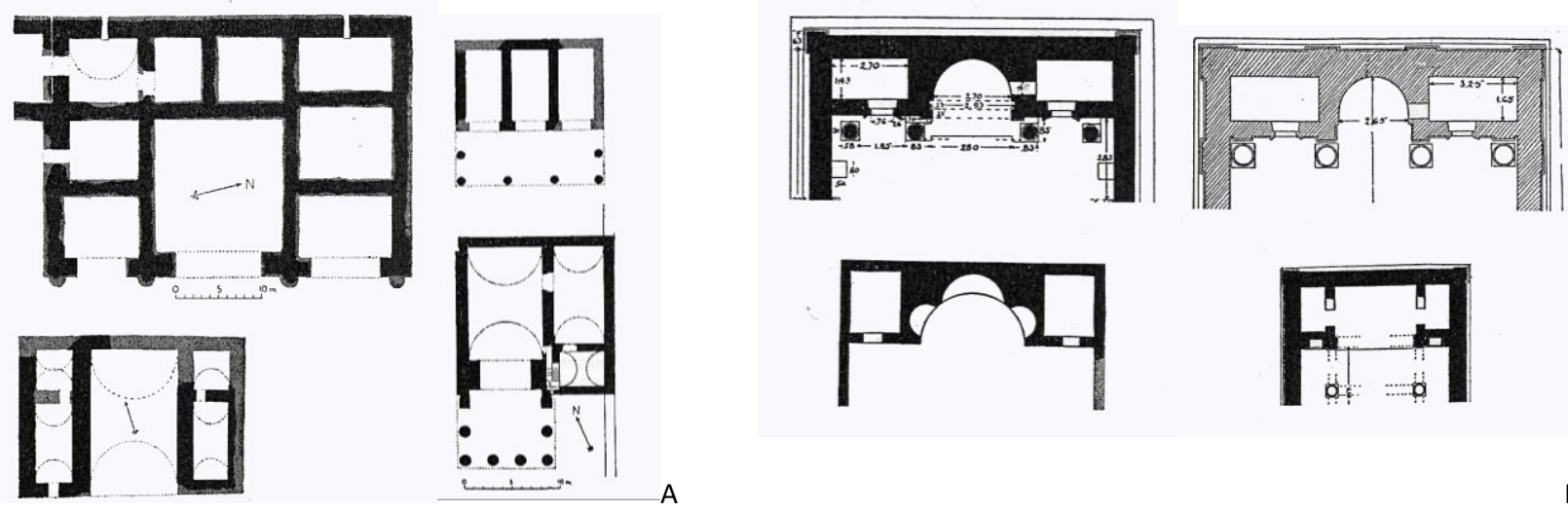

Figure I.1 Oriental tripartite buildings. A. Ivan palaces, Mesopotamia; B. Syrian tripartite sanctuaries.

All of these international influences, concepts and ideas, as previously by the Macedonian kingdom, were synthesized within the Roman Empire. Namely, the elongated rectangular monumental hall with internal peristyles will become one of the corner-stones of Roman architecture, often erected in the central urban cores, on the Forum or in its proximity, and given a variety of public functions. Although the roman basilica is not a typologically strictly defined building, it is without an exception a broad, spacious hall designed to welcome a numerous audience. Despite their variability, the basilicas regularly incorporate internal colonnades dividing the space into naves, with apses at one, and sometimes at both ends, ${ }^{6}$ often with an elevated podium housing the public servants and magistrates (Roth, 1999: 235). The

\footnotetext{
${ }^{4}$ The early-Christian basilicas in central Mesopotamia will continue this tradition, incorporating a fully developed tripartite sanctuary separated from the naos not by a short altar partition, but rather by a full wall, pierced by three entrances. These churches have either a single-nave naos with massive lateral pilasters forming rectangular niches and covered by a vault, or, as a more developed solution, a three-nave naos with particularly narrow lateral naves, of equal height as the central one. In the region of Tur Abdin in northern Mesopotamia, which remained for a longer period under Roman ecclesiastical rule, the churches follow two distinct models. The first type is an almost square building, with an adjacent narthex to the west, a transverse singlenave naos and a fully differentiated tripartite sanctuary to the east, analogue to the Persian ivan palaces. The central tract of the sanctuary evolves from a simple rectangular room, via an apse carved into the eastern wall, to a semi-circular protruding apse as the most developed solution. Examples of this typology are the monasteries of Mar Jakub, Mar Gabriel, Mar Ibrahim etc. The second typology consists of a longitudinal vaulted naos with massive lateral pilasters and niches, with a deep apse carved into the eastern façade wall. The narthex in this group is located, characteristically, to the south. Examples of this typology are Mar Kyriakos, Mar Azaziel, etc. (Hoddinott, 1963: 36-38).

5 "The tripartite nature of the symbol, whether Pagan or Christian, is of such ancient origin that it would be unwise to do more than note that it appears to be a particularly prominent feature of religions practised by the Indo-European group of peoples. Unquestionably, three, the figure of the Trinity and, in sacred arithmetic, the figure of the soul, reflected a fundamental concept accepted with relatively little dispute by all the leading western Asiatic religions - except the Semitic monotheisms of Judaism and Islam. As well as in art, Christianity was to make particular use of it in architecture, notably in the form of the tripartite sanctuary, in trefoil and triple apses, and in the adoption of the basilical nave and aisles" (Hoddinott, 1963: 21). The Syrian early-Christian basilicas, though built under strong European (Roman and Hellenistic) influence enforced by the local episcopal centre Antioquia, preserve the pre-Christian tripartite sanctuary with a deep altar apse and two lateral chambers carved into the mass of the eastern façade. In eastern Anatolia, however, emerges a relatively classical three-nave basilica with one apse and no lateral chambers, but incorporating a tripartite narthex as an echo of the Hittite's temples called the hilani, whose lateral spaces can be identified as the prototype of the prothesis and diaconicon (Ibid: 39-40). Such example is the church in Bin-bir-kilise.

${ }^{6}$ For example, a five-nave basilica with broad apses at both ends is the renowned basilica Ulpia located on Rome's Forum ( 98117). Following the same model, the audience hall called the Hrizotriclinios (the "Golden hall") was built in Constantinople during
} 
significant width of the building dictated a clerestory solution in the central nave, in order to bring in sunlight to the inevitably darker center. This is the prototype upon which early-Christian basilicas were based, at first with limited alterations of the original concept. Later, however, after the final official division between the Western and Eastern Church, their architectural styles will drift apart, following completely divergent paths.

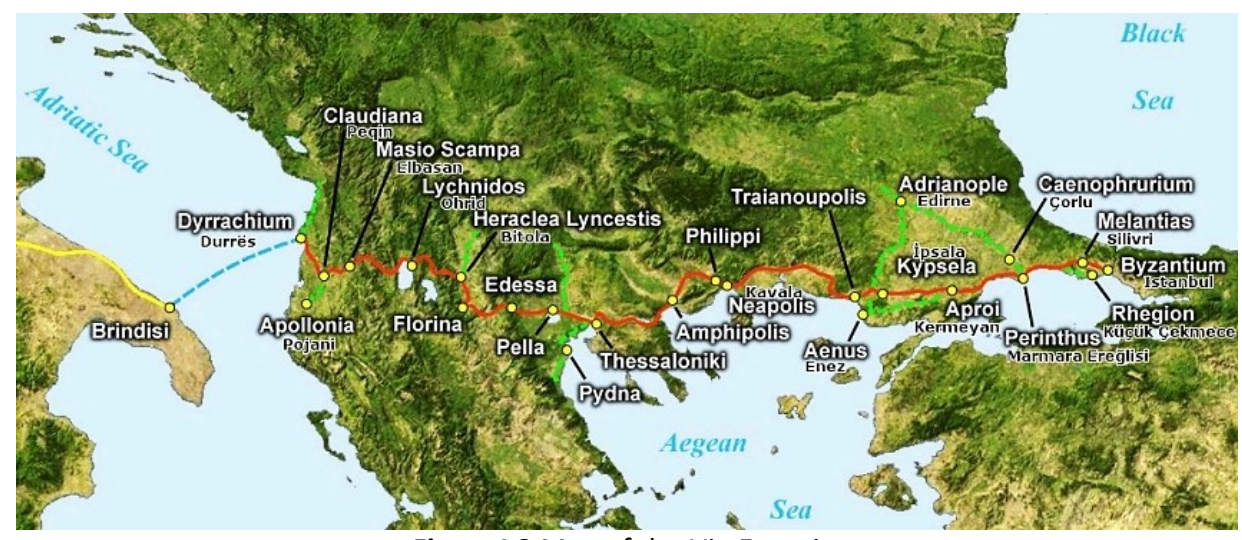

Figure I.2 Map of the Via Egnatia.

The oldest basilicas discovered in Macedonia belong precisely to this type of Roman civil building, built after the third Roman-Macedonian War (171-168 B.C.) which marked the beginning of a long period of Roman rule in the region. ${ }^{7}$ Almost immediately after being conquered, Macedonia was converted into a Roman province and a crucial base for Rome's upcoming military operations in the Balkans and the Near East (Јанакиевски, 1983: 158), initiating a thorough reconstruction of the existing road infrastructure. Given its central position on the Balkan peninsula, several important roads crossed Macedonia's territory: the Via Axia, following the river Axios (Vardar)'s valley in a north-south direction, linking the Aegean Sea with the northern provinces along the Danube Limes; the diagonal road linking Heraclea Lyncestis with the Via Axia at the ancient town of Stobi and stretching further to the north-east towards Serdica (Sofia) and the Black Sea; and the Via Egnatia, which linked the Ionian Sea to the west with the Aegean Sea to the east, stretching towards the Empire's eastern capital Byzantium (Constantinople). The Via Egnatia was of particular importance to the Empire, since it represented the shortest road connecting Rome and Byzantium by land, following an existing, ancient trajectory (fig. 1.2$).{ }^{8}$ It was along these roads that intensive trade, military, economic and cultural exchange regularly flowed from the west to the east and vice-versa, introducing a contemporary, cosmopolitan influence in the continental provinces (Чаусидис, 2012: 73). The same roads will be later used by the apostles and their disciples on their mission preaching Christianity on the Balkans and further into Europe (Шивачевъ, 1929: 7). Located in the center of this important communication, Macedonia will later for centuries be the subject of battle for political and religious domination between Rome and Constantinople.

After a certain period of cultural stagnation conditioned by the civil wars and "barbaric" conquests, came a period of relative peace and stability, when the Macedonian towns began to thrive and develop into "highly urbanized centers" (Јованова, 2013: 796) within the new Roman Empire. This development followed the roman urban pattern, yet preserving the existing Hellenistic architecture especially in those settlements where the same location was continuously inhabited. Independently from the terrain's

the reign of Justin II (565-574). It is important to note that a similar mirrored apse solution was also adopted by some Christian temples, such as the five-nave basilicas in Erment (Egypt) and Orleansville (Algeria) (Бошковић, 1967: 52, 54, 60).

7 The three Roman-Macedonian wars were fought in 215-205, 200-197 and 171-168 B.C. Macedonia came to loose its partial independence by 148 B.C., when it was granted the status of a Roman province under the same name (Јованова, 2013: 793).

8 The section to the west of Lychnidos was known as the Candavian road, named after the Candavian Mountains which lie to the west of Ohrid Lake (Битракова-Грозданова, 1988: 37). Some researchers use the term "Cadmean road" (Proeva, 2019: 189-201). 
topography, according to the roman system the towns followed an orthogonal network (urbs quadrata) of intercepting streets forming city blocks (insulae), into which the existing older urban tissue was adjusted and incorporated. In the center and along the main streets (the cardo and decumanus maximus) the necessary public buildings were often aligned: the forum-agora, squares, temples, a civil basilica, ${ }^{9}$ a theatre, public baths, a gymnasium, a horreum etc., accompanied by residential architecture and other important infrastructure.

Within multiple archeological campaigns in the large Roman urban centers on Macedonian territory, so far several civil basilicas have been discovered. ${ }^{10}$ The civil basilica in Scupi (basilica I) was erected in the early IV century on the city's forum (fig. I.3A). Typologically, it is a three-nave basilica, with an apse to the west (Koraćević, 1989: 102) as wide as the building itself, built in opus quadratum and strengthened by massive external pilasters $(90 / 90 \mathrm{~cm})$. The three-nave composition is achieved by a concentric multiplication of this structure within the building, thus forming a narrow $(2.4 \mathrm{~m})$ perimetral " $U$ "-shaped nave encircling the central nave. The square pillars supporting the arcade are paired with Corinthian columns supported on tall pedestals, which probably served only a decorative purpose (Микулчиќ, 1999: 255). Originally, there existed a narthex to the east of the complex. Fragments of highquality marble reliefs (columns, architraves and capitals) have been discovered along the external wall. While the floor in the lateral nave has not been preserved, the central nave was originally covered with mosaics of geometrical and circular ornaments, which also covered the walls (Кораќевиќ, 2002: 76-82).
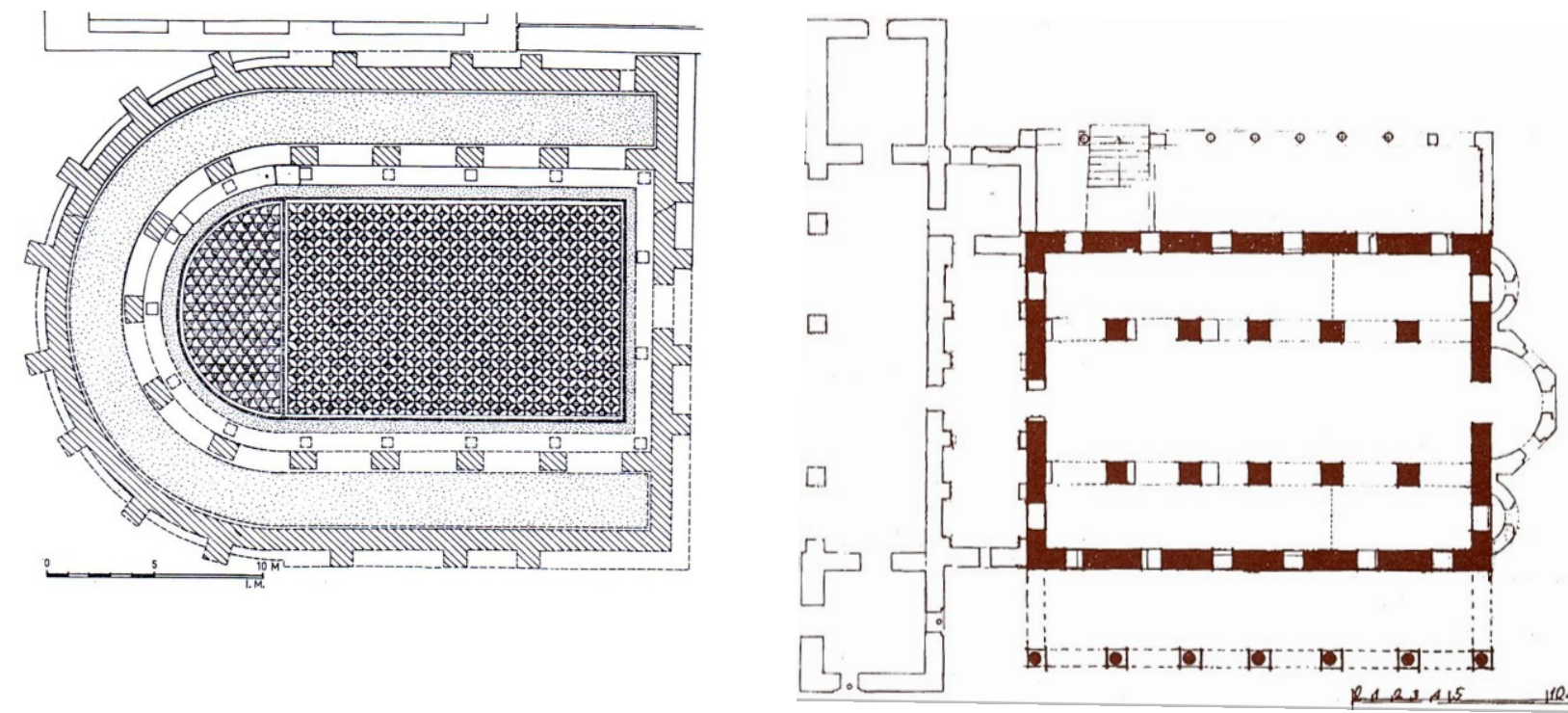

Figure I.3 A. The civil basilica in Scupi; B. The civil basilica under the naos of St. Sophia in Ohrid, according to Boris Chipan.

The civil basilica in Stobi is located in the northern part of the town. It was built over the remains of older buildings, as witnessed by several bronzes dating from the $V$ century B.C. discovered in its apse; Hellenistic layers dating from the III-II century B.C.; as well as remnants of fresco-paintings in the naos dating from the I century (Aleksova, 1989 (A): 47-48).

The limited scope of the archeological probes undertaken in the cathedral church of St. Sophia in Ohrid - the ancient town of Lychnidos, during the restoration of the church in the 1950s, confirmed that it was erected over the foundations of at least two older buildings (Љубинковиќ, 1955: 10). The older, whose remains lie $-3.9 \mathrm{~m}$ beneath today's naos' floor, presumably belong to a roman civil basilica (fig.

\footnotetext{
${ }^{9}$ Regarding the basilicas, whose location should be in the close vicinity of the Forum, Vitruvius will indicate that: "in breadth they should be not less than one third nor more than one half of their length, unless the site is naturally such as to prevent this and to oblige an alteration in these proportions (...) the columns of basilicas ought to be as high as the side-aisles are broad; an isle should be limited to one third of the breadth which the open space in the middle is to have" (Витрувиј, 1960: 132).

${ }^{10}$ Remains of civil basilicas have been unearthed in the ancient towns of Scupi, Lychnidos, Stobi, Heraclea Lyncestis.
} 
I.3B), dated in the III-IV century and likely serving a function linked to the town's market and the lake port located in its close proximity (Чипан, 1996: 25). In this oldest phase, the basilica spun the width of the naos of today's cathedral in a north-south direction; however, its length along an east-west axis is yet to be determined. ${ }^{11}$

In conclusion, the Roman towns in Macedonia regularly incorporated monumental civil basilicas serving different public functions. In such a setting, after Christianity became an official religion in the Roman Empire, it was only natural that the multiple churches erected for the worship of the Christian cult adopted the most luxurious, most monumental ceremonial building type available - the basilica.

\section{I.2. The Early-Christian Basilicas (IV-VI Century)}

The period between the IV-VI century belongs equally to the Roman and Byzantine history, spanning the last three centuries of the Roman civilization's existence and the first three of the Byzantine's. It is a transitional period, leading from an ancient into a medieval society, when "the Roman elements gradually disappear, and the new, byzantine elements gain greater importance" (Острогорски, 1959: 50). The foundation of the Byzantine Empire has traditionally been linked to the year 330 A.D., when Byzantium (later known as Constantinople) became Rome's new capital, shifting the balance towards the East which inevitably led to an increasingly evident Hellenistic and oriental cultural influence on the State, the Church and, subsequently, its art and architecture. The final division between the Western and Eastern Kingdom followed shortly, in 395 A.D., allowing for the formal recognition of Byzantium as an independent state, which despite its ups and downs survived the entire following millennium, as opposed to the Roman western kingdom which would soon disintegrate (Aleksova, 1989 (B): 96-97).

In addition to the political turmoil, the IV-V century also represents a period of "spiritual revolution" (Brown, 1971: 51), marked by the consolidation of the Christian dogma. In 313 A.D., during the reign of Constantine I (306-337), the Edict of Milan proclaimed Christianity as an official religion thus ending centuries of persecution and martyrdom. ${ }^{12}$ The first Ecumenical Councils held in the upcoming period ${ }^{13}$ settled the ongoing dogmatic disputes (Георгиева-Петковска, 2001: 25-39). Several bishops from the Macedonian towns of Heraclea Lyncestis, Stobi, Bargala, Zappara, Scupi, lustiniana Prima and Lychnidos are known to have participated (Манева, 1993: 18). These urban centers - bishop's seats represent the background for the establishment of new Christian religious architecture. In fact, precisely the high level of urban development of the Roman Empire and its well-maintained road network, as well as the political unity of many diverse autochthonous peoples coupled by the predominance of the Latin and ancient Greek languages among the well-educated Roman citizens, contributed toward the remarkably fast spread of Christianity, ${ }^{14}$ despite the initial resistance.

\footnotetext{
${ }^{11}$ In that context, the archeological remains to the west of the cathedral's exonarthex are particularly noteworthy, unearthed in 1967 during an archeological campaign led by Vlado Malenko, archeologist at the IPMCM - Ohrid. Then, remains of a monumental building were uncovered, including a semi-circular apse oriented to the west, which undoubtedly points to the period prior to the IV century, when the early-Christian basilicas begun to be regularly oriented towards the east.

12 The persecutions begun in Rome in 64 A.D., during the reign of Nero (54-68) and continued with different intensity until 313 A.D. (Алексова, 2003: 11). Sporadically, similar events marked the first decades of the IV century, finally ending in 381 A.D., when emperor Theodosius I (379-395) proclaimed Christianity as Rome's state religion (Алексова, 1995: 5).

13 The first ecumenical council was held at Nicaea in 325 A.D.; the second in Serdica (Sofia) in 343/344 A.D.; in Ephesus in 431 A.D.; Chalcedon in 451 A.D. etc.

${ }^{14}$ Namely, "the preachers of Christ's teachings, never leaving the Empire, speaking only Latin or Greek, could plant the seed of Christianity amongst all peoples of the Empire" (Шивачевъ, 1929: 10). As stated in various historic sources and the holy scriptures, in 49 A.D. the apostle Paul and the evangelist Luke travelled to Macedonia, founding the first christian municipality in the town of Philipi (Ibid: 14-15). Travelling westward along the Via Egnatia, the apostle Paul founded churches in the macedonian towns he passed, where he preached for several years himself, or sent missions (Ibid: 19). It is noteworthy, in that context, to mention a belief embedded in local folklore, according to which he founded one such church in Velika - the medieval bishopric seat of st.
} 
The earliest Christian liturgy, as is well known, was held in secrecy in adapted quarters within private residential buildings (oikos ekklesias - domus ecclesiae), as well as over the tombs of the martyrs within the towns' necropolis' (Алексова, 1995: 9-10), thus outlining the primary Christian cults. Most of these "temples" date to the III century and were in active use until the proclamation of the Edict of Milan. In Macedonia, one such example has been discovered in Stobi, under the consecutive layers of the episcopal basilica (Алексова, 2003: 13), which was used on the turn of the III towards the IV century. ${ }^{15} \mathrm{~A}$ similar concept was adopted by the other monotheistic religions in the Empire, an example to which is the so-called House of Tiberius Claudius Polycharmus in Stobi, dating from the II-III century, next to which

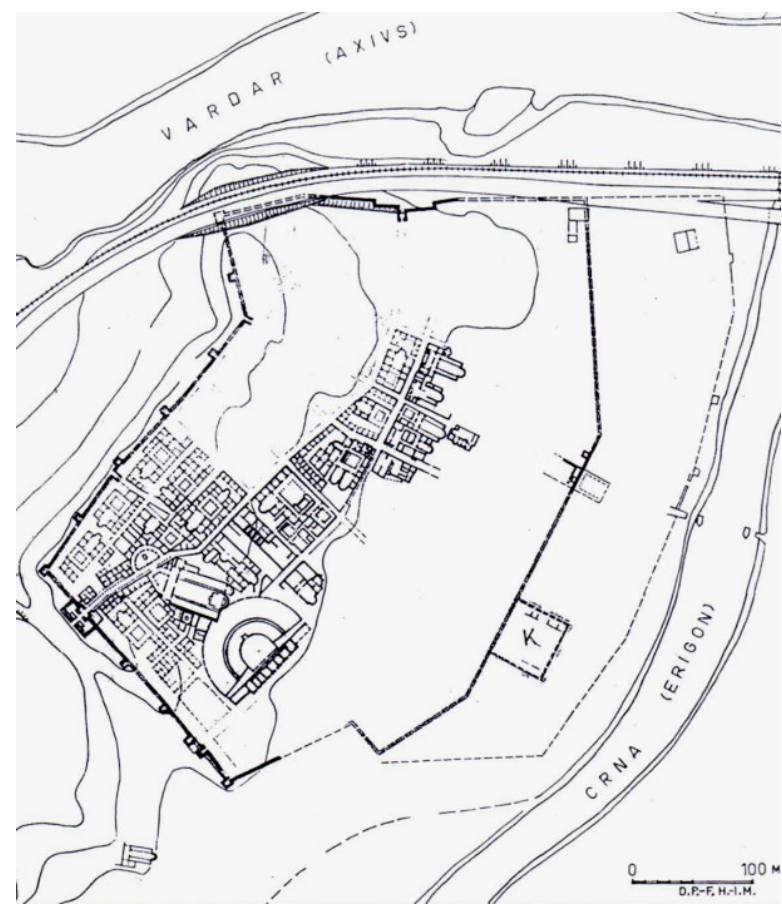

Figure I.4 Map of the town of Stobi in late antiquity. a basilica-synagogue was erected later and used until the late IV century, when it was ultimately replaced by an early-Christian basilica (Јованова, 2013: 810). In fact, the construction of a basilica over the remains of a public or residential building possibly serving as a secret Christian temple was fairly common. Such example is the north basilica in Stobi, erected over a spacious late-antique palace (Алексова, 1995: 14); the Palikura basilica in Stobi, built over a large older structure on the banks of the Erigon (the Crna River), possibly a villa rustica, reutilizing stone reliefs and other material from the very site (Алексова, 1983: 153-154), as well as from the town's theater which was already abandoned in the $\mathrm{V}$ century and used extensively as a quarry. In Scupi, the eastern half of a monumental earlyChristian basilica dating from the end of the $\mathrm{V}$ - the beginning of the $\mathrm{VI}$ century lies over an older luxurious town villa located next to the theater, boasting its own private thermae (Кораќевиќ, 2002: 86-93) later used as the basilica's baptistery. In Heraclea Lyncestis, the smaller basilica was built over a portion of the Forum, whereas the larger basilica stands over the remains of a civil basilica from the II century (Ѓоргиевска, 2003: 226, 229).

The Edict of Milan initiated a building spree of religious architecture dedicated solely to the Christian cult. As early as under Constantine I (306-337), the Christian temple adopted the basilical shape as most convenient for massive gatherings essential to the Christian liturgical ritual. Based on the nature of the ceremony it was meant to house, the new Christian architecture could not look for inspiration to the antique polytheistic temples as smaller, intimate, mystic buildings accessible only to a dedicated few. Therefore, it turned towards the predominant model of the large public buildings, establishing the basic features of the Christian temple. In addition to the general outline of the Roman civil basilica, the earlyChristian churches adopted some of the key features of the public spaces of the ancient civilizations (the agora, the stoa, the forum), such as the open porticoes, colonnades, the enclosed atrium. In addition, the already established tradition during several centuries of celebrating the Christian liturgy in residential buildings, specifically in their most representative room - the triclinium (dining room) which usually

Clement - on a location between the villages Veleshta and Vranishta, north of the town of Struga. It is there that the remains of a large middle-byzantine basilica dedicated to the Virgin have been discovered later on (see Chapter I.4.2).

${ }^{15}$ It has been dated according to a coin depicting Galerius Valerius Maximanus (293-311), as terminus ante quem non. This initial improvised temple measured $7 / 7.5 \mathrm{~m}$ and had a monumental western entrance through a representative tribelon, whose plinth has been discovered in situ. Over its remains were located the altars of all following phases in the history of Stobi's episcopal basilica. 
incorporated an apse at one end - should not be overlooked. It seemed only natural that, once free to publicly celebrate their religion, the early Christians chose the type of sanctuary they were accustomed to for generations, remembered not only as a place of worship but also of martyrdom in the centuries of persecutions (Hoddinott, 1963: 25-26). Therefore, it can be concluded that "the design of the first basilicas was a solution which, in the simplest way, achieved a clearly formulated social necessity in an urban setting. Basically, a hall, such was common at the time for various buildings: from civil basilicas up to royal aulas, was enlarged by lateral closed porticos. The upper construction of such a space was the simplest possible: a wooden architrave structure. The interior decoration of the building was determined by its founder's ambition" (Кораћ и Шупут, 1998: 17). Furthermore, since the spatial composition of the basilica is axial, it fitted the aim to focus the congregation's attention to one focal point: the altar apse (Roth, 1999: 260). In addition to the predominant type: the three-nave basilica, single-nave basilicas were also built throughout the early-Christian period, which included a semi-circular apse and often a narthex.

The second category of early-Christian cult buildings are the martyria, monumental tombs and baptisteries, built as annexes to the basilicas or as individual objects, which in response to their completely different purpose adopted a centralized typology from the ancient mausoleums, such as the rotunda (circular or octagonal) and the polyconch plan, according to their structural nature covered by a dome. In the $\mathrm{V}-\mathrm{VI}$ century the martyria were converted into churches "enlarged and adjusted to the necessities of a general cult" (Алексова, 1995: 11). Their role in the future development of the byzantine religious architecture must not be overlooked, for they contribute to a large extent to the expansion of the later mature typological solutions such as the trefoil and the inscribed cross.

The construction of new Christian temples will become especially frequent after 381 A.D., when Christianity became the state's official religion, thus allowing for the State itself as well as the Church to become their predominant founders and financiers, a role they will play in the entire upcoming millennium. The first basilicas, built in the IV century, according to their "forms and crafts belong to the late Roman architecture" (Кораћ и Шупут, 1998: 15), but differ in content compared to their Roman civil counterparts. As new functions differentiated, arising from the development and evolution of the Christian cult, the new program gradually materialized in the structure and arrangement of the temples, as well as their architectural detail and ornament. These novelties became more and more present in the following, $V$ century.

The lack of written sources regarding the development of the Church in the early centuries is "somewhat mitigated by the impressive number of religious buildings" (Маленко, 1989: 3) discovered in Macedonia so far. ${ }^{16}$ Most early-Christian basilicas were built in two waves: the second half of the IV century after the religion became legal and in the V-VI century (Снајвли, 2013: 1396), within a consolidated, stable and prosperous Byzantium following the invasion of the Goths in 479 A.D. (Brown, 1971: 22) and culminating under the famous emperor Justinian I (527-565). The main concentration of the early-Christian basilicas is found in the urban and episcopal centers; nevertheless from the $V$ century onwards cemetery basilicas were also erected within the existing necropolis (Snively, 2003: 67), usually built over the burial site of important saints and martyrs (Алексова, 1995: 13) as places of religious pilgrimage. The typology of these numerous newly-built or reconstructed basilicas will be discussed in further detail on the following pages.

\footnotetext{
16 Throughout Macedonia (up to 1997) a total of 235 early-Christian basilicas were registered (Лилчиќ и Илјоска, 1997: 21-25). More than 20 of them have been discovered along the shores of Ohrid Lake (Лилчиќ, 1989: 69); a similar number is known in the Skopje valley "located predominantly within former settlements and castles, and in smaller numbers in the countryside" (Микулчиќ, 1981: 98). Surely, their total number is expected to be significantly higher, since there are a number of archeological sites indicated by individual finds pointing towards the existence of early-Christian basilicas which are yet to be discovered (Лилчиќ, 1984: 108). Ivan Mikulchic, in that sense, proposes a number closer to 300 (Микулчиќ, 1999: 322).
} 


\section{Typological Analysis of the Early-Christian Basilicas in Macedonia}

In accordance to their typological nature, the early-Christian basilicas in Macedonia are exceptionally monumental buildings. The liturgical process dictated the spatial composition of the temple, its division, and the addition of auxiliary chambers with specific function (Aleksova, 1989 (B): 97-98). A general architectural plan prevails: a three-nave naos linked to the west to a rectangular narthex and, in some cases, additionally an exo-narthex; an atrium encircled by open porticos - peristyles; to the north and/or south of the narthex a system of auxiliary chambers appears, usually a diaconicon, a prothesis and a baptistery with a piscine (fig. I.5A). The location of the auxiliary rooms on the western end of the temple is intrinsic of the early liturgical period when the Bible and the Eucharistic gifts were solemnly carried into the naos from the diaconicon in the presence of the congregation (Mathews, 1982: 125). The establishment of the "grand entrance" under the reign of Justin II (approximately in 574 A.D.), marked a change of the liturgical process, dictating a shift in the position of the prothesis and diaconicon to the eastern end of the church, flanking the altar (Манева, 1989: 54), ${ }^{17}$ a position they will keep throughout the middle ages and in the XIX century Revival. In addition to this general spatial disposition, the earlyChristian basilicas in Macedonia also include typical regional features. One such example is the baptistery complex, which in the Ohrid-Prespa region is located without exception to the south of the narthex (Битракова-Грозданова и Пупалески, 1989: 29).

The naos is divided into three naves by two low stylobates which support a row of columns (fig. I.7, $\mathbf{1 . 8})^{18}$ or, less frequently, masonry pillars (fig. I.5, I.9), ${ }^{19}$ forming an arcade. The arcade system appeared in the $\mathrm{V}$ century, and was established as the dominant solution by the $\mathrm{VI}$, completely suppressing the traditional architrave system (Ѓоргиевска, 2003: 233). ${ }^{20}$ Light penetrated the interior through windows in the lateral façades and through the central nave clerestory, adorned with intricately elaborate marble window transennas with a variety of geometrical ornamental patterns, as well as Christian symbols. Marble columns-mullions encountered at various archeological sites point to representative double and triple windows which regularly adorned at least the eastern façade. The eastern end of the central nave is usually shaped as a protruding semi-circular apse, ${ }^{21}$ whose diameter equals the nave's span, and which housed the altar table and often a small vaulted crypt where the relics of an important saint or martyr were kept. There are no apses in the lateral aisles; however, they often have exits to the east of the church (fig. I.5). The presbytery is separated from the naos with a low chancel screen, comprised of slender marble columns and a low parapet of stone slabs with Christian symbols also found on the capitals and impost-capitals (Димитрова, 2003: 134-149). A characteristic of the early-Christian basilicas on the Balkans is the separation of the altar from the lateral naves and a " $U$ "-shaped entrance "projected towards the west" (Алексова, 1983: 142), known as solea (fig. I.5B). To the west, the narthex is usually connected to the naos through three entrances, dictated by the physical gender-based separation of the

\footnotetext{
17 Yet, in the previous centuries an influence from the Near-Eastern provinces of the Empire is evident, especially Syria - where the concept of a tripartite sanctuary was conceived and the general orthodox liturgical protocol was basically established. Evidence of that tendency has been found in the small basilica at Heraclea Lyncestis, for example, where traces of a curtain rail have been discovered at the eastern end of the southern aisle, allowing for the visual separation of its eastern half into an improvised chapel - diaconicon (Hoddinott, 1963: 160).

${ }^{18}$ The columns were carved in polished marble, while the bases, capitals and impost-capitals were sculpturally elaborated. Often, such elements were re-utilized as spoliae extracted from older Roman monumental buildings located in proximity to the construction site: theaters, forums, street colonnades, or residential objects, palaces etc. As preparation to be installed within the structure of a Christian temple, they regularly received various Christian inscriptions and symbols (Алексова, 1983: 152).

19 The basilica at Suvodol, near Bitola; St. Erasmus near Ohrid etc.

${ }^{20} \mathrm{An}$ interesting example is the basilica in Scupi, where fragments of the fresco-decoration found at the site suggest that the arcade was formed by double arches between the columns, set $2 \mathrm{~m}$ apart, on average (Кораќевиќ, 2002: 129).

${ }^{21}$ As an exception, some basilicas have an apse enclosed within the eastern wall, as was the case with some of the oriental prototypes of the basilica. Such example is the smaller basilica in Heraclea Lyncestis (Ѓоргиевска, 2003: 226-227).
} 
congregation in the lateral aisles. ${ }^{22}$ The more representative basilicas had a tripartite entrance to the central nave, with arches supported by pillars, as is the case of the basilica in Scupi (Кораќевиќ, 2002: 131), or columns, as in Begov Dab, the northern basilica in Stobi, etc.
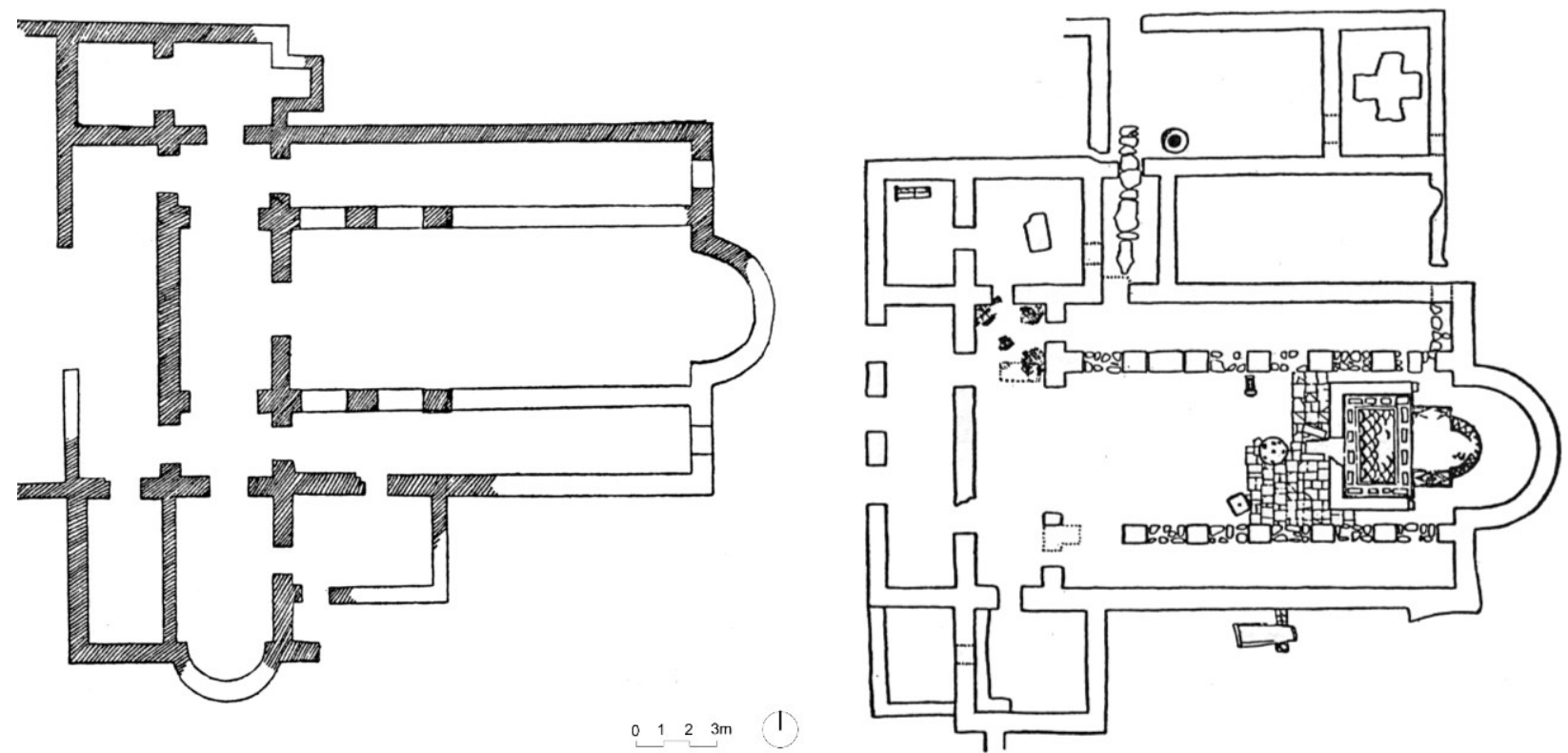

Figure I.5 A. the basilica at Radolishta (Struga); B. the basilica at Suvodol (Bitola).

Furthermore, the episcopal cathedral basilicas regularly incorporated a synthronon in the altar apse. ${ }^{23}$ Such examples are the episcopal, cemetery and Palikura basilicas in Stobi (Алексова, 1983: 143147), the basilica at Begov Dab near Makedonska Kamenica (see fig. I.10B), the one in Suvodol near Bitola (fig. I.5B), the small basilica in Heraclea Lyncestis, the two basilicas in Bargala (see fig. I.7). A synthronon is in fact a masonry tribune placed along the semi-circular apse used by the clergy during ecumenical gatherings, which sometimes included a monumental throne for the bishop himself (as in Begov Dab, Konjuh etc.). In some cases, such as the $\mathrm{V}$ century Stobi episcopal basilica, a significantly more complex solution was executed, where a semi-circular passage - an ambulatory separates the bema built over a crypt-confessio from the eastern apse wall, probably inspired by the complex crypt of St. Demetrius in Thessalonica (Hoddinott, 1963: 164).

The early-Christian basilicas usually have architrave ceilings covered, in the Hellenistic way, by a gabled roof over the central nave and skillion roofs over the lateral aisles. However, in the VI century, under the reign of Justinian I (527-565), the monumental architecture abandoned the strict subordination to the late-antique Mediterranean tradition (Несторова-Томиќ, 2003: 175) introducing the vaulted and domed basilicas, as well as central plan churches covered by monumental domes. The intrinsic characteristics of the new vaulted system, which will come to replace the architrave construction completely, above all the powerful lateral thrusts that need to be neutralized by means of structural reinforcements - buttress, pilasters or elements of contrasting lateral thrust such as lateral arches and vaults, will result in a thorough alteration of the churches' spatial composition and the creation of

\footnotetext{
22 Usually, between the columns over the low stylobate, parapet screens were plasced physically separating the central from the lateral naves, dedicated to the congregation. There are examples where the stylobates are double: lower ones which support the colonnades paired by higher ones which create not only a physical but also a visual barrier towards the central nave and the altar as "sacred places" where the liturgical ritual actually took place. Such is the case of the episcopal basilica in Stobi, the extra muros basilica in Philippi (today on the territory of Greece) where the stylobate reaches $0.65 \mathrm{~m}$ in height, while at the "basilica $\mathrm{A}^{\text {" in the }}$ same town it is as high as $1.7 \mathrm{~m}$ (Hoddinott, 1963: 102).

${ }^{23} \mathrm{~A}$ synthronon, as a characteristic feature of episcopal cathedras, is also regularly present in the X-XI century basilicas: at the church at Krupishte, St. Achilles in Prespa, St. Sophia in Ohrid, the basilica at Morodvis, St. Forty martyrs at Bansko, near Strumica (Филипова, 1997: 24).
} 
completely new, diverse typologies (Бошковић, 1967: 1). The impulse for this structural change originated in the eastern provinces, particularly Mesopotamia, Persia and later, at the beginning of the new millennium, the Sassanid state, where the local climate and the limited available building material contributed towards the development of vaulted solutions executed in stone and brick covering impressive spans (Ibid: 25-26), as well as domes supported on squinches. As a result of a long period of experimentation with the temples' structure, especially their upper construction, up to the middle of the IX century a new solution will be defined: "a new, in the spatial-constructive and artistic sense, finished concept, the well-known byzantine type of building is the inscribed cross with a dome (...) which will mark the entire architecture of the Byzantine world in the middle and late-Byzantine period" (Кораћ и Шупут, 1998: 99). From the Empire's capital, this tendency will quickly spread to the distant outer provinces. In Macedonia, on the contrary, the basilical typology will continue to dominate the monumental architecture production during Justinian's building expansion (Несторова-Томиќ, 2003: 176), defying the contemporary modern trends. ${ }^{24}$

Regarding the proportions of the early-Christian basilicas in Macedonia (fig. I.6) and the Balkans, the following models prevail: the width versus the length of the naos usually equals $2: 3$, occasionally 1:3; the width versus the length of the central nave is usually 1:3, while its ratio in relation to the side aisles is approximately 2:1 (Филипова, 1997: 23). The basic method used in the proportion of basilicas is the method of dynamic rectangles "based on the development of a rectangle fixed at one point on a square with intersecting diagonals. From it, through rational $(1: 2 ; 2: 1)$ and irrational proportions (V2:1; $33: 1$ and

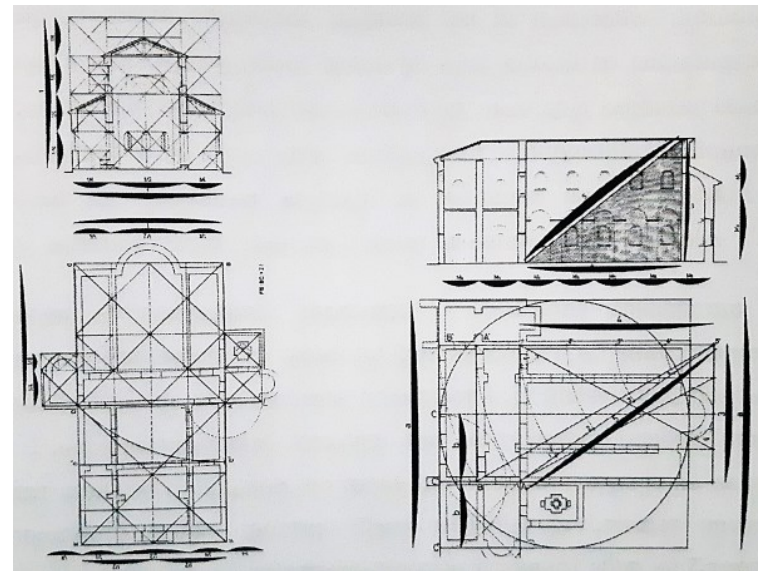

Figure I.6 Proportional analysis of the early-Christian basilicas at Studenchishta (Ohrid) and Radolishta (Struga).
V5:1) finally the selected form of the basilica is derived. Therefore, the dimensioning model required only the width of the object to be predetermined. It remains unchanged while the length develops through the diagonals" (Каранаков, 2013: 57).

In terms of exterior decoration, the earlyChristian basilicas were built with extreme modesty, unpretentiously (Roth, 1999: 280), using masonry comprised of crushed stone, mortar and brick and abundant use of spoliae selected from the easily accessible building material from older, mostly Roman buildings, often without articulation of the long, monotonous façades or application of luxury materials, and then plastered. In that manner, the contrast between the simplicity of the architectural "shell" and the abundance of the internal decoration is overwhelming (Каранаков, 2013: 58). Namely, the floors of the early-Christian basilicas were regularly richly and lavishly decorated with mosaics, especially in the nave, narthex, altar and baptistery, or using the opus sectile technique which was considered most expensive and prestigious and was therefore reserved for the presbytery (Снајвли, 2013: 1394), while the side aisles were usually decorated more modestly, with brick or stone slab pavement (Aleksova, 1989 (B): 108-110), or nicely smoothed horosan mortar (Aleksova, 1983: 148). On the walls, in some cases, fragments of fresco-decoration and wall mosaics have been preserved.

\footnotetext{
${ }^{24}$ Still, we encounter several examples of centralized solutions, derived from their particular nature as martyria. Such are the polyconch church at Plaoshnik (in Ohrid) built in the second half of the V - early VI century; the rotunda near the village of Konjuh (Kratovo); the circular church at Kletovnik near Krupishte (Shtip) and the trefoil at Tudence (Tetovo), dating from the second half of the VI century (Petrovska, 2010: 83-84).
} 


\section{Referent Examples of the Early-Christian Basilicas in Macedonia}

In terms of their function and subsequently their specific architectural typology, the early-Christian basilicas belong to one of the following categories:

\section{A. Monumental episcopal cathedral basilicas}

The churches built as episcopal cathedral temples are, logically, the most monumental ${ }^{25}$ and often architecturally most elaborate basilicas. They are regularly accompanied by residential and ecumenical content, as part of a complex episcopal ensemble. The oldest episcopal cathedral is Stobi's, built over the above-mentioned domus ecclesiae at the very beginning of the IV century, by bishop Budius (Bunius), one of the members of the Council at Nicaea. Later, this basilica was renovated and enlarged towards the east under bishop Eustatius in the second half of the century; only to be abandoned in the V century and substituted by a new, larger episcopal basilica under the bishop Philip (Алексова, 2003: 13). In Heraclea Lyncestis, the episcopal complex was comprised of two luxurious V-VI century basilicas (including a baptistery, episcopal synthronon and well preserved mosaic floors) and an episcopal residential palace.

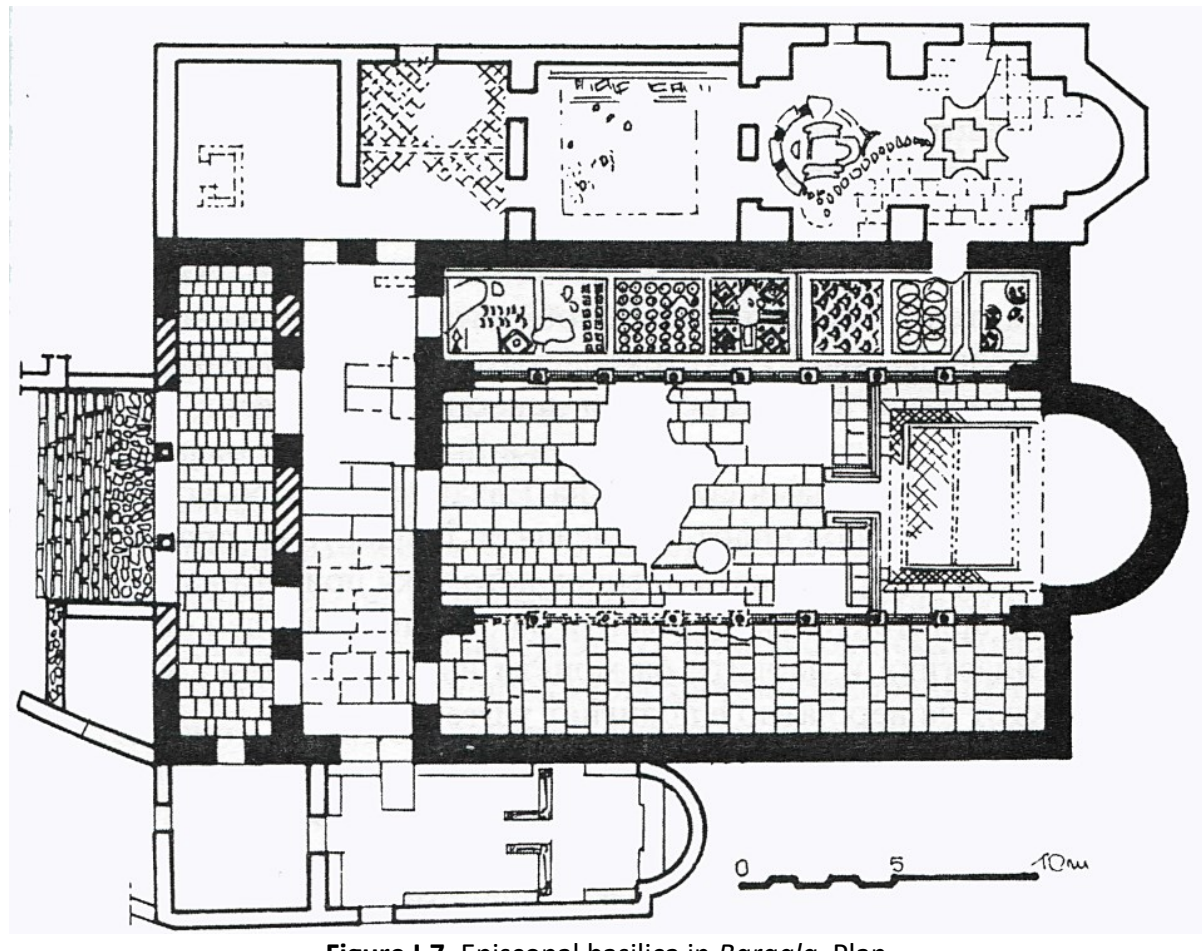

Figure I.7. Episcopal basilica in Bargala. Plan.

Another example is the early-Christian episcopal complex discovered in Bargala, the administrative center of the region to the east of the river Axios (Vardar), consisting of a basilica, baptistery, square, consignatorium, cistern, triclinium, horreum and residential area, built by the bishop Hermia in the IV and later renovated in the V century (Белдедовски, 2003: 221). The Episcopal basilica at Bargala, therefore, represents a distinctive category of early-Christian basilicas: the ecclesiastical cathedral. The naos measures $17.5 / 26 \mathrm{~m}$, including the apse, and a total of $22 / 40 \mathrm{~m}$ including the annexes. The internal three-

\footnotetext{
${ }^{25}$ The largest is bishop Philip's episcopal basilica in Stobi, which measures 29x53 m (Hoddinott, 1963: 162) not counting the western atrium, wich adds another $17 \mathrm{~m}$ in length; the basilica $C$ in Heraclea Lyncestis measures 24x45 m (Снајвли, 2013: 1350); the basilica at Plaoshnik in Ohrid is $47 \mathrm{~m}$ long; the episcopal church in Bargala measures 22x40 m (Белдедовски, 2003: 208); the basilica in Scupi 18×39 m, including the narthex and the altar apse (Кораќевиќ, 2002: 127). Bishop Philip's episcopal basilica in Stobi was spacious enough to allow for colonnades comprised of 11 columns (Микулчиќ, 1999: 314) separating the three naves of the naos, as is the case of the basilica $\mathrm{C}$ in Heraclea Lyncestis.
} 
nave division is achieved by two colonnades of seven columns each; the lateral naves are closed off using marble parapet screens (fig. I.7). To the west the naos is connected through three separate portals with the narthex and an open exo-narthex / portico. Additional chambers are located to the north, including a catechumenum and a monumental baptistery (with a cross-shaped piscine) with access to the northern aisle, whereas a small single-nave basilica - consignatorium with its own narthex was built, during the second building phase, adjacent to the south of the episcopal church (Белдедовски, 2003: 209). Remains of an ambo, chancel screen and luxurious mosaic and opus sectile pavements have been discovered on the site, predominantly in the presbytery, the baptistery ensemble and the northern nave, whereas the rest is paved with stone slabs.

\section{B. Medium-sized urban and cemetery basilicas}

The urban and cemetery basilicas are the most numerous group of early-Christian churches in Macedonia. They also have rather monumental dimensions ${ }^{26}$ and, with some variations, follow the previously described typological composition.

In the archeological site of Scupi, so far two early-Christian basilicas dating from the V-VI century have been discovered, as well as one cemeterial basilica built towards the end of the IV century within an existing necropolis (Алексова, 2003: 21). No remains exist today of another cemeterial basilica unearthed in 1935 outside the town's walls (Снајвли, 2013: 1387). In the old urban core of Ohrid (the ancient town of Lychnidos) a significant number of early-Christian basilicas has been discovered, as well as a bishop's residence (Снајвли, 2013: 1335). Most were built over late-antique buildings and the town's necropolis (Алексова, 2003: 22). Some of them have been discovered during urban communal work (the basilica Poparnica located between the streets Ilindenska and Klimentska; the basilica at the house of the Manchev family; the basilica located between the streets Ilindenska, Boro Shain and Hristo Uzunov, etc); some during archeological excavations; and some as foundations of later, medieval churches. Such is the case of the churches St. Nicholas Gerakomija, The Most Holy Mother of God Pandanos, St. Nicholas Chelnichki, St. John Arbanashki, St. Panteleimon (Маленко, 1989: 9) and the cathedral St. Sophia. The most monumental and lavishly decorated are the three-nave basilica at Deboj built over the older Hellenistic-roman necropolis at the end of the IV century (Битракова-Грозданова, 2000 (A): 10), and the complex of early-Christian basilicas at Plaoshnik, including a polyconch church-martyrium from the second half of the V - early VI century. Outside of the city walls of Heraclea Lyncestis several cemetery basilicas have been unearthed, such as the basilica at Suvodol (fig. I.5B), built over an antique necropolis (Алексова, 1995: 209-210), basilica $D$ in the eastern suburb and the remains of another basilica in the western suburbs of the town (Ѓоргиевска, 2003: 232). In Bargala, outside of the city perimeter (extra muros) four basilicas have been discovered, one of which has been excavated and researched (Алексова, 2003: 23). Similarly to Lychnidos, an important concentration of basilicas was also discovered in the archeological site of Stobi (fig. I.4), which "from a relatively small Payonian and later a Macedonian settlement during the Hellenistic period, grew into a vast and prosperous municipium in the early Roman Empire and, finally, as the capital of the roman province Macedonia Secunda (Salutaris) and a bishop's seat in the late Empire“" (Алексова, 1995: 87). Namely, so far nine monumental early-Christian basilicas ${ }^{27}$

\footnotetext{
${ }^{26}$ The basilica-synagogue in Stobi $(16 \times 43 \mathrm{~m})$; the Palikura basilica $(15 \times 33 \mathrm{~m}$, including the narthex and exо-narthex) (Алексова,

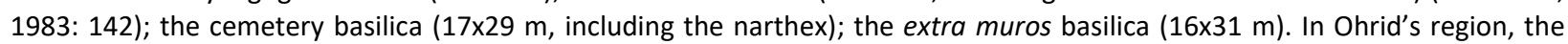
basilica under the naos of St. Sophia measures $15 \times 22 \mathrm{~m}$; the basilica in Radolishta 15×25 m, including the narthex (Hoddinott, 1963: 229-230). Similar in size are several basilicas from Skopje's region: the one at Gradishte (near Barovo) $13 \times 20 \mathrm{~m}$; Gradishte (near Govrlevo) 13×34 m, including the atrium; the basilica at Pelenica (near Drachevo) 12×20 m (Микулчиќ, 1981: 114-118). 27 The previously mentioned episcopal basilica; the basilica-synagogue; the civil basilica; the north basilica; the cemetery basilica; the extra muros basilica and the Palikura basilica.
} 
built in the IV and reconstructed and re-built in the V-VI century have been discovered in the town and in its vicinity, three of which incorporate an episcopal synthronon and a baptistery, implying that Stobi was an influential Episcopal seat and important regional Christian center (Алексова, 1995: 23).

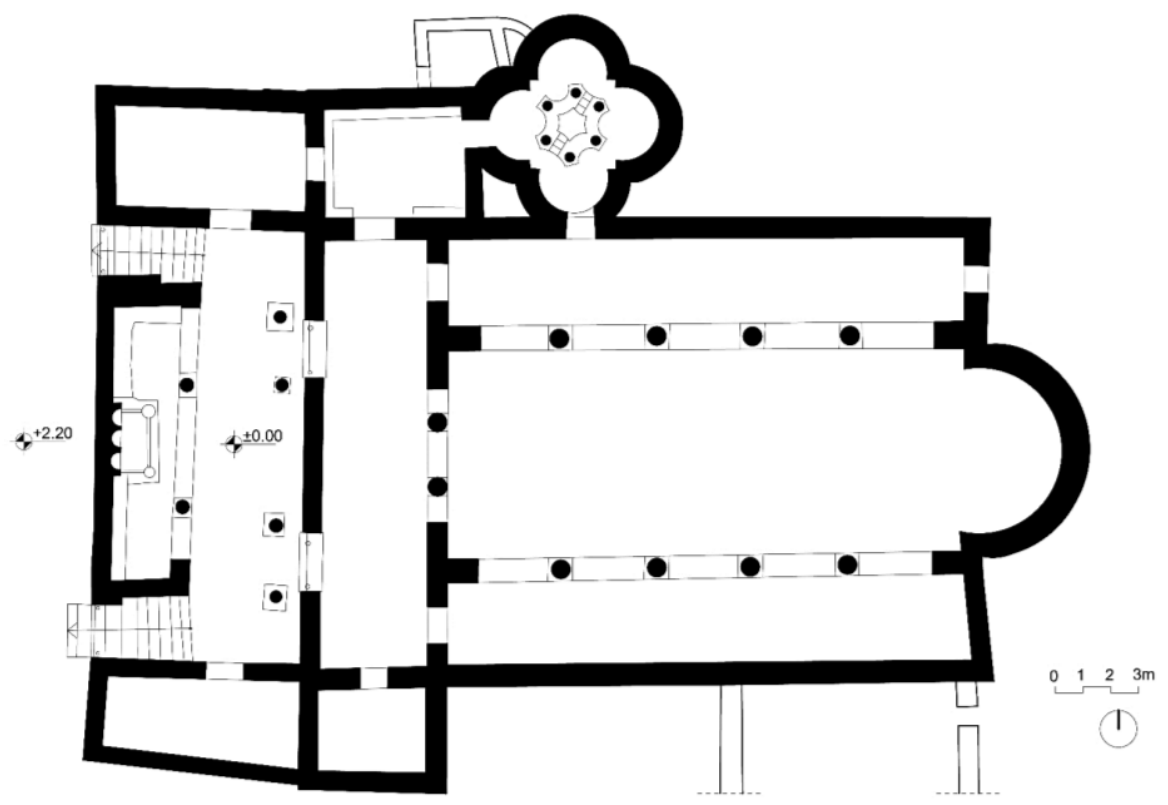

Figure I.8. The north basilica in Stobi. Plan $( \pm 0.00)$.

One such example is the so-called North basilica at Stobi, dating from the late V-early VI century, built over the remains of a Roman residential palace. The church follows the predominant early-Christian plan: a three-nave naos with a narthex and a rectangular, relatively narrow atrium to the west, both flanked by lateral annexes (fig. l.8). The north-eastern annex (which surely served as a catechumenum), leads to a quatrefoil baptistery with a piscine originally covered by a baldachin supported on slender porphyry columns (Petrova, 2008: 58-59). The baptistery is linked to the northern aisle of the naos via a passageway. Only the northern aisle has the usual exit to the east. The main (western) entrance to this basilica is from one of the town's main streets (Via Principalis Inferior), located at a higher level $(+2.2 \mathrm{~m})$ than the atrium's floor, conditioned by the local topography. Thus, from the street one descends via two symmetrically placed staircases into the atrium, from where, through two portals in, again, a symmetrical disposition, they enter the narthex. The rectangular space between the stairs, formerly a large, luxurious pool within the Roman palace's atrium (Алексова, 1995: 115), now incorporates a porch with a central fountain and benches along the walls, similar to the ones executed in the catechumenal annex. This annex is the only mosaic-clad space in the basilica: the narthex and atrium are paved with stone slabs, whereas the naos with brick which, along with the use of spoliae from older buildings, ${ }^{28}$ speaks of a more limited construction budget.

The basilica measures $16.8 / 28 \mathrm{~m}$ (including the narthex and the semi-circular altar apse), and a total of 27.5/35.7 $\mathrm{m}$ including the atrium and lateral chambers (Микулчиќ, 1999: 138). The naos is divided into three naves by the usual stylobates supporting a colonnade of 4 columns; their proportional relation, however, surpasses the usual ratio of 2:1, since the central nave spans $7.4 \mathrm{~m}$, as opposed to the lateral ones which only span $3.1 \mathrm{~m}$. Since the separation is impenetrable, each nave is connected to the narthex: the lateral naves through a simple portal, whereas the central nave through a monumental tribelon. The walls' thickness is approximately $70 \mathrm{~cm}$, which paired with the large nave spans, undoubtedly indicates to an architrave structural system.

\footnotetext{
${ }^{28}$ The columns on the western porch, seats from the theater embedded in the stylobates, etc. (Петрова, 2008: 58).
} 


\section{Monastery, pilgrimage and mansio mutatio basilicas}

A specific category of early-Christian basilical ensembles are the early monasteries and pilgrimage sites, as well as the basilicas built along important and busy roads, such as the above mentioned Via Egnatia, ${ }^{29}$ which housed travelers, foreigners, or served as hospitals nurturing the ill (Микулчиќ, 1999: 318). A representative example of this category is the St. Erasmus ${ }^{30}$ basilica near Ohrid (ancient Lychnidos) dating from the early $V$ century (Маленко, 1989: 7).

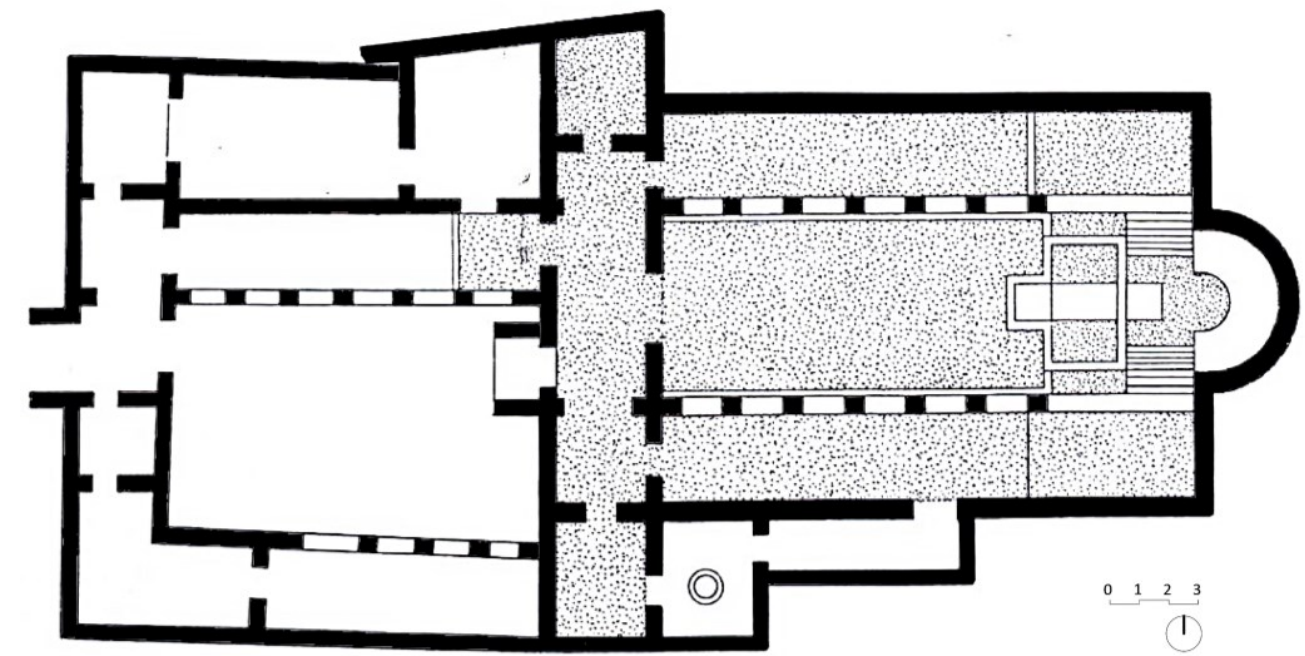

Figure I.9. The St. Erasmus basilica, Lychnidos (Ohrid). Plan.

It is composed of a three-nave naos, a western narthex flanked by lateral chambers to the north and south; on the southern side a baptistery with a circular piscine is accessed both from the south annex as well as from the southern aisle (fig. 1.9). The central nave is separated from the lateral ones by continuous stylobates which support a row of six masonry pillars, probably originally connected by arches. The proportional relation between the central nave (which spans $6 \mathrm{~m}$ ) and the lateral aisles (spanning a little under $3 \mathrm{~m}$ ) is 2:1. The altar is separated from the remaining central nave with a chancel screen, installed between the eastern-most pair of pillars. The presbytery has the usual " $U$ "-shaped entrance (solea); however, the complex synthronon with a cross-shaped crypt suggest a specific function of the basilical complex as a place of pilgrimage, likely dedicated, as its name so clearly conveys, to the cult of st. Erasmus (Алексова, 1995: 189-190). Mosaic and opus sectile pavements, remains of glass paste cubes and gold plating have been discovered, pointing to the luxurious interior decoration the basilica once had (Malenko, 1989: 7). To the west of the basilica, an open atrium flanked by porticos to the north and south, which give way to a most likely two-story residential structure, is designed to serve a clearly distinguishable function: to allow for the gathering and lodging of large groups of visitors, specifically pilgrims. In total, the basilica measures approximately $22 / 42 \mathrm{~m}$.

\footnotetext{
${ }^{29}$ Such examples are the basilicas in Radolishta, near Struga; the Palikura basilica near Stobi; in Heraclea Lyncestis' vicinity, possibly located in the context of the mansio mutatio along the Via Egnatia, several basilicas have been discovered: to the west Suvi Livadi, Ramenska Tumba, Capari; to the south Bukovo, Bistrica, Krstoar etc. (Снајвли, 2013: 1355). The mountainous and rather isolated location of the Krstoar and Bukovo basilicas, however, point to their use as churches for active monastic communities (Микулчиќ, 1999: 318).

30 St. Erasmus, a bishop from Antioquia (Мелоски, 1988: 70) is a Christian martyr and missionary who spent a decade (293-303 A.D.) preaching in Lychnidos (Ohrid) where he is believed to have baptized hundreds of locals in the waters of Ohrid Lake, during the reign of Diocletian (284-305) (И. М. H., 2000: 215-216). His cult is especially alive in the Ohrid region even today, as proven by the early-Christian basilica dedicated to this saint, as well as a medieval (XIII century) cave church and a one-nave basilica erected during the Revival in its proximity.
} 
In addition to the documented basilicas in the town of Ohrid and the St. Erasmus basilica, a significant number has been discovered on the shores of Ohrid Lake and in the broader Ohrid region, such as the basilicas near the villages of Studenchishta (Алексова, 1995: 200-201), Ljubanishta, Oktisi (Битракова-Грозданова, 1989: 23-25), Radolishta (fig. I.5A), Lin (Коцо, 2000 (Б): 71), Tashmarunishta (Снајвли, 2013: 1344), Koroshishta - Livada etc.

\section{Rural basilicas}

The rural basilicas, as expected, are built by / for less numerous and more modest congregations (Микулчиќ, 1999: 310) and are therefore smaller in size ${ }^{31}$ though not necessarily less luxurious in their ornamental elaboration. In addition to smaller three-nave churches (fig. I.10B), this group includes the single-nave typology. These types of smaller basilicas often incorporate lateral annexes to the eastern and / or western end of the naos (Снајвли, 2013: 1333), thus acquiring a " $\mathrm{T}$ "- shaped or cruciform composition (fig. I.10A). Such single-nave basilicas have been discovered at the archeological sites "Kula" near the village of Kalauzlija; "Kalata" near Makedonska Kamenica; the basilica A and B at "Davina Kula" near the village of Orman, region of Skopje; the basilica on the island Golem Grad in Prespa Lake (Алексова, 1995: 227), etc. Similarly, though three-nave, the basilica at "Begov Dab" near Makedonska Kamenica also acquired an overall " $\mathrm{T}$ "- shaped disposition. ${ }^{32}$
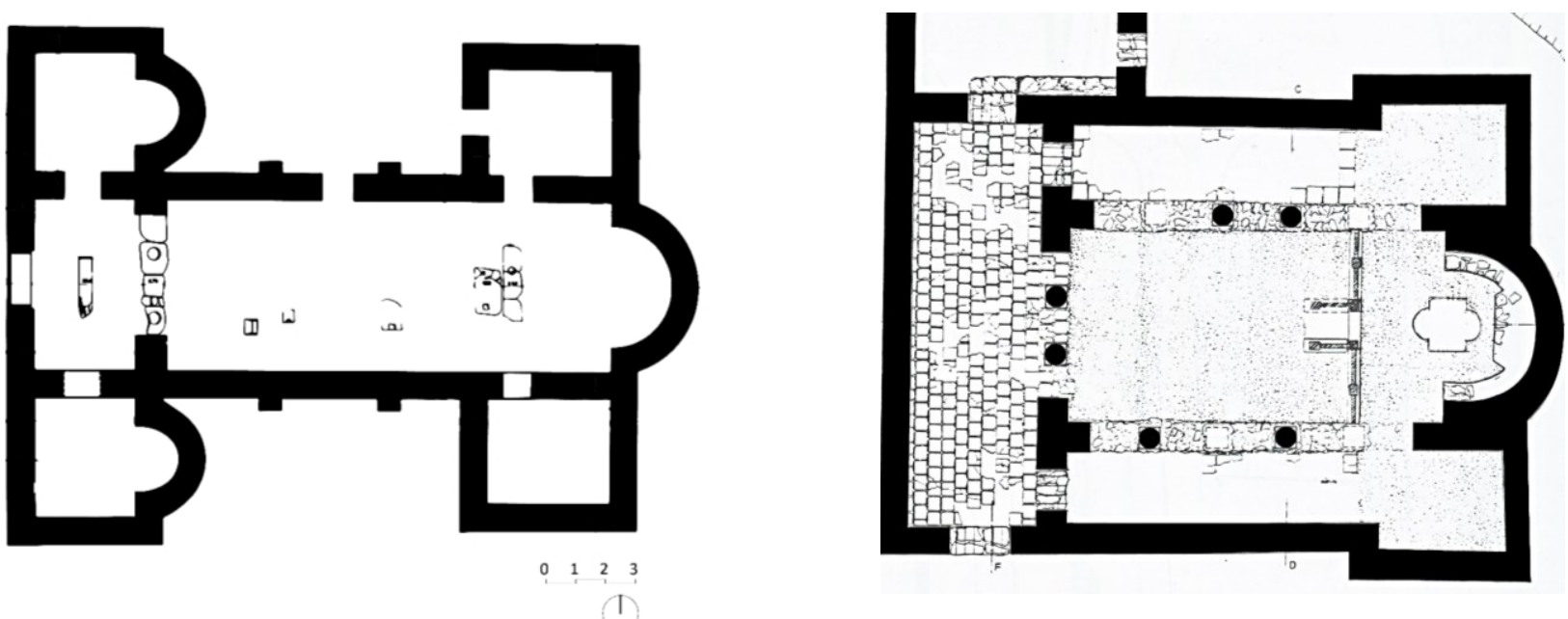

Figure I.10. A. Basilica at Davina Kula, Orman (Skopje); B. Basilica at Begov Dab, Makedonska Kamenica.

The basilica at Davina Kula near the village of Orman, belonged to Scupi's episcopal jurisdiction. Built over a late-antique necropolis, the relatively small cruciform church-martyrium (fig. I.10A) is comprised of a single-nave naos strengthened by external pilasters - buttresses, a western narthex and lateral chapels with semi-circular apses to the east. The narthex and naos are connected via a monumental tribelon, consisting of marble columns. The altar is tripartite, with separate rectangular chambers as prothesis and diaconicon. Remains of the altar marble chancel show that this church, as was habitual, also

\footnotetext{
${ }^{31}$ For example, both basilicas (A and B) at Davina Kula are 21m long; the basilica at Manastirishte (village of Slepche, near Prilep) measures $14 \times 18 \mathrm{~m}$; the one at Sokolica (near the same village) $9 \times 15 \mathrm{~m}$; the basilica at Manastirishte near the village of Nebregovo 15x20.5 m (Лилчиќ, 1984: 94-98); the one in Debreshte 11.4x16.7 m (Алексова, 1995: 234), etc.

32 The architectural composition of the Begov Dab basilica, dating from the VI century (Микулчиќ, 1999: 348) is rather specific: the ends of the lateral aisles to the east of the altar chancel are wider, thus forming distinct side chapels: prothesis and diaconicon. The church therefore is slightly " $T$ "- shaped, emphasized with the implementation of different floor techniques: polished horosan mortar in the tripartite sanctuary and the central nave; brick in the lateral naves and the narthex (Алексова, 1995: 151-152). Therefore, a parallel between this church and the basilica " $\mathrm{A}$ " in Philipi and St. Demetrius in Thesalonica can be drawn, which also have a transept to the west of the altar. Though geographically distant, St. Peter and St. John Lateran in Rome must also be mentioned in this context.
} 
had a protruding access towards the naos (solea). The church is built abundantly using spoliae harvested from a nearby antique sanctuary and other older buildings (Алексова, 1995: 225). Despite its modest size, the basilica at Davina Kula had polychrome mosaics (in the naos) and opus sectile pavements (in the presbitery), as well as decorative stone reliefs (columns, capitals, architrave beams, etc.). The closest typological analogy to the Davina Kula church is the cruciform church on the island of Golem Grad, on Prespa Lake.

Long after their demolition and complete disappearance, the early-Christian basilicas continued to be revered by the locals as important holy places where, in later moments, sacred buildings will be rebuilt, according to the established practice of re-using material from older churches. ${ }^{33}$ As an illustration, as early as the IX century the monastery St. Panteleimon was erected over the central nave of the three-nave basilica at "Plaoshnik" (in Ohrid); a single-nave building from the IX-X century erected over the central nave of an older early-Christian basilica has been discovered in Suvodol near Bitola and at the archeological site "Crkvishte" - Demir Kapija, where the side aisles were used as cemetery grounds after the reconstruction (Aleksova, 1995: 219); there is continuity of construction on the same location at Ohrid's cathedral St. Sophia from the XI century and St. Panteleimon in Nerezi from the XII century, which was also built over an early-Christian basilica (Petrov, 1982: 145). The same trend is evident in the lateByzantine period, when small churches were regularly erected over the remains of early-Christian basilicas: for example, on the site "Markov grad" at Matka (near Skopje), where the church St. Savior was built over an early-Christian basilica (Микулчиќ, 1981: 106), whereas part of the building material was reused for the construction of the Matka Monastery and the late medieval church of St. Sunday, today preserved in ruins (Лилчиќ, 1983: 288); at the site "Crkvishte" in Zelenikovo (near Skopje); the site "Crkvishte-Manastir" in Mirkovci (also near Skopje) over which the monastery St. Mercury was later erected (Микулчиќ, 1981: 120); in Krupishte near Shtip, in the area south of the village indicatively named "Podcrkvi" ("Under-church"), where the post-Byzantine church St. Nicholas was built in the central nave of an early-Christian basilica-martyrium using its abundant building material (Aleksova, 1989 (B): 116 117), etc. The practice continues in recent times, such as in the village of Brailovo (near Prilep) where today's monastery church St. Elijah was built by the local population in 1962 over the central nave of an early-Christian basilica immediately after its excavation (Лилчиќ, 1984: 90); in Oktisi (near Struga), where a small church was built in the central nave of the early-Christian basilica (Hoddinott, 1963: 233) and many, many more.

\section{I.3. The Ecclesiastical Typologies in the Following Centuries (VII-IX Century)}

After this short but intense development of the Christian religious architectural production, came a turbulent period in which not only did the construction activity almost completely cease, but also the early-Christian basilicas and the late-antique settlements in which they existed were completely destroyed and looted. Namely, in the VI century the territory of Macedonia fell victim to several strong earthquakes that had catastrophic consequences for the ancient cities such as Skupi, Stobi and Bargala,

\footnotetext{
${ }^{33}$ Referring to the newly-discovered medieval church of the St. Forty Martyrs in Ohrid, Vlado Malenko will write: "during the late Middle Ages numerous small single-nave churches were built and fresco-painted within the fortified urban core. Of particular note is their location over or adjacent to early-Christian basilicas, as well as near ruined and partially preserved medieval churches. Everything that has been destroyed by unknown circumstances and left without more specific written data, is supplemented by the preserved legends about the cult places, which are passed down from generation to generation. Often they are marked by placing carved stone blocks from old buildings or rough semi-finished stone blocks, but predominantly they are marked by a small wall covered by a gabled roof, with a niche on the front side in which the icon of the patron saint is placed. Gifts and candles are brought to these icons, especially on the patron saint's day" (Malenko, 2010: 8).
} 
destroyed in the earthquake of 518 A.D. (Aleksova, 1989 (A): 45) and Lychnidos, devastated by the earthquake of 559 A.D. (Томоски, 1983: 95). Society was further weakened by a long-running plague epidemic, which occurred in 541 A.D. and lasted for decades (Brown, 1971: 155). This situation, while the army of Emperor Justinian I (527-565) was busy re-conquering the western territories of the Empire and with the war with Sassanid Persia in the east, was used by the Slavs.

As early as the end of the V century, and especially during the VI century, under the pressure of the Avars who created their own state - the Avar Chaganat - on the Pannonian Plain, the Slavs began to cross the Danube in large numbers and in an organized manner and settled in previously devastated areas and abandoned ancient towns ${ }^{34}$ in the Balkans and Macedonia (Babić, 1989: 121). It is believed that during this migration they used the same roads as a large number of Turk-Mongol peoples had done before: the Huns, the Pechenegs and the Kumani (Fine, 1991: 25), and later, in the second half of the VII century, the Bulgarians and the Avars. Mass Slavic colonization continued with similar intensity during the first half of the VII century, when the entire territory of Macedonia, with the exception of Thessaloniki, was already completely Slavicized (Панов, 1985: 13). ${ }^{35}$ The Avar-Slavic invasion marks the end of many ancient Macedonian urban centers such as Stobi, Heraclea and Scupi which, destroyed by the strong earthquakes, were already largely abandoned (Aleksova, 1989 (A): 45) and later rebuilt at another location, while others, such as Lychnidos, survived under a new, Slavic name (Битракова-Грозданова, 2000 (A): 9). After the colonization of the abandoned and the establishment of new settlements, the Slavs returned to their traditional rural life based on agriculture and livestock (Babić, 1989: 126-127), organized in their already established tribal system from which autonomous Slavic principalities would soon be formed - the Sclaviniae, named after the respective Slavic tribes (Манева, 2013: 1265). Their conquests and colonization campaigns temporarily weakened the Byzantine administration and the church organization, while in the Balkan hinterland they even completely disappeared.

The period that followed - the VII-VIII century - was marked by the consolidation of the Byzantine state after the great crisis of the previous centuries, aggravated by the loss of almost all Middle Eastern territories of the Empire in the wars with the Arabs (Brown, 1971: 194). In relation to the Balkans, this period is dark, unexplored and scarce in terms of the number of preserved movable and immovable monuments, ${ }^{36}$ as well as historical and literary sources (Острогорски, 1959: 104). This situation gradually changed with the inevitable mixing of the population, as well as of the cultures of the autochthonous population and the Slavs, with mutual influences, especially in their customs, religion, language, material culture etc. In order to fully assimilate the Slavs into the Byzantine state, in the first half of the IX century and especially during the reign of Michael III (842-867), the Empire began sending diplomatic and religious missions ${ }^{37}$ whose task was to baptize the newcomers and spread Christianity and the Byzantine culture in the interior of the Balkans (Чаусидис, 1995: 93). ${ }^{38}$ Also, the missions aimed to engage the Slav population

\footnotetext{
${ }^{34}$ In many of the ancient and early-Christian sites the last minted coins belong to the reign of the emperor Tiberius I Mauritius (584-585) (Манева, 1993: 21).

${ }^{35}$ Namely, with the permission of the emperor Heraclius (610-641), the Slavs settled in the depopulated areas of the Balkans in order to serve as a liminal shield for the Empire against possible attacks from the Avars to the north (Манева, 2013: 1265).

${ }^{36}$ In Ohrid and the Ohrid region, for example, the circulation of Byzantine coins can be traced back from the emperor Anastasius I (491-518) to Justin II (556-578), followed by a large gap until the X century, in which almost no monetary finds have been identified. Then, the circulation went smoothly from Constantine VII Porphyrogenitus (945-959) to Manuel II Palaeologus (13691387), a large time-span which certainly indicates the cultural, economic and political prosperity of the town in the Middle and Late Middle Ages (Размоска-Бачева, 1988: 120).

${ }^{37}$ It is important to note that the Vatican had the same intention, to which end Catholic missions were sent to the Balkans (Бошковић, 1967: 119). That animosity between the still officially undivided churches would later be used by Balkan local rulers in an attempt to gain political independence from Byzantium and legitimacy for their new kingdoms and independent church organizations. More in Chapter I.4.1.

38 Historical sources point out that the Slavic population had already begun to convert to Christianity much earlier, in the VI century immediately after the colonization, under the influence of Christian missionaries whom Justinian I had sent to the northern regions of the Empire as "agents of Byzantine cultural imperialism" (Brown, 1971: 155). These missions were far more
} 
of this liminal region in the fight with the Bulgarian state formed after the settlement of the Bulgarians on the Balkans in the late VII century (Бошковић, 1967: 123). In this task, St. Cyril and Methodius led the way, sent on a mission to the eastern parts of Macedonia, along the river Bregalnica - the so-called "Bregalnica Mission" - where according to the legends they baptized over 50,000 people and where, in 855 A.D., they created the first Slavic alphabet - the Glagolitic, which they translated the gospels into and which will serve as the foundation of the first literary schools in Macedonia (Панов, 2003: $119-120$ ). Their work was continued by their disciples, especially St. Clement and St. Nahum, primarily in the southwestern parts of Macedonia where their missionary and educational activity took place and where, in the second half of the IX century, they established the Ohrid Literary School and the oldest Balkan University (Коруновски и Димитрова, 2006: 15).

After two centuries of artistic stagnation, precisely the specific period marked by the "reconstruction" of the Byzantine state in the Balkans, the re-establishment of Christianity and the conversion of the Slavs in the VIII-IX century allowed for a new wave of architectural activity. This moment coincided with the end of Iconoclasm (726 -843), which had shaken the Eastern Church from the root, followed by a "Hellenistic renaissance" (Hoddinott, 1963: 142) of the spiritual life as well as the ecclesiastical architectural and artistic production throughout the Empire. The wave of construction of sacred buildings, as a direct consequence of the re-establishment of the Christian cult, is one of several such distinct historical periods when, under the influence of different social conditions, typologically relatively unified and locally represented groups of monuments appeared. In Macedonia, the emergence of three broad typological categories can be traced to this period: 1 . Central cruciform churches (the inscribed cross solution), in accordance with the modern dominant trends in Constantinople, established immediately after the Iconoclastic movement; 2 . Trefoil churches, which follow the early-Christian tradition of this typology and 3. Basilicas, an archaic typology that had already been abandoned in the Byzantine capital (Каранаков, 2013: 62).

In Macedonia, the intensification of the construction activity is primarily related to the work of St. Clement and Nahum, whose founding churches are representatives of the second typological category. One of the oldest examples is the monastery church St. Panteleimon in Ohrid (fig. I.11A), which was built by St. Clement, while he occupied a position as a teacher in the area of Kutmichevica (in south-western Macedonia and part of the border areas in today's Albania), where he stayed between 886-893 A.D. (Панов, 2003: 122). The church of St. Clement, following the tradition of the old cult place, is located in the altar of the early-Christian basilica on the site of Plaoshnik which, judging by the monumental dimensions, is probably the early-Christian episcopal cathedral of Lychnidos (Снајвли, 2013: 13). ${ }^{39}$ In St. Clement' biography, written by the Ohrid archbishop Theophylact at the beginning of the XII century, it is said that St. Clement had "built a monastery in Ohrid ... acquired another church next to it ... Thus in Ohrid there were three churches: one cathedral and two of St. Clement, which were much smaller in size, but

successful in urban areas and less successful in the countryside, which was ruled by a "conservative tribal system whose hierarchical organization is such that it continues all the traditional elements of culture and protects them from any change. Secondly, the agricultural and livestock way of life makes the village relatively independent from the environment" (Чаусидис, 1995: 95). Thus, despite adopting Christianity, the Slavs retained a significant part of their pre-Christian customs and pagan celebrations, primarily related to nature and the calendar сусlе (Шивачевъ, 1929: 95). Although they merged with the autochtonous population in the organism of the Byzantine Empire, they managed to impose their language, as well as Slavic or Slavicized names of urban and rural settlements, personal names, and toponyms that have remained with the Macedonian people to this day (Панов, 1985: 592).

39 The position of St. Clement's monastery inside the city walls is an illustration of the trends in the IX-XI century, when the appearance and structure of the city (in this case - Ohrid) increasingly changed, abandoning the ancient model: the orthogonal raster was lost in the intertwining of narrow streets, the central role of the agora with the main cathedral disappeared and a multitude of small squares with smaller-scale, neighborhood churches were scattered throughout the urban fabric, stratifying the city into several local centers. In this context, monastery complexes and martyria appear in the town itself, built on "sacred" places or on the site of family tombs (Čekalova \& Poljakovska, 2003: 78). 
more beautiful with their round and spherical shape" (Коцо, 2000: 75-76). The cathedral church is certainly St. Sophia, and the spherical shape of St. Clement's churches is due to the trefoil plan of the monastery's catholicon, the small side apses intended for prothesis and diaconicon (fig. I.11A), as well as the central dome resting on, probably, a high cylindrical drum (Миљковиќ-Пепек, 1985: 71).

The concept of the monastery church dedicated to the Holy Archangels is similar (fig. I.11B). This church was built on the remains of an early-Christian martyrium (Алексова, 1995: 199), ${ }^{40}$ on a dominant hill at the southeastern end of Lake Ohrid (the region of Devol) by St. Nahum, who succeeded St. Clement at the position of teacher in the Ohrid-Devol region. This church is also characterized by a trefoil plan, a typology that was established in the early-Christian period as the most suitable for cemetery architecture and martyria (Hoddinott, 1963: 200).

Both cases, therefore, are tomb churches (and, at the same time, catholicons of important monasteries), which took not only the form from the immediate early-Christian heritage (such as the polyconch basilica and its trefoil baptistery, discovered on the site of Plaoshnik, in the immediate vicinity of the church of St. Clement), but also the purpose of the central solutions of Roman and earlyChristian provenience, as a symbolic model of a tomb church-mausoleum (Коруновски и Димитрова, 2006: 21). From these monastery churches, as well as from other sacred buildings built in the region (the trefoil churches in Gorica, Zlesti and Izdeglavje, as well as the church in the village of Vineni at Prespa) today unfortunately preserved mainly as archeological remains, as well as contemporary trefoil churches from the geographically relatively close region of Castoria (St. Transfiguration and the Holy Mother of God Kubelidiki), it is evident that the
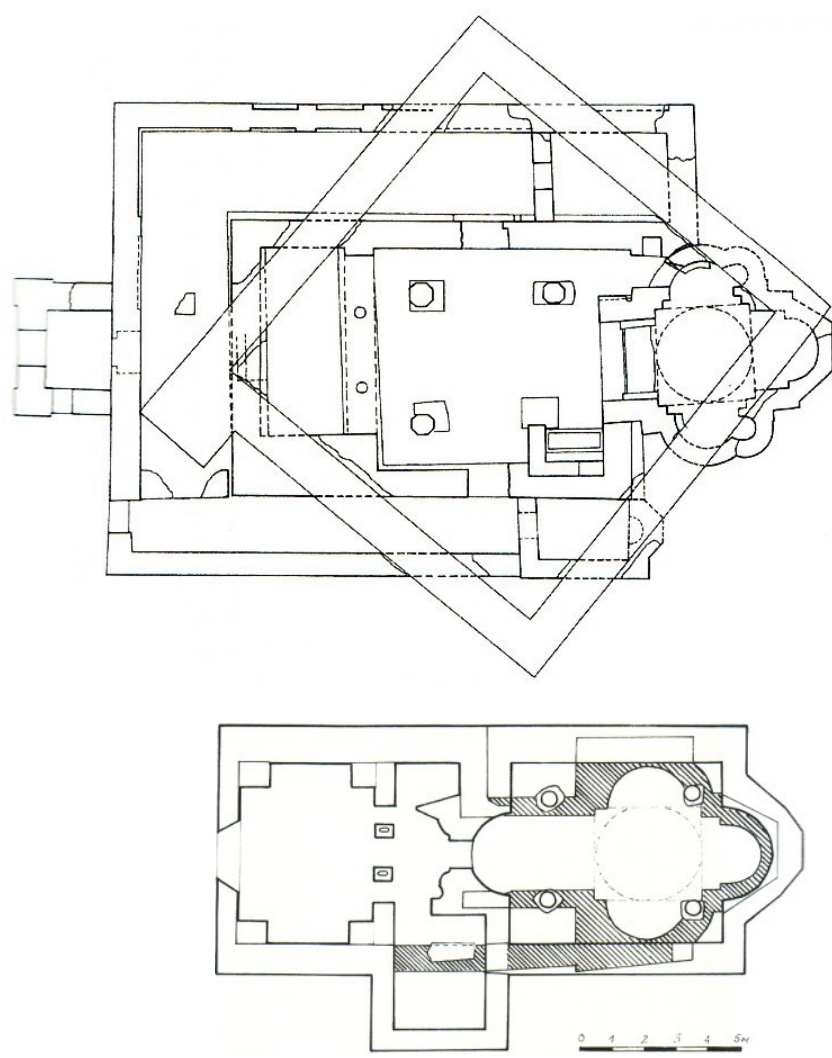

Figure I.11 A. St. Panteleimon (St. Clement) in Ohrid; B. Holy Archangels (St. Nahum) in Ohrid. monumental three-nave basilicas that marked early Christianity had already been abandoned, at the expense of different, more practical plans, such as the trefoil, especially characteristic of the Ohrid cultural area (Коруновски и Димитрова, 2006: 16-20). Namely, the monastery catholicons intended for the monastic communities they served consequently had a limited need for space; thus, "even the largest monastery churches do not have a larger square footage than a medium-sized basilica" (Кораћ и Шупут, 1998: 167). However, their plan arises from the specific necessities of the ritual that takes place within them daily and therefore regularly appeared in monasteries in the future as well. ${ }^{41}$

\footnotetext{
${ }^{40}$ This, in addition to the remains of the foundations, is evidenced by spoliae in secondary use, such as the pillars (placed on high pedestals) and the capitals of the entrance tribelon separating the current narthex from the naos, which are in fact early-Christian biforal columns.

${ }^{41}$ In the Balkans, as a regional feature atypical for the capital, the trefoil will remain a traditional model for a monastery catholicon in the following centuries. Such example is the cuatrefoil catholicon church of the Virgin Eleusa at the village of Veljusa, near Strumica, built in 1080 A.D.; the monasteries of Mount Athos; the monastery churches built in Serbia (the so-called Moravian school); and to a limited extent in Macedonia in the post-Byzantine period, which will be discussed later (see Chapter III.5.E).
} 
Throughout Byzantium there is an evident tendency to find new, structurally bolder architectural solutions in this period, under increasingly pronounced Middle Eastern influences, a region with which the capital maintains direct ties, while ancient traditions weaken (Бошковић, 1967: 99). As has been said, in Macedonia, apart from the trefoil solution, in this first period of intensified construction activity both the inscribed cross and the compact inscribed cross appear, under the influence of the contemporary Constantinople achievements of the transition from the IX to the X century. On one hand, this typology is a logical product of the centuries-long architectural evolution from the classical late-antique basilica model, through the domed basilicas of the so-called "capital type", to the central, more compact plans, namely the inscribed cross with a central dome or with additional four domes on or between the arms of the cross that appear on the fifth façade (fig. I.12).
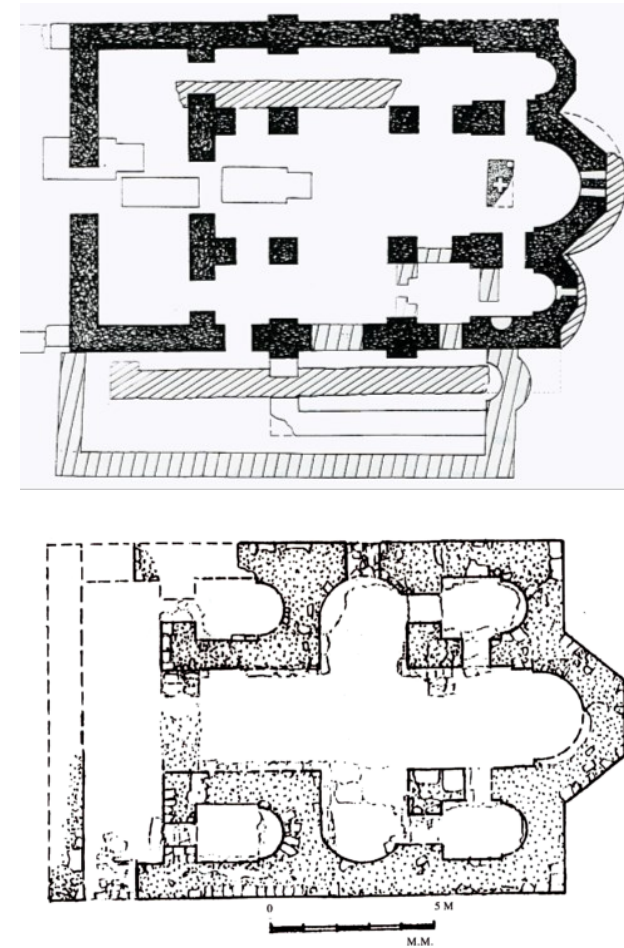

Figure I.12 A. St. Fifteen Tiberiopolis Martyrs in Strumica; B. the cruciform church at "Kale" Krupishte (near Shtip).

On the other hand, the function of the churches that were built in this specific period of religious reconstruction must not be overlooked. According to Vojislav Korać and Marica Shuput, "the circumstance that the appearance and affirmation of the churches of the inscribed cross with a dome type is connected to the monastic environment has a functional meaning. (...) To this observation should be added the fact that in the Byzantine world, from the beginning of the restoration onwards, the previously built monumental buildings for public use, the cathedrals, still stand. For this reason, primarily in the leading cities, Constantinople and Thessaloniki, new-built churches are either within the monasteries or modest sacred buildings with a specific purpose. In the further duration of the architecture of the wider Byzantine area, especially in later Christianized regions (Serbia, Russia) exclusively the cathedral churches are formed according to a scheme reminiscent of the early-Byzantine cathedrals" (Кораћ и Шупут, 1998: 138-139).

Several churches of this typological group are preserved as archeological ruin, all located in eastern Macedonia, as opposed to the trefoil solutions which, as has been discussed, were grouped in the far southwest. The oldest is the St. Fifteen Tiberiopolis Martyrs in Strumica (fig. I.12A), as part of a building ensemble built in several phases (Алексова 1995: 163-168). Furthermore, representatives of this architectural typology are a large group of monuments built along the valley of the river Bregalnica, associated with the strong construction activity of the newly established Bregalnica bishopric: the church of St. George at Goren Kozjak, a compact inscribed cross with a central dome and an additional bay in front of the altar; the cruciform churches at "Kale" near Krupishte (fig. I.11B), in Morodvis, near the village Zhiganci and a very similarly conceived church near the village of Teranci. Thus, we may conclude that, in addition to the small trefoil monastery catholicons and tomb churches, the inscribed cross appears in Macedonia as early as the IX-X century, in the period of the great ecclesiastical reconstruction related to the stabilization of the state and the mass baptism of the newcomers. This solution in the following period will grow into the dominant typology of the Byzantine religious architecture, with different variations and improvements over the centuries, at the expense of the basilical typologies which will be built less often and under special conditions in the following centuries, as will be demonstrated later. 


\section{I.4 The Resurrection of the Basilica as Royal Ecclesiastical Architecture of Samuel's Kingdom and the Ohrid Archbishopric (X-XI Century)}

\section{I.4.1 Historical Circumstances in the X-XI Century}

In 969 A.D., after the death of the Bulgarian tsar Peter (927-969), and as a result of the strong antiBulgarian mood, an uprising broke out in Macedonia under the leadership of the four "cometopuls" David, Aaron, Moses and Samuel, sons of Nicholas, who as a provincial administrator - comes (кó $\mu \eta \zeta)$ ruled the Devol committee ${ }^{42}$ within the Bulgarian tsardom (Бошкоски, 2012: 127). Taking advantage of Byzantium's involvement in wars with the Bulgarian and the Russian state of Kyev (Панов, 1985: 717), the uprising gained widespread momentum and, in the same year, the territory of present-day southwestern Macedonia was liberated from Bulgarian rule, laying the foundations for a new Balkan state. Opinions vary regarding the rule of the newly-established state in the first years after the uprising. Some historians believe that the four brothers ruled the liberated territories on the principle of tetrarchy (Панов, 1985: 45); while more recently the thesis has been placed that in the first years, according to the principle of primogeniture, they were ruled by the eldest brother, David, formally called king (Бошкоски, 2012: 130). In the early years, the political autonomy of the new state was limited, and it recognized Byzantine supremacy. The new state also gained its own autonomous patriarchate, invoking the tradition of the formerly abolished Bulgarian Church. Therefore, a new political and ecclesiastical center was established in the Balkans (Томовски, 1970: 2).

The death of the Byzantine emperor John Tsimiskes in 976 A.D. created the possibility of full autonomy (Острогорски, 1959: 281-283), rejection of Byzantine sovereignty and the establishment of complete and independent rule over the "liberated" territories. This second uprising quickly took on enormous proportions: crossing the borders of Macedonia, it would gradually occupy most of the Balkan Peninsula at the expense of the Byzantine territories, while the Empire was engulfed in internal unrest and clashes with the Arabs. Byzantium launched a counter-offensive under Basil II (976-1025) in 986 A.D., in response to Samuel's conquest of the city of Larissa, in which the Byzantine emperor suffered a catastrophic defeat. However, in this battle two of the brothers, David and Moses, lost their lives, while the next year, 987 A.D., after a political showdown between the two surviving brothers, Samuel (9761014) took the throne, thus becoming the sole ruler and founder of the imperial ruling dynasty. This medieval state is therefore known as Samuel's Kingdom.

After the initial great victory, and taking advantage of the internal unrest and power struggles that followed in Byzantium, Samuel created a state spanning almost the entire Balkan Peninsula, ${ }^{43}$ with its residence and administrative center on an island in Lake Prespa, today within the territory of the Republic of Greece (Битракова-Грозданова и Пупалески, 1989: 29). In the capital of the new state a palace and a cathedral were erected - the church of St. Achilles, which gave the name to the whole island. The vast territory he ruled and the power and influence he wielded enabled Samuel to elevate the rank of his kingdom and proclaim himself Tsar. To this end he, like formerly the Bulgarian and later the Serbian kings, took advantage of the centuries-old division between the Eastern and Western Churches and turned to

\footnotetext{
42 The committees were military-administrative units within the area of the former principality (sclavinia) of Berzitia, in the $X$ century part of the Bulgarian state. The Devol committee was based in Devol, an area on the southern shores of Ohrid and Prespa Lake. The origins of the Committees can be traced back to the frontier regiments of the Roman heavy cavalry of the same name, which would reorganize the Roman army and strengthen the state in the face of constant barbaric attacks in the second half of the III century (Brown, 1971: 24- 25).

${ }^{43}$ Samuel's Empire spanned the territory of Macedonia, Epirus, Thessaly, Albania, Serbia, much of present-day Bulgaria and the south-eastern part of the Adriatic coast (Коруновски и Димитрова, 2006: 11).
} 
the Vatican for support. ${ }^{44}$ Thus, during the reign of Pope Gregory V (996-999), first the Macedonian Church was recognized by the Pope as an independent patriarchate, and then in the cathedral of St. Achilles, in the presence of the papal legates who had brought the imperial crown, as well as the highest state and ecclesiastical dignitaries, Samuel was crowned as Tsar by the Prespa patriarch German (Панов, 1985: 48). With this act, the newly proclaimed Kingdom received international recognition.

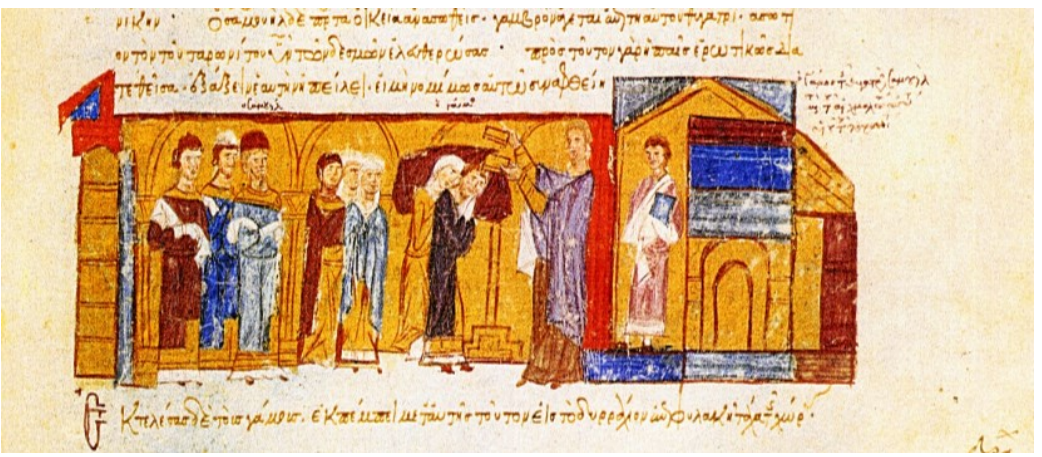

Figure I.13 Tsar Samuel officiates the wedding of his daughter Miroslava to the Byzantine nobleman Asotios Taronites at the patriarchal cathedral, 996 A.D.

In anticipation of the inevitable recurrence of the conflict with Byzantium, Samuel ordered the thorough reconstruction of several fortified towns and fortresses throughout Macedonia, in order to secure the territory before the impending war (И. М. H., 2000: 364-365). Around the year 1000 A.D., under the pressure of the Byzantine invasions, Samuel moved his capital and the seat of his autocephalous church to the west, from Prespa to Ohrid, which became the new capital of his Empire (see map I-1). The relocation of the imperial and ecclesiastical administration to Ohrid implied intensive construction of monumental buildings necessary for the new imperial administration (fig. I.14). In addition to the necessary buildings of military and civil character, he also undertook the construction of a cathedral as a residence for his patriarchate - the cathedral church of St. Sophia. Due to the circumstances, Samuel failed to complete the church, which was done after the Byzantine re-conquest of the city, under Ohrid's Archbishop Leon of Paphlagonia (1037-1056) (И. М. H., 2000: 639). Nevertheless, this church residence later known as the Ohrid Archbishopric - would outlive Samuel's Empire and Byzantium itself and play an extremely important role in the history of the southern Slavs (Острогорски, 1959: 287), surviving long after the Ottoman occupation, until the second half of the XVIII century.

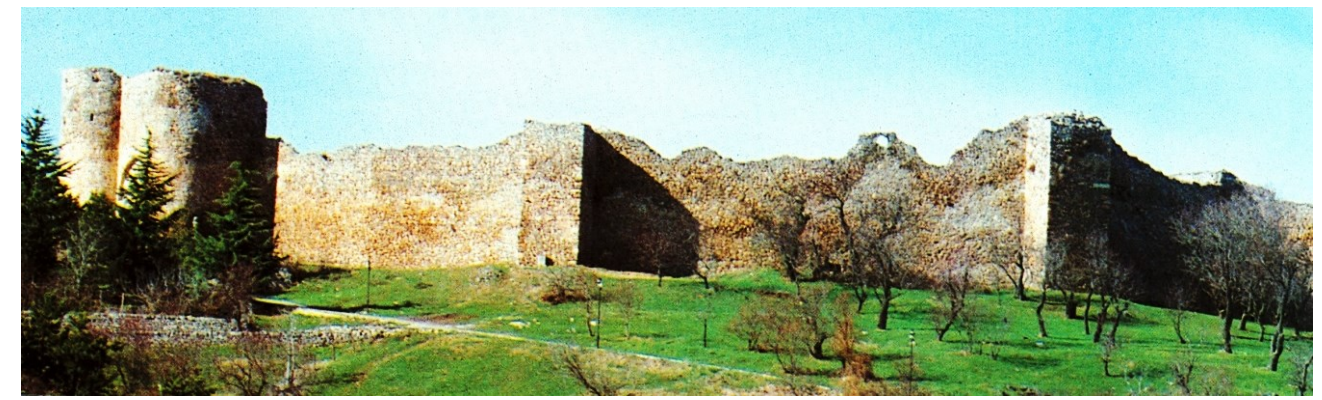

Figure I.14 Samuel's fortress, Ohrid ( 1000 A.D.).

\footnotetext{
${ }^{44}$ Namely, with the proclamation of Constantinople as the capital of the Roman Empire in 330 A.D., the Patriarchate of Constantinople was added to the previous church centers of Rome, Alexandria and Antioch, for the formation of which some of their dioceses were taken away: in 381 A.D. most of Asia Minor was taken away from Antioch's rule and, in the Balkans, the territory of Thrace was taken from Rome. However, the rest of the Balkan Peninsula, with the exception of the relatively short duration of the Archbishopric of Justiniana Prima (535 A.D.- beginning of the VII century) remains a field in which the influence of Rome and Constantinople will clash in the following centuries (Hoddinott, 1963: 29), which will be cleverly used by local power aspirants.
} 
In 1001 A.D., the expected Byzantine offensive began. Despite its initial success, Samuel's army could not compete with the military skills, technical readiness, financial means and long tradition of the Byzantine army. Shortly after the defeat, Samuel died in October 1014 A.D. (Панов, 1984: 65-66). His kingdom only outlived him for several years marked by bloody battle for the throne between his successors (Fine, 1991: 198).

As cruel as Basil II was in war, he proved to be moderate towards the subjugated countries, ${ }^{45}$ especially on sensitive issues, such as the ingrained tradition of the Ohrid Patriarchate. In 1019 A.D., Basil II issued several chrysovuls confirming the autocephaly of the local ecclesiastical seat at the rank of archbishopric, subordinated to the Patriarchate of Constantinople. In honor of the great emperor Justinian I (Бошкоски, 2012: 131), he equated the Ohrid Archbishopric with Justiniana Prima, ${ }^{46}$ declaring it as the legal heir to the former church's rights and privileges, a title it would retain until its abolition in the XVIII century. ${ }^{47}$ The re-conquered territories were annexed and subsequently divided into the Byzantine system of military-administrative units - themes (И. М. Н., 2000: 404). With that, the Byzantine rule was relatively stabilized, despite several significant liberation uprisings of the Macedonian people (in 1040 and 1072) which will mark the rest of the XI century. Thus, on the Balkan Peninsula, all the way to the natural border along the Danube River in the north, a single state ruled once more: Byzantium.

\section{I.4.2 The Basilical Churches in the X-XI Century}

The basilical form is the dominant solution in sacred buildings built in this specific, short time interval spanning the X-XI century, after which it was almost completely abandoned. In fact, it is a group of monumental basilical churches concentrated in the Ohrid-Prespa (Томовски, 1970: 7) and the region of Bitola, i.e. in the areas directly under the rule of Tsar Samuel and his successors (map I-1). ${ }^{48}$ In addition to the churches directly connected to Samuel's court and the seat of his independent church - the Ohrid Patriarchate, this group temporally and stylistically includes several other basilical churches built in its episcopal centers: northeast of the capital, along the valley of the river Bregalnica, two churches that are directly related to the Bregalnica bishopric have been discovered (map I-1). In other words, the X-XI century marked the existence and development of a distinctive, local ecclesiastic architectural school derived from the Ohrid Autocephalous Church Organization (Коцо, 2000 (B): 72-73).

\footnotetext{
45 However, fearing the resurgence of a liberation uprising, Basil II ordered the destruction of all Macedonian fortified cities (Панов, 1984: 68), and the displacement of the surviving members of the imperial family and the Macedonian feudal aristocracy to Asia Minor, depriving the people of their legal leaders.

46 In 535 A.D., in order to "put an end to further ecclesiastical disputes between Rome and Constantinople" (Шивачевъ, 1929: 77), the Byzantine emperor Justinian I (527-565) established the autocephalous (with "propio concilio") ecclesiastical institution in the newly founded city of Justiniana Prima - whose precise geographical location is still subject of discussion - as the first independent church organization in the area between Rome and Constantinople (Алексова, 2003: 27). Thus, the Balkan Peninsula ceased to be under the ecclesiastical jurisdiction of the Roman popes. Although the city disappeared in the turbulent centuries that followed, and the duration of the church institution itself was short-lived, its tradition remained rooted in Macedonia and continued to live embodied in the Ohrid Archbishopric as its formal successor, in the title of Ohrid Archbishops as in the geographical territory of its diocese (Шукарова, 2003: 129).

47 In the Byzantine church hierarchy, the Ohrid archbishops had a higher rank than all other archbishops subordinate to the patriarch in Constantinople, i.e. the Ohrid Archbishopric occupied the third place among the autocephalous Churches, immediately after Rome and Constantinople (И. М. Н., 2000: 482).

${ }^{48}$ As explained in more detail in the preceding chapter, Tsar Samuel founded his country's capital, Prespa, and then moved the state apparatus westward to Ohrid. His son and successor, Gavril Radomir, for his part, built his palace in present-day Bitola, which will suffer in the offensive of Basil II immediately after the death of Samuel. Shortly after those events a new fortress with a church dedicated to St. Nicholas was also built in Bitola by his cousin and rival for the throne - John Vladislav, after which the town was actually called Manastir (Monastery) in the Middle Ages (Томоски, 1992: 102).
} 


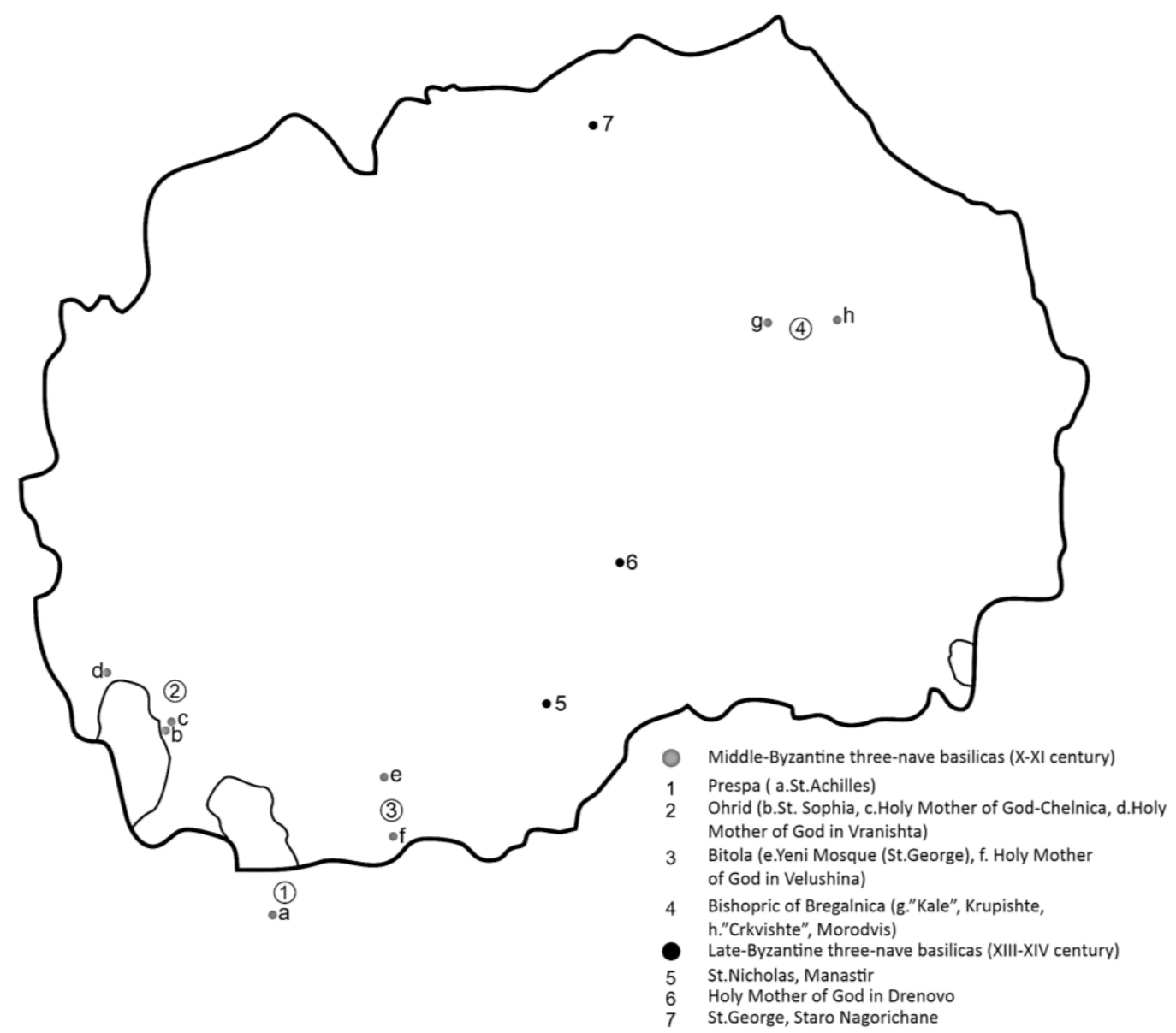

Map I-1 The middle and late-Byzantine three-nave basilicas in Macedonia.

The basilica during the reign of Tsar Samuel was obviously an important representative of the church architecture (Димитрова, Коруновски и Грандаковска, 2013: 1570). Namely, as was emphasized before, in this period the central solutions already dominated in the capital Constantinople, above all the cruciform buildings. Consequently, it is clear that the provincial architecture in Macedonia was stylistically separated from contemporary construction in Constantinople. The question arises: why did Samuel choose this already outdated, archaic architectural typology for his imperial endowments?

In science to date, various theses have been presented regarding the long existence of the basilica in middle-Byzantine architecture. Often, medieval basilicas are actually restored early-Byzantine buildings or are at least founded over the remains of this type of buildings. Some of the early-Christian basilicas that were rebuilt in the great renovation of the IX century, with inevitable changes after Iconoclasm and the period of riots, can be observed as examples of hesitant transitions from early-Christian and earlyByzantine concepts to the mature concepts that will appear in the region. Such renovated basilicas are the churches in Serres, Veria, Kalabaka (all in medieval Macedonia, and today within the territory of Greece). They still incorporate basic early-Christian features: columns instead of pillars, often a matter of reusing older spoliae; the lateral naves (in the prothesis and diaconicon) end flat - in Serres and Veria, but not in Kalabaka, where the large altar apse is flanked by smaller apsidioles; a triumphal arch appears in front of the altar apse; a classical clerestory brings light to the central nave. However, domes begin to appear over the prothesis and diaconicon, as is the case of Serres (fig. I.15A). Another possibility is the alternate placement of free-standing columns (single or in pairs) with elongated masonry pillars, as well as complete separation and closure of the prothesis and diaconicon in separate compartments, as is the case of the basilica in Veria (Каранаков, 2013: 62- 63). 

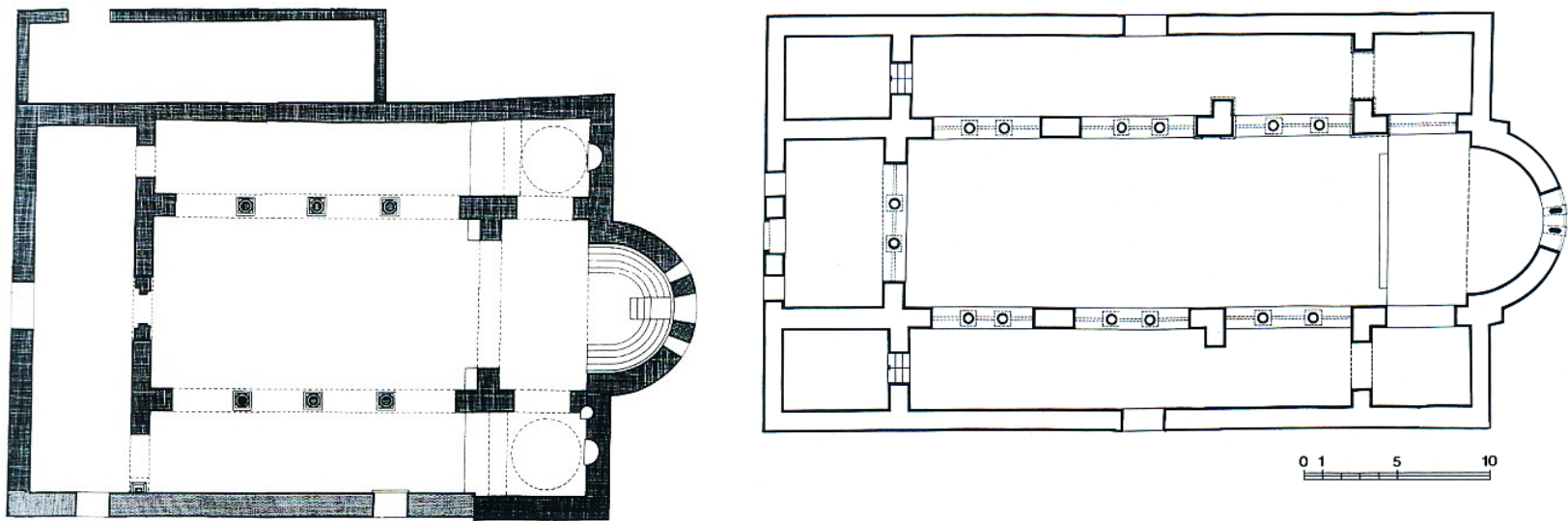

Figure I.15. Plans of the basilicas at A. Serres and B. Veria (Greece, medieval Macedonia).

At the basilicas of Kalabaka and Serres, an episcopal synthronon is preserved which speaks of their nature as cathedrals, while the church at Veria is a metropolitan cathedral. All have a simple rectangular narthex on the west side, with the exception of the basilica in Veria, where the narthex is divided into three separate compartments, i.e. the narthex is reduced in width to the central nave, while laterally chambers accessed only from the naos have developed. It is interesting that in some of these churches a monumental tribelon links the central nave with the narthex - in Kalabaka and Veria; while the lateral naves are linked to the narthex via a simpler portal. In Veria, analogue tribelons, placed between elongated masonry pillars, also connect the central and lateral naves (fig. I.15B). The easternmost tribelons, in the pre-apsidal space, correspond to a rudimentary transept, hinted with the " $\mathrm{L}$ "-shaped pillars, marking a place for the inexistent central dome, which links this basilica, although covered with a wooden roof structure, with the capital type of domed basilicas.

In addition to the restoration of older early-Christian basilicas, a significant number of basilicas will also be built from the ground up (map I-1). The continuous construction of this type of church in the middle-Byzantine period indicates that the basilica was not abandoned as a "notion of ceremonial cult construction" (Кораћ и Шупут, 1998: 115) despite the emergence and development of new solutions and types of plans. ${ }^{49}$ The impetus for building an imposing basilica was determined by several factors. Besides the general tendencies and inclination of the founders towards the buildings with a spatial basilical model, present in the Byzantine provinces of the Balkans, the most important factor that conditioned the appearance of the basilicas St. Achilles in Prespa and St. Sophia in Ohrid, for example, is the fact that the buildings were intended as headquarters of an important church organization.

The appearance of the numerous basilicas of that time, stylistically incompatible with the events in Constantinople, is related to the equating of a cathedral with a basilica, defined, as elaborated earlier, at the time of the formalization of the Christian dogma in the IV century. The second factor is the identification of the independent state tendencies of the new Balkan rulers with the type of basilica adopted as a model for the most solemn cult building. The form was sought in the period of creation of the Byzantine Empire, especially when its splendor was restored under the emperor Justinian I. The difference between the two concepts, early-Christian and Justinian, was expressed mainly in the upper structure with the appearance or absence of a dome above the main space in the nave. Samuel's Basilica on the island of Achilles in Prespa, with its wooden roof structure, is closer to the early-Christian basilicas

\footnotetext{
${ }^{49}$ In this context it is necessary to mention the middle-Byzantine churches in Castoria (St. Stephen, St. Cosma and Damian), which adopt the basilical typology because of the symbolic meaning of that spatial concept, adapted to their extremely small, modest dimensions: "a space built in this way, in extremely modest dimensions, in the overall layout could not be imposed by a real functional requirement. In other words, the basilica itself had a certain meaning, or a certain significance, as a kind of building created in previous times, found in the sight and consciousness of the founders of the new generation, ready to renew the spiritual life, and thus the culture of earlier times" (Кораћ и Шупут, 1998: 175).
} 
from the time of Constantine (Димитрова, Коруновски и Грандаковска, 2013: 1550). On the other hand, in the new capital Ohrid, perhaps in order to invoke the Justinian tradition of his young autocephalous patriarchate (Алексова, 1995 (В): 148-149), Samuel decided to erect a domed building modeled on the eponymous Constantinopolitan St. Sophia (Чипан, 1996: 86) i.e. the basilicas of the capital type. Certainly, the existing configuration of the early-Christian church, albeit found in archeology, which unequivocally indicated a vaulted structure with a transept and a central dome, may have also played a certain role.

All this contributed, within the architectural production of Samuel's court, to the creation and development of a new typological model of religious building. Namely, in the basilicas from the X-XI century, the old pattern from the early-Christian prototype has been reduced and changed. As a rule, they do not have an atrium, and a narrow narthex appears on the west side. The basic space is a three-nave naos that ends in the east with three semicircular apses, whose exterior is either circular or polygonal. The width of the apses equals the width of the respective naves, whose ratio is 2:1 in favor of the central nave. Instead of columns, pillars with a rectangular or square cross section are placed between the central and lateral naves, as simpler for construction. They are connected by arches, thus forming two longitudinal arcades that trace the three-nave disposition of the naos. The sanctuary is also tripartite: the altar is flanked by a prothesis and diaconicon, according to the liturgical requirements of the so-called "great entrance", established in the second half of the VI century. Additional annexes are rare, and only found in the basilicas intended for episcopal seats (Кораќ и Шупут, 1998: 115-119).

While all basilicas from the middle-Byzantine period generally adhere to this pattern, the key differences appear in the upper zone of the naos - the structure covering the internal space. Analyzing the constructive system of the upper parts of the representatives of the middle-Byzantine basilica typology, several solutions are evident:

1. Architrave coverage of the entire building;

2. Architrave-covered naves with domes in the altar zone (above the prothesis and the diaconicon);

3. Vaulted basilicas (with semi-cylindrical and groined vaults);

4. Basilicas with a central dome.

In other words, the evolution of the upper parts from a simple archaic wooden architrave construction to a vaulted one with semi-cylindrical and groined vaults (Каранаков, 2013: 64) is evident, as well as the appearance of combined systems with a central dome, or domes above the lateral spaces of the altar. Precisely in the appearance of a dome above a section of the building lies the importance of this group of churches as representatives of the transitional type of basilica, i.e. the evolutionary development from a simple architrave-covered basilica solution, through the complex typological concept of a domed basilica, to the central solutions of an inscribed cross in a rectangular naos.

The basilical churches built in Macedonia in the middle-Byzantine period are the following:

"Kale" in Krupishte (Shtip)

The archeological site "Kale", where the remains of this monumental cathedral were found, is located to the north-east of the village of Krupishte. According to the findings, it represents a fortified settlement dating from the late-antique and medieval times, strategically placed on the ancient road which linked Stobi and Serdica, following the valley of the river Bregalnica (see map I-1). The site was explored in 1984; however, the remains of the church existed at a height of up to $3 \mathrm{~m}$ until 1970, when they were completely destroyed (Филипова, 1996: 38). The preserved foundations speak of an exceptionally representative building, of which, unfortunately, only the eastern end up to the altar partition has been archeologically excavated. Despite this setback, what has been discovered so far is enough to testify to its architectural typology (fig. I.16). 
Namely, the church measures $29 \mathrm{~m}$ in width, ending in 5 apses at the east. The core of the building is a three-nave basilica; the central nave is separated from the lateral ones by high, $1 \mathrm{~m}$ wide stylobates, covered with marble slabs; the stylobates support a row of pillars built of masonry in stone and brick, indicating that they were probably originally connected by arches. The apses of the naos are polygonal (three-sided). The perimeter walls are executed using a precise and decorative masonry in opus listatum, composed of five rows of brick alternating with a row of stone blocks. In the central apse, foundations of a representative brick synthronon were discovered, as well as the base for the altar chancel which was found in situ, constructed using stone and marble blocks from older buildings, in secondary use. It extends transversely between the first pair of pillars from the east, of which the northern one is preserved and is "L"-shaped, as a support for the altar partition. Also, fragments of the floor in opus sectile, comprised of white and gray marble tiles, have been preserved, which originally paved the tripartite altar.

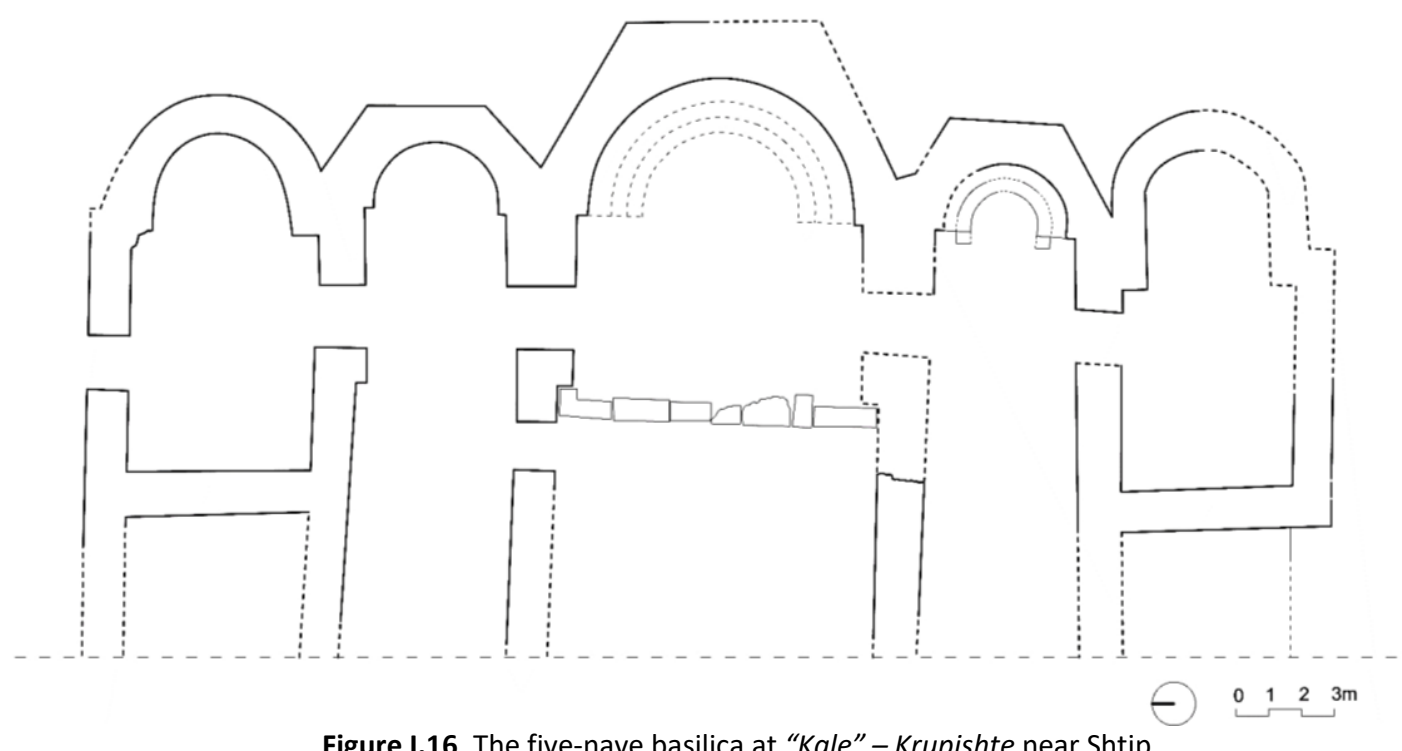

To the east of the pillars, there is a passage connecting the altar and the side compartments. The south compartment is rather specific: it has its own small synthronon on a raised platform in the apse, originally covered with a canopy supported on columns, the bases of two of which have been preserved. This construction is actually a cult church - martyrium, as evidenced by the pile of bones discovered in situ, and was built simultaneously with the church itself (Алексова, 1995: 145-147), unlike many other examples where the martyriae are independent, usually older buildings to which the new church building is added. This implies that the "Kale" five-nave basilica was built precisely on the basis of a cult of martyrs whose relics it kept in the martyrium provided for that purpose in the south nave. A possible identification of said martyrs is provided by later literary sources. Namely, in the Biography of the Fifteen Tiberiopolis Martyrs, ${ }^{50}$ whose author is Theophylact (1084-1107), Archbishop of Ohrid, it is said that in the IX century, during the reign of the Bulgarian archon Boris (852-889), the relics of three of the fifteen Strumica (ancient Tiberiopolis) saints were transferred to a coffin and kept to the right of the altar in the large church built for them on the river Bregalnica, as the seat of the newly established Bregalnica bishopric. During the reign of his successor Simeon (894-904) the relics of two more of the fifteen martyrs were transferred to the same church. Thus, judging by the historical sources, and especially by its preserved remains, architectural typology, masonry opus and decorative techniques, the monumental basilica at "Kale" Krupishte can be dated to the middle-Byzantine period, precisely the middle of the IX - beginning of the $\mathrm{X}$

50 Теофилакт (1931) Мъченичеството на Светите славни 15 свештеномаченици пострадали во Тивериопол, Сборник БАН XXVII: 239-269. 
century, ${ }^{51}$ which makes it the oldest church discovered so far dating from the specific period of reconstruction of the basilical typologies.

The specific cult purpose of the eastern end of the south nave imposed the need for two additional lateral chambers intended for prothesis and diaconicon, which flank the three-nave church from the north and south, and which are connected to the altar by passages. This contributed to the " $T$ "-shaped five-nave disposition of the basilica on its fifth façade. These side chapels end in apses to the east, semicircular both internally as well as externally. To the west, they extend slightly beyond the altar partition, after which they continue as either additional naves or open porches, which is yet to be determined by a muchneeded complete archaeological excavation of the site.

\section{"St. George - Yeni Mosque" in Bitola}

Under the foundations of Kadi Mahmud Çelebi or also called Yeni (new) mosque, built in Bitola in the second half of the XVI century (1558/1559 A.D.), during recent archaeological excavations (2003-2008) related to the restoration of the monument, the remains of an older Islamic building, as well as a Christian temple with several construction phases were discovered. That the mosque was built on an old Christian cult site is evidenced by local oral traditions, as well as historical sources according to which in the XVI century, immediately after the construction of the mosque, the local Christian population interfered with the prayers (Михајловски, 2009: 183, 185) since the cult of St. George ${ }^{52}$ was still very strong and linked to this precise location. Thus, it can be assumed that the discovered archeological remains are in fact the remains of the former church dedicated to this saint.

The three construction phases of the church date back to the VII, XI and XIII-XIV centuries. In the first phase, from the VII century, a single-nave basilica was built, which testifies that in the turbulent period immediately after the settlement of the Slavs, some churches were already being renovated and even newly-built (Николоска, 2015: 274). Over the remains of this original building, in the middleByzantine period (XI century) an exceptionally monumental basilica was built, whose size is much larger than that of the mosque and which unfortunately has only partially been discovered and explored (fig. I.17). It extends at $-3 \mathrm{~m}$ in relation to the mosque's floor, in an east-west direction. Despite the fragmentary nature of the excavated segments, they enable the reconstruction of the temple.

As was the case at "Kale" - Krupishte, with which they also share a very similar typological solution, St. George is also a five-nave basilica, composed of a three-nave core with two additional lateral naves or chapels, whose purpose and overall length have not been determined. The central nave is dominant, spanning almost $6 \mathrm{~m}$ in width, while the lateral naves are slightly less than $3 \mathrm{~m}$ wide. The ratio of the central to the side naves is, therefore, 2:1. The three naves are separated by parapet walls, with a thickness of over $1 \mathrm{~m}$, which most likely supported rows of columns or masonry pillars. To the east, all five naves end in apses, semicircular on the inside while three-sided externally. The thickness of the perimetral walls is approximately $60 \mathrm{~cm}$, which indicates an architrave wooden construction system, similar to the one at the cathedral of St. Achilles at Prespa, as well as the temple at "Kale" - Krupishte.

\footnotetext{
51 The precise time-frame is confirmed by the recovered coins, belonging to the Byzantine emperors Leo VI the Wise (886-912) (Алексова, 1995: 149) and John Tsimiskes (969-976), as well as a multitude of graffiti of the oldest Slavic alphabet - the Glagolitic as well as Cyrillic letters engraved on the decorative stone masonry, which implies that "there are more cultural layers from a period that lasted nearly an entire century" (Илиевски, 2003: 48-51).

52 According to the travelogue of Jovan Hadzi-Vasiljević, who noted the oral traditions of the local population during his travels to Bitola, as many as seven mosques were built over older Christian temples: the Nal mosque at the so-called "Pekmez" market over the church of St. George; the Hazreti Ishak mosque located at the "Bit" market over the church of the Holy Resurrection; the St. Cosma and Damian church was substituted by the Zandandzik mosque; St. Nicholas by the so called "Ruined" mosque; and the church of the Holy Apostles was converted into the Haydar Kadi mosque at the "Ovchki" market (Хаџи Васиљевиќ, Ј. „Град Битољ“, Кроз стару Србију и Македонију 1879 године, Братство 14, Београд 1911, 19-20, cited by Михајловски, 2009: 185).
} 


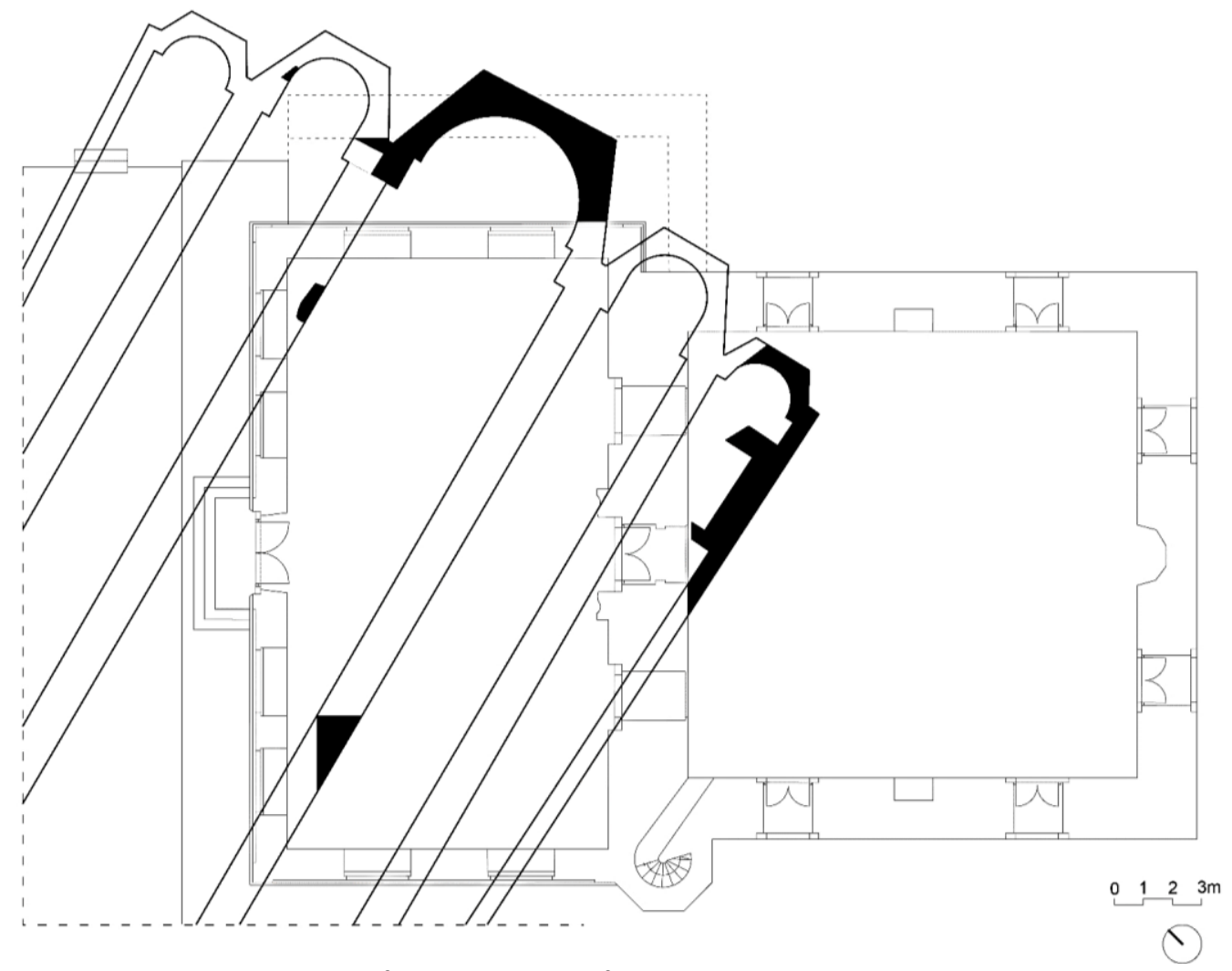

Figure I.17 The five-nave basilica of St. George - Yeni Mosque in Bitola.

The architecture of this former monumental temple, as well as the more precisely dated artifacts discovered at the site, date it to the middle-Byzantine period, as part of the local construction "school" which was manifested by the construction of archaic basilical solutions.

\section{"St. Achilles" on the Island of Achilles, Prespa}

The island of Achilles in the lake of Lesser Prespa, on which this church was built, is one of the main spiritual centers on the Balkan Peninsula (Томовски, 1970: 20). ${ }^{53}$ In the X century, it was the first residence of Samuel's state (map I-1), which meant intensive construction activity for the needs of the court. Thus, several churches were built on the island, the most monumental of which is the cathedral church of St. Achilles - after which the island itself was actually named - built in 985/986 A.D. as the seat of Samuel's Patriarchate, today unfortunately preserved in ruins.

The reasons why a conservative basilica solution was chosen in this case, as opposed to a modern cruciform type which was predominant in Constantinople, should be sought in the need not only of a representative, but also of a sufficiently spacious temple (Кораћ и Шупут, 1998: 119). Namely, St. Achilles is one of the largest churches of its time in general - its total dimensions are $22 \times 45 \mathrm{~m}$. It is believed that the founder, Tsar Samuel, opted for this type of construction inspired by the original early-Christian basilica in Larissa from where, after the capture of the city in 983 A.D., he transferred the relics of St. Achilles to Prespa (Алексова, 1995: 24). The act of transferring relics of saints, known as furta sacra, quite

\footnotetext{
53 The building activity on the island of Achilles continued after the collapse of Samuel's kingdom, as a well established cult site. Namely, in the later centuries, numerous smaller churches were built on the island, which today are found in different degrees of preservation: Most Holy Mother of God Porphyry (XIII century), St. Demetrius (XIV century), St. George (XVII century) and St. Anna, the Holy Twelve Apostles, St. Nicholas, St. Saviour and St. Athanasius, today preserved in ruins. Addressing the island of Achilles, Ilija Velev will write: "It is thought that except on Mount Athos, nowhere in the Balkans are there as many ruins of churches and monasteries as on this island. Probably most of the monuments on this island date back to before Samuel was proclaimed king" (Велев, 1990: 21-22).
} 
common in the Middle Ages, ${ }^{54}$ aimed to strengthen the newly-established ecclesiastical institution, relying on older Christian traditions and cults and, in addition to the religious effect, provided political credibility to the secular authority (Трајковски, 2013: 1516). Also, the church buildings in which the relics of the saints were placed, or the new churches built for their preservation, gained the highest reputation (Kopa и Шупут, 1998: 247). Keeping holy relics in a temple with a similar architectural conception could, therefore, be a way of respecting the continuity of the cult space (Ibid: 121). ${ }^{55}$ On the holy relics of this saint and fighter for Christianity from the period of its establishment as a religion, Tsar Samuel founded and organized his autocephalous church organization (Алексова, 1995: 34). Consequently, it was logical for his first endowment to choose a monumental basilica. On the other hand, it should not be overlooked that the royal enthronement of Samuel and the recognition of the autocephaly of his church were continuously supported by Rome where the basilica as a cult building will never be abandoned.

The church of St. Achilles was designed as a completely symmetrical structure, consisting of a threenave naos, a separate narrow narthex with two lateral compartments to the west and a tripartite altar space (fig. l.18). The central nave is markedly wide, with a ratio of 2:1 in relation to the lateral ones, which "provided space for all kinds of lavish imperial-patriarchal ritual ceremonies" (Каранаков, 2013: 67). The preserved remains of the basilica speak of the absence of a transept and a central dome, i.e. of continuous architrave ceilings covering the naves. In this context, it is logical to assume that the central nave exceeded the lateral ones in height, which provided clerestory lighting of the interior in the otherwise very spacious building. The narthex is connected to the naos by an entrance for each nave individually, opposite which, on the west façade, there are three entrance portals. ${ }^{56}$ The sides of the narthex are flanked by insufficiently explored compartments, probably staircase towers, as is the case in some Syrian and Asia Minor basilicas (Томовски, 1970: 20). It is logical to assume that the narthex did not develop only on the ground level, as an entrance hall, but also had a second floor, connected with the galleries above the side naves that stretched along their entire length, which as a concept indicates its solemn courtly nature. The basilica in Serres has similarly conceived tribunes (Томовски, 2000: 156).

The tripartite sanctuary is also extremely spacious, with fully separate compartments for prothesis and diaconicon. The semicircular altar apse is decorated with a representative triple window (fig. I.20A) and an elaborate synthronon, which is a basic feature of a patriarchal cathedral. Of special interest is the elaboration of the apse wall behind the synthronon, comprised of rhythmically arranged small semicircular arches and columns, bearing the names of the eight suffragettes from all the dioceses of Samuel's patriarchate written in pale pink, as "visual unity of Samuel's church institution and its formal and administrative independence" (Димитрова, Коруновски и Грандаковска, 2013: 1555). Obviously, this indicates the seating area reserved for them (Grabar, 1964: 163-164).

\footnotetext{
${ }^{54}$ As an example, in the IX century, the relics of the evangelist Mark were transferred to Venice from the eastern Christian territories; the relics of St. Anasthasia were transferred from Constantinople to Zadar; of St. Triphun to Kotor; of St. Nicholas from Asia Minor arrived in the Italian town of Bari, etc.

55 "The burial of the transferred relics of a saint in a temple with a similar space would be a common kind of pious respect for the integrity of the cult place, and not only for the relics" (Каранаков, 2013: 68). Such an example is the cathedral of St. Mark in Venice, which took the conceptual solution from Justinian's church of the Holy Apostles in Constantinople (Кораћ и Шупут, 1998: 249), which also inspired the church of St. Thomas in Prchanj, as well as other churches dedicated to one of the apostles.

${ }^{56} \mathrm{~A}$ similarly conceived narthex with three opposite entrance portals can be found at the northern church of the monastery Constantine Lips in Constantinople, dating to the X century, as well as the church of St. Theodore, built in the Byzantine capital in the XI century.
} 

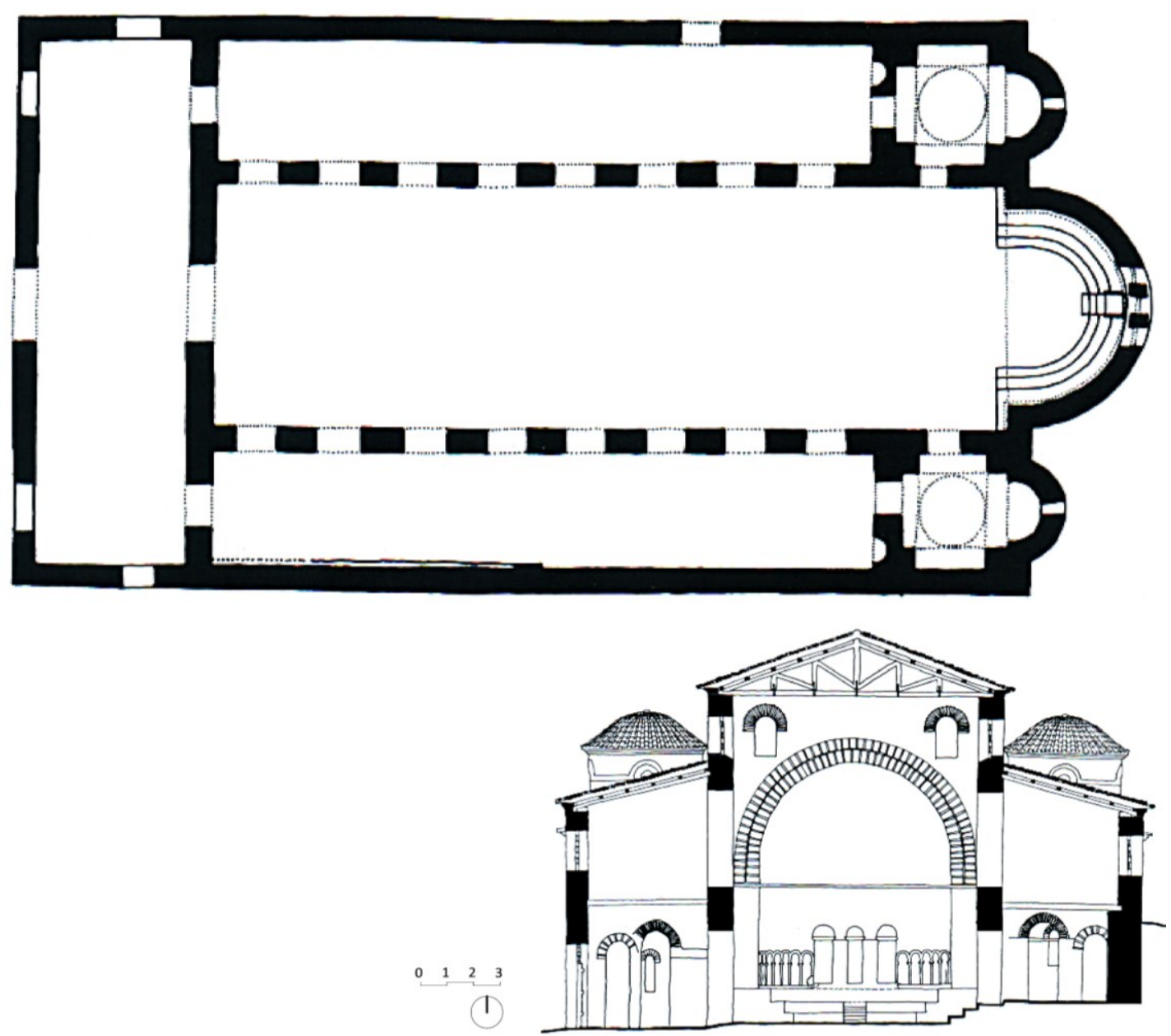

Figure I.18. St. Achilles, island of Achilles (Prespa). Plan and transversal section.

Furthermore, the internal structure of the basilica is of particular interest. The central and lateral naves are separated by a two-story system of seven rectangular, elongated masonry pillars, connected by semicircular arches, supported by pilasters on the west and east walls (fig. I.18). Both stories have equal height. Furthermore, the length of the pillars and the distance between them are equal. In that way, a regular and symmetrical rhythm is consciously created in the interior of the building (see fig. I.20A). An almost identical concept was applied at the Old Metropolis church in Mesemvria - present day Nesebr in the Republic of Bulgaria (fig. I.19), a contemporary and rather similarly conceived building (Томовски, 1970: 20)..$^{57}$

The prothesis and diaconicon have a unique solution: a compact inscribed cross, covered by a dome on a cylindrical drum supported on four pilasters placed in the corners of the chamber. Both communicate with the altar and the lateral naves through arched openings in the otherwise full wall, thus emphasizing their separation from the nave. North and south of this opening, on the east wall, semicircular niches are placed in a symmetrical

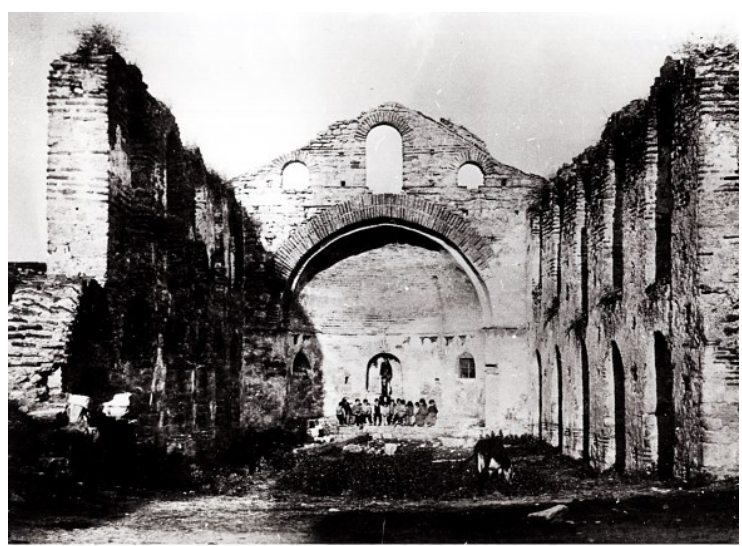

Figure 1.19 The remains of the Old Metropolis in Mesemvria (Nesebr), Bulgaria, photographed in 1899.

\footnotetext{
${ }^{57}$ Other examples with a similar solution are the basilica in the village of Vranishta near Struga (fig. I.20B), the small basilicas St. Cosmas and Damian and the Holy Archangels in Castoria. Analogies are also evident, mainly in the tripartite altar space, with the Great Basilica in Pliska, Bulgaria (Томовски, 1970: 17).
} 
composition. To the east, the prothesis and diaconicon end in semicircular apses with one centrally placed window. It is possible that these two separate compartments, in addition to the role of prothesis and diaconicon, also represented chapels where it has been assumed that the relics of St. Achilles of Larissa ${ }^{58}$ were buried. Of course, the appearance of these smaller domed spaces can be considered a symbolic replacement for a central, large dome, which should cover the middle part of the church in accordance with the cruciform trends stemming from Constantinople. Such a central dome in the concept of this basilica was impossible to implement; thus the church was covered by a gabled roof which, in itself, is a strong Hellenistic influence (Кораќ и Шупут, 1998: 119-121). The decorative masonry of the cylindrical drums (opus cloisonné and opus reticulatum) significantly differs from the façades of the lower parts of the temple, made of hewn stone with scarce layers of brick and brick-work arches which indicates they might have been subsequently rebuilt, certainly after the fire and devastation of the church in 1071-1072 (Мијатев 1965, quoted by Томовски, 1970: 21). ${ }^{59}$
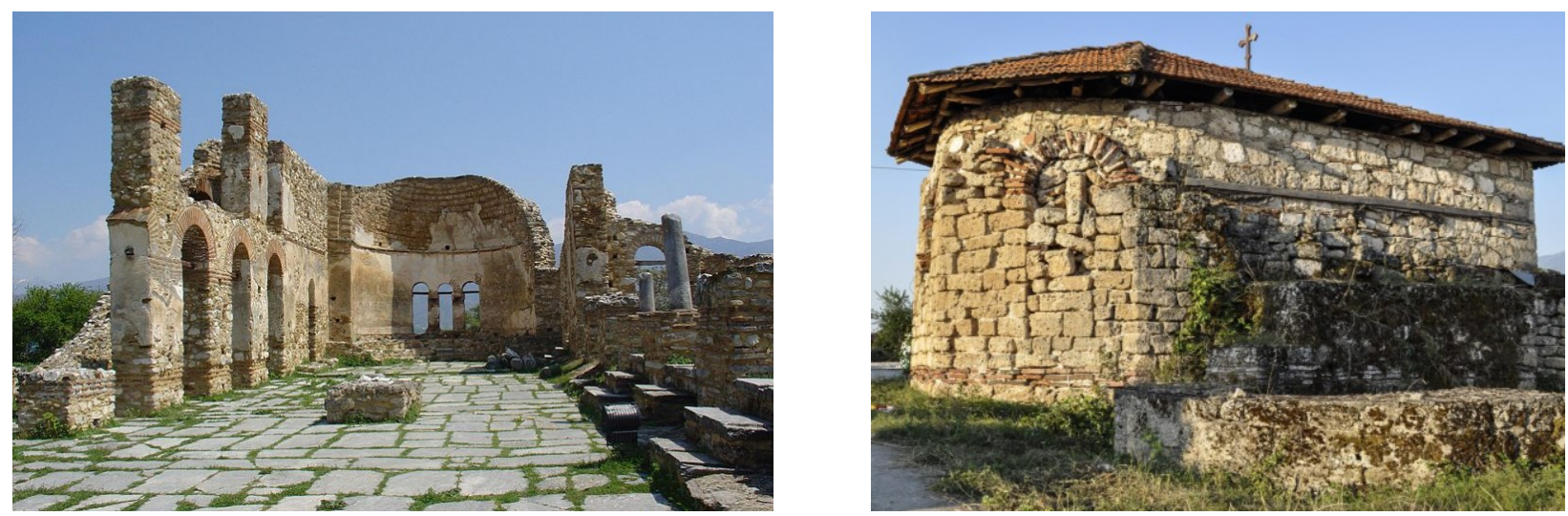

Figure I.20. A. St. Achilles, island of Achilles (Prespa); B. the remains of the Most Holy Mother of God in Vranishta (Struga).

In the solution of a basilica with two lateral domes ${ }^{60}$ "the transition from the archaic early-Christian prototype to a new medieval model, in which the late Roman traditions are balanced with the new Byzantine concepts" (Каранаков, 2013: 68) is evident. The very cylindrical shape of the drum, however, speaks of possible influences from Armenian architecture, which is evident in several buildings in the region: at St. German in the village of German (Prespa), as well as at Panagia Kubelidiki in Castoria. These influences, as well as the very re-use of the basilica solution, can be related to the reign of Tsar Samuel and his presumed ethnic origin. ${ }^{61}$

\footnotetext{
${ }^{58}$ According to Moutsopoulos, the relics of St. Achilles were kept in the diaconicon of the Prespa Cathedral. Miljković-Pepek assumes that the figures of St. Achilles and the two Thessalian saints, St. Ecumenos and St. Diodorus, participants in the First Ecumenical Council at Nicaea were painted there (Петар Миљковиќ-Пепек, "L`église de Saint - Elières du village de Grnčari", Byzantion, Revue Internationale des Etudes Byzantines, vol.38 (1968) 422-432, quoted by Михајловски, 2011: 154).

59 In 1072, the church was looted and desecrated by the Byzantine mercenaries consisting of Alemans and Franks during the suppression of the uprising of Georgi Vojtech (1072-1073), when the old capital Prespa and the imperial palaces were destroyed. However, historical sources inform that a little later the Ohrid Archbishop Theophylact (1081/1082-1115) held a church council in the cathedral, which means that to some extent it had already been restored. This restoration is evidenced by a second layer of fresco-painting in the naos, dated in the second half of the XI century, to which belongs the representation of st. Achilles on the north wall of the central nave, just in front of the altar chancel (Алексова, 1995: 34). Later, it was rebuilt by the Serbian king Stefan Dragutin (1274-1282) (Велев, 1990: 30). It was finally deserted in the XVII century, during the Turkish occupation.

60 Domed prothesis and diaconicon are also found at the basilica in Serres, with the difference that there they are an integral part of the lateral naves, and have no corner pilasters on which the upper structure is to be supported, meaning they typologically do not represent compact inscribed crosses (see fig. I.15A). Also, completely separate side compartments covered with domes characterize some slightly older examples of domed basilicas of the so-called "capital type", such as St. Sophia in Thessaloniki and the Asia Minor churches of Dormition of the Most Holy Mother of God in Nicaea, St. Clement in Ankara and the church in Dere Azi, dating from the VI-VIII century (see fig. I.27).

${ }^{61}$ Namely, Armenian influences are evident in other churches from the same cultural-geographical area, such as St. Nicholas in the village of Vineni, Prespa, which does not belong to the basilica typology - it is a trefoil erected in the XIII century. In the trefoil
} 
Even after the fall of Samuel's kingdom, the church of St. Achilles survived several turbulent centuries, and was in use until 1650 when it was abandoned and has since been preserved in ruins. Even today, the locals call its remains the Metropolis or the Great Church (Велев, 1990: 30).

\section{"Most Holy Mother of God" in Vranishta (Struga)}

The church dedicated to the Most Holy Mother of God in the village of Vranishta, near Struga, has been preserved at the level of archeology and is still insufficiently explored. Typologically, it is a threenave basilica, with a semicircular altar apse whose exterior is five-sided, ${ }^{62}$ pierced by three single arched window openings, very similar to the apse of the cathedral church of St. Achilles. In fact, the altar apse is the only part of the building preserved above ground today, still in use adapted as a chapel within the village's cemetery (fig. I.20B).

According to the discovered remains, the central nave is $5.3 \mathrm{~m}$ wide; its length is unknown, however, due to the lack of systematic archaeological research of the site. Only a small part of the central nave vault is preserved above the pre-apsidal space. The naves are separated by rows of square masonry pillars, approximately $1 \mathrm{~m}$ wide. So far, three pairs of pillars have been discovered at the eastern end of the basilica, placed about $2 \mathrm{~m}$ apart, and connected by brick arches. Thus, it can be concluded that the constructive system of the partition walls in the naos is very similar to that of the church of St. Achilles at Prespa (Бошковиќ, 2000: 47), which speaks of an approximately contemporary construction of both churches within the same cultural area defined by the then thriving kingdom of Samuel. ${ }^{63} \mathrm{~A}$ semicircular apse has been recognized at the eastern end of the southern nave, which parallels St. Sophia's spatial plan. According to the discovered traces, the southern nave was also vaulted. The northern nave, of course, had an identical structure. The church was built with hewn blocks of limestone, with the exception of the arches, and the thickness of the walls exceeds $1 \mathrm{~m}$. The whole structure was probably covered by a continuous gabled roof (Коцо, 1970: 329-330). The existence of western compartments, most likely at least a narthex, cannot be confirmed without further archaeological research of the site (Коцо, 2000: 7273). According to its characteristics, therefore, the church in Vranishta is a three-nave oriental vaulted basilica, which, based on its typology, can be dated to the X or XI century at the latest, i.e. during or immediately after the reign of Tsar Samuel.

\section{"Most Holy Mother of God Chelnica" in Ohrid}

The church of the Most Holy Mother of God Chelnica in Ohrid is one of the most enigmatic and least researched medieval monuments in Macedonia. According to historical sources, it is one of the churches mentioned within Samuel's Patriarchate, and in folk tradition it is associated with the death and subsequently the cult of John Vladimir, Samuel's son-in-law and prince of the region of Zeta. It is a specific basilical building, built adjacent to one of the entrance gates in the Ohrid old town - the so called "Front Gate", over which its eastern parts were in fact founded. From the original basilical disposition of the medieval church, today two vaulted naves are preserved, over which, on the second level, the church develops, again with a unique two-nave arrangement. The oldest frescoes, preserved in fragments, date from the XIV century. Later, the church was renovated during the XIX century Revival.

\footnotetext{
typologies, which were traditionally built in Macedonia earlier, in the IX century, as an Armenian influence can be considered the shape of the lateral conchs, carved into an externally rectangular wall (Томовски, 1970: 24).

${ }^{62}$ Very similar to the five-sided apse of St. Sophia in Ohrid, where the two end sides are completely minimal, almost negligible, and which also has three independent single-window openings.

${ }^{63}$ According to local oral traditions and folklore, this church is known as the "royal church" and is connected to Tsar Samuel or his brother David (Коцо, 1970: 330), see footnote 14.
} 
The preserved remains of the church (the eastern parts of the north and central nave), despite the many later alterations and the lack of archaeological excavations of the complex and, consequently, the lack of an accurate chronology of its construction phases, allow us to reconstruct its original architecture with some accuracy. According to its typology, the church of the Most Holy Mother of God Chelnica was, possibly, a three-nave basilica, with an altar apse to the east (fig. I.21A). Today, only the central and the northern nave exist. Whether it had a narthex, which is very likely, is not known. ${ }^{64}$ The basilical arrangement in the naos is achieved with a colonnade consisting alternately of masonry pillars with a rectangular cross-section and columns, connected to each other by semicircular arches. The naves might have originally been vaulted; today, however, they are covered with a flat wooden ceiling.
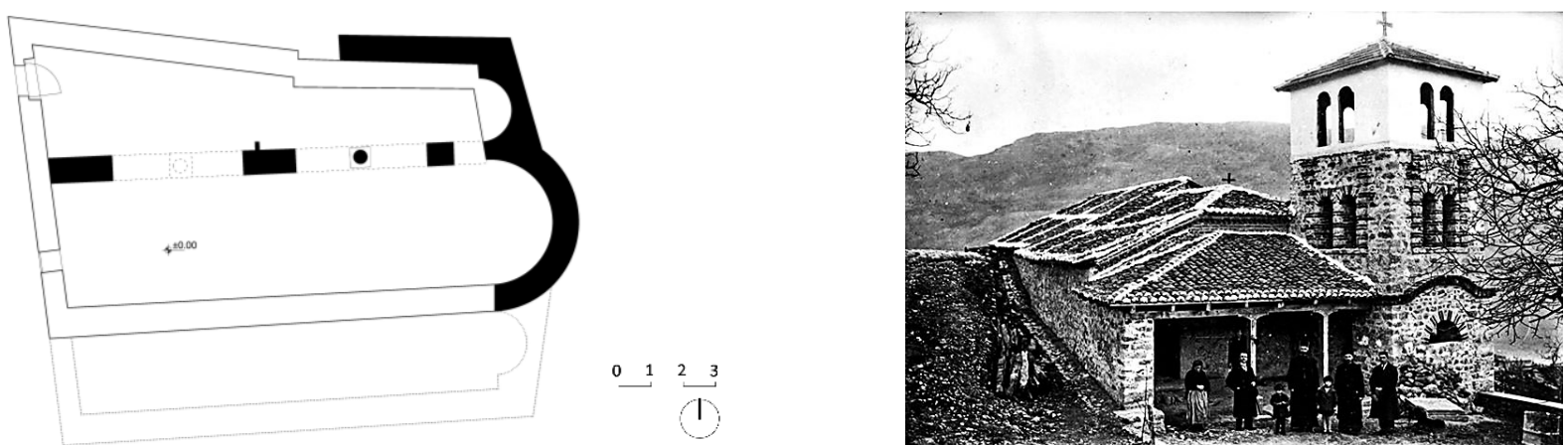

Figure I.21 Most Holy Mother of God Chelnica in Ohrid. A. Plan; B. View from the west.

A detailed observation of the structure of the colonnades, precisely the rhythm of alternation of pillars and columns, demonstrates clear parallels between the Chelnica basilica and the previously described basilicas in Serres, Veria and Kalabaka, which were built during the Byzantine reconstruction in the IX century (see fig. I.15). The main analogy is, of course, the appearance of double (in Kalabaka) and triple (in Veria) passages placed between rectangular masonry pillars through which the central nave communicates with the lateral ones. It is indicative that these churches had a narthex to the west side of the naos, and to the east a defined prothesis and diaconicon. In addition to this group of related, older monuments, a similar rhythm of pillars and columns is characteristic of the original three-nave basilica of St. George in Staro Nagorichane from the XI century, which will be discussed in detail later (see Chapter I.4.3), with the difference that the cross-shaped massive pillars and the transverse arches accepted by buttresses on the façades lead to the assumption that, in its first phase, the church in Staro Nagorichane was in fact a three-nave basilica with a central dome.

\section{"St. Sophia" in Ohrid}

St. Sophia, the cathedral church of the town of Ohrid, once the residence of the autonomous Ohrid Patriarchate / Archbishopric, is certainly the most important medieval cultural and historical monument in Macedonia and beyond, and also one of its most representative cult buildings. As a result of its millennial existence it is a very complex structure, whose history, chronology of construction and architectural typology have been thoroughly discussed by many researchers. ${ }^{65}$ Despite several substantial changes and additions to the complex of buildings that make up the church today, it has never been completely demolished since its erection in the early XI century, making it one of the oldest and most fully

\footnotetext{
64 Judging by older photographs (fig. I.21B), at the beginning of the XX century in front of the west façade stretched a wooden porch, as was fairly common for the Revival churches. It is quite possible that the area it occupied corresponded to the original narthex, i.e. that older foundations were used for its construction. Today, a closed narthex has been built on this position.

65 Detailed review of the older bibliography at Кораћ, В. (2008) „Света Софија у Охриду, простор, структура, облици. Извори“. Зограф 32. Београд: Филозофски факултет, 29-35; and, of course, Чипан, Б. (1996) Св. Софија: катедрален храм на Охридската архиепископија. Скопје: Сигмапрес, Универзитет “Св. Кирил и Методиј”, Архитектонски Факултет.
} 
preserved monuments not only in Macedonia, but on the whole territory of the former Byzantine Empire. Built on an old cult place (Љубинковиќ, 1955: 10), St. Sophia is a set of several construction phases since the Roman and early-Christian period. The oldest building, discovered at an elevation of $-3.9 \mathrm{~m}$ below the present floor of the church, might be a Roman civil basilica, dating to the III-IV century (see Chapter I.1, fig. I.3B). The second, discovered at $-2.7 \mathrm{~m}$, is an early-Byzantine basilica which probably belongs to the great restoration under Justinian I (527-565), ${ }^{66}$ judging by the used material, the dimensions of the bricks and the construction technique, as well as according to the fragmented remains of decorative stone reliefs today used as spoliae. A limestone slab found in the altar, with profiled edges, as well as the remains of a ciborium that covered it, suggest a mensae martyrum, for the relics of a saint-martyr on which the original basilica in the early-Christian period was built and consecrated (Алексова, 1995: 179). ${ }^{67}$ The dimensions of the lateral walls of the Justinian basilica, approximately $1 \mathrm{~m}$ wide, indicate a vaulted system, and the reduction of the width of the north and south walls, from the inside, by exactly $27 \mathrm{~cm}$, indicate the existence of a transept and, thus, a central dome (Чипан, 1996: 32). The early-Christian St. Sophia was therefore a representative of a specific typological transitional solution, with a dome consciously and deliberately incorporated within a basilica, which appeared in the capital during the reign of Justinian I and subsequently spread throughout the Empire. Geo-mechanical excavations carried out in the 1980s under the western façade of the narthex indicate that the early-Christian basilica already had a narthex, equivalent to the current $\mathrm{XI}$ century narthex, as well as a northern staircase tower, indicating that the narthex of the early-Christian basilica was a two-storey building. In the context of this building phase are the foundations of an annex, possibly a baptistery, discovered to the south of the narthex (typical of earlyChristian ecclesiastic architecture of the Ohrid-Prespa region) during the excavations in 1950/1951. ${ }^{68}$

The early-Christian basilica was destroyed in the dark centuries that followed, after which the church was completely rebuilt in the early XI century, as the second imperial endowment of Tsar Samuel, ${ }^{69}$ immediately after the proclamation of Ohrid as the new capital of his empire (in 1000 A.D.). In this middle-Byzantine phase, using the existing foundations and configuration of the building, St. Sophia was conceived as a three-nave basilica of the so-called "transitional type", with four specific upper level chapels in the lateral naves, two pairs east and west of the transept, so that the central nave and the transept form a two-storey cruciform volume in the center of which rests a dome (fig. I.22). Thus, the Ohrid cathedral is in a way a combination of two completely different, contrasting concepts: on the ground level, an archaic, "provincial" traditional three-nave basilica; ${ }^{70}$ on the upper floor, quite

\footnotetext{
66 Most likely built after the devastating earthquakes of 518 and 526 A.D.

${ }^{67}$ Blaga Aleksova assumes that these are relics of the forty Sevastian martyrs, because their cult is especially strong in Ohrid; in the cathedral itself in the $\mathrm{XI}$ century their portraits were painted in the apse of the prothesis, as an act of continuous respect (Алексова, 1995: 182).

68 In the context of this construction phase, an archeological find from the church itself should be mentioned. Namely, in the narthex of the church a relief brick was found, measuring 36/30/6 cm (Коцо, 1949: 354-356). It shows a model of an earlyChristian basilica consisting of a three-nave naos with a semicircular apse, a narthex and two side compartments on its north and south sides; the north room has an apse to the north, while the south on the east side. This plan is reminiscent in many ways of the basilicas from the nearby archeological sites Studenchishta and Radolishta, from the first half or the middle of the VI century (see fig. I.5A, I.6). Additional evidence are two identical relief bricks found during the excavation of the basilica in Radolishta, which places the basilica discovered under the foundations of St. Sophia in the same time frame (Hoddinott, 1963: 229).

${ }^{69}$ Due to the turbulent times, the construction of the church was completed later, after the fall of Samuel's kingdom, under the Ohrid archbishop Leon of Paphlagonia (1037-1056), when it was fresco-painted and consacrated. In addition, Leon equipped the cathedral with the necessary furniture: a pulpit, altar chancel, ciborium, etc. made in marble in the shallow relief technique, unfortunately today fragmentarily preserved. Thus, in historical sources, such as Du Cange's catalogue (Ch. Du Cange: Familiae augustae byzantinae I, Paris, 1680, page 175) Leon is considered the founder of St. Sophia, who "rebuilt the church from the ground up", neglecting the role of Samuel. The term "from the ground up" is used here to emphasize the merit of the founder, and not to accurately indicate the scope of work done (Суботиќ, 1985: 100-101).

70 On this level, St. Sophia has similarities with the slightly older church of Holy Mother of God in Skripu (Greece), which appears more heavy and archaic: the naves are separated by full walls, pierced by the transept and narrow passages in the altar and the western part of the naos; the transept protrudes outwards beyond the south and north façade of the naos; to the east lie three
} 
unexpectedly and despite the elongated volume, it turns into a sophisticated, modern cruciform solution, close to the contemporary Constantinople trends (for example, the northern church of the monastery of Constantine Lips built a century earlier, in 907 A.D.). Perhaps this different conception in the spatial structure of the church on the ground and second levels is in fact the greatest evidence of its construction in two phases in the first half of the XI century, under two founders - Tsar Samuel and Archbishop Leon whose different origin, ethnic background and political goals were reflected in the architecture of their most important endeavor (Димитрова, Коруновски и Грандаковска, 2013: 1566).

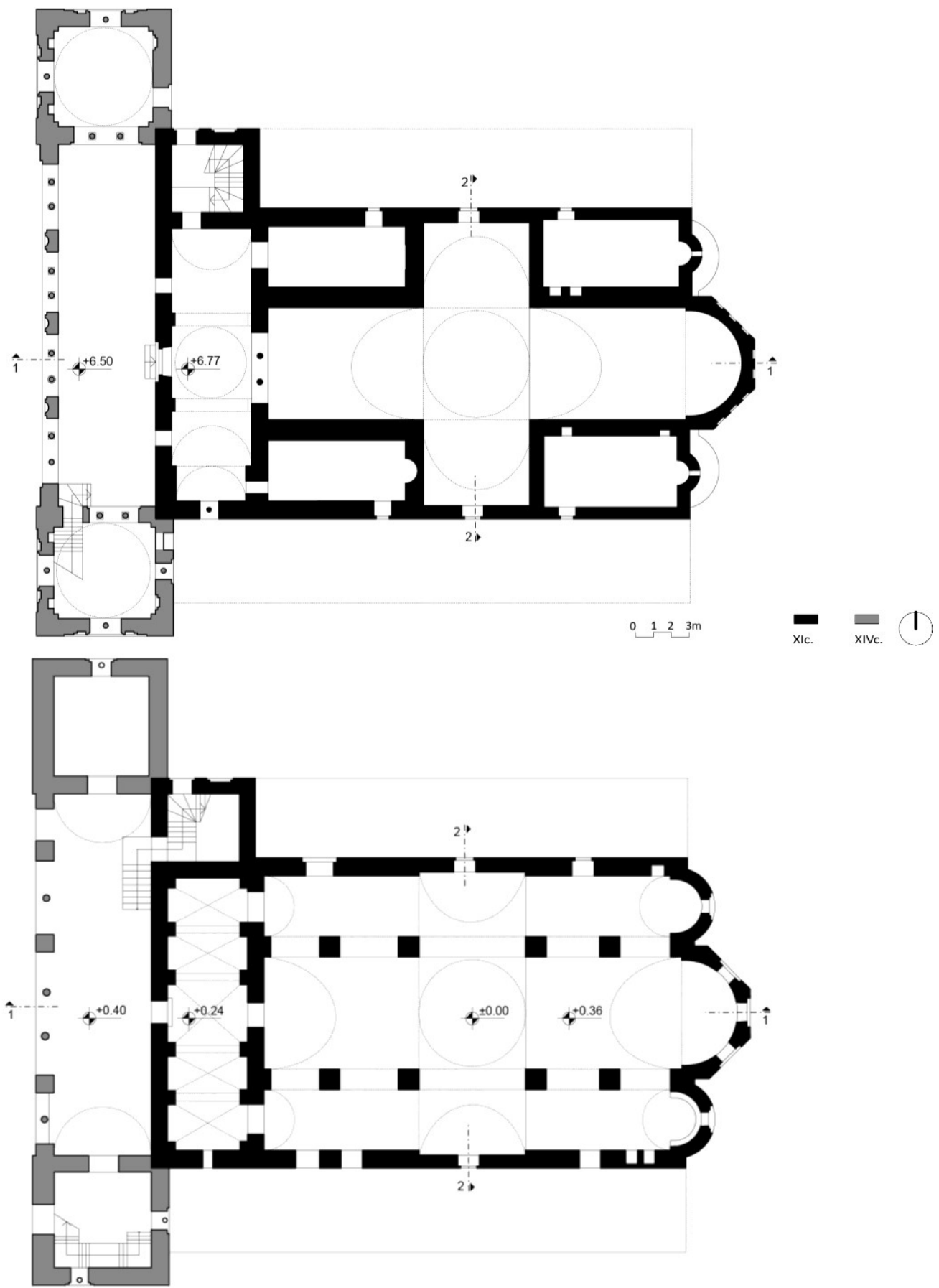

Figure I.22 St. Sophia in Ohrid. Ground floor plan $( \pm 0.00)$ and gallery plan $(+6.50)$. Authentic appearance of the cathedral in the XIV century, prior to the Ottoman reconstruction.

simple and equally tall semicircular apses (see fig. I.28). A similar concept was applied at the church of St. John in Mesemvria (present-day Nessebr, Bulgaria), whose four elongated pillars are closer to an inscribed cross than to a basilica. Both churches are dated to the end of the IX - beginning of the X century (Коруновски и Димитрова, 2006: 30). 
Furthermore, the consistent incorporation of contemporary capital concepts is evident in the used masonry, consisting of a combination of opus cloisonnè as a specific local technique (characteristic of Macedonia, Epirus and southern Greece), with fragmented preserved masonry of the "recessed brickwork" type, as well as a frieze of blind arched niches made of brick in the upper zone of the apse (fig. I.23B), a regular feature of the Constantinople churches from the XI-XII century (Коруновски $и$ Димитрова, 2006: 30-31). This complex dual nature of its architecture further enhances the historical importance of St. Sophia, as a church built on a stylistic turning point from the basilica solutions characteristic of the last epoch into the stylistic diversity of the inscribed cross typology with a vaulted construction and a central dome.

As the cathedral built on the island of Achilles, St. Sophia is an exceptionally monumental building, measuring $40 / 35 \mathrm{~m}$ in total, or an area of $720 \mathrm{~m}^{2}$. Its composition is the result of a precise proportional analysis: the naos, measuring $17 / 24 \mathrm{~m}$, has a ratio of $1: \mathrm{V} 2$ (in other words, the length of the naos is equal to the diagonal of the square whose side is its width). ${ }^{71}$ The naos is divided into three naves, the ratio of which is $2: 1$, by arcades consisting of four massive masonry pillars, measuring 1.15/1.15 m, connected by semi-circular arches. The central nave (as well as the transept) is $6 \mathrm{~m}$ wide, as opposed to the lateral naves, which measure $3.3 \mathrm{~m}$ in width. The perfection of this mathematical composition is evident in the height of the lateral naves $(6 \mathrm{~m})$, equal to the width of the central nave. The lateral naves are covered by semi-cylindrical vaults, while the central nave and the transept with a rampant vault that reaches $11.5 \mathrm{~m}$ in height, i.e. almost twice its span. ${ }^{72}$
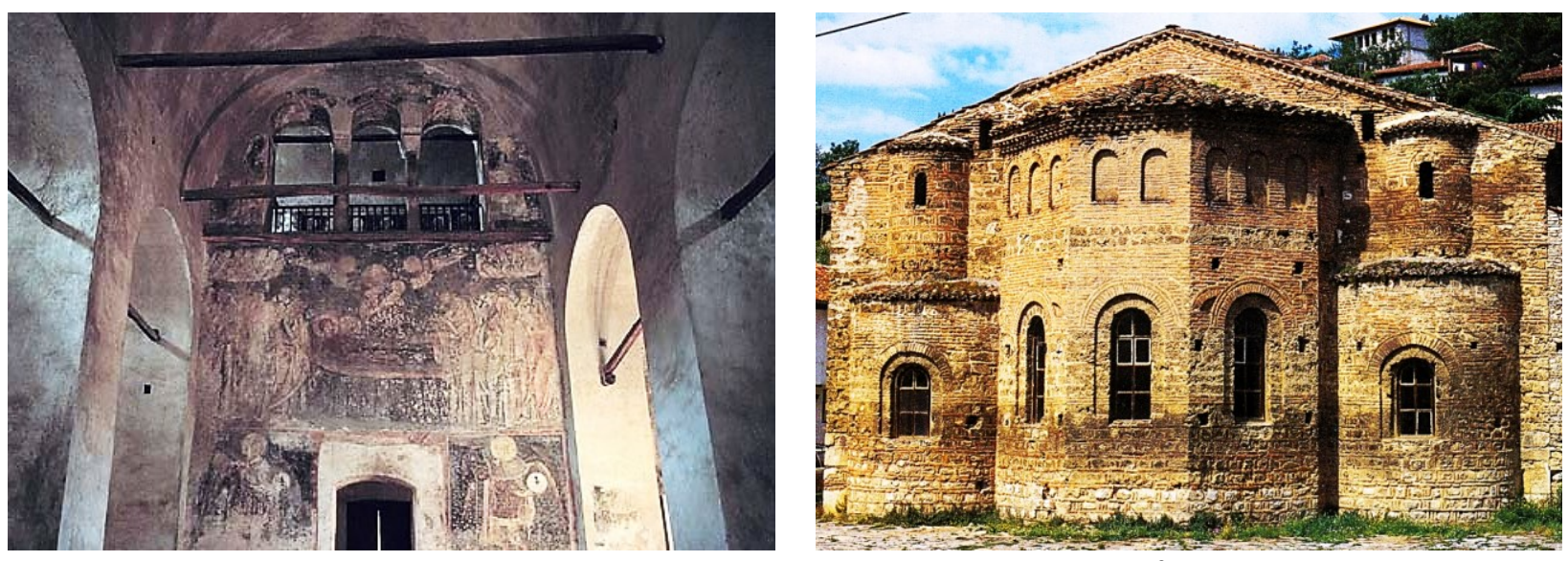

Figure I.23 St. Sophia in Ohrid. A. Naos, view to the west; B. Eastern façade.

To the east, the three naves end in apses, the inner diameters of which correspond to the spans of the respective naves. The lateral apses have a semicircular plan with a local, provincial tone, while the central high altar apse is five-sided, of which the two lateral sides are minimal, so that a three-sided composition dominates. Archaeological excavations carried out in the 1950s and 1980s confirmed the presence of an episcopal syntronon in the altar, which is absent today. Unlike its predecessor, the basilica of St. Achilles at Prespa, St. Sophia in Ohrid does not ponder the idea of complete separation of the prothesis and diaconicon into chambers, but rather of their incorporation within the lateral naves. Visual separation is achieved with the original marble altar partition which was placed on the altar platform under the triumphal arch. The complex system of the Ohrid cathedral incorporates a narrow two-storey

\footnotetext{
71 The exceptional commitment to a proportional model in the design of the Byzantine churches is confirmed by the fact that the naos of St. Sophia in Ohrid is also visually divided into a square consisting of the western part of the temple (including the transept and the central dome) dedicated to the congregation and the remaining rectangular space to the east dedicated to the altar whose mysticism was protected by a semi-transparent altar chancel screen.

72 Based on the graphical method of proportional analysis, Boris Chipan calculated the possible height of the dome drum as 17.4 m (Чипан, 1996: 99-100), and its diameter, according to the base, as $6 \mathrm{~m}$.
} 
narthex, with access to the second floor through the north staircase tower. On the ground floor, the elongated narthex is divided into five bays by pilasters connected by arches. These bays are covered with groined vaults, according to Byzantine custom without the use of ribs (Ненадовић, 1987: 99-100). The second floor of the narthex is connected to the central nave via a monumental tribelon ${ }^{73}$ which has been preserved (fig. I.23A), while separate entrances led to the lateral chapels. It is uncertain how the access to the eastern pair of chapels was solved. It is likely that their use was limited $^{74}$ and thus required sporadic entry. In the context of the upper floor chapels it is necessary to point, again, to the influence of the northern church of the monastery of Constantine Lips ${ }^{75}$ which also originally had four second floor chapels in the corners of the naos, connected to the narthex probably by galleries placed over the ground floor porticos (Mathews, 1982: 127-130), which might have been the case of St. Sophia in Ohrid as well.

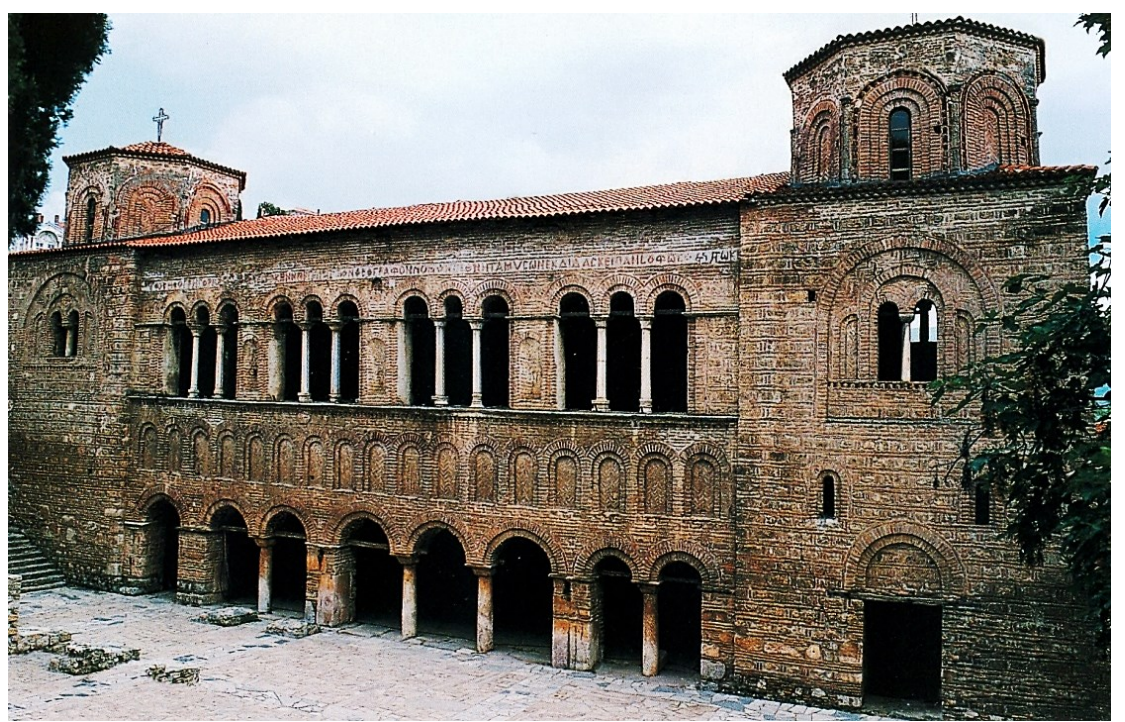

Figure I.24 The exo-narthex of St. Sophia in Ohrid, added in the early XIV century.

The next construction phase undertaken at St. Sophia dates back to the XIII century, under the Archbishop Konstantin Kavasilas (1255-1282), when the upper floor of the narthex ${ }^{76}$ was reconstructed. At the beginning of the XIV century, under Archbishop Gregory I ( 1300-1320), with the generous financial support of the emperor Andronicus II Palaeologus (1282-1328), a monumental exo-narthex was added to the west (fig. I.24), considered a master-piece of late-Byzantine architecture (Дероко, 1953: 18).

\footnotetext{
73 The representative tribelon, authentically preserved to this day, consists of marble columns and capitals in decorative shallow relief. A similarly conceived narthex, open to the naos through a representative tribelon on the second floor, is found at the church of Christ Pantepoptes (Eski Imaret Mosque) in Constantinople, built before the end of the XI century as an endowment of Anna Dalasena, mother of Emperor Alexius Comnene. Another parallel between the narthexes of the two churches are the groined vaults above the three bays of the narthex.

${ }^{74}$ Especially the northern one which, judging by the absence of fresco decoration, seems to have never been in use.

75 The northern church of the monastery of Constantine Lips (Feneri Isa Mosque) in Constantinople was built in 907 A.D. as one of the earliest examples of a "completed conception of an inscribed cross with a dome" (Кораћ и Шупут, 1998: 139). In addition to the lateral upper-level chapels, it has a similarly conceived two-storey narthex - the only difference being that it is divided into three bays covered by groined vaults, formed by transverse arches without pilasters, with three entrances to the nave and a staircase tower to the south. Hence, it seems that this very important and influential church inspired St. Sophia to adopt some of the current Constantinople tendencies, but not the basic typological idea, based on much older, early Byzantine patterns of a basilica with a central dome. Thus, in this case, the "well-known understanding of Krautheimer (...) applies, according to which (...) a work built following a model did not have to completely repeat the pattern, but could copy only a feature which seemed, to the client or builder, to be important for the essence of the conception" (Ibid: 9).

${ }^{76}$ Namely, then the second level of the narthex was divided into three bays: the lateral ones covered by barrel vaults, while above the central one a specific elevation was conceived which, based on fragments of pendentives discovered above today's vault, has been defined as a protruding dome upon a low drum (Коруновски, 2000: 148); a blind dome upon a low drum (Чипан, 1996: 121); or even a bell-tower (Schellewald, 1986: 162-165). This element was later demolished, and its fragmentary remains were discovered only during the church's restoration in the 1950s.
} 


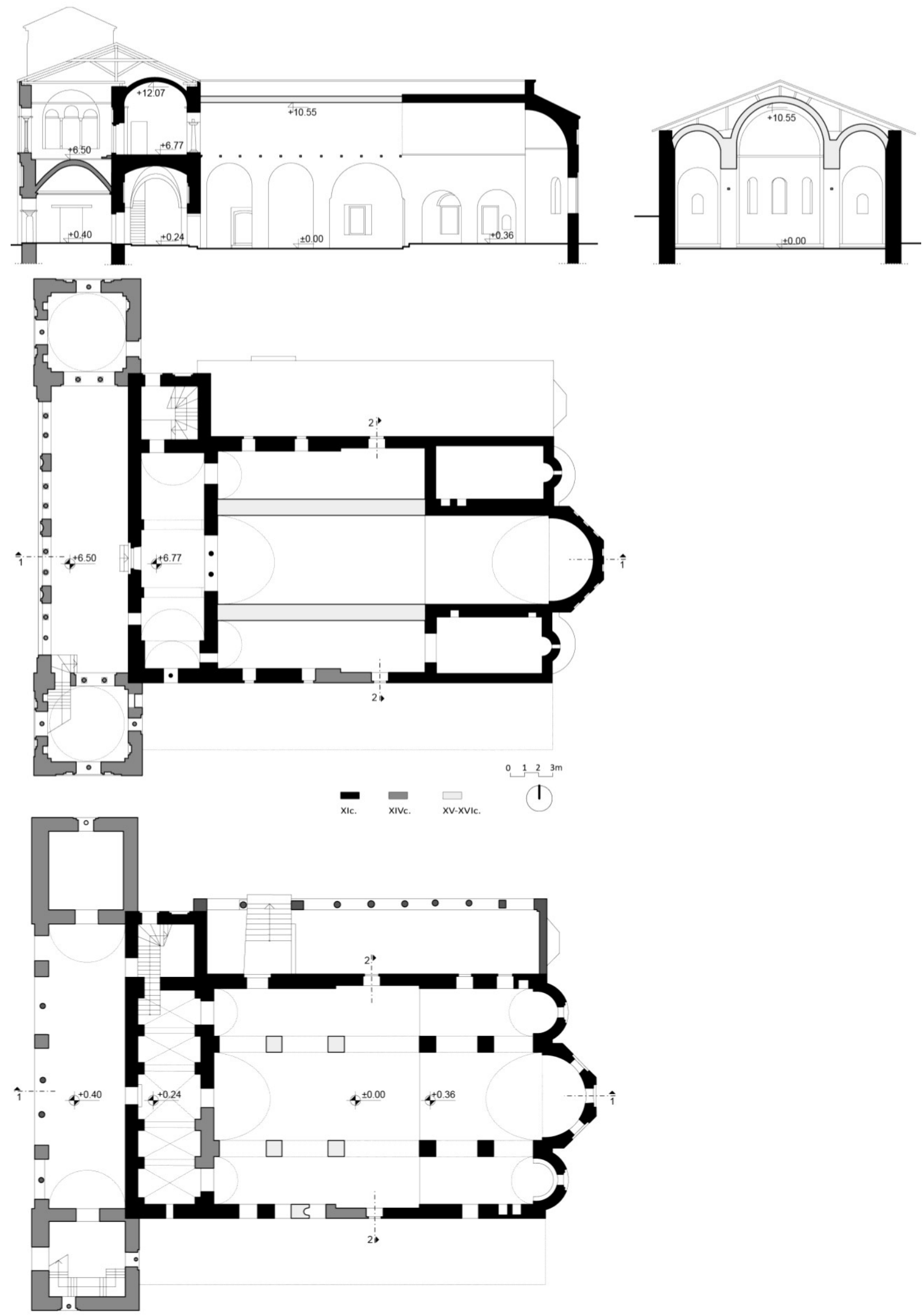

Figure I.25 St. Sophia in Ohrid, after the Ottoman reconstruction. Ground floor plan ( \pm 0.00$)$; gallery plan (+6.50); longitudinal section (1-1) and transversal section (2-2). 
After the Ottoman occupation in the late XIV century, the Ohrid Cathedral existed for a short time in a rather desperate state, after which it was officially seized from the Ohrid Archbishopric as a Fethiye Mosque (conquered mosque), a symbol of the newly-established power ("Евлија Челеби за Македонија“, 2007: 125). During its conversion into a mosque, in the XV-XVI century, a thorough reconstruction of the naos ensued, likely after the structure was already quite damaged by gradual decay, especially the central dome with a relatively large span of $6 \mathrm{~m}$. It was then that the transept and the dome were demolished, as well as the western pair of upper-floor chapels, and replaced with a classical, continuous three-nave basilical disposition, which in fact contributed towards the later misinterpretation of St. Sophia as a simple oriental basilica (fig. I.25). The southern entrance portal was completely closedoff, and the dominant role was given to the northern entrance, for which purpose an open porch was built along the northern façade reutilizing authentic building material. ${ }^{77}$ The western narthexes, although fortunately not demolished, were deprived of their ceremonial nature (Ненадовић, 1980: 111). The entire naos was covered by a massive gabled roof, as were both narthexes, and a minaret was built over the north tower of the exo-narthex. With the exception of the minaret, dismantled by the local population after the Balkan Wars (1912-1913), St. Sophia preserved to this day the appearance of a pseudo-basilica, with the intention to consistently present all its historical stages and complex nature.

\section{"Dormition of the Most Holy Mother of God" in Velushina (Bitola)}

The church of the Dormition of the Most Holy Mother of God in the village of Velushina, near Bitola, known to the locals as the "Old Church", is a complex monument built in several phases on an ancient cult site. It is located on the southeast of the village, near the section of the ancient Roman road Via Egnatia, which led from the early-Christian episcopal seat Heraclea Lyncestis (medieval town of Pelagonia, today's Bitola) to the south (see map I-1). According to archeological excavations, the oldest building was a threenave basilica from the period of early Christianity, namely the reign of Emperor Theodosius II (408-450) (Михајловски, 2011: 143-144). Built of large hewn stone blocks; the south and north walls are well preserved, up to a height of $1.80 \mathrm{~m}$ and a width of $0.75 \mathrm{~m}$, while the apse wall is approximately $0.5 \mathrm{~m}$ thick. It is probable that this oldest basilica was destroyed in the second half of the $\mathrm{V}$ century, during the Ostrogoth conquests, when several important late-antique settlements, such as Stobi and Heraclea Lyncestis, were raided and destroyed.

In the next, VI century, a thorough reconstruction of the devastated region was undertaken under Justinian I (527-562). According to the preserved remains, it can be concluded that "the basilica in Velushina is inspired by the basilicas in Thessaloniki from the fifth century, dedicated to the Virgin Acheiropoietos and St. Demetrius" (Михајловски, 2011: 144). These two very influential basilicas built in the second most important city in the Empire - Thessaloniki, inspired the system of separation of the narthex and the naos by means of monumental ceremonial tribelons. However, in the Thessaloniki churches the basilical disposition is classical, with two long arcades comprised of twelve columns dividing the naos into three naves, of which the central one ends with a large altar apse, while the lateral ones lack smaller apses and any hint of defined prothesis and diaconicon (Кораћ и Шупут, 1998: 21). Also, a tribelon links only the central nave with the western narthex. ${ }^{78}$

\footnotetext{
77 This porch is a necessary element in mosques, as a space for performing ablution (ritual washing) and preparation for prayer.

${ }^{78}$ Several early-Christian basilicas have a tribelon connection between the central nave and the narthex. Such is the case, in addition to St. Demetrius and the Acheiropoietos, with the basilica at the site Tumba in Thessaloniki, the basilica extra muros in Philippi, and some already mentioned early-christian churches in Macedonia (the basilica at Davina Kula near Orman, the North basilica in Stobi, etc.).
} 

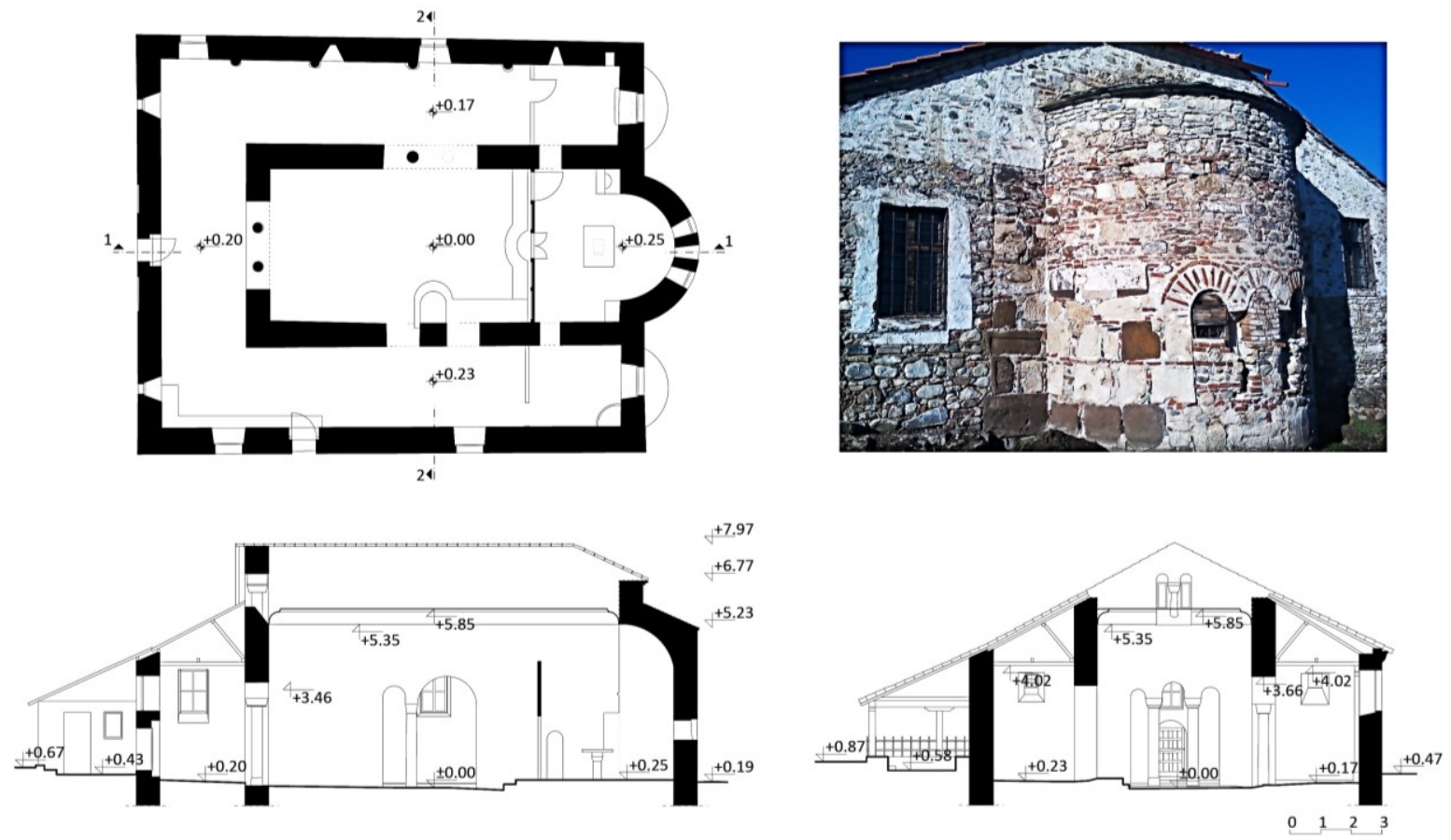

(1)

Figure I.26 Dormition of the Most Holy Mother of God in Velushina (Bitola). Plan ( \pm 0.00$)$, longitudinal section (1-1), transversal section (2-2) and view from the east.

At the church in Velushina, unlike them, the elongated central nave is separated from the lateral ones by a wall perforated by identical monumental tribelons, which is really rare and uncharacteristic of the Byzantine provinces (fig. I.26). The proportional ratio of the central compared to the lateral naves is $2: 1$, as was characteristic of the early-Christian and middle-Byzantine basilicas. The dimensions of the naos, without the altar apse and the later added porches, are 13.7/16.6 m. The central, higher nave is encircled on the northern, western and southern side (while visually integrated via the tribelons) by a continuous perimetral " $U$ "-shaped lower nave comprised of the lateral naves and the narthex, a solution that will be encountered later in several churches in Macedonia and Epirus, built under the influence of the Thessaloniki metropolitan cathedral St. Sophia (Кораћ и Шупут, 1998: 102), i.e. the basilicas with a dome from the so-called "capital type", whose conceptual and structural solution is based on the great churches of Constantinople from the era of Justinian I - St. Sophia and St. Irene. ${ }^{79}$ All the examples mentioned so far have upper-floor galleries, while a significant part have central domes, which leads to the question of the original upper construction of the Velushina basilica. Namely, the upper construction was damaged and later substituted by a wooden ceiling; therefore the original presence of a dome above the central nave cannot be ruled out. On the east side, the altar apse is flanked by two lateral apsidioles,

\footnotetext{
79 Unlike the church in Velushina, in these churches the central nave is compact, much closer to a square. It is indicative that all these churches had galleries above the lateral naves and the narthex, implying that the clerestory system was already abandoned. Also, the altar is tripartite, with a prothesis and diaconicon ranging from a compact inscribed cross covered with a smaller dome at the Thessaloniki St. Sophia; inscribed cross with elongated arms in a north-south direction and a dome at the church at Nicaea; to cuatrefoil compartments covered with groined vaults at the church in Dere Azi (fig. I.27). This solution continued to be influential in the following centuries to come. At the beginning of the XII century, the church of Christ Evergetis (Gül Mosque) was built in Constantinople, following the same concept of perimeter naves with galleries. Later, at the end of the XIII century, a similar concept was used in the southern church of the monastery of Constantine Lips. Although geographically distant, it is important in this context to mention the church in Qasr ibn-Vardan, Syria, dating from the second half of the VI century. Just like in Velushina, the naos is surrounded on all three sides by a continuous perimeter nave. Furthermore, its lateral walls are also full, with the appearance of a monumental tribelon to the north and south (and a simple single entrance to the narthex to the west). It is indicative that in the square field defined by the north and south tribunes, a dome supported on pendentives rises, whose loads are accepted directly by the north and south walls of the central nave, without load-bearing pilasters. This church also had upper-floor galleries accessed through a square external staircase tower, placed to the north of the narthex.
} 
constructed with smaller stone blocks and rows of brick. Unlike the above-mentioned domed basilicas built approximately at the same time or a little later, in Velushina the prothesis and the diaconicon are not separate chambers, but are integrated in the lateral naves, separated only by the altar partition.
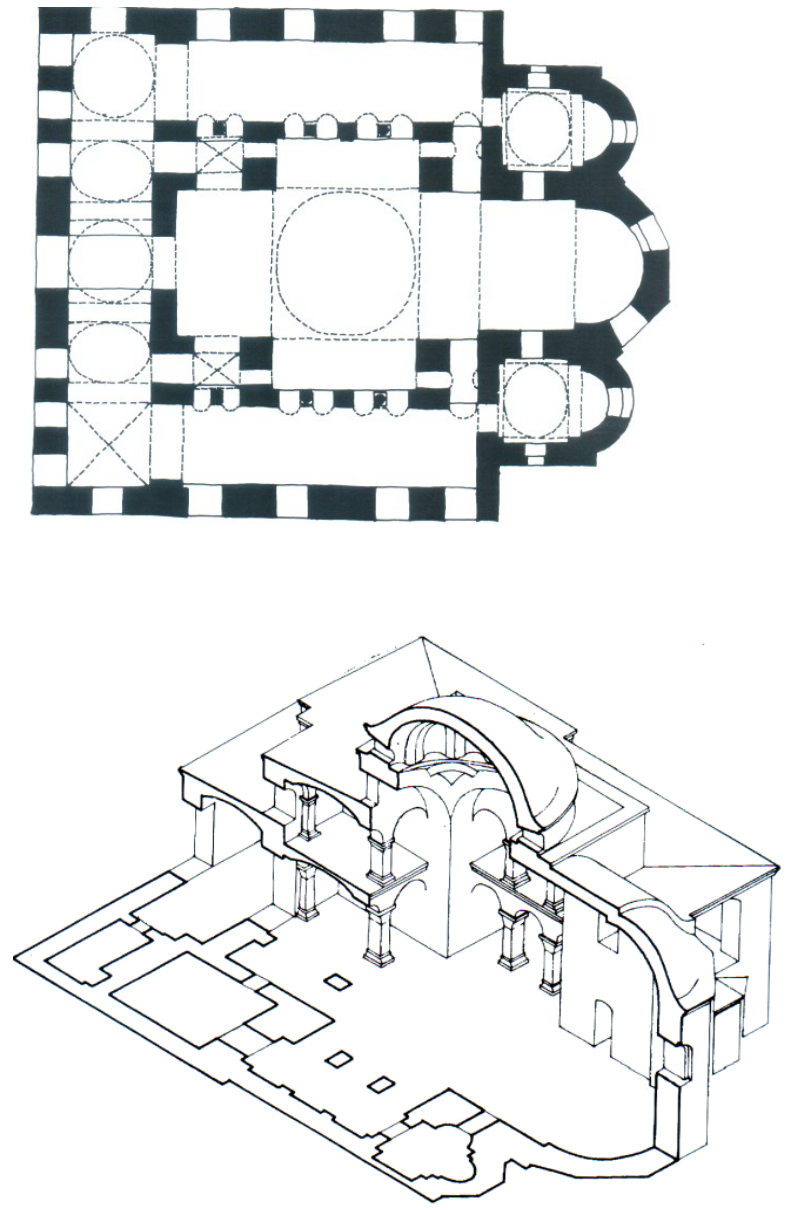
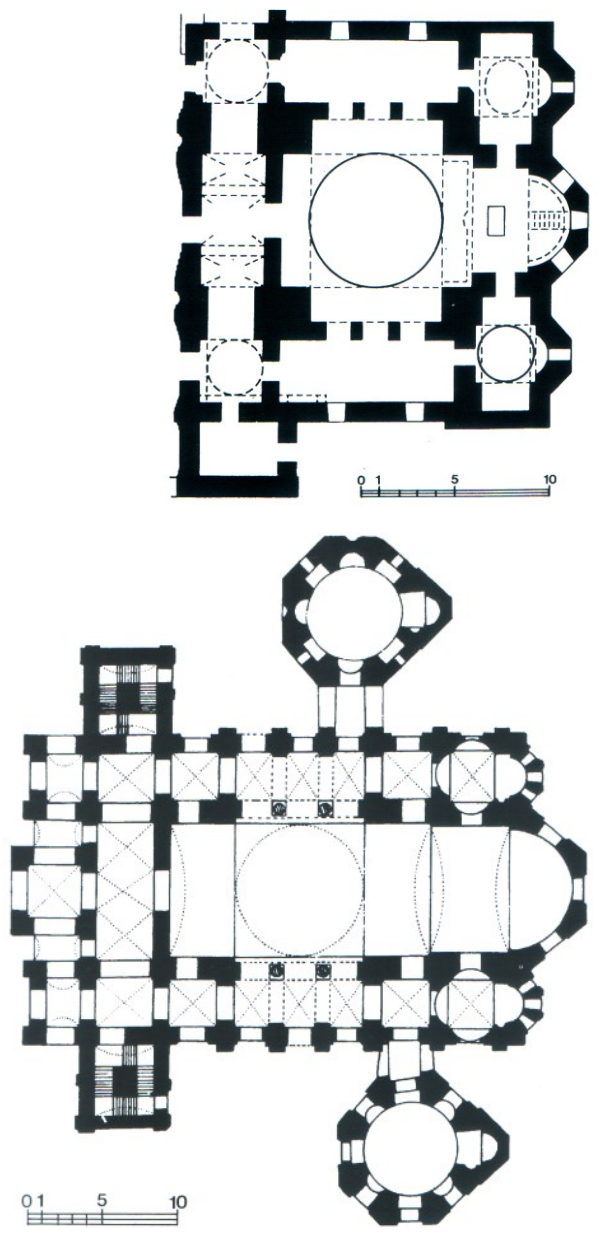

Figure I.27 St. Sophia in Thessaloniki; the Most Holy Mother of God in Nicea; St. Clement in Ankara and the church at Dere Azi.

In addition to the "capital type" of domed basilica, the church in Velushina has similarities with somewhat later buildings, such as the church of the Most Holy Mother of God in Skripu near Orchomenos, Greece (fig. 1.28), erected in the second half of the IX century (see footnote 70). In the context of the church in Velushina, mention must be made of the three apses on the east side, with integrated prothesis and diaconicon, triple windows in the apse and on the tympani of the transept and the central nave, as well as the division of the naves via a solid wall.
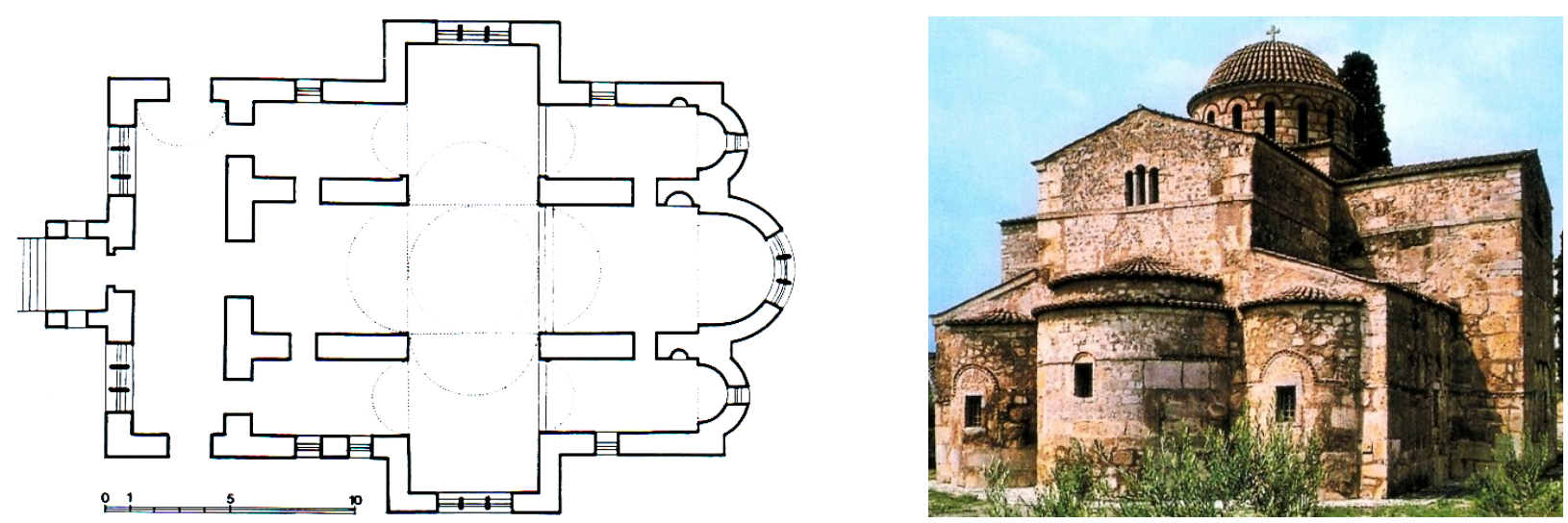

Figure I.28 The Most Holy Mother of God in Skripu (Greece). A. Plan; B. View from the east. 
What is missing at the church in Skripu are the tribelons, as an important element of Velushina's architectural concept; however, if it did not have upper-floor galleries, the upper construction of the church in Skripu could serve as a basis for reconstruction of the vaulted structure in Velushina. In fact, the church in Skripu originates from the same period as the next phase in the development of the church in Velushina (IX-XI century), when the narthex and apse were reconstructed and the whole building was covered with a "retarded gabled roof" (Михајловски, 2011: 146). Also, partially preserved frescoes date from this phase, as a manifestation of an active renewal of the temple in the process of Christianization of the local population.

In this context, it is important to point out certain similarities that the church in Velushina shares with several temporally and geographically close middle-Byzantine basilicas, namely the earlier described churches in Serres, Veria and Kalabaka. One analogy is of course the appearance of tribelons towards the narthex, and two-arched (in Kalabaka) and threearched (in Veria) passages to the lateral naves (see fig. I.15). The church in Veria, in addition, has a similarly conceived altar, with three apses to the east, without the physical separation of the prothesis and diaconicon; the basilica at Kalabaka, on the other hand, has a similarly conceived triple window in the altar apse. Furthermore, several churches built in Epirus and western Greece in the same period also defined as transitional basilicas: Mother of God Panaxiotisa in Gavrolimni, St. Demetrius Katsuri in Arta, Dormition of the Most Holy Mother of God in Labovo (present day Albania), share similarities with the church in Velushina (fig. 1.29). As an even more significant analogy, the church in Labovo (as well as the older capital churches of the domed basilica type) has a square nave covered with a dome upon a cylindrical drum, separated from the side naves and the

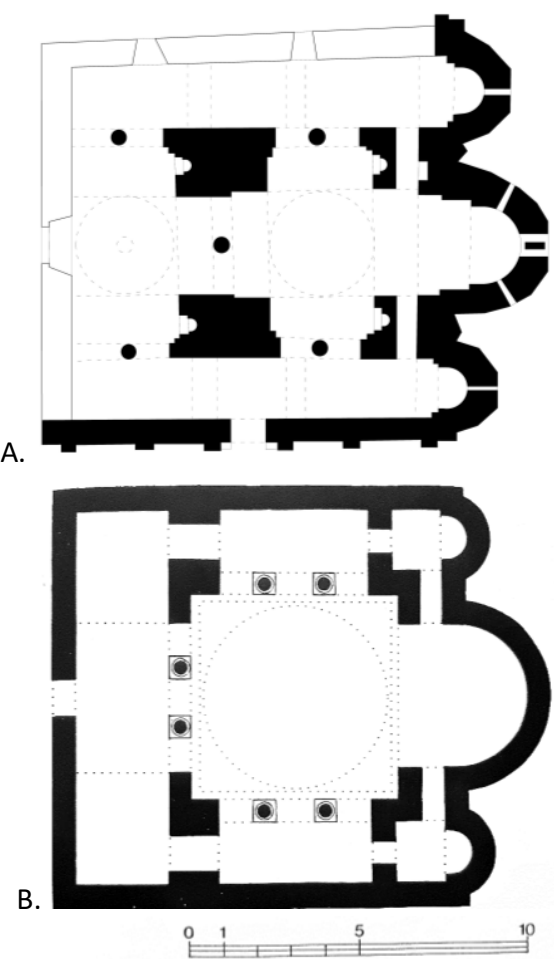

Figure 1.29 A. the Holy Mother of God in Drenovo (Kavadarci); B. the Holy Mother of God in Labovo, Albania. narthex by two-storey tribelons. Unlike the basilica at Velushina, in all these churches the narthex is completely separated, as well as the compartments intended for prothesis and diaconicon.

Consequently, in addition to the original typology of the basilica at Velushina established in the VI century, it can be concluded that its current architecture is the result of interventions on the structure in the middle-Byzantine period, which according to the mentioned contemporary examples were rather typical for the Balkan areas of the Empire at the time.
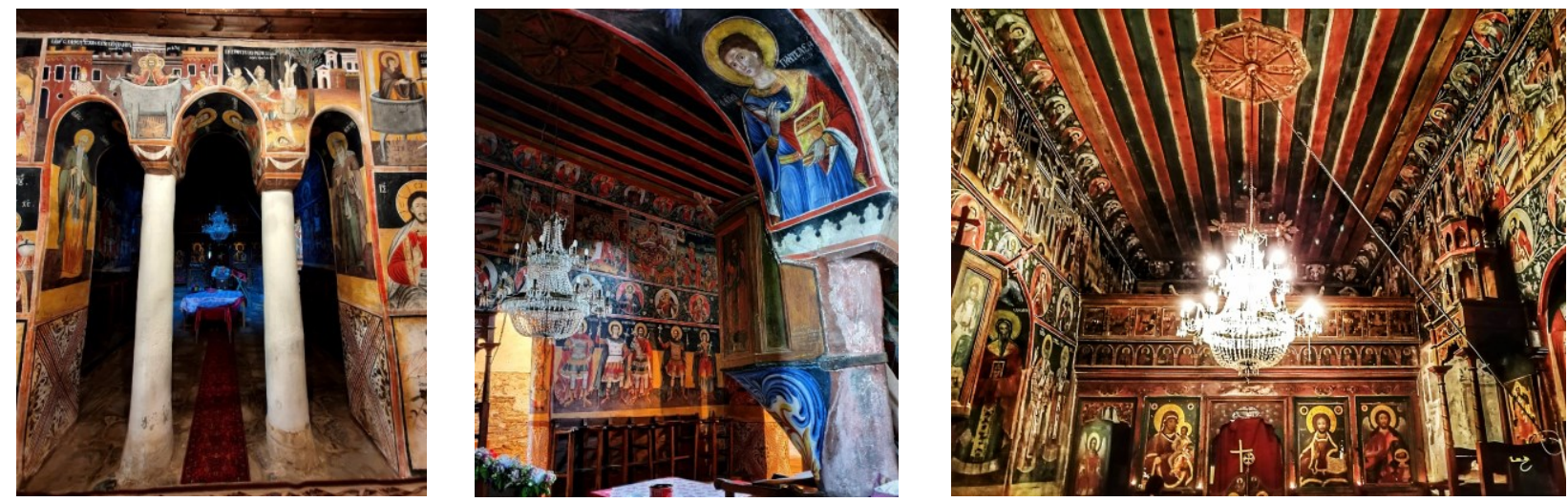

Figure I.30 Dormition of the Most Holy Mother of God in Velushina (Bitola). A. Western tribelon; B. Pulpit in the northern tribelon; C. View towards the altar. 
During the Ottoman occupation, like many other older monumental Christian temples, the basilica at Velushina found itself in a dilapidated state, reduced to a village church. As witnessed by written sources, the church was restored and repainted by the hieromonk Gabriel of Castoria in 1792, when the iconostasis was also made. Today's appearance is the result of the final interventions in the church in 1836, as one of the many older churches restored during the Revival, on which occasion it was completely

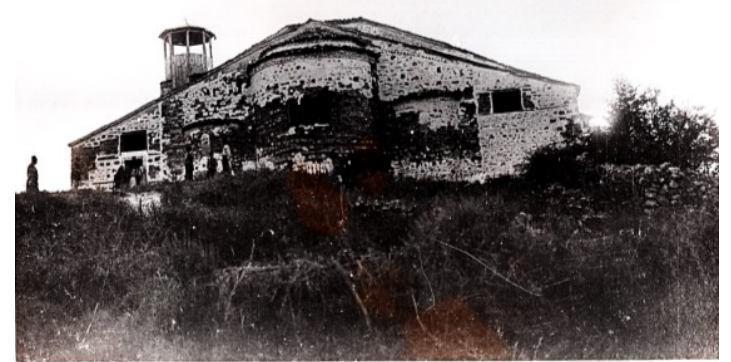

Figure I.31 St. Nicholas in Melnik, present day Bulgaria, photographed in 1899. fresco-painted (fig. I.30C) and covered by a large gabled roof, a common modification of older churches renovated in the XIX century (fig. I.31). Of the original three tribelons, the western one is authentically preserved (fig. I.30A); half of the northern one has been replaced by a pulpit (fig. I.30B); while in the southern one both columns are missing, and have been subsequently replaced by a single masonry pillar (fig. I.26). The side apses have been preserved only as archeological remains, while the central one has been rebuilt several times, judging by its complex stratigraphy and abundant re-use of older material. The temple is accessed through a west and south entrance portal, but in its original disposition very likely had had porches and entrance portals on all three sides, in a symmetrical composition.

\section{"Crkvishte" in Morodvis (Kochani)}

The settlement of Morodvis ${ }^{80}$ dates back to the Roman period, when it is mentioned as a stop on the Via Stopis usque ad Serticam road. It developed significantly in the early-Christian and medieval period (X century), when it grew into an important episcopal center - the seat of the Bregalnica bishopric. ${ }^{81}$ During the archeological campaign of 1980-1981, led by the archaeologist Kiril Trajkovski, the remains of a complex of monumental buildings was discovered at the foot of the acropolis of the fortified settlement, built in several distinctive phases - a site known as Crkvishte. The oldest construction phase is an earlyChristian single-nave basilica with a baptistery on the north side. With the help of the stylistic features of the discovered stone sculpture (Филипова, 1997: 44-45), it was dated to the V-VI century when it was erected from the north side of an older monumental underground vaulted tomb with early-Christian insignia, probably from the IV century (Трајковски, 1989: 89-90). The second phase of construction has been differently defined by several researchers. According to Blaga Aleksova, it is a one-nave church, which dates back to the early-Slavic period (Aleksova, 1989: 118); on the other hand, Kiril Trajkovski considers this a cruciform church "with a dome" (Трајковски, 2008: 80). This church was built on the ruins of the old temple, probably destroyed in the earthquakes of the VI century, as well as the subsequent military conquests of the region. Its construction is related to the VIII-IX century, i.e. the establishment of Christianity and the famous Bregalnica mission of St. Cyril (see Chapter I.3). Also, this construction phase can be related to the reign of the Bulgarian khan Boris and his successor Simeon in the $\mathrm{X}$ century, a period followed by intense construction activity (Трајковски, 2008: 80).

However, as was the case with the cathedral church of St. Sophia in Ohrid, this modest renewal intended for mass conversion of the Slavs and the spread of the Christian cult, was soon completely replaced by a new representative building, during the reign of Tsar Samuel (976-1014). Namely, in the

\footnotetext{
80 The village of Morodvis is located in the immediate vicinity of the late-antique and medieval settlement of Morobisdon

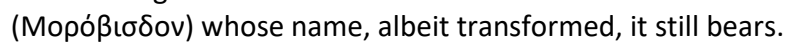

81 The episcopate of Morobisdon is first mentioned in the "Short History" of John Skilitses from 1018 A.D., and ceased to exist with the Serbian conquests of the region in the XIV century (Томоски, 1978: 93-96).
} 
above-mentioned early-Christian tomb, relics were discovered which have been introduced at a later time through a hole drilled in the vault precisely for that purpose, and later neatly repaired (Трајковски, 1989: 90), which are presumed to belong to five of the fifteen Tiberiopolis Martyrs, transferred to Morodvis in order to strengthen its newly established episcopal cathedra ${ }^{82}$ in the X-XI century, which enabled the third chronological phase of construction.
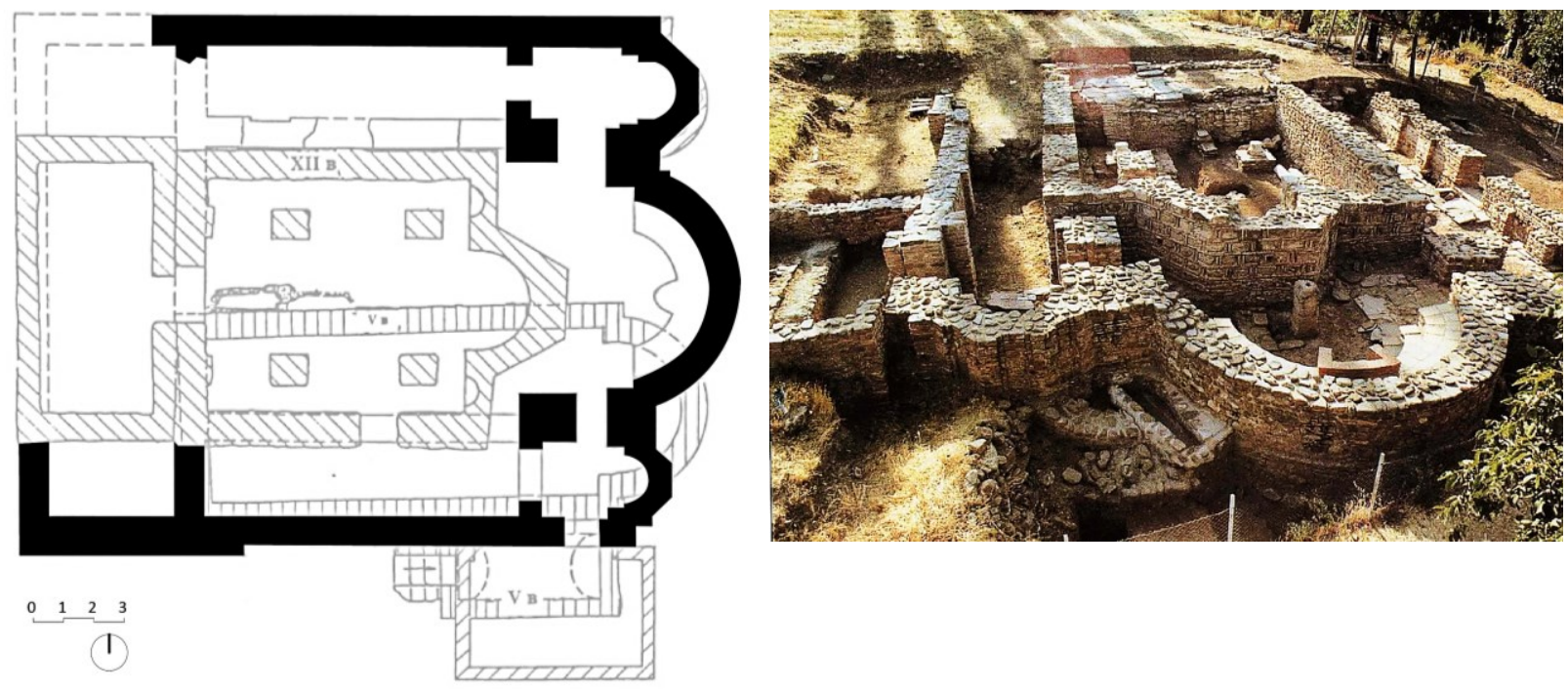

Figure I.32 "Crkvishte" - Morodvis. A. Plan; B. View from the east.

Judging by the excavated remains, the middle-Byzantine church in Morodvis is "one of the most harmonious architectural three-nave temples from the middle-Byzantine period in Macedonia" (Трајковски, 2008: 80). The preserved remains of a pulpit and a synthronon in the altar apse speak of its nature as an episcopal cathedral (fig. I.32). It is a very monumental construction: the total width of the naos is approximately $15 \mathrm{~m}$; the span of the central nave is almost $6.5 \mathrm{~m}$, while the lateral ones are approximately $2.5 \mathrm{~m}$ wide. To the east, the central nave ends in a spacious semi-circular altar apse, with an outer radius of $2.85 \mathrm{~m}$, while the side naves end in significantly smaller, three-sided apses comprised of shallow outer pilasters and double niches. The massive masonry pillars that divide the naos into three naves are square and measure approximately $1 / 1 \mathrm{~m}$. The relatively thin perimetral walls, approximately $75 \mathrm{~cm}$, indicate a probable architrave coverage of the temple, as their thickness is insufficient to accept the lateral thrusts from a possible vaulted upper structure, the spans of which, especially in the central nave, would be significant. However, the strengthening of the façade walls with internal and external pilasters indicates a possible vaulted, or domed structure covering parts of the temple. In that context, its undoubted stylistic connections with the archbishopric's cathedral of St. Sophia in Ohrid are of special importance. Analogies between these two contemporary churches exist in the fragmentary preserved opus sectile marmoreum floors in their altars, as well as in the composition and ornamentality of the marble church furniture (Филипова, 1997: 45-47) and the partially preserved frescoes.

Unfortunately, the middle-Byzantine three-nave basilica in Morodvis was soon destroyed. The last construction phase on the site dates from the XIII century, in the form of a significantly smaller temple incorporated in the central nave of the older building with a central solution: a typical late-Byzantine inscribed cross with a central dome, built with a regular façade elaborated in stone and brick in opus cloisonné and floors paved entirely with brick.

\footnotetext{
82 Once more appears the practise of transferring holy relics, furta sacra, whose purpose was to confirm the significance of a newly-established or renovated church seat, as was the case with the five-nave basilica at "Kale" - Krupishte and Samuel's Patriarchal Cathedral of St. Achilles on the island of Achilles, Lake Prespa.
} 


\section{I.4.3 The Basilical Typologies in the Period between XI-XIV Century}

Shortly after the demise of Samuel's independent state, Macedonia was reintegrated into the Byzantine Empire, with the exception of a few short-lived liberation uprisings led by his successors during the same century. But Byzantine society was already changing. Namely, the whole XI century, after the death of Basil II, was marked by economic, military, agrarian and cultural decline for Byzantium (Barreras \& Durán, 2010: 238). In 1054 A.D. the final rift between the Eastern and Western Churches occurred, an inevitable event with far-reaching significance and consequences worldwide, which had already been indicated in past centuries. The ecclesiastical schism was against the Emperor's will, as Byzantium lost its sphere of influence in Western Europe. In addition, in the second half of the XI century the Empire lost all the Asian territories in a poorly organized war with the Turkish Sultan Suleiman, as well as its centuriesold maritime trade primacy in the Mediterranean at the expense of the young Italian republics. All this contributed to a historically significant shift of the center of power to the West, which not coincidentally culminated with the Crusades and the temporary loss of Byzantine rule in 1204 A.D.

The Western European supremacy in Byzantium in the XIII century contributed to the completion of the process of feudalization, which had independently begun in the past. The dispersal of territory and the division of the centralized government was used by the young Balkan states aiming to expand their influence or for ecclesiastical gain. Thus, in 1217 A.D., the Serbian King Stephen I was crowned by the Roman Pope Honorius III; at the same time, to the east of the Balkan Peninsula, the renewed Bulgarian kingdom, with its capital in Veliko Trnovo, reached its zenith under Asen II (1218-1241). These new states soon established their own autocephalous churches, both to the detriment of the Ohrid Archbishopric and its diocese (Острогорски, 1959: 395). Their growing power and expansionist military campaigns to the south, at the expense of the Byzantine territories, cut short the rebuilding of Byzantium, which officially took place in 1261 A.D. under Michael VIII Palaeologus (1259-1282), the founder of the new and last - powerful imperial dynasty. Soon, the Serbian king Milutin (1282-1321) began an openly expansionist policy towards Byzantium and conquered Skopje in 1282 A.D., thus shifting the center of the Serbian state to the south (И. М. Н., 2000: 527). The Serbian state ocupied almost the entire territory of Macedonia in the first half of the XIV century under the Nemanjić dynasty (Манева, 2013: 1958), especially under Stephen Dushan (1331-1355), who was crowned Tsar in the new capital Skopje in 1346 A.D. The size of the Serbian Empire inevitably required an administrative division; separate towns and regions were governed by representatives of the Serbian aristocracy, awarded Byzantine titles, as well as by representatives of the local Byzantine feudal government who recognized Serbian supremacy. The administrative division of the state enabled the emergence of feudal separatism by the local powerful rulers, which are in fact the first signs of the weakening of the Serbian central government. Stephen $V$ Urosh (1355-1371), the successor of Tsar Dushan, failed to save the State from disintegration, since feudal anarchy was already widespread..$^{83}$

The fragmentation of Byzantium and the Serbian Empire meant that on the Balkan Peninsula, and even in Europe, there was no longer a force that could withstand the persistent onslaught of the Ottoman

\footnotetext{
${ }^{83}$ Namely, during the reign of Tsar Urosh, western Macedonia was ruled by the prefect, and from 1365 co-ruler, Dimitrija Volkashin; until the same year, Empress Jelena, the widow of Tsar Dushan, ruled Serres and the surrounding areas, afterwards taken over by Despot Jovan Uglesha, Volkashin's brother, who extended his dominions to the Aegean coast, including Mount Athos; Sevastocrat Vlatko ruled in northeastern Macedonia; despot Dejan, ruler of the northern districts soon expanded significantly to the east at the expense of the former dominions of Jovan Oliver; the southwestern areas around Ohrid were ruled by Branko Mladenović, and later by his sons Caesar Grgur, the monk Gerasim and the youngest, Vuk Branković, later ruler of Skopje until the conquest of the city by the Ottomans in 1392. At the end of the century, Ohrid was ruled by the praefect Andreja Gropa; the areas around Veria and Edessa by Duke Radoslav Hlapen, and to the southeast, the area between Thessaloniki and the confluence of the Struma River by Duke Bogdan (Манева, 2013: 1961-1962).
} 
Turks, a people of Central Asian descent, who would prove to be an invincible military force and the worst enemy of Byzantium, in more than 1000 years of the Empire's existence. As early as 1300 A.D., all of Asia Minor, with the exception of some major cities, was under Turkish rule (Острогорски, 1959: 458-459). Being under military pressure from two sides, the economically exhausted Empire was no longer able to cope. In 1352 A.D., a large Ottoman army arrived on European soil (Ѓорѓnев, 2013: 1872) and initiated a systematic conquest and colonization, especially intense during the reign of Sultan Murat I (13621389).The final battle with the combined armies of the independent Balkan rulers, led by the brothers Despot Jovan Uglesha and King Volkashin, took place at Chernomen, on the Maritsa River, in September 1371 A.D. and ended in victory for the conquerors. After the catastrophic epilogue of this final showdown, the Macedonian countries lost their independence; the same fate followed the rest of the Balkans. The last resistance was offered by Constantinople, which was officially conquered by the Turks only in 1453 A.D., after a long-lasting siege. With that, the millennial Byzantine Empire ceased to exist forevermore.

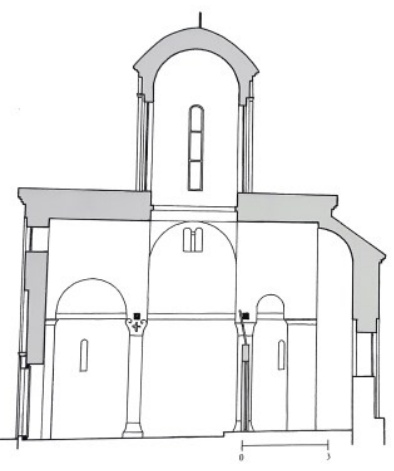

Figure I.33 Examples of late-Byzantine churches of the inscribed cross typology. A. St. Nicholas in Ljuboten (Skopje); B. St. Nikita in Banjani (Skopje).

Despite the turbulent times, the construction in Macedonia and the Balkans in the late-Byzantine period continued with increased intensity, first with reconstruction of the damaged or destroyed monuments, and then with construction of new ones (Ненадовић, 1980: 97). The founders of many newly-built churches and monastery complexes were representatives of the Byzantine aristocracy from the ruling dynasties (first the Comnenians and then the Palaeologans), and later the Serbian ruling families and local feudal lords who hired the best available construction and painting studios for this purpose. As for the represented typology in the monumental religious architecture, the inscribed cross undoubtedly prevailed, in accordance with the contemporary trends in Byzantium (fig. I.33). The churches became more compact, smaller, but regularly vaulted and covered with a central dome carried on semi-cylindrical vaults in both directions, a structure visible and accentuated from the outside in the upper parts of the buildings and their fifth façade; or a system of five domes - one central and four smaller ones rising at the corners of the nave. Usually, the complex system of vaults and domes was accepted by the perimeter walls and four internal pillars with a rectangular or square cross-section; rarely by columns. The height of the buildings was their determining feature, with a special emphasis on the façade canvases and their processing with pilasters and niches and particularly decorative masonry techniques, with an extraordinary wealth of ceramic and brickwork ornament, especially characteristic of Epirus and Macedonia, where it in fact originated from (Суботић, 1977: 48-49).

However, despite these dominant trends in architecture, basilical temples were sporadically built or renovated, which confirms that the basilica as a model of an "ideal" church building was not completely abandoned and was still a significant local determinant of Macedonian religious architecture. 


\section{Single-nave Basilicas}

In addition to the inscribed cross of the compact or developed type, which in the late-Byzantine period was the widely accepted typological solution, several single-nave vaulted buildings were erected as an architectural typology that was simple to build and appropriate to the more limited possibilities of the founders - representatives of the local feudal lords. It is important to note that all these churches are located in the Ohrid - Prespa region and in Varosh near Prilep, i.e. they are regionally determined and follow older local patterns (Коруновски и Димитрова, 2006: 51-52). Although few in number, they are very important for the typological continuity in the sacral architecture in Macedonia, because it is precisely this solution, in fact, that will be maintained in the post-Byzantine period in the centuries under Ottoman rule, when no central buildings such as the inscribed cross will be built.
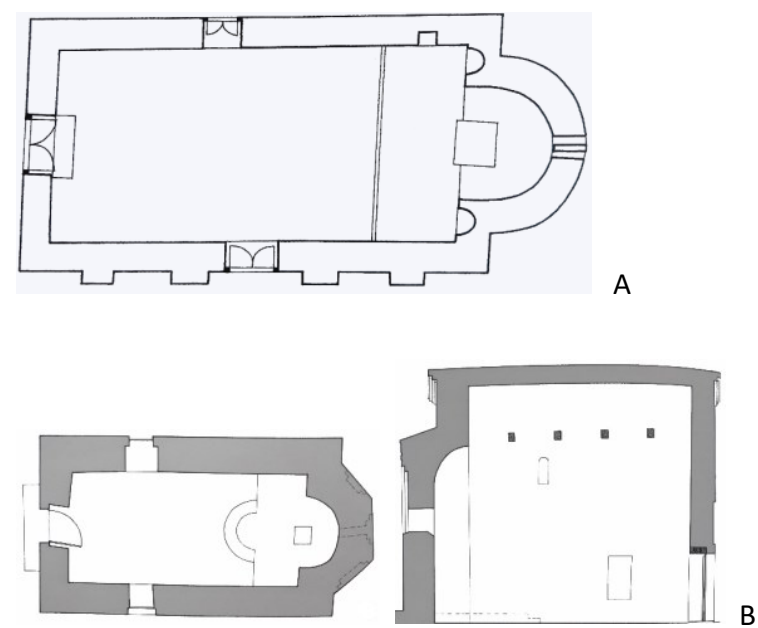

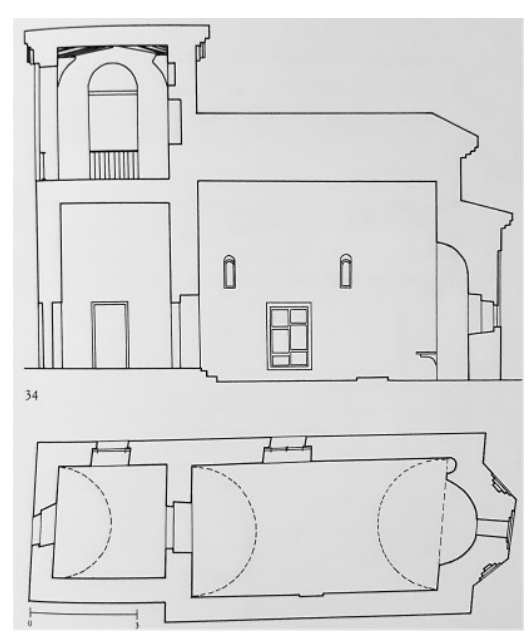

C

Figure I.34 Single-nave basilicas. A. St. George in Kurbinovo (Prespa); B. St. Demetrius in Varosh (Prilep); C. St. Demetrius in Veles.

St. George in Kurbinovo (Prespa) dates from the second half of the XII century. ${ }^{84}$ One of the largest single-nave basilicas in Macedonia, the church in Kurbinovo has an elongated naos and no narthex or additional chambers (there existed a chapel to the south, which was lost in a fire in the XVII century). It measures $7 / 15 \mathrm{~m}$, i.e. has a proportional ratio of 1:2 (fig. I.34A). To the east it ends with a deep semicircular altar apse, flanked on both sides by semicircular niches in the east wall, certainly intended for prothesis and diaconicon. The altar is illuminated by a double window in the axis of the apse. The church is entered from the west, as well as via entrances on the side façades that are not symmetrically placed. On the south façade, in the lower zone, exist the remains of four massive pilasters in a symmetrical arrangement.

The church in Kurbinovo was built in a simple manner, with available materials (mainly crushed stone, mortar and brick), and the representativeness is achieved by painting the façades - partially preserved on the west façade - which mimics masonry in opus cloisonné. Above this zone, flanking the patron saint's niche above the western entrance, scenes from the founder's composition were painted, today unfortunately preserved fragmentarily due to the long-term exposure to the weather.

\footnotetext{
${ }^{84}$ According to an inscription on the altar table, the church of St. George in the village of Kurbinovo, region of Prespa, was frescopainted in 1191 A.D., which places its construction in the second half of the XII century, probably in the years prior to the painting ensemble. Parallels can be drawn between Kurbinovo and the Mother of God Mavriotisa from the vicinity of Castoria, both in terms of masonry and the deep protruding apse, which implies that masters active in the Ohrid-Prespa-Castoria region worked in Kurbinovo (Коруновски и Димитрова, 2006: 52). In that context is the fresco-decoration of the temple, considered the successor of the fresco-ensemble of the church of St. Cosmas and Damian (the Holy Healers) in Castoria (Ibid: 81). The Kurbinovo fresco-ensemble is one of the masterpieces of Comnenian painting and Byzantine art in general.
} 
The church of St. Demetrius in Veles was erected in the second half of the XIII century. It is an elongated single-nave vaulted building (fig. I.34C), with a three-sided apse externally divided by tall triple niches made of brick (fig. 1.35). ${ }^{85}$ As a unique feature, the naos continues to the west into an approximately square narthex topped by a bell-tower, composed and executed with the same architectural language and using the same decorative motifs as the main building. Bell-towers, especially ones integrated in the church building itself, are extremely rare in medieval Macedonia and beyond; therefore it is considered that this element was imported, probably through the mediation of the Epirus architectural influences (Коруновски и Димитрова, 2006: 106).

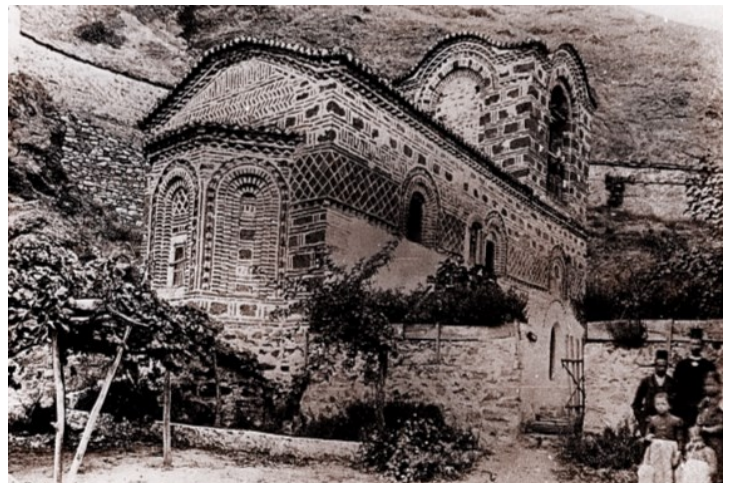

Figure I.35 St. Demetrius in Veles, photographed in 1899.

Other single-nave churches dating from the XIII-XIV centuries are St. Forty Martyrs and St. Cosmas and Damian (the Holy Healers) in Ohrid, St. Demetrius in Varosh (Prilep), ${ }^{86}$ St. Nicholas in Varosh (Prilep) (fig. I.34B), St. Elijah in Grnchari (Prespa), St. Peter on the island of Golem Grad (Prespa), etc.

Furthermore, in the second half of the XIV century, a group of monuments with a special, independent typology appeared in the Ohrid region. These are single-nave vaulted churches with a transverse vault as a replacement for a dome (fig. 1.36), thus approaching the typological solution of an inscribed cross (Коруновски и Димитрова, 2006: 91-92). This typology is specific of the region of Castoria, but is also present in the region of Prilep (the third construction phase of St. Demetrius in Varosh, see footnote 86), as well as at the Most Holy Mother of God in Dabnishte, Kavadarci, renovated in the Revival. In the region of Ohrid, this solution was used at the Most Holy Mother of God Bolnichka (1365-1367 A.D.) and St. Constantine and Helena ( 1400 A.D.) in the old town of Ohrid, as well as the church of St. George (mid-XV century) in the village of Godivje, near Ohrid. According to the typological solution, the single-nave naos is divided into three equal bays, of which the central one is bridged with a high vault in the transverse

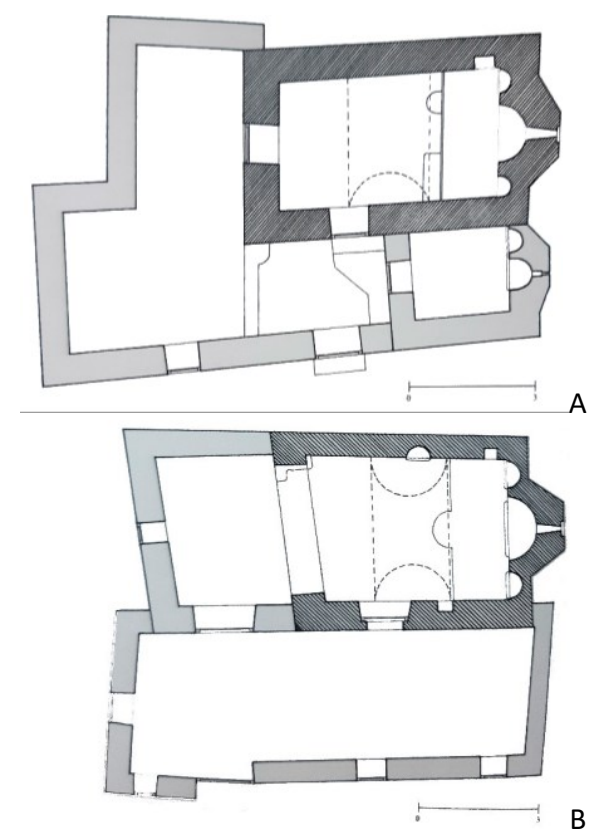

Figure 1.36 Single nave vaulted churches with transverse vault. A. St. Constantine and Helena in Ohrid; B. Most Holy Mother of God Bolnichka in Ohrid.

\footnotetext{
85 The façades are executed in precise opus cloisonné masonry, horizontally divided into belts with the help of a serrated cornice, which also defines the niches and the window openings (fig. I.35). A band in opus reticulatum masonry flows on all the façades of the building, topped by a high meander belt, followed again by masonry in opus cloisonné. Into the height of this decorative belt arched windows were placed, as well as patron niches above the entrance portals.

${ }^{86}$ In its oldest phase, this complex monument was a small, single-nave building. A representative open arcade portico was later added to the north side, consisting of three arched openings carried on massive pillars, with a semicircular apse to the east. The used masonry technique with recessed rows of bricks, whose origin is undoubtedly capital, as well as the chessboard decorative motif executed in brick and mortar, which will be especially characteristic of the later Ohrid churches (St. John the Theologian Kaneo, the Mother of God Perivleptos, the reconstruction of the floor of the narthex of St. Sophia) date the construction of the porch to the XIII century. In the next construction phase, the wooden ceilings were replaced with vaults; the porch was closed and the church recieved a two-nave basilical disposition with a specific transverse vault - a transept. In the last construction phase in the last decades of the century, in a symmetrical composition, another one-nave volume with a three-sided apse was added to the south, so that the church basically acquired a three-nave disposition. However, the purpose of this intervention becomes evident in the upper construction, which was to resemble an inscribed cross as the most fashionable church typology at that time. Thus, in the central bay above the oldest single-nave building, a massive dome supported on a tall twelve-sided drum was erected. The whole ensemble at this moment was united by a spacious narthex spanning the entire western façade.
} 
direction which, on the fifth façade, exceeds the roof of the main longitudinal vault. The timpani of the transverse nave on the façades are decorated with wide shallow niches. The apse is three-sided, flanked by semicircular niches in the east wall and illuminated by a narrow opening in the central axis; the masonry is unpretentious and in accordance with the change of socio-economic conditions. Their architecture reveals a return to the older Byzantine traditions, but also a simplification of forms, architectural elements and masonry techniques as an adaptation to the new times, thus hinting stylistically and typologically to the relatively uniform group of post-Byzantine single-nave churches built in the following centuries.

\section{Three-nave Basilicas}

As was the case with the single-nave churches, the three-nave basilicas were rarely constructed in the late-Byzantine period (see map I-1) and, as will be shown, were conditioned to a large extent by older, middle-Byzantine three-nave basilicas as their prototype.

"St. Nicholas" in Manastir (Mariovo), XI Century - 1266 A.D.

The church of St. Nicholas in the village of Manastir, region of Mariovo, is the only preserved lateByzantine three-nave basilica in Macedonia, constructed under the strong and ominously visible influence of the X-XI centuries basilicas: St. Achilles at Prespa and St. Sophia in Ohrid, which have constituted a prototype for churches built in the following centuries in the widest part of the Balkan region, such the small basilicas in Castoria (St. Stephen, Holy Archangels, Holy Healers), Pliska, Preslav and St. Nicholas in Melnik, built in the XIII century (see fig. I.31). According to its function - a catholicon of a monastery, which gave the village its name - it constitutes an exception from the thesis that in the middle and late-Byzantine period three-nave basilicas were only constructed as Episcopal cathedrals (Коруновски и Димитрова, 2006 : 86). The causes for the election of this atypical solution for the XIII century lie in the history of the building itself. Namely, this church was originally built in 1095 A.D., as an endowment of the protostrator Alexius, a relative of the Byzantine emperor Alexius I Comnenus. In 1266 A.D., immediately after the Crusades and the restoration of Byzantine rule (in 1261 A.D.), the abbot Akakius (whose civilian name was loanikius) built the present church "from the foundation up" over the older building, and in 1271 A.D. the church was fresco-painted (Велев, 1990: 135) thanks to the efforts of Deacon John, referendar of the Ohrid Archbishopric, who for that purpose "invited many prominent, skilled and excellent masters" (Баришић, 1964: 17). The significant dates and the names of the founders are listed in the long (over 17 $\mathrm{m}$ in total) and very decorative inscription in Greek lined above the arcades, along the south and to the middle of the north wall of the central nave (Петров, 1982: 148). Thus, although built and fresco-painted in the XIII century, the influences of the XI century are obvious, judging by the archaic architecture and certain features of the fresco-ensemble. ${ }^{87}$ However, in its otherwise archaic solution, it incorporated modern features from the period when it was created, especially in the treatment of the façades with a system of smaller blind arched niches (fig. l.37), and the applied and painted façade opus.

The church in Manastir is a compact three-nave basilica, with an irregular (trapezoidal) plan, without a narthex or auxiliary chambers (fig. I.37). The naos measures approximately $13 / 16 \mathrm{~m}$, not counting the altar apses, meaning that the church is almost square in plan. The division of the naos into three naves is via two rows of massive pillars with a rectangular cross-section and pilasters on the east

\footnotetext{
${ }^{87}$ According to the frescoes' stylistical language, at least three fresco-painters worked at the church in Manastir. While some compositions were dominated by contemporary Comnenian drawing with thin lines, two-dimensionality of the figures and a wealth of decoration, one of the painters nurtured the monumental style of the XI century (fig. I.38A), with sharper lines, wide eyes and a suggestive expression of the saints (Коруновски и Димитрова, 2006: 141).
} 
and west walls, connected by semi-circular arches (fig. I.37, I.38A). The massive pillars and the arches between them have almost equal dimensions, with the same rhythm of empty versus built, as was the case with the older, $\mathrm{XI}$ century basilicas such as St. Achilles on Prespa Lake, the basilica in Vranishta near Struga (Бошковиќ, 2000: 47), or the Old Metropolis in Mesemvria (Nessebr, Bulgaria), under whose evident influence it was composed (see fig. I.18-1.20). To the east, all three naves end in tall three-sided apses with three blind niches, illuminated through single windows in the lateral apses and a double window in the axis of the central altar apse (fig. 1.37, I.38B).
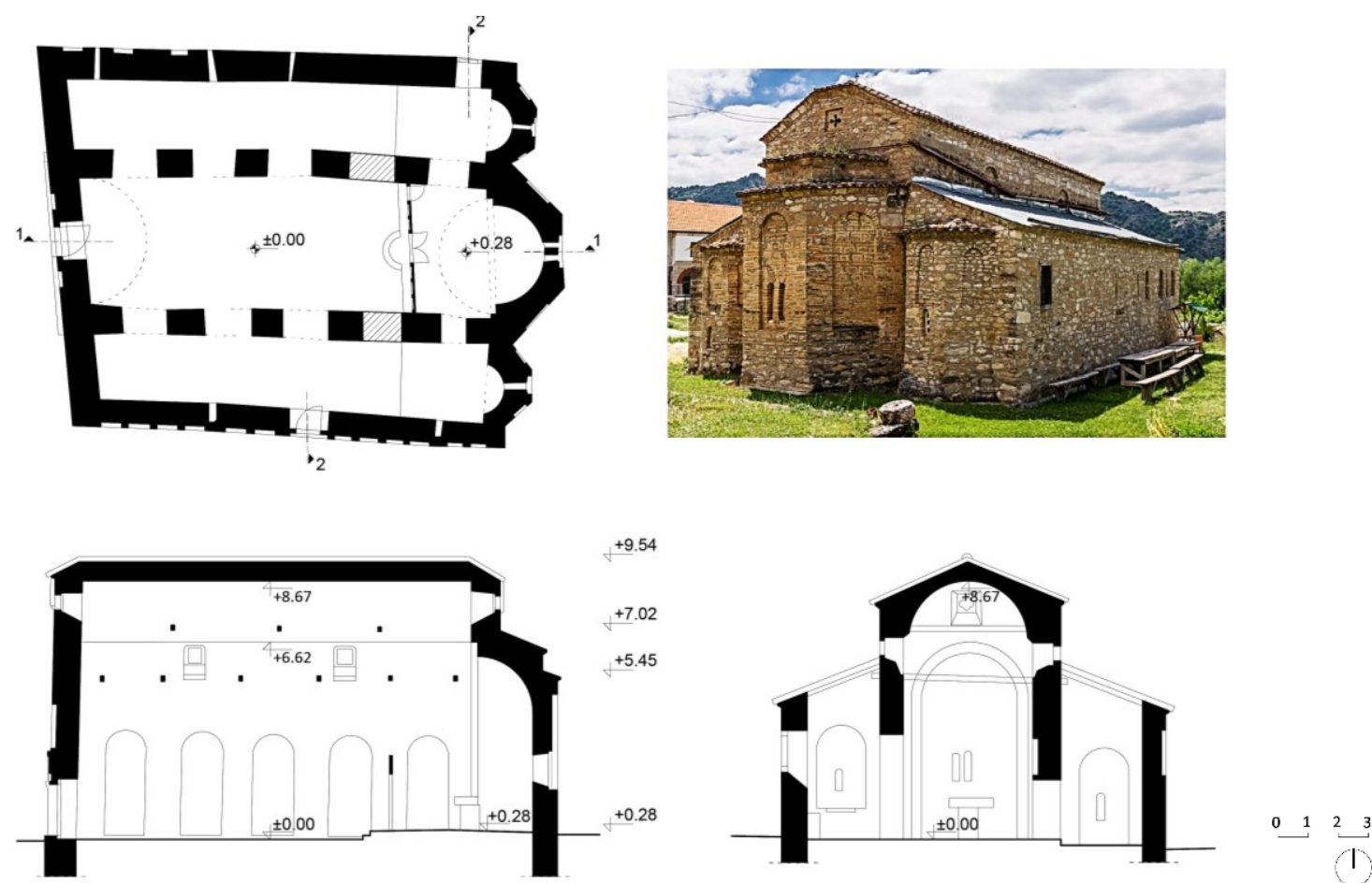

Figure I.37 St. Nicholas in Manastir (Mariovo). Plan ( \pm 0.00$)$, view from the northeast, longitudinal section (1-1) and transversal section (2-2).

The central nave, covered by a barrel vault, is considerably wider (the ratio is approximately $2: 1$ ) and higher than the lateral ones. The overhang of the central nave above the side ones is also emphasized on the fifth façade, where the lower lateral naves are covered by a lean-to roof, whereas the central nave clerestory is covered by a specific bonnet roof, with a shorter side to the east and west which result in a trapezoidal shape of these façades, which is one of the regular, typical features of the Revival basilicas (fig. I.38B). The central nave vault and its bonnet roof are, therefore, likely a XIX century reconstruction of a previously demolished original structure, which is confirmed by the different, newer fresco-painting. The church is illuminated via two arched windows on the longer façades, while high on the east and west façades appear square windows with embedded stone-carved transennas shaped into phytomorphic crosses (so-called crux florida), also a typical XIX century Revival feature.

The façades are mainly executed in quite irregular masonry of crushed stone and mortar, with a slightly more correct opus at the corners and cornices, and the exception of the altar apse built in a combined decorative masonry of stone and brick: at the bottom, under the three large semicircular niches (extending to the top of the apse), over a plinth of several rows of stone blocks, appears a belt made in opus cloisonné. The niches themselves, in the lower zone, are made of rows of bricks, followed by opus cloisonné with brickwork details - stylized motifs in the shape of the Cyrillic letter " $\Psi$ " between the stone blocks. The upper zone of the niches and the semicircular arches are built in stone, with the exception of the central niche, where the arch is made of brick. 

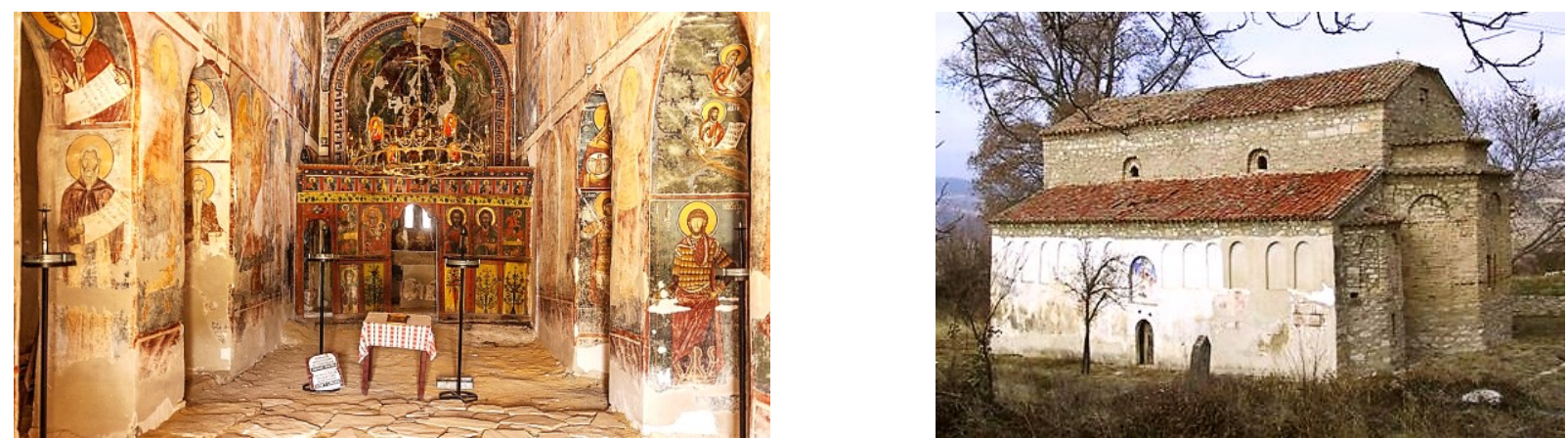

Figure I.38 St. Nicholas in Manastir (Mariovo). A. View towards the altar; B. View from the southeast.

The skill and mastery of the builders is obvious in the composition of the masses. Namely, the large altar apse ends with a cornice at the same height as the lean-to roofs above the lateral naves; topped by a smaller apse at a second level, as if on a pedestal, positioned inwards in relation to the lower apse, but also three-sided and executed in opus cloisonné. ${ }^{88}$ Furthermore, the three blind niches on the smaller lateral apses have the same dimensions and are placed at the same height as the rows of blind niches on the lateral facades, today preserved entirely on the south façade (fig. I.38B), ${ }^{89}$ interrupted only at the south entrance portal, above which appears a wider niche with the patron saint fresco. Precisely on this façade exist preserved fragments of the original mortar coating and painted imitation of a regular masonry in opus cloisonné with two vertically placed bricks between the stone blocks (fig. I.38B). ${ }^{90}$

In conclusion, while the used archaic architectural typology, structure and forms directly derive from the local middle-Byzantine school associated with Samuel's kingdom; the façade decoration, the used masonry and the façade painting connect the basilica in Manastir with the churches from the region of Castoria (as implied by the "W" brickwork motifs, similar to the ones on the façades of the Castoria basilicas), indicating the possible origin of its authors within the same master-builder groups that worked in the wider Ohrid-Prespa-Castoria cultural circle.

"St. George" in Staro Nagorichane (Kumanovo), XI Century - 1312/1313 A.D.

The monumental church of St. George in the village of Staro Nagorichane, region of Kumanovo, is a complex monument built in two distinctive phases. According to local tradition, the church was originally built during the reign of the Byzantine emperor Roman IV Diogenes (1067-1071), ${ }^{91}$ then partially demolished in the turbulent times that followed, to be rebuilt by the Serbian King Milutin (1282-1321) in

\footnotetext{
88 It is of great importance to emphasize that a similar pyramidal composition of the masses on the east façade, as well as the central nave clerestory illuminated via window tranennas made of stone and the trapezoidal "saddle"-shaped roof of the eastern and western façade will all be among the basic features of the most monumental urban five-nave Revival basilicas in Macedonia (see Chapter III.5.C).

${ }^{89}$ Rows of blind niches, which are a characteristic element for façade articulation in the XIII century, are also found in older churches in Macedonia: on the east façade of the Ohrid cathedral of St. Sophia, in the upper zone of the apse (see fig. I.23B); as well as on the façades of the church in Veljusa, both from the XI century. Later, at the beginning of the XIV century, a series of smaller blind niches was used for the horizontal division of the western façade of the exonarthex of St. Sophia (see fig. 1.24), on the lateral façades of St. George in Poloshko, near Kavadarci etc. Thus, despite the widespread use of this motif for division and composition of the long monotonous façades of basilicas and churches with perimeter " $U$ " naves, the influence of older, local building traditions must not be overlooked, which was evidently followed by the master-builders of St. Nicholas in Manastir.

90 Painting of the façades of this type, as mentioned earlier, was already used before, in the church of the Virgin Eleusa in Veljusa near Strumica in the XI century and at St. George in Kurbinovo in the XII century, which is temporally and geographically closest to the church in Manastir (Коруновски и Димитрова, 2006: 88).

${ }_{91}$ That the founding of the monastery in Staro Nagorichane by the emperor Roman IV Diogenes is a possibility is evidenced by similar cases. One such example is the charter for the founding of the monastery St. George in Skopje, by the emperor Roman III Argir (1028-1034); another is the monastery of St. Nicholas in Manastir, founded with a charter by Alexius I Comnenus (10811118) in 1095 A.D. (Петров, 1982: 187). Nenadović, however, suggests that the church in Staro Nagorichane might have been built as early as in the IX century (Ненадовић, 1980: 139).
} 
$1312 / 1313$ A.D., as stated in the founding inscription above the western entrance. It was fresco-painted in 1317-1318 A.D. by the famous Byzantine zographoi Michael and Eutichius.

The church of St. George in Staro Nagorichane, the previously (in 1306 / 1307 A.D.) erected cathedral of the Mother of God Ljevishka in Prizren (Kosovo) and the chronologically third church in a row, erected in Grachanica (also in Kosovo) in 1315 A.D., all three endowments of the Serbian King Milutin, represent examples of a complex fivedomed structure inserted in the remains of older basilicas, most likely as a token of respect for older places of worship, which is common in architecture (Ненадовић, 1980: 139; Кораћ и Шупут, 1998: 334). The five-domed solution was obviously influenced by the Thessaloniki five-domed churches (St. Apostles, St. Panteleimon, St. Catherine), from which also originated the idea of a perimeter " $U$ " - shaped nave applied at the oldest church in Prizren.
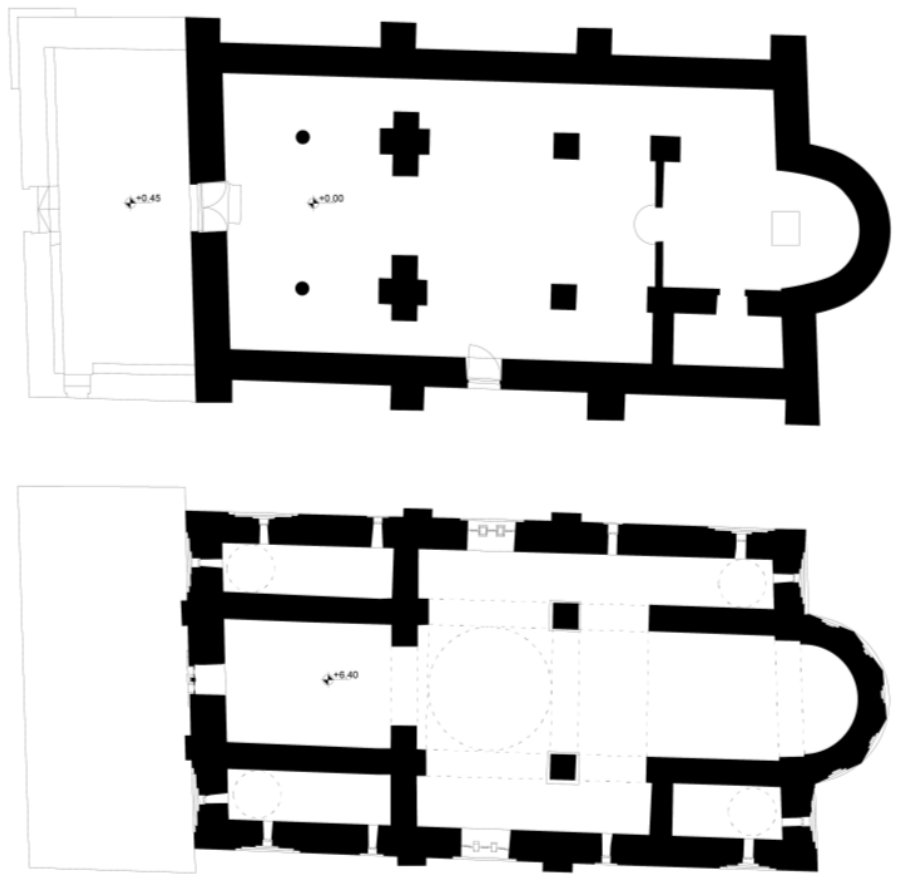

Figure I.39 St. George in Staro Nagorichane (Kumanovo). Plan of the XIV century church. A. Ground floor $( \pm 0.00)$; B. Upper construction (+6.40).

Unlike the Prizren church's predecessor preserved only as foundations, in the case of St. George in Staro Nagorichane the perimeter walls of the original XI century basilica were preserved at a considerable height of over $5 \mathrm{~m}$, built with extreme precision, with arranged layers of well-processed blocks of trachyte stone, which is characteristic for all religious buildings in the wider Kumanovo-Zhegligovo region. ${ }^{92}$ Above them lies the second phase - the XIV century reconstruction, using the same type of stone blocks, possibly harvested as spoliae from the ruined upper structure of the basilica, arranged using brick in the opus cloisonné façade technique and with abundant brickwork ornaments characteristic of the XIII-XIV century. The division of the naves in the naos was established with the help of various types of supports, arranged in an unbalanced rhythm, which was conditioned by the previous architecture. Namely, the western pair of supports are free-standing columns with a circular section; the next pair to the east are very massive masonry cruciform pillars that support the large central dome set upon a square field and accept its load to its west, while to the east the dome is supported on smaller pillars with a simple square section (fig. I.39A). The last pair of supports to the east is asymmetrically arranged: to the north lies a pillar, while a masonry wall appears to the south, which separates the diaconicon as an independent chapel with access only from the altar, in accordance with its nature as a burial chapel of the Serbian ruling dynasty. The altar apse was proportionately large, originally semi-circular, illuminated through a single window in its axis, while in the second construction phase the apse was five-sided, decorated with shallow double niches.

\footnotetext{
92 Unlike the widely established construction system in Byzantium which used carved stone blocks and brick arranged in specific decorative façade opus techniques, in the region of Kumanovo-Zhegligovo masonry exclusively executed in stone (trachyte and travertine) predominates. In science, an opinion has been expressed that the reasons for that local peculiarity (as well as for certain decorative elements, forms and patterns found in Byzantine and post-Byzantine construction in the region) should be sought in Armenian-Georgian influences, caused by migration processes within the Empire. Historical sources confirm this possibility: during the rule of the Serbian king Milutin, the monastery Treskavec, among others, had in its possession a village by the name of Armenohor; also, during the reign of Tsar Dushan, "Armenian villages" are mentioned along the river Pchinja, precisely in the Zhegligovo region (Бошковић, 1967: 149).
} 
Lateral apses are lacking, as are niches in the east wall that would normally take the role of prothesis and diaconicon, which is clearly a remnant of the authentic middle-Byzantine basilica's plan.

The preserved perimeter walls
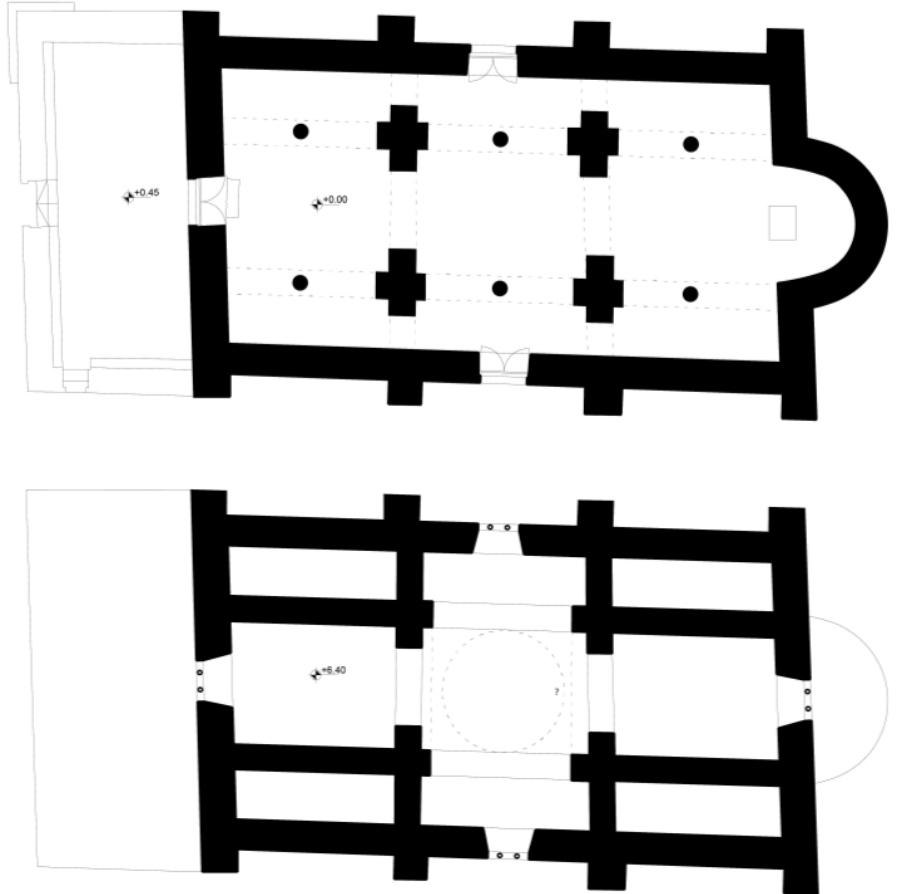

Figure I.40 St. George in Staro Nagorichane (Kumanovo). The XI century basilica (reconstruction by the author). A. Ground floor $( \pm 0.00)$; B. Upper construction $(+6.40)$.

in the western half of the temple, the original composition of the middle-Byzantine basilica is hinted by the partially preserved remains of external pilasters on the perimeter walls, later demolished, which had authentically divided the façades into three equal bays in a symmetrical fashion (fig. I.40), unlike the current façade pilasters which appear cantilevered in the upper zone of the transept and the central nave, contributing to greater visibility of the inscribed-cross five-dome solution (see fig. I.41).

Namely, the western pair of façade pilasters on the lateral façades correspond to the cruciform massive pillars in the interior and are connected to them with transverse arches. In the opposite, eastwest direction, through the double-arched passage, the cruciform pillars are connected with the pilasters on the west façade, in a geometrically clear and precisely constructed composition. If the eastern pair of

\footnotetext{
93 The church dedicated to the Most Holy Mother of God in Drenovo (near Kavadarci) has so far been dated in the XIV century, as an endowment of the Serbian Tsar Dushan, based on a fragmentary preserved inscription within the patron fresco in the arch of the niche above the southern entrance portal. However, the architecture of the temple as well as the characteristics of the extremely rich preserved stone sculpture and reliefs, speak of a different possible dating of this hitherto insufficiently studied temple. Namely, the stone reliefs can be categorized as early-Christian (Димитрова, 2003: 147-148) in secondary use, and Byzantine, widely dated by various researchers as belonging to the VII-VIII, X-XI, XII-XIII and even the XIV century (Филипова, 1995: 227). However, comparing it with the preserved examples of stone reliefs from the XI century, especially from the cathedral of St. Sophia in Ohrid, the XI century imposes itself as the most probable dating. Regarding the typological solution, the church in Drenovo belongs to the specific "renovation" of the basilica of the capital type, primarily based on the Thessaloniki Metropolitan church of St. Sophia from the VII century, whose influence as a model in the region was significant. Thus, on two occasions we come across churches whose architectural structure derives from the capital typology of a domed basilica. First in the middleByzantine period (IX-XI century), when the church in Drenovo was built, the church in Velushina was renovated, and in a wider context, St. Sophia in Drama, Panagia Kunturiotisa near Katerini (Greece), Pidna, the church in Labovo (Albania) and Stara Pavlica (near Rashka, on the river Ibar) were built, i.e. churches primarily concentrated on the territory of Macedonia and Epirus. Later, in the late-Byzantine period (end of XIII - first half of XIV century), the same typology in a more developed form is found in several Thessaloniki churches: St. Panteleimon, St. Apostles and St. Catherine; as well as the second phase - the reconstruction of the church Panagia Parigoritisa in Arta, Epirus and the Panagia Olympiotisa in Elasson, Thessaly (Кораћ и Шупут, 1998: 306-307).
} 
pillars of the central bay were actually reconstructed in the second building phase - when it can be assumed that they were moved to the west ${ }^{94}$ and constructed as smaller pillars with a square cross-section in order to reduce the original span of the dome - while originally they had been equal to the western ones (as is logical to assume), then by replacing them with identical massive cruciform pillars as the western pair, an equal division of the naos into three identically long bays will be obtained. In the transverse direction, these original pillars were connected by arches to the second pair of external pilasters. As is the case with the reconstruction of the church in King Milutin's time, it is very likely that the original three-nave basilica from the XI century also had a central dome. The very cruciform pillars, their massiveness and the transverse arches received by the pilasters on the lateral walls; all indicate a vaulted and domed construction. If the basilica was bridged with a plain wooden ceiling, as some researchers believe, ${ }^{95}$ it would be logical for the structure to consist of simple square pillars between the naves, connected into an arcade only in the longitudinal direction. The transverse arches and the division into bays, as well as the transfer of loads both transversally as longitudinally, in such a scenario would be superfluous. Lastly, analyzing closely the remnants of the original basilica, remains of a spiral staircase placed in the thickness of the wall in the south-west corner of the building have to be acknowledged, which suggest the existence of a gallery space in the nave.

In the turbulent times of the first half of the XIII century, the upper structure of a basilica conceived in this way was possibly damaged and later replaced by a complex five-domed inscribed-cross solution (fig. I.41). The stratigraphy of the façades belonging to the original phase of construction: the remains of the original massive pilasters and their lateral expansion in the upper zone in the form of capitals, directly above which are rhythmically arranged rectangular openings within a horizontal strip, speak of the existence of open porches to the north and south of the older three-nave basilica as well as its lateByzantine successor, ${ }^{96}$ while later a closed narthex was added to the west.

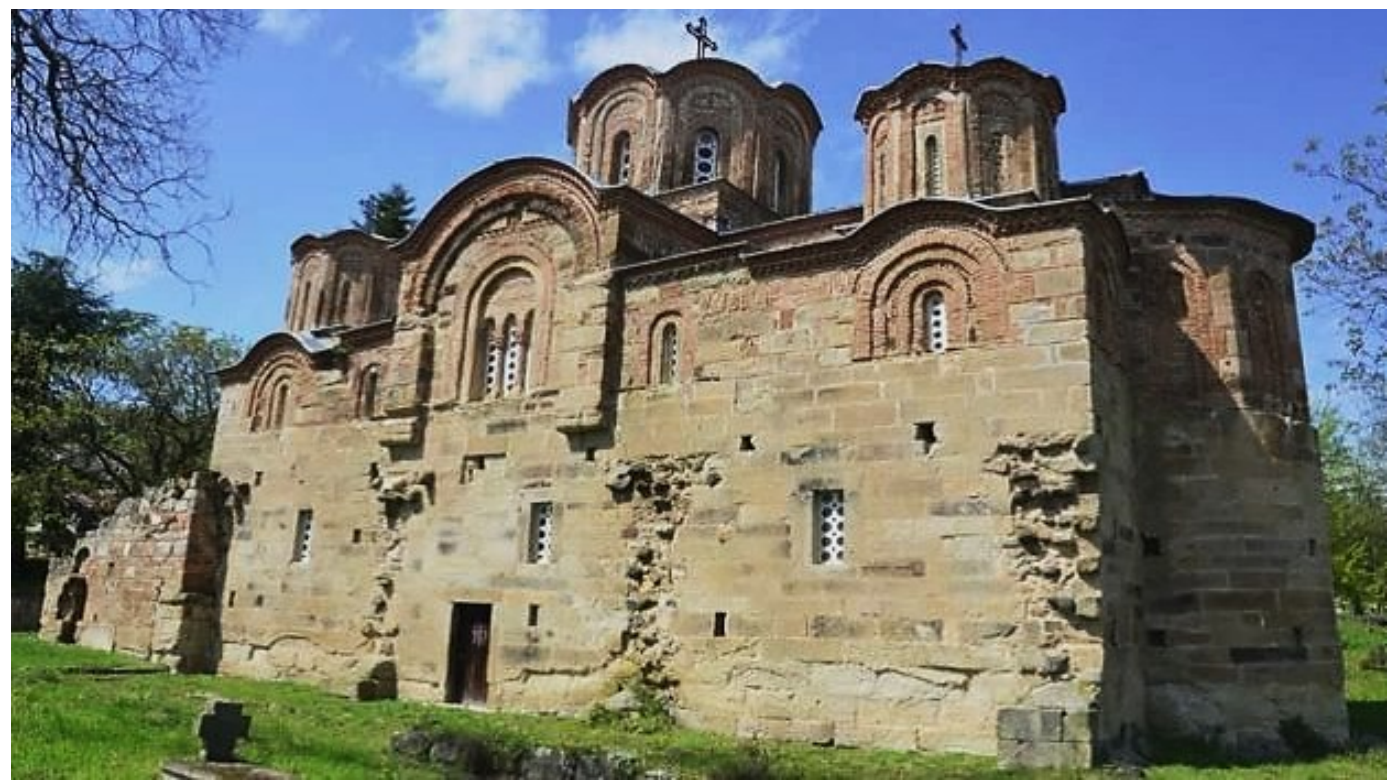

Figure I.41 St. George in Staro Nagorichane (Kumanovo). View from the southeast.

\footnotetext{
${ }^{94}$ A similar case, as mentioned before, is the Ottoman reconstruction of the naos of St. Sophia in Ohrid.

${ }^{95}$ Although with some expressed reservation, Nenadović believes that the original basilica in Staro Nagorichane had a wooden ceiling without a dome or vaults, and a gabled roof, following the example of St. Achilles in Presра (Ненадовић, 1980: 108).

96 This is also evidenced by the model of the temple painted in the founder's fresco-composition (Ненадовић, 1980: 139-140), which shows an open porch shaped as an arcade comprised of three arched openings on the south side of the church, which correspond to the distances between the pilasters of the south façade of the naos. A symmetrical composition to the north side of the church can be assumed in a "five-nave" solution, conditionally speaking, as the one found at the Holy Mother of God Ljevishka in Prizren. The painted model has no narthex, which confirms it as a later construction.
} 
It can therefore be concluded that in the late-Byzantine period, although to a limited extent, there is continuity of construction, at least as far as the smaller, single-nave temples are concerned; at the same time there occur several cases of renovation and fresco-decoration of older three-nave basilicas according to contemporary concepts. However, it is extremely important to emphasize that these are basilicas originally erected in the XI century, i.e. churches built at the specific temporal, historical and geographical moment correspondent to Samuel's kingdom and its autocephalous, independent church institution. Later, these basilicas were damaged, partially or largely destroyed, which enabled their reconstruction after the Crusades, in the XIII-XIV century, i.e. after the stabilization of the social and economic conditions in Macedonia. They therefore already (with the exception of the church in Manastir) accepted the modern typological solution of an inscribed cross with one or more domes, which was adapted to the existing dimensions, structure and architectural typology. Although these few three-nave basilicas are an exception to the dominant typological line in the period when they were restored, their importance for the survival of the basilica solutions is enormous and greatly explains the sporadic appearance of large three-nave basilicas in the next, post-Byzantine period, as will be explained in more detail further on.

\section{I.5 The Churches in the Post-Byzantine Period (XV-XVIII Century)}

With the conquest of Constantinople by the Ottoman Turks in 1453 A.D., another Empire spread from Mesopotamia to the Adriatic Sea; with its center, once again, in Constantinople - Istanbul. The Ottoman Empire was a feudal, theocratic centralized state ruled by a sultan as an absolutist ruler who held both secular and spiritual power (Ѓорѓnев, 2013: 1875). Within this new state, the social changes in Macedonia were comprehensive. The properties of the local aristocracy were confiscated and included in the so-called Timar-sipahi feudal and military administrative system (Панов, 1985: 100) that was based on state ownership of the land; a number of new taxes were introduced, targeting mainly non-Muslims; the city councils were abolished; the autochthon population was often forcibly islamized or displaced throughout the Empire according to current political requirements in parallel with the colonization of the towns with Muslim population brought in from Anatolia; both Turkish language and Islam were imposed, the latter as the official religion; the justice system was replaced by sharia - the Islamic religious law; and the power and reputation of the church institutions were greatly diminished. The very social order of the Empire required a sharp class social division based solely on religious grounds: on one side was the feudal ruling class headed by military, administrative and Islamic religious institutions, whose representatives were elected without exception from the privileged Muslim population, whereas on the other side was the rayah - a subordinate class of dependent population consisting of peasants, farmers, merchants and craftsmen, who came from the conquered nations, mostly Christians. The rayah had no rights or freedom and was subjected to economic exploitation and cultural and religious discrimination.

In those newly created political, social and religious conditions, in fact in a new, completely different civilization, life both in the cities and in the smaller rural settlements changed drastically. After the Ottoman occupation, the towns were displaced from medieval fortifications located in mountainous and inaccessible places, which were largely destroyed during the conquests, to their lowlands, where they began to spread and develop according to completely different urban rules. The absolute change of the society meant accelerated orientalization and Islamization of the cities, through the construction of the characteristic systems of the Ottoman Bazaar, as a social, public and work zone of the city, with the necessary additional contents such as inns, baths, bedestens, clock towers, fountains, shadirvans (Панов, 
1985: 372). Furthermore, meeting the requirements of the new religion, after the conquest many churches were confiscated and converted into mosques. ${ }^{97}$ Later, with the stabilization of Ottoman rule and the expansion of the Empire in the XV and XVI centuries, systematic construction of an Islamic religious program began, consisting of mosques, tekkes, madrasas, mausoleums - türbes, etc. The new architecture was based on the Turkish Islamic ideological, philosophical and artistic foundations, certainly under the strong influence of Byzantium, from whose millennial tradition Ottoman architecture would adopt the typological solutions, as well as construction systems and masonry techniques i.e. the well established local aesthetic, cultural and architectural traditions (Томовски, 1995: 239-240).

The conditions in the new Empire imposed a complete stagnation of the Christian architectural production, primarily as a result of the policy of marginalization of Christianity and its institutions, ${ }^{98}$ the imposition of legal restrictions on the construction of new ${ }^{99}$ and renovation of old churches and monasteries (Ѓор́́nев, 2013: 1911), and of course as a consequence of the reduction and gradual disappearance of the power of potential donors. While in previous eras, it was not only the local rulers and prelates of the Ohrid Archbishopric, but also members of the Byzantine imperial family, and often the emperor himself who appeared as donors of the more important churches and monastery complexes, after the Ottoman occupation the construction of new churches and the maintenance of the existing ones - that had not been destroyed in the war or confiscated and converted into mosques - fell entirely on the local Christian population. As a result, Christian religious architecture lost the monumentality that was characteristic of previous eras. Yet, despite these aggravating circumstances, churches continued to be built. The total fund of preserved post-Byzantine churches (see Chapters I.5.1, II.6) speaks of an intense tradition whose strength "was the impetus on which belief was based that creation in the spiritual realm is a condition for survival and future liberation from foreign government" (Кораћ и Шупут, 1998: 399).

In such an atmosphere and under those severely limited conditions, churches were built mostly in rural areas where the Christian population dominated and where the Ottoman government was more tolerant of their religious needs; in addition to small hermits (ascetics), chapels and monastery catholicons isolated in mountainous regions where the active monastic communities withdrew after the conquest (map I-2). In fact, it is in the remote mountain monasteries that the artistic and illumination centers relocated, where the monks in their isolation continued to nurture the Christian and Macedonian spiritual and material culture (Balabanov, 1989: 226). Thus, the monasteries developed into the main Christian spiritual centers in Macedonia during the Ottoman occupation, such as Slepche and Toplichki in the Demir Hisar region; the Slivnica Monastery at Prespa; Treskavec and Zrze near Prilep; Karpino near Kumanovo, etc. Starting from the XVI century, Mount Athos emerged as the most important cultural and spiritual center in the Balkans with its complex of multiple monasteries which, thanks to its special position both geographically and politically, largely preserved details of the Byzantine construction and artistic tradition that had disappeared in other regions (Кораћ и Шупут, 1998: 392). Precisely on the construction and artistic crafts of Mount Athos, where continuity was almost completely maintained, the sacral

\footnotetext{
${ }_{97}$ During the conversion, the church buildings mostly kept their shape, but the iconostasis were regularly destroyed, the frescoes and all Christian symbols were destroyed (or over-plastered), and Islamic ones were added, such as a mihrab, minaret, a porch for ablution and preparation for prayer etc.

98 However, despite the limitations in that period, the Archbishopric of Ohrid continued to exist and act as the only preserved pre-Ottoman institution in Macedonia (Манева, 2013: 1988) and protector of Christian traditions until the XVIII century (1767 A.D.), when under the influence of the Greek Church it was abolished and subordinated to the Patriarchate of Constantinople. After the Ottoman occupation, the continuous activity of the Archbishopric was one of the key factors for the stylistic continuity in the Western Balkans and the regions around Ohrid, Prespa and Pelagonia. In the first decades of Ottoman rule, the Archbishopric gathered an active group of artists and craftsmen, united under the common name of the Ohrid painting school, who spread their stylistical expression in the neighboring territories of the diocese (Михајловски, 2011: 150).

${ }_{99}$ The general provision was the ban on construction of church buildings where they did not exist prior to the Turkish conquest, i.e. only the reconstruction and renovation of former buildings was allowed. The construction of domes and bell towers was also prohibited, which was especially respected in the urban centers (Кораћ и Шупут, 1998: 393).
} 
architecture in the European territories of the Ottoman state would be established and developed in the following centuries, a process which would culminate in the XVIII century when it would significantly influence the formation of Macedonian master-builders, icon and fresco-painters and wood-carvers who would work and dwell there. At the same time, numerous painting and architectural workshops left the occupied territories and moved in search for work in the remaining free Christian countries, where there was a greater demand for their art, especially throughout Eastern Europe and Russia, and often in Western Europe, where they brought their classical and Byzantine experiences, and influenced the formation of artistic expression in the then Renaissance world.

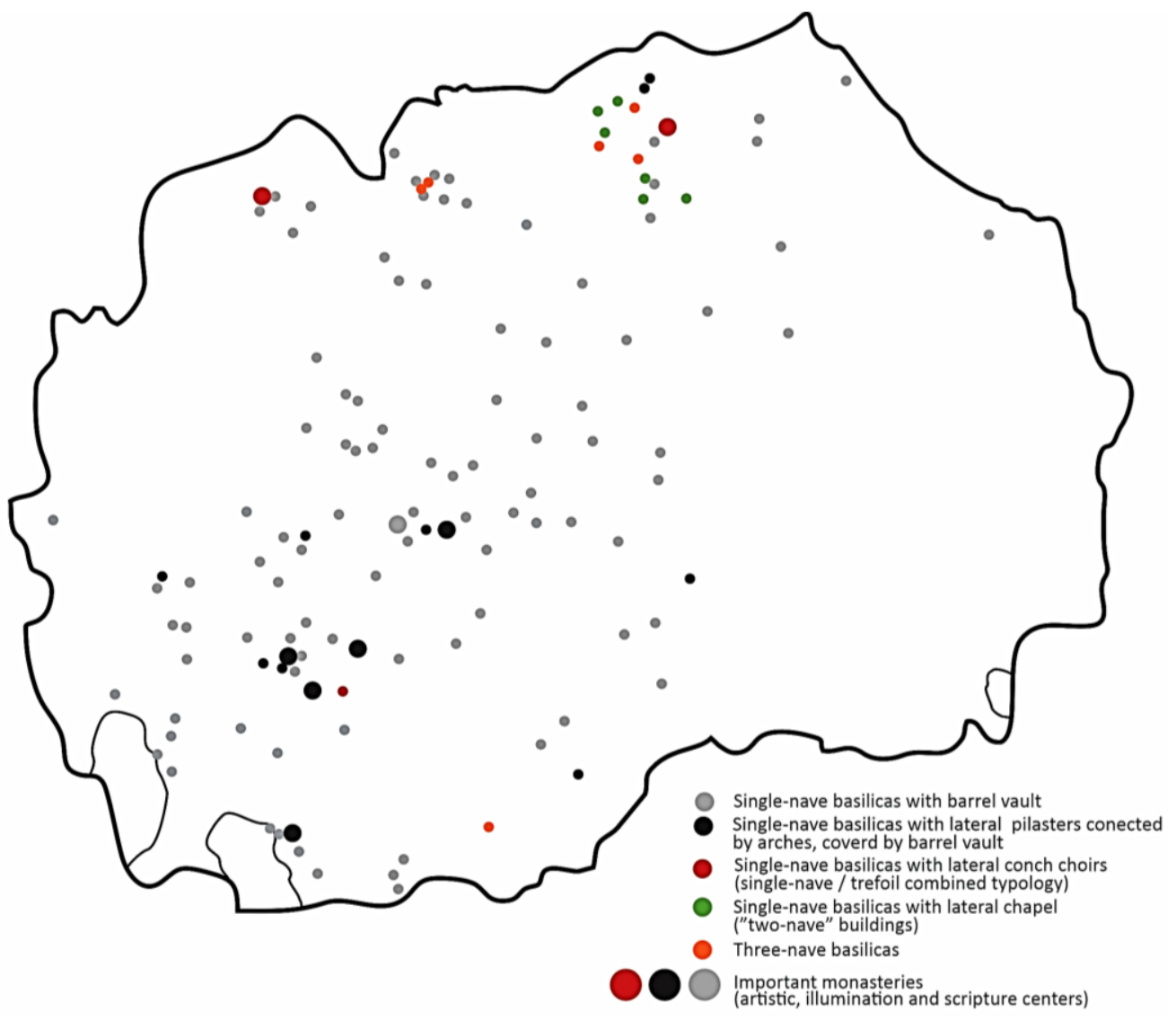

Map I-2. Post-Byzantine churches in Macedonia.

As for Macedonia, with the stabilization of the political situation in the new Islamic state, the construction activity was renewed as a continuation of the architectural tradition of the last epoch. Thus, it is clear why this architecture is called post-Byzantine. "Under Islamic occupation, building churches was an expression of the desire to survive in one's own spiritual and cultural world (...). There was an awareness of the deep connection of the people's destiny with the church and tradition through it. The contribution of tradition was crucial for the formation and maintenance of the nature of construction and artistic work" (Кораћ и Шупут, 1998: 392). Logically, the Church turned to the past and its proven values, maintaining a high level of conservatism and opposition to innovation coming from other backgrounds within the complex, assimilative, multi-national system of the Ottoman Empire. That conservative atmosphere would last until the XIX century Revival, when society and architecture would finally open up to Europe and the world. 


\section{I.5.1 Post-Byzantine Antecedents of the XIX Century Revival Single-nave Basilicas}

The architecture of the temples built in the post-Byzantine period corresponds to the circumstances in which it was created. Namely, the post-Byzantine churches are quite small in size, ${ }^{100}$ usually single-nave, vaulted buildings built of crushed stone, sometimes with the use of brick, with usually a semi-circular or three-sided altar apse. They are commonly covered by a gabled roof, traditionally made of stone slabs, which today can rarely be found in situ, occasionally preserved in the altar apses, or in fragments, while in the recent past the authentic roof covering in almost all post-Byzantine churches was replaced with roof-tiles or metal cladding. Usually they had only one entrance, most often placed in the axis of the western façade, and in some examples to the south, depending on the terrain configuration. An arched niche regularly appears above the entrance, in which a fresco of the patron saint was painted. ${ }^{101}$ Lighting is very scarce, usually through a very narrow window in the apse and one or two small windows in the nave, usually on the south side. Many of these churches later had an additionally constructed narthex, dining room or porch, while authentically they did not include auxilliary rooms (fig. I.42). In general, there is almost no external façade decoration: ${ }^{102}$ the post-Byzantine churches are characterized by simplicity of forms and decorative elements if, in fact, they do have decorative cornices, niches or any other architectural features.

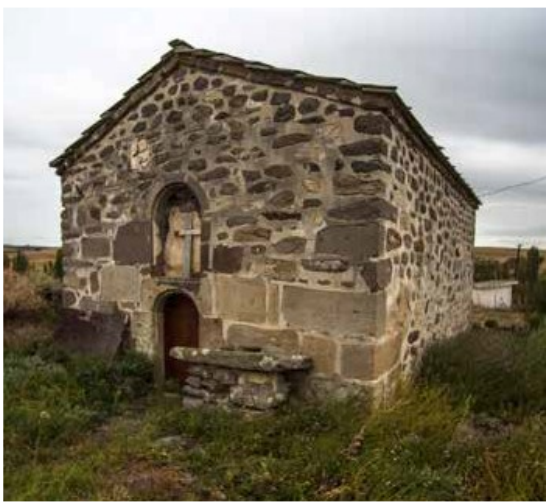

Figure I.42 Post-Byzantine vaulted single-nave

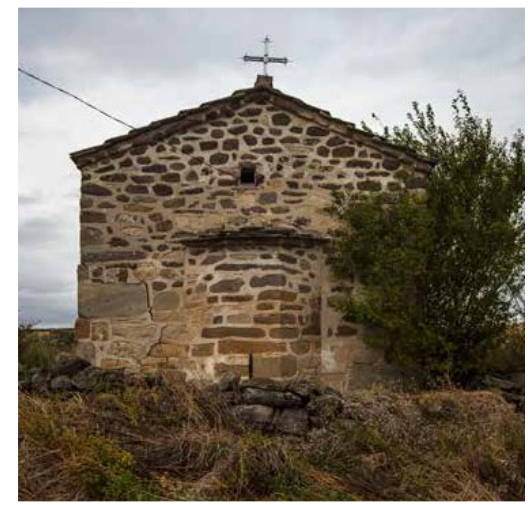
churches: St. George in Gjuzumelci
east; plan and longitudinal section.

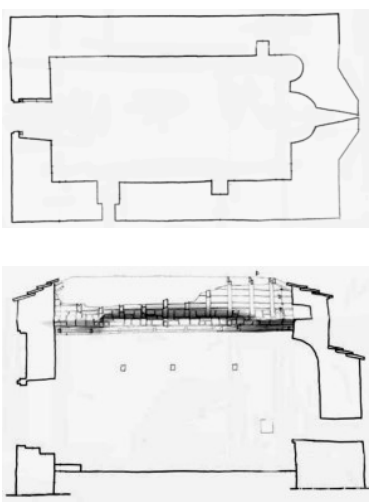
View from the southwest and

Emphasis was placed on interior design, especially fresco painting which, according to traditional Byzantine canonic tradition, covers virtually the entire inner surface of the temple, in a somewhat reduced

100 As an illustration, the nave of the church of St. Nicholas in Trnovo, near Kriva Palanka, built in 1505 A.D., internally measures 4 / 5.7 m, including the altar (Митевски и Веселиновски, 2005: 15).

${ }^{101}$ As an exception, in the region of Veles there are several examples of post-Byzantine churches where a patron saint niche is placed on the east façade, above the apse: at the Immaculate Mother of God in Drenovo; St. Demetrius in Pomenovo; while at St. George in Martolci, quite unusually, in addition to the usual patron saint niche above the western entrance, there are two arched niches in the wall of the apse (Николовски, 2017: 269, 279).

102 Of course, there are exceptions. Such an example is the church of the Immaculate Mother of God in the village of Graeshnica, near Bitola, whose eastern façade and particularly the semi-circular altar apse, in addition to the presence of a decorative façade opus cloisonné masonry as a specific local landmark, was richly decorated with brickwork ornaments (tree of life, cruciform motifs, arches, solar motifs, fishbone, zigzag line, rhombic elements, ceramic ornament in the shape of the Cyrillic letter " $\mathcal{C}^{\prime}-\mathrm{a}$ phenomenon typical of the Ohrid-Prespa-Castoria area, a region under direct influence of the Ohrid Archbishopric, then a square ornament made of pieces of brick with the inscription " $x$ " placed alternately between two squares framed in opus cloisonné - a motif known as the Christogram, etc.). This is clearly an attempt for consistent continuity of the late-Byzantine architectural façade aesthetics typical of the Palaeologan churches. The ornamental masonry of the apse is in stark contrast with the rest of the church, which is an unpretentious building made of unhewn stone and mud, so that "it differs slightly from the village houses" (Михајловски, 2011: 151). An exception is also the church of the Immaculate Mother of God in the village of Velmej, near Ohrid, whose lower parts are built in a correct opus cloisonné (Ангеличин-Жура, 1996: 149), followed by a messier masonry, which speaks of at least two construction phases: first in the late-Byzantine period and a subsequent one in the post-Byzantine period. 
program due to the smaller scale of the churches. Most often, they have a simple wooden iconostasis in which special emphasis is placed on the entrance to the altar - the so-called carski dveri (royal doors), from which representative specimens made in shallow relief have been preserved. In addition, although not as commonly, the post-Byzantine churches had wood-carved decorative ambos, doors and completely wood-carved iconostasis (Ќорнаков, 1987 (А): 14). In fact, it is the preserved specimens of royal doors that are kept today in some Revival churches ${ }^{103}$ that testify to older, probably post-Byzantine temples, on the ruins of which new churches were built (Николовски, 2013: 191-193, 196) as soon as the sociopolitical conditions became favorable for that purpose.

In the XV century, immediately after the occupation, there was a certain stagnation in the church construction activity due to the adaptation to the new conditions and the uncertainty caused by the Ottoman conquest of Macedonia. Few churches of the mentioned post-Byzantine type were built, mostly in rural areas. ${ }^{104}$ In the following period, however, after the stabilization of the new state, their construction became more frequent, retaining the mainly described architectural typology. ${ }^{105}$ It should be noted that the post-Byzantine churches are predominantly grouped in the western parts of Macedonia (see map I.2), where the most important monasteries of the Ottoman period are located. In addition to the described modest typological pattern, somewhat more complex typological solutions appear in the

\footnotetext{
${ }^{103}$ For example, in the church of St. Athanasius in Bogomila, near Veles; Dormition of the Most Holy Mother of God in the neighboring village of Bistrica; St. Nicholas in Popadija and St. Savior in Nogaevci, near Veles; St. Savior in Kozhle, near Skopje; St. Savior in Drachevo, near Skopje; St. George in Drmeni, Prespa and many, many more.

104 These are the churches of the Most Holy Mother of God in Varosh (Prilep); St. Constantine and Helena in Ohrid; St. Apostole Peter in Crneec (Bitola); St. Elijah in Dolgaec (Prilep); St. Petka in Brajchino (Prespa); St. Savior in Leskoec (Ohrid), renovated in the XIX century; St. Nicholas in Plasnica (Kichevo); St. George in Godivje (Ohrid); the Most Holy Mother of God in Graeshnica (Bitola); St. Petka in Pobozhje (Skopje), which in the XIX century was fully incorporated as the central nave of a larger three-nave basilica; the Dormition of the Most Holy Mother of God in Velestovo (Ohrid) and St. Elijah in Raotince (Tetovo), whose western annex is an extension dating from 1852.

105 From the period XVI - XVIII century date: St. George and St. Petka in Mlado Nagorichane (Kumanovo); the Most Holy Mother of God in Pobozhje (Skopje), expanded during the Revival; St. Demetrius in Zhvan (Demir Hisar); St. Nicholas in Burilovci (Sveti Nikole); St. George in Gjuzumelci (Sveti Nikole); St. Nicholas in Mrzen Oreovec (Kavadarci); St. Savior in Stirkovo (Prespa); the Most Holy Mother of God in Bela Crkva (Krushevo); St. Nicholas in Trnovo (Kriva Palanka); St. Savior in Mrenoga (Demir Hisar); St. Savior and St. Demetrius in Chebren (Mariovo); St. Nicholas in Vladilovci (Veles); St. Nicholas and St. George in Radishani (Skopje); St. Nicholas in Arvati (Prespa); St. Nicholas in Krupishte (Shtip), in 1880 expanded with a single-nave, vaulted porch; St. Nicholas in Koince (Kumanovo); St. Elijah and St. George in Banjani (Skopje); St. Archangel Michael in Neproshteno (Tetovo), renovated in 1914; St. John in Vetreno (Veles); St. Nicholas in Chagor (Bitola); St. Nicholas in Shopsko Rudare (Kratovo); St. Athanasius in Sloeshtica (Demir Hisar); St. Demetrius in Rakitnica (Demir Hisar), renovated and rebuilt in the Revival; St. Savior and St. George in Dovezence (Kumanovo); St. George in Blace (Skopje); Dormition of the Most Holy Mother of God in Divlje (Skopje), renovated in the XIX century; St. Nicholas in Ljubanci (Skopje), renovated and fresco-painted in 1881; St. Athanasius in Shishevo (Skopje); St. Savior in Dobri Dol (Skopje); St. Panteleimon in Rusjaci (Makedonski Brod); the Most Holy Mother of God in Tearce (Tetovo); St. Triphun in Govrlevo (Skopje); St. Savior in Cer (Demir Hisar); St. George in Gradovci (Skopje); St. George and St. Nicholas in Beljakovce (Kumanovo); St. Athanasius and St. Elijah in Velushina (Bitola); St. Athanasius in Kovach (Makedonski Brod); St. Nicholas in Zlatari (Prespa); St. Barbara in Dragosh (Bitola); St. Petka in Sirichino (Tetovo), renovated and expanded to the west in 1884; St. George in Lazarovci (Kicevo); St. Demetrius in Trebino (Makedonski Brod); St. Athanasius in Galichani (Prilep); St. Savior in Mogilec (Makedonski Brod); St. Athanasius in Samokov (Makedonski Brod); St. Nicholas in Gabrovnik (Veles); the Most Holy Mother of God in Kozhle (Skopje); St. Nicholas in Ulanci (Veles); St. George in Crkvino (Veles); St. Barbara in Rajchica (Debar); the Nativity of the Most Holy Mother of God in Kostinci (Prilep); St. Athanasius in Drenovci (Prilep); St. Petka in Pezovo (Kumanovo); St. Savior in Drenovo (Veles); St. Elijah in Brezovo (Demir Hisar); St. Petka in Golemo llino (Demir Hisar); St. Demetrius in Zhvan (Demir Hisar); the Most Holy Mother of God in Dolenci (Demir Hisar), renovated and expanded in the XIX century; St. Savior in Pravednik (Kavadarci); St. Trinity in Ubogo (Veles); St. Archangel Michael in Asamati (Prespa); St. Demetrius in Pomenovo (Veles); St. Sava in Pretor (Prespa); St. George and St. Elijah in Vranehstica (Kichevo); St. Nicholas in Krushje (Prespa); St. Nicholas in Omorani (Veles); St. Trinity in Buchinci (Skopje); St. George in Bistrica (Veles); St. John in Oreshe (Veles); St. Trinity - St. Nicholas in Belica (Makedonski Brod); St. Nicholas in Izhishte (Makedonski Brod); St. Petka in Murgash (Kumanovo), renovated in the second half of the XIX century; St. Elijah in Tazhevo (Makedonski Brod); St. George in Martolci; the Presentation of the Most Holy Mother of God, St. Peter and Paul and St. Sunday in Zdunje (Makedonski Brod); St. Athanasius in Galishte (Kavadarci), renovated and expanded to the west in 1934; St. Athanasus - Modrishki monastery (Makedonski Brod); St. Nicholas in Rakovec and St. Petka in Creshnevo, near Veles; St. Archangel Gabriel in Oreovec (Makedonski Brod); St. Archangel Michael in Klinovo (Mariovo); St. Elijah in Bogomila (Veles), in the XIX century incorporated as an altar space of a larger three-nave dining room; the Most Holy Mother of God in Brazda (Skopje), expanded and extended in the XIX century; All Saints in Leshani (Ohrid) and others.
} 
post-Byzantine period, though in smaller numbers. Thus, in the south-western (mainly concentrated in the Demir Hisar region) ${ }^{106}$ and the northern parts of Macedonia (concentrated in a segment of the region of Kumanovo which historically was known as Zhegligovo), ${ }^{107}$ a separate group of post-Byzantine churches with characteristic architectural specifics appeared: single-nave buildings vaulted with a continuous semicylindrical vault, with one or two pairs of massive pilasters that strengthen the north and south walls connected between themselves and with the west and east wall with arches, so that deep arched niches are formed in the lateral walls of the naos (fig. I.43B).
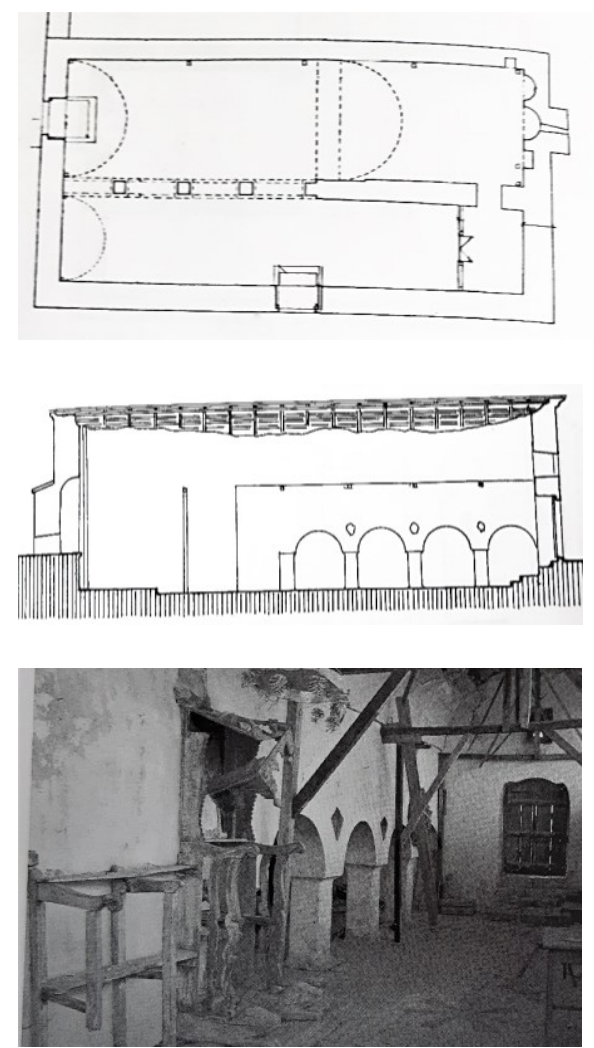

A

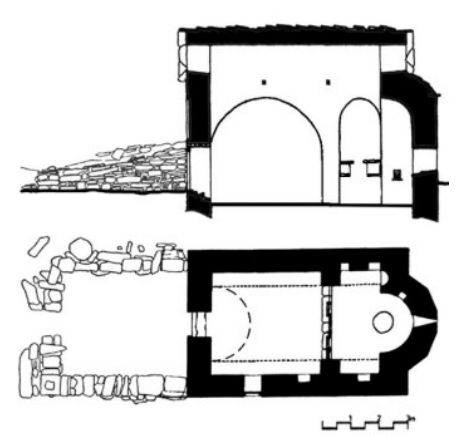

B1
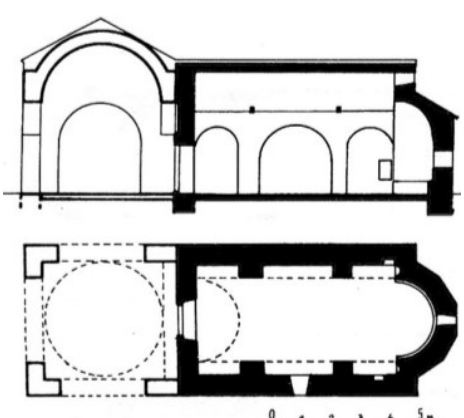

B2

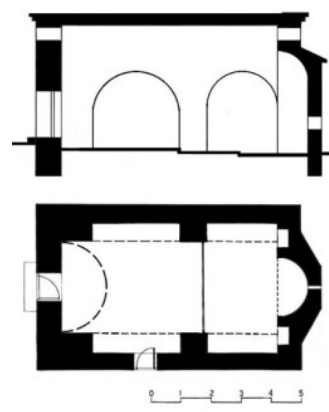

B3
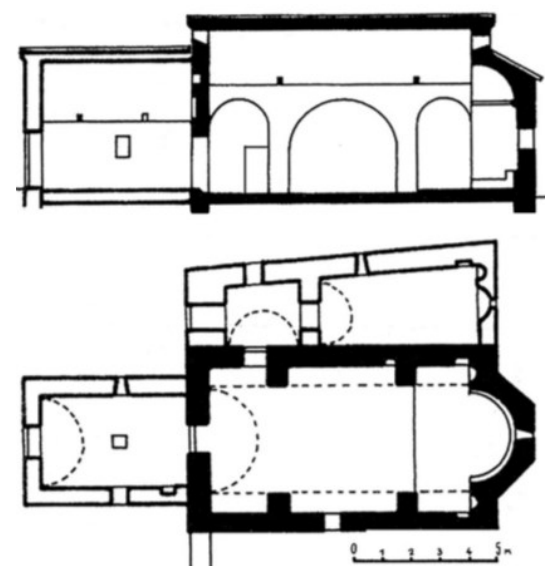

B4

Figure I.43 A. Two-nave churches: St. Savior in Dovezence (Kumanovo). Plan, longitudinal section and view towards the west; B. Single-nave churches with pilasters connected by arches and covered by barrel vault: St. Nicholas in Oreovec (B1); St. Athanasius - Zhurche monastery (B2); St. George in Vrbjani (B3) and St. Nicholas - Toplichki monastery (B4).

The appearance of side pilasters and arches is, above all, constructive, because this system reduces the total transverse span of the nave, which should be bridged by a heavy vaulted structure; the constructive load-bearing capacity of the lateral walls increases, and at the same time they are relieved (Ненадовић, 1980: 33). Of course, the original prototype must not be forgotten: the Byzantine one-nave and compact inscribed cross churches with a dome carried on four supporting pillars or directly on the façade walls (see Chapter 1.4.3) which unambiguously influenced these later post-Byzantine churches. Conditioned by the formal ban on the construction of domes and the restrictions in the height and overall dimensions of the temples, the post-Byzantine master-builders adapted the older, Byzantine model to the

106 St. Demetrius in Gradeshnica (Mariovo); St. Nicholas - Toplichki monastery, village of Babino (Demir Hisar) (fig. I.43B4); St. Nicholas - Oreovechki monastery, village of Oreovec (Makedonski Brod) (fig. I.43B1); St. Nicholas - Moklishki monastery, village of Vatasha (Kavadarci); St. George in Vrbjani (Ohrid) (fig. I.43B3); Nativity of the Most Holy Mother of God - Slivnichki monastery, near the village of Slivnica (Prespa); St. Athanasius- Zhurche monastery (Demir Hisar) (fig. I.43B2); St. Athanasius in Rilevo (Prilep); St. John the Theologan - Slepche monastery (Demir Hisar); St. Nicholas in Slepche (Prilep) and St. Petka in Zhvan (Demir Hisar). 107 St. George in Zhegljane (Kumanovo); St. George in Stepance (Kumanovo); the narthex of St. Petka in Mlado Nagorichane (Kumanovo); the double church St. George - St. Nicholas in Suv Orah (Kumanovo); the narthex of the monastery of Presentation of the Most Holy Mother of God in Karpino (Kumanovo); St. Nicholas in Mlado Nagorichane (Kumanovo), preserved only as archeological remains, and the Holy Spirit in Dobracha (Kumanovo) which is a three-nave pseudo-basilica (see Chapter I.5.2). 
contemporary conditions and circumstances (Шупут, 1984: 60), and as a substitute for the crucial architectural element - the dome supported on an elevated drum - they applied a simple, legally permitted solution: the barrel vault. As for their remaining architectural and artistic features, these churches follow the general post-Byzantine stylistical tendency.

In the region of Kumanovo, more precisely in the historical area of Zhegligovo, there are several churches that belong to a "heterogeneous group of church buildings (...) with unusual architectural solutions" (Машниќ, 2008: 74). In addition to the double cemetery church St. Nicholas / St. George in the village of Suv Orah, dated to the very beginning of the XVII century, which has two altar apses, two patron saint niches on the western façade and a two-nave naos connected through an arcade, all under one gabled roof, a group of churches with a rather complex plan were also built in the region. Typologically, they are single-nave churches with an additional chapel (paraklis) to the south and a large narthex to the west. The naos and the chapel are connected by an arcade resting on low masonry pillars, resulting in the impression of a two-nave basilica. Such examples are the churches of St. Petka in Murgash, Holy Trinity in Chelopek, whereas at the churches of St. Savior in Dovezence (fig. I.43A), St. Petka in Pezovo, St. George in Algunja and St. Petka in Mlado Nagorichane the separation between the naos and the chapel is achieved with a wall pierced only by a narrow passage, which in the western parts of the church transforms into an arcade dividing the narthex into two naves.

Lastly, albeit in a very limited number, there appeared a specific typological solution of a singlenave vaulted building combined with a trefoil model, ${ }^{108}$ as well as several very important three-nave basilical churches, which will be discussed in more detail on the following pages.

\section{I.5.2 Post-Byzantine Antecedents of the XIX Century Revival Three-nave Basilicas}

Considering the social circumstances in the Ottoman Empire and consequently the described types of religious Christian architecture that prevailed almost without exception in that period, several temples with monumental dimensions and a different, archaic typology ${ }^{109}$ built in Macedonia in the XVIXVIII century are of exceptional importance. Namely, "everywhere heritage represented a basis for new construction, for renovation. When circumstances allowed and when more significant means became available, more ambitious works were realized. Larger works were created, inspired by those medieval achievements which, in an ideological sense, were especially respected. In Greece and Bulgaria, the greatest achievements took after Mount Athos' architecture, in Serbia after the Morava school, later after Rashka" (Кораћ и Шупут, 1998: 399). In that sense, it should absolutely come as no surprise that in Macedonia the model according to which the most monumental post-Byzantine churches were built was sought in the X-XI century, among the monumental church architecture associated with Samuel's independent state. Thus, in several rural areas - where, as has been said, the Christian population

\footnotetext{
108 St. Thomas - Shuti Monastery, located between the villages Graishte and Vardino, region of Demir Hisar (see fig. III.253); Presentation of the Most Holy Mother of God - Karpino Monastery, near the village of Suv Orah (Kumanovo) and the Most Holy Mother of God - Leshok monastery, near the village of Leshok (Tetovo). More details in Chapter III.5.E.

${ }^{109}$ So far, attention has been paid to the nurturing of basilical typologies in post-Byzantine architecture. Vojislav Korać and Marica Shuput attribute it, as a characteristic phenomenon, to return to tradition. However, according to these authors, basilicas with vaults and domes were exceptionally built, and three-nave or single-nave basilicas with wooden roof construction prevail, as easier to execute. As an example of an urban environment in which a large number of such post-Byzantine basilicas were built, they name the town of Castoria (Кораћ и Шупут, 1998: 393). In this regard, it must be emphasized that Castoria belonged to the diocese of the Ohrid Archbishopric, as well as to the centuries-old regional tradition of building basilicas, related to the middleByzantine period, the state of Samuel and its independent church institution.
} 
withdrew and enjoyed somewhat greater religious freedom - three-nave churches were built significantly earlier than the comprehensive social changes that would define the XIX century Revival, as true harbingers of its most characteristic architectural typology: the three-nave basilica. In this context, these few very rare and unique representatives of the three-nave basilica typology from the post-Byzantine period are extremely important because they represent an evolutionary thread that connects the middleByzantine and the Revival basilicas, built under their influence eight centuries later.

The three-nave post-byzantine basilicas are grouped predominantly in the northern part of Macedonia, located in neighboring villages on the mountain slopes of Skopska Crna Gora near the town of Skopje and in several villages in the region of Kumanovo (historical region of Zhegligovo); however, to the far south there is one more lonely example of equal importance (see map I-2). These churches will be discussed in more detail on the following pages.

\section{"St. Nicholas" in Mirkovci (Skopje), XVI-XVII Century}

The church of St. Nicholas in the village of Mirkovci, located on the slopes of Skopska Crna Gora Mountain, is an older temple renovated during the Revival, more precisely in 1873. It is a monumental building with total dimensions of $10.1 / 16.8 \mathrm{~m}$, i.e. a ratio of 1:1.66, which corresponds to an almost perfect golden ratio. ${ }^{110}$ The eastern parts of the church, approximately half of the naos, are remains of a post-Byzantine basilica, authentically preserved and very skillfully incorporated into the later, Revival church. ${ }^{111}$ From these remains, it can be concluded that it was originally a three-nave basilica, dated in the XVI-XVII century (Велев, 1990: 135).
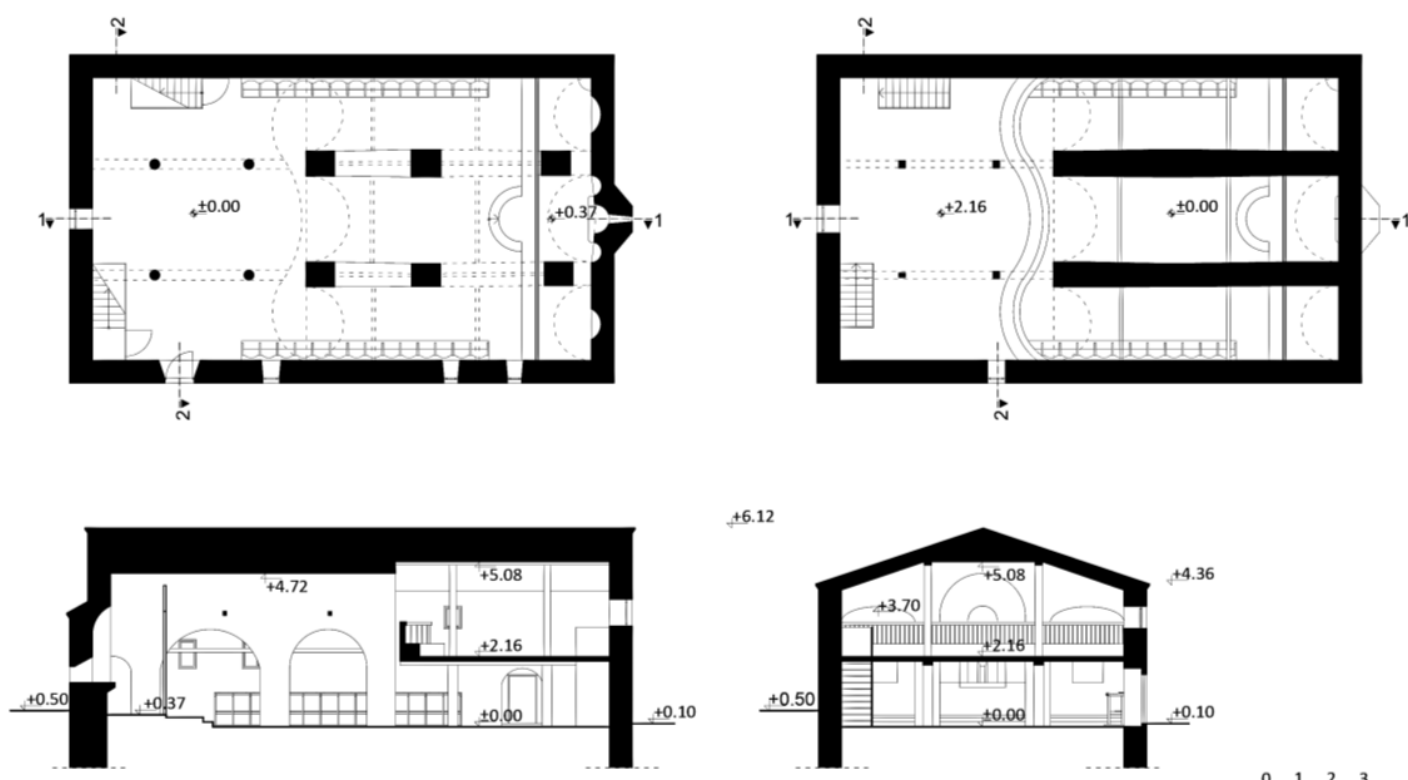

Figure I.44 St. Nicholas in Mirkovci (Skopje). Plans of the ground floor $( \pm 0.00)$ and gallery $(+2.16)$; longitudinal section (1-1) and transversalal section (2-2).

Three pairs of massive masonry pillars, with a cross section of approximately $90 / 90 \mathrm{~cm}$ are preserved, dividing the naos into three naves of slightly irregular shape. It is interesting that the width of the three naves is almost equal: the central nave, whose width varies around $265 \mathrm{~cm}$, exceeds the lateral

\footnotetext{
110 The golden ratio is the ratio between two unequal quantities ( $a$ and $b$ ), such that $a: b=b:(a+b)$. If the smaller quantity has the value $a=1$, then $b=1.61804$...(Roth, 1999: 65).

111 It is quite logical to assume that the current size of the church is identical to its authentic, post-Byzantine plan, and if the perimeter walls in the western parts of the building were completely or partially demolished, they were certainly rebuilt on the existing foundations as the most economical and convenient solution.
} 
naves by only forty centimeters. It is covered by a barrel vault whose height reaches $4.72 \mathrm{~m}$, exceeding the lateral ones, covered by low elliptical vaults, by $1 \mathrm{~m}$. The pillars are connected with semi-circular arches, forming two arcades (fig. I.44). To the east, the last pair of pillars is connected by a smaller quarter circle arch directly to the east wall, without the mediation of pilasters or consoles. The solution of the unusually small three-sided altar apse is especially interesting and specific. On the inside it is slightly rounded, with three semicircular niches, of which the central one is larger and illuminated by a narrow window opening in its axis. Laterally, a prothesis and diaconicon develop in the side naves, marked by appropriate shallow and relatively wide niches in the eastern wall.

The remains of the older church end with the third pair of pillars from the east. The overall dimensions of the naos and the distances between the preserved pillars imply that the original building probably had another pair of pillars to the west, which collapsed for unknown reasons. Knowing the historical circumstances in the region of Skopje and beyond throughout Macedonia, it is very likely that the large three-nave basilica in Mirkovci, built in the XVI-XVII century, was destroyed in the Austro-Turkish War (1683-1699) and the Karposh Uprising of 1689 A.D.: during the arson and destruction of Skopje undertaken with the withdrawal of the Austrian armies to the north, passing by the villages on the lower slopes of the Skopska Crna Gora Mountain, or in the cruel repressions against the Macedonian population after the re-establishment of Ottoman rule. To the west of the last existing pair of pillars develops the section added in the XIX century, which bears distinctive features of the Revival religious architecture specific to the region of Skopska Crna Gora.
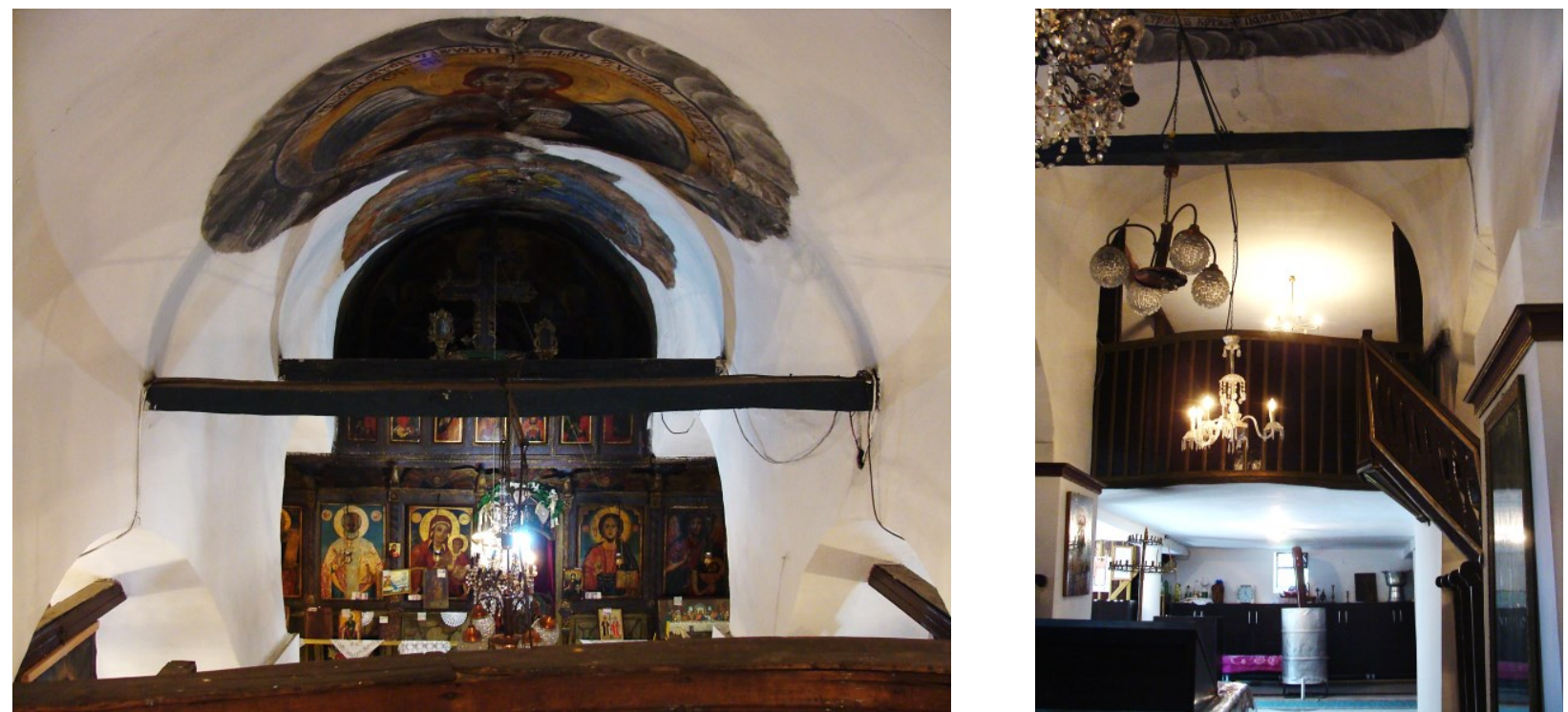

Figure I.45 St. Nicholas in Mirkovci (Skopje). A. View of the central nave post-Byzantine vault; B. View towards the Revival gallery.

Namely, almost to the very edge of the western pair of pillars stretches an extremely deep gallery, supported on its own constructive system comprised of two pairs of wooden columns (with a circular cross-section below the gallery and a rectangle one above it) and beams, which consistently re-utilize the older concept of a three-nave basilica (fig. I.44, I.45B). The depth of the gallery is $6.5 \mathrm{~m}$ and it covers such a large area that in the western zone of the church there are two independent staircases leading to the upper floor. The gallery of the church in Mirkovci is characterized by a convex extension (balcony) in the central nave, and concave depressions in the lateral naves, thus achieving baroque curvature of the forms characteristic of the Revival architectural expression (fig. I.44). The railing is made of wooden boards with smaller planks at their joints, with a parapet that runs along its entire length from the inside, which today is used for displaying icons. Within the railing, in a symmetrical composition, two decoratively executed tall pedestals are placed between the central and lateral naves, which serve to exhibit larger, so-called 
throne icons. The entire western extension is covered by a wooden ceiling, flat above the central nave (which extends at an elevation of $+36 \mathrm{~cm}$ compared to the apex of the original vault) and inclined above the lateral naves, so that the ceiling of the gallery has a trapezoidal cross-section.

While the interior of the temple is preserved in a relatively authentic condition, ${ }^{112}$ the façades have unfortunately been completely destroyed. Namely, the church is located in a lively, active village and is therefore in active use by the local community. It has, unfortunately, been unprofessionally renovated by the church board and the local population in the second half of the XX century. During this renovation, the façades were completely altered, with coatings of new, uncharacteristic materials (external grid of reinforced concrete, cement mortars, prefabricated façade brick, decorative stone), as well as the windows and the roof of the building, to such an extent that it has become impossible to distinguish the authentic external appearance of the post-Byzantine building today.

\section{"St. Nicholas" in Gluvo (Skopje), XVI-XVII Century}

The church of St. Nicholas in the neighboring village of Gluvo (on the slopes of Skopska Crna Gora mountain) also consists of an older eastern zone incorporated in a church built in the Revival, more precisely in 1855 . The older basilica is from an unknown date, but the similarities with the church in Mirkovci allow for the same broad time frame: XVI-XVII century. The approximate dimensions of the church in Gluvo are 11.6/15.7 m, and as with the church in Mirkovci, it has an irregular, trapezoidal plan. However, unlike the church in Mirkovci, the proportion of the church in Gluvo is 1:1.35, i.e. it has an extremely pronounced width versus length. This is due to the topography of the terrain which caused, quite unusually, the church to have no western entrance at all. The only entrance is the south one from which, through several stairs that overcome a height difference of $60 \mathrm{~cm}$ (being that the depth of the church dug into the ground), the naos is accessed directly (fig. I.46).
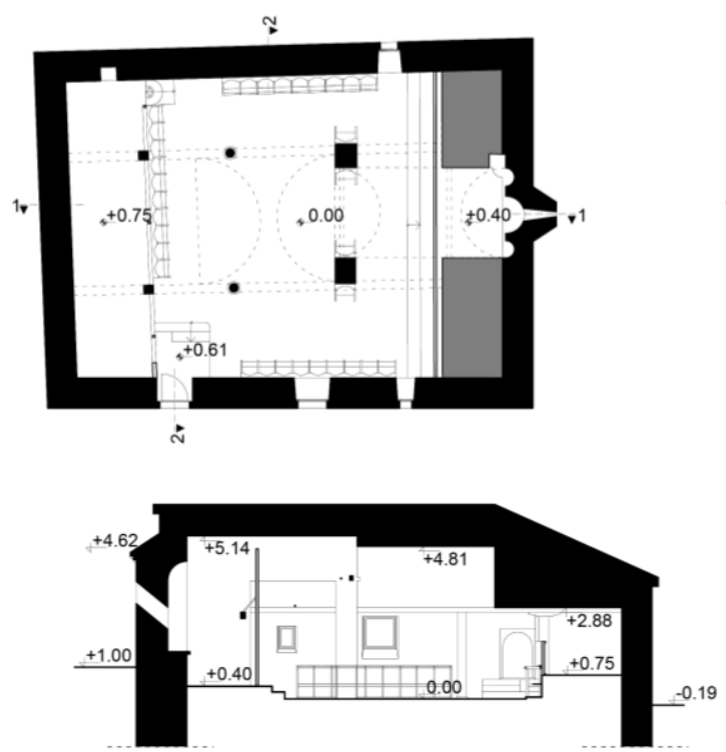

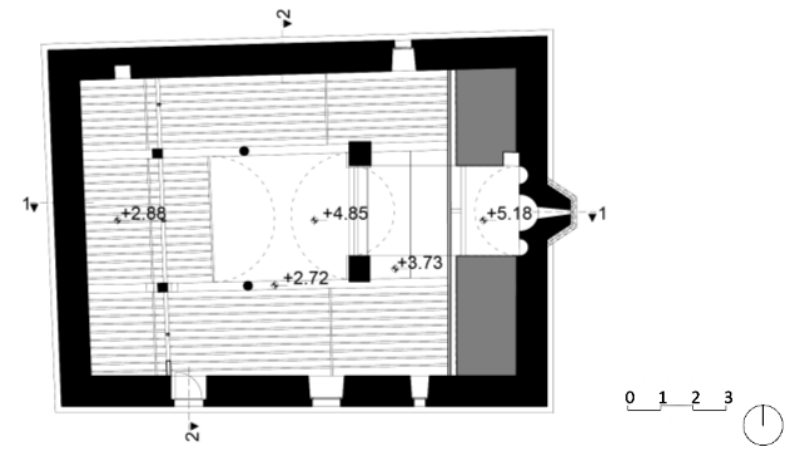

$+6.14$

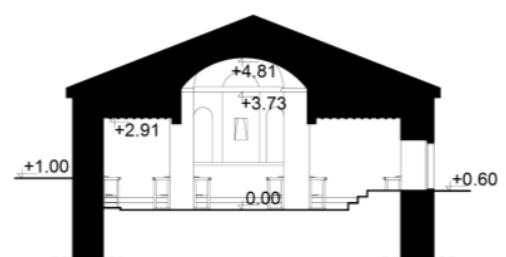

Figure I.46 St. Nicholas in Gluvo (Skopje). Plan ( \pm 0.00$)$, ceiling (+2.88), longitudinal (1-1) and transversal (2-2) section.

From the older post-Byzantine church there remains the altar and a pair of massive masonry pillars, measuring $70 / 80 \mathrm{~cm}$. The apse, the width of the altar and the eastern bay are almost identical to those of the basilica in Mirkovci. In the church in Gluvo, however, the inside of the altar apse is completely flat,

\footnotetext{
112 In addition to the two-zone iconostasis, painted fresco-compositions are preserved on the lateral walls, in the altar, as well as circular medallions painted on the vaults above the central (Christ Pantocrator and St. John) and the south nave (St. Prophet Elijah and Arhangel Michael). All remaining walls, vaulted surfaces and flat ceilings were simply whitewashed (fig. I.45).
} 
whereas on the outside it is three-sided and quite small compared to the dimensions of the eastern façade. In the upper zone, the apse is finished with a crown of brick, later plastered, as well as the entire exterior of the church. A very narrow slit-like window is placed in the axis of the apse. On the inside, the apse has three symmetrically arranged semi-circular niches, of which the central one is wider. From the apse to the preserved eastern pair of pillars extends a rectangular bay covered by a semi-cylindrical vault whose height reaches $5.18 \mathrm{~m}$ (fig. I.46, I.47A). The lateral naves with the prothesis and diaconicon, which of course must have flanked this bay analogous to the church in Mirkovci, are missing. Today their remains are inaccessible from the altar, from which they are separated by solid masonry walls (in the north wall, next to the apse there is a small rectangular niche that serves as a prothesis), as well as from the nave, because they are located behind the tall altar partition, interrupted only by the royal doors and one additional door to its north side. By analogy with the basilica in Mirkovci, instead of full lateral masonry walls the altar of the church in Gluvo originally must have had a pair of pillars connected to the east wall of the church with arches, which would allow communication between the altar, the prothesis and the diaconicon. In order to confirm their existence, as well as the precise dating of the original church in Gluvo (of course, the case is the same with the church in Mirkovci), it is necessary to undertake more comprehensive archaeological research of the basilica, including its walls, vault and arches. Namely, in the church in Gluvo, older layers of frescoes are visible under the Revival ones, and their discovery can help date the first phase of the church, for which we have no confirmed data yet.
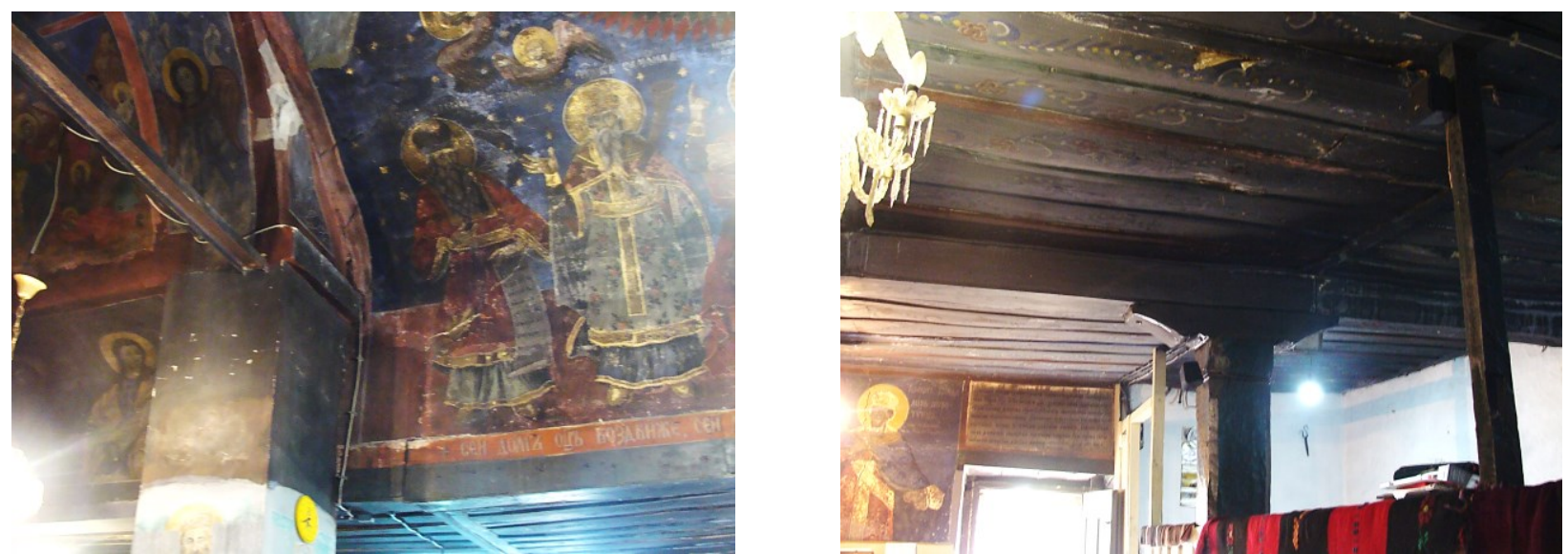

Figure I.47 St. Nicholas in Gluvo (Skopje). A. View of the remaining southern pillar where the post-Byzantine masonry vault and the Revival false vault meet; B. View towards the narthex and the entrance to the naos.

To the west of the described bay and the preserved pair of pillars extends the Revival reconstruction of the church, composed as a three-nave basilica, which uses the original size in plan and follows the typology of the preserved older building, but with obvious changes in the solution. Namely, the Revival basilica uses different materials: the central nave is covered by a light (so-called "fake") vault of mortarcoated wooden construction as opposed to the masonry vault of the original post-Byzantine church, from which it is also $33 \mathrm{~cm}$ lower; the two pairs of pillars to the west are made of wood (the eastern pair has a circular cross-section, and the western a square one), as is the flat ceiling above the lateral naves and the narthex. The span of the central nave in the newer construction increases from the original $2.8 \mathrm{~m}$ between the massive pillars (quite similar to the span of the central nave in Mirkovci!) to $4.2 \mathrm{~m}$ between the wooden pillars (fig. I.47A). Unusually, the vault in the central nave extends approximately to the middle of the span between the two pairs of wooden pillars, i.e. a wooden vault covers an approximately square field. To the west of this vaulted bay, the central as well as the lateral naves are covered by a flat wooden ceiling, at a height of $2.9 \mathrm{~m}$, i.e. lower by $\sim 80 \mathrm{~cm}$ in comparison to the level of the simple rectangular capitals of the original pillars (at an elevation of $3.73 \mathrm{~m}$ ). 
Furthermore, the church in Gluvo lacks a classical gallery, which has been replaced by a raised area $(+75 \mathrm{~cm}$ in comparison to the floor of the naos) west of the square wooden pillars. Since the wooden ceiling here is set at $+2.9 \mathrm{~m}$, it is a very low and dark, intimate part of the temple. This zone, fenced with a flat railing made of wood, took on the role of a "women's church", and can only conditionally be called a "narthex" since it lacks a western entrance to the temple which is one of the main purposes of a narthex (fig. 1.47B). Instead of a staircase, in the south-west corner in front of the raised gallery / narthex there is a late-antique marble column base in secondary use. ${ }^{113}$ Unlike the church of St. Nicholas in Mirkovci, in Gluvo the vaulted parties were completely fresco-painted, by the greatest and most famous Revival artist Dicho Zograf (Василиев, 1946: 377), whose signature is found at the end of the long inscription that encircles the central wooden false vault (fig. I.47A).

To the east of Skopje, in the region of Kumanovo - historical Zhegligovo (see map 1-2), there are several other post-Byzantine three-nave basilicas which also form a stylistically and typologically rather uniform group, with "heterogeneous, almost complex spatial solution" (Машниќ, 2008: 78).

\section{"St. Nicholas" in Strezovce (Kumanovo), XVII Century}

St. Nicholas, the cemetery temple of the village of Strezovce, is a post-Byzantine church built on older remains - likely from the Byzantine period - of a slightly larger basilica, as evidenced by the discovered archeological remains. It dates from the very beginning of the XVII century: it was built and fresco-painted in 1606 (Kiel, 1985: 249), as stated in its well-preserved donor inscription painted above the entrance, from the inside, as was customary in Byzantine and post-Byzantine temples. According to this inscription, the construction of the temple was a result of the efforts of the prezbyters Kir Constantine and Kir Petko, as well as the inhabitants of Strezovce, under the Patriarch John of Pekj (1592-1614) and the Bishop Macarius of Skopje (Крстиќ, 2009: 203-204). ${ }^{114}$
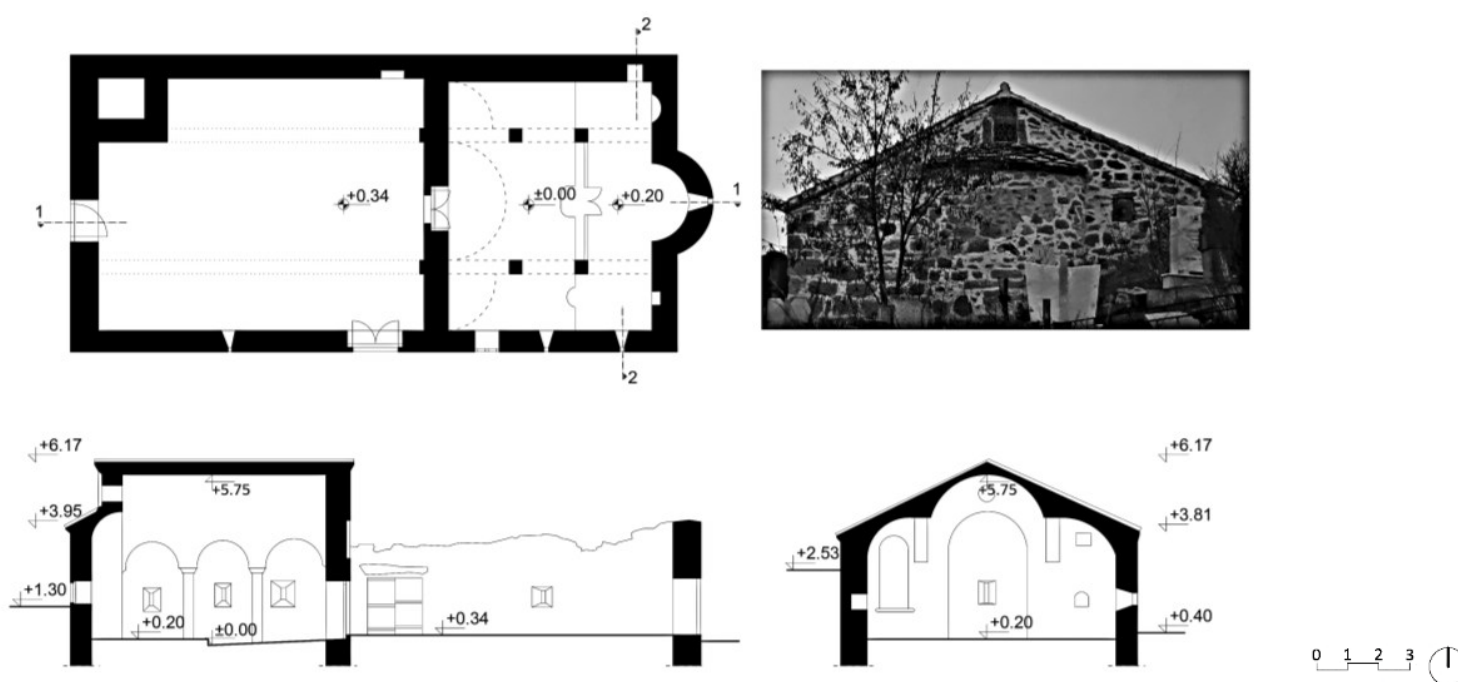

Figure I.48 St. Nicholas in Strezovce (Kumanovo). Plan ( \pm 0.00$)$, view of the eastern façade, longitudinal section (1-1) and transversal section (2-2)

\footnotetext{
${ }^{113}$ Most probably brought to the church from the early-Christian basilica on the site "Orashec", located only $2 \mathrm{~km}$ from the village of Gluvo, from where other fragments of late-antique spoliae originate and today are displayed in the churchyard (Микулчиќ, 1981: 114-117).

114 Namely, after 1557, the northern parts of Macedonia as well as a large fraction of the western parts of today's Bulgaria, were taken away from the diocese of the Ohrid Archbishopric and annexed to the renewed Patriarchate of Pekj (Kiel, 1985: 222-224), in a gradual process of reduction of the Archbishopric's power, which would culminate in its complete abolition in 1767 A.D.
} 
The church in Strezovce is characterized by a three-nave disposition of the compact, almost square naos (fig. 1.48), divided into naves with two relatively low arcades comprised of only two pairs of square pillars connected by semicircular arches, which is a rather unusual solution. The central nave is bridged by a barrel vault, and the lateral ones, which are lower, by a quarter-cylinder vault. ${ }^{115}$ To the east, a semicircular altar apse develops, flanked by prothesis and diaconicon niches, as well as smaller semicircular niches in the southern and northern wall. The whole building is covered with a massive gabled roof, without a central nave clerestory, initially covered with stone slabs, today preserved on the roof over the apse. It was built of hewn blocks of trachyte stone, specific for the monumental architecture in Macedonia's wider north-eastern region (Kratovo, Kumanovo, Slavishte, Kriva Palanka). Furthermore, the execution of the window transennas as intricate arabesques carved into stone slabs (including crosses, solar motifs, David's star, etc.) is a unique local feature characteristic of the region, present in the churches in the villages Staro Nagorichane (St. George), Mlado Nagorichane (St. George and St. Petka) and Zhegljane (St. George), which date from the Byzantine and post-Byzantine periods.

To the west of the church, a spacious three-nave narthex was erected at the same time; thus, the church measures 10/22 $\mathrm{m}$ in total. Later, unfortunately, the pillars, arches and vaults of the narthex were demolished, and subsequently the construction material was used to build a bell tower in its northwestern corner. Thus, today only the perimeter of the narthex is preserved. As a decorative element, the arches above the entrances (from the south and west) to the narthex are constructed with alternating blocks of stone with a lighter and darker shade, as is also the case of the transept at the church of St. George in the nearby village of Mlado Nagorichane (Машниќ, 2008 (В): 70), which dates roughly from the same period (fig. I.50). Originally, along the south and north walls of the narthex were placed long low tables made of stone, around which the local population gathered for a meal during memorials, celebrations and church ceremonies. Similar stone tables are preserved near the church St. George in Mlado Nagorichane (Машниќ, 2008 (B): 73), which also has a three-nave narthex - dining room, as a local architectural feature specific to the Zhegligovo area.

\section{"Holy Trinity - Holy Spirit" in Dobracha (Kumanovo), XVI-XVII Century}

The church dedicated to the Holy Spirit, also known as the Holy Trinity church, was built as the cemetery temple of the village of Dobracha (region of Kumanovo), probably at the same time with the similar church in Strezovce - the end of the XVI - beginning of the XVII century, over the remains of a larger late-Byzantine monument (Крстиќ, 2012: 123). The church in Dobracha is also basically a threenave basilica (fig. I.49A), with the rare and unusual solution of arcades comprised of only two pairs of columns separating the naves, which in Dobracha are octogonal and made of stone blocks arranged with great precision. All three naves are covered by masonry barrel vaults.
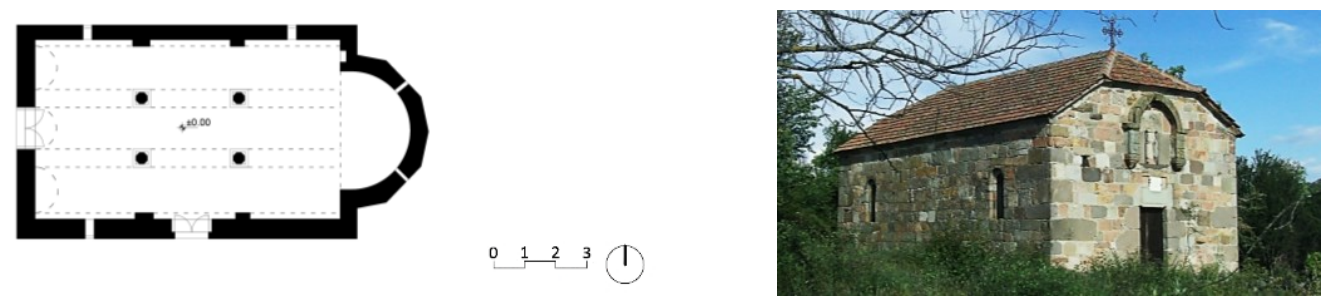

Figure I.49 Holy Spirit in Dobracha (Kumanovo). A. Plan ( \pm 0.00$) ;$ B. View from the north-west.

Unlike the basilica in Strezovce, the lateral walls of the naos in Dobracha are strenghtened by pilasters connected by arches, therefore forming tall blind niches in the lateral walls, which links this

115 Quarter-cylinder vaults are also found in the southern chapels of the churches dedicated to St. Petka in Mlado Nagorichane and in Murgash, both in the Kumanovo (Zhegligovo) region (Крстиќ, 2009: 206-207). 
church with the before mentioned specific group of post-Byzantine one-nave vaulted basilicas with lateral pilasters and niches as an important stylistic branch of the post-Byzantine religious architecture of the region (see previous chapter). As the other monuments from the region, it was built entirely in well hewn trachyte blocks, with abundant decoration in shallow relief and sculptural elements, such as the column separating the double window on the west façade, and the console archivault which covers it (fig. I.49B). Elements of stone reliefs are preserved on the frames of the windows of the western façade - intertwines, vines, geometric ornaments and even completely stylized animals (a rooster, a deer, a snake and a lion) for which stylistic analogies exist in other contemporary churches of the region (Бошковић, 1967: 149), such as St. George in Mlado Nagorichane and St. George in Zhegljane (see fig. III.87A). The nature of these reliefs, as well as the prothesis niches to the north of the altar apse, shaped as Saracene, pointed arches (Крстиќ, 2012: 124), similar to the niches flanking the apse at the church of St. George in the village of Kokino, are evidence to the already strong islamic and oriental influences which leaked from the Islamic to the Christian religious architecture as early as the XVI-XVII centuries.

\section{"St. George" in Mlado Nagorichane (Kumanovo), XVI-XVII Century}

In addition to these two three-nave basilicas, one more complex church from the same region must not be overlooked: the church of St. George in Mlado Nagorichane, one of the largest and most representative monuments of the post-Byzantine era in Macedonia in general. Although several authors have expressed varying opinions regarding the dating of this monumental building, spanning from the XIIIXIV century possibly built over older remains from the XI century, such was the case of the church dedicated to the same saint in the nearby village of Staro Nagorichane (see Chapter I.4.3), the postbyzantine period has generally been accepted as a plausible time-frame for its construcction (Крстиќ, 2012: 60-61, with an overview of older bibliography).
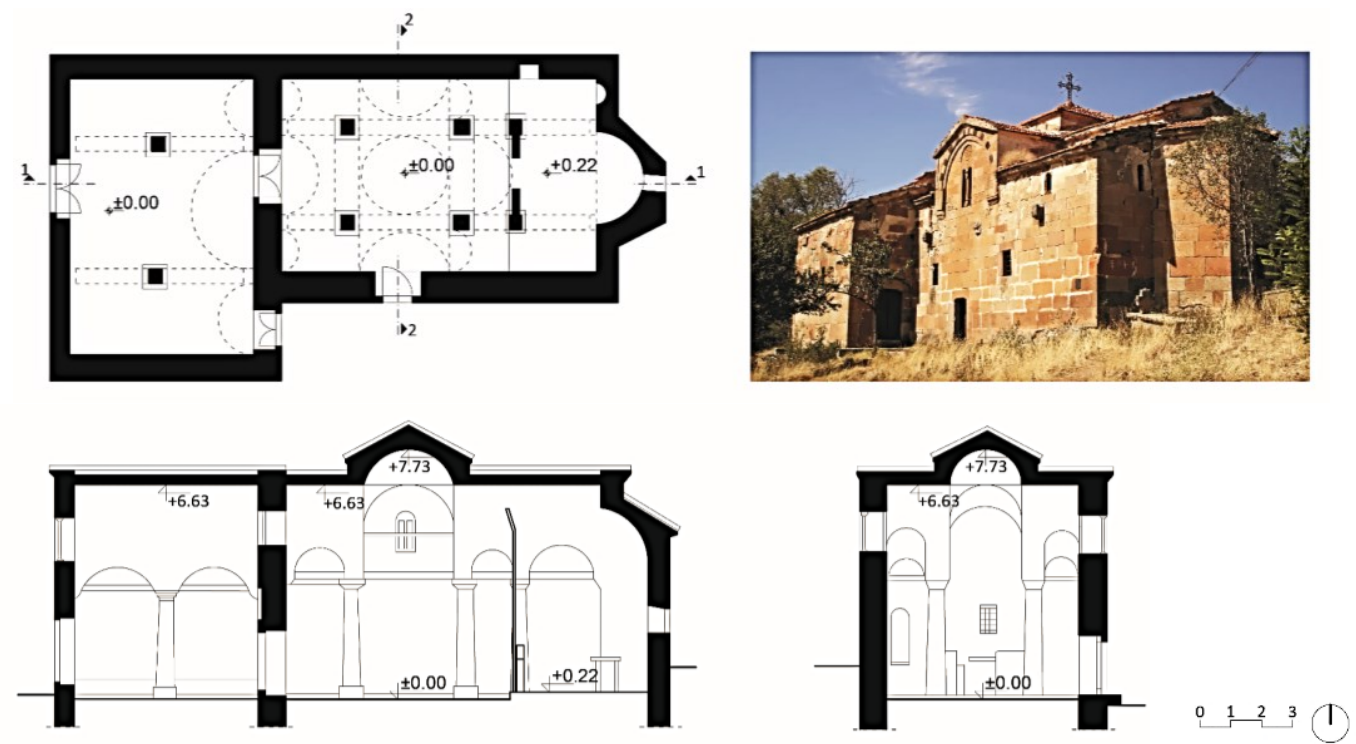

Figure I.50 St. George in Mlado Nagorichane (Kumanovo). Plan ( \pm 0.00$)$, view from the southeast, longitudinal section (1-1) and transversal section (2-2).

As was the case of the church in Strezovce, it is comprised of a naos and a large, even wider threenave narthex - dining room. The naos, however, is based on other typological models and is clearly significantly influenced by the older church in nearby Staro Nagorichane (see fig. I.41). Namely, St. George in Mlado Nagorichane is a vaulted basilica with a transept. In a rectangular, generally three-nave naos (divided into naves by three pairs of square stone columns), a developed inscribed-cross solution is introduced, with emphasized central nave and transept which are slightly higher than the lateral naves 


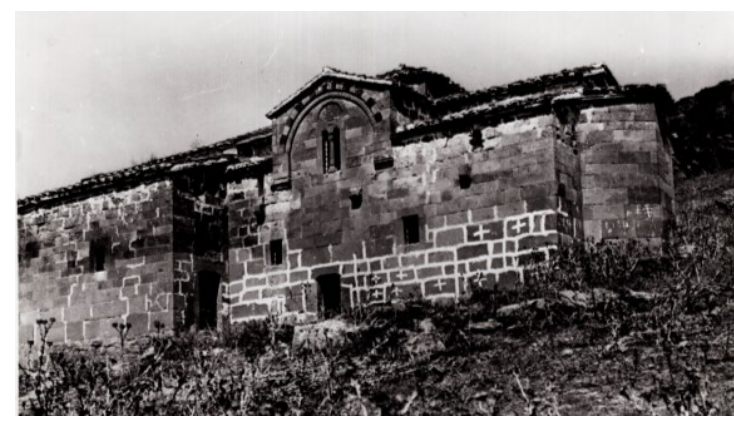

Figure I.51 St. George in Mlado Nagorichane (Kumanovo), photographed in 1899. (fig. 1.50). Since the construction of an externaly manifested dome supported on a tall, protruding drum was strictly forbidden, a blind dome rests on their intersection, externally shaped as a low cubic postament on the fifth façade. The altar apse is threesided and as tall as the lateral naves (fig. I.51). The extreme height of the apse is another hint to the older church of St. George in Staro Nagorichane as the prototype for this later religious building (see fig. I.41). The preserved stone consoles suggest that the church had open wooden porch(es) to the south (and north) of the naos (fig. I.51), the southern of which was restored in the Revival.

\section{"Nativity of the Most Holy Mother of God" in Tepavci (Bitola), XVIII Century}

In the context of the previously described post-Byzantine three-nave churches from the regions of Skopska Crna Gora and Kumanovo, the last church belonging to this characteristic typological group: the Nativity of the Most Holy Mother of God, stands out both geographically - it is located in the village of Tepavci, near Bitola, far to the south from the other churches (see map 1-2), as well as temporally, because it was built significantly later, in $1767 .{ }^{116}$ It was fresco-painted in 1795 , as stated in the inscription in Greek painted above the northern entrance portal. Typologically, it is a large three-nave basilica with a slightly irregular, trapezoidal plan that expands from west to east. The building measures $17.75 \mathrm{~m}$ in length (19 $\mathrm{m}$ including the altar apse) and $11 \mathrm{~m}$ in width; its proportional ratio, therefore, is 1:1.6 which is equivalent to a golden ratio. The naos is divided into three naves by means of two rows of five masonry pillars with a cross section of $80-90 / 100 \mathrm{~cm}$. The lateral naves are narrower - their average width is $2 \mathrm{~m}$, while the span of the central nave is about $3 \mathrm{~m}$. Thus, the ratio of the spans of the central compared to the lateral naves is 1:1.5 and even less if we take into account the trapezoidal form of the north nave. The total internal height is $5.6 \mathrm{~m}$ in the central nave, and $4.7 \mathrm{~m}$ in the lateral naves, i.e. the difference in height between the naves is only $90 \mathrm{~cm}$. Consequently, it can be concluded that both in plan as well as in section the central nave is not particularly emphasized in comparison to the lateral ones; in other words, the naos is fairly evenly divided into three naves, as was the case with the other previously described postByzantine three-nave churches.

The pillars form two arcades of semicircular and horseshoe arches. Instead of a capital, the passage from a pillar to an arch is marked by a simple rectangular profile, similar to the church in Gluvo (see fig. I.47A). The westernmost pair of arches are accepted by massive pilasters, while in the east the arches are supported directly by the eastern wall, without additional consoles or pilasters. In the transverse direction, the whole system is rendered rigid with wooden ties, placed in one level in the lateral naves and two levels in the central one, which is enabled by its greater height. The three naves are bridged by semi-cylindrical vaults, and to the east they end with three semi-circular apses, without any decorative arrangement with shallow pilasters or blind niches. Only the central, larger apse originally had a single

\footnotetext{
116 The church in Tepavci is one of the few churches built in the XVIII century when, due to the extremely unfavorable socioeconomic conditions in the Empire, construction of Christian temples was reduced to a minimum. Other churches dating from this paticularly scarce period have not been originally preserved until today. Such example is the church of St. Cyril and Methodius in Strumica, built in 1750-1760, which today is preserved as a crypt dedicated to the Fifteen Tiberiopolis martyrs, over which the present-day temple dedicated to St. Cyril and Methodius was built in 1905-1911. A similar example is the church of St. Demetrius in Ilovica near Strumica, built in 1796, destroyed later, and re-built in 1915.
} 
window, which was later filled with drywall. As the only decorative element in their exterior finish, the apses in the upper zone have a profiled cornice, which has also been plastered. An additional shallow semicircular niche is placed in the north wall of the altar, dedicated to a prothesis (fig. I.52).

Unlike the post-Byzantine churches that were entirely massively built, including their vaults, the church in Tepavci was built using a combined constructive system specific of the religious architecture of the next, XIX century. Namely, while the supporting pillars and perimeter walls, whose thickness varies between 85-95 cm, were built massively of crushed and hewn stone with leveling layers of wooden lattices, and then covered by layers of mortar, the vaults were made of light-weight wooden construction coated with mortar coating and fresco-painting - so-called "fake" vaults. In addition to this typical Revival constructive solution, a number of other architectural features confirm its role as an antecedent of the Revival church architecture. Such feature is the continuous gabled roof which covers the entire naos of the church in Tepavci, despite its considerable dimensions, without a central-nave clerestory. Additionally, the west and east façades have a trapezoidal shape instead of a triangular one, since the roof can actually be defined as a hip, instead of a gabled roof. This is specific to the XIX century Revival churches, as is the authentic roof covering of stone-slabs, still preserved above the altar apses (fig. I.53A).
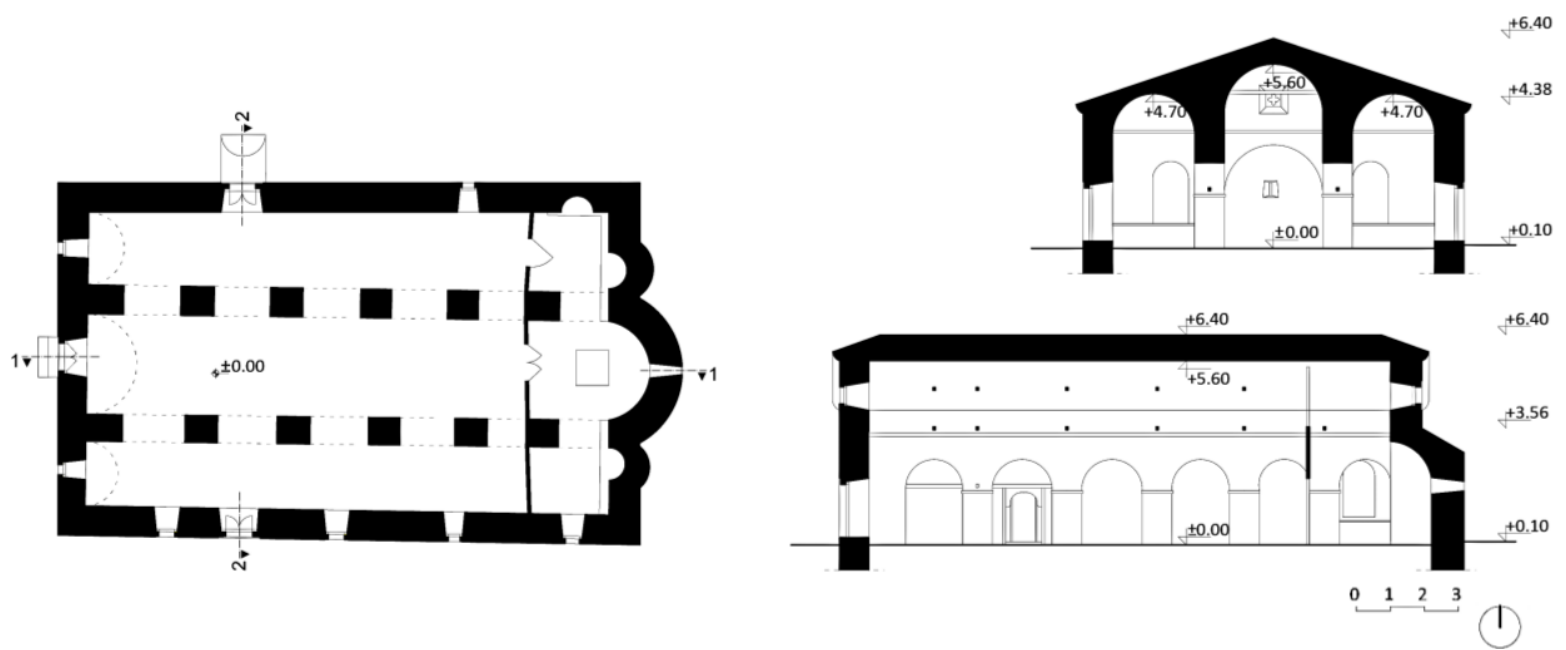

Figure I.52 Nativity of the Most Holy Mother of God in Tepavci (Mariovo). Plan ( \pm 0.00$)$, transversal section (2-2) and longitudinal section (1-1).

On the otherwise uniformly plastered façades, stand out the window frames and entrance portals made of hewn stone blocks (fig. I.53B). There are three entrance portals in a symmetrical composition: one centrally placed on the west façade and two lateral ones. This disposition of the entrance portals, as well as the stratigraphy of the facades, speak of the initial existence of open porches on all three sides, in the shape of " $U$ ", whereas today exist later added closed porches on the north and west side (fig. I.53A). Arched patron saint niches were formed above the entrance portals, with the exception of the southern one (fig. I.53B).
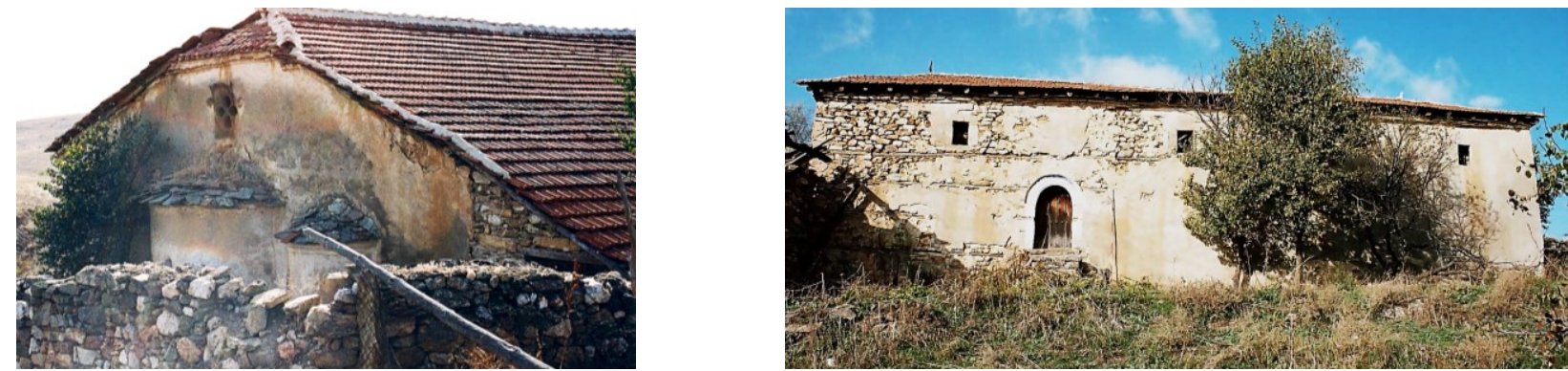

Figure I.53 Nativity of the Most Holy Mother of God in Tepavci (Mariovo). A. View from the north-east; B. Southern façade. 
The windows located high on the east and west façades received decorative stone-carved transennas shaped into a phytomorphic motif - a four-leaf clover, i.e. a cross shaped like a flower with four petals (tetraphylia or crux florida). In addition to these two decorative windows and the small single window in the altar apse, the naos of the church is illuminated via two symmetrically placed rectangular windows on the west façade, four on the south and only one on the north façade (fig. I.53).

Unlike the Revival basilicas, the church in Tepavci does not have a gallery in the western part of the naos, and it can be assumed that the gender-based segregation took place on one level, in the lateral naves, as was the case with the older, early-Christian and Byzantine basilical temples. The altar space is separated from the naos by a chancel partition, placed on the west side of the easternmost pair of pillars. Since there is no altar platform, the iconostasis lies directly on the floor. Despite the monumental dimensions of the church, the altar can be entered only through the royal doors and one side door (from the north nave to the prothesis), and there is no direct connection with the diaconicon. The iconostasis is made of wood, without relief carving, but rather with rich tinting and painted decoration. According to a preserved inscription in the lower zone, it was built in 1890, which implies that initially, during the frescopainting of the church in 1795, another iconostasis must have certainly been built, which was replaced with the existing one almost a hundred years later. Testimony to the older iconostasis are a number of damaged older icons that are displayed in the church today.
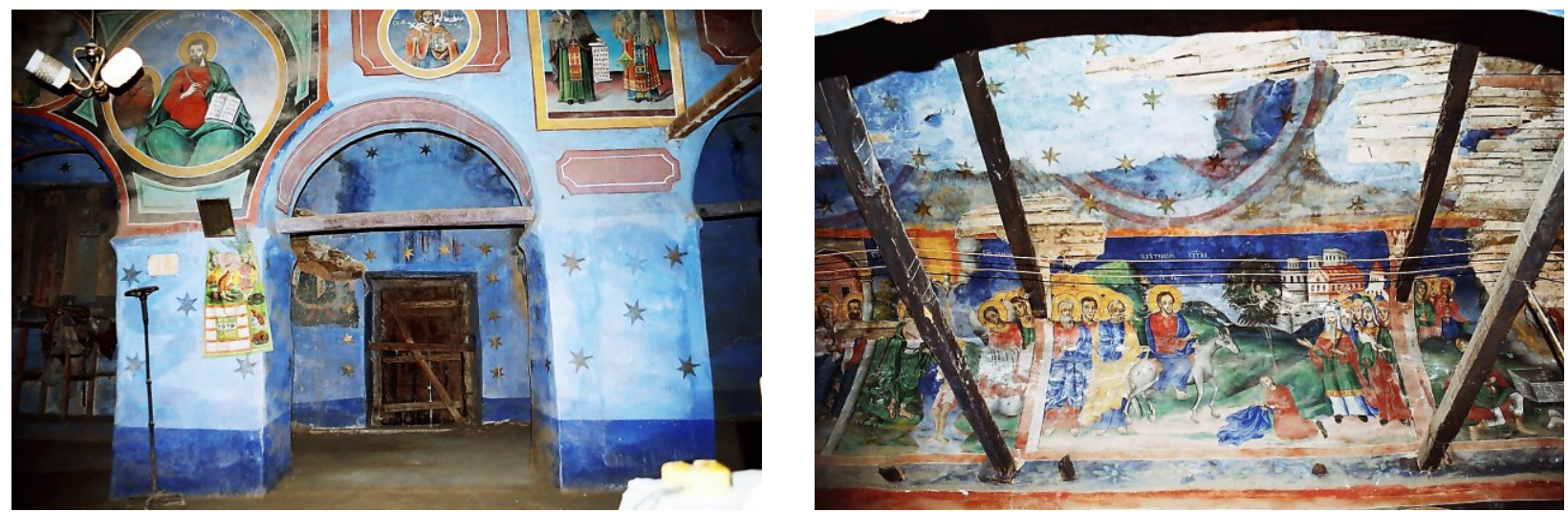

Figure I.54 Nativity of the Most Holy Mother of God in Tepavci (Mariovo). A. Detail of the southern arcade; B. Detail of the central nave vault.

The fresco-painting of the church in Tepavci was executed on two separate occasions, since at least two layers can be identified (fig. I.54): the older certainly belongs to the original painting ensemble from 1795. The two phases of the frescoes can also be recognized according to the used language/alphabet: an authentic text in Greek is left in some areas, while somewhere its subsequent covering with Slavic signatures is evident. This second painting of the church can be related to the construction of the second, newer iconostasis as part of a more comprehensive renovation of the church interior at the end of the XIX century, a hundred years after its construction and original decoration. ${ }^{117}$ Unfortunately, the painting ensemble of the church in Tepavci is very damaged: riddled by deep cracks, underlayment of the plaster, fallen fragments, especially in the vaults, where the wooden vaulted structure is exposed, often itself

\footnotetext{
117 The presence of signatures and inscriptions in two alphabets (Greek and Slavic) is primarily a result of the social conditions in the period from which the two painting phases of the church in Tepavci date. Namely, the first layer of frescoes dates precisely from the abolition of the Ohrid Archbishopric in 1767 (Снегаров, 1946: 340-341), an act which made the Patriarchate of Constantinople the competent religious institution for the region, whose official language was Greek. The second layer of frescoes, on the other hand, was introduced after the founding of the Bulgarian Exarchate Church in 1870 (Kiel, 1985: 230), which relatively quickly expanded its influence on the territory of Macedonia, including the region of Bitola (Mariovo), suppressing the Patriarchate, above all because of the use of a Slavic alphabet and language, which was close to Macedonian and understandable to the local congregation. Exactly those essential changes in the religious life are evident in the church in Tepavci, which with the change of the competent church institution received a new iconostasis and a partial fresco re-decoration.
} 
considerably dilapidated. So far, no measures have been taken for its cleaning and restoration, making it impossible to study it in full. In fact, the church in Tepavci is generally found in a very poor state of preservation (fig. I.54, I.55), which, if not intervened immediately, will soon inevitably lead to its complete demolition. Besides the institutional negligence as a basic factor, the reasons for this situation are, as in the dominant number of churches in rural areas throughout Macedonia, of demographic and social character. Namely, the village of Tepavci during the XX century was almost completely abandoned in the migration processes, ${ }^{118}$ both to neighboring towns and to distant overseas countries. As a consequence, its vernacular and religious architecture was left to complete and irreversible decay.
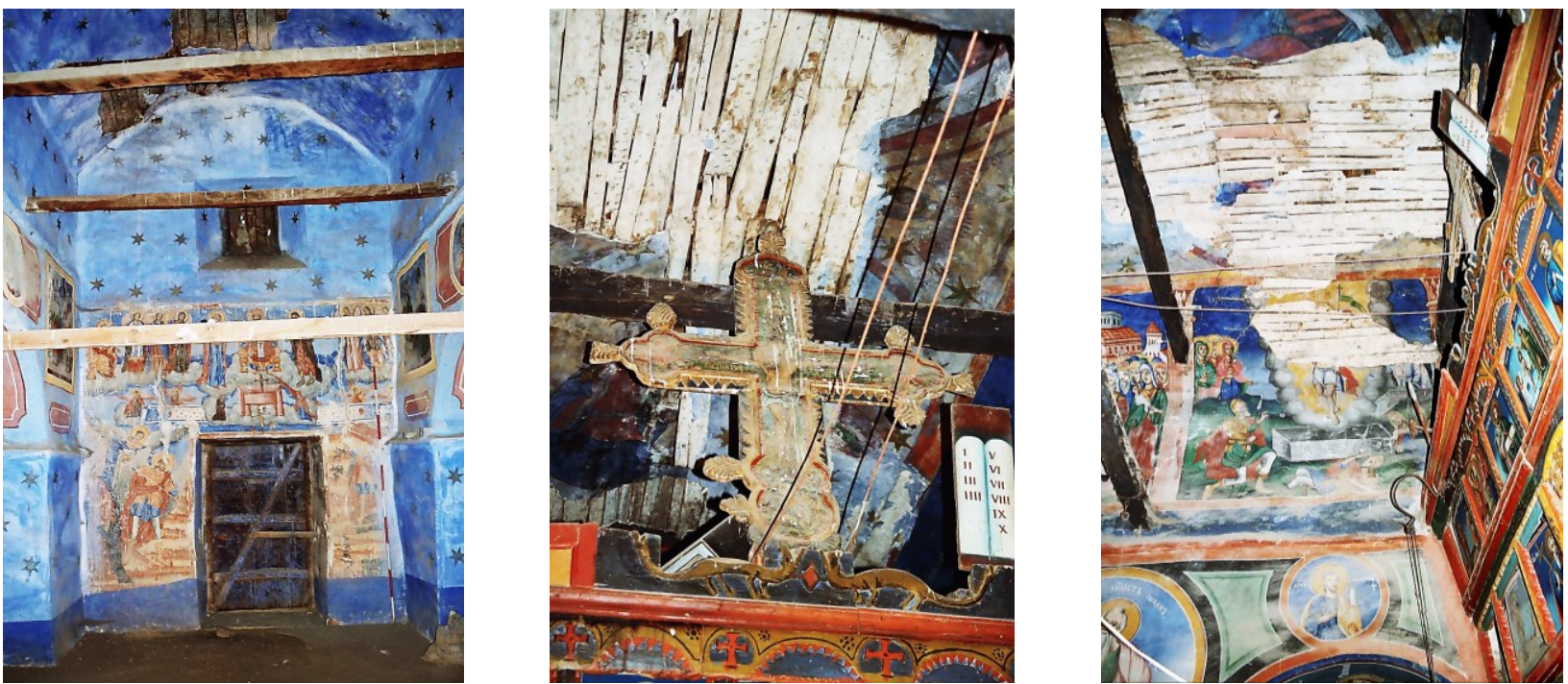

Figure I.55 Nativity of the Most Holy Mother of God in Tepavci (Mariovo). Interior details.

Comparing the church of the Nativity of the Most Holy Mother of God in Tepavci with the slightly older three-nave basilicas from the regions of Skopje and Kumanovo, it can be concluded that they share a number of common features: relatively small nave spans with very similar dimensions in all churches; uniform division of the naos into three almost equal naves, both in plan as in section; similar dimensions of the pillars and their arrangement into arcades; and similar total proportions of the temples covered by gabled roofs. However, the church in Tepavci is also distinguished by characteristic architectural elements: three semi-circular apses, ${ }^{119}$ three entrance portals with appropriate open porches that are not found in the other post-Byzantine three-nave basilicas. Thus, for its specific architecture, it is necessary to look for additional, geographically closer sources of influence, which undoubtedly contributed to the choice of this archaic solution.

It is impossible to talk about the origin of the chosen basilica in the case of the church in Tepavci without referring to the cathedral of the Ohrid Archbishopric, the church of St. Sophia in Ohrid. In the XVIII century - the period of construction of the church in Tepavci - St. Sophia had already been reconstructed and converted into a mosque (see Chapter 1.4.2). Exactly this phase of its construction history, which was available to the master-builders in the XVIII century, can be recognized in the church in Tepavci both in the shape and dimensions of the pillars and their rhythm, as well as in the connecting arches, the vaults, the triple disposition of the altar with lateral apses, as well as the covering of the entire monument with one massive gabled roof (see fig. I.25). Furthermore, certain influences may have arrived

\footnotetext{
${ }^{118}$ According to the census conducted during the previous, XX century, the number of inhabitants of Tepavci decreased from 454 in 1953, to 25 according to the last official census from 2002, to only 5 permanent residents in 2018.

${ }^{119}$ The small, three-sided apses are one of the characteristics of the churches in Mirkovci and Gluvo that connect them directly with the contemporary post-Byzantine single-nave churches, where this solution prevails. Unlike them, the church in Tepavci with its three semicircular apses was certainly composed under other influences.
} 
in Tepavci from the geographically closer church of St. Nicholas in Manastir. Its influence in the wider Mariovo region must not be neglected; both in terms of the consistent application of the unusual, archaic basilical typology, and in certain architectural elements, such as the three altar apses, the window openings with stone-carved transennas, the trapezoidal shape of the shorter façades in their upper zone etc. (see fig. 1.37, I.38). Lastly, the role of the church of the Dormition of the Most Holy Mother of God in Velushina, near Bitola, renovated at the end of the XVIII century, approximately at the same time as the construction of the church in Tepavci, should not be overlooked. It is evident that such an old and important monument influenced the architecture of later church buildings in the area, especially in periods when it itself was subject to renovation (see fig. 1.26). Although the complex internal concept of the church in Velushina may not have served as a direct inspiration for the church in Tepavci, a reminiscence of its external articulation, especially relevant to the eastern façade with three archaic exterior semicircular apses can be clearly recognized.

From all of the above it can be concluded that, although rarely, monumental three-nave basilicas continued to be built in the post-Byzantine period. The post-Byzantine basilicas from the region of Skopska Crna Gora, as well as those from the nearby Kumanovo region are two separate groups of monuments with their own local features and characteristics. The churches of Skopska Crna Gora, originally very similarly composed three-nave basilicas, testify to a mature and masterful approach in their incorporation into buildings built with Revival architecture adapted to the existing architectural typology. In the churches from the Kumanovo region, their characteristic burial purpose (Крстиќ, 2009: 203), as well as the construction on older remains contributed to the complexity of the chosen uncharacteristic solution. In both groups, their evident mutual parallels speak of possible authorship within the same master-builder groups or of building according to a model-church as a sign of belonging to a local "building school". Namely, in addition to the older Byzantine building over which the church in Strezovce was founded, the proximity and undoubted influences of the church of St. George in Staro Nagorichane should not be underestimated (Серафимова, 2008: 64). The applied typological solution, as well as certain architectural features connect them with the extremely important older basilicas from the region built in several phases, but especially in the middle-Byzantine period with its specific turn to the archaic basilica patterns after which the three-nave basilica was (seemingly) completely abandoned, in order to be "resurrected" again during the Revival. That is why the post-Byzantine three-nave basilicas are extremely important monuments, a link that connects the numerous Revival basilicas of the next, XIX century, with their middle-Byzantine and, indirectly, early-Christian antecedents; proof that the monumental basilica solutions, despite the social conditions during the Ottoman Empire, were not forgotten, but rather survived in the collective memory and continued to be nurtured as a tool for identification with the brightest epochs of the past.

In the case of the church in Tepavci, its contribution as a key link in the evolutionary development of the three-nave basilica in these territories is particularly significant: on one hand its basic architectural lexic, the archaic tone of the inner volume with heavy, massive, relatively low pillars connect it directly with the middle-Byzantine prototypes; on the other hand, the shape of the roof with characteristic trapezoidal shorter façades, the articulation of the entrance portals and the window transennas, and above all the applied material and the construction system of the false vaults directly connect it with the Revival basilicas, making it their true antecedent. 


\section{THE SOCIAL "RENAISSANCE" OF THE XIX CENTURY AND THE PROSPERITY OF THE RELIGIOUS ARCHITECTURE}

\section{II.1 Historical, Social, and Economic Circumstances in Macedonia in the XIX century}

The XIX century represents an exceptional period in history, when the process of genealogy of the nations throughout Europe reached its maximum intensity. This is the period when the European states reached a previously unimaginable leap in their transformation, creating the middle class, as well as the phenomenon of nationalism (Донев, 2013: 2097). The same process can also be traced on the Balkan Peninsula, where the Ottoman Empire gradually lost the majority of its European territories in various liberation movements, which consequently shaped new, independent countries. The predominant factor in the inevitable collapse of the Ottoman Empire was the stagnation and incommensurability of its regime: a despotic and theocratic system firmly rooted in the Middle Ages. ${ }^{120}$ It became obvious that this system as such was unsustainable: without an educated elite, industrially and agriculturally underdeveloped, socially, religiously and ethnically divided, with an exceptionally corrupt bureaucratic apparatus and lacking a developed judicial system. The whole power was concentrated in the hands of a single individual, the Sultan and, with the decline of his authority, lawlessness, internal unrest and territorial disintegration were on the rise (Ibid: 2095). Consequently, the previous, XVIII century was characterized by a state of social anarchy, which was predetermined by the weakness of the previously untouchable central governance, the insubordination and separatist tendencies of the local feudal lords, and the appearance of outlaw gangs engaging in robbery and violence (Алексиев, 2013 (А): 2188), especially from the territories of contemporary Albania, which regularly raided Macedonia. ${ }^{121}$

In addition to the imminent internal collapse, the Ottoman Empire was also faced with significant external pressure. Namely, since the middle of the XVII century, it was almost constantly at war. Beside the Austro-Turkish war of 1683-1699, which stopped the Ottoman Empire's expansion to the north and west and established its borders along the Danube River, the Ottomans were faced with a new opponent,

\footnotetext{
${ }^{120}$ Namely, the Ottoman Empire and the Russion Tsardom were the last feudal states in Europe, preserved as such almost into the $X X$ century.

${ }^{121}$ Several official documents - Sultan's fermans and correspondence - dated between 1799-1803, inform that the Sultan intended to stop this by closing all passages from Albania into Macedonia (Турски документи..., 1951: 11-13; 19-21; 83-85; 113; 121-126), but not even the enforced control and permitted use of force were sufficient to deter violence and lawlessness.
} 
the Russian Tsardom. Namely, considering itself as the heir to Byzantium, so-called "Third Rome" (after the Ottoman conquest of Constantinople in 1453 A.D.) and sole guardian and protector of Orthodox Christianity in Europe (Донев, 2013: 2101), Russia began a series of military actions against the Ottoman, primarily focused on the Balkan and Crimean Peninsulas as liminal areas between the two Empires (fig. II.1). Thus, up to the beginning of the XX century and the final demise of the Ottoman Empire, Russia and Turkey were at war in 1686-1699, 1710-1711, 1735-1739, 1768-1774, 1787-1792, 1806-1812, 1828-1829, the Crimean War of 1853-1856 and in 1877-1878 (Figes, 2010: 10). This almost continuous state of war predetermined the intense economic exploitation of the autochthonous non-Turkish population, worsening their already harsh life conditions, which inevitably led to various forms of resistance, gradually channeled into a series of liberation uprisings.

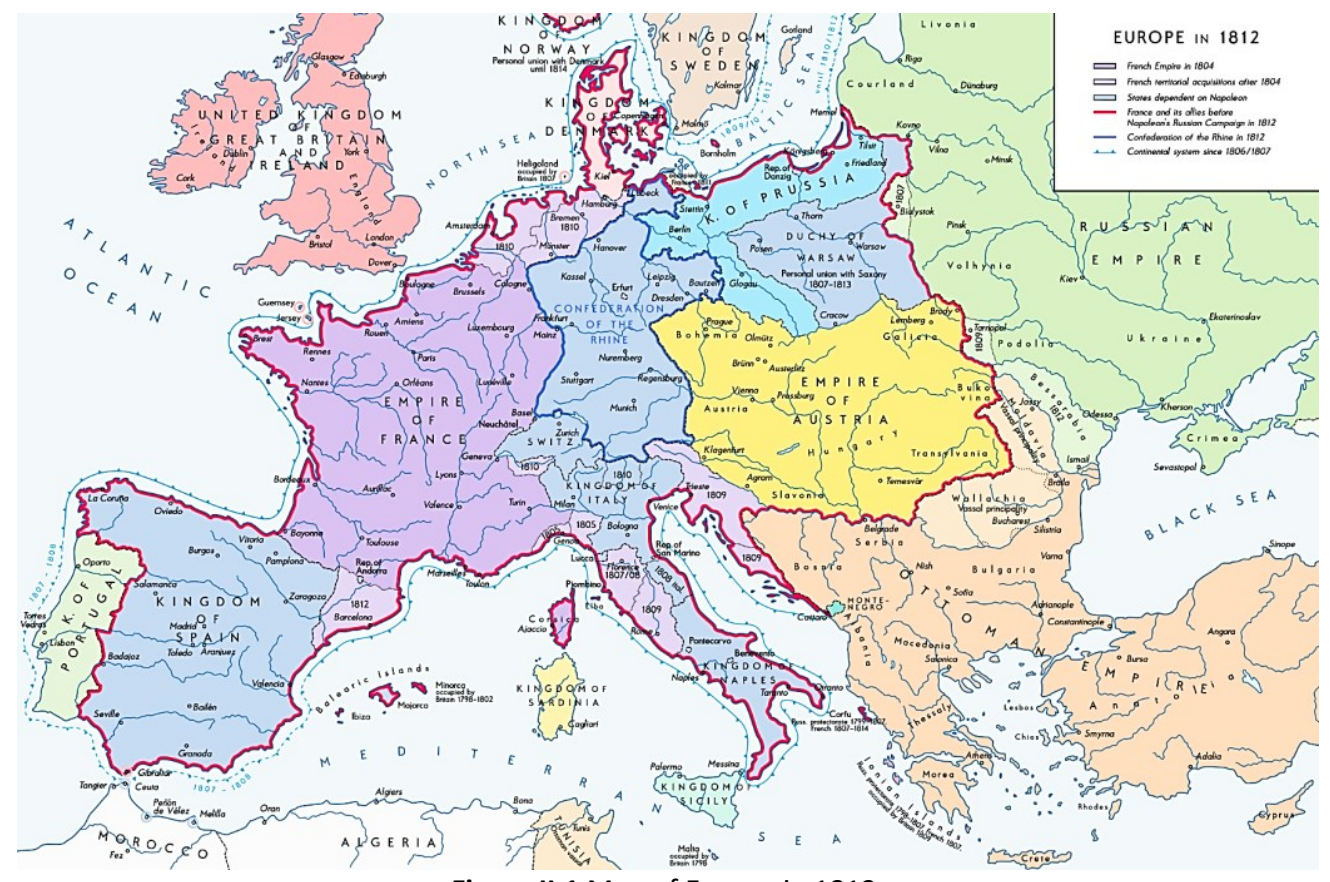

Figure II.1 Map of Europe in 1812.

In addition to the military activities, Russia was intensely engaged in financing and supporting the liberation movements on the Balkans, led by the idea of Pan-Slavism and the union of all Orthodox Christians into one state under its leadership. Namely, the majority of the non-Islamic population of the Ottoman Empire was composed of Orthodox Christians, approximately 10 million inhabitants (Ibid: 2728). The population of the Ottoman Empire was administratively divided into so-called millets, based on their religious beliefs. Thus, until the 1870s, the Orthodox Christian population was grouped into a single millet: Millet-I Rum or the Roman millet (people), the name of which points to the previous long-standing ruler of the region: Byzantium, which considered itself a direct heir to Rome (Brown, 1971: 42). Hence, the European territory of the Ottoman Empire was known as Rumelia. ${ }^{122}$ Placing the entire Orthodox population into one millet, regardless of their ethnic diversity, enabled centralized control of the religious and, to a great extent, the secular life of this population. The control was placed in the hands of the Constantinople Patriarchate, as an informal ruler of the Christian subjects of the Empire (Донев, 2013: 2099-2100), on Macedonia's territory especially after the abolition of the independent autocephalous church - the Ohrid Archbishopric in 1767. During the second quarter of the XIX century, the Bulgarian and Serbian national churches gradually enlarged the scope of their influence, decreasing the power of the Constantinople Patriarchate, which was dominated by the Greeks. The Greek domination of Orthodox

\footnotetext{
122 Rumelia - Rumeli - “Roman Land” (“Турски документи за македонската историја 1800-1803”, 1951: 11).
} 
affairs, including the education and the judiciary system, was unacceptable to many Slavs, who increasingly turned to their Churches in search of national identity and leadership against the Turks. Nationalism was a powerful force for the various groups of Balkan Christians who, united on the basis of their language, culture and religion, fought for independence from Ottoman control. The Serbs were the first to achieve liberation, mediated by Russia, which financed the uprisings between 1804 and 1817, prompting Turkey to recognize Serbian autonomy and establish the Kingdom of Serbia with its own constitution and parliament, led by the Obrenović dynasty (Figes, 2010: 29). On the other hand, England and France directly contributed to the formation of the Greek state in 1830 , in the extreme south of the peninsula, after which the Patriarchate of Istanbul became the official Greek Church that protected and propagated Greek political interests, imposing the Greek language and culture on the vast territory of its diocese. Furthermore, the Russian Empire, in accordance with its program to support Orthodox Christianity, continued its work on the process of creating a Bulgarian nation (Донев, 2013: 2102), an independent church - the Bulgarian Exarchate (in 1870) and lastly, independent Bulgarian state (in 1878). After that, intense work was done on its dissemination in a wider area through the establishment of schools and liturgy in Bulgarian, a Slavic language. The formation of independent churches by the newly-established states resulted in the segregation of the Millet-i Rum (fig. II.2), since orthodoxy lost "its universal significance, is fragmented on a linguistic basis and enters a higher stage of ethnic mobilization with a Slavic or anti-Greek dimension" (Ibid) which further weakened the Ottoman rule on the Balkan Peninsula. The weakness of the

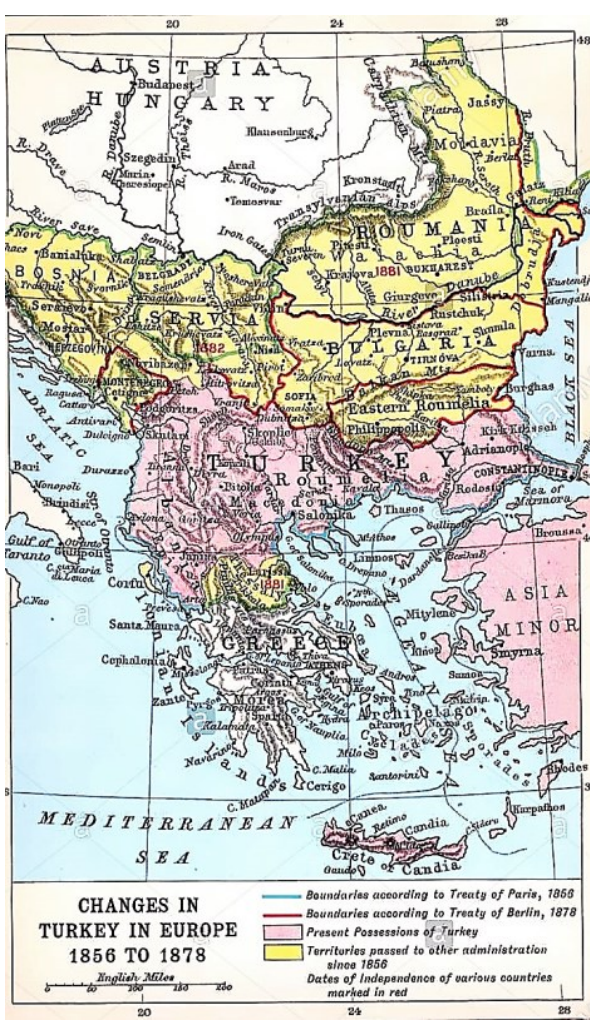

Figure II.2 Map of the Ottoman Empire and the new independent states on the Balkans.

Ottoman Empire was such that its complete collapse in the remaining Balkan territories seemed only a matter of time. ${ }^{123}$

In those conditions, "only a combination of external circumstances keeps the Empire from complete disintegration" (Ibid: 2096). As it weakened to the point of imminent collapse, the great powers frequently intervened in its internal relations - ostensibly in order to protect the Christian minorities, but in fact with their own ambitions and goals (Figes, 2010: 31). Namely, the Western European countries insisted on prolonging the established borders as much as possible, thus maintaining the Ottoman Empire as a counterweight to the growing Russian state. Under their strong diplomatic pressure, the Porte will be forced to agree to fundamental social reforms i.e. liberalization and Europeanization of the state in search of economic modernization (Figes, 2010: 25). These reforms are known as the Tanzimat reforms. The reformation movement was initiated by Sultan Selim III (1789-1807) who intended, introducing the socalled "new order" (Nizam-i Çedid), to implement centralization in order to strengthen the shattered authority of the government through reorganization and modernization of the military forces according to the Western European model (Алексиев, 2013 (A): 2188). More serious efforts in the reformist

\footnotetext{
123 Namely, in 1857 the territory of Montenegro was defined; in 1861 Wallachia and Moldavia were united in the independent principality of Romania (Ѓорѓnев, 2013: 1925). The "Great Eastern Crisis" (1875-1878) followed, beginning with the liberation uprisings in Bosnia and Herzegovina in 1875, in Bulgaria in 1876, and in Macedonia in 1876 and 1878, culminating in the RussoTurkish War of 1877-1878, which prompted the subsequent creation of the Montenegrin and Bulgarian states. Thus, at the end of the century, thanks to political decisions, from the large European territories that it ruled in the past, the Ottoman Empire managed to keep only Macedonia, Albania and Kosovo under its control.
} 
direction were taken by his successor, Sultan Mahmud II (1808-1839). In 1826, after the abolition of the Janissary Military Corps whose uncontrolled power and expressed arbitrariness was one of the reasons for the weakening of the Empire's central government, the Sultan established a regular army, which practically abolished the feudal system (Ѓорѓnев, 2013: 1916). Then, the modernization of the state began, through agrarian and administrative reforms, opening to Western European capital, as well as raising the level of education, especially among the ruling elite (Донев, 2013: 2097).

The entire reign of his successor, Sultan Abdul Majid (1839-1861), was subject to reforms that would culminate after his death with the formation of the first Ottoman Parliament in 1876. Immediately after his enthronement, at the age of barely 16, Sultan Abdul Majid would issue an extremely important document: the Sultan's edict Hatt-i Sharif, proclaimed in Gülhane in 1839 (fig. II.3). The document itself is the work of Minister Mustafa Rashid Pasha, the Sultan's chief reformer, written under significant influence of England and its diplomats. The Gülhane Hatt-i Sharif affirmed the Tanzimat reforms and the thorough reorganization of the Empire, proclaiming the equality of all citizens of the Empire, regardless of their ethnicity or confessional denomination. It guaranteed the right to life, honor and property of all the subjects of the Sultan, regardless of their religious affiliation; guaranteed the rule of law, religious tolerance, the modernization of the institutions, as well as an honest and rational centralized tax system and military service (Figes, 2010: 56-58). Also, this act facilitated the activities of the independent churchschool communities (Ѓорѓnев, 2013: 1917), as the only form of self-organization of the Macedonian Christian population, i.e. anti-Patriarchal, and thus anti-Greek movement.

However, this attempt to transform the existing system of the Ottoman Empire and bring it closer to the modern model of European capitalist states fell short, because it was "not based on the social reality" (Алексиев, 2013 (А): 2188) and as such encountered a strong resistance among the Turkish population. Despite the will for fundamental transformation manifested by the Ottoman Court, the Christians continued to be treated as second-class citizens. Pressure to correct this reality by the Western European powers, and especially by Russia, which sought moral compensation for its losses in the recently-concluded Crimean War, resulted in the issuance of another decree by the court of Sultan Abdul Majid in 1856: the Hatt-i Hümayun (known as the "Second Tanzimat") which deepened the proclaimed rights and freedoms given by the Hatt-i Sharif. The decree promised religious and legal equality to all nonMuslim subjects of the Empire meaning that, for the first time, the rights of the Muslim and Christian populations were equalized. The decree also gave Christians the right to property and free entry into the military and administrative service of the State on a merit-based system (Figes, 2010: 414-415). Furthermore, the Hatt-i Hümayun introduced new political principles imposed by the British lobby, which re-emerged as the true author of the decree, this time even without the mediation of Ottoman reformers: an annual government budget, a codification of criminal and civil law, a system of progressive taxation of all subjects of the Empire, a reform of the Turkish prisons and ethnically-mixed courts to oversee disputes involving the Muslim and non-Muslim populations. Also, this decree enabled the establishment of a banking system, as well as the right of foreign citizens to own property in the Empire, which enabled the development of capitalist relations and the inflow of foreign capital into the country (Ѓор́́neв, 2013: 1917). The second decree of the Tanzimat reforms was, in fact, the result of a thorough program of "westernization" of the Ottoman Empire. ${ }^{124}$

\footnotetext{
124 In almost every aspect of life, the Crimean War and its aftermath enabled a reversal and opening of Turkish society to Western European influences. The mass influx of refugees from the Russian Empire is just one of the ways in which the Ottoman state became more exposed to external influence. The Crimean War brought new ideas and technologies to the Ottoman traditional world, accelerating the country's integration into the global economy, and greatly increasing Turkey's foreign contacts. More Europeans stayed in Constantinople during and immediately after the Crimean War than at any time in its history: diplomats, financiers, military advisers and soldiers, engineers, tourists, merchants, religious missionaries and priests, leaving a deep
} 


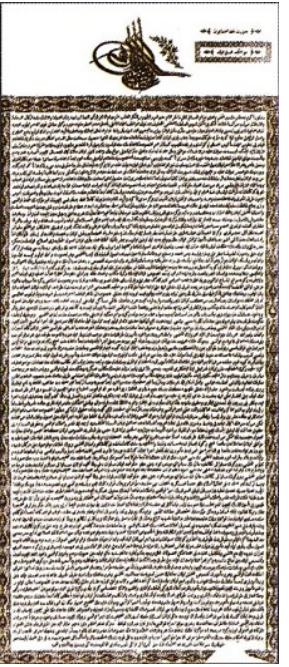

Figure II.3 A. The Gülhane Hatt-i Sharif of 1839; B. Ottoman Legislation published in 1874; C. Illustration of the proclamation

\section{LEGLISLATION OTTOMIINE, \\ Recueil des lois, réglements, ordonnannces, trailés, capitulations el autres documents officiels \\ DE L'EMPIRE OTTOMAN}

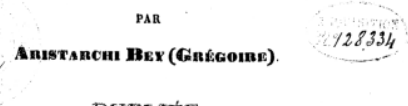

UBL.IÉE

PAB

DEMÉTRIUS NICOLAIDES

Dire teerr.tilitear da jornal Throbty.

DEUXIĖME PARTIE.

Droit Publie Intérieur.

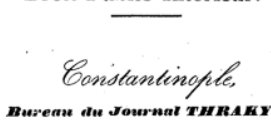

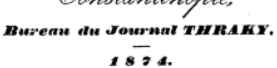

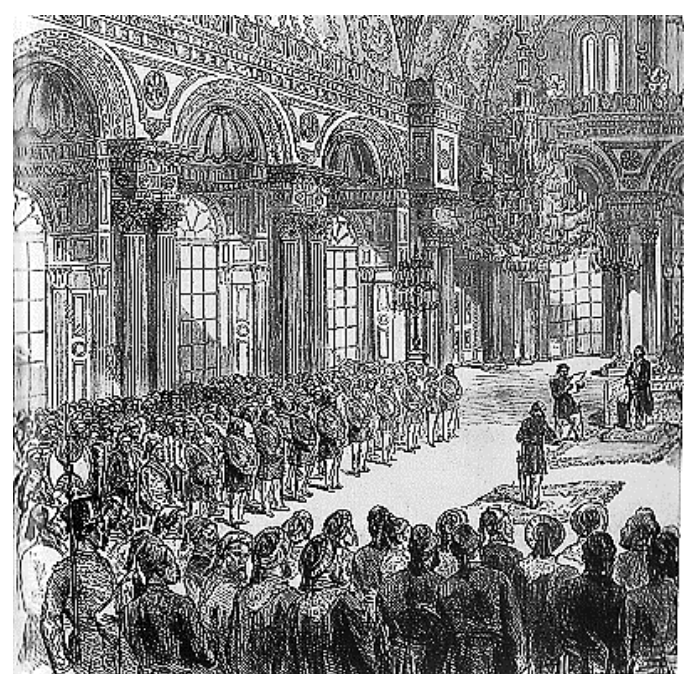
of the first Ottoman Parliament in 1876.

Macedonia, despite many years of riots, uprisings and liberation movements, frequent especially in the XVII-XVIII century, formally existed within the Ottoman Empire ${ }^{125}$ until the Balkan Wars (1912-1914). Due to its geostrategic position, it "will remain the last desperately defended territory, because its loss for the Empire means the loss of the entire Balkan Peninsula" (Алексиев, 2013 (A): 2185). Thus, in Macedonia in the XIX century there remains an apparent political status-quo. With the gradual implementation of the reforms and its organization as an important military-political region for the defense of the Empire in the 1830s, a period of relative stability occurs. In fact, significant social, economic and cultural transformation is noticeable throughout Macedonia. For the Macedonian population, the reforms of the Ottoman state apparatus implemented in the first half of the XIX century presented a new opportunity for education (to which end numerous schools were established and built ${ }^{126}$ and textbooks were printed in Macedonian); liberty to practice the Christian ritual and thus the renewal and construction of church temples; liberty of displacement, etc. Namely, as a result of centuries of Ottoman rule the Macedonian towns were previously inhabited mainly by Muslims and were strongholds of the Turkish government, while Christians lived in rural areas in administrative and economic subordination. The freedom of displacement caused an important influx of Christian rural population to the urban settlements resulting in a significant demographic change. The urban population soon multiplied: in Bitola (from 8,000 to 40,000 inhabitants), Ohrid (from 3,000 to 11,000 inhabitants), Veles (from 5,000 to 20,000 inhabitants), Skopje (from 15,000 to 32,000 inhabitants), etc. (Намичев и Намичева, 2013: 78).

The change in the composition of the urban population in favor of the Macedonian element contributed towards a complete urban transformation, both in appearance as well as character. Namely, in the urban areas, the development of handicraft production was gaining momentum. Economic power traditionally concentrated in the hands of the Sultan and the ruling elite was now partially dispersed

impression on Ottoman society. The War also led to widespread expansion of foreign capital and investment in the Empire, and thus an increase in Turkish financial dependence on Western European banks and governments. Namely, foreign loans to finance the Crimean War and the Tanzimat reforms grew from approximately 5 million in 1855 to a staggering 200 million pounds by 1877. The financial support stimulated the infrastructural development of the country, through the construction of roads, telegraph and railway (Figes, 2010: 427-428).

125 As confirmed by the Berlin Peace Congress of 1878, held after the Russo-Turkish War of 1877-1878.

126 The first schools were built with the efforts of the local church-school communities, usually within the churchyard or in the immediate vicinity. As an example, in the yard of the newly built church of the Most Holy Mother of God in Skopje (finished in 1835), as soon as in 1839 a school building was erected; in Prilep in 1843 a school was built near the cathedral St. Annunciation (dating from 1838), etc. Towards the middle of the century, the first secular schools in the Macedonian language were opened, first in Ohrid (in 1840), and then in other towns and villages throughout Macedonia. The definitive substitution of the Greek language with the Macedonian followed in 1869 (Кировска, 1999: 36-37). 
among the local population, including the Christians, especially among the manufacturing class, organized in appropriate guilds and primitive unions (Tchipan, 1989: 251-252). The increased production of handicrafts and agricultural products, as well as the improvement of the infrastructure network ${ }^{127}$ throughout the provinces and the establishment of contacts in and outside of the Empire constituted the basis for rapid development of an intensive internal and external trade. The rapid economic growth of the towns, turned into economic centers where the Macedonian Christian population suddenly became dominant in number, enabled the formation of a Macedonian citizen class, which bore the socio-economic and educational-cultural life of the Macedonian people (Алексиев, 2013 (A): 2189). ${ }^{128}$ Along with the rise of the urban Christian population, the process of opening the market to Europe began, and thus the improvement of the production and the development of a proto-industry. Trade ties and contacts with Europe caused drastic changes in the overall urban life, which rose to a significantly higher level. ${ }^{129}$ Economic prosperity led to the creation of a trade aristocracy, and the artisan guilds ${ }^{130}$ came to significantly influence all aspects of social and political life (Хаџиева-Алексиевска и Касапова, 2001: 6).

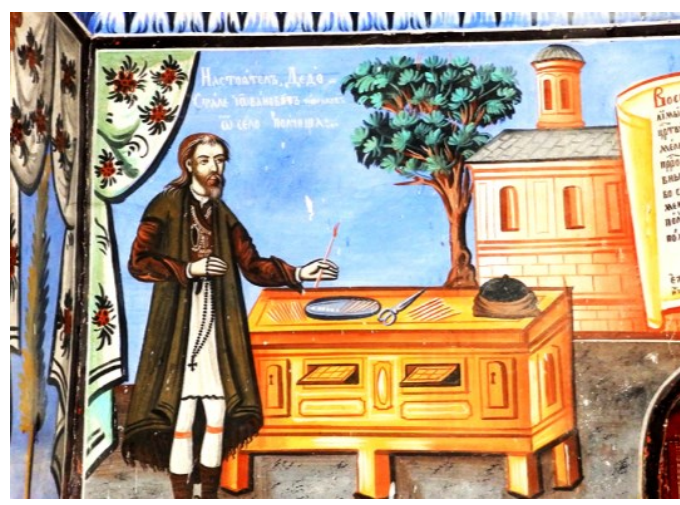

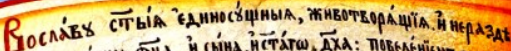

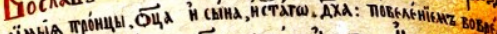

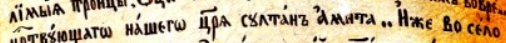

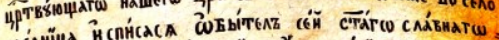
MénHïд H

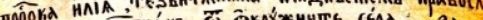
"R

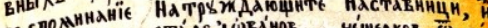

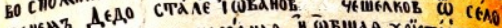

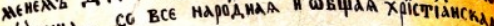

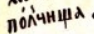

nómo $4^{\mathrm{th}}$

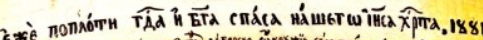

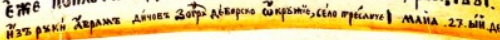

Figure II.4 Portrait of Stale Cheshelkov, founder of the monastery of St. Elijah in Melnica (Mariovo) and the founder's inscription, painted by Avram Dichov.
As a result of these social and economic changes, in the Revival the towns underwent a comprehensive urban transformation realized through intense construction activity of both profane and sacral content. Until the Tanzimat reforms, social life in the Ottoman Empire "took place in a closed circle of Muslim egocentrism and the distant tradition of the Orient. Without public social institutions, life is limited to the intimate circle of the private house" (Чипан, 2000 (В): 27). Namely, during the Ottoman occupation, Christians were forbidden to visit public places (restaurants, bars, baths); thus their entire socialization within the community took place in their homes (Грабријан, 2000: 22), or in the local church, where they gathered on major religious holidays. Consequently, it may come as no surprise that the Christian population, hitherto completely excluded from social processes and events, manifested the newly acquired rights, freedoms and material power primarily through two building lines: on one hand through the construction of residential architecture, and on the other through churches, which in the past centuries were the

\footnotetext{
127 In 1860 a new road network was established connecting the major towns, as well as the first telegraph line between Skopje and Prishtina, connected via Belgrade to the rest of Europe. In 1873, the first railway line Thessaloniki-Skopje-Kosovska Mitrovica was finished (Донев, 2013: 2105).

${ }^{128}$ As an illustration, the respectable Robev family from Ohrid in the middle of the XIX century took on the role of "patron" of the cultural life in the town, similar to the Renaissance families in Italy. They commisioned the most famous Revival architects and artists, finansing "almost all church and school endeavors in the town, as well as the prominent intellectuals" (Грозданов, 2004: 236). The first secular primary school, built in the town in 1840 was their donation; a few years later, between 1845 and 1850 , Ohrid will also receive a secondary school (Ibid: 273-274).

129 In the comprehensive process of "westernization" of the Ottoman Empire, domestic culture also changed, adopting European manners, cutlery, clothing and fashion (known as "a-la-franca"), furniture and decorative items in the homes of the Ottoman elites in Constantinople, a tendency that gradually spread to both the provincial regions and among the non-Muslim population. 130 In fact, the craftsmen in the urban areas of the Byzantine Empire were united in guilds, "solid organizations that completely regulate their production" (Бошковић, 1967: 106). Architecture as a craft was subject to the same rules, and the system of work in hierarchically organized master-builder groups, which will culminate during the Revival (see Chapter II.3), was established much earlier, under the Byzantine Empire.
} 
only place of public domain for the Christian resident of the Ottoman Empire. The attitude towards culture, education, architecture and arts changed, as did the aesthetics in the perception of the ordinary citizen who, for the first time, appeared in the role of a founder of monumental profane and sacral architecture (fig. II.4).

In addition to architecture and urbanism, the XIX century marked a Revival in all other spheres of the spiritual and cultural life of the Macedonians. The economic prosperity of the citizens directly contributed to the formation of the Macedonian Christian intellectual class, educated mainly in the Balkan centers (Thessaloniki, Sofia, Belgrade, Bucharest, Zagreb), but often also in European capitals (Vienna, Leipzig, Budapest, Moscow). In these centers, the Macedonian Diaspora was organized in various clubs and cultural societies, which nurtured the Macedonian national thought, primarily through the publishing of newspapers and magazines. These associations of the young Macedonian intelligence are in fact the beginning of the organized national liberation movement of the Macedonians whose basic demands were recognition of the nation, literary language and culture, political autonomy and an independent church the renewal of the Ohrid Archbishopric, as well as an autonomous secular education (Алексиев, 2013 (A): 2213). Thus, the cultural and educational struggle slowly turned into a national liberation one, and the national aspirations culminated in the revolutionary uprisings of the last quarter of the century: the Razlovci (1876), Kresna (1878) and llinden uprisings (1903) which will herald the end and the collapse of the occupying Empire, that followed less than a decade later, in the Balkan Wars (1912-1913).

\section{II.2 Origin and Influences of the Revival Religious Architecture}

The social development during the XIX century Revival inevitably resulted in a renaissance in all spheres of social activity: in architecture, crafts, education, arts, music, literature, etc. Therefore, it can be freely said that the material and spiritual culture of the Macedonian people reached a zenith of sorts in the XIX century. The past centuries, filled with struggles and various conquests, did not leave the opportunity to fully express the folk genius. For generations, repressed creativity erupted where it had the opportunity - in textile ornamentation, vernacular architecture, folklore, crafts, as well as in iconography, woodcarving and sacral architecture within the imposed limitations. After the Turkish Empire changed its attitude towards the subjugated peoples, the accumulated experiences resulted in a remarkable construction boom. The application of, on one hand, the long-established experiences in working with local materials, as well as the for centuries known construction systems and techniques and, on the other hand, the exposure to completely different architectural concepts ${ }^{131}$ as a result of increased movement across Europe and the intensification of labor migration, ${ }^{132}$ enabled the architects who worked

\footnotetext{
131 In this context is the reception of influences from Western European architecture and art, starting from the XVIII century, which was known with the term "Levantine Baroque". The new style had the most striking expression in the Islamic profane architecture, in the 'copying' of the architectural plans for the construction, interior and exterior arrangement of the palaces of the Turkish aristocracy after the French court palaces. The decoration of painted or embossed ornaments, stylistically elaborated according to the French applied decorative art from the Baroque and Rococo period (Ampire, Biedermeier, Neo-Renaissance, etc.), also entered the sacred buildings - the mosques. The centers through which Western European artistic influences spread in Ottoman art were Constantinople and the Aegean and Mediterranean coasts - the main trade points connecting Turkey with Europe, but the influence also came through the direct participation of invited foreign master-builders, artists, decorators (Тричковска, 2008: 33). All these influences, of course, did not simply pass by the Christian inhabitants of the Empire.

${ }^{132}$ As an illustration, the Macedonian master-builders who worked at the residence of Prince Milosh in Kragujevac, immediately after the declaration of independence of Serbia, had the opportunity to meet master Antonie "Talian", who worked on the ceilings in stucco "because that skill was not known to the locals masters". Furthermore, according to historical sources, in the new Serbian state, in addition to the Macedonian master-builder groups and local builders, Italian, Austrian and German masters, stonemasons, carpenters, painters and the like worked in parallel (Светиева, 1992: 77-78).
} 
during the Revival to develop a "brand new, unique, logically shaped, deeply humane and highly aestheticized architecture" (Томовски, 1973: 272-273).

The Macedonian Revival churches are a typologically separate group of monuments, built in a period of very specific political and economic conditions. The reforms of the Ottoman state administration, which were felt even before the proclamation of the Gülhane Hatt-i Sharif, enabled the construction of monumental cathedrals in the larger and more important towns as early as the first decades of the century, especially in the 1830s. In those ten years, new town cathedrals were built in Bitola (St. Demetrius, 1830), Skopje (the Most Holy Mother of God, 1835), Struga (St. George, 1835), Prilep (St. Annunciation, 1838), Ohrid (St. George, 1838 and the Dormition of the Most Holy Mother of God Kamensko, 1839) and Veles, immediately after the Hatt-i Sharif (St. Panteleimon, 1840). To allow the construction of a Christian temple in an urban area, it was necessary to carry out a long and complex procedure that required organizational skills and a lot of finances. To this aim, the Christian guilds and the merchant aristocracy which, unlike previous epochs, became major investors in the renovation, construction, decoration and equipping of the Christian temples, ${ }^{133}$ founded the so-called "churcheducational communities", which were engaged in collecting voluntary contributions and donations, providing land for the construction of the church temple (the so-called $W^{\prime}$ kaf land) by buying out houses from Christian families, thus clearing a plot for construction. Then, to obtain a building permit (a ferman) issued by the Sultan, one had to go as far as Constantinople, for which purpose the church communities sent a delegation that stayed in the capital for a significant time, even up to several months. ${ }^{134}$ After obtaining the permit and the collected funds, usually with contributions from the entire local Christian population, construction could begin.

In the churches built in the villages, where the Christian population dominated and the state control was less pronounced, the procedure was somewhat easier, and the restrictions were somewhat more flexible. In addition to providing material resources intended for the master-builder group, the villagers themselves actively participated in the construction, clearing the terrain, providing necessary building material, additional labor, transport with cargo animals (Пандевски и Стоев-Трнката, 1969: 157) and so on, which may explain the construction of an incredibly large number of churches in a relatively short period of time (Томовски, 1970: 19). Despite the limitations in height and spatial plasticity, the village churches are focal points, the most monumental and most emblematic buildings in the villages around which the residential agglomerations develop. In terms of limited size and simple geometric purity of the exterior of the church buildings, to some extent an exception are the monastic catholicons, where Turkish control was least pronounced, and which were built mostly in mountainous and remote locations, based on solid, centuries-old unchanged architectural traditions regarding the conceptualization of monastic church typologies.

During the XIX century, hundreds of monumental churches will be built throughout Macedonia, both in the important urban centers and in the rural areas. ${ }^{135}$ The great demand for construction and

\footnotetext{
133 That the guilds appear as one of the main founders of the cathedral churches in the urban areas is evidenced by inscriptions, preserved primarily on the donated icons and various other church objects. Such an example is the iconostasis of the cathedral church of St. Annunciation in Prilep, whose throne icons were donated by the various guilds that existed in the town: the icon of st. Athanasius by the scale-makers and blacksmiths' guilds; st. Spiridon by the saddle-makers' guild; st. Tryphon by the gardeners' guild; the Council of the Holy Apostles by the tailors' guild; Resurrection of Lazarus by the atlases' guild and st. Charalampius by the caldron-makers' guild (Ќорнаков, 2016: 113). Another example is the cathedral church of St. Trinity in Vranje, Serbia, where the large throne icons painted by the Macedonian paintor Dicho Zograf in 1859-1860, in addition to certain prominent town folk, were commissioned by the slipper-makers', dyers', rope-makers', grocers' and hospitality guilds (Томовски, 1967: 20-23).

${ }^{134}$ For example, a delegation sent by the prominent citizens and craftsmen from Prilep, led by the town leader Hadzi-Riste Logotet, stayed in Istanbul for 3-4 months in 1835, waiting for the royal decree to build the town cathedral church of St. Annunciation (Ќорнаков, 2016: 105-106).

135 According to the extensive research undertaken for the needs of this doctoral dissertation, $\mathbf{8 0 4}$ Revival churches, newly built or renovated, have been registered on the territory of Macedonia. To this number should be added churches that no longer exist,
} 
renovation of sacred buildings, as well as the new and hitherto unknown social conditions caused the Revival architects to face a significant challenge: what kind of architecture to build? Which style to choose? To make an attempt for continuity with the post-Byzantine sacred architecture, built during the centuries of Turkish occupation and, consequently, more modest in nature? Or to look back at the glorious past of Byzantium, in itself a typical phenomenon for the romantic historicism intrinsic of the XIX century? In that direction, Jovan Donev will conclude: "in the era of romantic nationalism, it was inevitable to search for the past, to rediscover and retell it. To seek historical or quasi-historical arguments for inciting nationalism, in order to create own nations and states. The Balkan peoples, in this sense, were no exception" (Донев, 2013: 2116). Thus, for the new architecture, it is natural that the models were sought among the existing (primarily Byzantine and post-Byzantine) monuments in Macedonia, as a retrospective of the construction of the past, based on continuity of the building traditions. ${ }^{136}$

However, the specific constellation of the XIX century, the fluidity of the borders, the newly acclaimed rights and freedoms, the growing intensity of movement across Europe, the modernization and industrialization of the society, and the strong established trade ties must not be overlooked. Thus, the architects could have chosen the exact opposite direction: to recognize contemporary European architecture as the most adequate to overcome this new challenge. After all, both the clients and the master-builders already had direct contact with Europe. Namely, as was the case with the fresco and icon painters with their painting manuals (called erminias), the master-builders also used literature available at that time ${ }^{137}$ through which, as well as through direct contact enabled by migrant labor, they drew experiences from Western European architectural styles: Renaissance, Baroque and Rococo, French Empire, Classicism, and even older styles such as the Romanesque and Gothic, upgrading their knowledge of the Byzantine and post-Byzantine, Islamic, as well as the traditional profane and vernacular architecture that surrounded them. ${ }^{138}$ Therefore, their understanding of beauty, their attitude towards architecture and art changed, creating "conditions for liberation from the medieval canonical traditions in the conceptualization of architecture" (Хаџиева-Алексиевска и Касапова, 2001: 6).

\footnotetext{
i.e. that were completely destroyed or reconstructed from the ground up, as well as churches that, due to inaccessibility or complete displacement of the region's population, are not found in any official records. Thus, as expected, the total number of churches built during the Revival is even greater.

${ }^{136}$ Krum Tomovski, analyzing the monumental Christian architecture in the region of Prespa in the long time span from the $\mathrm{X}$ to the XIX century, will write: "the elongated type of plans, i.e. single-nave and three-nave basilical plans prevail in this area, while central solutions, for example buildings with an inscribed cross, or radially solved plans, for example trefoil buildings are less common. Thus, we come across buildings, in large numbers, designed as single-nave churches (...) This type of plans, in Prespa, we actually follow in a very long period of time from the XII to the XX century" (Томовски, 1970: 6).

${ }^{137}$ Asen Vasiliev cites a very important fact that in the archive materials of the famous master-builder family Renzovi-Damjanovi, kept by their descendant - the paintor Gjorgji Zografski, among other literature there was an Italian edition illustrated in detail with drawings of different styles, published in the first half of the XIX century (Василиев, 1965: 158). Although the cover was missing, Vasiliev cited the preface in its entirety, in its original Italian. Based on this preface, it can be concluded that it was edited by Giuseppe Vallardi (1784-1861) who, together with his brother Pietro (1770-1819), ran a publishing house dedicated to art publications in Milan, Italy, founded in 1812 under the name "Fratelli Vallardi". The Renzovi-Damjanovi's archive also included a Russian edition - Литография А. В. Малюкова въ Москвъ - with drawings of plans and façades of various, primarily Russian buildings and wooden houses (Ibid: 176).

138 In this sense, the openness of the Ottoman Empire to different cultures and styles, both from the Orient and Western Europe, must not be overlooked. Namely, at the very end of the XV century, after the persecution of 1492, there was a mass influx of Spanish Jews and their subsequent settlement throughout the Empire, especially in the coastal cities - Constantinople and Thessaloniki, but also inland. On the territory of today's Macedonia, a significant concentration of Jewish population was established in Bitola, Skopje, Shtip and other towns, where they were primarily engaged in trade, but also in other crafts, especially weaving and textile production. Thus, domesticated terms in the Macedonian language, as far as textile production is concerned, are in fact often derivatives of the Ladino language or of Spanish origin (Светиева, 1992: 30). In their new settlements, the Jews built isolated, fortified ghettos, where houses (described by travelogue writers as "houses on multiple floors, with extroverted conception, with balconies, terraces, common passages, etc. grouped around a large common courtyard, often with a common fountain"), synagogues, schools, etc. were concentrated (Ibid: 43-44). What influences the architecture which they knew in their previous homeland and which they brought with them could have had on the architecture in Macedonia is a topic that is yet to be the subject of more extensive research.
} 
The answer to this dilemma is precisely the Revival monumental sacral architecture, with its clear, easily recognizable architectural lexicon, a specific typological diversity, simultaneous simplicity and opulence and the incredible quantity of buildings built in the span of one century. Referring to the extensive and very important work of the Revival architect Andreja Damjanov (1813-1878), Jasmina Hadzieva-Aleksievska and Elizabeta Kasapova will write: "his work in different geographical areas shapes him as a cosmopolitan spirit and a great connoisseur of the then architectural movements in Western and Central Europe, but also of the Byzantine-Slavic and Islamic traditions in the Balkans and Asia Minor. Choosing his own architectural syntax, he opted for a supranational expression and dismantling of the medieval canonical closedness. Hence, in his architecture, a remarkable symbiosis will reign between the Byzantine-Slavic traditions and the Western or Central European neo-Baroque, Neo-Renaissance, NeoRoman features, as well as the Islamic. Most of his works were created with honest and serious contemplation about history. He treats it with attention and patience, searching for its sedimentary layers of identity, meanings and sensibilities. His architecture is based on preserving experiences and seeking opportunities for their unification in a new pattern" (Хаџиева-Алексиевска и Касапова, 2001: 13). This deeply cognitive, multidisciplinary approach in designing architecture as a conceptual creation will certainly come to full expression in the works of Andreja Damjanov, as the supreme master of his craft. However, the new architecture is not characteristic only for a few selected masters and their collaborators and followers, but extends to the entire architectural production of sacred buildings throughout Macedonia and beyond throughout the Balkan Peninsula, as the materialization of an adopted common, universal architectural language. Thus, the same typological solutions, forms and patterns (of course with appropriate adaptation of the architectural solution to the conditions of the site, the available construction material, the possibilities of the founders and the master-builders themselves) can be traced both in the main urban centers, where extremely monumental churches were built, as well as in remote, isolated rural areas, where they were intended to meet the needs of a significantly smaller audience.

A common, unifying feature of these numerous monuments is the dominant use of the basilica as a universal architectural archetype. The "resurrection" of the basilical typological solutions, especially the three-nave and multi-nave basilicas, is the key element in defining the new Revival architecture and its specific architectural expression. Namely, the Revival XIX century is not a precedent in history when the use of the basilical architectural typology, characteristic of the early-Christian period (IV-VI century) and the establishment of the Christian religion and the Church as an institution in Europe, was restored. As explained in detail earlier (see Chapter 1.4.2), the same process of re-utilization of the basilica was characteristic of another very important period in the history of Macedonia: the Kingdom of Samuel (X-XI century). Parallels between the monumental basilicas from the early-Christian period, those from the middle-Byzantine period and the Revival churches can be drawn especially in the case of the churches built as cathedrals in the developed urban centers, the dimensions of which are so imposing that they do not lag behind the basilicas built in the glorious eras of the past (see Chapter $\mathbf{V}$ ), whose founders, unlike the founders of the churches in the Revival, were representatives of the highest classes of society: emperors, members of royal families or the highest ecclesiastical clergy.

Also in favor of this claim is the continuity (or restoration) of the cults of some saints that link the Revival churches directly to the monuments of the middle-Byzantine period on the territory of the Ohrid Patriarchate / Archbishopric, both in terms of the dedication of the temples as of the representation of their characters in the icons and fresco repertoire. Such an example is the church of St. Achilles of Larissa built in 1840 in the village of Trebishte near Debar, as a convent of the Bigorski monastery (Тричковска, 1993: 119), where there is an evident return of the cult of this saint on which the Ohrid Archbishopric was founded, since its first temple - the basilica of St. Achilles on the island of the same name in Prespa Lake 
- was Tsar Samuel's first endowment. ${ }^{139}$ In the same context is the frequent representation of the allSlavic saints who lived and worked in the IX-X century - Ss. Cyril and Methodius and their successors Ss. Clement and Nahum in the Revival frescoes and icons, painted individually or as part of their collective representation in group - the so-called Sedmochislenici - Seven wise men (Ss. Cyril, Methodius, Clement, Nahum, Sava, Gorazd and Angelarius), to whom in some cases are added the portraits of St. Erasmus and / or St. John Vladimir, ruler of the medieval state of Zeta and son-in-law of Tsar Samuel, whose cult is especially alive in Macedonia and eastern Albania, directly related to the territory and tradition of the Ohrid Archbishopric (Грозданов, 2004: 92).

It is clear that one of the reasons for returning to the monumental basilica typologies is the fact that this architecture is an ideal framework suitable for mass gatherings, as a result of the significant increase in urban population; in other words "the monumental dimensions of these basilicas arose from necessary demographic reasons" (Кадијевић, 1997: 16). However, the significant change in the nature of the church liturgy in the XIX century should not be overlooked, colored much more with national messages and meanings, than with purely religious ones, which is characteristic of the Revival (ХаџиеваАлексиевска и Касапова, 2001: 14). It is certainly not surprising that the dominant secular, humanistic, anthropocentric component of this new architecture - as opposed to the traditionally exclusively sacral character of church buildings - is a manifestation of aroused romantic and patriotic feelings and national aspirations of the bourgeoisie, as the founder of the Revival architecture. In Emil Aleksiev's words, "the complex type of basilica that begins to be built at this time is becoming more and more profane, which is determined by a number of external factors such as the projection of the social suprastructure in the architectural structure of the temple" (Алексиев, 2013 (А): 2202).

Thus, the Revival sacral architecture in Macedonia and the Balkans, as well as all other cultural phenomena and manifestations in society (music, literature, painting, education and even fashion) are included in the Romantic movement characteristic of this time (Томовски 1970: 17-18) throughout Europe. Namely, during the XIX century, several directions in architecture will appear and formulate, such as the neo-Romanesque, neo-Gothic, neo-Renaissance, neo-Baroque, neo-Classicism, arising from the retrospective approach in architecture, especially towards the medieval built heritage, ${ }^{140}$ whose elements are "often mixed and transposed into layered architectural compositions" (Кадијевић, 1997: 1-2). It is the romantic quest into the past that largely defined the Macedonian Revival sacral architecture, which in turn had a tremendous and significant impact on the national style in the architecture of the already established neighboring countries, especially Serbia and Bulgaria, where many Macedonian masterbuilders regularly participated in the design and construction of crucial public and residential buildings. ${ }^{141}$

If the Revival sacral architecture in Macedonia chose for its base the monumental church architecture from the middle-Byzantine period, as well as its prototype - the early-Christian basilica as top

\footnotetext{
139 In this context is the fact that the temple in Trebishte is popularly known among the locals as St. Achilles of Prespa. In fact, the cult of St. Achilles did not diminish after the end of Samuel's state, and is especially present on the territory of the Ohrid Archbishopric and the wider Balkan area under Byzantine rule. Namely, his portrait was often painted within the frescoprogramme of various Byzantine and post-Byzantine temples throughout Macedonia and the Balkans. Furthermore, he is especially present in the frescoes of the Revival churches (Велев, 1990: 24).

140 "... towards the middle of the century, a more determined and meaningful interest in historical monuments is shown, seeing in them primarily values of historical sources, testimonies of the lost medieval state glory" (Кадијевић, 1997: 12).

${ }^{141}$ In that direction, it is important to refer to the work of Andreja Damjanov in Serbia, who spet his mature years in this newly established state. Namely, working on the church of St. George in Smederevo (which, unlike his works in Macedonia, is a combination of a five-domed basilica with a trefoil, apparently inspired by the Moravian monuments), "when possible he went to Manasia and Ravanica to observe, to learn, to сору" (Поповиќ, П. Прилози за књижевност, језик, историју и фолклор, Београд, 1927: 162, quoted in Томовски, 1966: 16), since in accordance with the client's requirements the church was to be inspired by the monastery Manasia (Кадијевић, 1997: 17). In fact, the church in Smederevo is considered to be the initiator in the creation of the Serbian "national style" and the central person in the period of its establishment was exactly the great Macedonian architect.
} 
representatives of the local building tradition, its architectural expression is a sublimate of eastern and contemporary western influences (Томовски, 1961: 162). Namely, the open porches which arose from the need for covering, i.e. protection of the entrance portals and providing a partially closed space for gathering of the believers before and after liturgy are ancient or early-Christian in origin, and certainly arrived in the Revival architecture indirectly through available Byzantine examples, especially among the churches from the middle-Byzantine period. The prototype for these porches can be recognized in the original porticos at all three entrances to the Ohrid cathedral St. Sophia, later replaced by a long northern open porch and the western exo-narthex (see fig. 1.24).

Later, in the post-Byzantine period - the first half of the XVIII century - on the southern border of Macedonia, in the important Vlach ${ }^{142}$ center Moskopole and its rural surroundings (today within the Republic of Albania) a group of extremely similar monumental three-nave basilicas ${ }^{143}$ was built, which had open porticos to the south or both to the south and west, in a "L" shape (fig. II.5). In fact, these are pseudobasilicas, because despite the monumental dimensions, they are covered with a gabled roof that often extends continuously over the southern porch. The whole churches, including the vaulted parties, are made of stone, which is one of the key differences in relation to the Macedonian Revival three-nave basilicas (fig. II.6). Furthermore, the Moskopole group of churches incorporate the Byzantine style of brickwork masonry, characteristic of the Palaeologan era (saw-like crown cornices, fish bone motifs, ceramic ornaments, crosses, solar and tree of life motifs, brick inscriptions, etc.). ${ }^{144}$ Despite the threenave disposition, the rhythm of the columns in the naos of the Moskopole basilicas is not uniform, but narrower and wider fields appear alternately (in the central nave vaulted with blind domes), while the side naves are usually vaulted in the shape of a quarter cylinder (fig. II.5B).
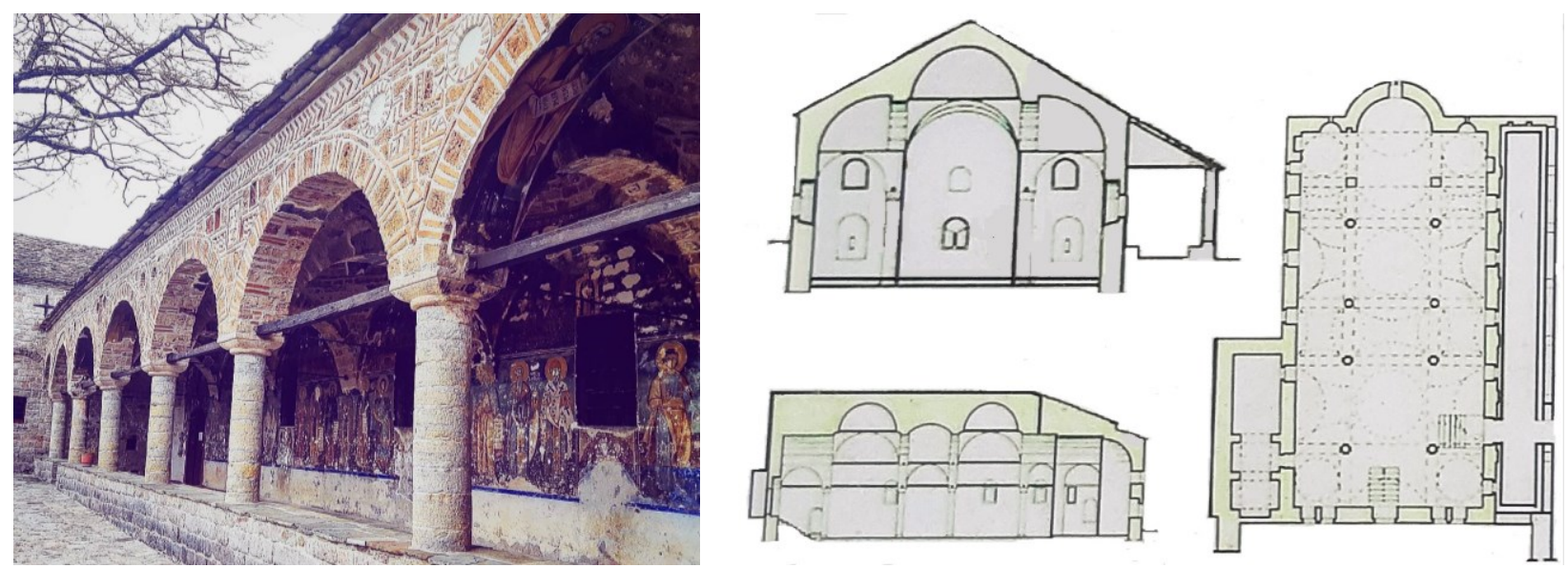

Figure II.5 A. View of the open porch of the church of St. Nicholas; B. Plan, longitudinal and transverse sections of the church of the Holy Mother of God, both in Moskopole (Albania).

The open porches, in turn, are divided into a series of bays covered with blind domes (fig. II.6). They are supported on arches resting on consoles on the façade of the naos and an arcade on the opposite

\footnotetext{
142 The Vlach, also known as Aromanian, are an ethnic community native to the Balkans, today predominantly settled in Macedonia, Greece and Albania.

143 The Holy Mother of God (1712); St. Archangels (1722); St. Athanasius (1724) and St. Nicholas (1726). At the church of St. Athanasius a preserved inscription in a piece of brick on the southern façade of the porch lists the names of the master-builders, originating from the region of Castoria (at that time part of Macedonia, today on the territory of Greece). This fact, the extremely short period in which they were built, as well as the evident similarities in their typological solution and decoration speak of their likely authorship within the same master-builder group.

144 It is important to emphasize that the frescoes in almost all of these churches are the work of Constantine Hieromonk from Korcha who is the author of the icons of the monastery of St. Nahum on Lake Ohrid (dating from 1711), located only fifty kilometers north of Korcha and Moskopole. Their fresco-ensambles regularly include representations of the local saint cults, such as St. Clement, St. Nahum and St. John Vladimir (Tsar Samuel's son-in-law), confirming their link to the Ohrid Archbishopric.
} 
side, with columns made of ring-shaped stone blocks (fig. II.5A). To the east a tall semicircular altar apse is regularly divided into very shallow niches with the help of subtly marked corner pilasters. The niches of the apse and the arches or the windows are executed in a masonry opus consisting of stone and brick, while the entire façade canvases are built exclusively in stone.

Certainly, the geographical proximity of Moskopole and the wider Korcha area to Ohrid, which in the given period was a spiritual and cultural center of the region, spreading its building traditions through the still active Ohrid Archbishopric, should not be neglected. The influence of these churches and their typology was certainly not limited to the relatively isolated mountainous area of Moskopole, but penetrated deep into Macedonia, where the Vlachs from that region (Epirus and present-day southern Albania) immigrated en masse only a few decades later, in the second half of the XVIII century. Namely, due to the frequent raids of the Albanian gangs in the areas populated by Vlachs in today's southern Albania, on the mountain Gramos, Pind, in Epirus and Thessaly, a large number of Vlachs began to migrate to the north. These migrations took place in three waves: in 1769 immediately after the destruction of their cultural center Moskopole, in 1788, after the attacks of Ali Pasha of Janina, and ultimately in 1812-1821. The Vlachs settled in Macedonia, mostly in its western parts: in Krushevo (previously a small mountain rural settlement); in Bitola and the surrounding mountain villages (Malovishte, Magarevo, Gopesh); the villages Gorna and Dolna Belica in the region of Drimkol near Struga; in Ohrid, where even today there are two town quarters called Gorna and Dolna Vlashka Maala (the Upper and Lower Vlach Quarter), and a Vlach church - St. Nicholas, built in 1863; in the western and southern part of Aegean Macedonia; as well as in the mountainous areas along the valley of the river Bregalnica in

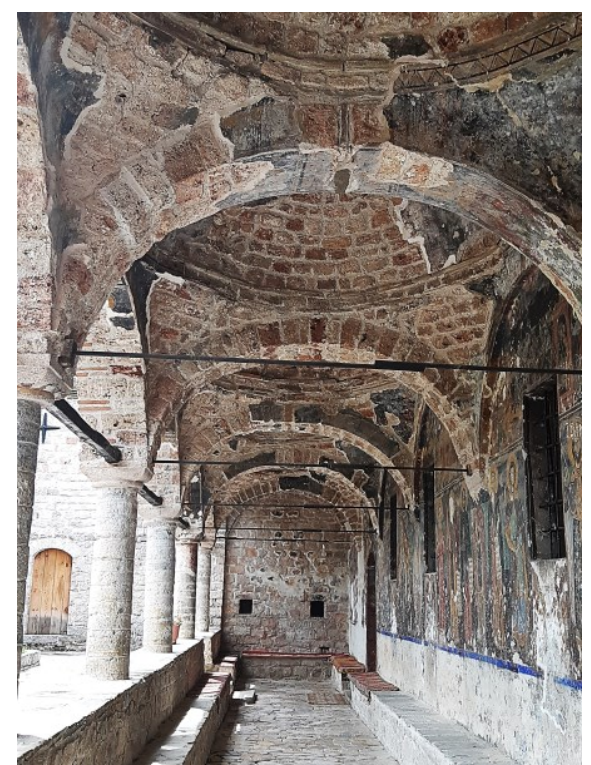

Figure II.6 The southern porch of St. Nicholas in Moskopole (Albania).

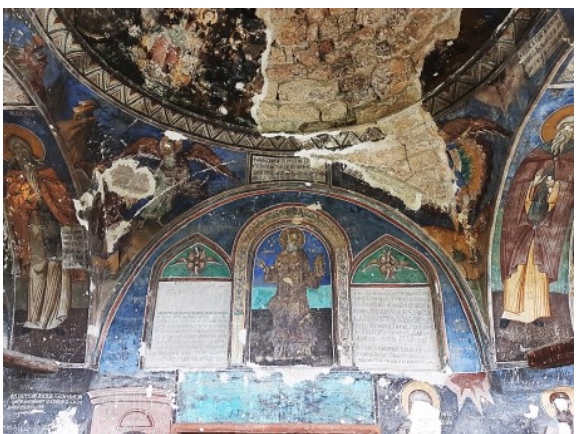

Figure II.7 Pointed (Saracene) arched niches at St. Nicholas in Moskopole (Albania).

Shtip, Kochani and Ovche Pole. Of course, along with their culture, the Vlachs brought, established and transferred their previous construction experiences, traditions and techniques.

Other important source of influence was the Islamic architecture and art brought (and likely imposed) by the Ottoman Empire (fig. II.7). Namely, under the influence of Islamic architecture, and in accordance with the specific status of women in the Turkish society, the Revival churches incorporate galleries on their second level (so-called "women's churches"), analogous to the mahvil ${ }^{145}$ which appears in some mosques. The galleries are often visually further separated by semi-transparent decorative fences known as musharabia ${ }^{146}$ executed as a diagonal interweaving of thin wooden slats, placed above the parapet (see Chapter III.3). The musharabias are by nature an evident Islamic element, domesticated as a result of centuries of Islamic cultural and social domination. ${ }^{147}$ In that spirit, in fact, is the very division

\footnotetext{
${ }^{145} \mathrm{~A}$ mahvil is a part of the mosque dedicated for prayer of the women. It can be completely separated into a gallery space, often with separate access and entrance, such as at the Colorful Mosque in Tetovo. Sometimes, the mahvil is a narthex closed with a semi-transparent partition, which provided visual segregation.

146 The term musharabia is derived from the standard Arabic: musta'arabim (مستعرب), or the Romanized term musta'rib, which means something "arabized", which "adopted the ways of the Arabs" or which originated under Arab influence.

147 It is interesting to note that in Bosnia, which was almost completely Islamized, wooden shutters made in the same way, called "mushebek", "kavasi" or "cages", were placed on the windows of Balkan-oriental houses facing the street (Светиева, 1992: 91).
} 
of the "male" and "female" church into separate levels, which in some cases used completely separate entrances (see Chapter III.1) in order to fully gender-segregate the faithful. In addition to this import of the musharabia as a pronounced Islamic element, under the influence of the Ottoman architecture the Revival basilicas sometimes included Saracene arches (fig. II.7), threeleaf-shaped arches, stalactite pendants, hexagram motifs etc., as well as porches covered by blind domes, as can regularly be found in the mosques throughout the Balkans, and in some Revival basilicas (the Osogovo Monastery, the monastery in Rajchica), as well as the previously mentioned Moskopole basilicas (fig. II.6).
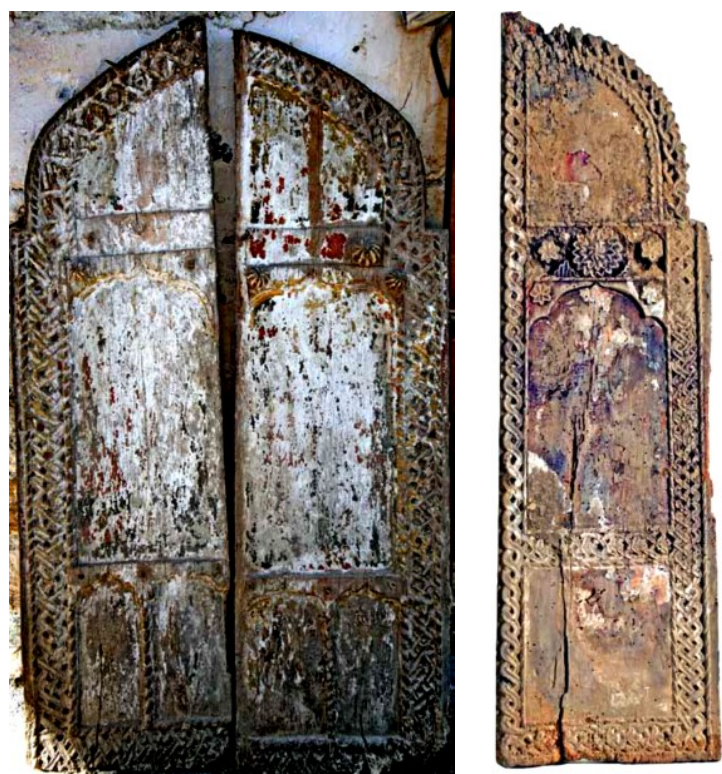

Figure II.8 Examples of post-Byzantine royal doors, which incorporate Saracen arches and Islamic elements. A. Bistrica, near Veles; B. Chelopek, near Tetovo.
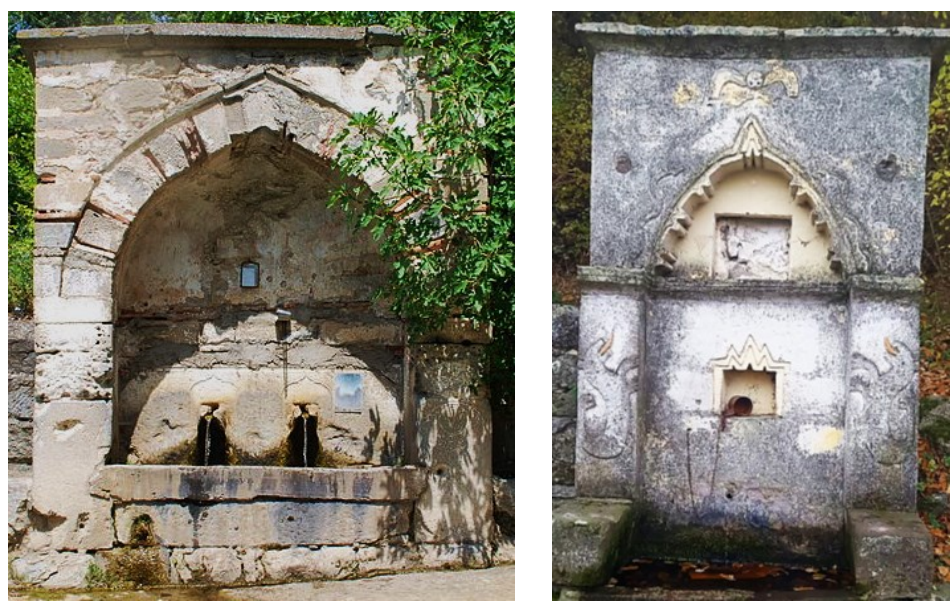

Figure II.9 Oriental influences in the decoration of the water fountains in the villages of Gjurishte and Vince, near Sveti Nikole.

Oriental elements and influences in the Balkans were present, to a greater or lesser extent, even before the Ottoman occupation, at the turn of the XIII-XIV century, when the Byzantine art (architecture, painting, illumination of manuscripts, as well as applied arts and crafts) in its final development stages received them as a result of intensified trade with the neighboring Ottoman state (Шево, 2016: 575). ${ }^{148}$ The intertwining of traditional patterns with oriental elements intensified in the following centuries, when Macedonia was formally included within the Ottoman Empire. Although the post-Byzantine sacred architecture itself (see Chapter 1.5) remained as strictly adherent to Byzantine traditions as possible within the many legal and material constraints under which it was built, Islamic influences permeated fresco painting ${ }^{149}$ and woodcarving, as is evident at the preserved royal doors of the iconostasis in Slepche, Kucheviste, Trnovo, Bistrica, Chelopek (Николовски, 2013: 201-202) from the XVI-XVII century (fig. II.8), which include Saracene arches, interweaves, hexagram motifs, rose blooms etc. Also, Islamic decorative elements and ornaments are often found in the internal decoration of the residential architecture, on household objects and utensils, as well as in the architectural expression of

Similar window formations are found in the Iberian Peninsula, in present-day Spain and Portugal, in areas that belonged to the Caliphate of Cordoba in the Middle Ages; in Malta and other Mediterranean regions which in the past have been exposed to strong influence from Islamic architecture and culture.

${ }^{148}$ An oriental influence is the so-called "Pseudo-Kufic" style that in Macedonia, for example, can be found in the church furnishings commisioned for the cathedral St. Sophia in Ohrid by Archbishop Gregory at the very beginning of the XIV century; the ornament and the appearance of saracen arches in the medieval fresco-painting, and so on.

149 "Some details in the iconography of the saintly figures and scenes are also interpreted as oriental influxes. St. Mercury is depicted in the XVI century (in Kuchevishte, Toplichki monastery, Zrze monastery) checking an arrow - after the model of the warriors from the Persian manuscripts. In the monastery Zrze and in Kuhcheviste in the scene of the Last Judgment, a group of sinners appear in kaftans, with fez hats, marked with the inscription "Turks" (Шево, 2016: 578). However, Islamic influences will remain strictly limited in their role as an ornament, a purely decorative detail, without substantially contributing to changes in the traditional art forms rooted in the Byzantine period. 
purely utilitarian buildings and structures, such as the village water fountains (fig. II.9).

Western influences, on the other hand, are evident especially in the external shell of the church buildings - the façades, with legible classicist, neo-Renaissance and non-Baroque elements in the treatment of the entrance portals, their composition and, often, completely three-dimensional sculptural processing. ${ }^{150}$ In the same Western and Central European style, the brickwork decoration characteristic of the Byzantine heritage was almost completely abandoned, and the façades were made almost exclusively out of stone, while brick appears quite sporadically. ${ }^{151}$
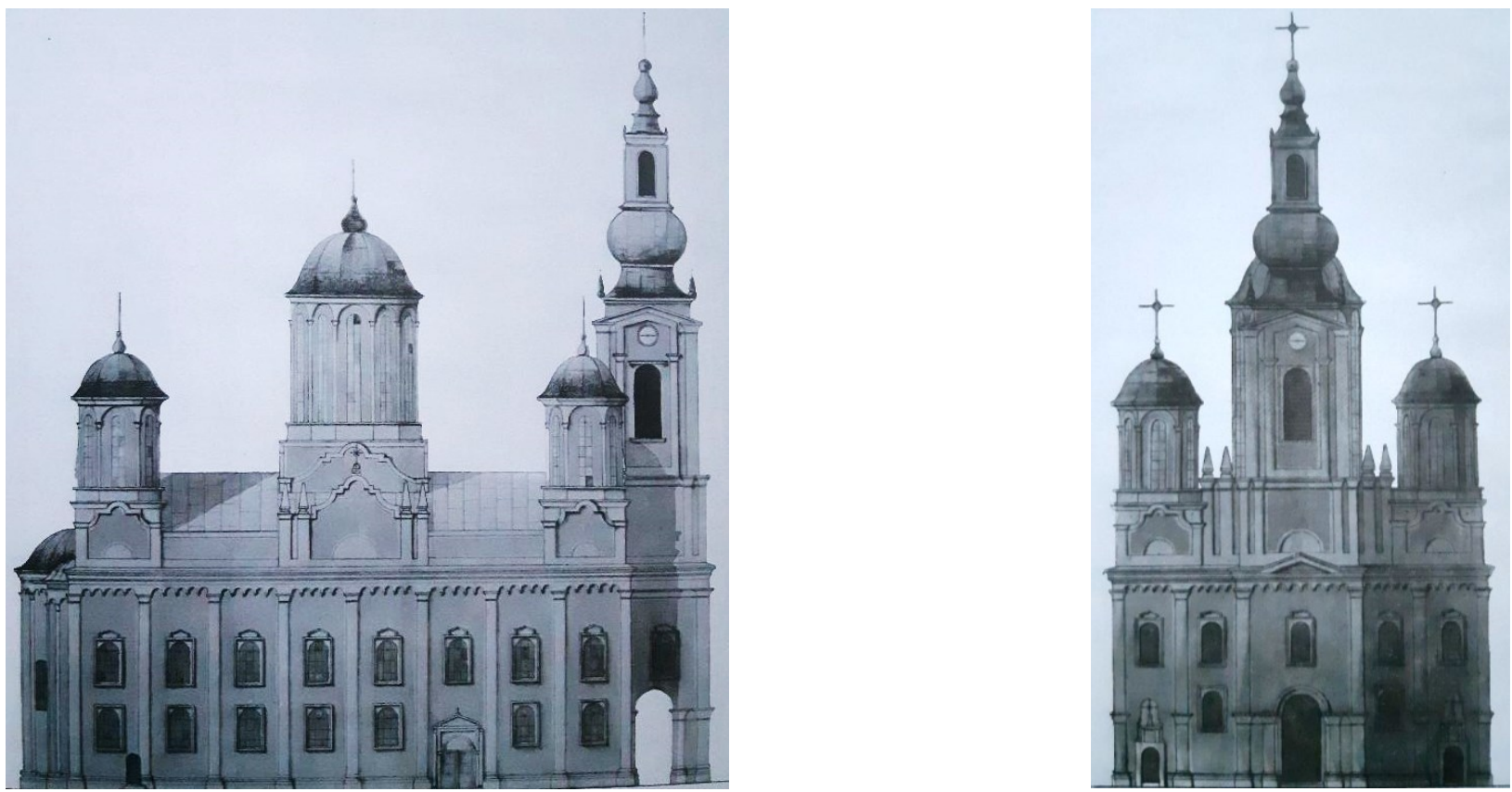

Figure II.10 The church of the Most Holy Mother of God built in 1868 in Sarajevo (Bosnia and Herzegovina) by the Macedonian Revival master-builder Andreja Damjanov. Northern and western façades, as drawn by the architect himself.

In some Revival churches, the stone masonry is of such high quality and precision, with clean lines and minimal mortar joints, that it clearly drew some influence from the Romanesque and the Gothic; ${ }^{152}$ as opposed to those cases that were built with poorer quality material, where the façades were usually

\footnotetext{
150 In this context, it must be mentioned that the Gothic, Renaissance and Baroque architecture arrived in the Balkans via Italy and the Adriatic coast with some delay. Thus, Baroque style buildings were erected only in the XVII-XVIII century, on a territory along the western borders of the Ottoman Empire, i.e. in today's Slovenia, Croatia, Vojvodina (Ненадовић, 1980: 280), where the engagement of Macedonian master-builders, painters, woodcarvers and coppersmiths was already quite frequent. Furthermore, it should not be overlooked that in the previous centuries, cultural exchange between the West and the "exotic" Orient had already begun, at first shy and then with growing intensity. France was the first of the Western European countries to establish diplomatic relations with the Ottoman Porte in the XVI century "securing economic privileges that over time became more complex. The Enlightenment and Liberalism - the key Western European gains of the eighteenth century and the ideological postulates of the bourgeoise revolution that began in France - would be a major impetus for the modernization of the medieval Ottoman state" (Тричковска, 2008: 9). In terms of cultural benefits and mutual influences, oriental features can be seen in many forms of French art from this period: in interior design, decoration and other applied arts and crafts, as well as in the operas, ballet, dramas, etc. At about the same time, interest in European culture, especially the French, was growing in the Turkish Empire: "It can be seen in the construction of the more significant palaces of Constantinople, in the decoration of the interior, where the spirit of the Rococo style permeates, which in a specific fusion with the Turkish traditional art builds strange, often hybrid structures" (Светиева, 1992: 38). Furthermore, the process of "Westernization" and "Europeanization" of the Ottoman state in the first half of the XIX century involved the construction of new, hitherto unknown types of public and industrial buildings (hospitals, factories, warehouses, railway stations, army barracks ...) built according to the drafts and under the direction of foreign architects, primarily from Italy, France, Austria (Грчев, 2003: 60).

${ }^{151}$ Namely, the appearance of brick is almost always limited to the eastern façade, especially the altar apse, where it appears in horizontal rows between the rows of carved stone as an echo of the Byzantine opus listatum (for example, at the church of St. John the Forerunner in Jankovec and St. Athanasius in Dolno Perovo, both in the region of Prespa), or with an additional vertically placed brick inserted between the stone blocks, in the so-called opus cloisonnè (at St. Nicholas Gerakomija in Ohrid). 152 For example, the church of St. Nicholas in Vevchani, near Struga. See Chapter III.4.B.3.
} 
plastered, with the exception of the built-in stone reliefs, cornices and portals, which in turn points to the Central European sacral architecture as a certain source. There are even examples where the desired effect of precise masonry in hewn stone was impossible to achieve due to the poor quality of the available material, so the east façade (and, in some cases, the remaining façades) was plastered and then painted as an imitation of this type of masonry. ${ }^{153}$ Western European influences are also evident in the appearance, although sporadic, of a bell tower, usually placed in the axis of the western façade. ${ }^{154}$
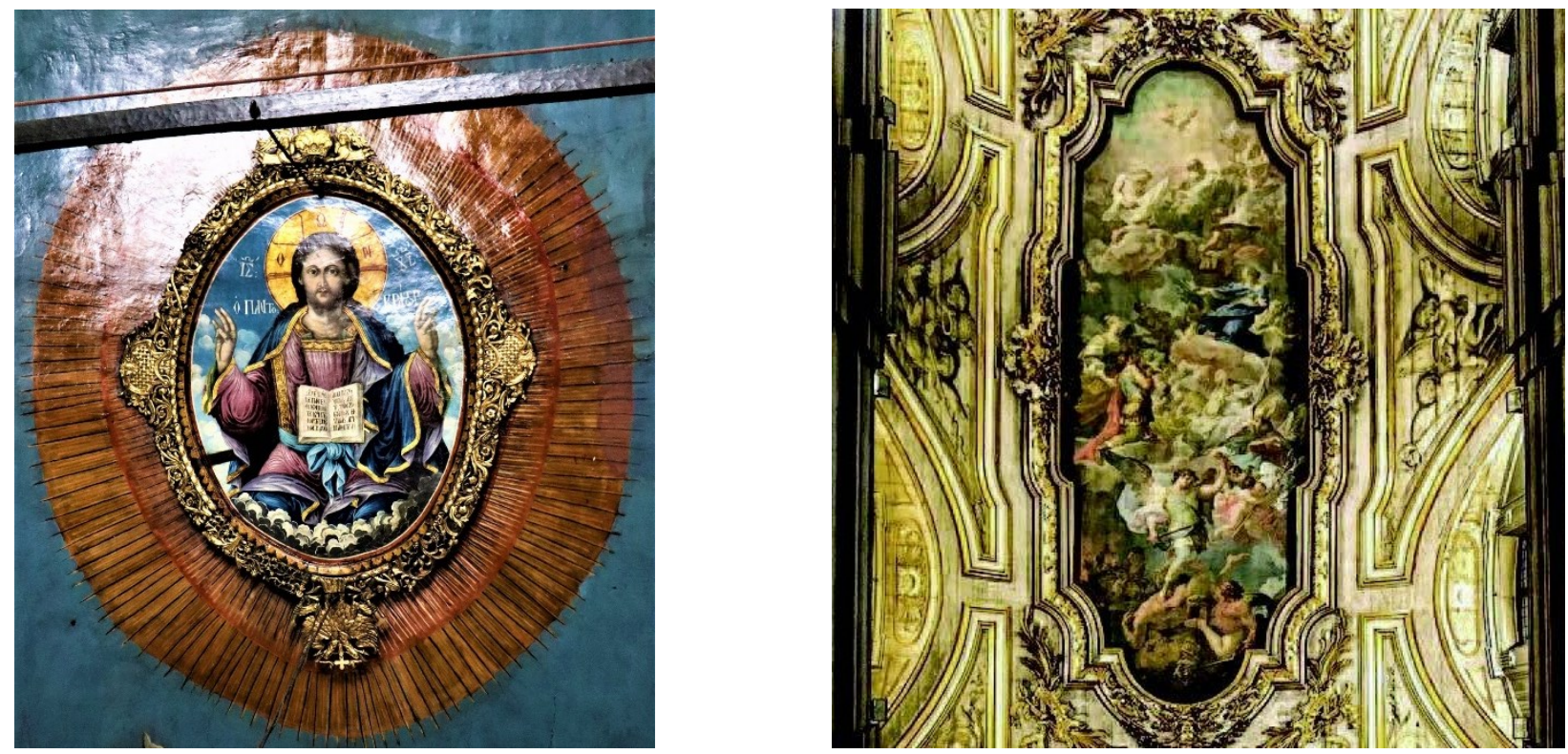

Figure II.11 A. Baroque mandorla molding frame of the fresco Christ Pantocrator in the vault of the central nave, church of St. Demetrius in Bitola (1830); B. Detail of the ceiling of the church of Santa Croce in Gerusalemme, Rome (XVIII century).

Contrary to the restrained, reduced expression of the façades, the interior of the Revival churches is dominated by abundant, lavish and ornate decoration (fig. II.11A), with an emphasis on the tall, elaborate filigree-like iconostasis (fig. II.12), suppressing the fresco-ensembles to the background. Still, even when the fresco-ensemble was limited in scope, at least the ceilings and constructive elements were regularly painted complementing the picturesque impression.
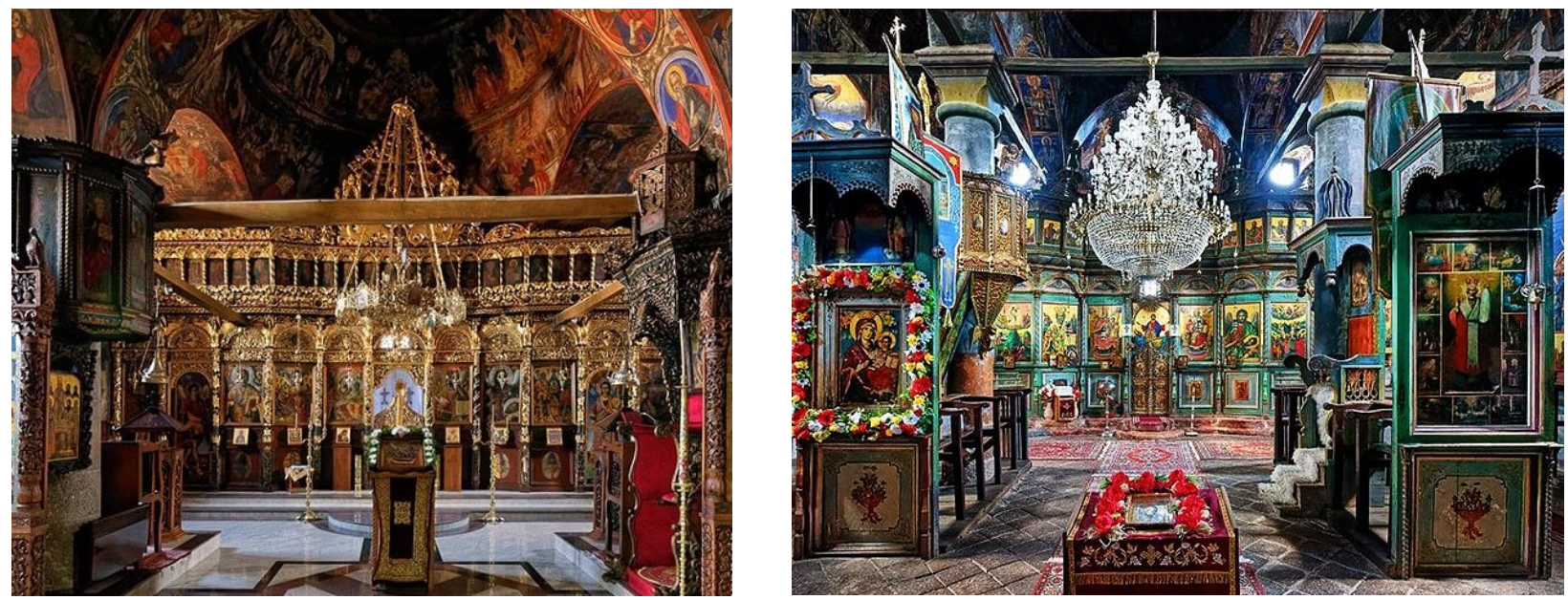

Figure II.12 Abundant interior decoration in the Revival churches: A. Dormition of the Most Holy Mother of God - Kamensko in Ohrid; B. St. Nicholas in Vevchani (Struga).

153 This type of painted masonry can be found at St. Elijah in Ezerani and St. John in Ljubojno, both in the region of Prespa; St. Demitrius in Bitola, and so on.

${ }^{154}$ A bell tower shaped according to Baroque models will be incorporated, for example, into some churches that Andreja Damjanov built throughout Serbia and Bosnia and Herzegovina: in Smederevo, Sarajevo (fig. II.10), Mostar. 
This decorative abundance in the interior - as opposed to the relatively strictly and formally composed façades and the absence of external gradation of the masses in most Revival churches - is attributed by some researchers to the influence of late Baroque church interiors in Central Europe (Кадијевић, 1997: 16). In this regard, the "fake" wooden vaults covered with stucco decoration (so-called scagliola) are worth remembering (fig. II.11B), complemented with a wealth of ornaments, paintings, gilding, imitation of marble and other types of precious stone, which are present in the Rococo churches built throughout Italy, Germany and Austria towards the middle of the previous, XVIII century (see Chapter III.2). According to L. M. Roth, this interior design is "coherent with the baroque lack of interest in expressing structural reality, in this case overemphasized to the point where the stucco vaults are hung on the wooden roof structure. The vaults are nothing more than ambient shells, subtly applied to define interpenetrated spaces and to manipulate natural light, making it bounce off the columns so that the space is bathed in mild and mysterious light. The interior is a bright world of delicate and playful craftsmanship, which is in the maximum possible contrast with the sober outside world" (Roth, 1999: 427-428).

Thus, based on all these different sources, through an eclectic but inventive and deeply intellectual, critical approach, the master-builders created and developed the Revival sacral architecture, as "a unique, contemporary kind of architectural creation, based as much on inspiration in the national tradition of past epochs, as on the interpretation of the new aspirations in European construction" (Кадијевић, 1997: 8).

\section{II.3 Master-builder Groups}

During the XIX century Revival, the role of the master-builder became the most prominant; while the fresco-painters were forced to adapt their increasingly abbreviated iconographic program to the imposed architectural model of the temple. For the first time in history, the master-builders emerged from the obscure anonymity intrinsic of the monumental architecture of the previous epochs in Macedonia. Oftentimes, their names (and / or the name of the fresco-painter) were carved into stone blocks embedded into the church portals or included in the patronage inscriptions in addition to the financier and commissioner of the building, and thus their remembrance was ensured for eternity. In the spirit of Romanticism, the Revival churches were treated for the first time as an author's creation. The master-builders were valued and appreciated, invited to create ecclesiastical (as well as residential) architecture at different and remote locations thanks to their wide-spread reputation, and even awarded for their service by the ruling elite of the newly-established Balkan states as well as the Sultan. Of course, they could not have achieved this on their own.

The impressive quantity of production of sacral and profane buildings in the Revival is due to the organized structure that characterizes the creators of this architecture - the master-builder groups, socalled "tajfi", which employed master craftsmen of various profiles: masons, stonemasons, mortar makers, blacksmiths, carpenters, woodcarvers, icon and fresco painters. With the different education, background and experience of their members, the groups gained versatility necessary for the complete construction as well as the interior design of buildings of various types: churches, mosques, public buildings, bridges, residential and economic buildings, etc. Such groups intensified the development of certain crafts that were elevated to the level of real art: construction, stone masonry and stone carving, wood carving, carpentry and furniture making, icon and fresco painting. This caused the emergence of narrowly specialized groups, primarily in the field of interior decoration and arts and crafts - woodcarving and painting, as well as groups specialized in the construction of specific types of buildings. ${ }^{155}$

\footnotetext{
${ }^{155}$ For example, the masters from the village of Kodzadzik were most famous for building mills; those from the village of Lukovo were primarily commissioned to build bridges (Томовски, 1973: 269), etc.
} 
The organizational structure of the master-builder groups was, to some extent, hierarchical. ${ }^{156}$ The group was lead by a protomaster - "ustabashija" who organized and managed the work, prepared the design and the work plan, distributed the earnings, often directly participated in the construction and also performed an important ritual function (Покропек и Стрончек, 1992: 112). Depending on their experience and education, the master-builders were further divided into several categories: "majstori" (masters), "ortaci" (partners), "glaveni" (hired workers) and the lowest category consisting of "kalfi" and "chiraci" (apprentices) who were usually beginners in the stage of mastering the craft. The group also hired several general workers, called "argati", who performed unskilled work, often recruited among the young men from the village where it was hired, or its vicinity. The number of members of the group was adjusted depending on the type and size of the building in question: for example, for the complete construction of churches, the master-builder group often consisted of 30 to 40 members (Томовски, 1973: 269). As an illustration of the volume of the most successful and famous master-builder groups, the group of Avram Gulibegovski, an ustabashija from the village of Lazaropole, for a certain period had as many as 70 members, who besides from his native village were recruited from the neighboring villages of Rostushe, Bitushe and Gorno and Dolno Melnichani (Томовски, 1969: 224). The respect of the same patron saint, certain beliefs, customs and rituals related to different phases of the masonry work, as well as the existence of secret, so-called "dungjarski" (masons') speeches - dialects, ${ }^{157}$ characteristic for the regions in Macedonia where construction was traditionally the most common craft, speak of the level of organization of the master-builder groups and also of the construction guild itself.

The master-builder groups were in fact one of the main representatives of the migrant labor in Macedonia. They usually left for work in the early spring and returned in the autumn, ${ }^{158}$ whereas if they went to more distant lands, they often remained there for several years. Thus, in addition to the entire territory of Macedonia, the Macedonian master-builder groups cruised throughout the Balkan Peninsula - in Bulgaria, Serbia, Albania, Greece, Romania, Hungary, Bosnia, Turkey, Dalmatia and beyond, further to the east and south, in Asia Minor and even Egypt. In addition to Macedonia, works of Macedonian masterbuilders are especially common throughout Serbia, Montenegro, Bulgaria, which during the XIX century formed their independent states. Namely, the creation of the new Serbian state created favorable conditions for the development of architecture, and thus arose the need for a larger number of

\footnotetext{
156 In the context of the phenomenon of the master-builder groups, of particular importance are the notes of the French architectural historian Auguste Choisy, who had the opportunity to closely observe the construction of buildings in Macedonia in the XIX century and subsequently, in 1883, published his impressions in the work $L$ 'art de batir chez les byzantins: "the way a construction enterprise is usually managed in Macedonia, where I have studied the situation closely, is as follows: the owner

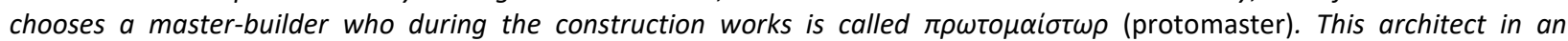

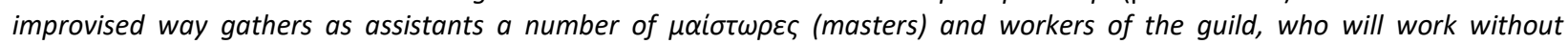
distinction, both in excavation of foundations, in masonry of walls, and in the wooden construction of ceilings. Only blacksmithing and carpentry tasks are reserved for special craftsmen. The idea of a systematic distribution of work seems alien to Oriental notions" (Choisy, 1997: 179).

157 Such examples are the so-called "Fornichki" speech from the region of Kratovo - Kriva Palanka (Светиева, 1992: 122), "Boshkachki"" speech in Veles brought by the immigrant Mijak masters from the region of Reka (Debar) and "Gurabarski" speech in the Ohrid - Struga region. The master-builder groups from the region of Bitola also had their secret speech.

158 The work migration was tied to the summer construction season, marked by important religious holidays: it began at Sunday of Forgiveness prior to the great Easter lent (in March) or on St. George's Day (in early May), and lasted until St. Demetrius' day (in early November). The group members traveled to their destination on foot, for several days, carrying their tools, and slept under the open sky, at previously known, customary locations (Светиева, 1992: 148). At their destination they were welcomed by colleagues from the construction guild. Again, contemporary insight is provided by Auguste Choisy who, in the work quoted earlier, has written: "Let's add that, in every single city, these associations (the construction guilds) maintain relations of hospitality and brotherhood, which remind us of Western knightly customs. Thus, every summer Salonika gathers workers from (..) Debar (incorrectly spelled as Derbe), who come to participate in the construction ventures. These foreigners have secured support and, if necessary, protection from their colleagues, who see in this cooperation more reinforcement than rivalry. This mutual support explains so many non-sedentary customs of the construction workers throughout the Orient that I have had the opportunity to observe myself" (Choisy, 1997: 180).
} 
experienced builders. This caused a number of complete master-builder groups ${ }^{159}$ to leave Macedonia and take over the construction of a number of important buildings in the Serbian capital Belgrade ${ }^{160}$ and in other towns, which visibly influenced the formation and development of the national architecture of this country (Томовски, 1972: 155). The same applies to the somewhat later founded Bulgarian state, whose rapid economic development after the liberation required a skilled workforce (Донев, 2013: 2127). The Macedonian master-builder groups built various buildings there: churches, monastery lodgings, houses and residences, schools, warehouses, military barracks, bridges, and so on. The diversity of their extremely wide repertoire of buildings with different purposes implies a great deal of knowledge overcoming functional, location-wise, constructive and aesthetic problems, creating a "very impressive, functionally and constructively logically conceived architecture" (Томовски, 1969: 222).

The master-builder groups were based on family tradition, according to which knowledge and skills, constantly upgraded and improved, were passed from generation to generation through theoretical and practical work, which meant involvement of boys from an early age in the work of the family group, immediately after the completion of their primary school education (Константиновски, 2001: 11). Depending on the talent they displayed, they further focused on architecture and construction, fresco and icon painting, woodcarving, carpentry, etc. The transfer of skills within the family led to maximum improvement in knowledge of materials, techniques, statics, aesthetic principles and proportions (Хаџиева-Алексиевска и Касапова, 2001: 7).

Engaging in architecture and construction, in addition to within certain families, was a tradition for entire regions where in the Revival, through an intensive construction activity with centuries of tradition, regional construction schools were developed, of which the most famous are the Debar-Reka (Mijak) and Veles schools. Construction, in addition to woodcarving and painting, had traditionally been nurtured in a wider area in Western Macedonia and under the name "Debar School" unites the three listed artistic crafts (Томовски, 1973: 267). The masters from the Debar school originated from the area around the town of Debar: the regions of Reka, Debarsko Pole, Debarska Zhupa, Debarski Drimkol and Golo Brdo (Ibid: 267-268) as well as from the town itself. ${ }^{161}$ The traditional occupation of the local population of western Macedonia with construction and related trades was actually caused by the uncertainty that prevailed in this mountainous, cruel region in previous centuries as a direct result of the continuous violence of the Albanian gang raids against the local population (Миронски, 1995: 11). Under the pressure of physical insecurity, the population gradually abandoned animal husbandry as a basic profession and begun to engage more intensively in trade and construction, occupations that imposed seasonal work migration. ${ }^{162}$ Thus, instead of evolving into smaller towns, for which they met all the conditions, the villages in the region of Reka, according to the migrant customs, were seasonally deserted, later (in the XX century) followed by the process of their complete abandonment. Previously, during the XVIII-XIX century, due to

\footnotetext{
159 According to the records of Gjorche Petrov, only from the Kratovo-Kriva Palanka region masonry groups of about three thousand people in total went to work in Romania and Bulgaria every season (Светиева, 1992: 147).

160 For example, master-builders and façade workers from the village of Vevchani (near Struga) worked at the National Assembly, the Ministry of Transport, the Agrarian Bank, the State Printing House and other facilities. In the period between the two World Wars (1918-1940), over 200 master-builders from Vevchani participated in the construction of all major buildings in Belgrade and throughout Serbia, where their activity is most noticeable (Константиновски, 2001: 26).

161 In the area of Reka, the master-builders were inhabitants of the villages Trebishte, Bitushe, Velebrdo, Rostushe, Janche, Skudrinje, Gorno and Dolno Kosovrasti and Gorno and Dolno Melnichani; in the area of Mala Reka, the villages Tresonche, Lazaropole, Selce, Gari, Rosoki, Sushica and Galichnik; in Debarsko Pole, the villages of Rajchica, Tatar Elevci and Banjishta; in Debarska Zhupa the villages of Gorenci, Broshtica, Kodzadzik, Novaci, Gorno and Dolno Elevci, Osolnica and Pralenik; in Debarski Drimkol, the villages of Lukovo, Modrich, Jablanica and Piskupshtina, and in Golo Brdo, the villages of Drenok and Dzepishta.

162 "The masonry craft is, as a rule, the occupation of the population from the poor mountain places. Poverty has been a major factor in the past forcing residents of villages in Reka to leave their homes for long periods of the year (sometimes more) to earn a living, first as manual or masonry workers. Masonry is by nature a nomadic craft, as is cattle breeding" (Брезовски, 1993, сіted bу Филиповски и Бошковски, 1995: 23).
} 
the constant pressure of the Albanian robber gangs, a mass migration started from the Debar-Reka region to central and southern Macedonia, ${ }^{163}$ in search of calmer, safer living conditions. Thus, the Veles and Krushevo construction schools are actually descendants of the Debar school, from which they emerged, and the most famous Veles and Krushevo masters are actually Mijak descendants, ${ }^{164}$ originating from the region of Debar (map II-1).

One of the most fertile villages in the region of Debar - Reka in terms of construction arts and crafts is the village of Tresonche. According to the testimonies of the elderly residents, there was almost no house in the village that did not engage in at least one craft (Миронски, 1995: 9). Of them, the most

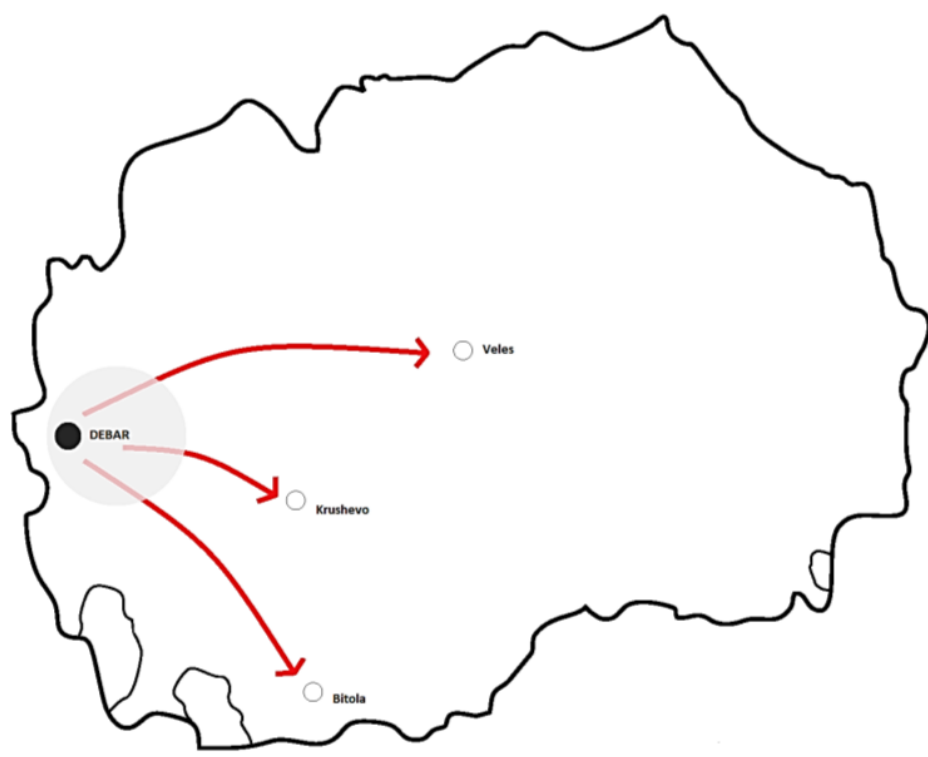

Map II-1. Migration of the Mijak population from the region of Debar to the safer regions of Veles, Krushevo and Bitola in central Macedonia. famous will become the lineage of the Krstev-Avramovski family (also known as Zografski), whose representatives are the most prolific and influential painter of the Revival, Dimitar Krstev (1819-1872), better known as Dicho Zograf; his son Avram Dichov (1844-1923) and nephew Krsto Avramov (1866-1939). From the lineage of the Stanishevi family, stood out Gesho, who founded his own group after working in the group of Renzovci (Константиновски, 2001: 14) and his sons Dimitar (1806-1866) and Andon Stanishev (1820-1896), who were wellknown woodcarvers, settled in Krushevo. From the same village came several other prominent clans of master-builders, painters and woodcarvers: the clan Danailovi, whose founder was Danail and his successor was Mojso Danailov (Миронски, 1995: 9); the brothers Nestor and Mirche lliev, who relocated to Bulgaria (Константиновски, 2001: 15); Vezenkovi (migrated to Krushevo); the brothers Janche and Vangel Vasilev; the clan of Ognjanovi (moved to Bansko, present-day Bulgaria); Angelkovi; Yurukovski; Boshkovski; Siljanovi; Pacharovski and many others (Томовски, 1973: 271).

From the village of Lazaropole, where construction and painting were the main occupation of the population (Томовски, 1969: 222), the most prominent construction groups came from the lineages of the families Gulibegoski, Mazhoski, Dojchinoski, Ralkoski, Bashlakoski, Blazheski, Perinski, Ljapcheski, Chuckovski, etc. (Ibid: 224). From the village of Galichnik, where painting and wood-carving were traditionally nurtured, came the most famous wood-carving family - Frchkovski, as well as the families Tomovski, Nestorovi, Maurovci, Pulevci, Kuzmanovi, Stanishevci, Ginovci, Stojanovi (Константиновски, 2001: 18), whereas a well-known master-builder was the ustabashija kara-Ivan, who worked on the defensive ramparts of the Danube River in Vidin, Bulgaria (Василиев, 1965: 231). From the village of Gari came several families that were engaged in construction and woodcarving (Ognjanovci) and painting (Angelkovci). Especially prominent was the Filipovci family whose most famous member, Petre Filipovski called Garkata (1765-1854), was the author of several masterpieces of Revival woodcarving. The most

\footnotetext{
163 They settled in the villages of Papradishte and Oreshe near Veles as well as in the regions of Krushevo and Bitola; some families even moved to Aegean Macedonia, to the towns of Thessaloniki and Edessa (Василиев, 1965: 152). As many as four hundred families settled in the town of Krushevo alone (Ibid: 278).

164 The Mijak are a macedonian ethnic group that has populated the mountainous region of Reka for millennia, conservatively nurturing their specific dialect, customs, traditions and folklore.
} 
famous master-builder from this village is Todor Petkov (1814-1899) from the Ognjanovci family, the author of several Revival houses in Ohrid built for the new Christian bourgeoisie, of which the most monumental is the house of the brothers Anastas and Angel Robevi. He was also author of the church in the village of Gorna Belica near Struga, as well as several churches in villages along the shores of Ohrid Lake that today are located on the territory of Albania. Lastly, the famous master-builder families Filipovci, Mirchevci, Ginovci and Aleksievci came from the village of Osoj, while the families Ilkovci and Naumovci came from the village of Bitushe (Константиновски, 2001: 21-23). Master Ilko Ilkoski from Bitushe was the author of the church in his native village, while Sare llkoski built the churches in the nearby villages of Novo Selo, Vrutok and Zdunje, region of Gostivar.

The most famous representatives of the Veles master-builder school are the RenzovskiDamjanovi family and their descendants the Zografski, originally from the village of Tresonche, settled in the village of Papradishte (formerly called Zvezdanovo), near Veles in the second half of the XVIII century. The RenzovskiDamjanovi-Zografski family is one of the most famous and prolific (fig. II.13). The activity of the brothers Gjorgji (Gjorche), Andreja, Kosta and Nikola Damjanovi, who worked in one masterbuilder group, is especially important. According to the custom, the brothers focused on various art forms: Gjorgji was a painter, Andreja an architect, Nikola a woodcarver and Kosta an architect and a painter (Томовски, 1961: 162163). Andreja Damjanov (1813-1878) soon took

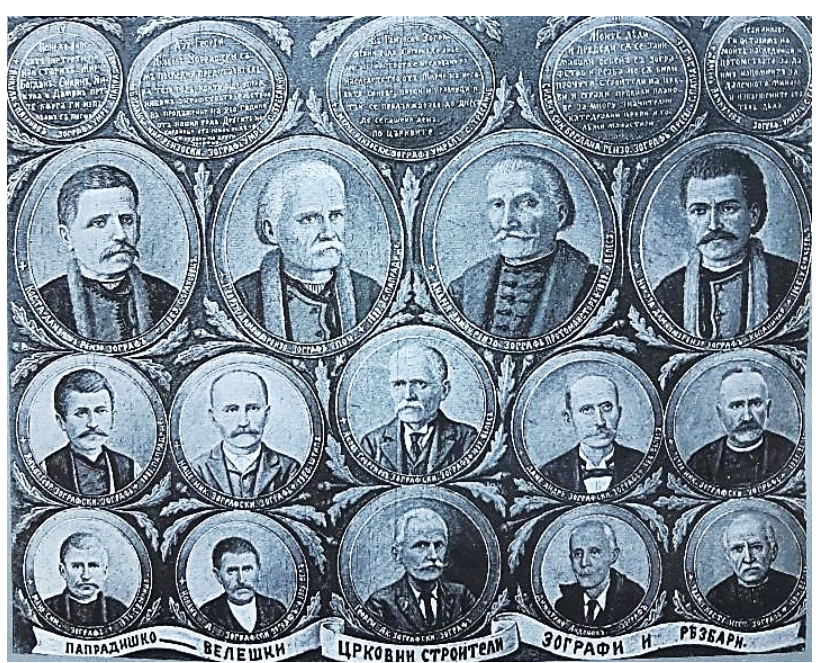

Figure II.13 Group portrait of the prominent members of the Renzovski-Damjanovi-Zografski family, painted by Gjorgji Zografski (bottom center). Another famous painter, Dimitar Andonov Papradishki, is depicted to his right. The largest medallions in the top row are dedicated to the brothers Kosta, Gjorgji, Andreja and Nikola Damjanovi. over the leadership of the group and is responsible for the construction of the most important monumental cathedrals not only in Macedonia, but also in Bulgaria, Serbia and Bosnia and Herzegovina where he traveled with his group at the request of the highest representatives of the newly established states. In Macedonia, his works (see fig. III.213A, III.214, III.236B, III.237) are the church of the Most Holy Mother of God in Skopje (1835), St. John in Kratovo (1836), St. Panteleimon in Veles (1840), St. Joachim Osogovski in Kriva Palanka (1847-1851), the Most Holy Mother of God in Novo Selo, near Shtip (1850), St. Nicholas in Kumanovo (1851) and St. Archangel Michael in the village of Gorno Chichevo, near Veles (1861). ${ }^{165}$ Leaving behind forty completed works, it can be rightfully concluded that Andreja Damjanov is one of the most prolific masters of the Revival period (Томовски, 1961: 163). His successful work was continued by his sons, of which Damjan (Dame) Andreev (1847-1921) stood out as an architect and painter

\footnotetext{
165 Andreja Damjanov's opus in Serbia is very extensive. There, he builds the churches St. Elijah in Pechenjevac (1844), St. Apostles in Turekovac (1845), St. George in Smederevo (1851-1854), Holy Spirit in Nish (1857-1872), as well as St. Trinity in Pirot (1868). His brother Kosta was the architect of the church of St. Trinity in Vranje (1859) (Томовски, 1967: 14). In Bosnia and Herzegovina, Andreja Damjanov built the churches of the Most Holy Mother of God in Chajniche (1857-1863), the Most Holy Mother of God in Sarajevo (1863-1868) (fig. II.10) and St. Trinity in Mostar (1873). In the design of these churches, Damjanov drew even more from the classicist and baroque influences, adapting his already established architectural expression to the different historical, social and cultural circumstances in these areas, "responding to the task of merging the Byzantine and Western ways of building" (Грчев, 1998: 28). Namely, unlike the buildings of Andreja Damjanov built in Macedonia "which follow certain lines of development of church construction through the application of traditional patterns for solving the spatial structure, composition, treatment of façade decoration and interior design, the churches he will build outside Macedonia will show how the individual approach to solving the same problems can produce buildings that bear not only the stamp of individuality, but also very serious compilation behavior when it comes to the compactness of stylistic expression and respect for diverse traditional patterns" (Ibid: 27-28).
} 
(fig. II.13, second row, second medallion from the right). His works are the churches of the Most Holy Mother of God in Veles, St. Cyril and Methodius in Tetovo (see fig. III.263), St. Constantine and Helena and St. Demetrius in Skopje (see fig. III.262), as well as the churches in Kosovska Mitrovica and Prizren, both on today's territory of Kosovo (Миланова, 1990: 125). The last descendant of the Renzovski-DamjanoviZografski family, which had been continuously engaged in construction for more than two hundred years, was Gjorgji Zografski (1871-1946), a painter working at the very end of the Revival and well into the new, XX century.

As was the case with the Damjanovi family, the Dzongar family also migrated from Tresonche to the village of Papradishte near Veles. The oldest known member of this family is master Novak, whose son Gjorgji Novakov-Dzongar is one of the most prolific master-builders of the Revival. He built cathedral churches in Serbia and Bulgaria; on the territory of Macedonia, however, among his other works, the most prominent and monumental are the churches of St. Peter and Paul in his native village of Papradishte (see fig. III.213B), St. Elijah in Star Dojran, St. Panteleimon in Pantelej, near Kochani (see fig. III.216A) and the cathedral of St. Nicholas in Shtip (see fig. III.227).

The lineage of the Angelkovi family from Tresonche can be traced back to the XVIII century, when master Angelko, like many other villagers, relocated his family and his practice to the village of Papradishte. His activity was continued by his son Petar, and especially by his nephew Kitan Petrov (17931866) who, in addition to being a successful master-builder and leader (ustabashija) of a master-builder group consisting of 50-60 members (Василиев, 1965: 205), also tried his hand at woodcarving and painting. He mainly worked on churches in Aegean Macedonia. ${ }^{166} \mathrm{His}$ son Andon Kitanov (1829-1914) was also a famous and extremely prolific master-builder, woodcarver and icon painter. ${ }^{167}$

In addition to the region of Veles, many Mijak families from the region of Reka (more precisely from the villages of Galichnik, Lazaropole, Gari and Tresonche) moved en masse to the region of Bitola, precisely to the village of Smilevo (map II-1), where they continued the construction, painting and woodcarving tradition of their ancestors. Although self-taught, they were famous architects-builders and authors of most public buildings in Bitola, the capital of Rumelia ${ }^{168}$ (Траичев, 1941, quoted by Константиновски, 2001: 26), as well as residential buildings, roads, military buildings, railway facilities, etc. ${ }^{169}$ The most famous family of master-builders from the village of Smilevo is the Darkovci family (Gjorgji Darkovski and his sons Petre and Ilija Darkovski); as well as the families Troshevci, Igumenovci, Kochovci, Trampevci; while Tanaskovci and Dukovci were engaged in woodcarving. The master-builder groups from the village of Smilevo, together with masters from Struga are mentioned as authors of some of the Revival churches in the region of Prespa (Томовски, 1970: 19), in their native village and the surrounding area.

\footnotetext{
166 Within Macedonia's current political borders, his works are the church of the St. Annuciation in Prilep; St. Demetrius in Kriva Palanka (Светиева, 1992: 139) and St. Athanasius in the village of Bogomila near Veles.

167 In the region of Veles, his works are the churches in the villages Orizari, Elovec, Rashtani, Busilci, Lisiche, Kapinovo, Dolno Vranovci, Bistrica, Teovo, Nezhilovo, Podles, Sogle. In the eastern part of Macedonia, he built the church in the monastery St. Panteleimon in the region of Kochani. His extensive activity can be followed in south-eastern Macedonia (regions of Gevgelija, Valandovo and Dojran): the churches in the villages Prdejci, Petrovo, Kovanec, Brajkovci, Balinci, Gabrovci, Sermenin, the old church in the village Mrzenci, which does not exist today, he also renovated the churches in the villages of Smokvica and Gjavato, and is the author of many other churches in the villages throughout Aegean Macedonia, today on the territory of Greece. In addition to architecture, he sometimes engaged in wood-carving and icon-painting: he is the author of the icons and wood-carved iconostasis in the monastery of St. George in Kochani, the church of St. Nicholas in Shtip (as part of the master-builder group of Gjorgji Novakov-Dzongar), St. Athanasius in Dojran and St. Cyril and Methodius in Gevgelija.

${ }_{168}$ Rumelia is the name used for the European provinces of the Ottoman Empire, derived from the millet-I Rum (see Chapter II.1)

169 In fact, the Macedonian master-builders were extremely appreciated, not only by the local population, but also by the Ottoman government, which for their work on public buildings endowed them with various privileges: the right to free movement throughout the Empire; sultanic decorations (for example, Andreja Damjanov was gifted a decorated sword and had the right to carry it on himself); the right to ride a horse; to have an armed escort; they were awarded land properties, еtс. (Василиев, 1965: 150).
} 
The master groups from Krushevo also worked with significant success, building and decorating churches mainly in the town and its wider surroundings, but also abroad, such as the neimar Hadzi Nikola Zhivkovic (called Hadzi Neimar), who was one of the main architects in Serbia after its liberation and one of the founding contributors of its national style. ${ }^{170}$ Furthermore, from the region of Krushevo came master Nedelko, ${ }^{171}$ master Stojan Vezenko(vić) who was a mimar (architect) in the service of the Ottoman imperial administration in Bitola, as well as several well-known painting and woodcarving families, including descendants of the Renzovi-Damjanovi family from Tresonche, formerly settled in Krushevo (Василиев, 1965: 176).

The masters Kosta Lauco and Riste Taslamiche from Prilep ${ }^{172}$ are the builders of the town's cathedral church St. Annunciation (see fig. III.236A). Apart from Prilep and the villages in the town's vicinity, these masters also worked in the neighboring regions, especially in Mariovo.

Lastly, the inhabitants of the region of Kriva Palanka, to the far north-east, have also traditionally been engaged in construction. Thus, the builder of the town's clock tower is master Stojan Petrov Mezin from Kriva Palanka, who also built the church St. Theodore Tyron in the village of Konopnica, near Kriva Palanka (in 1881-1885). Apart from being a builder, he was also a woodcarver, and among his works are the royal doors and the crucifixion on this church's iconostasis.

\section{II.4 Fresco and Icon Painting}

While the exterior of the Revival temples is simple, clear, and even ascetically conceived in its concept and articulation, their interior contains an impressive splendor and complexity of structure, both constructively and aesthetically (see fig. II.14). ${ }^{173}$ The artistic crafts represented in the interiors of the churches: fresco painting, icon painting, woodcarving and carpentry perfectly complement the architecture, often conveying one idea through the same decorative elements and symbolic motifs executed in different techniques and materials, as part of an integral design. In other words, the churches of the XIX century were treated as a complete, integral work of art as a result of a "unified architectural and artistic action that integrates complex experiences, tested and established systems for the realization of a complete work of art" (Грчев, 1998: 23). In this feature of theirs, the Revival churches evoked the ideal of Baroque design - to dissolve the boundaries between the components of the whole work of art: architecture, painting and sculpture (Roth, 1999: 421).

The integral construction of the Revival churches is due to the affiliation of masters and artisans with various education and background within the same group. Thus, the woodcarvers and painters who

\footnotetext{
170 Nikola Hadzi Zhivkovic (1792-1870) was in essence the court architect of Prince Milosh Obrenović, leading the entire construction activity of the newly established Serbian principality between 1834-1842. He is the author of several important public and residential buildings, including the residence of Prince Milosh in Kragujevac, the residence of Princess Ljubica in Belgrade, the Prince's court in Belgrade, two military barracks, a girls' high school, the residence of Prince Milosh in Topchider, Belgrade etc., some of which still exist and are in use (Томовски, 1972: 156-157).

171 Whose name is associated with the construction of churches in the villages of Buchin, Dolno Divjaci and Arilevo in the region of Krushevo, erected in the second half of the century (Николовски, 1990: 133-134), as well as several churches and other buildings in Belgrade, Serbia where he worked with his son Nikola (Светиева, 1992: 141).

172 The name of Kosta Lauco is associated with the construction of the clock tower in Prilep in 1858, as well as the monastery lodgings of Treskavec, where it is mentioned in an inscription dating from 1867. Riste Taslamiche, on the other hand, built the churches St. Peter and Paul in the village of Radobor, region of Bitola in 1891 and St. Savior - Ascension of Christ in the village of Malo Ruvci, region of Prilep, in 1892 (Ќорнаков, 2016: 107).

173 By this characteristic, the Revival basilicas are related to the early-Christian ones, which also had a very simple, modest exterior, even in the most monumental temples, such as St. Sophia in Constantinople: "Everyone who has written about St. Sophia, from travelers passing through Constantinople to modern architectural researchers, has noticed the difference between the interior and exterior of the building. There is no doubt that in that aspect the general practice in sacral architecture has been continued, according to which the interior space is the entire meaning of the building" (Кораћ и Шупут, 1998: 49).
} 
decorated the churches and the profane objects, created decorations that complemented the architecture (Томовски, 1969: 221). Depending on the economic power of the church boards, the painting and construction of the iconostasis were carried out immediately after the construction of the churches, or in an extended period, sometimes decades after the construction of the temple (Николовски, 1987: 41). The sanctification of the church took place after its fresco painting, therefore, in fact, often the years that were marked in the founding records or in the fresco ensembles mark precisely that later date. ${ }^{174}$

As was the case with architecture, the fresco and icon painting were now carriers of a new idea, a product of centuries of tradition and layered experiences from the Byzantine and post-Byzantine period, but also of new understandings in art and aesthetics influenced by Western Europe, i.e. by a completely different, other artistic tradition. Namely, in the XVIII century, through the workshops of Mount Athos, Thessaloniki, the Ohrid-Castoria region and Epirus (Moskopole, Korcha and Elbasan), as well as the influences coming from the Aegean and lonian coast, the Levantine baroque was transferred to Macedonia and established in all its artistic manifestations. ${ }^{175}$ Following the contemporary trends in art, the painters accepted as "a convention of the time the baroque and rococo ornamental applications, lavish draperies, excessive gilding and intense color" (Алексиев, 2013 (А): 2198).
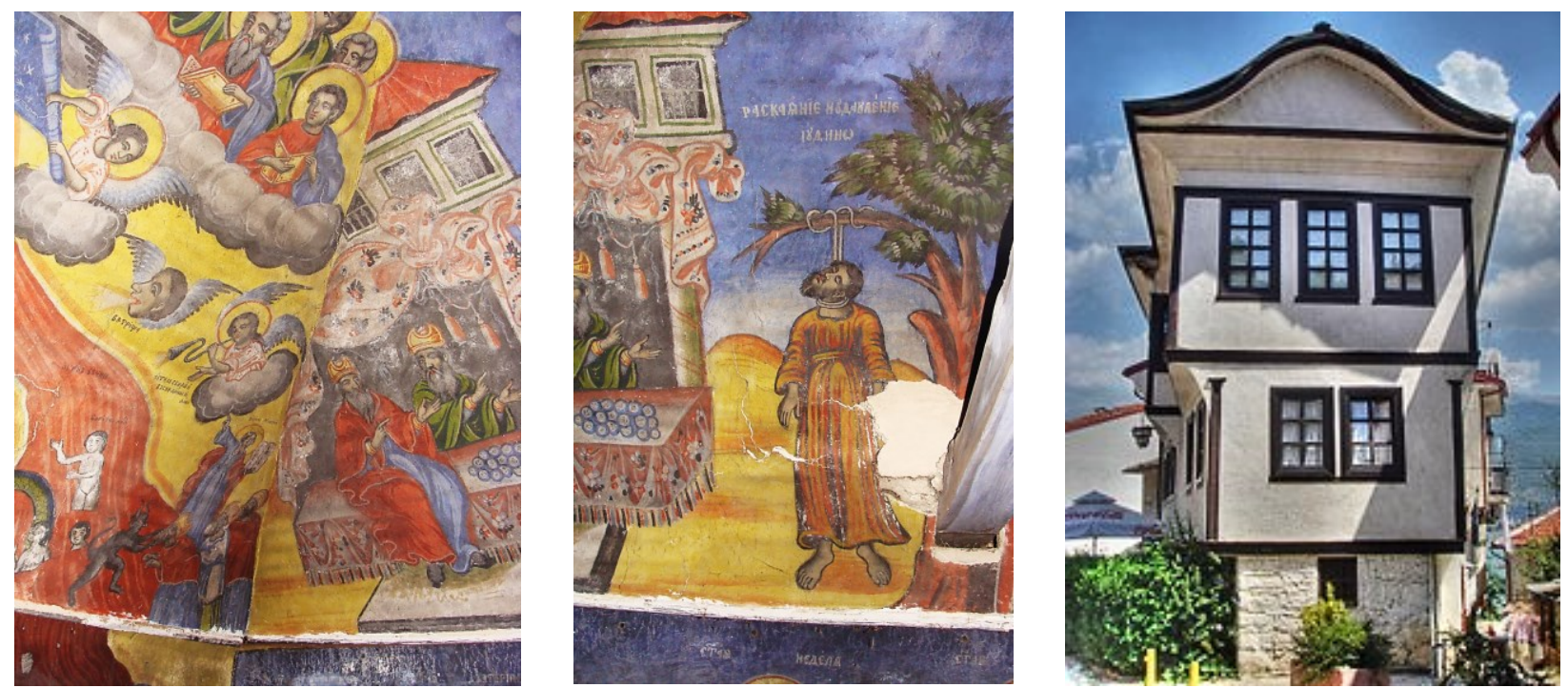

Figure II.14 Traditional profane architecture (variants of the Balkan-oriental house) in the Revival fresco-painting. A-B. Details of the composition Judas' remorse, church of St. Savior in Rashtak, near Skopje; C. XIX century house in Ohrid.

Thus, an explosion of color reigns in the interior of the Revival churches; even in those that were not fresco-painted according to the canons, or where the fresco-ensembles were limited to the vaulted and altar parties. The columns, capitals, arches, gallery parapet, as well as the iconostasis themselves (see fig. II.18) and even the space under the stairs leading to the galleries or others unusual places were regularly painted (see Chapter III.3). The richness of the chosen tonality, the vibrant and contrasting tones, as well as the painted motifs are astonishing: floral ornaments, vines, often with baroque shapes and curvatures; the tree of life motif or its alternative representations (floral bouquets, leaves, twigs, branches); geometric motifs (rhomboids, triangles, circles); interweaving inspired by medieval illuminated manuscripts; mythological and magical creatures; wild and domesticated animals and beasts; solar,

174 "It took many years to raise funds to complete the multi-storey iconostasis, which contributes to the image of a heterogeneous painting ensamble, often unequal in quality, since it was created by several painters at different times" (Тричковска, 2008: 67).

175 In that sense, of exeptional significance was the contribution of Hristifor Zhefarovich from Dojran, who later moved north to the Austro-Hungarian kingdom, whose copperplates printed in Vienna in the middle of the XVIII century nurtured the baroque and rococo aesthetics. In the next period they became especially popular among the Mijak painters, who "accepted the compositional, spatial and ornamental solutions of the Renaissance-Baroque European tradition in the Macedonian monasteries that were attached to the Byzantine art tradition" (Грозданов, 2004: 202-203). 
cosmogonic and astronomical symbols (see fig. II.16); ${ }^{176}$ inscriptions; and even entire landscape compositions (fig. II.15). Also, the abstract background scenery and archaic draperies which were characteristic of the Byzantine artistic tradition were abandoned, and substituted by local, familiar and well-known architectural scenography based on profane buildings (fig. II.14, II.15), ${ }^{177}$ as well as elements of local folk costumes, jewelry and decoration which the local believer - who was also founder of the church itself and in the rural areas oftentimes a direct participant in its construction and decoration (see fig. II.4) - could easily identify with.
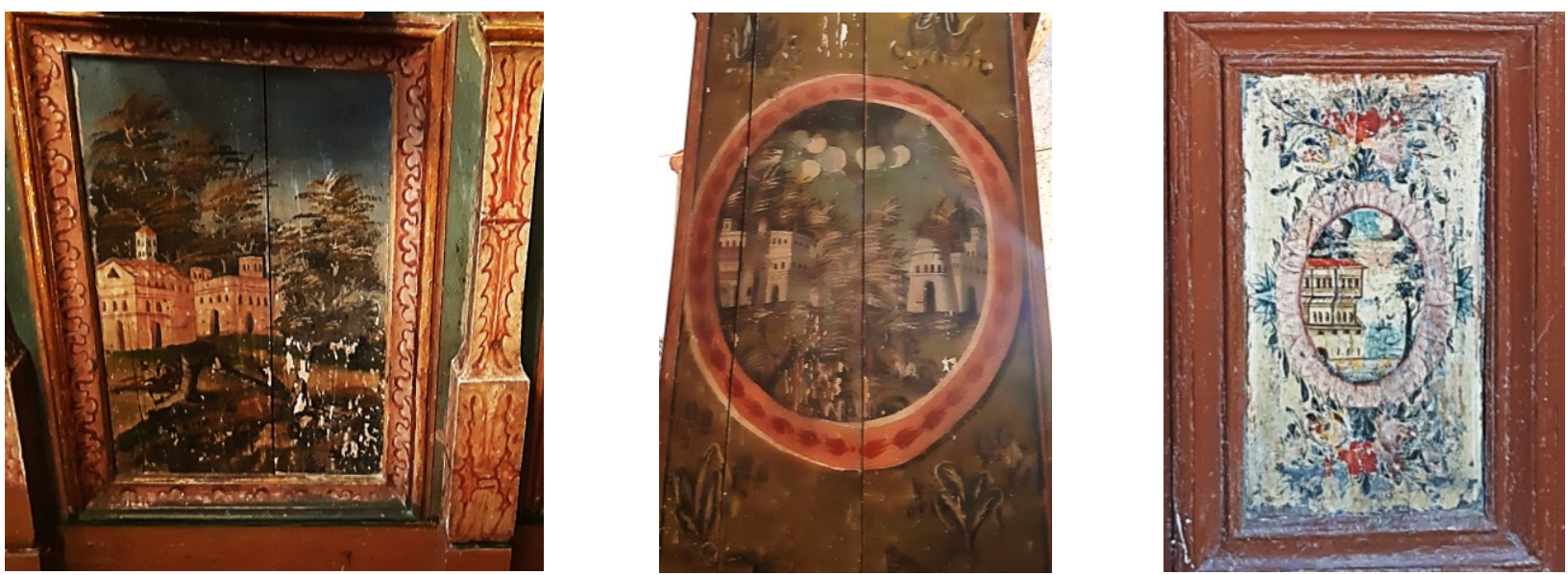

Figure II.15 Landscapes and architectural scenography: A. Socle of the iconostasis and B. Back of the bishop's throne, church of the Holy Healers (St. Cosmas and Damian) in Ohrid; C. Icon pedestal, church of St. John in Kratovo.

As was the case with the top master-builders, a number of the masters of the arts and crafts also became famous and celebrated, whose work was most appreciated and sought after, and who therefore were the most influential in shaping the local and regional artistic expression. At the very beginning of the XIX century, the activity of the masters from the region of the Ohrid diocese (the cultural circle KorchaMoskopole-Ohrid) from the previous period, before the abolition of the Ohrid Archbishopric, was still dominant. In 1800-1806, the painter Trpo from the village of Potkozhani, near Korcha, worked on the frescoes of the monastery St. Nahum on the shores of Lake Ohrid (Грозданов, 1995: 192). It is known that the icons for the same monastery were made by his ancestor Constantine Hieromonk in 1711 (see Chapter II.2). Sometime later, in the 1820s, the name of Mihail Zograf appeared on the art scene (Николовски, 1987: 44), a native of the village of Samarina in Epirus who later joined the great migration of the Vlach population to Krushevo and became one of the leading figures in the art of the Revival. In the first phase of his fruitful work in Macedonia, he collaborated with his eldest son Dimitrie, and later with his youngest, Nikola Mihailov. In the 1830s Mihail and Dimitrie worked intensly on the decoration of St. John - Bigorski monastery, where they established their own workshop. ${ }^{178}$ It was there that Dimitrie became a monk and was given the monastic name Danil (Алексиев, 1995: 31). Soon, they were celebrated as true innovators of icon painting in the region ${ }^{179}$ and contributed, through the education of young fresco and icon painters

\footnotetext{
${ }^{176}$ As many other Christian symbols, the composition Christ Pantocrator depicted between the Sun and the Moon originates from the ancient pre-Christian civilizations and their iconography, as God "frater Solis et Lunae" (Hoddinott, 1963: 9).

177 Elements of folk architecture are inserted, for example, in the compositions painted in the middle nave of the church St. Athanasius in Bogdanci (Ќорнаков, 1987: 162); on the iconostasis of the Holy Healers in Ohrid (fig. II.15), etc.

178 They are the authors of 44 icons for the monumental three-story iconostasis painted in 1831-1833, the painted panels of the royal doors, the crucifix, the relics box (Тричковска, 2008: 79), as well as a series of portraits in the monastery's dining room, commissioned by the abbot of the monastery, the Archimandrite Arsenie (1807-1838).

179 Mihail's works (frescoes and/or icons) can be found in the churches in Lazaropole; Trebishte; Rajchica (together with his son Danil); Gorna Vlashka Maala in Ohrid (Грозданов, 2004: 69); Bitola; Resen; Bogomila and the monastery Treskavec (Bacилев, 1965: 280), in cooperation with the painter Zisi from Krushevo. Nikola Mihailov's independent mature works include the churches in Slepche, Demir Hisar; the Osogovo monastery; Kriva Palanka; St. Nicholas in Kumanovo; Blatec near Vinica (Балабанов, 1970: 32); Trkanje near Kochani; Gorni Lipovich near Radovish; Monospitovo, Novo Selo and Gabrovo near Strumica; Rashtak near
} 
in their studio, to an accelerated development of painting and the formation of the painting style characteristic of the XIX century Revival.

During their work at the Bigorski monastery and the church of St. George in Lazaropole, Mihail and Danil met and greatly influenced the creative expression of Dimitar Krstev (1819-1872/73), known as Dicho Zograf, a young painter from the village of Tresonche (Грозданов, 2004: 72). The works of this master-painter, considered in science the best and most productive Revival fresco and icon painter

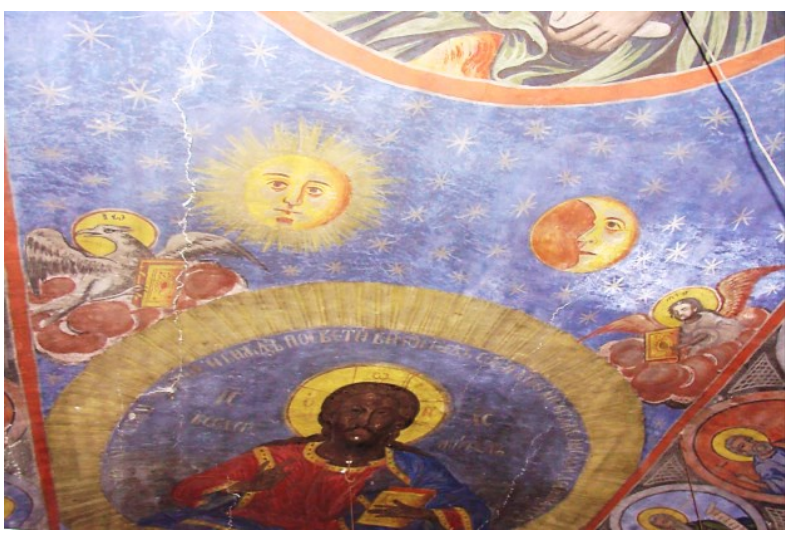

Figure II.16 Detail of the vault of St. Savior in Rashtak (Skopje). Cosmogonic symbols (the Sun and the Moon).
(Николовски, 1989: 278), who in his thirty active working years produced a fascinating number of over 2,000 icons and several complete fresco ensembles, ${ }^{180}$ can be traced throughout Macedonia, but also in the neighboring countries Serbia, Bulgaria and Albania. Although self-taught, his exceptional talent and organizational skills are undeniable. Namely, in the studio he established in his native village many young painters were educated in the art, including his sons Avram Dichov (1840-1923) ${ }^{181}$ and Spiridon (Spiro) Dichov, as well as his most prominent students and followers Petre Novev Pacharov, ${ }^{182}$ Maksim Nanev,

Josif Radevich Mazhoski from Lazaropole and Hristo Makriev from Galichnik (Алексиев, 1995: 31). Аpart from frescoes and icons, he also created some of the oldest portraits in the Macedonian fine arts (Алексиев, 1995: 31). In addition to the baroque decor, the glitter of gilding and precious stones, his frescoes and icons reveal a sensibility and unmistakable uniqueness of his expression, his personal, author's signature. The precise drawing, anatomically correct and harmonious proportions, warm colors and refined characters, richness of the golden background tones, subtle but lavish ornamentation and decoration, baroque whimsical draperies against the solid and balanced composition, as well as the incredible quantity of this author's opus will grant him the attribute of an unattainable "miracle artist" even within his lifetime (Алексиев, 2013 (A): 2198), who was often emulated by contemporaries and whose work marked the art of the XIX century.

Besides Tresonche, other Mijak villages became famous for their numerous painting families. From the village of Lazaropole came the brothers Josif (1830-1910), Jakov (1835-1920), Ivan and Isaac - Isaiah (1858-1926) Radev(ich) Mazhoski, sons of the painter and woodcarver Radul Mazhoski (1790-1886). ${ }^{183}$

Skopje (Николовски, 1990 (А): 22-28). In Krushevo he worked in all of the town's churches: Dormition of the Most Holy Mother of God; Ascension of Christ - St. Savior, St. John and St. Nicholas; St. Transfiguration in Prilep; in Aldanci; in Kozica near Kichevo; in Buchin, where he colaborated with Konstantin from Krushevo (Николовски, 1990: 134); in Zhegljane near Kumanovo, etc.

180 In his native region of Debar - Reka he painted in the churches in Trebishte, Rajchica and Selce; at the monastery of the Immaculate Mother of God near Kichevo; in the town of Ohrid he worked in the churches of the Most Holy Mother of God Chelnica (Василев, 1965: 184-185), St. Nicholas Gerakomija and Dormition of the Most Holy Mother of God Kamensko, where he collaborated with his sons Avram and Spiro and the painter Petre Novachev from Tresonche (Грозданов, 2004: 129).

${ }^{181}$ Avram worked on the frescoes of several churches in the Ohrid-Struga region: Prisovjani, Draslajca, Vevchani, Slatino (with his brother Spiridon). He also worked at the monastery of the Immaculate Mother of God near Kichevo; in Vraneshtica he collaborated with Grigorij Petrov and his brother Spiridon (Грозданов, 2004: 145); in Melnica; in Stenche, together with master Petre Novachev (Миљковиќ-Пепек и Николовски, 2010: 43); and several churches near Kriva Palanka (the Osogovo monastery and the villages of Rankovce and Konopnica) where he worked together with Miron lliev and Grigorij Petrov from Tresonche.

182 Although only a few years younger than Dicho Zograf (he was born in Tresonche in 1825), Petre Novev Pacharov is considered his most talented student, with whom he collaborated in St. Peter and Paul in their native village in 1846/1847 (Грозданов, 2004 : 87). Together with his son Grigorij, he worked in several churches in the Tikvesh region: in Bohula, Rozhden, Kumanichevo.

${ }^{183}$ According to the preserved records and inscriptions in the churches, it can be confirmed that Josif Radevich worked on the frescoes and/or icons in several villages in the region of Prespa-Bitola: Srpci, Crnobuki, Lisolaj, Beranci, Carev Dvor, Vasharejca, Zlatari, Gorno Dupeni, as well as the village of Vrben in the region of Mavrovo. Jakov worked in Lazaropole; Chelopeci near 
The family Chuchkoski from the same village was engaged in painting and woodcarving, as well as the Krstevi-Nikolovi family, to which several fruitful painters belong. The sons of Makarija Frchkovski, the painters Risto and Kuzman Makarievi and Vasil Ginovski (who in 1871 painted the porch of the Bigorski Monastery) came from the village of Galichnik (Василиев, 1965: 232); from the village of Gari, stood out the painter Andon Petrov(ich), ${ }^{184}$ the brothers Dimitrija and Georgi Andonovi (Ќорнаков, 1987 (Б): 150) ${ }^{185}$ and the painters of the Angelkovci family; from the village of Osoj, the Dzikovski family, etc.

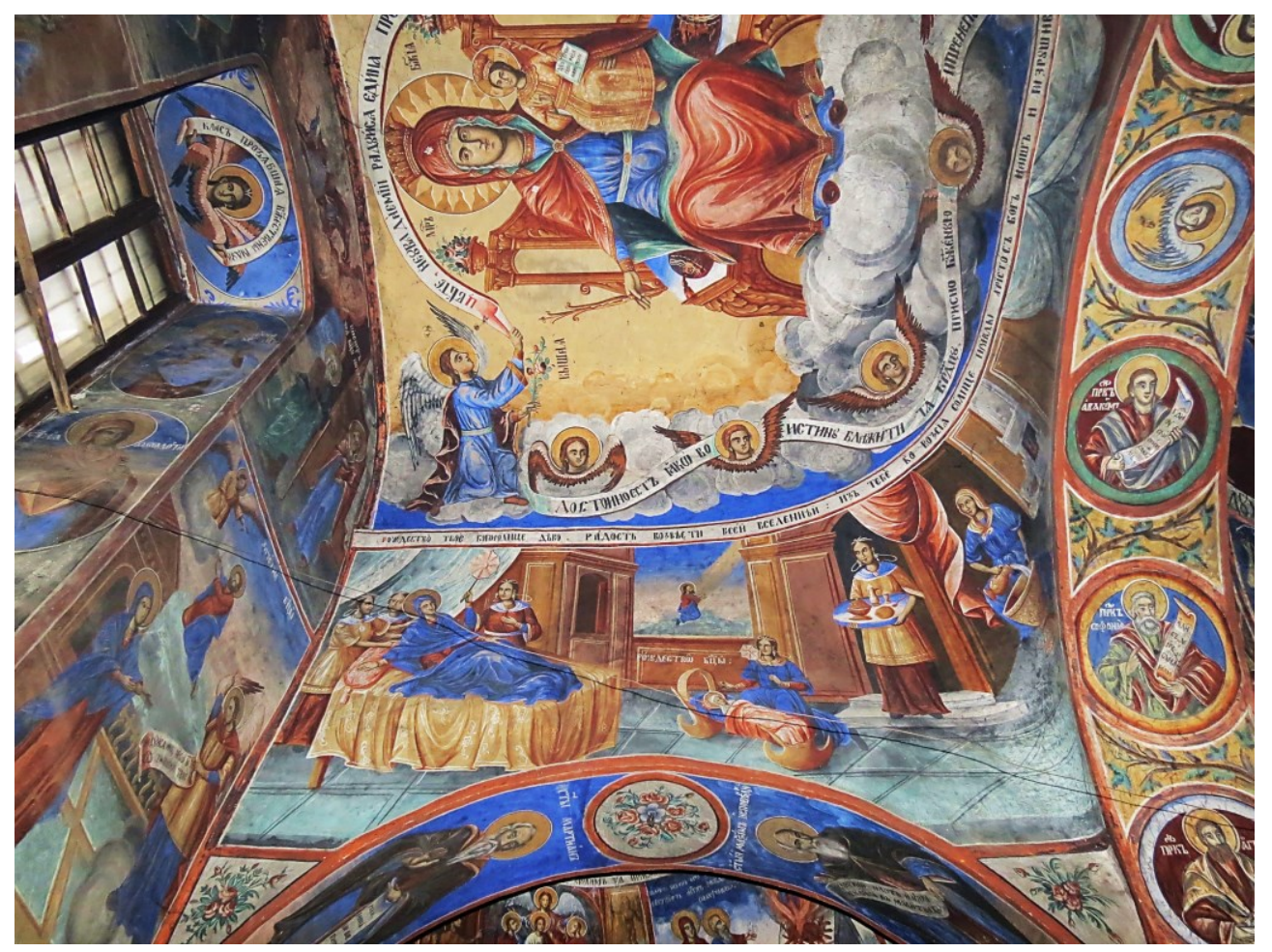

Figure II.17 Detail of the fresco-painting of the church of St. Nicholas in Vevchani, near Struga, by Avram Dichov.

As in architecture, the region of Veles also gave particularly fruitful painters. Among them were Teodosij of Veles; Hadzi Koste Zograf who, in addition to painting frescoes and icons, was one of the first photographers in the Balkans and Dimitar Andonov Papradishki (1859-1954) who marked the end of the Revival and the beginning of a new era in art. He came from a traditional painting, woodcarving and architecture family - Angelkovi (Алексоска, 2005: 8), which like many others was part of the great migration from the region of Reka (village of Tresonche) to safer parts of central Macedonia in the second half of the XVIII century. Having completed the traditional education in the family master-builder group of his father Andon Kitanov, he also attended the Kyiv Iconographic School. In his long and fruitful life he created an extraordinary number of painting ensembles and icons ${ }^{186}$ for about eighty churches and

Kichevo; Glodji, Janchishte, Tearce, Neproshteno and Tudence in the region of Tetovo; and Sveta near Demir Hisar (МиљковиќПепек и Николовски, 2010: 41). The two brothers worked together at several churches in the regions of Mariovo, Bitola and Demir Hisar (Митревски, 2011: 296-297): in Babino (Дапчев, 1996: 218), Capari (Николовски, 1993: 172), Gopesh, Oleveni, Gjavato and Sopot. The signature of Ivan Radev(ich) is present in Ivanjevci, near Bitola (Николовски, 1993: 162). Isaac, on the other hand, mostly developed his activity in Bulgaria (Томовски, 1969: 226). Josif, Isaac and Ivan collaborated in the villages of Gorna Belica and Radozda, both near Struga.

184 The signature of the "calm painter Andon from Gari, kaza of Debar" can be found in several churches around Strumica: in Monospitovo, Bosilovo, Novo Selo, Zubovo and Makrievo (Пандевски и Стоев-Трнката, 1969: 156).

185 In the village of Kalen (Mariovo), as well as in the church in Ropotovo, near Prilep.

186 Dimitar Andonov Papradishki is the author of over 1200 icons (Алексоска, 2005: 17), which, in terms of quantity, place him right behind Dicho Zograf, the most prolific painter of the Revival. He fresco-painted the Osogovski monastery near Kriva Palanka and the churches in Novo Selo near Shtip, Skopje, Kratovo etc. In addition to many icons, he left behind a number of portraits of prominent citizens, members of his family and self-portraits, which go beyond the limits of the church founders as the only representatives of portrait art in the past centuries. Towards the end of the century, he painted landscapes which, like the civic 
monasteries throughout Macedonia, Bulgaria, Serbia and Bosnia and Herzegovina (Томовски, 1961: 165). Finally, the last of the Renzovci-Damjanovi family - the painter Gjorgji Zografski (1871-1945), who was born in Papradishte and educated in Moscow and St. Petersburg, dedicated his extremely realistic style predominantly to portrait painting (Алексоска, 2005: 14).

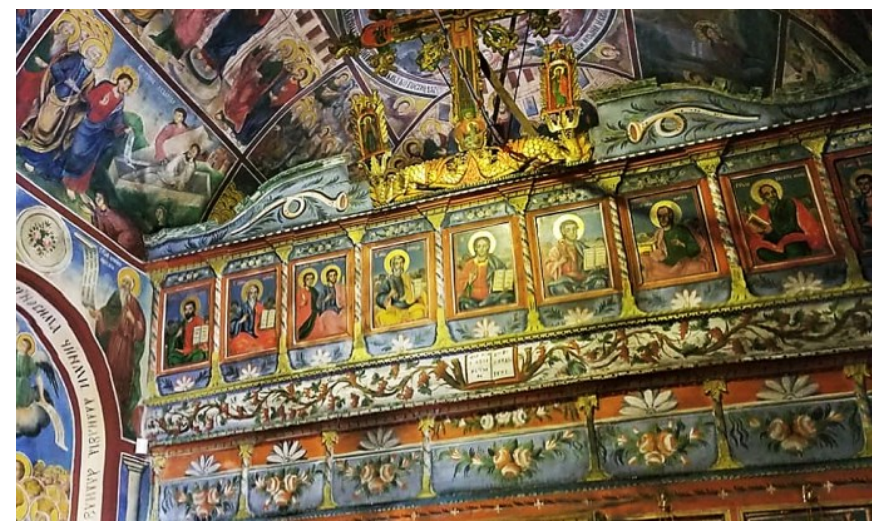

Figure II.18 Detail of a painted iconostasis, church of Dormition of the Most Holy Mother of God in Botun, near Ohrid.

Masters from other regions were also well known. For example, the brothers Vangel, Kosta and Nikola Anastasovi, sons of the painter Anastas (Atanas-Tashe), came from Krushevo (Митревски, 2011: 297). Their works adorn many churches in south-eastern Macedonia (Ќорнаков, 1987 (Б): 164-166, 169-170) as well as the villages near Krushevo, Bitola and Demir Hisar (Николовски, 1990: 133-134). ${ }^{187}$ According to tradition, Kosta's son, Tashku Kostov and Vangel's son, Nake, also became painters. Other painters from Krushevo include Stanko and his son Stojan

(Stojche) Stankov, whose family stems from the Renzovci clan (Николовски, 1990: 133); both worked mostly in Krushevo and the surrounding villages. ${ }^{188}$ Adamche Najdov Janov (1816-1882) ${ }^{189}$ and Jovan Budimov (1846-1908) ${ }^{190}$ came from Prilep. From Strumica, the most prolific fresco and icon painter whose works are scattered throughout eastern Macedonia and in neighboring Bulgaria was Grigorij Pecanov; ${ }^{191}$ as was the case of Gjorgji Veljanov ${ }^{192}$ and his son Vasil Gjorgjiev (Николовски, 284); Gavril Atanasov (18631945) from Berovo ${ }^{193}$ and others. The painter Dimitrija Andonov from Bitola (village of Magarevo) worked mostly in the Bitola - Prespa region; ${ }^{194}$ as did the painter Anastas (Николовски, 1993: 171) and his son Konstantin Anastasov (Василиев, 1965: 277).

Also, painters from the Aegean and Pirin part of Macedonia worked in certain border regions today. Thus, in the region of Prespa commonly found are the names of the painters Apostol Steriev and Atanas Dimitri, born in Aegean Macedonia (Николовски, 1987: 45); some painters from the towns of Melnik and Thessaloniki worked in the region of Strumica, etc.

portrait, were a novelty for the Macedonian painters, still firmly obsessed with tradition, as well as folklore themes and historical compositions. Thus, in fact, the opus of Papradishki marked the essential transition from iconography with Byzantine roots to contemporary easel painting with profane motifs (Величковски, 2005: 5), as an announcement of the modern art in Macedonia.

${ }^{187}$ Icons with their signature can be found in the churches in their hometown Krushevo, as well as many villages in the neighboring regions: Drenovci; Aldanci; Nebregovo; Arilevo; Bela Crkva (Николовски, 1990: 133). For some time, the three brothers worked in the Tikvesh region, in central Macedonia: in Przhdevo; Klisura; Bohula; Konopishte; Chiflik; Dolna Boshava; Begnishte; Resava; Negotino. Then, they returned to their hometown and worked in Dolno Divjaci (Ibid: 135); Pusta Reka; in Struga; Godivje; Ostrilci; Zagoriche; Gabalavci; Rastojca; Edinakovci; Bach; Belche; Zashle; the Slepche Monastery; Zhurche; Bazernik (Дапчев, 1996: 219). As for the ancestor of this painting family, Anastas, his signature can be found in Brezovo and Zletovo.

188 The churches in Krushevo, as well as the villages Aldanci; Malo Konjari; Gorno Divjaci; Borotino; Krivogashtani etc.

${ }^{189}$ Adamche Najdov was an apprentice of the famous painter Nikola Mihailov from Krushevo. He worked mostly in Prilep: the cathedral church St. Annunciation; the monastery St. Archangel Michael in Varosh; in Nebregovo (Грозданов, 2004: 306); in Vranche, etc. Later, his son Stefan Zografov and the painter Jovan Budimov also worked with him (Василиев, 1965: 283).

190 Jovan Budimov above all worked in the Prilep-Bitola region: in the villages of Malo Ruvci, Dupjachani, Aglarci, Dedebalci, Sogle, Varosh and Prilep's cathedral St. Annunciation.

${ }^{191}$ Grigorij Pecanov is the author of icons or whole iconostasis ensembles in the villages of Przhdevo, Klisura, Dabile, Raklish, Voislavci, Gabrovo, Gradec, Smojmirovo, Smolari and so on.

192 Gjorgji Veljanov worked at the monastery St. Archangel Michael in Berovo, the church in Razlovci (Василиев, 1965: 289), еtc. 193 Gavril Atanasov studied painting in the monastic studios of Mount Athos, where he worked primarily on icon commisions for Russia. His icons from the first decades of the XX century can be found in several villages throughout eastern Macedonia: in Badilen; Istevnik; Voislavci; Pogulevo; Trenchovci, Grad, etc.

194 In Ivanjevci (Николовски, 1993: 162), Graeshnica (Палигора, 2011: 34), Resen (Николовски, 1987: 47). 
The Revival painting is characterized by a foundation derived from the Byzantine medieval canons and traditions, upgraded with new artistic impulses, a multitude of Western European neo-baroque ${ }^{195}$ and Levantine Baroque influences, as well as a recognizable, individual author's expression. With its rich expressiveness, but also humanization and idealization of the characters, many precise details such as ornaments on the clothes and a particular interest in solving the space and volumes through complex scenery with skillfully developed architectural elements, rhythm and proportion, as well as a baroque anxiety of the line and the forms, the painters from the XIX century will mark this epoch, achieving a separate, unique and recognizable pictorial expression of the Revival art in Macedonia.

\section{II.5 Woodcarving}

The emphasis in the interior of the Revival churches, more than on the fresco-painting itself, was actually placed on the iconostasis that develops in two or more zones at the eastern end of the naos, and the opposite, western parts of the naos, usually defined by one, or two superimposed galleries. They were regularly processed with an elevated level of carpentry skill and craftsmanship, both in the constructive and decorative sense, especially regarding the altar partition as the most monumental object in the church interior, with lavish ornamentality and rich symbolic, semiotic and theological connotation (see fig. II.12).

The altar partition marks a symbolic boundary between the two worlds: material and spiritual, through a visual representation of the gates of heaven; therefore, it contains pictorial and relief interpretations of complex theological interpretations (Филипова, 1997: 81-82). The concept of the iconostasis as a ceremonial portal (a façade with a passage in its axis, flanked by two lateral wings) is extremely ancient: the earliest prototypes are the propylaea of the Egyptian temples, the portals of the Persian and the palaces of the Orient and, in the more recent past, the scenae frons of the Roman theaters and the entrance façades of public buildings in the Roman Empire. In Christian ecclesiastical architecture, the equivalent to the Orthodox iconostasis in the Western European cathedrals is their western façade, which also assumes the role of a threshold of spiritual passage (Hoddinott, 1963: 120-121).
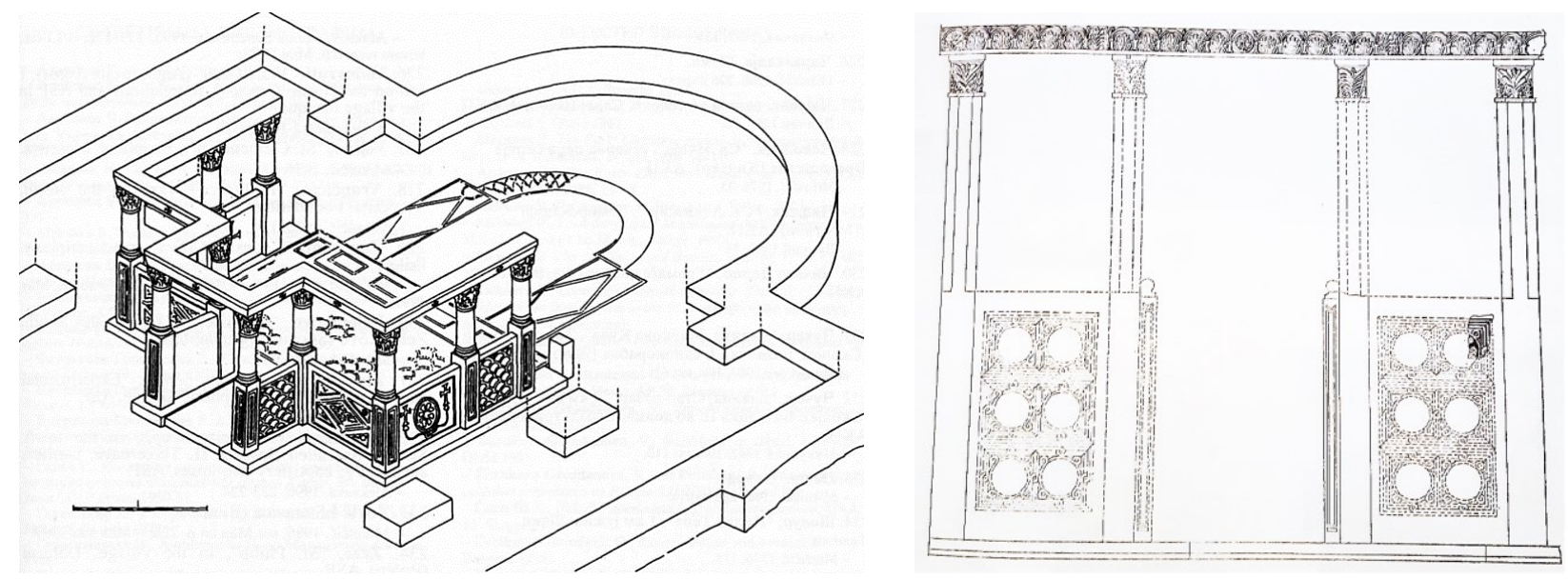

Figure II.19 Reconstruction of early-Christian and Byzantine chancel screens: A. The early-Christian basilica at Suvodol, near Bitola; B. The middle-Byzantine church of the Mother of God Eleusa in Veljusa, near Strumica.

\footnotetext{
195 Baroque influences are evident in the oval shape of the medallions (for example, in the central nave of St. Demitrius in Bitola, see fig. II.11A; on the plinth of the iconostasis at the church in Nebregovo, near Prilep; in small icon panels embedded in the royal doors, and even as painted oval frames on large rectangular throne icons, for example in Gabrovo and Makrievo near Strumica. A multitude of floral decorative elements were imported from the Levantine baroque: garlands, flower pots and vases with flower bouquets, ribbons, "S" volutes, etc.
} 
Throughout the centuries of development of Christianity, the altar partition evolved both in height as in content. In the early-Christian period, the partition separating the sanctuary from the naos was a low parapet comprised of relief marble slabs embedded between short columns (fig. II.19A). In the middle-Byzantine and late-Byzantine architecture, a medium-height iconostasis dominated, still made of the same material - precious stone, and with essentially the same structure, with the difference that the columns gain height and support an architrave beam - cosmitis (fig. II.19B). The free spaces - "windows" that were left between the columns, above the stone relief parapets, were closed with curtains as needed. However, the practice of filling these windows with large, so-called "throne icons" had already begun (Миљковиќ-Пепек, 1996: 96-97). ${ }^{196}$

Judging by the preserved examples of middle-Byzantine iconostasis, they also included the western sides of the pillars between which the partition was stretched enclosing the altar, incorporated in its composition as "fresco-icons", where the painted fresco was framed with a decorative relief frame (fig. II.20) executed in marble (for example, at the church of St. Sophia in Ohrid, XI century) or stucco technique (at St. Panteleimon in Nerezi, XII century). From this Byzantine prototype, during the post-Byzantine period, and especially in the Revival, a tall iconostasis developed which as such completely isolated the altar from the eyes of the faithful. Namely, the altar partition in the XIX century was a completely opaque and continuous structure, ${ }^{197}$ extending from the north to the south wall of the naos, reaching the ceiling in height. Its structure remained the same even though the material had changed: wooden columns carried an architrave beam - cosmitis, while parapet panels were placed between them. Instead of "windows" to the altar, the space between the columns was filled with icons: above the plinth

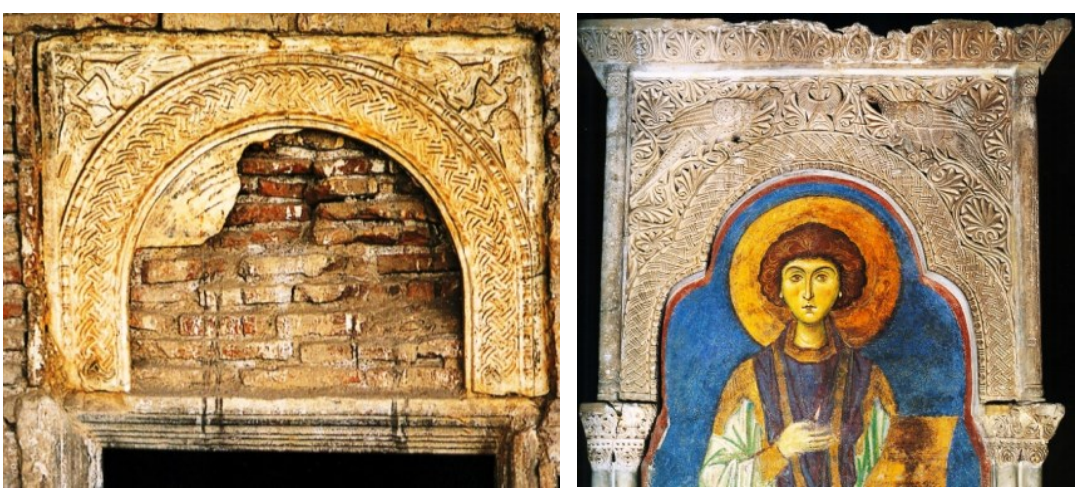

Figure II.20 Examples of middle-Byzantine fresco-icon frames. A. St. Sophia in Ohrid, XI century (re-used on the cathedral's northern façade); B. St. Panteleimon in Nerezi, near Skopje, XII century (in situ). monumental throne icons were placed, of which the Mother of God and St. John flanked the royal doors, the main entrance to the altar located in the axis of the church. A curtain was placed above the royal doors, which are low, particularly richly decorated double doors. In more luxurious iconostasis, the cloth curtain was replaced with an arched wood-carved panel (usually in the shape of an oriental segment arch), executed in filigree-like openwork technique. This panel is known as perde (Turkish for "curtain") in the woodcarving terminology. ${ }^{198}$ The side entrances (leading to, conditionally speaking, the prothesis and diaconicon) were closed with tall doors located in the side intercolumniums, depicting the archangels Michael and Gabriel as "guardians of the entrance" (Алексиев, 2013 (A): 2203). ${ }^{199}$ Above the cosmitis, in the case of a dual-zone iconostasis, a series of smaller icons appear, with a central representation of Deisis as an "abbreviated artistic variant of the Last Judgment" (Коруновски и Димитрова, 2006: 180), flanked by icons of the apostles. In case of a high

\footnotetext{
${ }^{196}$ It is of interest to emphasize that the origins of this medium-high type of altar partition date back to the VI century, as evidenced, for example, by the early-Christian basilica in Suvodol near Bitola (fig. II.19A) and the rotunda in Konjuh (Kratovo). 197 This is due to the Revival iconostasis' position on the western side of the easternmost pair of columns which support it structurally, as opposed to in between the larger massive masonry pillars which was customary in the previous epochs.

198 The same woodcarved element (under the same name) appears in the doorways as part of the wooden built-in furniture (the system of built-in closets), found in the representative houses built in the Revival (Светиева, 1992: 109).

${ }^{199}$ They were often painted in the middle-Byzantine period in this same function, for example on the west wall of the naos of the Ohrid cathedral St. Sophia where they flank the main entrance from the narthex to the naos (see fig. I.23A).
} 
triple-zone iconostasis, a series of holiday icons appears between the throne and deisis icons. Above the last architrave stands a tall, highly decorative crucifix, usually placed on a painted motif of memento mori, also known as "snake cross" ${ }^{\prime 20}$ because it is regularly flanked by two winged dragons - snakes that carry in their jaws two panels depicting the Mother of God and St. John flanking the cross itself. The Crucifix is usually joined by solar motifs and a variety of other Christian symbols (see fig. II.21, II.23). ${ }^{201}$

In other words, the altar partition evolved from a low barrier (in the early-Christian temples), through a semi-transparent element (in the medieval Byzantine churches), to its final manifestation precisely in the Revival: a tall, fully enclosed, opaque backdrop that provides ample space for the presentation of icons in large numbers, allowing for this painting technique to over-shadow the frescoes. This change in the appearance of the altar partition took place in parallel with the liturgical changes and the withdrawal of the liturgical act itself from the naos to the altar, i.e. its gradual transformation from a public to a secret, mystical act (Mathews, 1982: 125-127). The conceptual changes related to the essence and purpose of the altar partition are complemented by a change in its construction material: instead of stone or marble processed in the technique of shallow relief, woodcarving dominates with a highly emphasized three-dimensionality of the relief and a sculptural effect. As the other artistic skills, woodcarving developed under the influence of Byzantine medieval art: in fact, in the middle Ages, relief woodwork developed in parallel with stone sculpture (Lichenoska, 1989: 287), using a similar repertoire of geometric, zoomorphic and vegetative motifs, as well as ornamental patterns in the form of interweaves and medallions. ${ }^{202}$ Unfortunately, due to the instability of wood as a material and its susceptibility to destruction by fire, as well as frequent robberies, demolitions and hostilities in this region, from these early stages of woodcarving in Macedonia only a few preserved specimens remain. ${ }^{203}$ After the establishment of the Ottoman Empire in the last decades of the XIV century, relief stone processing was completely abandoned while woodcarving experienced a real flourishment of the craft.

In the following period (XV-XVII century) the high relief and the bas-relief were abandoned and substituted by shallow relief with abundant plaited and stylized geometric ornamentation, as well as representation of human and animal figures and mythological creatures. This already established tradition was especially influenced by the Italian and Levantine Baroque manner in the XVII-XVIII century (Lichenoska, 1989: 288-290), ${ }^{204}$ creating a "symbiosis of Orthodox traditional patterns and Western

200 The "snake cross", as is the case with many other Christian symbols, can be traced back to the pre-Christian times, when in the religious iconography of various middle-eastern peoples a tripartite image of a godly deity flanked by two beasts (snakes, lions, etc.) or two mounted horsemen was a common symbol of eternal life and re-birth (Hoddinott, 1963: 21-22). Also, the presence of the snakes / dragons can be interpreted as a materialization of the Bible verse: "and the great dragon was chased away, the old snake, called devil or Satan" (Apocalipse, XII, 9).

${ }^{201}$ As an echo of the pre-Christian adoration of the Sun God, on which Christianity will build its iconography.

202 The medallion style, established as early as the VI century, comprises complex ornamental patterns based on intertwined or connected round medallions. Due to its versatility, it was used in all media but reached the greatest lavishness in mosaics, textile and architectural sculpture, not only as a decorative pattern by itself, but also as a backdrop for the "incorporation of figures or even entire scenes in the ornament without compromising its artistic integrity" (Филипова, 1997: 18-19).

203 The oldest preserved woodcarved objects from the Byzantine period, which to this day remain in limited numbers - such as the high relief of St. Clement, the partially preserved iconostasis of the church of the Holy Healers and the door of the church of St. Nicholas Bolnicki, all found in Ohrid (Lichenoska, 1989: 287-288), are representatives of the Ohrid Woodcarving Center which was active in the XIII-XIV century (Ќорнаков, 1987 (A): 5-7). The royal doors from the church of St. Andrea on the river Treska originate from the same period (Ќорнаков, 1998: 16), as do the ones from the church of St. Nicholas in Varosh near Prilep. More on these preserved woodcarved items in Ḱорнаков (2016), who provides an overview of existing literature on the topic.

204 "In harmony with the modification of the iconostasis constructions, fully integrated in the compositional - spatial organization of the monumental temples, the ecclesiastical woodcarving will be the freest and thus the most creative medium for finding new forms and expressions. Emphasized architectural monumentality, plastic mobility and decorative line that will culminate in the multi-storey iconostasis of the XIX century, is the closest thread to Western European decorative art, recognized in the complex façade compositions in deep relief and independent sculptures on the Renaissance and Baroque buildings. According to the researchers, the influences came primarily from Italy, i.e. Venice, due to its centuries-old political and cultural domination of the Ionian Islands" (Тричковска, 2008: 35). From the lonian and Aegean coasts, through the monastic art workshops on Mount Athos, the Macedonian woodcarvers and painters received these influences, upgrading their traditional expression. In addition to the 
European novelties which led to unusual mixtures and ideologically intertwined views" (Тричковска, 1993: 124). In Macedonia, in addition to royal doors preserved in several churches and monasteries (see fig. II.8), ${ }^{205}$ from this phase date the iconostasis of the monastery St. Nahum in Ohrid, dating from 1711 (fig. II.21), as well as the iconostasis of the old chapel dedicated to St. Demetrius in Bitola, dating from $1738 .{ }^{206}$ These are considered to belong to the same local workshop, formed under the influence of Mount Athos (Ќорнаков, 2016: 54).
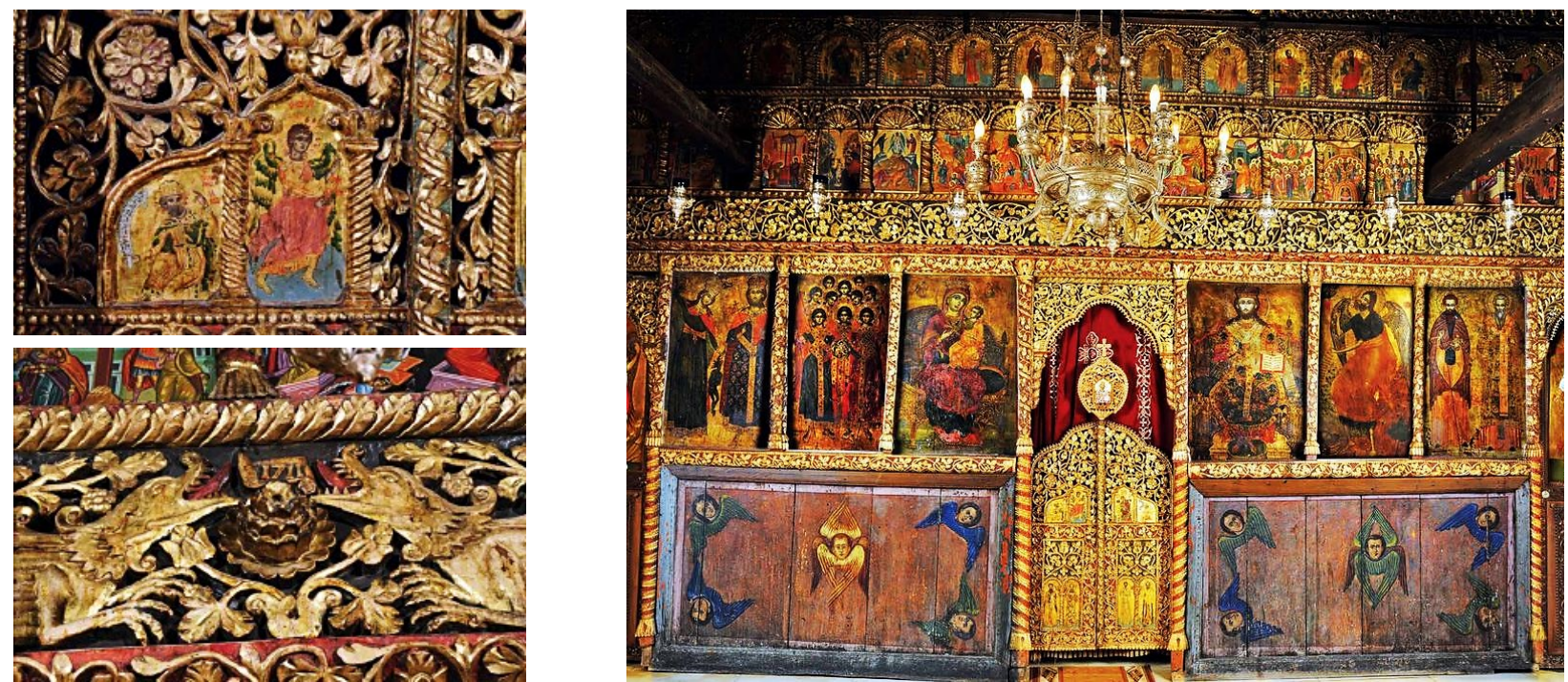

Figure II.21 Details of the iconostasis of the monastery St. Nahum near Ohrid, dating from 1711.

Based on this continuous development of several centuries, the XIX century Revival is a period when woodcarving reached a culmination of its artistic achievements, surpassing the iconostasis as the only focal point and spreading to the church furnishings (pulpits, bishop's thrones, seats, canopies, icon pedestals, icon frames, chants, chandeliers, candlesticks, lamps, wooden lecterns, etc.) and to the western galleries. Unlike previous centuries, the Revival woodcarvers adopted a deep relief and an openwork technique (Ќорнаков, 1998: 82), thus placing the emphasis on the plasticity and sculpturality of the figures and ornaments. Working in walnut wood, gradually getting rid of gilding and color (Алексиев, 2013: 2196), they will fully harness the possibilities and characteristics of this noble material.

In addition to construction and painting, the Mijak masters from the region of Debar - Reka also stood out in the art of woodcarving, creating their own, unique style known as the Mijak woodcarving school. The Italian Baroque strongly influenced their work, so it is no coincidence that the Mijak masters were known as "teladuri" ${ }^{207}$ In their workshops, the woodcarving craft was raised to the level of a

abundance of ornamentation, a pronounced Western European Baroque influence are the oval mandorlas in which painted compositions were placed (for example, at the iconostasis of St. Annunciation in Prilep), the " $\mathrm{S}$ "-shaped branches and garlands, twisted columns, etc., which in addition to woodcarving are also present in icon-painting (Ќорнаков, 2016: 53). The Western European influences are also expressed through the direct import of topics unusual for Orthodox painting, where they entered through painting hand-books (erminias), graphic illustrations and copies of copper engravings of Western European origin. Furthermore, in the spirit of the epoch, woodcarving as well as architecture received certain influences from Islamic art, such as the pointed profiled arch and the threfoil arch (see fig. II.8).

205 From the church of the Immaculate Mother of God in Kichevo (XVI century); St. George in Ohrid (XVI century); Nativity of the Most Holy Mother of God in Kanino near Bitola (XVII century); St. George in Petralica near Kriva Palanka (XVII century); St. Demetrius in Zletovo (XVII century); St. Demetrius in Buchin near Prilep (XVII century); Holy Mother of God in Rankovce, Kriva Palanka (XVII century); St. Cyril and Methodius in Gevgelija (XVIII century), etc.

206 Today, this older iconostasis is displayed in two sections: in the southern chapel (dedicated to St. Transfiguration) and the northern chapel (dedicated to St. Gregory) on the gallery floor of the XIX century Revival cathedral of St. Demetrius in Bitola (Ќорнаков, 1993: 129-130).

207 Derived from the Italian word intagliatore - carver. Thus, one of the procedures in the deep, so-called "dug-out" woodcarving and the openwork woodcarving was called "tetladisuvanje" by the master-woodcarvers themselves (Светиева, 1992: 115), or "alafranga" - "the French manner" (Василиев, 1965: 251). 
prominent artistic branch enriched, for the first time, with folklore content ${ }^{208}$ inserted into otherwise Christian motives and concepts (fig. II.22). The genealogy of the most famous families that were traditionally engaged in woodcarving can be traced back to the middle of the XVIII century. Blazhe Frchkovski, his son Negrija Blazhev Frchkovski (1783-1843) and his sons Makarija (1800-1849), Gjurchin and Trajan Negrievi Frchkovski from Galichnik were the first to engage exclusively in woodcarving, at the end of the XVIII century, organized in woodcarving groups. At the same time, Petre Filipovski - Garkata from Gari and Simon Maksevski from Trebishte also studied the woodcarving craft in Thessaloniki. Then, learning from these first oldest masters, all the other carvers mastered the art (Lichenoska, 1989: 294).

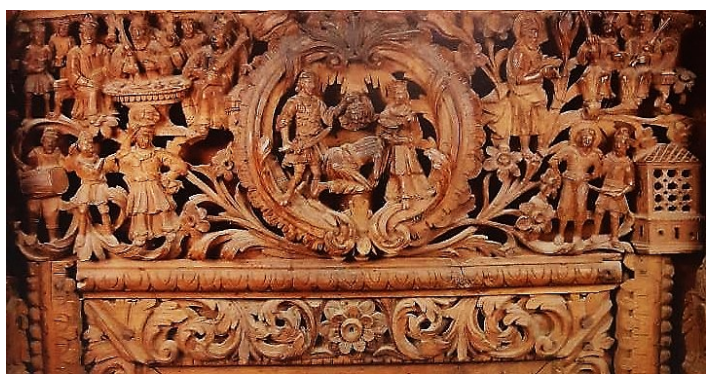

A

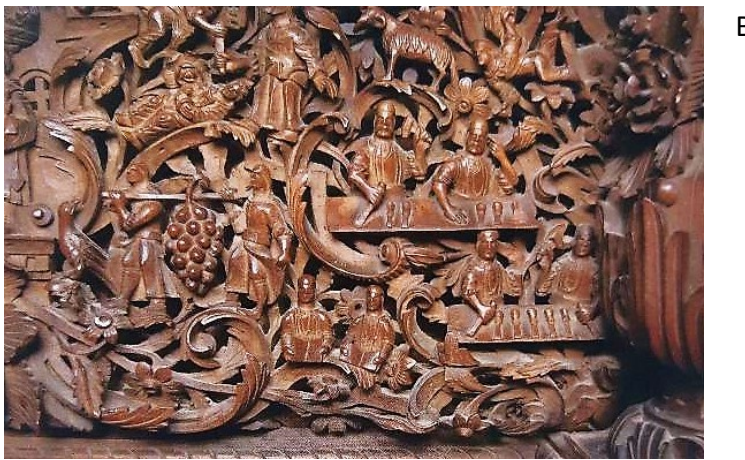
B

Figure II.22 Details of XIX century Revival wood carved iconostasis by Petre Filipovski Garkata's woodcarving group: A. St. Gabriel, Lesnovo monastery; B. and C. St. John, Bigorski monastery.

As most talented Mijak woodcarvers are considered Petre Filipovski - Garkata (called Petre Teladur, and, sometimes, Petre Zograf) and Makarija Negriev Frchkovski, who worked intensively in the first half of the XIX century in a joint master group ${ }^{209}$ which also included the brothers of Garkata, Marko and Jovan Filipovski, Dimitar Stanishev from Tresonche, Simon Maksevski from Trebishte and Avram Filipovski from Osoj (Константиновски, 2001: 20). Around 1840, Makarija Frchkovski left Garkata's goup and together with his brothers Gjurchin and Trajan established his own woodcarving group, working mainly outside the

\footnotetext{
208 Local folk instruments were inserted in the compositions, such as the kaval, the tapan (drum) and the zurla, most commonly used by the Mijaks (fig. II.22C); stylized folk costumes characteristic of the given period; fruits and berries characteristic of Macedonian soil, etc.

${ }^{209}$ Their most significant works, masterpieces of the Revival woodcarving from the Mijak school, are the iconostasis of the Lesnovo monastery (1811-1814); the iconostasis, bishop's throne and pulpit of the church of St. Savior in Skopje (1819-1824); the iconostasis, bishop's and abbot's throne in the monastery St. John Bigorski (completed in 1835) and the iconostasis, bishop's throne and pulpit in the Most Holy Mother of God in Skopje (1835-1836). Afterwards, Garkata's group left for (present-day) Bulgaria, where in 1836-1837 they worked on the large iconostasis of the Rila Monastery, as well as other iconostasis in the chapels (together with master Atanas Teladur, founder of the Samokov woodcarving school). Together, Petre Garkata and Dimitar Stanishev worked on the pulpit and the bishop's throne for the church of St. Annunciation in Prilep; while Petre Filipovski Garkata independently worked on the icons, iconostasis and gilding of the church of St. George in Prizren (Kosovo) in 1829. In Kosovo, in addition to woodcarving, he also established himself as a successful painter (Петровиќ, 1987: 117), in other words, a complete, comprehensive renaissance artist. As a masterpiece of Petre Filipovski - Garkata, stands out the iconostasis in the church of St. Nicholas in Krushevo, which unfortunately was set on fire by the Turks after the llinden Uprising of 1903 and no longer exists today. This iconostasis was his last work, which took almost 15 years to complete and was the result of a collaboration of the old master and his son-in-law Dimitar Stanishev - master Mitar (Lichenoska, 1989: 299), as well as other masters of the craft.
} 
borders of Macedonia, primarily in Bulgaria. ${ }^{210}$ Dimitar (Mitar) Geshev Stanishev (1806-1866), son of Gesho (1780-1830) came from the famous woodcarving line of the Stanishevi family which, as many others, had moved to Krushevo from Tresonche in the second half of the XVIII century. After three decades of work in Petre Garkata's group, master Mitar established his own group, which included his brother Andon as an apprentice, with whom he worked throughout the Balkan Peninsula. ${ }^{211}$

In addition to Petre Garkata and his brothers, another famous woodcarving family from the village of Gari were Ognjanovci, especially Jakim Todorov, son of the famous master-builder Todor Petkov, who worked in several churches, especially in the Ohrid region ${ }^{212}$ as well as the canopy and the chandeliers of the Slepche Monastery (Василиев, 1965: 242). The tradition of the Angelkovski family from Tresonche began with master Angelko and his son Petar. Petar's son, Kitan Petrov (1793-1866), was especially celebrated as a woodcarver, icon painter and master-builder, i.e. another versatile Revival artist, who

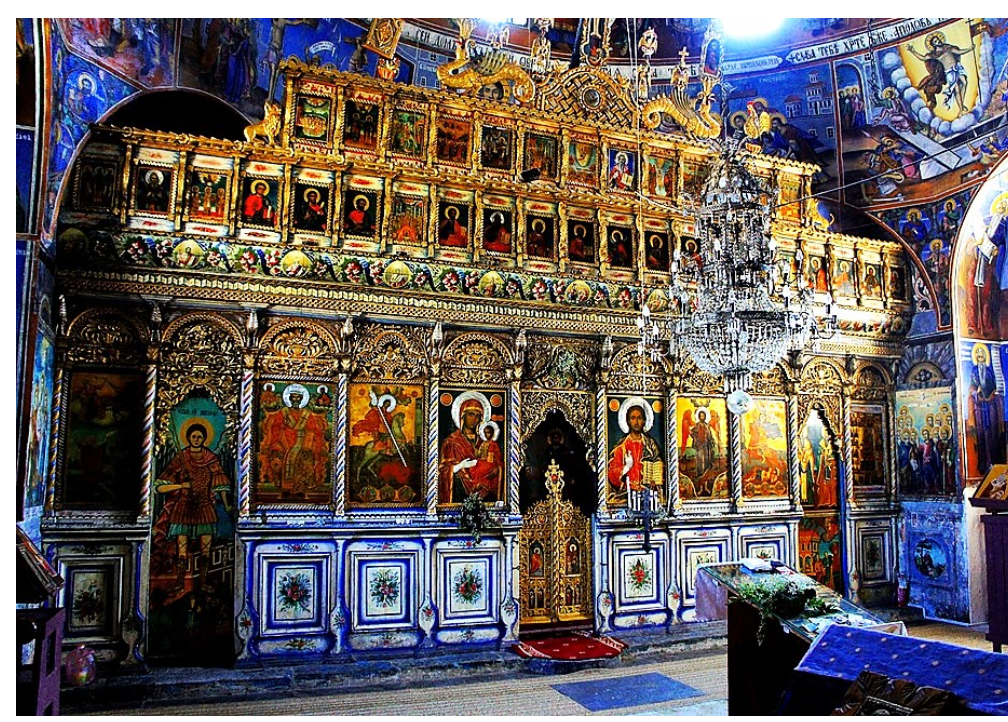

Figure II.23 The iconostasis of the church of St. George in Lazaropole (Debar). worked with his group mostly in Aegean and Pirin Macedonia (present-day Greece and Bulgaria). From the village Lazaropole, on the other hand, came the woodcarvers Nikola Darkovski Karadzović, who worked on the iconostasis of the Most Holy Mother of God Bolnichka in Ohrid (1833); master Krste, who built a balcony in the Rila Monastery in 1834; Radul Mazhoski (17901886), whose sons are famous painters (see previous chapter); master Danil, who worked on the iconostasis of the church of St. Nicholas in Krushevo; Naum Dojchinoski from the family of Chuchkovci, who made the pulpit of the church of St. George in his native village, and others. The first of the Filipovski family from the village of Osoj to engage in the woodcarving art was Avram, who as a member of Garkata's group participated in the making of the Bigorski iconostasis. His sons Vasil (1812-1903) and Filip (1814-1900) Avramovi established their own woodcarving group, comprised of their numerous sons as equal members, which worked extensively in Western Macedonia, Albania, Kosovo and Bulgaria. ${ }^{213}$ Another woodcarving clan from the same Reka village was the Mirchevski family, whose first known woodcarvers are master Mladen and his son Despot.

\footnotetext{
${ }^{210} \mathrm{He}$ worked on the iconostasis of the church of the Most Holy Mother of God in Pazardzhik; St. Demetrius in Gorno Brodi, Serres (Aegean Macedonia) and St. Nicholas in Prishtina (Kosovo), which was unfortunately destroyed in the war in Kosovo in the 1990s. In his individual work, Macaria will differ from Petre Garkata, using simpler and more stylized floral ornaments, as well as his characteristic motifs: marsh birds, snakes, griffins, winged sphinxes, etc., which are not present in Garkata's work (Ḱорнаков, 2016: 89). However, his treatment of human figures is not as realistic and successful as Garkata's.

${ }^{211} \mathrm{His}$ most famous works are the iconostasis of the Dormition of the Most Holy Mother of God Kamensko in Ohrid (see fig. II.12A) and the one at St. Elijah in Dojran (destroyed in the First World War). He also worked in Plovdiv, Pleven and Kalofer, Bulgaria; in Chachak, Serbia; in Pec in Kosovo, etc. After the death of master Mitar, his brother Andon Stanishev continued to work in Bulgaria (Василиев, 1953: 191).

212 The iconostasis in the church of St. Petka in Gorna Belica (Struga), built by his father; the canopy and bishop's throne in St. Clement in Ohrid, where he collaborated with his brother Nestor; the bishop's throne in the monastery of St. Nahum; the iconostasis, pulpits and bishop's thrones in St. Nicholas in Mramorec, St. George in Zlesti and St. Peter and Paul in Mesheishta. In Izdeglavje, he worked on the woodcarved ceilings in the Turkish konaks (Василиев, 1965: 242-243).

213 They worked on the carved ceilings of the konaks (residences) of Ismail Sarach in Debar and Osman Beg in Ohrid, on the konak of the Bigorski Monastery, as well as in many rich houses in Skopje, Prishtina, Gjakova, Prizren (Василиев, 1965: 247). Also, they worked on various iconostasis in Tetovo, Leunovo, Elbasan (Albania), Bulgaria, Aegean Macedonia, and their masterpiece is the iconostasis of the church of St. Annunciation in Prilep (1838) which measures impressive 17/5 m.
} 
Later, Despot's son Mirche Despotov (1802-1883) was also engaged in woodcarving and construction, as was Nestor Aleksiev (1878-1969), one of the last woodcarvers of the Mijaks (Ќорнаков, 2016: 33), after almost two centuries of uninterrupted artistic tradition.

The wood carved iconostasis from the XIX century are characterized by lavish decoration (fig. II.23), including various floral ${ }^{214}$ and zoomorphic ${ }^{215}$ motifs, miniature compositions with biblical themes and numerous human figures that the Mijak woodcarvers, especially those who worked in the first decades of the XIX century, skillfully incorporated into biblical and mundane scenes, with folklore elements and features as well as characters often presented in local costume. This kind of figurative representations with secular character ${ }^{216}$ inserted within the iconostasis with predominantly ecclesiastical content is in fact a unique feature of the Mijak carvers. The baroque abundance of elements and motifs is especially skillfully composed, with harmoniously arranged masses, accentuated three-dimensionality through extremely deep relief that allows a play of bright and shaded surfaces, with extraordinary narrative aided by the realistic expression. Thus, it can be concluded that the woodcarving ensembles made for the Revival sacred architecture are real masterpieces of the Macedonian woodcarving, surpassing a purely decorative skill and turning into art in its own right.

\section{II.6 State of Conservation and Protection Status}

Based on all of the above, the meaning and importance of the XIX century basilicas are therefore a fact beyond any doubt. Yet, architecture and art scholars have predominantly focused their attention on older monumental architecture, especially byzantine monuments. Furthermore, woodcarving and icons were traditionally considered as the sole artistic achievements of the XIX century basilicas, without taking into account that, in their case especially, architecture and applied arts form an inseparable unity. ${ }^{217}$ As a result, untill now, only a handful of the Revival basilicas, predominantly the large urban five-nave basilicas as crown achievements of the XIX century architecture, have been researched, documented, published and legally protected as "monuments of culture" according to the vigent law regulation in Macedonia. Unfortunately, the remaining hundreds of Revival basilicas, which based on their characteristics form a stylistically relatively unified group, have not, so far, received the institutional treatment they deserve.

Namely, according to the Map of Religious Objects in the Republic of Macedonia, by Pavlovska, Nikiforović \& Kocevski (Павловска et al, 2011), a total of 1842 orthodox Christian temples had been registered up to the year it was published. The largest part of this total number are contemporary buildings, built during the XX-XXI centuries: 889 churches or $48.3 \%$. The second largest group are the Revival churches, built during the XIX century - according to the Map of Religious Objects a total of 680, or $36.9 \%$, which does not reflect their real number. ${ }^{218}$ The third group are the post-Byzantine monuments,

\footnotetext{
${ }^{214}$ From the plant ornamentation, the Mijak woodcarvers preferred grape vines; laurel, palm and acanthus leaves; tame and wild rose flowers; daffodils; pomegranates; figs; oak acorns and leaves, etc. (Ќорнаков, 2016: 42).

215 Exotic and forest animals: lions, elephants, rabbits, deer, chamois, snakes; domestic animals: sheep, horses, cows, dogs; various marsh and other birds - in the work of Makarija Frchkovski, for example, the pelican regularly appeared (Корнаков, 2016: 60); as well as fantastic beings: dragons, griffins, mermaids, etc.

${ }^{216}$ Scenes of everyday life include vine pruning, grape harvesting, pastoral scenes, etc.

217 In that context, in his iconic work Teoria del Restauro (1963), Cesare Brandi will turn his attention to the unity of the monument, which should be regarded as a whole, as opposed to a sum of its parts. The same concept will be accepted and implemented in the Venice Charter (ICOMOS, 1964), which clearly defines that the monument includes also "items of sculpture, painting or decoration which form an integral part of a monument" (article 8).

${ }^{218}$ Several years of intense field and cabinet research as part of the author's PhD thesis have resulted in a detailed overview of the XIX century basilicas, which have been classified according to known years of construction, renewal or fresco-painting, depending on available information. According to this list (see Annex), the total number of Revival churches is much larger and exceeds $\mathbf{8 0 0}$. They therefore represent a much larger percent of the sum of all orthodox Christian churches in Macedonia. This is
} 
dating from the XV-XVIII century, with a total of 112 churches, or $6.1 \%$. The medieval Byzantine monuments dating from the IX-XIV century are represented by 82 churches, or $4.5 \%$. The smallest group are small chapels: a total of 79 , or $4.3 \%$ (chart II-1A).
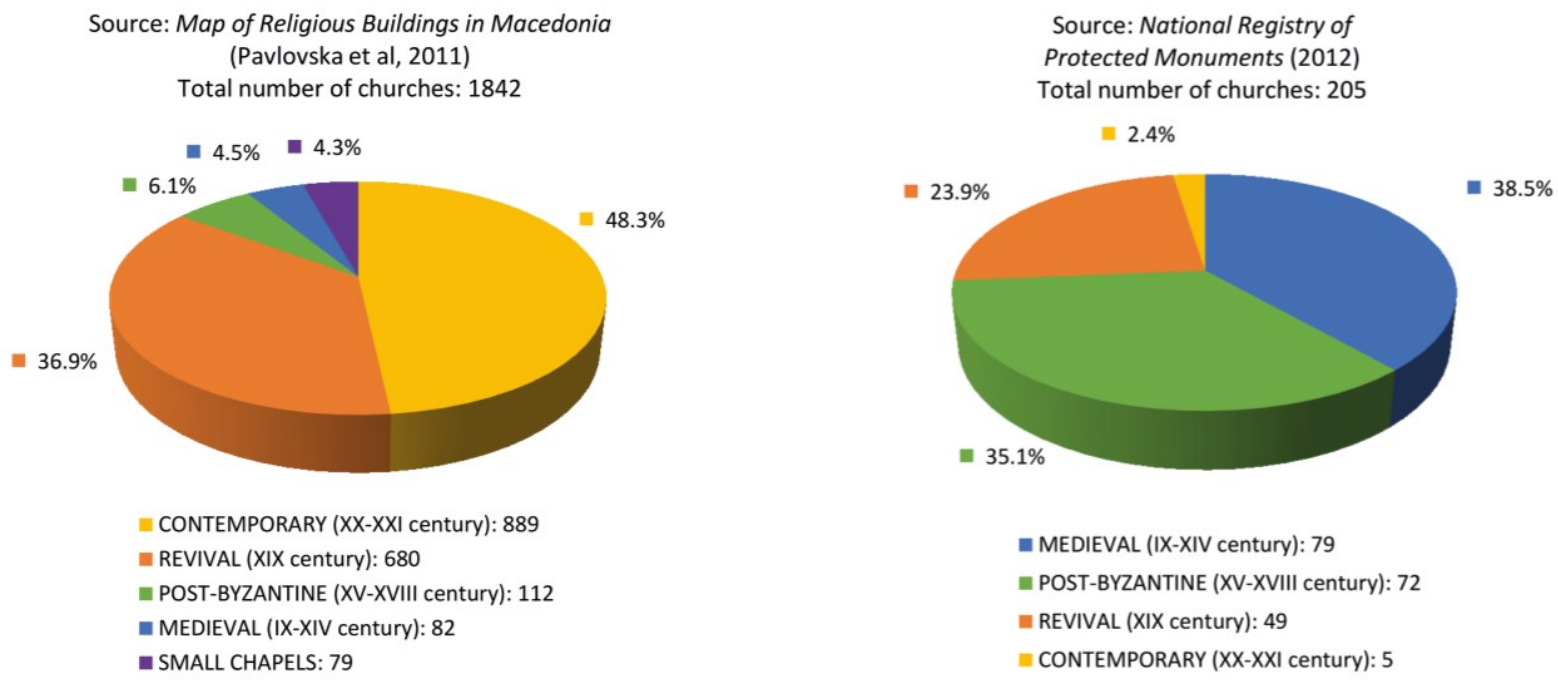

Chart II-1 Orthodox Christian churches in Macedonia A. historic distribution; B. protected monuments.

Despite their dominant part in the total number of Orthodox Christian temples in Macedonia, the Revival basilicas are not accordingly represented among the legally protected monuments of culture. In other words, for the most part they are not percieved nor treated as cultural heritage. According to the National Registry of Protected Monuments of Culture (as of 31.12.2012), the total number of protected monuments is 1210, of which 205 are churches and monasteries (chart II-1B), or 16.9\%. From the total number of protected churches and monasteries (205), the largest group are the medieval Byzantine monuments: 79 , or $38.5 \%$. If this number is compared with the before given data from the Map of Religious Objects (according to which there are 82 medieval Byzantine monuments), it can be concluded that the medieval churches have been declared monuments of culture and placed under legal protection almost without exeption (i.e. 96\%) and have therefore been accordingly valued in the scientific circles in particular and in society in general. Next are the post-Byzantine churches: 72 , or $35.1 \%$ of the total number of declared monuments of culture. Comparing this number with their total number according to the Map of Religious Objects - 112, once more it can be concluded that a significant part of the postbyzantine temples have been placed under legal protection (i.e. 65\%). Then come the Revival basilicas, with 49 protected buildings, or $23.9 \%$ of the total of protected religious (Orthodox Christian) architecture in Macedonia, and just $4 \%$ of the total number of protected monuments of culture. Taking into account their total number of 804 (or, even if we consider their number according to the Map of Religious Objects - 680), it is clear that a very small percent of all Revival basilicas have received some sort of legal designation, barely $\sim 6 \%$. This is truly a defeatist statistics, made all the worse considering that, for some of them, the protection status only refers to their iconostasis, as stated in their respective designation files and the National Registry of the Directorate for Protection of Cultural Heritage (DPCH). ${ }^{219}$ The situation is worse only for the contemporary religious architecture, represented by 5 protected monuments or $2.4 \%$ of the total number of protected churches (250), a mere $0.5 \%$ of their registered total number (chart II-1B).

further confirmed by the fact that in Macedonia, in 1897, the Bulgarian Exarchate had jurisdiction over "1180 Macedonian churches, 43 monasteries and 89 chapels, whereas this numbers will rise, in 1911, to 62 monasteries and 1294 churches" (Трајановски, А. „Македонското црковно прашање од 1892 година до Балканските војни“, гласник на МПц бр.2, 1977: 63). 219 The Dormition of the Most Holy Mother of God Kamensko in Ohrid, St. John in Krushevo, St. Annunciation in Prilep. 
What are the causes for this alarming situation?

There are, of course, many different reasons which have contributed to the lack of institutional attention towards the XIX century Revival churches. The first one is clearly the influence of the social conditions in which protection of cultural heritage has taken place. Namely, conservation science in Macedonia was established officialy in the Post-War period ${ }^{220}$ and developed and reached its peak in the second half of the XX century which, marked by the transition of the 1990s, was followed by a process of staganation in the field. In those first few decades (1949-1990) hundreds of churches and monasteries (and other types of built heritage) were legally protected, documented and restored, with a special emphasis on the Byzantine and select post-Byzantine churches. The Post-War Heritage Conservation in Europe was marked by a material-based approach which focused on the preservation of the material / fabric (Poulios, 2014: 20), best epitomised in the Venice Charter (ICOMOS 1964). After 1991 and the inevitable period of consolidation of the State and its institutions after declaring independancy from Yugoslavia, came a period marked by intense archaeological research campaigns, as well as the controversial government mega-project "Skopje 2014" whose main goal was to re-create the image of the capital through looking back (and through import) of an eclectic historicist architectural language in the service of (re)shaping national identity. In such a complicated context, conservation and restoration of architectural heritage, especially the Revival churches which have traditionally been considered less "valuable" compared to the older monuments, were once again on the margins of social occurrences.
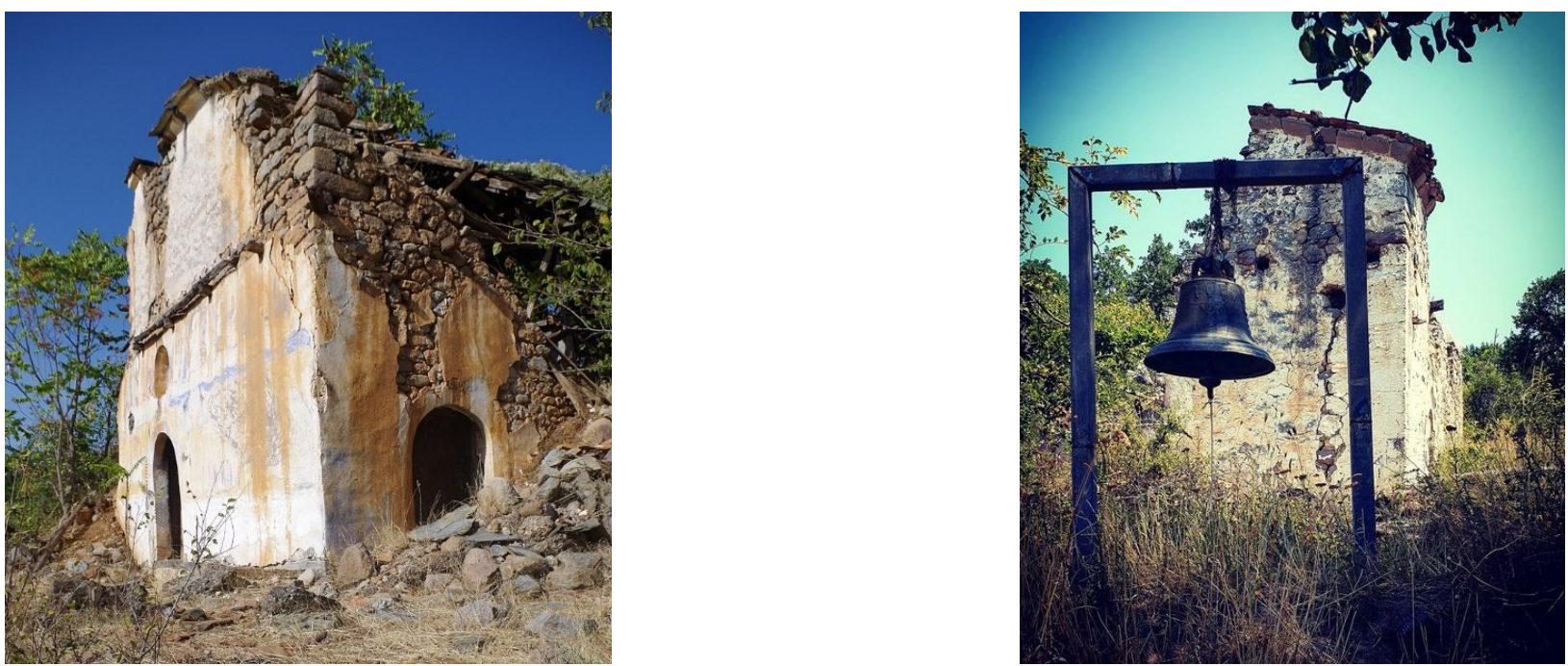

Figure II.24 Examples of abandoned Revival churches: A. the church of St. Mina in Garnikovo, near Kavadarci; B. the church of St. Athanasius in Koshani, near Kavadarci.

In order to determine why XIX century Revival religious architecture has not been considered equaly "valuable", we must primarily establish what values should in fact a material object possess to be considered as cultural heritage. A values-based approach focuses on the values that society ascribes to heritage (Poulios, 2014: 21). Namely, all manifestations of material culture - be they works of art, architecture, or ethnographic artefacts - have different meaning and purpose for different individuals, groups or communities, and society in general. What ascribes them greater importance compared to other objects and transforms them from regular places and objects to "heritage" are their values. Of course, the perception of what constitutes as "valuable" varies from one community / group to the next,

\footnotetext{
220 Immediately after the end of the Second World War, in 1944, the National Library and the National Museum in Skopje were founded. In 1947, the Commision for protection of cultural-historic monuments and natural rarities was established. The next year, 1948, the first Law on protection of monuments of culture and natural raritites came into force. Finally, in 1949, the Central office for the protection of monuments of culture and natural raritites of Macedonia was established in the capital, Skopje.
} 
as well as with the passing of time, and is strongly shaped by social contexts and processes. It is therefore almost impossible to give a definite, ultimate definition of as complex a term as "value".

The values that are generally ascribed to cultural heritage are usually contained within the term cultural significance. In that sence, the very term is used to define the act of conservation as "all the processes of looking after a place so as to retain its cultural significance" (the Burra Charter, ICOMOS Australia, 1999). Cultural Significance is a social construct of the present; therefore, the values it embodies differ greatly according to the point of view. Lucía Gómez Robles, for example, recognizes the following categories (Gómez Robles, 2010): typological, structural, constructional, functional, aesthetic, architectural, historical and symbolical value. Appliyng these categories of values to the phenomenon of the Revival basilicas, it may be concluded that it can be considered "valuable" as per each of them. The typological value of the Revival basilicas is perhaps their key feature, since they represent the revival and evolution of a neglected architectural typology. As for structural and constructional value, the XIX century Revival architecture is an overwhelmingly abundant source of traditional building, stone-mason and wood-crafting techniques (which constitute components of immaterial - intangible heritage) and bears witness to centuries of transferred knowledge as well as the personal style and excellence of each and every Revival master-builder. ${ }^{221}$ The aesthetic and architectural value of the Revival basilicas lie in the use of classical proportion and anthropometric design; the intricate reliefs of the portals; the apse(s) decorated with niches, pilasters, arcades and consoles; the elaborate stone-work of the window transennas and cornices; as well as in the abundance of internal decoration and ornamentation. However, the general modesty of the façades in the majority of XIX century churches, the simplicity of their external form, the lack of decorative brickwork so characteristic of the medieval monuments, as well as the predominant use of wood - a material traditionally considered less luxurious, have all contributed to the perception of their architecture as less valuable.
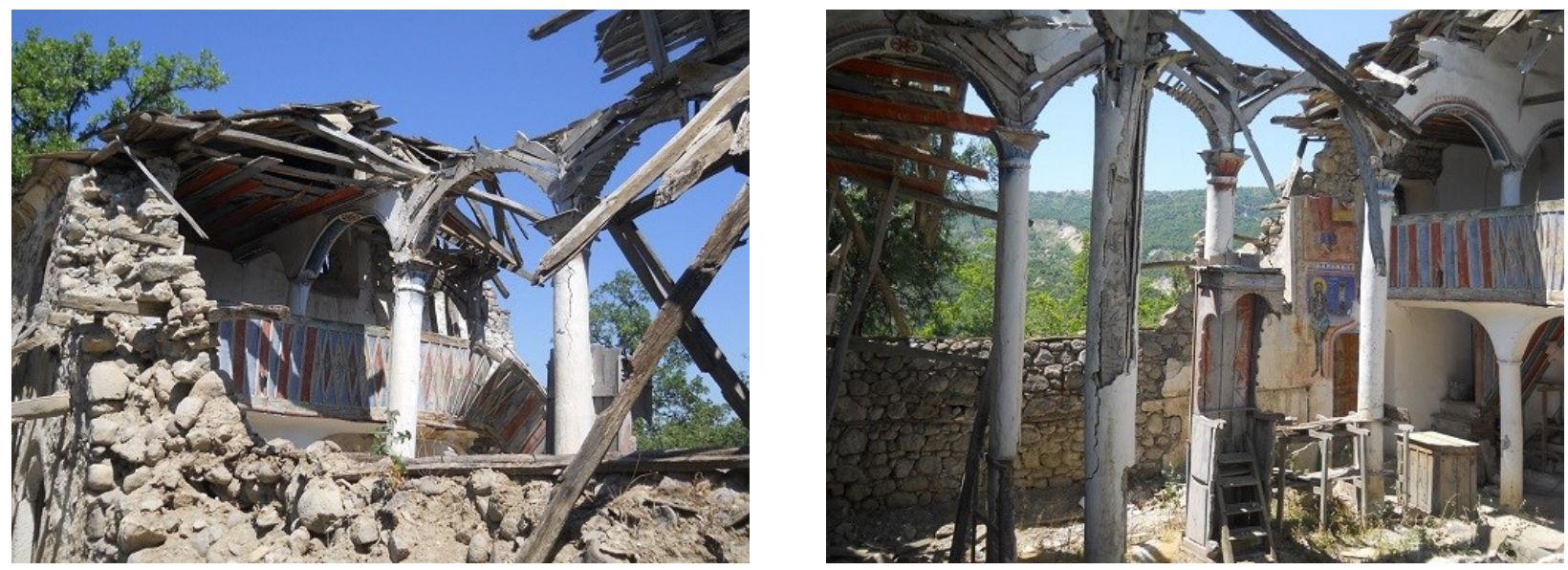

Figure II.25 The church of St. Elijah in Veshje, near Negotino.

As for the historical and the closely linked symbolical value, the Venice Charter (ICOMOS 1964) establishes that the notion of "monument" refers not only to grand creations but also to modest objects which have, with time, adhered a cultural significance, emphasizing the condition of "testimony" of a precise moment in history or a particular culture (Conti, 2014: 103). The XIX century churches are, in that sence, testimony to one of the most important historic periods; a materialization of processes of thorough social and religious change: liberty, humanism, and freedom of creation. In that sense, they should be recognized as an important corner-stone of Macedonian identity. On the other hand, regarding their

\footnotetext{
${ }^{221}$ According to Uffe Juul Jensen, "in the Ruskinian tradition - which is still alive - the particularity and value of an object inhere in the material used by the craftsperson. The particularity of the object in a way reflects the individuality of the artisan" (Jensen, 2000: 42).
} 
functional value, the loss of function is one of the crucial problems which the Revival basilicas are faced with. Intense migration throughout the entire XX century from underdeveloped and economically passive rural areas to urban settlements, as well as abroad, has caused a severe demographic strain on a significant number of previously thriving mountain villages, which now have less and less inhabitants, or are already completely deserted (see table II-1, chart II-2). Against that bleak background, many churches have become victims to societal oblivion and have fallen into total disrepair (fig. II.24, II.25).
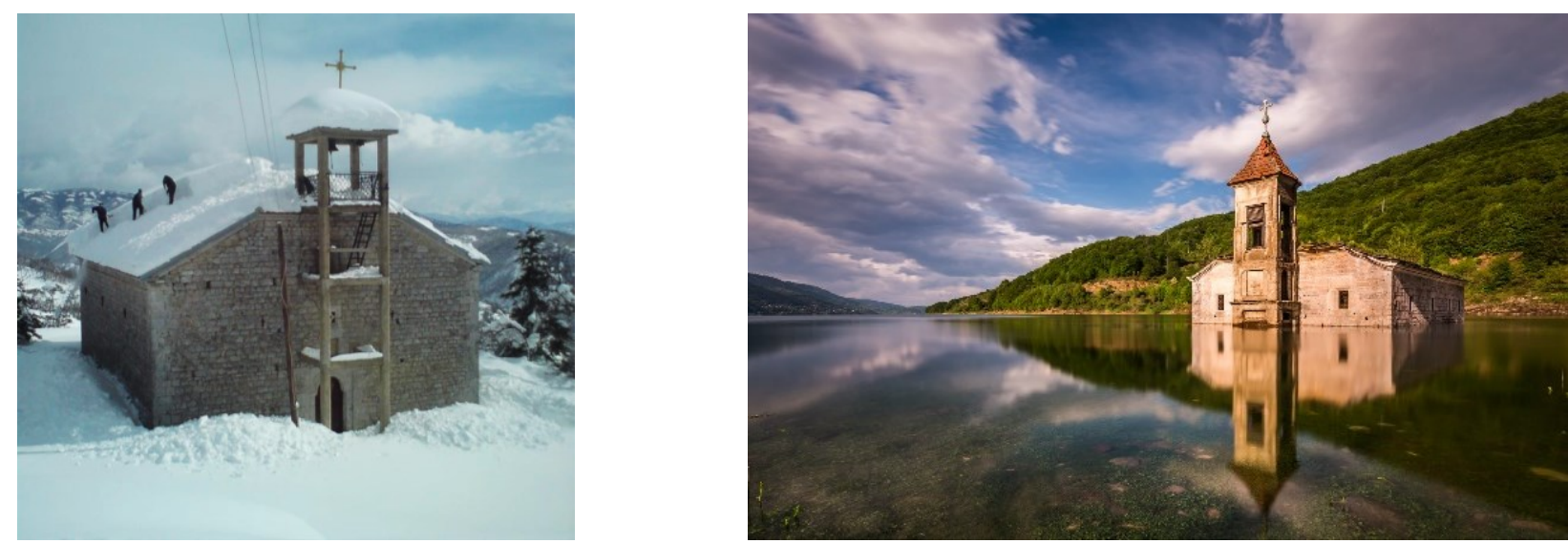

Figure II.26 A. The church of St. Elijah in Jablanica, near Struga in winter; B. The church of St. Nicholas in Mavrovo during high water levels of the Mavrovo artificial lake.

To this list of basic values embodied in the term "cultural significance" according to L. Gómez Robles, many more can be added depending on the (potential) heritage in question. As far as the XIX century basilicas are concerned, the author believes that the following factors have been crucial to their state of protection:

Uniqueness (or exclusivity) is one of the crucial characteristics of built heritage; in that sense, the significant overall number of XIX century basilicas has contributed to them seldom being considered as valuable heritage, to an extent where less than 50 have been protected as most representative and monumental (or most particular) examples. This approach is, clearly, wrong. As stated by Uffe Juul Jensen, "objects of cultural heritage embody the dialectics between the particular and the universal" (Jensen, 2000: 42). It is precisely their large quantity and their consistently applied architectural syntax (which unites them into an easily recognizable, typologically distinctive group despite the various geographical, financial or other conditions), that defines this heritage as a building "school" which expanded its influence geographically, outside Macedonia's borders, as well as temporaly, deep into the following $X X$ century, when a decades-long continuity of building one-nave and three-nave basilicas under the Revival's architectural influence is clearly evident. It is precisely their mass construction that allowed for the development of a plethora of local typological varieties. In their vast tipological diversity lays, in fact, their uniqueness, their individuality and, ultimately, their monumental "value" worthy of legal protection.

Antiquity is a significant factor in the process of determining a building's heritage value, where

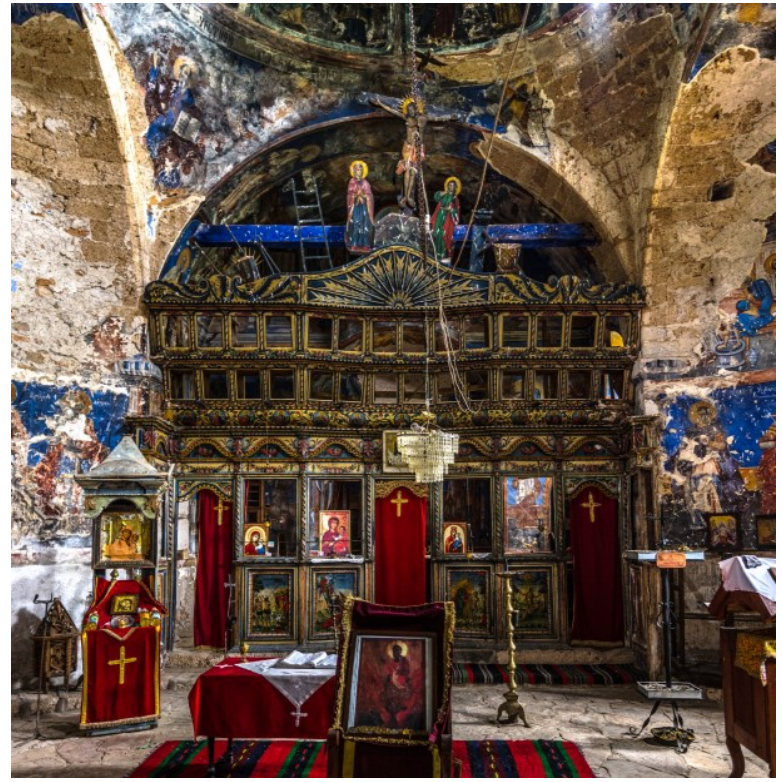

Figure II.27 The barren iconostasis of the church of St. Elijah in Selce, following the theft of all of its icons. 
traditionally, "older" equals "more valuable". This is mainly due to the fact that in order to be able to "value" an object as a monument of culture or architectural heritage, it is necessary to have some temporal distance between the moment of its creation (and its social context) and the observer (i.e. the present). In the second half of the XX century, when conservation and restoration of architectural heritage in Macedonia were at their prime, the XIX century architecture was still considered relatively "new". The concept of ascribing value predominantly to the old is still unfortunatelly very much present. Apart from the Revival religious architecture, expert valorization of XX century profane architecture in Macedonia is lacking almost entirely, including significant examples of the modernist, post-modern, contemporary and industrial realm. As far as the XIX century basilicas are concerned, the majority of which are already 150200 years of age, this arbitrary condition of "antiquity" has been met and should not represent an obstacle in their legal protection.

Bearing in mind all of the above, it is beyond any doubt that the XIX century basilicas can and should be considered valuable cultural heritage. The ultimate goal of conservation is not only to preserve the material per se, but also precisely to sustain (and shape) the values that cultural heritage possesses and transfers, with physical preservation being but one method towards that goal. It is of great importance to make a distinction between to value (to respect a pre-existing intrinsic value) and to valorize (to add value), because precisely in this subtle difference lays the essence of the interpretative and intervention aspects of identifying an object as heritage. In that sense, the XIX century Revival religious architecture in Macedonian society has been valued (as a direct consecuence of the intrinsic values it possesses), but not sufficiently valorized (as a consecuence of a consious, planned, scientific and expert-based activity).

It can not come as a surprise, then, that a significant number of the XIX century Revival basilicas are currently in a poor state of conservation (fig. II.24, II.25, II.26B). Apart from the serious lack of institutional protection, scientific conservation and restoration, the XIX century basilicas also face many different threats, both natural and man-made. Natural threats to their fragile interior wooden construction consist of, but are not limited to, atmospheric and capillary dampness (caused predominantly by the often significant depth of the terrain in which the churches were, as was previously mentioned, deliberately dug

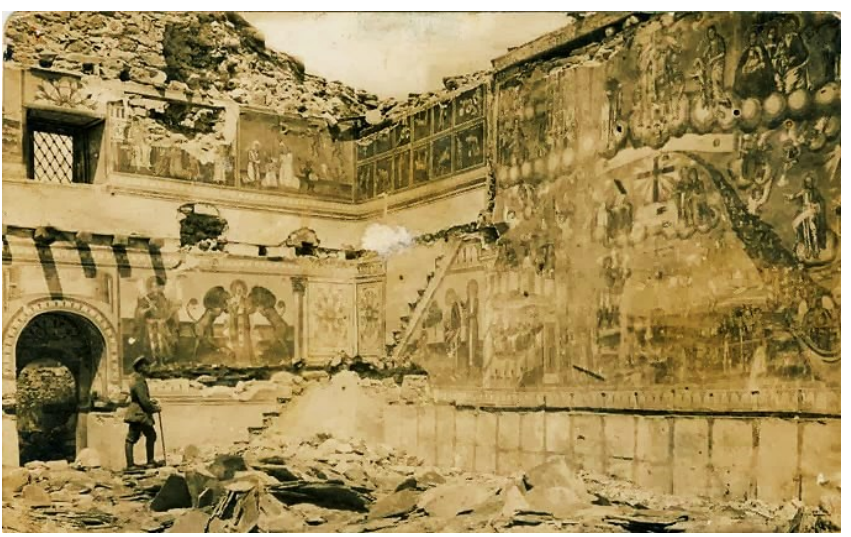

Figure II.28 The condition of the church in Gradeshnica (Mariovo) in 1917, after its bombardment in the First World War. into), ${ }^{222}$ mold, rot, xylophages insects' attacks, as well as the nature of their own construction prone to fire and material decay. Also, a common weakness to their structural integrity is their heavy stone-slab covered roof, whose important dead load combined with heavy winter snowfall and frost inevitably leads to collapse of the upper parts of the building (fig. II.26A). In addition, we must not forget climate change, natural disasters, such as wildfires, floods and seismic activity to which the Balkan Peninsula is particularly susceptible.

Man-made threats tend to be even more serious, and span from poorly executed electrical wiring, introduction of wood-burning or electric heating systems within the churches which are still regularly in use, vandalism and theft. Namely, the Revival churches in Macedonia are regularly targeted by organized crime, focusing on their valuable icons, relics, books, jewellery, and other liturgical items, which are then sold on the black market. In the last few decades we have sadly witnessed entire iconostasis stripped to

\footnotetext{
${ }^{222}$ As an illustration, at St. Nicholas in Brod the terrain is $+1.7 \mathrm{~m}$ in comparison to the level in the naos (see Chapter III.5.A.4); while at many mountainous villages the entire western half of the church's naos is dug into the sloping terrain, allowing for the gallery to be accessed directly from the outside (see footnote 225).
} 
their barren construction (see fig. II.27). This irreversibly impoverishes their interiors, the authentic cohesion between their architecture and complementary arts is forever lost, and they are subsecuently significantly de-valued.

\begin{tabular}{|l|c|c|c|c|c|c|c|c|}
\hline \multirow{2}{*}{$\begin{array}{l}\text { VILLAGES IN MACECONIA } \\
\text { (according to the number of } \\
\text { permanent inhabitants) }\end{array}$} & \multicolumn{9}{|c|}{ Official Census Data } \\
\cline { 2 - 10 } & $\mathbf{1 9 4 8}$ & $\mathbf{1 9 5 3}$ & $\mathbf{1 9 6 1}$ & $\mathbf{1 9 7 1}$ & $\mathbf{1 9 8 1}$ & $\mathbf{1 9 9 1}$ & $\mathbf{1 9 9 4}$ & $\mathbf{2 0 0 2}$ \\
\hline With 0 inhabitants & 47 & 49 & 55 & 104 & 130 & 259 & 163 & 151 \\
\hline With 1-10 inhabitants & 4 & 3 & 11 & 26 & 51 & 124 & 114 & 160 \\
\hline With 11-20 inhabitants & 2 & 2 & 16 & 23 & 43 & 100 & 87 & 93 \\
\hline With 21-50 inhabitants & 24 & 15 & 44 & 60 & 116 & 176 & 165 & 205 \\
\hline With 51-100 inhabitants & 84 & 75 & 81 & 139 & 169 & 202 & 210 & 181 \\
\hline With 101-200 inhabitants & 275 & 239 & 226 & 272 & 288 & 232 & 231 & 209 \\
\hline With 201-500 inhabitants & 709 & 691 & 664 & 557 & 416 & 329 & 337 & 293 \\
\hline With 501-1000 inhabitants & 462 & 493 & 473 & 365 & 311 & 204 & 233 & 211 \\
\hline
\end{tabular}

Table II-1. Categorization of the rural settlements in Macedonia according to the number of permanent inhabitants. Source of official census data: http://makstat.stat.gov.mk (accessed on 14.09.2020).

In that sense, men's influence on the Revival religious architecture varies between two extremes, both unfavorable to its state of conservation as heritage. One extreme is the neglect and elementary lack of maintenance of those churches which are located in severely or completely depopulated rural areas (table II-1, chart II-2). ${ }^{223}$ The lack of maintenance, defined as an elementary conservation activity (ICOMOS 1964), is the first step towards deterioration, degradation and, ultimately, complete ruin and loss of the built heritage which, being located in completely displaced, economically passive regions, loses its function rendering many of these churches completely obsolete.

The other extreme happens often in still well populated and economically thriving villages and towns, where the churches are in the hands of active church councils, comprised of local inhabitants and representatives of the Macedonian Orthodox Church - Ohrid Archbishopric (MOC-OA). With funds collected from the local community, these councils regularly carry out repairs and "embelishments" of the churches without necessary expert advice and supervision: incompatible additions (dining rooms, church offices, narthexes), visible reinforcement in reinforced concrete, new ceramic tiled floors, new iconostasis and church furniture, façade cladding in tiles, brick or cement mortars, new

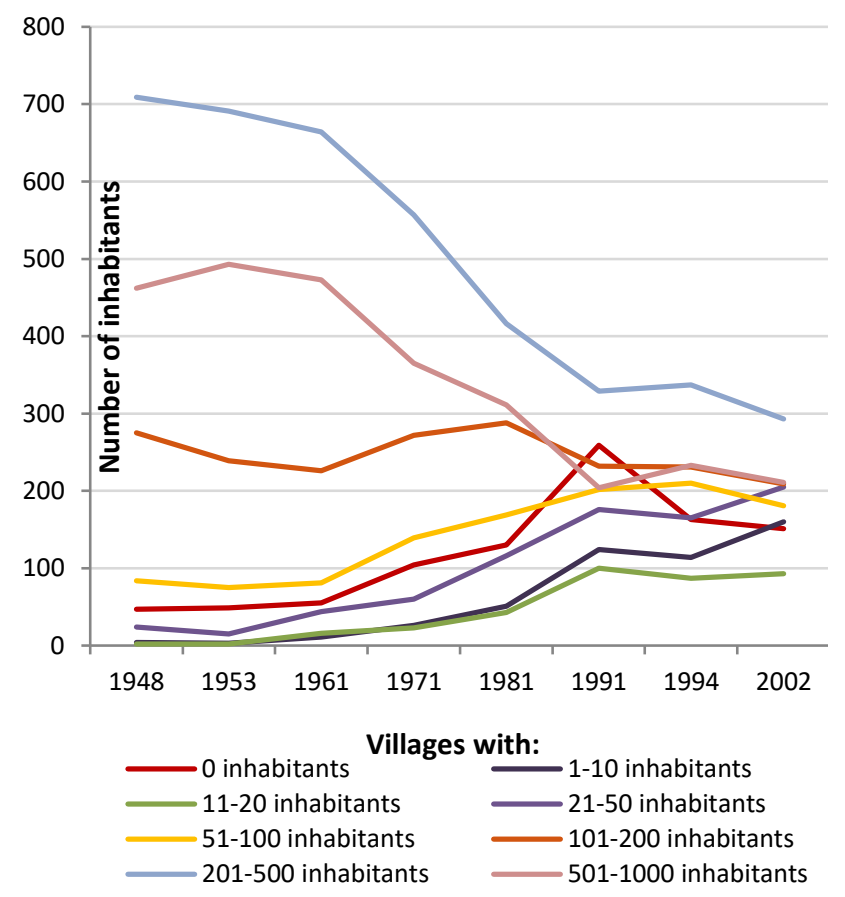

Chart II-2 Processes of transformation of the rural settlements in Macedonia in the second half of the XX century. Source of census data: http://makstat.stat.gov.mk (accessed on 14.09.2020).

\footnotetext{
${ }^{223}$ Based on the data analyzed in table II-1 (chart II-2), along the second half of the XX century there is an evident trend of increasing numbers of fully displaced and villages with extremely small number of inhabitants (relative to less than 100 permanent residents). In contrast, the number of medium-sized villages is declining, as more and more villages are transformed from the second to the first category.
} 
fresco-painting where there was orignally none, or even over original fresco-ensambles which have not been accordingly valorized, polished cement mortars, metal sheet roof cladding etc. Given the lack of a national strategy for the protection of the heritage of the XIX century Revival, these repairs, albeit driven by the best of intentions, more often than not have irreversibly altered, or even completely destroyed the authentic Revival architecture, its structure, construction and decoration. ${ }^{224}$

Thus, in addition to the scientific contribution in the context of the study of the Revival architecture in Macedonia, the author hopes that this work will initiate an appropriate level of treatment by the professional institutions for protection of cultural monuments, thus preventing further decline of the most endangered Revival churches and allowing for the preservation and survival of their unique characteristics, the supreme masterful skill in the processing of stone and wooden structures, as well as the many decorative elements that constitute the specific and unique stylistic expression of the Revival architecture.

\footnotetext{
${ }^{224}$ According to David Lowenthal, "heritage is never simply preserved or protected; it has been modified - both improved and degraded - by each new generation" (Lowenthal, 2000: 23). Thus, more and more Revival basilicas have completely lost their authenticity in the face of various unprofessional reconstruction works and today they are no longer recognizable. Such examples are the churches of St. Nicholas in Cerovo (Gostivar), St. Cyril and Methodius in Gevgelija, etc., where the original false vaults and wooden columns have been replaced with reinforced concrete, the iconostasis were replaced, new fresco-paintings were commitioned, etc.
} 


\section{THE REVIVAL BASILICAS}

\section{III.1 Architecture: Plan and Section}

The XIX century Revival churches share a multitude of stylistic features that allow for their incorporation within a temporally (XIX century) and geographically (the territory of Macedonia) defined regional architectural expression - regional "architectural school". Their common features: their constituent architectural elements; building materials and construction systems; decorative techniques, procedures and motifs, as well as their general typological features in both plan and section unite them in a stylistically complete and clearly recognizable group of monuments.

In plan, the Revival churches are almost without exception elongated, rectangular buildings (fig. III.1), in contrast to the centralized plans of past epochs, such as the early-Christian and Byzantine inscribed crosses, trefoils or rotundas. The proportional analysis undertaken for the referent churches studied in detail for the purpose of this doctoral thesis, many of which are presented in Chapter III.5, has shown that the proportion predominantly used in the Revival churches' layout is 2:3 (1:1.5), approximations of the golden ratio (1:1.618) and other combinations leading up to $1: 2$. This rectangular volume was further developed into a single-nave or three-nave basilical solution, the latter achieved with two colonnades comprised of commonly tall, slender columns, whose number depends on the monumentality of the temple (from as little as three, to as many as eight in the large town cathedrals, see Chapter III.5.B and III.5.C). The proportional relationship of the central and lateral naves in the multi-nave basilicas is usually $3: 2$ (1.5:1) up to $2: 1$. To the east, the Revival basilicas end in a single altar apse, or three apses in the case of the most monumental churches (see Chapter III.3), flanked by blind niches whose function is linked with the liturgical necessities of a prothesis

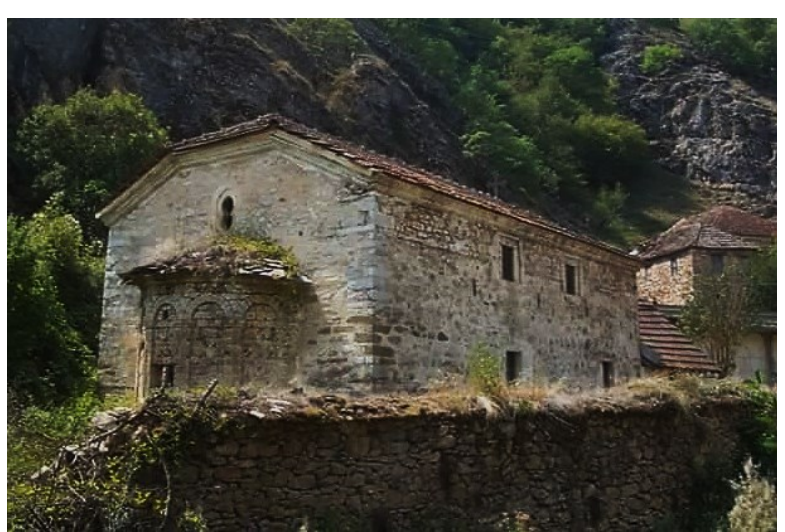

Figure III.1 The church of the Most Holy Mother of God in Zheleznec (Demir Hisar). View from the northeast. and diaconicon which are not separated into enclosed chambers. The altar is distinguished by a denivelation of regularly 2 steps $(\sim 20-30 \mathrm{~cm})$, thus creating a platform on top of which rests the tall two or three level iconostasis which completely visually segregates the altar from the naos. To the west, a common feature of the Revival basilicas is the presence of an upper level - a gallery, known as "women's church", accessed from the naos and, sometimes, additionally also via a direct access from the outside, 


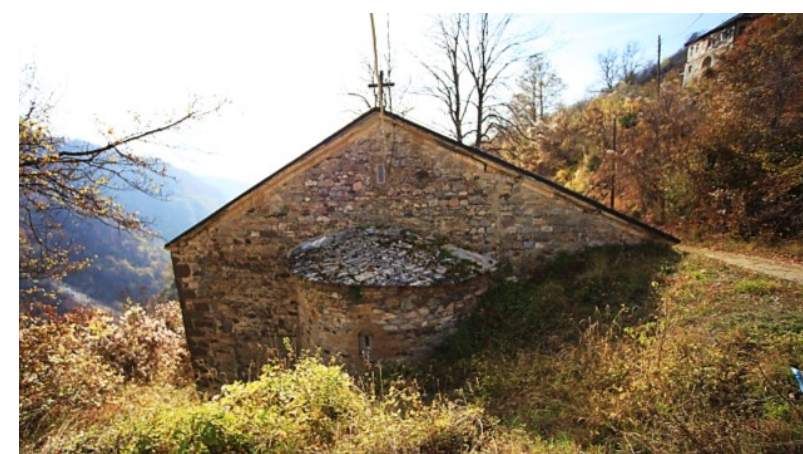

Figure III.2 St. Petka in Galichnik (Debar). View from the east.

through a separate staircase or making use of pronounced terrain slopes ${ }^{225}$ so that part of the building is significantly dug into the ground, while the rest is free at its full height (fig. III.2). This was fairly common for the Revival churches as a direct consequence of the social circumstances of the epoch. Namely, the building conditions under which permits were issued for the construction of religious buildings in the period before the formalization of Christian rights in the Empire significantly limited the architecture of the temples, especially in terms of size and height, as a basic precondition was that temples of other religious communities do not overshadow the mosques. Thus, the churches built in the first decades of the XIX century are externally modest in terms of architectural expression, without clerestory or domes on the fifth façade, and their true volume is experienced only on the inside. Namely, they were regularly dug into the ground for several stairs, or using its natural slope, allowing for the temples to gain the height and monumentality that they were otherwise legally denied.

The Revival churches almost without exception lack a separate narthex to the west, which was usually added at later dates. However, the role of the narthex as a space marking the monumental western entrance into the temple, a place for preparation for prayer and even baptizing if a separate room was not designated for this purpose remained of great significance within the church's spatial disposition.

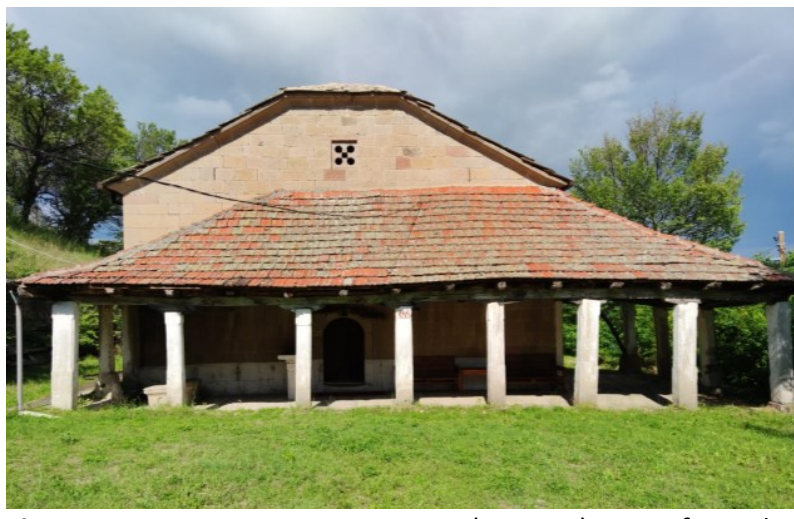

Figure III.3 St. Demetrius in Stracin (Kratovo). View from the west. In the Revival basilicas, this function was assumed by the low space beneath the western gallery, defined towards the naos to the east by the gallery substructure. This "narthex" was visually and physically separated or, conversely, integrated into the naos using several variant solutions: it was left completely open to the naos, or was closed off with a low parapet, a semi-transparent parapet, or even completely separated by a lightweight wooden division, thus truly becoming a narthex as the ones commonly present in the earlier epochs (see Chapter III.3).

The length of the Revival basilical temple allowed for additional direct lateral entrances to the naos in addition to the central western entrance, most commonly on the southern façade, and less frequently on the northern one, or both. The entrances to the church were regularly protected by open porches (fig. III.3). Depending on the disposition of the entrances, the open porches were added to the west of the temple, or they surrounded the basilical prismatic volume of the Revival temples from their west and south sides - in an " $L$ " shape, or on all three sides (to the west, north and south) - in a " $U$ " shape (see Chapter III.3). These open porches were initially regularly lower than the basilicas' longitudinal central block (Кадијевић, 1997: 15), however, they reach its full height in the monumental "five-nave" basilicas, where they are composed of an open, mostly arcade porch on the ground floor and a gallery on the upper floor, resulting in a five-nave disposition of the basilica (see Chapter III.5.C).

\footnotetext{
225 Such examples are the churches of the Holy Mother of God in Duf, St. Elijah in Selce, St. Nicholas in Tresonche and St. Petka in Galichnik, the latter of which is dug into the ground to the level of the gallery from the north side, culminating at the north-east corner of the naos where the terrain reaches as high as the cornice below the roof (fig. III.2).
} 
Viewing the Revival churches in section, the dominant solution is the so-called "pseudo-basilica", or "hall-church", which is again a direct consequence of the vigent Ottoman legislature. A "hall-church" (Hallen Kirche) is a three-nave structure comprised of a central and lateral naves of approximately equal height, often united under one massive gabled roof (fig. III.1-3). The term first appeared in the mid-XIX century, when it was used by Wilhelm Lübke (1826-1893), professor of architecture and art history at several universities (Berlin, Zurich, Stuttgart) and a pioneer of German history of art. A "pseudo-basilica", in turn, is a variation of a hall-church, in which the central nave is taller than the lateral naves; regardless this is not visible from the outside, i.e. the three naves are again covered with a massive gabled roof structure. The Revival basilicas, therefore, more often belong to this category. However, despite this limiting feature of their roof structure, the interior upper structure of the Revival churches' naos displays a broad array of spatial variations arranged in different compositions, including flat ceilings, often complemented by decorative rosettes, moldings and cornices; semi-cylindrical, ribbed and other types of vaults; one or more blind domes or, though less frequently (as will be discussed in detail later), domes supported on elevated drums. It is precisely the great variety arising from the solution of the churches in their upper parts, i.e. the way the naves are covered ("bridged") in the basilical arrangement, which is suitable for a typological analysis of the imposing total number of Revival sacred buildings, in addition to their general basilical disposition as a single or multi-nave basilica or a combined typological solution. This typological categorization of the Revival churches will be discussed in further detail in Chapter III.5.

\section{III.2 Materials, Structure and Construction}

The structural systems of the ecclesiastical architecture built in the XIX century differ from those used regularly in the Middle Ages. Namely, as explained before, the Byzantine monumental architecture was built massively, with masonry in hewn stone, lime mortar and baked brick; it was dominated by vaulted and domed buildings, with arches, vaults and domes usually made of brick without the use of wooden formwork (Choisy, 1997: 62), and with their extrados directly covered with strips of lead. The iconostasis and the floors were made of stone; in the more representative buildings there were mosaic pavements as well as floors in opus sectile. Wood was used only as an auxiliary material - for leveling of the masonry walls, for tension ties in the arches and vaults, etc. The post-Byzantine period, with all its social, material, as well as political and legal limitations meant simplification of forms, reduction of dimensions and spans and reconciliation with lower quality, often re-used building material. Yet, the construction techniques and procedures inherited from Byzantium conservatively persevered in the centuries following its disintegration, without major structural and constructive novelties: religious architecture was still dominated by vaulted massively built structures using stone and mortar, and less often brick, while wood retained its supporting role. Lead was completely abandoned as a precious material, and stone slabs or roof tiles were used for roof covering.

In the Revival, on the contrary, the application of a completely different construction system prevailed, which consisted of a massive masonry structure combined with a wooden frame structure. The perimeter walls were massively built, mostly made of stone and lime mortar as a binder, while the wooden frame construction was applied in the construction of arches, vaults, domes, flat ceilings and galleries. It was, therefore, used as a lighter construction to build the upper parts of the building. Why this constructive system was chosen, under what (domestic and / or foreign) influences it developed and was accepted, is the subject of interest of this chapter. 
The Revival churches, as well as the residential and vernacular architecture, were built with the most readily available material that abounds in the immediate surroundings of the construction site: stone, wood, reed, lime, clay. These materials were well known, processed and applied by the masterbuilders according to their function "with a logical sense of the constructive laws of a unique architecture in which they have introduced their sense of proportion, relation and beauty" (Томовски, 1969: 223). A

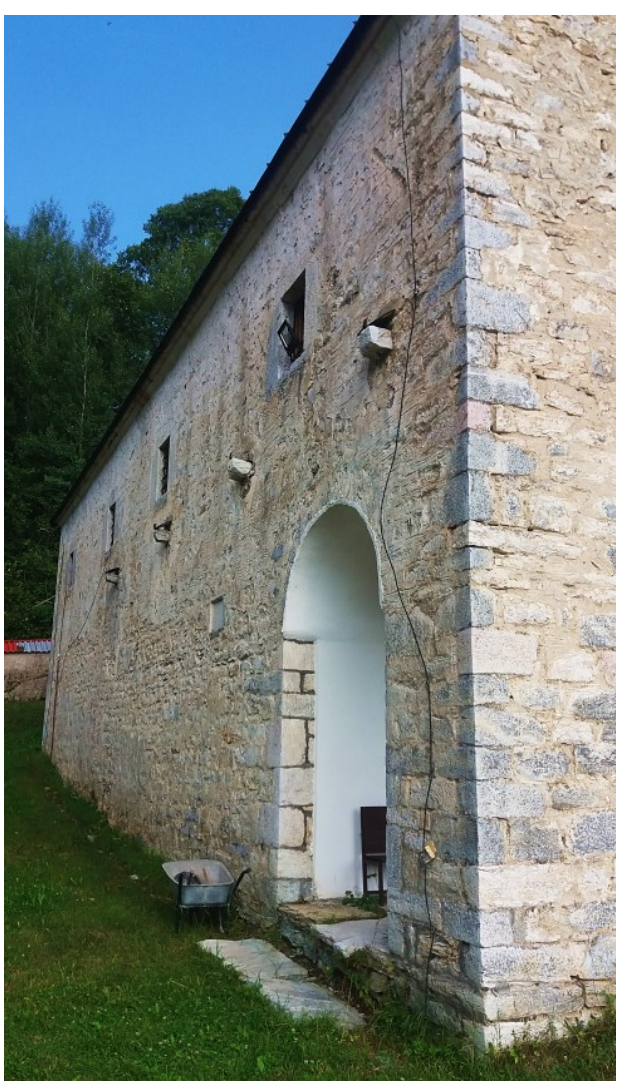

Figure III.4 View of the north-west corner of the church of the Most Holy Mother of God in Leunovo (Mavrovo). novelty in the Revival ecclesiastical architecture is the exceptional work in wood and wooden constructions. With the skill resulting from the long-term development of profane architecture, which is essentially based on a combination of massive and wooden frame techniques, the master builders of the Revival churches will develop an incredible variety of constructive and decorative elements in wood. This new, different treatment of a material that was traditionally underestimated in monumental architecture of past eras, where it was reduced to an auxiliary tool in the construction system, reaffirms the tendency to draw experiences from the local construction tradition, not only in relation to monumental buildings but also from other spheres of architectural practice, such as the residential and rural architecture.

The first phase in the construction of the churches was the preparation of the construction site, which was usually leveled, and in some cases strengthened by inserting (stacking) a base of stone slabs ${ }^{226}$ or by compacting wooden piles - spikes. The temples were usually founded on oak posts $^{227}$ that were interconnected in a structural system (Николовски, 2018: 17). The foundation walls themselves were built in the same way as the façade ones, but with usually less processing of the stone blocks, which were only partially hewn, and the space between them was filled with smaller pieces of crushed stone. The perimeter walls of the building rest on the foundations, the dimensions of which vary depending on the spans that needed to be overcome, the loads that needed to be received and transferred, as well as the height to be reached. Thus, we come across walls with a thickness of $\sim 75 \mathrm{~cm}$, which corresponds to one $\operatorname{arshin}^{228}$ an anthropometric unit of length regularly used in the past; furthermore, most of the Revival churches have walls that are about $90-100 \mathrm{~cm}$ thick, i.e. approximately 1.5 arshins (fig. III.4). More massive walls are less common. Following the

\footnotetext{
226 According to the oral testimony of Ljube llievski, caretaker of the church of St. Demetrius in the village of Stracin, region of Kratovo (registered in October 2020 during the author's field research in the region), before the construction of the village church began, the land was first leveled, stone slabs were laid, and then covered with a layer of earth. The foundation thus prepared was left to "sink" for several seasons, and only then did the construction of the foundation begin.

227 The quality of oak in underground constructions and foundations was known as early as in Roman architecture, as is pointed out by the Roman theorist of architecture Vitruvius in his treatise "Ten books on architecture" (Vitruvius, 1960: 60).

${ }^{228}$ An arshin is an anthropometric measurement unit which equals one outstretched arm (measured from the shoulder to the tip of the middle finger of the palm), or one elbow plus one palm. It was used, in addition to construction, in other trades and crafts such as tailoring. Therefore, beside the construction or also called "neimar" arshin, other types of measuring arshins existed, such as "charshi" (bazaar) arshin, "endeze" (tailor's) arshin, and so on. The construction arshin is on average $75 \mathrm{~cm}$. In addition to the arshin, the master builders regularly used other anthropometric measurements, such as a finger, a thumb, a palm, a toe, an elbow, a foot, growth (reach), a step (Хаџиева-Алексиевска, 1985: 23-29). In addition to a unit of measurement, the arshin was also the basis of the modular proportion of buildings, both of secular and sacral character.
} 
constructive logic, the thickness of the walls often gradually reduced from the foundation to the top, thus reducing their own total weight.

For the construction of the perimeter walls stone connected with lime mortar was dominantly used. Most often it is a locally available stone processed as hewn or crushed stone, cut into relatively small blocks - usually 20-30 cm high and 20-50 cm long (Покропек и Стрончек, 1992: 126-127), which were easier to transport and manipulate; however, there are also examples of larger and significantly longer blocks, especially used as corner stones (fig. III.4). Also, for practical reasons, older building material was often reutilized: stone blocks, fragments of stone reliefs, parts of columns, capitals and brick, which most often originated from demolished Byzantine or early-Christian churches located near the construction site. In this context, the stone reliefs and spoliae with figurative representations were treated with certain respect, often embedded on the façades, within the portals or another prominent place (see fig. III.94). There are also examples where massive early-Christian and Roman capitals and column bases were used as a base for the altar table, as part of a staircase, and so on.

In many buildings, the material from which the wall canvases are made was not plastered, but rather left visible. Irregularly crushed river-bed stone was often used, as the most easily available and cheapest construction material, with abundant use of lime mortar. In fact, it can be said that mortar is the dominant material, and masonry made in this way is, to a certain extent, a concrete based on lime. ${ }^{229}$ The most important structural points of the building were usually made with special attention in hewn stone: the corners of the buildings, where larger elongated blocks were installed crosswise - alternately on the shorter and then on the longer façade (fig. III.4); the entrance portals, doors, windows and cornices, which were regularly made of beautifully and precisely carved stone blocks. Furthermore, usually the whole altar apse was made of carved stone, often limestone, in well-arranged blocks with thin, regular joints.
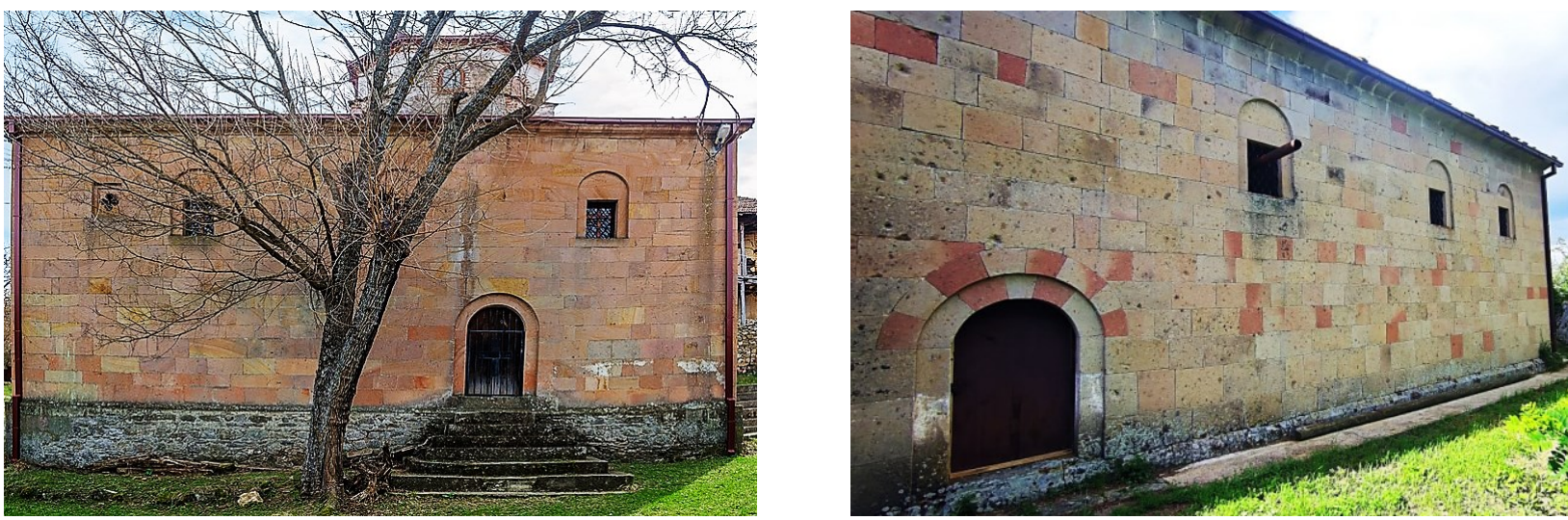

Figure III.5 A. The northern façade of the Zabel Monastery, near Kumanovo; B. The southern façade of the church of St. Demetrius in Stracin (Kratovo).

Granite was considered the strongest and highest quality type of stone, which has good loadbearing capacity, remains compact for a long time, does not crack, is not porous and does not absorb water; but which was also considered the most difficult to work with. The corners and sometimes the window frames were made of granite blocks (Покропек и Стрончек, 1992: 103). Limestone was a

\footnotetext{
229 This type of masonry was established in the Roman period, and the practice was maintained during the Byzantine Empire. It is known that from the material used to build the walls of the Vlacherna Palace in Constantinople, for example, as much as $2 / 3$ is mortar (Choisy, 1997: 9). Usually this type of masonry was used for the core of the wall, and its faces were made with a masonry of better quality. Additionally, in Byzantium, a whole range of masonry techniques were developed as combinations of stone and brick, arranged in horizontal layers and between stone blocks, in function of better cohesion of the core and the cladding of the wall, equal proportional representation of mortar between them and smooth joints (Ibid: 12). The specific Byzantine decorative masonry styles and the brickwork ornament gradually developed from them. In the Revival churches, as well as in their predecessors from the post-Byzantine period, these techniques were almost completely abandoned, at the expense of the dominant construction in stone and wood.
} 
particularly popular type of stone since the Middle Ages, as porous, light, relatively accessible and very easy to process because "while it still has quarry moisture, it is so soft that it can be cut with an ordinary aхе" (Ненадовић, 1980: 33). Besides limestone (so-called "white" stone), other types of stone were often used, according to their local availability, such as sandstone; in the north-eastern areas of Macedonia a reddish sandstone (called "red stone" by the locals) was often used, originating from the vicinity of the village of Stracin (Томовски, 1966: 27), as well as trachyte and travertine which, with their characteristic intense yellow-reddish hue, represent a specific feature of this region's architecture. ${ }^{230}$ The churches of

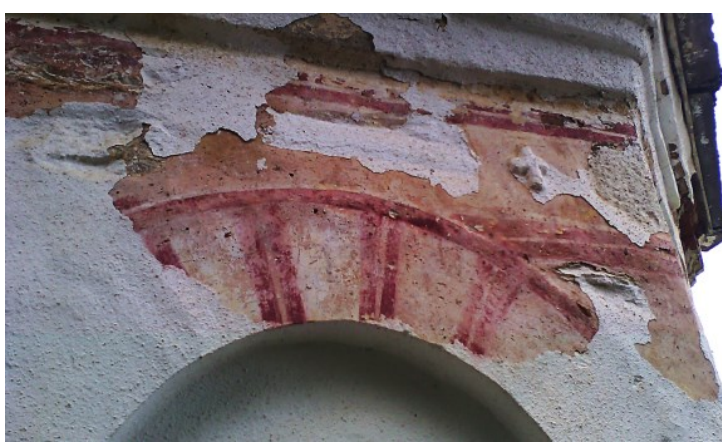

Figure III.6 St. Demetrius in Bukovo (Bitola). Detail of the painted maonry opus on the altar apse façade.
St. John and St. Nicholas in Kratovo (see fig. III.77B-C), the Zabel Monastery (fig. III.5A), the churches in the villages of Stracin (fig. III.3, III.5B), Rugjince, Radibush, Opila were built using this stone, as well as the older sacred buildings in this region - the churches in Staro and Mlado Nagorichane (see fig. I.41, I.50), Zhegljane (see fig. III.87A), etc. Furthermore, local stone, often crushed stone or river-bed stone ${ }^{231}$ which had worse properties but was easier to process, more accessible and cheaper than other types of stone (for which animals freight had to be organized from the appropriate quarries to the construction site) was often used to fill-in the walls, or even at the façades. Thus, because on the corners of the churches processed blocks of granite or limestone were used, while the façade canvases were often saturated with local stone of different type, i.e. stone of various texture and color (with variations of white, through different tones of gray, bluish, green, up to yellowish, ocher, brown, and even reddish tones), the exterior walls "are characterized by different structure and color" (Покропек и Стрончек, 1992: 103-104). Of course, in some churches built with more financial means, availability of better material or better skilled stone-masons, all façades in their entirety are executed in precise, clean masonry, with carved blocks arranged in regular rows with minimal mortar joints (for example, the churches in Mavrovo, Vevchani, Zabel, Stracin, Kratovo...). Less often, the façade walls were plastered and painted, usually in buildings that were later renovated. There are even cases where the

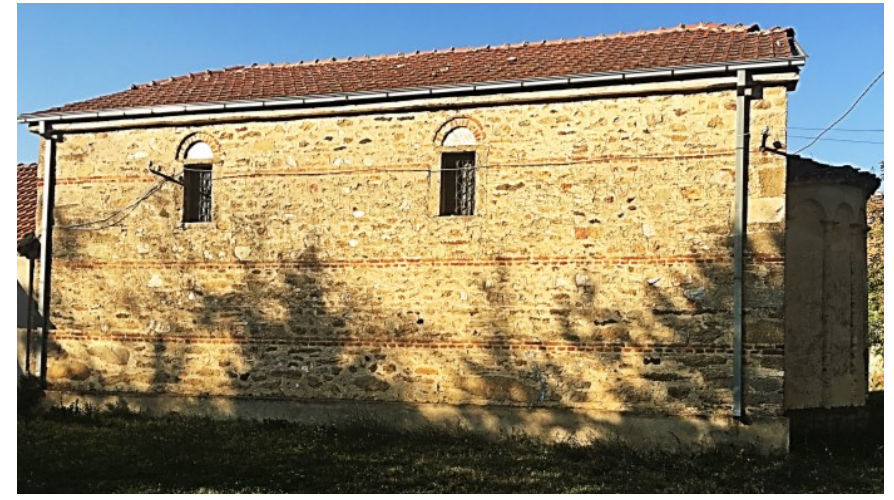

Figure III.7 St. Athanasius in Senokos (Prilep). Horizontal leveling layers of the façade, executed in brick. View from the southeast. white-washed façades are painted imitating masonry (fig. III.6) in carved stone and even brick, with regular, horizontal, thin joints: at the church of St. Elijah in Ezerani (Prespa) this painted masonry runs along the eastern façade and continues along the polygonal apse, while at the church of St. John in Ljubojno (Prespa) this type of painted decorative façade processing continues on the other remaining façades.

In addition to stone, brick was also used, albeit in a limited volume and often in

\footnotetext{
230 In the region of Kriva Palanka, where construction is considered a traditional craft, in addition to the "red stone", the masterbuilders distinguished three other types of stone: "mramorit" - which can be carved and cut into blocks; "I'scarliv" - which was used for corner-stones, cornices etc. and "black" stone, which was considered difficult to work with, and from which thin plates for roof cladding and paving were fashioned (Светиева, 1992: 148).

${ }^{231}$ In the village of Jablanica near Struga, for example, this type of stone was called "grabor" or "krshnjak" and was extracted in the surrounding territory of the village, near the local river (Покропек и Стрончек, 1992: 103).
} 
secondary use. ${ }^{232}$ Most often, brick was used on the east façade or only at the apse, while on the remaining façades it is absent. Such is the case of the church of the Holy Trinity in Ropotovo, near Prilep, where a thin row of bricks appears between every two precisely arranged rows of carved stone on the altar apse, in continuous rows flowing over the corner pilasters and into the five shallow niches. The apse of the church of St. Nicholas in Belche, near Demir Hisar, is simillary treated. At the church of St. Savior in Dolneni, near Prilep, the altar apse is partially built in an opus listatum, with alternating layers of hewn stone blocks and two layers of brick (fig. III.8A). The same type of decorative masonry is found in the villages of Jankovec (the church of St. John the Forerunner), Dolno Perovo (the church of St. Athanasius) and Drmeni (the church of St. George, see fig. III.28C) in the region of Prespa, built with alternating rows of brick and sandstone, with sporadical appearance of vertical pieces of brick between the blocks of stone. Alternating rows of stone blocks and two horizontal rows of brick are found on the apse of the church of
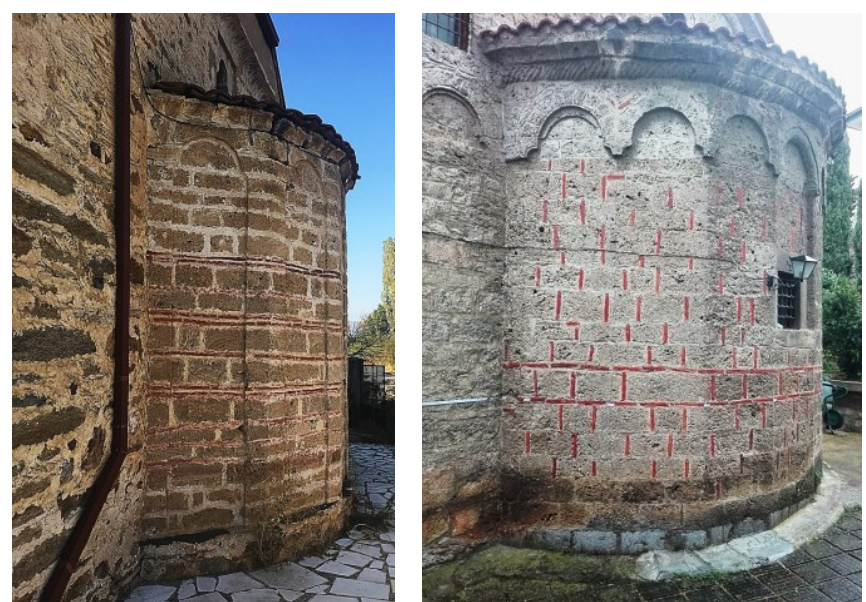

Figure III.8 Details of the altar apse of A. St. Savior in Dolneni (Prilep); B. St. Nicholas Gerakomija in Ohrid.

St. Demetrius in Bukovo, near Bitola, painted imitating a decorative façade opus (fig. III.6), later completely plastered. The case is similar with the church of St. Demetrius in Bitola, which will be discussed in more detail later (see Chapter III.5.C), and which in accordance with its role as the town's cathedral greatly influenced the subsequently built churches in the region. At the church of St. Nicholas Gerakomija in Ohrid, all façades are made of stone with the exception of the seven-sided apse, where the central zone between the low plinth and the frieze of cantilever arcades was executed in an uneven opus cloisonné, Byzantine masonry typical for the territory of Macedonia; in the upper zone of the apse, the brick was inserted only vertically, between the stone blocks (fig. III.8B).

Examples of use of brick on the other façades are rare. Such a case is the church of St. Athanasius in the village of Senokos, near Prilep, where three layers comprised of two rows of brick encircle the whole building, serving to level the otherwise unpretentious masonry in crushed stone (fig. III.7). The arches of the windows are also made of brick. At the church of St. Nicholas in Kratovo, vertically embedded pieces of brick are found between the elongated, precisely carved and arranged blocks of stone, in every second row; in addition, in the upper zone above the windows brick is arranged in horizontal rows as well, which enriches the main entrance façade coloristically and gives it a certain decorativeness (see fig. III.77B).

The abundant use of mortar, especially in the inner core of the wall where the arrangement of the stone blocks was less correct, inevitably dictated the appearance of a system for leveling and binding the wall mass. Thus, in the massive load-bearing walls, hidden wooden braces (called "santrachi" or "kushaci") were inserted, which served for horizontal leveling of the wall mass, uniform transfer of loads, neutralization of lateral thrusts as well as prevention of horizontal movement caused by frequent earthquakes. ${ }^{233}$ This wooden grids were placed at a certain distance, which varies from 1 arshin $(75 \mathrm{~cm})$

232 Thus, the brick used often originates from ruined Byzantine or post-Byzantine buildings and has classic dimensions: width of 1-1.5 feet $(30-45 \mathrm{~cm})$ and thickness of 3 fingers $(4-6 \mathrm{~cm})$ (Choisy, 1997: 9). However, there is evidence that there was also a production of baked brick in the Revival, in masonry built kilns called "tularnici" (Покропек и Стрончек, 1992: 109), which were also used to make roof tiles. The production of adobe, unbaked molded brick (or sun-dried brick) - called "kerpich" or "plit" which was regularly used in residential buildings as a complement to wooden frame structures, was highly developed.

233 This constructive technique is extremely old and originates from the ancient civilizations of the Orient whose construction is based on domed buildings built in an extremely seismicly active area (Choisy, 1997: 117-118). In Macedonia, it was regularly used 
to approximately 1.5 arshin - usually about $1.2 \mathrm{~m}$ (Ненадовић, 1980:100) and consisted of wooden beams connected in a transverse direction with smaller beams called "klepi" (Покропек и Стрончек, 1992: 127). They were predominantly made of oak, as the strongest available wood. Also, between the arches and in the span of the vaults wooden beams were placed (at least at one level, and if necessary more), which acted as ties and prevented the "expansion" of the perimeter walls under the force of lateral thrusts, while also stiffening the upper construction where deformation often appears due to uneven leveling of the foundations.
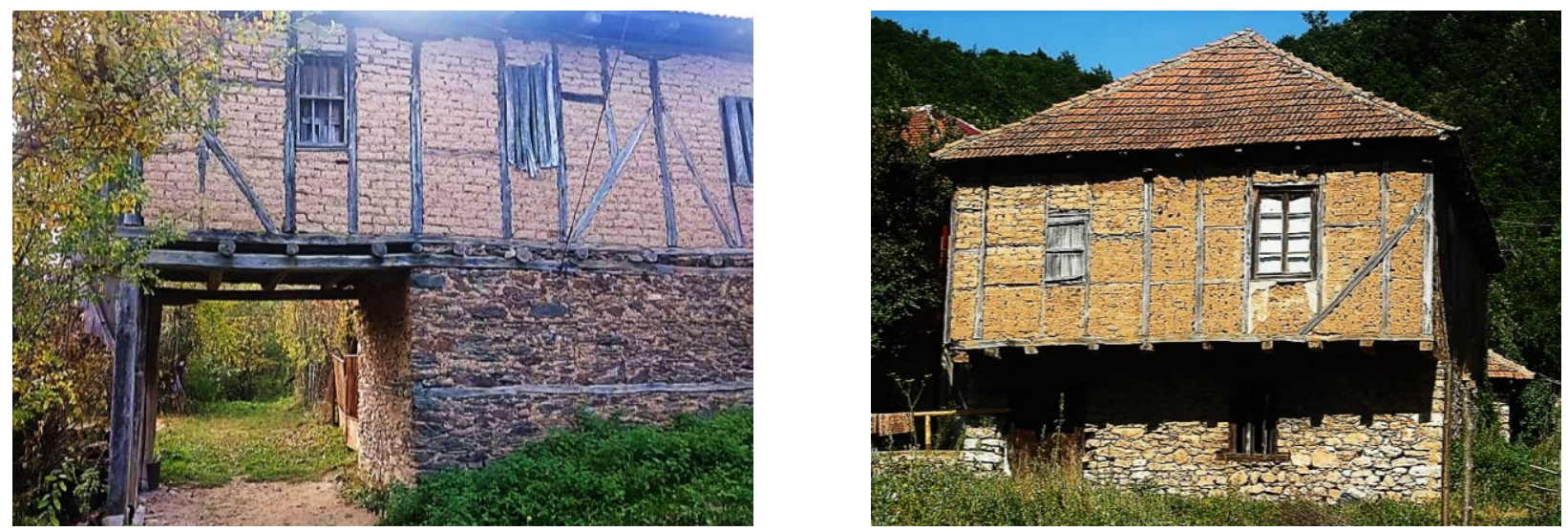

Figure III.9 Examples of vernacular architecture. Use of combined construction systems: massive stone masonry with visible wooden braces and wooden frame with adobe brick infill. A: village of Vrbjani B: village of Mramorec.

The system of wooden braces was regularly left visible on the façades of residential and economic buildings (fig. III.9), while in the ecclesiastical architecture this is not common. However, there are exceptions, such as the church of the Nativity of the Most Holy Mother of God in the village of Setole near Tetovo, where visible wooden beams placed in four belts are left on the façades; the wooden braces are partially visible on the western façade of the church St. Athanasius in the village of Sovich near Bitola, at the monastery St. Archangel Michael in Berovo, etc.

The perimeter walls constructed in the described system, which form the load-bearing shell of the church, support the vaulted upper-structure. In a relatively small number of churches the vaults and

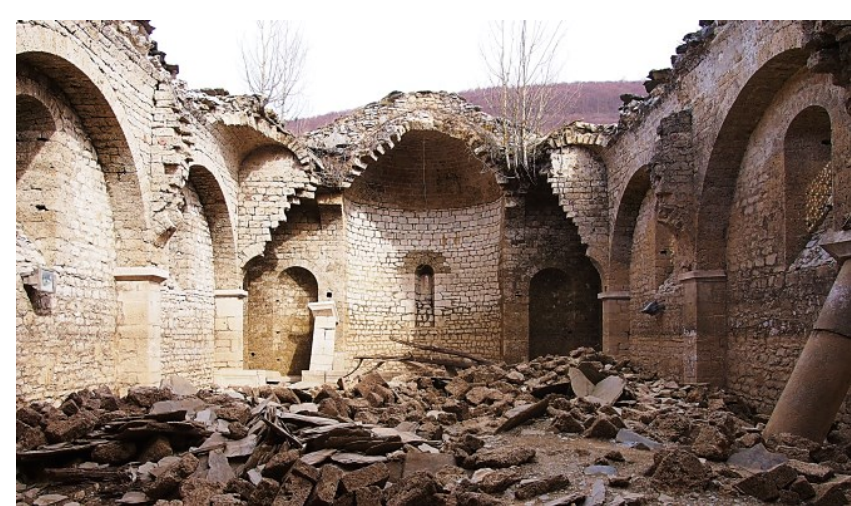

Figure III.10 Interior view of the church of St. Nicholas in Mavrovo, after 70 years of submersion in the artificial lake Mavrovo. domes are made of massive construction, built of stone (see fig. II.25, III.10). ${ }^{234}$ These are, in fact, precisely those churches whose masonry is entirely made of cut and hewn stone. Here, the skill of the stone-masons and the masterbuilders themselves, the availability of material resources and better quality construction material enabled these churches to be completely built using a massive system, including of course the vertical supports - the columns, which in that case had the task of carrying significantly larger loads.

in construction throughout the Middle Ages, both in residential and ecclesiastic buildings. Namely, key points of the building were strengthened with such a system of wooden braces: the bottom of the perimeter walls, the base of the vaults and the drums of the domes where wooden rings were inserted. The whole system was connected with wooden ties, which connected the pillars (or columns), with the pilasters and the side walls and solidified the entire structure of the temple in its upper zone.

${ }^{234}$ St. Elijah in Selce (Debar); St. Nicholas in Mavrovo; St. George in Gorna Vlashka Maala and the Holy Mother of God - Kamensko, both in Ohrid; St. Nicholas in Vevchani (Struga), St. Nicholas in Tresonche (Debar), etc. 
However, as opposed to these most representative examples of completely massively built churches, in most of the Revival churches a light wooden construction prevails in the upper parts. Of course, one of the basic factors is the economy - the significant cost of stone vaulted structures, as well as the complexity and longevity of their execution. However, this factor was not crucial, as confirmed by the Revival basilicas made entirely of stone. The application of lighter construction in the vaults enabled faster construction of buildings with significantly smaller lateral thrusts and loads, simplifying in turn the lower, massively built masonry structure, which in this case did not have to be particularly precise. The vaults and domes were constructed of timber ${ }^{235}$ - wooden beams, ties and planks, arranged into the desired "vaulted" structure and supported by the above-mentioned wooden braces built into slots prepared for this purpose along the perimeter load-bearing walls (fig. III.11). In fact, the structure of the "false" vaults is a wooden lattice very similar to the ones used as temporary load-bearing scaffolding for the construction of masonry vaults, with the difference that in this case they are mirrored and transformed from temporary to permanent structures. Depending on the design, these wooden lattices were used to make various flat, vaulted or combined ceilings: blind domes, semi-cylindrical vaults, vaults with a cross-section of a quarter cylinder, groined vaults, segmental, raised or lowered vaults, flat and coffer ceilings etc. The intrados of this intricate wooden lattice was then coated with thin wooden slats to obtain a solid surface, upon which belts of tied reed were nailed as a mortar base, a regular practice in residential and vernacular buildings preserved in the region deep into the XX century. ${ }^{236}$ Several layers of mortar were then applied to the reed substrate; first a coarser mortar composed of larger quantities of binder - straw or animal fibers (wool, fur); subsequently a finer, smoother lime mortar was applied, which received the final white-wash or fresco-painting.
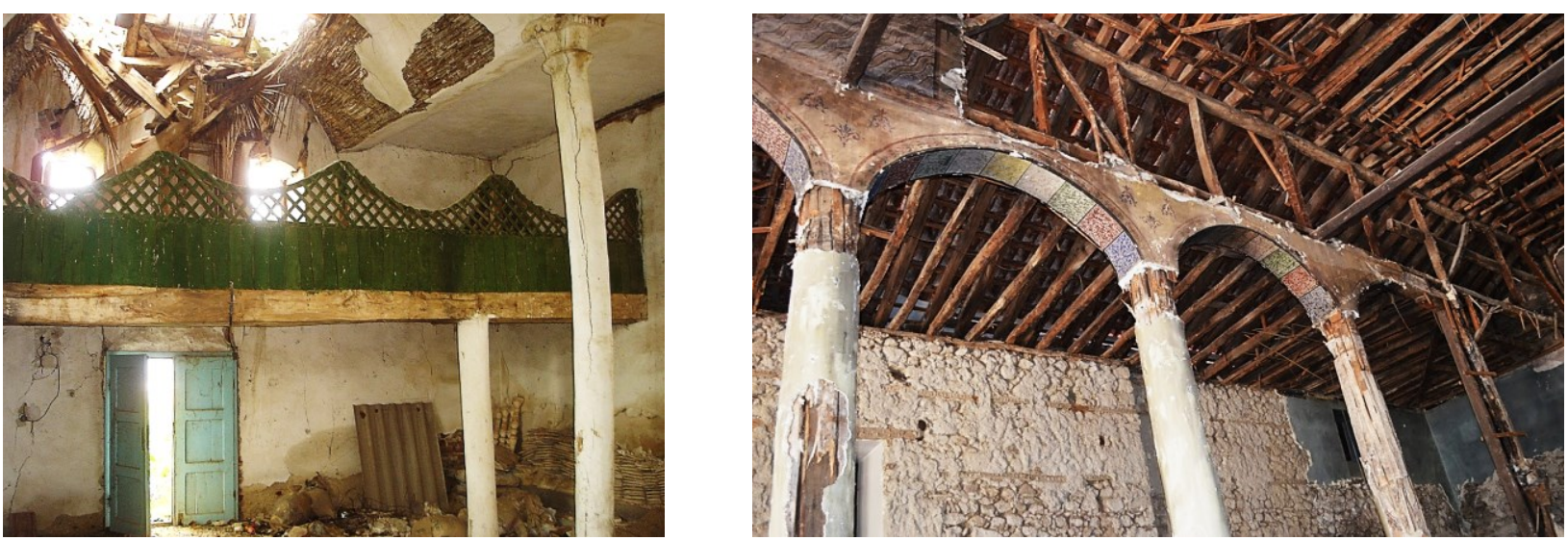

Figure III.11 Examples of "false" wooden vaults and flat ceilings. A. St. Savior in Gabrevci (Radovish); B. St. Demetrius in Kavadarci.

With the multiple mortar coatings and the application of fresco painting on this light-weight wooden construction, the goal was to achieve the effect of massively built masonry vaults, successful to the extent that it is often difficult to distinguish the massive from the wooden construction, i.e. the interior of the churches has a monolithic appearance. Thus, the physical true load-bearing structure and the visible structure in the interior of the church building are in fact two different categories (Roth, 1999: 19). The

235 The highest quality wood was used for this construction. For example, the master-builder Todor Petkov used chestnut beams for the construction of the domes of the church of St. Petka in the village of Gorna Belica, near Struga (Василиев, 1965: 242). Indicatively, baroque wooden vaults in Italy were constructed using the same type of wood, such as the church of San Pietro in Vincoli in Rome, whose wooden vaulted ceiling was designed by Francesco Fontana in 1705 (Fernández Cuadros, 2014: 94). Chestnut wood has "average hardness, is easy to work with, a chemical composition with a large amount of tannins and low permeability give it great natural durability and resistance to rot and xylophagous insects, which contributed to it being a frequently used material in construction for roofing, as well as in shipbuilding" (Ibid: 112).

${ }^{236}$ The same practice is noted in the I century B.C. by Vitruvius, who explains the procedures for making wooden vaults covered with stucco (Vitruvius, 1960: 205-206), which testifies to the antiquity of these structural systems and their prevalence in the wider Mediterranean region. 
wooden ceilings of the Revival basilicas can therefore be called "false" vaults, since they are such only in appearance, and not in their constructive function. In the construction of false vaults and domes lies the deeply rooted belief, the deeply instilled need in the Christian symbolism for a physical, material, tangible representation of the celestial vault constructed with the help of any available materials, means, possibilities and techniques (fig. III.14). ${ }^{237}$

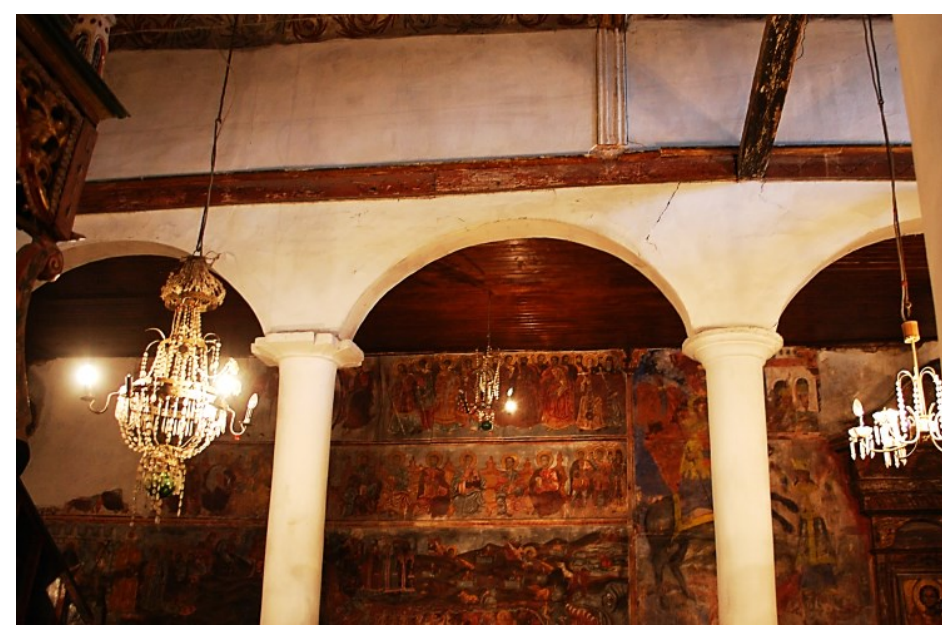

Figure III.12 View of the northern arcade of the church of St. Nicholas in Bashino Selo (Veles).

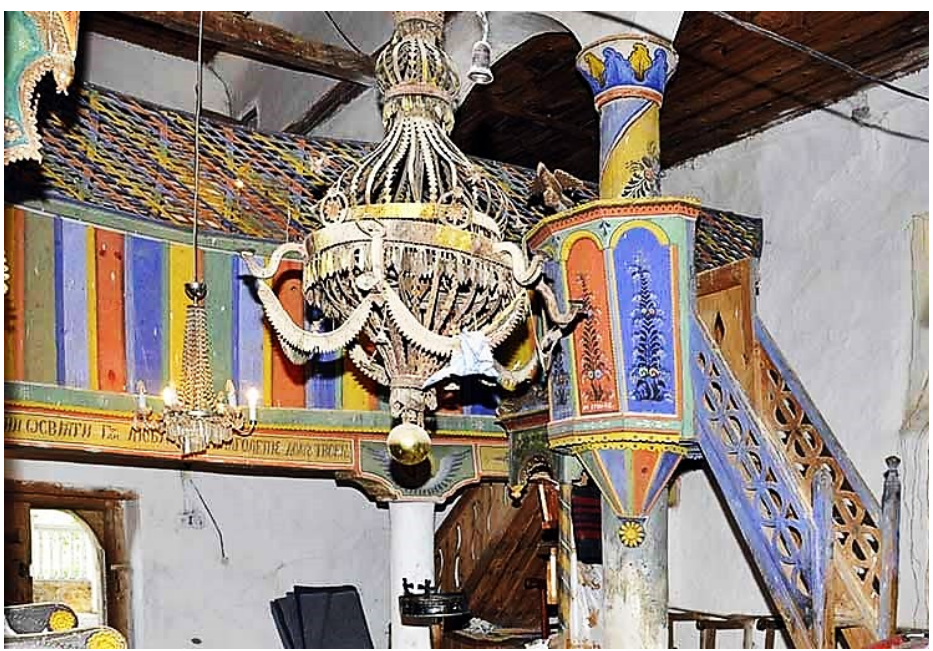

Figure III.13 St. Demetrius in Pancharevo (Pehchevo). View of the gallery.

Specific to the Revival multi-nave basilicas is the appearance of columns instead of masonry pillars (usually found on the porches of the five-nave and some three-nave basilicas - see fig. III.4) which, as was discussed earlier, dominated the Byzantine monumental architecture. The columns are usually circular in crosssection, but square, hexagonal or octagonal trunks are also found (for example in the churches in Radibush and Stracin, see fig. III.98). As with the vaulted structures, there are two types of load-bearing vertical supports in terms of the material used: stone and wooden columns. In those churches that have masonry vaulted structures, the columns were, logically, also made of stone, whether as monolithic pieces (such as the lower pillars that carried the gallery of the church of St. Nicholas in Mavrovo see fig. III.10, as well as the polygonal pillars of the church of St. Demetrius in Stracin, near Kratovo), or composed of cylindrical blocks shaped out of ring-like blocks that were stacked on top of each other, encircling a common metal core (for example, at the church of St. George in Gorna Vlashka Maala in Ohrid (see fig. III.100B); at the Most Holy Mother of God - Kamensko in Ohrid; St. George in Struga; St. Sotir - Bukovo monastery near Bitola; St. Elijah in Jablanica, etc.).

In contrast, the tall, slender load-bearing columns on which the lightweight wooden ceiling structure rests were predominantly also wooden (fig. III.11-13). It is of particular interest to note the construction of these columns. Most often, these are tall monolithic wooden posts (beams) with a square or approximately square cross-section, and cut and somewhat rounded corners. To obtain a circular crosssection, wooden slats of ascending width were nailed on top of the posts; then, a thick hemp rope was spirally wrapped around them and they were subsequently plastered in the same way as the wooden vaults. The rough structure of the rope enabled better adhesion of the mortar, which tends otherwise to poorly adhere to wooden substrates (Томовски, 1967: 18). Finally, the plastered columns were painted

237 "If the dome form of a temple is essential to human religious expression, he will create it, whether the materials and skills available are concrete, stone, brick, rock, wood, woven materials, or leather. His work may differ in execution and in technical perfection, but that will not diminish the practical achievement of its purpose" (Hoddinott, 1963: 23). 
to achieve an effect of a masonry structure, marble or stone, or painted with a variety of decorative ornaments (fig. III.13, III.17A-B).

The capitals of these wooden columns were processed in a very specific way, dictated by the need for a decorative element with the least possible weight. The masters who specialized in making capitals were known as sculptors or kjulumjis, named after the mixture they worked with called kjulum (derived from the Turkish word külünk) which consisted of cotton, lime, wax and oil. The procedure was the following: the skeleton of the capital was formed of sheet metal and metal wire, and the prepared kjulum mixture was then applied to that substrate. When the mixture hardened, usually the next day, plaster was applied and then ornaments and sculptural shapes were cut, carved and modeled according to the desired design (plant motifs, intertwining, garlands, branches, leaves, flowers, birds, animal figures, angels, etc.). Finally, the capitals were colored, painted or gilded (see Chapter III.4). The same procedure was used to make bas-relief ornaments, rosettes, frames, moldings, cornices. This specific craft

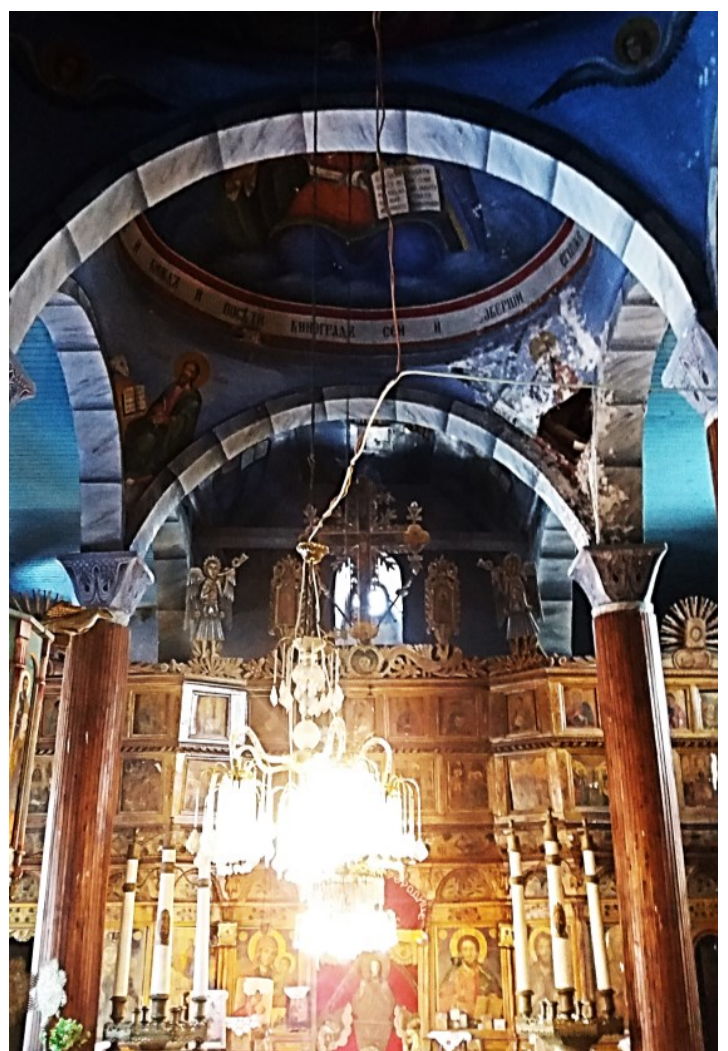

Figure III.14 The Most Holy Mother of God in Duf (Gostivar). View of the false blind dome in the central nave and its wooden substructure. was practiced by many masters, and some devoted themselves exclusively to that line of work (Василиев, 1965: 211-212). ${ }^{238}$

The arches connecting the columns in the arcades were also made of wood (with the exception, again, of those churches where the arches and columns themselves were classically constructed in stone). In fact, the load-bearing element are wooden beams spanning between the columns (fig. II.22, III.11), while the "arches" between them are only decorative, hung on the hidden beams. In other words, the constructive system formally remains architrave, despite its appearance. As was the case of the vaults and ceilings, the arches were also made of wooden slats and planks, and then plastered and painted (fig. III.1114). They are usually semicircular; however, elliptical, horseshoe and pointed arches can also be found, though less commonly. The gallery, regularly located on the west side of the naos, was also made of wood. On the ground floor it is carried on wooden columns connected by beams; the span of which is usually shortened and the load-bearing capacity augmented through lateral shorter wooden beams, decoratively profiled, so that they appear as wooden capitals called "futi" or "kushaci" (fig. III.13). This system supports the upper construction of the gallery. The parapet of the galleries is made of wood or wooden frame construction and then plastered, while the semi-transparent grids placed above them, if any, are usually made of thin diagonally arranged slats, often decoratively painted.

Furthermore, blind domes, half-domes, rosettes, pendants, curved and profiled railings, arcades, consoles, cornices, as well as the whole church furnishings were built in wood with top craftsmanship: iconostasis, seats for the faithful, bishop's throne, pulpit (ambo), icon pedestals (so-called "celivanija"), and even ornate, filigree chandeliers. ${ }^{239}$ Even the porches were originally made of wooden material (see

\footnotetext{
${ }^{238}$ Makaria Negriev ( 1800-1862) from the family Frchkovski from the village of Galichnik, Aleksa Mirchev Despotov (1836-1906) from the family Mirchevci from the village of Osoj, etc. are known to have been engaged in "sculpture".

239 These chandeliers made of wood, which were undoubtedly regularly made as a basic and indispensable part of the church furnishings, are today extremely rarely preserved, certainly due to the impermanence of the material, as well as the later
} 
Chapter III.3) or a combination of monolithic stone pillars and wooden upper construction, such as the church of St. Demetrius in Stracin ${ }^{240}$ in the region of Kratovo (see fig. III.3, III.49) and the similarly conceived church of St. Petka in the neighboring village of Rugjince, region of Kumanovo.

In terms of types of wood which were commonly used, walnut (Juglans regia) was considered the highest quality wood, but since it is a slow growing tree and is not very common in nature, it was considered an expensive material and as such was reserved for the most monumental wood-carved elements - iconostasis, choirs and liturgical objects (gift boxes, relics, etc.). Furthermore, linden (Tilia europaea), oak (Quercus trojana), ${ }^{241}$ beech (Fagus sylvatica), chestnut (Castanea sativa) as well as, though less commonly, fruit trees - bulb (Pyrus communis) and apple tree (Malus domestica) were used for woodcarved and structural elements (Светиева, 1992: 122). The coniferous trees - fir (Abies alba), pine (Pinus sylvestris) etc. were the most accessible and easiest to work with and, in most cases, used for the wooden frame construction. Acacias, poplars, willows and similar trees were avoided because they do not have much construction value (Покропек и Стрончек, 1992: 106).
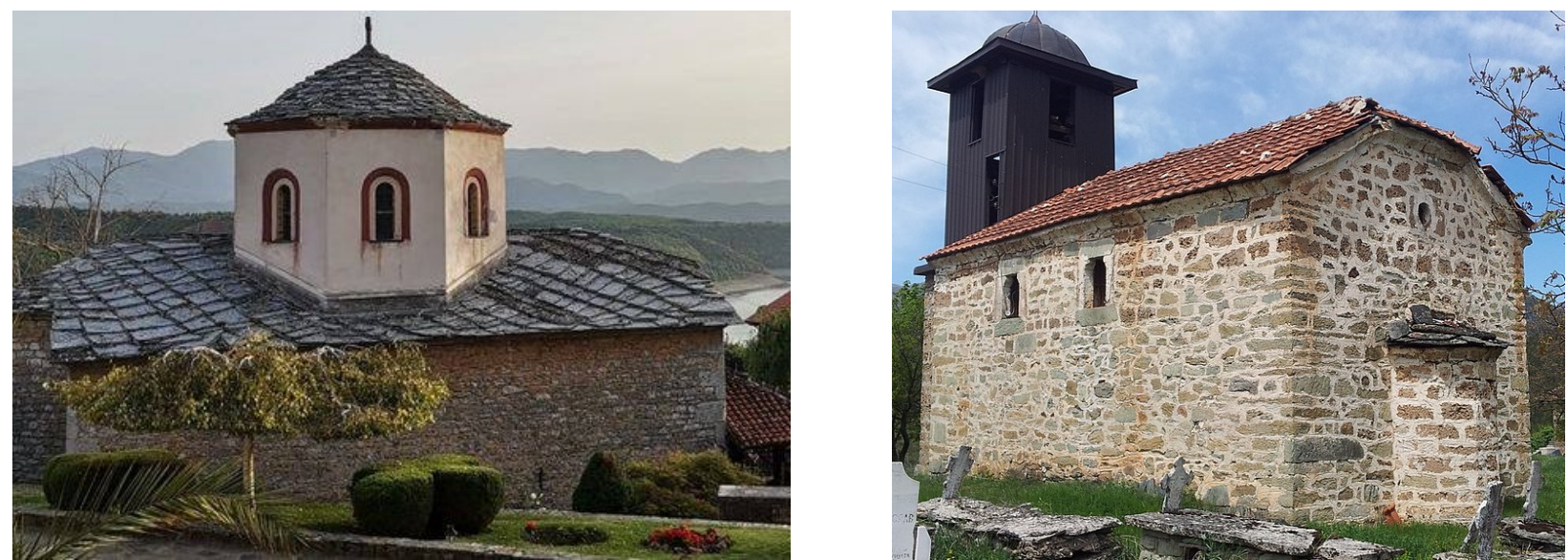

Figure III.15 Examples of partially or entirely preserved stone-slab roofs: A. St. George in Rajchica (Debar); B. St. Savior in Trebovlje (Makedonski Brod).

The Revival basilicas were covered by a gabled roof, so that in most cases the three-nave basilica solution of the churches is not manifested externally. In the churches covered with light wooden vaulted construction, in fact, the same structure that comprised the roof supported the "false" vaults, i.e. the wooden structural systems were not doubled; in the massively vaulted buildings, a wooden roof structure rested on the vaulted shells. As for the roofing material, thin stone slabs arranged with overlap were generally used (fig. III.15). Because this is a very heavy roof, ${ }^{242}$ it was often later replaced with roof tiles, and more recently with metal or plasticized sheet metal, but there are isolated cases where it is authentically fully preserved (for example, at St. John in Kratovo, where the roof has been recently

introduction of electric lighting. Fortunately, several examples exist in churches in abandoned villages, which are preserved in their almost original form to this day, i.e. which have not been subject to unprofessional interventions by the local population. Such examples are the churches St. Demetrius in Pancharevo near Delchevo; St. Petka in Prdejci, Gevgelija; St. Theodore Tyron in Piperovo, Shtip, which unfortunately is found in an alarming state of preservation.

${ }^{240}$ At the church of St. Demetrius in Stracin, for example, the row of monolithic stone pillars on the west façade of the porch support a single, continuous wooden beam made of a single tree trunk, over $12 \mathrm{~m}$ long! (see fig. III.3, III.49).

241 In Macedonia, oak is one of the most common trees: as much as $40 \%$ of the forests are oak, and several species grow autochthonously: Quercus pubescens, Quercus petraea, Quercus trojana / Quercus macedonicus, Quercus coccifera, the oak called "cer" (Quercus cerris), and so on. Understandably, some villages in Macedonia were named after their location in oak forests: Cer, Golemo and Malo Crsko in the region of Demir Hisar; Cerovo in the region of Gostivar, etc.

242 In fact, under the weight of the stone roof and often cold and snowy winters, in the Revival churches in almost all abandoned villages, the roof and the vaulted structure collapse first, which unfortunately is followed by complete abandonment and irreversible demolition of the building (see fig. III.10). 
restored; in the monastery in Rajchica near Debar - fig. III.15A, etc.), and most often in fragments, i.e. only at the roof of the altar apse (fig. III.15B). ${ }^{243}$

Besides the basic building material: stone, brick and wood, the Revival architecture also used lime, wrought iron, glass, clay, straw, reed, sand, animal fibers (sheep wool, goat hair and fur), eggs, etc.

What is the origin, under what influences did the Revival basilicas adopt this combined structural system? First of all, it is worth mentioning that wood is one of the first materials used for construction: it is available and abundantly found in nature, it is flexible, easy to transport, process, shape and install, it is lightweight and compatible with all other building materials used in the past (Fernández Cuadros, 2014: 29). Due to its fibrous nature, it is highly resistant to tension, thus wooden beams are suitable for bridging large spans (Roth, 1999: 24). The proto-Slavs, who according to historical sources and preserved artifacts were extremely skilled carpenters, used wood not only for building their dwellings, but also sanctuaries, defensive architecture and cult objects. ${ }^{244}$ In fact, throughout the medieval period, long after the settlement of the Slavs on the Balkans, unlike the monumental public, defense and religious buildings, the residential and economic architecture was predominantly built of wood. ${ }^{245}$ In fact, the residential architecture of the Slavic peoples in Central and Eastern Europe was built of wood until well into the XX century (Покропек и Стрончек, 1992: 41). Unfortunately, the instability of the material, the harsh climate and the susceptibility to fire have caused the historic wooden structures to disappear to a great extent. We thus learn about them indirectly, from historical sources, travelogues, through preserved residential buildings such as monastery cells or newer buildings, dating from the XVIII and XIX century.

Nevertheless, this centuries-old experience in wooden constructions certainly contributed to the cumulative development of techniques and skills in carpentry and the woodcarving craft, which culminated in the ornamental repertoire and the quality of workmanship during the XIX century Revival. After all, one of the main features of the so-called "Balkan-oriental house" and more specifically the Macedonian traditional town house is the installation of decorative wooden architectural elements (doors, rosettes, decoratively processed ceilings, cupboards, and furniture) made of carpentry or woodcarving. ${ }^{246}$ Precisely in the luxurious wooden ceilings of the Revival basilicas and their church furniture made in woodcarving one can recognize an incredible similarity with the architectural elements

\footnotetext{
${ }^{243}$ Such is the case with the churches St. Savior in Zhivojno, Mariovo; Holy Trinity in Ropotovo, Prilep; St. Elijah in Dolno Vranovci, Veles; St. Theodore Tyron in Krklino, Bitola; St. Theodore Stratilat in Dolno Orehovo, Bitola; Ascension of Christ in Grumazi, Mariovo; St. Nicholas in Kichinica, Mavrovo; Dormition of the Most Holy Mother of God in Paralovo, Mariovo; St. Demetrius in Dunje, Mariovo; St. Elijah in Aldanci, Krushevo; Dormition of the Most Holy Mother of God in Rastojca, Demir Hisar; St. Nicholas in Bashino Selo, Veles; Dormition of the Most Holy Mother of God in Marena, Kavadarci and so on.

244 Influenced by the architecture of other peoples they came in contact with, they sometimes even replaced the traditionally architrave constructive system with a "vaulted" one, conditionally speaking. The vaults in their rectangular houses were constructed by means of longitudinally arranged beams or planks grooved into each other, whose bearings were on the opposite walls of the building, so that the result was a vault in shape, but not in structural function, which remained in fact unchanged architrave (Бошковић, 1967: 122).

245 In this regard, Alexander Deroko will quote a travelogue through the Serbian state in the early XIV century, according to which "there are no cities in the entire Serbian Empire, but there are still many fortresses and large settlements with 300-400 houses of wood or logs" (Дероко, 1951: 22). It is important to mention that according to records from the historical archives of the city of Dubrovnik, in the XIV century a boy from Macedonia, from the town of Debar, came to study the carpentry trade with members of the town's carpentry guild (Historijski arhiv Dubrovnika, Diversa notariae, 9, fol. 110). Later, during the Ottoman occupation, it was precisely the local carpenters from the region of Debar who were hired in the construction of the Kodhadzik Fortress (Турски документи за историјата на македонскиот народ, опширни пописни дефтери од XV век, т.III, 1976: 315-316). In fact, even in the Revival period, mainly the Macedonian population and the Islamized Macedonians worked in construction, and much less the Turks (Томовски, 1973: 269).

${ }^{246}$ Thus, in the descriptions of residential architecture in his travelogue of 1660, Guillaume Grelot noted: "as for the other houses, they are not distinguished by anything beautiful, except by a few rooms lined with wood, plaster or guilding" (quoted by Светиева, 1992: 40).
} 
applied in the residential architecture, mostly in the towns but also, in some cases, in the richer villages during the Revival (fig. III.16-17). ${ }^{247}$ This, in addition to the logical conclusion that both types of architecture (residential and ecclesiastical) were executed by essentially the same master-builders (Томовски, 2000 (B): 80), ${ }^{248}$ speaks of a unified, comprehensive taste and dominant aesthetic tendency in architecture as a product of centuries of construction experience and tradition.
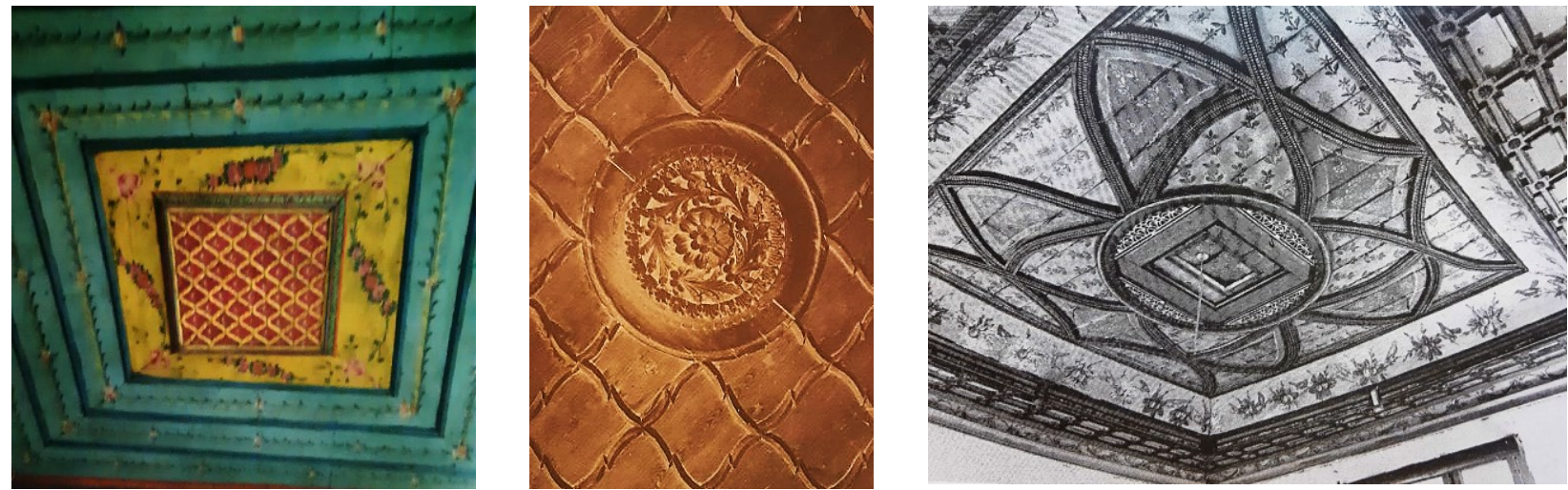

Figure III.16 Details of flat wooden ceilings: A. The church of St. Demetrius in Kriva Palanka; B. The house of Shekir-bey in Skopje and $\mathrm{C}$. The house of the Chokalovci family in Veles.
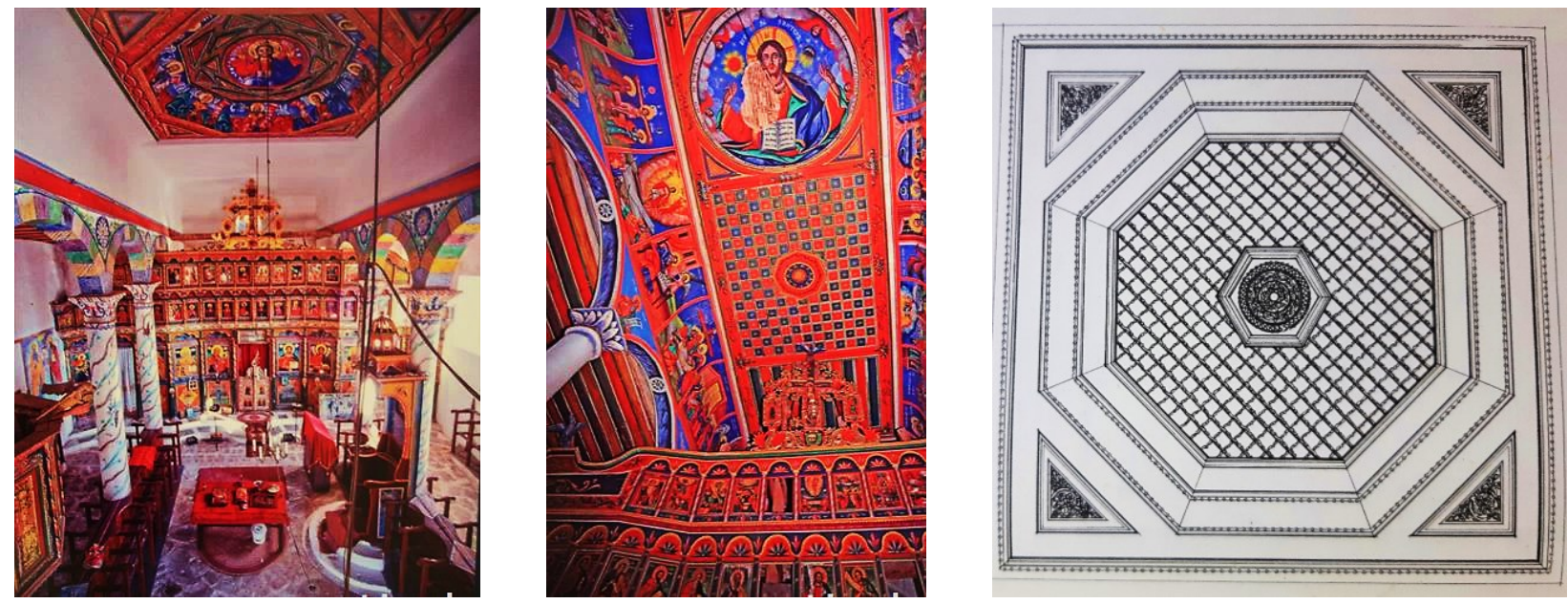

Figure III.17 Examples of flat wooden ceilings: A. St. Athanasius in Novachani (Veles); B. St. Nicholas in Krajnici (Veles); C. The house of the Topalovski family in Debar.

In that direction can be sought the reasons for adopting the combined construction systems from the profane and vernacular architecture and their adaptation to the monumental sacred construction (fig. III.18). Namely, the combination of massive masonry and light wooden frame constructions (consisting of wooden pillars, beams and ties, with various forms of infill of the walls such as unbaked adobe brick "kerpich", wooden planks or braided wooden rods, then plastered and lined with wooden decorative moldings) are characteristic of the vernacular residential and commercial architecture throughout the eastern Mediterranean, the Balkans and Macedonia (see fig. III.9, III.18B-C). Usually, the ground floor of the buildings and the northern walls along their entire height were made of masonry of crushed, hewn or cut stone with wooden leveling strips, most often left visible on the façades. Over this ground floor

\footnotetext{
${ }^{247}$ Namely, in the rich "chorbadziski" houses in the villages carved ceilings are present in the representative guest rooms (fig. III.16B-C, III.17C), formed in the same way: with a central rosette, triangular corner fields, an interweaving of triangles and squares and floral and geometric ornamentation (Покропек и Стрончек, 1992: 140).

248 In that context, we know that the master-builder Todor Petkov designed and built the house of the Robevi family in Ohrid in 1862 and Dicho Zograf fresco-painted it (see fig. III.19C). Analogous examples of distinguished master-builders, woodcarvers and painters who were hired to build or decorate residential buildings for the richest and most prominent representatives of the new Christian bourgeoisie can be found in other towns throughout the Balkans.
} 
"plinth" (comprised of the economic content of the house), one or more floors developed, made of light wooden frame construction, with verandas, balconies and abundant lighting through individual or grouped (strip) windows, enabled by the nature of the construction system itself (fig. III.18). The roofs were made of stone slabs, roof tiles or straw, depending on the local climate and the available materials. The typological solutions of the buildings are extremely diverse and arise from the required program, local climatic conditions, available building material, configuration and topography of the terrain, etc.
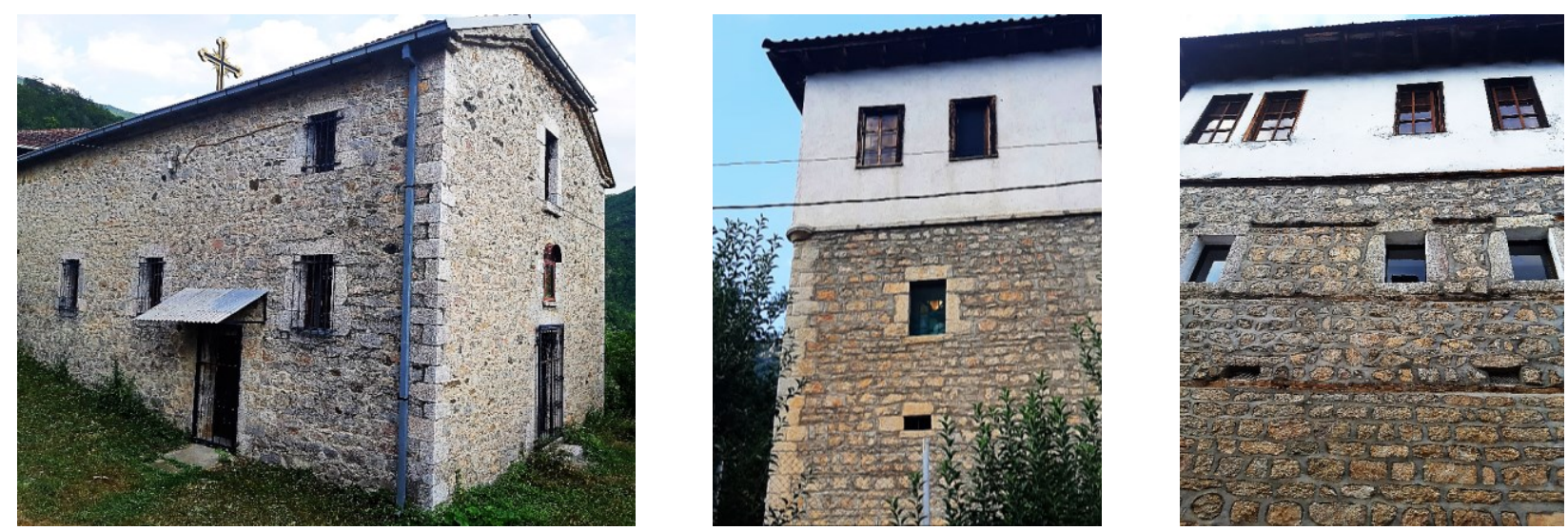

Figure III.18 A. View of the church of the Most Holy Mother of God in the village of Janche (Debar); B. and C. Examples of vernacular residential architecture in the same village.

As has been emphasized many times before, both the sacred and the profane architecture reached their crown achievements, as a result of "centuries of improvement of the construction procedure" (Волињец и Алексиевска, 1987: 59) precisely in the Revival period, when the Macedonian master-builder groups were especially appreciated and famous and worked throughout the Balkans and beyond. Referring to the wooden frame constructions of the monumental Revival basilicas, specifically the cathedral church of the Holy Trinity in Vranje (Serbia) built by the master-builder Kosta Damjanov, Krum Tomovski will write: "the constructive solutions achieved with this material, at such large buildings as the cathedral in Vranje, are really admirable. They are bold and functionally applied, which is a real constructive virtuosity" (Томовски, 1967: 19).

On the other hand, the influence of the Islamic architecture must not be overlooked, from which, as was said, the Revival basilicas took various motifs and forms: semi-transparent lattice fences, arabesques, Saracene and pointed arches, ${ }^{249}$ and which perhaps also inspired the domed single-nave basilicas as a special unique typological solution. ${ }^{250}$ Of course, the Revival architecture also imposed its influences on Ottoman architecture, as did the Byzantine monumental architectural heritage in the centuries following the occupation, both in terms of architectural typology as of the construction and masonry techniques. ${ }^{251}$ Furthermore, in the XIX century and the period that preceded it, of course, the Islamic and Christian buildings in the region were undoubtedly built and decorated by the same master-

\footnotetext{
249 In the context of the Revival wooden vaults, it is important to recall the plastered timber structures in Islamic architecture and its Arabic roots, such as the Moorish buildings built in the far west of Europe, the Iberian Peninsula and beyond. Conditioned by the climate conditions, the nomadic character and the limitation of the construction resources, the Arabs in their desert homeland used light wooden constructions, adobe, brick, rammed earth and applied stucco mortar to produce rich polychrome decorative elements (Бошковић, 1967: 321). In the Balkans, all these techniques are domesticated primarily in residential architecture, in the multitude of local and regional variants of the Balkan-oriental house, while stucco is used in the decoration of ceilings and fireplaces in the representative guest rooms of the Revival town houses.

${ }^{250}$ As an example, immediately after the conquest of Jerusalem by the Arabs in the VII century, the Kubet-es-Sacra mosque was built, which had a central space vaulted with a light wooden dome, surrounded by double octagonal naves covered with flat ceilings (Бошковић, 1967: 329).

${ }^{251}$ In addition to directly copying existing monuments, Byzantium also influenced Ottoman monumental construction indirectly, through churches converted into mosques, demolished churches whose material was used to build new mosques, and through the hiring of local construction groups.
} 
builder groups (fig. III.19). ${ }^{252}$ Namely, in addition to mosques, inns, hammams and other public Ottoman buildings, the residential buildings, tekkes, madrasas were dominantly built with the same combined massive / wooden frame techniques that will mark the Christian ecclesiastical and profane architecture in Macedonia. Such example of eclectic Revival architecture is the Colorful Mosque in Tetovo; ${ }^{253}$ a similar combination of massive and wooden frame systems, with wooden constructions of exceptionally high quality and decorative workmanship can be found at Arabati-baba tekke, an Islamic religious complex, approximately contemporary and also located in the town of Tetovo; another example is the Faik-Pasha Mosque in Madzir-maalo, Skopje, built during the Revival, ${ }^{254}$ etc.
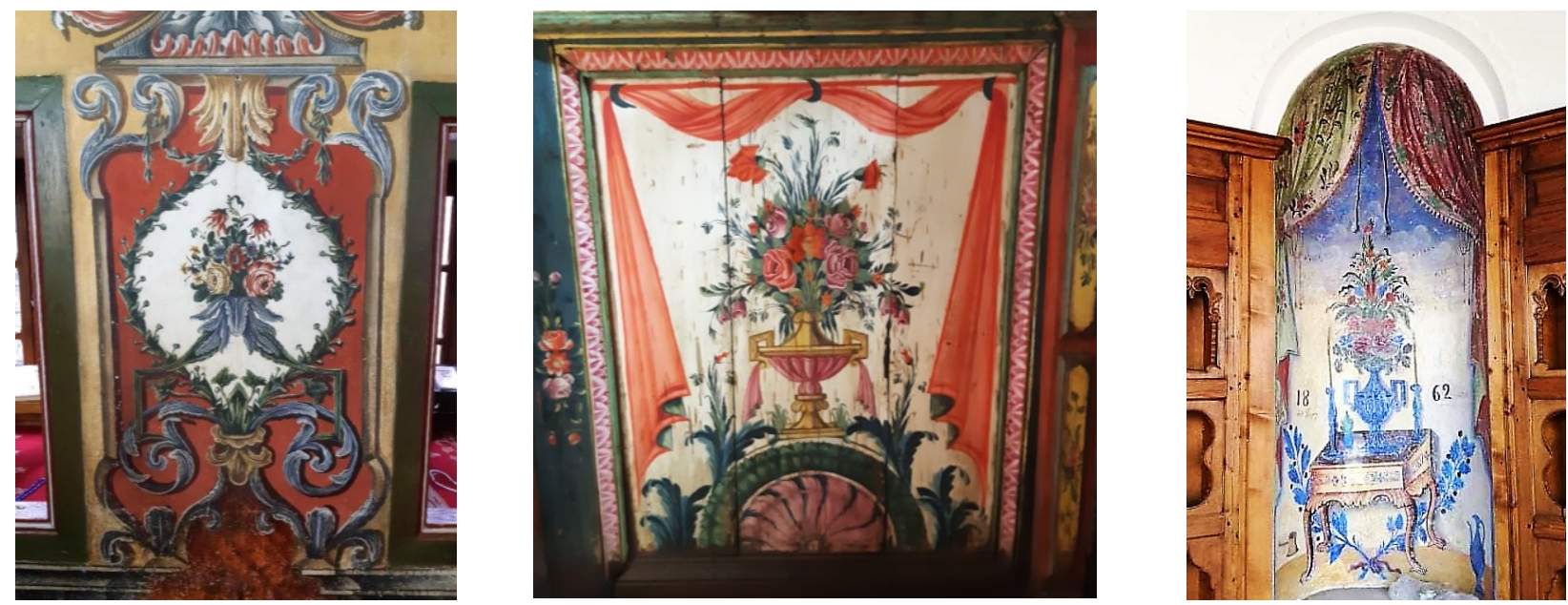

Figure III.19 Comparison between examples of bouquet motifs in various cases of Revival painting: A. The Colorful Mosque in Tetovo. Detail of the internal wall-painting; B. The church of St. Demetrius in Kriva Palanka. Detail of the iconostasis; C. The house of the Robevi family in Ohrid. Painting in the reception room, by Dicho Zograf.

In addition to centuries of domestic experience in lightweight wooden frame structural systems, as well as the mentioned Islamic influences "domesticated" in the post-Byzantine Balkans, it is likely that the Revival master-builders were also inspired to build wooden vaulted structures from more distant sources. Unfortunately, today we do not have an insight into which printed editions they had at their disposal; however, from what is known from older sources, ${ }^{255}$ some of them had illustrated Western European

\footnotetext{
252 Namely, it is known that Mahmud Pasha's palace in Shkodra was built by master Veljan from the village of Selce, near Debar; the construction and decoration of the Yeni Mosque in Debar was entrusted to the famous master-builder and wood-carver Mirche Despotov (1802-1883) from the village of Osoj and his group; his work is also the Haki-pasha konak in Tetovo and the bey's palaces in the village of Lukovo, which he built together with master-builder Aleko Cherepnalkovski (Tomovski, 1989 (B): 245-246). The bridge near Shpilje, today submerged in the waters of the artificial lake by the same name, is the work of master Ivan from Lukovo. Macedonian master-builder groups are also authors of the Gorenichki bridge on the river Radika, and they participated in the construction and decoration of the Colorful Mosque and the Arabati-Baba tekke in Tetovo. Master Stojan Vezenkov is the author of the garrison barracks in Bitola and Sarajevo, as well as the bridge over the river Nishava near Nish (Serbia) and Marica near Edirne (Nikolovski, 1989: 274), and so on.

253 The original appearance of the mosque, built in 1495, is unknown, as it was thoroughly restored under Abdurrahman Pasha in 1815-1833. Perhaps the original massively built dome (whose existence is indicated by the perimeter walls with an extremely large cross section of almost $2 \mathrm{~m}$ ) collapsed at some point, which initiated a reconstruction performed in the spirit of the epoch. Namely, the mosque has a square nave today, bridged with a "false" vaulted Revival wooden structure (Ненадовић, 1980: 301302) shaped as a low blind dome covered with a pyramidal bonnet roof. As in some of the Revival churches with blind domes, there is no imitation of squinches or pendentives - the corners of the nave are covered by a flat ceiling. In this mosque the mahvil (gallery) develops above the open wooden porch, projecting three semicircular balconies with a baroque curved profile which has direct parallels with the balconies of the galleries in the Revival churches (see fig. III.39). The extraordinary ornamental painting on the façades and the mosque's interior was performed by Revival painters from the Debar school (fig. III.19A).

254 It was built in 1883-1884, significantly damaged in the 1963 earthquake and finally completely demolished in 1989. This mosque had a vaulted porch supported by four slender wooden pillars placed on stone pedestals; perimeter brick walls and, according to the few preserved photographs taken after 1963, most likely a false dome of light wooden construction; both wings of the front door, in the spirit of the epoch, were executed in wood in shallow relief (Кумбараџи-Богоевиќ, 1993: 139).

255 See footnote 137.
} 
(Italian) and Russian editions in their personal libraries. It is possible that some of the extensive treatises on architecture that were frequently published in Western Europe starting from the Renaissance (fig. III.20) were among them. ${ }^{256}$ From these publications, in addition to ideas for baroque and classicist façade elements, ornaments and decoration, the Revival architects could also copy details of constructive systems, thus upgrading their traditional skills with wood and wooden constructions. ${ }^{257}$ Therefore, it is possible that through contemporary literature, or through their frequent travels and labor migration, the Macedonian master- builders became acquainted on one hand with the Italian and German Baroque churches with wooden vaulted ceilings, with Gothic and Renaissance public buildings and palaces in Italy, France, Spain where the execution of wooden coffer and vaulted ceilings had traditionally been nurtured and, on the other hand, with the Russian and Nordic all-wooden churches. ${ }^{258}$

The analogies with the baroque wooden ("fake") vault systems seem especially important. Wooden vaulted structures were especially widespread throughout Europe during the late Baroque, in the XVII-XVIII century, applied in churches, palaces and public buildings, mainly as a result of the
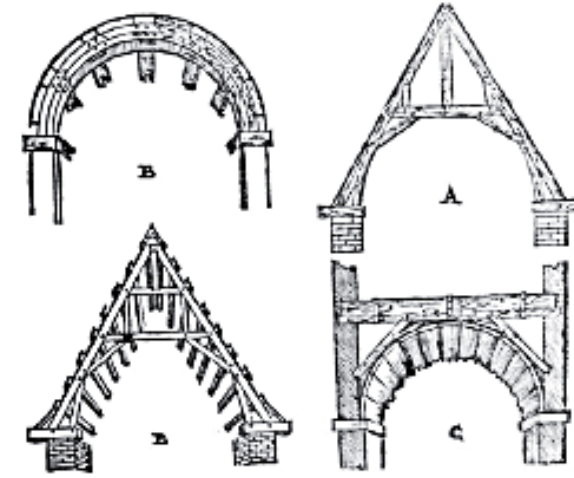

Figure III.20 Detail of a drawing of wooden vaults. Sebastiano Serlio, I sette libri dell'architettura, XVI century. same factors that contributed to their application and development in the Macedonian Revival ecclesiastical architecture: lower cost, lower weight and their decorativeness (Fernández Cuadros, 2014: 23). They are especially specific for the Baroque renovations of older churches, where it was impossible to insert heavy massive vault systems that involve large loads, so false wooden vaulted structures were executed as an alternative solution. As in the Macedonian Revival basilicas, in the Baroque churches in Western and Central Europe the wooden structure was covered with the intention of imitating semi-luxurious materials (carved stone, marble), with a specific baroque ornamental abundance, bas-relief, stucco, painting and gilding. It is clear that "according to the baroque artistic conceptions, the aesthetic aspect goes beyond the structural, that is, it is not the material from which the vaults are made that is important, but the final result that that material offers" (Ibid: 94). In that context, it seems important to recall that in the works of the Revival woodcarvers, fresco and icon painters, science has so far recognized and valued the imported Western European element, especially the so-called "Italo-Cretan" masters and the influences from the Levantine Baroque precisely in the XVII$\mathrm{XVIII} \mathrm{century.} \mathrm{There} \mathrm{is} \mathrm{no} \mathrm{reason,} \mathrm{then,} \mathrm{to} \mathrm{reject} \mathrm{the} \mathrm{role} \mathrm{of} \mathrm{Western} \mathrm{European} \mathrm{imports} \mathrm{in} \mathrm{architectural}$ constructions.

Consequently, it can be concluded that as the Revival architecture itself, the methods and techniques with which it was created were eclectic and open to foreign influences, but still firmly based on the local building tradition and long, millenial experience with the available building materials.

\footnotetext{
${ }^{256}$ For example: Philibert de L'Orme (1561) Traitès d'architecture: nouvelles inventions pour bien bastir et a petits fraiz; Sebastiano Serlio I sette libri dell'architettura from the XVI century (printed in separate volumes from 1537 to 1575), the published works of Giuseppe Valadier at the beginning of the XIX century, etc.

${ }^{257}$ Whether and to what extent Western European written sources or the already built structures themselves could have had an impact on the Macedonian Revival wooden "false" vaults can not be estimated at this point. The reasons are complex: on one hand, the wooden vaulted structures of the Revival churches are inaccessible and can only be studied after the partial or complete dismantling of the roofs, for which an opportunity rarely arises; on the other hand, as pointed out in the Introduction, there exists a lack of professional literature on this topic, as well as previous research and detailed documentation of individual examples. 258 Wooden churches, called "brvnari", were also built in the northern regions of the Balkans, especially throughout Bosnia (Светиева, 1992: 60).
} 


\section{III.3 Architectural elements and design}

Conditioned by their architectural typology, the Revival churches, unlike the Byzantine ones, do not commonly have a pronounced external spatial plasticity, with the exception of their eastern façade. Consistent application of the same architectural vocabulary is present in the processing of their elements, which contributes to their immediate and easy recognition as Revivalist, i.e. as part of a specific, temporally and geographically defined building school.

\section{Roof}

The churches built in the XIX century are covered almost without exception with a gabled roof. Even at the three-nave basilicas, the solution of covering the whole building with a continuous gabled roof is dominant, so that in the spatial plastic there is no expression of the basilical solution which, in turn, develops flawlessly in the interior. Therefore, in science these churches were called "hall-churches" or "pseudo-basilicas" (as described in Chapter III.1).

Why was this solution chosen? Where does it stem from?

Of course, it can be assumed that, both for the architectural typology and the way of covering the buildings, the Revival builders in the spirit of XIX century romanticism sought inspiration in the past, i.e. in the basilicas of the early-Christian and middle-Byzantine period. ${ }^{259}$ However, in the Revival, the earlyChristian basilicas in Macedonia still hadn't been "discovered" and archaeologically explored, ${ }^{260}$ thus their

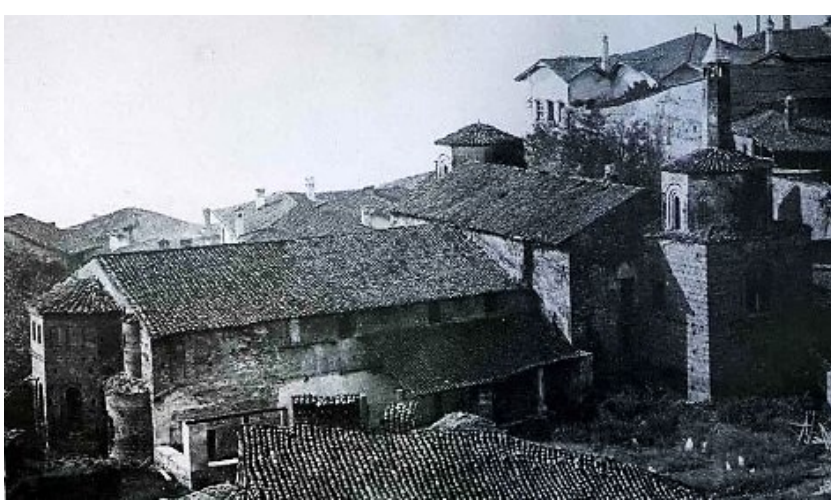

Figure III.21 The cathedral of St. Sophia in Ohrid in 1863.

influence on the Revival sacral architecture came indirectly, through the middle-Byzantine and late-Byzantine churches, some of which were also preserved in ruins (St. Achilles in Prespa; the Most Holy Mother of God in Vranishta; Crkvishte in Morodvis), some had preserved, partially or completely, their original form (St. Sophia in Ohrid; St. George in Staro Nagorichane; St. Nicholas in Manastir), while others were renovated and in active use during this period (the Holy Mother of God Chelnica in

Ohrid; Dormition of the Most Holy Mother of God in Velushina; the church in Drenovo). Therefore, the middle-Byzantine churches with a purely basilical typology, without transitional elements such as transepts, domes, etc., i.e. those that are considered to have been covered in the traditional way characteristic of a basilica - with a central nave clerestory (Achilles, Vranishta, Morodvis, Manastir), are those that the Revival masters, if they had the opportunity to study them at all, would only meet at the level of archeology (with the exception of the church in Manastir). Thus, they could copy the architectural solution of the plan, but not the elevation of the church. Those that had been better preserved are examples that have undergone later reconstructions and whose architecture is an expression of their complex history, as is the case with St. Sophia, the Holy Mother of God Chelnica in Ohrid and the church in Velushina, which arrived to the Revival period as pseudo-basilicas (fig. III.21).

\footnotetext{
259 Not to be overlooked is the fact that, in a wider region of Byzantine influence - in Armenia, in the early-Christian period just before the Arab conquests, three-nave vaulted basilicas covered with a gabled roof with a central nave clerestory were built (Кораћ и Шупут, 1998: 85-86).

260 Archaeological research of ancient and early-Christian sites throughout Macedonia will be done mostly during the next, XX century. The first significant discoveries were made at the very end of the XIX century, but still too late to directly affect the Revival sacral architecture.
} 
The church of St. Sophia in Ohrid got its present form after the great reconstruction of the naos in the XV-XVI century during its conversion into a mosque. On that occasion, or earlier, the upper parts of the cathedral were formed in their present appearance: three vaulted naves, the central one with a higher pointed vault and the lateral with lower barrel vaults, covered by one continuous gabled roof. The individual roofs above the narthex and exo-narthex were previously replaced by a single gabled roof. Furthermore, it must be taken into account that despite the opinion of some scholars (Коцо, 1949: 349353), the nave of St. Sophia was not even in its original appearance covered by a central nave clerestory, which was disabled due to the concept of the lateral chapels (see Chapter I.4.2). Thus, even during its construction in the XI century, St. Sophia was covered by a gabled roof, with a transept that manifested itself on the side façades with a triangular tympanum and a centrally placed dome upon a drum (see fig. 1.22). In the collective memory of this most important church on the territory of the Ohrid Archbishopric, its architecture bore the mark of a pseudo-basilica, further emphasized after the Ottoman reconstruction of the temple only two hundred years prior to the Revival (fig. III.21).

Of course, the influence of this church on the later architecture in the entire Ohrid diocese is indisputable and can be taken as a prototype of the basilica temples erected in the following centuries. In this context, it is interesting to mention that several Revival churches took over the element of transept in the form of a tympanum on the side facades. Such an example is the church St. Demetrius built in the village of Magarevo,

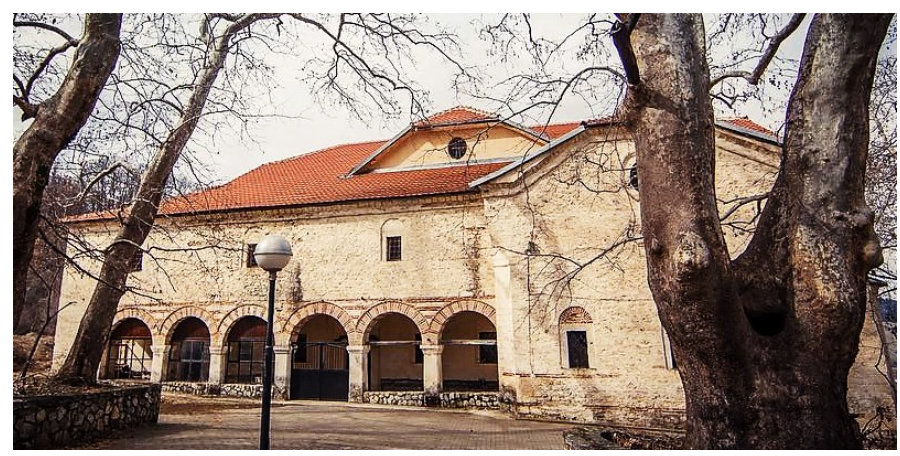

Figure III.22 St. Demetrius in Magarevo (Bitola). View from the south. near Bitola, in 1835 (fig. III.22). It has a transept that corresponds to the eastern half of the naos, illuminated on the lateral façades with the help of single windows - oculi. A transept indicated by a tympanum, in the center of which rises a dome supported on a tall drum characterizes the monastery of St. Sotir in Bukovo, also near Bitola (see fig. III.215). Similarly conceived, although with as many as nine domes ( 5 raised on a drum arranged in the shape of a Greek cross and 4 blind domes in the corners of the naos, in the layout of which we can recognize a hint to the nearby late-Byzantine church at Staro Nagorichane), is the roof of the Osogovo Monastery near Kriva Palanka (see fig. III.214), built by the protomaster Andreja Damjanov in 1847-1851.

In addition to the middle-Byzantine basilicas covered in a similar way, in the long centuries of the post-Byzantine period the small single-nave churches were regularly covered with a simple gabled roof. In fact, especially in the smaller buildings built during the Revival, above all the single-nave basilicas, the parallels with the postByzantine churches are the clearest.

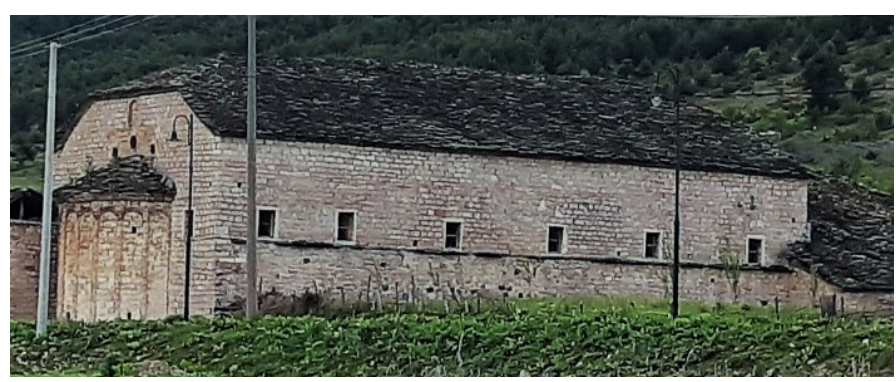

Figure III.23 The church of the Holy Archangels in Moskopole (Albania), XVIII century.

Undoubtedly, the monumental three-nave basilicas of the Moskopole circle built in the first half of the previous, XVIII century, covered without exception with a massive gabled roof without central nave clerestory (fig. III.23), which in some cases even extends continuously over the south porch, clearly also influenced the Revival gabled roof. The Moskopole roofs, as the churches themselves, were made entirely of stone (see Chapter II.2). 
In addition to fully gabled roofs (see fig. III.2), in most Revival churches the roof belongs, in essence, to the bonnet type. Namely, two very short triangular segments of the bonnet roof appear above the east and west façades; in consequence they do not end in a triangular tympanum, as would be the case of the roof was gabled, but rather in the shape of a trapezoid, which Kadijević defines as an "obtuse gable" (Кадијевић, 1997: 24), while Vasiliev names it a "saddle-shaped roof" (Василиев, 1965: 158). Older examples of trapezoidal shaping of the shorter façades date to the late post-Byzantine period, such as the

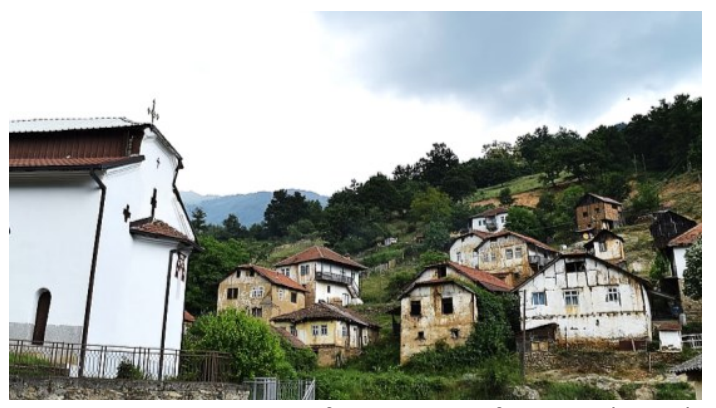

Figure III.24 Panorama of the village of Oreshe (Veles).

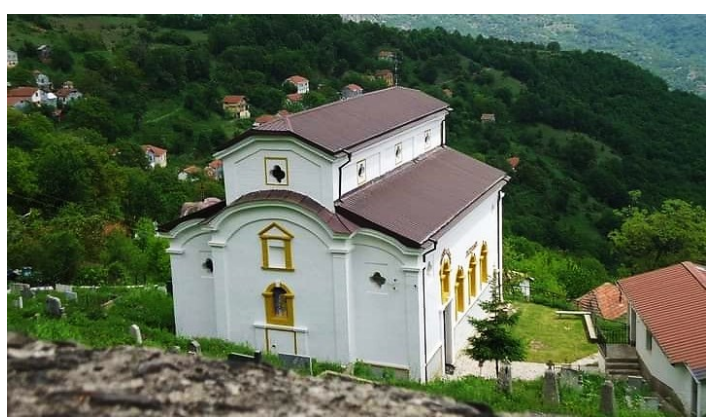

Figure III.25 St. Peter and Paul in Papradishte (Veles) XVIII century's churches of the Moskopole circle (fig. III.23). Also, it must be taken into account that an identical type of roof was fairly common in the rural residential architecture, especially in the villages of the central part of Macedonia, such as Papradishte, Nezhilovo and Oreshe near Veles (fig. III.24), some villages near Makedonski Brod, Demir Hisar, etc.

Finally, in addition to the dominance of the pseudo-basilica type of continuous gabled roof and the bonnet roofs described above, there are also several Revival churches where the basilical disposition from the inside of the temple is reflected on its fifth façade in the form of a central-nave clerestory. Such examples are the three-nave basilicas of St. Nicholas in Krushevo, St. Peter and Paul in Papradishte near Veles (fig. III.25), the later renovated church of Dormition of the Most Holy Mother of God in the neighboring village of Oreshe (fig. III.24), St. Savior in Drachevo (Skopje), the Nativity of the Most Holy Mother of God in Sogle (Veles), Dormition of the Most Holy Mother of God in Delchevo; as well as some of the five-nave basilicas: St. Panteleimon in Veles, Most Holy Mother of God in Novo Selo (Shtip), St. Nicholas in Kumanovo, St. Nicholas in Shtip. Although few in number, several churches can be distinguished as a separate category, which have a transept with a blind dome (see Chapter III.5.E).

As a rare exception, classical bonnet roofs also appear, such as at the church of St. Cosmas and Damian in Peshtani (Ohrid); Nativity of the Most Holy Mother of God in Sogle (Veles); the church in the village of Mrenoga, near Demir Hisar; the medieval church of St. Nicholas in the village of Chelopek near Tetovo, renovated during the Revival; as well as the Most Holy Mother of God in Sretkovo and St. Nicholas in the neighboring village of Cerovo, both in the region of Gostivar, as a local characteristic feature.

\section{Altar apse}

Characteristic for the Revival sacral architecture is that the façade surfaces are rather simple, except for the eastern one which usually received additional detail, especially as far as the altar apses are concerned. While the dominant part of the Revival churches have one altar apse, all of the five-nave basilicas as well as some of the larger (and more significant) three-nave basilicas have three apses: a central altar apse and two smaller lateral apses that house the prothesis and diaconicon. Such is the case of the basilicas in the villages Capari and Magarevo near Bitola (fig. III.26), the church of St. Athanasius in Przhdevo (Demir Kapija), Nativity of the Most Holy Mother of God in Sogle (Veles) (see fig. III.204), the monastery of the Immaculate Mother of God near Kichevo, St. Panteleimon in Pantelej (Kochani), St. Elijah in Star Dojran, etc. 
The altar apse is always semicircular on the inside, while on the outside it can be solved in several ways: semicircular, ${ }^{261}$ rectangle, ${ }^{262}$ three-sided, ${ }^{263}$ up to a polygonal apse - with five, ${ }^{264}$ seven, ${ }^{265}$ nine ${ }^{266}$ or even more sides ${ }^{267}$ while, although less common, there are churches whose apses have an even number of sides. ${ }^{268}$ From the outside, the altar apse is often dissected with the help of shallow blind arched niches, ${ }^{269}$ a frieze of blind cantilevered arcades and shallow pilasters, while the altar is illuminated through a centrally placed single or double window. Depending on the size, the apse sometimes has more symmetrically arranged windows. ${ }^{270}$
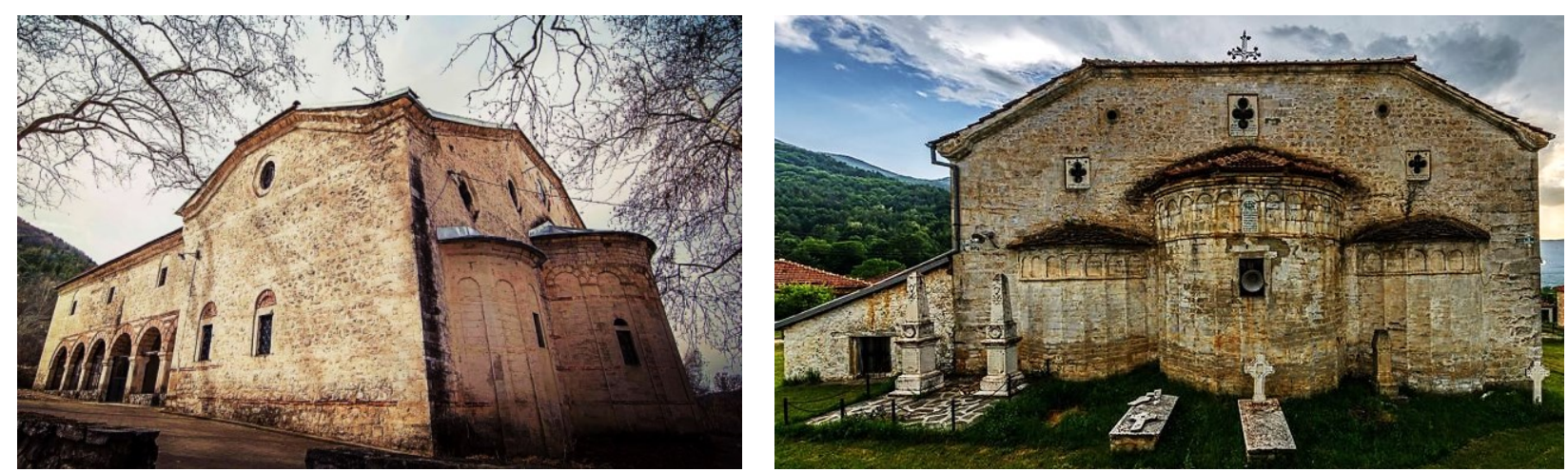

Figure III.26 A. St. Demetrius in Magarevo (Bitola); B. St. George in Capari (Bitola).

${ }^{261}$ At the churches St. Athanasius in Gostirazhni (Prilep); the Immaculate Mother of God in Ljubojno (Prespa); St. Athanasius and St. Archangel Michael in Dolno Dupeni (Prespa); St. Demetrius in Dobroveni (Bitola); St. Petka in Dolno Egri (Bitola); St. George in Poeshevo (Bitola); St. Demetrius in Gorno Divjaci (Krushevo); Dormition of the Most Holy Mother of God in Dragozhani (Bitola); Resurrection of Christ in Dragarino (Bitola); St. Athanasius in Novaci (Bitola); Nativity of the Most Holy Mother of God in Crnichani (Bitola), Dormition of the Most Holy Mother of God in Selce (Prilep); St. Cosma and Damian in Pletvar (Prilep); St. Athanasius in Sekirci (Prilep); St. Nicholas in Vardino (Demir Hisar); Dormition of the Most Holy Mother of God in Rastojca (Demir Hisar); St. Elijah in Bunish (Probistip); St. Nicholas in Kichinica (Mavrovo); St. Athanasius in Teovo (Veles); St. Nicholas in Mokreni (Veles); Dormition of the Most Holy Mother of God in Bistrica (Veles); Dormition of the Most Holy Mother of God in Marena (Kavadarci); St. Savior in Chemersko (Kavadarci); St. Stephen in Konopishte; St. Demetrius in Kovanec (Gevgelija); Holy Mother of God in Duf (Gostivar) and others.

${ }^{262}$ At the church of St. Nicholas in Slivica (Bitola), St. Athanasius in Gradec (Valandovo) and St. Nicholas in Dren'k (Kumanovo), which was influenced by several post-Byzantine churches from the north-eastern region which have similarly conceived rectangular apses, while for the Revival temples they are extremely rare and atypical.

${ }^{263}$ At St. Nicholas in Pavleshenci (Sveti Nikole); St. Trinity in Podles (Veles); St. Petka in Dolno Egri (Bitola), etc.

${ }^{264}$ At St. Nicholas in Nakolec (Prespa); St. Athanasius in Dolno Chichevo (Veles); St. Nicholas in Leskoec (Prespa); St. Nicholas in Arilevo (Krushevo); Resurrection of Christ in Dedebalci (Bitola); St. Peter and Paul in Radobor (Bitola); St. Petka in Radibush (Kriva Palanka); St. Demetrius in Bogdevo (Gostivar); St. Nicholas in Bashino Selo (Veles), St. Nicholas in Sopotnica (Demir Hisar), etc.

265 At St. George in Podmochani (Prespa); St. George in Resen; Dormition of the Most Holy Mother of God in Evla (Prespa); St. Theodore in Gorno Dupeni (Prespa); St. Demetrius in Zlatari (Prespa); St. Elijah in Ezerani (Prespa); St. Athanasius in Beranci (Bitola); St. Petka in Gorno Orehovo (Bitola); St. Sotir - Transfiguration of Christ in Bukovo (Bitola); St. George in Vasharejca (Bitola); St. Nicholas in Karamani (Bitola); St. Demetrius in Dolna Charlija (Bitola); Nativity of the Most Holy Mother of God in Begnishte (Kavadarci), St. Nicholas Gerakomija in Ohrid, etc.

${ }^{266}$ At St. John in Ljubojno (Prespa); St. George in Drmeni (Prespa); St. Nicholas in Carev Dvor (Prespa); St. Nicholas in Dragosh (Bitola); St. George in Belica (Kichevo).

267 For example, at the church of St. George in the village of Capari, near Bitola (fig. III.26B), the altar apse has 13 sides, and the lateral, smaller apses have 7 sides (Николовски, 1993: 172).

268 The churches St. Elijah in Aldanci (Krushevo) and St. Theodore in Svetododori (Bitola) have six-sided apses (Nikolovski, 1990: 133); St. Nicholas in Trn (Bitola) has an eight-sided apse. At the church of St. Athanasius in Mojno, near Bitola, the apse is divided into 4 shallow, arched niches, without decorative processing; at the church of St. Theodore Tyron in Drenovci (Prilep), there are 8 shallow niches. In the apse of the church of St. Nicholas in the village of Popoec near Kichevo, a small tall window literally interrupts the central column.

${ }^{269}$ At St. Nicholas in Brajchino (Prespa); St. Athanasius in Dolno Perovo (Prespa); St. Elijah in Dolno Vranovci (Veles); St. Athanasius in Negorci (Gevgelija), where the large semicircular apse is dissected with as many as 12 shallow blind semicircularly arched niches etc. As a specific example, the church of St. Demetrius in Dihovo, near Bitola, built in 1830, has a semicircular apse on the outside, with a centrally placed window that is flanked by 6 niches on each side, marked by grooves. An independently conceived frieze of 5 blind cantilevered arches appears in the upper zone of the apse (Николовски, 1993: 160).

270 For example, at St. Peter and Paul in Ratevo, the large semicircular altar apse is divided into seven shallow blind niches with slender columns and illuminated through three extremely narrow slot-like windows placed in a symmetrical composition. 
Often, the shape and form of the apse are the result of local building traditions - a local "school", so that in a certain region one solution is prevalent. ${ }^{271}$ Furthermore, in certain regions a representative Revival basilica assumed the role of a prototype by which other churches were later formed. Such is the case of the villages on the slopes of the mountain Pelister near Bitola, where the prototype are the churches St. Petka in Malovishte and Transfiguration of Christ in Gopesh, as exceptionally monumental five-nave basilicas. Under their influence, the church of St. George in Smilevo ${ }^{272}$ was built in 1911, where the double shallow arched niches on the apse are almost an identical copy of the decorative processing of the eastern façade of the two older Revival churches, especially the one in Malovishte (fig. III.27).
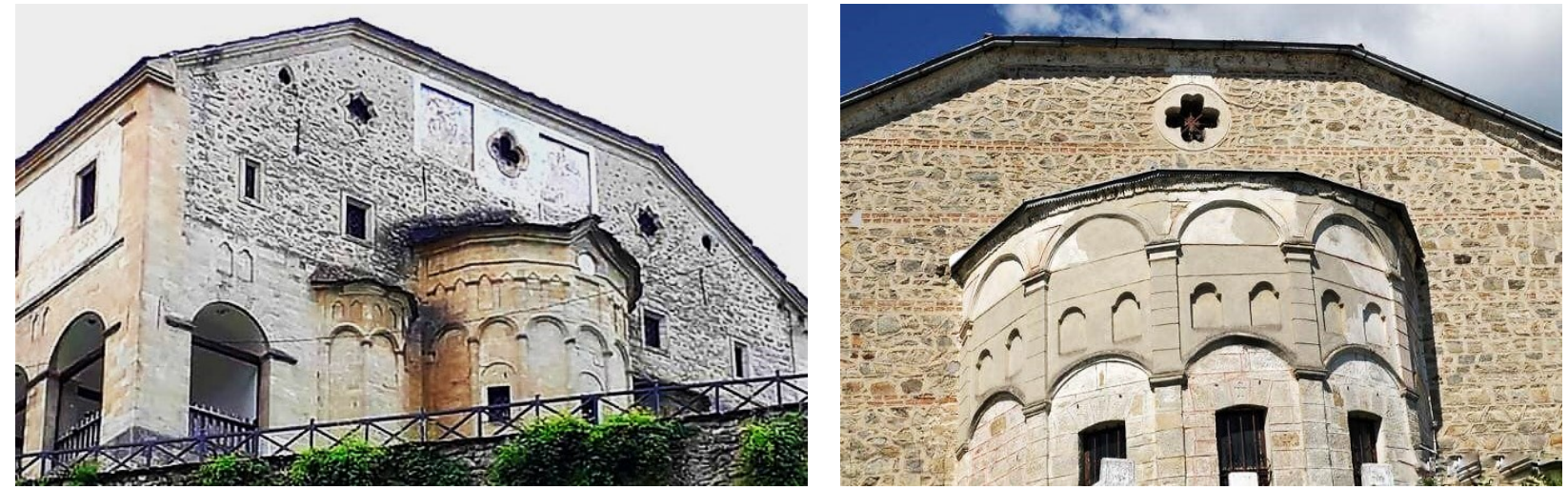

Figure III.27 A. St. Petka in Malovishte, Bitola (1856); B. St. George in Smilevo, Demir Hisar (1911). Detail of the altar apse.

In some churches, at the top of the otherwise polygonal altar apses, under the crown cornice, appears a frieze of cantilevered semicircular blind arcades. Such is the case of St. George in Resen, the churches of the same name in the nearby villages of Podmochani and Drmeni and St. Nicholas in Carev Dvor, all in the region of Prespa (fig.III.28); St. Nicholas in Karamani, St. Nicholas in Trn (see fig. III.72B), St. Athanasius in Beranci (see fig. III.92A), St. Theodore in Krklino (see fig. III.31B) and St. Demetrius in Dihovo, all in the region of Bitola; St. Nicholas Gerakomija in Ohrid (see fig. III.8B); St. Savior in Kozhle, near Skopje etc. The appearance of rows of blind arcades in the upper zone of the façades of the Revival churches, especially on the eastern façade or the apse, can be associated with certain Western European influences, primarily from the Romanesque. However, the source can also be sought in the local Byzantine heritage, especially in the churches from the late-Byzantine period. Namely, similarly conceived arcades in the upper zone of the eastern façade can be found at the southern church of the monastery complex Constantine Lips in Constantinople, as well as at St. John Aliturgitos in Mesemvria (present-day Nessebr, Bulgaria), both representative buildings from the reign of the Palaeologan dynasty (Кораћ и Шупут, 1998: 305). On Macedonia's teritory, older buildings where the concept of arcade rows on the facades is clearly legible - formed by blind arched niches instead of console arcades, which undoubtedly influenced the appearance of this architectural element in the churches of the Revival are: the Most Holy Mother of God in Drenovo, St. George in Poloshko, St. Nicholas in Manastir (see fig. I.38B), the eastern façade and the exo-narthex of St. Sophia in Ohrid (see fig. I.23B, I.24), the lateral facades of the Dormition of the Most

\footnotetext{
${ }^{271}$ For example, in the region of Malesija and Drimkol near Struga, single-nave churches prevail with a semicircular, relatively tall apse, built of crushed stone, without decorative composition of blind niches. Such is the case of the churches Dormition of the Most Holy Mother of God in Modrich (1894); St. Nicholas in Prisovjani (1852); Ascension of Christ in Lokov (renovated in 1930); the Most Holy Mother of God in Borovec, etc.

272 The church of St. George in Smilevo (Demir Hisar) is a three-nave basilica with monumental dimensions, a vaulted central nave with a false wooden vault, lateral naves bridged with a flat wooden ceiling, a gallery in the western part of the naos and a fivesided altar apse. It is built of crushed stone with façade painting, while the windows, the three entrance portals and the apse are more decoratively elaborated in carved stone (Дапчев, 1996: 235). It was not fresco-painted, and the authors of the iconostasis and the bishop's throne are wood-carvers from the same village (Василиев, 1965: 298).
} 
Holy Mother of God in Leshok, etc. In this context, of exceptional importance are those Revival churches whose altar apses have rows of small blind arched niches, most often in the upper zone - in Malovishte, Smilevo, Logovardi (fig. III.29A), or even at the bottom of the apse, such as at St. Nicholas in Dragosh, all near Bitola (fig. III.29B).
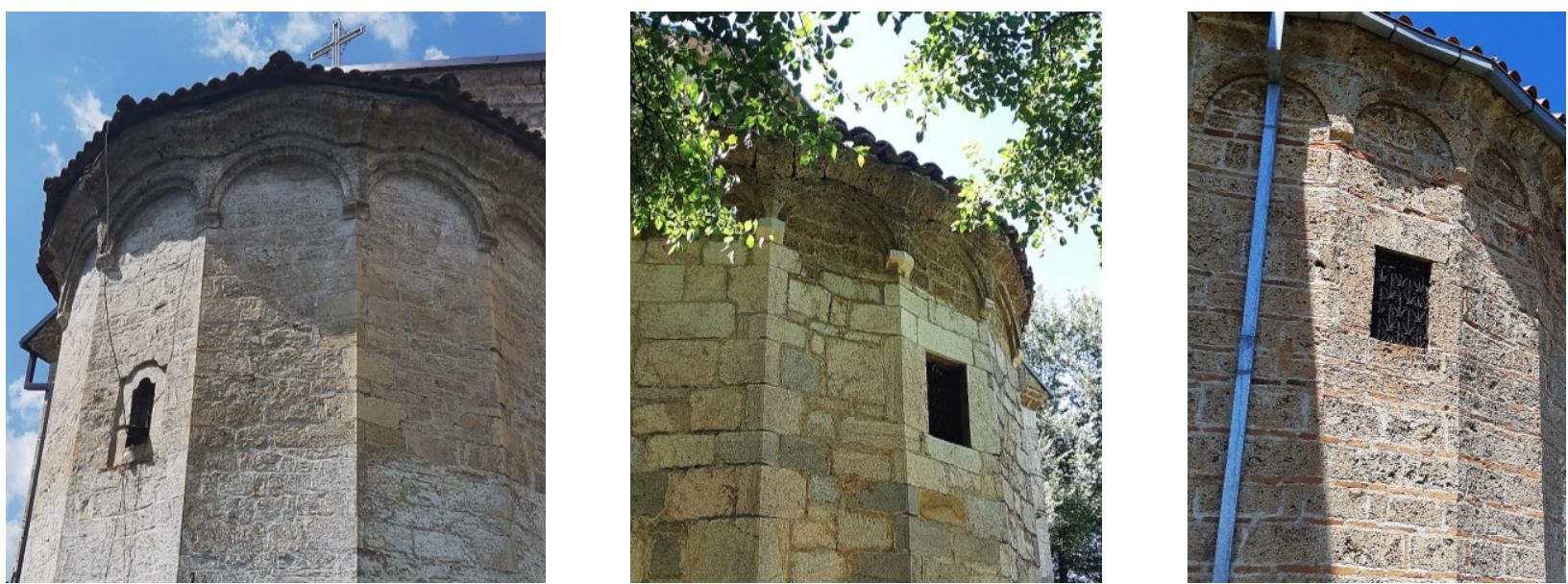

Figure III.28 Examples of altar apses with a frieze of cantilevered arcades: A. St. George in Resen; B. St. Nicholas in Carev Dvor and C. St. George in Drmeni, all in the region of Prespa.
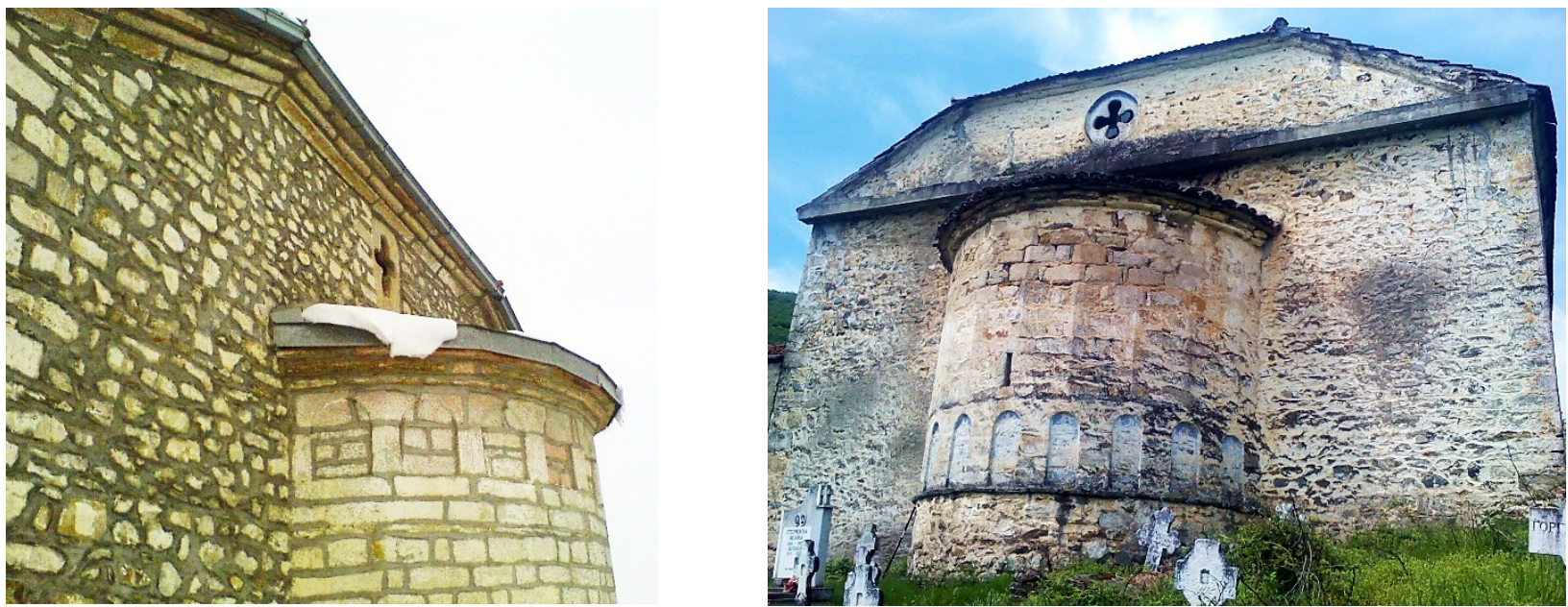

Figure III.29 Examples of altar apses with a frieze of blind arched niches. A. St. George in Logovardi; B. St. Nicholas in Dragosh, both in the region of Bitola.

Ultimately, in some churches, on the other hand, the polygonal apse was divided with tall pilasters connected by arches. They are diverse both in depth, ranging from quite shallow to protruding pilasters; as well as in cross-section: rectangular (see fig. III.112A), ${ }^{273} \operatorname{triangular}^{274}$ or semi-circular $^{275}$ (fig. III.30). The pilasters were made of stone or a combination of stone and brick (for example, at the church of St. Savior in Dolneni (see fig. III.8A); St. Demetrius in Bukovo; St. Archangel Michael in Sredno Egri), and often the decorative effect of this type of façade composition was complemented by simple capitals, a pedestal -

${ }^{273}$ At St. George in Struga; St. Archangel Michael in Tashmarunishta and Dormition of the Most Holy Mother of God in Dolna Belica, all in the region of Struga; St. Panteleimon in Nikiforovo, Mavrovo (see fig. III.97A); St. Archangel Michael in Sredno Egri, Bitola; St. Savior in Malo Ruvci, Prilep, etc.

274 At St. Savior in Krushevo; the Most Holy Mother of God in Zheleznec, Demir Hisar (see fig. III.1); St. Savior in Dolneni, Prilep (see fig. III.8A); St. George in Gorna Vlashka Maala - Ohrid, etc.

275 In some of the works of Andreja Damjanov: St. Panteleimon in Veles, the Osogovski monastery near Kriva Palanka, the Most Holy Mother of God in Novo Selo (Shtip), as well as many more churches, such as the Transfiguration of Christ in Gopesh (fig. III.30B) and St. Petka in Malovishte (fig. III.27A), both in the region of Bitola; St. Constantine and Helena in Tomino Selo, Makedonski Brod; St. Nicholas in Popoec, Kichevo; St. Athanasius in Senokos, Prilep; St. Nicholas in Vevchani, Struga; Resurrection of Christ in Dedebalci, Bitola; Melnichki monastery (see fig. III.244C); Kalen (Mariovo); Topolnica (Makedonski Brod), etc. 
plinth, doubling of the niches in the upper zone etc. Also, in addition to the simplest solution of blind semicircular arch, there appear pointed and segmented arches, as well as examples of more complex profiling, i.e. a combination of concave and convex segments: at the church of the Most Holy Mother of God in Sence, Mavrovo (fig. III.30C); St. Savior in Rashtak, Skopje (see fig. III.119A), etc.
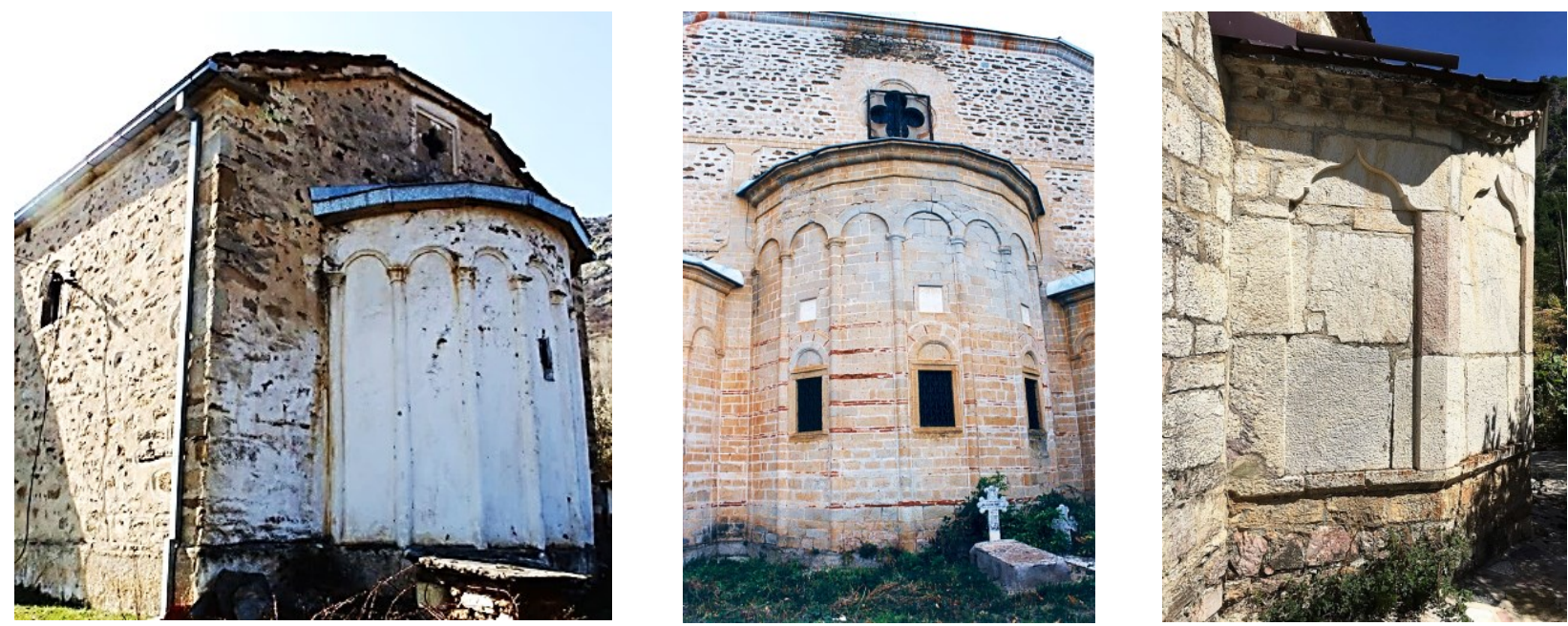

Figure III.30 A. St. Archangel Michael in Kokre (Mariovo); B. St. Transfiguration in Gopesh (Bitola); C. Holy Mother of God in Sence (Mavrovo). Detail of the altar apse.

In some Revival churches, although very rarely, the altar apses are wavy and the number of waves depends on the size of the apse itself. Such examples are the churches St. Nicholas in Podgorci, Struga; St. Savior in Drachevo, Skopje (see Chapter III.5.B.4), etc.

\section{Façades}

The façades of the Revival basilicas are simply conceptualized, subordinated to the interior decoration of the temples, which "traditionally from the early-Byzantine times (...) was the most important part of both the program and the construction work" (Кораћ и Шупут, 1998: 143). Of course, in addition to ideological reasons, the limited means and available building materials also contributed to the simple design of the façades. However, even in the most representative buildings, where obviously enough finances as well as gifted master-builders and premium building materials were available, the façades were simplified, and emphasis was placed on certain details such as the entrance portals, windows, porches and the altar apse. In addition to the apse, as the main accent of the outer shell of the Revival temple, the remaining part of the eastern façade also received appropriate decorative treatment, with profiled stone crowns, ocular openings, stone-carved window transennas, as well as relief decoration.

The façades were less commonly additionally sectioned into horizontal belts: the first zone is usually a plinth, the second zone is the wall canvas itself, and the last one is composed of the finishing cornice. ${ }^{276}$ Sometimes, in addition to distinctive horizontal bands, there is also a division of the façades into fields (bays) with the help of shallow pilasters. Examples of this method are the churches of the Transfiguration of Christ in Gopesh (Bitola); St. Nicholas in Vevchani (Struga); Nativity of the Most Holy Mother of God in Kadino Selo (Prilep); St. Elijah in Veselchani (Prilep); St. Demetrius in Dunje (Mariovo); Dormition of the Most Holy Mother of God in Selce (Prilep); ${ }^{277}$ St. Nicholas in Vranche (Prilep); Dormition of the Most Holy Mother of God in Dolna Belica (Struga); ${ }^{278}$ St. Petka in Gorna Belica (Struga); St. Trinity in Dabile

\footnotetext{
276 Such examples are the churches in the villages of Carev Dvor and Drmeni in Prespa.

277 In this church the pilasters are additionally highlighted with yellow paint against the whitewashed walls.

278 It is interesting that in this church the pilasters are densely distributed: on the side façades there are ten pilasters with capitals, connected to each other with semicircular arches, so that nine tall shallow arched niches are formed.
} 
(Strumica), ${ }^{279}$ etc. Even when this sectioning of the façades is completely absent, it appears almost without exception on the eastern façade, that is, at least on the altar apse, which was regularly enriched with either shallow niches, columns or rows of blind cantilevered arcades. In some churches, although rather rarely, these rows also appear on the other façades - for example at the church of the Nativity of the Most Holy Mother of God in Malo Konjari, Prilep, where rows of cantilevered semicircular arches flow in the upper zone on all four façades and pilasters appear at the corners of the building. Similarly solved cantilevered arcades on all four façades can be found at the church of St. Theodore in the village of Krklino, near Bitola, work of the master-builder Kosta from Cer (fig. III.31B). On the longer façades of the church St. Peter and Paul in Ratevo (Berovo), a series of six semicircular arches is formed in the upper zone, while two such semicircular arches are formed on the east façade, which frame the large semicircular altar apse, and unlike the longer façades, here they are accentuated with simple, shallow corner pilasters (fig. III.31A). In the lower zone, the apse and the façades have a plinth that flows around the building, and at the top there is a continuous cornice, with a cross-section of simple rectangular segments.
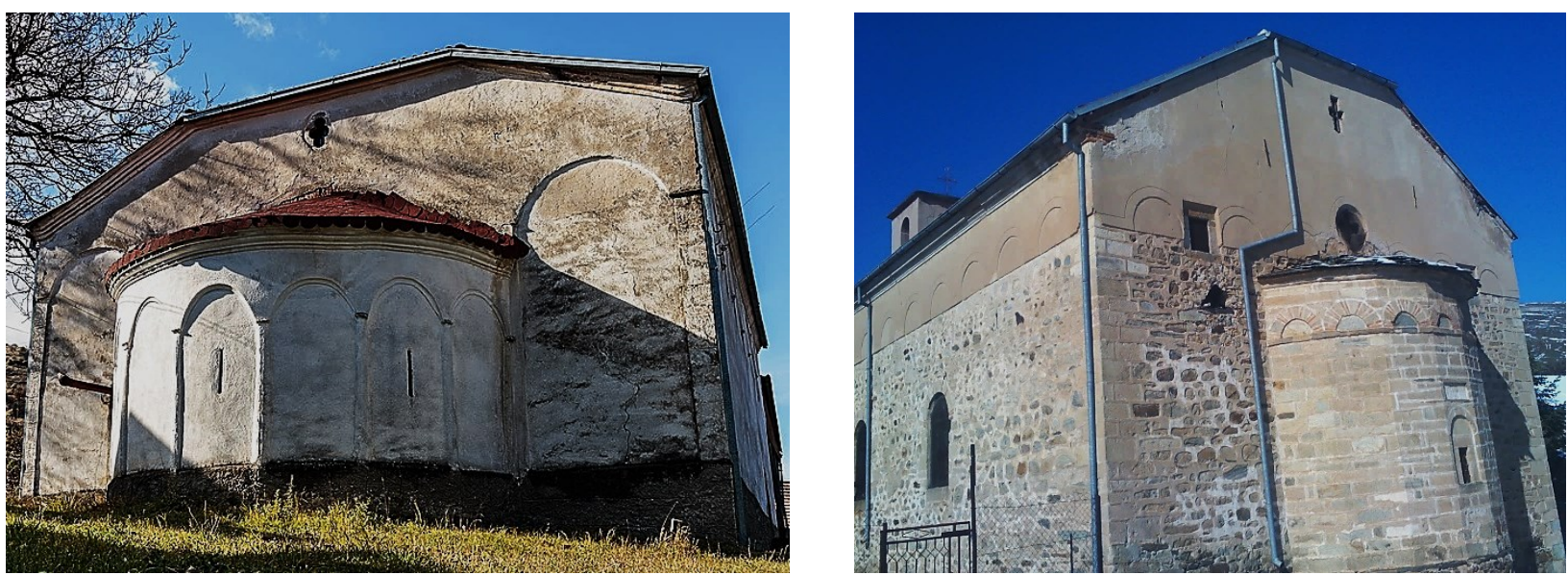

Figure III.31 A. St. Peter and Paul in Ratevo (Berovo); B. St. Theodore in Krklino (Bitola). View from the east.

In some cases the façades were additionally processed in a decorative way, so that the irregular blocks of crushed stone were covered on all sides with protruding mortar joints, which gives the wall canvas a decorative relief effect. ${ }^{280}$ There are also examples where the joints were elaborated in this fashion only fragmentarily: for example, at the church Ascension of Christ in the village of Injevo near Radovish, only the arches of the window openings are processed in this way, emphasizing them against the otherwise imprecise masonry of crushed stone. In others, such as the churches in the villages Svinishte and Popoec in the region of Kichevo, the protruding joints are executed with such precision, with almost ideally straight, horizontal joints, which creates a very effective decorative appearance of the façade, with an almost textile-like texture, visible despite the additional whitewashing of the façades (fig. III.32). This façade technique is a local feature, because it is predominantly found in the western part of Macedonia: in the regions around Makedonski Brod, Demir Hisar, Kichevo and Prilep, as a result of a local building

\footnotetext{
279 In this church, the shallow pilasters end in capitals, and are connected to each other by arches of unequal size. Namely, on the west and east façades there are four pilasters connected by three arches, of which the middle one is significantly larger than the lateral ones, so that the effect of a "triumphal arch" is achieved, a solution typical for the late-Byzantine churches of the inscribed cross type. Today, unfortunately, this effect is disturbed by the addition of a bell tower adjacent to the façade. The end pilasters are not placed in the corners of the building, but are pulled towards the middle, and are connected to the corner by a high semiarch. The same concept is applied on the lateral façades, resulting in an arcade that encircles the entire building.

280 Such examples are the churches St. Constantine and Helena in Tomino Selo (Makedonski Brod); St. Panteleimon in Belica (Makedonski Brod); St. Theodore Tyron in Drenovci (Prilep); the church of the same name in Konopnica (Kriva Palanka); St. Nicholas in Belovodica (Prilep); St. Elijah in Chelopeci (Kichevo); St. Nicholas in Popoec (Kicevo); St. Cosma and Damian in Svetorache (Kichevo); St. George in Zashle (Demir Hisar); St. Nicholas in Svinishte (Kichevo); St. Nicholas in Slansko (Makedonski Brod); St. Panteleimon in Sveta (Demir Hisar); St. Peter and Paul in Lupshte (Makedonski Brod) etc.
} 
school and tradition. However, this decorative technique is much more common in residential buildings from the Revival period, both in rural and urban areas. The most famous example is the residence of the Robev family (today Museum of the town of Ohrid) in Ohrid, whose ground floor façade was treated with this technique, while the upper floors, made of light wooden frame construction, were mortar-coated.
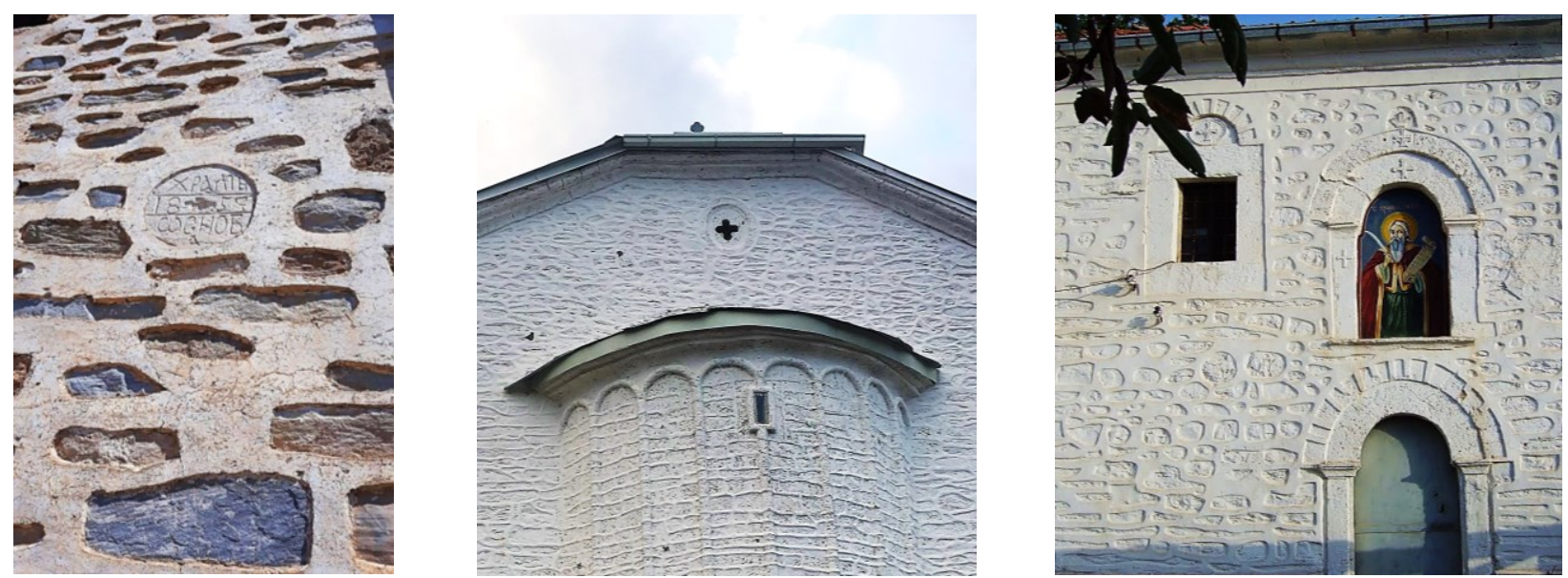

Figure III.32 Examples of façades with protruding mortar joints. A. St. Constantine and Helena in Raklish (Radovish); B. St. Nicholas in Popoec (Kichevo); C. St. Elijah in Chelopeci (Kichevo).

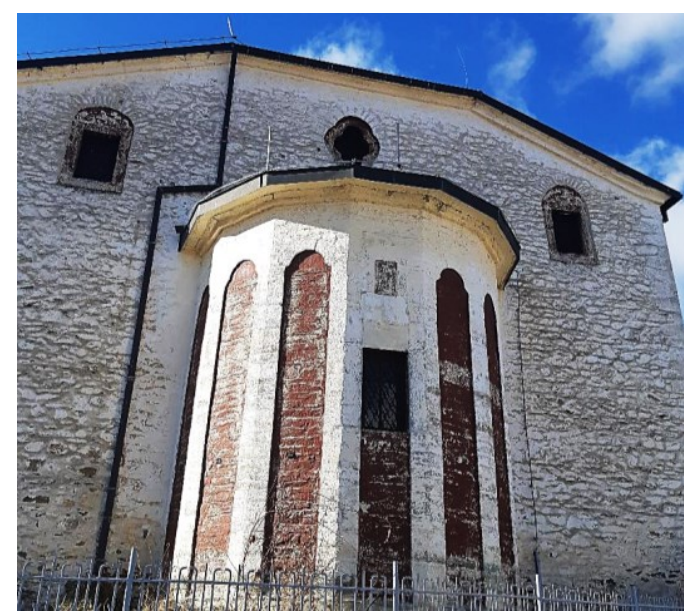

Figure III.33 Dormition of the Most Holy Mother of God in Krushevo. Detail of the altar apse.

Sometimes, the façades of the churches were whitewashed later, after their construction. ${ }^{281}$ Often, all façades were plastered, with the exception of the altar apse, whose decorative stonework was left visible. To the contrary, there are churches where only the altar apse is whitewashed, while the remaining façades are left with visible masonry: for example, at St. Archangel Michael in Kokre, Mariovo (see fig. III.30A); St. Nicholas in Nebregovo (Prilep), etc. Furthermore, in several examples only the shallow blind niches of the apses were painted, while the remaining masonry was left visible. Such is the case of the churches of St. Nicholas in the village of Krstec (Prilep); St. Nicholas in Golemo Radobil (Prilep); St. Nicholas in Dragosh (Bitola); Dormition of the Most Holy Mother of God in Krushevo (fig. III.33), etc. The fragmentarily preserved paint in a bluish tonality at the church in Dragosh, as well the burgundy tone used at the church in Krushevo imply that the Revival churches' facades sometimes received pigmented mortars in addition to the prevalent white-wash.

Also, in those churches that have domes supported on drums, even when the façades were left with authentic, visible stone masonry, the drum was almost regularly whitewashed: for example, at the Zabel Monastery, where the only exception are the brick arched windows (see fig. III.5A); at St. George in Rajchica (see fig. III.15A); St. Archangel Michael in Lisolaj (see fig.III.244A); St. Sunday in Bitola, etc.

\footnotetext{
281 Such is the case of the churches of St. Savior in Rashtak (Skopje); St. Elijah in Velmevci (Demir Hisar); St. Petka in Zhvan (Demir Hisar); St. Theodore Stratilat in Dolno Orehovo (Bitola); St. Athanasius in Krusheani (Prilep); St. Athanasius in Godivje (Prilep); St. Athanasius in Sekirci (Prilep); St. Elijah in Veselchani (Prilep); St. Elijah in Chelopeci (Kichevo); Ascension of Christ in Grumazi (Mariovo); St. Athanasius in Rakle (Prilep); Nativity of the Most Holy Mother of God in Malo Konjari (Prilep); St. Nicholas in Belo Pole (Prilep); St. Peter and Paul in Radobor (Bitola); Resurrection of Christ in Dedebalci (Bitola); St. Demetrius in Puturus (Bitola); St. Demetrius in Polchishte (Mariovo); St. George in Ribarci, Mariovo (renovated in 1971); St. Nicholas in Vranche (Prilep); St. Elijah in Aldanci (Krushevo); St. Elijah in Zashle (Demir Hisar); St. Nicholas in Zagoriche and the church of the same name in Sopotnica, Demir Hisar; Dormition of the Most Holy Mother of God in Rastojca, Demir Hisar; St. Nicholas in Svinjishte, Kichevo; St. Nicholas in Sopot (Sveti Nikole); St. John the Baptist in Dreveno (Probistip), etc.
} 
In addition to whitewashing, some Revival churches also have decorative painting on the façades. For example, at the church of St. Nicholas in the village of Sekirani near Bitola (fig. III.34) only the crown cornices were painted, on all façades, with baroque curved floral motifs and zig-zag lines in a blue tonality, in addition to a painted imitation of a serrated brick cornice, which was a typical feature of the Byzantine churches. Remains of a similar floral ornamental painting have been fragmentarily preserved high on the apse of St. Nicholas in Cer near Demir Hisar (see Chapter III.5.A.3).

Sometimes, in addition to the interior of the

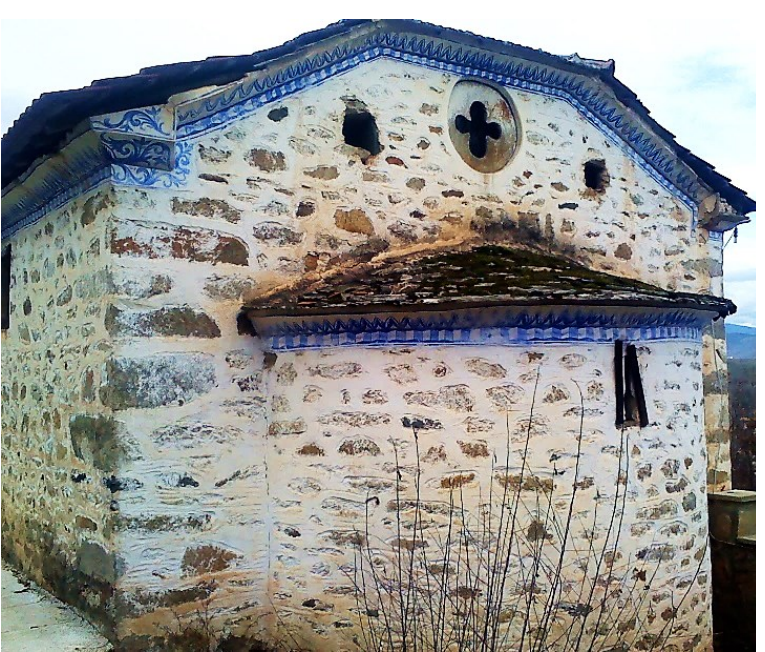

Figure III.34 St. Nicholas in Sekirani (Bitola). Eastern façade. arched niches above the entrance portals, in which frescoes of the patron saint of the temple were regularly painted, the arch of the blind niche was also painted, as well as the entrance portals themselves, usually in contrasting colors: for example at the church of St. Demetrius in Konsko (Gevgelija), where the portal painted in yellow-gold hue stands out against the whitewashed uniform background of the façade canvas. As for the patron saint niches, they usually contain a calligraphic painted inscription of the year of construction or consecration of the temple.
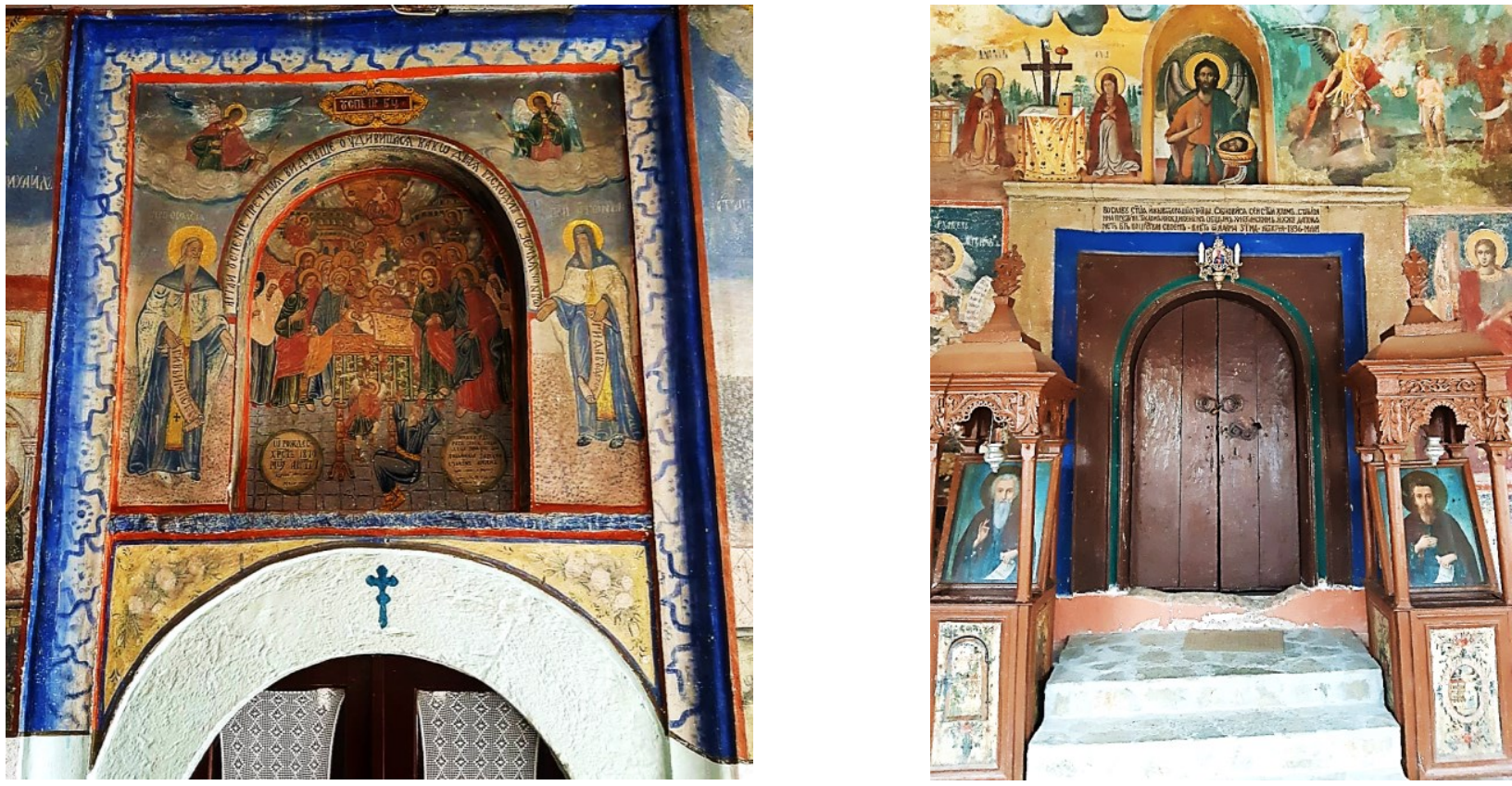

Figure III.35 Examples of fresco-painted western façades / entrance portals: A. Dormition of the Most Holy Mother of God in Krushevo; B. St. John in Kratovo.

Although rather rarely, in some cases fresco-painting appears on the façades of the Revival churches, which is yet another nod to the older Byzantine ecclesiastical architectural tradition. ${ }^{282}$ This applies especially to the western façade, which could be painted in its entirety, with division into several zones - such as at the Osogovo Monastery, where besides the façade the blind domes over the porch were also completely fresco-painted; the church Dormition of the Most Holy Mother of God in Pantelej, Kochani; St. George in Rajchica, Debar; St. John in Kratovo (fig. III.35B), etc.; or only partially, with several

282 Remains of fresco-painting on the exterior of the church have been preserved at the Byzantine churches of St. George in Kurbinovo, St. Nicholas in Manastir, the Most Holy Mother of God Eleusa in Veljusa, etc. 
compositions that frame the entrance portal - for example, at the church of St. Nicholas in Slepche; the Holy Trinity in Smolari; Dormition of the Most Holy Mother of God in Krushevo (fig. III.35A); St. Sunday in Bitola, etc. Frescoes on the east façade are significantly less common, usually placed in the upper zone above the apse. Such an example is the church of St. Petka in Malovishte (Bitola), where the large centrally placed window shaped as a phytomorphic cross made of stone is flanked by two fresco compositions painted in large square fields (see fig. III.27A).
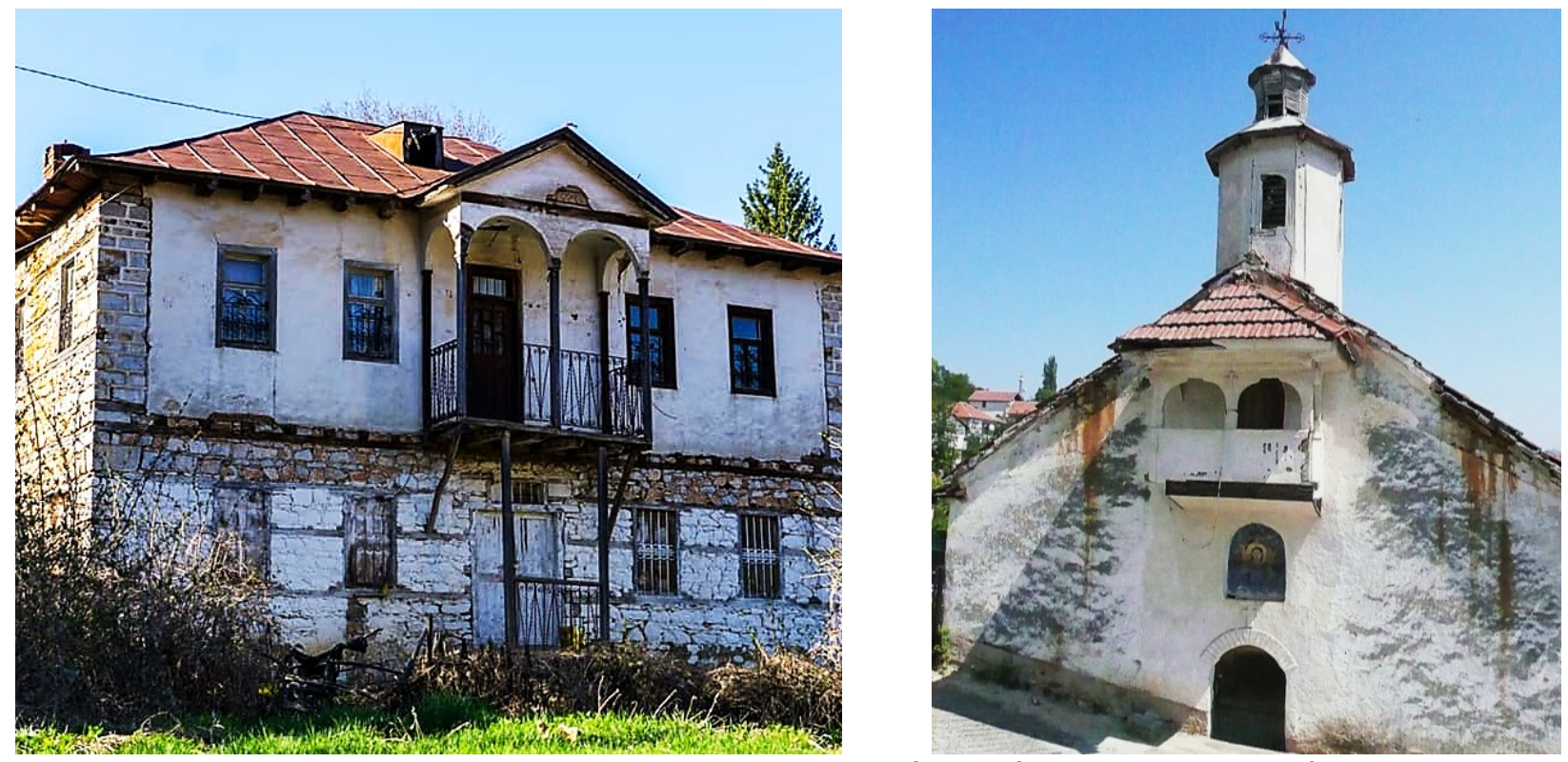

Figure III.36 Comparison between Revival wooden balconies: A. Main façade of a house in the village of Prostranje, near Kichevo; B. Western façade of the church of St. Savior in Rogachevo (Tetovo).

As a very specific and quite rare element, some Revival churches have a balcony on the west façade, placed high above the west portal and the patron saint niche. Such an element can be found in the church of St. Savior in the village of Rogachevo near Tetovo (fig. III.36B), where above the solid parapet on the frontal side the balcony is divided into two segments bridged with profiled arches, while laterally there is one arch, all supported on wooden pillars. The balcony placed high on the west façade of the church of the Dormition of the Most Holy Mother of God in Novo Selo near Shtip is similarly conceived. The overall appearance of this type of balconies, the wooden cantilevered structure on which they are supported, their shape and profile are a product of direct influence by the balconies of the profane Revival architecture, both in urban as well as in rural residences (fig. III.36A).

\section{Gallery}

Unlike the post-Byzantine churches, which develop exclusively on the ground floor, the Revival basilicas with few exceptions have an upper floor in the western zone of the naos, usually supported on an independent wooden sub-structure, with access from the inside of the temple, and sometimes directly from the outside, using the topography of the terrain ${ }^{283}$ or a staircase made specifically for that purpose. ${ }^{284}$ The gallery served as a "women's church", as a dedicated space for women during liturgy. In this sense, the segregation of women in a specifically dedicated space is a hallmark of centuries of Islamic rule and its inevitable influences on the Christian population as well. However, it should not be forgotten that even in the early-Christian basilicas certain parts of the naos received a specific purpose related to the gender of the believers who dwelled there, as well as their status in relation to the religious hierarchy

${ }^{283}$ At St. Nicholas in Tresonche; the Most Holy Mother of God in Duf; St. Petka in Galichnik, St. Elijah in Selce, etc.

${ }^{284}$ At St. John in Kratovo; St. Peter and Paul in Tresonche (Debar); the Holy Healers in Ohrid and others. 
in the community. Furthermore, opinions have been expressed in science regarding the appearance of upper-floor galleries in Byzantine churches, as a rule in those of the highest rank built in the ruling courts and archbishopric seats (see fig. I.23A). One theory is that local government officials followed the example of the capital Constantinople where galleries were created in the service of the ceremonial appearance of the emperor and his family as part of the liturgical rite. However, a different theory according to which the galleries were intended for women in general, especially in the town cathedrals that were open to all citizens, has not been excluded either (Кораћ и Шупут, 1998: 377).

The Revival basilicas adopted their model, adapting it to a specific function arising from the current social conditions. Sometimes, in the most representative temples, such as the large town cathedral basilicas as well as some rural churches whose height and spatial structure allowed it, two superimposed galleries appear, one of which acts as a "women's church" while the other houses the choir during the solemn holiday liturgies. Such examples are St. Panteleimon in Veles (fig. III.37) and St. Nicholas in Kumanovo by Andreja Damjanov; as well as the churches of St. Savior in Kozhle (Skopje), the Holy Healers (St. Cosmas and Damian) in Ohrid, etc.

The gallery was shaped depending on the space of the church itself. In smaller buildings it is usually separated from the naos by a flat full parapet partition, ${ }^{285}$ often complemented by a centrally placed balcony which can be rectangular (at St. Demetrius in Zlatari, Prespa), semicircular (at St. Savior in Rashtak, Skopje), or in the form of a convex baroque curved extension.

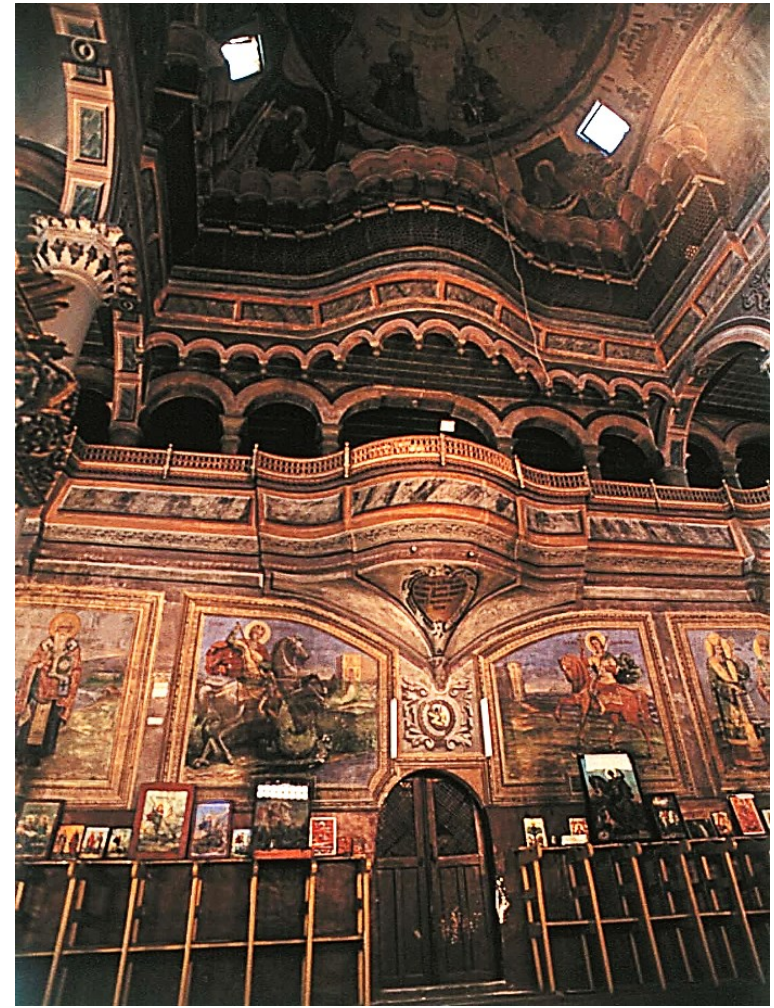

Figure III.37 St. Panteleimon in Veles. View from the naos towards the superimposed galleries.

In the larger, three-nave basilicas, the gallery fence usually took on a more complex shape. ${ }^{286}$ Often, convex cantilever extensions appear correspondant to each of the naves. These extensions can be clearly, sharply separated from the otherwise flat partition, in the form of balconies (at St. Savior in Drachevo, see fig. III.39A; Holy Trinity in Smolari, Strumica, etc.), or the whole fence can be shaped as a continuous curved "S"-shaped line with a baroque effect (fig. III.37). ${ }^{287}$ Furthermore, in some churches the gallery fence is a combination of a concave balcony in the central nave and convex segments in the axis of the lateral naves. Less common are galleries shaped the opposite way, concave in the central nave, ${ }^{288}$ or in a " $U$ " shape, with the arms of the gallery in the lateral naves serving as balconies (fig. III.38B, III.40). ${ }^{289}$

\footnotetext{
285 At St. Savior in Creshevo, near Skopje; Dormition of the Most Holy Mother of God in Evla (Prespa); St. Demetrius in Dihovo (Bitola); St. Demetrius in Dobroveni, etc.

${ }^{286}$ Although, there are three-nave basilicas with a simple flat wooden gallery fence, without profiling or extensions. Such example is the church of St. John in Ljubojno; St. Nicholas in Brajchino; St. George in Drmeni and St. Nicholas in Carev Dvor, all in the region of Prespa; St. Nicholas in Rotino (Bitola); St. Athanasius in Barbarevo; St. Athanasius in Kuklish; St. Savior in Stinik and St. George in Murtino, all in the region of Strumica; as well as the church in the village of Klisura in Demir Kapija.

${ }^{287}$ At the Holy Trinity in Dabile, St. Panteleimon in Makrievo, St. George in Zubovo (all in the region of Strumica).

${ }^{288}$ At St. George in Budinarci; St. Savior in Vladimirovo; St. Constantine and Helena in Negrevo; Dormition of the Most Holy Mother of God in Robovo; St. Peter and Paul in Pehchevo; St. George in Novo Selo (Strumica), etc.

${ }^{289}$ At St. John in Kratovo (see fig. III.38B); St. Demetrius in Kriva Palanka (see fig. III.40); St. Archangel Michael in Berovo; St. Elijah in Blatec (Vinica), etc.
} 

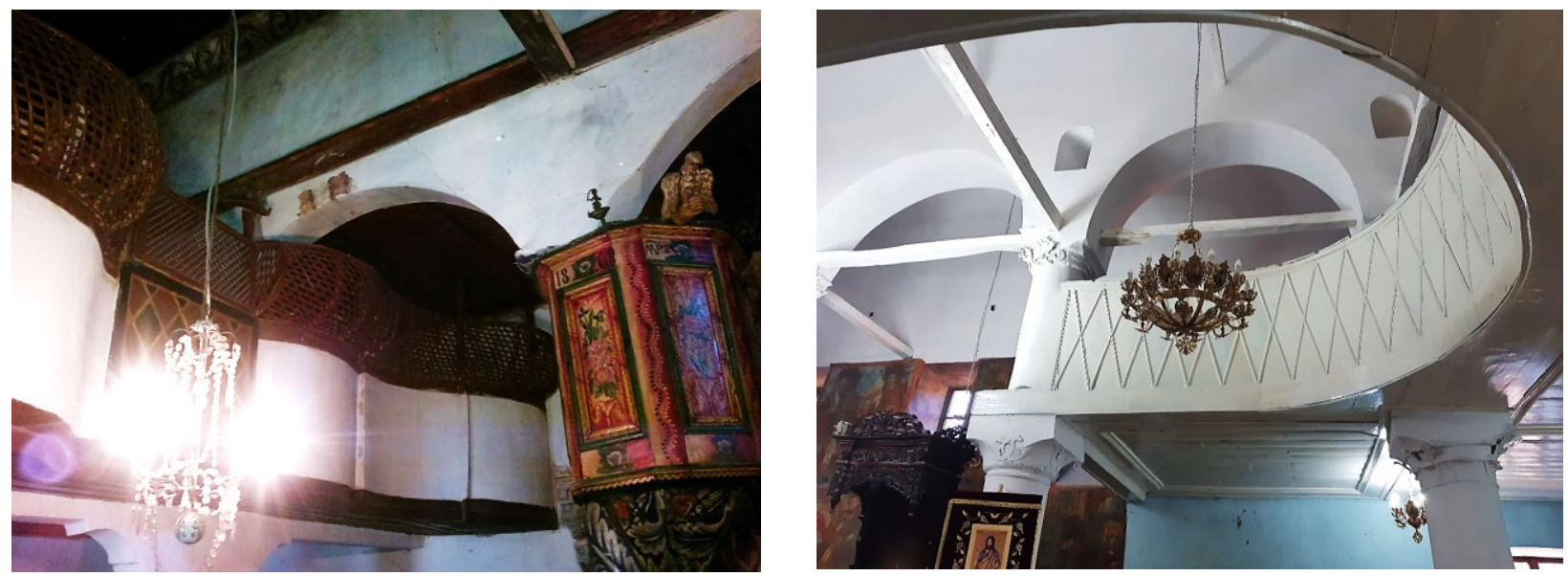

Figure III.38 A. St. Nicholas in Bashino Selo (Veles); B. St. John in Kratovo. View of the gallery.

It is interesting to compare the three clearly defined balconies in the galleries of the Revival basilicas, such as at St. Savior in Drachevo near Skopje (fig. III.39A) with those found in some mosques from the Ottoman period, such as the Colorful Mosque in Tetovo (fig. III.39B), which speaks of the pronounced Islamic influence in the existence and formation of the "women's churches", as well as the continuity of the architectural expression in the region and its fluidity in relation to the types of architecture in which it is encountered (see Chapter III.2).
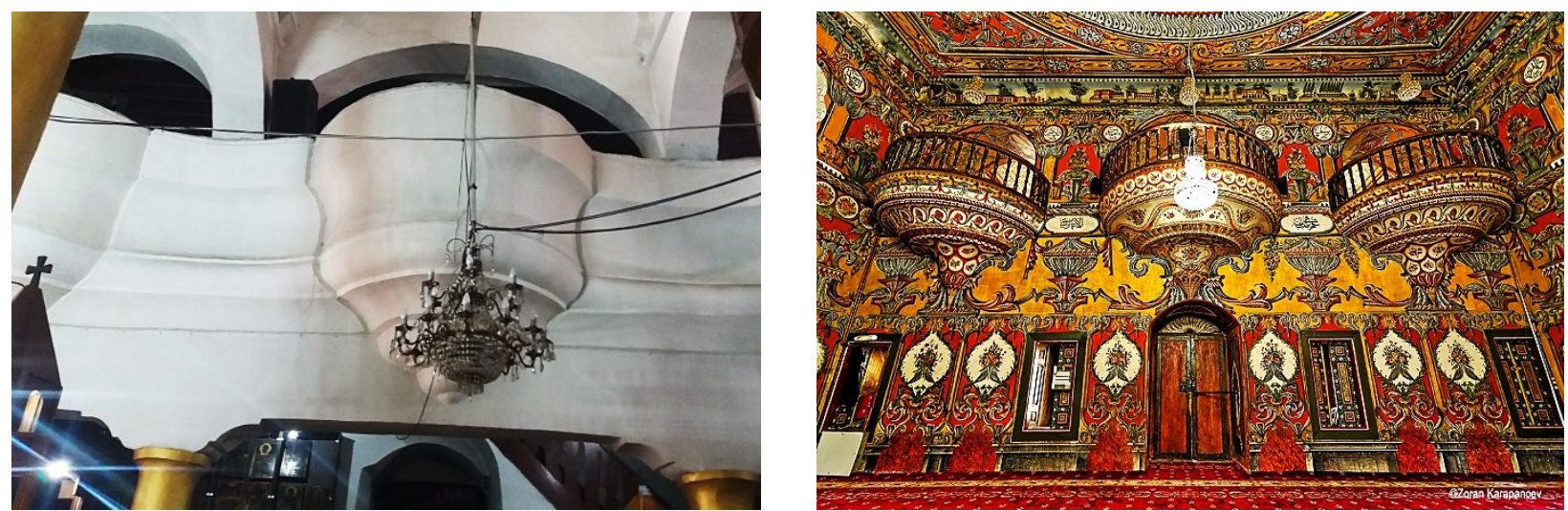

Figure III.39 A. The church of St. Savior in Drachevo (Skopje); B. The Colorful Mosque, Tetovo. View of the gallery balconies.

Also, the fence of the gallery often recieved additional decoration, profile or relief ornament: a frieze of cantilevered blind arcades, columns, consoles, suspended arches, rhomboid applications made of wooden planks, etc. Above this solid wooden, plastered or painted partition often appears an additional semi-transparent partition of diagonally placed thin wooden planks - a musharabia. ${ }^{290}$ In addition to strictly following the shape of the lower partition, the musharabia itself often has a decoratively curved "S" cross-section (fig. III.41), since the " $\mathrm{S}$ " line was indeed a characteristic, extremely common element in the Revival art, especially regarding the fresco-painted decoration and the secondary plastic processing of the entrance portals, patron's niches, cornices, iconostasis, church furniture, etc.

Quite often, the gallery fences were also decoratively painted (fig. III.42). ${ }^{291}$ In addition to the solid wooden or plastered parapet, which was often adorned with elongated rhomboid aplications, color was applied on the wooden substructure, especially the wooden capitals and the load-bearing wooden beam,

\footnotetext{
290 This additional visual separation is quite common: at St. George in Resen; St. George in Drmeni (Prespa); St. Theodore in Gorno Dupeni (Prespa); St. Savior in Rashtak (Skopje); St. Nicholas in Sopotsko (Prespa); St. John the Forerunner in Jankovec (Prespa); Holy Trinity in Dabile (Strumica); St. George in Novo Selo (Strumica); St. Athanasius in Bosilovo (Strumica) and many, many more. ${ }^{291}$ For example, in the church of St. Elijah in Sachevo; St. George in Novo Selo and St. George in Zubovo, all in the region of Strumica; in St. Demetrius in Kriva Palanka; St. Athanasius in Dolno Chichevo (Veles) and many more.
} 
as well as the musharabia itself. In addition to color, a wide array of decorative motifs were often painted on the gallery fences: floral arrangements (at St. Elijah in Sachevo, near Strumica, for example); single rose or lily-of-the-valley blooms; ivy or vine branches as a simplification of the tree of life motif; geometrical or whimsical wave-like meanders (at St. Athanasius in Dolno Chichevo, near Veles, see fig. III.42); garlands; baroque acanthus and "S"-shaped motifs, chess-field or opus reticulatum motifs (at St. Nicholas in Bashino Selo, near Veles, see fig. III.38A), etc.

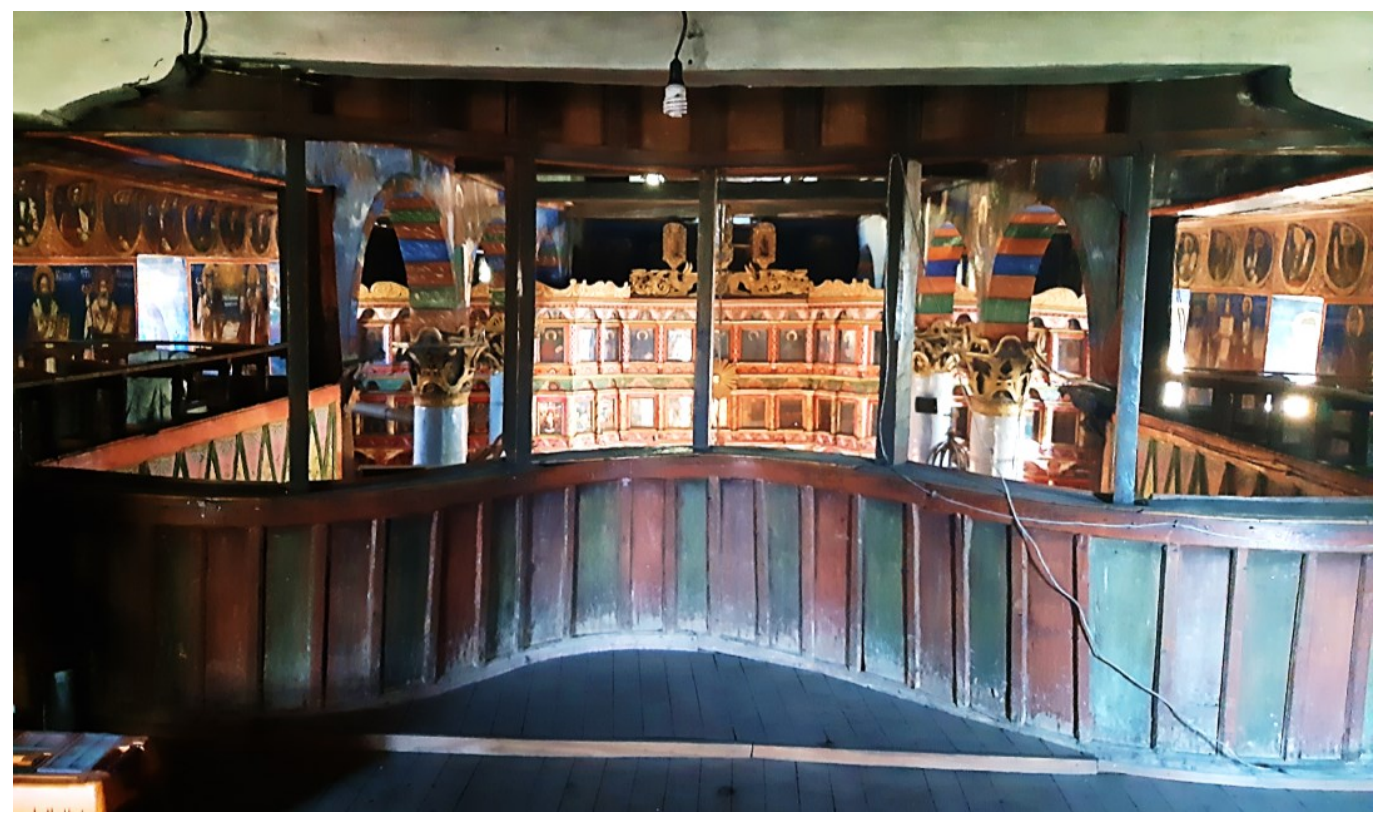

Figure III.40 St. Demetrius in Kriva Palanka. View from the gallery to the naos.
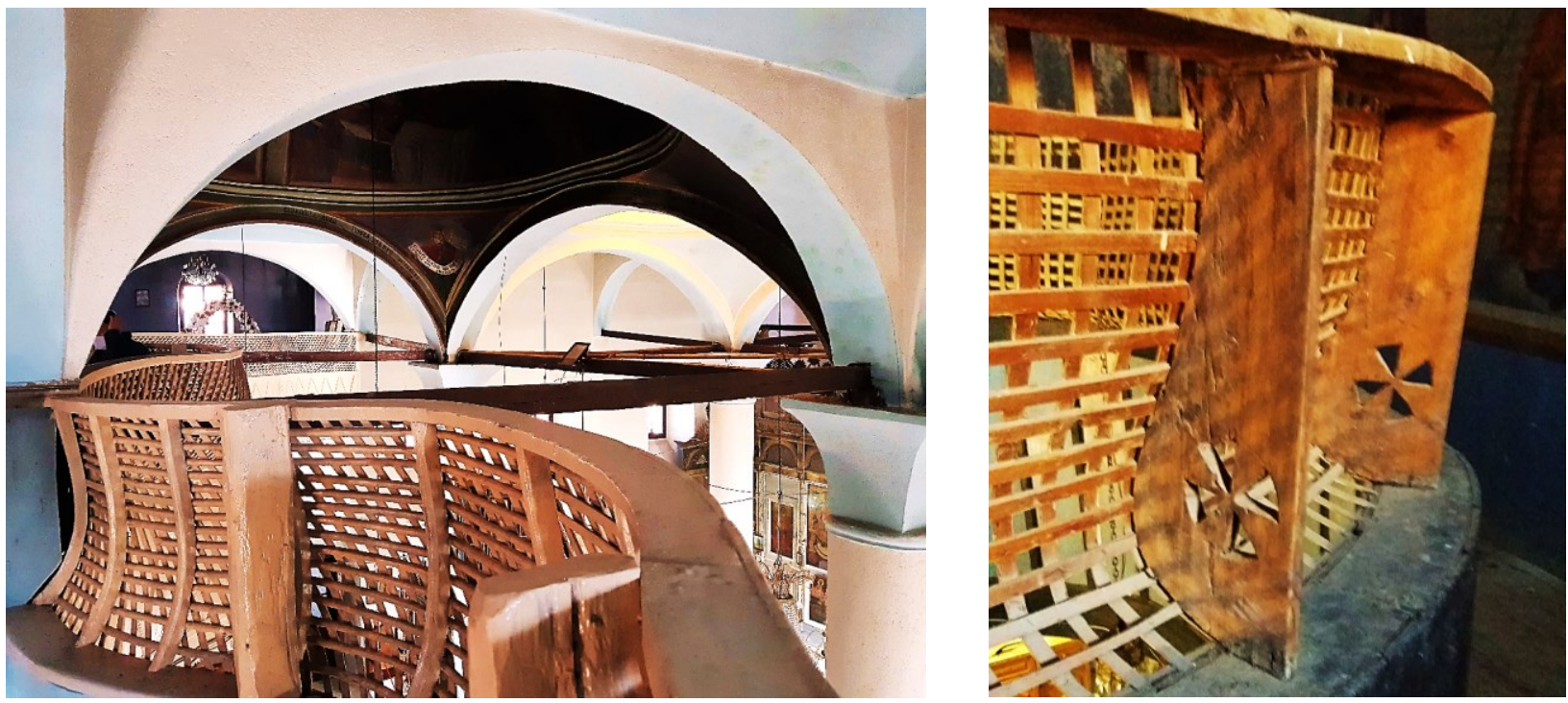

Figure III.41 Examples of musharabia railings, placed above the gallery parapet: A. The Most Holy Mother of God in Krushevo; B. The Most Holy Mother of God in Duf (Gostivar).

The same tonality as well as similar motifs appear on the pillars and arches in the naos, the pulpit, the bishop's throne, the flat and coffer ceilings and all remaining available surfaces for painting in the church (fig. III.42). As was said, this painting spree often transferred in the same splendor to the iconostasis, where the cosmitis, the lunettes above the icons, the columns, the plinth were all also painted, resulting in a particularly picturesque, vivid and dynamic decorative composition (see fig. II.18). 


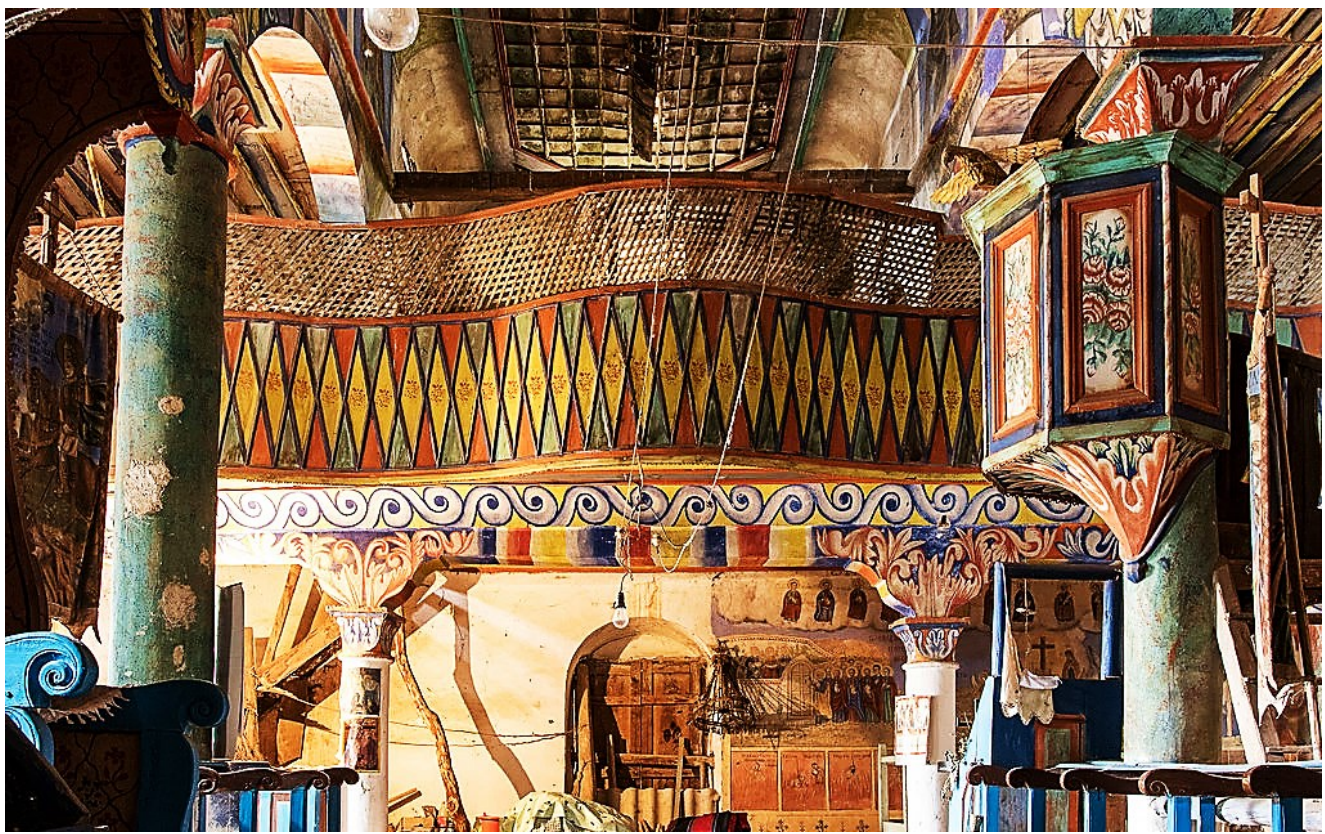

Figure III.42 St. Athanasius in Dolno Chichevo (Veles). View towards the gallery.

In some churches, the fence of the gallery towards the naos was not only painted with floral or geometric motifs, but was rather fresco-painted with compositions along its entire length (fig. III.43), ${ }^{292}$ or with individual images of saints or scenes depicted in separate medallions. ${ }^{293}$

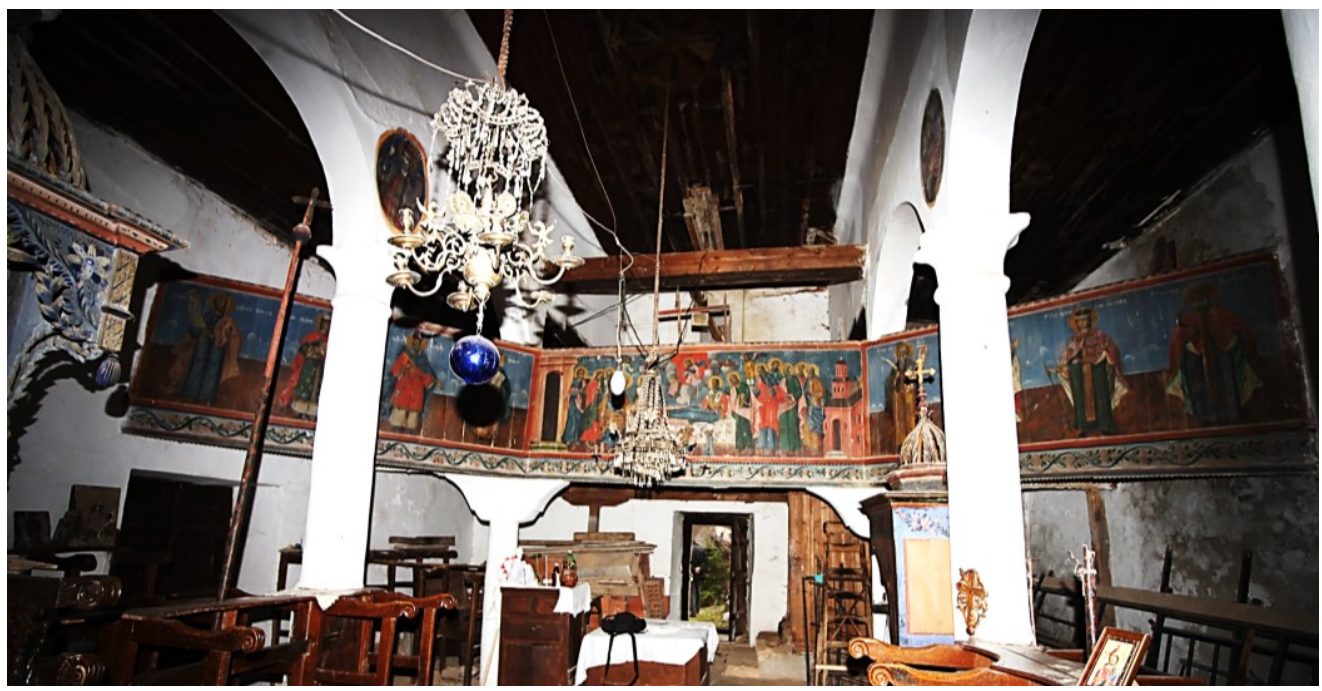

Figure III.43 The Most Holy Mother of God in Rosoki (Debar). View towards the gallery.

Furthermore, there are several churches where abstract landscapes and architectural scenes were painted on the solid gallery parapet. For example, at the church of St. Elijah in the village of Blatec (Vinica), a landscape depicting the sea with fortified towns on its shores and ships with fluttering sails was painted along the gallery parapet, adorned with medallions with representations of Macedonian vernacular architecture (fig. III.44A-B). At the church of St. Savior in Rashtak (Skopje), in addition to the decorative painting of geometric motifs on the parapet itself, the capitals of the wooden pillars that support the gallery were also painted with minuscule landscape scenes. In this context, it is necessary to point out,

\footnotetext{
292 At St. George in Novo Selo (Strumica); St. George in Murtino (Strumica); quite often in the churches in the region of Debar Reka (in the villages of Tresonche, Selce, Rosoki), etc.

${ }^{293}$ At the Holy Trinity in Dabile (Strumica), where the famous local painter Grigorij Pecanov painted the prophets Daniel, Isaiah, Ezekiel and Amos; at St. Petka in Skochivir, Mariovo; St. Nicholas in Vevchani (Struga) which was painted by Avram Dichov, etc.
} 
once more, to the similarity of this painted decoration, especially the landscape scenes, architectural scenography of local provenance and floral arrangements in decorative vessels, with the Islamic religious and secular objects of the same period, which have been mentioned before (fig. II.13, III.44C).
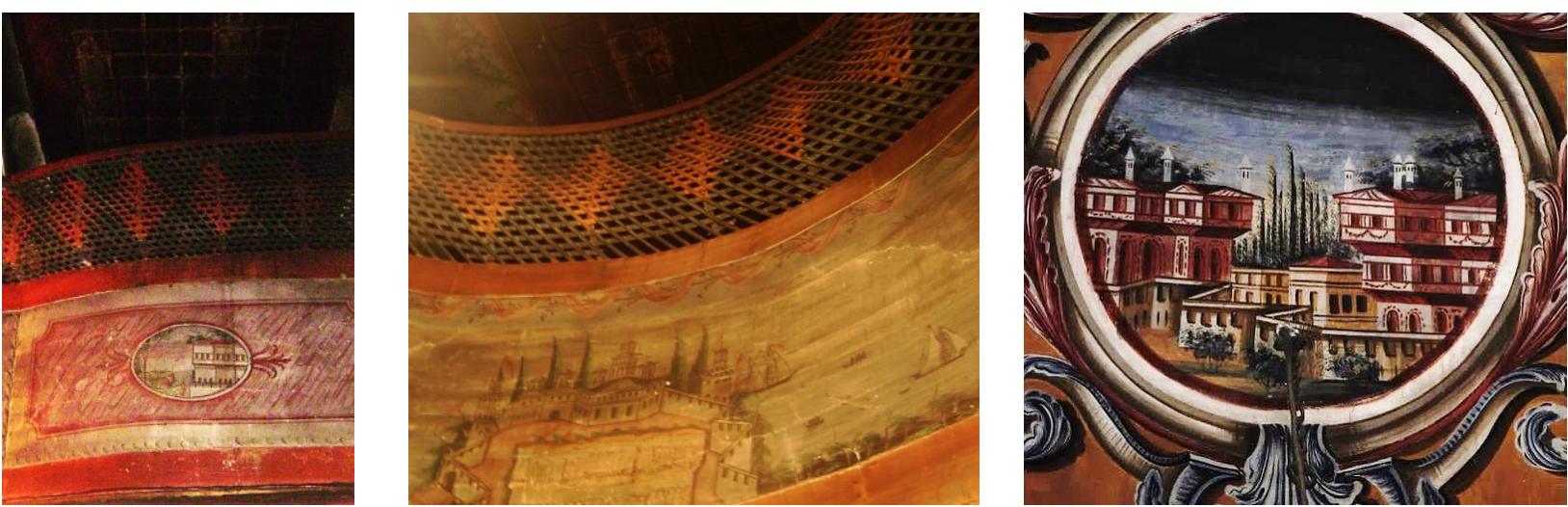

Figure III.44 Painted landscapes and architectural scenography: A - B. Gallery parapet of the church of St. Elijah in Blatec (Vinica); C. The Colorful Mosque in Tetovo.

The gallery space itself is usually quite simply arranged, paved with wooden boards or brick, without built-in church furniture, which indicates that its users attended the liturgy on foot. In some churches, on the inside along the gallery fence appears a short elevated platform on which icons were displayed, and even (although rarely) including decorative pedestals for larger holiday icons, as was the case of the church of St. Nicholas in Mirkovci, described earlier (see Chapter II.5.2).

As a result of the social changes, especially regarding the status of women in society, the church galleries completely lost their function in the XX century. Thus, they were slowly turned into storage rooms often housing older icons, older royal doors, fragments of crucifixes, etc. thus turning into mini church treasuries of sorts, which testify to the past of the churches themselves or their missing Byzantine or post-Byzantine predecessors. Furthermore, in several larger churches, the galleries have been institutionally converted into official icon galleries - museums, such as at St. George in Struga, the Dormition of the Most Holy Mother of God - Kamensko in Ohrid, St. Cyril and Methodius in Gevgelija and the Most Holy Mother of God in Novo Selo near Shtip.

\section{Narthex}

Unlike the Byzantine and post-Byzantine churches, the Revival ones very rarely have a separate narthex in accordance with the Byzantine prototypes. In those churches where a distinct narthex does appear, it is usually a later added structure, in the role of a vestibule, and often that function is adopted by the open porches in front of the entrance portals, which run along one (the western), two (usually the western and the southern) or three sides of the naos. The appearance of a gallery plays an important role in the omission of the narthex, since "in such an elongated naos the classical form and the ideologicalfunctional connection of the naos with the narthex are suppressed" (Тричковска, 2008: 37). In fact, it is the space under the gallery which takes on the role of an integrated narthex, based on the late-Byzantine prototype found in several XIV century churches: the second phase of St. George in Staro Nagorichane, the Most Holy Mother of God in Matejche, St. Demetrius - Marko's Monastery and St. Nicholas in Psacha (see Chapter II.4.3). ${ }^{294}$

\footnotetext{
294 The churches from this specific group are basically basilicas in plan, whose three naves are formed by three pairs of masonry pillars or monolithic columns; however in section it becomes clear that the idea of their architects was in fact a classic Byzantine inscribed cross with a central dome supported on a drum (Marko's Monastery and Psacha) or with a five-dome solution (Matejche, built under the influence of Staro Nagorichane) with an integrated narthex covered by an additional dome (in Psacha) or a blind calotte (in Marko's monastery). The narthex is "integrated" since it is not separated from the naos with a wall pierced
} 
The Revival temple is accessed through the integrated under-gallery "narthex", which also serves for communication with the "female church", commonly through a wooden staircase in its northwest corner. In this "narthex" the congregation prepares for prayer and from there it "enters" the naos and experiences it at its full height. The act of "entering" the naos, despite the common lack of a physical barier, is nevertheless clearly defined, a major role played by the contrast in the transition from a relatively low, covered and darker space beneath the gallery to the high, open and luminous space of the naos.
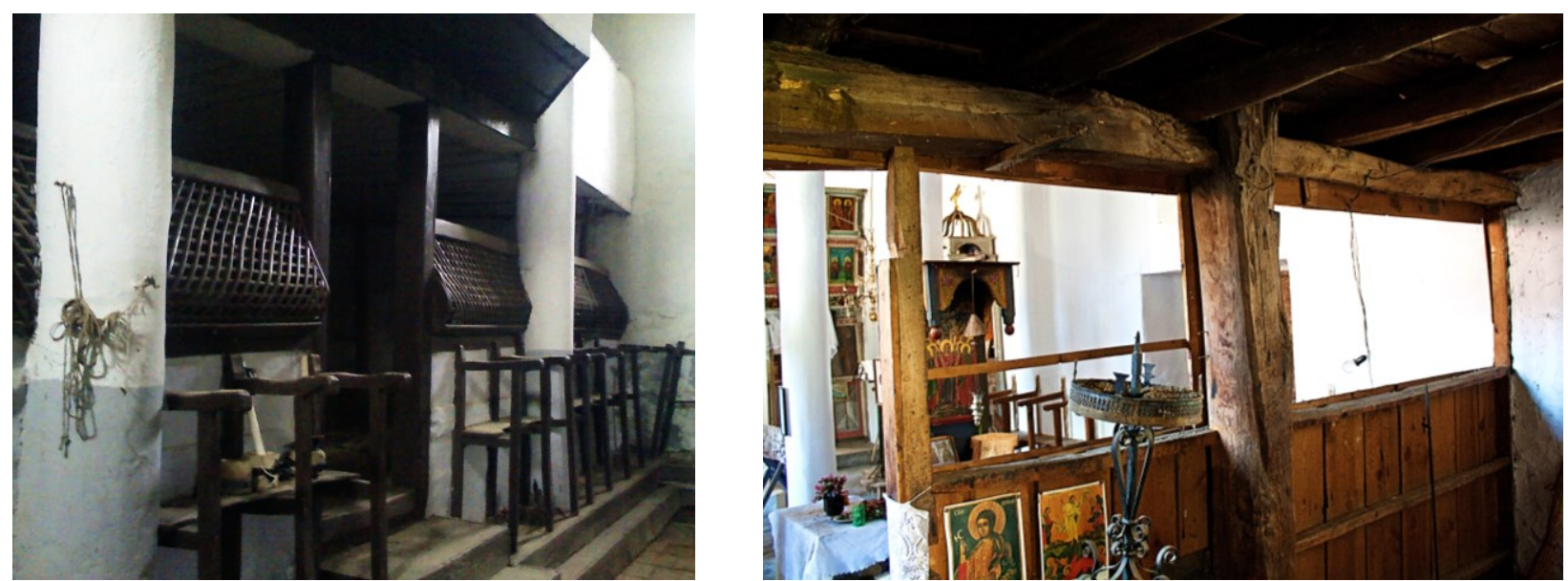

Figure III.45 Examples of a semi-integrated narthex: A. St. Nicholas in Dragosh (Bitola). View from the naos towards the narthex; B. St. Savior in Graeshnica (Bitola). View from the narthex towards the naos.

In most Revival churches, this space is completely connected to the nave, visually separated only by the wooden substructure which supports the gallery. In some, on the other hand, there are two additional wooden pillars that visually emphasize the narthex-naos differentiation, as is the case at the churches in Garnikovo, Dragozhel and Resava, all within the region of Tikvesh (Negotino / Kavadarci) as a local feature. However, there are examples where the space under the gallery was completely separated from the rest of the nave with low wooden partitions (at St. Savior in Graeshnica, near Bitola - fig. III.45B) or semi-transparent partitions consistent with the musharabia regularly placed above the gallery parapets (at St. Petka in Prdejci near Gevgelija; St. Nicholas in Dragosh near Bitola - fig. III.45A, etc.). ${ }^{295}$ Often, wooden seats were included within these light wooden partition systems, as the ones regularly distributed along the north and south wall of the naos and between the columns of the arcades in the larger threenave basilicas. Furthermore, at some churches the partition of the "narthex" under the gallery was complete, reaching the gallery substructure in height, ${ }^{296}$ which as such belong to the classical definition of a narthex (fig. III.46A). In some churches, on the other hand, the narthex is defined by a low full wooden partition, ${ }^{297}$ which creates the effect of a balcony; in other words, the gallery space was "multiplied" on two superimposed levels, and the visual separation of the western section of the temple was thus further defined. Additionally, the effect of separation was achieved with a significant difference in the floor levels

by separate entrance(s), as was common before. However, it is visually separated both in the interior itself - with the help of a monumental tribelon placed between the first pair of pillars (as is the case in Matejche) or with lower western columns (as is the case in Marko's monastery) - as well as externally, by arranging the volumes of the narthex and naos in an ascending fashion. For more on the specific late-Byzantine solution of the "integrated narthex" see Касапова, 2010: 152-160.

295 Such is the case of the church St. Nicholas in the village of Dragosh, Bitola (fig. III.45A), where the narthex is separated by a low, solid plastered parapet on top of which a baroque curved musharabia is placed, as was usual for the galleries' partitions. A musharabia placed above a solid parapet can also be found at the church of St. Petka in Capari (also in the region of Bitola), where the narthex is separated from the naos by a denivelation.

${ }^{296}$ Such examples are: St. Savior in Kozhle, Skopje (fig. III.46A); St. Nicholas in Nakolec, Prespa; St. Nicholas in Slivica, Mariovo; St. Petka in Nizhepole, Bitola; St. Demetrius in Gradec, Valandovo; the Most Holy Mother of God in Belovishte, Tetovo, etc.

297 For example, the churches St. Demetrius in Bukovo, Bitola; St. Nicholas in Rotino, Bitola; St. Nicholas in Brajchino, Prespa; St. Nicholas in Klisura, Demir Kapija; the Holy Healers (St. Cosmas and Damian) in Ohrid, which will be discussed in more detail later (see Chapter III.5.B.2). 
of the narthex and the naos (as in the churches in Kozhle, Brajchino, Klisura, Oleveni, Brusnik, Rotino, and Gorno Orehovo). Thus, one has to descend via several stairs from a relatively low space into the naos which contributes to a masterfully achieved emphasis on its contrasting spaciousness and height.
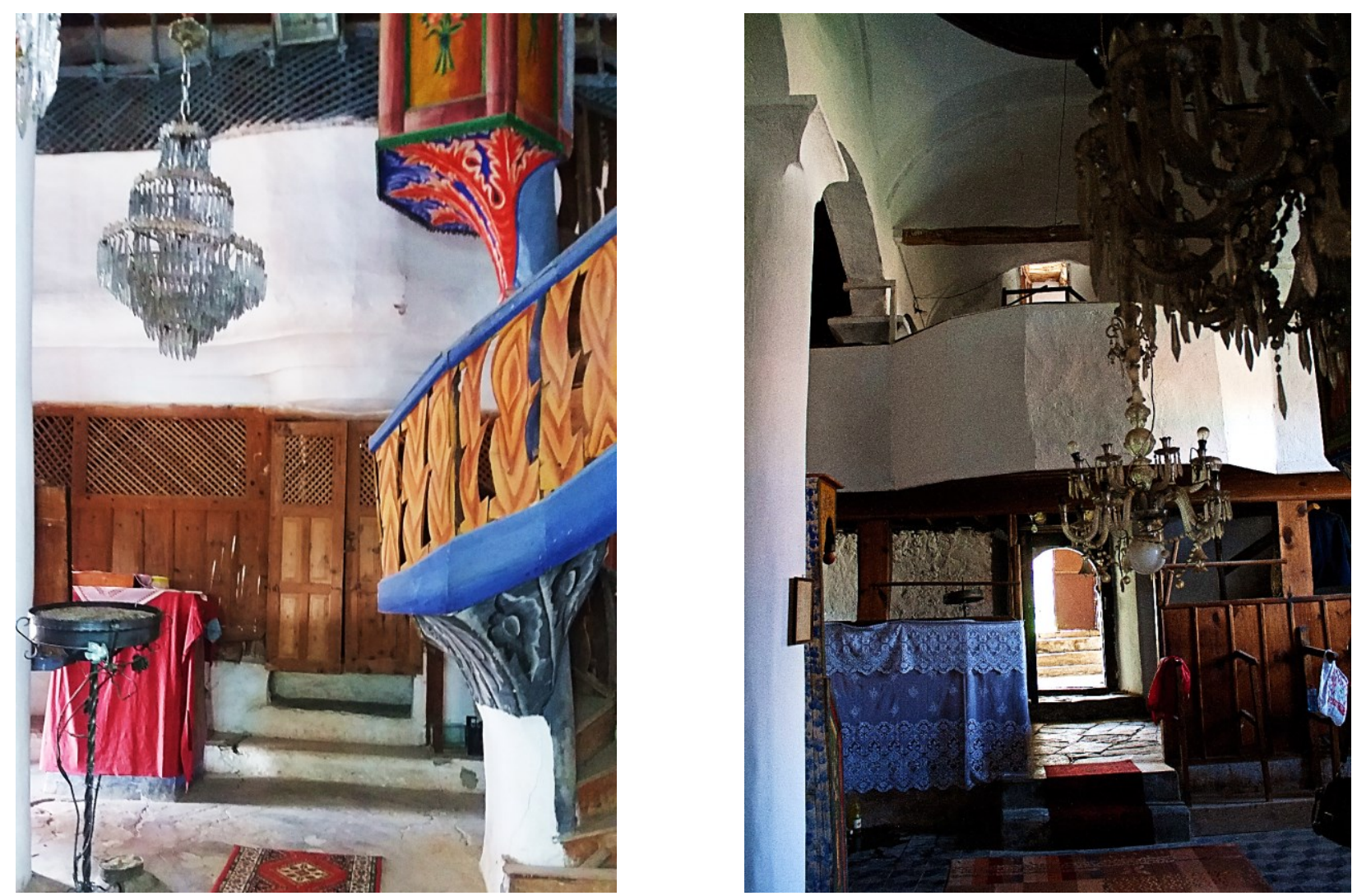

Figure III.46 View from the naos towards the narthex. A. St. Savior in Kozhle (Skopje); B. St. Savior in Graeshnica (Bitola).

Although very rarely, there are examples of churches that have a "narthex" instead of a gallery. In these Revival churches the "women's church" is not located on an upper floor, but is rather separated from the naos by a fence, and is sometimes elevated. In other words this space simultaneously acts as a narthex and a "women's church". Such is the case of the church of St. Athanasius in the village of Gabalavci (Николовски, 1993: 159) and the Dormition of the Most Holy Mother of God in Gjavato, both near Bitola (Ibid: 161). ${ }^{298}$ This category also includes the churches St. Nicholas in the village of Gluvo, Skopje (see Chapter II.5.2) and St. Athanasius in Dolno Dupeni (Prespa), where a wooden lattice (musharabia) is placed above the solid partition. The last two churches are renovations of significantly older buildings, so the lack of a gallery may be due to the adaptation of the building to the existing architecture and the configuration of the terrain. Furthermore, no gallery but rather a physically separated narthex appears at the church of St. Athanasius in Sovich (Bitola), where the western part of the temple (up to the first pair of wooden columns from its three-nave disposition), marked by a very small denivelation, is physically separated by a tall wooden parapet (fig. III.47). The partition is complemented by built-in wooden seats facing the naos. On top of the partition are placed, alternately, shorter solid panels and longer semitransparent fields executed as musharabia of diagonally arranged wooden planks. The solid panels are used for the display of icons. In the center, a decoratively processed portal is executed, closed with a curtain (as are the "windows" covered with musharabia), through which the narthex, whose described features also define it as a "women's church", communicates with the main space - the naos of the church.

\footnotetext{
298 In this church, in addition to the denivelation, the space intended for the "women's church" was separated from the naos also by means of elaboration of the ceiling. Namely, in the naos of this three-nave church, all three naves are covered with a flat wooden ceiling, while in the narthex / "women's church" the central nave is semi-cylindrically vaulted (Николовски, 1993: 161).
} 


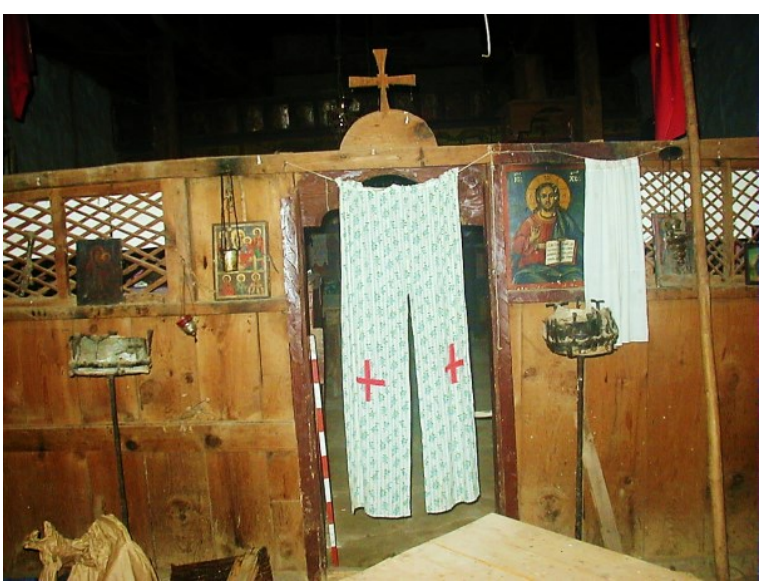

Figure III.47 St. Athanasius in Sovich (Bitola). View towards the narthex.

Furthermore, the "narthex" below the gallery regularly incorporates the baptistery, usually placed in the south-west corner, while the staircase to the upper floor is usually placed on the opposite side, in the north-west corner. Long ago, as early as during the mass acceptance of Christianity in response to the Byzantine Christian missions in the Balkans (see Chapter 1.3), the concept of baptism as a rite of initiation of adults was abandoned, which had demanded special rooms with a pool for immersion into holy water for that purpose, a regular feature of the early-Christian basilicas (see Chapter I.2). In the Revival churches, on the contrary, the baptistery is a small vessel made of stone or metal and placed on a monolithic or masonry pedestal and as such serves for the baptism of newborn babies.

Of course, there are Revival churches that completely lack a narthex or a designated "woman's church", in which the nave is a complete, uninterrupted, elongated space. These are usually smaller, single-nave temples. Such are the churches in the villages Rapesh, Paralovo and Grunishta in the region of Mariovo; a significant part of the churches in the regions of Demir Hisar (see Chapter III.5.A.3) and Makedonski Brod, etc.

\section{Porches}

The porches, which are a mandatory accompanying element of the Revival basilicas, are based on the millennial Mediterranean tradition, in the area of Macedonia materialized in the early-Christian basilicas, then in the Byzantine churches, and later in the Islamic religious buildings. The need to expand the surface of the compact naos with a covered area near the temple came to the fore especially during the XIX century. These expansions, which are the result of the need for more useful space for gathering of the congregation before and after the liturgy, especially on the important religious holidays or more significant rites and ceremonies, as well as the essential need to cover the entrance to the temple as basic protection from the weather, are manifested in the form of an open porch on the west side of the church or as a closed narthex. Some churches, on the other hand, have a southern entrance in addition to the western one; in these churches there is an extended porch also on the southern side (fig. III.48). Less commonly there are churches that have an additional entrance from the north side, mostly due to the configuration of the terrain. In this case, the extension covers the west and north side of the naos (Томовски, 1970: 7), in an „L“-shape. The largest basilicas have a "U"-shaped porch that encloses the naos on all three sides (north, west and south), which protects the three entrance portals. In addition to the large "five-nave" basilicas, such churches can be found in the Prespa region: St. George in Resen, St. George in Drmeni, St. Nicholas in Carev Dvor (Николовски, 1987: 36-40), etc.

The porches, according to their authentic concept, were open, mostly made of wooden construction for which during the construction of the churches cantilever stone consoles were inserted into the façade walls above the level of the patron saint niches and under the windows of the west and/or south façade. These cantilever consoles were made of a single block of stone, often with a certain decorative carving, and rarely sculpturally processed (see fig. III.88). The consoles supported a wooden beam connected in the transverse direction to the porch structure. On the opposite side, the porches 
usually consisted of a series of masonry pillars, monolithic stone pillars (fig. III.49), ${ }^{299}$ or wooden columns (fig. III.48), connected to each other with architrave wooden beams or wooden or masonry arches - in a masonry or wooden-frame structural system. The architrave system consisted of wooden beams placed on lateral shorter beams - so-called "futi" (pillows), which in addition to serving a purely statical function of receiving and transferring loads to the wooden columns (which could thus be of smaller cross section), were also regularly decoratively cut (fig. III.48B).
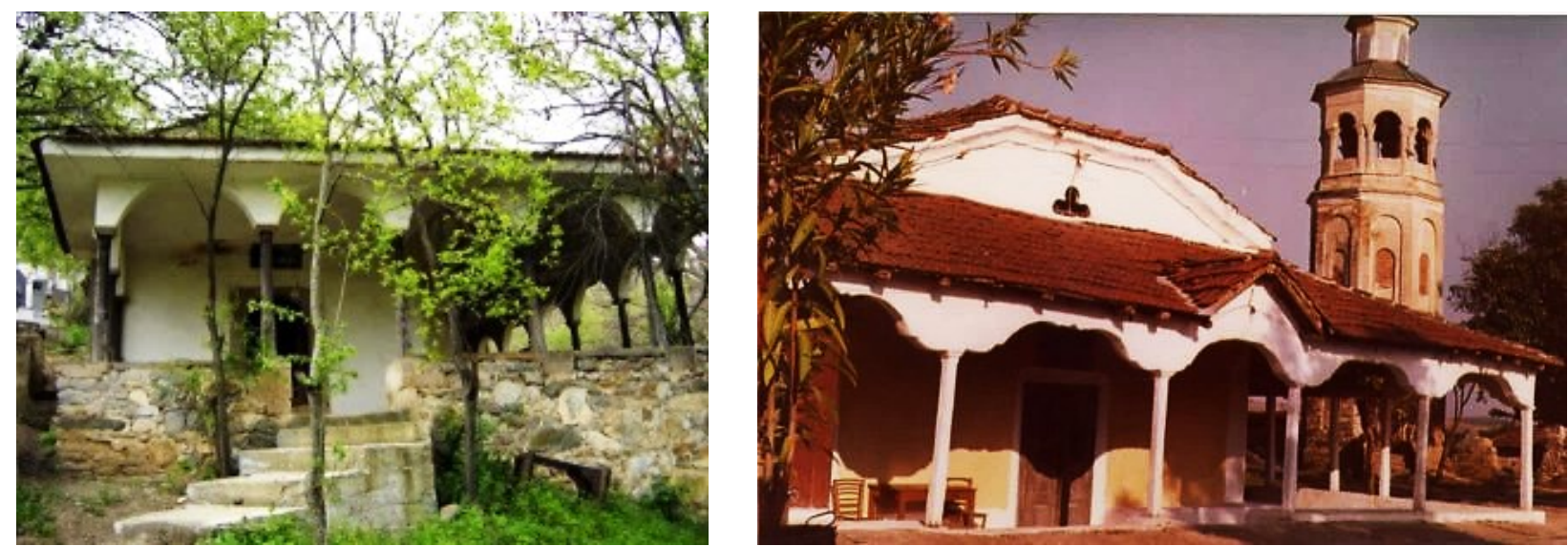

Figure III.48 Examples of wooden "L"-shaped open porches: A. St. Nicholas in Orashac (Kumanovo); B. St. Nicholas in Sveti Nikole (the church was demolished in the 1980s).

The space between the columns was usually closed off with a solid wooden parapet, and the window openings were closed with wooden shutters. Later, due to the obsolescence of the material, this construction was often replaced by masonry, so that today it can extremely rarely be found in its authentic condition (Томовски, 1970: 11-13). One such example is the " $\mathrm{L}$ "-shaped porch (from the west and south side of the naos) at the single-nave church of St. Nicholas in the village of Orashac near Kumanovo (fig. III.48A), which consists of arcade rows (10 arches on the southern, 6 on the western and 2 on the northern side) made entirely of wood, with decorative cuts, as well as pedestals and capitals shaped within the wooden monolithic pillar. The pillars were not subsequently plastered - their loadbearing constructive material was left visible - while in the upper zone, in the arcade, the surface formed with wooden slats was plastered and whitewashed.

In addition to light-weight wooden constructions, stone masonry arcade systems were also employed in some Revival churches' porches, such as at St. John in Kratovo (fig. III.50B) and St. Joachim - Osogovo monastery (see fig. III.100A), both work of the master-builder

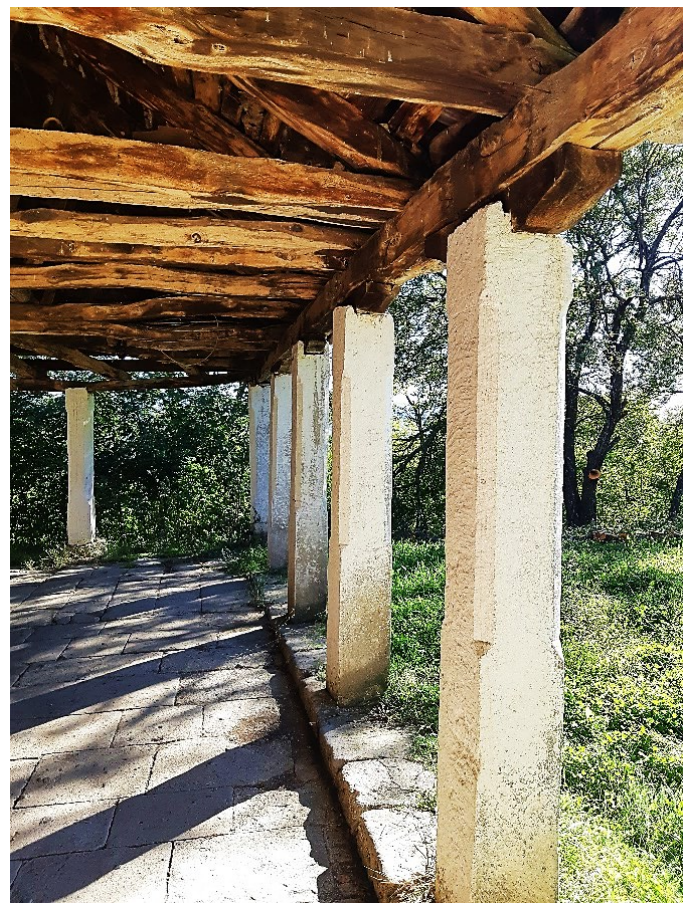

Figure III.49 St. Demetrius in Stracin (Kratovo). Detail of the "L"-shaped open porch. Andreja Damjanov.

\footnotetext{
299 Monolithic stone pillars with a square cross-section are found, for example, on the porches of the churches in the neighboring villages of Stracin and Rugjince, on the border between the regions of Kratovo and Kumanovo (fig. III.49), as well as the Osogovski monastery near Kriva Palanka. In all these churches the porches are " $\mathrm{L}$ "-shaped and extend to the west and south of the temples.
} 

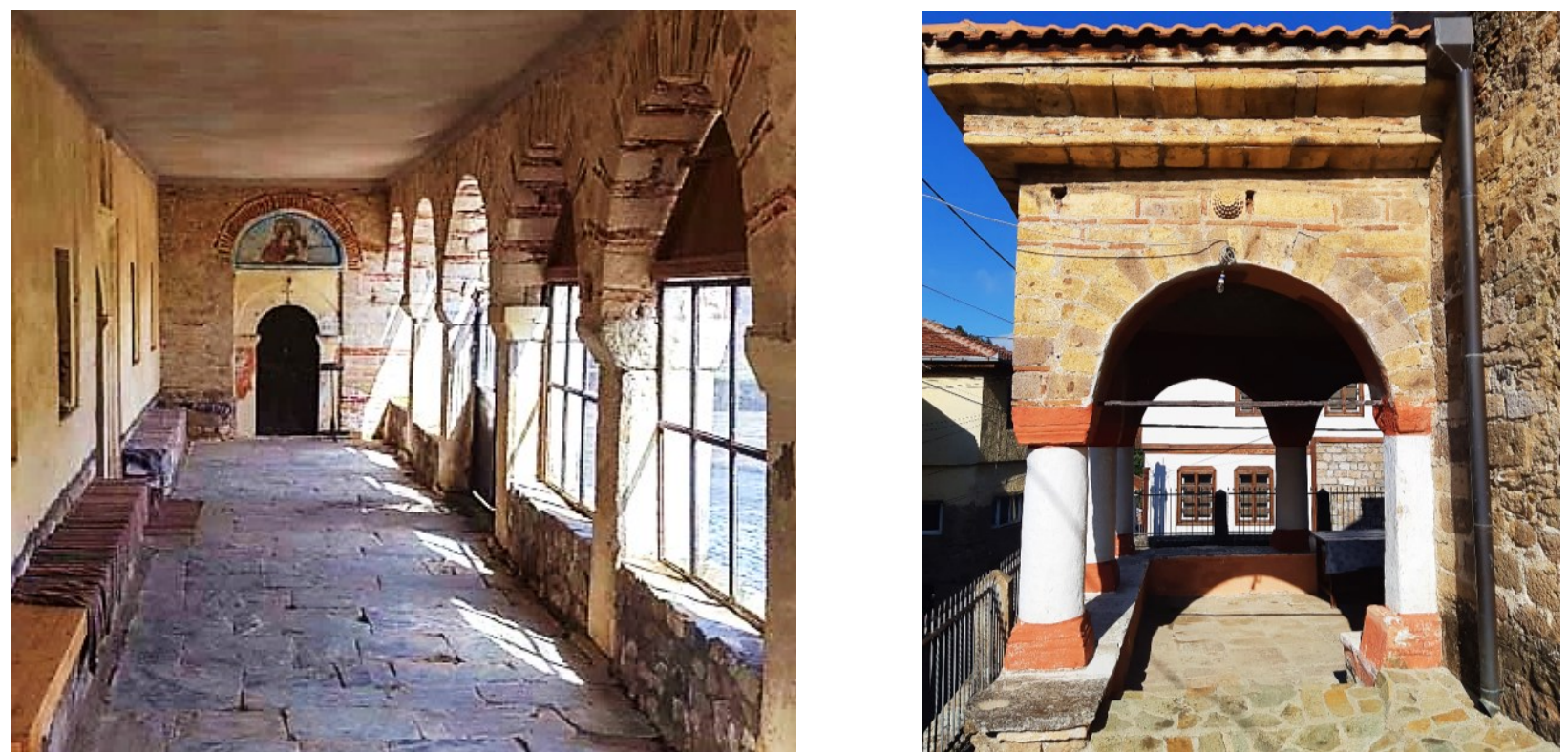

Figure III.50 A. St. Demetrius in Magarevo (Bitola); B. St. John in Kratovo. View of the masonry open porches.

A specific group of Revival churches are characterized by masonry arcade porches, extending to the west of the naos, which support not only a roof, but rather a second level, housing the "women's church" - the gallery. Such is the case of St. Nicholas in Star Istevnik near Delchevo (fig. III.51); the Most Holy Mother of God in Leunovo, Mavrovo (see fig. III.4, fig. III.52A); St. Nicholas in Golemo Radobil, near Prilep (fig. III.52B); St. Nicholas in Virche, near Delchevo; St. Elijah in Selce, near Debar (see Chapter III.5.E.1); St. Sunday in Bitola (see Chapter III.5.B.5). The arcade construction of the porches rests on heavy, massive masonry pillars (in Leunovo, Selce, Golemo Radobil, Virche, Bitola), or monolithic stone columns (in Star Istevnik). It is significant to note that in addition to this massively built porch, the churches from this group also originally had lateral open porches made of wooden construction, which protected the lateral entrances to the naos and complemented the main western porch, as confirmed by the stratigraphy of the lateral façades (fig. III.51), or by the preserved stone consoles embedded on them (fig. III.52A).

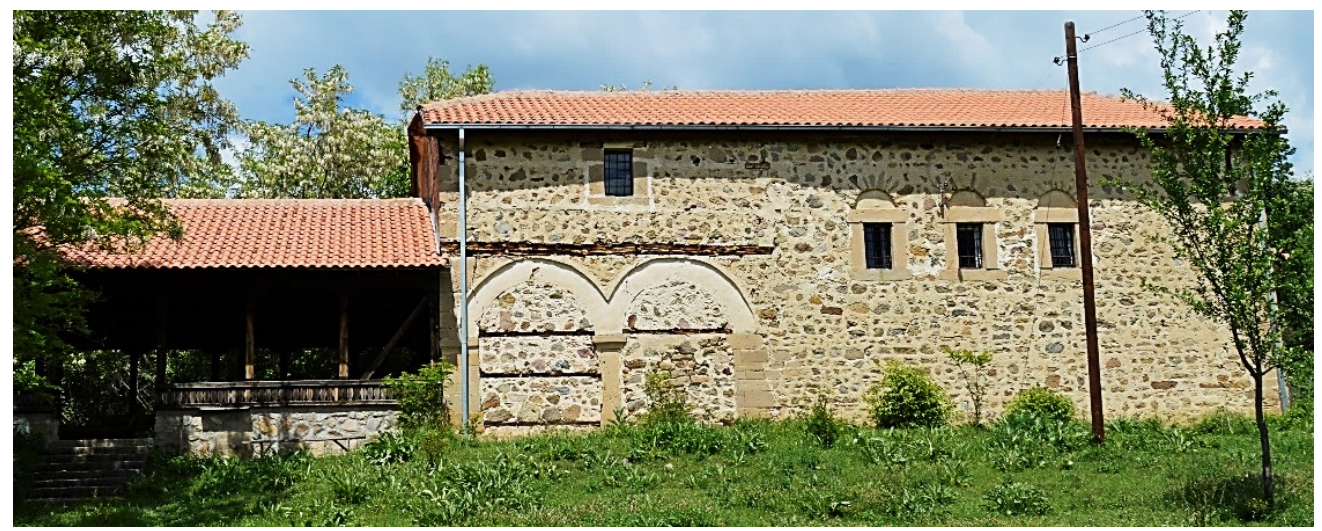

Figure III.51 St. Nicholas in Star Istevnik (Delchevo). View from the south.

This specific group of churches, according to their characteristics, is especially important in the context of the study of the large "five-nave" basilicas as a separate typological category, where the same element (open arcade porch on the ground floor which supports the gallery on the upper floor) develops not only to the west but also on the lateral sides of the naos, which thus transforms from a three-nave plan at the ground floor level to a five-nave arrangement at the upper gallery level. More on this evolutionary development in Chapter III.5.C, dedicated to the "five-nave" basilicas. 

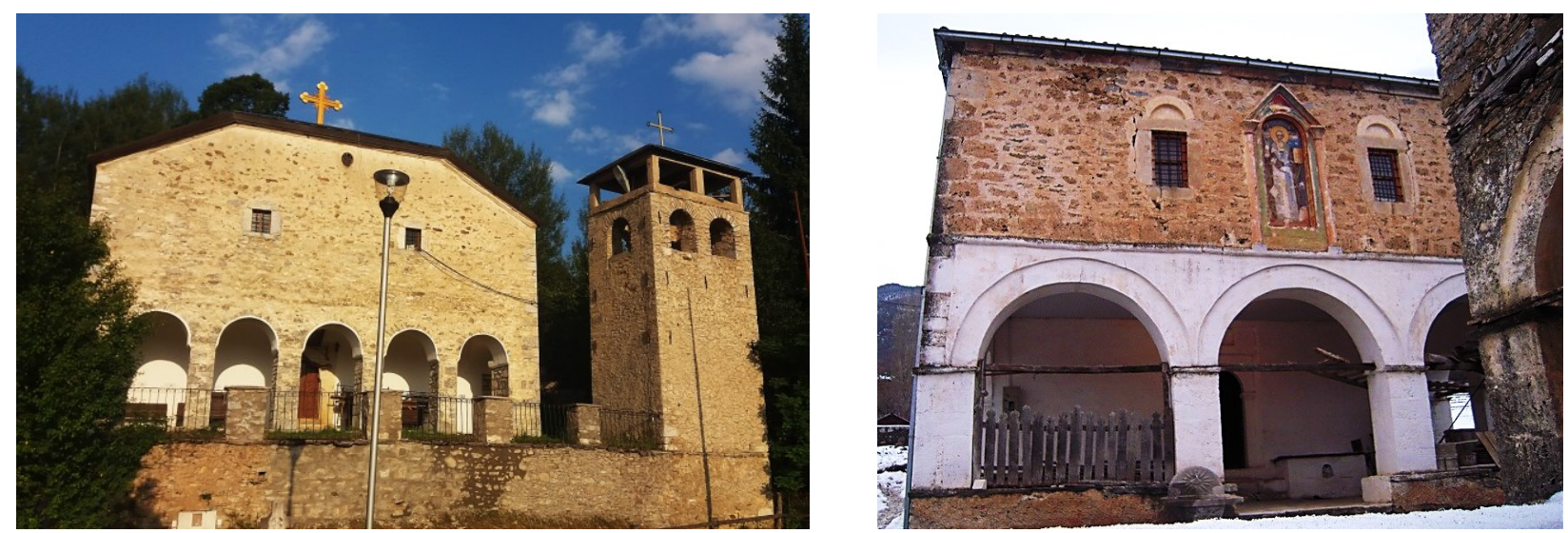

Figure III.52 A. The Most Holy Mother of God in Leunovo (Mavrovo); B. St. Nicholas in Golemo Radobil (Prilep).

\section{Bell towers}

The construction of bell towers was generally accepted and widespread in the construction practice of the late-Byzantine period (Кораћ и Шупут, 1998: 381). However, unlike the Western European tradition, in Byzantium the bell towers were rarely incorporated in the temple itself; instead they usually constituted separate buildings. In Macedonia, the only example of an incorporated bell tower is found at the church of St. Demetrius in Veles (see Chapter I.4.3). The articulation of the bell tower as a separate building continued in the post-Byzantine period, and was transferred as a practice in the Revival.

In the Revival, the bell towers were not unified in their typology. A variety of solutions can be identified, ranging from completely open, light wooden skeleton structures (fig. III.53); ${ }^{300}$ through combinations of a massively built cubic or octagonal pedestal and wooden frame upper parties, very similar to the Ottoman clock towers built in all urban areas throughout Macedonia; to completely massively built towers. Examples of the combined bell towers can be found in the Osogovo monastery near Kriva Palanka, as well as the similarly conceived bell towers within the fortified churchyards in the neighboring villages of Tresonche and Lazaropole in the region of Debar (Reka) which consist of three belts: a massive masonry pedestal and two superimposed wooden frame octagonal levels (see fig. III.160-161), the second of which constitutes the belfry itself. One of the most striking examples of this category is the bell tower of the church in Shlegovo (region of Kratovo), which is comprised of a tall masonry octagonal body (itself divided into two zones with a profiled cornice), a slender octagonal tower of light wooden construction with arched openings on the sides shaped as balconies, on the roof of which rises a smaller octagonal analogous belfry (fig. III.54). This bell tower most closely resembles the clock towers, built in the bazaars of the urban centers, such as the ones in Prilep, Bitola, etc. Later, at some bell towers of this type which had lost the upper wooden frame construction due to dilapidation, it was replaced by a concrete and/or brick masonry structure (for example, at the churches in the villages of Osoj, Lokvica, etc.). The

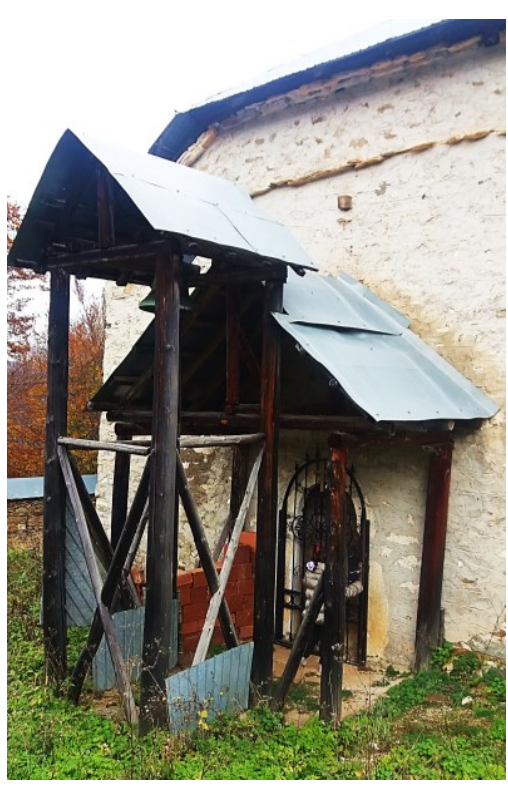

Figure III.53 The bell tower at St. Nicholas in Kichinica (Mavrovo).

300 Such bell towers were built at St. Stephen in Nezhilovo (Veles); St. Panteleimon in Belica (Kichevo); St. Savior in Skopje; St. Nicholas in Kichinica (Mavrovo) etc. At the church of St. George in Resen, the authentic bell-tower was built within the wooden porch, in the north-east corner: supported on a very low masonry foundation, rose the cubic whitewashed body of the tower made in wooden frame construction, toped by a smaller tower made of wooden skeleton, without plaster coatings nor fillings. 
third abovementioned category is comprised of massively built masonry bell towers, which could be cubical in shape (for example, at the church of St. Elijah in Dojran, the Most Holy Mother of God in Leunovo, Mavrovo - see fig. III.52A), or octagonal (as in the church of the Nativity of the Most Holy Mother of God in Uma, Gevgelija).

Furthermore, there are also examples of bell towers incorporated within the churches themselves, usually located above the western gallery and made of wooden framework construction and then

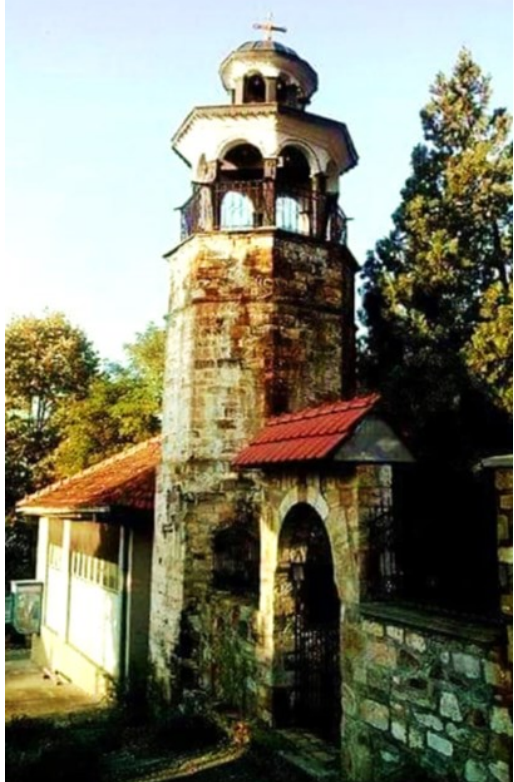

Figure III.54 The bell tower at the Introduction of the Most Holy Mother of God in Shlegovo (Kratovo).

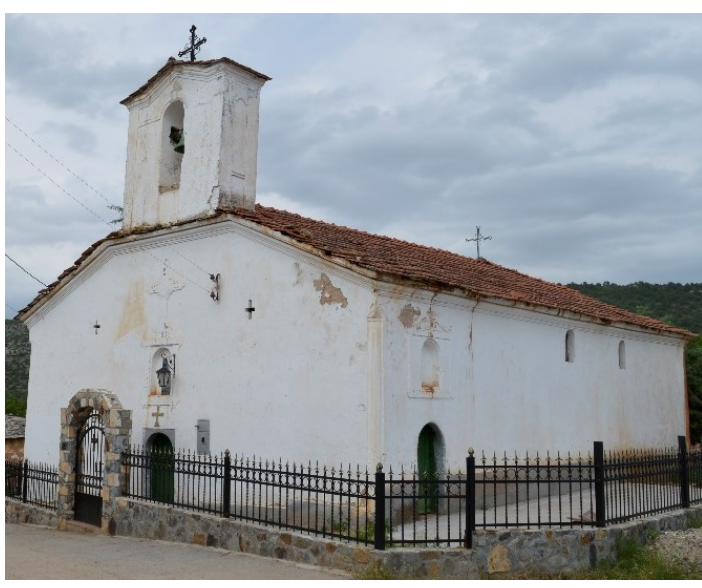

Figure III.55 St. Savior in Oraovec (Veles). plastered, as is the case at St. Transfiguration in Gopesh, Bitola; St. Demetrius in Volkovija, Mavrovo; St. Savior in Rogachevo, Tetovo (see fig. III.36B), etc. In the churches whose massively built structure allowed it, the incorporated bell towers were built entirely out of stone masonry, or as a combination of masonry and light wooden framework construction. Such example is the church of St. Elijah in the village of Selce, region of Debar (Reka), which will be discussed in further detail in Chapter III.5.E.1. The famous Revival masterbuilder Andreja Damjanov also incorporated bell towers into his work: at the Dormition of the Most Holy Mother of God in Novo Selo (Shtip) as well as the churches he built in Serbia and Bosnia (see fig. II.10); while the bell towers at his churches in Kratovo and Kumanovo are in fact later additions (Хаџиева-Алексиевска и Касапова, 2001: 33). In addition to Damjanov, Gjorgji NovakovDzongar also incorporated a slender polygonal bell tower above the gallery of the church of St. Nicholas in Shtip (see fig. III.227).

As a specific sub-type, in several Revival churches there appears a specific bell tower built on top of the western façade wall: at St. Savior in Oraovec, near Veles (fig. III.55), built by the brothers Kosta and Nikola Damjanovi; ${ }^{301}$ at St. Demetrius in Balinci, Valandovo, built by Andon Kitanov, etc. Later, this type of bell tower was built at the church of St. Peter and Paul in Kichevo, placed on top of its baroque western façade (see fig. IV.1). The prototype for this type of belfry can be traced back to the late-Byzantine period, when a similar structure was built at the church of St. Nicholas Bolnichki in Ohrid, as well as several churches in the geographically and culturally connected region of Castoria.

Lastly, many Revival churches received a bell tower adjacent to the western façade, covering the western entrance to the naos later, in the first half of the next century, ${ }^{302}$ which will be discussed in further detail in Chapter IV, dedicated to the churches of the XX century built under the influence of the XIX century Revival.

\footnotetext{
${ }^{301}$ Kosta and Nikola, together with the whole Damjanov family, moved to this village from Papradishte in 1835 and remained there until their death, unlike their brother Andreja Damjanov who later, in 1850, settled in the nearby town of Veles with his immediate family (Василиев, 1965: 156).

302 Such as the churches of St. Nicholas in Mavrovo (see fig. II.26B); St. Archangel Michael in Skochivir (Mariovo); St. Ana in Malovishte (Bitola); St. Elijah in Laktinje (Ohrid) and many others.
} 


\section{III.4 Decoration}

Despite their generally modest, simply conceptualized and stylistically reserved external appearance, in the Revival temples special attention was paid to several key focal points: the entrance portals which regularly include arched patron saint niches; the altar apse; the windows, especially those on the west and east façade which almost without exception incorporate a window transenna carved out of a stone slab; or which are shaped as a rosette - oculus; the crown cornice; as well as, very often, the appearance of individual stone blocks with biblical, Christological, solar and cosmogonic motifs processed in shallow relief and embedded into the masonry of the façades. Inside the churches, in addition to the altar partition as the most decorative element, a wealth of painted or relief ornaments abounds on the columns, capitals, ceilings, choirs, bishop's throne and gallery parapets.

\section{III.4.1 Decoration of the Exterior of the Revival Churches}

\section{Entrance Portals}

Unlike the post-Byzantine churches, which without exception have only one entrance, located centrally on the west façade, the Revival basilicas are characterized by the regular appearance of at least two entrance portals, one of which retains the traditional position in the axis of the west façade, and the other is placed on one of the lateral façades, usually the south one, and rarely the north ${ }^{303}$ where it was placed if it was a requirement of the conditions of the construction site and the terrain. The monumental three-nave and five-nave basilicas usually have two lateral entrance portals, and in some cases even another additional entrance or a pair of entrances placed at the eastern end of the lateral façades, which lead(s) directly to the altar. ${ }^{304}$ The entrances to the churches were regularly covered with open porches, whose disposition was dictated by the placement of the entrance portals (see Chapter III.3).

Special attention was paid to the processing of the entrance portals. In fact, unlike the simply conceived entrances in the post-Byzantine churches, which in accordance with the conditions in which they were built lacked a decorative profile or relief, as well as the monumental Byzantine temples in Macedonia which usually had simple architrave lintels, the entrance portals of the Revival churches reach exceptional wealth both in terms of the profiling of the stone blocks as well as of ornamentation executed in a wide range: from shallow relief, through deep carving, to almost entirely three-dimensional sculpture. On one hand, the composition, profile, as well as the represented elements and motifs ("S"- volutes, garlands, lily-of the-valley, vases and cantharos, sculpted beasts, mythological creatures and wild animals, etc.) of the Revival portals directly emulate the Renaissance and Baroque Western European tradition; while the Christian and cosmogonic motifs date back to the early-Christian iconography preserved on stone plastic specimens (pillars, capitals, panels and slabs) as well as preserved mosaic pavement. On the other hand, the frequently used pointed and segmented arch indicate a domesticated Islamic influence. In fact, of all the decorative elements incorporated in the Revival temples, the entrance portals may in fact have the most eclectic character, in accordance with the nature of the architecture of which they represent an integral part.

The entrance portals of the Revival churches are usually semi-circularly arched and built of precisely hewn stone blocks. Even in the simplest conceived portals, the jambs and the lintel were made of

\footnotetext{
${ }^{303}$ For example, at the Nativity of the Most Holy Mother of God in Shtavica (Mariovo); Dormition of the Most Holy Mother of God in Selce (Prilep); St. John in Bogoslovec (Sveti Nikole); St. Nicholas in Rajca (Prespa), etc.

${ }^{304}$ At St. Nicholas in Vevchani (Struga); St. George in Zashle (Demir Hisar); St. Demetrius in Kriva Palanka, etc.
} 
monumental monolithic blocks, ${ }^{305}$ often with blocks shaped as semi-capitals placed above the jambs, shaped with several profiles inwards, towards the entrance opening, thus reducing the span of the lintel arch (fig. III.57A). The most common profile is a combination of concave and convex segments, which was rather common in the Revival and used in the composition of the window openings, the wooden capitals of the galleries' substructure, the shallow pilasters and cornices, etc. Furthermore, quite commonly the arch itself was shaped as a complex composition of concave and convex segments (fig. III.58B, III.59), as is the case of the Most Holy Mother of God in Sence (Mavrovo), where the entrance portal is equivalent to the profile of the niches on the church's apse (see fig. III.30C).

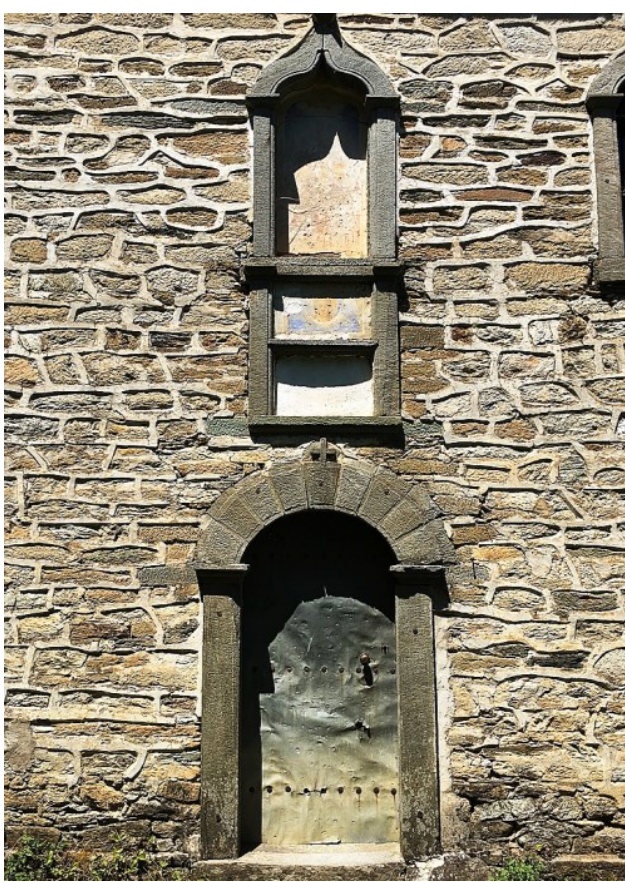

Figure III.56 View of the southern entrance portal with the patron saint niche at the church of St. Constantine and Helena in Tomino Selo (Makedonski Brod).

In addition to the quality of the hewn stone, the Revival portals were often additionally decorated with ornaments in shallow relief on the stone blocks themselves, the most common motifs being crosses (Maltese, procession, Greek, elongated), or stylized leaves that form a cross (Томовски, 1970: 14-15), rosettes, solar motifs, etc. The simplest composition consists of a single cross carved into the arch, ${ }^{306}$ or a symmetrical arrangement of crosses on the jambs of the portal, which sometimes include the year of construction or consecration of the church itself. ${ }^{307}$ Another common motif is a simplified lily-of-the-valley (for example, at the entrance portal of the church of the Most Holy Mother of God in Sence, Mavrovo), as well as the tree of life motif (at the entrance portal of St. Elijah in Ezerani, Prespa). Also, figural representations are quite common: angels - winged cherubim and seraphim (fig. III.58B); ${ }^{308}$ the representation of St. Demetrius or St. George on horseback, ${ }^{309}$ etc.

In addition to single motifs made in shallow relief within the lintel or the jambs, there are also portals with more complex iconography of the decorative ornamentation.

The Eucharistic connotation of this ornamentation is prevalent. Such example is the western entrance portal of the church of St. Nicholas in Mavrovo (fig. III.57A), which is one of the top achievements of the Revival masonry skill. ${ }^{310}$ The monolithic arched lintel of this portal, executed in very shallow relief, depicts a wreath of spirally curved leafy vines, emerging at both ends from the jaws of two opposing dragons. A Greek cross marks the top of the arch, decorated with a centrally placed flower and leafs on each arm of the cross, which is flanked by two facing pigeons shown pecking at ripe bunches. ${ }^{311}$ Above the arch of the

\footnotetext{
${ }^{305}$ Because it is a monolithic block, although shaped into an arch, it still constitutes an architrave load-bearing element.

${ }^{306}$ At the Most Holy Mother of God in Leunovo (Mavrovo); the southern portal at St. Nicholas in Mavrovo; St. Archangel Michael in Optichari (Bitola), etc.

${ }^{307}$ For example, at the church in Carev Dvor (Prespa).

${ }^{308}$ At the western portal of the church in Carev Dvor (Prespa); the southern portal of the church of St. George in Resen, etc.

${ }^{309}$ At churches dedicated to this saint: at the southern portal of St. George in Gorna Vlashka Maala (Ohrid); the western portal of St. George in Podmochani (Prespa) where this representation is combined with a cross and a flower (Николовски, 1987: 49), еtc. ${ }^{310}$ This church, built in 1850, was submerged in the waters of the artificial acumulation "Mavrovo" in 1953. Seasonal fluctuations of the water levels of the lake cause the remains of the church to be alternately almost completely submerged in spring/summer, and then dry in the winter season. Despite this extremely unfavorable environment, with cold winters and exposure to snow and ice, the walls, columns, the stone parapet of the iconostasis partition, and partially the vaults and domes of the church remain almost unchanged, due to the exceptional quality of the stone and its precise processing and installation in the wall mass.

311 The motif of a centrally placed cross (or cantharos from which water springs or leafy shoots grow in a high stream) flanked by two birds (or deer) drinking from its waters or, as an alternative, pegging from ripe grapes, is one of the oldest Eucharistic motifs in Christianity and is quite common in the early-Christian basilicas in Macedonia.
} 
portal is the patron saint niche, supported by two decorative lateral consoles, which today is only partially visible, while the rest, unfortunately, is hidden by the reinforced concrete structure of the bell-tower attached to the west façade of the church in the first half of XX century (see fig. II.26B).
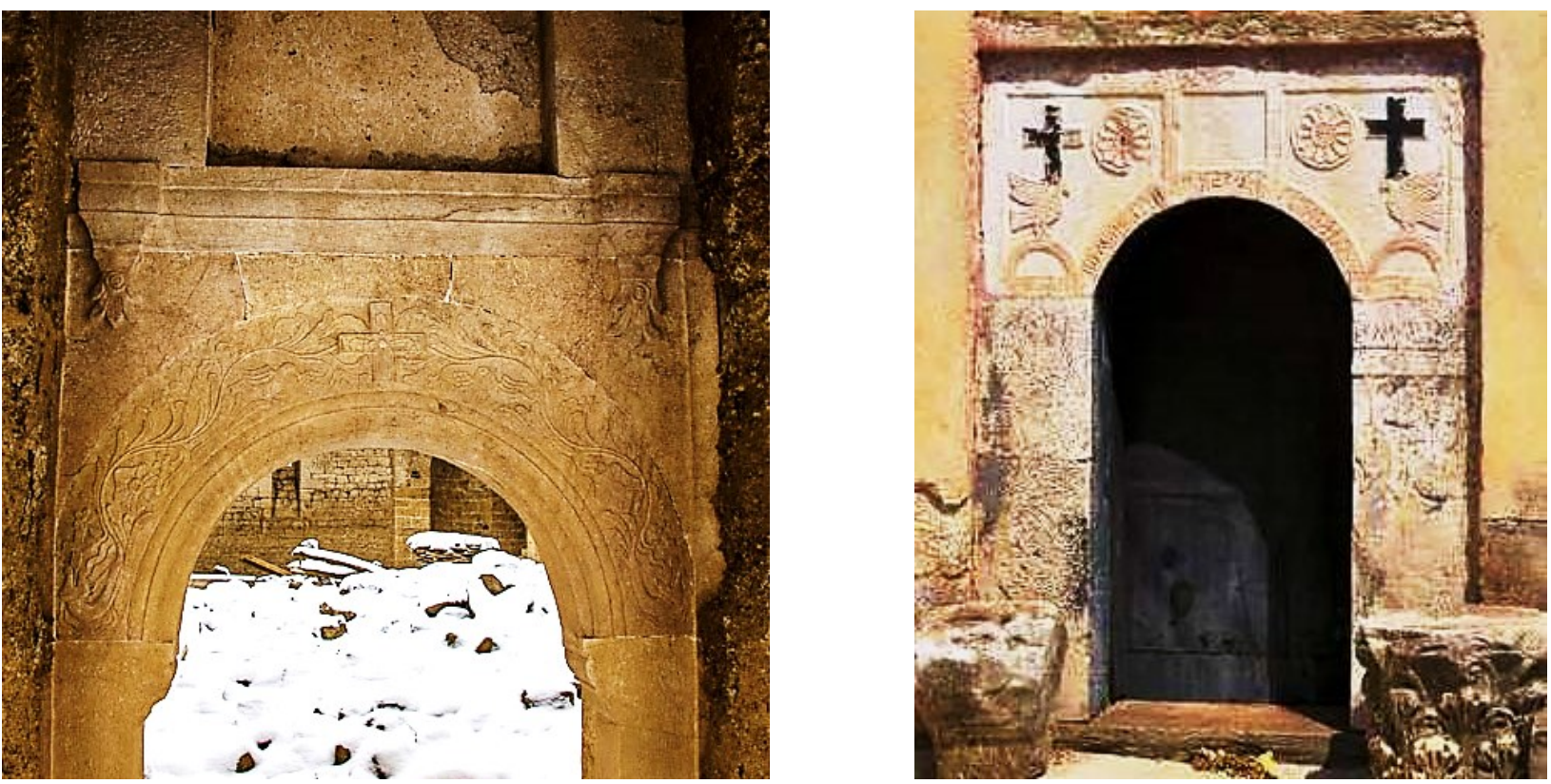

Figure III.57 A. St. Nicholas in Mavrovo; B. St. George in Ivanjevci (Bitola). Details of the western portals.

A simplified Eucharistic composition, consisting of symmetrically arranged birds (usually doves) flanking a central cross, often complemented by floral or solar rosettes, is also quite common. Such example is the western portal of the church of St. George in Ivanjevci, near Bitola (fig. III.57B).
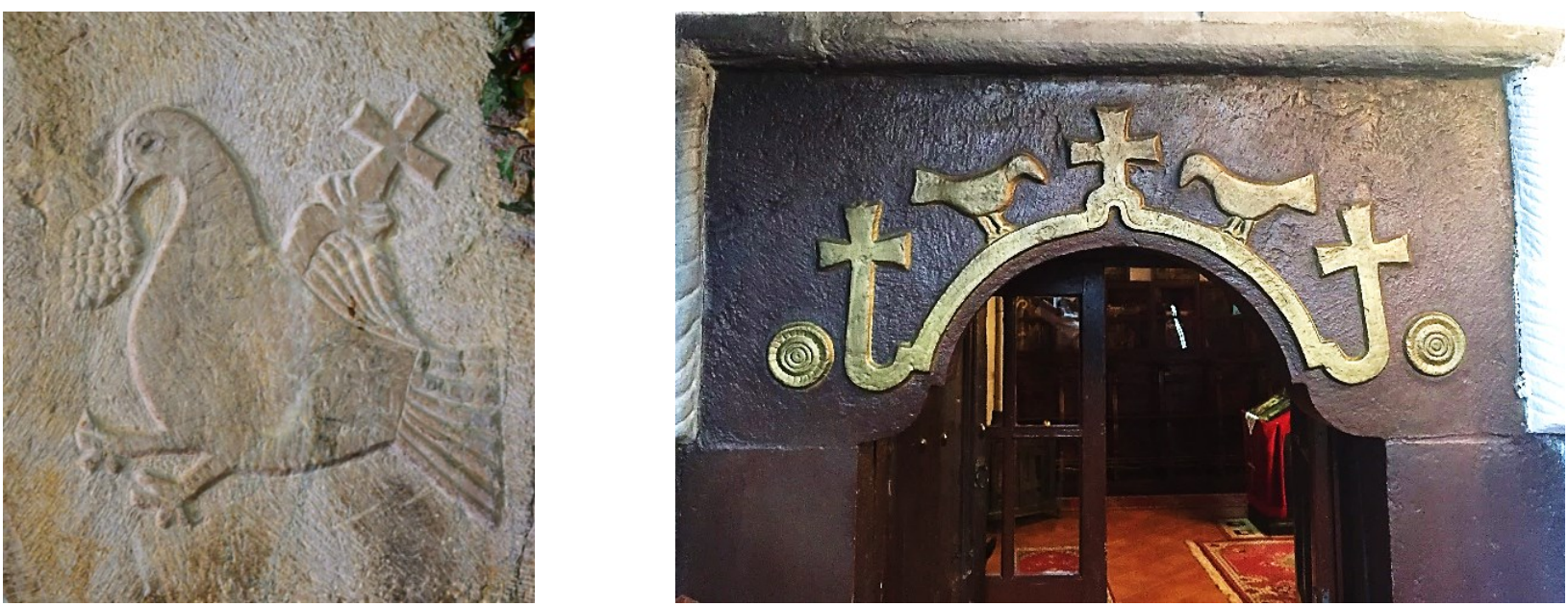

Figure III.58 Details of entrance portals with Eucharistic iconography: A. Western portal of St. Nicholas in Vevchani (Struga); B. Southern portal of St. Nicholas Gerakomija in Ohrid.

At St. Nicholas Gerakomija in Ohrid, for example, a parallel curved strip follows the line of the arched lintel in the center of which is placed a procession cross with extended arms (of the Maltese type) flanked by two facing pigeons. At both ends the ribbon is rolled upwards as a pedestal for two additional elongated Maltese crosses, and a solar rosette is placed on their outer sides (fig. III.58B). At the church of St. Nicholas in Vevchani (Struga) the western portal comprises a symmetrical composition of two facing doves, on whose wings rest Greek crosses, and which in their beaks carry an ornament in the form of a pine cone (fig. III.58A). The birds themselves are characterized by anatomical realism, with vivid imitation of feathers on the wings and tails and precise, gentle processing of their heads and feet. Another variant 
of a simplified Eucharist scene is one consisting of leafy ornaments in intricate intertwining complemented with angels and a central cross - at St. Nicholas in Virche, near Delchevo (fig. III.59A); or angels-seraphim in shallow relief (at the southern portal of St. George in Resen (fig. III.59B).
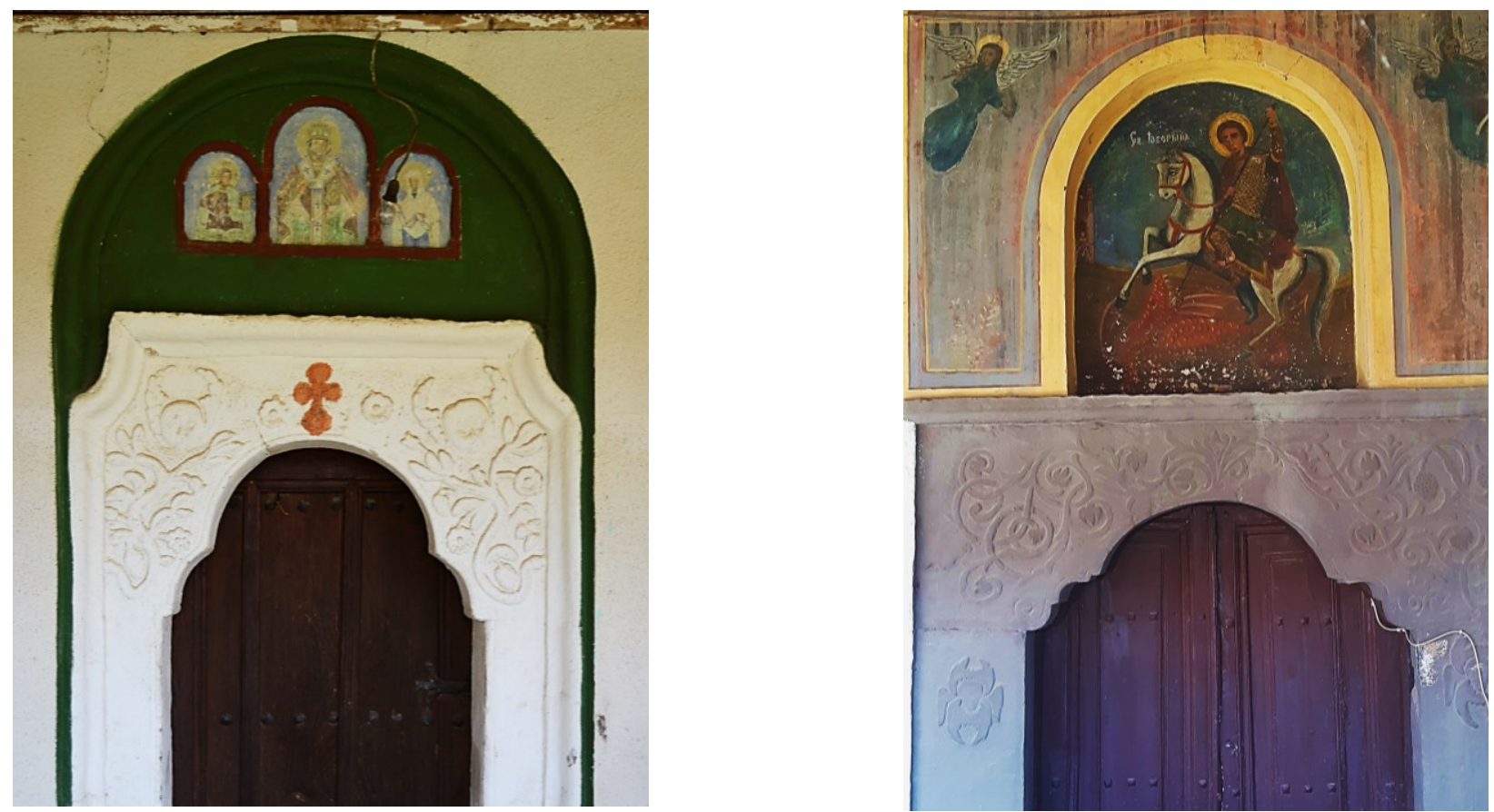

Figure III.59 A. St. Nicholas in Virche (Delchevo); B. St. George in Resen. Details of the southern portals.

Within the portals, in the upper zone above the entrance, a shallow arched niche regularly appears, in which a fresco of the saint to whom the temple was dedicated was painted, often including an inscription of the year of construction or consecration of the church. The patron saint niche placed above the entrance to the temple was not a novelty characteristic of the Revival, but rather appeared in the Byzantine churches, and was then regularly incorporated in the churches of the post-Byzantine period (see fig. 1.42). Unlike the Byzantine and post-Byzantine prototypes, which were simple, semi-circularly arched blind niches (see fig. I.38B), the patron saint niches during the Revival, as the portals themselves, developed and evolved both in terms of shape as in terms of ornamentation. For example, on one hand, they could be narrow and elongated (as is specific for the churches in the region of Makedonski Brod), or on the contrary, low and wide (frequent in the region of Prespa).
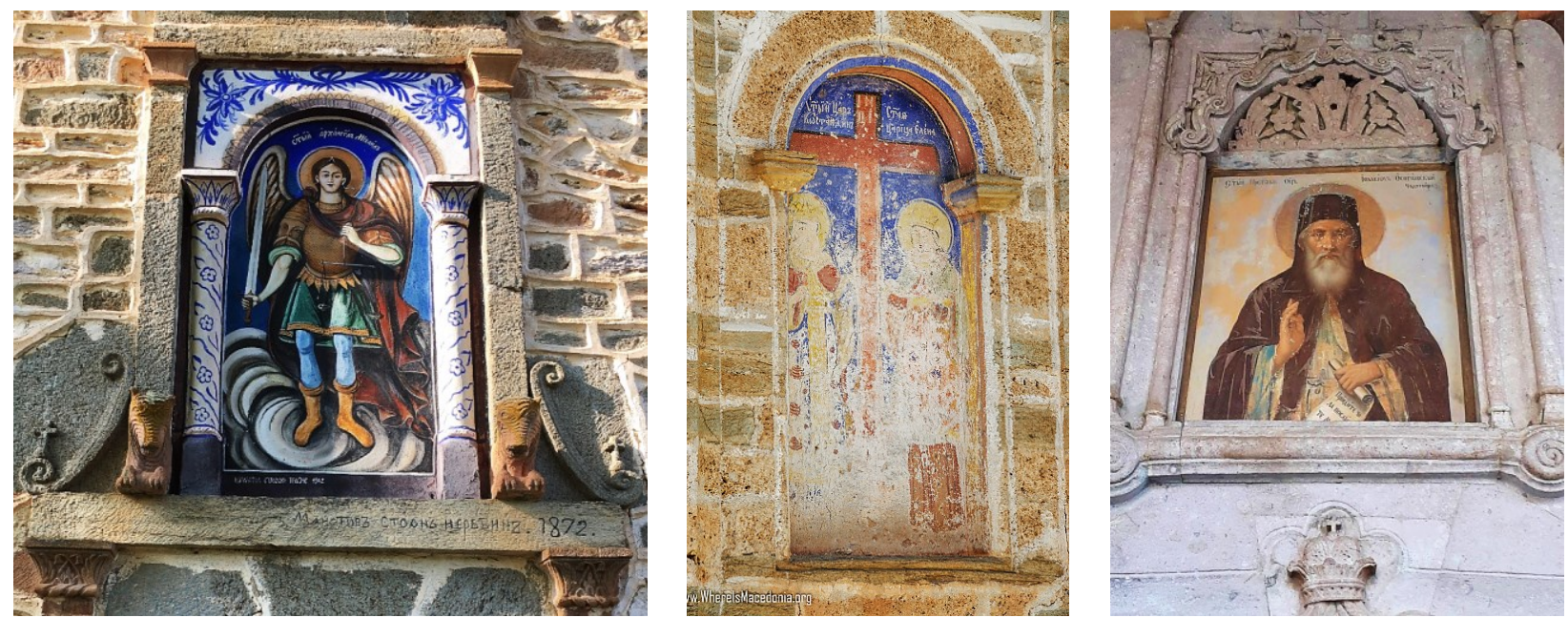

Figure III.60 Details of patron saint niches: A. St. Nicholas in Orlanci (Kichevo); B. St. Nicholas in Slepche (Demir Hisar); C. St. Joachim Osogovski, Kriva Palanka. 
Furthermore, they often received additional decorative treatment in stone plastic, shallow relief and fresco-painting, which converted them into focal points against the otherwise simplistic façade elaboration. Among the finest and most sculpturally elaborate patron saint niches (as are the entrance portals to which they belong, of course) are the ones at the cathedral churches built by Andreja Damjanov (fig. III.60C) and Gjorgji Novakov - Dzongar (fig. III.61) in the important urban and monastic centers. Perhaps their Revival portals demonstrate the most easily legible Renaissance and Baroque elements: " $\mathrm{S}$ " volutes, crowns and coat of arms motifs, etc.

Furthermore, the jambs of the semi-circular niche embedded within a larger rectangular niche, were sometimes composed as pilasters adorned with decorative capitals, as is the case of the western portal of St. George in Zashle, as well as the southern portal of St. Nicholas in Slepche (fig. III.60B), both villages in the region of Demir Hisar. The difference between these two very similarly conceived patron saint niches is that at the church in Zashle the lateral columns also have bases. Furthermore, in some churches the semi-circular niche is flanked by protruding columns with almost completely circular cross-section, also adorned with decorative capitals and bases, such as the church of St. Nicholas in Orlanci (fig. III.60A). In addition to a floral decoration painted on the structure of the patron niche itself: floral spirals on the columns, palm leaves on the capitals and a floral wreath across the arch of the niche, in this case the niche is further enhanced by placing it within a sculpturally processed frame, with lateral monolithic pilasters topped by capitals in the shape of an upsidedown pyramid. The bases of these pilasters are, in fact, sculptures of crouching animals, flanked by elegant baroque "S" volutes.

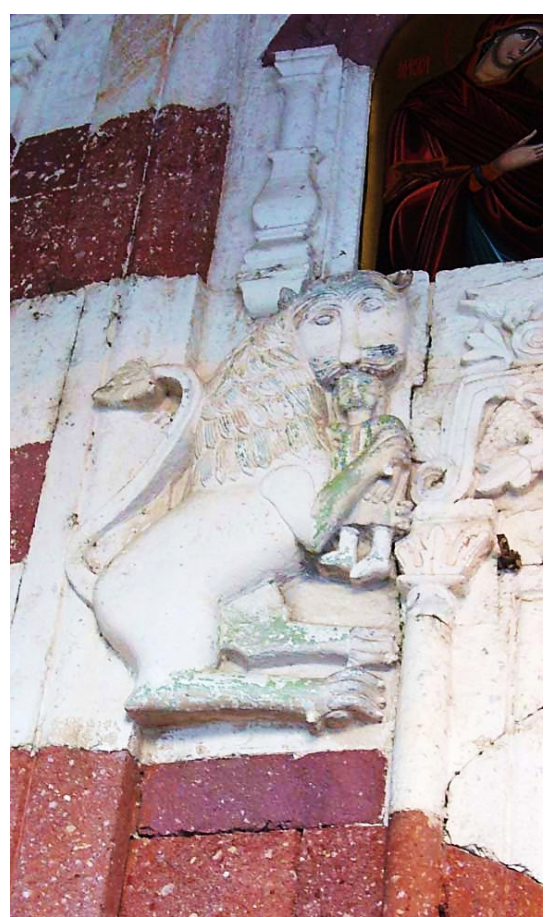

Figure III.61 Detail of the entrance portal of St. Nicholas in Shtip.
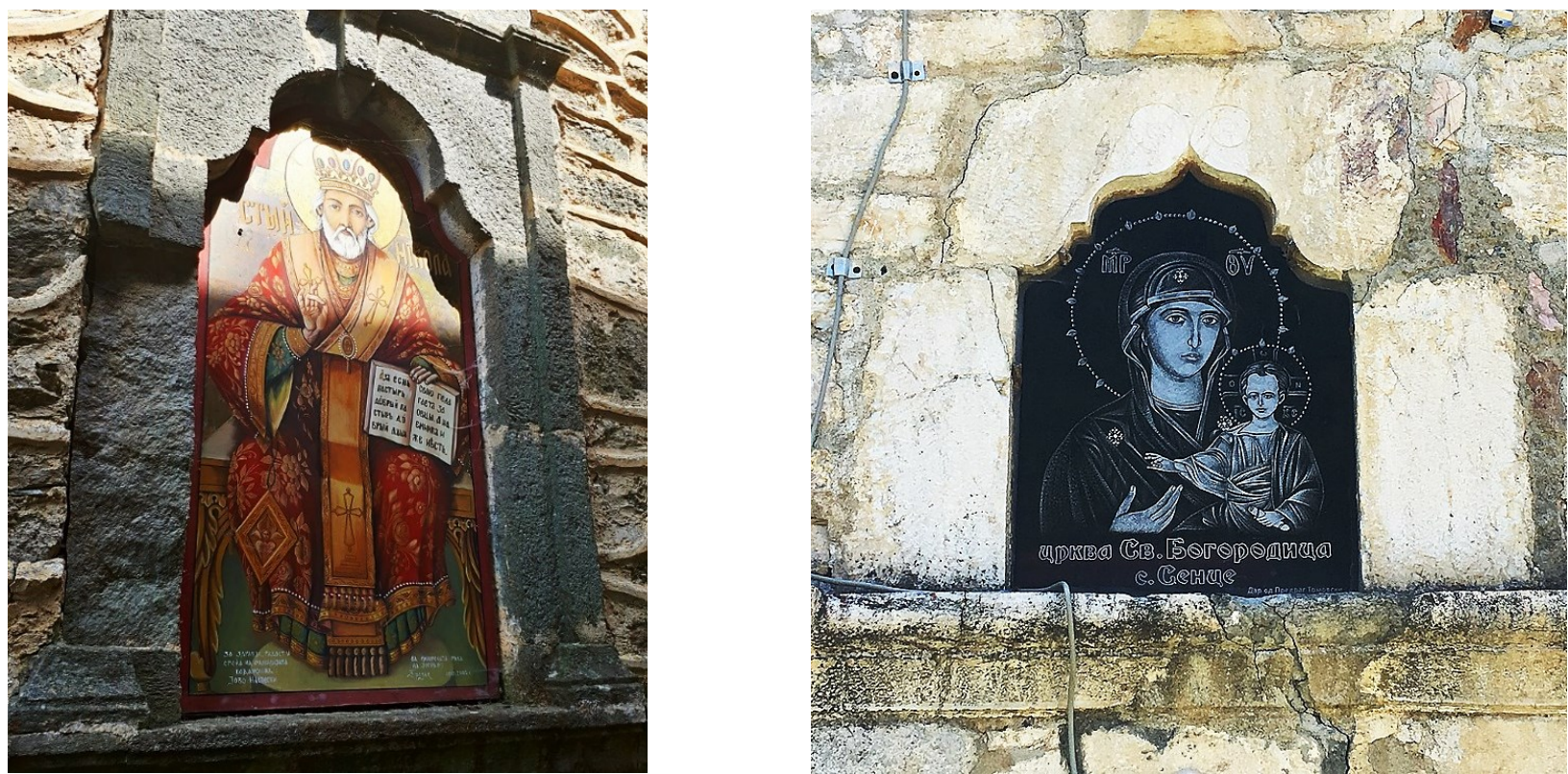

Figure III.62 Patron saint niches: A. St. Nicholas in Slansko (Makedonski Brod); B. the Most Holy Mother of God in Sence (Mavrovo).

A similarly shaped patron niche, made of precisely carved granite, with lateral pilasters with profiled bases and capitals, can also be found at the church of St. Nicholas in the village of Slansko, region of Makedonski Brod (fig. III.62A). The main difference is the shape of the arch itself, which in this case is not 
semi-circular but rather a more complex profile consisting of concave and convex segments, adorned with a "false", purely decorative key-stone. In addition to the church in Slansko, there are other examples where the patron saint niche's arch was composed in a similar way, with the typical Revival combination of concave and convex arch segments, with a key difference: instead of a semi-circular center, they display a pointed arch as an evident Islamic influence. Such examples are the niches within the entrance portals of the church of the Most Holy Mother of God in Sence (fig. III.62.B), as well as St. Barbara in Zhuzhnje, both in the region of Mavrovo.
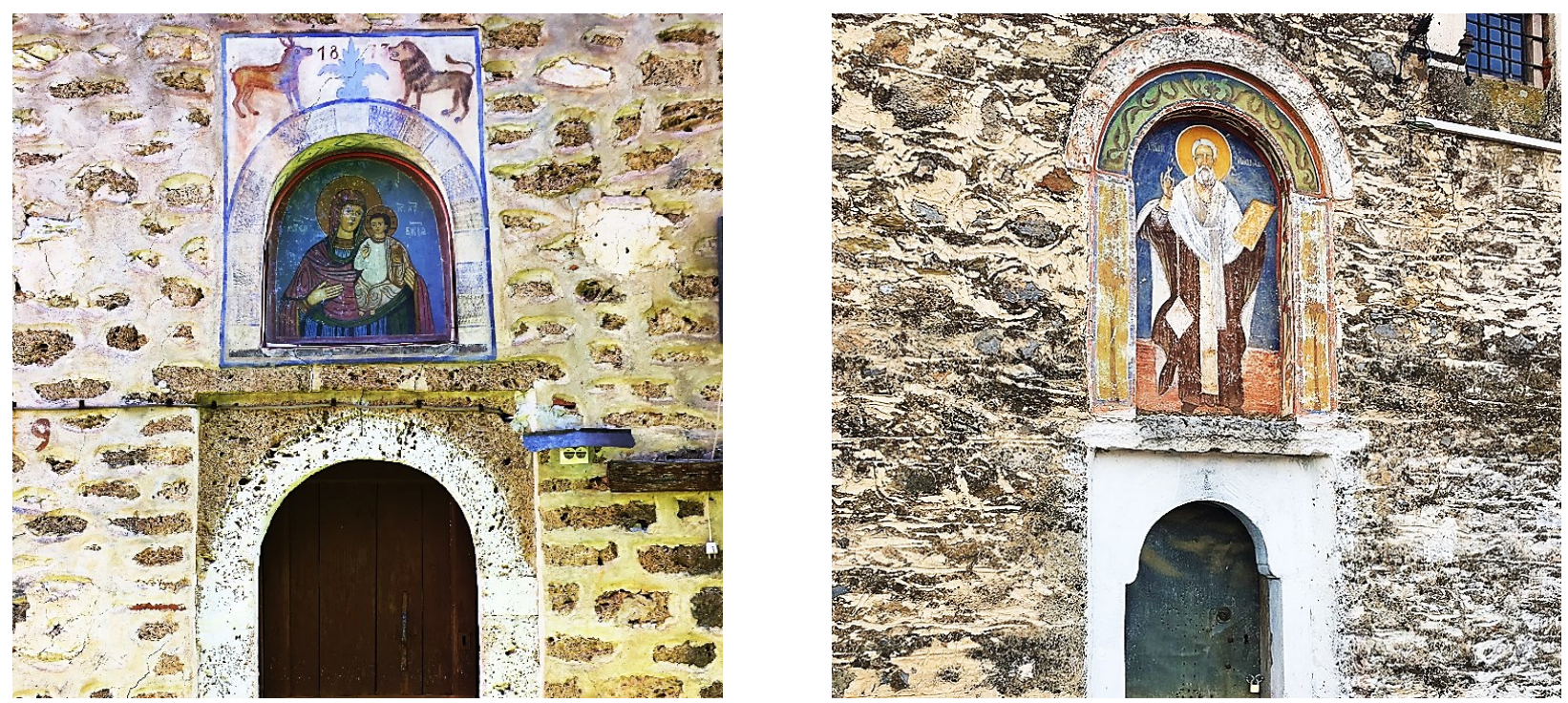

Figure III.63 Patron saint niches: A. St. Panteleimon in Belica (Kichevo); B. St. Nicholas in Golemo Radobil (Prilep).

Furthermore, in addition to the exceptional processing of the stone, the entrance portals and the patron saint niches were often additionally painted, which further emphasized their decorative nature. Alternating painting of stone blocks in two shades within the semi-circular arch is fairly common, ${ }^{312}$ while floral ornaments were painted less frequently (see fig. III.60A). Such an example can be found in the church in Prostranje, where the sides of the arch of the patron saint niche (in which St. Nicholas was painted) were painted with blue branches while in the arch's crown an elongated cross was painted, along with the year of construction (1889). A similar concept was employed at St. George in Malo Crsko, where on the arch of the patron saint niche (with the usual composition of St. George on horse-back, slaying the dragon with a spear) a wreath of palm leaves in blue tonality was painted over a terracotta background. The patron saint niche of the church of Resurrection of Christ in Dedebalci (Bitola) is similar. Another example of a floral wreath adorning the arch of the patron saint niche can be found at the church of St. Nicholas in Golemo Radobil, region of Prilep (fig. III.63B). In this case the narrow, elongated double arched niche, in which the patron saint was depicted in full height, was enriched with floral ornamentation in the form of baroque curved branches on both arches, while their supports are painted with tall, slender treeof-life motifs against a uniform ocher background, in blue framed rectangular fields. The narrow spaces in the depth of the niche were also completely painted.

At the church of St. Panteleimon in Belica, near Kichevo (fig. III.63A), the frame of the patron niche (jambs and arched lintel) were painted in three shades, emphasizing the stone blocks from which they were built, with additional texture of the stone achieved with a painted porosity effect. Above the crown of the arch is a motif of a fleur-de-lis in blue, flanked by the inscription of the year of construction: 18-73. This motif is further flanked by two animal figures: a deer to the left and a lion to the right.

${ }^{312}$ For example, on the west façade of the church of St. Petka in Capari (Bitola); the Most Holy Mother of God in Pobozhje (Skopje); St. Savior in Creshevo (Skopje); St. Trinity in Podles (Veles), etc. 
Two curved vine branches, heavily adorned with ripe grapes plucked by two birds encircle the elongated semi-circular patron saint niche at St. Peter and Paul in Tresonche (Debar - Reka), painted by one of the most prominent Revival fresco and icon painters - Dicho Zograf (fig. III.64A). Another patron saint niche painted by the same author is the one within the southern portal of the Great Holy Healers (St. Cosmas and Damian) in Ohrid (fig. III.64B), where the short semi-circular niche which houses the fresco-composition of the two healer saints in full height is flanked by two baroque " $\mathrm{S}$ " palmette volutes and topped by a floral crown executed in indigo tones.
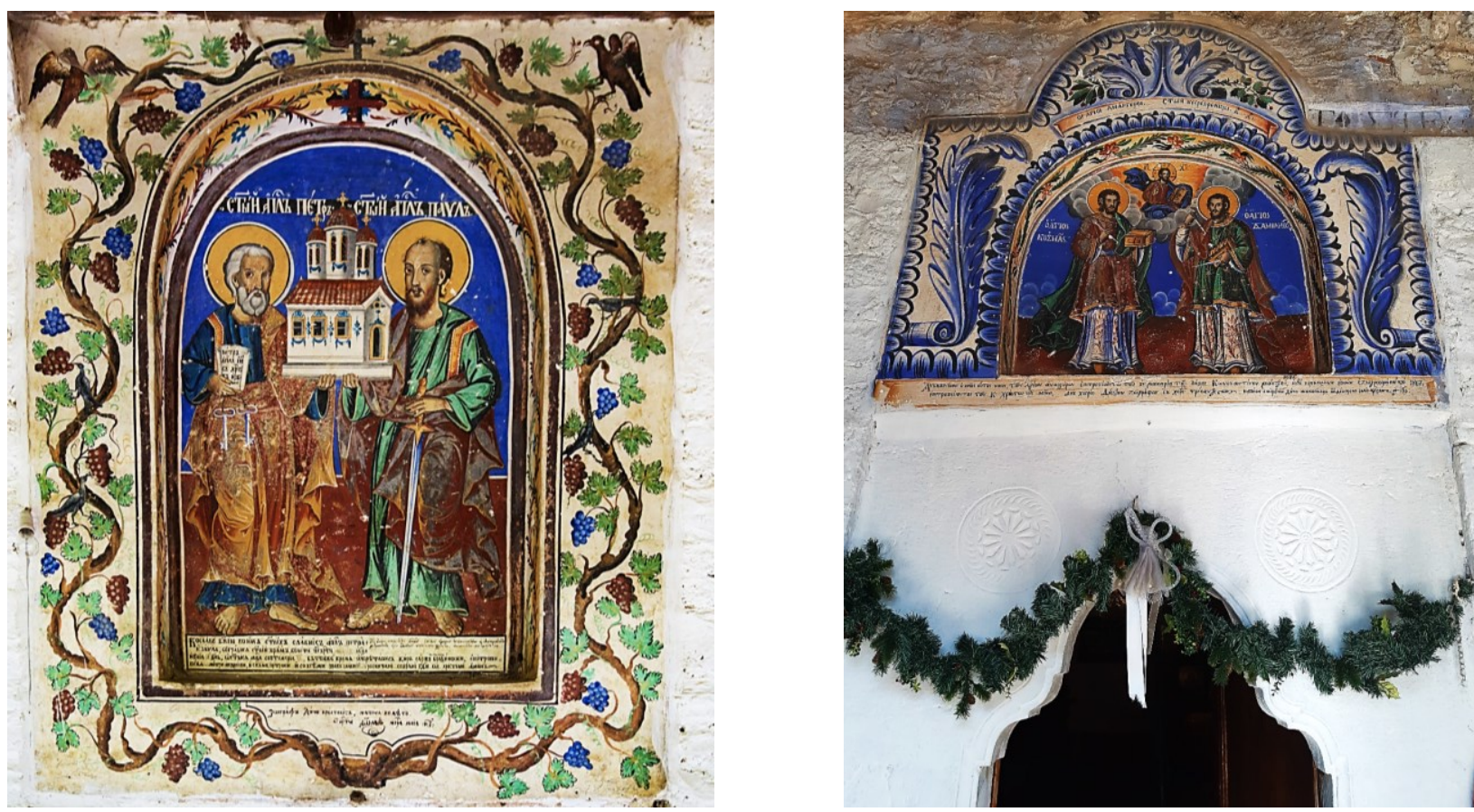

Figure III.64 Examples of patron saint niches painted by Dicho Zograf: A. St. Peter and Paul in Tresonche (Debar); B. the Great Holy Healers (St. Cosmas and Damian) in Ohrid.

Occasionally, the doors themselves, regularly made of wood, were also decorated with crosses, as well as geometrical (square, rhombic and circular) or solar motifs. ${ }^{313}$

\section{Windows and Window Transennas}

Unlike the Byzantine and post-Byzantine churches, the Revival temples were illuminated through larger and more numerous windows, which "reflect the changed relationship of the inner and outer world, break the contemplative atmosphere of the Byzantine temple at the expense of the humanistic view of the citizens" (Тричковска, 2008: 37). An exception to this tendency were the altar apse windows, which were usually quite narrow and often resemble slots within the masonry of the apse.

The single architrave or arched window openings (fig. III.65) prevail in the Revival ecclesiastical architecture; however, double windows, circular windows - oculi and cross-shaped windows are also common. They usually lie flat on the façade plane, but there are also examples where the windows were embedded within a rectangular ${ }^{314}$ or arched $^{315}$ shallow niche, as a reminiscence of the façade articulation in the late-Byzantine architecture. This contributes to achieving greater fragmentation and depth through the play of light and shadow, in contrast to the otherwise uniform flat façade canvas.

\footnotetext{
313 Such an example is the church of St. Archangel Michael in the village of Optichari, region of Bitola.

${ }^{314}$ At the church of St. George in Belica (Kichevo), for example, the windows on the lateral façades are rectangular, placed in slightly larger rectangular shallow niches; at St. Elijah in Dojran the rectangular niches are extremely high, thus transitioning from an element for definition of the window openings to an element for articulation of the façades themselves.

315 For example, at St. George in Capari (Bitola); St. Demetrius in Stracin; the Zabel Monastery near Kumanovo (see fig. III.5), etc.
} 
Furthermore, a common solution is a window with an architrave lintel on top of which a shallow arched niche appears, which, in addition to its decorative role, serves for lateral transfer of the loads from

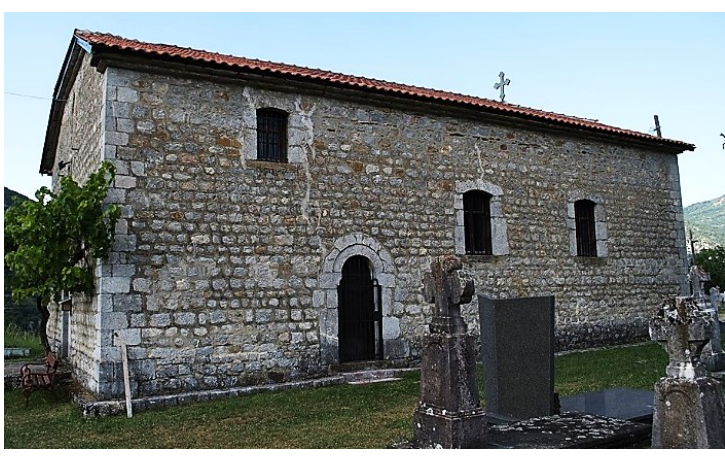

Figure III.65 St. Athanasius in Modrich (Struga).

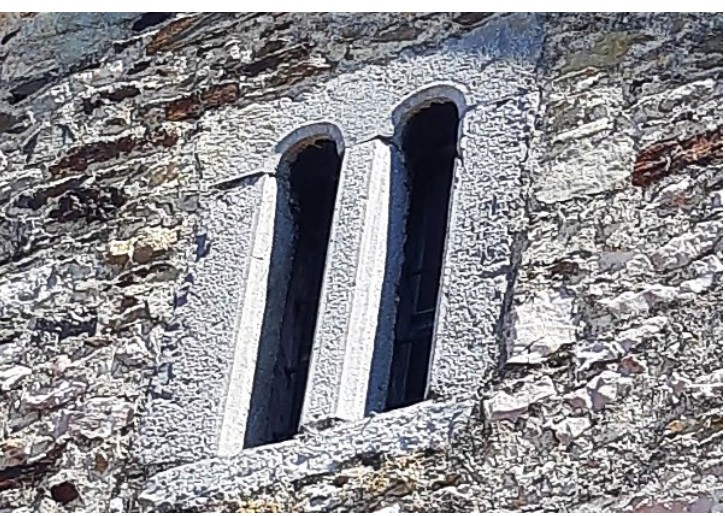

the wall mass above the window. This niche can be made only of stone, ${ }^{316}$ a combination of stone and brick, ${ }^{317}$ or even just brick. ${ }^{318}$ Sometimes, above the shallow niche (placed over the architrave window made of stone) there is another additional brick arch, such as at the church of St. John in Kratovo by Andreja Damjanov (see fig. III.15A), as well as the church of St. Nicholas in the same town, heavily influenced by the older nearby church.

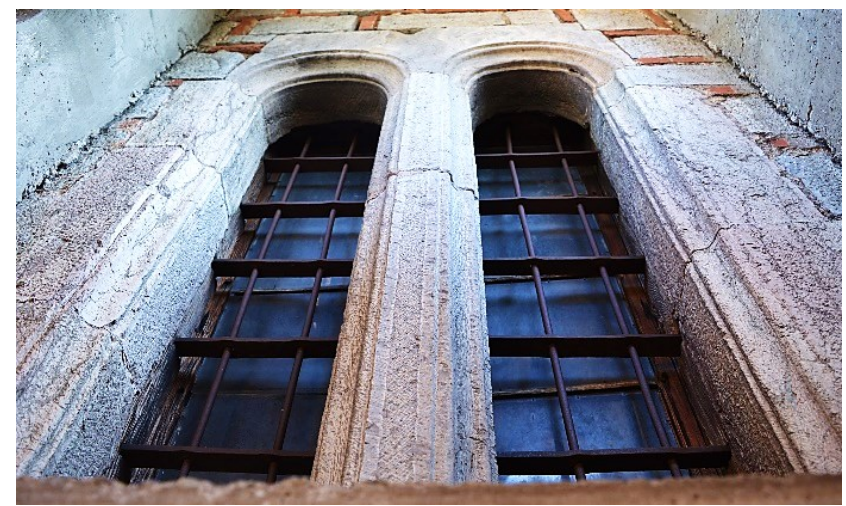

Figure III.66 Examples of double windows: A. St. George in Drmeni (Prespa); B. St. Nicholas in Vevchani (Struga).

The more representatively built churches often had double, slender, elongated semi-circularly arched windows placed in the axis of the west and/or east façade (fig. III.66). Such windows were a common feature of the middle-Byzantine churches: for example, the triple arched windows in the altar apses of St. Achilles, the Most Holy Mother of God in Vranishta and the apse and the western façade of the church in Velushina (see Chapter I.4.2). Since all of the Revival churches with double windows are located within the Ohrid-Prespa region, ${ }^{319}$ the transfer of this characteristic element from the Byzantine prototype to the Revival ecclesiastical architecture becomes all the more clearer.

Even in the simplest conceived window openings care was always taken to use usually monolithic high quality hewn stone blocks for the lintel, jambs and sill, as well as to arrange the windows in a horizontal line and in a uniform rhythm, so that even the most modestly processed façades achieved a certain quality of moderation and elegance (see fig. III.51, III.65, III.68). Furthermore, even the simple single windows on the lateral façades often received decorative treatment in stone plastic: hewn, carved and profiled stone was used for the window frames, both in the arched as in the architrave windows. The prevalent profile is analogous to that common for the crown cornices, which is a combination of rectangular, concave and convex segments. ${ }^{320}$ In addition to the decorative profile of the window frames, the window lintels (and sometimes even the jambs) often received ornaments executed in shallow relief. The most common motifs are crosses, ranging from simple Greek crosses to elaborate procession crosses

\footnotetext{
${ }^{316}$ As in the church in Gari near Debar, the church in Star Istevnik near Delchevo (see fig. III.51), etc.

317 For example, at St. Nicholas in Nebregovo (Prilep), at St. Sotir - Bukovo monastery near Bitola (see fig. III.215), etc.

318 At St. Savior in Creshevo (Skopje).

${ }^{319}$ At the western façade of St. Nicholas in Vevchani (Struga); St. George in Drmeni (Prespa) and St. Nicholas in Leskoec (Prespa); at both façades of St. John the Forerunner in Jankovec (Prespa).

320 For example, at the church of St. Athanasius in Bohula (Kavadarci); the Most Holy Mother of God in Gari (Debar - Reka); St. Peter and Paul in Tresonche; the church in Malo Crsko and so on.
} 
with a trapezoidal pedestal (fig. III.67); Maltese crosses; phytomorphic crosses with four leaf clover-shaped arms, etc. Furthermore, though not as commonly, solar and cosmogonic motifs appear, as well as rosettes, hexagram motifs and winged angels - cherubim. Lastly, in some cases the windows copied the eclectic nature of the entrance portals and displayed a variety of evident Western European Renaissance and Baroque influences, such as decorative profiled consoles below the window sills (fig. III.68B), elongated baroque " $\mathrm{S}$ " volutes, the fleur-de-lis motif, etc. Another influence possibly derived from the Gothic architecture are the windows shaped into pointed, segmental arches (fig. III.68A), which at the same time could also constitute an Islamic import.

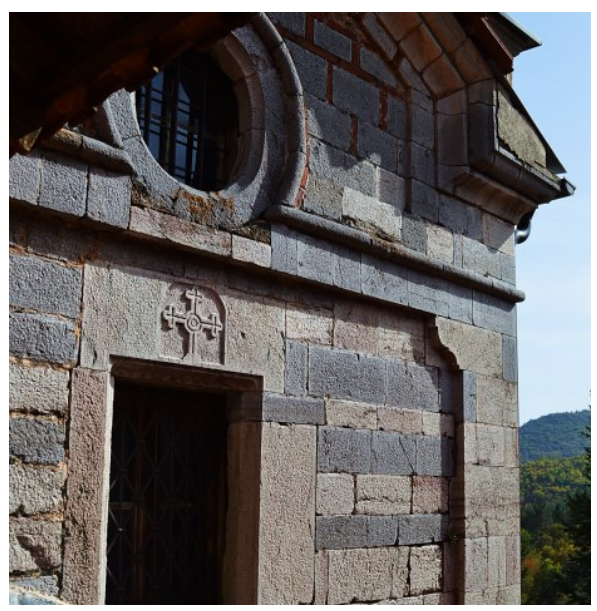

Figure III.67 Detail of the western façade of $S t$ Nicholas in Vevchani (Struga).
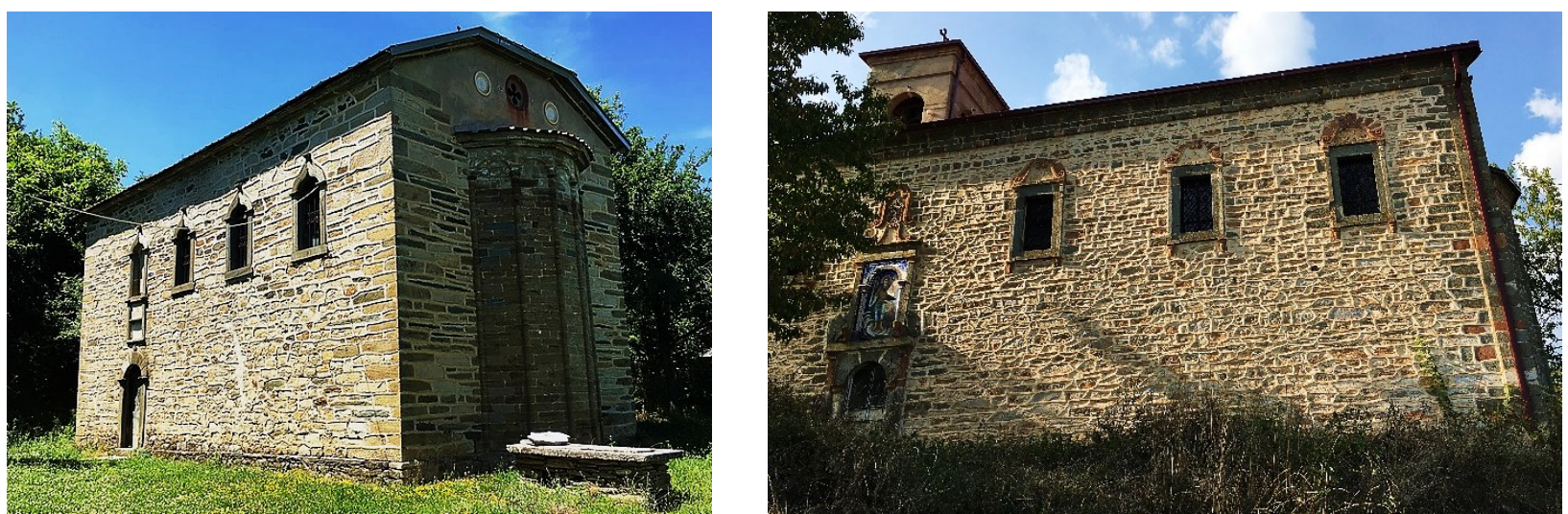

Figure III.68 A. St. Constantine and Helena in Tomino Selo (Makedonski Brod); B. St. Nicholas in Orlanci (Kichevo).

On the inside, the windows have a simple rectangular or arched finish (fig. III.69). Without exception, the inner opening of the window is significantly larger than its outer face which tends to be rather small, approximately 1-1.5 arshin $(75-90 \mathrm{~cm})$ wide. Thus, the windows spread in the shape of a funnel within the thickness of the wall, allowing light to enter the temple at a wider angle, which contributes to the bright, ethereal, immaterial effect of the Revival church interiors.
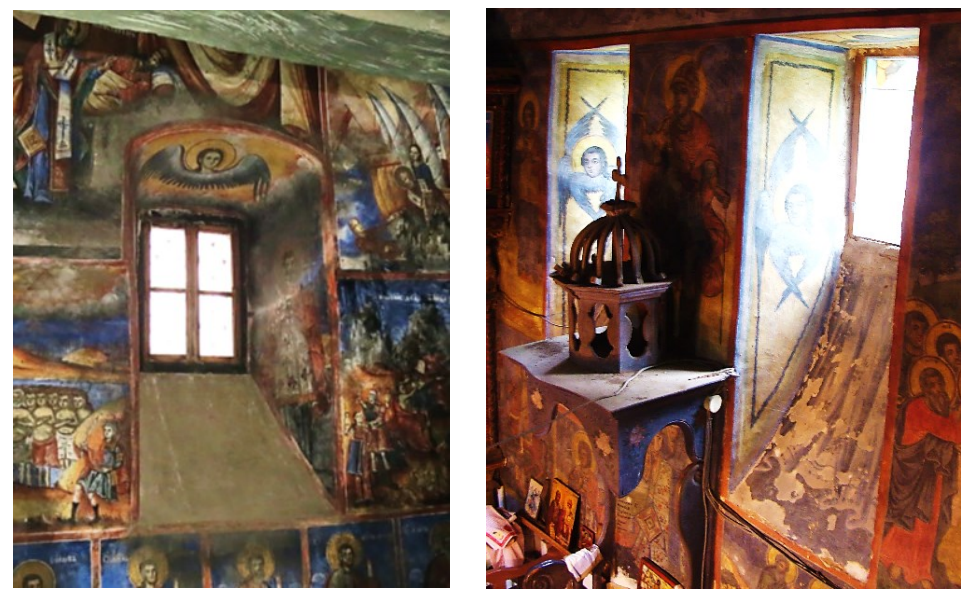

Figure III.69 View of the windows from the interior of the church: A. St Nicholas in Vevchani (Struga); B. St. Savior in Rashtak (Skopje).

While the windows on the lateral façades (and the double windows) were most commonly covered with glass panes and protected by decorative cast iron bars, the windows on the eastern and western façade regularly received an additional decorative elaboration materialized in stone carved window transennas. To begin with, these windows themselves - prevalently located in the axis of the appropriate façade (above the altar apse on the eastern façade; above the patron saint niche of the entrance portal on the western façade) could significantly vary in form. The dominant solution is a square or rectangular window (fig. III.70A), through arched windows (fig. III.70B) to circular windows (oculi), ovals (mandorlas), octagons (fig. III.71) and complex cross or clover - shaped windows, often with decorative profiled frames. 

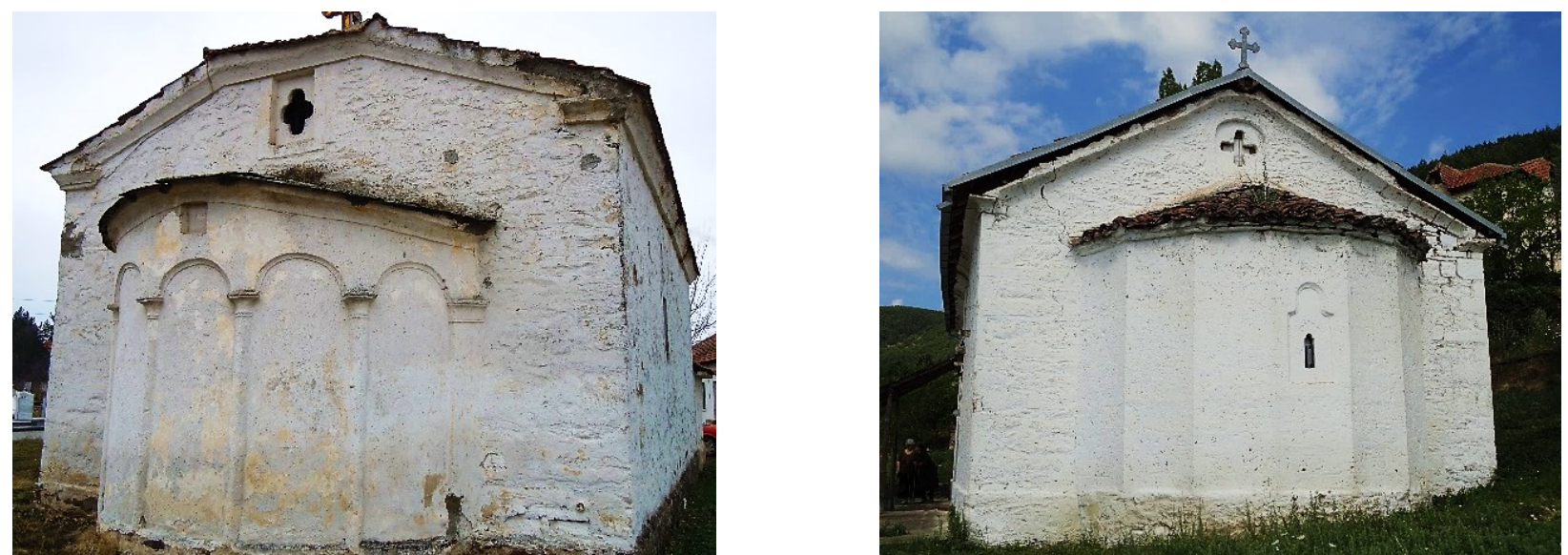

Figure III.70 View of the eastern façade of: A. Resurrection of Christ in Dedebalci (Bitola); B. Dormition of the Most Holy Mother of God in Evla (Prespa).

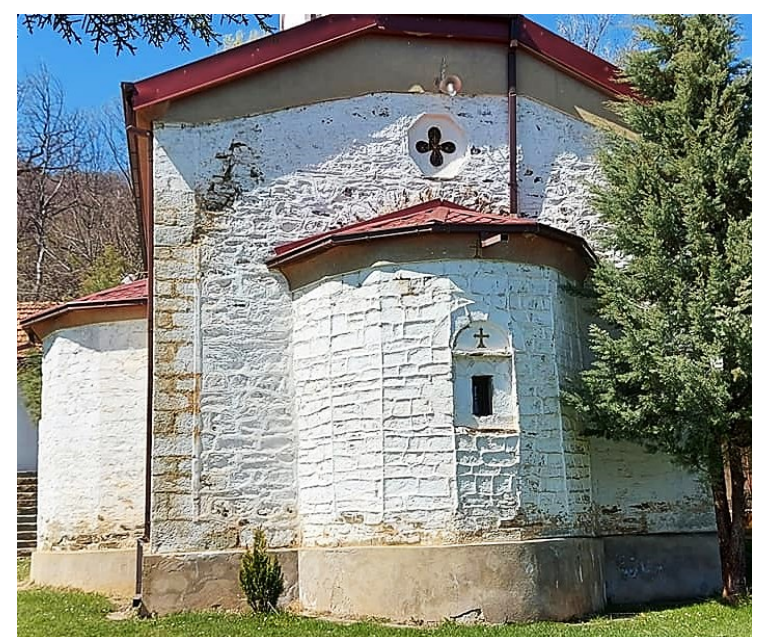

Figure III.71 The eastern façade of St. John the Baptist in Beranci (Bitola).

Within the window openings, regardless of their shape, stone slab transennas were embedded, which could be carved and elaborated into a variety of decorative motifs. The most commonly used are the cross-shaped motifs. ${ }^{321}$ The simplest solution is, obviously, the greek cross, which has four equally long, straight arms; or an elongated cross with straight arms. $^{322}$ This simplest type was often further decoratively processed so that the cross' arms gradually spread wider towards the edge of the transenna, as in a Maltese cross (fig. III.74B). Furthermore, the cross' arms were very often ended in a rounded instead of square fashion (fig. III.70, III.71). ${ }^{323}$ The phytomorphization of its ends allows the cross motif to slowly evolve into a four-leaf clover or simple four-petal flower motif known as tetraphyllia or crux florida which, despite its flower-like appearance still preserves its essential Christian symbolism and, as such, is a common motif in the Christian iconography that can be traced back to the early-Christian stage. ${ }^{324}$ In fact, the phytomorph cross is the prevalent typology of the Revival window

321 While in the medieval sacral construction in Macedonia there were no cross-shaped windows, cross-like motifs were very common in the decorative elaboration of the façades, especially in the late-Byzantine period, but also much earlier. Cross motifs made of brick can be found on the façades of St. Sophia in Ohrid since its first construction phase (XI century) as well as on the western façade of archbishop Gregorius' exonarthex; on the southern façade of St. Panteleimon in Nerezi from the XII century; in the brickwork decoration of the late-Byzantine churches in Lesnovo, Staro Nagorichane, Varosh near Prilep, etc.

${ }^{322}$ At the western façade of St. Peter and Paul in Gorno Aglarci (Bitola); St. Stephen in Nezhilovo (Veles); the eastern façade of the church in Janche (Debar); St. Nicholas in Podgorci (Struga); the apse of St. Demetrius in Bogdevo (Gostivar) and the western façade of St. Savior in Oraovec (Veles), built by Andreja Damjanov's brothers Nikola and Kosta.

${ }^{323}$ At the eastern and western façade of the Dormition of the Most Holy Mother of God in Paralovo, Mariovo (fig. III.71); St. Athanasius in Strugovo (Demir Hisar); the Resurrection of Christ in Dedebalci (fig. III.70A); Nativity of the Most Holy Mother of God in Crnichani (Bitola); St. Peter and Paul in Radobor (Bitola); Dormition of the Most Holy Mother of God in Bistrica (Veles); St. Athanasius in Bohula (Kavadarci) and many, many more.

${ }^{324}$ It is important to emphasize the fact that this type of transennas were used in Macedonia earlier, for example at the church in Tepavci from the late XVIII century, or St. Nicholas in Manastir. In both churches, the location of windows processed in this way coincides with the Revival model: they are installed high on the west and east façade. Furthermore, the four-leaf clover as a motif of phytomorphization of the cross was not always limited to the window openings, but was also used in the decorative brickwork procedure of the façades. Such an example can be found on the southern façade of the church of the Lesnovo Monastery, dating to the XIV century, where a cross-shaped motif made of brick is embedded in a stylized four-leaf clover. Going back to the early-Christian period, the motifs of a cross placed in a four-leaf clover, with lateral shoots of pointed ivy leaves, can be found on the parapet slabs at the Palikura basilica near Stobi (Алексова, 1983: 153). In the later period, the same motif within window transennas, oculi or rosettes was widely used in the Gothic architecture of the Adriatic coast from the XV century. 
transennas, and one of their most easily legible and defining external features. As such, it reached an abundance of varieties in both shape and size, as well as further development of the four-leaf clover motif from the basic cross-shape (fig. III.72A) to an increased emphasis on its floral appearance (fig. III.72B).
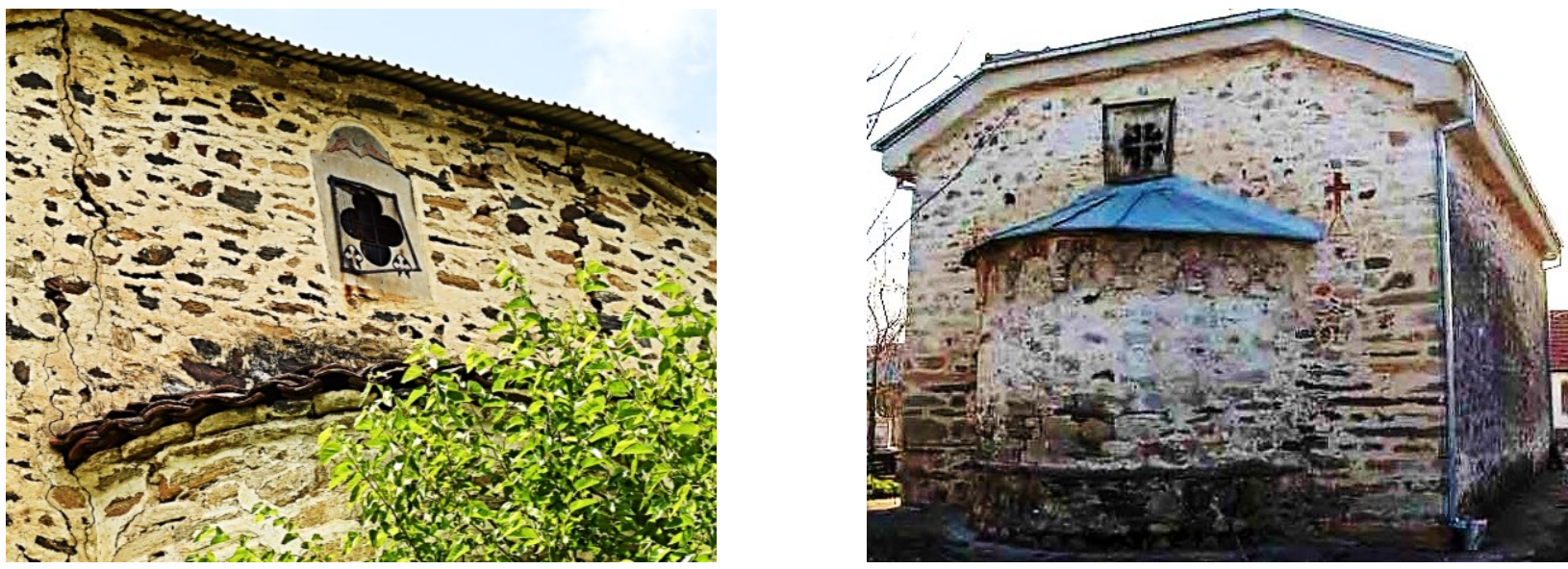

Figure III.72 Examples of four-leaf clover transennas: A. St. Nicholas in Mokreni (Veles); B. St. Nicholas in Trn (Bitola).

In addition, the four-leaf clover transennas often received further ornamentation in shallow relief, mostly with cross-shaped motifs, inscriptions, winged angels (fig. III.72A), or were placed within a larger decorative window opening with the same four-leaf clover shape (fig. III.73), ${ }^{325}$ or other geometrical shapes, such as an oval or an octagon. ${ }^{326}$

Furthermore, in some cases the four-leaf clover (phytomorphic cross) motif was rotated by $45^{\circ}$ which as such visually additionally abandons the cross as a symbol approaching purely phytomorphic motifs. ${ }^{327}$ Such example is the window transenna on the eastern façade of St. Nicholas in Trn (Bitola) where the clover

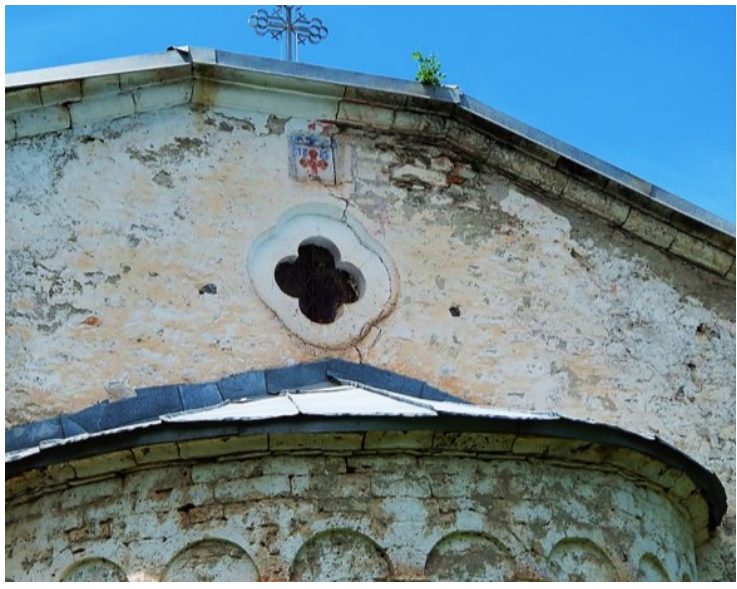

Figure III.73 Detail of the window transenna on the eastern façade of St. George in Belica (Kichevo). appearance is further accentuated by indenting each leaf radially toward the center (fig. III.72B).
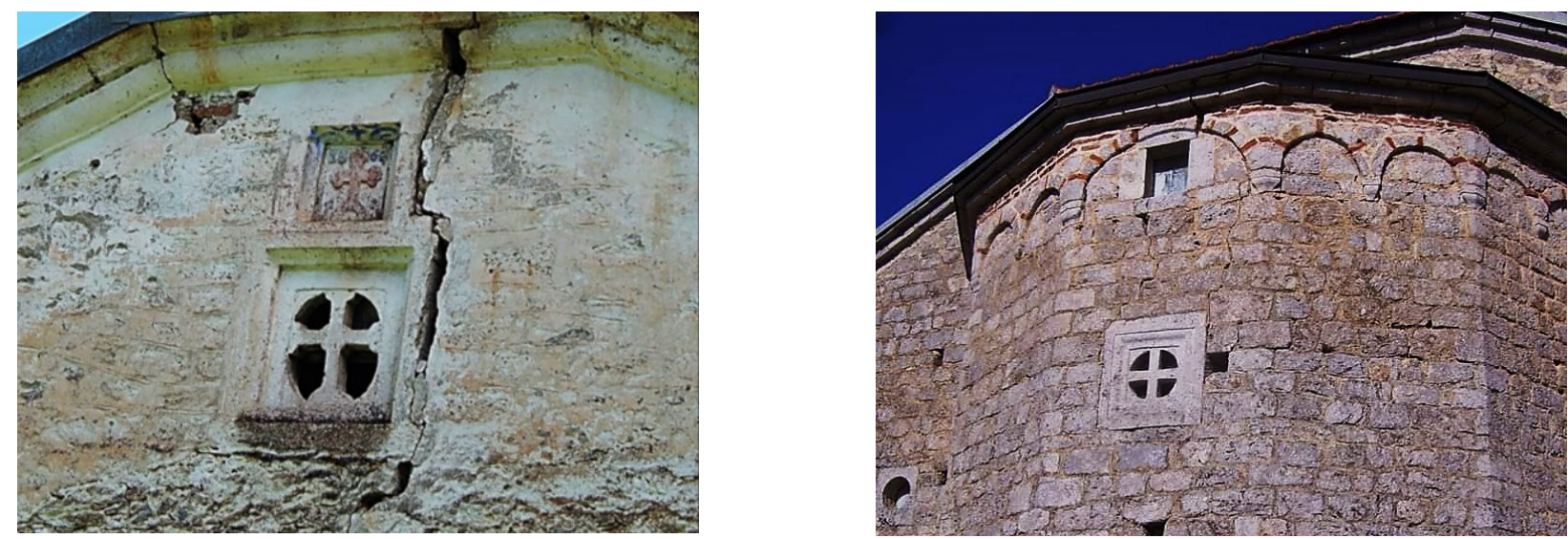

Figure III.74 A. St. George in Belica (Kichevo). Detail of the window transenna on the western façade; B. St. Elijah in Jablanica

(Struga). View of the window transenna on the eastern façade.

\footnotetext{
${ }^{325}$ At St. Elijah in Zashle (Demir Hisar); St. Nicholas in Slepche (Demir Hisar); St. Peter and Paul in Ratevo (Berovo), etc.

${ }^{326}$ At the western façade of the church of St. George in Podmochani (Prespa); the eastern façade of St. John the Baptist in Beranci, near Bitola (fig. III.71).

${ }^{327}$ At the church of St. Athanasius in the village of Bazernik, Demir Hisar; St. Theodore Tyron in Drenovci, Prilep; etc.
} 


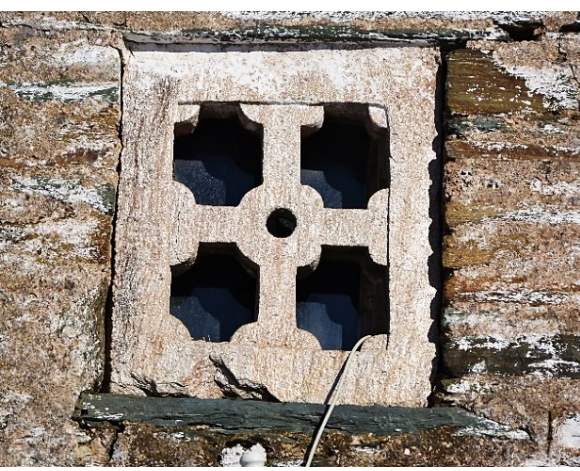

Figure III.75 Detail of the window transenna on the western façade of the church of $S t$. Athanasius in Beranci (Bitola).
Other types of crosses often used in the design of stonecarved window transennas are the procession cross, which is usually slightly elongated and placed on a trapezoidal base (in accordance with the nature of its prototype which is a cross used in the holiday processions, carried outside of the church and paraded on the streets), as well as the Maltese cross. In their case it is not the void carved out of the stone slab that is shaped into a cross, but rather the opposite: the void is square (fig. III.75), circular (fig. III.74B) or oval (fig. III.74A) and the cross motif itself is actually formed by a horizontal and vertical bar which dissect it. In other words, the cross is what remained of the stone slab once the negative space was carved out.

With further simplification of this method, there are many cases where the cross was but subtly insinuated with a combination of four carved out circles arranged around a central one, which is usually different in size. The arrangement can be genuinely cross-like (fig. III.76A), ${ }^{328}$ or the circles can be rotated by $45^{\circ}$ (fig. III.76B); ${ }^{329}$ in both cases the four outer circles are connected with the central one via thin slits, thus forming a cross. At the church of St. Demetrius in Dunje (Mariovo), additional four circular openings appear symmetrically placed at the corners of the transenna (fig. III.76A), which contributes to the resemblance of this particular cruciform motif to the apotropaic crosses that contain written formulas and abbreviations, such as IC-XC; IC-XC NI-KA or $\Phi X-\Phi \Pi$, which were a common façade brickwork decoration of the late-Byzantine churches (fig. III.76C).

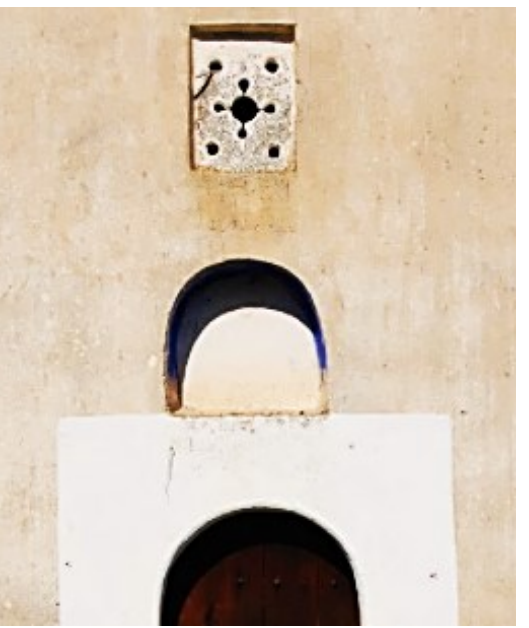

Figure III.76 A. St. Demetrius in Dunje (Mar
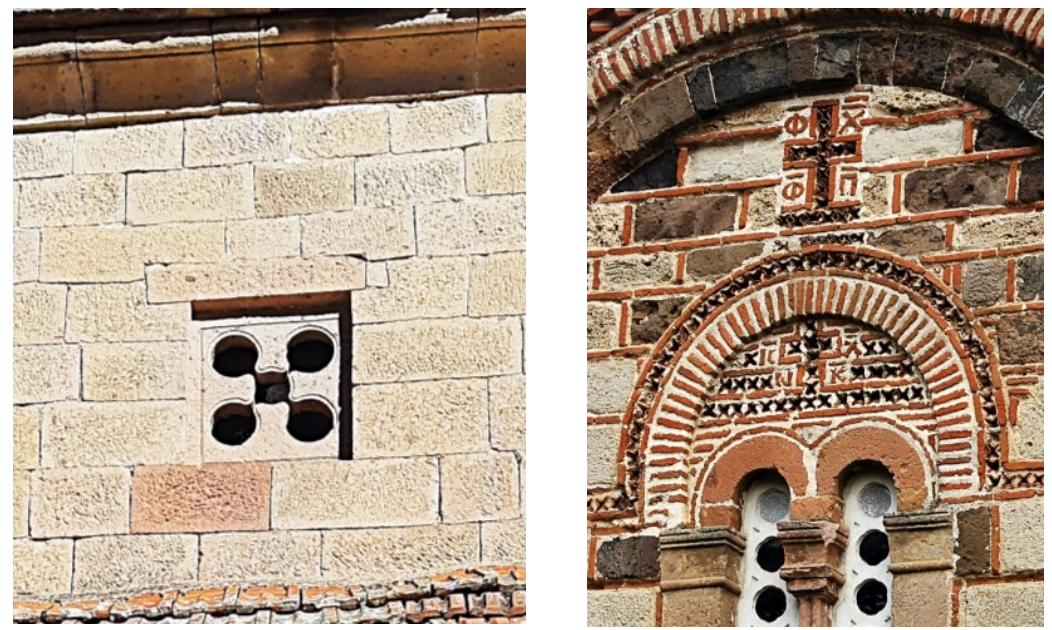

riovo); B. St. Demetrius in Stracin (Kratovo); C. St. George in Staro Nagorichane (Kumanovo), II phase - XIV century.

Exceptional wealth in the ornamentation of the window transennas is characteristic of the northeastern region of Macedonia, ${ }^{330}$ as a specific regional feature, in addition to the use of local stone (trachyte and travertine) which was discussed earlier (see Chapter III.2). The stone carved window transennas were processed in the form of intertwined, lacy, filigree-like arabesques, hexagrams and floral rosettes, whose overall impression is distinctly oriental (fig. III.77B-C).

\footnotetext{
${ }^{328}$ At St. Demetrius in Dunje (Mariovo); St. Petka in Rugjince (Kumanovo); the Most Holy Mother of God in Pobozhje (Skopje); the monastery Zabel (fig. III.80B); St. George in Zhegljane (Kumanovo) (see fig. III.), etc.

${ }^{329}$ At St. Demetrius in Stracin (Kratovo) (see fig. III.3, III.76B); at the monastery Zabel (fig. III.80B), etc.

330 In the regions of Kratovo, Kumanovo and Kriva Palanka: at St. John (fig. III.77.C); and St. Nicholas in Kratovo (fig. III.77.B); the churches in Opila (see fig. V.4); Shlegovo; the Zabel Monastery as well as the older, post-Byzantine temples in Zhegljane, Mlado Nagorichane and Strezovce.
} 

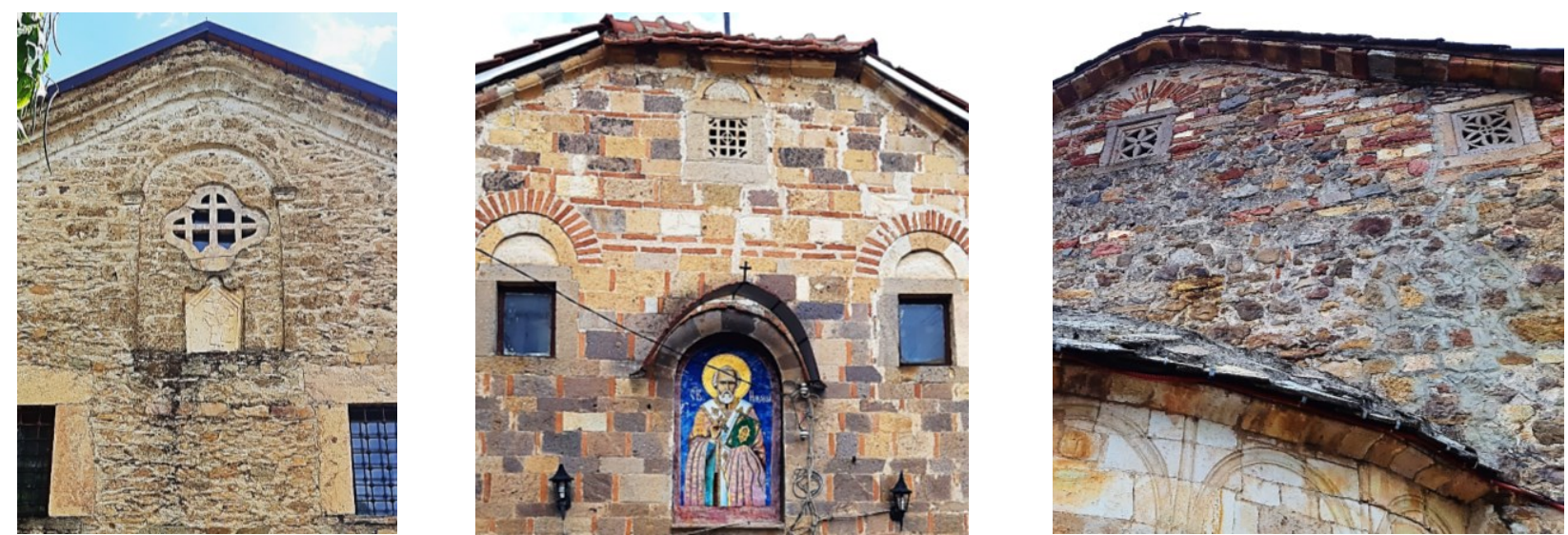

Figure III.77 Transennas with a complex design: A. St. George in Resen; B. St. Nicholas in Kratovo; C. St. John in Kratovo.

Lastly, there are also window transennas of unique, more complex design, such as the one at the western façade of the church of St. George in Resen (fig. III.77A), where the window opening itself shaped as a phytomorphic cross is covered with a decorative stone carved transenna consisting of three vertical and two horizontal bars that intersect at right angles, forming a complex procession cross disposition. The window is framed with a high, shallow arched niche, whose arch consisting of hewn blocks of stone is supported by two pilasters with profiled capitals. A re-used Roman funeral stelae is embedded into the masonry of the niche, beneath the window (see pages 183-184).

\section{Oculi and Mandorlas}

Another common solution for the main accent window on the eastern and western façade of the Revival churches is a circular (oculus) or an oval window opening (mandorla). As with the stone transennas, the origin of the oculus window is local and should be sought in the architecture of past eras. Namely, in the middle Ages (in addition to one example of a gothic-influenced stone-carved rosette discovered at the archeological site of the church of St. Athanasius in Leshok, near Tetovo, likely influenced by the architecture of the Adriatic coast) circular windows were executed on the façades of the (predominantly) late-Byzantine churches, most often made of radially arranged brick. Such example is the northern façade of the church of St. Demetrius in Varosh (Prilep), where above the central arch of the open porch and below the monumental triple window, a brick oculus appears in the axis of the façade. Large circular rosettes made of brick were installed high on the western front façades of the late-Byzantine churches in Ljuboten and Matejche, while at St. Nicholas Shishevski at Matka (fig. III.78) the oculus is in fact a re-used spoliae. A smaller oculus also appears on the north façade of the church of St. Demetrius Marko's Monastery, near Skopje.

In addition to ocular windows, significantly older examples where circular motifs were used within the decorative brickwork ensemble of the Byzantine and post-Byzantine façade canvases are quite common. Such an example is the church dedicated to the Dormition of the Most Holy Mother of God at the Leshok

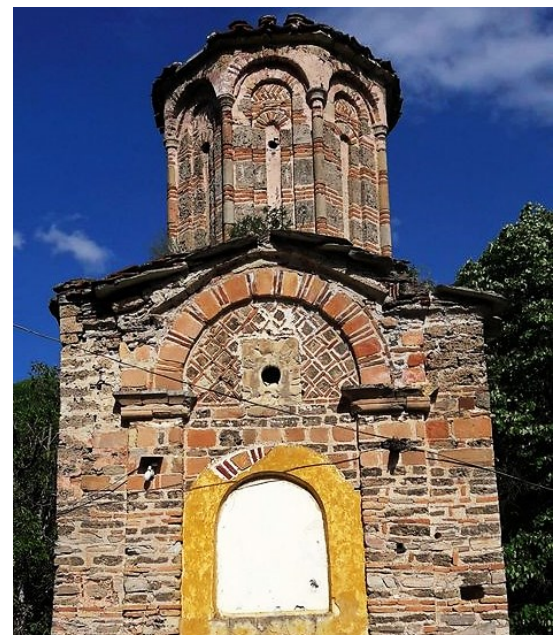

Figure III.78 The western façade of St. Nicholas Shishevski at Matka (Skopje), XIV century.

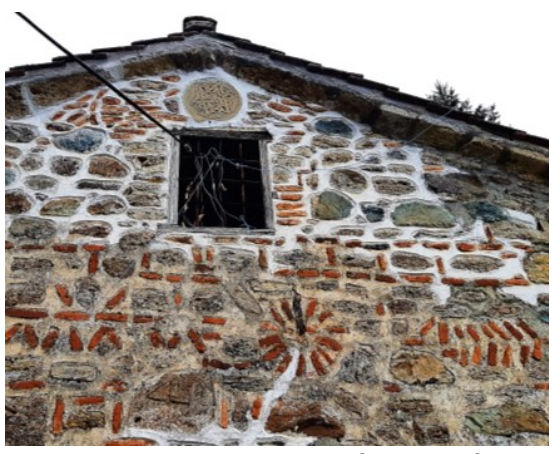

Figure III.79 The western façade of the Dormition of the Most Holy Mother of God in Leshok (Tetovo), XVI century. 
monastery, near Tetovo (fig. III.79); whereas at the southern façade of the XI century church of the Most Holy Mother of God Eleusa in Veljusa (Strumica) within the painted façade opus, above the specific cross with interweaving arms, there is a painted circular solar motif.

Drawing from these older locally present traditions, as well as from influences of the geographically wider context in which the Macedonian master-builder groups travelled for work, ${ }^{331}$ the Revival builders incorporated circular motifs into their work, predominantly as window openings placed high on the west $^{332}$ or east façade. ${ }^{333}$ These windows can be executed in several ways: carved out of a single block of stone, much like the window transennas, often with a decorative frame, profiles or relief ornamentation; or constructed out of several blocks of stone; a combination of stone and brick or using only radially arranged brick. The applied building material and technique, especially in the case of oculi constructed by radial placement of alternating limestone blocks and brick, framed within a circle shaped by pieces of brick, is a clear reminiscence of the Byzantine style of masonry, a return to the medieval patterns not only in the typology of the building but also in the construction method itself.
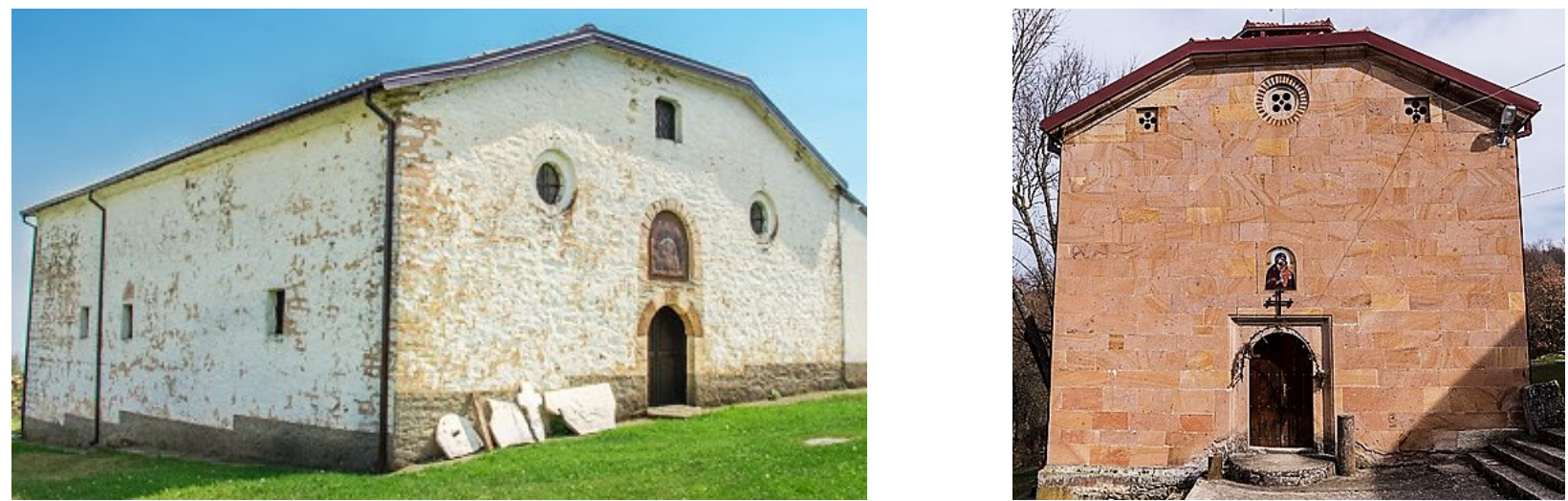

Figure III.80 A. St. Mercury in Bareshani (Bitola); B. Dormition of the Most Holy Mother of God - Zabel monastery (Kumanovo).

In addition to circular windows covered with a glass pane (fig. III.80A), ${ }^{334}$ the prevalent solution is a circular opening in which a typical Revival window transenna was embedded. The motifs used in these transennas are the ones described earlier: the dominant motif is the cross, either carved out of the stone slab and usually shaped into a four-leaf clover (crux florida), ${ }^{335}$ or shaped by four segments carved out of the circle, leaving a vertical and horizontal bar which form the arms of the cross. ${ }^{336}$ Furthermore, the cross' arms sometimes extend towards the frame thus resembling a Maltese cross. ${ }^{337}$ Another variant of a cross motif transenna placed within a circular window is the cross formed by circles carved out of the stone slab

\footnotetext{
331 The numerous monumental churches from the post-Byzantine so-called Moravian school (within today's Serbia) which regularly incorporated large circular sculpturaly executed windows as one of the most elaborate elements of their façade articulation must not be overlooked.

332 At St. Barbara in Zhuzhnje (Mavrovo); St. Nicholas in Karamani (Bitola); St. Constantine and Helena in Mokrino (Strumica); St. Peter and Paul in Radobor; the Most Holy Mother of God in Gorno Selo (Prilep); St. George in Poeshevo; St. Athanasius in Sovikj; Nativity of the Most Holy Mother of God in Shtavica; St. George in Novo Selo (Strumica); St. Nicholas in Meglenci; St. Savior in Kalen; St. Savior in Malo Ruvci (Prilep); Resurrection of Christ in Dedebalci; St. Athanasius in Kuklish (Strumica); St. Demetrius in Dolna Charlija; St. Archangel Michael in Krushevica; St. Nicholas in Slepche; St. George in Logovardi, etc.

${ }^{333}$ At St. Peter and Paul in Tresonche (Debar); St. Demetrius in Dobroveni; St. Theodore Stratylate in Dolno Orehovo (Bitola); St. Elijah in Dolno Vranovci (Veles); St. Nicholas in Nakolec (Prespa); St. Nicholas in Belche (Demir Hisar); St. Athanasius in Suvo Grlo (Demir Hisar); St. Archangel Michael in Novo Selo (Demir Hisar); Dormition of the Most Holy Mother of God in Sloeshtica (Demir Hisar); the Most Holy Mother of God in Duf (Gostivar); St. Petka in Nizhepole (Bitola), etc.

${ }^{334}$ At the western façade of St. Mercury in Bareshani (Bitola) (fig. III.80A) as well as St. George in Zlesti (Ohrid); the eastern façade of the Nativity of the Most Holy Mother of God in Kanino (Bitola), etc.

${ }^{335}$ At the east façade of the church of St. Petka in the village of Lisolaj (Bitola); St. George in Ramna (Bitola); St. Nicholas in Dragosh (Bitola); the west façade of St. George in Novo Selo (Strumica), etc.

336 On the east façade of the church St. Nicholas in Kichinica (Mavrovo); St. Athanasius in Gostirazhni (Prilep); St. Cosma and Damian in Svetorache (fig. III.81B); as well as St. Elijah in Plakje (Ohrid).

${ }^{337}$ At St. Nicholas in Svinjishte (Kichevo) (Николовски, 1993: 165); the eastern façade of St. George in Zlesti (Ohrid), etc.
} 
and arranged in a Greek cross pattern, or rotated by $45^{\circ}$. Both variants of this cross-like composition can be found at the western façade of the Dormition of the Most Holy Mother of God - Zabel monastery (fig. III.80B), located near the town of Kumanovo, in whose proximity several churches are located which have this specific type of window transenna (at Stracin, Rugjince, Zhegljane), as a regional stylistic feature.
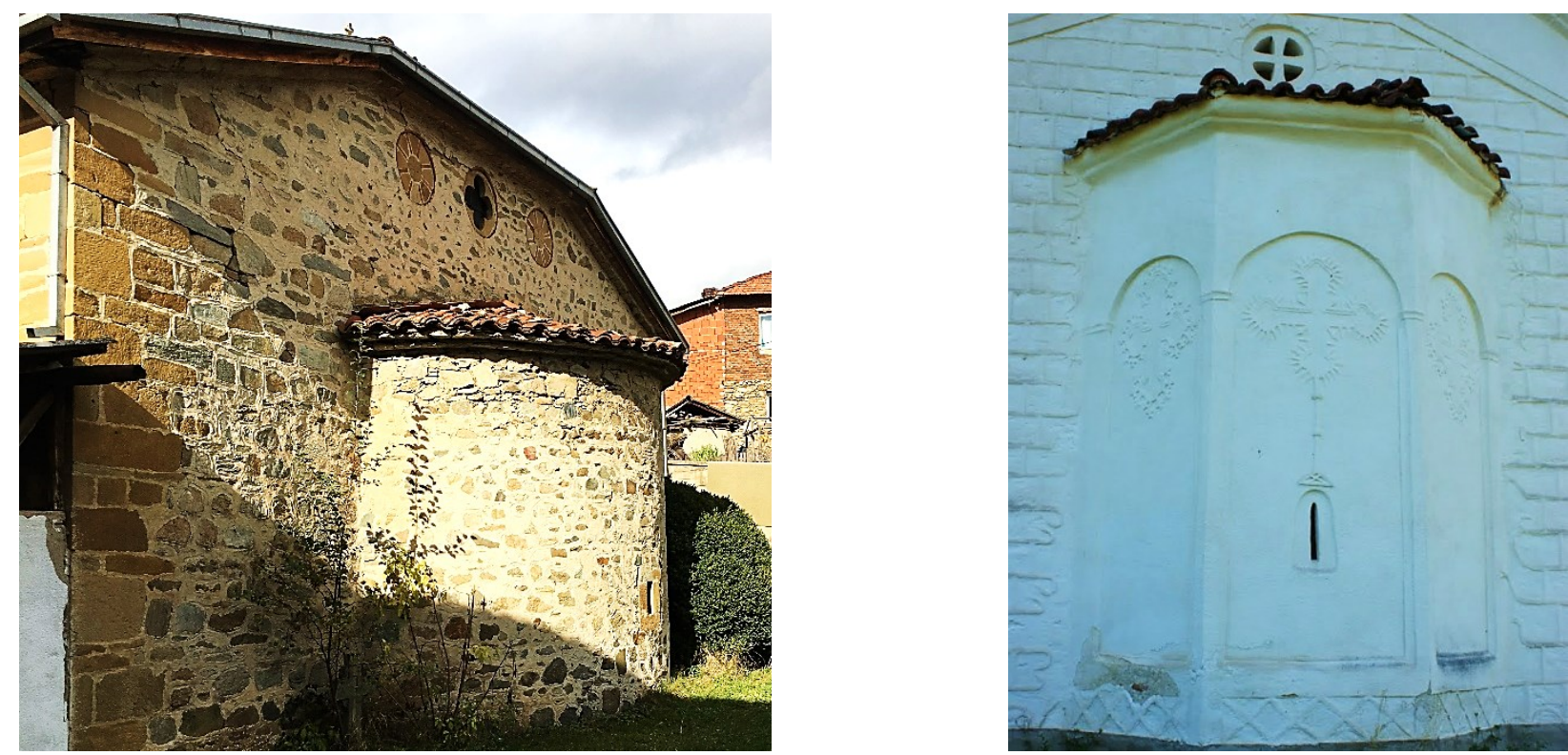

Figure III.81 A. St. George in Budinarci (Berovo); B. St. Cosmas and Damian (the Holy Healers) in Svetorache (Kichevo).

Furthermore, in some churches appear oculi that do not frame a window, but are rather part of the decoration of the façades. Often, these are simple circular stone blocks, carved in shallow relief, bearing an inscription of the year of construction or consecration of the church, as in St. Constantine and Helena in Raklish, near Radovish (see fig. III.32A). Additionally, the block is sometimes encircled with a ring of brick, such as the one above the western portal of the church of St. Athanasius in the village of Dolno Perovo (Prespa). At St. Nicholas in Brajchino (Prespa) on both sides of the apse, in the upper zone of the east façade, two circular oculi made of angularly arranged bricks in the shape of a solar symbol - kolovrt are embedded in the masonry. Within the eastern façade of the church of St. George in the village of Budinarci (Berovo), above the semicircular apse, three equally large circular oculi are lined beneath the crown cornice, of which the central one is a window with a four-leaf clover transenna, while the lateral ones serve only a decorative function (fig. III.81A). Their circumference is made of brick, while a circular stone with an elongated procession cross with phytomorphic trefoil arms is placed in its center, executed in shallow relief. Around this central motif alternate radially arranged blocks of stone and one vertically placed brick. The same oculus appears on the west façade, high above the entrance portal and, as a confirmation of the theme, the arched windows are also built with alternating radial arrangement of brick and stone. An absolutely identical oculus can be found in the axis of the west façade of the church of St. Constantine and Helena in the village of Razlovci (Delchevo) and at the Dormition of the Most Holy Mother of God in Robovo (Berovo), which is only partially preserved. The windows of this church (as well as the church in Razlovci) are formed with an arch made of radial arrangement of brick and stone, which speaks, together with the geographical proximity of all three temples, as well as the typological solution used, ${ }^{338}$ of their possible authorship within the same master-builder group. ${ }^{339}$

\footnotetext{
338 Namely, both churches in Robovo and Budinarci are three-nave basilicas with a semicircular apse and a flat wooden ceiling (decorated with cassettes and rosettes), complemented by a blind dome in the central nave (Николовски, 1987: 176).

339 The preserved inscription next to the niche of the western entrance portal of the church in Budinarci lists the master-builders of the temple: Nikola, Nesho, Tasho and Ilo, while the founder of the church is Stoilko. According to the locals, master Nesho was born in Smojmirovo (Николовски, 1987), a village near Berovo, which speaks of a master-builder group of local origin.
} 
Circular oculi made of radially arranged brick, in which filigree-like processed window transennas were embedded, are especially characteristic of the north-eastern region of Macedonia (Kratovo, Kriva Palanka, and Kumanovo). One such example is found on the west façade of the church in Opila (Kriva Palanka), where a spacious oculus frames a lacy hexagram transenna (see fig. V.4). A similar concept is applied in the church in Shlegovo (Kratovo), where transennas with circular arabesques are embedded within rectangular window openings on the west façade, as the ones at the churches of St. John and St. Nicholas in Kratovo (see fig. III.77B-C).
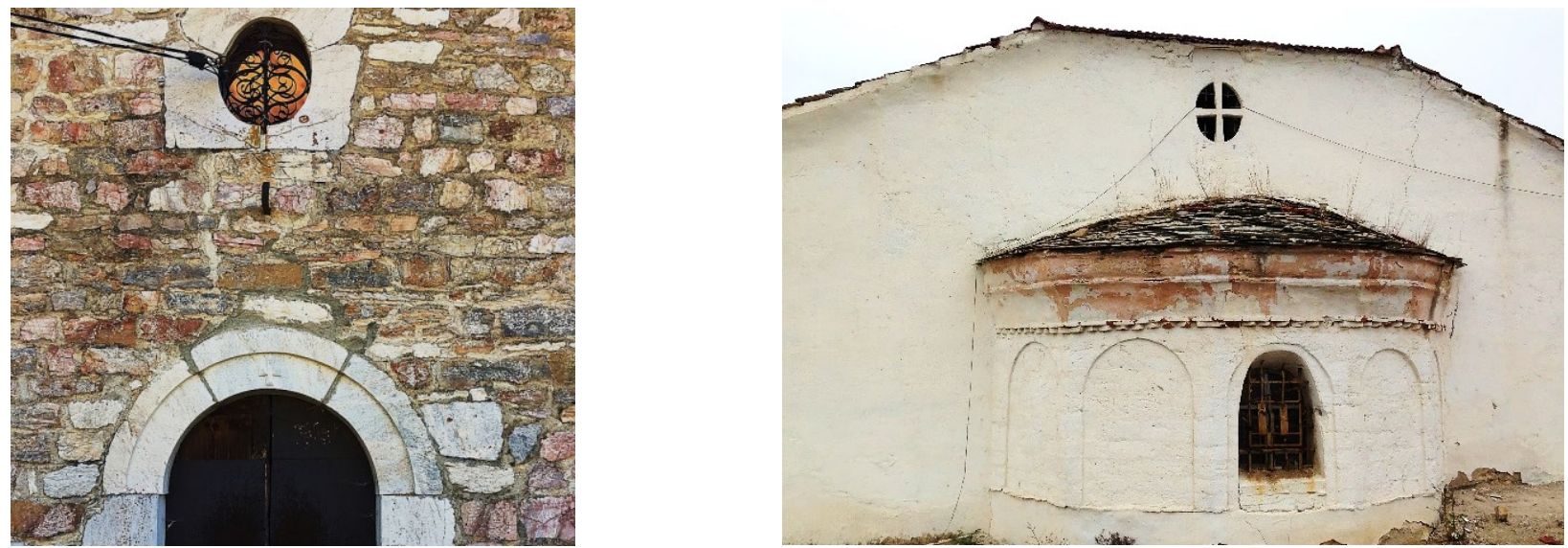

Figure III.82 Examples of oval mandorlas: A. St. Barbara in Zhuzhnje (Mavrovo); B. St. Nicholas in Bashino Selo (Veles).

In addition to circular oculi-shaped windows, elongated, oval shaped windows - mandorlas ${ }^{340}$ often appear in the Revival churches which, as the circular windows, can be covered by a glass pane (fig. III.82A), or include a wide variety of stone transennas, displaying the previously elaborated motifs: simple crosses, Maltese crosses (fig. III.82B), ${ }^{341}$ procession crosses $^{342}$ and phytomorphic four-leaf crosses. ${ }^{343}$ As a rarer variant of oval window transennas, there are cases of ovals composed of two or three vertically arranged and interconnected circles, so that they form an " 8 "-shaped motif (see fig. III.1). ${ }^{344}$ Circular or oval windows can extremely rarely be found on the lateral façades of the Revival churches. Such an example is the church of St. Athanasius in Strugovo, near Demir Hisar (Дапчев, 1996: 236-237), whose diaconicon window is a circular oculus constructed out of radially arranged bricks.

\section{Shallow and High Relief}

As was mentioned earlier, unlike the Byzantine and post-Byzantine churches, the Revival basilicas incorporated decoration in shallow and high relief in their façade articulation almost without exception. In addition to the entrance portals, patron saint niches and altar apses, which sometimes included motifs executed in such high relief that almost resembled completely three-dimensional, sculptural elements, the Revival churches often incorporated individual shallow or high relief stone-carved blocks whether as purely decorative elements - such as within the corners of the naos, the niches of the altar apse, the pilasters; or serving a functional or structural purpose - such as the consoles supporting the open porches'

\footnotetext{
340 On the east façade of the church of St. Athanasius in Teovo (Veles); at the church in Belche (Demir Hisar); high on the west façade of St. Nicholas in Oraov Dol (Veles); in Makrievo, Strumica; at St. Peter and Paul in Ratevo (Berovo); at St. Elijah in Selce (Mavrovo); the Most Holy Mother of God in Sence (Mavrovo); on the western and eastern façade of the church of the Dormition of the Most Holy Mother of God in Klenoec (Kichevo), etc.

${ }^{341}$ At St. Nicholas in Bashino Selo (Veles); the west façade of St. Nicholas in Popoec (Kichevo); St. Nicholas in Brzhdani (Kichevo); St. Athanasius in Judovo (Kichevo).

${ }^{342}$ For example, at the west façade of St. George in Belica (Kichevo).

${ }^{343}$ At the east façade of St. Nicholas in Popoec (Kichevo) (see fig. III.32B); at St. Stephen in Konopishte (Kavadarci), etc.

${ }^{344}$ At the church of the Most Holy Mother of God in Zheleznec (Demir Hisar); St. Elijah in Popchevo (Strumica) and St. Petka in Trebichino (Strumica), where three vertically stacked circles are interconnected within a complex transenna, etc.
} 
wooden construction system or as founders' inscriptions. As the entrance portals and their decoration in shallow and high relief, the appearance of these relief details, the chosen motifs and their articulation demonstrate one of the most easily legible manifestations of the eclectic nature of the Revival churches' architecture, i.e. an obvious influence derived from the Western European architectural styles to which the Revival master-builders had been exposed in various ways (directly through labor migration and indirectly through professional literature and contacts with foreign architects).

The most common motifs found on the individual shallow relief stone blocks, installed predominantly within the corners or the pilasters of the façades, are crosses - procession or Maltese (fig. III.83A); solar symbols - stars, rosettes, hexagrams; animal figures (see fig. III.140C) or winged angels, including various angels of the celestial hierarchy, such as the cherubim and seraphim (fig. III.83B-C).
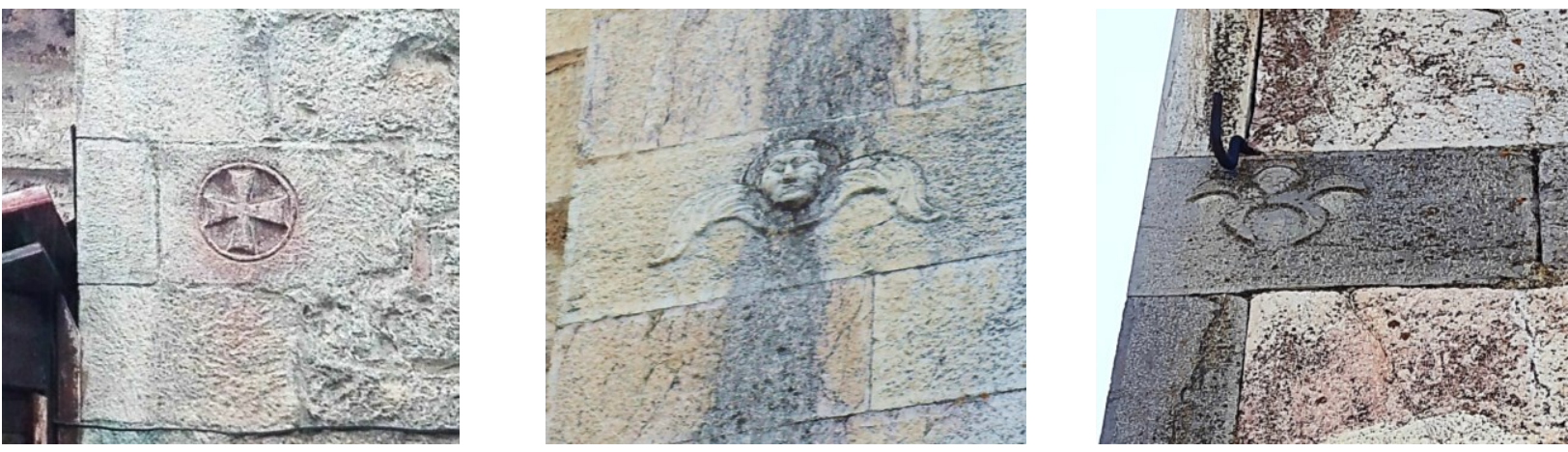

Figure III.83 A. St. Nicholas Gerakomija in Ohrid; B. St. Nicholas in Vevchani (Struga); C. St. George in Drmeni (Prespa).

Regarding the stone-carved founders' inscriptions, there are a variety of solutions, ranging from simple square or circular blocks embedded within the masonry (see fig. III.32A), or within a defined oculus, to significantly larger and more delicately processed slabs. The founder's inscriptions always incorporated the year of construction or consecration of the temple and sometimes the names of the founders, the bishop and even, though not as commonly, the name(s) of the master-builder(s) or frescopainters of the temple (fig. III.84). These usually square or rectangular slabs almost without exception included a decoratively elaborated, elongated cross of the procession type, with or without phytomorphization of the arms, ${ }^{345}$ or other decorative elements and motifs.
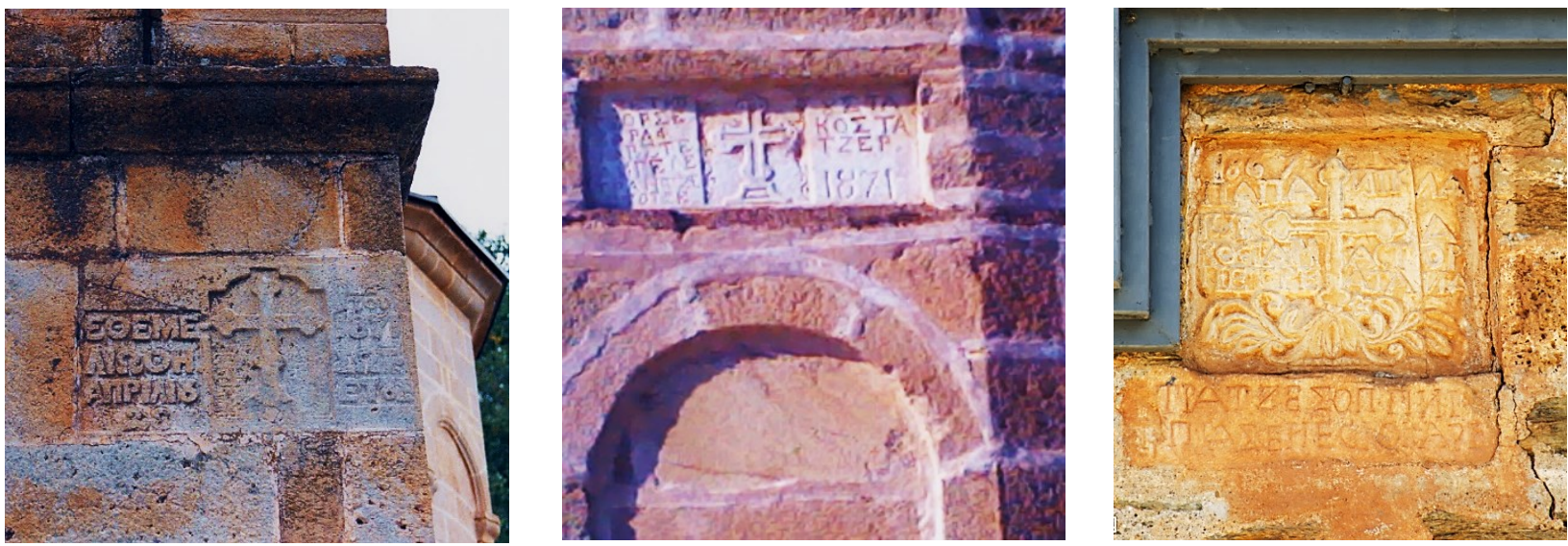

Figure III.84 Examples of founder's inscription relief slabs embedded within the façade: A. Holy Transfiguration in Gopesh (Bitola); B. St. Theodore in Krklino (Bitola); C. St. Nicholas in Slepche (Demir Hisar).

\footnotetext{
${ }^{345}$ Such examples can be found on the eastern and western façade of the church of St. George in Belica, near Kichevo (see fig. III.73, III.74A), which have even partially preserved their original decorative painting; at the eastern façade of St. Nicholas in Brzhdani (Kichevo); the western façade of St. George in Malo Crsko (Demir Hisar); the Most Holy Mother of God in Zheleznec (Demir Hisar). Similarly conceived and executed founder's inscription slabs can be found at the churches in Gopesh and Krklino near Bitola and Slepche near Demir Hisar, all three built by the prominent Revival master-builder Kosta from Cer (fig. III.84).
} 
In addition to these shallow relief stone blocks embedded within the façade masonry, there are often examples of significantly higher relief, with an almost completely sculptural quality placed within key, accent elements of the Revival church's articulation, such as the corners of the building, the altar apse, the load-bearing stone consoles and the entrance portals and patron saint niches. The prevalent motifs are symbolic representations of angels, and a variety of domesticated or wild, even exotic animals from faraway lands, as well as mystical imaginary beasts and mythological creatures. Such examples can be found at the church of St. John in the village of Bogoslovec (Sveti Nikole), where the sculpturally conceived western portal is additionally adorned with two stone slabs with the ancient motif of a pouncing lion which flank the patron saint niche. Centrally, above the niche's arch, the composition is completed with a relief slab depicting a typical Eucharistic scene with two symmetrically arranged birds. High, sculptural relief of symmetrically arranged animals was also used the patron saint niche of the southern entrance portal of St. Nicholas in Orlanci, near Kichevo (see fig. III.60A); as well as at St. Petka in Rugjince (Kumanovo), where the western patron saint niche is supported by two mystical beings with wide-open jaws executed in high relief, while the southern one incorporates two eagles, shaped with an exquisite sense, plasticity and attention to detail.

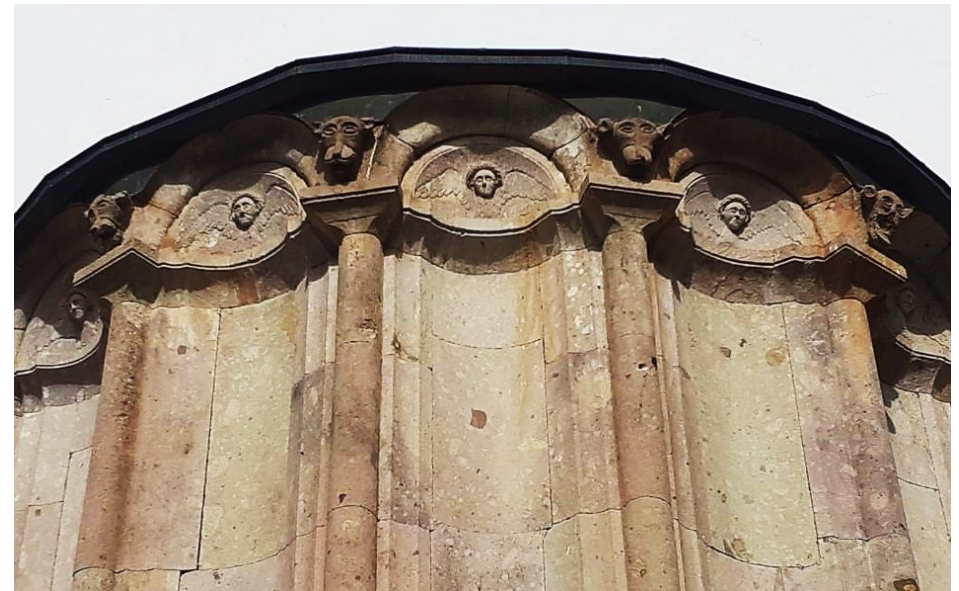

Figure III.85 Detail of the masonry and high relief decoration of the altar apse of St. Joachim - Osogovo monastery near Kriva Palanka.

In addition to the entrance portals and patron saint niches, a sculptural approach to the exceptionally high relief elements can be found in the altar apses of certain more representative churches. Such example is the catholicon of St. Joachim - Osogovo Monastery (fig. III.85), work of the master-builder Andreja Damjanov, where threedimensionally shaped monkey heads appear above the capitals of the apse pilasters, while winged angels are depicted in the arches of the shallow niches themselves.

In addition to winged angels (fig. III.86C), wild or domesticated animal representations are also prevalent in the elaboration of exceptionally high relief corner-stones. Such examples are located on the western façade of the church of St. Demetrius in Kriva Palanka (fig. III.86A), shaped into an anthropomorphized lion - a sphynx; whereas the north-eastern corner of the naos of St. John in Bogoslovec (Sveti Nikole) is adorned with a corner-stone depicting a realistically carved ram head (fig. III.86B), originally additionally emphasized with paint in an indigo tone.

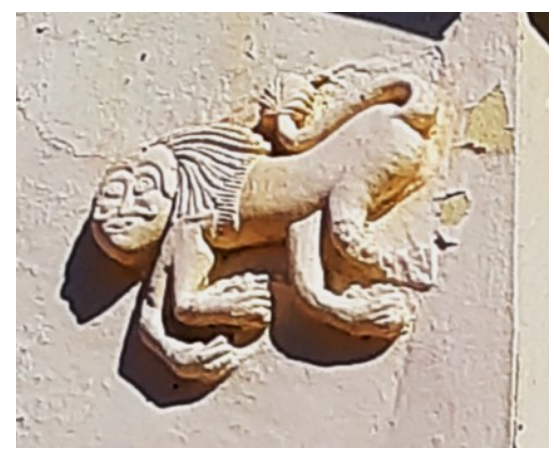

Figure III.86 Examples of high relief corner-st
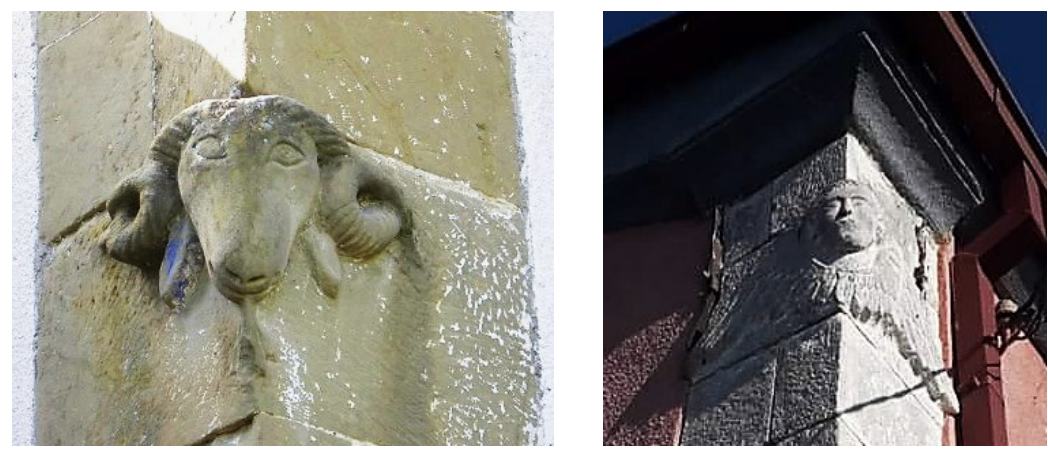

-stones: A. St. Demetrius in Kriva Palanka; B. St. John in Bogoslovec (Sveti Nikole); C. The Holy Trinity in Brezica (Skopje). 

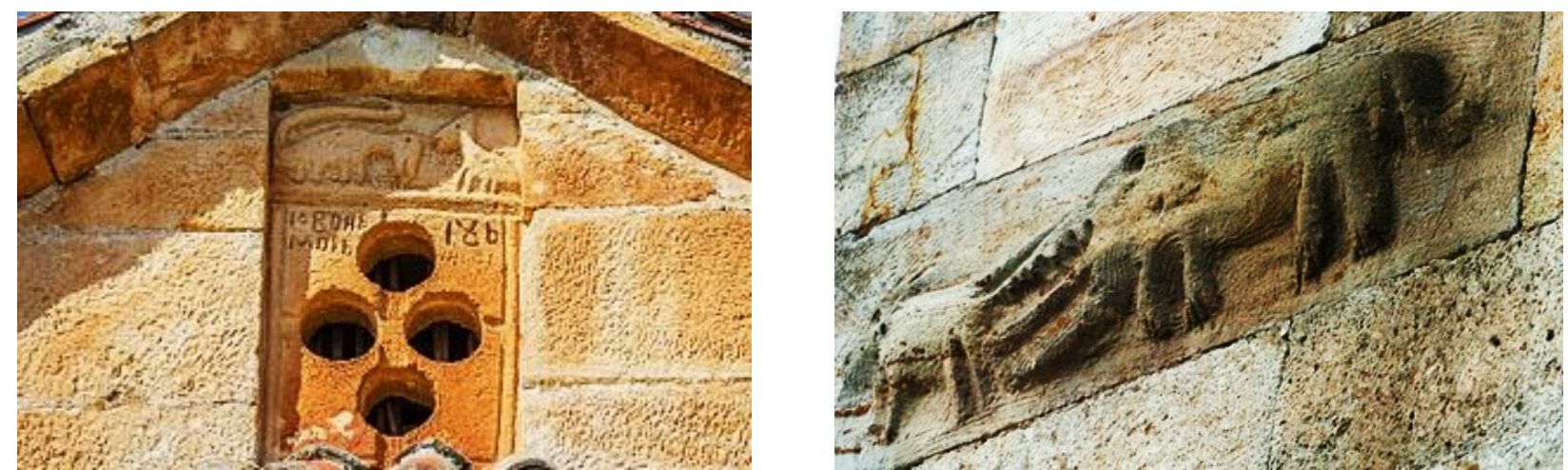

Figure III.87 A. St. George in Zhegljane (Kumanovo); B. Introduction of the Most Holy Mother of God in Shlegovo (Kratovo).

Another example of high relief sculptural processing of unusual wild animals embedded in the masonry of the façades can be found at the church in the village of Shlegovo (Kratovo), where representations of an elephant and a giraffe were carved in an elongated stone block (fig. III.87B). In that context, the window transenna of the church of St. George in Zhegljane (Kumanovo) must not be overlooked, which depicts two very unusual, dragon-like animals (fig. III.87A).
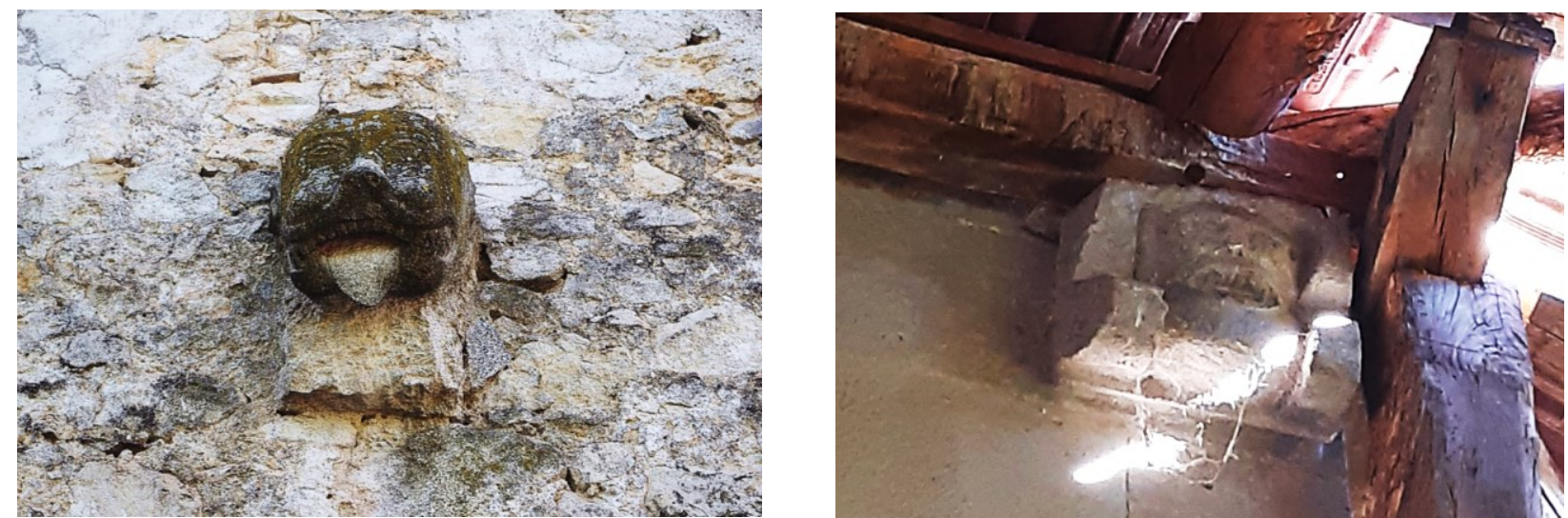

Figure III.88 Examples stone consoles in high relief: A. Nativity of the Most Holy Mother of God in Begnishte (Kavadarci); B. St. Petka in Rugjince (Kumanovo).

Furthermore, a certain sculptural processing was employed in the elaboration of the cantilever girders for the porch wooden construction, carved out of a single block of stone. Such example can be found at the church of the Nativity of the Most Holy Mother of God in Begnishte (Kavadarci), where the stone console is shaped into an animal head with a wide open mouth and a protruding tongue (fig. III.88A). At the church of St. Petka in Rugjince (Kumanovo), relatively large sculpturally processed consoles support the porch structure, shaped into a crouching monkey-like imaginary beast (fig. III.88B). These type of stone consoles, vaguely resembling gargoyle watersprouts, are yet another sign of import of architectural elements derived from the Western European styles, in this case the Gothic.

In the Revival churches, albeit rarely, there are also examples of figural representations in shallow and high relief consisting of saintly and human figures - portraits of the church's founders or the masterbuilders themselves. Such an example is the above mentioned Roman funeral stela embedded within the patron saint niche of the church of St. George in Resen (see fig. III.77A). Within the stela, which had preserved its original shape and features, the image of the master-builder of the church was carved out. Posing frontally, he is dressed in traditional folk costume (a skirt known as fustanela, a vest and a fez hat); in his right, high-raised hand he holds a large hammer; in his left an open book - both symbols of his craft. Above the figure of the master-builder, appears a smaller figure of a saint, who blesses the endeavor. An identical example of a re-used Roman funeral slab depicting the image of the Revival master-builder in shallow relief can also be found at the church of the Dormition of the Most Holy Mother of God in the 
village of Evla (Prespa) (fig. III.89C). His portrait is presented in the middle, in an upright position, also dressed in folk costume, with a fustanela skirt, a vest and a fez hat. He holds a hammer in his outstretched right hand and a stick in his left. Given his profession, i.e. the fact that he is presented with his "tools of the trade", it is most likely a measuring tool - an arshin. His dominant figure is flanked by smaller figures, male and female, with halos, while in the triangular gable of the stela a female act is placed. On the frame of the stela are carved, quite clumsily, the year and date of construction - 1848, October 6 , as well as the name of the master-builder himself - "Rareto". The geographical proximity of these two cases of figurative representations, as well as their obviously identical features, motif and technique can be interpreted by their authorship within the same master-builder group (Николовски, 1987: 49) which worked in the region of Prespa towards the middle of the XIX century. The origin of this unique type of master-builder portrait, as was the case of other elements of the Macedonian Revival ecclesiastical architecture (see Chapter II.2), can be sought in the slightly older monumental churches built in the Aromanian (Vlach) cultural center Moskopole. Namely, a similar concept of a figural representation of the master-builder, albeit executed in a rather more primitive, rudimentary fashion, can be found embedded within the brickwork of the southern porch façade of the church of St. Nicholas (fig. III.89B).
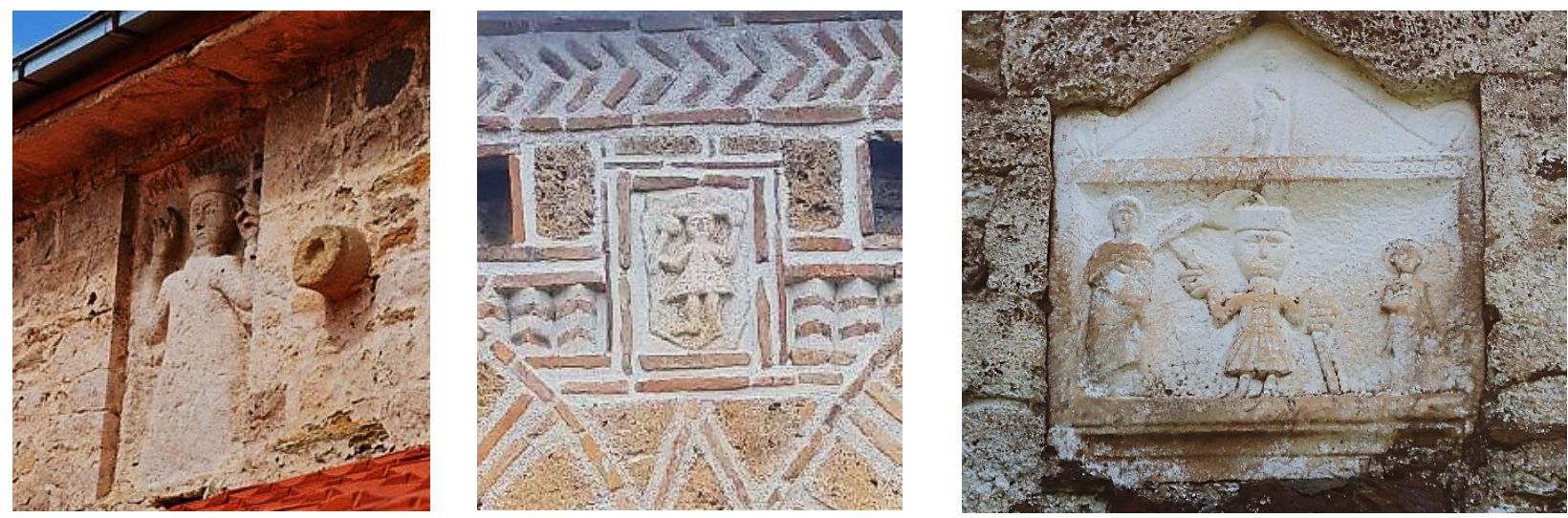

Figure III.89 Examples of relief figural representations: A. St. Petka in Beshishte (Mariovo); B. St. Nicholas in Moskopole (Albania), XVIII century; C. the Most Holy Mother of God in Evla (Prespa).

In addition to the portraits of the master-builders, there are also cases of relief portraits of the church founders or the patron saint of the temple. For example, high on the east façade of the church of St. Demetrius in Kriva Palanka, a saintly figure is carved in shallow relief into a single block of stone (fig.

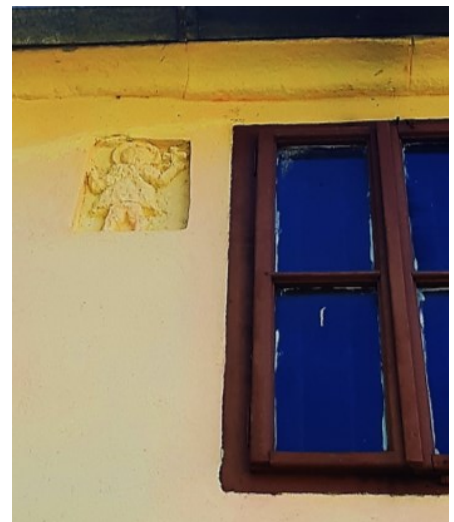

Figure III.90 Detail of a relief of a saint on the eastern façade of St. Demetrius in Kriva Palanka. III.90). In his left hand he holds a maltese cross; while blessing the onlookers with the other hand. A similar composition was executed on the south façade of the church of St. Petka in the village of Beshishte (Mariovo), where the image of the patron saint herself was carved in particularly high relief within a rectangular niche, presented rigidly, frontally, in a praying position (fig. III.89A). She also blesses with her right hand raised high; in her left hand she holds a procession cross. Very similarly executed examples of figural high relief representations can be found at the church of St. Nicholas in the village of Zovich (also in the region of Mariovo), where the church's founders (two of the richer villagers who helped build it: grandfather Bogdan Sekilkovski and grandfather Angele Angelevski) were presented as saints in high relief above the two entrance portals to the church. Although very stylized and quite naïve in terms of proportion and technical achievement, these church founders' portraits represent a true rarity in the region, appearing as a manifestation of an almost patron saint cult, characteristic of 
the Middle Ages when the founders of the temples were regularly painted in the so-called "donor compositions" in the fresco ensemble of the churches, accompanied by the patron saint whom they present with a model of the temple itself. This is confirmed by the crosses that these two characters ${ }^{346}$ hold in their raised right hand, while the left rests peacefully in their lap. Despite the primitiveness in the workmanship, in both characters the elaborate costume typical of the region of Mariovo is clearly visible, with all its constituent elements, with specific combing of the hair and an appropriate hat. The same rigid position of the body characterizes the relief of St. Petka in Beshishte, complemented with the same rough, primitive forms and features, which is a very reliable indicator that both of these temples originated within the same construction group that worked in the region of Mariovo in the second half of the XIX century, closely linked (if not the same) with the one responsible for the abovementioned churches in the geographically close region of Prespa.

\section{Cornices}

The Revival churches are characterized by the presence of elaborate cornices which top the façades, regularly made of high-quality hewn stone blocks, and rarely of brick, which encircle the whole naos, following the roof line: in a horizontal line along the longer façades and in a trapezoidal line on the shorter ones. These cornices vary in terms of their decorative profiling. The simplest solution is a cornice with a rectangular cross-section obtained by cantilevering several (two or more) rows of stone blocks (see fig. III.89A). ${ }^{347}$ The most common solution, on the other hand, is a decoratively profiled cornice consisting of straight, concave and convex sections, i.e. a combination of the classical cyma, torus and trochilus, which in itself is one of the Revival elements clearly influenced by the classical orders and their Renaissance transformations (see fig. III.29A, III.77A, III.80B, III.84A). Furthermore, the crown cornices were additionally emphasized using different, multi-colored stone blocks (for example, at St. John and St. Nicholas in Kratovo, see fig. III.77B-C), with painted blocks in alternating colors, or even with painted floral and geometrical ornamentation, as the ones at St. Nicholas in Sekirani, near Bitola (see fig. III.34).

In addition to crowning the façades, in the Revival ecclesiastical architecture cornices of a purely decorative nature were regularly used at the altar apses, to divide them into horizontal belts. As for their type, a variety of cornices were used at the altar apses: made of stone blocks, thin stone slabs or bricks, and sometimes a combination of stone and brick in various façade opuses, as a nod to the traditional brickwork techniques specific to Byzantine architecture. At the church of St. Nicholas in Bashino Selo (Veles), for example, the low five-sided apse is divided into three zones: simple low plinth; then a zone of shallow, semi-circularly arched niches of which the central one comprises a window; and a third final zone, separated from the second one by a serrated brick cornice, specific to the Byzantine architecture (see fig. III.82B), topped by a row of brick which extends over the serrated cornice. This is the only accent on this church's façades otherwise made of crushed stone, and subsequently plastered. ${ }^{348}$ Another example of a typical Byzantine serrated brick cornice can be found at the church of the Most Holy Mother of God in Sence (Mavrovo), both on its façades as on the apse divided into belts (low plinth and area of blind niches) with the help of a simple, geometrically profiled cornice (see fig. III.30C). In addition to serrated cornices,

\footnotetext{
346 The families Sekilkovci and Angelevci are among the most respected and oldest genera in the village of Zovich. Their roots are traced to the former village of Lenishte, with the displacement of which, due to the Turkish oppression at the end of the XVII century, the present village of Zovich was established, with these two families among its founders (Радовановиќ, 1927: 99-104). ${ }^{347}$ For example, at the church of St. Peter and Paul in the village of Ratevo (Berovo), where the same type of cornice crowns the altar apse as well as the façades; at St. Nicholas in Kichinica (Mavrovo); the Most Holy Mother of God in Duf (Gostivar) etc.

348 Unfortunately, as is the case with many other Revival churches, the unprofessional interventions to strengthen the building, undertaken by the church administration and the local population in 2014, irreversibly destroyed the architecture and the façade articulation of the church. Namely, the walls were strengthened on the outer side with the help of a reinforced concrete grid on all façades, including the altar apse; the previously open porch was closed off, etc.
} 
more complex solutions also appear, such as the spiral cornice above the cantilever arcades at the apse of St. Nicholas Gerakomija in Ohrid (see fig. III.8B). Even at the simplest conceived altar apses, the plinth and the area with blind niches are usually separated with a cornice.

Less commonly, in addition to the apses, a decorative separating cornice can be found on the western and/or eastern façades. For example, at the church in Orlanci the crown cornice of the lower, lateral façades continiously runs along the eastern and western façade as well. Under this cornice and along the corner pilasters composed of beautifully hewn blocks flows a zone of blocks with decorative protruding mortar joints, in the form of the Cyrillic letter " $W$ ", a common motif in the brickwork decoration of the late-Byzantine churches in Macedonia. A division cornice at the level of the altar apse's crown cornice runs along the eastern and western façades of the church in Mojno near Bitola, as well as on the western façade of the church of St. Nicholas in Vevchani (see fig. III.67).

\section{Spoliae}

Given the fact that the Revival churches were often built on older cult sites, or represent renovations of older, mostly post-Byzantine churches, the frequent use of spoliae in their construction

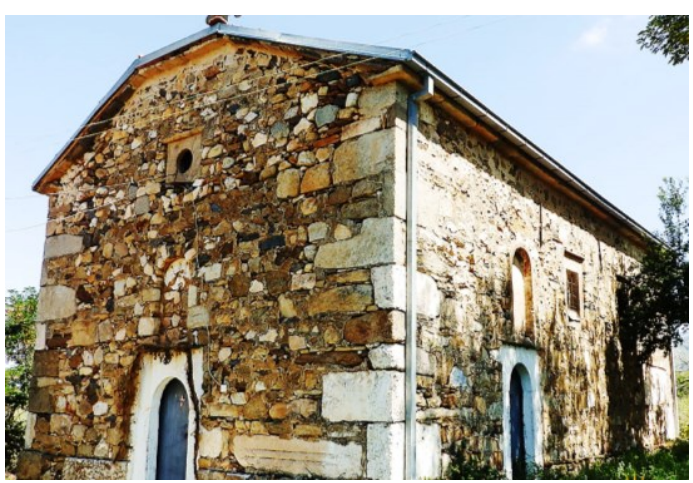

Figure III.91 St. Savior in Malo Ruvci (Prilep). View from the south-west. may come as no surprise, as well as the presence of spoliae preserved and displayed in their courtyards, as objects of value. In addition to this, some Revival churches were built using pre-existing material from older churches demolished during the Ottoman occupation - for example, St. Savior in Drachevo (Skopje), while others were built near archeological sites dating from antiquity and the Middle Ages, from which the available material was regularly re-used in the construction practice of the past. ${ }^{349}$

The most commonly used spoliae are fragments of columns, bases, capitals, slabs, as well as massive hewn stone blocks which were often re-used as corner stones in the Revival churches: for example, at St. Nicholas in Nebregovo (Prilep) and St. Savior in Malo Ruvci (Prilep), whose walls were quite irregularly constructed of crushed stone and lime mortar (fig. III.91, see fig. III.112A). Spoliae were also used as basis for the columns supporting the gallery of the Nativity of the Most Holy Mother of God in Rankovce (Kriva Palanka), which is a XIX century renovation of an older, partially preserved post-Byzantine church to which belonged the altar apse, fragments of the frescopainting and the XVII century royal doors.
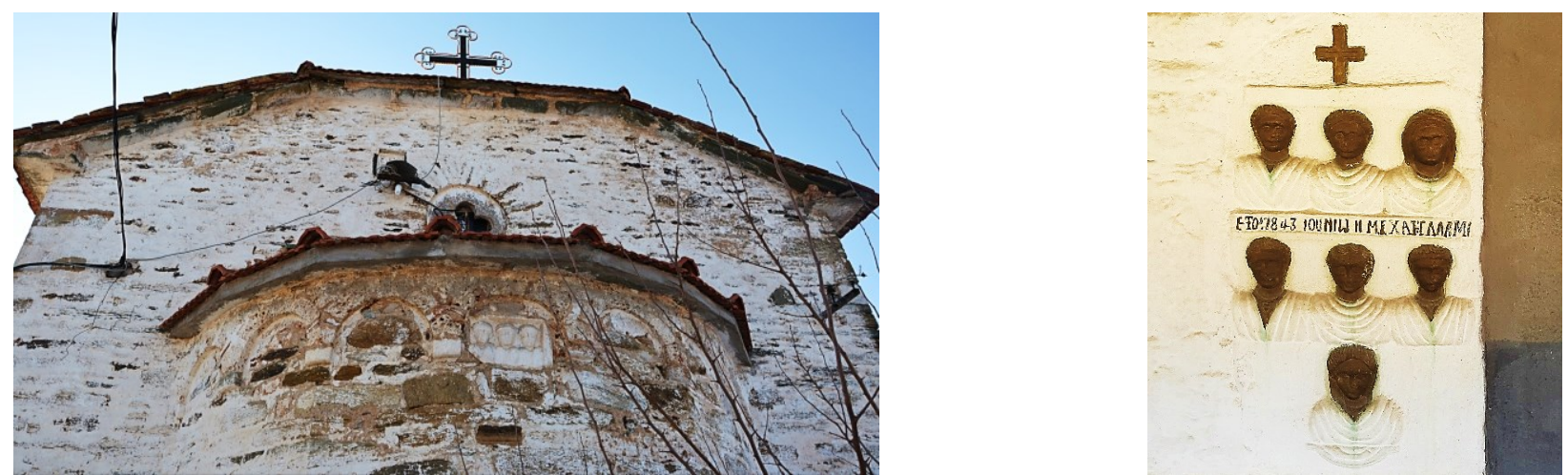

Figure III.92 A. St. Athanasius in Beranci (Bitola), detail of the altar apse; B. St. George in Resen, detail of the western portal jamb.

${ }^{349}$ For example, on the western façade of St. Nicholas in Ulanci (Veles), which incorporates the remains of an older post-Byzantine church, ancient spoliae were used, which probably originate from a nearby archeological site (Николовски, 2018: 305). 
However, there are also fragments of stone reliefs, most often from Roman or early-Christian provenance, and rarely from the Middle Ages, built-in at prominent places on the façades of the Revival churches, most commonly in the context of the entrance portals (fig. III.92B, III.95) or the altar apses, which implies that these fragments were respected and revered, i.e. they were considered in some way as sacred objects, and not just easily accessible building material. Many times, these were in fact Roman funeral stelae extracted from nearby archeological sites or necropolis (fig. III.92, III.95A). ${ }^{350}$ In addition to funeral slabs, other reliefs were also frequently used: for example, on the southern façade of St. Nicholas in Nebregovo (Prilep), a marble slab dating from the Roman imperial period is embedded within the masonry, with a relief representation of Heracles and Athens (Грозданов, 2004: 305-306). Also, antique marble slabs with inscriptions (in Latin and ancient Greek) were also quite commonly re-used within the Revival churches' masonry, within their entrance portals (fig. III.93), ${ }^{351}$ or within the structure of the churches' auxiliary buildings.

A common source for spoliae were the early-Christian basilicas, used as quarries not only for large blocks and columns, but also for parapet slabs and chancel screen reliefs which were particularly revered since they already presented Christian symbolism. For example, at the church of St. Athanasius in Loznani (Bitola) a marble slab with a cross motif placed on top of two dragons, each flanked by one cherubim (Николовски, 1993: 166) was built-in above the niche of the western entrance. The modesty of the construction of this church: a single-nave vaulted basilica with a semicircular altar apse, built of crushed stone and later whitewashed, indicates that this relief originates from another, more luxurious building. To the west of the south entrance portal of the church of Dormition of the Most Holy Mother of God in Margari, there is a fully preserved parapet marble slab in shallow relief, with the motif of an elongated procession cross within a profiled frame.

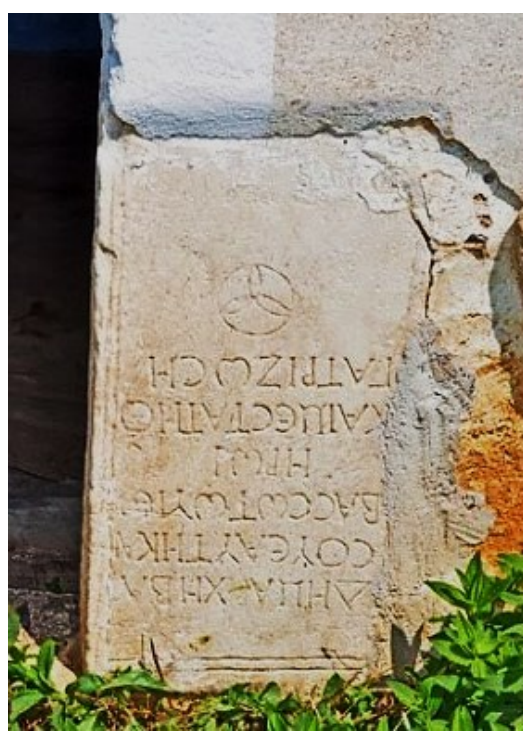

Figure III.93 St. Demetrius in Dunje (Mariovo). Detail of the portal jamb.

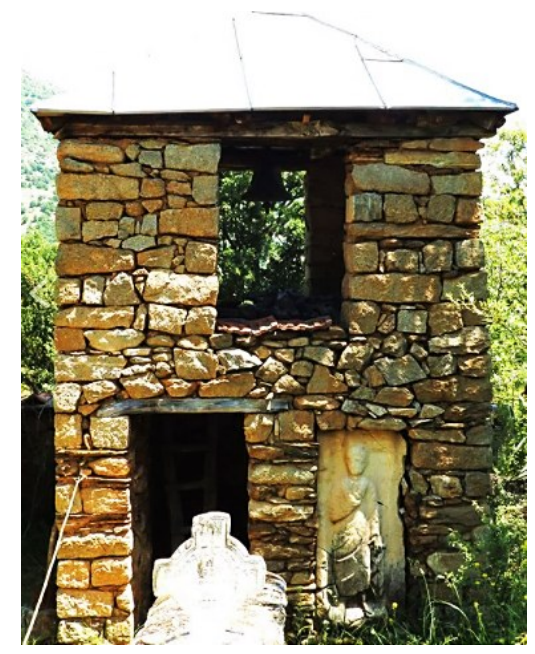

Figure III.94 The bell tower of St. Archangel Michael in Kokre (Mariovo).

In addition to ancient or early-Christian re-used elements, there are also cases of medieval reliefs used as spoliae. Such example can be found at the church of St. Athanasius in the village of Beranci (Bitola)

\footnotetext{
350 For example, at the church of St. George in Resen, adjacent to the north jamb of the western entrance portal is a large lateRoman funeral stela with seven portraits busts in high relief (fig. III.92B) arranged in a symmetrical composition in three rows. During its re-use in the Revival church, a cross was carved at the top of the slab, and an inscription of the year of construction of the church was added (Николовски, 1987: 36). A Roman funeral stone with six figures in high relief was also embedded over the western entrance of the church St. George in Ivanjevci (Bitola). At St. Athanasius in Beranci (Bitola), in the axis of the altar apse, within the cantilevered arcade, a fragment of a Roman stela with three sculptural busts is embedded (fig. III.92A). Another example of a Roman funeral relief slab, likely originating from an unknown local necropolis, can be found in the niche above the western entrance portal to the church of St. Nicholas in Brod (Mariovo), substituting a patron saint fresco (fig. III.95A).

${ }^{351}$ For example, at the southern portal of the church of St. Demetrius in Dunje (Mariovo) such fragments were embedded in both jambs (fig. III.93); a plaque with an inscription (in addition to two column bases and several fragments of stone plastic) was reused in the church of St. Nicholas in Belo Pole (Prilep); at St. Athanasius in Senokos (Prilep) a marble tombstone with an inscription in Greek was built into the façade, in addition to various stone sculpture elements preserved in the church (one relief with 3 busts, fragments of pillars and an architrave marble beam); at the church of the Dormition of the Most holy Mother of God in Dabnishte (Kavadarci), which is a Revival renovation of an older church from which fragments of frescoes and brickwork decoration have been preserved, in the northern entrance portal fragments of an ancient figural relief and a slab with an inscription were re-used, etc.
} 
(fig. III.95B), where the patron saint niche is in fact a re-used Byzantine marble fresco-icon frame (Николовски, 1993: 157), such as the ones preserved at St. Sophia in Ohrid (XI century) and St. Panteleimon in Nerezi (XII century) (see fig. II.20).
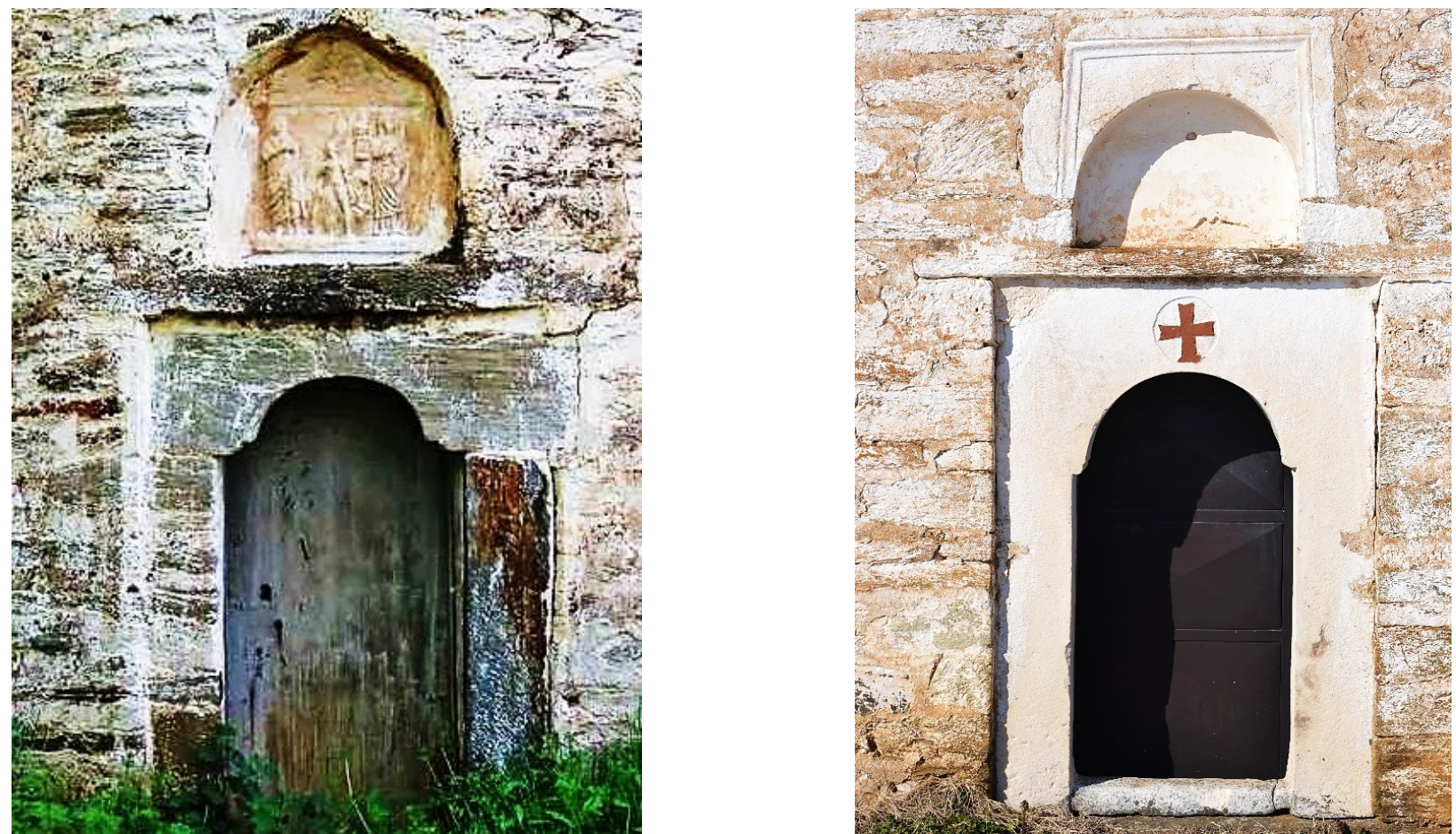

Figure III.95 Spoliae re-used as patron saint niches: A. St. Nicholas in Brod (Mariovo); B. St. Athanasius in Beranci (Bitola).

Lastly, many Revival churches and their courtyards have in fact taken on the role of treasuries for ancient spoliae, ${ }^{352}$ complementing their already mentioned role as treasuries for older icons, royal doors and church furniture deposited usually in their galleries. Thus, in many villages, throughout the church courtyard and cemetery lie scattered spoliae of different provenance: fragments of marble columns, bases, capitals, older transennas, fragmentarily preserved parapet slabs, chancel screens, funeral reliefs, etc. In many cases, some of these stone fragments were re-used in the repairs of the church walled fences, as in the case of the church in Nebregovo (Грозданов, 2004: 305-306), and even within their bell-towers as, for example, at the church in Kokre (fig. III.94).

\section{Decoration in Brick}

In addition to the local use of brick in the façade masonry syllable, decorative motifs executed in brick, albeit rarely, are also found on the façades of the Revival churches. The prevalent motifs are cruciform, ranging from simple Greek and elongated crosses to more complex solutions. The crosses of simpler design are predominantly embedded within the window niches, for example at the church of St. John (fig. III.96B) and St. Nicholas in Kratovo; St. Savior in Creshevo (Skopje), etc. In addition to simple, elongated crosses, more refined Maltese crosses were also executed, such as at the eastern façade of the Most Holy Mother of God in Duf (Gostivar), or the church of St. George in Resen, where in the upper zone of the façades appear circular motifs made of bricks arranged in a zigzag line, in the middle of which are placed large Maltese crosses also made of brick (fig. III.96A).

\footnotetext{
352 For example, at St. Nicholas in Nebregovo and St. Nicholas in Chepigovo, both villages in the region of Prilep; St. Archangel Michael in Kokre and St. George in Peshtani (both in the region of Mariovo); the Most Holy Mother of God in Farish (Kavadarci); the Holy Trinity in Podles (Veles); in Shopsko Rudare (Kratovo); Ivanjevci (Bitola), etc.
} 

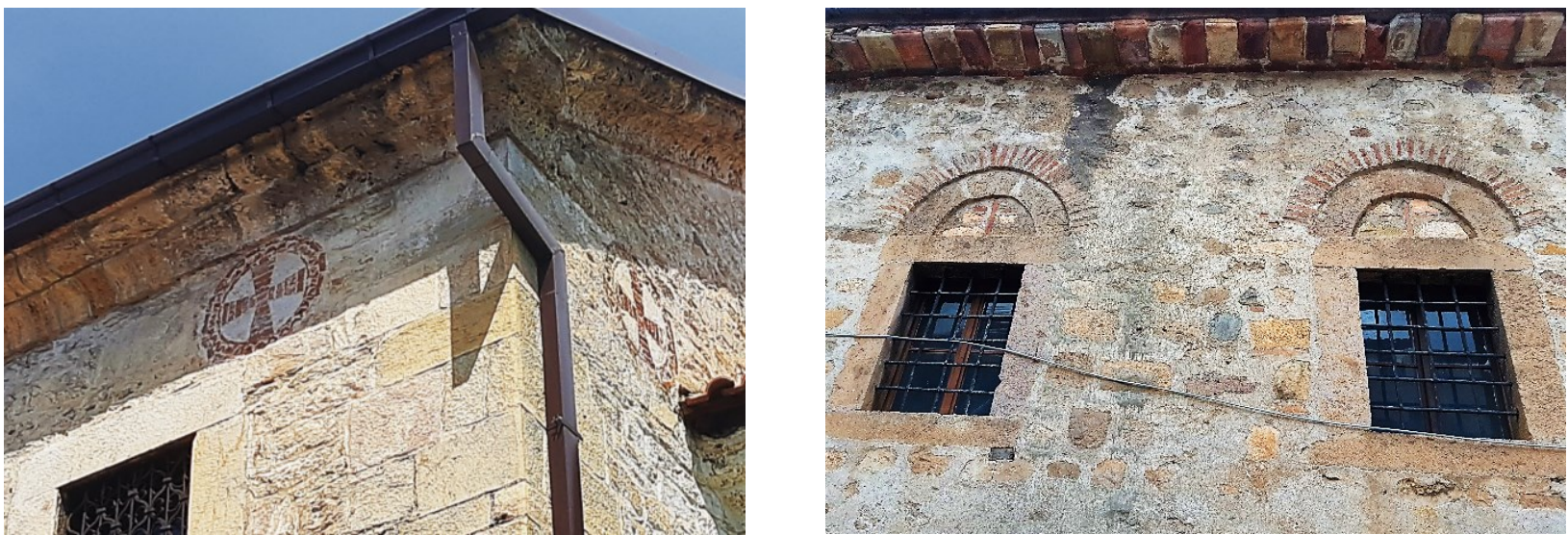

Figure III.96 Details of façade decoration in brick: A. St. George in Resen; B. St. John in Kratovo.

The most common type of cross is the procession cross, placed upon a simple, stylized triangular pedestal. Such crosses were executed in brick on the eastern façade and within the portal of the southern façade of St. Nicholas in Trn (Bitola) ${ }^{353}$ (see fig. III.72B); on the eastern façade of the church of St. Panteleimon in Nikiforovo (Mavrovo) (fig. III.97A); at St. Elijah in Blatec (Vinica); St. John in Kratovo, etc.
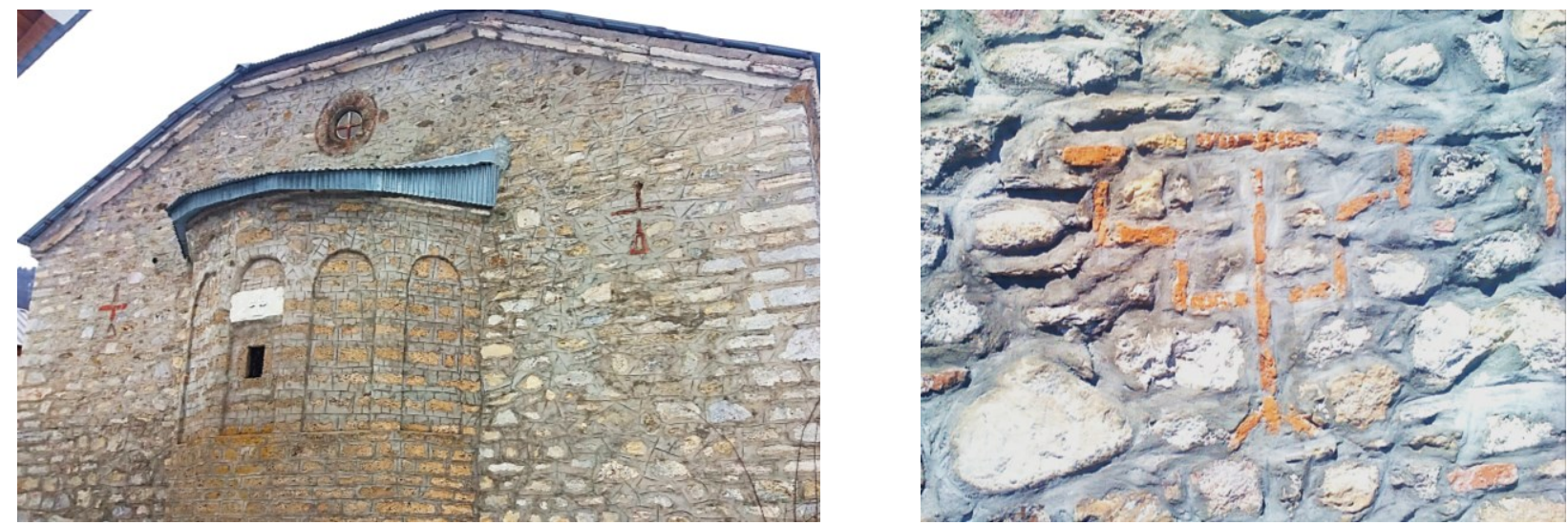

Figure III.97 A. St. Panteleimon in Nikiforovo (Mavrovo); B. St. Archangel Michael in Sredno Egri (Bitola).

Brick crosses as decorative elements were built into the façades of the church of St. Petka in Dolno Egri near Bitola (Николовски, 1993: 161); between the arches of the blind niches of the altar apse as well as high on the sides of the east façade of the church of St. Archangel Michael in the nearby village of Sredno Egri, where tall, more complex, branched procession crosses with a pyramidal pedestal appear (fig. III.97B) within the irregular façade masonry of crushed stone.

\section{III.4.2 Decoration of the Interior of the Revival Churches}

In addition to the significant emphasis on the iconostasis partition and the gallery fence to which, as explained earlier (see Chapter II.5, III.3), exceptional attention was paid, other architectural elements in the interior of the Revival churches also received decorative treatment: the flat wooden ceilings, the columns, capitals and the arcade sequence that they form (within the three-nave basilicas), as well as the church equipment, built-in furnishings (a pulpit - ambo, a bishop's throne, seats for the elder members of

\footnotetext{
${ }^{353}$ At the southern portal of this church, made of three monolithic pieces of stone, above the patron saint niche, develops an arch of whole pieces of one foot long brick, above which, in the center, is a decorative motif of an elongated cross with a triangular (pyramidal) pedestal - a cross of the procession type - including the Masonic symbol of the all-seeing eye.
} 
the congregation, altar table ciborium etc.) and movable furniture (icon pedestals, gospel book pedestals, relics boxes, chandeliers, etc.).

\section{Columns and Capitals}

The columns of the Revival multi-nave churches, as well as their capitals and bases (if any) did not follow fixed stylistic rules; they rather abound in the most varied solutions resulting from their free, unrestrained artistic treatment. The columns and capitals made of stone were given a more classic look, with monolithic trunks for the shorter pillars, for example the ones supporting the galleries or the ones which compose the open porches (fig. III.98, III.100), or trunks composed of circular segments in the case of the taller columns in the naos. In these churches the capitals were usually carved with a geometric, purified profile, while some of them were additionally decorated in shallow relief, usually with stylized crosses, floral motifs, solar and cosmogonic ornaments, "fleur-de-lis" motif etc. ${ }^{354}$
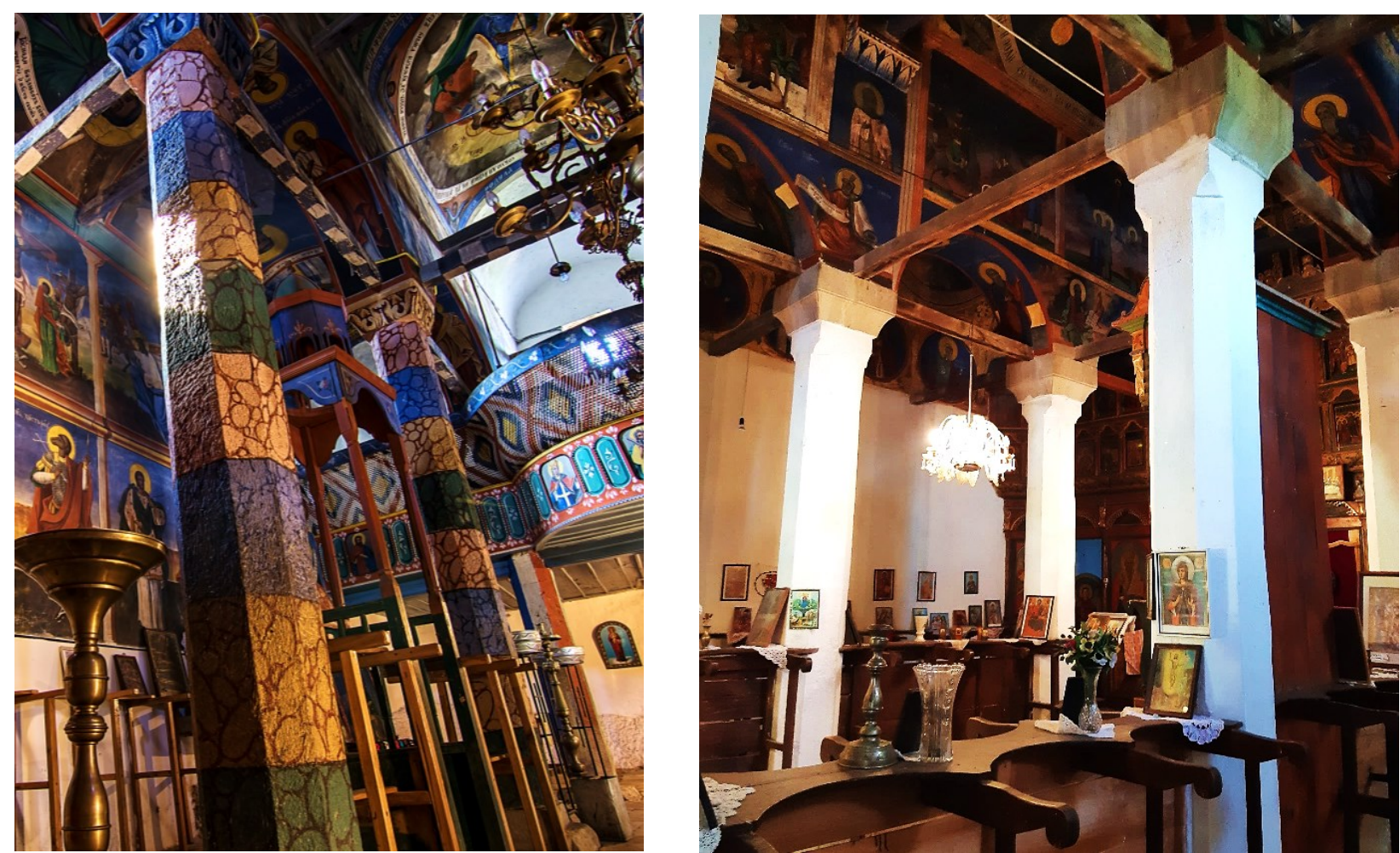

Figure III.98 Examples of columns made of stone: A. St. Petka in Radibush (Kriva Palanka); B. St. Demetrius in Stracin (Kratovo).

In some churches with columns and capitals made of stone, there is additional decorative painting of the same. Such example is the church of St. Petka in Radibush (Kriva Palanka), where the octagonal trunks of the stone pillars are painted as follows: the trunk is divided into eight segments, painted alternately in indigo-blue, yellow and light pink tones; complemented by an imitation of rounded pieces of stone with different dimensions, in order to achieve a masonry effect (fig. III.98A). In most cases, however, they retained their natural finish or were alternatively later whitewashed (fig. III.98B).

The solutions of the columns and capitals made of wood are far more diverse. As described before (see Chapter III.2), the wooden core of the columns was encircled with wooden planks, hemp rope and coated with mortar to obtain a circular cross-section and the effect of a massively built and then plastered column. In many of the churches, the columns were left plastered white, while the capitals and arches were painted in vivid colors (for example, at the church of St. Savior in Kozhle near Skopje and the

\footnotetext{
354 Such examples are St. Nicholas in Mavrovo, St. Nicholas in Vevchani, the Osogovo Monastery, St. Demetrius in Stracin, etc.
} 
churches in the region of Veles); nevertheless, there are also many examples where they received painted ornamentation. Often, the columns were painted to achieve the effect of a masonry structure in marble or stone. Furthermore, in many churches they were completely covered with ornamental patterns: imitation of lonic fluting on the column's trunk, palm, vine, ivy or flower branches, acanthus leaves, interweaving, lines, stripes and other decorative motifs and their multiple combinations. For example, painted alternating stripes in blue and yellow tones spiral upwards on the columns of the church in Pancharevo (see fig. III.13), complemented by a thin leafy branch painted in between; at the church of the Holy Trinity in Smolari (Strumica) the stripes were painted in blue and burgundy; similarly painted are the slender columns of the church at Bohula (Kavadarci), etc. Furthermore, at times the columns were adorned with geometric motifs - for example, concentric rhombic motifs in burgundy, ocher and blue tones, in the center of which appears a bouquet of flowers at the eastern pair of columns of the church St. Panteleimon in Makrievo (Strumica), while the remaining columns in the church were decorated with garlands and branches. In addition to the geometric patterns, the prevailing ornamentation consists of elements spiraling around the body of the column, predominantly floral motifs, vine shoots, grapes, garlands, palm leaves, etc. (fig. III.99). ${ }^{355}$

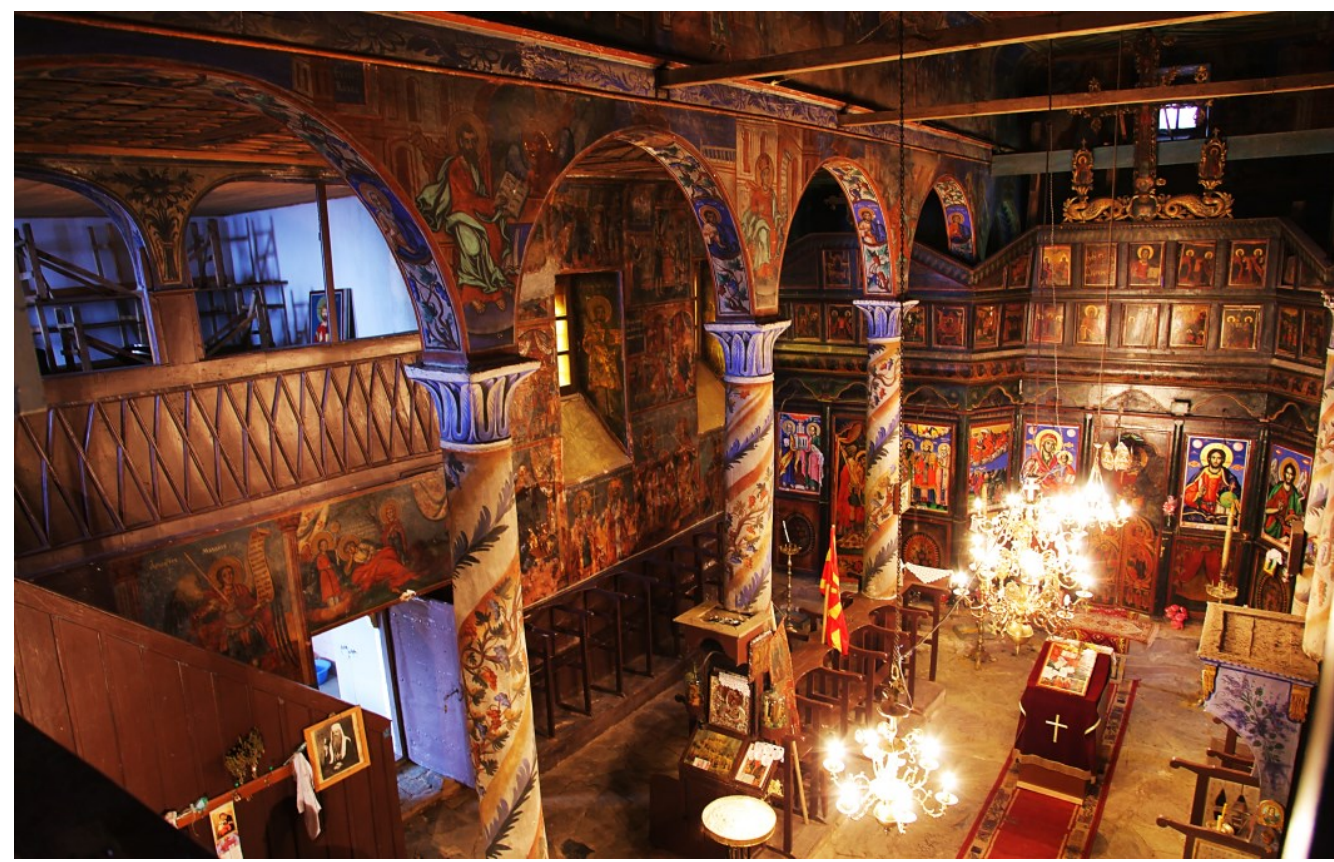

Figure III.99 St. Elijah in Stenche (Tetovo). View from the gallery towards the naos.

A similar decorative treatment was applied at the columns in the churches in Petralica, Opila and Rankovce, all in the region of Kriva Palanka, where the trunks of the columns were spirally covered with painted tendrils; in Petralica and Opila they were comprised of blooming branches; in Rankovce on the other hand, of lily shoots and vine branches with ripe grapes. In the case of the church in Rankovce (see fig. III.156), these painted branches were twisted around the columns to a certain height, followed by a painted imitation of vertical grooves under the capitals. As a very interesting and quite unique feature, in the churches of this regional group, the capitals of the columns were similarly shaped in a very specific way that resembles the lotus flower capitals of the ancient Egyptian temples, ${ }^{356}$ subsequently painted with floral motifs or imitation of stylized acanthus leaves.

\footnotetext{
${ }^{355}$ As is the case, for example, at the church of St. Nicholas in Klisura (Demir Kapija); St. Elijah In Sachevo (Strumica); St. Elijah in Stenche (Tetovo) (fig. III.99); the church in Kunovo, etc.

356 Similar capitals are also found in the church in Belichica.
} 
The capitals of the columns, sculpted in stone ${ }^{357}$ or in the kjulum technique described before (see Chapter III.2), were regularly decorated with a variety of profiles as well as painted motifs. In terms of the prevalent profiles, these vary from simple, stylized segmental profiles; capitals shaped like an inverted pyramid; $; 38$ to complex geometric profiles and combinations of a torus, trochilus, the Egyptian cyma, etc., as well as imitations of the classical orders (fig. III.100B). ${ }^{359}$ In addition to complex profiles and decorative painting, the Revival capitals often feature an almost completely free, three-dimensional sculpture: primarily motifs of birds, winged angels, animals, as well as wreaths, garlands and floral motifs in very deep relief. At the church of St. John in Kratovo, for example, unlike the capitals below the gallery (see fig. III.38B) and those within the porches (see fig. III.50B), which are of simpler design, the capitals in the naos consist of a rich filigree-like decorative composition of a wreath of leaves at the bottom, on which flowers are placed with wide open petals with sharp, jagged edges, at the corners stand birds with outstretched wings, and in the axes of the capital stylized angels - seraphim, with three pairs of wide flared wings (fig. III.101B). A similarly rich sculptural elaboration in particularly high relief and the appearance of seraphim also characterize the gilded capitals at the church of St. Demetrius in Kriva Palanka (fig. III.101A).
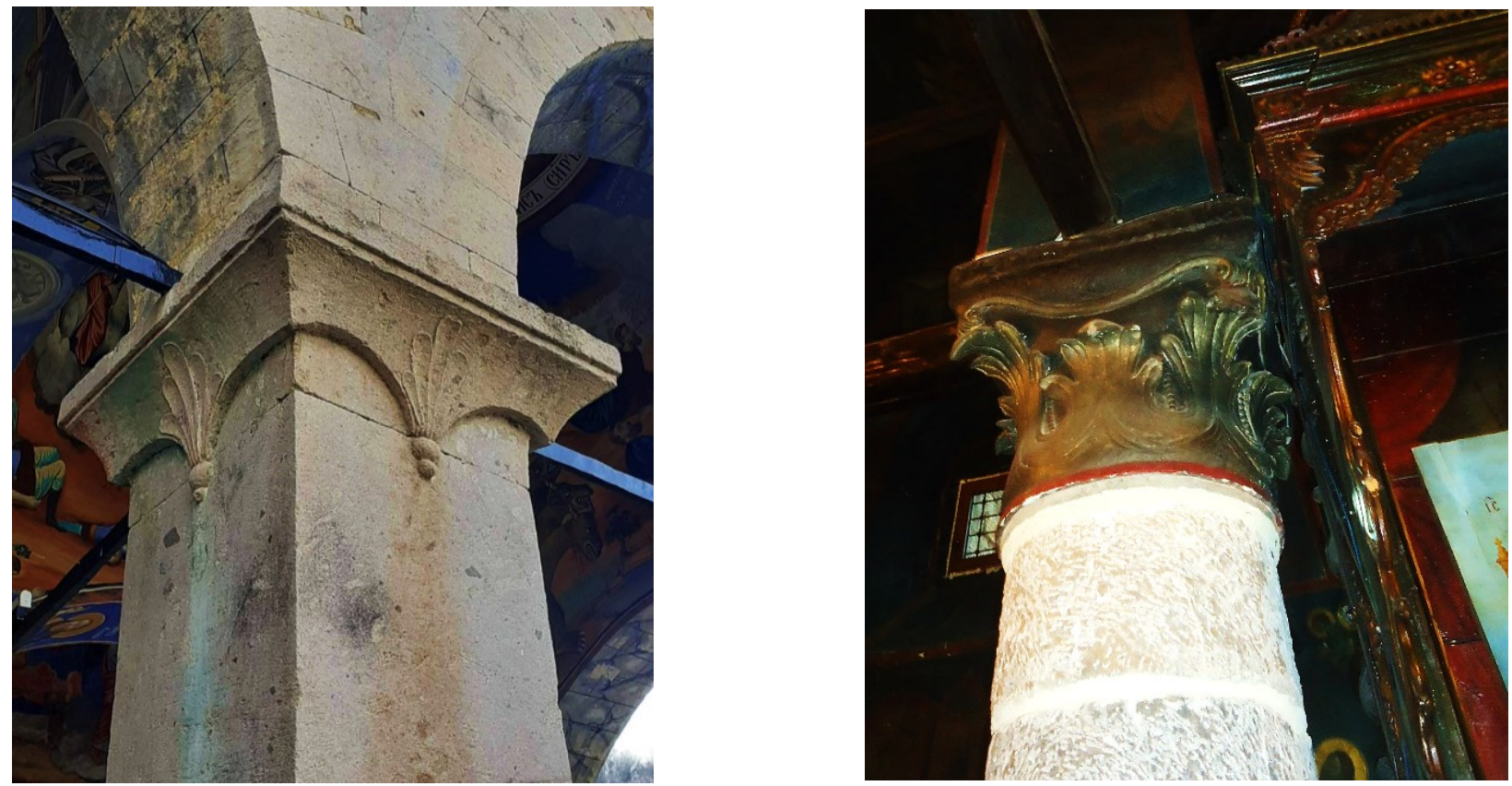

Figure III.100 Details of stone columns and capitals: A. St. Joachim - Osogovo monastery (Kriva Palanka); B. St. George in Gorna Vlashka Maala, Ohrid.

In addition to sculptural processing, the capitals of the Revival churches often received decorative painting. Most often, it is a painted imitation of acanthus leaves, ${ }^{360}$ which is one of the most common motifs for their decoration (and is found abundantly in the painting treatment of the bishop's thrones, ambos, icon pedestals and other church furniture); followed by palm leaves; ${ }^{361}$ as well as floral motifs in the form of individual blooms, groups of three flowers or floral bouquets. ${ }^{362}$

\footnotetext{
${ }^{357}$ At the churches in Skochivir, Jablanica, St. Nicholas in Mavrovo, St. George and the Most Holy Mother of God - Kamensko in Ohrid, St. Nicholas in Vevchani (Struga) and many others.

358 For example, at the churches in Pehchevo, Prilep, Brajchino, Pantelej, etc.

${ }^{359}$ At the church of the Most Holy Mother of God in Janche (Debar - Reka), the capitals were shaped in the lonic style, with volutes on all four faces of the capital and were also completely gilded; at St. George in Gorna Vlashka Maala in Ohrid, where while the capitals of the columns beneath the gallery have geometrically profiled capitals, the remaining columns in the naos were treated with sculpturally carved acanthus leaves, similar to the classical Corinthian capitals from the early-Christian period (fig. III.100B). ${ }^{360}$ At the churches in Stenche, Duf, Sachevo, Kozhle, Novachani, Dolno Chichevo, Krajnici, Veshje and many others.

${ }^{361}$ At St. Nicholas Gerakomija in Ohrid, the church of the Most Holy Mother of God in Farish (Kavadarci), etc.

${ }^{362}$ At the churches in the villages of Bohula (Kavadarci), Popadija (Veles), etc.
} 

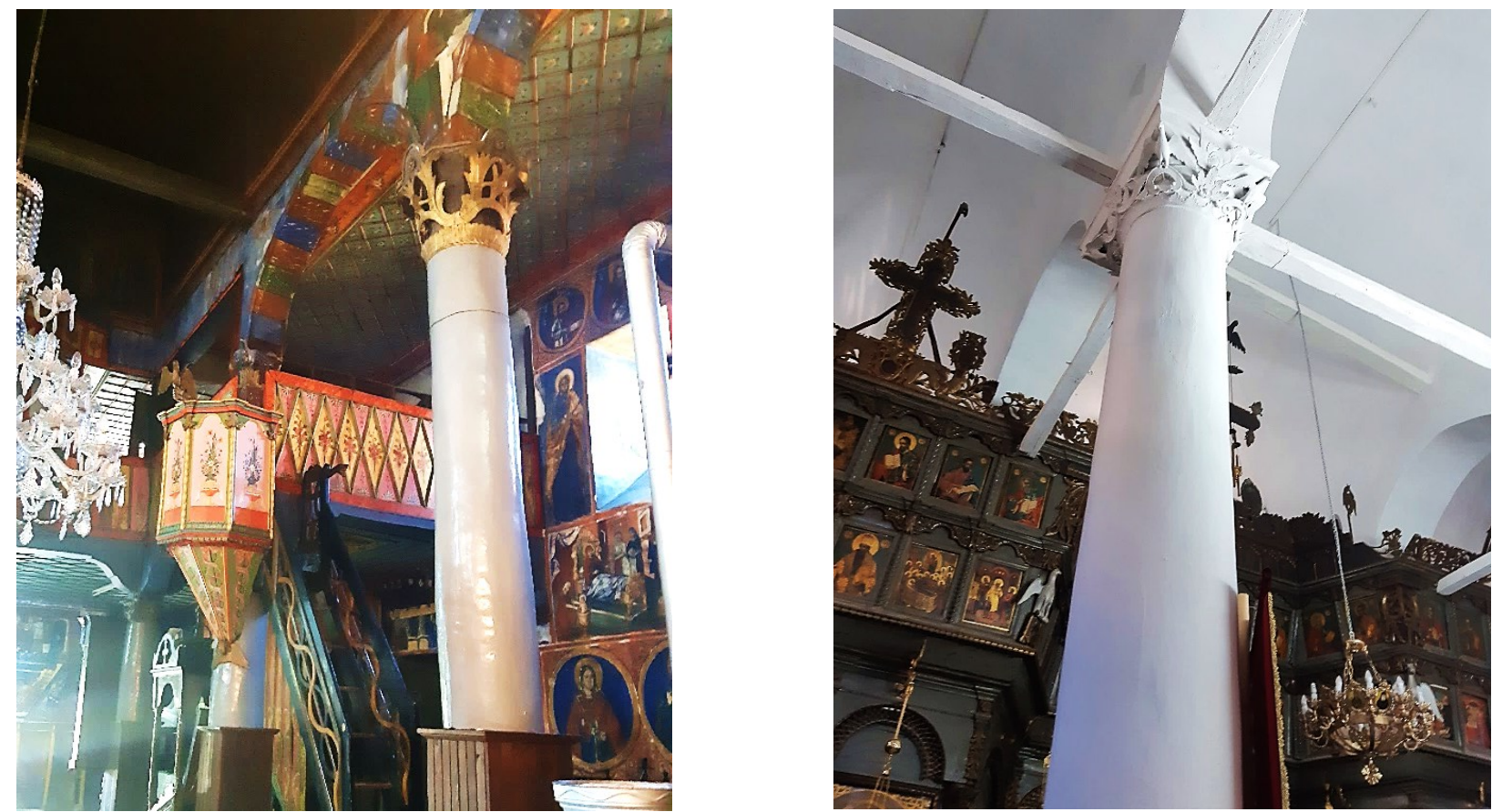

Figure III.101 Details of wooden columns and wooden (kjulum) capitals: A. St. Demetrius in Kriva Palanka; B. St. John in Kratovo.

Lastly, there are many examples of Revival churches where the entire wooden structure is left completely visible, without plaster coatings or decorative painting. Such example is the church in the village of Stinik where the wooden ceilings, the ambo, the gallery fence, the seats for the congregation; all wooden elements are left in their natural form, without painting, which emphasizes their contrast with the pristine whiteness of the whitewashed walls, columns and arches, therefore the only coloristic accent in the interior being the iconostasis.
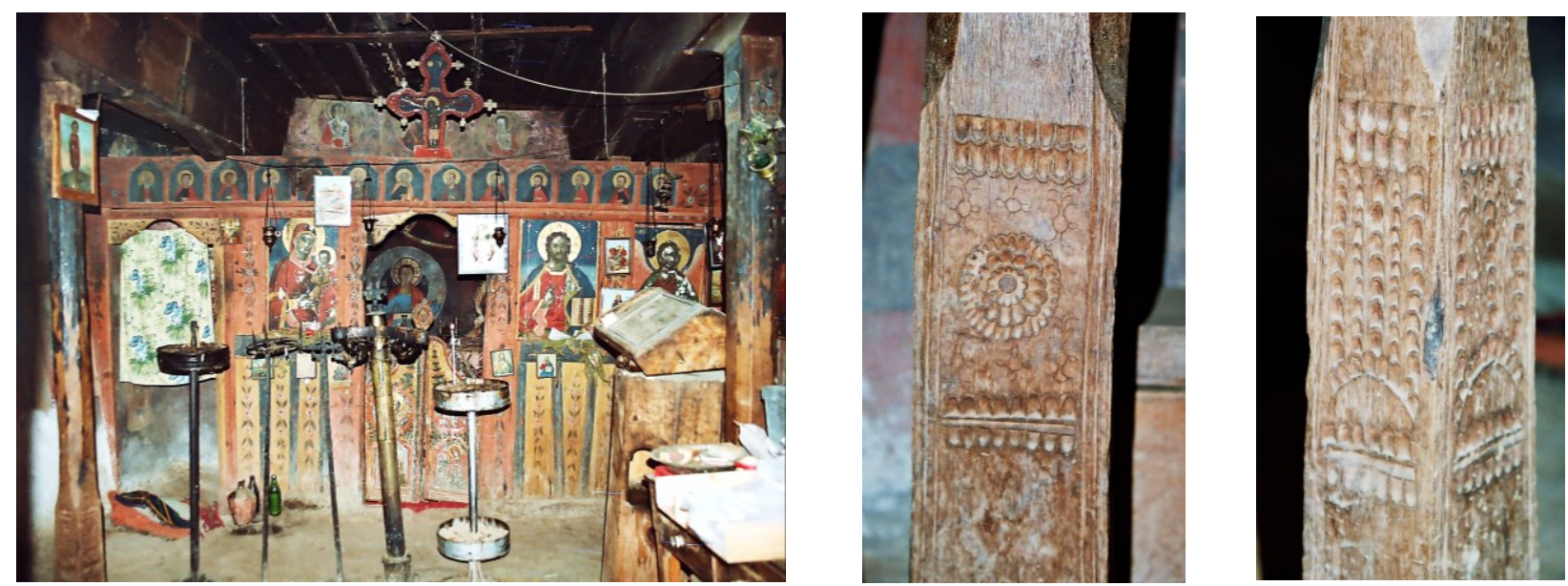

Figure III.102 St. Demetrius in Grunishta (Mariovo): A. Naos, view towards the east; B. and C. Details of the wooden columns.

A particularly interesting example of a decoratively processed wooden structure without any mortar coating or painting is found at the church of St. Demetrius in the village of Grunishta, region of Mariovo (fig. III.102). It is a small, compact building which, despite its limited dimensions, is composed as a three-nave basilica, which speaks of the importance and preference of this typological solution in the Revival, even in cases where the spans allow for the naos to be bridged without any structural supports. ${ }^{363}$ Namely, the naos is divided into three naves by means of wooden pillars with a small cross-section, which

${ }^{363}$ A similar solution can be found at the church of St. Athanasius in Sovich (Mariovo), the only difference being that this church lacks decorative woodcarving of the load-bearing elements. 
support an architrave wooden structure. The middle nave has a clerestory, covered with a flat wooden ceiling (as are the lateral ones); the ceilings as well as the entire wooden substructure were left in their

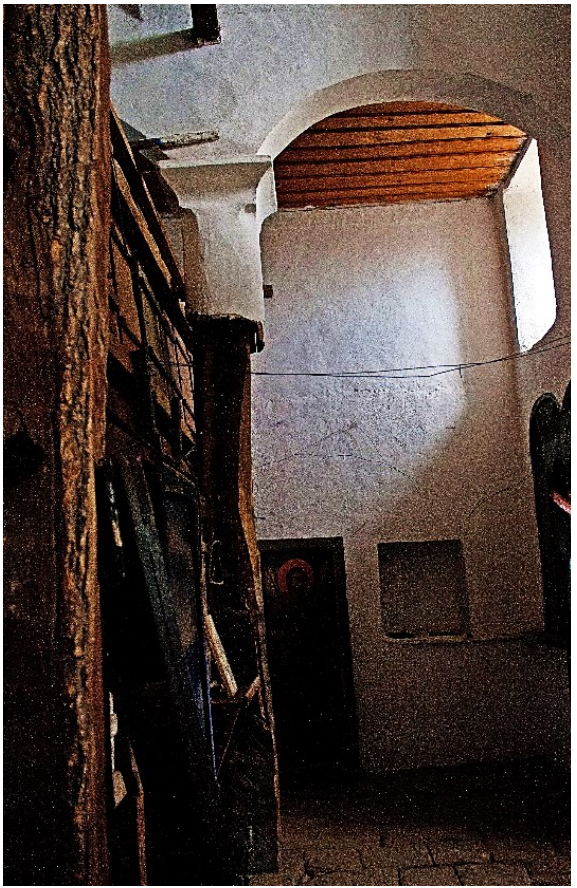

Figure III.103 Detail of the unprocessed eastern pair of columns behind the iconostasis, St. Savior in Graeshnica (Bitola). natural color and appearance. The processing of the wooden pillars is quite specific. The trunk of the pillar was divided into belts by means of different cuts: the bottom was formed as a "base" with a square cross-section, followed by a hexagonal "trunk" and, in the upper zone, a "capital" which again has a square cross-section. The accentuated bases and capitals were additionally carved with vertical grooves, floral petals and detailed floral rosettes, twigs, strings, shoots and similar ornaments, often found in the wood-carved elements of the vernacular residential architecture of the same period.

In stark contrast to the decoration of the columns in the naos, in order to make the construction more economical (which was a general tendency during the Revival), often the last pair of columns to the east, which regularly supported the altar partition on their west side and were therefore partially covered by it, did not receive any decorative elaboration, and were rather left completely bare, stripped to the mere wooden support. There are even examples where the tree trunk acting as a column received little to no straightening (for example, at St. Savior in Kozhle, near Skopje) and, as a rather extreme example, at times not even the bark of the tree trunk had been entirely removed prior to its installation in the church's interior (for example, at St. Savior in Graeshnica, near Bitola, fig. III.103).

\section{Flat wooden ceilings}

Another surface suitable for ornamental elaboration within the interior of the Revival church was its ceiling. Without exception, a flat wooden ceiling was elaborated beneath the gallery, because its construction was always made of wood. In addition to this particular location, a significant number of churches (see Chapter III.5) also have flat wooden ceilings above the lateral naves, in the altar area, and even throughout the entire naos. The simplest model of a wooden ceiling is made of transversely or longitudinally arranged wooden boards joined with carpentry methods such as the "tongue and groove" and often additionally enriched with thin profiled planks that were inserted at their joints, which provided greater three-dimensionality, i.e. gradation of the surfaces in depth within this basic type of ceiling. Furthermore, they were often additionally painted, usually with contrasting colors alternating between the base boards, ${ }^{364}$ or between the boards and the thin planks that covered their joints. ${ }^{365}$

In addition to this basic use of color on the flat ceilings, they were also quite commonly decoratively painted: with individual floral motifs arranged in a repetitive raster; ${ }^{366}$ with blooming, spiraling branches

\footnotetext{
${ }^{364}$ At St. Athanasius in Bohula (Kavadarci); at the churches in S'Ip and Krajnici, both in the region of Veles, where contrasting bright tones of red and blue-green were used; a similar solution, although the colors are quite faded and the church is generally in a more neglected state, can be found at St. Athanasius in Dolno Chichevo near Veles (see fig. III. 42); etc.

365 At the church in Popadija (Veles); in the villages Gabrovo, Dabile and Makrievo in the region of Strumica, where the boards are painted in blue (in Gabrovo the tone is green), with the planks over their joints painted in a contrasting burgundy hue, etc. ${ }^{366}$ For example, in the altar space and beneath the gallery of the church of St. Savior in Kozhle (Skopje), where the entire ceiling is painted with small white blooms set against a dark background.
} 
(fig. III.104A), leafy palm or ivy branches (fig. III.104B) along the entire length of the boards; or with solar, mostly star-shaped motifs. ${ }^{367}$
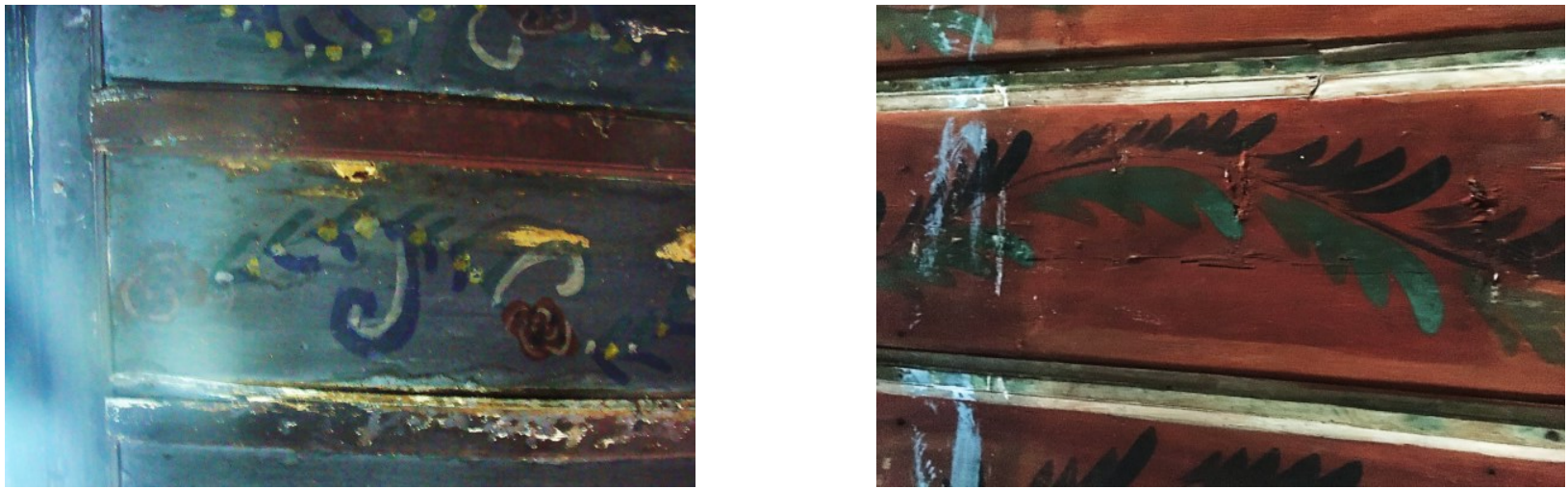

Figure III.104 Details of painted wooden ceilings: A. St. Nicholas in Gluvo (Skopje); B. St. Nicholas in Vevchani (Struga).
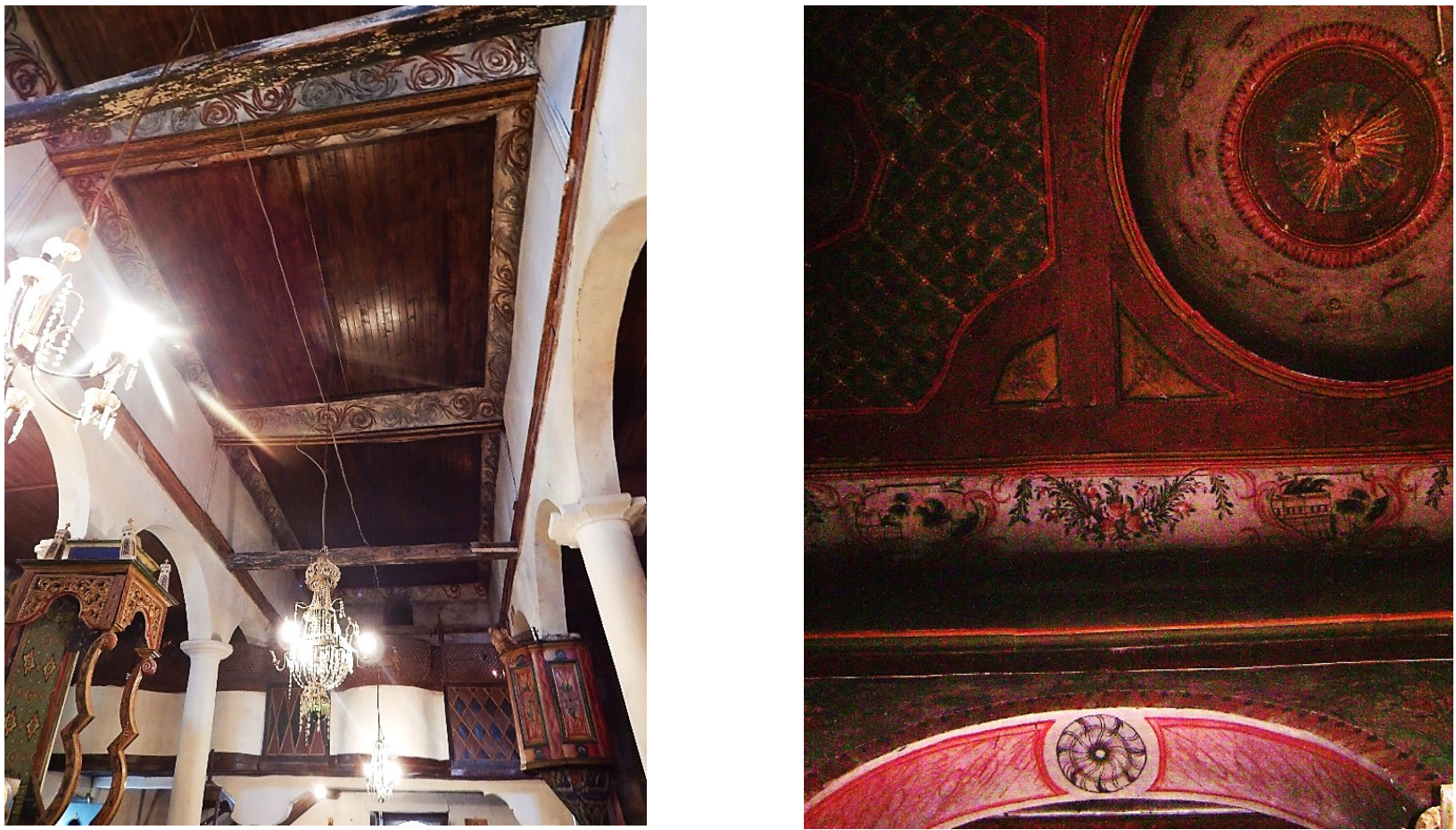

Figure III.105 Details of flat wooden ceilings: A. St. Nicholas in Bashino Selo (Veles); B. St. Elijah in Blatec (Vinica).

Another variant is decorating the profiled rim (border frame) of the field(s) covered with a flat wooden ceiling: for example, in the central nave of the church of St. Nicholas in Bashino Selo (Veles) the simple flat wooden ceiling is divided into bays encircled by a concave plastered border painted with floral motifs - leafy branches curled into baroque "S" volutes (fig. III.105A); the wooden tie beams that span the central nave were also pained. Sometimes the border of the central nave ceiling received quite complex painted compositions, such as at the church of St. Elijah in Blatec (Vinica) (fig. III.105B), where medallions depicting imaginary landscapes and townscapes with recognizable elements of the local Balkan-oriental residential architecture (which, as was said, was a motif also painted on the church's gallery parapet, see fig. III.44A-B) alternate with symmetrical floral arrangements. In addition to painting, the border which framed the flat ceiling was sometimes additionally decorated using three-dimensional wood-carved

${ }^{367}$ For example, at the church of St. Savior in Creshevo (Skopje); at the XIX century re-painting of the Nativity of the Most Holy Mother of God in Tepavci near Bitola (see Chapter I.5.2); at the Holy Trinity in Smolari (Strumica), where the motifs are circular shaped into a simple medallion with radial rays, without profiling or wood-carving, etc. 
elements as, for example, at the church of St. Savior in Creshevo (Skopje), where gilded wood-carved floral rosettes alternate with complex "S" volutes (see Chapter III.5.A.2).

A more complex solution of the flat wooden ceilings was achieved with their decorative division into smaller fields in one direction (usually transverse), or in both directions - the so-called coffer ceilings (fig. III.105-107). The wooden boards and planks with which the coffer ceiling was formed were cut into squares, triangles, as well as diagonally and then assembled into a mosaic composition according to a complex previously traced design (Светиева, 1992: 105).
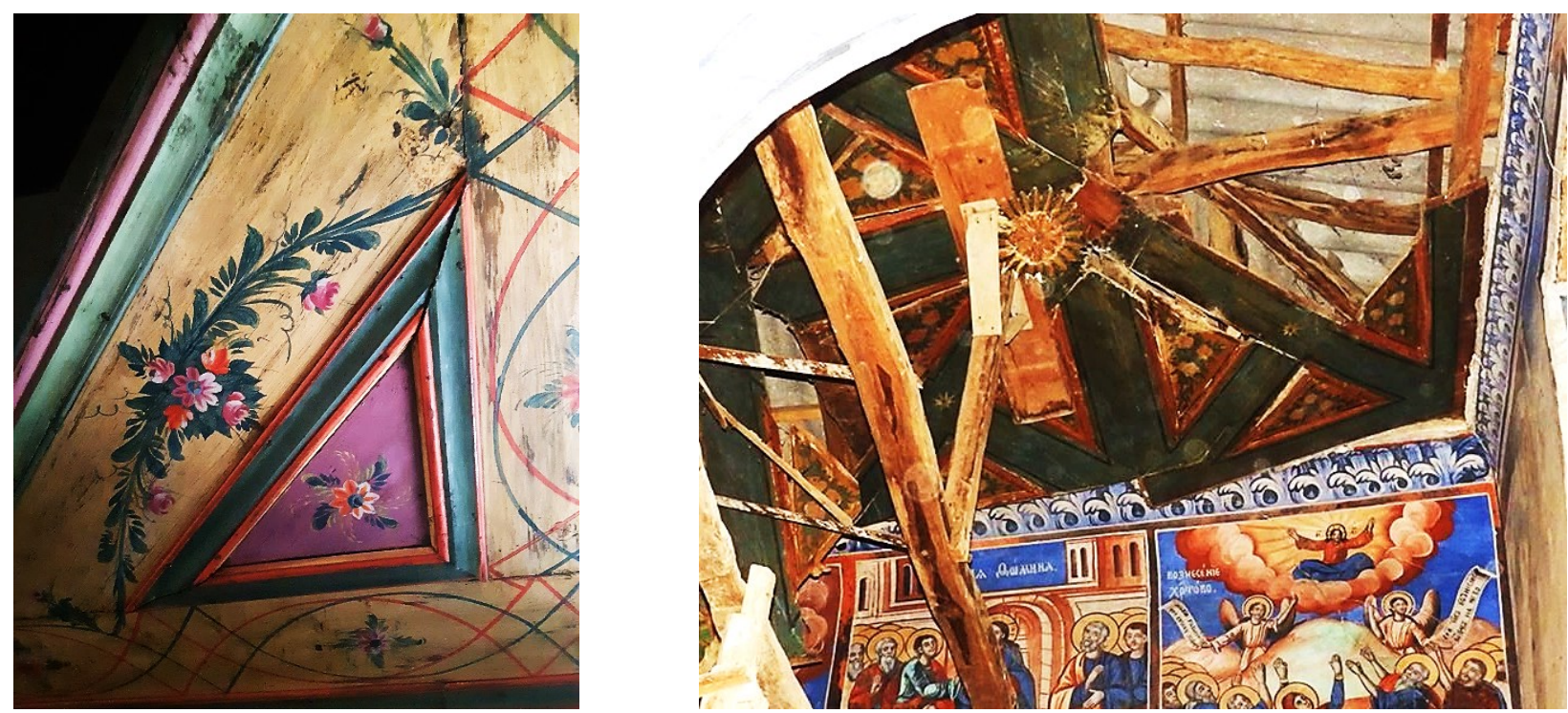

Figure III.106 Details of wooden ceilings: A. St. Demetrius in Kriva Palanka; B. the Most Holy Mother of God in Farish (Kavadarci).

Furthermore, the coffer ceilings, in addition to the decorative profiles and sculptural processing, were almost regularly painted in several complementary or contrasting warm tones, ${ }^{368}$ usually with additional painted solar ${ }^{369}$ or floral ornaments and motifs: bouquets, flowers, twigs etc. (fig. III.106-107). An example of a very decorative and richly conceived ceiling is found at the church of St. Demetrius in Kriva Palanka, where the coffer ceilings in the lateral naves are rotated by $45^{\circ}$ and additionally enriched with large decorative octagonal rosettes (fig. III.107). The square fields painted in blue-green tone were complemented by a rose flower placed centrally, while the thin planks were painted in a warm red tone, as well as the corner frame additionally painted with floral garlands. In fact, the decorative treatment of the wooden coffer ceilings of this church extends consistently on all available surfaces, including the ceiling beneath the " $U$ "-shaped gallery; the arches between the pillars (where fictional stone blocks were painted with alternating terracotta, indigo and muted green tones); the gallery parapet; ${ }^{370}$ the octagonal rosettes in the lateral naves (similarly painted as the gallery fence); the square rosette on the ceiling beneath the gallery (see fig. III.16A); the stairs leading to the gallery; the ambo and bishop's throne, etc. In addition to this colorful abundance, the walls of the naos and the three blind domes in the central nave were entirely fresco-painted.

\footnotetext{
${ }^{368}$ At the church of the Nativity of the Most Holy Mother of God in Lopatica (Bitola) the ceilings are made of planks painted in a greenish tone (Николовски, 1993: 166); at Bohula the square fields of the coffer ceiling were painted in red and blue-green tones; at St. Elijah in Sachevo (Strumica) the coffer ceiling along the entire length of the central nave consists of small squares alternately painted in ocher and blue tones, while the wooden profile of the planks with which they were framed received a burgundyreddish shade; the ceilings at the churches in the nearby villages of Dabile, Makrievo, Gabrovo and Mokrino were similarly conceived. At the church in Gabrovo, the coffer ceiling was also framed with a thin strip painted with floral decoration.

${ }^{369}$ A white eight-pointed star is painted in the center of each field of the coffer ceiling at St. Elijah in Sachevo (Strumica).

370 Decorated with elongated rhomboid motifs made of thin planks: the rhombus-shaped fields were painted in yellow, with centrally placed branches - tree of life motif, the planks that shape them were painted in a green tone, while the background consists of triangular fields whose gentle pink hue is complemented by radiant stars.
} 

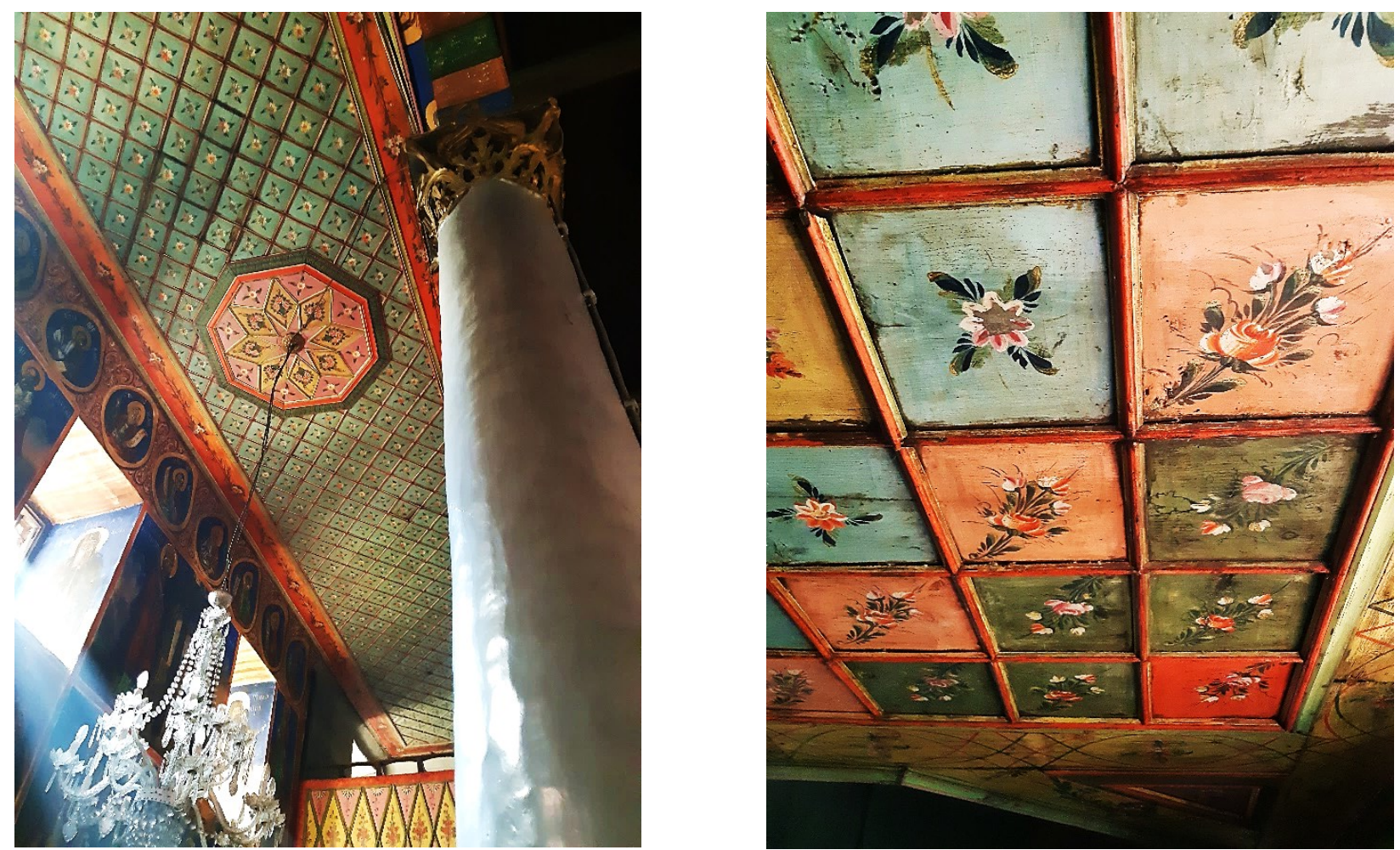

Figure III.107 St. Demetrius in Kriva Palanka: A. View of the flat wooden ceiling in the southern nave;

B. Detail of the wooden ceiling above the gallery.

Among the churches with luxuriously painted coffer ceilings, the Most Holy Mother of God in Farish (Kavadarci) also stands out (fig. III.106B), where the squares are further divided with diagonal planks painted in dark green, while the triangular segments formed in this way are painted in a contrasting burgundy red. In the corners between the cassettes three-dimensionally processed floral motifs are placed, and the passage from the fully fresco-painted walls to the coffer ceiling, shaped into a concave cornice, is decorated with a stylized meander of blue acanthus leaves.

In the most luxuriously treated flat wooden ceilings, profiled wooden rosettes were installed, often comprised of several layers, gilding and wood-carved details, as the ones which adorned the representative rooms in the rich town houses of the Revival bourgeoisie. Furthermore, in the longitudinal axis of the churches with a flat ceiling there often appear one or more blind calottes and other threedimensional concave elements as dome substitutes. ${ }^{371}$ These hollow elements were fresco-painted with the usual iconographic program reserved for domed spaces: Christ Pantocrator, the Holy Trinity or the Mother of God with Christ or depicted in the position of Oranta. Even in the churches where there is no rosette or blind calotte, round plastered and fresco-painted medallions are often present, again as a clear dome substitute, whose symbolism and significance had not been abandoned despite its absence in the churches covered with flat wooden ceilings.

\section{Ambos, Bishops' Thrones and Church Furniture}

The interior decoration of the Revival churches included several necessary liturgical elements which were also subject of abundant symbolic ornamentation, such as the bishop's throne, the ambo, as well as a wide array of church furniture: icon pedestals; gospel pedestals, gift and relics boxes, seats for the faithful, candle chandeliers etc. All these elements were made of wood and are an expression of the

${ }^{371}$ These could be circular - for example, at the church of St. Savior in Creshevo (Skopje); or polygonal, for example octagonal, at the church of St. Petka in Dolno Egri, near Bitola (Николовски, 1993: 161). 
exceptional skill in carpentry and woodcarving of the Revival masters. In the most representative temples these elements, like the iconostasis itself, were executed in deep woodcarving, commisioned from the most famous woodcarving workshops; while in the more modestly equipped churches they were made of wood in a carpentry technique, but still enriched with details in woodcarving, profiling and sculpture and abundant colorful painting, in the spirit of the epoch, on all available surfaces.
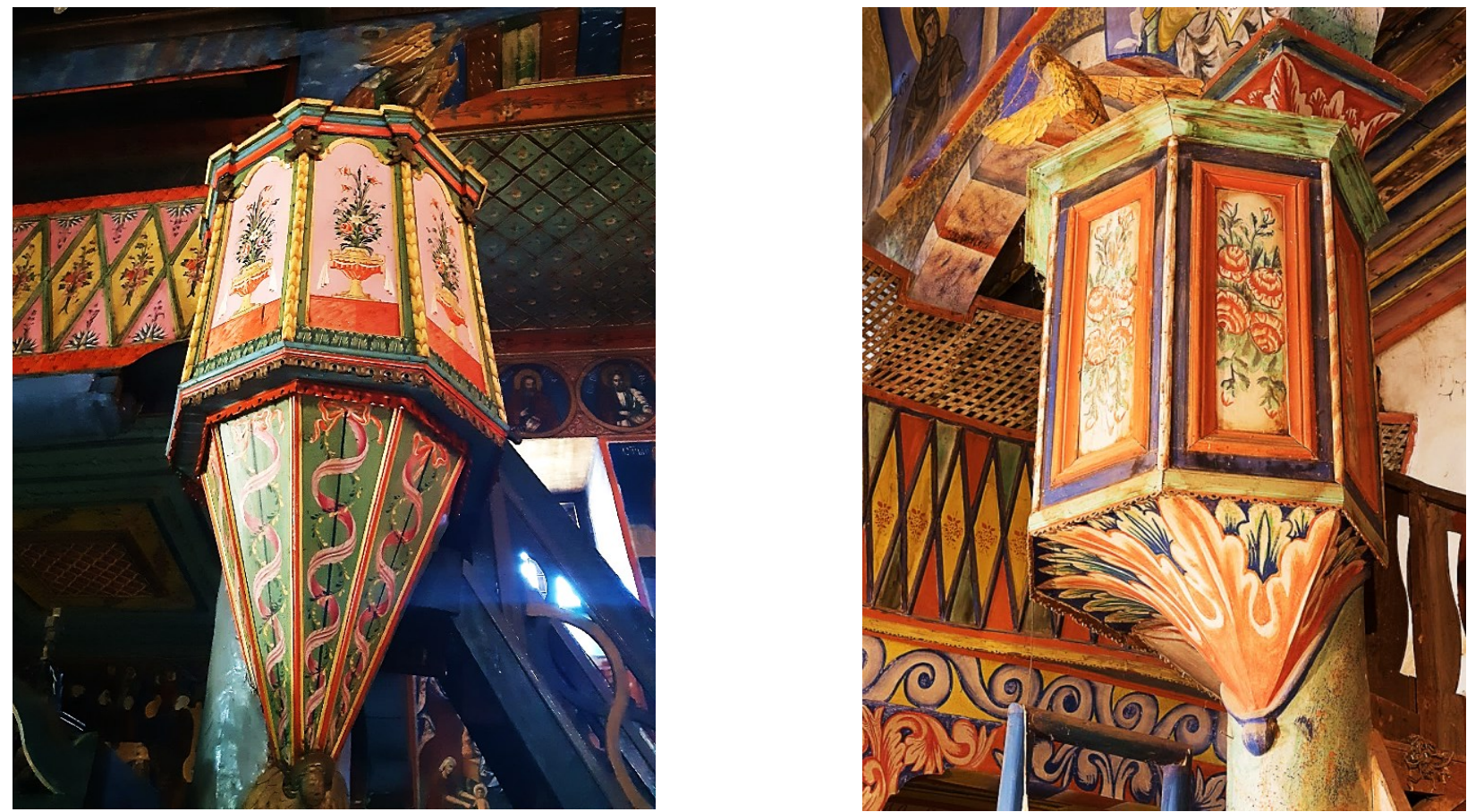

Figure III.108 Examples of Revival wooden ambos: A. St. Demetrius in Kriva Palanka; B. St. Athanasius in Dolno Chichevo (Veles).

The ambos (pulpits) were regularly made of wood, shaped as cantilevered balconies placed high on one of the columns in the northern colonnade of the three-nave basilicas, or on the north wall in the single-nave churches (fig. III.108). They were reached via a spiral staircase with a decorative fence at the three-nave basilicas, and usually via a wooden ladder at the single-nave ones. The pulpit parapet was regularly solid and polygonal, and each side was painted, or used as a base for the display of an icon, usually within a profiled or woodcarved frame. The balcony was usually supported on a base shaped as an inverted pyramid or cone which was also subject to decorative woodcarving or fresco-painting. The prevalent motifs used are the same ones found on the railings of the galleries and on the iconostasis: acanthus leaves, floral bouquets, tree of life, garlands, spirals, profiled capitals, pendants, and the regular appearance of a dove with outstretched wings sculpted out of wood, usually placed above the ambo's fence. Additionally, the pulpits were painted, partially or completely, and sometimes gilded.

The bishops' thrones were also a mandatory element of church furniture. They were without exception

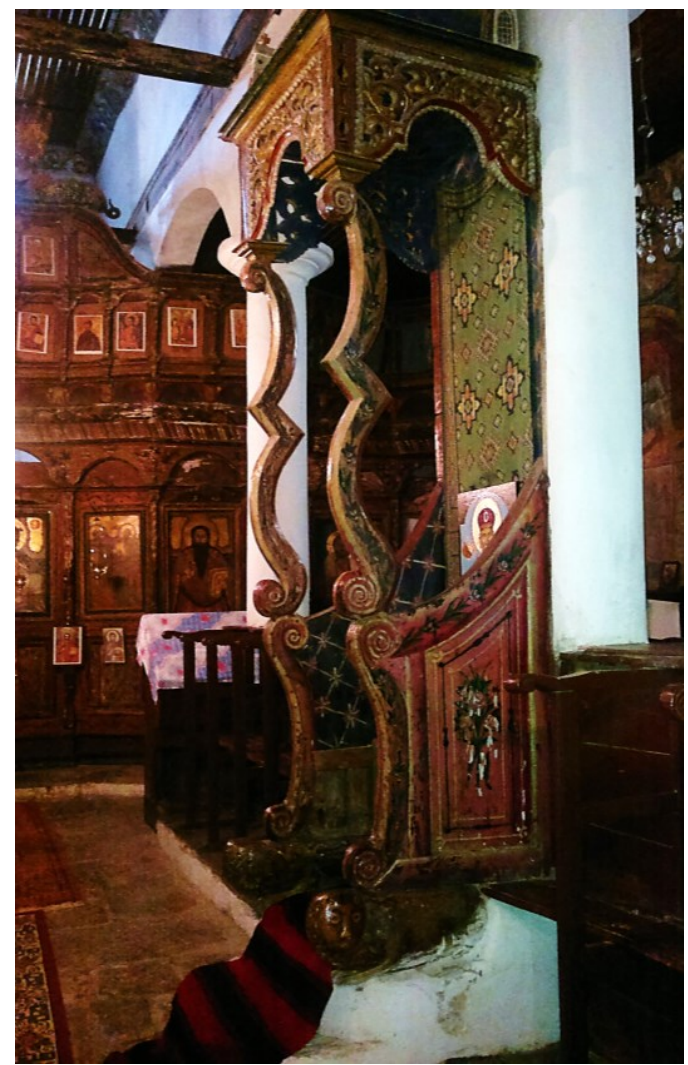

Figure III.109 Detail of the bishop's throne at the church of St. Nicholas in Bashino Selo (Veles). 
made of wood, using woodcarving, painting and gilding techniques, and were installed between the congregation seats on the south wall, or within the southern colonnade of the three-nave basilicas. These are very representatively conceived, high thrones, usually placed on a raised pedestal with access via several stairs made of wood or stone (fig. III.109). Special treatment is given to the armrests, often shaped using " $\mathrm{S}$ " volutes and complex profiles, as well as the front legs, which often rest on sculptural representations of wild animals, beasts or mythological creatures, which symbolizes the victory of Christianity over evil. The background of the throne is solid, allowing for a large format icon to be placed above the seat. High above it develops the most decorative element - a canopy arranged in the form of a tall dome placed on a square base, often accompanied by four smaller dome elements in the corners, which is a clear parallel of the bishop's throne with the church itself and its sanctity marked with the representation of the heavenly vault under which it rests. In addition to the dome, sometimes presented in the form of a crown, the canopy and the entire throne are enriched with a multitude of decorative wood-carved elements: pendants, capitals, intertwined motifs, semi-transparent bars, twisted columns, profiled wreaths, painted panels (with floral decoration, tree of life motifs, circular or oval medallions with landscape scenes, etc.), sculptural motifs (crosses, doves, angels), etc.

The composition of the icon pedestals is quite similar, with the difference that they are covered by a slightly simpler canopy, and in the lower zone instead of a seat appears a pedestal on which the icon is displayed, which often contains a box for donations within. The decorative motifs, ornaments and colors used in the entire church furniture in most churches correspond to those used on the iconostasis and the gallery, which gives the interior of the temple a uniform, unified, well studied appearance.

\section{III.5 Typological Classification}

The years of research work related to the preparation of this doctoral dissertation, both in terms of research of primary sources - the Revival churches themselves, i.e. field work, and in terms of research of existing documentation, archives and bibliography, resulted in a hitherto non-existent and unpublished review of the Revival sacred architecture in Macedonia. Namely, within the realized research, over $\mathbf{8 0 0}$ Revival basilicas have been recorded so far, of which 605 were precisely dated (according to the year of construction, consecration of the temple or its fresco-painting), using preserved inscriptions, bibliographic and historical references, etc. This statistically significant number allows various types of further research, such as analysis of the intensity of their construction by years / decades; analysis of their geographical distribution within the present borders of Macedonia ${ }^{372}$ and, of course, the analysis of their typology.

In fact, the typological analysis provided by a statistically large enough group of monuments, in this case the Macedonian Revival basilical churches, despite its shortcomings is the only method by which such a group can be classified most clearly and legibly. In this context, the following statement of Vojislav Korać and Marica Shuput seems extremely relevant: "We abandon for a reason the typological method as unsuitable to explain the nature of a complex construction work, however, the views of a larger whole, which should clarify the general trends in architecture, inevitably acquire a typological framework. The basilica is a basilica in all variants, as is the church with an inscribed cross with a dome or the trefoil.

\footnotetext{
372 As stated in the introduction, the overall interest of this doctoral thesis focuses on the present territory of Macedonia, with certain exceptions (such as the church of St. Achilles on the island of Achilles, Prespa Lake, today on the territory of Greece) whose inclusion is essential to the set hypothesis. It is clear that such a conceptualized research does not integrate the entire Macedonian Revival architecture, given the significantly larger territory that Macedonia occupied until 1912 and its subsequent division between the neighboring countries, as well as the vast territory cruised by the Macedonian master-builder groups in their seasonal work. However, the limitation of the field of interest, for practical reasons, to the current political boundaries of Macedonia imposed itself as a logical consequence of the need to give temporal and spatial boundaries to a research to which, it seems, to devote an entire lifetime would be insufficient.
} 
However, if the typological benchmarks were excluded, it would be difficult to grasp the origin and significance of architecture" (Кораћ и Шупут, 1998: 211).

The adopted methodological principle for the study of the Revival churches in Macedonia is, therefore, the typological comparative method. The typological solution of the churches helps us to discover their possible author / master-builder group, through comparative analysis and definition of related features with other churches where the same architectural typology, processing, interior design, ornamentation or decoration was applied. Furthermore, the typological analysis helps to geographically locate the area of work of certain master-builder groups as well as their development and movement within Macedonia or outside its borders, and thus the mutual exchange of stylistic influences. The typological analysis also helps to determine the influences of the older buildings of the basilica typology (basilicas of the early-Christian, middle-Byzantine and post-Byzantine period) as well as other older typological patterns, on the appearance and development of the Revival basilicas, which is one of the main goals set for this doctoral dissertation.

Based on all of the above, upon their further in-depth analysis, of the Revival basilicas recorded so far a total of $\mathbf{5 3 3}$ were grouped and catalogued according to their architectural typology. In that sense, the distribution of the Revival basilicas according to their typological solution is as follows:

Types of Revival basilicas:

A. Single-nave basilicas (total: 251)

A.1 Single-nave basilicas with a semi-cylindrical vault (total: 101)

A. 2 Single-nave basilicas with flat wooden ceiling (total: 30 )

A.3 Single-nave basilicas with lateral pilasters connected with arches, covered by barrel vault (total: 40 )

A.4 Single-nave basilicas with "three-nave" ceiling disposition (total: 12)

B. Three-nave basilicas (total: 243)

B.1 Three-nave basilicas with flat wooden ceiling (total: 118)

B.2 Three-nave basilicas with semi-cylindrical vaults (total: 51 )

B.3 Three-nave basilicas with blind domes (total: 24)

B.4 Three-nave basilicas with central nave clerestory (total: 6)

B.5 Three-nave basilicas with one or more domes supported on elevated drums (total: 15)

C. Five-nave basilicas (total: 12)

D. Domed single-nave basilicas (total: 16)

E. Combined solutions (total: 11 )

Independently of the type of ceiling / vaulting, the churches with a defined narthex (separated from the naos by a low fence, a combination of a solid and semi-transparent partition or a continuous wall) can be distinguished as a separate category. ${ }^{373}$ However, each of them according to the typology of their upper parties belongs to one of the above listed groups. In order to avoid confusion and repetition of individual buildings, the churches with a defined narthex will not be considered as a separate category, but rather in the context of the typological groups (according to the way of coverage of the naves) to which they belong. The appearance of the narthex and the degree of its physical separation from the naos were discussed in Chapter III.2. The same system is used regarding the appearance or absence of a gallery

\footnotetext{
${ }^{373}$ St. Peter and Paul in Krstoar (Bitola); St. Savior - Ascension of Christ in Kozhle (Skopje); St. George in Oleveni (Bitola); St. George in Velushina (Bitola); St. Athanasius in Zhabjani (Bitola); St. Petka in Gorno Orehovo (Bitola); St. Petka in Nizhepole (Bitola); St. Trinity in Nikodin (Prilep); St. Savior in Graeshnica (Bitola); St. Petka in Prdejci (Gevgelija); St. Nicholas in Nakolec (Prespa); St. Nicholas in Slivica (Mariovo); St. Demetrius in Gradec (Valandovo); St. Demetrius in Bukovo (Bitola); St. Nicholas in Rotino (Bitola); St. Nicholas in Brajchino (Prespa); St. Nicholas in Klisura (Demir Kapija); the Most Holy Mother of God in Belovishte (Tetovo). From these examples it can be concluded that, with a few exceptions, the churches with a separate narthex (with full or partial partition) are concentrated in the Prespa-Bitola-Mariovo region.
} 
("women's church") and open porch(es), i.e. examples of churches with/without gallery and with/without porch(es) will be considered within the groups of churches with the same typological solution.

However, as has been said, the typological method has its drawbacks. The main disadvantage of the typological classification of such a large group of monuments, many of which have a complex architectural solution, is the need to place them in only one category, although according to their individual characteristics they could rightfully also belong to another. ${ }^{374}$ This problem has emerged as particularly acute in some of the three-nave basilicas whose typological classification has proven to be a difficult task. In that sense, the classification made in this doctoral dissertation cannot be considered final either by the number of typological sub-categories, or by the number of churches belonging to those subcategories, because with the classification made so far their total number is not exhausted. However, despite its weaknesses, this typological classification of the Revival churches in Macedonia is a very satisfactory base, which can be upgraded, expanded and refined with future research, both horizontally (by discovering new, additional typological sub-categories) as well as vertically (with a detailed study of individual monuments).

\section{III.5.A SINGLE-NAVE BASILICAS}

The statistical analysis of the so far typologically identified Revival churches shows that the dominant type of sacral construction in the Revival were the three-nave and the single-nave basilicas, which represent $47.1 \%$ of the so-far categorized Revival churches (see Chapter V). The single-nave churches are found mostly in smaller rural settlements, since their construction was simpler, cheaper, and at the same time the church building was intended for a smaller congregation compared to the threenave and five-nave basilicas; thus, their solution was dictated by the lower need for an adequately large space for mass gatherings. The single-nave churches, therefore, represent the simplest typological variant of the Revival basilicas. Within their basic volume, in a simplified form, all the necessary contents that a temple was supposed to have were inserted, in such a way that "in the organism of the single-nave building, what was considered a necessary part of the normal cult church building is replaced with secondary elements" (Кораћ и Шупут, 1998: 234). For example, the prothesis and the diaconicon were replaced by semicircular niches in the east wall, and sometimes in the north and south walls; to the west sometimes even the gallery as a regular element was omitted; the central dome as a symbol of the celestial space was replaced by a semi-cylindrical vault, and in cases where no such replacement was possible, its function was taken over by a polygonal rosette, a blind dome or fresco-painted medallion(s) (see fig. III.111A); and often, especially in the churches with flat wooden ceilings, at least the transition from the vertical plane of the walls to the ceiling was executed as a segment of a vault, which hints to some extent at the role of the ceiling as the embodiment of the celestial vault. Often, the desired effect was enhanced by fresco decoration - the ceilings were painted with solar motifs, medallions or in the form of a starry sky against a uniformly colored, dark background.

In the single-nave churches, the influence of the church typologies from the post-Byzantine period, or continuity in the construction tradition, is most obvious despite the significant novelties and borrowed

\footnotetext{
${ }^{374}$ As an illustration, the church of St. Elijah in the village of Selce is a domed building, with a dome that extends over the entire span of the naos; therefore, it would be logical to place it in the category of "domed single-nave basilicas". Towards this classification is its geographical location: in the heart of the Debar - Reka region, where, as shall be demonstrated later, the domed basilicas actually originate from. However, at the same time, it is not a simple basilica, but rather a combination with a trefoil, which is imposed as its dominant feature; thus, it seems logical to place this church in the category of "combined solutions". This is one of the several examples that have emerged as problematic points in the adopted concept of typological comparative research.
} 
elements that were accepted and introduced into the Revival sacred architecture. Namely, the postByzantine churches were accessible to the Revival master-builders in the immediate vicinity, so that their single-nave architectural typologies rely heavily on post-Byzantine patterns. In this regard, it is important to emphasize that the Revival single-nave churches were often built on older foundations or, in other words, it is among the single-nave church buildings that cases of older, mostly post-Byzantine temples are often found, renovated, expanded or reconstructed which was a very common practice in the Revival as a result of the liberalization of the social context (see Annex). Such examples are the churches of St. Athanasius in Dolno Dupeni, Prespa (Николовски, 1987: 35); the Nativity of the Most Holy Mother of God in Rankovce (Kriva Palanka); St. Demetrius in Rakitnica ${ }^{375}$ and St. Petka in Zhvan (Demir Hisar), and many others. Through the centuries-long stage of building a unified model, which is the post-Byzantine singlenave vaulted church, the evolutionary development can be traced, starting from the Byzantine singlenave domed buildings, as well as the churches of the compact inscribed cross type, into the rich variety of Revival single-nave temples. Of course, despite the visible parallels, the Revival single-nave basilicas differ in many ways from the post-Byzantine ones.

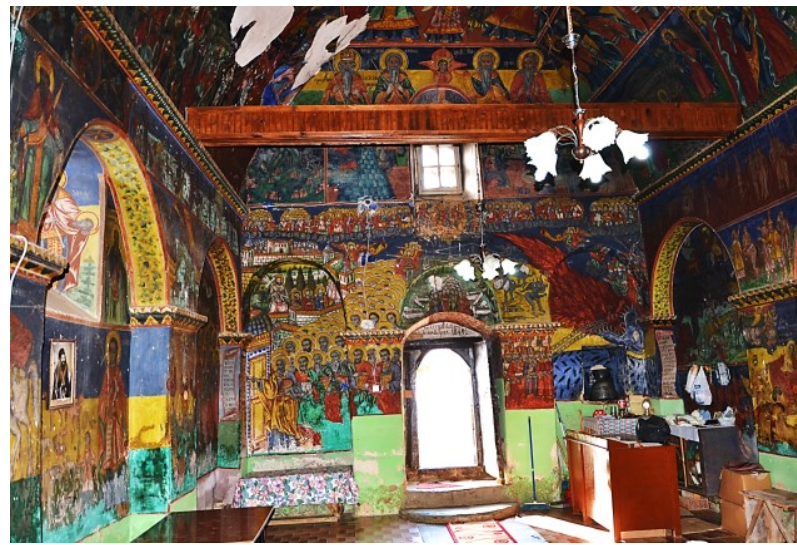

Figure III.110 St. Athanasius in Beranci (Bitola). Interior view towards the western entrance.

Firstly, the Revival single-nave buildings have far more monumental dimensions, larger spans and height; in fact, they often do not lag significantly behind the three-nave basilicas in terms of space. ${ }^{376}$ Consequently, the single-nave naos of the Revival churches, unlike the Byzantine and post-Byzantine ones, got a spatial definition with a specific purpose: to the west, the height of the Revival single-nave basilicas allowed for the appearance of an upper floor gallery - the socalled "women's church", supported by a wooden load-bearing structure and fenced with a solid wooden or plastered parapet fence, which was often complemented by a semi-transparent "musharabia". The galleries were illuminated through windows on the lateral façades, as well as a high central window on the west façade, which regularly received special treatment, with a window transenna in stone relief executed decoratively. An identical window appears above the apse on the east façade, which illuminates the altar space. Beneath the gallery, a "narthex" was distinguished with different degrees of physical barrier and/or denivelation; to the east a high iconostasis completely isolated the altar. Nevertheless, there are dozens of examples of Revival single-nave churches without an upper floor gallery (fig. III.110), as an even more direct reference to the post-Byzantine antecedents of this church typology.

In the context of the used constructive system, an essential difference is the combination of a massive and wooden frame system, as opposed to the entirely massive construction of the post-Byzantine churches. Differences are also evident in the external design of the buildings. Namely, the post-Byzantine churches are covered with a gable roof (see fig. I.42), they have an entrance only from the west side, and

\footnotetext{
375 St. Demetrius in Rakitnica is a single-nave, elongated church with a three-sided apse, built of crushed stone and mortar, using carved limestone for the cornice. It was originally vaulted, and today is architravely covered. According to the frescoes preserved fragmentarily in the altar space, it can be dated to the XVI-XVII century. In the XIX century it was significantly remodeled: perhaps the previously demolished vault was replaced by a flat wooden ceiling, and in the western part of the naos, in the spirit of the era, a gallery ("women's church") was erected, carried on 3 wooden pillars with a square cross section along the perimeter walls. ${ }^{376}$ As an illustration, the dimensions of the naos of the single-nave basilicas, not counting their altar apse, are: at St. Nicholas in Slepche (Demir Hisar) 7/13 m; St. Savior in Creshevo (Skopje) 7.15/14.8 m; St. Savior in Rashtak (Skopje) 8/12.9 m; St. Nicholas in Cer (Demir Hisar) 9.3/17 m, etc.
} 
to the east there is a low altar apse with relatively small dimensions, almost without exception threesided, with a centrally placed single window and without pilasters or blind niches. The Revival single-nave basilicas, on the other hand, predominantly have "saddle-shaped" shorter façades (fig. III.112). However, there are also churches with a classic gable roof, such as the churches in the region of Demir Hisar, as their local characteristic mark: St. George in Brezovo, Dormition of the Most Holy Mother of God in Dolenci, which is an extension of an older XVII century church, as well as St. Nicholas - St. Archangel in Vardino.
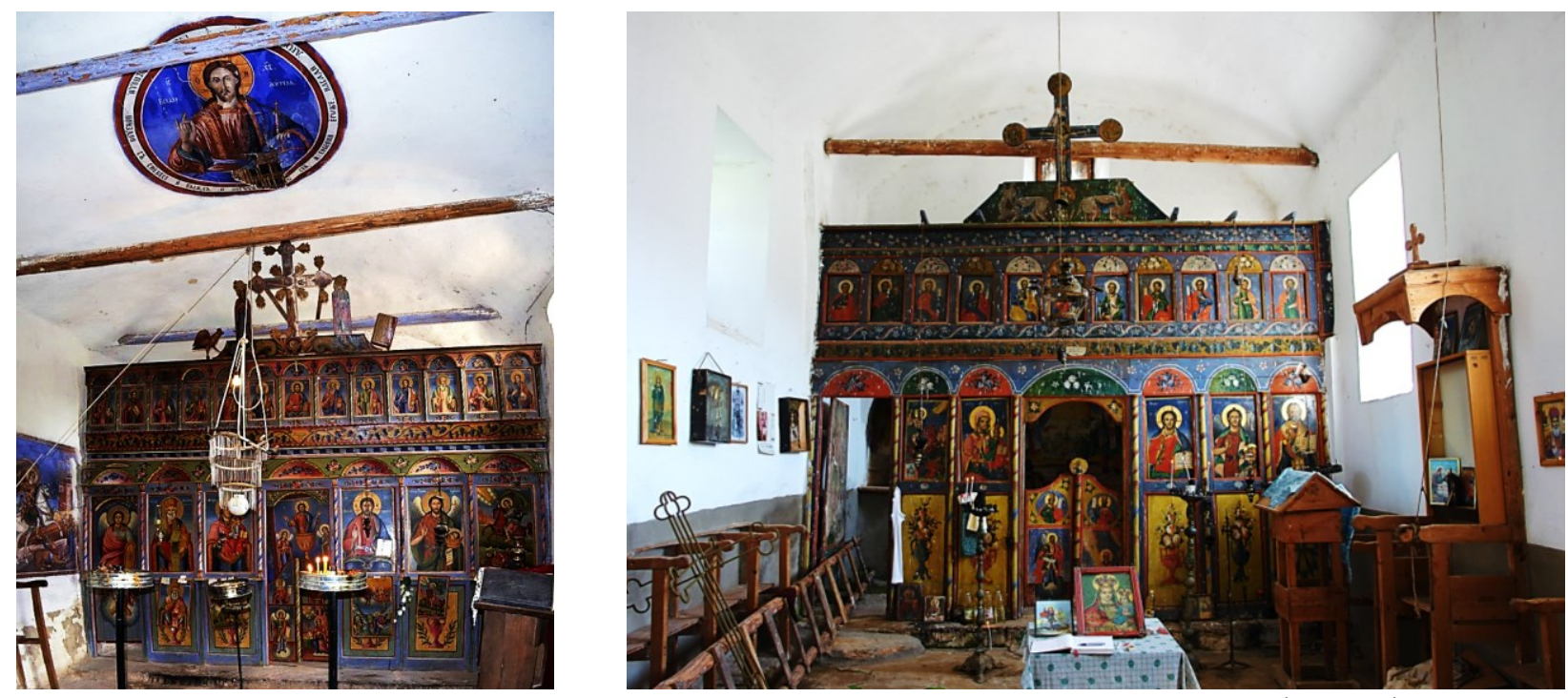

Figure III.111 Single-nave basilicas. Interior, view towards the altar: A. St. Nicholas in Zovikj (Mariovo);

B. St. Demetrius in Brnik (Mariovo).

Regarding the treatment of the altar apse, it evolves from a small three-sided apse to a higher and polygonal one: with five, seven or more sides, often defined by pilasters. This elaboration of the apse occurs in cases where it is semicircular on the outside, but partitioned with the help of blind niches (fig. III.112A) or cantilever arcades in the upper zone. A three-sided apse is rare among the Revival churches (for example, at the church of St. Nicholas in Babino, Demir Hisar; St. Marina in Borotino, Prilep), often in buildings built under heavy influence of a nearby important post-Byzantine church.
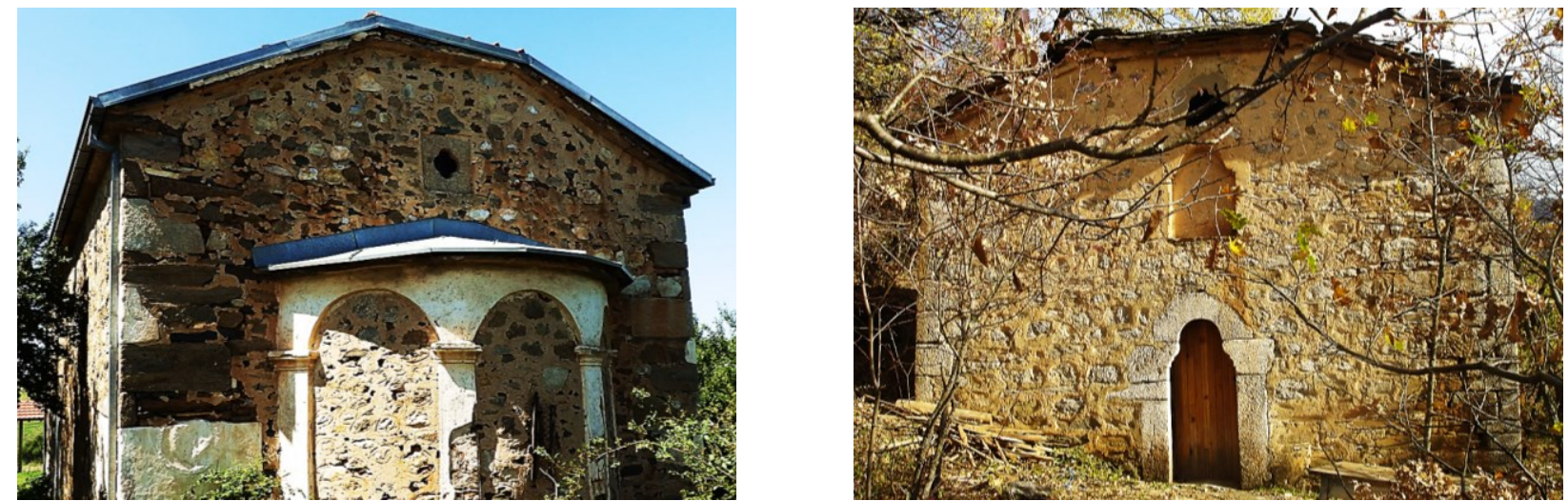

Figure III.112 A. St. Savior in Malo Ruvci (Prilep). Eastern façade; B. St. Athanasius in Rajchica (Debar). Western façade.

The more monumental dimensions, the larger span and height of the Revival single-nave basilicas allow a different treatment of the entrance portals, which are always at least two, placed on the west and usually the south façade, and sometimes as an exception on the north one. As was said before (see Chapter III.3), in the Revival the portals included a high arched niche (fig. III.112B), in which a composition dedicated to the patron saint of the temple was usually painted, often accompanied by an inscription informing about the year of construction or fresco-decoration, the names of the founders of the church 
as well as its master-builders. In the post-Byzantine churches, this data was usually inserted into the fresco-ensemble on the west wall of the temple. In front of the entrances to the building, an open porch was regularly made, usually along the entire length of the façade. If the church had two entrances, the porch was "L"-shaped (see fig. III.48A), while in some churches it received a "U"-shape.

In addition to all these common features of the single-nave basilicas, they often shared regional specific elements, which speak of their belonging to a local building "school". For example, in the villages around Prilep the majority of churches have a semicircular altar apse divided by seven shallow blind niches: St. Nicholas in Nebregovo; Nativity of the Most Holy Mother of God in Malo Konjari; the Most Holy Mother of God in Gorno Selo, etc. In the villages near Demir Hisar, as was said, the churches usually have a gable roof without the characteristic Revival trapezoidal shape of the shorter façades. Furthermore, unlike the post-Byzantine churches, which according to the medieval canons were completely frescopainted, the Revival single-nave basilicas usually have a limited fresco-repertoire, mostly covering the vault and the altar space, rarely all interior surfaces (see fig. III.110), and quite exceptionally the western façade (the churches in Babino, Slepche, Velmevci, Boishte, Rastojca, Sveta, Sopotnica - all within the Demir Hisar region; Trojaci near Prilep, etc.). Furthermore, often the frescoes on the vault are limited to a few circular medallions against a completely whitewashed background (see fig. III.111), which is in fact an imitation of a system of blind domes, achieved through the painting of the vault. Such examples can be found at the churches in Velmevci (Demir Hisar), Mirkovci (Skopje), Zovikj (Mariovo), etc.

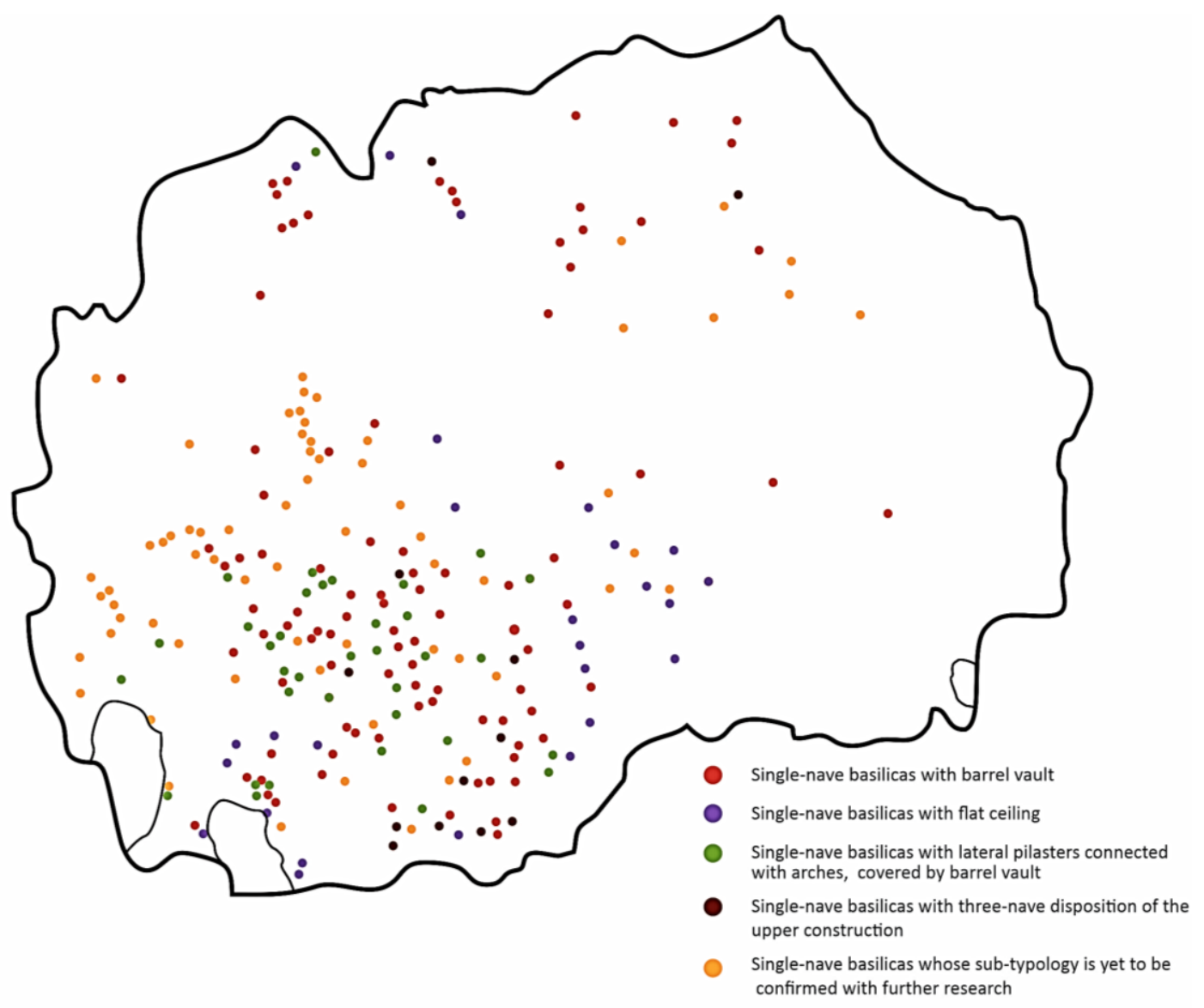

Map III-A Distribution of the Revival single-nave basilicas.

In terms of their distribution, the Revival single-nave basilicas are found throughout Macedonia, but undoubtedly prevail in its western parts, and above all in the south-western region (map III-A). In the eastern parts of Macedonia they are found sporadically, and often it is a matter of renovation of older, 
post-Byzantine buildings (for example in the villages of Ljubanci, ${ }^{377}$ Petralica $^{378}$ (see fig. III.113), Rankovce, ${ }^{379}$ Zletovo, $^{380}$ Ginovce $^{381}$ etc.). Precisely this geographically defined distribution, in addition to the clear analogies in the typological solution, point to their direct source in the older, single-nave postByzantine church buildings, which, as can be seen in map 1-2, are also mostly concentrated in the same central and western region of Macedonia. Among them, the most important focal points are several churches of exceptional spiritual importance in the region, located primarily in the monastery complexes, such as the Toplichki and Slepche monasteries in Demir Hisar, Slepche in Prilep, Slivnichki in Prespa and Karpino in Kumanovo.

In terms of their typological classification into sub-categories, the single-nave basilicas can be divided into the following groups (see chart III-1):

A.1 Single-nave basilicas with a semi-cylindrical vault (total: 101)

A.2 Single-nave basilicas with flat wooden ceiling (total: 30)

A.3 Single-nave basilicas with lateral pilasters connected with arches, covered with a vault (total: 40)

A.4 Single-nave basilicas with "three-nave" disposition of the upper construction (total: 12).

\section{Single-nave basilicas}
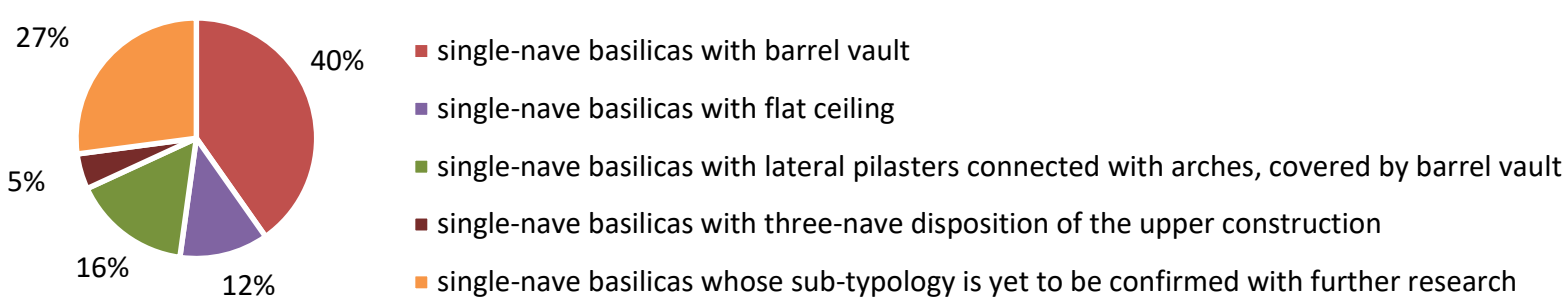

Chart III-1 Typological classification of the single-nave Revival basilicas.

The single-nave Revival basilicas whose interior architectural composition (architectural subtypology) has not yet been confirmed during the research for this doctoral thesis with the available resources (existing publications, documentation and personal field-work of the author) and which thus require further investigation are given in the following table (table III-1):

\begin{tabular}{|l|l|l|l|l|l|}
\hline & CHURCH & VILLAGE & REGION (TOWN) & $\begin{array}{c}\text { YEAR } \\
\text { ADDITIONAL INFORMATION } \\
\text { fresco-painting / icons, renovations }\end{array}$ \\
\hline 1 & St. Athanasius & Zhabeni & Bitola & 1837 & \\
\hline 2 & St. Savior & Gorno Chichevo & Veles & 1840 & \\
\hline 3 & St. Athanasius & Judovo & Kichevo & 1845 & \\
\hline 4 & St. Nicholas & Podgorci & Struga & 1845 & \\
\hline 5 & St. John the Baptist & Leski & Vinica & 1848 & $\begin{array}{l}1874 \text { (inscription in the patron saint } \\
\text { niche) }\end{array}$ \\
\hline 6 & St. George & Malo Crsko & Kichevo & 1848 & \\
\hline 7 & St. Panteleimon & Ehlovec & Kichevo & 1850 & \\
\hline 8 & Dormition of the Most Holy Mother of God & Zbazhdi & Struga & 1852 & \\
\hline 9 & St. Nicholas & Prisovjani & Struga & 1852 & \\
\hline 10 & St. Athanasius & Sekirci & Prilep & 1856 & \\
\hline 11 & St. Savior & Dolneni & Prilep & 1857 & \\
\hline
\end{tabular}

377 The church in Ljubanci is a restoration of an older temple, in the medieval period known as Vunesh Monastery.

378 Restoration of a XVII century church - the older part (nave and altar) is integrated with the new one (extended nave with western gallery and a narthex beneath) through a tribelon on the site of the original west façade wall (see fig. III.113).

${ }^{379}$ Restoration of a fragmentarily preserved XVII century church (the altar apse and the royal doors) converted into a three-nave basilica with a western gallery supported on a monumental tribelon, similar to the one at the church in nearby Petralica.

${ }^{380}$ The Revival phase is a renovation and extension of the narthex and porch of a church dating from the XIV century, from which the altar apse with fragments of frescoes remained, and then was incorporated in a single-nave post-Byzantine church from the XVII-XVIII century (Велев, 1990: 40).

${ }^{381}$ Restoration of a church from the XVII century - expansion to the west and north, after the demolition of the original west and north façade walls. 


\begin{tabular}{|c|c|c|c|c|c|}
\hline 12 & St. Elijah & Elshani & Ohrid & 1859 & \\
\hline 13 & St. Nicholas & Popoec & Kichevo & 1860 & \\
\hline 14 & St. Athanasius & Staravina & Mariovo & 1860 & \\
\hline 15 & St. Peter and Paul & Tajmishte & Kichevo & 1861 & \\
\hline 16 & St. Nicholas & Svinishte & Kichevo & 1868 & \\
\hline 17 & St. George & Magarevo & Bitola & 1871 & \\
\hline 18 & The Most Holy Mother of God & Pantelej & Kochani & 1871 & \\
\hline 19 & St. Nicholas & Ivanchishta & Kichevo & 1871 & \\
\hline 20 & St. Athanasius & Podvis & Kichevo & 1871 & \\
\hline 21 & St. Elijah & Plakje & Ohrid & 1871 & \\
\hline 22 & St. Athanasius & Topolnica & Makedonski Brod & 1872 & \\
\hline 23 & St. Archangel Michael & Spanchevo & Kochani & 1874 & \\
\hline 24 & St. Nicholas & Pavleshenci & Sveti Nikole & 1874 & \\
\hline 25 & St. Archangel Michael & Benche & Makedonski Brod & 1875 & \\
\hline 26 & St. Peter and Paul & Lupshte & Makedonski Brod & 1879 & \\
\hline 27 & St. Nicholas & Meglenci & Bitola & 1880 & \\
\hline 28 & St. Stephen & Shivec & Kavadarci & 1882 & \\
\hline 29 & St. Athanasius & Kozichino & Kichevo & 1883 & \\
\hline 30 & The Most Holy Mother of God & Margari & Prilep & 1887 & \\
\hline 31 & St. Nicholas & Sushica & Makedonski Brod & 1890 & \\
\hline 32 & St. Talalej & Brest & Makedonski Brod & 1891 & \\
\hline 33 & St. Nicholas & Vir & Makedonski Brod & 1891 & \\
\hline 34 & St. Savior & Malo Ruvci & Prilep & 1892 & \\
\hline 35 & St. George & Zlesti & Ohrid & 1892 & \\
\hline 36 & St. Savior & Trebovlje & Makedonski Brod & 1892 & \\
\hline 37 & St. Peter and Paul & Zvechan & Makedonski Brod & 1892 & \\
\hline 38 & St. George & Kosovo & Makedonski Brod & 1895 & \\
\hline 39 & St. Savior & Creshnevo & Makedonski Brod & 1898 & \\
\hline 40 & St. Savior & Cer & Demir Hisar & 1899 & \\
\hline 41 & St. Peter and Paul & Zhivovo & Mariovo & & \\
\hline 42 & St. Demetrius & Melnica & Mariovo & & \\
\hline 43 & St. Nicholas & Dabnica & Prilep & & \\
\hline 44 & St. Nicholas & Knezhje & Sveti Nikole & & \\
\hline 45 & St. Petka & Sudikj & Shtip & & \\
\hline 46 & St. Archangel Michael & Lavchani & Kichevo & & \\
\hline 47 & Dormition of the Most Holy Mother of God & Klenoec & Kichevo & & \\
\hline 48 & St. Petka & Cer & Demir Hisar & & \\
\hline 49 & St. Athanaius & Golemo Crsko & Demir Hisar & & \\
\hline 50 & Introduction of the Most Holy Mother of God & Burinec & Struga & & \\
\hline 51 & St. Athanasius & Vishni & Struga & & \\
\hline 52 & St. Sunday & R'zhanovo & Struga & & \\
\hline 53 & St. Athanasius & Selci & Struga & & \\
\hline 54 & St. Archangel Michael & Brchevo & Struga & & \\
\hline 55 & St. Savior & Rogachevo & Tetovo & & \\
\hline 56 & St. George & Prikovci & Kratovo & & \\
\hline 57 & Dormition of the Most Holy Mother of God & Dabnishte & Kavadarci & & renovation of a XIII century church \\
\hline 58 & St. Petka & Grbovec & Kavadarci & & \\
\hline 59 & St. Erasmus & Podmolje & Ohrid & & \\
\hline 60 & St. Nicholas & Biljanik & Bitola & & renovated in 1926 \\
\hline 61 & St. John the Baptist & Bonche & Mariovo & & \\
\hline 62 & St. Demetrius & Slivnica & Prespa & & \\
\hline 63 & St. Athanasius & Crvena Voda & Ohrid & & \\
\hline 64 & St. Nicholas & Slansko & Makedonski Brod & & \\
\hline 65 & St. Talalej & Gorno Krushje & Makedonski Brod & & \\
\hline 66 & St. Peter and Paul & Srbjani & Kichevo & & \\
\hline 67 & St. Athanasius & Gorno Falishe & Tetovo & & \\
\hline 68 & St. Barbara & Zhuzhnje & Gostivar & & \\
\hline
\end{tabular}

Table III-1 Single-nave Revival basilicas of yet un-confirmed sub-typology.

The single-nave basilicas were so deeply rooted in the sacred construction of the XIX century that this typology, with all the characteristic features of the Revival churches, continued to be the predominant typology erected intensively in the first decades and further, deep into the next, XX century. 


\section{III.5.A.1 SINGLE-NAVE BASILICAS WITH BARREL VAULT}

The vaulted single-nave basilicas are the most numerous not only among the single-nave churches, but among all types of Revival churches in general: namely, they represent as much as $40 \%$ of the singlenave (see chart III.1), and $18.9 \%$ of the total number of so far typologically classified Revival churches. Though built all over Macedonia, they prevail, as do all types of single-nave Revival buildings, in the southwestern region, as can be easily concluded from map III-A. The single-nave basilicas with a barrel vault identified to-date are listed in detail in the following table:

\begin{tabular}{|c|c|c|c|c|c|}
\hline & CHURCH & VILLAGE & REGION (TOWN) & YEAR & $\begin{array}{c}\text { ADDITIONAL INFORMATION } \\
\text { fresco-painting / icons, renovations }\end{array}$ \\
\hline \multicolumn{6}{|c|}{ with a gallery } \\
\hline 1 & St. Nicholas & Ulanci & Veles & 1820 & \\
\hline 2 & St. Archangel Michael & Krushevica & Mariovo & 1830 & renovated in 1929 \\
\hline 3 & St. Nicholas & Vraneshtica & Kichevo & 1858 & \\
\hline 4 & St. Nicholas & Sopotsko & Prespa & 1860 & \\
\hline 5 & St. John & Bulachani & Skopje & 1861 & \\
\hline 6 & St. Savior & Rashtak & Skopje & 1861 & \\
\hline 7 & St. Theodore Tyron & Piperovo & Shtip & 1863 & \\
\hline 8 & St. Petka & Kozica & Kichevo & 1870 & \\
\hline 9 & St. Athanasius & Zapolzhani & Prilep & 1872 & \\
\hline 10 & St. Demetrius & Gorno Divjaci & Krushevo & 1884 & \\
\hline 11 & St. Demetrius & Dobroveni & Bitola & 1886 & \\
\hline 12 & St. Constantine and Helena & Dolna Bela Crkva & Prespa & 1888 & \\
\hline 13 & St. Demetrius & Carevikj & Prilep & 1899 & \\
\hline 14 & St. Athanasius & Grnchari & Prespa & & \\
\hline 15 & St. George & Petralica & Kriva Palanka & & \\
\hline 16 & St. Archangel Michael & Krakornica & Gostivar & & \\
\hline \multicolumn{6}{|c|}{ without a gallery } \\
\hline 17 & St. George & Brezovo & Demir Hisar & 1835 & renovated in 1888 \\
\hline 18 & St. Nicholas & Vince & Kumanovo & 1846 & fresco-painted in 1875 \\
\hline 19 & Nativity of the Most Holy Mother of God & Gorni Manastirec & Makedonski Brod & 1846 & \\
\hline 20 & St. Nicholas & Ljubanci & Skopje & 1847 & \\
\hline 21 & St. Nicholas & Jagol & Kichevo & 1848 & \\
\hline 22 & Dormition of the Most Holy Mother of God & Dolenci & Demir Hisar & 1851 & \\
\hline 23 & St. Archangel Michael & Radovo & Demir Hisar & 1856 & fresco-painted in 1875 \\
\hline 24 & St. George & Ostrilci & Krushevo & 1857 & fresco-painted in 1884 \\
\hline 25 & St. Nicholas & Rajca & Prespa & 1857 & \\
\hline 26 & Holy Trinity & Ropotovo & Prilep & 1859 & \\
\hline 27 & St. Athanasius & Loznani & Bitola & 1860 & \\
\hline 28 & St. Demetrius - St. Paraskeva & Rapesh & Mariovo & 1860 & \\
\hline 29 & Dormition of the Most Holy Mother of God & Paralovo & Bitola & 1860 & \\
\hline 30 & St. Sunday & Orle & Mariovo & 1860 & \\
\hline 31 & St. Nicholas & Zovikj & Mariovo & 1862 & renovated in 1925 \\
\hline 32 & St. Nicholas - St. Talalej & Gneotino & Bitola & 1862 & \\
\hline 33 & St. George & Vasharejca & Bitola & 1862 & fresco-painted in 1883 \\
\hline 34 & St. Athanasius & Glogji & Tetovo & 1863 & \\
\hline 35 & St. Athanasius & Cer & Demir Hisar & 1863 & \\
\hline 36 & St. Savior & Grumazi & Mariovo & 1864 & \\
\hline 37 & St. Demetrius & Crnobuki & Bitola & 1866 & fresco-painted in 1872 \\
\hline 38 & St. Athanasius & Capari & Bitola & 1868 & dated according to a preserved icon \\
\hline 39 & St. Athanasius & Premka & Kichevo & 1871 & \\
\hline 40 & the Most Holy Mother of God & Jeloshnik & Tetovo & 1872 & over foundations of an older church \\
\hline 41 & Nativity of the Most Holy Mother of God & Malo Konjari & Prilep & 1873 & fresco-painted in 1875 \\
\hline 42 & St. Nicholas & Sopotnica & Demir Hisar & 1874 & \\
\hline 43 & St. Demetrius & Oreovec & Prilep & 1874 & \\
\hline 44 & St. Petka & Trebichino & Strumica & 1875 & \\
\hline 45 & St. Elijah & Cerovo & Demir Hisar & 1875 & \\
\hline 46 & St. George - Paralovo monastery & Paralovo & Bitola & 1876 & \\
\hline 47 & St. Athanasius & Suvo Grlo & Demir Hisar & 1886 & renovation of an older church \\
\hline 48 & St. Nicholas & Belche & Demir Hisar & 1887 & dated according to the frescoes \\
\hline 49 & St. Demetrius & Brnik & Mariovo & 1887 & frescoed in 1889, renovated in 1927 \\
\hline 50 & St. Athanasius & Gabalavci & Bitola & 1890 & frescoed in 1890, icons from 1839 \\
\hline 51 & St. Nicholas & Sekirani & Bitola & 1891 & fresco-painted in 1892 \\
\hline
\end{tabular}




\begin{tabular}{|c|c|c|c|c|c|}
\hline 52 & St. Elijah & Malo Ilino & Demir Hisar & 1898 & dated according to the frescoes \\
\hline 53 & St. Elijah & Nikuljane & Kumanovo & 1900 & \\
\hline 54 & St. George & Sushica & Skopje & & \\
\hline 55 & St. Nicholas & Chepigovo & Prilep & & \\
\hline 56 & St. Nicholas & Obrshani & Prilep & & \\
\hline 57 & St. Nicholas & Carev Dvor & Prespa & & \\
\hline 58 & St. Archangel Michael & Novo Selo & Demir Hisar & & \\
\hline 59 & Holy Trinity & Nikodin & Prilep & & \\
\hline 60 & St. George & Shemshevo & Tetovo & & \\
\hline 61 & St. Nicholas & Ginovce & Kriva Palanka & & \\
\hline 62 & St. Nicholas & Orashac & Kumanovo & & \\
\hline \multicolumn{6}{|c|}{ with/without a gallery (unconfirmed) } \\
\hline 63 & St. Savior & I & Krushevo & 1826 & \\
\hline 64 & St. George & Gorno Srpci & Bitola & 1831 & renovated in 1924 \\
\hline 65 & St. George & Novoselani & Prilep & 1837 & \\
\hline 66 & St. Elijah & Velmevci & Demir Hisar & 1838 & \\
\hline 67 & St. Nicholas & Trn & Bitola & 1848 & \\
\hline 68 & The Most Holy Mother of God & Zletovo & Probishtip & 1853 & \\
\hline 69 & St. Nicholas & Noshpal & Bitola & 1856 & fresco-painted in 1860 \\
\hline 70 & St. Nicholas & Korenica & Prilep & 1859 & \\
\hline 71 & St. Athanasius & Krusheani & Prilep & 1860 & \\
\hline 72 & St. Athanasius & Godivje & Prilep & 1860 & \\
\hline 73 & St. Athanasius & Iveni & Mariovo & 1860 & \\
\hline 74 & St. Athanasius & Mojno & Bitola & 1861 & fresco-painted in 1892 \\
\hline 75 & St. Marena & Borotino & Prilep & 1862 & \\
\hline 76 & St. Archangel Michael & Kokre & Mariovo & 1866 & \\
\hline 77 & St. Petka & Chanishte & Mariovo & 1870 & frescoed in 1882, renovated in 1929 \\
\hline 78 & Holy Trinity & Brezica & Skopje & 1871 & \\
\hline 79 & St. Nicholas & Brzhdani & Kichevo & 1872 & \\
\hline 80 & St. Panteleimon & Belica & Makedonski Brod & 1873 & \\
\hline 81 & St. Nicholas & Leskoec & Prespa & 1874 & \\
\hline 82 & St. Athanasius & Senokos & Prilep & 1874 & \\
\hline 83 & St. Nicholas & Belo Pole & Prilep & 1874 & \\
\hline 84 & Dormition of the Most Holy Mother of God & Kladnik & Kichevo & 1874 & \\
\hline 85 & St. Theodore & Sveto Todori & Bitola & 1875 & dated according to the frescoes \\
\hline 86 & St. George & Miletino & Tetovo & 1875 & renovation of an older church \\
\hline 87 & St. Archistrateg Michael & Klepach & Bitola & 1877 & \\
\hline 88 & St. Archangel Michael & Krkle & Mariovo & 1884 & \\
\hline 89 & St. Nicholas & Slivica & Mariovo & 1887 & dated according to the frescoes \\
\hline 90 & St. Athanasius & Vojnica & Veles & 1890 & renovation of an older monastery \\
\hline 91 & St. George & Peshtani & Mariovo & 1891 & \\
\hline 92 & St. Petka & Zhivovo & Mariovo & 1893 & \\
\hline 93 & St. Cristopher - Krstoar monastery & Krstoar & Bitola & 1898 & \\
\hline 94 & St. John the Baptist & Dobroshte & Tetovo & 1898 & \\
\hline 95 & St. Eremius & Gorni Disan & Negotino & & \\
\hline 96 & St. Elijah & Staro Selo & Prespa & & \\
\hline 97 & St. Nicholas & Koshino & Prilep & & \\
\hline 98 & St. Athanasius & Brezhani & Ohrid & & renovated, the apse is authentic \\
\hline 99 & St. Nicholas & Kopance & Tetovo & & \\
\hline 100 & St. John the Baptist & Preljubishte & Tetovo & & \\
\hline 101 & St. Constantine and Helena & Tomino Selo & Makedonski Brod & & \\
\hline
\end{tabular}

Table III-2 Single-nave Revival basilicas covered by a barrel vault.
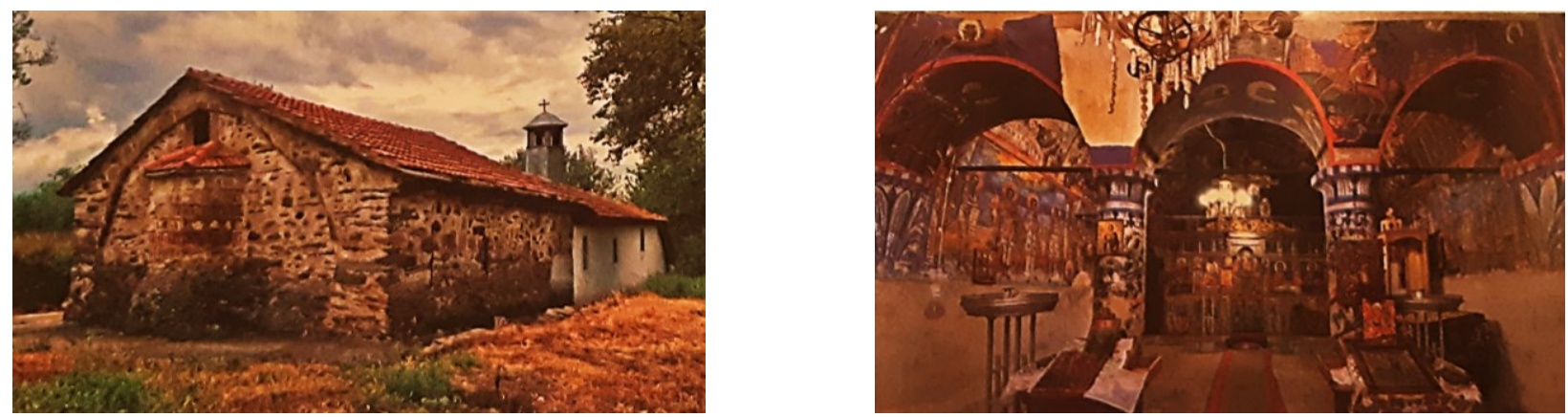

Figure III.113 St. George in Petralica (Kriva Palanka). Exterior view from the north-east and interior view from the XIX century extension to the older, XVII century naos. 
The reasons for choosing this solution, i.e. for the continuity of construction of simple, vaulted single-nave structures, were elaborated on the previous pages. As a spatial solution, the single-nave vaulted building was dominant throughout the post-Byzantine period and thus presented a numerous and well-preserved foundation on which the Revival master-builders based and further developed the new single-nave typology. Some of the Revival single-nave vaulted basilicas were actually renovations of older, post-Byzantine churches, which were rebuilt from the ground up ${ }^{382}$ or expanded in the Revival when the need for such interventions arose and the right conditions were created (fig. III.113). ${ }^{383}$

In addition to this type of renovations, single-nave vaulted churches were built en masse during the Revival XIX century. Of course, the post-Byzantine typology was not blindly replicated: as was said, the post-Byzantine churches were smaller, with a continuous interior separated into a nave and an altar with a lower altar partition usually placed on a small platform, without an upper gallery that will only appear and develop as a specific element during the Revival. The post-Byzantine churches were built in the traditional way, with stone blocks and abundant use of lime mortar, and the same materials were used

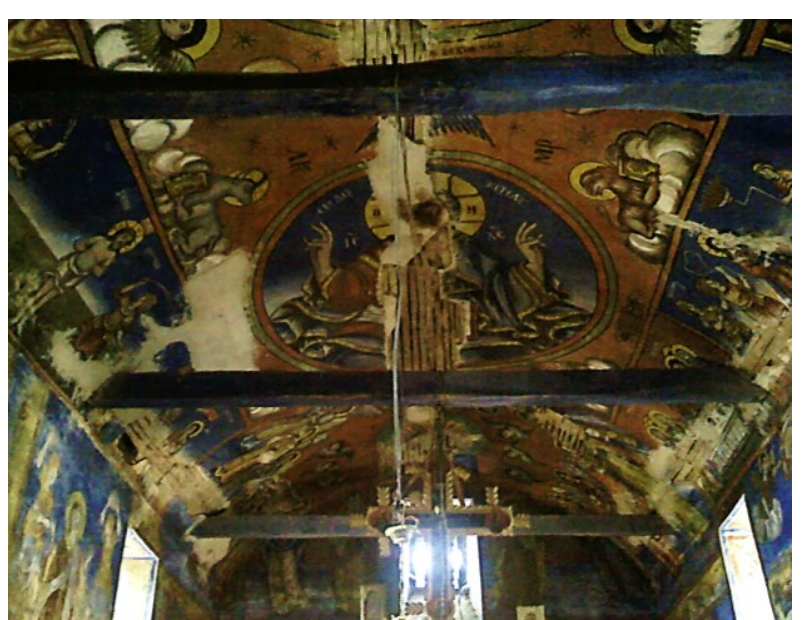

Figure III.114 St. Nicholas in Sekirani (Bitola). View towards the "fake" vault construction.

for the construction of the vault, which was enabled by the smaller dimensions of these temples, i.e. their shorter spans. In contrast, the Revival vaulted single-nave churches often have significant, monumental dimensions, in some cases almost corresponding to three-nave basilicas. The vaults of the Revival single-nave basilicas are almost without exception "fake", made of light wooden construction (fig. III.114), dictated by the larger spans that had to be overcome, as well as by the new architectural tendencies and the new construction method that was established in the Revival. Of all the vaulted constructions, the semi-cylindrical vault was the easiest to construct, regardless of the applied structural system, which is why this sub-typology is the most numerous among the single-nave basilicas. Namely, "the vault is generated by elongation of a semicircular arch along the longitudinal axis of the vault. Its geometric shape is a cylinder divided in half, it is formed without angles at the walls on which it rests and covers a rectangular space. The regularity of its expansion facilitates both its construction and its design, compared to other types of vaults. Furthermore, its longitudinal development also facilitates its cladding with wooden planks or boards, as it is carried out on a surface that is curved in one direction only" (Fernández Cuadros, 2014: 88). The vaulted wooden ceiling conceived in this way was regularly plastered and fresco-painted, completely or with individual compositions within one or more circular medallions (see fig. III.111A). ${ }^{384}$ The height of the

382 For example, the Nativity of the Most Holy Mother of God in Gorni Manastirec (Makedonski Brod), built in 1846 on the foundations of an older, medieval church burned to the ground during the Ottoman occupation. At St. Nicholas in Ulanci (Veles), an older, post-Byzantine church was rebuilt between 1800-1820, incorporating the low three-sided altar apse originating from the XVI-XVII century into a taller and larger single-nave vaulted building (Николовски, 2018: 305). The vault was later covered with a flat wooden ceiling.

383 Such an example - in addition to the churches in Petralica (fig. III.113), Rankovce, Ginovce, Zletovo which have already been mentioned - is the church of the Dormition of the Most Holy Mother of God in Dolenci (Demir Hisar). Originally, this church was a small, elongated single-nave post-Byzantine building, with a three-sided apse, vaulted and fresco-painted. Around 1851 it was renovated and extended to the west integrating the older church and the extension into a continuous one-nave space. The extension is also vaulted, but according to the contemporary Revival construction techniques, a wooden ("fake") vault was used, placed slightly higher than the original massive vault of the post-Byzantine church (Дапчев, 1996: 225).

384 The solution of the vault at the church of St. Nicholas in the village of Jagol (Kichevo), built in 1848, is particularly interesting: the single-nave naos is covered with a longitudinal vault with a "transept", i.e. an identical vault in the transverse direction, a 
churches allows for the appearance of a gallery ${ }^{385}$ in the western zone and high iconostasis on the altar tribune, as well as illumination on the western and eastern façade through decorative stone-carved windows, which are all general features of the Revival construction regardless of the applied typological solution. Also, there are usually two entrance portals, accompanied by open porches.

Based on all of the above, it can be concluded that within the numerous group of Revival singlenave vaulted churches, a division can be made into:

- a simpler type, represented by smaller buildings without a gallery and with only one, western entrance portal, i.e. a type closer to the post-Byzantine models, and

- a more developed type, consisting of churches with larger dimensions, a gallery and two or more entrance portals, i.e. a type that includes all Revival architectural features. Examples of both types will be elaborated in more detail as follows.

\section{"St. Athanasius" in Cer (Demir Hisar), 1863}

This church is a representative of the simpler typological matrix of smaller single-nave vaulted buildings without an upper floor gallery, which were built in rural areas, mostly as neighborhood or cemetery churches. Namely, the church of St. Athanasius is not the main church in the village of Cer, but rather a neighborhood church ${ }^{386}$ located on the outskirts of the village. Three inscriptions from the church itself testify to its construction. The first inscription, located on the parapet of the west window on the south wall of the nave, contains only the year of construction - 1861. The second inscription is painted above the entrance to the nave (fig. III.115), on the inside where, besides the year - 1863, the inscription also states the names of the Archbishop Mileti(j)a, the village priest $A(n)$ gele, the prominent founders of the building, as well as its builder, master Kosta from the same village of Cer, in the inscription named as Kosta Tanasof. Therefore, it can be concluded that the church was built in 1861, while the iconostasis was completed and the church consecrated a little later, in 1863. The third inscription, located on the south wing of the royal doors, where the year 1863 is written under the signature Annunciation, confirms this.

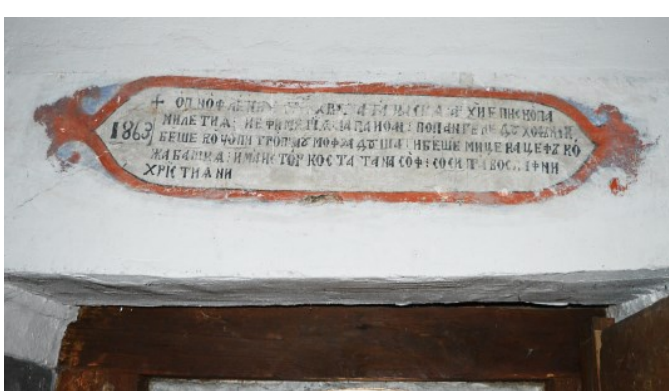

Figure III.115 St. Athanaius in Cer (Demir Hisar). Founder's inscription painted above the western entrance to the naos.
St. Athanasius is a small, single-nave building, with a slightly irregular, trapezoidal plan adapted to the steep, rocky terrain on which it was directly founded (see fig. III.118). The dimensions of the nave are $\sim 5 / 7.5 \mathrm{~m}$, i.e. the ratio of the width to the length of the temple is 2:3. Inside, the floor is paved with stone slabs, authentically preserved. To the east, the altar space is raised on a very low tribune, paved in the same way. The total volume of the nave is bridged with a semi-cylindrical vault whose height at the apex is $4 \mathrm{~m}$, and just in front of the east and

solution very similar to the group of single-nave vaulted churches with a superimposed transverse vault which appeared in the Ohrid region at the transition from the XIV-XV century (see Chapter II.4.3). It must not be forgotten that the region of Kichevo is adjacent to the region of Ohrid, and the influences from the medieval Ohrid tradition were especially intense there. However, unlike them, in the Revival church in Jagol the vault arrangement is not visible on the fifth facade, i.e. it is covered with a gable roof in the Revival fashion. Furthermore, both vaults are at the same height and at their junction a blind dome rests on very shallow pendentives. The dome and the pendentives are fresco-painted according to the canons, with a representation of Christ Pantocrator in the medallion and the four evangelists on the pendentives.

385 However, it must not be forgotten that a significant part of the single-nave vaulted basilicas do not have a gallery or a narthex, which brings them even closer typologically to the post-Byzantine prototype.

386 The appearance of several churches in one village: one central ("main"), also called "congregational" church, in which the big holidays were celebrated - Christmas, Easter and the patron saint's day, and several smaller churches or chapels located in the outer neighborhoods of the village was quite common. In the village of Jablanica (near Struga), for example, there are as many as six churches, three of which have an altar, a pulpit and an iconostasis, and three are small chapels that have only small altars with icons (Покропек и Стрончек, 1992: 99-100). 
west walls (approximately 60 and $90 \mathrm{~cm}$ respectively) it increases by twenty centimeters in a specific way. ${ }^{387}$ The vault is reinforced with three wooden ties placed at a height of approximately $3 \mathrm{~m}$.

The church was built quite massively: the width of the perimeter walls varies around $70 \mathrm{~cm}$, with the exception of the east wall which is significantly more massive, as well as the south wall in its lower zone. In fact, the walls in cross section have a slightly trapezoidal shape - they are more massive in the lower zone, and narrower towards the top. They were built in an irregular syllable of crushed stone and mortar, and then the facades were plastered. An exception are the window openings, which were made of better hewn stone. Namely, the church is illuminated through only two small windows on the south façade, in the nave, and two on the east façade, in the altar. The windows in the nave are treated completely differently. One is placed in the middle of the wall measured from the west façade to the altar tribune, with a parapet of over $1 \mathrm{~m}$ and a rectangular window opening formed with blocks of hewn stone. The other is located next to the altar tribune, placed quite low, only $30 \mathrm{~cm}$ above it. In this zone the south wall expands considerably outwards and its thickness reaches $90 \mathrm{~cm}$. The opening of this window is arched, formed by blocks of hewn stone of the same type (fig. III.116A). The altar is illuminated in the usual way: a narrow elongated slit is left in the altar apse; high above it a square window is covered with a stone-carved transenna shaped into a phytomorphic cross with rounded arms (fig. III.116B).
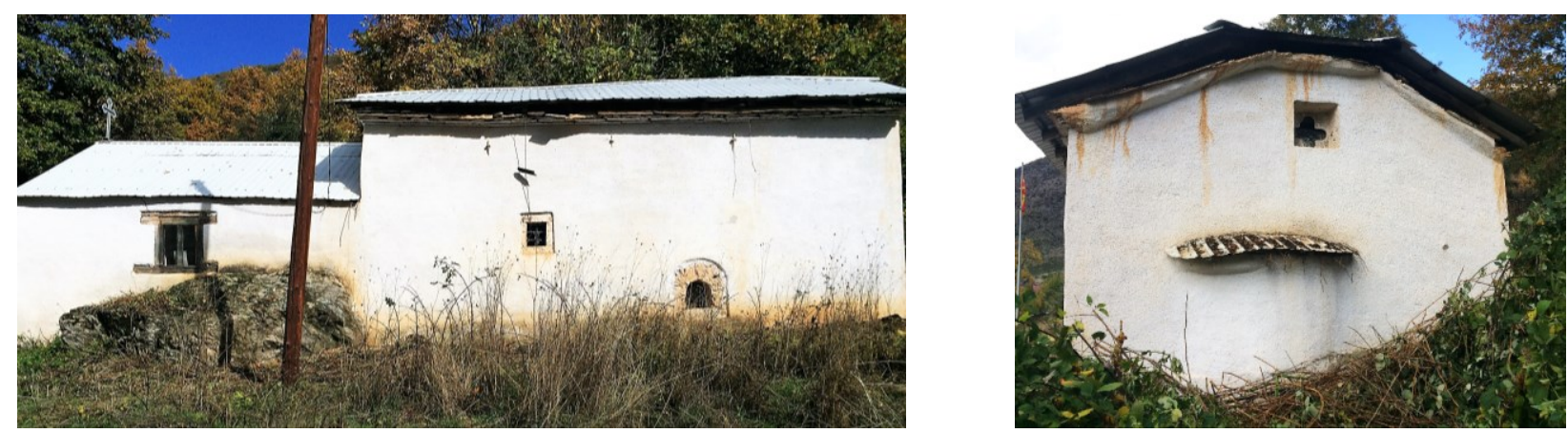

Figure III.116 St. Athanasius in Cer (Demir Hisar): A. View from the south; B. View from the east.

In fact, the altar apse is solved in a rather unusual way. From the outside, it is a small, three-sided apse that protrudes from the façade plane by only $30 \mathrm{~cm}$, i.e. it is almost imperceptible, which is contributed by the painting of the façade and the extremely simple treatment of the apse without dividing cornices, pilasters or any decoration, except for the crown cornice which has also been plastered (fig. III.116B). From the inside, the east wall is extremely massive and reaches a width of $115 \mathrm{~cm}$ in the lower zone (even $150 \mathrm{~cm}$ including the extension of the apse); at the height of $80 \mathrm{~cm}$ a bench is formed along its entire length, above which the thickness of the east wall decreases to approximately $85 \mathrm{~cm}$. Furthermore, two apses actually appear in the altar: the "real" apse, $70 \mathrm{~cm}$ wide, is deviated from the longitudinal axis of the church to the south and is funnel-shaped, narrowing along the entire imposing thickness of the east wall in this zone up to the window opening in the form of an elongated slit. To its north there is another, smaller, $50 \mathrm{~cm}$ wide apse, which has no projection on the façade, i.e. it is in fact a semicircular niche in the east wall (fig. III.117B). Another semicircular niche of the same width is located in the north wall, in the north-east corner of the altar, certainly serving as a prothesis.

The nave is accessed through a single entrance placed in the axis of the west wall, architravely covered, above which is painted the founding inscription mentioned above (fig. III.115). The threshold of the door is made of a single block of stone, protruding outwards in the form of a semicircular stair. The whole building is covered with a gable roof, with the typical Revival solution of trapezoidal shorter façades

387 It is interesting to compare this elliptical overhang at both ends of the vault with the way in which the cruciform arches were solved in Byzantine construction, where also the vertices of the two arches that intersect at their very ends are similarly higher. 
which actually results in a bonnet roof. The façade canvases are topped with a cornice of protruding thin stone slabs, today in a very poor state of preservation, with irregular lines and dilapidated segments. Originally, of course, the roof was covered with stone slabs, the remains of which can still be seen above the crown cornice.
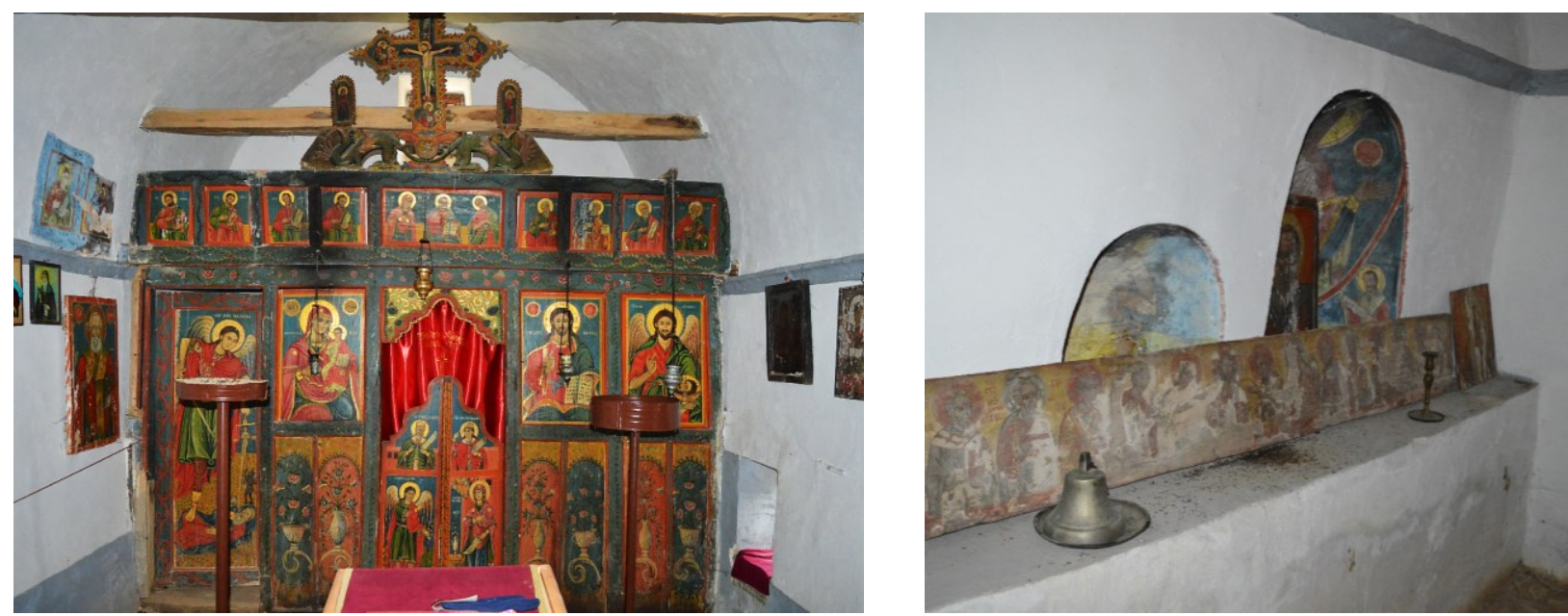

Figure III.117 St. Athanasius in Cer (Demir Hisar): A. View towards the iconostasis; B. The altar apse(s).

Despite the simplicity of the whole construction, the purity of the forms and the very modest dimensions, the skill of the master builder is clear and evident in the details with which it was executed, which confirms that due attention was paid to all churches, regardless of their purpose and the material wealth of the founders. Thus, the whole nave is encircled by a small $(10 \mathrm{~cm}$ high) decoratively profiled cornice, which flows horizontally at the level of an imaginary plane $185 \mathrm{~cm}$ below the apex of the vault. The cornice covers the lintel of the west entrance, the window sill of the south window in the nave and flows uninterruptedly above the apse in the altar; as the most striking detail, it coincides with the cosmitis of the altar partition, thus framing the nave with a continuous accent line on all four sides. The limited dimensions of the church conditioned the construction of a simple iconostasis in two zones - separated by the decorated cosmitis - but still extremely skillfully and harmoniously shaped, performed with full symmetry and richly painted in warm tones with floral and geometric ornaments. The interior of the church is completely whitewashed, which contributes to the iconostasis with its richness of warm tones to be especially emphasized as the focal point of an otherwise simplified space (fig. III.117A). However, several fragments of the original frescoes have been preserved: in addition to the aforementioned painted inscription above the entrance, fresco-compositions have also been preserved in the two apses inside the altar. According to the canons, the Mother of God Oranta accompanied by two saints in a symmetrical composition was painted in a circular medallion within the altar apse. On the other hand, the image of Christ was painted in the niche next to the apse (fig. III.117B).

In the altar, on the eastern wall parapet, a faded and slightly damaged Deisis icon from an older iconostasis is displayed, composed as a single, elongated board, on which the figures of all the apostles are painted against a gold background, and in the center the Deisis composition itself is depicted (fig. III.117B). ${ }^{388}$ Also, several small, older icons are kept in the nave. These fragments of an older iconostasis, together with the irregular, unusually thick walls of the building, the unusual arrangement of the window openings and the solution of the altar with an asymmetrically placed apse, leads to the conclusion that

\footnotetext{
${ }^{388}$ As a comparison, a very similarly conceived, elongated Deisis icon is preserved (along with a fragment of the Crucifix, the royal doors, and the royal doors curtain panel shaped into a Saracen arch depicting the composition of Christ the Sleepless Eye) within the XIX century Revival reconstructed iconostasis of the post-Byzantine church of St. Nicholas in the village of Trnovo (Kriva Palanka), built in 1505. The Deisis icon actually comprises the entire second zone of the iconostasis, and consists of two monolithic segments of unequal length (Митевски и Веселиновски, 2005: 26-27).
} 
the church of St. Athanasius in Cer is in fact a reconstruction of an older, post-Byzantine church that existed at this location and whose remains were incorporated in the newer building respecting the older cult site, as was often the case in the Revival period.
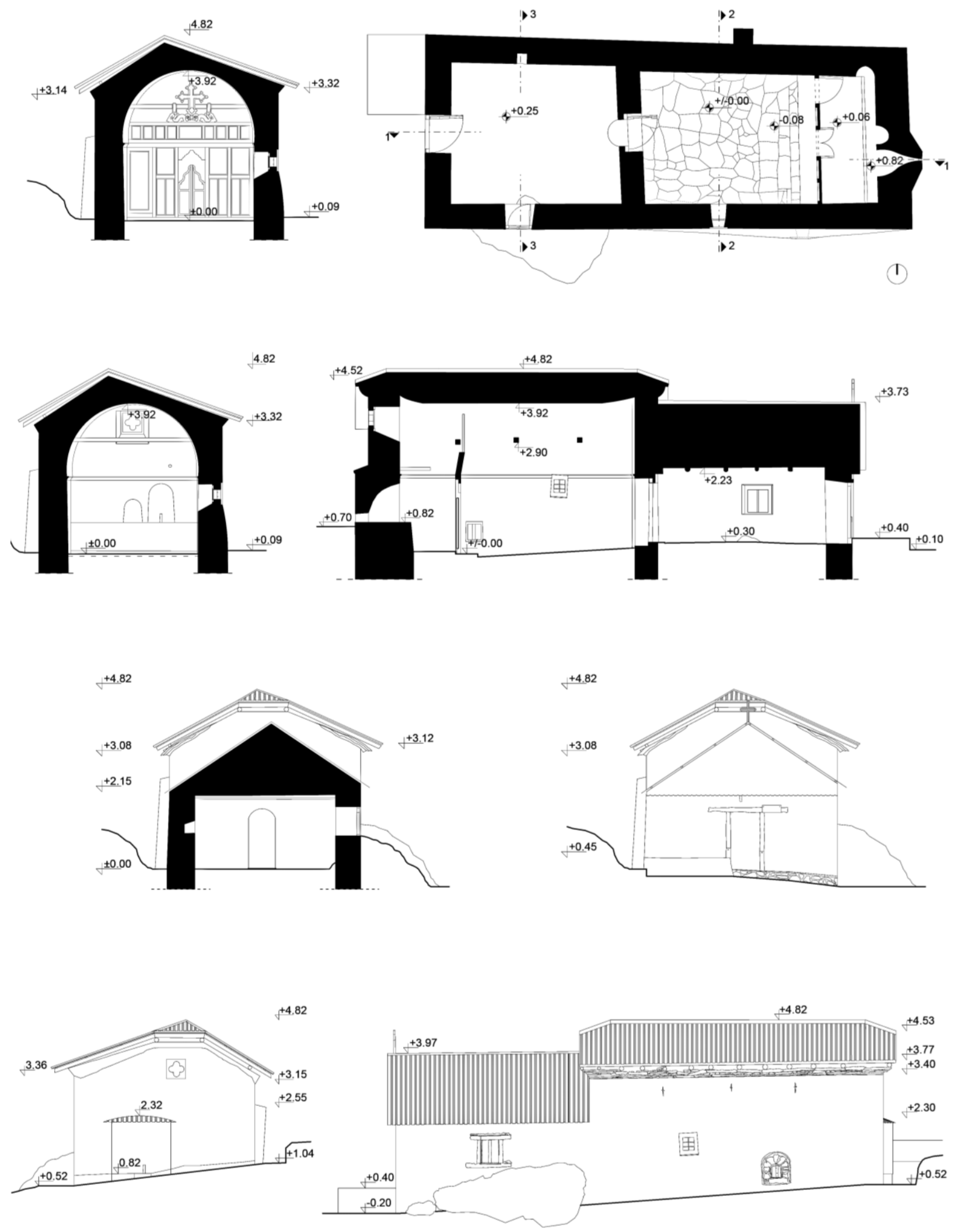

$3 m$

Figure III.118 St. Athanasius in Cer (Demir Hisar): plan $( \pm 0.00)$, longitudinal section $(1-1)$, transversal sections $(2-2$, with and without represented iconostasis, and 3-3) and western, southern and eastern facades. 
To the west of this small, compact building, a slightly lower, closed narthex was later added that follows the trapezoidal shape of the church, i.e. it has an irregular square plan of approximately $5 \mathrm{~m}$ in width. The narthex is accessed through an entrance in the axis of the west façade, and is illuminated through a window on the south façade wall, with jambs and a lintel made of wood. On the opposite side of the window, in the north wall, an icon is displayed within a small rectangular niche. The narthex is covered with a flat ceiling with visible wooden beams arranged in a transverse direction, and a gable roof. The entire southern part of the narthex is founded on a massive rock (fig. III.116A, fig. III.118), which even penetrates its interior.

\section{"St. Savior - Ascension of Christ" in Rashtak (Skopje), 1861}

The church of St. Savior (also dedicated to the Ascension of Christ), built on the bank of the Rashtavska river which flows through the village of Rashtak located on the slopes of the mountain Skopska Crna Gora, serves as the main village and cemetery church and, as such, is a representative of the second category of the Revival single-nave vaulted basilicas. As is quite common with the churches built in the Revival, on the site of today's church there previously existed an older religious building. ${ }^{389}$ The existing small and ruined church was rebuilt "from the ground up" in 1861 by the local population. The iconostasis was completed in 1866 and the fresco-ensemble in 1872 (Грозданов, 2004: 90), when the church was consecrated.
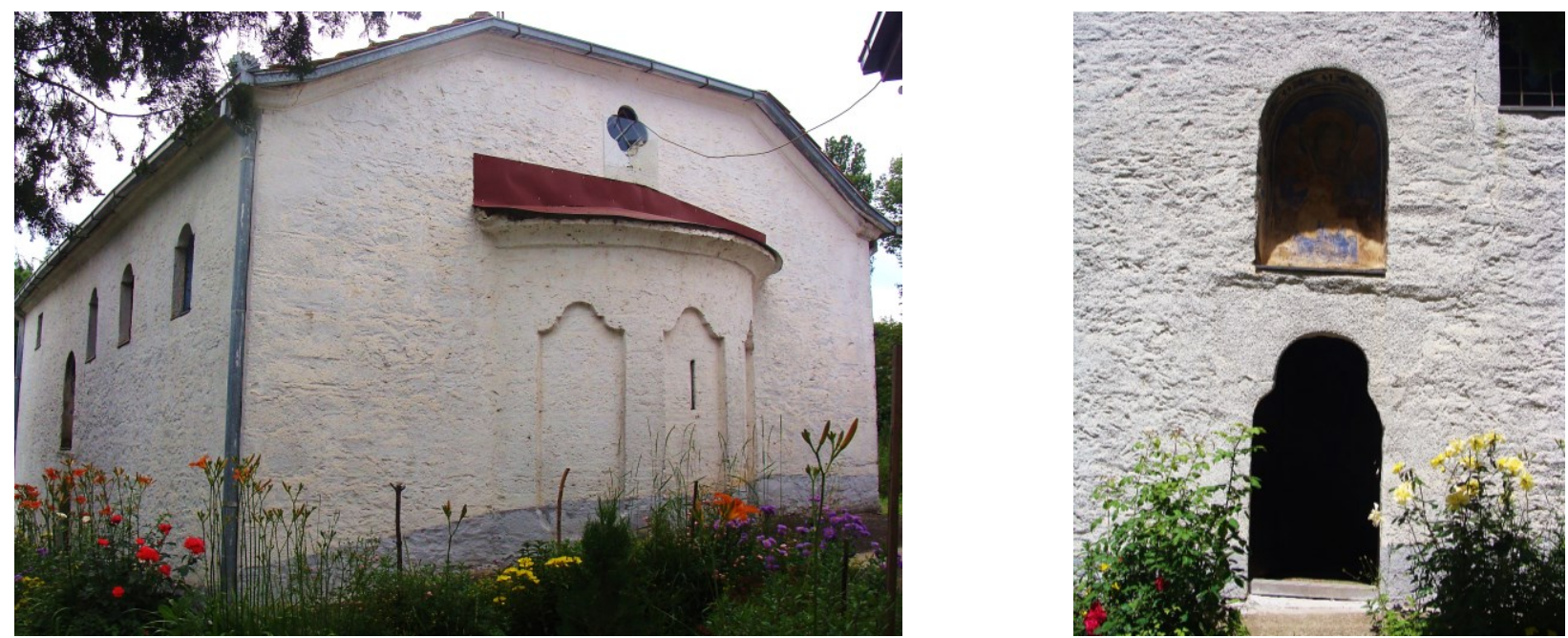

Figure III.119 St. Savior in Rashtak (Skopje): A. View from the south-east; B. View of the southern entrance portal.

St. Savior in Rashtak is a single-nave basilica, with a very compact plan measuring $8 \times 13 \mathrm{~m}$, without a narthex, an open porch or other auxiliary rooms (fig. III.122). The ratio of the width to the length of the naos is 1:1.625, which means a golden section was applied in the proportion of the temple. According to the established construction method characteristic of the Revival basilicas, the perimeter walls of the church are built in a massive system, with a significant thickness of almost $1 \mathrm{~m}$ (or almost 1.5 arshin), using crushed stone and lime mortar. It is impossible to determine whether the masonry was originally left visible, as today all the façades of the church are covered with several mortar coatings. The corners of the building were treated with more care, as well as the entrance portals, doors, lintels, window sills, the crown cornice and similar elements, which were made of hewn stone, today also covered with layers of lime mortar. The floor in the building, in accordance with the religious rights and freedoms already

389 There is no confirmed information of the possible dating of the older church. However, it is worth mentioning that in today's church of St. Savior an old church book printed in Venice in 1537 was found, today kept at the National and University Library in Skopje, which could help date the original church to the post-Byzantine period. 
acquired at the time of construction, is laid almost at the level of the external terrain, without digging deep into the ground which was common earlier (fig. III.123). Today, the authentic pavement of stone slabs has been preserved only within the altar.

To the east, the naos ends in a semicircular apse, whose façade is divided into three wide and shallow niches, with a complex decorative profile in the upper and lower zone. Namely, the niches of the apse are bridged with an arch composed of a combination of convex and concave segments, while at the bottom the pilasters between the niches have arched extended bases. An elongated, very narrow slit window is placed in the axis of the central niche. Towards the top, the apse is defined by a profiled crown cornice made of stone, later plastered (fig. III.119A). In the altar, the apse is flanked by the prothesis and the diaconicon, marked by shallow semicircular niches in the east façade wall. Along the eastern wall of the altar extends a $112 \mathrm{~cm}$ high plinth whose northern corner is shaped into a semicircular sink for liturgical hand-washing, a relatively common element of the Revival churches.
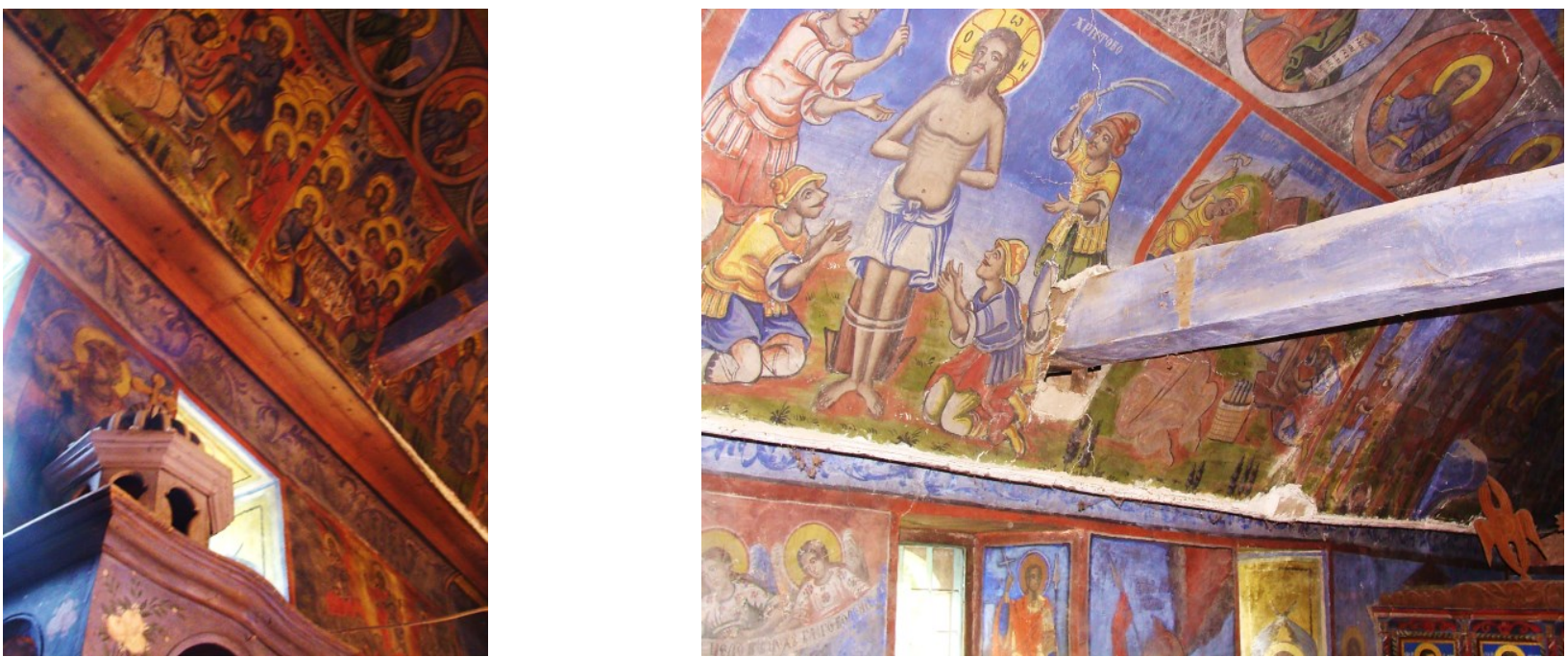

Figure III.120 St. Savior in Rashtak (Skopje): Views towards the wooden "false" vault.

As is usual for the Revival basilicas, the upper parts of the church St. Savior in Rashtak are made of light, wooden construction elaborated as a monumental semi-cylindrical vault along the entire nave, which in the western parts of the church turns into a half-dome. The span of this barrel vault exceeds 6 $\mathrm{m}$. The transition from the massive perimeter walls to the light vaulted construction was executed in a very inventive and elegant way: along the south, north and west wall of the nave there is a strip of flat wooden ceiling, $\sim 60 \mathrm{~cm}$ wide, which frames the centrally placed semi-cylindrical vault causing it to seemingly float and creating a feeling of lightness (fig. III.120). The effect of a levitating vault is further emphasized by a very skillfully executed profiled recess of the flat wooden ceiling at its very junction with the massive façade walls, the depth and shade of which contribute to a further visual separation of the vault from the lateral walls, hovering high above the visitors. ${ }^{390}$ The church in Rashtak is covered with a

\footnotetext{
390 As an active temple located in the heart of a thriving village, the church St. Savior in Rashtak is found in relatively good condition, especially in terms of its exterior architecture. However, weaknesses are evident in the internal wooden vaulted construction, which seriously jeopardize the further survival of the vault, and subsequently its valuable fresco decoration. Namely, under the action of its own weight and fatigue of the material, the semi-cylindrical vault, made of light wooden construction and a thick coating of plaster with fresco base and fresco paintings, slides downwards, which is especially evident at the key points where the wooden ties penetrate the vault (fig. III.120B), where the vault has cracked and crumbles. Tectonic movements have further weakened the load-bearing capacity of the wooden structure, as well as the adhesion of the plaster to its wooden base, so that often large pieces of fresco painting fall off, leaving the wooden sub-structure exposed. It is therefore extremely important to take urgent conservation activities that would ensure the stability of the upper parties of the church and prevent their further damage and even collapse which, in addition to the permanent destruction of parts of the frescoes, will result in an irreversible loss of the traditional construction techniques characteristic of the Revival monumental church architecture.
} 
bonnet roof in an unusually asymmetrical way: the east façade has the characteristic Revival trapezoidal shape, while on the west the roof is a classical bonnet roof, conditioned by the half-dome vault beneath.

The gallery is made entirely of wood. It extends at a level of $+2.80 \mathrm{~m}$ above the ground floor of the church and covers a rectangular space, with a central cantilevered semi-circular balcony above the nave. A particularly characteristic typological feature of this church is the extremely emphasized depth of the gallery, which at the most prominent point of the balcony reaches over $4.20 \mathrm{~m}$, i.e. it occupies almost half of the length of the nave measured to the altar partition (fig. III.122-123). Thus, the remaining space of the nave is actually almost square in plan. The gallery is supported by a sub-structure of two wooden pillars with a square cross-section with profiled wooden capitals, placed on small torus-shaped stone bases. The capitals of the pillars extend laterally in the form of saddles, with a specific decorative profile (fig. III.121B), made of a wooden structure coated with lime mortar and subsequently painted. Identical semi-capitals can be found at both ends of the load-bearing beam, at the junction of the wooden structure of the gallery with the massive longitudinal walls of the nave. The beam supports the gallery parapet, itself especially decoratively processed: up to a height of $1 \mathrm{~m}$ it is solid, made of wooden boards with small planks over their joints; the second zone of the fence (whose total height is over $1.5 \mathrm{~m}$ ) is a musharabia composed of diagonal intertwining of thin wooden planks (fig. III.121A), which achieves partial transparency and allows for unobstructed views towards the nave.
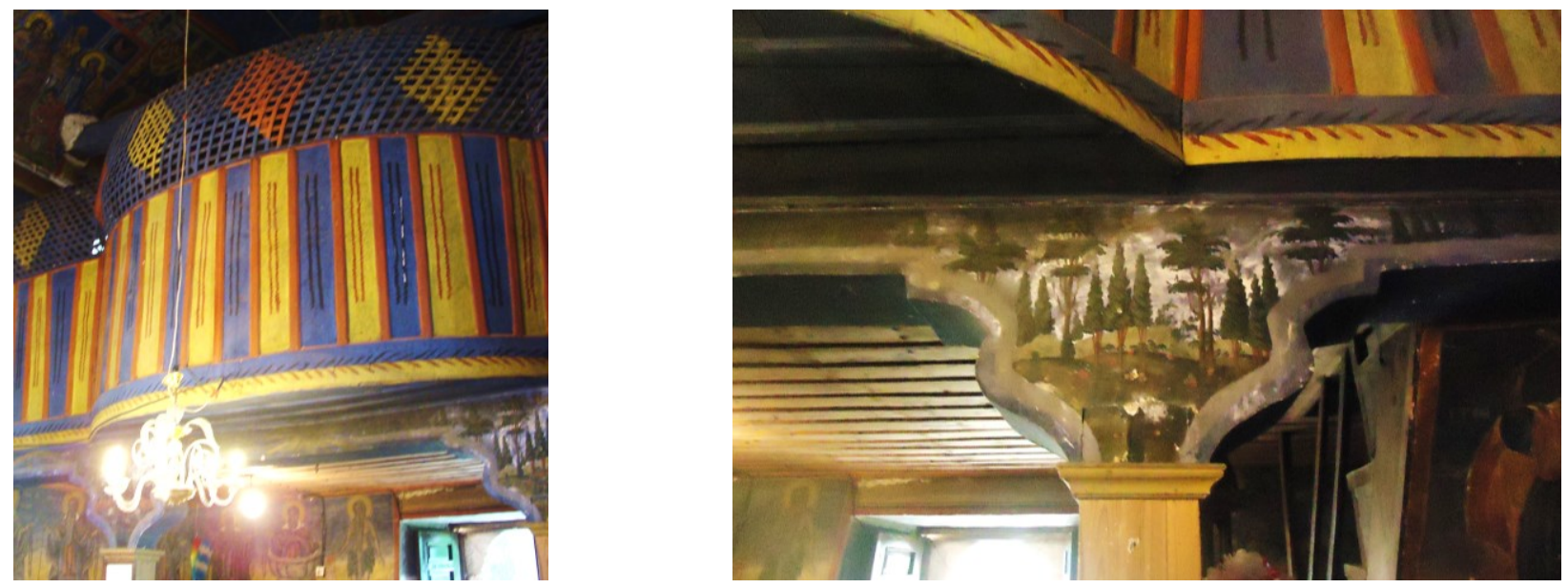

Figure III.121 St. Savior in Rashtak (Skopje): A. View towards the gallery; B. Detail of the gallery capitals.

The natural light in the building enters through a series of windows placed in the upper zone of the nave - two on the north wall and three on the south (see fig. III.69B). The windows in the nave are arched, which gives additional value to the otherwise simple, modestly conceived façades. In addition, a window on the south wall illuminates the gallery, as the only source of direct light in the gallery space, which lacks the usual window placed high on the west façade. The altar space is illuminated through the previously mentioned narrow slit in the apse itself, as well as an additional window placed high above the apse on the east façade (fig.III.119A). This window received the usual decorative stone-carved transenna in the form of a four-leaf clover - i.e. a stylized cross.

The temple is accessed through two entrance portals on the west and south façades. The portals are simply conceived, with a semicircular arched opening, and jambs made of hewn stone blocks, which have been covered by mortar. In the upper zone, the jambs extend inwards with a profile which was commonly used for the Revival crown cornices, but which has lost its precise edges beneath the mortar coatings. Above the portals, as was common, are semicircular, relatively deep patron saint niches with fresco-painted compositions: Ascension of Christ within the western niche, in accordance with the dedication of the temple itself, and Archangel Michael in the southern one, which has also preserved a baroque floral ornament in blue tonality painted in the depth of the wall (fig. III.119B). 

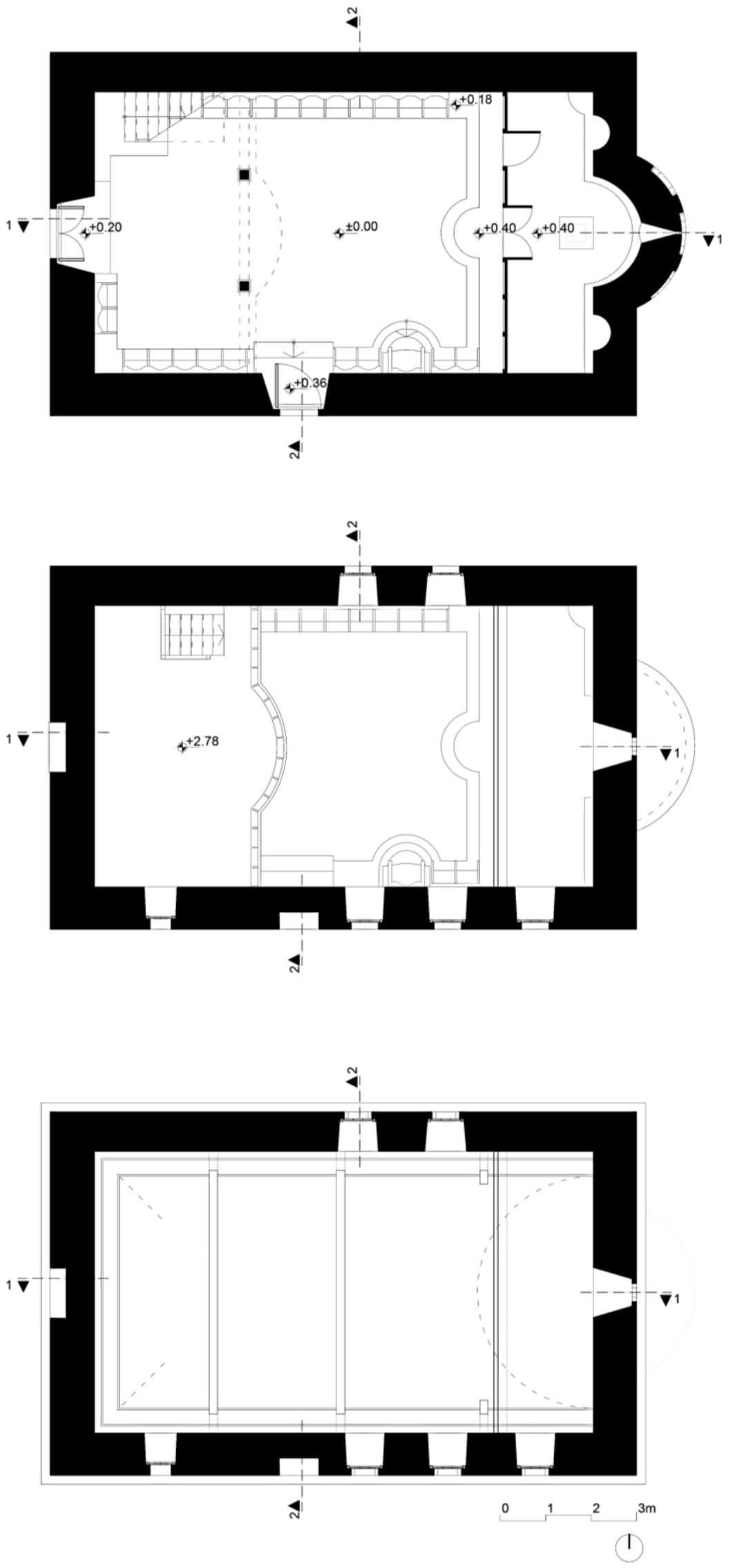

Figure III.122 St. Savior in Rashtak (Skopje). Plans: A. Ground floor ( \pm 0.00$) ;$ B. Gallery (+2.78); C. Ceiling $(+4.81)$. 

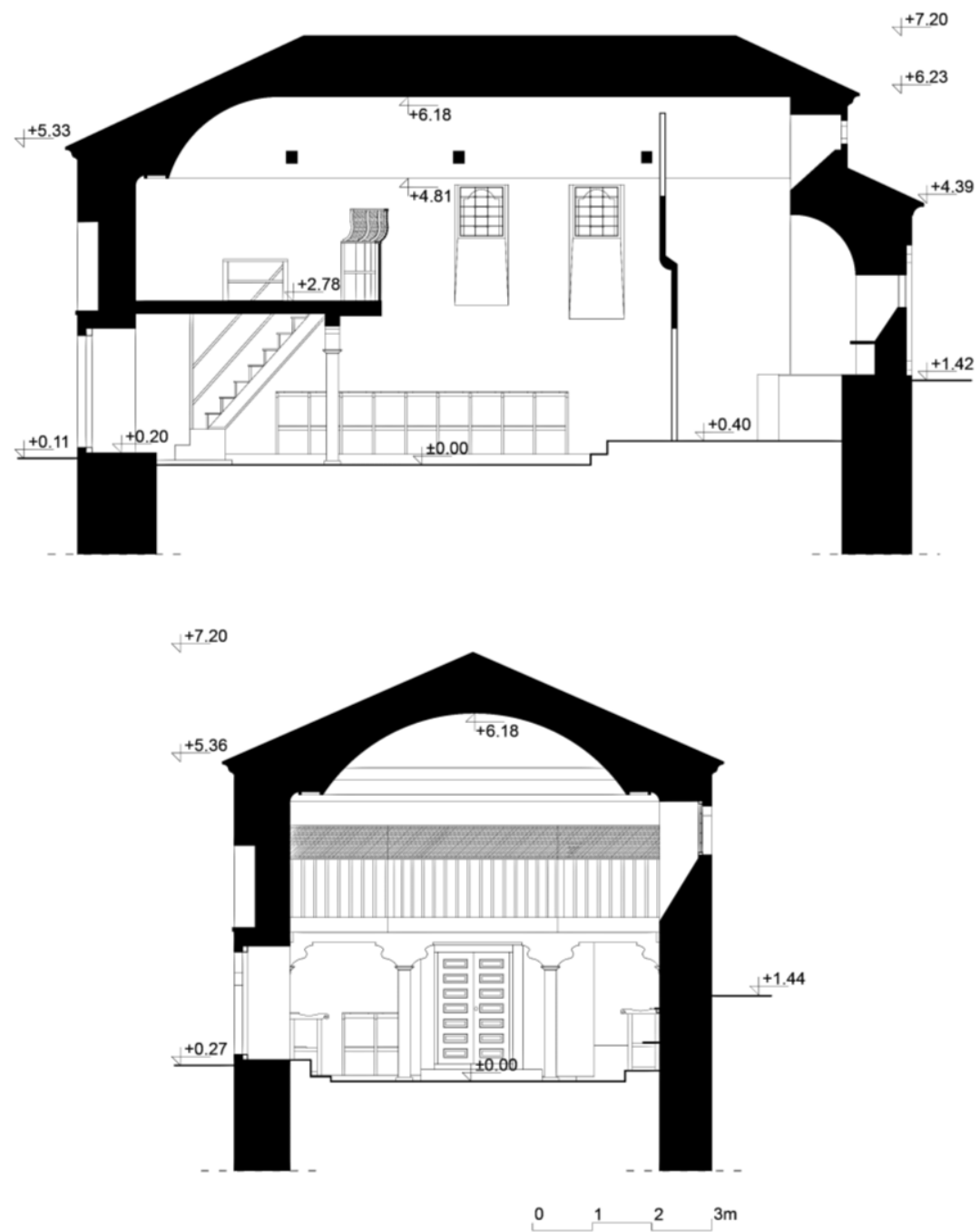

Figure III.123 St. Savior in Rashtak (Skopje). Longitudinal section (1-1); Transversal section (2-2).

The main entrance portal of the church in Rashtak is the western one, ${ }^{391}$ as a representative entrance to the temple itself, which on one hand provided women with direct access to the gallery, through a staircase placed immediately to its north, and on the other provides a gradual perception of the volume of the nave (fig. III.123). Namely, approaching through the western entrance, the believers first reside in the relatively low space beneath the gallery, which assumes the role of a narthex, or vestibule. It is only passing beneath the gallery parapet that one enters the nave itself and experiences its entire height, especially accentuated by the semi-cylindrical vault and its floating, light, almost immaterial effect.

In terms of interior design, the church in Rashtak is characterized by fresco-painting that completely covers all available surfaces, as well as an outstanding wood-carved iconostasis. ${ }^{392}$ According to the preserved founder's inscription on the south wall, west of the entrance, the fresco-painting of the temple is the work of the brothers Vangel, Nikola and Konstantin Atanasovi (Anastasovi), renowned painters from Krushevo. It is fully preserved, which allows a rare overview of the overall thematic and iconographic conception of its program. The fresco-ensemble of the church in Rashtak is characterized by exceptional artistic qualities. The figures are skillfully painted, with individual features of the characters and a

\footnotetext{
${ }^{391}$ According to the tradition, which is still alive today, in the churches that have more than one entrance, the congregation enters the church exclusively through the western entrance, while the southern one is used by the church servant or the priest himself, who then opens the western portal from the inside and "lets" the believers into the temple.

392 The church of St. Savior (Ascension of Christ) is categorized as significant cultural heritage, according to the Law on Protection of Cultural Heritage (Official Gazette of RM no. 20/04, 115/07, 18/11), with Decision no. 08-888/8 from 14.09.2010.
} 
multitude of details on their decoratively treated clothes, adorned with evident folklore influences and a local tone (fig. III.124A). The scenes narrative is characterized by elegant proportions, skilled treatment of the background scenography with elements of the local vernacular architecture instead of abstract backdrops (see fig. II.14A-B, II.16), vegetation, whirling draperies etc. This defines the frescoes of the church in Rashtak as one of the Revival art's master-pieces.
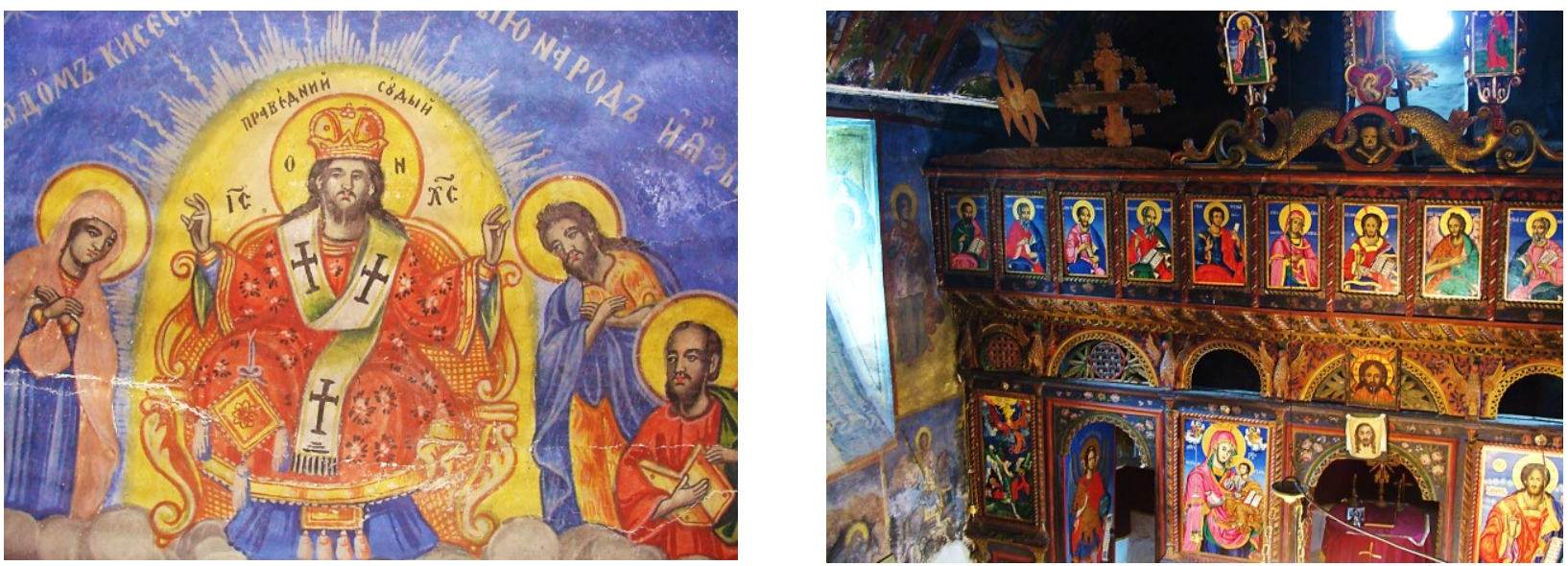

Figure III.124 St. Savior in Rashtak (Skopje): A. Detail of the fresco-ensemble; B. View of the iconostasis.

In addition to the walls and the vault of the church, the painting ensemble of the church in Rashtak flows inside the window openings, over the gallery fence and its sub-construction and on the iconostasis itself, with an evident tendency for a traditional, comprehensive painting treatment of all free areas whose opulence is contrary to the ascetic treatment of the façades. Namely, the wooden planks of the solid parapet of the gallery were alternately painted in yellow and blue, accentuated with red colored planks over their joints and stylized floral ornaments. Above it, on the musharabia, yellow and red rhombuses were painted against an indigo blue background (see fig. III.121A). Beneath the fence, the load-bearing beam was painted blue, with a centrally placed radiant sun, as were the columns of the pillars, on whose eastern sides meticulous landscape scenes were depicted (see fig. III.121B); on the western there appear doves in flight.

As the fresco-ensemble, the tall, two-zone iconostasis of the church in Rashtak is a masterpiece in itself (fig. III.124B). According to the preserved signature on the north door, the author of some of the icons is Nikola Mihajlov, also from Krushevo (Грозданов, 2004: 165). Ornamentally painted in its entirety, the altar partition also boasts wood-carved and gilded accents, such as the royal doors and the large crucifix (the snake cross). Its proportions, the skill of the workmanship, the delicacy of the details, both ornamental and painted, speak of a true masterpiece whose authorship should be sought among the best wood-carving master groups that worked in the region and beyond.

\section{III.5.A.2 SINGLE-NAVE BASILICAS WITH FLAT WOODEN CEILING}

The single-nave basilicas with flat wooden ceilings are not as common as the vaulted ones. They represent $12 \%$ of the single-nave churches and, according to the current records, $5.6 \%$ of the total number of typologically classified Revival churches. According to the geographical distribution of the single-nave Revival basilicas (see map III-A), the churches with this typology are mostly found in the central (region of Veles) and southern parts of Macedonia (the regions of Prespa, Bitola, Tikvesh and Mariovo), with individual examples in the western and northern parts, such as the region of Skopska Crna Gora. All known churches of this typology are listed in the following table (table III-3): 


\begin{tabular}{|c|c|c|c|c|c|}
\hline & CHURCH & VILLAGE & REGION (TOWN) & YEAR & $\begin{array}{c}\text { ADDITIONAL INFORMATION } \\
\text { fresco-painting / icons, renovations }\end{array}$ \\
\hline \multicolumn{6}{|c|}{ with a gallery } \\
\hline 1 & St. Petka & Dolno Egri & Bitola & 1832 & fresco-painted in 1845 \\
\hline 2 & St. Nicholas & Lera & Bitola & 1837 & dated according to the icons \\
\hline 3 & Dormition of the Most Holy Mother of God & Evla & Prespa & 1848 & \\
\hline 4 & St. Demetrius & Zlatari & Prespa & 1852 & \\
\hline 5 & St. Savior & Creshevo & Skopje & 1854 & \\
\hline 6 & The Most Holy Mother of God & Bojanchishte & Kavadarci & 1865 & dated according to the frescoes \\
\hline 7 & St. Athanasius & Koshani & Kavadarci & 1871 & \\
\hline 8 & St. Stephen & Nezhilovo & Veles & 1887 & \\
\hline 9 & St. Archangel Michael & Dolno Dupeni & Prespa & 1893 & \\
\hline 10 & The Most Holy Mother of God & Belovishte & Tetovo & & \\
\hline 11 & St. Nicholas & Gabrovnik & Veles & & \\
\hline 12 & St. Nicholas & Gorni Disan & Negotino & & \\
\hline \multicolumn{6}{|c|}{ without a gallery } \\
\hline 13 & St. Nicholas & Bolno & Prespa & 1826 & \\
\hline 14 & St. Elijah & Gradeshnica & Mariovo & 1829 & \\
\hline 15 & Holy Trinity & Podles & Veles & $1840-50$ & \\
\hline 16 & St. George & Boishte & Demir Hisar & 1850 & fresco-painted in 1878 \\
\hline 17 & The Immaculate Mother of God & Ljubojno & Prespa & 1852 & \\
\hline 18 & St. Athanasius & Dolno Dupeni & Prespa & 1864 & \\
\hline 19 & St. Demetrius & Dunje & Mariovo & 1864 & \\
\hline 20 & St. Nicholas & Dren & Prilep & 1866 & \\
\hline 21 & St. Archangel Michael & Vrpsko & Mariovo & 1868 & fresco-painted in 1881 \\
\hline 22 & St. Demetrius & Glishikj & Kavadarci & 1869 & $\begin{array}{l}\text { dated according to the royal doors, } \\
\text { abandoned and demolished in } 1982\end{array}$ \\
\hline 23 & St. John & Debrishte & Kavadarci & 1873 & \\
\hline 24 & St. Demetrius & Polchishte & Mariovo & 1882 & \\
\hline 25 & St. Athanasius & Asamati & Prespa & & \\
\hline 26 & The Most Holy Mother of God & Gradishte & Kavadarci & & \\
\hline 27 & St. Athanasius & Stenje & Prespa & & \\
\hline 28 & St. George & Blace & Skopje & & \\
\hline 29 & St. Demetrius & Gugjakovo & Mariovo & & \\
\hline 30 & St. Elijah & Ljubojno & Prespa & & \\
\hline
\end{tabular}

Table III-3 Single-nave Revival basilicas with flat wooden ceiling.

Many of these churches are compact buildings, without additions (a porch or a narthex), while some have preserved traces of open porches made of wooden construction. Such an example is the church Dormition of the Most Holy Mother of God in Evla (Prespa), on whose southern façade under the windows cantilever stone blocks are preserved which originally supported the structure of the wooden porch. Also, many of them, especially the smaller, lower buildings, do not have a gallery or any physical separation of the "women's church". However, the small size is not crucial for the appearance or absence of a gallery; the reasons are rather of an ideological nature. For example, the church St. Stephen in Nezhilovo (Veles) is a small single-nave basilica covered with a flat wooden ceiling, whose internal dimensions are only 4.2/7.9 m, yet a spacious gallery with a baroque curved fence was constructed in its western half.

As the vaulted single-nave buildings, the representatives of this group of churches are also at times reconstructions of older, mostly post-Byzantine churches. ${ }^{393}$ Sometimes, the flat wooden ceiling represents a second phase of construction, installed in single-nave churches that originally had a vault that was damaged or demolished for some reason, i.e. it is a kind of "lowered ceiling". Such an example is the abovementioned church of Dormition of the Most Holy Mother of God in Evla (Prespa), where the flat ceiling and the fence of the gallery have recently been covered with wooden paneling, painted white. That in this church the authentic height of the nave is much bigger is evidenced by the extremely low

${ }^{393}$ For example, the churches St. Nicholas in Bolno (Prespa); St. George in Blace (Skopje), which is a renovation of a church from the XVI-XVII century; St. Nicholas in Gabrovnik (Veles), which is a reconstruction of a church from the XVII century, the remains of which are preserved in the altar apse, including fragments of authentic frescoes. This church had a flat coffer ceiling, a tall twozone iconostasis and a wooden wavy gallery, with musharabia on top of the fence, as well as the usual church furnishings and furniture. Today, unfortunately, it is found in a state of complete destruction and devastation (Николовски, 2017: 273). 
ceiling above the gallery, the absence of a Crucifix above the iconostasis, which had been dismantled (the cross is preserved and hanged in front of the second zone of the iconostasis), as well as the filled-in window transenna, high above the apse of the east façade, which today is found above the level of the ceiling, i.e. in the attic of the church (see fig. III.70B). A similar case is found the church of St. Savior in Creshevo (Skopje), which will be discussed in detail on the following pages.

In addition to simply conceived flat wooden ceilings, lined with wooden boards, the ceilings at most of these churches received different kinds of decorative processing. For example, in some churches a vaulted belt runs along the edges of the nave, facilitating the transition from the plastered vertical wall surface into the horizontal plane of the ceiling. Such a solution was applied, for example, at the church of St. Petka in Dolno Egri (Bitola). In some churches of this group, a field higher than the rest of the ceiling was formed within the flat ceiling: for example, at St. Demetrius in Zlatari (Prespa), where this slightly raised field is square in shape (Nikolovski, 1987: 37). Furthermore, some incorporated one ${ }^{394}$ or more ${ }^{395}$ blind domes within the flat wooden ceiling. In addition to blind domes, the ceilings were adorned with coffer ceilings, rosettes, carved details and painted segments. In fact, it is in the decorative carpentry or wood carved wooden elements that the ceilings of the basilicas of this typological sub-group most resemble the ceilings and furniture in the profane Revival and older architecture, above all the houses of the Macedonian citizenry, the Turkish officials' konak residences, etc. A representative of this type of single-nave basilica is the church of St. Savior in Creshevo.

\section{"St. Savior - Ascension of Christ" in Creshevo (Skopje), 1854}

The church dedicated to the Ascension of Christ - St. Savior in the village of Creshevo (region of Skopje) was built around 1850, while the iconostasis and frescoes were completed in 1854, when the church was consecrated. It sits on an artificially flattened plateau, adjacent to the bed of the Bulachanska River which flows along its western side, a specific condition which proved to be unfavorable for its static stability. ${ }^{396}$ Since it was built after the implementation of the Ottoman social reforms, the church in Creshevo lies almost on the same level as the outside terrain, without the specific digging into the ground common in the earlier decades of the century.

According to its typology, the church in Creshevo is a single-nave basilica, without a narthex or other auxiliary rooms. The naos is very elongated, measuring 7.8/14.2 $\mathrm{m}$; in other words its width to length ratio is approximately 1:2. According to the usual practice in the Revival, the perimeter walls - the thickness of which exceeds $90 \mathrm{~cm}$ - were built in a massive system, with crushed stone and abundant use of lime mortar. While the façade canvases were quite impurely built, the corners of the building, as well as its crown cornices, door jambs, lintels and windowsills were made of blocks of hewn stone of various types,

\footnotetext{
${ }^{394}$ For example, the churches St. Savior in Creshevo and St. George in Blace, both in the region of Skopje, each have one small blind dome within the flat ceiling of the naos; St. Nicholas in Dren (Prilep) has a large blind dome within a coffer ceiling, etc.

395 The Most Holy Mother of God in Belovishte (Tetovo) has as many as 3 large blind domes and a separate, enclosed narthex beneath the gallery.

396 The church of St. Savior (Ascension of Christ) in Creshevo, a village located on the slopes of Skopska Crna Gora mountain, is an active church cared for by a village church board, and is therefore found in generally good condition. In that direction, it is of great importance that the north and east façade have been excavated from the sloping terrain, which prevents the appearance of capilar moisture and devastation of the frescoes, which is quite common in below-ground walls. The local population also repaired the damaged mortar joints in those areas, as well as a section under the roof on the east façade, unfortunately with cement mortar, an intervention using a harmful material which of course should be reconsidered. Also, the authentic stone slab floor (today preserved only in the altar) in recent decades has been replaced by non-representative ceramic tiles of industrial production. However, despite the generally satisfactory condition of the church, deep cracks in the masonry testify to structural damage in the south-west corner that extends through the thickness of the wall and appears also in the interior of the church (see fig. III.128). This crack implies uneven alignment of the foundations, i.e. instability on the terrain, likely caused by destructive action of the nearby river. Comprehensive research is needed for the existing damage and the properties of the terrain, in order to avoid major consequences for the stability of the temple in the future.
} 
with clean, regular joints and precise masonry. Particularly elongated hewn blocks of travertine appear at the four corners of the building. Furthermore, the masonry of the exterior of the five-sided altar apse was also skillfully executed, with extreme precision in the arrangement of the blocks of travertine, with thin, precise mortar joints. The façades of the apse are treated as a cast, monolithic structure, without accentuating their corners with pilasters, nor is there a horizontal articulation with the help of cornices. In the axis of the apse there is a narrow slit window which illuminates the altar space. Towards the top, the apse is crowned with a profiled stone cornice (fig. III.125). On both sides of the altar apse, the altar houses the prothesis and the diaconicon, marked by shallow semicircular niches in the east wall. Another slightly deeper niche is located in the north wall of the altar.
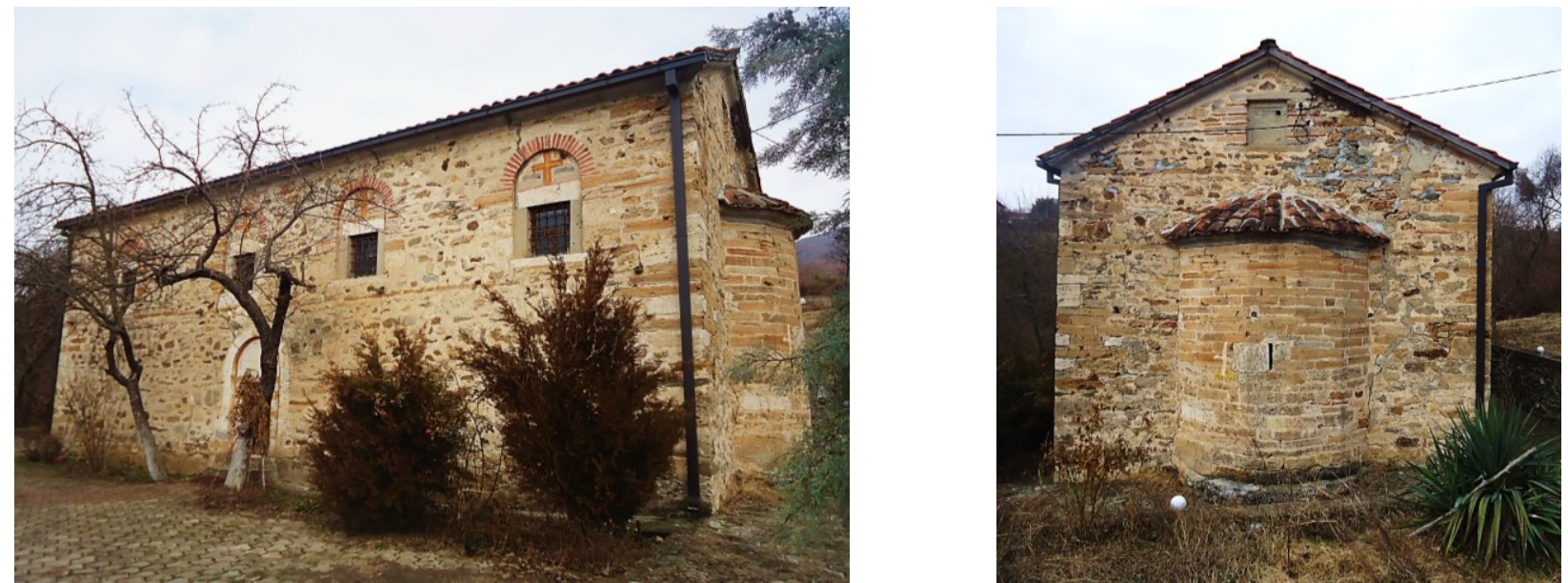

Figure III.125 St. Savior in Creshevo (Skopje): A. View from the southeast; B. East façade.

The elongated nave of the church in Creshevo was masterfully divided into three zones (three bays) in its interior (see fig. III.129-130). The eastern zone of the church is the altar space, completely separated from the nave with a high iconostasis. The remaining prismatic volume of the naos to the west of the iconostasis partition has a precise ratio of 1:2. Furthermore, according to the already established tradition characteristic of the sacred architecture of the Revival, a gallery develops in the western zone of the church, accessed via a wooden staircase in the north-west corner of the building. In the spirit of the local construction practice, characteristic for the churches at the villages of Skopska Crna Gora mountain, the gallery of the church in Creshevo (as was the case with the churches in Rashtak and Mirkovci, see Chapter I.5.2), is quite large, with a depth of over $4 \mathrm{~m}$, extending to the east almost to the middle of the naos. The elaborate design process is further evident in the space formed between the plane of the gallery and the altar, which is almost square in plan (it is an ideal square measured from the edge of the gallery to the altar platform), whose sides correspond to its height up to the flat wooden ceiling, so that the volume of the nave is actually a cube. It is evident that the composition of the internal volume occurred as a result of careful proportional analysis and, undoubtedly, of the proficient dexterity of its builders.

The division of the naos into three bays (zones) was consistently implemented to the extent that the structural system used for the gallery was mirrored on the east side of the church, behind the iconostasis. Namely, the gallery rests on two wooden pillars with a square cross-section, which carry the load-bearing beam through additional wide, decoratively profiled wooden capitals. The gallery parapet is a horizontal strip, continuous from the north to the south façade wall, emphasized by its complete nontransparency. It is decorated with a frieze of intertwined elongated rhombic motifs made of thin wooden planks, with a certain folklore tone. On top of the parapet rest wooden pillars analogous to those of the lower zone, which alludes to their continuity, an additional centrally placed pillar in the longitudinal axis of the church, as well as two half-pillars (pilasters) on the north and south corners of the gallery, adjacent 
to the lateral walls. The columns of the second zone of the gallery are interconnected by arches made of wooden panels with a specific profile, with the two central fields being narrower than the end ones (fig. III.126B). Instead of the usual wooden floor, the floor of the gallery in Creshevo is laid with brick and is preserved in its authentic condition. Although the church has no narthex, its role is taken by the low space beneath the gallery. The transition from the narthex under the gallery to the high, undisturbed and much brighter naos gives it a note of monumentality.
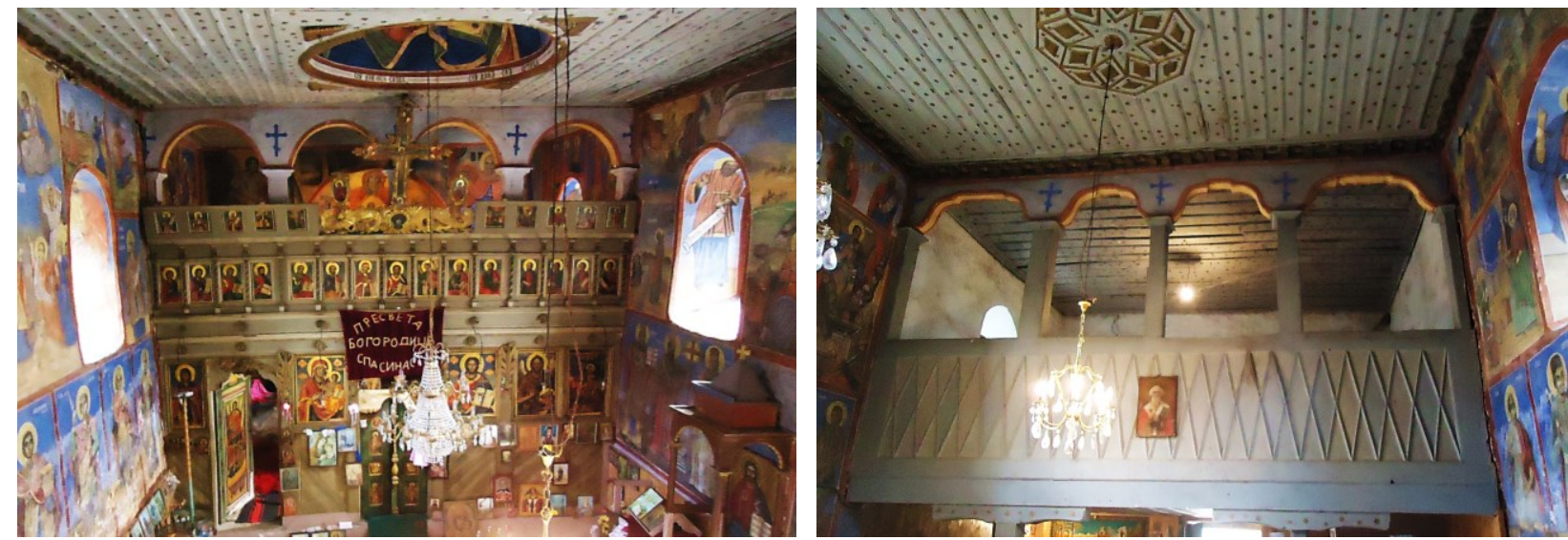

Figure III.126 St. Savior in Creshevo (Skopje): A. View towards the altar B. View towards the gallery.

The consistency in the implementation of the concept of division of the internal volume of the building is evident on its eastern side (fig. III.126A). Namely, behind the iconostasis, analogous to the constructive system of the gallery, appear three pillars and two half-pillars, identical to their counterparts on the west side of the nave as part of a very cleverly executed symmetry. They are made of wood with a square cross-section, connected to each other by semicircular arches, which is the only difference compared to the shallower, profiled arches that were elaborated in the gallery. Of these five pillars, only two are actually load-bearing pillars, extending the entire height from the floor of the altar to the arcade, while the central pillar and the lateral pilasters are fake and serve no structural purpose (in fact, they are short pieces of wood hung on the constructive system of the adjacent iconostasis). Their role is clear: a consistent, mirror image of the west and east partitions of the nave, which define and frame it.

An additional element of the architectural design of the nave, which speaks of its treatment as a whole divided into three independent but still connected zones, is the processing of the flat wooden ceiling that extends continuously at the same elevation $(+5.10 \mathrm{~m})$ above the gallery, in the nave and in the altar space (fig. III.127). The only difference is the direction of arrangement of the wooden planks: east-west in the nave, north-south in the gallery and the altar. However, despite the same height, the three bays received a slightly different treatment in terms of decoration. The conceptually simplest is the ceiling in the gallery, made of shorter boards with decorative thin

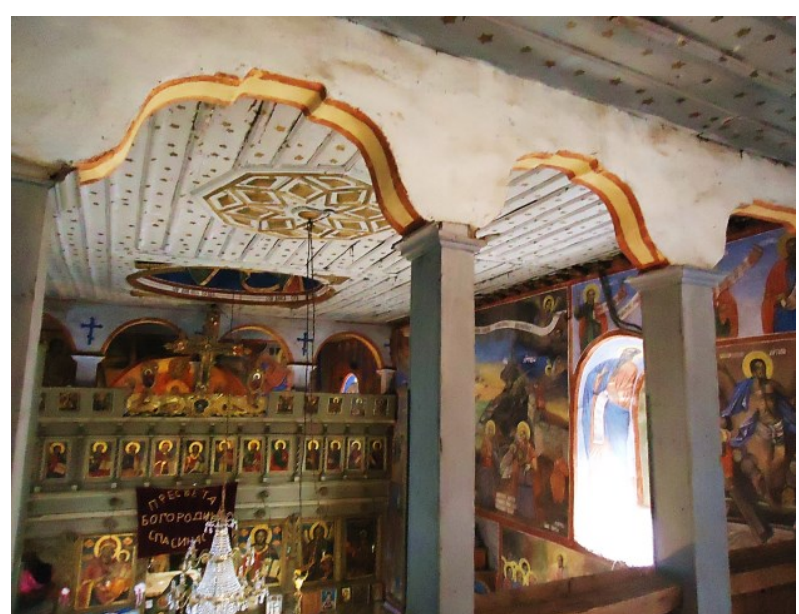

Figure III.127 St. Savior in Creshevo (Skopje). View from the gallery towards the naos and the altar to the east. profiled planks placed over their joints. The ceiling in the altar is similarly executed, with the difference that the planks run along its entire width in a rectangular field lined on all four sides with a continuous frieze, along the perimeter walls and behind the iconostasis. The most decorative treatment, of course, 
was given to the ceiling above the nave. In the longer axis of the church, following the concept of absolutely precise and symmetrical approach inherent to the architecture of the church in Creshevo, are placed two decorative elements. To the east, a small blind dome inscribed in a square field was inserted in the flat wooden ceiling. The dome has a span of $170 \mathrm{~cm}$ and a depth of $85 \mathrm{~cm}$. The field in which it is inscribed, with approximate dimensions of $2 \times 2 \mathrm{~m}$, is enriched with triangular decorative wood-carved elements placed in its four corners (fig. III.126-127). These decorative elements undoubtedly have their roots in the wood-carved ceilings characteristic of the contemporary Revival residential architecture built for the newly formed bourgeoisie. The analogy is even clearer in the wooden octagonal rosette located in the longitudinal axis of the church, to the west of the blind dome. The rosette, with its shape of a pendant, acts as a counterweight to the concave cavity of the dome. In its center there is a circular medallion, surrounded by an octagon with double inscribed rhombus motifs, which are repeated along the edges of the octagon. The concept of the wooden ceiling is complemented by another small octagonal rosette, placed in the altar, to the east along the longitudinal axis of the church. Its concept is simpler: in the center there is again a circular medallion, from which triangular fields radiate to the edges of the octagon. Finally, of special interest is the decorative wood-carved frieze which encircles the ceiling of the nave on its south, west and north sides, emphasizing its square plan. This frieze consists of alternately placed highly sculptural, three-dimensionally processed flower-shaped elements with eight petals and consoles with a baroque curved profile, at the bottom of which is a motif of a branch - a tree of life. This frieze, as well as the rosettes and other wood-carved components of the ceiling were also additionally gilded.

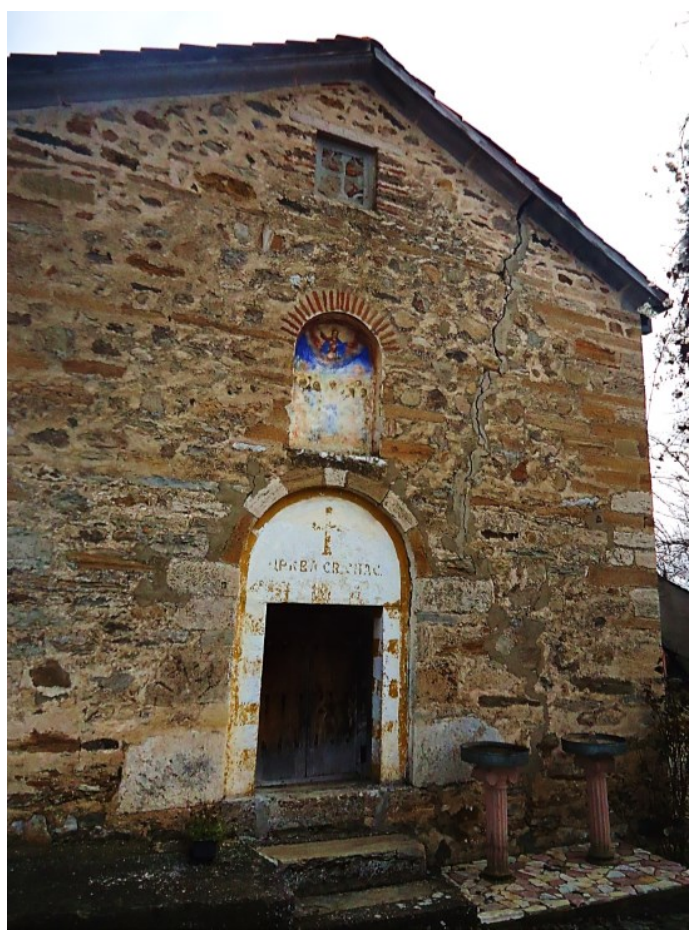

Figure III.128 St. Savior in Creshevo (Skopje). View of the west façade.

A special quality of the space in the nave is the abundance of light. Namely, the nave is illuminated through large windows, which spread in a funnel-like fashion in the thickness of the walls, directing the light inwards at the greatest possible angle, a typical feature of the Revival architecture (see fig. III.69). The windows are placed in shallow semicircular niches on the façades, with arches made of brick, as a nod to the architectural language characteristic of Byzantium (fig. III.125). In the fields that remain above the rectangular window openings, there are crosses with elongated arms, also made of brick. The rectangular windows were defined by massive limestone window sills and were arranged in a harmonious rhythm: in fact, two pairs of windows on the north and south facades correspond to the nave of the church, placed in a symmetrical and harmonious composition, while the remaining two windows on the south façade belong to the gallery and the altar (fig. III.129, III.130A). In addition to the windows, the facades of the church are enriched with two entrance portals. The western, main entrance portal consists of an elegant semicircular arch made with alternating stone blocks in two shades - white (limestone) and yellow-brown (travertine). Above the portal is a semicircular vaulted lunette with a brick arch, identical to the window openings. In the niche of the lunette in fresco technique, as usual, the patron saint of the temple was painted, in this case the composition Ascension of Christ (fig. III.128). The fresco is quite damaged as a result of long-term exposure to the weather. The south entrance portal has a more modest conception, without a lunette and alternation of two types of 
stone blocks in its arch; instead, it was entirely made of limestone blocks, but still corresponds to the western one in its form (fig. III.131).
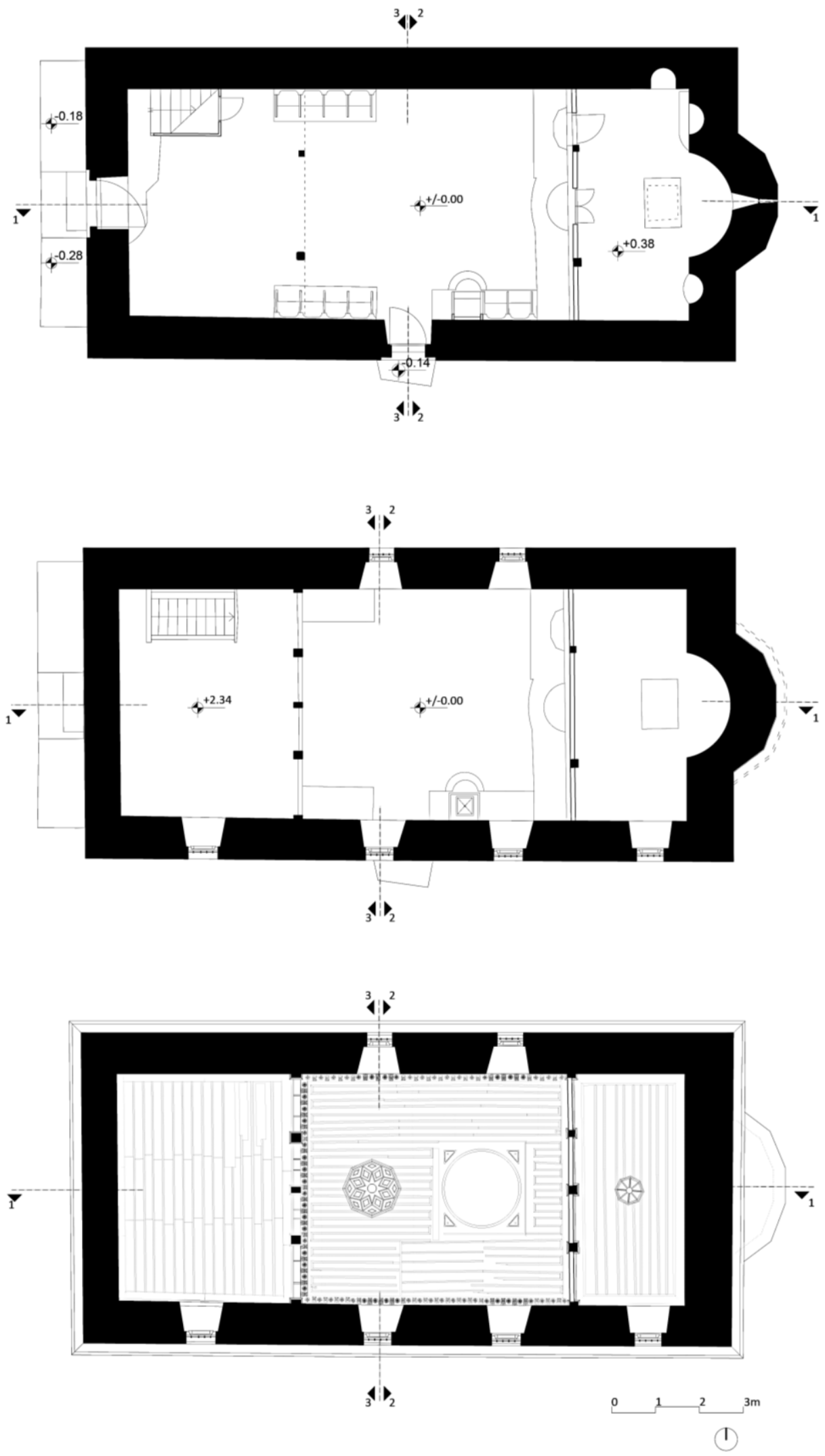

Figure III.129 St. Savior in Creshevo (Skopje). Plans: A. ground floor ( \pm 0.00$)$; B. gallery (+2.34); C. ceiling (+5.10). 

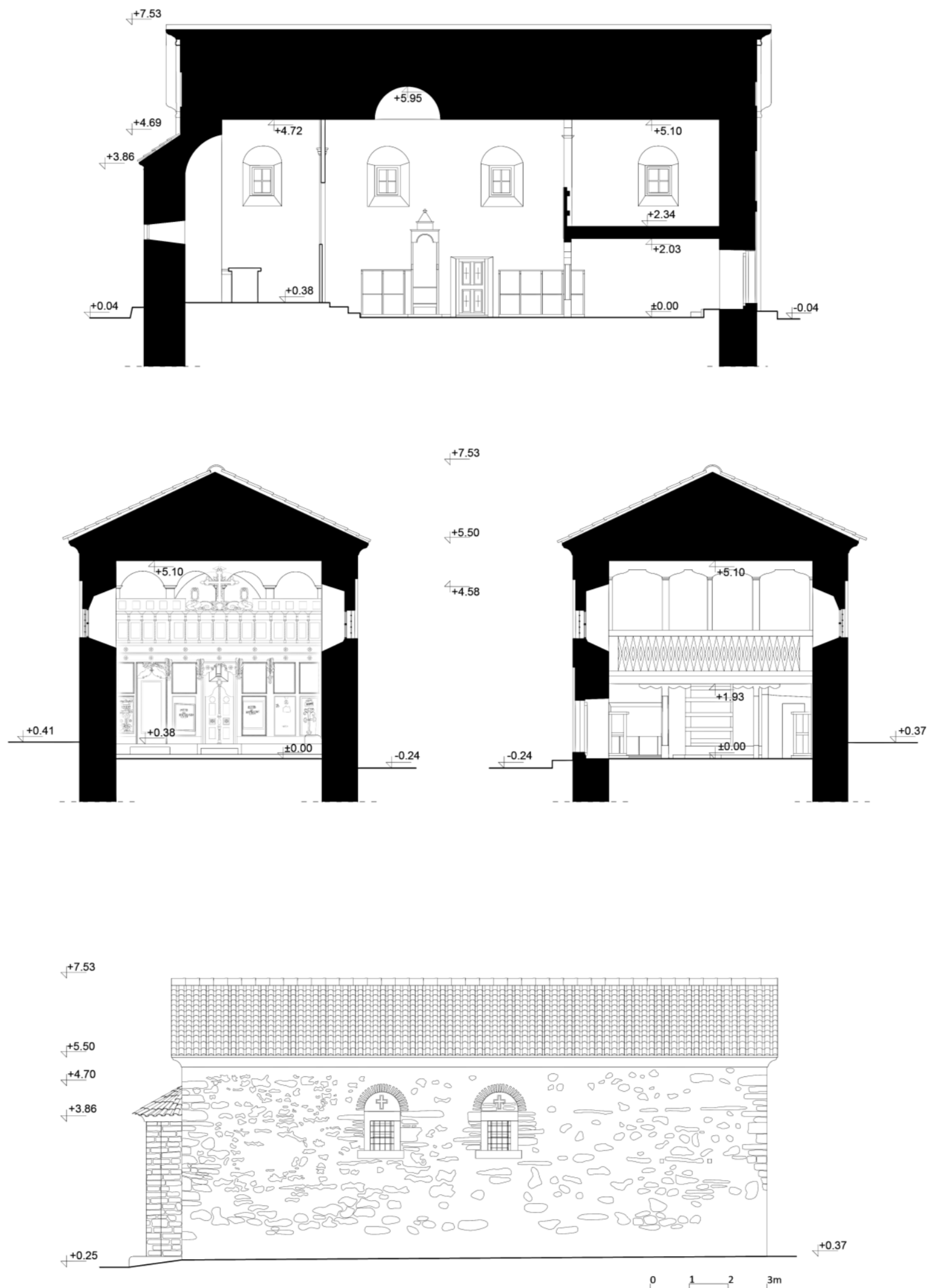

Figure III.130 (this page) St. Savior in Creshevo (Skopje). A. Longitudinal section (1-1); B. Transversal sections (2-2 and 3-3); C. North façade.

Figure III.131 (opposite page) St. Savior in Creshevo (Skopje). A. Southern façade; B. Western and eastern façades. 

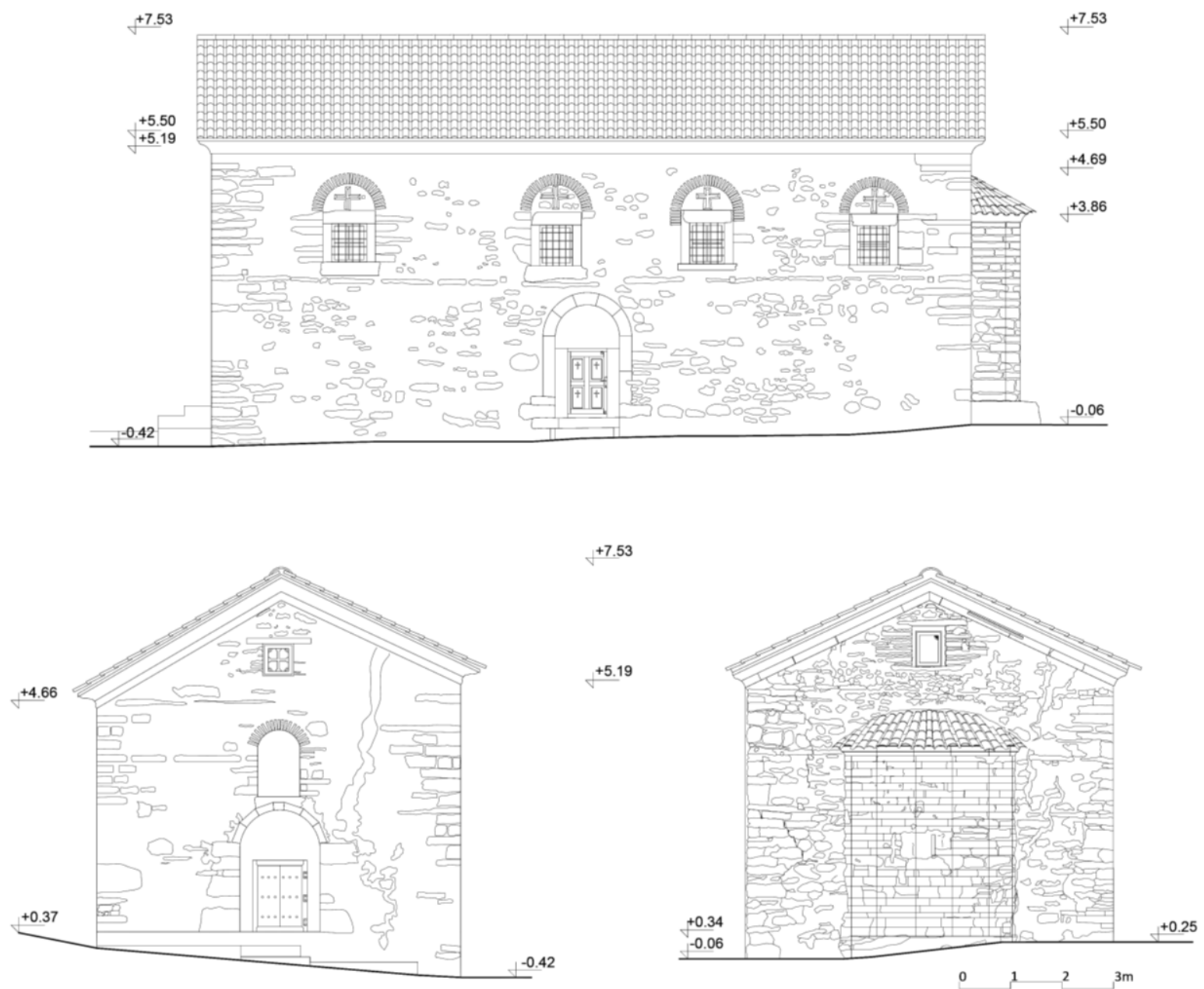

High above the lunette of the western entrance portal and, analogously, above the altar apse at the east façade, appear small square windows with long stone window sills. ${ }^{397}$ They house stone-carved transennas which have both been subsequently filled in with pieces of brick and mortar; however, with the west being in a better state of preservation, its conceptual design is still legible (fig. III.128, III.131A). It comprises a Maltese cross with profiled extensions at the ends of its arms; circular segments are carved in the corners of the transenna, between the arms of the cross. The transenna on the east façade was almost completely plastered, with the exception of the circular segment in the upper north corner, which inadvertedly leads to the conclusion that it was originally identical to the west one (fig. III.125B, III.131B). The need to install these two stone-carved decorative windows is unusual: they are located high above the flat ceiling of the church (see fig. III.130A), which has made them redundant, and they were therefore later closed off. Since the placement of stone-carved transennas on the west and east façades, often decorated in the form of a four-leaf clover or a stylized cross, is one of the basic stylistic features of the Revival basilicas (see Chapter III.4), did the author of the church in Creshevo feel obliged to include them in his design as a necessity arising from the contemporary architectural fashion? Perhaps in the original idea, which he later abandoned, the master-builder had planned a gradation of the wooden ceilings in the three bays of the church, so that the west and the east would be set higher than the central one? Or maybe these two windows made of stone-carved slabs were originally part of a completely different interior, in which instead of a flat ceiling one can imagine a semi-cylindrical vault as, for example, the one

\footnotetext{
${ }^{397}$ Here, too, appear bricks, alternating with thin blocks of stone in a horizontal syllable on either side of the east and west
} window transenna. 
at the church in the neighboring village of Rashtak? If in the future the upper parts of the church which today are hidden above its ceiling are investigated, it may be possible to answer these dilemmas.

In terms of interior design, despite the limited dimensions, the church of St. Savior in Creshevo was quite representatively adorned (see fig. III.126-127). The altar and naos were completely fresco-painted (while the walls in the gallery were whitewashed), and even on the sides of the window openings figures of saints in full height were painted. But the artistic qualities of the painting are more modest: the tonality is less clean, the strokes are clumsier, the draperies are almost two-dimensional, the general absence of depth and perspective in the compositions speak of a weaker master-painter, compared to the ones who worked in the nearby village of Rashtak. However, the arrangement of the compositions, their adaptation to the architecture of the monument, as well as the dominant uniform blue tones of the background give the interior of the church a sleek and elegant look. In a typical Revival manner, color overflows beyond the boundaries of icon and fresco painting: the church furniture, the structural and decorative wooden elements, the gallery fence, the iconostasis, the flat ceilings, all received decorative painting against a background of a gentle, light blue-gray tone. The wooden ceilings are especially decorative, with gilded wood carved elements, as well as a multitude of stars painted in the same golden shade, which creates the effect of a starry sky. The same painting treatment was consistently applied to the ceilings in the altar, the nave and the gallery.

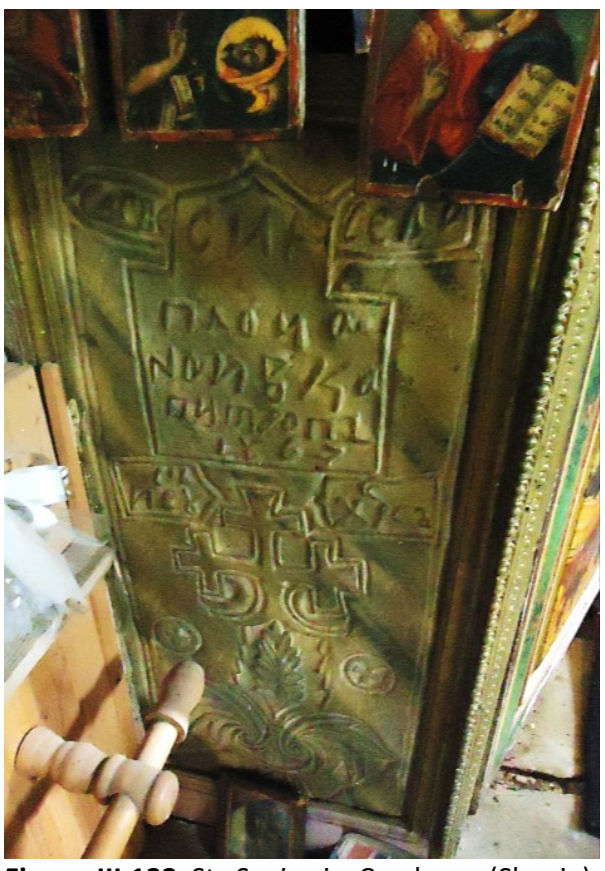

Figure III.132 St. Savior in Creshevo (Skopje). Detail of the iconostasis stone parapet slabs.

The iconostasis is compact and flat, with no angled panels in the corners or baroque curved shapes which were otherwise quite common for the Revival iconostasis. ${ }^{398}$ The placement of the entire iconostasis in one plane is another tool used to emphasize the mirror symmetry of the church nave, by mirroring the flat fence of the gallery, which also lacks the characteristic Revival curved shapes and a centrally placed balcony. The tall iconostasis was vertically divided into three zones. A specific feature of this iconostasis in particular is the processing of its parapet in the lower zone (fig. III.132). Namely, instead of the usual wooden panels (decorated with floral, geometric motifs, architectural scenes and abstract landscapes or fresco-painted scenes from the Old Testament), massive stone slabs ${ }^{399}$ support the throne icons in the second zone of the iconostasis. These stone slabs were decorated with engravings in shallow relief consisting of various motifs with Christian symbolism (crosses, tree of life, fleur-de-lis, rosettes, cross-filled monograms, etc.). In addition to the ornamental shallow relief repertoire, the parapet slabs also contain dated dedications from donor families from the village of Creshevo, from which it can be concluded that the slabs were made and inserted in the iconostasis at the time of the consecration of the church, as well as in the subsequent years, as their gifts to the new village church.

\footnotetext{
398 In 1854, the famous painter Dicho Zograf worked in the church of St. Savior in Creshevo. For this temple he made the entire iconographic ensemble (the throne icons, the Deisis composition, the apostles and holiday icons and the Crucifix), which together with the iconographic ensembles of the churches of St. George in Banjani and St. Nicholas in Gluvo (see Chapter I.5.2), is considered one of the most beautiful and richest of his works in the region of Skopje. His typical author's signature is evident in the drawing precision and the exceptional proportions of the caharacters, as well as their fresh color.

${ }^{399}$ A similar concept of an iconostasis consisting of a stone parapet on which the throne icons with classical wooden construction were placed, albeit rather rare and exceptional, can be found in several other churches: at St. Archangel Michael in Tashmarunishta (region of Struga); at the church of St. Nicholas in Mavrovo and St. George in Struga.
} 


\section{III.5.A.3 SINGLE-NAVE BASILICAS WITH LATERAL PILASTERS CONNECTED WITH ARCHES, COVERED BY BARREL VAULT}

The single-nave vaulted basilicas with lateral pilasters connected with arches, as a specific subgroup, represent $16 \%$ of the single-nave and $7.6 \%$ of the total number of typologically classified Revival churches. They are concentrated in a relatively small, geographically limited region - in the south-western part of Macedonia. The core of distribution of this architectural typology is composed of the regions of Demir Hisar, Krushevo, Prilep and Bitola, where it is a dominant typological solution, with several examples in the surrounding regions of Prespa, Ohrid, Struga and Kichevo to the west and Mariovo to the east, where its influence was less pronounced (see map III-A).

The origin of this typology is local and can be traced to the post-Byzantine period, when this specific architectural solution was used in several very important monastic churches in the XVI-XVII century. Namely, as discussed earlier (see Chapter I.5.1), in addition to the usual widespread solution of a simple single-nave vaulted temple, during the Ottoman occupation churches of the specific sub-group defined as single-nave vaulted churches with lateral pilasters and arched niches were also built, predominantly in the south-western part of Macedonia (see map I-2). They are:

- St. Demetrius in Gradeshnica (Mariovo), dated in the XV century according to its frescoes (fig. III.133); 400

- St. Nicholas - Toplichki monastery, village of Babino (Demir Hisar), 1536/1537 (Расолкоска-Николовска, 1989: 323-333) (see fig. I.43B4);

- St. Nicholas - Oreoechki monastery, village of Oreovec (Makedonski Brod), 1595 (see fig. I.43B1); ${ }^{401}$

- St. Nicholas - Moklishki monastery, village of Vatasha (Kavadarci), 1595 (Ќорнаков, 1995: 201-205); ${ }^{402}$

- St. George in Vrbjani (Ohrid), 1605 (Ангеличин-Жура, 1997: 99126) (see fig. l.43B3);

- Nativity of the Most Holy Mother of God - Slivnichki Monastery, village of Slivnica (Prespa), 1607 (fig. III.134); 403

- St. Athanasius - Zhurche monastery (Demir Hisar), 1617 (see fig. I.43B2); ${ }^{404}$

- St. Athanasius in Rilevo (Prilep), 1627; ${ }^{405}$

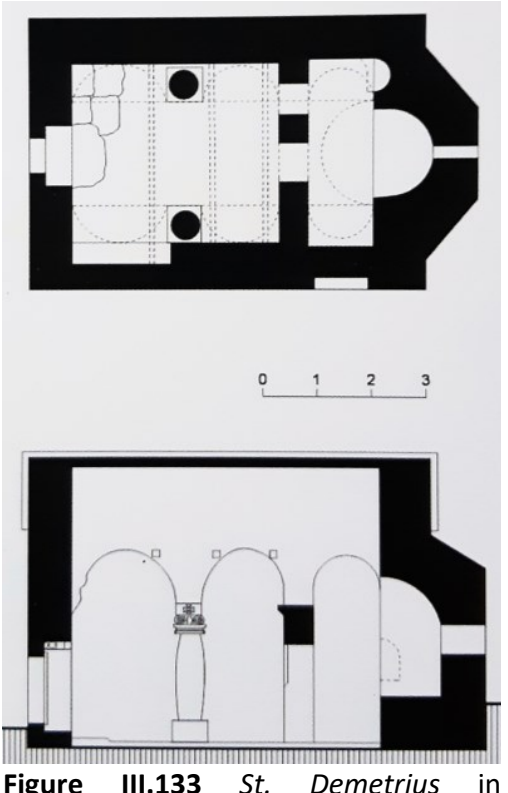
Gradeshnica (Mariovo): Plan and longitudinal section.

400 In this church, the described typological solution is achieved in a more specific way: namely, while the eastern pair are very deep, massive pilasters - between which is placed a specific masonry iconostasis (found in but a few churches in Macedonia), the western pair of pilasters are substituted by marble columns with bases and capitals in shallow relief, used as spoliae, adjacent to the side walls, connected with arches to the west façade wall and to the east pilasters (fig. III.133).

401 Single-nave vaulted church, built of limestone. To the east it ends with a high five-sided apse, to the west the remains of a porch are preserved. A single pair of massive pilasters appears, thus forming two pairs of niches in the lateral walls. The western is larger, while the eastern one, which corresponds to the altar space, is narrower and separated from the nave by an altar partition spread between the pilasters (Машниќ, 1990: 6).

402 The church in Moklishte has two pairs of massive pilasters in a symmetrical disposition, which form three semi-sircular niches in the lateral walls. However, a specific feature of this church is the considerable difference in height of the central niche, in comparison with the lateral, lower niches (Касапова, 2020).

${ }^{403}$ Soon, in 1612, a closed narthex was added on the west side of the naos. According to the founder's inscription in the nave, the church was built by master Navar (Поповска-Коробар, 2015: 209-211). This master-builder, along with Ivan from Kichevo (see footnote 405) are so-far the only post-Byzantine architects who worked in Macedonia known by their name.

404 In 1621/1622, a square open porch covered with a spacious, completely fresco-painted blind dome, carried on masonry pillars connected by arches, was built on the west side (see fig. I.43B2).

${ }^{405} \mathrm{~A}$ specific feature of this church is that the side niches are low on the walls. It is a single-nave church, with a barrel vault, a gable roof and a five-sided altar apse. It was built in 1627 by master Ivan from Kichevo (Поповска-Коробар, 2015: 211), and 
- St. John the Theologan - Slepche monastery (Demir Hisar), 1617, fresco-painted in 1627;

- St. Nicholas - Slepche monastery (Prilep), 1672/1673), ${ }^{406}$ with extended narthex and monastery lodgings built in 1860 (Поповска-Коробар (В), 2008: 153);

- St. Petka in Zhvan (Demir Hisar), XVI-XVII century (Дапчев, 1996: 226-227) with a Revival extension of the same typology.

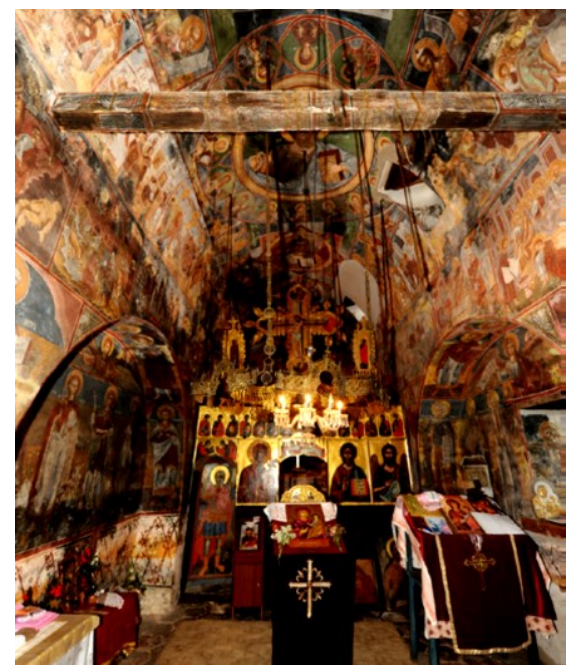

Figure III.134 Nativity of the Most Holy Mother of God in Slivnica (Prespa). View towards the altar.

It can therefore be concluded that the churches from this specific group were built from the $X V$ to the XVII century, predominantly in the region of Demir Hisar and the neighboring areas. ${ }^{407}$ According to their interior composition, they can be divided into two categories. The first group is comprised of singlenave vaulted churches with two pairs of pilasters and, subsequently, three arched niches in the lateral walls, arranged in a symmetrical composition, with a larger central niche than the lateral ones. Such are the churches in Gradeshnica and the monasteries Toplichki, Zhurche, Moklishki, Slepche (Demir Hisar) and Slivnichki. The second category differs by the number of pilasters - one pair, and niches they form - two on each wall, of unequal size, the one corresponding to the naos being much larger that the eastern niche in the altar. This group comprises the churches in Oreovec, Vrbjani, Rilevo, Slepche (Prilep) and Zhvan (Касапова, 2020). These post-Byzantine churches served as a prototype for a specific typological pattern of the Revival single-nave basilicas in the wider south-west region, the representatives of which are stated in the following table (table III-4):

\begin{tabular}{|l|l|l|l|l|l|}
\hline & CHURCH & VILLAGE & REGION (TOWN) & YEAR & $\begin{array}{c}\text { ADDITIONAL INFORMATION } \\
\text { fresco-painting / icons, renovations }\end{array}$ \\
\hline 1 & St. Archangel Michael & Optichari & Bitola & 1838 & dated according to the frescoes \\
\hline 2 & St. Cosmas and Damian & Peshtani & Ohrid & 1844 & \\
\hline 3 & St. George & Ivanjevci & Bitola & 1847 & \\
\hline 4 & St. George & Podmochani & Prespa & 1848 & \\
\hline 5 & St. Athanasius & Beranci & Bitola & 1849 & \\
\hline 6 & St. Nicholas & Kukurechani & Bitola & 1851 & frescoed in 1875, renovated in 1920 \\
\hline 7 & The Most Holy Mother of God & Zheleznec & Demir Hisar & 1852 & \\
\hline 8 & St. Marina - St. Savior & Sveto Mitrani & Krushevo & 1856 & \\
\hline 9 & St. Nicholas & Vrbjani & Prilep & 1856 & \\
\hline 10 & St. Elijah & Veselchani & Prilep & 1857 & \\
\hline 11 & St. Elijah & Ezerani & Prespa & 1858 & \\
\hline 12 & St. Nicholas & Babino & Demir Hisar & 1858 & \\
\hline 13 & The Most Holy Mother of God & Botun & Ohrid & 1859 & \\
\hline 14 & St. Petka & Lisolaj & Bitola & 1860 & \\
\hline 15 & Dormition of the Most Holy Mother of God & Staravina & Mariovo & 1860 & \\
\hline 16 & St. Nicholas & Cer & Demir Hisar & 1866 & \\
\hline
\end{tabular}

painted by the painter John from Linotopi (region of Castoria). In the Revival (in 1871) it was extended to the west and frescopainted by Stojan (Stanko) Cvetkov from the Renzovi family from Tresonche, previously immigrated to Krushevo. Of interest is that part of the east façade above the apse, very unusually, was painted with large representations of the archangels Michael and Gabriel. In that context, it is important to mention that in the Revival, although rare, at times frescoes were painted on the east façade, for example at the church in Malovishte near Bitola (see fig. III.27A).

406 What is specific about this church is that the shallow altar apse and the prothesis and diaconicon niches are embedded in the east wall. It was painted immediately after its construction, in 1674, and the founders are the abbot of the monastery, the hieromonk Sergius and his student, the hieromonk Michael. The inner walls are completely covered with frescoes, the author of which is considered to be Kosta from Linotopi, region of Castoria, whose workshop also made the frescoes in the church in the neighboring village of Rilevo, painted by John from Linotopi (Василиев, 1965: 277), as well as in the monastery in Zrze. In the region of Demir Hisar, masters from this group worked on the frescoes in Zhvan, Zhurche and Slepche.

407 However, it must be mentioned that a smaller group of similarly conceived post-Byzantine churches also appeared in the region of Kumanovo (Zhegligovo), in north-eastern Macedonia. See Chapter I.5.1, footnote 107. 


\begin{tabular}{|l|l|l|l|l|l|}
\hline 17 & St. Nicholas & Slepche & Demir Hisar & 1867 & fresco-painted in 1884 \\
\hline 18 & St. George & Belica & Kichevo & 1867 & \\
\hline 19 & St. Nicholas & Nebregovo & Prilep & 1868 & \\
\hline 20 & Dormition of the Most Holy Mother of God & Rastojca & Demir Hisar & 1874 & dated according to the frescoes \\
\hline 21 & St. Nicholas & Golemo llino & Demir Hisar & 1874 & fresco-painted in 1896 \\
\hline 22 & St. Nicholas & Vranche & Prilep & 1874 & \\
\hline 23 & St. Nicholas & Budimirci & Mariovo & 1875 & \\
\hline 24 & Dormition of the Most Holy Mother of God & Draslajca & Struga & 1875 & renovation of an older church \\
\hline 25 & Nativity of the Most Holy Mother of God & Buchin & Krushevo & 1876 & \\
\hline 26 & St. Nicholas & Virovo & Demir Hisar & 1878 & dated according to the icons \\
\hline 27 & St. Nicholas & Krstec & Prilep & 1881 & renovated in 1913 \\
\hline 28 & Nativity of the Most Holy Mother of God & Shtavica & Mariovo & 1881 & \\
\hline 29 & St. Nicholas & Edinakovci & Demir Hisar & 1884 & \\
\hline 30 & Dormition of the Most Holy Mother of God & Zhurche & Demir Hisar & 1885 & dated according to the frescoes \\
\hline 31 & St. Nicholas & Zagoriche & Demir Hisar & 1885 & dated according to the frescoes \\
\hline 32 & St. Nicholas & Arilevo & Krushevo & 1887 & dated according to the frescoes \\
\hline 33 & St. Nicholas & Dolno Divjaci & Krushevo & 1887 & dated according to the frescoes \\
\hline 34 & St. Nicholas & Pusta Reka & Krushevo & 1887 & dated according to the frescoes \\
\hline 35 & St. Elijah & Zashle & Demir Hisar & 1888 & \\
\hline 36 & St. Constantine and Helena & Zagorani & Prilep & 1890 & \\
\hline 37 & St. Athanasius & Bazernik & Demir Hisar & 1891 & fresco-painting in 1891-1895 \\
\hline 38 & Resurrection of Christ & Dedebalci & Bitola & & \\
\hline 39 & St. Petka & Zhvan & Demir Hisar & & extension of a XVII century church \\
\hline 40 & St. Elijah & Leskovo & Demir Hisar & & \\
\hline
\end{tabular}

Table III-4 Single-nave Revival basilicas with pilasters connected by arches, covered with a barrel vault.

The Revival churches that based their composition on the post-Byzantine prototype display evident changes of the basic architectural solution. Their architecture is much more complex both in terms of plan and elevation, as in terms of the decoration of the temple; in other words, they further developed this specific typology. One basic change is the use of the typically Revival mixed structural system, with wooden "false" vaults, which allowed for the appearance of significantly shallower pilasters since their function was now less structural and more compositional and decorative, which is why they were regularly adorned with capitals (fig. III.135-136). Furthermore, their number grew: from the "traditional" two pairs (at the churches in Ezerani, Edinakovci, Zagoriche and Zhurche); to three (in Bazernik, Golemo llino, Zheleznec, Zashle, Leskovo, Slepche, Podmochani, Dedebalci, as well as the Dormition of the Most Holy Mother of God in Sloeshtica (1908); to four pairs of pilasters (in Babino, Virovo, Cer, Nebregovo, Beranci, as well as St. Panteleimon in Sveta (1905) which, although does not belong chronologically to the XIX century Revival, follows the same architectural typology (fig. III.135). The pilasters were connected to each other with semicircular arches, thus forming niches in the lateral walls, although there are exceptions where the niches are architrave (in Leskovo and Edinakovci, for example). In some churches the western and/or eastern niche were distinguished by their dimensions: for example, in Zhurche the easternmost niche that corresponds to the altar space is wider than those in the nave; in Zagoriche pilasters and niches appear only in the nave, not in the altar area; in others, the rhythm and dimensions of the niches are uniform throughout the building (for example, in Bazernik, Zashle and Zheleznec), etc. The eastern and western arch are supported on one side by a pilaster, and on the other by a console (in Babino and Nebregovo) or a semi-pilaster (in Bazernik, Golemo Ilino, Slepche, Zagoriche, Zheleznec, Cer, etc.). Furthermore, in some cases the central pilaster is larger, such as at St. George in Podmochani. ${ }^{408}$

Also, in some churches of this typology, the pilasters are connected to each other by transverse arches - ribs on the vault. Such is the case of the churches in Virovo, Optichari, Edinakovci, Leskovo, Ezerani, Rastojca, Zhvan, Nebregovo and Zhurche. In some churches of this type only one pair of pilasters are connected with a transverse rib, for example at St. George in Podmochani, where only the eastern

408 Peculiarly, the disposition of the niches on the south and north wall in the naos of this church is not symmetrical: there are four niches on the south and three on the north side (Николовски, 1987: 36). 
pair of pilasters (at the altar partition) are connected transversely with a "triumphal arch" of sorts. Furthermore, the strengthening of the vault with ribs that connect the pilasters appears also in churches built in the region later, under clear Revival influence, such as St. Panteleimon in Sveta (Demir Hisar).
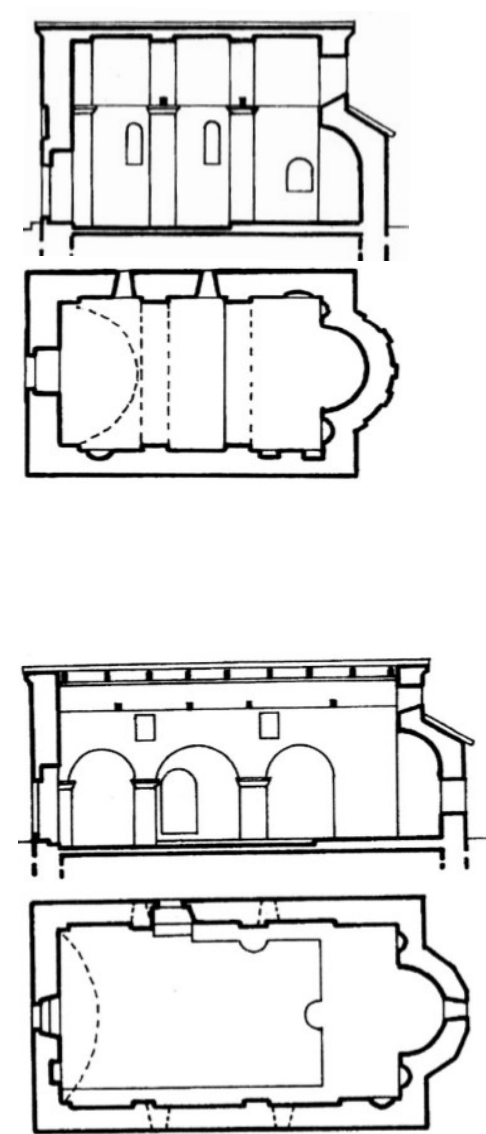

A $\quad 2 \quad 2 \quad 3 \quad 5 m$
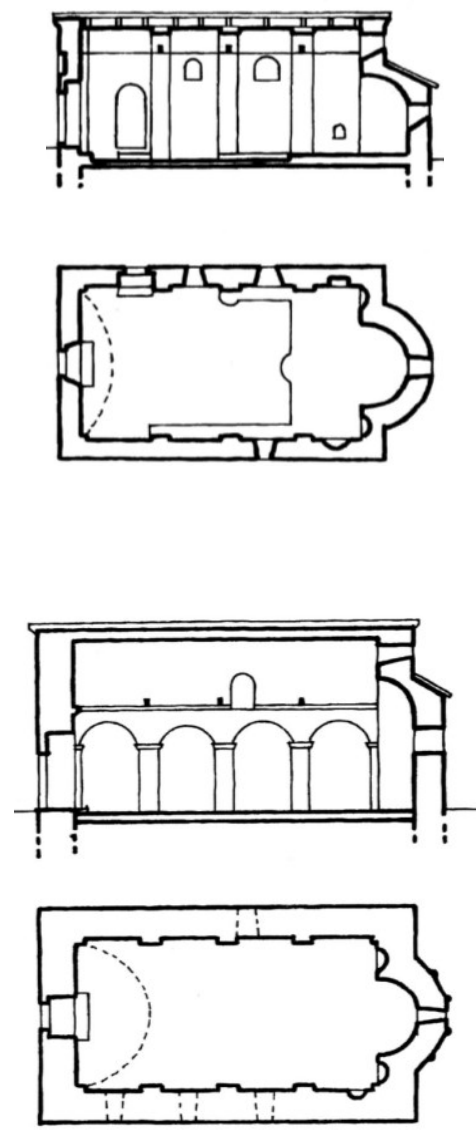

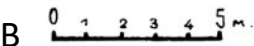
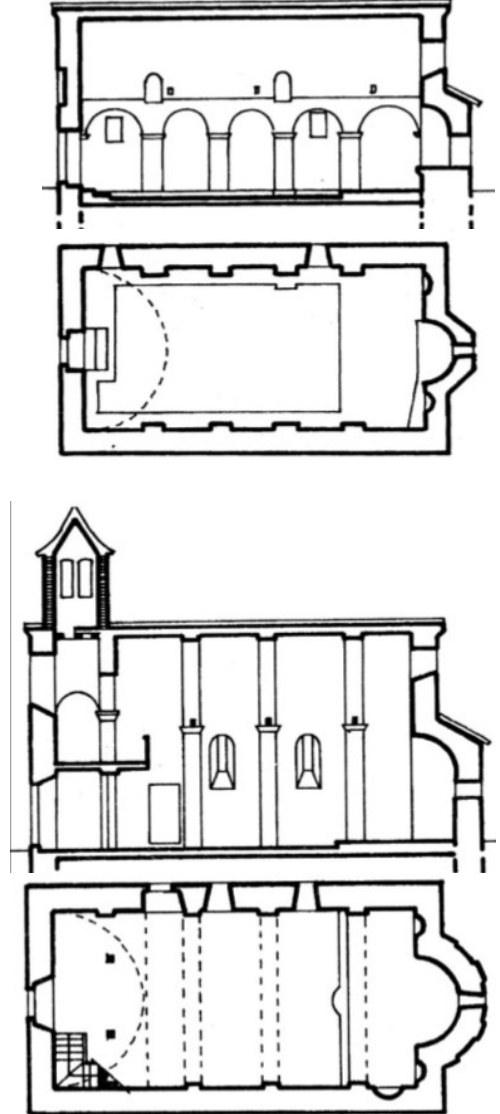

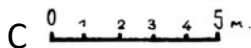

Figure III.135 Single-nave Revival basilicas with lateral pilasters connected by arches and covered by a barrel vault. A. with two pairs of pilasters: St. Nicholas in Edinakovci and St. Nicholas in Zagoriche; B. with three pairs of pilasters: St. Elijah in Leskovo and the Most Holy Mother of God in Zheleznec; C. with four pairs of pilasters: St. Nicholas in Babino and St. Panteleimon in Sveta. All in the region of Demir Hisar.

The connection of the pilasters with transverse arches has, above all, a constructive role - it serves to strengthen the whole constructive system of the church and to facilitate the transfer of loads to the lateral walls. However, another benefit of the transverse arches between the pilasters is the division of the inner space into several bays, or a visual separation of parts of the church with different purposes within a common space. For example, at St. Elijah in Ezerani (Prespa) the side walls are reinforced with two shallow pilasters, the eastern one placed at the very altar tribune, and the western one at the edge of the gallery, transversely connected with semicircular arches. In this way the prismatic volume of the temple was divided into three distinctive bays: a western zone, marked with a "narthex" on the ground floor and a gallery above, a central zone - nave and an eastern zone - altar. This division is confirmed by the subtle elevation of the vault in the central zone, which speaks of the skill of the master-builders.

Unlike the post-Byzantine churches of this type, the Revival basilicas with lateral niches almost without exception have large polygonal altar apses, mostly five-sided (in Bazernik, Virovo, Golemo llino, Zheleznec, Zhurche, Zagoriche, Slepche, Kukurechani, Arilevo, Draslajca), or seven-sided (in Ezerani, Ivanjevci, Beranci, Optichari). Another variant are semicircular apses with shallow niches (in Leskovo, Zashle, Edinakovci, Cer, Belica, Nebregovo, etc.). The apse of the church in Nebregovo is divided into seven shallow niches with the help of tall slender semicircular columns with profiled capitals (Грозданов, 2004: 
307). At the churches in Podmochani and Ezerani, on the other hand, the apse is decorated with a series of shallow cantilever arcades in the upper zone, which as a solution is specific for the regions of Prespa (see Chapter III.3) and Bitola (in Beranci and Ivanjevci). In the churches in Zashle and Edinakovci, quite unusually, the semicircular apse is divided into an even number of shallow niches (four in Edinakovci and six in Zashle), defined by semicircular columns with capitals. The churches in Babino and Zhvan have three-sided altar apses that consistently reflect the post-Byzantine traditions.
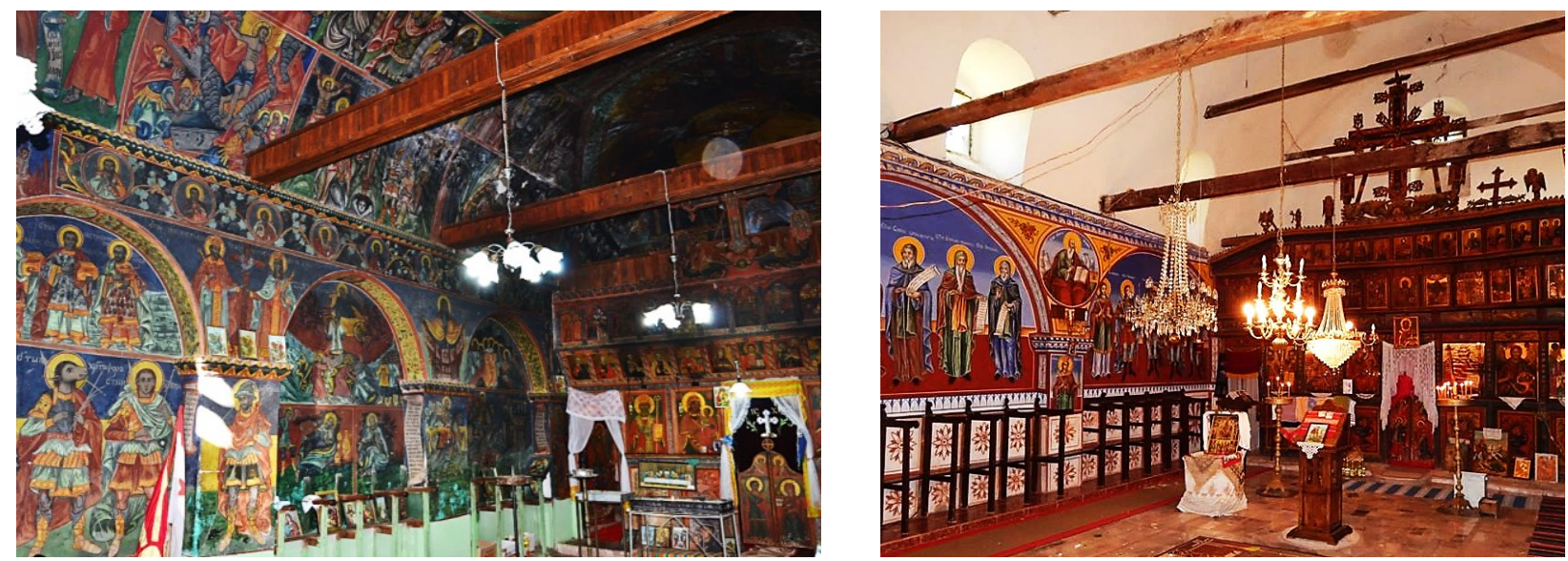

Figure III.136 A. St. Athanasius in Beranci (Bitola); B. St. George in Belica (Kichevo). View of the naos towards the altar.

A western gallery ("women's church") is quite rarely present in the Revival churches of this category: at the churches in Staravina, Ezerani, Dedebalci, Slepche, which also has a central semicircular balcony. In all of these examples, the gallery corresponds to the western bay (the distance from the western wall of the naos to the first pair of pilasters) and is made of a wooden structure and accessed via a wooden staircase in the northwest corner. Also, a gallery appears at St. Panteleimon in Sveta (see fig. III.135C), over which a bell tower was later built. The frequent absence of a gallery in this group of Revival churches is another confirmation of their construction according to an older model since, as has been said, the post-Byzantine churches were not familiar with the concept of a "women's church" or of division of the temple into different levels according to the need for gender segregation. Additional evidence for the firmly rooted local post-Byzantine architectural patterns in this group of churches is the existence of only one, western entrance portal in many of them: in Babino, Virovo, Edinakovci, Zhvan, Zheleznec, Zhurche, Zashle, Vrbjani; while the rest follow the Revival model and have an additional southern entrance: in Bazernik, Golemo llino, Zagoriche, Leskovo, Slepche, Podmochani, Ezerani, Nebregovo, Cer, Beranci, Dedebalci, Ivanjevci, Lisolaj, Vranche and Sveta. As an exception, the church in Sloeshtica has a northern and southern entrance, symmetrically arranged; the church in Belica has a second entrance only from the northern side.

The continuity of the same typological solutions as respect and perseverance of a long-established local tradition can best be seen in the church of St. Petka in the village of Zhvan (Demir Hisar), built in two phases: the eastern part is an older phase from the XVIXVII century, while the extension to the west dates from the Revival (fig. III.137). The post-Byzantine church is single-nave, reinforced with two massive pilasters on the north and south walls, which form deep arched niches with unequal dimensions: the eastern pair of niches is much smaller than the western one, which correspond to the approximately square nave, while the eastern bay is occupied by

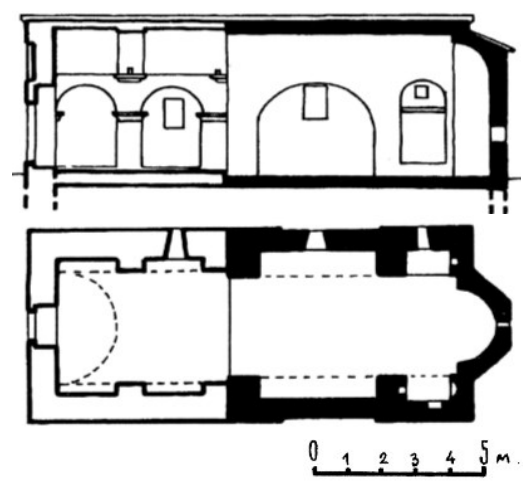

Figure III.137 St. Petka in Zhvan (Demir Hisar): Plan and longitudinal section. the altar. A very high three-sided apse develops in the east. The division of the inner space into two bays 
is indicated on the façades, where the larger, western bay is marked by a slight indentation of the façade canvas, which brings this church closer to the Byzantine single-nave domed pattern. ${ }^{409}$ In the XIX century, this original building was expanded to the west, making the length of the church very pronounced. The extension and the original church are fully integrated - the addition is not a narthex, but an extension of the church nave, following the same typological pattern: a single-nave vaulted space with lateral pilasters and niches, with the difference that the Revival pilasters are less massive, form equal semicircular arched niches and are connected by a transverse rib that strengthens the "false" vault, additionally reinforced with wooden ties unlike the post-Byzantine one (Дапчев, 1996: 226). The rib is supported on a console profiled identically to the capitals of the pilasters.

Another example of continuity of the post-Byzantine traditions can be clearly seen in the village of Zhurche in Demir Hisar, where the Revival church of Dormition of the Most Holy Mother of God was built according to the model of the older XVII century monastery church of St. Athanasius, which was a spiritual center and an architectural ideal that was significant and necessary to achieve. Thus, the Revival masterbuilders took the older typology with 2 pilasters forming 3 niches on the longitudinal walls, a semicylindrical vault and a five-sided altar apse, flanked with two small niches for prothesis and diaconicon in the east wall, as well as one centrally placed window which corresponds to the nave. Two centuries later, unlike the prototype, the new church in Zhurche has a slightly narrower and more elongated plan, a smaller apse compared to the east façade and transverse ribs on the vault between the pilasters.

The multitude of churches built in the wider south-western region according to the same typological pattern, speaks of a local school that took as an example the most representative, most easily accessible and still active churches built in the region in the previous centuries. That all these churches came from a local workshop is confirmed by the fact that many of them were painted by the same painting masterpainter's group of the Atanasovi brothers from Krushevo, in the second half of the XIX century.

\section{"St. Nicholas" in Cer (Demir Hisar), 1866}

The church of St. Nicholas is the main village and cemetery church in Cer, although it is not the oldest temple in the village. ${ }^{410}$ It was most probably built in 1866 , a year inscribed on the eastern corner of the southern façade. In this regard, it is of particular importance to mention the evident similarities with the church of St. Nicholas in the nearby village of Slepche (Demir Hisar), built in the following year (1867) by the famous master Kosta from Cer and his master-builder group (see fig. III.84C) who, as was mentioned earlier, was also the author of the smaller church of St. Athanasius built in the village of Cer itself in 1861-1863 (see Chapter III.5A.1). Whether Kosta was the author of the main church of St. Nicholas in his native village, though very likely, has not been confirmed so far. However, the possibility of an earlier date of construction remains, since the royal doors of the iconostasis were made in 1839, as stated in their donors' inscription. An earlier date would explain why the church was dug into the ground for 40-50 $\mathrm{cm}$ on the south and west side, and almost $1 \mathrm{~m}$ on the north side.

Originally St. Nicholas in Cer was a compact building with no narthex or open porches; the low closed narthex - dining room was added later to the west side of the naos (fig. III.138A). Although singlenave, it is a relatively large and quite elongated building. The total dimensions of the church, not counting the altar apse, are 9.3/17 m, which means that the proportion in which it is laid out exceeds 1:1.8. The elongation of the nave is emphasized in the interior as well. Namely, the altar space completely enclosed with a high iconostasis is relatively narrow in the zone of the prothesis and the diaconicon, $\sim 2 \mathrm{~m}$, and

\footnotetext{
${ }^{409}$ Today this feature is lost as a result of the external reinforcement with concrete buttresses and beams in the recent past.

410 In the village of Cer there are as many as 5 churches, including St. Athanasius which was elaborated in detail earlier (see Chapter III.5.A.1). Three of them, including St. Nicholas, have been protected as cultural heritage.
} 
significantly expands in the middle where the altar apse strongly protrudes outwards. Thus, inside the church, the ratio of the width of the nave $(6.5 \mathrm{~m})$ to its length measured from the west wall to the iconostasis $(12.5 \mathrm{~m})$ is slightly over 1:2. As the majority of the churches from this typologically uniform group, St. Nicholas in Cer also lacks a gallery (see fig. III.142).
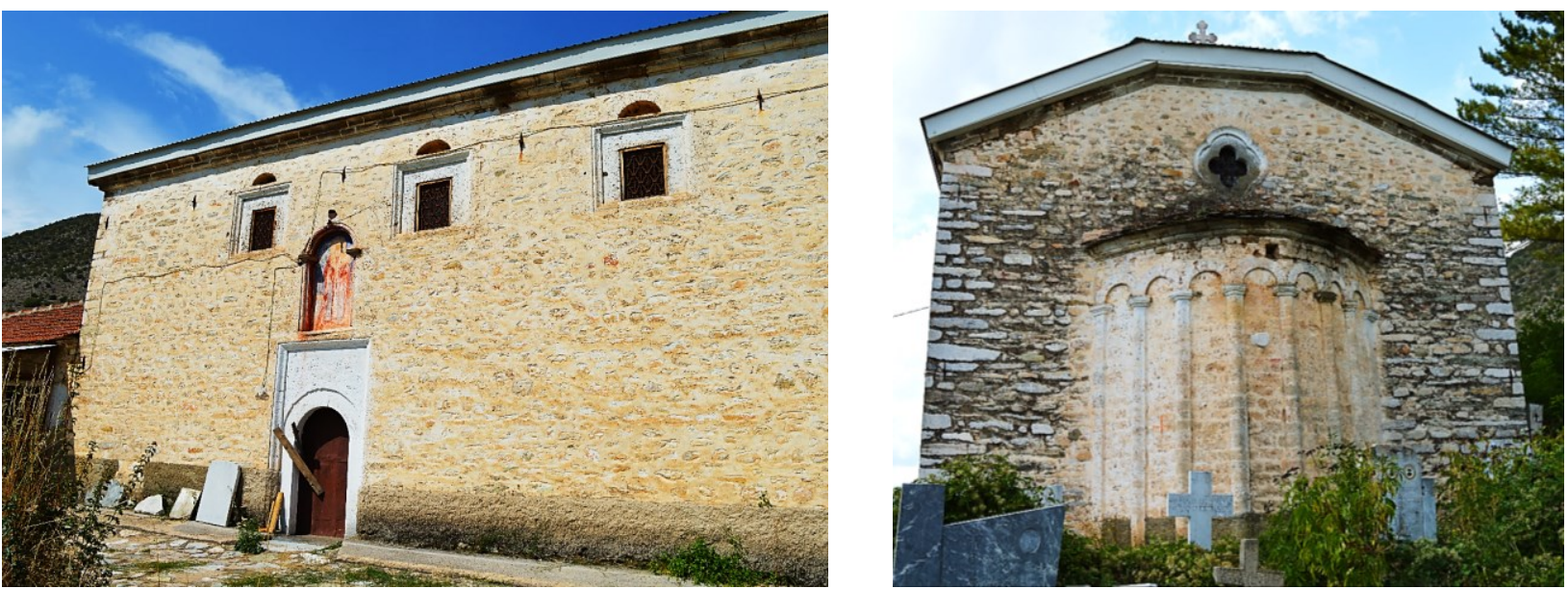

Figure III.138 St. Nicholas in Cer (Demir Hisar): A. Southern and B. Eastern façade.

It was built extremely massively: the thickness of the perimeter walls varies from $80-90 \mathrm{~cm}$ at the north and south walls, to over $100 \mathrm{~cm}$ at the east and west. The walls conceived in this way are additionally reinforced with massive rectangular pilasters: four on the north and south walls, two on the west and four half-pilasters in the corners of the building. The pilasters are lined in an even rhythm (on the side walls their distance is 2.9 to $3 \mathrm{~m}$ ) and in a relatively symmetrical composition. The lateral pilasters are especially massive, reaching a depth of $60 \mathrm{~cm}$, while the western pair are significantly shallower and do not exceed $40 \mathrm{~cm}$. In other words, within the pilasters and in the upper zone, the walls reach an impressive thickness of approximately $1.4 \mathrm{~m}$. The weight of the perimeter walls conceived in this way is lightened by the system of semicircular arches with which the pilasters are connected to each other and to the semi-pilasters in the corners, so that deep arched niches are formed, the height of which varies from 3.3 (on the west) to $3.9 \mathrm{~m}$ (on the lateral walls). The base of the arches is marked by simple profiled capitals which adorn the pilasters. This constructive system not only strengthens the massively built perimeter walls, but also reduces the span of the vault (from 7.6 to $6.5 \mathrm{~m}$ ). The vault is not semi-cylindrical, but slightly pointed, reaching a maximum height of $8 \mathrm{~m}$, reinforced with a series of five transverse wooden ties. There are no ribs between the pilasters; the vault rather flows from the west to the east wall of the nave (fig. III.139), without interruption.

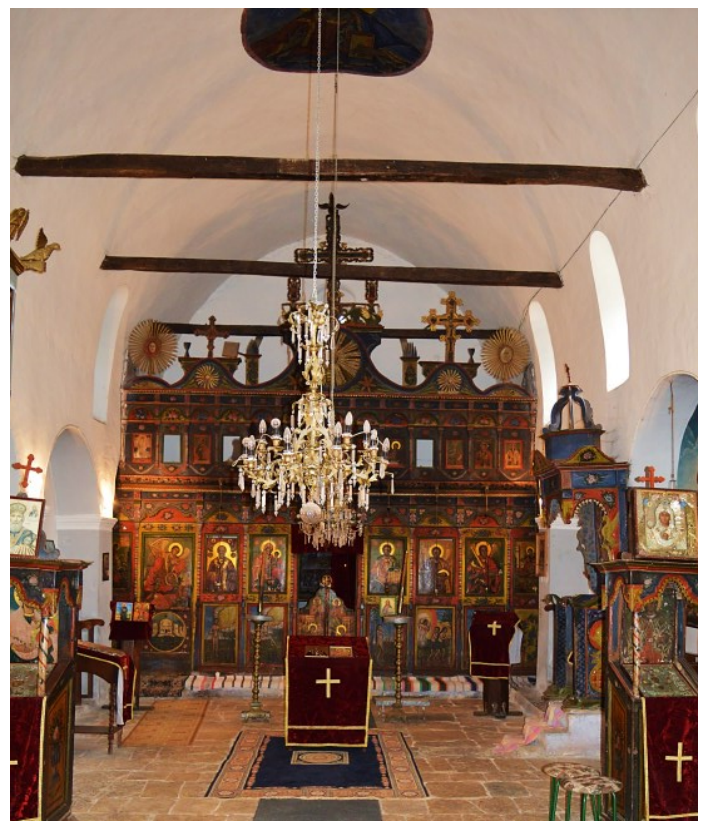

Figure III.139 St. Nicholas in Cer (Demir Hisar). View of the nave, towards the altar.

The façades are made of masonry of irregular crushed stone and lime mortar, with longer blocks used at the corners. Individual stone blocks were also carved in very shallow relief, depicting various Christian motifs: simple elongated crosses, crosses with phytomorphic arms, rosettes, and even an animal figure (see fig. III.140). As usual, the apse, entrance portals, windows and crown cornice were executed with much care, out of porous hewn sandstone. Namely, the rectangular windows were placed in shallow 
niches of carved stone with nicely profiled frames on all four sides (fig. III.138A). Above the niches appear smaller semicircular arches devised to relieve the windows' sills from the weight of the wall above. There are four such windows on the south and two on the north façade, arranged in a harmonious composition and even rhythm. In fact, inside the nave the windows are placed in the axis of the pilasters, and the skill in the architectural design is visible in their precise composition with the other architectural elements in the nave - the transverse wooden beams, placed in the axis of the niches' arches (fig. III.139). Somewhat higher are the windows on the east façade, above the apse and on the west façade, above the west entrance portal. The eastern window is particularly decorative: a phytomorphic cross formed by a radial arrangement of thin stone blocks incorporates a transenna with the same motif - a slightly elongated fourleaf clover with rounded petals (fig. III.138B). High on the west façade, just below the cornice, there is a smaller, shallow, arched niche which houses a stone slab with an elongated cross in shallow relief. Below this niche is the western window, shaped as an oculus.
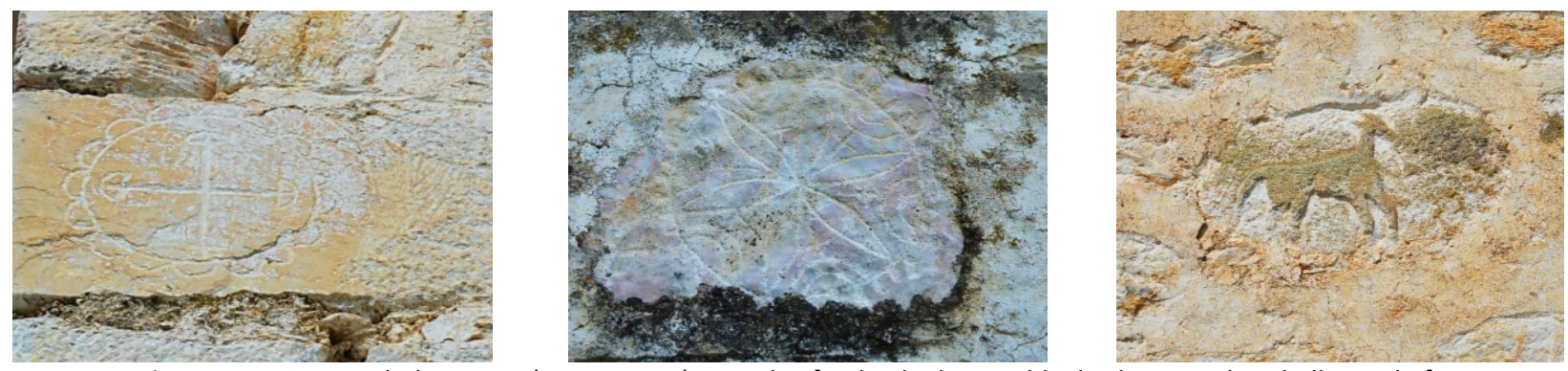

Figure III.140 St. Nicholas in Cer (Demir Hisar). Details of individual stone blocks decorated in shallow relief.

The apse, made of precise, horizontally arranged hewn blocks, is semicircular, divided into seven high shallow semicircular arched niches (fig. III.138B, III.141A). Between the niches circular pilasters (columns) are placed, with decorative profiled capitals which support the arches themselves. As a very specific solution, there is not a single window in the apse, not even the basic narrow slit in its axis. Of particular interest are the very fragmentarily preserved remains of mortar coating with decorative painting on the upper part of the apse, above the arcade (fig. III.141). Namely, the remaining painted ornament depicts a baroque " $\mathrm{S}$ " volute floral wreath in blue tonality, much like the one at the church in Sekirani, near Bitola (see fig. III.34) which has luckily been preserved in better condition.
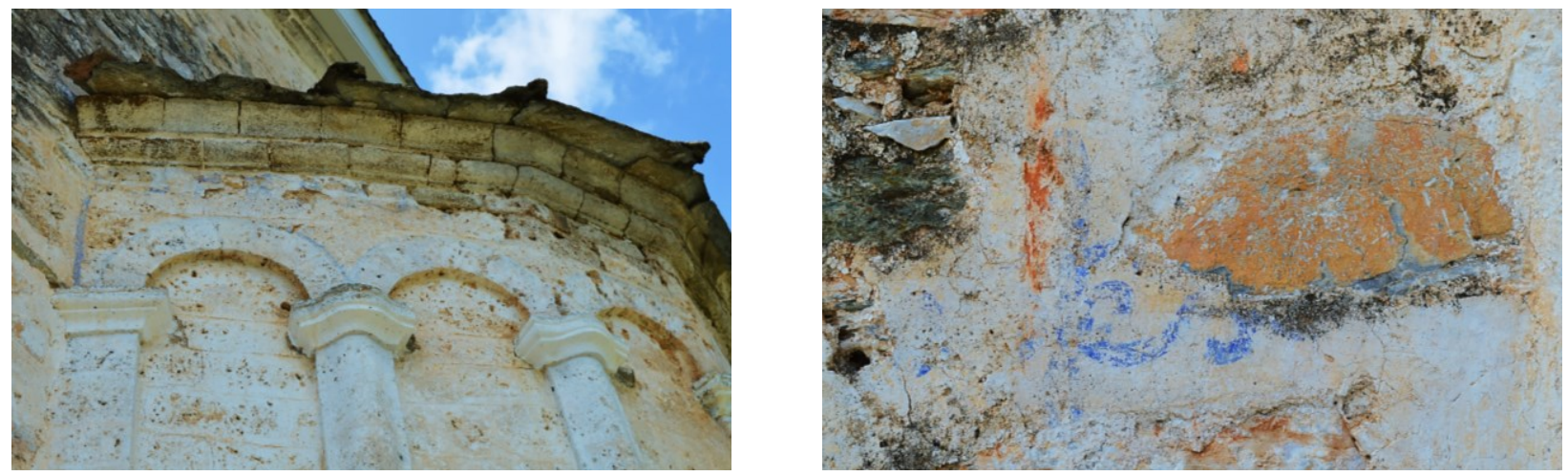

Figure III.141 St. Nicholas in Cer (Demir Hisar). Fragments of the painted ornaments on the altar apse.

The roof of the apse is preserved with its authentic cover of overlapping thin stone slabs (fig. III.141), while the roof above the naos (which according to the usual solution is a gable/bonnet roof with saddle-shaped east and west façades) has been recently replaced with corrugated sheet metal. The crosssection of the crown cornice which frames it is composed of a concave and a convex segment, which was the predominant solution in the Revival churches. 

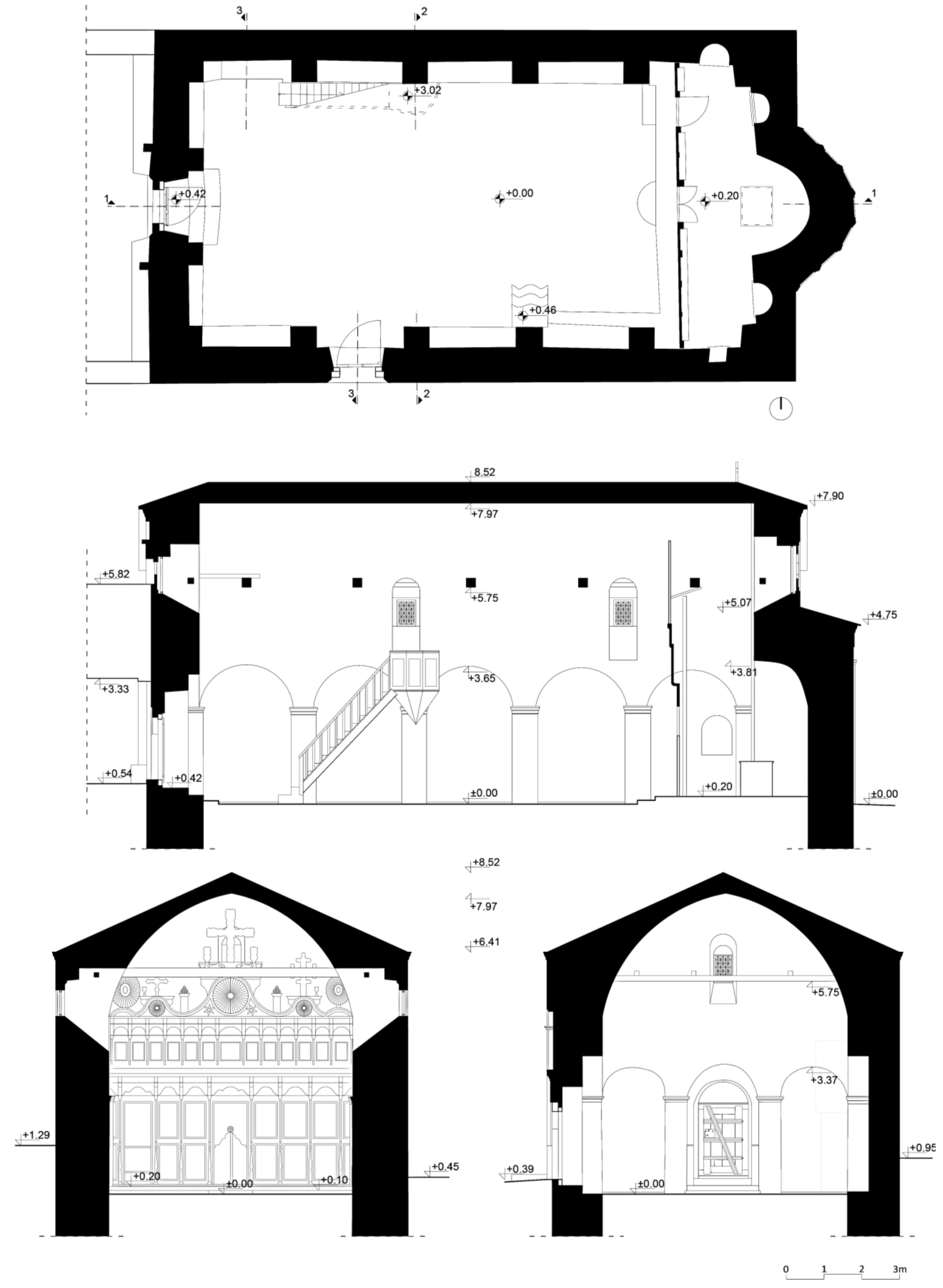

Figure III.142 St. Nicholas in Cer (Demir Hisar). A. Plan ( \pm 0.00$)$; B. Longitudinal section (1-1); C. Transversal sections (2-2 and 3-3). 

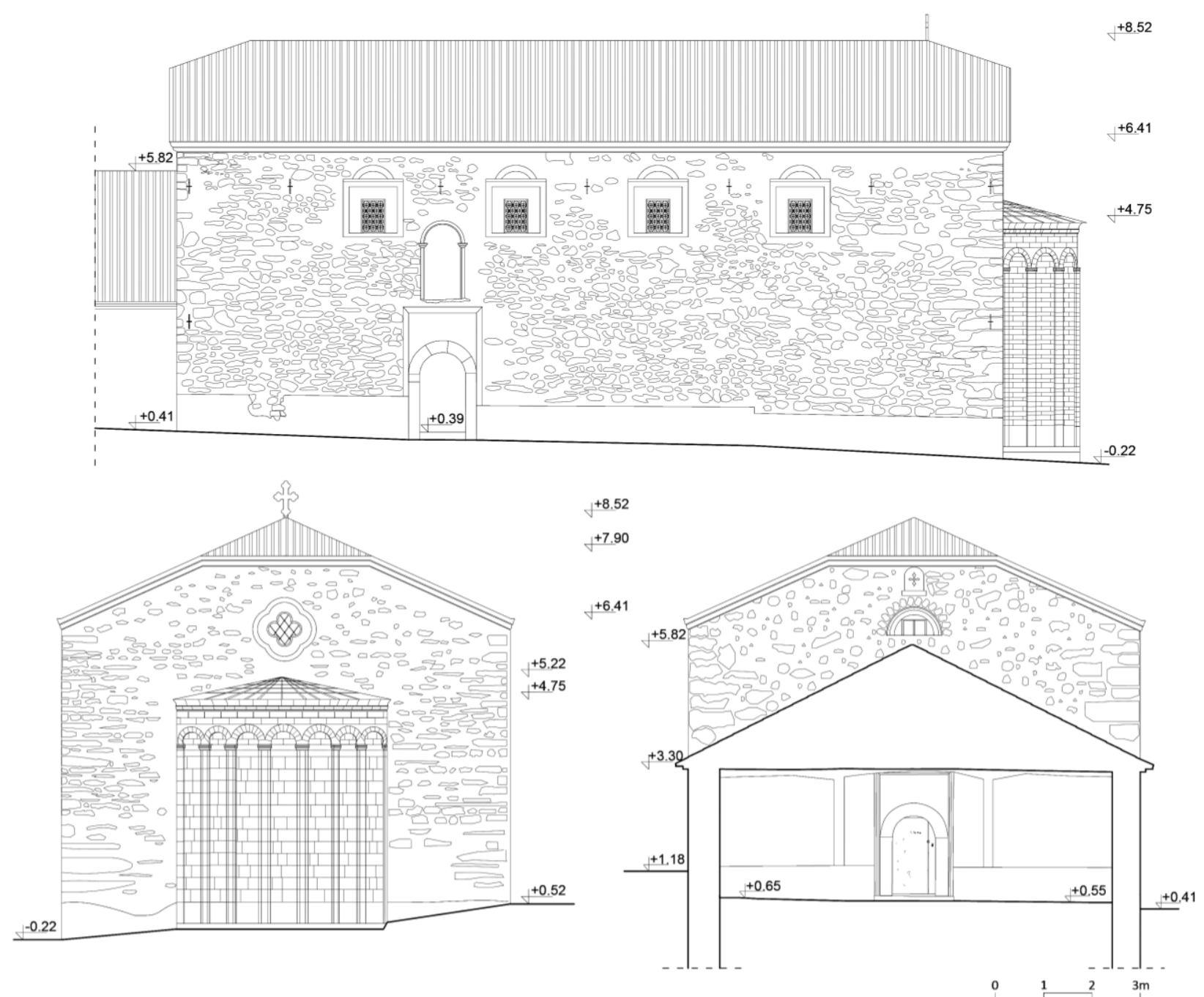

Figure III.143 St. Nicholas in Cer (Demir Hisar). A. Southern and B. Eastern and western façade (transversal section through the added narthex).

Special emphasis is placed on the design of the entrance portals. Namely, the naos is accessed through two entrances: one in the axis of the western façade and in the second bay (viewed from the west) on the southern one (fig. III.143A, III.138A). They were shaped in a similar way: in the wall canvas of irregular masonry a wide and rather tall rectangular shallow niche was built, made of hewn stone and lined with the same profiled frame as the window openings. In its axis is the arched entrance, formed by monolithic door jambs and a semicircular arch of radially arranged stone blocks. If there was a patron niche above the western entrance, which is logical to assume, today it is hidden within the roof construction of the narthex, which implies that it would have been smaller. Fortunately, the patron saint niche above the south entrance is quite well preserved. It is a very high, semicircular niche made of carved and precisely arranged blocks of sandstone, identical to the portals and windows, additionally enriched with an arched frame and appropriate columns, with decorative capitals. Traces of painting of the frame of the niche in blue and terracotta tones have been preserved, although significantly faded. A fresco of the patron saint of the temple, St. Nicholas, is painted in full height in the niche, made possible by the considerable height of the patron niche itself. ${ }^{411}$

\footnotetext{
${ }^{411}$ The composition of the portals, and especially the patron saint niche is almost identical to the one at the southern portal of the church of St. Nicholas in Slepche (see fig. III.60B), where the portrait of St. Constantine and Helena was painted, also in full height. The identical concept of the patron saint niches is one more common element of these two churches implying their possible authorship within the same master-builder group, namely the one lead by master Kosta from Cer.
} 
The interior of the church is simple, yet elegant and proportional. The floor was paved with large, intricate stone slabs, and the walls and pilasters were whitewashed, with the exception of a few fresco compositions in the altar and within the medallions in the vault (the compositions within the lateral niches are contemporary interventions). As with the other single-nave churches, the furniture is placed along the perimeter walls: between the pilasters, there are chairs for the congregation placed on a very low platform; the bishop's throne, placed on a masonry pedestal with 3 curved steps, leans on the third pilaster (viewed from west to east) on the south side; the pulpit is located of the second pilaster on the opposite side. The balcony of the ambo, with its irregular, polygonal solid wooden fence, placed at a height of $3 \mathrm{~m}$, is accessed via a wooden staircase placed along the north wall (see fig. III.142).
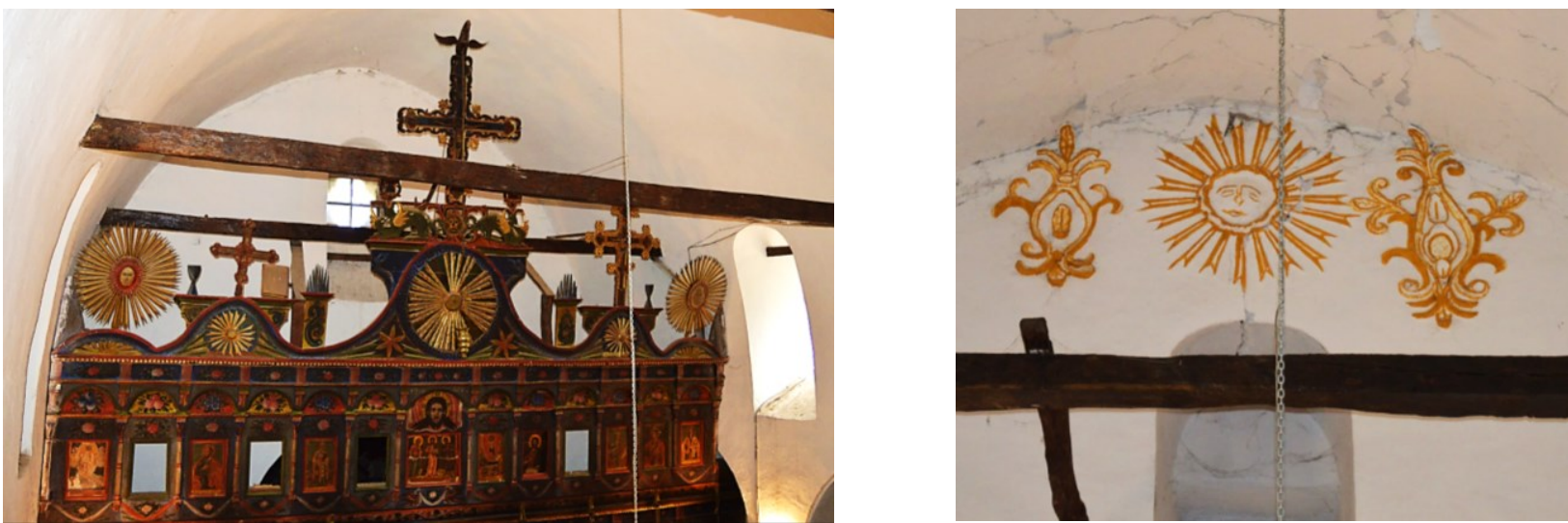

Figure III.144 St. Nicholas in Cer (Demir Hisar). Solar motifs: A. medallions on the iconostasis; B. bas-relief on the western wall.

Special emphasis is placed on the high, two-zone iconostasis. Of special interest is its crown, shaped with a curved " $\mathrm{S}$ " profile, similar to the western façades of the Italian baroque churches, with a central rosette depicting a three-dimensional, gilded solar motif (fig. III.144A). Identical solar motifs are placed laterally, in smaller circular medallions, as well as on the very corners of the iconostasis where they are completely free-standing. High above the central medallion is the Crucifixion - the snake cross. The entire iconostasis (the pillars, capitals, background panels, cosmitis) is decorated with floral motifs, stylized acanthus leaves, Eucharistic compositions (birds flanking a variety of painted floral arrangements), etc. In addition to the iconostasis, the bishop's throne, the ambo and the icon pedestals are also decorated with floral ornaments, spiraling branches, tree of life motifs, geometric and solar motifs, set against a background painted in strong red, blue and ocher tones.

Another rare and unique detail found in this church is the gilded bas-relief located high on the western wall (fig. III.144B), on the opposite end of the naos from the iconostasis. Composed of a central solar personification flanked by two complex fleur-de-lis representations, this ornament, inspite of its quite primitive and irregular execution, represents a visual and symbolic counterpart of the solar woodcarved and gilded elements present on the iconostasis.

\section{III.5.A.4 SINGLE-NAVE BASILICAS WITH A THREE-NAVE DISPOSITION OF THE UPPER CONSTRUCTION}

The single-nave basilicas with a three-nave disposition of the upper construction (internally or externally) represent quite a rare sub-typology, and are subsequently the smallest group among the single-nave basilicas: only $4.8 \%$ of the single-nave and $2.3 \%$ of the total number of Revival churches so far classified according to their typological solution. The churches so far identified within this group are listed in the following table (table III-5): 


\begin{tabular}{|l|l|l|l|l|l|}
\hline & CHURCH & VILLAGE & REGION (TOWN) & YEAR & $\begin{array}{c}\text { ADDITIONAL INFORMATION } \\
\text { fresco-painting / icons, renovations }\end{array}$ \\
\hline 1 & St. Archangel Michael & Sredno Egri & Bitola & 1830 & renovated in 1996 \\
\hline 2 & St. George & Oleveni & Bitola & 1839 & \\
\hline 3 & St. George & Velushina & Bitola & 1839 & fresco-painted in 1848 \\
\hline 4 & St. Nicholas & Brod & Mariovo & 1840 & renovated in 1921 \\
\hline 5 & St. Nicholas & $/$ & Kratovo & 1848 & \\
\hline 6 & St. Demetrius & Vranjevci & Bitola & 1869 & \\
\hline 7 & St. Savior & Kalen & Mariovo & 1890 & fresco-painted in 1891 \\
\hline 8 & St. Nicholas - St. Archangel & Vardino & Demir Hisar & & \\
\hline 9 & St. Archangel Michael & Makovo & Mariovo & & \\
\hline 10 & St. Elijah & Skochivir & Mariovo & & \\
\hline 11 & Introduction of the Most Holy Mother of God & Sredorek & Prilep & & \\
\hline 12 & St. Elijah & Brodec & Skopje & & \\
\hline
\end{tabular}

Table III-5 Single-nave Revival basilicas with three-nave disposition of the ceiling.

Based on the fact that these churches are intrinsically single-nave and that their elongated naos is covered by flat or vaulted ceilings, it may seem logical to incorporate them within the already elaborated categories of single-nave basilicas with barrel vault (Chapter III.5.A.1) or with flat wooden ceiling (Chapter III.5.A.2). However, upon further insight, the type of ceiling structure is secondary to another unique feature of theirs, which has been identified as crucial and which unifies them in a separate category: their tendency to form a three-nave disposition in the upper parts of the naos (internally: of the ceiling or vault, or externally: of the roof), despite the fact that they are, in fact, single-nave basilicas. ${ }^{412}$ In some of them,
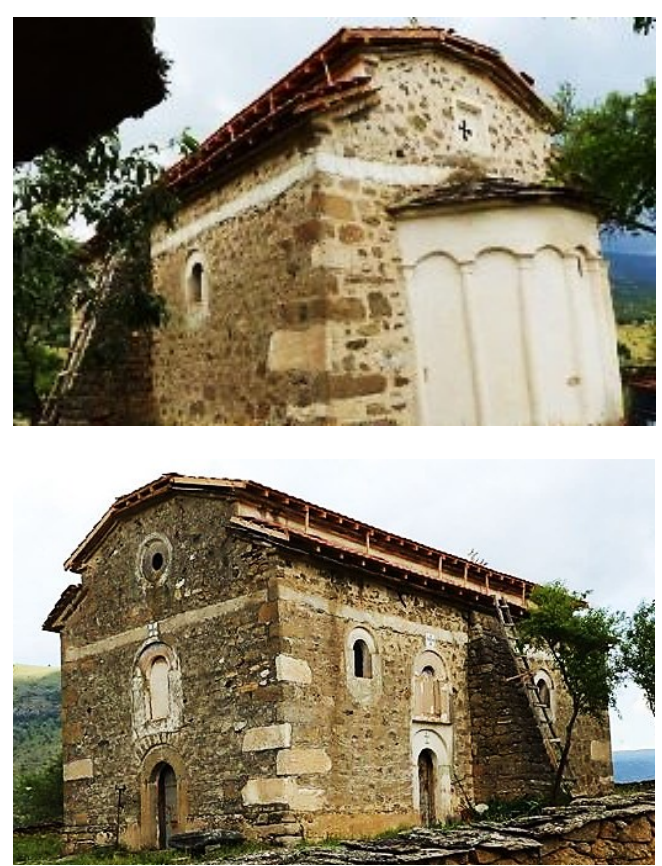

Figure III.145 St. Savior in Kalen (Mariovo). View from the south-east and south-west. the reason for this more complex solution of the ceiling or the vault above the nave can be sought in the consideration of older representative three-nave basilicas built in their surroundings, which were seen as models. Such example is the church St. Nicholas in Kratovo (from 1848) where the influences from the nearby three-nave basilica of St. John built in 1836 (by Andreja Damjanov) are obvious not only in the three-nave arrangement of the ceiling, but also in the design of the gallery, the façades, porches, stone reliefs and so on. In that context, a particularly interesting case is the church of St. Savior in the village of Kalen (Mariovo) which, although typologically belongs to the category of the singlenave basilicas with lateral pilasters and niches covered by barrel vault, externally (on the fifth façade) is composed as a three-nave basilica with a central clerestory (fig. III.145). In this case clear analogies can be recognized with the nearby late-Byzantine church of St. Nicholas in Manastir (see Chapter I.4.3, fig. I.33, I.34), which was a monastic and spiritual center for Mariovo and the wider region.

As can immediately be concluded from map III-A, as well as from table III-5 above, this sub-type of single-nave basilicas is found primarily in the neighboring regions of Mariovo and Bitola, and sporadically in more distant places - in other words, as was the case for the other typological categories studied so

\footnotetext{
412 This tendency, although rarely, is also evident in previous epochs, meaning it is not exclusively characteristic only for the Revival when, however, it will become more frequent and will develop into more complex solutions. For example, a similar threenave concept embedded in the upper parts of an otherwise single-nave church can be found in the post-Byzantine church of St. Elijah in the village of Dolgaec (Kichevo), built and fresco-painted in 1454/5. It is a small one-nave cemetery church with a trapezoidal plan, rustically built with stone and lime mortar. On the east side it ends with a shallow rectangular apse, covered with overlaping stone slabs. A characteristic of this church is the three-part vault and the attempt to decorate the south façade with crushed stone in the fish bone motif (Subotić, 1980: 54-55, quoted by Михајловски, 2011: 150).
} 
far, it is a regionally represented solution. That the three-nave typology was of particular importance in this region is also testified by the architecture of the churches of St. Athanasius in Sovich and St. Demetrius in Grunishta (see fig. III.102), both in the region of Mariovo, where despite the limited dimensions and subsequent short spans, a three-nave solution of the nave was adopted, with its division into naves via wooden pillars with architrave wooden ceilings without plaster coating. At St. Archangel Michael in Sredno Egri (Bitola), the massive wooden beams that bridge the single-nave volume (divided in the upper parts into three naves) were later on propped up by wooden pillars, which further articulate the impression of a three-nave structure.

The three-nave arrangement in the upper parts of these churches has been solved in many ways, but in all the examples it is made of wood, as a combination of a flat wooden ceiling and/or "false" wooden vaults. One solution that is encountered is the division of the ceiling into three longitudinal belts ("naves"), of which the middle one is wider and covered with a semi-cylindrical vault, while the lateral ones are covered with a flat wooden ceiling. Such is the case of St. Archangel Michael in Sredno Egri (Bitola), where the lateral naves are covered with a coffer ceiling, while the central vault is completely frescopainted with the usual circular medallions that often replace domes in the single-nave vaulted churches. The passage from the central vault to the lower lateral flat ceilings is executed with a convexly curved strip decorated with floral motifs (identical to the ones that appear on the transverse wooden beams). Identical three-nave division of the ceiling into a central semicircular vault and lateral flat ceiling can be found at St. George in Oleveni and St. George in Velushina (fig. III.146), built simultaneously (in 1839) in

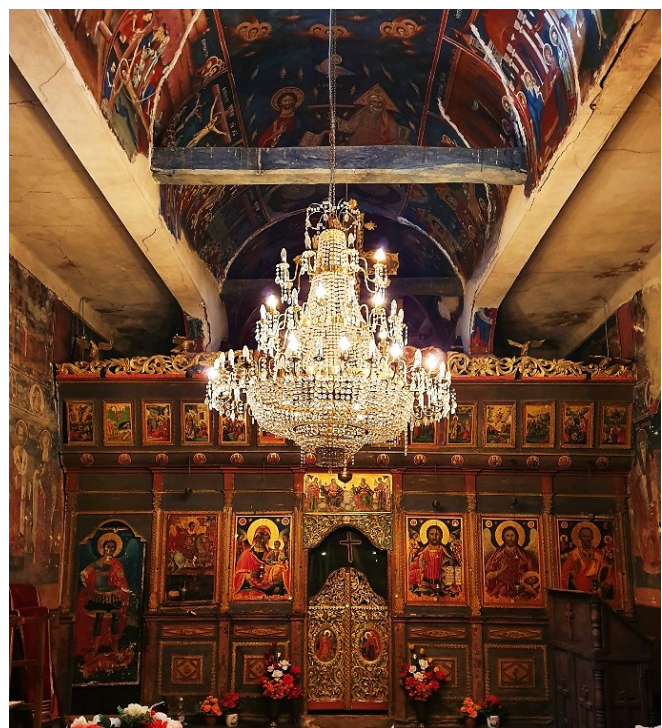

Figure III.146 St. George in Velushina (Bitola). View of the naos towards the altar. the region of Bitola (Ќорнаков, 1990: 144-145), as well as at the church of St. Nicholas in Kratovo.

The second type of three-nave composition of the upper parts is a monastery vault: a higher central "nave" with a flat wooden ceiling, flanked by "side naves" covered with a ceiling placed at an angle, which results in a cross section of trapezoidal shape. This solution can be found at St. Nicholas - St. Archangel in Vardino (Demir Hisar), St. Archangel Michael in Makovo (fig. III.147B) and St. Elijah in Skochivir (Mariovo).
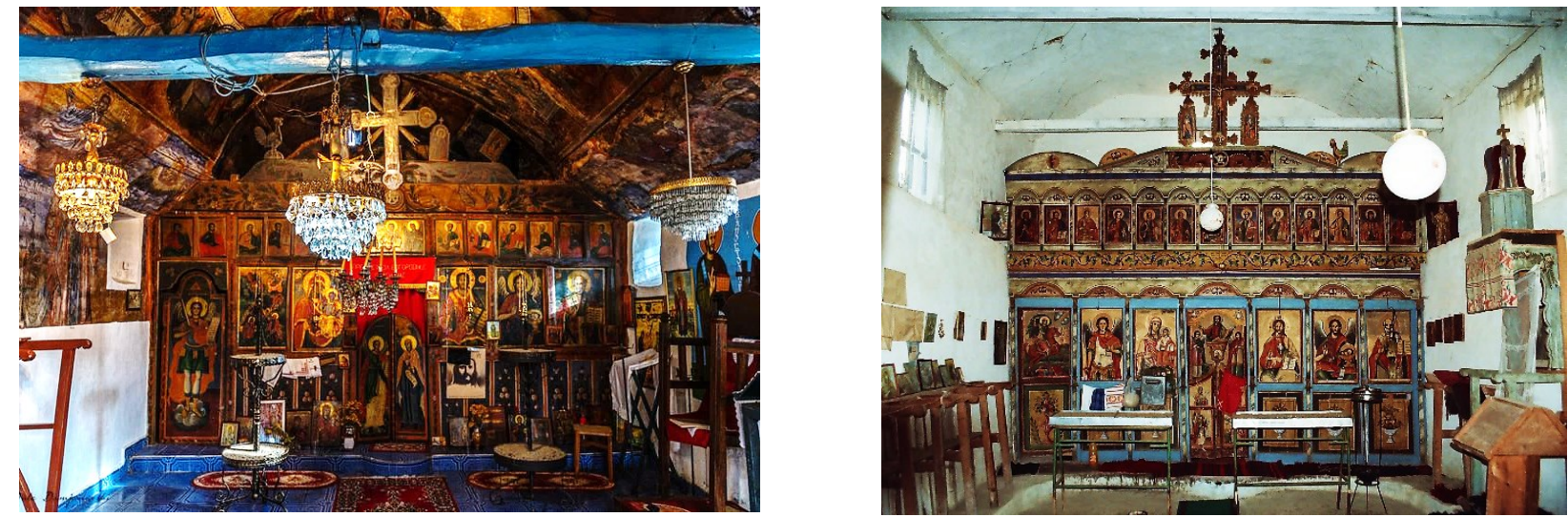

Figure III.147 A. St. Elijah in Brodec (Skopje); B. St. Archangel Michael in Makovo (Mariovo). View of the nave towards the altar.

Lastly, this group includes churches where the ceiling is divided lengthwise into three "naves", covered with a combination of concave, convex and straight segments. For example, at the church of the Introduction of the Most Holy Mother of God in Sredorek (Prilep) the central "nave" is bridged with a false 
vault while the lateral ones with a flat ceiling that ends with a rounded segment towards the north and south walls. At the farthest church from this typological group, St. Elijah in Brodec (Skopje) (fig. III.147A), the ceiling is divided into a central vault with a slightly sloping line, while the side belts are covered with convex strips towards the side walls. This more complex shaping of the three-part disposition of the ceiling is also found at St. Nicholas in the village of Brod, region of Mariovo.

\section{"St. Nicholas" in Brod (Mariovo), 1840}

The church of St. Nicholas in the village of Brod (Mariovo) was built in 1840, as confirmed by the simple carved inscriptions on the lintel of its south and west entrance portal. According to local oral tradition, it was built on the foundations of an older church. It is located to the northwest of the village, on a slightly elevated plateau, and is significantly dug into the ground $(-170 \mathrm{~cm})$ resulting in a descend by as many as eight stairs from the south and west side entrance into the nave (see fig. III.150). It is a compact construction, without preserved extensions or porches (the portico and the bell-tower on the south façade are newer interventions). The perimeter walls were built of crushed stone and lime mortar. Their thickness varies between $90-100 \mathrm{~cm}$ on the ground floor, while in height their section decreases to $60-80$ $\mathrm{cm}$ at the level of the gallery. Its exterior design is modest, without decorative masonry. A certain emphasis was placed on the corners of the building, where somewhat better processed and longer blocks of stone were installed; as well as on the crown cornice with a simple rectangular two-tiered profile; and the entrance portals. Namely, both portals (west and south) are relatively small and low, providing for a single-leaf door. They consist of monolithic blocks for the jambs and the massive lintel which was

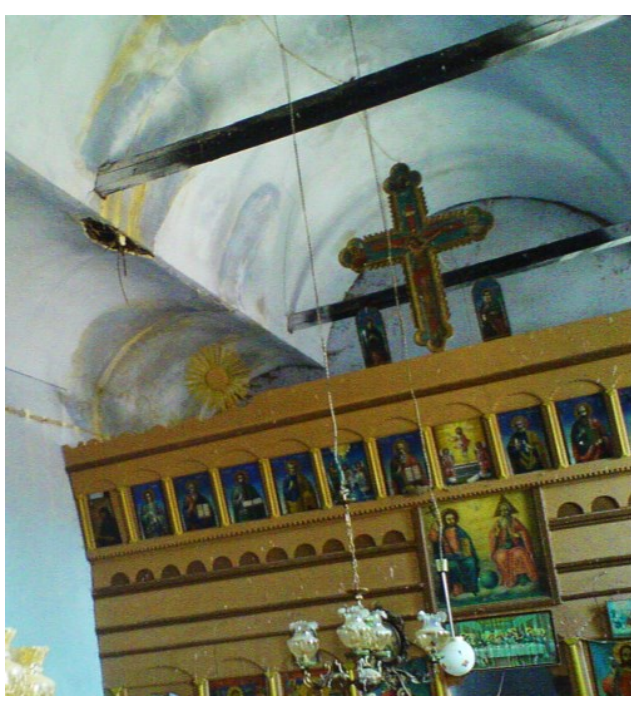

Figure III.148 St. Nicholas in Brod (Mariovo). View towards the altar. decoratively shaped into a semicircular arch with additional profiled ends, which create the effect of lateral semi-capitals in the context of the portal jambs. All windows are simple, rectangular, without any decorative finishing. The only exception is the window just above the apse on the east façade, which is semicircularly arched and houses a stonecarved transenna with an opening shaped into a small cross with extended phytomorphized arms (crux florida). Above the western entrance portal, in its axis, a reused marble Roman tombstone slab was embedded within the masonry (see fig. III.94A) as a substitute for the western patron saint niche. In the lower zone of the slab three figures are presented in relief, of which the lateral (male and female characters) are dressed in draperies and pose in the same position, with the right hand over the chest, and the left extended straight along the body. In the center, between them, a smaller male act is depicted; an altar can be seen in the background of the scene. Above this composition, in the gable of the stela, a horseman in fast gallop is depicted shooting from a bow. In addition to this accent on the western façade, in its axis a simple rectangular window was placed, and high above it, under the crown cornice, appears a small circular oculus (fig. III.150), quite damaged.

According to its typology, the church of St. Nicholas in Brod is a single-nave basilica (fig. III.149, III.150). The naos, not counting the altar apse, measures $8.6 / 16 \mathrm{~m}$; the proportional ratio thus being approximately 1:2. On the west side there is a gallery, with access through wooden stairs located in the north-west corner of the naos. It is $4.3 \mathrm{~m}$ deep, carried on a wooden sub-structure and paved with a wooden plank floor. The gallery is fenced with a $90 \mathrm{~cm}$ high solid wooden parapet, with a slightly arched 
extension - a balcony in its center. Busts of several saints were originally painted on its eastern side. The naos is illuminated through three windows in the north, south and west walls. On the east side of the nave is a semicircular altar apse composed of seven shallow blind semicircular niches, illuminated by a narrow single window opening. The apse is flanked by semicircular niches for prothesis and diaconicon in the east wall, with a similar niche in the north wall of the altar. Authentic frescoes are preserved in the apse, while the remaining walls were simply whitewashed (fig. III.148).

In the upper parts of the naos a complex ceiling system with a three-nave disposition was introduced (fig. III.150). Namely, the ceiling is divided longitudinally into three vaulted belts - three "naves", which create a trefoil section. The maximum height at the top of the vault is $7 \mathrm{~m}$, while the lateral vaults reach $5.6 \mathrm{~m}$. The whole system is made rigid with wooden ties in a transverse direction, placed in a regular rhythm, which in fact carry the entire structure of the false wooden vaults and the roof.
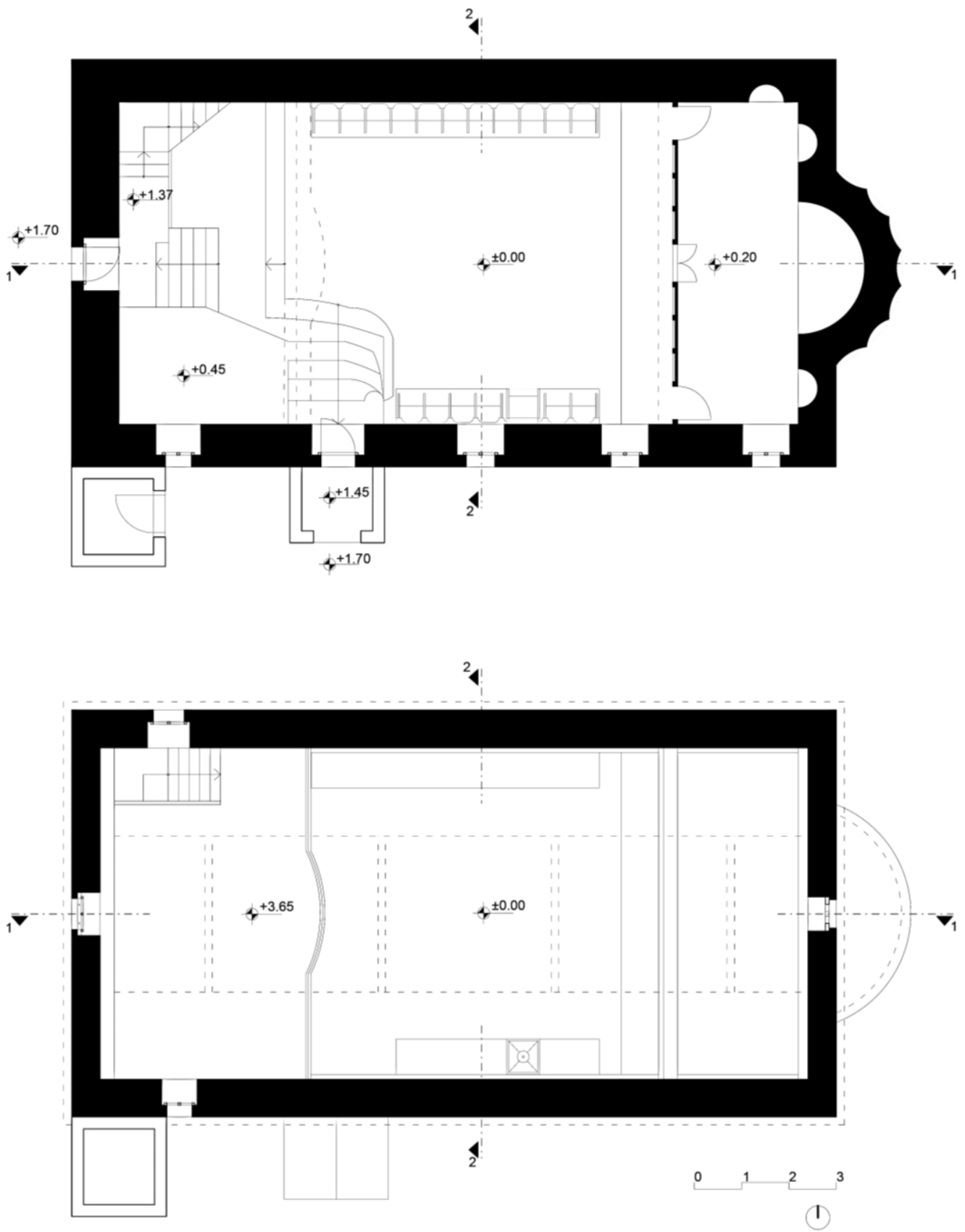

Figure III.149 St. Nicholas in Brod (Mariovo). Plans: A. Ground floor ( \pm 0.00$) ;$ B. Gallery (+3.65). 
244

THE XIX CENTURY BASILICAS IN MACEDONIA: ORIGIN, TYPOLOGY AND INFLUENCES

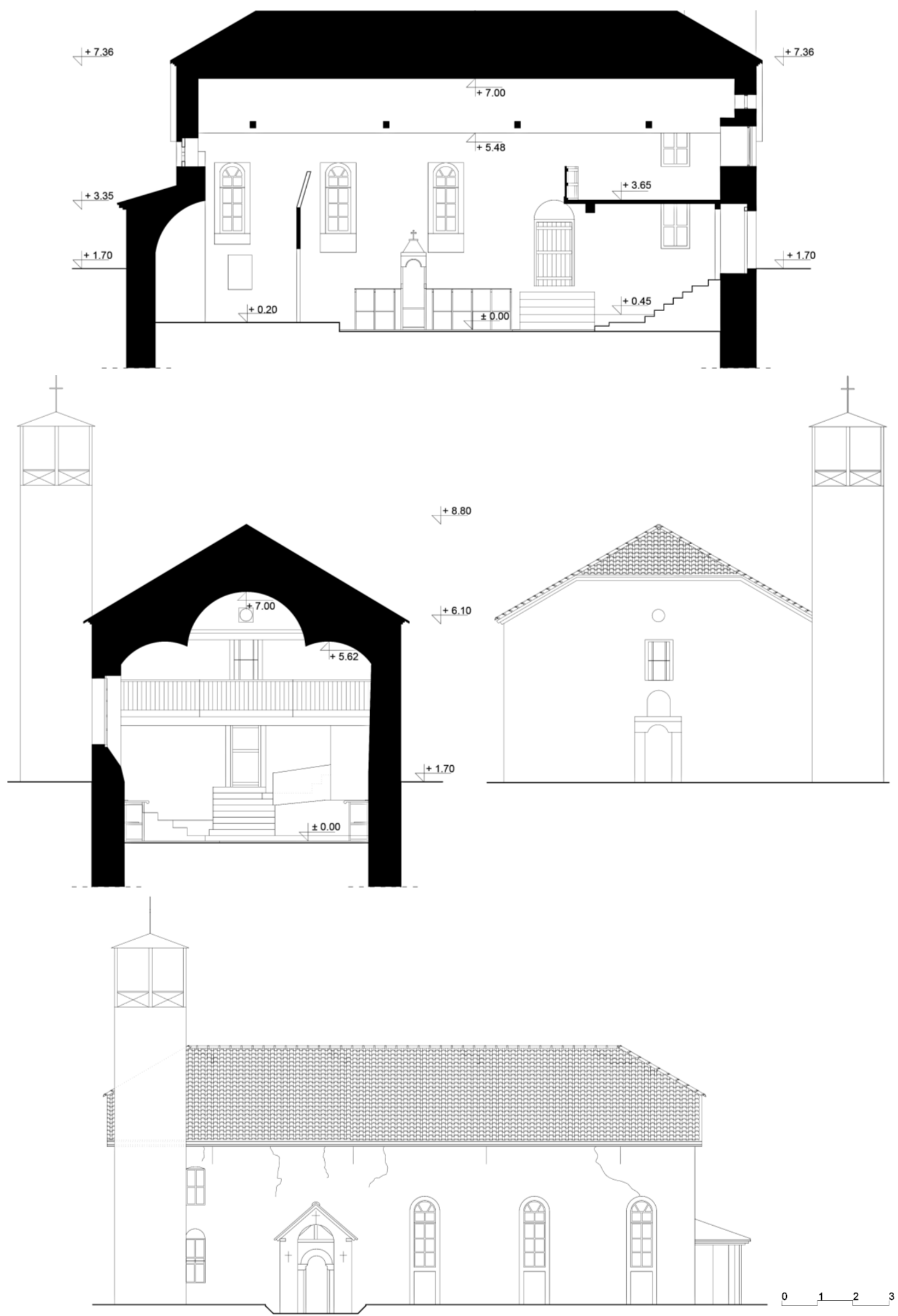

Figure III.150 St. Nicholas in Brod (Mariovo). A. Longitudinal section (1-1); B. Transversal section (2-2) and western façade; C. Southern façade. 
The vaults themselves were made using the previously elaborated Revival method (see Chapter III.2): wooden planks were nailed on the load-bearing wooden structure, joined at an angle in a symmetrical composition, so that the approximate shape of the trefoil vault was obtained. A precise curvature of the vaulted surfaces was then achieved with the help of thin wooden planks nailed longitudinally, followed by a base of tied reed and, finally, mortar coating. The church was covered in the usual way, with a gabled/bonnet roof, with saddle-shaped shorter facades.

The church in Brod has been the subject of two interventions. First, in 1921, in a period of some stability and prosperity after the two Balkan Wars and the First World War in which it had been partially ruined, ${ }^{413}$ the church was restored, especially the southern façade where the windows were rebuilt (and quite enlarged) and it, unlike the rest of the temple, was completely whitewashed. The authentic floor was covered with a coating of cement, and the stairs from the west and south entrances were rebuilt using concrete. Also, the current iconostasis was installed, surely substituting the original one which was lost in the wars. Then, a bell tower was built next to the south-west corner of the nave, as well as a small portico in front of the southern entrance which begun to be used as the main entrance to the building, instead of the west one, which has since been largely abandoned. Lastly, the church recently underwent thorough interventions, prompted by its extremely poor state of preservation with many presented pathologies and significant damage to its structure. ${ }^{414}$

\section{III.5.B THREE-NAVE BASILICAS}

The three-nave basilicas are one of the most numerous typological categories among the Revival churches: they represent $45.6 \%$ of the total number of classified Revival churches. They are spread all over Macedonia; however, as can be seen on the map III-B, they are predominant in the central, eastern and south-eastern regions, while the western ones are dominated by single-nave typologies (see map IIIA). It is important to emphasize that even in smaller, rural settlements, monumental three-nave basilicas were often built, which due to their substantial dimensions and the richness of their interior processing and decoration are by no means inferior to the urban ones. Namely, as a general rule the three-nave basilicas are very monumental buildings. ${ }^{415}$ Comparing their overall dimensions with those of the middle-

\footnotetext{
413 In the immediate vicinity of the village, namely, was the line of the Macedonian (Thessaloniki) Front in the First World War (1914-1918). During these military operations, a considerable part of the churches in Bitola and Mariovo were damaged and partially or completely destroyed, including the church of St. Nicholas in Brod. Later, most were restored.

414 Until recently, the church was in extremely poor condition. The interior, especially along the north and south walls, was rich in capillary moisture to the height of the surrounding terrain (almost $+2 \mathrm{~m}$ in relation to the floor of the nave). Frequent deep cracks were visible on the inside and outside, and the south-west corner of the nave, where a gallery-level entrance to the bell tower was previously opened, was then unprofessionally filled-in with pieces of stone and brick and improvised wooden supports, in order to prevent the complete demolition of this segment of the building, and thus most likely the church itself. The ceiling was also in poor condition, with crumbling mortar and exposed wooden sub-construction and reed substrate, which itself had already fallen apart. All this was due, of course, to the already mentioned institutional negligence, as well as the unfavorable demographic situation in the village and the region, which made its maintenance difficult or completely impossible for the remaining few inhabitants. However, the church was restored in 2012 with funds provided by the village church board. The perimeter walls were strengthened with reinforced concrete beams framed with steel transverse ties, the crown cornices were repaired using brick, the improvised south-west corner was repaired with stone masonry, the facades were freed of capilary moisture using trenches, the roof structure was changed, the cracks were filled, and the interior was smoothed and then frescopainted and a new iconostasis was made. In other words, although the actions taken ensured the church from certain ruin, they also irreversibly altered it significantly, causing an unfortunate loss of the authenticity of the Revival architecture.

415 The total dimensions of the naos in some of the three-nave Revival basilicas, not including the altar apses, are: at St. Sunday in Bitola 13.6x24 m; St. Nicholas in Mavrovo $13 \times 22$ m; St. Nicholas in Vevchani 12.7×16.8 m; the Most Holy Mother of God in Veles

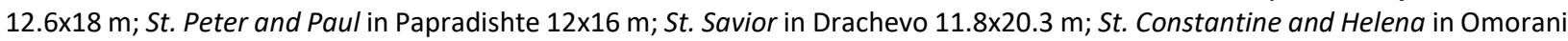
11.2×17 m; St. George in Gorna Vlashka Maala, Ohrid 10.6×15.2 m; St. Archangel Michael in Berovo 10x25 m; St. Savior in Kozhle $8.2 \times 17.5 \mathrm{~m}$ and so on. Of course, there are smaller, more compact three-nave basilicas, such as St. Demetrius in Stari Grad $7.2 \times 11.2 \mathrm{~m}$; St. Nicholas Gerakomija in Ohrid 9x14 m, etc.
} 
sized urban/cemetery and the smaller rural early-Christian three-nave basilicas (see footnotes $\mathbf{2 6}$ and $\mathbf{3 1}$ ) as well as the later middle-Byzantine and late-Byzantine churches, it is evident that the Revival three-nave basilicas took from them not only the basic typological pattern, but also the monumentality. The length of the monumental naos conceived in this way allowed it to be divided into three naves with longitudinal arcades consisting of columns connected by, most commonly, semi-circular arches, or with an architrave structure. The number of columns is dependent on the overall dimensions (primarily the length) of the naos and ranges from a minimum of 3 pairs; ${ }^{416}$ through 4 pairs; ${ }^{417} 5$ pairs; ${ }^{418}$ to 6 pairs of columns. ${ }^{419}$ As the number of columns increases with the length of the building, it is only logical that the largest Revival churches - some of the three-nave and the five-nave basilicas - have as many as 7 pairs of columns. ${ }^{420}$

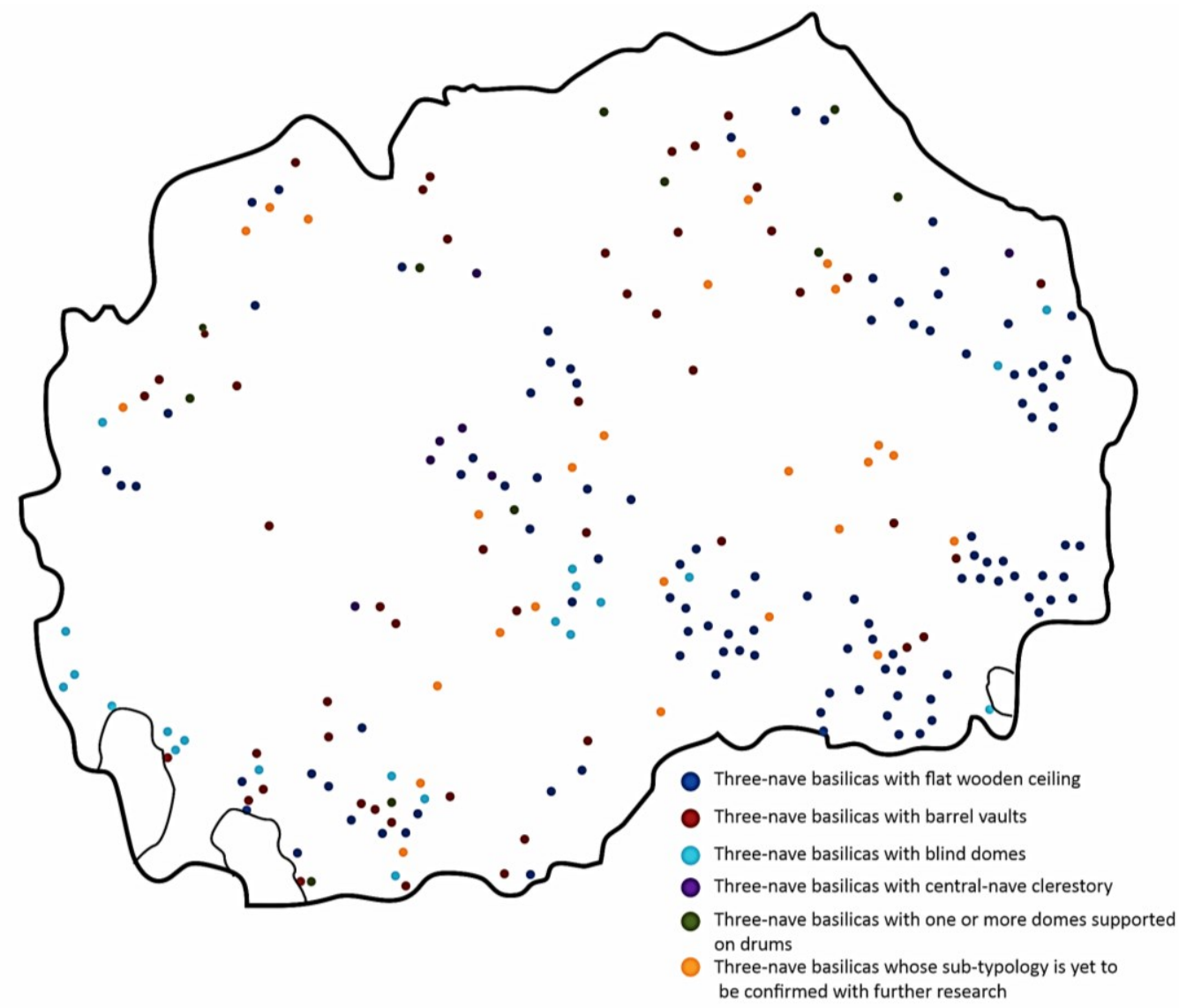

Map III-B Distribution of the Revival three-nave basilicas

In the three-nave disposition of the naos formed with the help of the two rows of columns, the central one is of greater width and height, but is rarely raised above the roof of the lateral naves as a clerestory, in a "true" basilical disposition. The churches conceived in this way will be elaborated later, as a distinctive sub-category (see Chapter III.5.B.4). Unlike them, for the most part the central nave

\footnotetext{
${ }^{416}$ For example, at St. Peter and Paul in Krstoar (Bitola); Dormition of the Most Holy Mother of God in Krushevo; St. Nicholas in Vevchani (Struga); St. Demetrius in Stari Grad (Veles); St. George, St. Nicholas Gerakomija and the Great Holy Healers in Ohrid; St. Nicholas in Mavrovo, etc.

${ }^{417}$ At St. Sotir - Transfiguration of Christ and St. Demetrius in Bukovo (Bitola); St. John in Kratovo; St. Savior in Kozhle (Skopje); the Most Holy Mother of God in Veles; St. Elijah in Stenche (Tetovo); St. Constantine and Helena in Omorani (Veles), etc.

418 At St. Petka in Gorno Orehovo (Bitola); St. Demetrius in Brusnik (Bitola); the Most Holy Mother of God in Rankovce (Kriva Palanka); St. Nicholas in Bashino Selo (Veles); St. Peter and Paul in Tresonche (Debar); St. Athanasius in Bogomila (Veles); St. Athanasius in Teovo (Veles); the Most Holy Mother of God in Bistrica (Veles); the Most Holy Mother of God in Rosoki (Debar); St. Peter and Paul in Papradishte (Veles); St. Savior in Drachevo (Skopje), etc.

${ }^{419}$ At St. Panteleimon in Uma (Gevgelija); St. George in Budinarci (Berovo); St. Elijah in Blatec (Vinica); St. Savior in Veles, etc.

${ }^{420}$ At St. Arhcangel Michael in Berovo, which is a very elongated three-nave basilica (see Chapter III.5.B.1) and the five-nave basilicas of St. Nicholas in Kumanovo and St. Panteleimon in Veles (see Chapter III.5.C).
} 
clerestory is hidden beneath a large continuous gabled roof spanning across the entire naos, which is why the three-nave Revival basilicas in Macedonia are in fact predominantly "pseudo-basilicas". The three naves usually flow uninterruptedly from the west to the east wall of the naos; however, there are examples where the columns are connected to each other with arches in a transverse direction as well, in the central or in all three naves, so that in the upper zone the central nave or the whole naos is divided into square or rectangular bays. This solution is specific to the three-nave basilicas with one or more blind domes supported on pendentives, whose construction requires a square base as a structural necessity.

Almost without exception, the three-nave basilicas have a gallery at the western end of the naos, accessed via an internal staircase, and sometimes via direct external access. Furthermore, in some churches of this type, the height of the temple and its richer program allowed for the appearance of two superimposed galleries, one of which was a "women's church", while the other housed the church choir. ${ }^{421}$ The western end of the naos, though rarely, also housed a bell tower accessed through the gallery (Кадијевић, 1997: 15), as is the case, for example, of the church of St. John in Kratovo, whose bell-tower was built posterior to the church itself. The gallery was supported on its own sub-structure, so that underneath it, in a relatively low and dark space, a "vestibule - narthex" is formed, which in some churches was completely separated from the naos with a solid, semi-transparent or combined, low or high partition (see Chapter III.3).

In some three-nave basilicas a similar low wooden partition was executed between the naves, placed between the columns - for example, at the church of the Most Holy Mother of God in Duf, near Gostivar (fig. III.151). Rows of wooden seats were often placed on both sides of this partition, and sometimes there was no full partition, but the physical separation was achieved only with the help of the seats, this time double, with north-south orientation - for example, at the Revival renovation of the post-Byzantine church of St. Nicholas in Mirkovci, near Skopje (fig. III.152). The origin of this physical barrier between the three naves can be traced back to the early-Christian period, when the colonnades separating the naves were placed on masonry

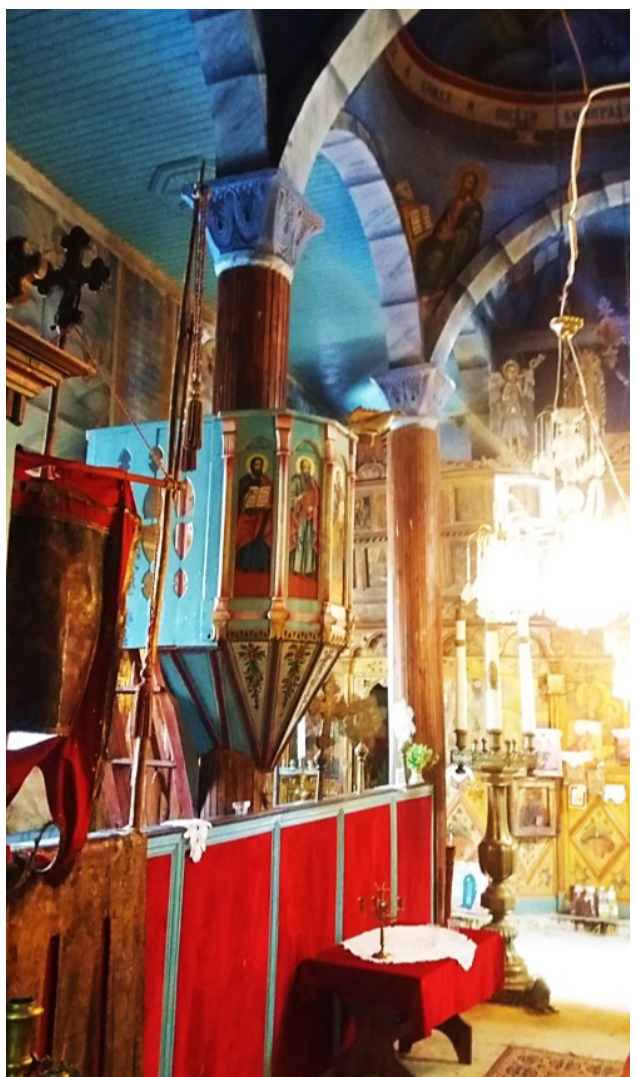

Figure III.151 The Most Holy Mother of God in Duf (Gostivar). View from the central nave towards the altar.

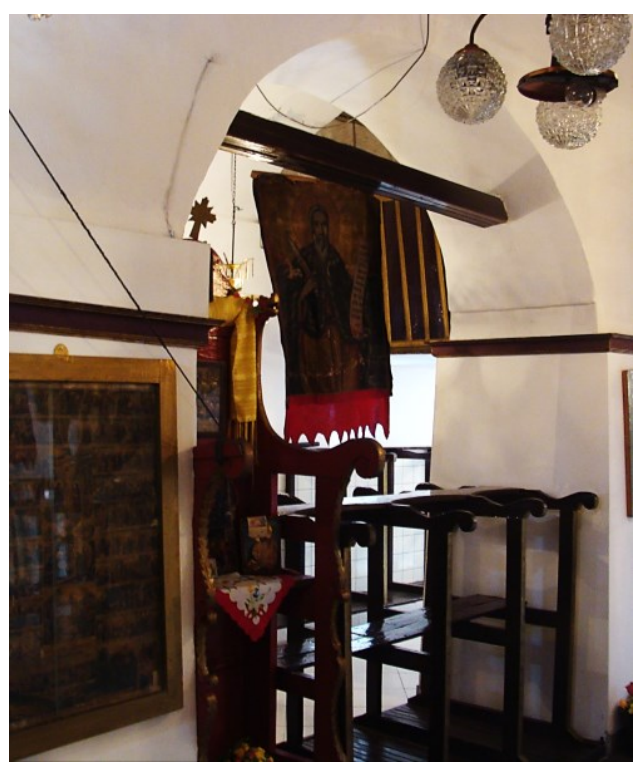

Figure III.152 St. Nicholas in Mirkovci (Skopje). View from the central towards the southern nave. stylobates of varying height (see Chapter I.2, footnote 22), which stretched along the entire length of the naos, meaning the central nave had no communication with the lateral ones and all three were accessed

\footnotetext{
${ }^{421}$ In addition to some of the large five-nave urban basilicas by Andreja Damjanov, such examples are the churches of St. Savior in Kozhle (Skopje); the Great Holy Healers in Ohrid, etc.
} 
only from the narthex to the west (Коцо, 2000: 32). The concept of placing seats along the lateral walls, built in the form of masonry benches, also originates from the early-Christian basilicas. ${ }^{422}$ In the Revival basilicas, the bench was actually a low pedestal, over which was placed a series of joined high chairs made of wood, which were intended for the elderly believers, used especially during the long festive liturgies. Although there are examples of very simple, carpentry chairs, in the representative temples this secondary church furniture also received decorative ornamentation, with curved " $\mathrm{S}$ " volutes on the armrests and even wood-carved details.

As in all Revival churches, to the east of the three-nave basilicas, close to the western edge of the altar platform a high two or three-story iconostasis was placed. The three-nave disposition altered the position of the ambo and the bishop's throne, which in the case of the single-nave basilicas were always adjacent to the north and south walls of the naos. Within the three-nave churches, on the other hand, the pulpit, usually shaped into a circular or polygonal balcony, was set high on one of the columns of the northern arcade, with access via a spiral wooden staircase; the bishop's throne was placed on the opposite side, between the columns of the southern arcade.

Unlike the single-nave basilicas, where the limited space and span that had to be overcome dictated adherence, mainly, to one type of structure covering the nave (architrave or vaulted), which greatly facilitates their typological categorization, the three-nave basilicas achieved an extraordinary wealth of combinations of architrave, vaulted and domed systems. Therefore, for the needs of this doctoral dissertation, the three-nave basilicas (a total of 243 studied churches) were divided into the following groups (see chart III-2):

B.1 Three-nave basilicas with flat wooden ceiling (total: 118)

- with flat wooden ceiling in all three naves (total: 111)

- with flat wooden ceiling combined with vaulted segments (total: 7)

B.2 Three-nave basilicas with semi-cylindrical vaults (total: 51 )

- with a semi-cylindrical vault in the central and flat ceiling in the lateral naves (total: 35 )

- with semi-cylindrical vaults in all three naves (total: 16)

B.3 Three-nave basilicas with blind domes (total: 24)

B.4 Three-nave basilicas with central nave clerestory (total: 6)

B.5 Three-nave basilicas with one or more domes supported on drums (total: 15).

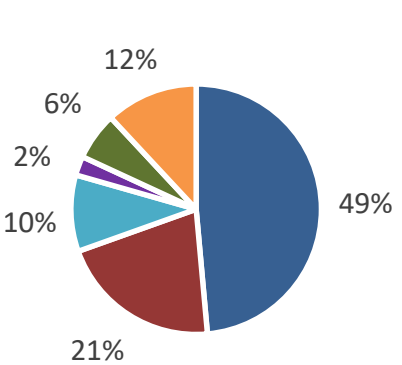

$21 \%$

\section{Three-nave basilicas}

- three-nave basilicas with flat wooden ceiling

- three-nave basilicas with barrel vaults

- three-nave basilicas with blind domes

- three-nave basilicas with central-nave clerestory

- three-nave basilicas with domes supported on drums

three-nave basilicas whose sub-typology is yet to be confirmed with further research

Chart III-2 Typological classification of the three-nave Revival basilicas.

However, the categorization of the three-nave basilicas according to their typological solution, as stated earlier, proved to be a more complex task, especially considering that there are a significant

\footnotetext{
422 Such example is the second phase of the extra muros basilica in Philippi from the VI century, where $45 \mathrm{~cm}$ high brick benches were added to the original walls of the older building (Hoddinott, 1963: 102). A similarly conceived bench is found in the singlenave chapel, which extends along the south side of the episcopal basilica in Bargala (see fig. I.7).
} 
number of three-nave basilicas that can be placed in two or more typological sub-categories. ${ }^{423}$ In that sense, the "dominant" classification - the dominant solution of covering the upper parts of the Revival churches - was crucial for this research. Of course, during the research conducted for this doctoral dissertation a number of Revival churches were recorded as three-nave basilicas, but without the possibility of their more detailed study (due to lack of published information, lack of documentation in the archives of professional institutions and the limited field research undertaken by the author) and consequently without the possibility of their precise typological classification, which remains to be a future task. These three-nave basilicas are listed in the following table:

\begin{tabular}{|c|c|c|c|c|c|}
\hline & CHURCH & VILLAGE & REGION (TOWN) & YEAR & $\begin{array}{c}\text { ADDITIONAL INFORMATION } \\
\text { fresco-painting / icons, renovations }\end{array}$ \\
\hline 1 & St. Athanasius & Vojnica & Veles & 1821 & \\
\hline 2 & Nativity of the Most Holy Mother of God & Kanino & Bitola & 1830 & \\
\hline 3 & St. Nicholas & Trkanje & Kochani & 1830 & $\begin{array}{l}\text { demolished and renovated in } 1883 \text {, } \\
\text { frescoes and icons from } 1889\end{array}$ \\
\hline 4 & St. Elijah & / & Radovish & $\begin{array}{l}1831- \\
1859\end{array}$ & \\
\hline 5 & St. Constantine and Helena & Lubnica & Radovish & 1840 & \\
\hline 6 & Nativity of the Most Holy Mother of God & Vasilevo & Strumica & 1840 & renovated in 2008 \\
\hline 7 & St. Nicholas & Mechkuevci & Sveti Nikole & 1846 & \\
\hline 8 & St. Nicholas & / & Tetovo & 1847 & \\
\hline 9 & St. Nicholas & Opila & Kriva Palanka & 1853 & \\
\hline 10 & St. Constantine and Helena & Raklish & Radovish & 1854 & \\
\hline 11 & St. Demetrius & Drachevica & Demir Kapija & 1858 & $\begin{array}{l}\text { almost completely demolished, } \\
\text { located in an abandoned village }\end{array}$ \\
\hline 12 & St. Petka & Miletkovo & Gevgelija & 1860 & renovated in 1932 \\
\hline 13 & St. George & Otunje & Tetovo & 1860 & \\
\hline 14 & Introduction of the Most Holy Mother of God & Shlegovo & Kratovo & 1861 & \\
\hline 15 & St. Cosma and Damian & Pletvar & Prilep & 1862 & \\
\hline 16 & St. Savior - Ascension of Christ & Topolchani & Prilep & 1864 & \\
\hline 17 & Holy Trinity & Nivichani & Kochani & 1864 & \\
\hline 18 & St. George & Leskovica & Shtip & 1867 & \\
\hline 19 & Dormition of the Most Holy Mother of God & Selce & Prilep & 1871 & \\
\hline 20 & St. Savior - Ascension of Christ & Injevo & Radovish & 1872 & \\
\hline 21 & St. Panteleimon - St. Clement & Velgoshti & Ohrid & 1872 & \\
\hline 22 & St. Savior & Rozhden & Kavadarci & 1872 & frescoes from 1874 \\
\hline 23 & Holy Trinity & Brushani & Kavadarci & 1878 & $\begin{array}{l}\text { submerged in the artificial lake } \\
\text { Tikvesh in } 1968\end{array}$ \\
\hline 24 & St. Nicholas & Belichica & Mavrovo & 1885 & \\
\hline 25 & St. Nicholas & Oraov Dol & Veles & & \\
\hline 26 & St. Nicholas & Karamani & Bitola & & \\
\hline 27 & St. Nicholas & Bukovo & Bitola & & \\
\hline 28 & St. Petka & Tudence & Tetovo & & \\
\hline 29 & St. Elijah & Neproshteno & Tetovo & & \\
\hline
\end{tabular}

Table III-6 Three-nave Revival basilicas of yet un-confirmed sub-typology.

\section{III.5.B.1 THREE-NAVE BASILICAS WITH FLAT WOODEN CEILING}

The three-nave basilicas covered with a flat wooden ceiling belong to one of the most widely spread typologies of Revival basilicas; in other words, they represent one of the most common architectural solutions. As many as $49 \%$ of the three-nave basilicas registered so far belong to this category, making it the most numerous among the three-nave churches. Although cast throughout Macedonia, they are

\footnotetext{
${ }^{423}$ For example, there are churches that belong to the category of three-nave basilicas with semi-cylindrical vault in all naves, or three-nave basilicas with a flat wooden ceiling, that at the same time have one or more blind domes in the central nave. Furthermore, a problem in the classification arises in a group of three-nave basilicas which in the upper parts are separated by arches in both directions so that square or rectangular fields are formed; but that group was not considered a separate subcategory because in those fields a flat wooden ceiling, a vault, a blind dome or a dome upon a drum may appear, which allows for the classification of the same churches according to these "dominant" typological patterns.
} 
especially specific for the central "Povardarje" region (along the Vardar river) and the south-eastern areas of the country, where they represent the dominant Revival typological solution, and are far less present in its western parts (see map III-2). The reasons for this regional "concentration" of the three-nave basilicas with a flat wooden ceiling in central and eastern Macedonia is due to the regional movement of certain master-builder groups which nurtured their own expression and often worked according to an already built model that was considered successful and had already been accepted among the local population. In this case, most of the three-nave basilicas located in the south-eastern parts of Macedonia are the work of a famous master-builder family (the family Angelkovci from the village of Papradishte near Veles, originally from the village of Tresonche), i.e. the master-builders Kitan Petrov (1793-1866) ${ }^{424}$ and his son Andon Kitanov (1829-1914), ${ }^{425}$ who was a particularly long-lived and prolific Revival architect, woodcarver and icon painter, in other words, a true Renaissance versatile artist.

The three-nave basilicas covered with flat wooden ceilings are monumental buildings, with a naos divided into three naves by means of two rows comprised of 3, 4, 5 or more columns connected with semicircular or profiled arches in the longitudinal direction, so that two arcades are formed. In the transverse direction, there is usually no connection with arches between the columns, i.e. the aisles are continuous in their entire length, with the exception of wooden beams - ties for tightening the system, which appear in some of these buildings, especially in the central nave which has usually a significantly larger span. Often, though not without exception, the central nave is taller than the lateral, narrower aisles, but the "clerestory" is visible only in the interior, and is not manifested on the fifth façade, where the whole naos, as is usual for the Revival basilicas, is covered with one continuous gabled roof, regularly with two small triangular cut-outs on the east and west sides, which actually define the roof as bonnet, and give the east and west façades a saddle-like appearance (see Chapter III.3). The dimensions of the three-nave basilicas of this sub-category ${ }^{426}$ allow for the regular appearance of a gallery in the west, and a monumental two or three-story iconostasis placed on the edge of the altar platform to the east.

\section{Three-nave basilicas with flat wooden ceiling in all three naves}

In the majority of churches within the category of three-nave basilicas covered with a flat wooden ceiling, the architrave coverage is present in all three naves (table III-7). Despite the lack of vaults, or their

\footnotetext{
${ }^{424}$ So far identified works of master Kitan Petrov are St. Demetrius in Kriva Palanka (1833); St. Athanasius in Bogomila, Veles (1837) and St. Trinity in Podles, Veles (1840-1850), where he worked together with his son Andon.

425 Andon Kitanov's opus is dominated by three-nave basilicas with a flat wooden ceiling: St. Athanasius in Gabrovo, Gevgelija (1851); Dormition of the Most Holy Mother of God in Bistrica, Veles (1853); St. Demetrius in Konsko, Gevgelija (1858); St. Demetrius in Kovanec, Gevgelija (1860); Nativity of the Most Holy Mother of God in Davidovo, Gevgelija (1860); St. Petka in Prdejci, Gevgelija (1861); St. Savior in Petrovo, Gevgelija (1867); St. George in Brajkovci, Valandovo (1870); Dormition of the Most Holy Mother of God in Gjavato, Bogdanci (1893), which is a reconstruction of a church dating from 1834; St. Constantine and Helena in Miravci, Gevgelija (1893), when he rebuilt the church dating from 1860; St. Athanasius in Teovo, Veles (1895); St. Cyril and Methodius in Gevgelija (1896); St. George in Sermenin, Gevgelija, which dates from 1834, and was rebuilt by Andon Kitanov at the end of the century; St. Demetrius in Smokvica, Gevgelija (1905), when the church dating from 1830 was rebuilt; St. Elijah in Dolno Vranovci, Veles; St. Petka in Marvinci, Valandovo; Nativity of the Most Holy Mother of God in Bogorodica, Gevgelija (1911); St. Elijah in Busilci, Veles; St. Athanasius in Bogdanci, as well as a significant number of churches that today are on the territory of Greece, Aegean Macedonia (the villages Kandzalija, Gabrovci, Machukovo and others). At the church of St. Demetrius in Balinci, Valandovo (1860), on the other hand, he replaced the flat ceiling in the central nave with a semi-cylindrical vault, including a bell tower on the western façade. Furthermore, he is the author of three very important monumental three-nave basilicas with domes supported on elevated drums in the central nave: the Most Holy Mother of God in Sogle, Veles (1855); St. George in Negotino (1860) and St. Panteleimon in Pantelej, Kochani (1885) (see Chapter III.5.B.5). As for smaller, single-nave basilicas, they are not inherent to his opus. In fact, he built only two such churches: St. Trinity in Podles, Veles (1840-1850), where he worked with his father; as well as St. Stephen in Nezhilovo, Veles (1887).

${ }^{426}$ Namely, this typological solution allowed the master-builders to achieve truly monumental dimensions of the buildings, such as at St. Demetrius in Kavadarci $(16 \times 34$ m); the Most Holy Mother of God in Vatasha (10.5 x 23 m); St. Elijah in Blatec (10.7 / 17 m); St. Athanasius in Bogomila (11.25 / 19 m); St. Athanasius in Teovo (12.4 / 18.4 m); the Most Holy Mother of God in Bistrica (12 / 17.8 m); St. Peter and Paul in Tresonche (11.6 / $16.1 \mathrm{~m})$; St. Nicholas in Bashino Selo (12.5 / 19 m), etc.
} 
very limited appearance, the flat wooden ceilings are not without a decorative finish. In the more representative buildings appear coffer ceilings, especially in the central nave (see fig. III.154) ${ }^{427}$ while the lateral ceilings usually consist of wooden planks arranged in one direction. Next, there appear profiled frames, cornices, decorative elements, medallions and rosettes, characteristic of the representative "audition" chambers in the most distinguished town houses and bey's residences (see fig. III.16-17), as well as painting and gilding of their decorative elements (see Chapter III.4.2, fig. III.104-107).

\begin{tabular}{|c|c|c|c|c|c|}
\hline & CHURCH & VILLAGE & REGION (TOWN) & YEAR & $\begin{array}{c}\text { ADDITIONAL INFORMATION } \\
\text { fresco-painting / icons, renovations }\end{array}$ \\
\hline 1 & St. Petka & Galichnik & Debar & 1807 & \\
\hline 2 & St. Demetrius & Smokvica & Gevgelija & 1830 & frescoes from 1846 \\
\hline 3 & St. George & Sermenin & Gevgelija & 1834 & frescoes from 1847 \\
\hline 4 & Dormition of the Most Holy Mother of God & Gjavato & Bogdanci & 1834 & renovated in 1893 \\
\hline 5 & St. Demetrius & / & Kavadarci & 1834 & \\
\hline 6 & Introduction of the Most Holy Mother of God & Rosoki & Debar & 1835 & \\
\hline 7 & St. Petka & Nizhepole & Bitola & 1835 & $\begin{array}{l}\text { renovated with flat wooden ceilings } \\
\text { in } 1960\end{array}$ \\
\hline 8 & Dormition of the Most Holy Mother of God & Gjavato & Bitola & 1835 & \\
\hline 9 & St. Mina & Garnikovo & Kavadarci & 1837 & demolished in the 1980s \\
\hline 10 & St. Athanasius & Bogomila & Veles & 1837 & \\
\hline 11 & St. Constantine and Helena & Monospitovo & Strumica & 1838 & icons from 1858 \\
\hline 12 & St. Nicholas & Bashino Selo & Veles & 1838 & \\
\hline 13 & St. George & Trojaci & Prilep & 1838 & \\
\hline 14 & St. Archangel Michael - Boshava monastery & Dolna Boshava & Kavadarci & 1839 & frescoes from 1880 \\
\hline 15 & St. Archangel Michael & Resava & Kavadarci & 1840 & \\
\hline 16 & Dormition of the Most Holy Mother of God & Leunovo & Mavrovo & 1840 & \\
\hline 17 & St. Savior - Ascension of Christ & Koleshino & Strumica & 1840 & $\begin{array}{l}\text { demolished by heavy snow, } \\
\text { renovated in } 1961\end{array}$ \\
\hline 18 & St. Savior - Ascension of Christ & / & Gevgelija & 1842 & \\
\hline 19 & St. Athanasius & Bosilovo & Strumica & 1842 & \\
\hline 20 & St. Savior - Ascension of Christ & Vladimirovo & Berovo & 1842 & $\begin{array}{l}\text { burned almost entirely in a fire in } \\
2014\end{array}$ \\
\hline 21 & St. Peter and Paul & Tresonche & Debar & 1844 & \\
\hline 22 & St. Peter and Paul & Ratevo & Berovo & 1845 & \\
\hline 23 & St. Athanasius & Novachani & Veles & 1845 & \\
\hline 24 & St. Demetrius & Grunishta & Mariovo & 1848 & $\begin{array}{l}\text { the flat ceiling is a later intervention } \\
\text { in an originally vaulted basilica }\end{array}$ \\
\hline 25 & St. Archangel Michael & Grchishte & Valandovo & 1849 & frescoes from 1860 \\
\hline 26 & St. Athanasius & Gabrovo & Gevgelija & 1851 & frescoes from 1870/1871 \\
\hline 27 & St. George & Zubovo & Strumica & 1852 & \\
\hline 28 & St. Elijah & $S^{\prime} \mid \mathrm{p}$ & Veles & 1852 & \\
\hline 29 & Dormition of the Most Holy Mother of God & Bistrica & Veles & 1853 & \\
\hline 30 & Nativity of the Most Holy Mother of God & Lopatica & Bitola & 1857 & renovated in 1945 \\
\hline 31 & St. Demetrius & Konsko & Gevgelija & 1858 & frescoes from 1881 \\
\hline 32 & St. Constantine and Helena & Negrevo & Pehchevo & 1858 & \\
\hline 33 & St. Peter and Paul & 1 & Pehchevo & 1858 & demolished \\
\hline 34 & St. Archangel Michael & / & Vinica & 1858 & demolished in 1970 \\
\hline 35 & St. Athanasius & Przhdevo & Demir Kapija & 1858 & built over older foundations \\
\hline 36 & St. Sunday & Stojakovo & Bogdanci & 1860 & $\begin{array}{l}\text { partially destroyed in World War I } \\
\text { and later renovated }\end{array}$ \\
\hline 37 & St. Demetrius & Kovanec & Gevgelija & 1860 & \\
\hline 38 & St. Constantine and Helena & Miravci & Gevgelija & 1860 & burnt in 1892, renovated in 1893 \\
\hline 39 & St. Demetrius & Gradec & Valandovo & 1860 & \\
\hline 40 & St. Savior - Ascension of Christ & Stinik & Strumica & 1860 & \\
\hline 41 & St. Savior - Ascension of Christ & Chemersko & Kavadarci & 1860 & burnt in a fire and later renovated \\
\hline 42 & St. Athanasius & Sovikj & Bitola & 1860 & \\
\hline 43 & Nativity of the Most Holy Mother of God & Davidovo & Gevgelija & 1860 & \\
\hline 44 & St. Petka & $\begin{array}{l}\text { Gorno } \\
\text { Orehovo }\end{array}$ & Bitola & 1861 & \\
\hline 45 & St. Petka & Prdejci & Gevgelija & 1861 & \\
\hline
\end{tabular}

${ }^{427}$ For example, at the church St. Athanasius in Dolno Chichevo, Veles (see fig. III.42); at St. Demetrius in Kriva Palanka, where the side naves and the ceiling beneath the gallery are covered with a coffer ceiling, while a system of blind domes and rosettes developes in the central nave (see fig. III.155); at St. Elijah in Sachevo, St. Athanasius in Bosilovo, St. Constantine and Helena in Mokrino, St. Trinity in Dabile, St. Panteleimon in Makrievo, St. Elijah in Gabrovo, St. Savior in Stinik, all from the region of Strumica; St. Athanasius in Bohula, Kavadarci and many others. 


\begin{tabular}{|c|c|c|c|c|c|}
\hline 46 & St. Nicholas & Gradeshnica & Mariovo & 1862 & frescoes from 1884 \\
\hline 47 & St. Panteleimon & Uma & Gevgelija & 1862 & \\
\hline 48 & Nativity of the Most Holy Mother of God & Setole & Tetovo & 1862 & \\
\hline 49 & St. Savior - Ascension of Christ & Robovo & Strumica & 1864 & \\
\hline 50 & St. Elijah & Gabrovo & Strumica & 1865 & \\
\hline 51 & Dormition of the Most Holy Mother of God & Krani & Prespa & 1865 & \\
\hline 52 & St. Nicholas & Klisura & Demir Kapija & 1866 & frescoes from 1879 \\
\hline 53 & St. Savior - Ascension of Christ & Petrovo & Gevgelija & 1867 & \\
\hline 54 & Holy Trinity & Dabile & Strumica & 1868 & \\
\hline 55 & Nativity of the Most Holy Mother of God & Barovo & Demir Kapija & 1868 & renovated in 1934 \\
\hline 56 & Dormition of the Most Holy Mother of God & Marena & Kavadarci & 1869 & $\begin{array}{l}\text { royal doors from 1869, fresco- } \\
\text { painting in } 1879\end{array}$ \\
\hline 57 & St. George & Brajkovci & Valandovo & 1870 & \\
\hline 58 & St. George & Piperevo & Strumica & 1870 & \\
\hline 59 & St. Athanasius & Bohula & Kavadarci & 1870 & $\begin{array}{l}\text { frescoes from } 1879 \text {, icons and royal } \\
\text { doors from } 1870\end{array}$ \\
\hline 60 & St. Elijah & Sachevo & Strumica & 1870 & \\
\hline 61 & St. George & Murtino & Strumica & 1870 & \\
\hline 62 & Holy Trinity & Smolari & Strumica & 1870 & \\
\hline 63 & Dormition of the Most Holy Mother of God & Smojmirovo & Berovo & 1871 & \\
\hline 64 & The Most Holy Mother of God & Farish & Kavadarci & 1873 & \\
\hline 65 & St. Panteleimon & Makrievo & Strumica & 1874 & \\
\hline 66 & St. Nicholas & Krajnici & Veles & 1875 & \\
\hline 67 & St. Constantine and Helena & Mokrino & Strumica & 1876 & \\
\hline 68 & St. Elijah & Furka & Dojran & 1880 & \\
\hline 69 & St. Elijah & Veshje & Negotino & 1878 & dated according to the iconostasis \\
\hline 70 & St. Demetrius & Kumanichevo & Kavadarci & 1878 & dated according to the iconostasis \\
\hline 71 & St. Stephen & Konopishte & Kavadarci & 1879 & dated according to the iconostasis \\
\hline 72 & St. Athanasius & Dolno Chichevo & Veles & 1880 & \\
\hline 73 & Nativity of the Most Holy Mother of God & Begnishte & Kavadarci & 1880 & \\
\hline 74 & Dormition of the Most Holy Mother of God & Dragobrashte & Vinica & 1883 & \\
\hline 75 & St. Nicholas & Strmashevo & Demir Kapija & 1885 & abandoned and demolished \\
\hline 76 & St. Petka & Rusinovo & Berovo & 1887 & dated according to the icons \\
\hline 77 & St. Athanasius & Teovo & Veles & 1895 & \\
\hline 78 & St. Cyril and Methodius & / & Gevgelija & 1896 & \\
\hline 79 & St. Savior - Ascension of Christ & Umlena & Delchevo & 1898 & \\
\hline 80 & St. Athanasius & Gradec & Valandovo & & \\
\hline 81 & St. Athanasius & Negorci & Gevgelija & & renovated in 1996 \\
\hline 82 & St. Athanasius & 1 & Bogdanci & & \\
\hline 83 & St. Athanasius & Stragovo & Kavadarci & & \\
\hline 84 & St. Demetrius & Stragovo & Kavadarci & & \\
\hline 85 & St. Demetrius & Bunarche & Kavadarci & & abandoned and almost demolished \\
\hline 86 & St. Nicholas & Dragozhel & Kavadarci & & \\
\hline 87 & St. John the Baptist & Laki & Vinica & & \\
\hline 88 & St. George & Poeshevo & Bitola & & renovated in the upper parts \\
\hline 89 & St. Savior - Ascension of Christ & R'levci & Veles & & \\
\hline 90 & St. Nicholas & Stepanci & Veles & & the flat ceiling is a later renovation \\
\hline 91 & St. Petka & Marvinci & Valandovo & & \\
\hline 92 & Nativity of the Most Holy Mother of God & Bogorodica & Gevgelija & & \\
\hline 93 & St. Demetrius & Stari Grad & Veles & & \\
\hline
\end{tabular}

Table III-7 Three-nave Revival basilicas with flat wooden ceiling in all three naves.

At some three-nave churches of this type, the ceiling in the altar or in the gallery was treated differently than within the naos itself. Such is the case, for example, of the church of the Dormition of the Most Holy Mother of God in Gjavato (Bitola), which has flat wooden ceilings everywhere, except in the central nave above the gallery, where a semi-cylindrical vault extends. Often, in the central nave, the flat wooden ceiling is complemented by circular medallions depicting fresco-painted busts of Christ Pantocrator, the Mother of God, or the Holy Trinity as replacement for the omitted domes. ${ }^{428}$ These circular medallions were often framed with decorative, profiled elements made of wood, in the form of a polygonal rosette, with wood-carved or painted details. Such an example can be found in the central nave of the church of St. Athanasius in Novachani, near Veles (see fig. III.17A). In this church the lateral naves

${ }^{428}$ At the churches in Bistrica (Veles); Gorni Disan (Negotino); Sachevo, Dabile, Murtino, Mokrino and Robovo (all in the region of Strumica), and many others. 
are covered with a flat ceiling composed of wooden planks, while the central one is plastered, with the exception of the central bay which received a very luxurious and picturesque treatment. Namely, an octagon is inserted in this rectangular field, formed with the help of triangular elements in the corners, which then rises vertically in the form of a blind octagonal dome, intersected by a horizontal octagonal rosette, in the center of which appears a circular medallion depicting a waistlength image of Christ Pantocrator. The truncated blind dome was also painted with busts of saints against a blue sky-like background, as was the rosette itself, with floral and geometric motifs against a warm ochre-red tone. The rich painting of the ceiling in the central nave, together with the iconostasis, the church furniture and the painted surfaces of the columns, the capitals and the arches that connect them, ${ }^{429}$ in contrast to the whiteness of the ceiling creates a very picturesque ambience inside the church.

At the churches in the villages Sachevo, Mokrino and Dabile in the region of Strumica, the similarly conceived circular medallion in the central nave is complemented by radially arranged gilded wooden rods, individual or grouped in bundles (in Mokrino), ${ }^{430}$ which create a threedimensional effect, emphasized by their contrast with the dark background. The medallion in the central nave of the church in Makrievo, unlike the others, has an oval shape. At the church in the village of Krajnici near Veles (see fig. III.17B), the same contrasting approach is applied in the central nave, which is completely painted and divided into bays: behind the iconostasis the processing of the ceiling is identical with the lateral naves; however, just in front of it, a rectangular chessboard bay depicts a centrally placed octagon with a small radiant rosette; the next bay to the west contains a painted medallion with a waist-length representation of Christ Pantocrator, as a consistent replacement of a central dome which, according to the

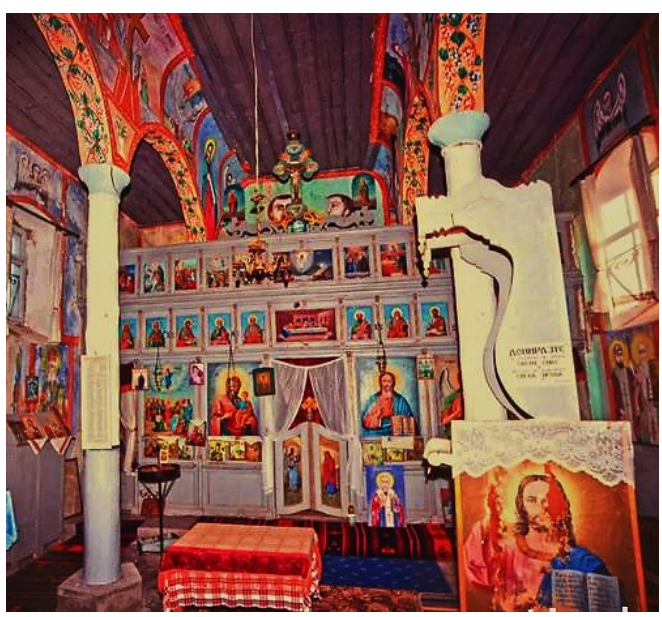

Figure III.153 St. Savior in R'levci (Veles). View from the central nave towards the altar.

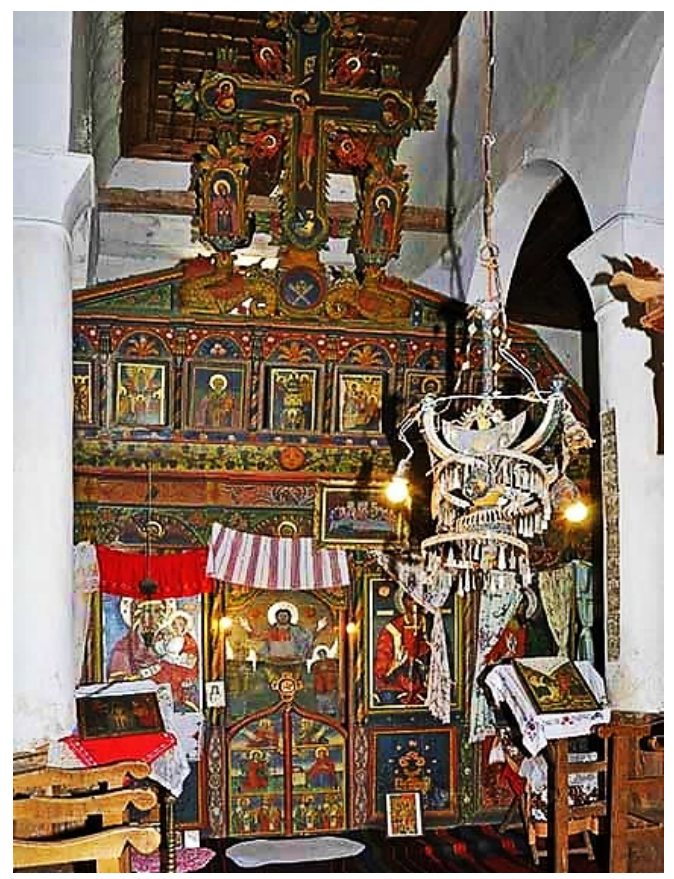

Figure III.154 St. Constantine and Helena in Negrevo (Pehchevo). Central nave, view towards the altar. legal restrictions on construction, is naturally absent. The fields above and between the arches of the arcade rows were also painted as well as the vaulted passage from the vertical plane of the wall to the horizontal plane of the ceiling, where scenes from the great feasts and the life of Christ were painted, in accordance with the Canons.

\footnotetext{
429 The arches that connect the columns were divided into "stone blocks" with the help of painting in soft pastel tones: blue, purple, ochre and green, and between two arches, i.e. above each capital, a circular medallion was painted. This method can be found in the churches of several villages in the region of Veles, in addition to Novachani: S'Ip, Popadija, as well as Kozhle (see upcoming Chapter), a village in the region of Skopje, but located on the border with the region of Veles, which speaks of regional specifics in the general trends of the Revival sacral construction.

${ }^{430}$ Except around the ceiling medallion, the same motif of radiant beams is repeated on the iconostasis of the church in Mokrino, in the upper zone, between the smaller icons under the Crucifixion, where circular solar motifs made of such carved rods are placed, as well as at the ends, where $1 / 4$ circle segments were executed. A similar concept of three-dimensional solar representations within the iconostasis, as was said earlier, can also be found at the church of St. Nicholas in Cer (see fig. III.144).
} 
Namely, quite commonly the basilicas of this type incorporate a vaulted transition from vertical wall to horizontal ceiling (fig. III.153), often painted with scenes from the important holidays, figures of individual saints placed in circular or oval medallions, etc. ${ }^{431}$ In addition to painting and carved ornaments on the ceilings, most of the three-nave basilicas of this type had fresco-painted altars, as well as the area above the columns, i.e. on and between the arches that connect them (fig. III.153), where medallions or

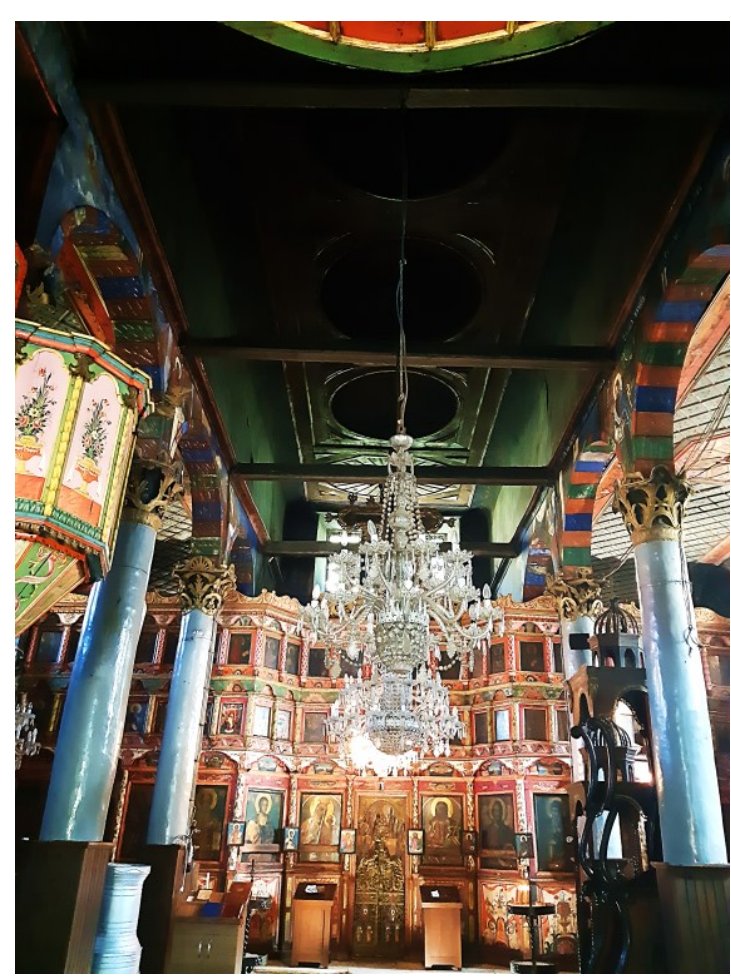

Figure III.155 St. Demetrius in Kriva Palanka. View of the central nave, towards the altar.

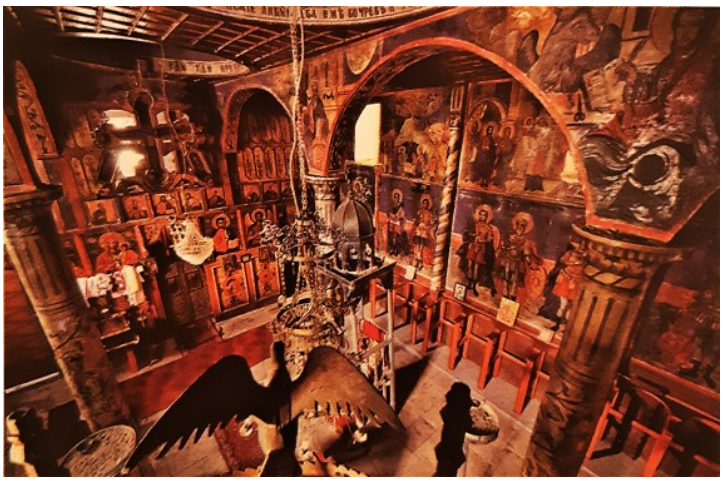

Figure III.156 The Most Holy Mother of God in Rankovce (Kriva Palanka). View from the ambo (in the northern colonnade) towards the south-east of the naos. scenes from the important holidays were painted. Also, though rarely, there are churches of this type that were completely frescoed (for example, the churches in Klisura, Przhdevo, Veshje, Bohula and other villages in the region of Tikvesh).

In some examples of three-nave basilicas covered with a flat wooden ceiling, a trapezoidal crosssection was executed in the central nave, very similar to the solution found in some of the single-nave churches with a three-nave disposition of the upper construction (see fig. III.147B). Such example is the church of St. Petka in Galichnik, one of the oldest Revival basilicas, built in 1807.

As a separate sub-category of the three-nave basilicas covered by a flat wooden ceiling, a quite common solution is the incorporation of blind domes within the flat ceiling of the central nave, without transverse arches, pendentives, squinches, or any appropriate sub-construction, meaning that these blind domes are actually three-dimensional (concave) medallions, whose diameter is usually smaller than the span of the central nave (fig. III.155-156). The number of blind domes was preset on either one, in the simpler architectural compositions, ${ }^{432}$ or three, in the more complex and representative temples. ${ }^{433}$ Clearly, these two options are directly derived from Christian symbolism, based on one hand on the one, sole, almighty God or, on the other, on the concept of the Holy Trinity. In addition to the concave construction of the blind dome, it was often embedded in a square or polygonal profiled frame, with decorative elements such as wood-carved triangular panels in the corners, and was also almost regularly painted, with one of the compositions that according to the canons were deemed suitable for the church domes: Christ Pantocrator, the Mother of God and the Holy Trinity.

In the vast family of three-nave basilicas covered with a flat wooden ceiling, one or more blind domes can be found in:

\footnotetext{
431 The churches in Krajnici, in R'levci and S'lp in the region of Veles; Klisura (Demir Kapija); Kavadarci; Sachevo, Mokrino, Makrievo, Robovo and Gabrovo in the region of Strumica; Trojaci (Prilep) and many others.

432 At the churches in Pancharevo; Makedonska Kamenica; Robovo; Zrnovci; Tearce; Lipec; Capari; Blatec; Razlovci; Budinarci; Grljani; Barbarevo; Stenche (see fig. III.99).

${ }^{433}$ At the churches in Rankovce (fig. III.156); Novo Selo; Gradec and Kriva Palanka (fig. III.155).
} 


\begin{tabular}{|c|c|c|c|c|c|}
\hline & CHURCH & VILLAGE & REGION (TOWN) & YEAR & $\begin{array}{c}\text { ADDITIONAL INFORMATION } \\
\text { fresco-painting / icons, renovations }\end{array}$ \\
\hline 1 & St. Demetrius & / & Kriva Palanka & 1833 & \\
\hline 2 & St. George & Novo Selo & Strumica & 1842 & icons from 1849 \\
\hline 3 & Dormition of the Most Holy Mother of God & Robovo & Pehchevo & 1847 & \\
\hline 4 & St. Athanasius & Orizari & Kochani & 1848 & $\begin{array}{l}\text { partially demolished and renovated } \\
\text { in } 1876\end{array}$ \\
\hline 5 & St. Savior - Ascension of Christ & Lipec & Vinica & 1849 & \\
\hline 6 & St. Demetrius & Zrnovci & Kochani & 1849 & \\
\hline 7 & St. Petka & Capari & Bitola & 1849 & \\
\hline 8 & St. Elijah & Blatec & Vinica & 1850 & \\
\hline 9 & St. Constantine and Helena & Razlovci & Delchevo & 1850 & \\
\hline 10 & St. George & Budinarci & Berovo & 1854 & \\
\hline 11 & St. Nicholas & Gradec & Kriva Palanka & 1857 & icons from 1869 \\
\hline 12 & St. Elijah & / & Makedonska Kamenica & 1866 & \\
\hline 13 & St. Nicholas & Tearce & Tetovo & 1866 & \\
\hline 14 & St. Elijah & Stenche & Tetovo & 1867 & \\
\hline 15 & St. Athanasius & Barbarevo & Strumica & 1870 & \\
\hline 16 & St. Demetrius & Pancharevo & Delchevo & 1886 & \\
\hline 17 & St. Demetrius & Grljani & Vinica & & \\
\hline 18 & The Most Holy Mother of God & Rankovce & Kriva Palanka & & with an older XVII century phase \\
\hline
\end{tabular}

Table III-8 Three-nave Revival basilicas with flat wooden ceiling with blind domes.

Often, however, these blind domes are quite large, making it difficult to distinguish whether the churches from this particular group should be considered as three-nave basilicas with flat wooden ceiling with blind domes or as three-nave basilicas with blind domes. Thus, the crucial distinction was made based on the presence / absence of a dome sub-structure: transverse arches which form a square base and pendentives which shape the circular base of the dome. The lack of such structure firmly places these eighteen (so far) identified churches within the largest group of Revival basilicas: the three-nave basilicas with a flat ceiling. However, despite this classification, they certainly represent a link with the three-nave basilicas with blind domes, and then with those that have domes supported on drums, which will be discussed in detail later (see Chapters III.5.C.3 and III.5.C.5).

\section{"St. Peter and Paul" in Tresonche (Debar), 1844}

The village of Tresonche, as explained in detail before (see Chapters II.3 and II.4) was the epicenter of the Debar school of construction, icon painting and woodcarving, from which most of the Revival master builders and artists originated and under whose influence they were educated in their respective crafts. It comes as no surprise, then, that in this mountainous, relatively isolated village several churches were built, two of which - St. Peter and Paul and St. Nicholas (see Chapter III.5.D) - are very important, monumental buildings.

According to the inscription preserved in the lunette above the entrance portal on the western façade (see fig. III.64A), painted by the famous Revival artist Dicho Zograf in May of 1849, the church of St. Peter and Paul was built in 1844 under the auspices of bishop Meletija of Debar and the founder Sarzho Bradinoski from Tresonche (Алексиев, 1995: 26). Belonging to the order of large three-nave basilicas covered with a flat wooden ceiling in all three naves, St. Peter and Paul has quite impressive dimensions: the naos measures $11.6 / 16.1 \mathrm{~m}$ (not counting the large altar apse) and reaches a total height of $8 \mathrm{~m}$. The proportion of its plan is, therefore, 1:1.4. It was built of crushed stone with abundant use of lime mortar, with hewn limestone blocks at the profiled crown cornice, the corners of the building (where long, properly hewn blocks were arranged alternately on the shorter and longer façade) and the altar apse, which was built in precise horizontal rows of carved stone. The apse is semicircular, illuminated by a single window. Initially, the church was covered with overlapped stone slabs, which is characteristic of the architecture of the mountainous Reka region, both sacred and profane. On the west side of the naos there is an open porch, made of wooden construction: it consists of simple wooden pillars placed on a masonry 
pedestal, supporting an architrave wooden beam, which rests on short lateral wooden beams - profiled wooden capitals. Between the pillars is placed a low, decorative semi-transparent wooden fence (see fig. III.161B).

Decoratively shaped windows line the longer façades. The window jambs are made of monolithic blocks, on which a profiled semi-capital is placed, reducing the arched span of the opening (fig. III.157B). The only exception is the gallery window, which is smaller and has an architrave lintel. Above the roof of the apse, high on the east façade, there is a window shaped into an oculus made of carved stone (fig. III.157A). On the west façade, quite unusually, any windows were completely omitted. Instead, on this façade the main emphasis was placed on the entrance portal, whose door is shaped in the same way as the windows. Special attention was paid to the high arched patron saint niche in which the figures of the apostles Sts. Peter and Paul were painted in full height, with their usual attributes (St. Peter holds a keychain, and St. Paul a sword) presenting in their hands a model of the church (see fig. III.64A). The mentioned founding inscription was painted underneath this composition, which is framed with a wide border of intertwined grape leaves and ripe grapes (Алексиев, 1995: 27).
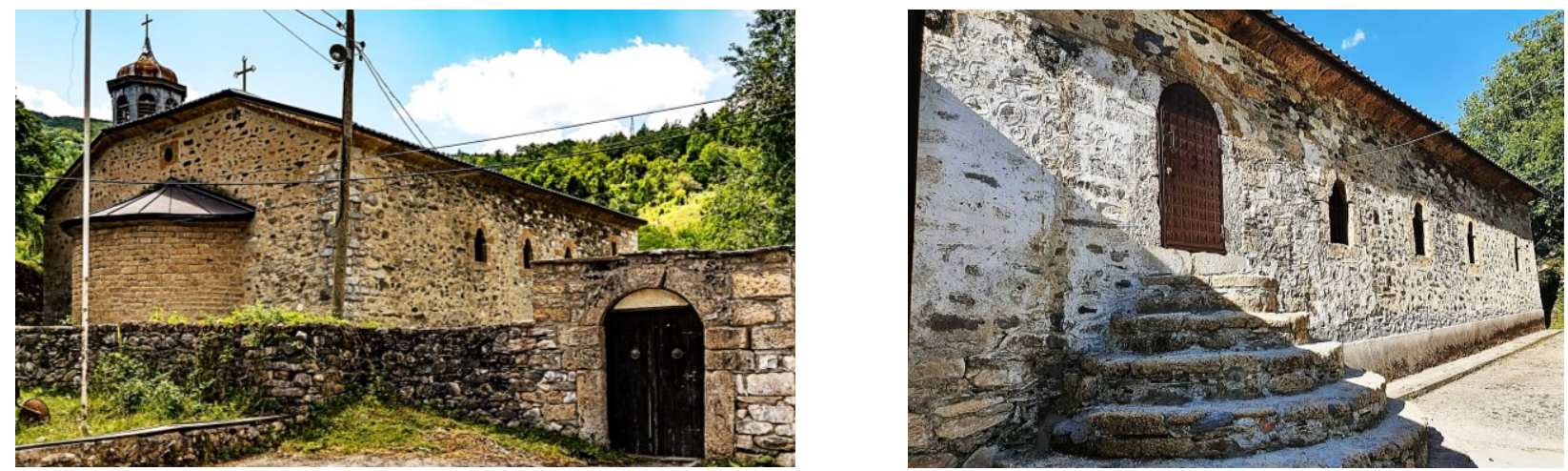

Figure III.157 St. Peter and Paul in Tresonche (Debar): A. View from the north-east; B. The southern façade.

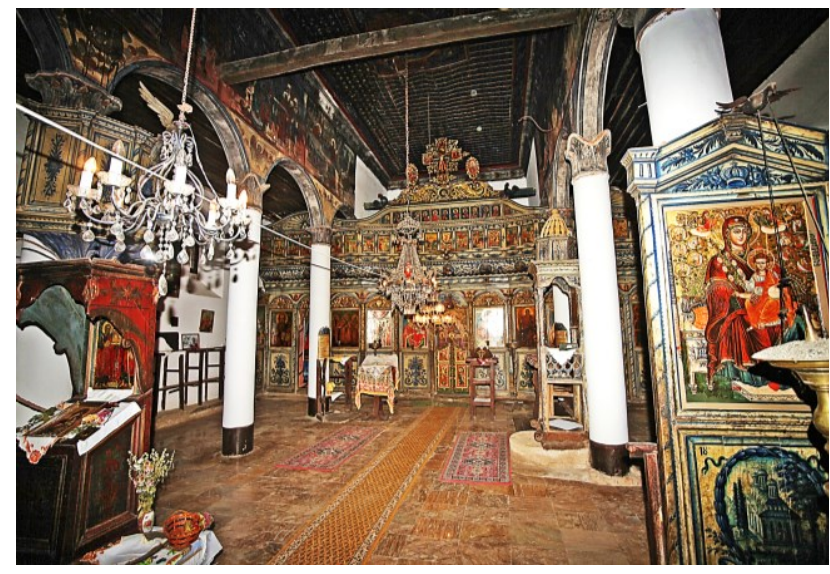

Figure III.158 St. Peter and Paul in Tresonche (Debar). View of the naos towards the altar.
Inside, the church is divided into 3 zones: a central naos, an altar to the east and a "women's church" on the gallery to the west, with a fully integrated narthex beneath (fig. III.159-160). The naos is divided into three naves by means of two rows of wooden columns, 5 in each row. Of these, the columns in the naos have a circular cross-section and were plastered, while the eastern pair of columns placed behind the altar partition were not further processed and are in fact wooden posts with square crosssection. Above the columns are placed decoratively painted capitals, processed with

different profiles in a symmetrical arrangement in pairs (fig. III.158), which support the semicircular arches (with the exception of the end spans - east and west, which were bridged by a combination of an architrave and lateral half-arches) so that they form two arcade colonnades. The basilical disposition of the temple was emphasized by a significantly taller central nave as opposed to the lateral ones, which are lower (fig. III.160B); this spatial composition was dictated by the gabled roof of the temple, with trapezoidal shorter façades. In the central nave, three wooden ties extend transversely. All three naves were covered with a flat wooden ceiling: in the lateral naves it is simpler and comprised of longitudinally arranged planks; in contrast, a coffer ceiling was formed in the central nave by placing profiled slats $(2 \mathrm{x}$ 
$5 \mathrm{~cm}$ ) in a regular raster of $20 \mathrm{~cm}$ in both directions (Филиповски и Бошковски, 1995: 22). The slats were painted in a reddish tone, against a blue background, complemented by white eight-pointed stars painted in each square field (fig. III.158, III.162).
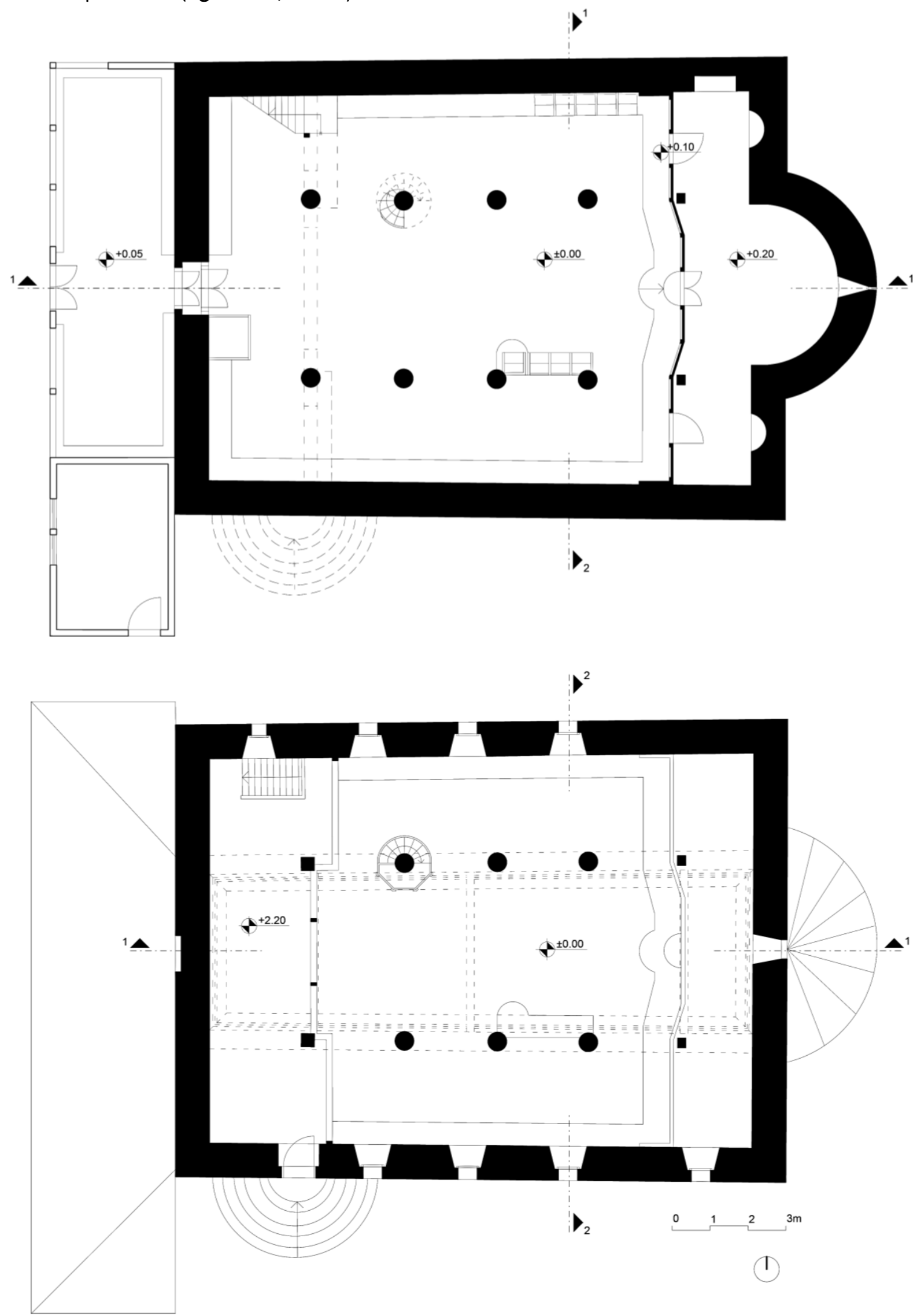

Figure III.159 St. Peter and Paul in Tresonche (Debar). Plans: A. Ground floor $( \pm 0.00)$ and B. Gallery (+2.20). 

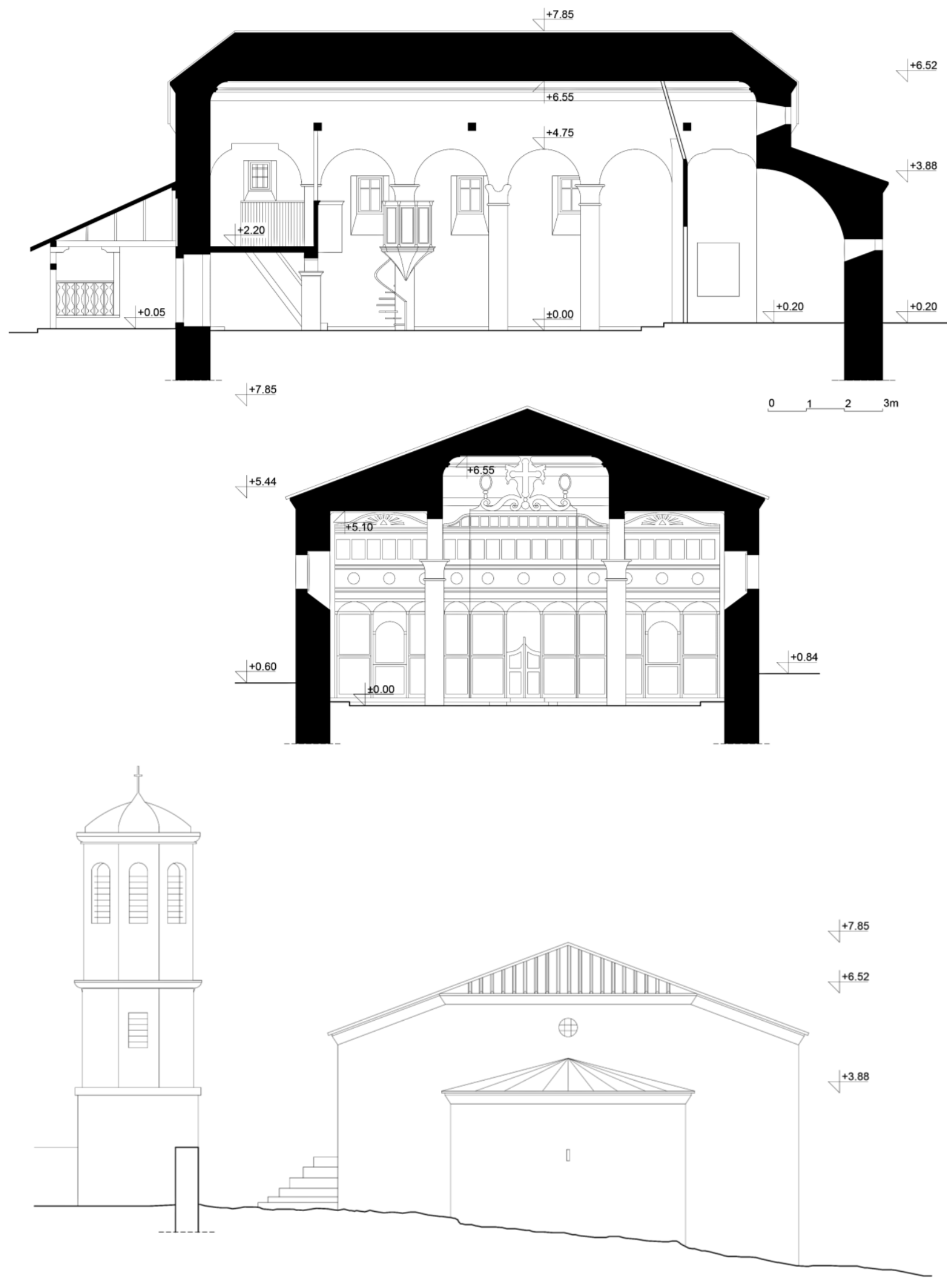

Figure III.160 (this page) St. Peter and Paul in Tresonche (Debar). A. Longitudinal section (1-1); B. Transversal section (2-2); C. Eastern façade.

Figure III.161 (opposite page) St. Peter and Paul in Tresonche (Debar). A. Southern façade; B. Western façade. 


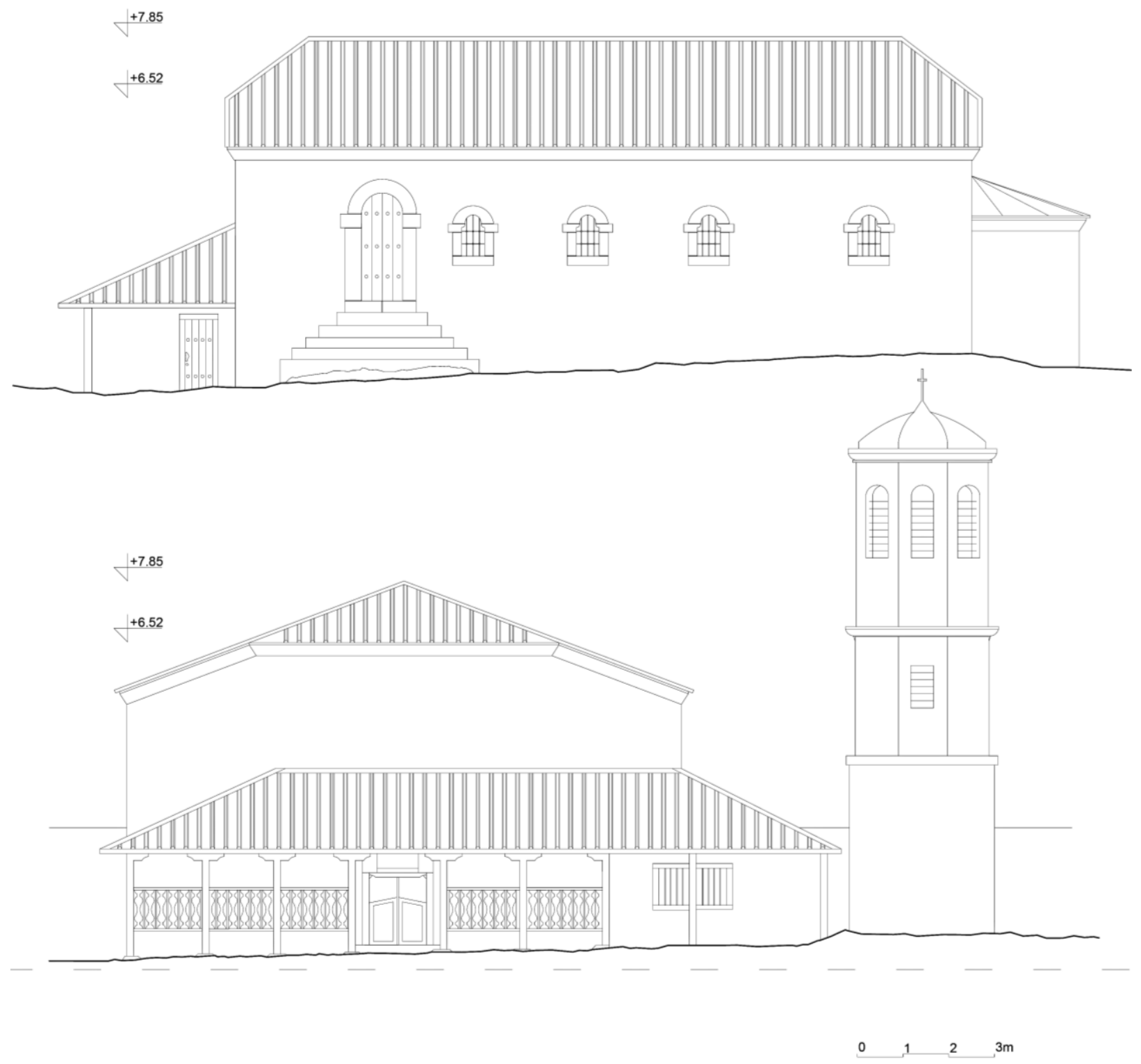

Unfortunately, during a recent renovation undertaken by the local church board, the elaborate coffer ceiling was replaced with an ordinary arrangement of wooden planks, identical with the ceilings in the lateral naves (see fig. III.163). The original coffer ceiling field was framed on all sides with a narrow strip painted with " $\mathrm{S}$ " - meander of blooming floral motifs, on the outer edge of which was placed a profiled hem, also painted in red. At the transition from the vertical wall canvases of the arcades to the horizontal plane of the ceiling in the central nave, there was a concave vaulted strip painted with floral bouquets comprised of 3 flowers (fig. III.162). In the middle of the coffer ceiling field in the central nave a rectangular surface was formed with the help of profiled frames, in which the usual representation of Christ Pantocrator was painted within a circular medallion. To the west of this framed

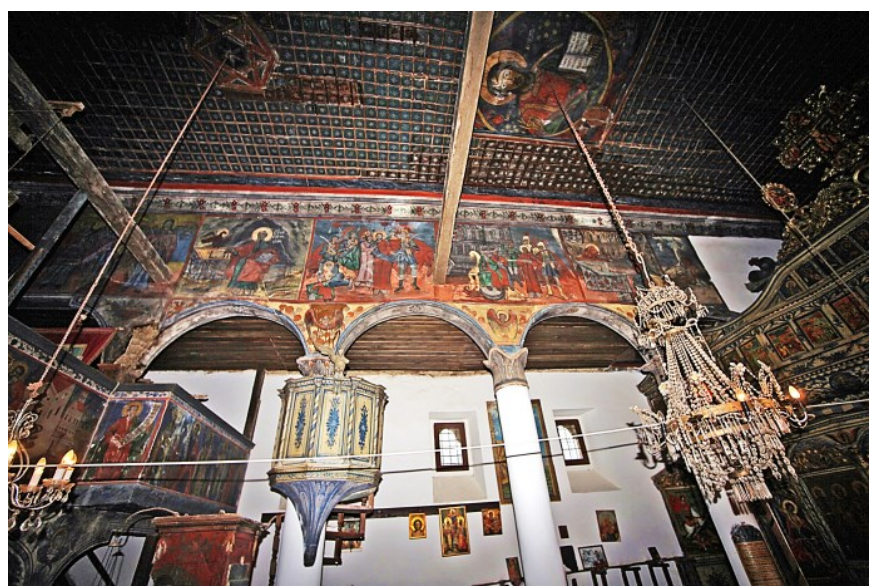

Figure III.162 St. Peter and Paul in Tresonche (Debar). View of the northern colonnade in the naos and the original coffer ceiling in the central nave. 
composition, also in the axis of the nave, a small hexagram rosette made of wood was placed, in the center of which appeared a flower with six petals. A chandelier was hung from the center of this rosette.

The gallery is accessed via wooden stairs placed in the northwest corner of the temple, and at the same time, using the topography of the sloping terrain, there is a direct entrance from the outside, from the south side, through the south entrance portal (fig. III.157B, III.161A) which is accessed by means of 6 concentric semicircular stone stairs (Филиповски и Бошковски, 1995: 21). Inside, the wooden structure of the gallery rests on the western pair of columns (Алексиев, 1995: 27) in such a way that they are in fact two sets of superimposed columns; its parapet is formed with straight lines as a very slightly hinted "U" shape - slightly drawn inwards in the central nave (fig. III.163A). The parapet is solid, made of wood, and towards the nave it was plastered and completely covered with several compositions in frescopainting. The pulpit was placed on the second column of the northern colonnade, viewed from the west, while the bishop's throne, raised on a stone pedestal with 2 semicircular stairs, is located within the southern colonnade (fig. III.163B). On both sides of the apse semicircular niches - prothesis and diaconicon - were inscribed in the east wall, as well as an additional rectangular niche in the north wall of the altar. The floor pavement of the church, which authentically consisted of stone slabs arranged over a base of compacted earth, was later (during the abovementioned renovation of the church) replaced by an elevated floor $(+20 \mathrm{~cm})$ of travertine tiles with regular, industrial dimensions. The floor of the gallery, on the other hand, has been preserved as authentic, made of wide wooden planks nailed directly to the wooden mezzanine structure.
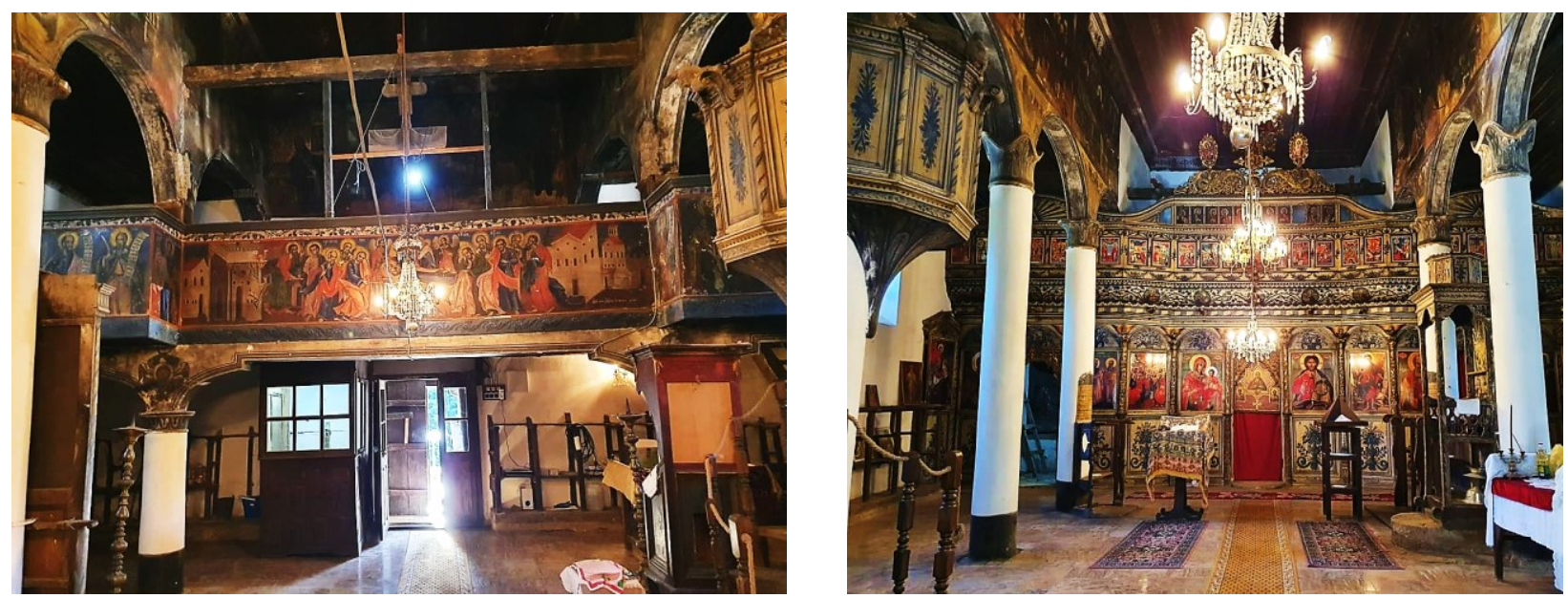

Figure III.163 St. Peter and Paul in Tresonche (Debar): A. View from the naos towards the gallery and its frescoed emporia; B. View towards the east of the naos (view of the iconostasis).

From the original fresco painting, whose author was Dicho Zograf, but few compositions remain: in addition to the lunette above the western entrance portal, one composition (the Laying in the grave) has been preserved in the prosthesis, dating from 1845. The remaining fresco ensemble (on the walls above the arcades separating the three naves, the walls in the gallery and the gallery parapet) was painted later, in 1881, by Dicho's son, Spiro Krstev (fig. III.162-163). In addition, busts of angels were painted above the column capitals, themselves also decoratively painted with acanthus leaves in blue-gray and terracotta tones. Lastly, all the elements of the church furniture were also painted: the bishop's throne, the pulpit, the icon pedestals and so on. The usual motifs prevail: floral garlands, draperies, shoots, spirally curved ribbons, acanthus leaves, birds, etc. One icon pedestal placed against a column of the southern colonnade (see fig. III.158) was painted with a three-dimensional model of a church with a central nave clerestory and three domes on tall drums, very similar to the one depicted in the patron saint composition within the western portal (see fig. III.64A), both indicatively similar to the church in the village of Sogle, near Veles, built in 1855 (see fig. III.204). 
As in all other Revival churches, the dominant role in the interior of St. Peter and Paul in Tresonche is played by the luxurious iconostasis, with icons made by Dicho Zograf, as one of his earliest iconographic works. Namely, in this church in his native village he worked on several occasions: in 1845, 1846 and 1851. Several icons are attributed to his best student and fellow villager, Petre Novev Pacharov. Finally completed in 1854, the iconostasis of the church St. Peter and Paul is very impressive, which was dictated by the very dimensions of the temple. It developes in two zones; its width enabled a symmetrical disposition with two entrances to the altar placed laterally from the royal doors (fig. III.163B). The gilded wood-carving of the columns and their capitals between the throne icons, in the lunettes above, as well as on the Crucifixion are later added elements. In its original appearance, as it has been preserved to this day, the iconostasis was characterized by decorative painting in a register of gray-blue to intense blue tones (Алексиев, 1995: 29). The spacious interior of the temple was decorated in the same style and tonality as the iconostasis, which also appears as a local feature in other churches in the region: at St. Nicholas in the same village (Tresonche), the churches in the villages Nikiforovo, Leunovo, Duf, and so on.

\section{Three-nave basilicas with flat wooden ceiling combined with vaulted segments}

This small group of three-nave basilicas (table III-9) is very similar to the previous, far more numerous group of churches with a flat wooden ceiling covering all three naves. The churches of this typological sub-group are characterized by a combination of a flat ceiling and a false wooden vault in several combinations. One solution is the appearance of a flat wooden ceiling above the central nave, while the lateral ones are covered with shallow vaults with a cross-section of a very slight circle segment (for example, at the church of St. Savior in Kozhle, near Skopje). Then, some are covered with flat wooden ceilings in the lateral naves and a truncated semi-cylindrical vault in the central nave, resulting in a sort of mirrored vault. Several churches with this specific solution are found in the region of Prespa: St. Theodore in Gorno Dupeni; St. Athanasius in Dolno Perovo (Томовски, 2000: 162), where in the middle of the vault appears a horizontal strip of flat wooden ceiling complemented with wood-carving (Николовски, 1987: 39) and St. Nicholas in Brajchino (fig. III.164).

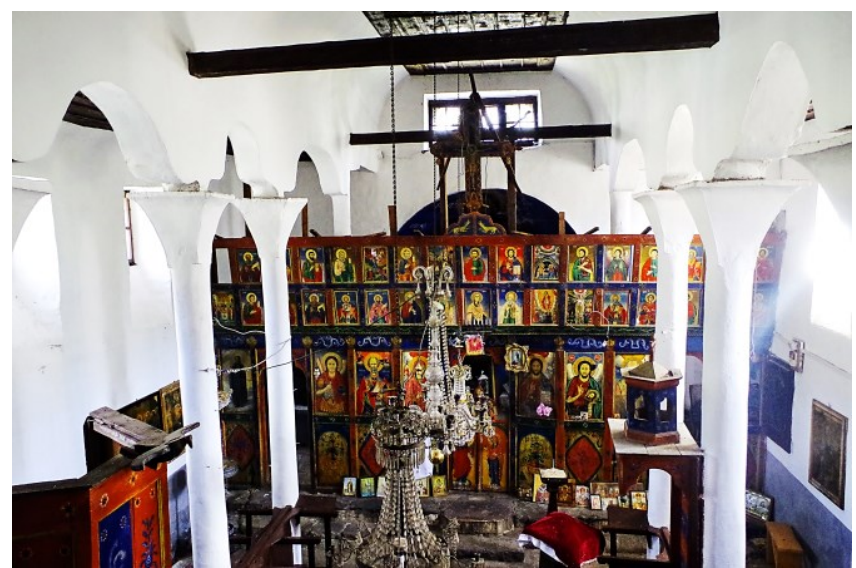

Figure III.164 St. Nicholas in Brajchino (Prespa). View of the naos, towards the east.

\begin{tabular}{|l|l|l|l|l|l|}
\hline & CHURCH & VILLAGE & REGION (TOWN) & YEAR & $\begin{array}{c}\text { ADDITIONAL INFORMATION } \\
\text { fresco-painting / icons, renovations }\end{array}$ \\
\hline 1 & St. Archangel Michael & $/$ & Berovo & 1818 & \\
\hline 2 & St. Savior - Ascension of Christ & Kozhle & Skopje & 1847 & \\
\hline 3 & St. Theodore & Gorno Dupeni & Prespa & 1848 & \\
\hline 4 & St. Athanasius & Kuklish & Strumica & 1862 & \\
\hline 5 & St. Athanasius & Dolno Perovo & Prespa & 1867 & \\
\hline 6 & St. Nicholas & Brajchino & Prespa & 1871 & \\
\hline 7 & St. Peter and Paul & Krstoar & Bitola & 1890 & \\
\hline
\end{tabular}

Table III-9 Three-nave Revival basilicas with flat wooden ceiling combined with vaulted segments.

The oldest church in this group is the monastery of St. Archangel Michael, built as early as 1818 in Berovo. In the very elongated naos $(10.2 \times 25 \mathrm{~m})$, divided into 3 naves with as many as 7 pairs of columns, a complex ceiling composition was executed, with exceptionally decorative wooden ceilings. Namely, the 
western span was covered with a continuous flat wooden ceiling which extends across all three naves, complemented with a decorative circular rosette in the longitudinal axis, with a flower motif comprised of 16 rhomboid petals, a common element on the ceilings of the most prestigious and representative town houses. In addition to the three naves separated by walls above the northern and southern arcade, the ceiling is further separated into compartments: the second span from the west in the lateral naves and the last span to the east in the central nave. The ceilings in the fields thus obtained are solved in different ways: above the side naves the planks are arranged in the shape of concentric rhombuses; above the altar they are arranged parallel to the shorter façade complemented with a central blind dome shaped like an inverted, truncated cone (fig. III.165).
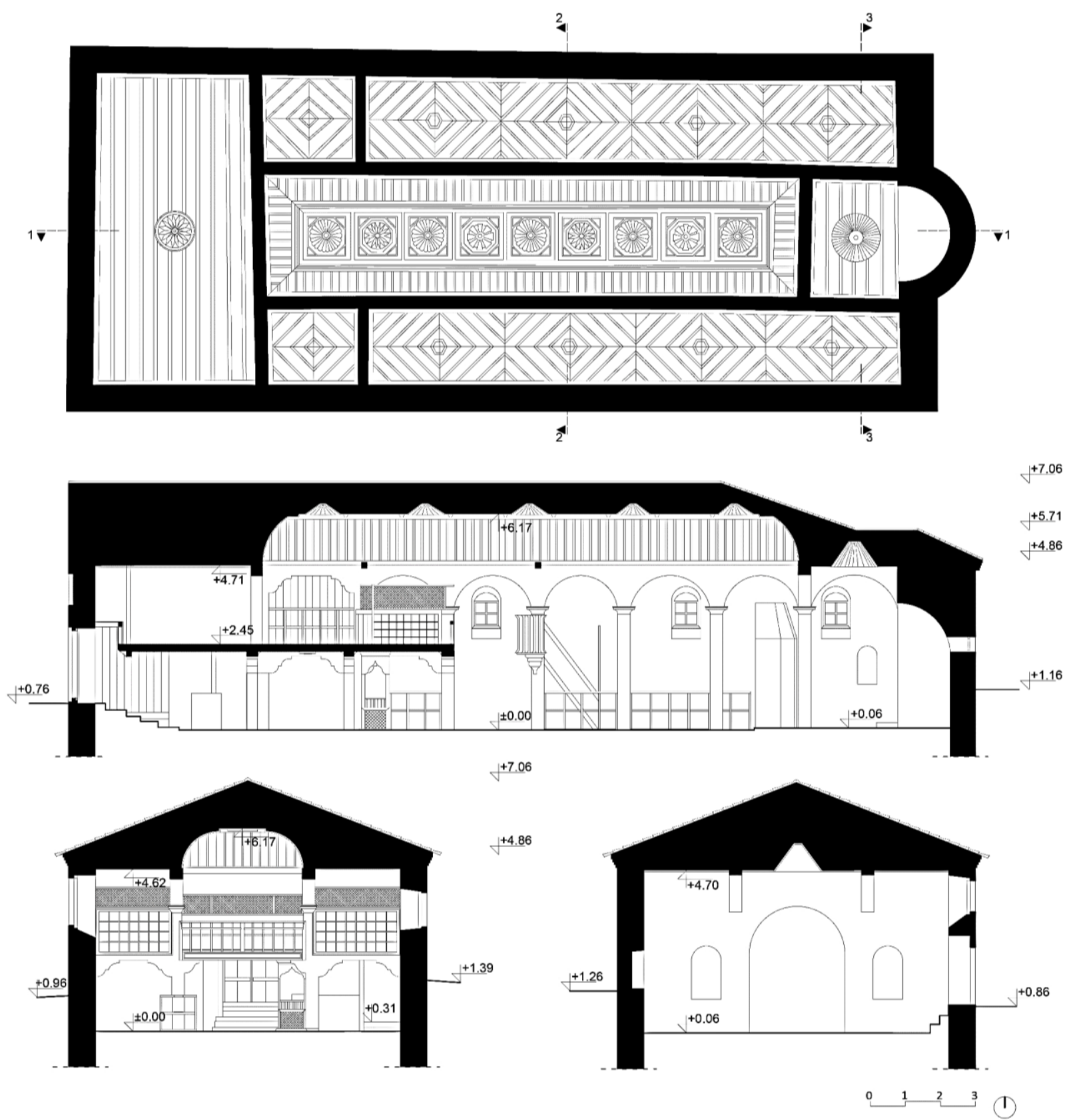

Figure III.165 St. Archangel Michael in Berovo. A. Plan of the ceiling; B. Longitudinal section (1-1); C. Transversal sections (2-2 and 3-3).

The richest and most decorative solution was used in the central nave which, in essence, is bridged with an elongated truncated semi-cylindrical vault (monastery vault). The height of the vault is $\sim 120 \mathrm{~cm}$; the flat wooden ceiling field in the middle measures $2 \times 14 \mathrm{~m}$ and is divided into 9 square fields, 
approximately $120 \times 120 \mathrm{~cm}$ each. All 9 squares are further shaped into octagons, separating the triangular segments at the corners; within the octagons alternate blind domes (shaped into an inverted, truncated cone, similar to the dome in the altar) with rosettes (circular rosettes with a flower motif with 16 rhombic petals, identical to the rosette above the gallery, and octagonal rosettes with a solar motif with an eightpointed pattern) (fig. III.165).

The roots of this typology can be traced to the three-nave basilicas with a flat wooden ceiling, among which, as was elaborated earlier, there is a significant number of churches where the passage from the vertical wall canvas to the horizontal plane of the wooden ceiling in the central nave was covered with a very narrow concave vaulted strip, plastered and decoratively painted (see fig. III.42, III.105). From such a limited vaulted arrangement surrounding a dominant field covered by flat ceiling, the quarter-vault characteristic of this stylistic subgroup developed, which will contribute to these few churches being treated as a separate typological category, halfway between the three-nave basilicas with flat wooden ceiling and those with semi-cylindrical vaults.

\section{"St. Savior - Ascension of Christ" in Kozhle (Skopje), 1847}

The church of St. Savior in Kozhle dates from 1847, as stated in the inscription ${ }^{434}$ located centrally above the royal doors of the iconostasis (fig. III.166), according to which the church as well as its frescoes ${ }^{435}$ are the work of the master-builder Georgia and his nephew Manasia from the village of Papradishte (region of Veles), home to some of the most famous master - builders, painters and woodcarvers active in the Revival (see Chapter II.3).

St. Savior in Kozhle is a three-nave basilica with, rather unusually, a very elongated plan (fig. III.170): it measures $8 \times 17 \mathrm{~m}$, which means that its proportional ratio exceeds $1: 2$ (it is precisely 1:2.125). As was customary for the XIX century monumental sacred architecture, the exterior walls of the church were built massively of crushed stone and lime mortar, while the interior structure was made entirely of wood. The naos of the church is divided into three naves with the help of two rows of four wooden columns. The eastern pair carry the iconostasis and,

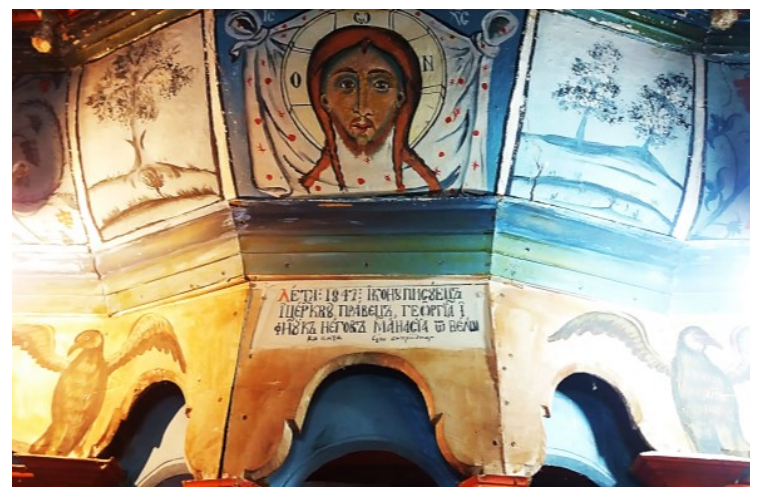

Figure III.166 St. Savior in Kozhle (Skopje). Detail of the founder's inscription on the iconostasis.

since they are hidden behind it, they were left incomplete, rough and without decorative processing. The elongation of the nave conditioned the placement of an additional pair of columns to the west, which would add to a total of five pairs; however this westernmost pair of columns was completely omitted, and the construction of the upper parts rests on the gallery system and its supporting wooden sub-structure. The columns are extremely slender and high ( $5 \mathrm{~m}$ in total), with a circular section, without bases but with simple wooden capitals in the shape of an inverted truncated tetrahedron under which a narrow torus develops (fig. III.167). ${ }^{436}$ Above the capitals, the columns are connected to each other and to the lateral

\footnotetext{
434 It reads: ЛЕ́TА 1847 ІКОН४ПИС४ЕЦZ І ЦЕРКВ४ ПРАВЕЦZ ГЕФРГІӐ І ФН४КZ НЕ́ГОВZ МӐНАСІА папрадища.

${ }^{435}$ As has been said before, it was not uncommon for the same master-builder group to take over the building and painting of a church, especially in the rural areas.

${ }^{436}$ Identical capitals, both in shape and in terms of their painted decoration, can be found at St. Nicholas in Popadija, St. Elijah in S'Ip, St. Athanasius in Novachani and St. Nicholas in Krajnici, all villages in the region of Veles. Thus, it is evident that, as a church built in a village on the border between the regions of Skopje and Veles, the church in Kozhle typologically approaches the Veles Revival basilicas, which of course is mainly due to the origin of its master-builder group.
} 
massive walls of the naos through a system of semicircular arches, which in the upper zone of the church transform the three-nave disposition of its plan into a more complex system of twelve approximately square fields, four per nave. These twelve fields are covered with a combined solution: the fields in the central nave (at an elevation of $+6.7 \mathrm{~m}$ ) are covered with a flat ceiling consisting of wooden planks covered with mortar and frescoes, while the fields above the side naves were covered with slightly rounded segments of a vault decorated in the same way. In the altar space there is no division of fields and naves - it is completely covered with a continuous wooden ceiling at an elevation of $+6.2 \mathrm{~m}$ (fig. III.171A). A wide and unusually shallow altar apse develops to the east, flanked by semicircular niches in the east wall

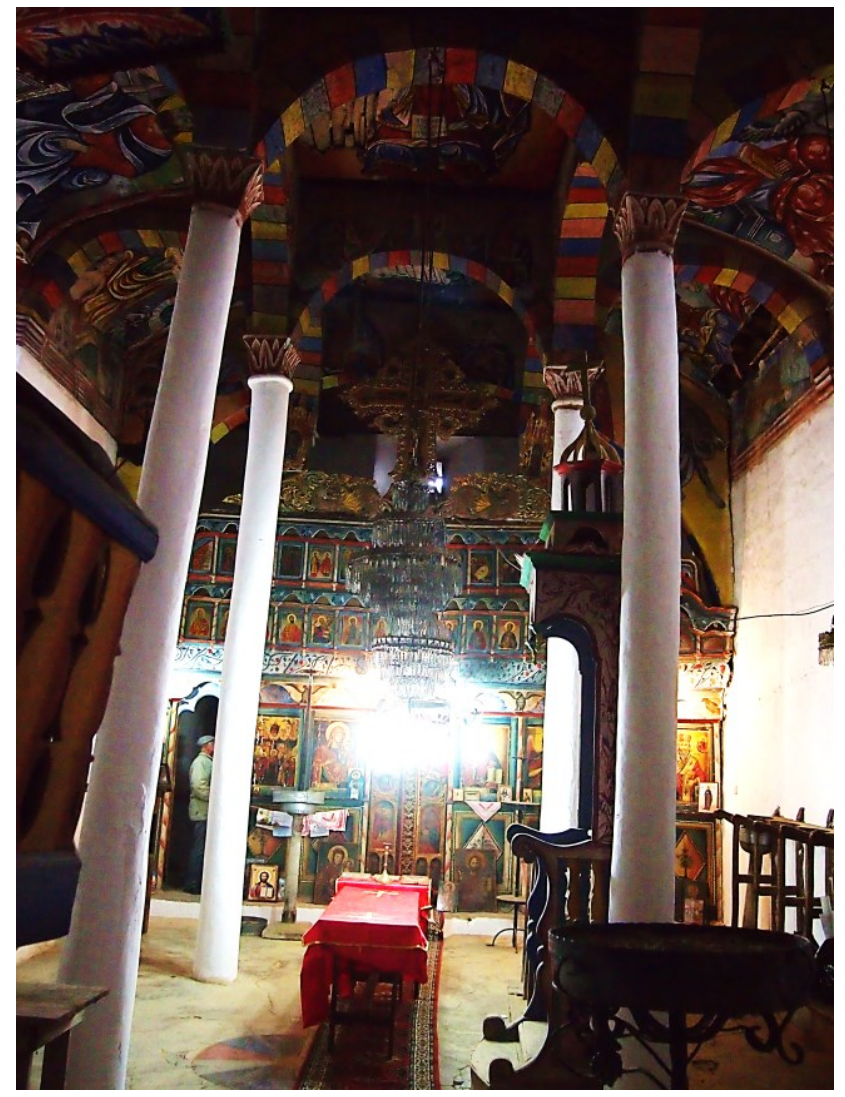

Figure III.167 St. Savior in Kozhle (Skopje). View of the naos, towards the east. (prothesis and diaconicon), with similar niches in the north and south walls. In addition to the tall iconostasis, the altar space is separated from the nave by a wide monumental semicircular arch that bridges the overall width of the nave of over $6.5 \mathrm{~m}$ (fig. III.167, III.171B). The entire width of the nave, as was common, is covered by a large gabled roof with characteristic saddle-shaped façades to the west and east (see fig. III.172). The church was originally covered with thin overlapping stone slabs, which today are preserved only over the apse, while the naos in the recent past has been covered by the locals with corrugated metal sheet to protect the frescoes from the penetration of atmospheric moisture, as well as to reduce the weight of the roof. The authentic stone paved floor is preserved only in the altar and the narthex.

Particular attention is drawn to the western parties of the church which are quite intricately designed and richly decorated. Namely, on the western side of the naos, appears a "true" narthex, whose width equals

the westernmost intercolumnial span, entirely separated from the naos by a high partition made of wood (see fig. III.46A, III.168, III.171B). The partition comprises a solid parapet topped by a semi-transparent musharabia, arranged in two rectangular fields on each side of the centrally placed double door through which the narthex and the naos communicate. The door is composed in the same way as the partition, evidence of the concept of complete and consistent design of the interior of the church, analogous to modern architectural projects, largely inspired and conditioned by the tradition of making built-in wooden furniture in residential architecture in the Revival and in the previous centuries. The narthex itself is divided into three bays through a central stone staircase, which overcomes a significant difference in height (of over $-165 \mathrm{~cm}$ ) from the western entrance portal to the naos. This was dictated by the nature of the terrain itself, since the church was built on a steep slope. The bays obtained to the north and south of the staircase were paved with spoliae - fragments of broken stone cross-shaped tombstones. ${ }^{437}$

\footnotetext{
${ }^{437}$ Identical cross-shaped tombstones abound to the north-east of the church, which implies that the village of Kozhle must have had an older (post-Byzantine) church located near the Revival one, or even beneath it, which was demolished and substituted with the church of St. Savior. This is also confirmed by two older royal door wings which today are deposited on the first gallery.
} 
As a very specific solution, not one, but two superimposed galleries develop above the narthex (fig. III.170-171). The first one, at an elevation of +3.6 $\mathrm{m}$, is accessed via a wooden staircase to the north of the western entrance portal. This gallery was intended for the choir, which accompanied the priest during liturgy, especially on the important church holidays. ${ }^{438}$ It is defined by the perimeter walls of the church on the north, west and south sides, illuminated through one very narrow slit-like window on the south wall, through which very little light penetrates, which makes this area of the church extremely dark and mystical. In contrast to this closed atmosphere that reigns at the bottom of the gallery, to the east it spreads and opens towards the naos, cantilevered for $180 \mathrm{~cm}$ beyond the partition of the narthex, into a monumental, baroque "S"- shaped curvature. Up to a height of approximately one meter from the floor, the fence is executed as a wooden construction coated with mortar. Above this solid parapet, along the entire curved line of the fence flows a musharabia (fig. III.169), analogous to the one on the ground floor of the church. On the outer (eastern) side, it is complemented by a dense row of thin wooden columns with capitals and specific decorative pendants instead of bases. As an addition to the extremely complex and rich articulation of the gallery fence, these wooden columns carry an arcade of shallow arches. Behind the fence develops a series of four wooden columns connected with wooden arches covered with plaster which support the structure of the second gallery (fig. III.169). The floor of the first gallery was made of wooden planks, as well as the ceiling, which was decorated with painted floral motifs, also found on the ceiling of the narthex, in the altar and on the stair railings.

Above this very intricately conceived and representatively processed gallery, an additional second, much smaller (less than $9 \mathrm{~m}^{2}$ ), intimate gallery appears, tucked beneath the roof at an elevation of +5.6 $\mathrm{m}$. This gallery actually took on the role of a "women's church", used primarily by young girls from the village, of age suitable for marriage. ${ }^{439}$ The second gallery is accessed via wooden " $L$ "-shaped stairs placed in the southwest corner of the first gallery. Though small, unlike the first gallery which is dark and visually maximally secluded (fig. III.169), the second gallery is illuminated by a window placed high on the west façade (fig. III.172A), though modest, with completely whitewashed walls and no additional decoration.

\footnotetext{
${ }^{438}$ According to the oral testimony of the caretaker of the church of St. Savior in Kozhle, interviewed during the author's field research at this church in the spring of 2017.

439 The same informant.
}

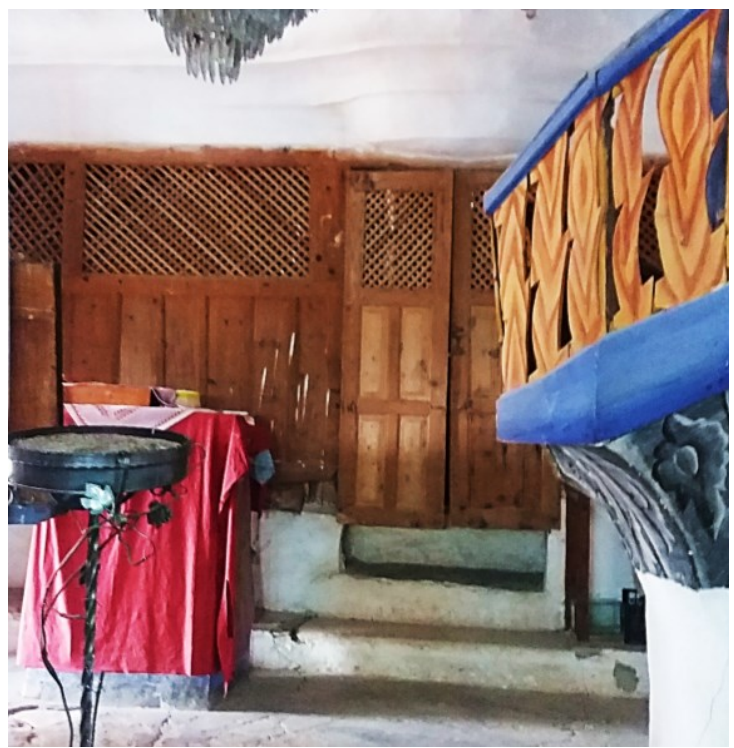

Figure III.168 St. Savior in Kozhle (Skopje). View of the narthex partition.

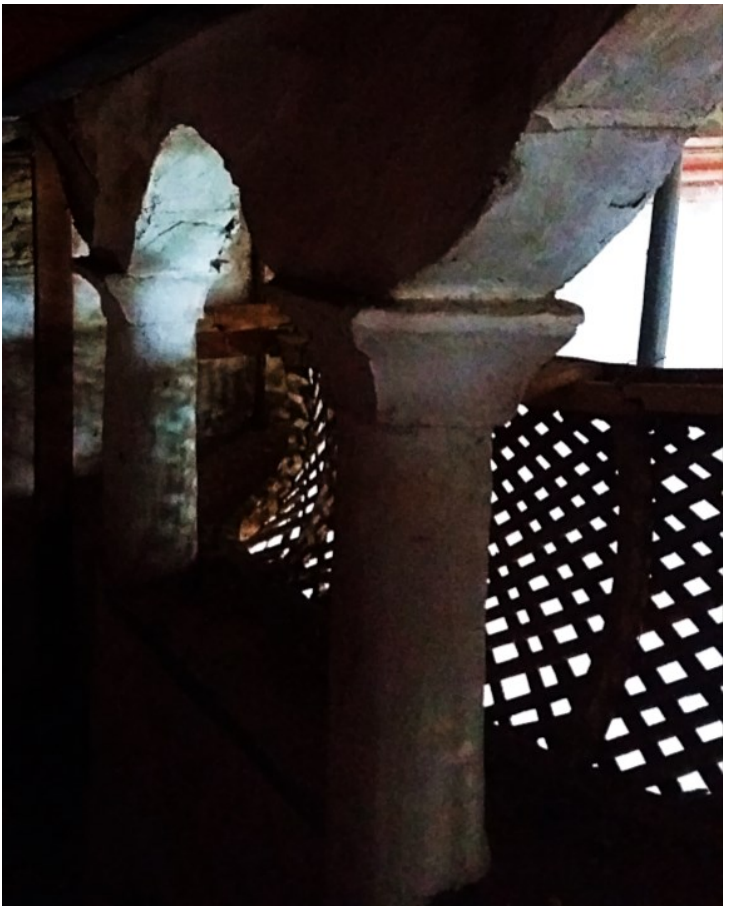

Figure III.169 St. Savior in Kozhle (Skopje). Detail of the first gallery construction, parapet and musharabia.

The same informant. 

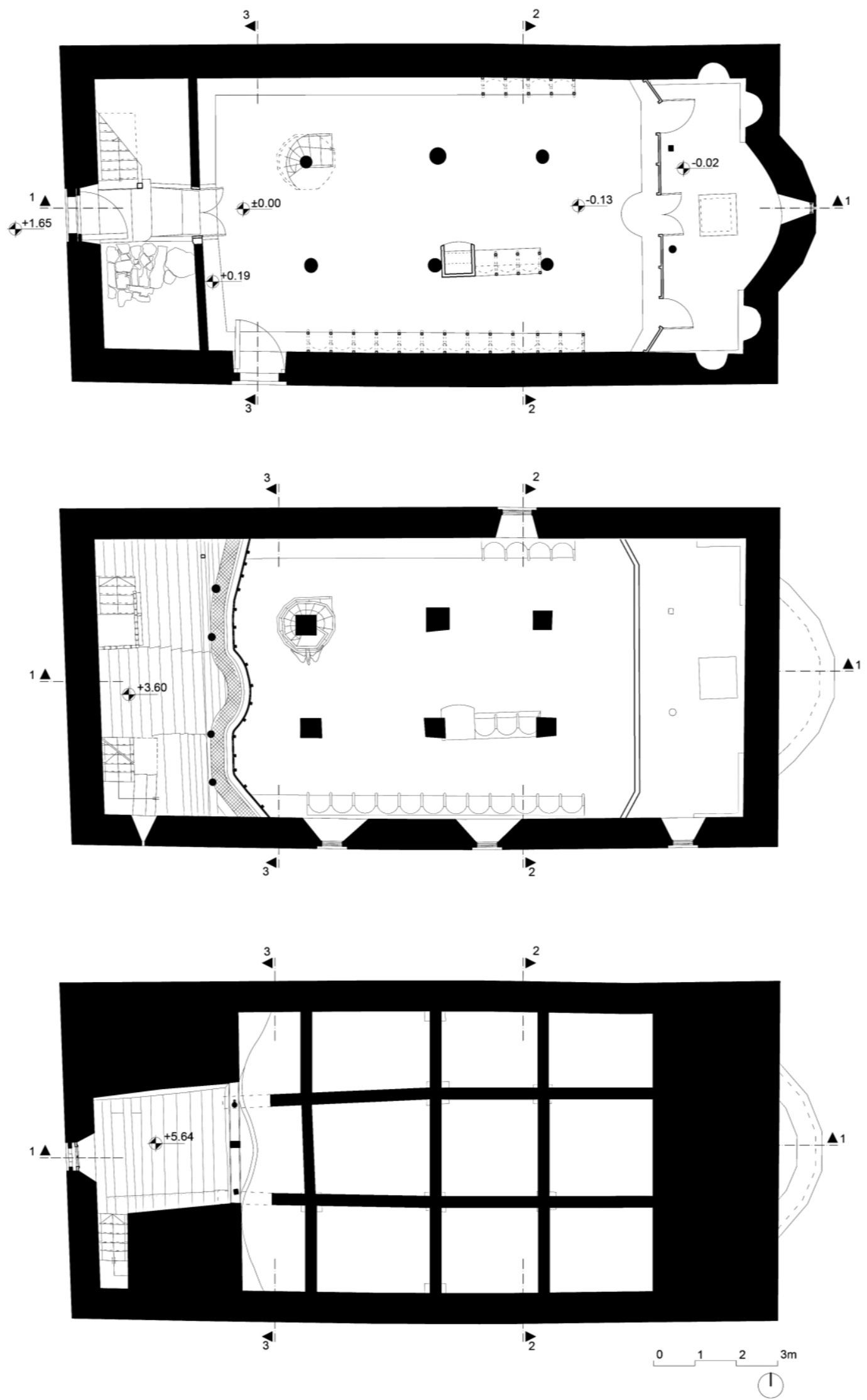

Figure III.170 St. Savior - Ascension of Christ in Kozhle (Skopje). Plans: A. Ground floor ( \pm 0.00$)$; B. First gallery $(+3.60)$; C. Second gallery (+5.64). 

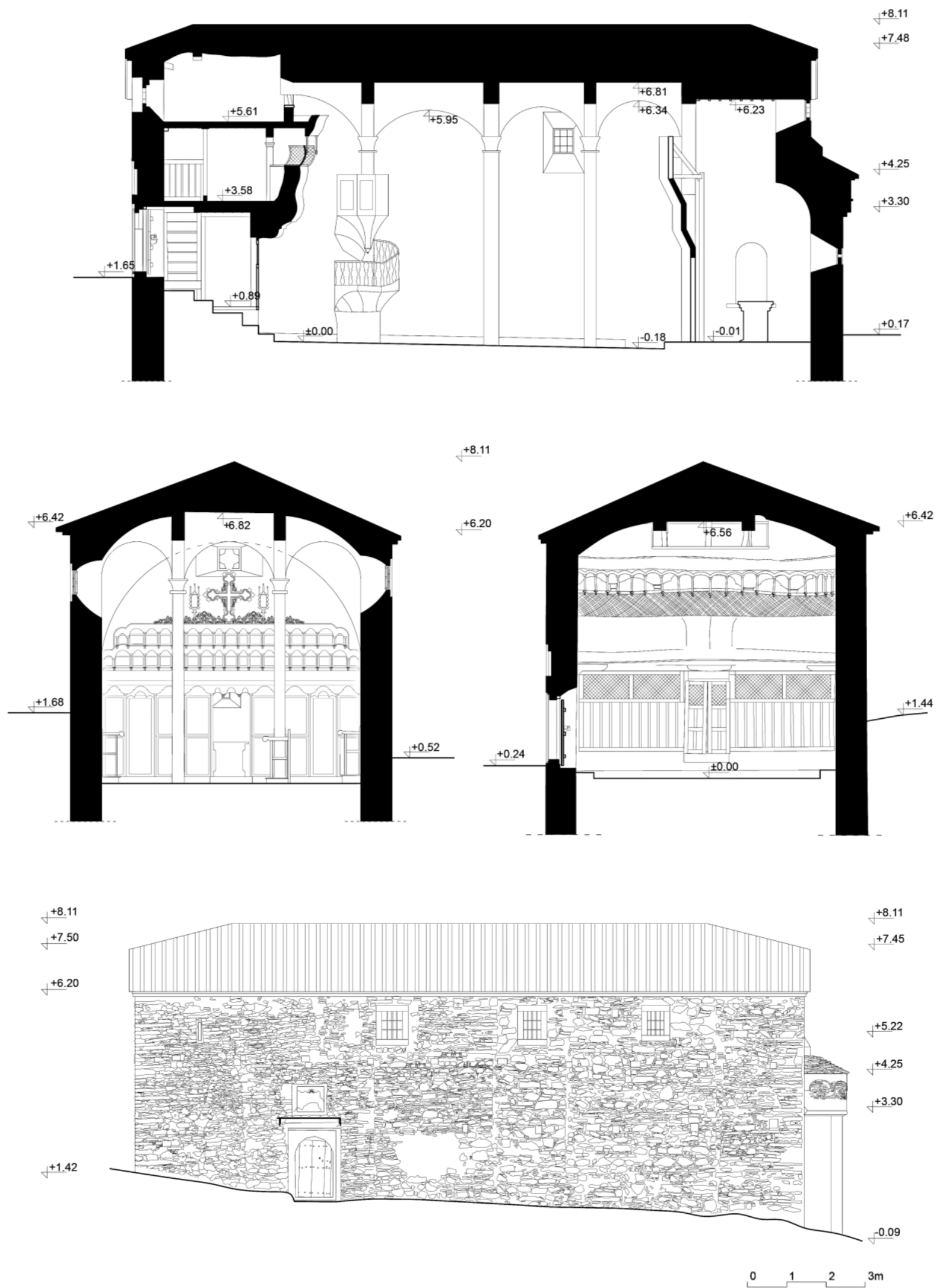

Figure III.171 St. Savior - Ascension of Christ in Kozhle (Skopje). A. Longitudinal section (1-1); B. Transversal sections (2-2, 3-3); C. Southern façade. 


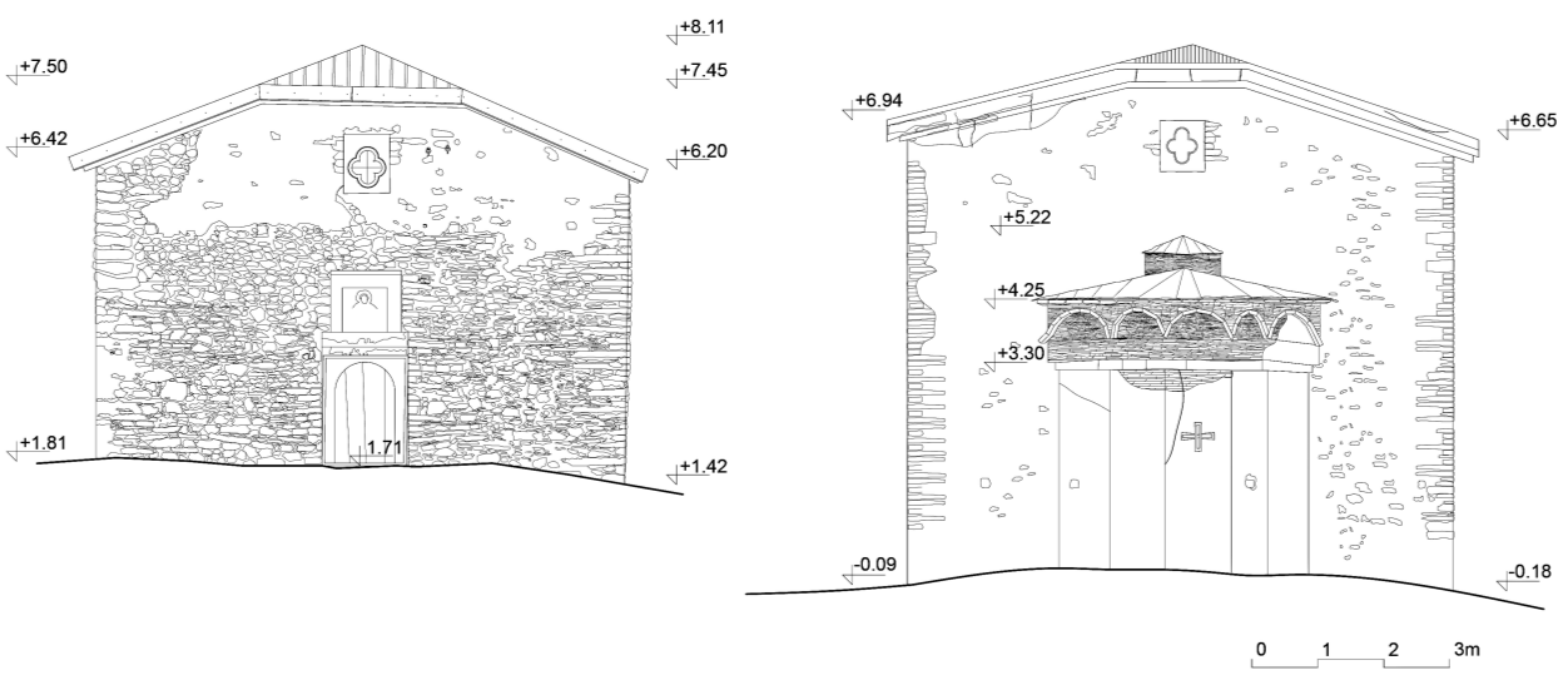

Figure III.172 St. Savior - Ascension of Christ in Kozhle (Skopje). Western and eastern façade.

The two galleries on the west side of the church, as well as their disposition and decorative processing testify to the likely model for this church, bearing in mind that very similarly conceived galleries, although significantly more monumental in size and quality of construction, are found at the church of St. Panteleimon in Veles, built by master Andreja Damjanov in 1840, i.e. only a few years prior to the church in Kozhle (see fig. III.37, III.174B). The influence that this church, recognized in science as a masterpiece of the Revival architecture (Хаџиева Алексиевска и Касапова, 2001: 49), had on the other master-builder groups that worked in the region is beyond any doubt. The presence of two galleries in the western zone results in the church developing on three levels vertically: "by superimposing the galleries the Christians climb higher and higher, feeding with a sense of sublimity, but also domination. The man here, in the second gallery, ascends to "heaven" because the vaults are his symbols. He now sees from above the sublime sanctuary - the altar, and not from a distant horizontal and unconceivable perspective as in the early temples" (Ibid: 50-51). Of course, this exceptional masterpiece of Andrea Damjanov was taken as a concept and adapted to the more modest possibilities of both the founders and the architects themselves in the case of the church in Kozhle (fig. III.173). In that direction, evident similarities exist in the baroque curvature of the

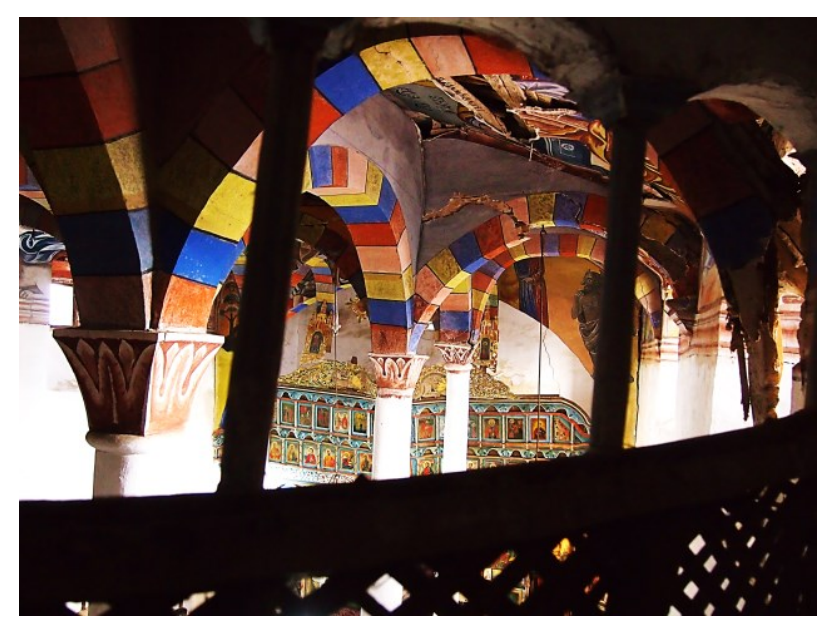

Figure III.173 St. Savior in Kozhle (Skopje). View towards the southern nave from the first gallery.

first gallery, as well as the profile used for its definition, although the damage, neglect and deformations evident in the church in Kozhle ${ }^{440}$ to some extent annulled the authentic appearance. Namely, behind the gallery parapet in Veles an arcade of wooden columns connected by semicircular arches appears, whose

\footnotetext{
${ }^{440}$ On this occasion, the extremely poor condition of the church of St. Savior in Kozhle must be noted, caused by negligence, lack of maintenance and wear and tear of the materials, as well as by external influences, primarily detonations used during the construction of the highway Skopje - Veles which passes at a short distance. Thus, deep cracks in the floor, apse and the walls are evident, the south façade is tilted outwards which caused the wooden interior structure to be almost completely separated from its massive support, especially in the south side nave. Damage to the fresco-painting and its sub-construction of plaster and wood is also visible. It can be concluded, therefore, that the condition of the church is alarming and if measures are not taken immediately, there are real chances for its upper and western parties to cave in, leading to irreversible loss of its unique architectural, craft and artistic values.
} 
capitals, unlike those in the naos which are very decorative and sculpturally processed, are shaped like an inverted tetrahedron, and for the similarities between the two churches to be further emphasized there is a torus that defines their basis. Above the gallery fence appears a series of shallow arches with the specific decorative pendants that are also present at the gallery in Kozhle. The similarities in the processing of the upper gallery at St. Panteleimon with the first gallery at St. Savior are even more bluntly evident (fig. III.174). The second gallery in Veles is significantly cantilevered in the nave, and above the fence as well as in Kozhle develops a curved musharabia, above which an absolutely identical solution was introduced: thin wooden posts (columns) with capitals and pendants instead of bases, connected by a series of semicircular arches over which an additional arcade of shallow curved arches develops, identical to those in Kozhle.
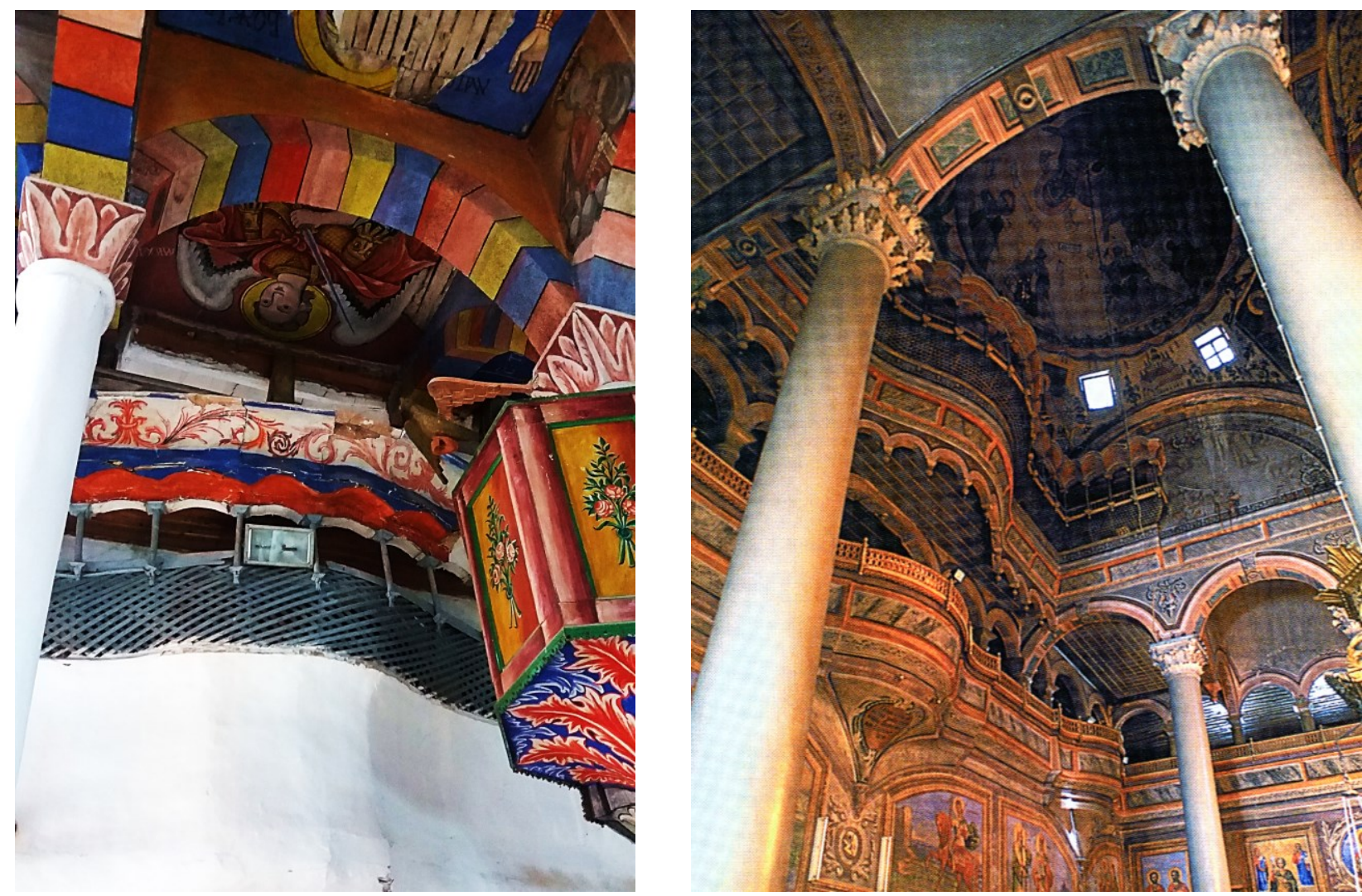

Figure III.174 View from the naos towards the superimposed galleries: A. St. Savior in Kozhle (Skopje); B. St. Panteleimon in Veles.

The fresco painting in the church in Kozhle is present on its ceiling, as well as in the upper zone of the lateral walls (fig. III.167, III.173, III.174A). Intense, bright colors were used, as well as large, monumental scenes and characters which cover an entire field of the ceiling, painted with wide strokes, heavy draperies and a specific bright background in red, blue and green tones. While the drawing has a somewhat naïve tone and not always precise proportions, the rich tonality creates a picturesque impression in the church interior, especially through its contrast with the whiteness of the lower zones of the walls, the columns and even the floor. The arches between the columns were also decoratively painted in segments in different shades: yellow, red, blue, pink; ${ }^{441}$ the capitals of the columns in the naos have stylized palm leaves painted in burgundy tones; the gallery fence including the musharabia, in contrast to the whitewashed solid parapet, was painted in gray, red and blue tones, and the final cornice was decorated with baroque floral motifs in reddish shades against a white background (fig. III.174A).

\footnotetext{
${ }^{441}$ In addition to the similarity in the treatment of the capitals, this is another feature in common with the churches in the villages of Popadija, Novachani and S'Ip (region of Veles) which were painted in more muted tones, while in Kozhle primary colors with stronger contrast were used.
} 
In addition to the constructive elements, the same richness of color was applied on the church furnishings as well. The ambo balcony displays realistically painted rose bouquets, while radiant, stylized thorny acanthus leaves in strong red and blue tones were painted on its cone-shaped base (fig. III.174A). The bishop's throne canopy, on the other hand, was painted with the same baroque floral motifs as the western gallery. Identical pendants as the ones found on the gallery fence appear on the iconostasis and the canopy. All available surfaces on the iconostasis itself were also painted: imitation of marble on the columns, floral motifs on the arches above the icons, tree of life motifs (see fig. III.166) in rhombic frames on the parapet, as well as on the cosmitis where, in addition to this ancient motif, vine shoots with ripe grapes and birds with outstretched wings were depicted. ${ }^{442}$
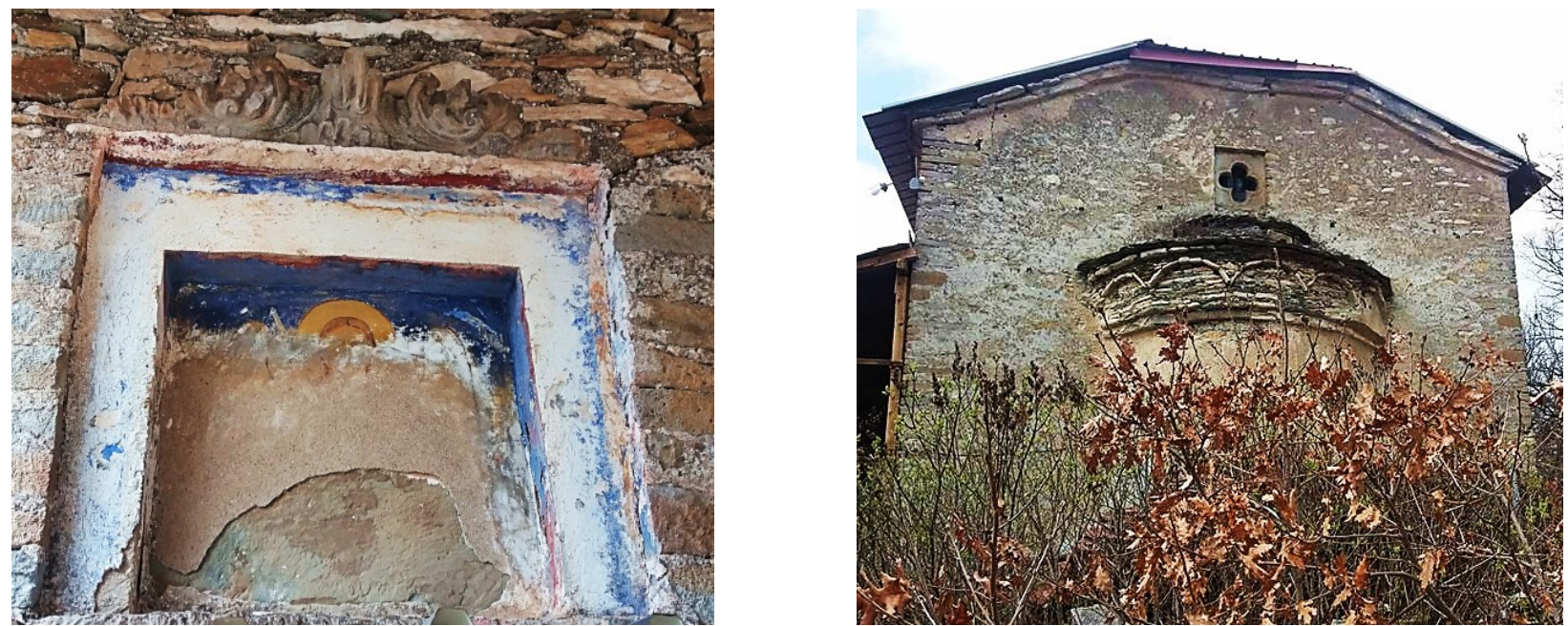

Figure III.175 St. Savior in Kozhle (Skopje): A. Detail of the southern patron saint niche; B. View of the eastern façade.

While the interior of the church is complex and richly decorated, its façades, as was often the case with the Revival churches, were simply conceptualized: made of crushed stone and mortar, without the use of decorative techniques (fig. III.171C, III.172), while the remains of plaster coatings, especially on the east façade, at the apse and in the upper parts of the west façade, speak of their complete plastering. Exceptions are the corners of the building, the windows and two-tiered stone crown cornice, which is quite damaged and has largely lost its shape. The windows high on the west and east façades received stone transennas in the form of a four-leaf clover (crux florida). Furthermore, the narrow elongated slitlike window on the apse is in fact the vertical of a simple cross whose horizontal arms, trapezoidal in shape, are made of stone. Greater attention is paid to the east façade, especially to the processing of the apse, which ends in semicircular cantilevered arcades marking each of its five sides (fig. III.172B, III.175B). A specific element is the very small additional apse placed over the first, a seemingly insignificant and almost imperceptible detail which is yet another proof that the master-builders Georgia and Manasia were inspired by the arrangement of two superimposed apses at the lateral naves of the cathedral of St. Panteleimon in Veles (see fig. III.213A), built by their famous fellow villager Andreja Damjanov.

The entrance portals (west and south) were also made of hewn stone, originally with sculptural decoration around the lunettes, which today is missing, but its traces are evident, especially at the southern portal where a fragment has been preserved (fig. III.175A). The patron saint frescoes, as a result of long-term exposure to the destructive effect of the atmospheric influences, are preserved only fragmentarily. Of course, the entrances to the temple were originally protected by open porches, probably

${ }^{442}$ All of these motifs, although archaic (pre-Christian) in origin, are visual transmitters of powerful religious messages and have been used regularly in Christian temples since the early-Christian period. 
" $L$ "-shaped, which is confirmed by the stratigraphy of the façades. Today there is only one newly built porch that partially covers the south façade.

From all of the above, it can be concluded that the structure, composition, constructive system, as well as many stylistic and decorative features connect the church of St. Savior - Ascension of Christ in Kozhle with the cathedral church of St. Panteleimon in Veles, work of Andreja Damjanov. The stylistic analogies unequivocally point to inspiration and even imitation of the slightly older church, certainly as a result of the influence that its extraordinary architecture undoubtedly had on the expression of the other master-builder groups in the years following its consecration, especially considering the origin of both groups (Damjanov's and that of master Georgia) from the same village: Papradishte, and their certain acquaintance and possible professional cooperation.

\section{III.5.B.2 THREE-NAVE BASILICAS WITH BARREL VAULTS}

The three-nave basilicas with semi-cylindrical vaults are the second most numerous typological subcategory in the large family of three-nave Revival basilicas (see map III-B, chart III-2). They represent $21 \%$ of the three-nave churches, and $9.6 \%$ of all so far typologically classified churches. Depending on whether all three naves were covered with semi-cylindrical vaults, or that particular construction was reserved only for the central nave, while the lateral ones were covered in a simpler way - with a flat wooden ceiling, this category of monuments can be further divided into two sub-groups:

1. Three-nave basilicas with a semi-cylindrical vault in the central and flat ceiling in the lateral naves;

2. Three-nave basilicas with semi-cylindrical vaults in all naves.

A more detailed study of referent examples from both sub-groups indicates their dominant distribution in different regions of Macedonia, as well as their possible conceptual base inspired by completely different older monuments, which played a role of a model in the process of their internal composition.

Three-nave basilicas with barrel vault in the central nave and flat wooden ceiling in the lateral naves

This sub-group represents a significant segment of the three-nave Revival churches: $14.4 \%$ of their total number, spread throughout the territory of Macedonia, but predominantly in its central and western parts (namely the regions of Bitola, Prilep, Mariovo, Prespa), as can be concluded from the following table (table III.10) where all of these basilicas are listed:

\begin{tabular}{|l|l|l|l|l|l|}
\hline & CHURCH & VILLAGE & REGION (TOWN) & YEAR & $\begin{array}{c}\text { ADDITIONAL INFORMATION } \\
\text { fresco-painting / icons, renovations }\end{array}$ \\
\hline 1 & St. Savior - Ascension of Christ & $/$ & Skopje & 1820 & $\begin{array}{l}\text { renovation of a post-Byzantine } \\
\text { church }\end{array}$ \\
\hline 2 & St. John the Baptist & Bogoslovec & Sveti Nikole & 1825 & \\
\hline 3 & St. Demetrius & Dihovo & Bitola & 1830 & \\
\hline 4 & St. Demetrius & $/$ & Valandovo & 1830 & \\
\hline 5 & St. Athanasius & Lenishte & Prilep & 1836 & \\
\hline 6 & St. Athanasius & $/$ & Negotino & 1837 & \\
\hline 7 & St. Cosma and Damian & $/$ & Ohrid & 1842 & \\
\hline 8 & St. Marena & Zubovce & Gostivar & 1845 & icons from 1859 \\
\hline 9 & St. Nicholas & Krivogashtani & Prilep & 1847 & fresco-painting from 1860 \\
\hline 10 & St. Nicholas & Vrben & Mavrovo & 1849 & fresco-painting from 1834? \\
\hline 11 & St. Nicholas & Nakolec & Prespa & 1854 & \\
\hline 12 & St. Nicholas & Gluvo & Skopje & 1855 & \\
\hline 13 & St. Nicholas & Virche & Delchevo & 1857 & \\
\hline 14 & St. Theodore Tyron & Drenovci & Prilep & 1857 & \\
\hline 15 & St. Savior - Ascension of Christ & Zhivojno & Bitola & 1860 & \\
\hline
\end{tabular}




\begin{tabular}{|c|c|c|c|c|c|}
\hline 16 & St. Petka & Skochivir & Mariovo & 1860 & fresco-painting from 1867 \\
\hline 17 & St. Demetrius & Balinci & Valandovo & 1860 & $\begin{array}{l}\text { damaged in the earthquake of } 1931 \\
\text { and later renovated }\end{array}$ \\
\hline 18 & St. John the Forerunner & Jankovec & Prespa & 1866 & \\
\hline 19 & St. Elijah & Aldanci & Krushevo & 1867 & dated according to the icons \\
\hline 20 & St. Panteleimon & Nikiforovo & Mavrovo & 1867 & renovated in 1923 \\
\hline 21 & St. Athanasius & Novaci & Bitola & 1868 & dated according to the frescoes \\
\hline 22 & St. Nicholas & Rotino & Bitola & 1870 & \\
\hline 23 & St. Elijah & Dragosh & Bitola & 1871 & demolished and reconstructed \\
\hline 24 & St. Nicholas & Orlanci & Kichevo & 1872 & $\begin{array}{l}\text { renovated in 1908, after a fire in } \\
1903\end{array}$ \\
\hline 25 & St. George & Kunovo & Gostivar & 1876 & \\
\hline 26 & St. George & Gorni Lipovikj & Radovish & 1877 & \\
\hline 27 & St. Nicholas & Sopot & Sveti Nikole & 1878 & \\
\hline 28 & $\begin{array}{l}\text { Dormition of the Most Holy Mother of } \\
\text { God - Vlach church }\end{array}$ & / & Veles & 1882 & \\
\hline 29 & St. Nicholas & Odri & Tetovo & 1883 & \\
\hline 30 & St. Petka / St. Demetrius & Beshishte & Mariovo & 1884 & dated according to the frescoes \\
\hline 31 & St. Demetrius & Brusnik & Bitola & & \\
\hline 32 & St. Athanasius & Strugovo & Demir Hisar & & $\begin{array}{l}\text { later enlarged to the west, added a } \\
\text { small dome on a octagonal drum }\end{array}$ \\
\hline 33 & St. John & Strezhevo & Bitola & & \\
\hline 34 & St. Nicholas & Strezhevo & Bitola & & \\
\hline 35 & St. Nicholas & Popadija & Veles & & \\
\hline
\end{tabular}

Table III-10 Three-nave Revival basilicas with a barrel vault in the central nave and flat wooden ceiling in the lateral naves.

Analyzing their architecture, it can be concluded that the churches of this specific typological subgroup directly emulate the middle-Byzantine and late-Byzantine basilicas, such as St. Nicholas in Manastir (see Chapter I.4.3), as well as the post-Byzantine three-nave basilicas, such as St. Nicholas in Gluvo near Skopje (see Chapter I.5.2), both of which were renovated precisely in the Revival. This typological concept is especially evident in the church in Gluvo, where the post-Byzantine massive masonry vault was extended to the west using a light wooden construction, whereas the lateral naves and the narthex were covered by flat wooden ceilings (see fig. I.46).

As for the Revival three-nave basilicas elaborated earlier, the predecessor of this typology can be found among the three-nave basilicas with a flat wooden ceiling with vaulted segments at the passage from the vertical walls to the horizontal plane of the ceiling in the central nave, and even more so in the three-nave basilicas with flat wooden ceilings over the lateral naves and a mirrored (monastery) vault in the central nave, composed of a semi-cylindrical vault cut (truncated) at the apex with a strip made of flat ceiling (see fig. III.164, III.165).

\section{"St. Cosmas and Damian - the Great Holy Healers" in Ohrid, 1842}

The church St. Cosmas and Damian (also known as the "Great Holy Healers", because in the old urban core of Ohrid there was already another smaller late-Byzantine church dedicated to the same saints, which in turn is known as the "Lesser Holy Healers") was built in the neighborhood of Varosh in the old town of Ohrid (fig. III.176), on the foundations of an older church inscribed in historical sources and in the collective memory of the local population. That there used to be an older church with the same dedication and within the same church parish (the second parish in Varosh, to which six other smaller churches belonged), is evidenced by the records of Cosmas Kitiski dating from 1694, where all churches in Ohrid were categorized according to their respective church parishes (neighborhoods). Several significantly older (Byzantine) icons testify to the existence of the older, original church, which are now kept in the Ohrid Gallery of Icons; two metal candlesticks with Greek inscriptions dating from 1795 (АнгеличинЖура, 2010: 82); as well as the older royal doors that were originally part of the iconostasis of the Great Holy Healers, which date from the XVI-XVII century and are a true master-piece of the Ohrid woodcarving 
school from the post-Byzantine period. These post-Byzantine royal doors today adorn the iconostasis of the church of the Most Holy Mother of God Perivleptos in Ohrid. ${ }^{443}$ Also, various marble spoliae are kept in the yard of the Great Holy Healers or have been built-in the porch: mostly fragments of columns, one fragment of a column with an inscription, two antique marble heads built into the supporting wall on the lower, eastern plateau (fig. III.176), as well as a monumental impost-capital with the monogram of Christ, which today supports the altar table (АнгеличинЖypa, 2010: 81). It is very likely that these fragments were brought from the ruins of the early-Christian basilica "Manchevci", which were discovered several years ago, located nearby, south of the Great Holy Healers church.

According to the preserved inscription ${ }^{444}$ within the patron saints fresco painted in the lunette above the main (southern) entrance portal (see fig. III.64B), the church of the Great Holy Healers was renovated in $1842,{ }^{445}$ under the

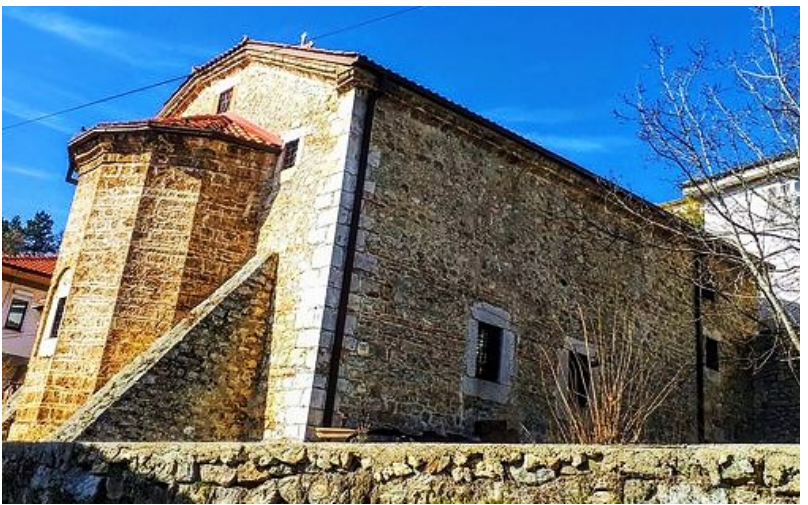

Figure III.176 St. Cosmas and Damian (the Great Holy Healers) in Ohrid. View from the north-east. auspices of the epitrope Konstantin Manchev, and fresco-painted in 1867 by Dicho Zograf from the village of Tresonche, who was commissioned by the epitrope Hristo Papa Niko. It was built on a very steep slope, on an artificially flattened plateau, ${ }^{446}$ which largely conditioned its specific solution. Namely, the western façade of the church is dug into the ground more than $4 \mathrm{~m}$, leaving less than $3 \mathrm{~m}$ between the terrain and the western crown cornice (fig. III.179180). As such, it is completely blind, without any interior illumination or decorative processing. Since the western entrance to the temple is completely absent, and the terrain denivelation is so pronounced that the western part of the church is basically a cellar, the church was divided into a smaller, almost perfectly square naos (whose total, external dimensions are 10.8 / $10 \mathrm{~m}$, not counting the apse) and a completely separate narrow narthex to the west, with an irregular (trapezoidal) plan adapted to the conditions of the terrain, with its own direct entrance from both sides, of which the south is a wide representative entrance portal, and the north is a more modestly shaped, secondary exit (fig. III.178). The narthex was also used as a baptistery, as evidenced by a small baptistery basin and a stone bench (Касапова, 2019: 320). From this narthex, which today is not in use, the naos is accessed through a wide double door.

According to its typology, the church of the Great Holy Healers is a three-nave pseudo-basilica. The naos is divided into three naves by means of three pairs of columns. The columns are very high $(5.4 \mathrm{~m}$ including the simple profiled capitals), slender and cylindrical along their entire height, with a diameter of $40 \mathrm{~cm}$. They are interconnected by semicircular arches, whose height at the apex is approximately $6.5 \mathrm{~m}$,

\footnotetext{
443 The original post-Byzantine royal doors of the church of St. Cosmas and Damian were relocated to the Perivleptos church as a replacement for its original royal doors after their forcible seizure by the Bulgarian army during World War II. Today the original Perivleptos royal doors are kept at the National History Museum in Sofia, Bulgaria.

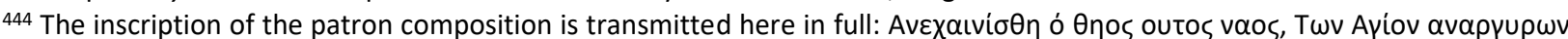

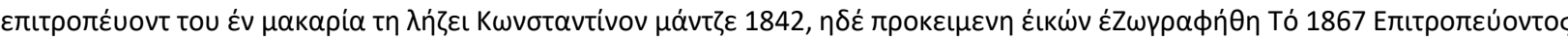

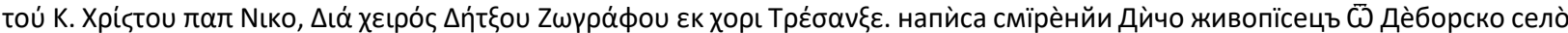
Тре́санче.

445 The log of the monastery St. Nahum informs that "in the first half of the XIX century the abbot of the monastery St. Nahum, Seraphim I (1835-1847), intended to demolish Nahum's church and build a new one. Although he received permission from the Sultan, for unknown reasons he abandoned his intention and donated the building material for the construction of the church of the Holy Healers, Cosmas and Damian” (Целакоски, Н. „Летопис на манастирот Св. Наум“ во Наум Охридски, Охрид 1985: 32, 49, quoted by Ангеличин-Жура, 2010: 81-82).

446 This disposition of the terrain has caused instability, especially in the eastern parts of the church, where there is evidence of uneven settlement of the foundations, which in the past was mitigated by two massive masonry buttresses that support the eastern façade of the church.
} 
with the exception of the eastern, much shorter span, overcome by a smaller and consequently lower arch (5.8 m measured from the floor of the naos). On the east and west walls the arches are accepted by very small consoles, shaped identically as the capitals. In the transverse direction, however, there are no arches between the columns, i.e. all three naves are covered in a continuous fashion (fig. III.177A). Only wooden ties appear in the central nave: above the last (eastern) pair of columns and above the gallery. The central nave is dominant, with a span of approximately $4.3 \mathrm{~m}$ while the lateral ones are extremely narrow, with a span of about $2 \mathrm{~m}$. In other words, their ratio is 2:1. Regarding the solution in the upper parts of the church, the central nave is covered with a semi-cylindrical vault whose maximum height reaches $8.2 \mathrm{~m}$, while the lateral naves are covered with a flat wooden ceiling at a height of $6.6 \mathrm{~m}$. The western end of the vault is interestingly shaped: it does not reach the western wall in the same way as the eastern one, but instead transforms into a slightly curved blind semi-dome (fig. III.179). In an identical way, as was said, was solved the western end of the semi-cylindrical vault at the one-nave vaulted church of St. Savior in Rashtak, near Skopje (see Chapter III.5.A.1).
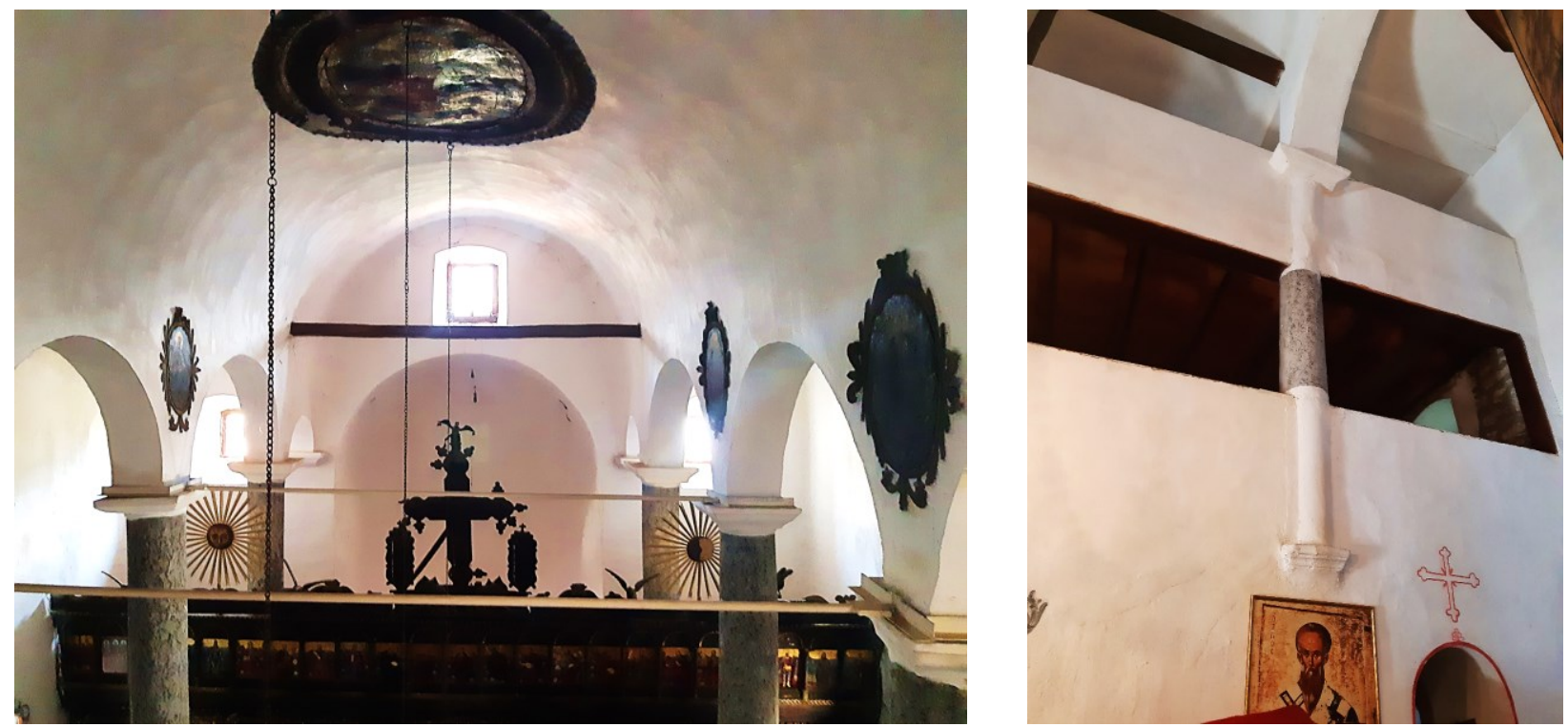

Figure III.177 St. Cosmas and Damian (the Great Holy Healers) in Ohrid: A. View from the second gallery towards the naos; B. View from the naos towards the galleries.

The impressive height of the temple allowed for two galleries to develop above the narthex. The first gallery, which extends at an elevation of $+2.45 \mathrm{~m}$, is accessed via a staircase at the southern end of the narthex, as well as through a direct entrance from the outside via external stairs made of stone, located in the western corner of the later built open porch, which in turn was closed at a later date with brick walls and glazing. The gallery basically follows the trapezoidal shape of the narthex and has variable depth (in the longitudinal axis of the church it is $3.4 \mathrm{~m}$ ). Towards the nave it has a solid flat parapet fence, without a balcony, as a continuum from the wall that separates the nave and the narthex (which in turn is interrupted by the central door flanked by two small, arched "window" openings). The fence of the second gallery (which extends at an elevation of $+4.7 \mathrm{~m}$ ) is shaped in the same way; it can therefore be said that the western wall of the naos is complete, perforated by two horizontal slits with which the gallery users (the parish women and the choir) were provided with a view of the naos. This western wall of the naos is complemented by pilasters that correspond to the profile of the columns in the naos, including their capitals (fig. III.177B). However, they do not start at floor level, but are cantilevered at a height of $2.5 \mathrm{~m}$, carried by identical consoles as the capitals themselves, which consist of a thin torus, on which is placed a wide trochilus and a segment with a rectangular cross-section. The access from the first to the 
second gallery is through wooden stairs. In addition to indirectly through the penetrations towards the naos, both galleries are illuminated through windows on the south and north facades (fig. III.178-179).
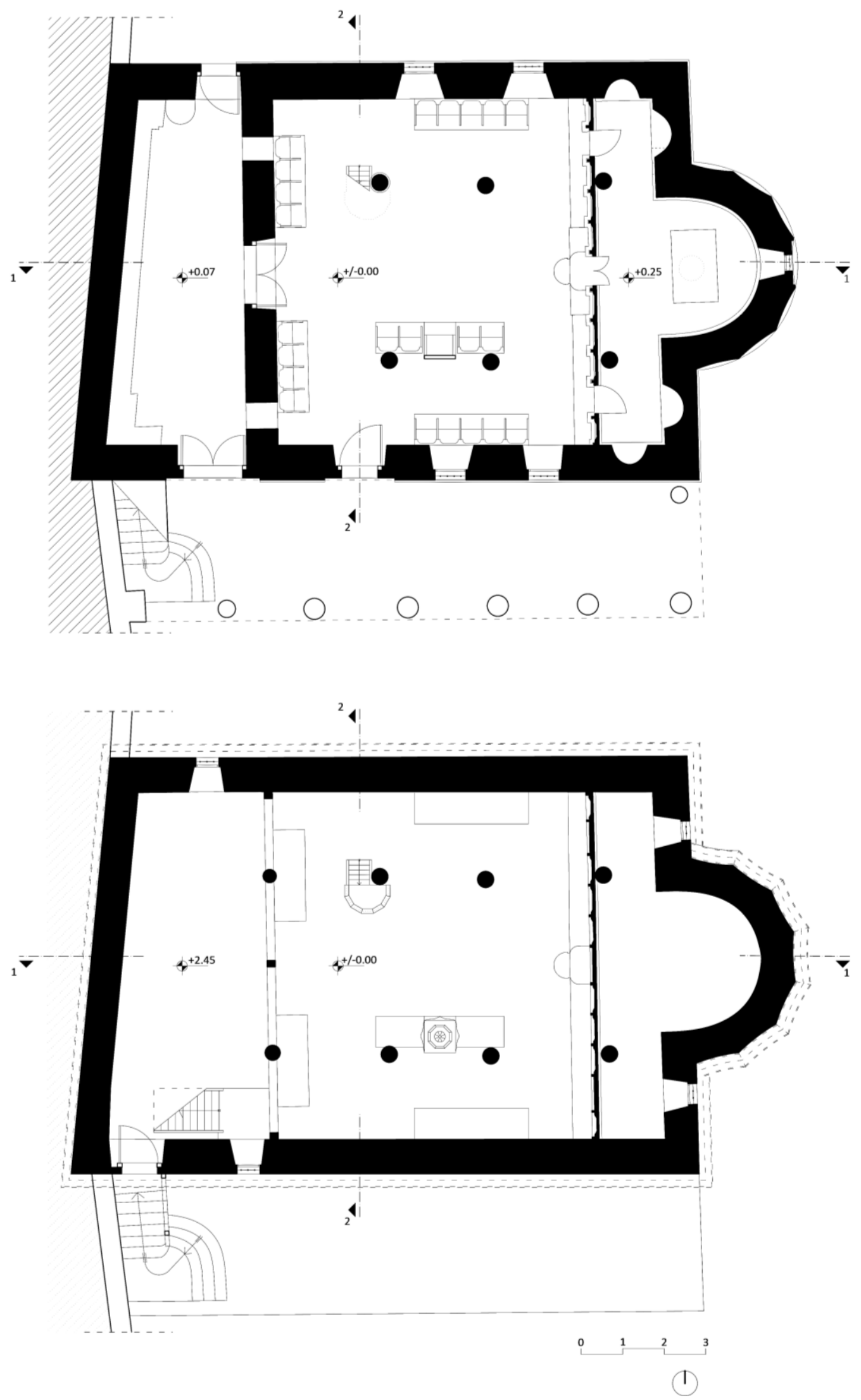

Figure III.178 St. Cosmas and Damian (the Great Holy Healers) in Ohrid. Plans: A. Ground floor ( \pm 0.00$) ;$ B. First gallery (+2.45). 

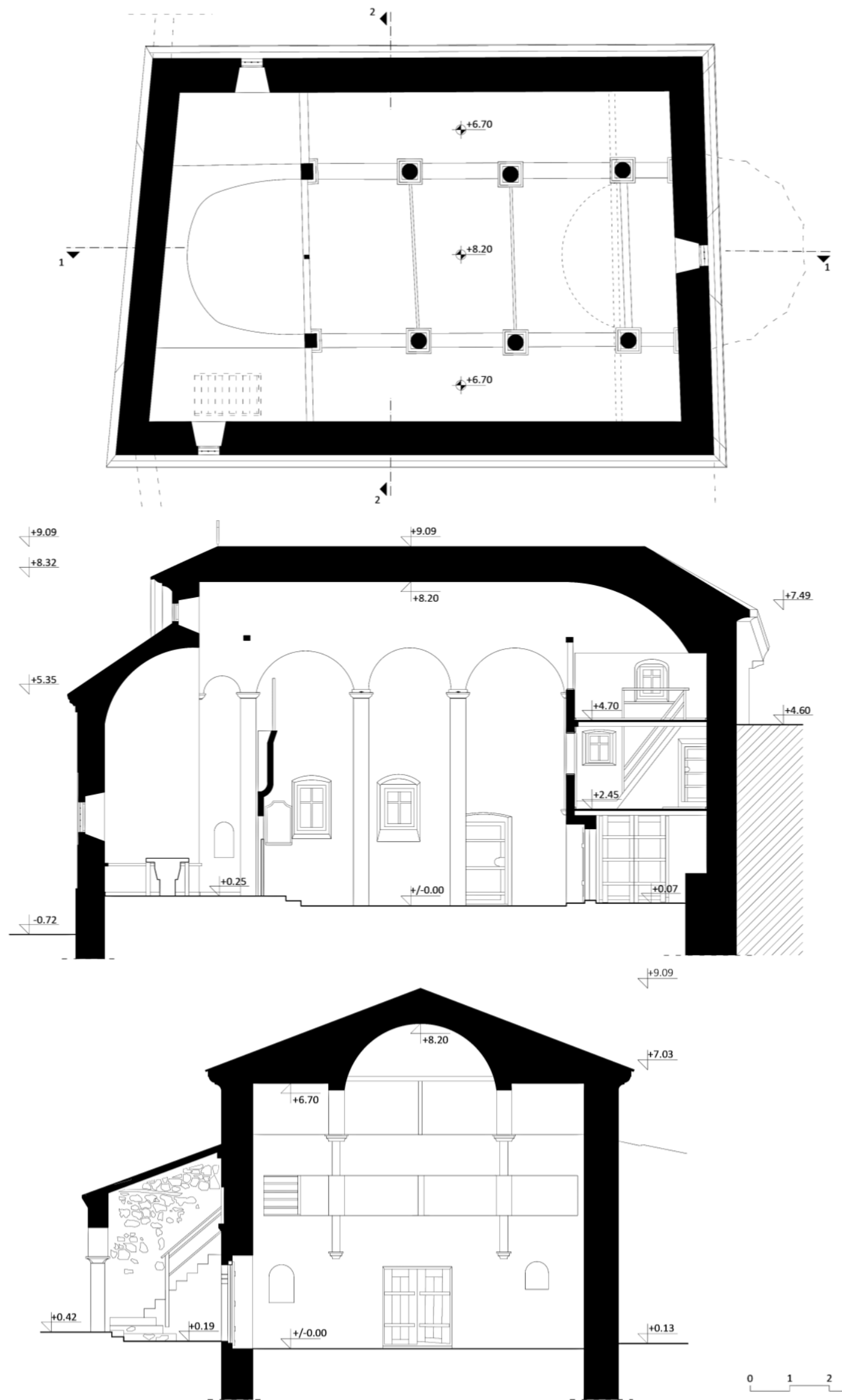

Figure III.179 St. Cosmas and Damian (the Great Holy Healers) in Ohrid: A. Second gallery (+4.70), view towards the ceiling; B. Longitudinal section (1-1); C. Transversal section (2-2). 

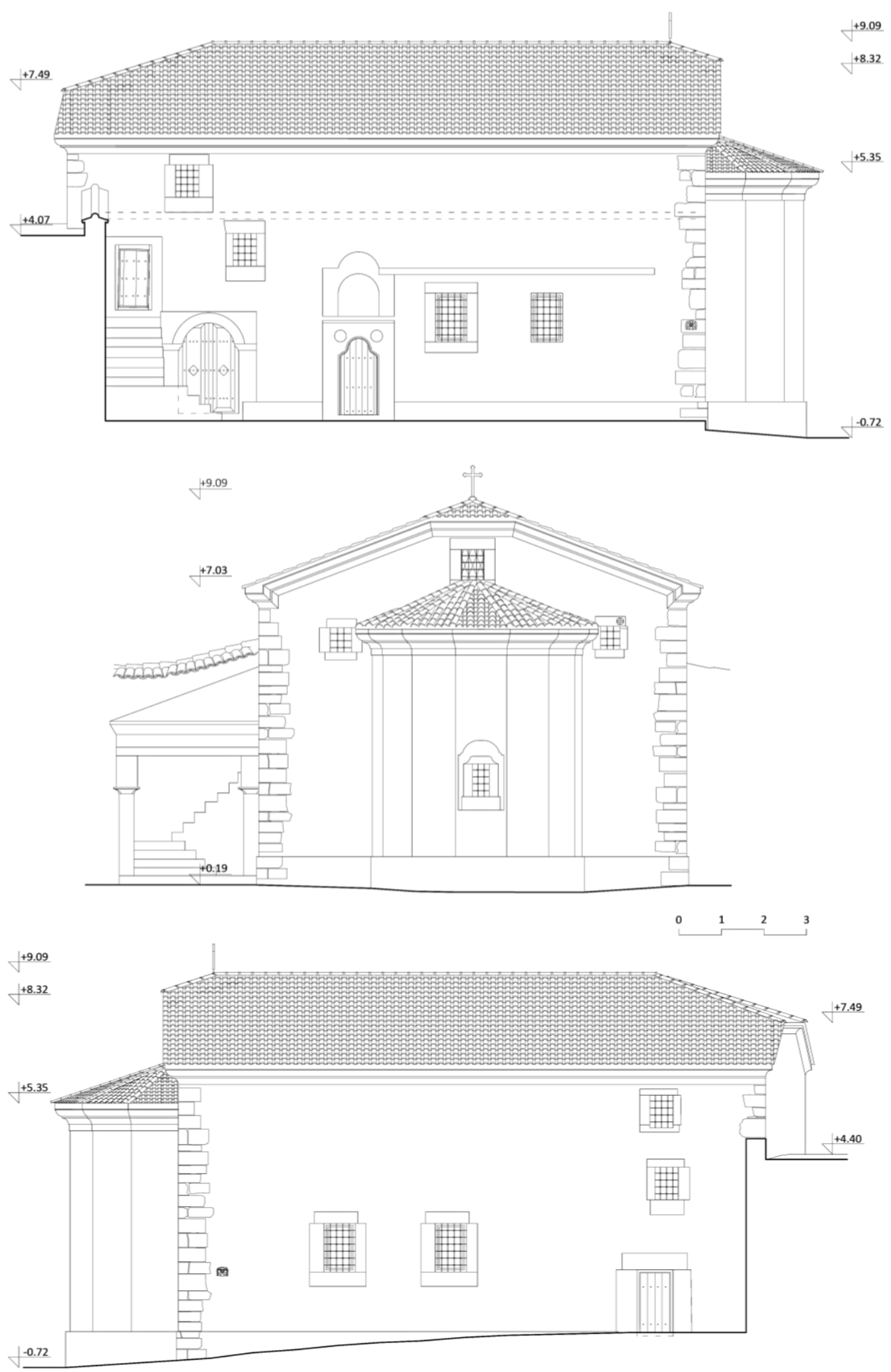

Figure III.180 St. Cosmas and Damian (the Great Holy Healers) in Ohrid: A. Southern; B. Eastern; C. Northern façade.

In addition to the windows in the gallery, the naos is illuminated via two windows placed quite low on the north and south facades, as well as one window in the axis of the seven-sided altar apse and three on the east façade, in a triangular composition: one high above and one on each side of the apse (fig. III.180B). All are rectangular, with lintels and jambs made of monolithic pieces of stone. The corners of 
the building were made of the same type of large hewn stone blocks, while the facades were made of loosely cut stone and, as a quite rare feature, brick. Namely, on the north and south façade, in their lower halves, appear remains of two layers of brick; brick is especially present on the east façade, especially the apse built in a traditional opus cloisonné masonry, with one vertical brick between the stone blocks and alternating rows of stone and brick. Also, the window in the axis of the apse is placed in a shallow, arched niche, constructed with brick. In addition to the windows and the corners, the crown cornices were also made of precisely hewn stone blocks.
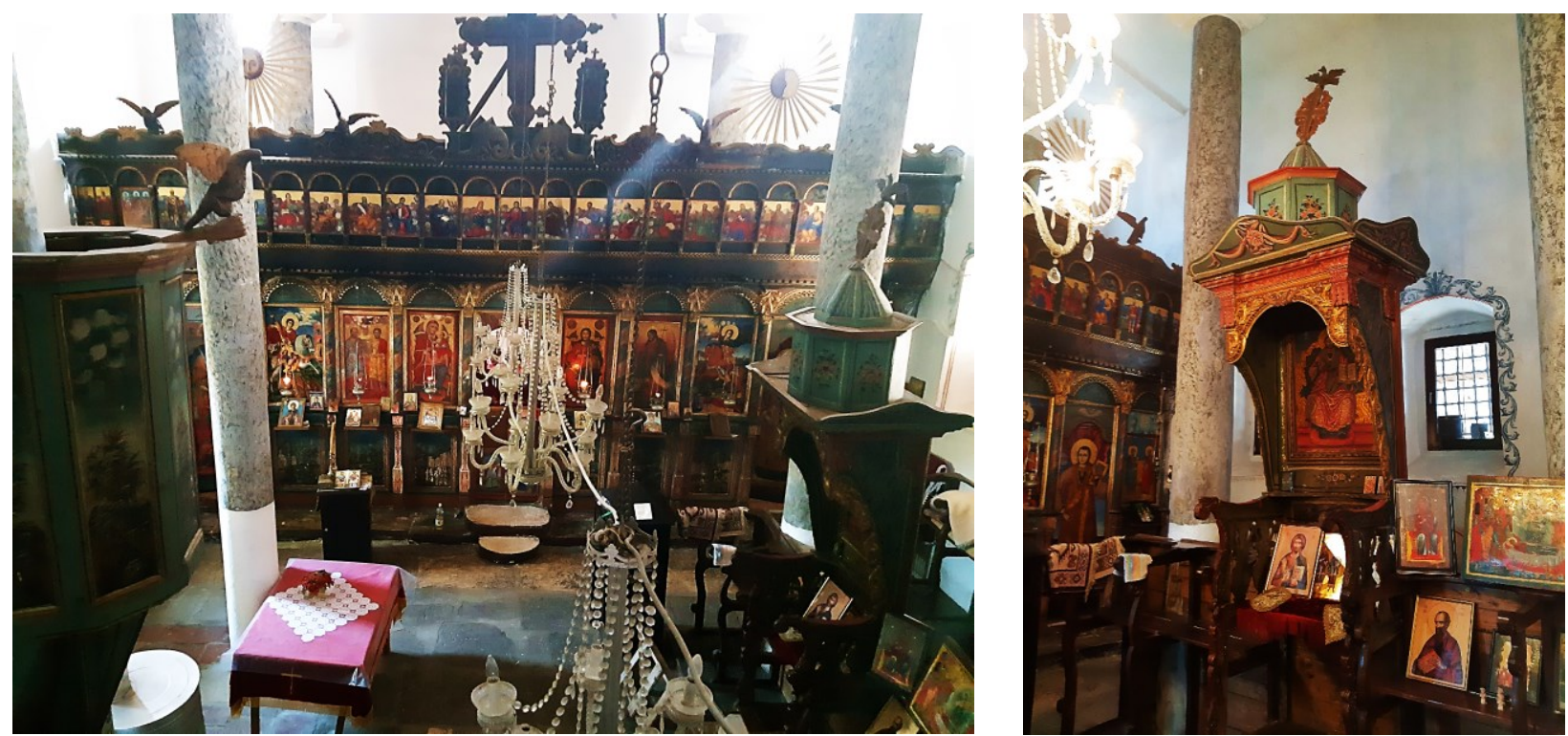

Figure III.181 St. Cosmas and Damian (the Great Holy Healers) in Ohrid: A. View from the first gallery towards the naos; B. Detail of the bishop's throne.

The interior was decorated in the spirit of the Revival. The trunks of the columns were plastered and painted as an imitation of precious stone. The floor was paved with large stone slabs, in the altar later unfortunately replaced by ceramic tiles. All the walls, ceilings and the vault are whitewashed, with the exception of a circular medallion with the fresco of Christ Pantocrator painted in the axis of the central nave vault (fig. III.177A). In addition, above the capitals of the columns in the central nave, between the arches, four small oval mandorlas depicting the four evangelists were painted and framed with a floral bas-relief frame. The mandorlas, the medallion and also the patron saint niche, are the work of the famous painter Dicho Zograf who worked in Ohrid in the given period (specifically in 1867). The patron saint composition is especially impressive (see fig. III.64B). In its composition the concept that Dicho Zograf applied to the patron saint niche of the church of St. Peter and Paul in Tresonche (from 1844) can be recognized (see fig. III.64A): the two saints are depicted in full height, dressed in richly ornamented garments, with floral motifs and whimsical robes in green and burgundy tones; presented with their usual attributes related to their profession in their hands. Between them descends Christ from the clouds with a whirling drapery; he holds the gospel in his left hand and blesses the scene with his right. The lunette is framed with a wide frame in blue tones lined with a series of simplified palm leaves, large phytomorphic " $\mathrm{S}$ " volutes, and above the lunette appears a leafy motif in the form of a crown. The inscriptions are made in the Greek and Cyrilic alphabet. To the east of the lunette along the southern façade flows a long narrow inscription in Greek, of which only a fragment is preserved, while the rest is illegible due to long-term exposure to atmospheric influences. The patron saint niche is actually part of the beautifully shaped south entrance portal, whose opening was made as a combination of concave and convex arched segments. Additionally, the portal was complemented by decoration in shallow relief: in a symmetrical composition two circular medallions appear in which identical twelve-sided rosettes were inscribed. The other 
entrance portal which leads directly to the narthex, placed to the west of this main entrance, is made of precisely shaped blocks, but without any relief ornaments (fig. III.180A).

The main emphasis in the interior is, as always, on the tall, two-zone iconostasis (fig. III.181A). It was made in 1850 and contains sixty icons by several prominent Revival painters: Manuil Georgiev and Konstantin Jovanov from Selica, Aegean Macedonia; Anastas from Magarevo and his associate the priest Hristo Konstantinov; Mihail from Magarevo (Ангеличин-Жура, 2010: 82), etc. The icons date from the 1820s and 1850-1851 and have signatures in Greek. The iconostasis was conceived in a symmetrical composition: it is divided into 11 fields, of which the central one is wider and houses the royal doors, while in the penultimate ones to the north and south there are tall doors leading to the altar, more precisely the spaces intended for prothesis and diaconicon. It was completely painted, with floral bouquets, branches, spiral stripes on the columns between the throne icons, etc. The plinth panels are especially unique, where instead of the usual vases with flowers or the tree of life motif appear painted urban scenes, architecture and landscape (see fig. II.13A). As usual, a Crucifix was placed above the second row of smaller icons, flanked by sculptural

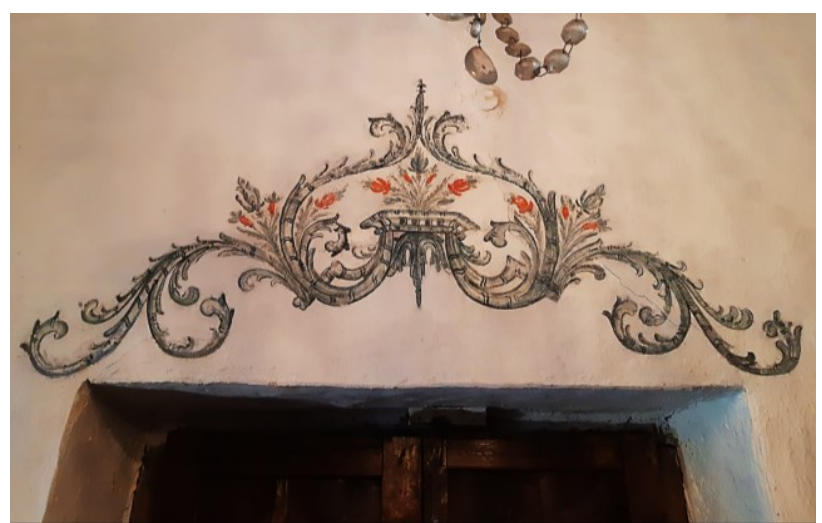

Figure III.182 St. Cosmas and Damian (the Great Holy Healers) in Ohrid. Detail of the painted ornament. representations of birds with outstretched wings, solar motifs etc.

In addition to the iconostasis, the church also houses appropriate church furnishings. Namely, the lateral naves are separated from the central one with a low partition with wooden seats for the congregation placed on both sides (as well as along the north and south walls). A richly decorated and fully painted bishop's throne was placed within the southern colonnade, complemented by details in woodcarving and gilding (fig. III.181B). Its background, analogous to the plinth of the iconostasis, was painted with an oval mandorla depicting a landscape scene complemented by urban architectural scenery (see fig. II.13B). Within the northern colonnade appears a pulpit with a polygonal balcony fenced with a full parapet, whose sides were painted with landscape scenes - "tree of life" motifs. Additionally, above the window and door lintels, highly decorative ornaments consisting of floral shoots, baroque whirled garlands and " $\mathrm{S}$ " volutes were painted using a predominantly bluish-gray hue (fig. III.181B, III.182), which enhances the contrast of this decoration with the uniformly white background.

\section{Three-nave basilicas with barrel vaults in all three naves}

Unlike the three-nave basilicas with a semi-cylindrical vault only above the central nave, the basilicas where all three naves are bridged with a semi-cylindrical vault are significantly smaller in number. So far, only 16 such buildings have been registered (i.e. $6.6 \%$ of the total number of three-nave basilicas), which certainly does not mean that this number is final. Also, unlike the first group, the churches of this typological sub-group are not concentrated in one region. A more detailed analysis of their distribution (see map III-B, table III-11) suggests their concentration in primarily two regions: the north-eastern region (Kriva Palanka, Kratovo, Kumanovo, Sveti Nikole, Kochani, i.e. the wider Osogovo region) and the southwestern region (Bitola and Prespa). The similarities between individual churches from one region speak of their construction by the same master-builder group that moved for work through the given region, as 
well as of their construction according to a more representative local model. The three-nave basilicas covered by barrel vault in all three naves are listed in the table below:

\begin{tabular}{|l|l|l|l|l|l|}
\hline & CHURCH & VILLAGE & REGION (TOWN) & YEAR & $\begin{array}{c}\text { ADDITIONAL INFORMATION } \\
\text { fresco-painting / icons, renovations }\end{array}$ \\
\hline 1 & St. Elijah & Dobrejci & Strumica & 1812 & \\
\hline 2 & St. John & $/$ & Kratovo & 1836 & \\
\hline 3 & St. Athanasius & Kokoshinje & Kumanovo & 1842 & \\
\hline 4 & St. Demetrius & Stracin & Kratovo & 1847 & demolished, a new church was built in \\
\hline 5 & St. Nicholas & $/$ & Sveti Nikole & 1847 & its place in 1983 \\
\hline 6 & St. Petka & Radibush & Kriva Palanka & 1859 & \\
\hline 7 & St. George & Ramna & Bitola & 1861 & \\
\hline 8 & St. Savior - Ascension of Christ & Beli & Kochani & 1870 & \\
\hline 9 & St. George & Drmeni & Prespa & 1871 & \\
\hline 10 & St. Nicholas & Mirkovci & Skopje & 1873 & \\
\hline 11 & St. Nicholas & Carev Dvor & Prespa & 1875 & \\
\hline 12 & St. Elijah & Zhivenje & Kumanovo & 1885 & \\
\hline 13 & St. Constantine and Helena & Sokolarci & Kochani & 1890 & \\
\hline 14 & St. Petka & Rugjince & Kumanovo & 1894 & \\
\hline 15 & St. Demetrius & Bukovo & Bitola & 1895 & \\
\hline 16 & St. John the Baptist & Dreveno & Probishtip & & \\
\hline
\end{tabular}

Table III-11 Three-nave Revival basilicas with barrel vaults in all three naves.

The churches from this group are characterized by a large naos, divided into three naves with the help of two arcades of 3, 4 or more columns, covered along their entire length by semi-cylindrical vaults. In some of them, for example, the churches of St. Demetrius in Stracin (fig. III.183); St. George in Drmeni, etc., the semi-cylindrical vaults, especially in the central nave, were reinforced with arched ribs, supported on consoles. On the fifth façade, there is no central nave clerestory; these churches are rather pseudobasilicas. They regularly have a tall iconostasis and a gallery on the west side of the naos.

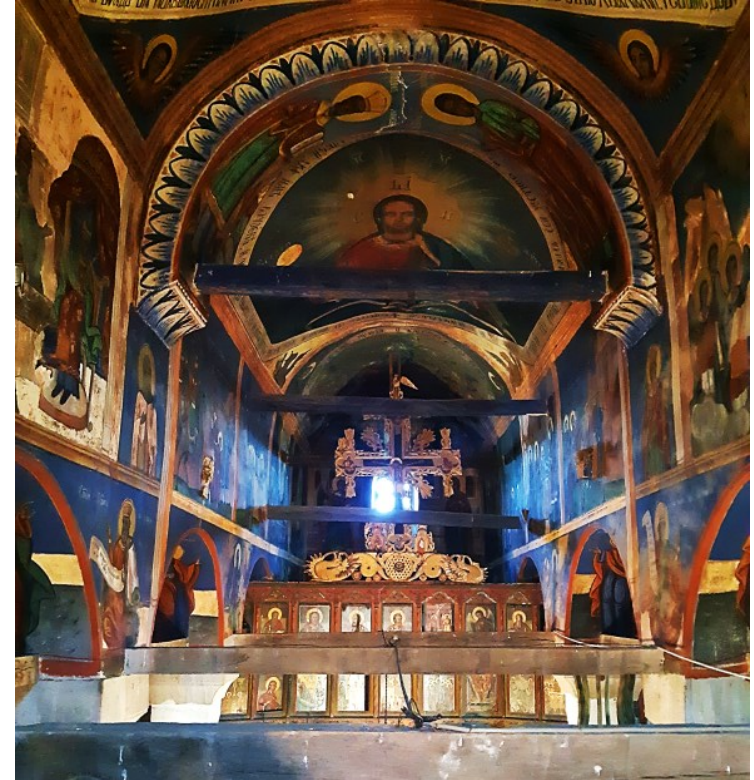

Figure III.183 St. Demetrius in Stracin (Kratovo). View of the barrel vault in the central nave.

In the churches of this group, in fact, parallels can be drawn with the middle-Byzantine vaulted basilicas and the basilicas with a central dome, above all with St. Sophia in Ohrid in its last phase (after the Ottoman reconstruction); the Most Holy Mother of God in Vranishta; the Most Holy Mother of God Chelnica in Ohrid. Of course, the post-Byzantine vaulted three-nave basilicas must not be overlooked: St. Nicholas in Gluvo; St. Nicholas in Mirkovci (from the XVI-XVII century) and the Nativity of the Most Holy Mother of God in Tepavci (from the XVIII century) were all basilicas of precisely this type (see Chapter II.5.1). The main difference is the used structural system (massive in the post-Byzantine, as opposed to combined in the Revival churches) which, as explained in detail before, had already appeared in the second half of the XVIII century at the church in Tepavci. Also, the Revival three-nave basilicas of this type are tall, monumental buildings, while the postByzantine ones (especially the older ones, i.e. the churches in Gluvo, Mirkovci, Strezovce) are still quite low and dug into the ground, which was conditioned by the social conditions of that particular period within the Ottoman Empire. The post-Byzantine three-nave vaulted basilicas, although very rare and few in number, undoubtedly had a huge impact on the emergence and development of this particular typological solution during the Revival, especially knowing that some of them (the churches in Gluvo and 
Mirkovci) were restored, extended and expanded precisely in the 1800s, as were some of the middleByzantine churches, such as the Most Holy Mother of God Chelnica in Ohrid and the church in Velushina, which was certainly a great opportunity for the Revival master-builders to get acquainted with their architectural typology and then to apply, develop and upgrade it in their own work.

"St. George" in Drmeni (Prespa), 1871

The church of St. George is the main and cemetery church in the village of Drmeni, ${ }^{447}$ also one of the largest churches in the region of Prespa. It was built in 1871, according to the inscription on the north jamb of the western entrance portal, where an arched niche was carved in shallow relief, including an elongated procession cross, complemented with the year of construction (Томовски, 1970: 32-33). On the south portal, in a symmetrical composition, identical decorative niches were executed. ${ }^{448}$ Within the arched lintel, placed on simple capitals with geometric profile and constructed of three stone blocks (two arched ones and a central trapezoidal one, in an ideally symmetrical composition), the name of the temple

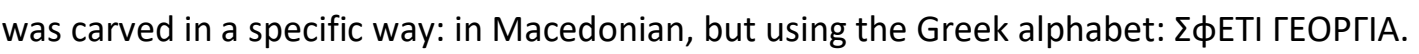

St. George in Drmeni is a three-nave basilica with quite impressive dimensions, covered with a continuous gabled roof, without the typical Revival saddle-shaped (trapezoidal) shorter facades. Later, a closed porch was built on the west and south sides of the church. The preserved stone consoles along the north façade testify that, originally, the church in Drmeni had open porches made of wooden construction on all three sides of the naos, i.e. in the shape of " $U$ " (fig. III.184). The naos, whose total internal dimensions not counting the altar apse are 10.25 / $17.90 \mathrm{~m}$, was divided into 3 naves by means of colonnades of 4 columns connected to each other with semicircular arches. Of these, the 3 pairs in the naos have a circular section and decorative profiled capitals (fig. III.185A), without bases, while the eastern pair of columns hidden behind the altar partition are simpler, with a square section, without plaster coatings or decoration, which was a common Revival practice. They are $5.6 \mathrm{~m}$ high in total, and their slenderness was emphasized by being painted completely white, including the capitals, without any painted ornaments. During the last renovation of the temple, in 1995, the columns that were

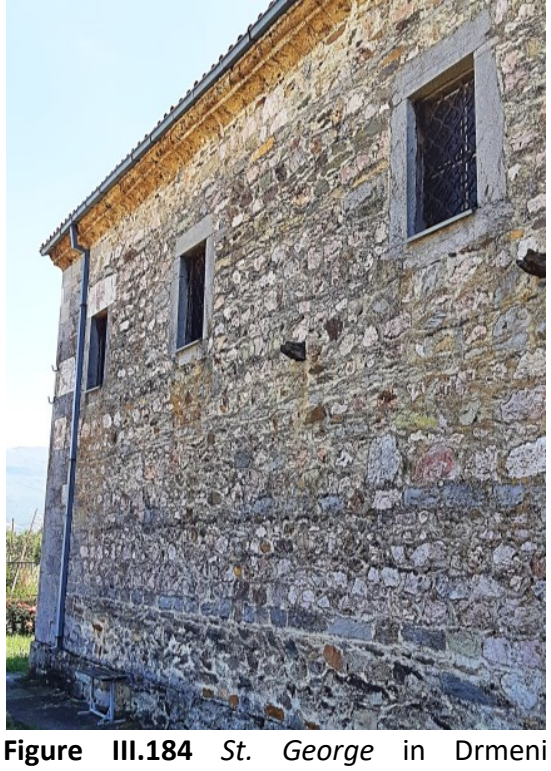
(Prespa). Detail of the northern façade. badly damaged by capillary moisture were shortened by approximately one meter, and a prismatic reinforced concrete pedestal was placed underneath. The same occurrence is observed in the church of St. Nicholas in the neighboring village of Carev Dvor, with the difference that there this intervention is quite recent. ${ }^{449}$

\footnotetext{
447 In the village of Drmeni there used to be an older church, built on the same or another location, as evidenced by the royal doors and several icons, quite damaged, which today are kept in the gallery, and which bear the date - 1811.

${ }^{448}$ An identical conception can be found at the church St. Nicholas in the neighboring village of Carev Dvor, built but 4 years later, in 1875. In addition to the shallow niches, the other elements of the portal (the monolithic jambs, profiled capitals, the threepart symmetrically arched lintel, the low and wide patron saint niche) indicate the identical construction of both churches. At the church in Carev Dvor, the western portal received a slightly more decorative treatment in shallow relief, where a niche with a cross was carved on the southern jamb, and on a northern one, an angel - cherubim.

449 During the field research of these two churches, in August 2020, the author was informed by the caretaker of the church of St. Nicholas in Carev Dvor that the moisture in the temple is a consequence of the recent replacement of the authentic floor in the church (of stone slabs) with a polished granite cladding. Despite the proximity of Lake Prespa, the terrain in the area of these villages is sandy and well drained, which excludes the occurrence of capillary moisture and water retention in the upper soil layers. The cut segments of the original wooden columns were deposited in a corner of the churchyard, where they remain, and
} 
To the east, the central nave ends with a nine-sided apse; in the lateral naves, on the other hand, there are 2 semicircular niches in the altar space: one in the east wall, the other in the north or south wall, respectfully, serving as prothesis and diaconicon. On the west side there is a gallery (women's church) whose depth ( $3.5 \mathrm{~m}$ in the central nave and $4 \mathrm{~m}$ in the lateral ones) corresponds to the first span from the west wall to the first pair of columns on which it was suspended, without additional sub-construction. The gallery is accessed via steep wooden stairs, placed to the north of the west entrance. Towards the naos, the gallery is formed with straight lines and indentation of the central field in the main nave, without baroque curves or balconies (fig. III.185B). The gallery fence was divided into two parts: a solid parapet and a semi-transparent musharabia with a curved " $\mathrm{S}$ "-shaped cross-section, with rhombuses painted in ocher against a light blue background. The parapet was made of solid wood panels with a simple, geometrically profiled frame of wooden planks. It was decorated with rhombic and floral motifs, in a quite muted tonality (green, blue and ocher tones). The ceiling below the gallery and the stairs have been recently (perhaps as part of the 1995 renovation?) covered with wooden paneling, but of course were originally also made of wood.
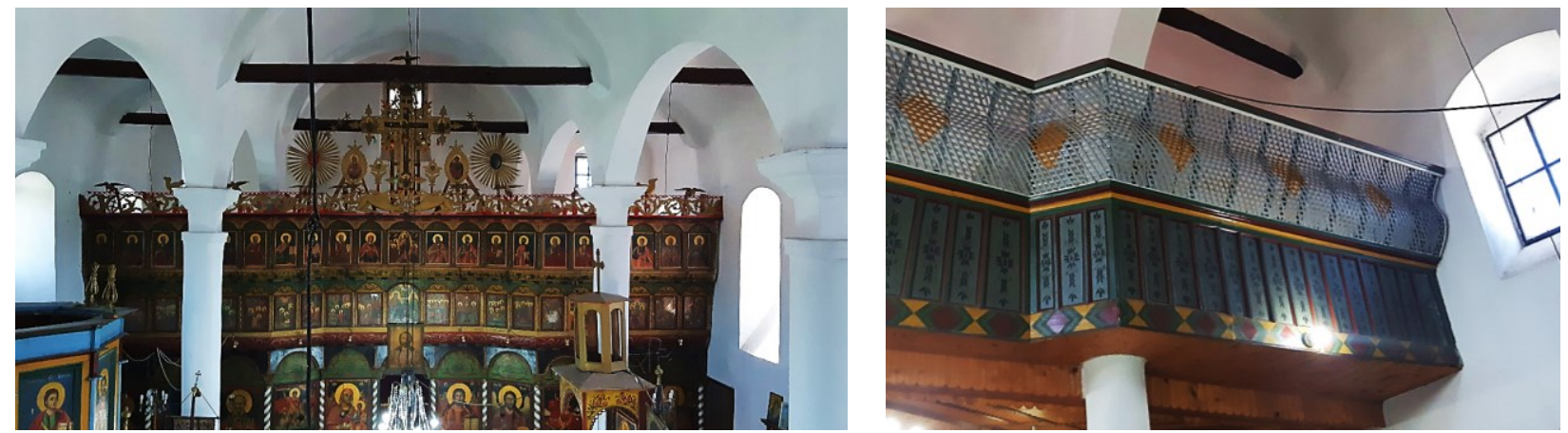

Figure III.185 St. George in Drmeni (Prespa): A. View from the gallery towards the altar; B. View towards the gallery parapet.

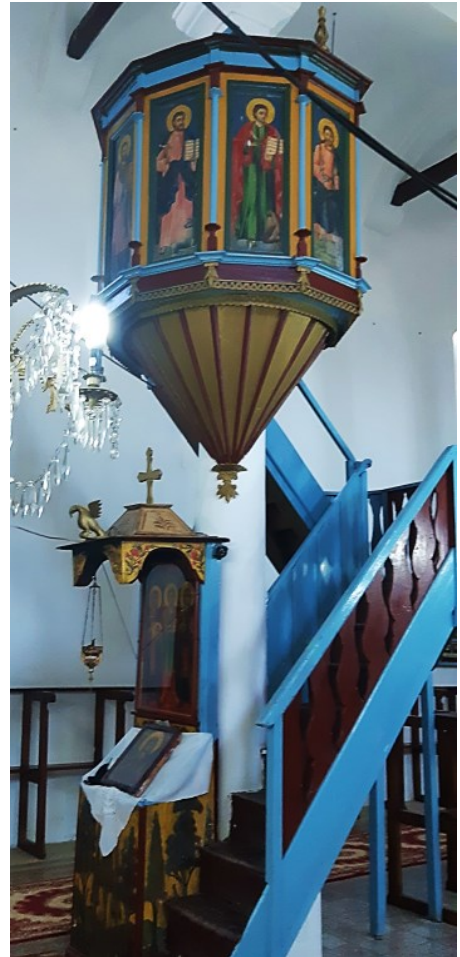

Figure III.186 St. George in Drmeni (Prespa). View of the ambo.

All three naves were covered with semi-cylindrical vaults, for structural reasons reinforced with semicircular arches placed between the columns (fig. III.185A), also reinforced by wooden ties. The maximum height at the apex of the central vault, measured from the floor, is 8.40 $\mathrm{m}$, and the lateral ones are $80 \mathrm{~cm}$ lower. The vaults, in the spirit of the Revival construction methods, were made of light wooden structure covered with plaster. As the entire interior of the church, they were whitewashed, although the church originally had a partial frescoensemble, fragmentarily preserved, which was largely destroyed in the previous repairs of the church undertaken in 1955 (Николовски, 1987: 39). The only color accents in the monumental naos are the altar partition to the east and the gallery to the west, whose shape is symmetrical, which indicates a thoughtful, detailed approach to the construction of the church. Namely, the iconostasis is richly painted with floral motifs, spiral stripes, shoots and the like. In all three zones (the first is dedicated to the monumental throne icons, the second to the festive ones, and the third to the prophetic and deisis icons) the icon fields are arched and separated by profiled pillars. The plinth on which the throne icons were placed consists of solid panels decorated with vases and cantharos with

their imposing section could still be seen, as well as remains of the wooden slats with the help of which the square trunk of the pillar obtained a circular shape. 
flower arrangements, framed with whirling draperies in ocher, red and blue tones. Particularly decorative is the zone of the Crucifixion which, in addition to the embossed cross - placed as usual on two opposing winged dragons - and the two oval medallions depicting the Mother of God and St. John, comprises angelscherubs, fully sculpted birds an face and in profile, large solar disks with radially arranged rays, etc. In addition to these enumerated elements in woodcarving in deep relief or in full sculpture, a completely transparent lattice in full relief, shaped into a meander of leafy, baroque, horizontal "S" volutes crowns the iconostasis. The icons were commissioned by the villagers themselves, in the period immediately after the construction of the church (in 1873, 1875 ...), as stated in their preserved founder's inscriptions.
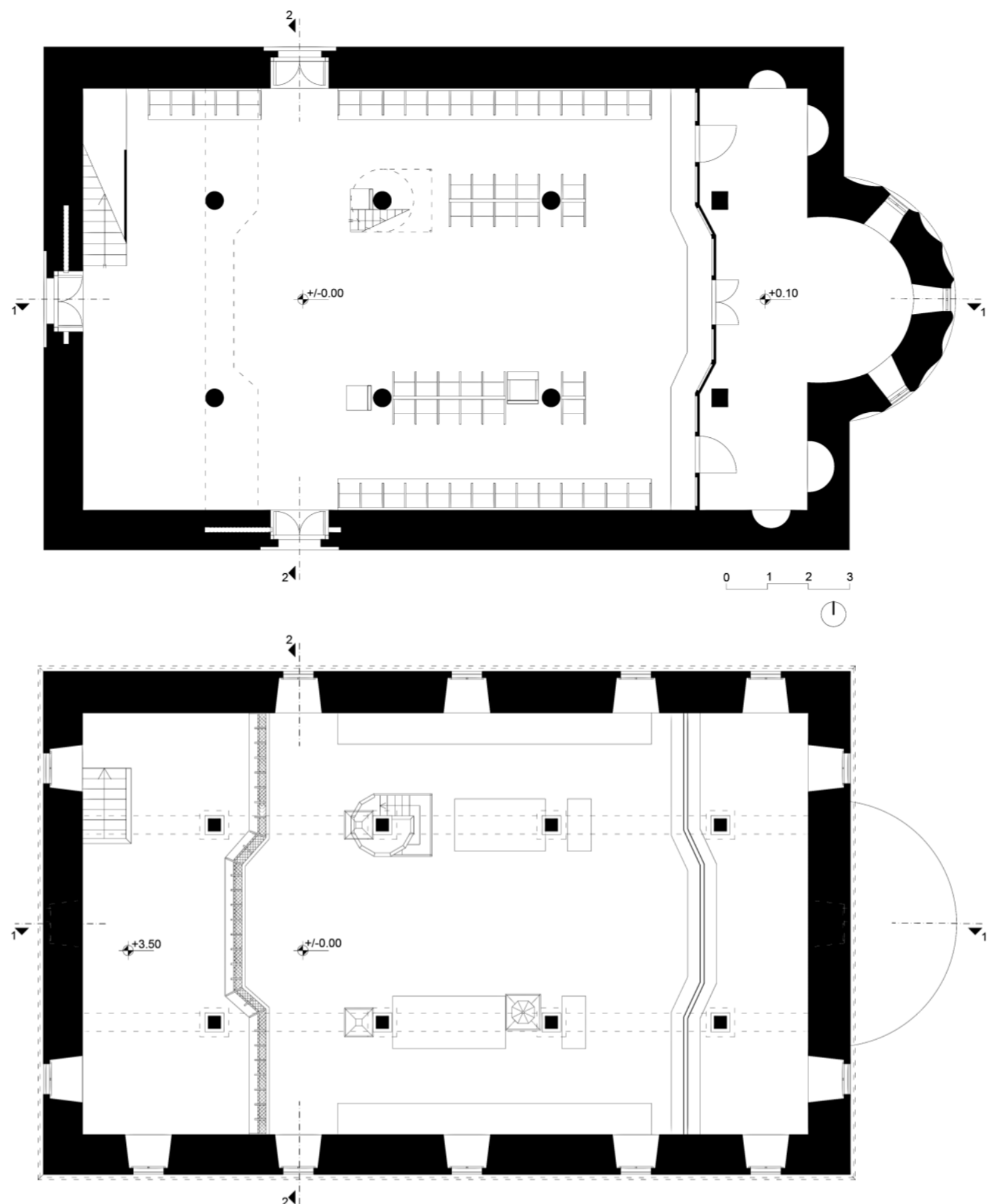

Figure III.187 St. George in Drmeni (Prespa). Plans: A. Ground floor ( \pm 0.00$)$; B. Gallery $(+3.50)$. 

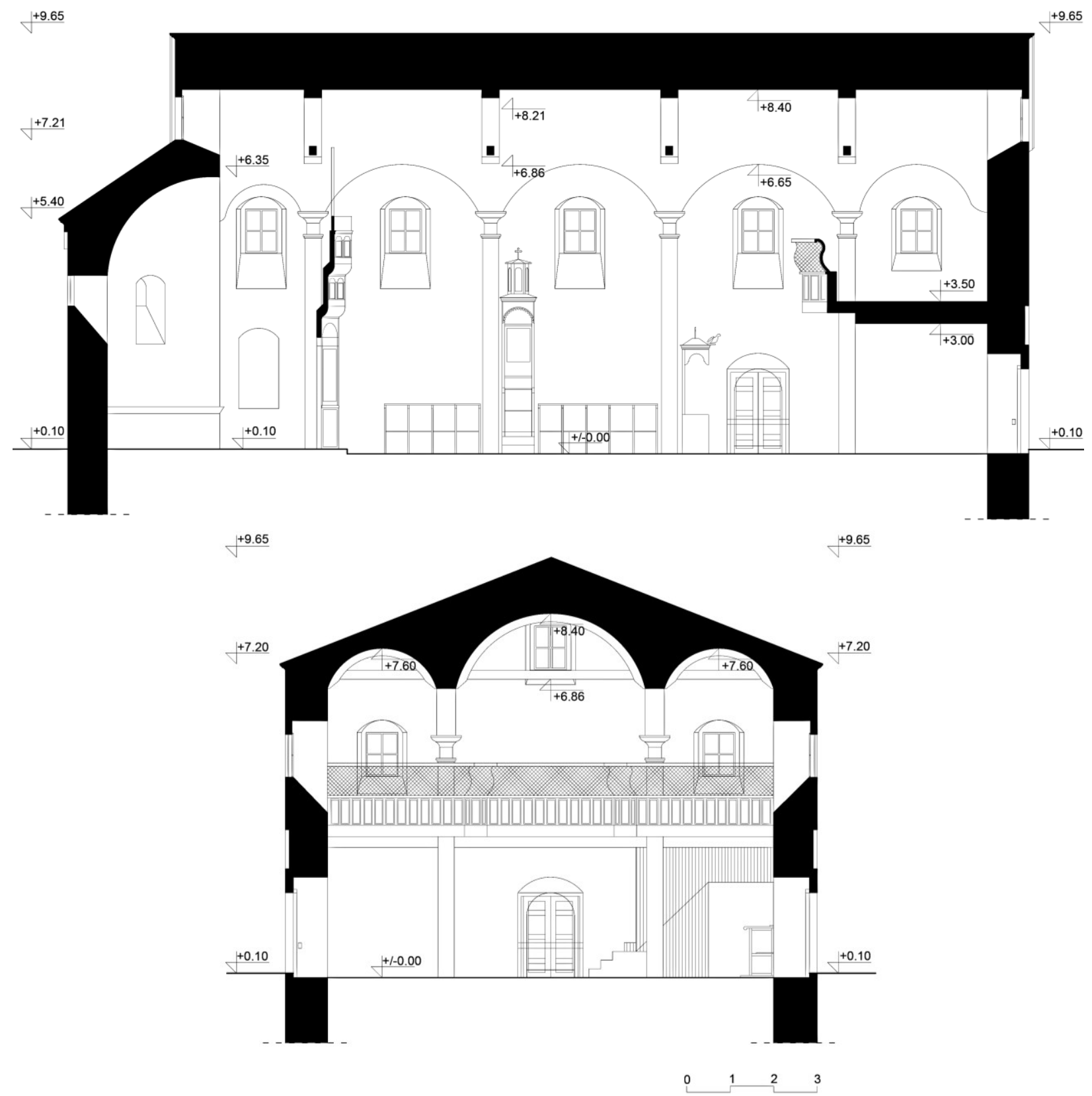

Figure III.188 St. George in Drmeni (Prespa): A. Longitudinal section (1-1); B. Transversal section (2-2).

In addition to the altar partition, the bishop's throne, placed in the southern colonnade, received an exceptionally decorative treatment, as did two icon pedestals, whose arched perde (curtain) within the canopy was painted with floral motifs, and the box pedestal with a symmetrical composition of 5 tall, slender trees - the tree of life motif (fig. III.186). The canopies were topped with gilded sculptures of birds with outstretched wings (fig. III.186, 188A). Rows of wooden seats were placed along the side walls and between the naves. The pulpit, in turn, was placed high on the second column from the west within the northern colonnade, accessed via a wooden staircase. It was shaped into a balcony with a solid fence, whose eight sides consist of panels serving as icon backdrops, framed by thin cylindrical pilasters, which at both ends end symmetrically with a flower-shaped profile and a rectangular capital / pedestal. A separate profiled cornice flows under the pedestals, and in the axis of each pilaster a gilded fleur-de-lis was placed. The bottom of the pulpit is, as usual, an inverted cone, the pinnacle of which was also adorned with a relief gilded fleur-de-lis (fig. III.186). 
The perimeter walls, as was usual for the Revival churches, were built very massively, with crushed and roughly hewn stone and lime mortar. In their lower zone appears a slightly protruding plinth, built in the same way (fig. III.184). The corners of the building, the window jambs and lintels, the crown cornices, the apse as well as the entrance portals were carefully built, using hewn stone. In the apse, built of sandstone and brick arranged in alternating layers (opus listatum), each of the nine sides is concave, in the form of a very shallow niche, without emphasis on the corners by means of pilasters (fig. III.28C). The upper zone is marked by a series of blind cantilever semicircular arches made entirely of stone blocks, without the use of brick. The sequence of cantilever arcades on the altar apse is a specific feature of the Revival churches from the region of Prespa (see Chapter III.3), regardless of their typology: in addition to the church in Drmeni, it appears at St. George in Podmochani, St. Nicholas in Carev Dvor (fig. III.28B), St. George in Resen (fig. III.28A), St. Nicholas in Nakolec, St. Elijah in Ezerani. The altar is illuminated through 3 single windows on the apse, in a symmetrical composition. The architrave window lintels, as well as the jambs, were made of finely hewn monolithic sandstone blocks. The rest of the east façade follows the same level of decorative finishing. Immediately above the roof of the apse, instead of a window with a stone-carved transenna, appears a tall bifora made of carved stone; an identical window appears also on the opposite, west façade (see fig. III.66A). At the top of the east façade, above the bifora, a small oculus was placed, made of stone with a central decoration in the form of a cross inscribed in a circle. Under the roof, all the facades are crowned by a continuous cornice of hewn sandstone, profiled into two segments (concave and convex), with clean, straight lines. Several of the precisely hewn blocks built into the corners of the building also contain ornaments in shallow relief: high in the east corner of the north façade, an angel cherubim (see fig. III.83C); on the south corner of the east façade, an elongated procession cross in shallow relief, with trefoil arms and a pyramidal pedestal, very similar to those carved on the west and south entrance portal jambs (fig. III.189).

The naos is accessed through three entrance portals: west, placed in the longitudinal axis, as well as south and north, placed in the second intercolumnal span viewed from the west, i.e. immediately to the east of the gallery. All three portals are identical in their composition (described earlier) and execution in hewn and carved stone; all but the northern one also received decoration in shallow relief. Above all three

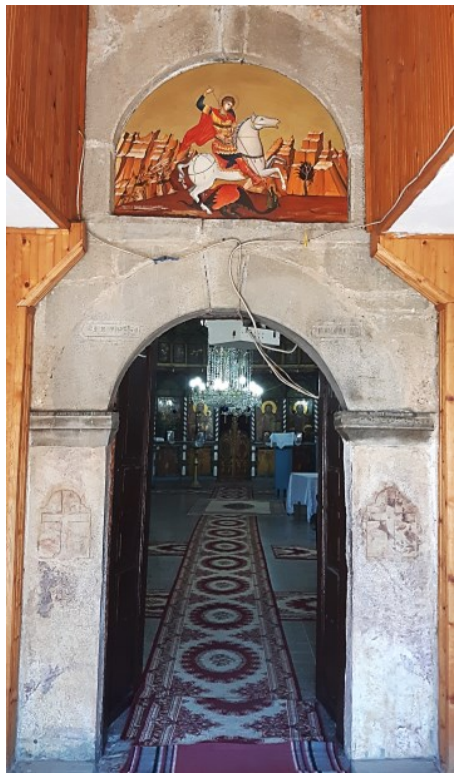

Figure III.189 St. George in Drmeni (Prespa). External view of the west entrance portal.

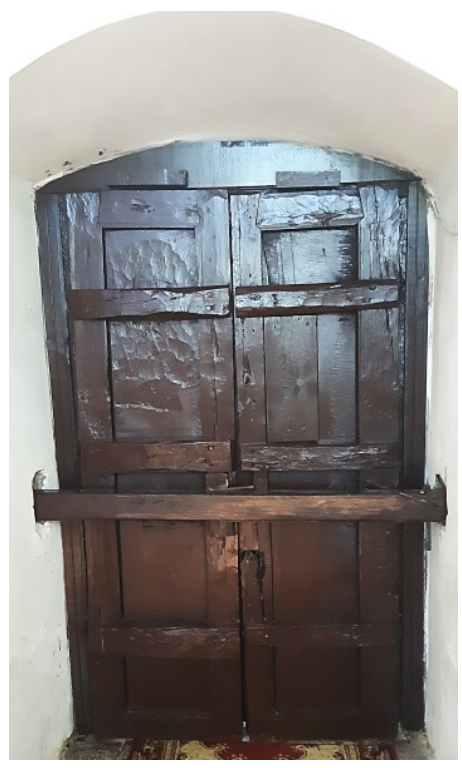

Figure III.190 St. George in Drmeni (Prespa). Internal view of the west entrance portal. appears a semicircular arched patron saint niche, quite wide and low (fig. III.189), which is specific to some of the churches in the region of Prespa. The doors are quite massive and heavy, made of solid wood (fig. III.190) and decorated on the outer side with engraved rhombic motifs. ${ }^{450}$

\footnotetext{
450 In addition to the locking mechanism from the outside, the portals also had a closing system from the inside, with the help of a massive wooden beam that was kept in a deep lateral horizontal strip within the wall and, when necessary, was pulled out and fixed in an opening on the opposite side, thus blocking the doors from opening inwards (fig. III.187A, III.190). The existence of such a defense mechanism, which is quite regularly present in the Revival churches, implies that they, as the most solidly built and largest buildings in the village, in addition to their basic purpose, were also used as a shelter for the local population in extreme situations.
} 
The entire architecture of the church in Drmeni speaks of the expertise and skill of its masterbuilders, of a higher level of architectural and artistic achievement. Namely, the church is harmoniously designed, with an elegant silhouette and accentuated aesthetics, with precise lines, correct plan and harmonious proportions. The windows are arranged absolutely symmetrically, with a sharpened sense of composition which is also seen in their layout, in the uniform rhythm of the columns in the naos and so on. The large number of windows, their significant dimensions, as well as the purity of the interior without unnecessary constructive elements and its complete whiteness; all of these features contribute to the achievement of an atmosphere of contemplative tranquility within the church's interior, but also romantic humanism, aided by the abundance of light.
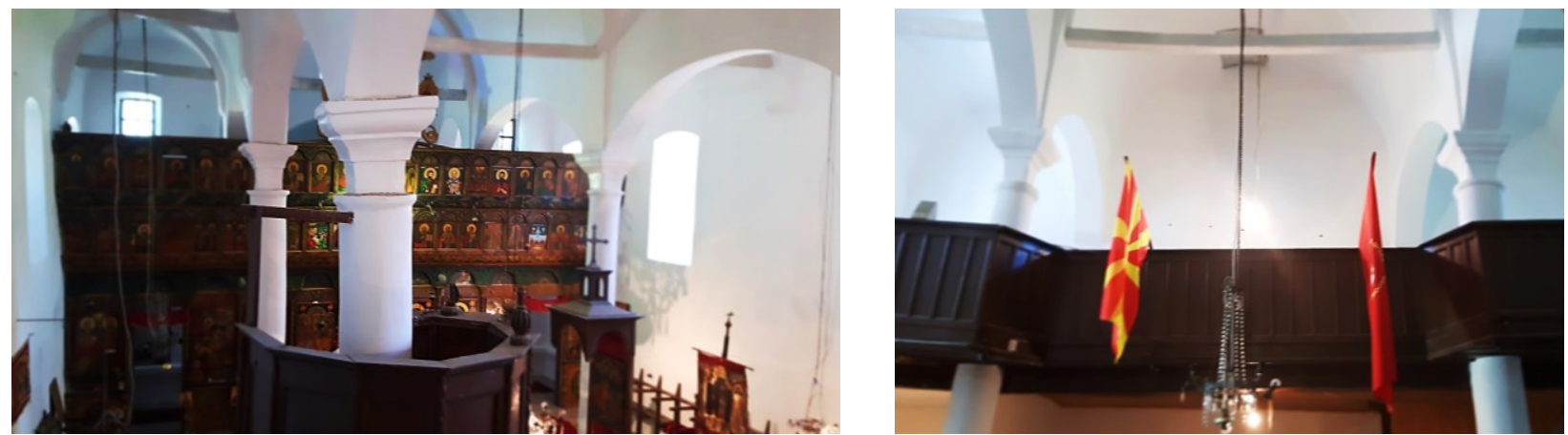

Figure III.191 St. Nicholas in Carev Dvor (Prespa): A. View from the gallery towards the altar; B. The gallery parapet.
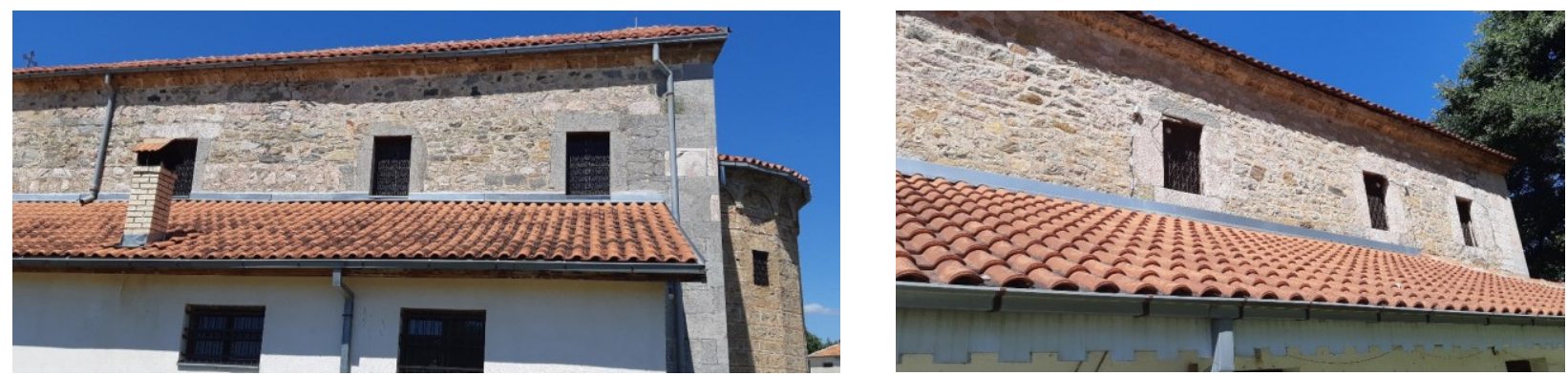

Figure III.192 The southern facades of: A. St. George in Drmeni; B. St. Nicholas in Carev Dvor (Prespa).

It seems that the construction of the church in Drmeni was so successful and so well received by the local population, that the same master-builder group was immediately invited to work in the neighboring village of Carev Dvor, ${ }^{451}$ where the church of St. Nicholas was built in 1875 (Томовски, 1970: 33-34). In support of this assumption speak not only the identically conceived three entrance portals, as discussed earlier, but also all the features of the temple's architecture: the typological solution (threenave pseudo-basilica with semi-cylindrical vaults in all three naves, reinforced with ribs and transverse wooden ties (fig. III.191A); the proportions and almost identical dimensions of the temple; the used masonry; the processing of the cornices, corners and window openings in analogly carved and shaped stone (fig. III.192); identical tall bifora on the east façade; the false vault construction; the profiling of the capitals and the shape of the columns themselves (and their number: 4 pairs); the semicircular arches with which they are connected so as to form arcades; the nine-sided altar apse (this time made entirely of stone blocks, without the use of brick) with a frieze of cantilever blind arcades at the top, illuminated by three single windows; a stone oculus with a centrally placed cross built-in high on the east façade; the design of the gallery parapet (fig. III.191B); and even the small motifs (cherubim and procession cross) executed in shallow relief in the large stone blocks embedded in the eastern corners of the building. Thus,

\footnotetext{
${ }^{451}$ Namely, the village of Carev Dvor is located only $2 \mathrm{~km}$ to the north of Drmeni.
} 
we can rightly conclude that both churches are indeed the work of the same master-builder(s), i.e. the same construction team that worked in the region of Prespa in the 1870s.

\section{III.5.B.3 THREE-NAVE BASILICAS WITH BLIND DOMES}

The dome as a symbol of the kingdom of heaven, projected over a square base or placed in a rectangular elongated basilical building, is a basic architectural element characteristic of the Byzantine architecture since the era of Justinian I, to become widely accepted in the middle and late-Byzantine period as the main accent of the central solutions and the churches of the inscribed cross type. The duration and survival of the concept of the dome is based on the understanding of the church building as an "image of the cosmos" (Кораћ и Шупут, 1998: 87). ${ }^{452}$ Although in the post-Byzantine period, i.e. in the sacred construction under Ottoman occupation, the dome as a type of vaulted structure almost completely disappeared, dictated by the socio-economic circumstances and their limitations in which this architecture occurred, yet its meaning and symbolism was still deeply ingrained in the religious architecture and regularly present in the temples via its alternative substitutes: the barrel vault and the fresco-painted circular medallions.

Therefore, when in the XIX century a wide opportunity opened for the design and construction of larger and more monumental buildings, especially of the basilica type, again emerged a return to older, historically significant patterns, such as the early-Christian, and especially the middle-Byzantine local examples of domed basilicas (see Chapter I.4.2). Thus, in the Revival basilicas appear variations that range from completely flat ceilings with a hint of a dome (which is missing) via their appropriate painting, ${ }^{453}$ or via polygonal decorative wood carved rosettes; through one or more blind domes in an otherwise flat wooden or plastered ceiling, usually placed along the middle nave (in the case of the three-nave buildings); three-nave basilicas with blind domes in several approximately square fields into which the naos is divided via a system of transverse and longitudinal arches; all the way up to the "real" domes supported on drums which pierce the gabled roof, bringing a completely different effect to the fifth façade.

The three-nave basilicas of this type can, therefore, actually be:

- Three-nave basilicas with a flat wooden ceiling in which one or several smaller blind domes are inserted, without supporting arches or pendentives and whose span is usually smaller than that of the nave in which they appear; in other words, these blind domes are basically three-dimensional (concave) medallions. Therefore, it can be concluded that these churches belong more to the category of three-nave basilicas with flat wooden ceilings, where in fact they were classified and examined in more detail (see fig. III.155-III.156).

- Three-nave basilicas with one or more blind domes that are supported on a system of transverse arches and angular pendentives, and whose diameter corresponds to the entire span of the nave (whether the central or the lateral ones), i.e. they are, conditionally speaking, "real" blind domes. Precisely this typology will be further elaborated in this chapter.

The churches that belong to this typological sub-group are listed in the following table (table III.12):

\footnotetext{
452 This phenomenon is also expressed lexically: namely, the Revival masters-painters refered to the vaults and ceilings of the churches as the "sky" (Василиев, 1965: 306).

${ }^{453}$ As was particularly common in the post-Byzantine period, there are examples in the Revival architecture where the lack of domes was overcome through painting of scenes in circular medallions in the central nave, as a visual replacement for the dome. Such is the case, for example, of the church of St. Nicholas in the village of Sopot (Sveti Nikole), which is a three-nave basilica with a flat wooden ceiling in the lateral naves and semi-cylindrical vault in the central nave, where three medallions were painted with the representations of Christ Pantocrator, the Holy Trinity and the Mother of God Oranta with the little Christ in an oval mandorla.
} 


\begin{tabular}{|l|l|l|l|l|l|}
\hline & CHURCH & VILLAGE & REGION (TOWN) & YEAR & $\begin{array}{c}\text { ADDITIONAL INFORMATION } \\
\text { fresco-painting / icons, renovations }\end{array}$ \\
\hline 1 & Dormition of the Most Holy Mother of God & Vatasha & Kavadarci & 1817 & $\begin{array}{l}\text { royal doors from 1818, icons from } \\
1819\end{array}$ \\
\hline 2 & St. George & $/$ & Struga & 1835 & \\
\hline 3 & St. George & $/$ & Ohrid & 1838 & \\
\hline 4 & The Most Holy Mother of God Kamensko & $/$ & Ohrid & $\begin{array}{c}1839- \\
1843\end{array}$ & $\begin{array}{l}\text { iconostasis from 1845; frescoes from } \\
1863 / 1864\end{array}$ \\
\hline 5 & The Most Holy Mother of God & Sence & Mavrovo & 1841 & \\
\hline 6 & St. George & $/$ & Resen & 1843 & \\
\hline 7 & St. Elijah & $/$ & Star Dojran & 1848 & demolished in a 1916 bombing, \\
& & & & 1850 & \\
\hline 8 & St. Nicholas & Mavrovo & Mavrovo & 1852 & \\
\hline 9 & The Most Holy Mother of God & Duf & Gostivar & 1852 renated \\
\hline 10 & St. Nicholas & Dragosh & Bitola & 1859 & \\
\hline 11 & St. George & Logovardi & Bitola & 1859 & \\
\hline 12 & St. Nicholas & Toplica & Prilep & 1860 & a western porch was added in 1892 \\
\hline 13 & St. Nicholas Gerakomija & $/$ & Ohrid & 1860 & dated according to the frescoes \\
\hline 14 & St. Savior - Ascension of Christ & Graeshnica & Bitola & 1860 & fresco-painted in 1868 \\
\hline 15 & St. Athanasius & Rakle & Prilep & 1864 & \\
\hline 16 & St. Nicholas & Vevchani & Struga & $1834 / 64$ & icons from 1867, frescoes from 1879 \\
\hline 17 & St. Nicholas & Star Istevnik & Delchevo & 1868 & \\
\hline 18 & St. Nicholas & Golemo Radobil & Prilep & 1870 & \\
\hline 19 & St. Theodore Tyron & Krklino & Bitola & 1871 & $\begin{array}{l}\text { damaged in World War I, renovated } \\
\text { afterwards }\end{array}$ \\
\hline 20 & St. Nicholas & Belovodica & Prilep & 1885 & \\
\hline 21 & St. Elijah & Jablanica & Struga & 1886 & \\
\hline 22 & St. George & Capari & Bitola & 1888 & \\
\hline 23 & St. Petka & Gorna Belica & Struga & 1889 & \\
\hline 24 & St. Elijah & Mitrashinci & Berovo & 1894 & dated according to the frescoes \\
\hline
\end{tabular}

Table III-12 Three-nave Revival basilicas with blind domes.

The three-nave basilicas with blind domes are spread all over Macedonia, as can be concluded from map III-B. However, their presence in the urban areas (Ohrid, Struga, Resen, Dojran) and in the richer and more developed rural settlements is indicative, and is certainly due to the fact that their construction was more complex and required more resources and higher level of expertise of the master-builder team. They represent a relatively small group: $10 \%$ of all so-far registered three-nave Revival churches (see chart III-2). Unlike the three-nave basilicas with flat ceilings and those covered with semi-cylindrical vaults, where the same type of construction is generally present throughout the temple, the churches of this particular typological group contain the greatest variety in the used construction solutions and their different combinations. Namely, in terms of the typological solution that can be found in their upper parts, in addition to the blind domes supported on pendentives carried by a system of longitudinal and transverse arches as a basic determining factor (predominantly in the central and sometimes also in the lateral naves), the three-nave basilicas with blind domes incorporate various combinations of flat ceilings, coffer ceilings, barrel vaults, ribbed arches, semi-domes etc. Furthermore, the domes themselves can be placed over a round or oval base. In other words, the most daring and innovative solutions of the Revival have been achieved precisely in the churches of this category, i.e. they are representatives of the top skill of the Revival masters-builders.

The most common solution among this group is the combination of one or more blind domes in the central nave, and a flat wooden ceiling in the lateral ones. The ceilings can be plastered, simply processed with longitudinally or transversely arranged wooden planks, or coffer ceilings, often also containing wood carved elements, rosettes, etc. Examples of this solution are the Most Holy Mother of God in Duf, near Gostivar, which has one blind dome in the central nave flanked by semi-domes which continue into a barrel vault to the west above the gallery and a monastery vault to the east above the altar (see fig. III. 151, III.193A); St. Nicholas in Belovodica (Prilep); St. Nicholas in Dragosh (Bitola) and St. George in Logovardi (Bitola), which have two blind domes each (Николовски, 1993: 166); the Dormition of the Most Holy Mother of God in Vatasha (Kavadarci) which has four blind domes in the central nave, of which the 
middle two are larger and depict frescoes (Mother of God with Christ and Christ with angels); St. Savior Ascension of Christ in Graeshnica (Bitola), where two elongated oval blind domes, fresco-painted in 1868, were placed in the central nave, while its remaining bays (towards the altar and the gallery) were vaulted; St. Athanasius in Rakle (Prilep), which has three blind domes in the central nave, while its end bays to the east and west were vaulted.
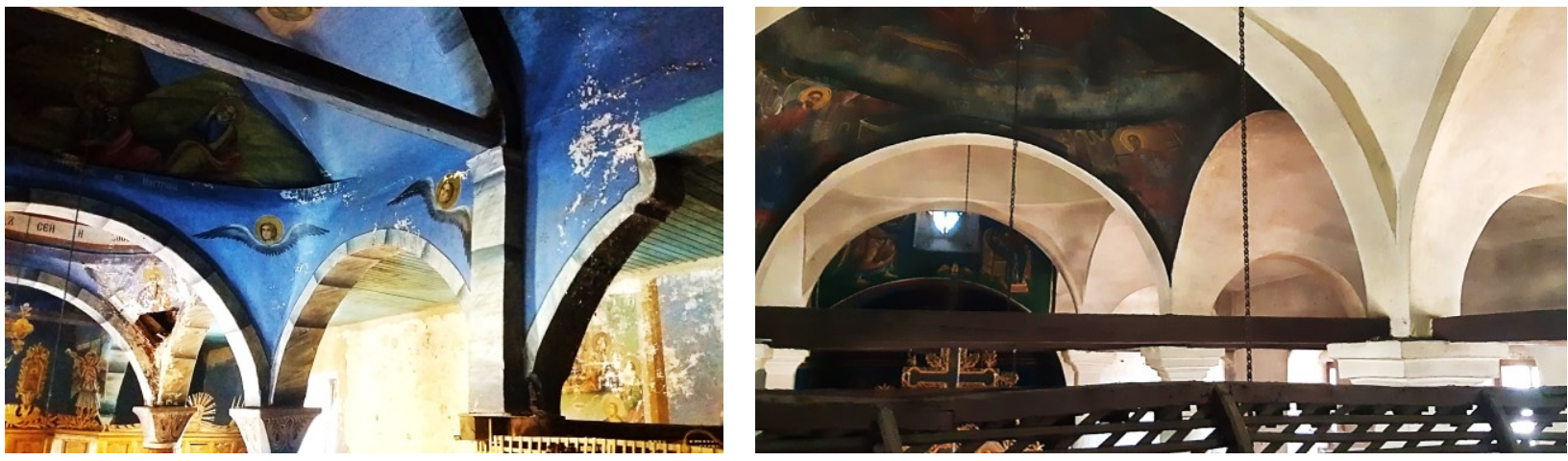

Figure III.193 View of the blind dome(s): A. The Most Holy Mother of God in Duf (Gostivar); B. St. George in Resen.

Another solution found in this typological sub-group is the combination of blind domes placed in square fields in the central nave with barrel vaults in the lateral naves, instead of a flat ceiling. The number of blind domes varies from three at the churches of St. George in Resen (fig. III.193B), St. Nicholas in Golemo Radobil (Prilep) and St. Theodore in Krklino near Bitola; through four at St. Elijah in Jablanica (Struga); five at St. George in Capari (Bitola); to even more at St. Petka in Gorna Belica (Struga), which has three blind domes on pendentives and nine callottes in the remaining flat wooden ceiling covering the central nave (Василиев, 1965: 242). ${ }^{454}$

Particularly representative examples of three-nave basilicas with blind domes were built in the town of Ohrid, the old seat of the Ohrid Patriarchate / Archbishopric, where in addition to the multitude of early-Christian and medieval churches (as well as post-Byzantine ones in the surrounding villages) there are as many as five Revival temples. ${ }^{455}$ The oldest is the church of St. George (fig. III.194A) in Gorna Vlashka Maala (Ohrid), built in 1838, a date engraved in a block of stone embedded in the south corner of the east façade. In this church, the naos was fairly evenly divided into bays, of which the ones in the central nave were covered with three almost equal blind domes (one of which is in fact above the gallery), with an approximate span of $3.4 \mathrm{~m}$ and a maximum height of $8 \mathrm{~m}$. In the altar, the central bay was covered with a semi-cylindrical vault, and the ones in the lateral naves with a ribbed vault. In the naos, the bays in the lateral naves were bridged in a very interesting way: with a semi-cylindrical vault towards the colonnades, which gradually turns into a ribbed vault towards the perimeter walls. ${ }^{456}$

At the church of the Most Holy Mother of God - Kamensko (fig. III.194B), whose construction began in $1839,{ }^{457}$ in the middle nave there are as many as four large blind domes, placed over bays of a relatively irregular shape, formed by the transverse arches between the columns. The most monumental of these are the central two, with a span of almost $4.5 \mathrm{~m}$ and an equal height of $\sim 7.8 \mathrm{~m}$ measured from the floor in the nave. In contrast, the field over which the west dome was placed (above the gallery) is almost half

\footnotetext{
454 This church is the work of master Todor Petkov from Gari, and the wood-carving was done by his son Jakim Todorov.

455 The Most Holy Mother of God - Kamensko in the neighborhood of Mesokastro, St. George in the Gorna Vlashka Maala neighborhood, St. Nicholas Gerakomija and St. Cosmas and Damian (the Great Holy Healers) in the neighborhood of Varosh and St. Nicholas in the Dolna Vlashka Maala neighborhood.

456 Elizabeta Kasapova refers to this specific vault construction as a "trough vault", or cloister vault (Касапова, 2019: 314).

457 Until recently, it was accepted in science that this church was built in 1832, as a reconstruction of an older temple. Accurate dating was recently provided by Elizabeta Kasapova, based on an identified inscription on a terracotta tile built-in above the south entrance to the altar, which marks the beginning of construction (Касапова, 2019: 316).
} 
the size, and the most unusual is the solution of the easternmost dome (in the altar), which is supported via pendentives towards the transverse arch between the eastern pair of columns of the naos, while the whole eastern half of the dome actually rests on the altar apse. In other words, the usual semi-dome does not appear in the altar, but rather a complete blind dome, slightly lower than those in the nave (6.6 m). The lateral naves are covered with quite irregular ribbed vaults, formed by the arches between the columns and between them and the northern or southern perimeter wall.
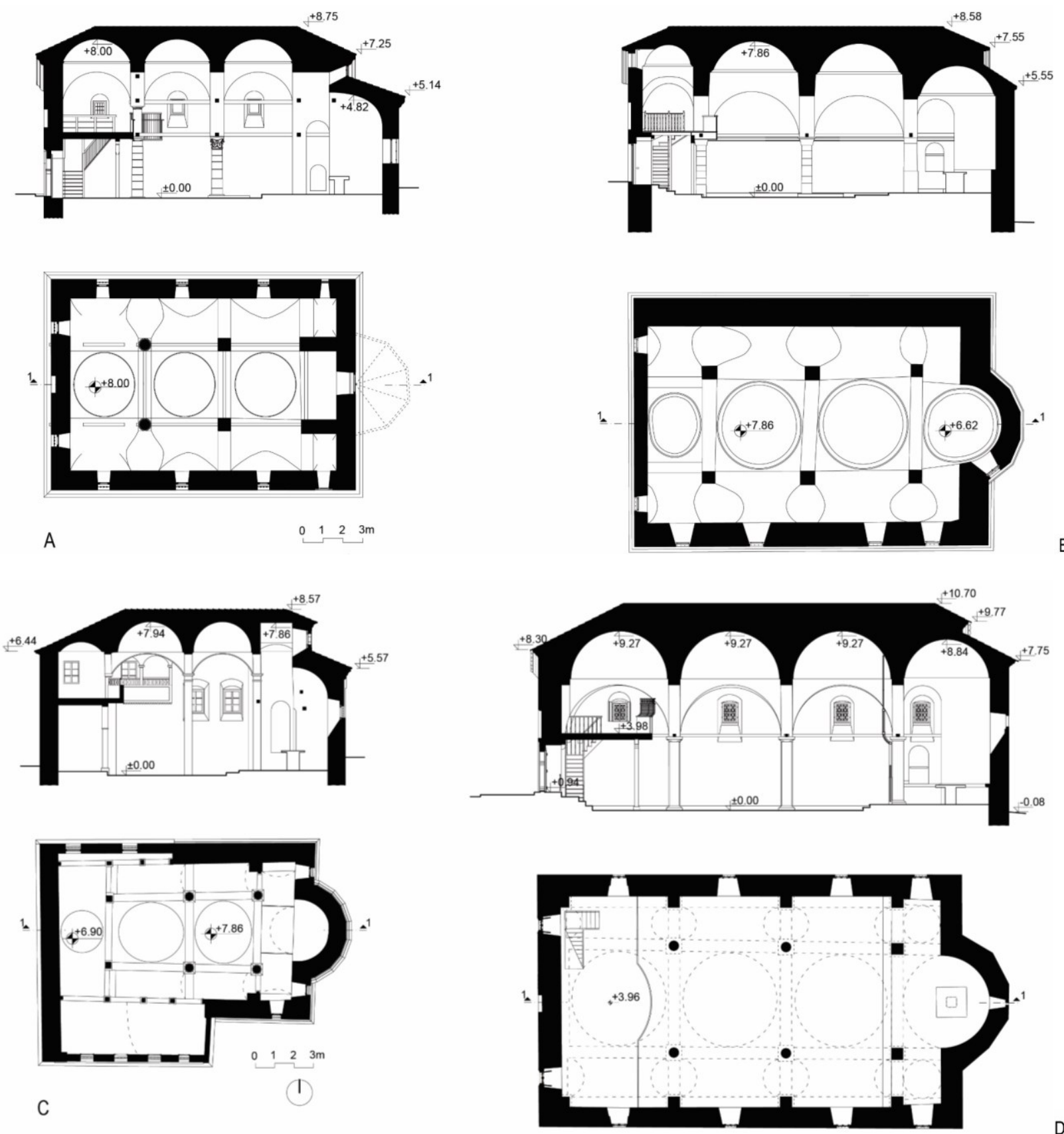

D

Figure III.194 Examples of three-nave basilicas with blind domes. Plan of the ceiling and longitudinal section. A. St. George in Ohrid; B. The Most Holy Mother of God - Kamensko in Ohrid; C. St. Nicholas Gerakomija in Ohrid and D. St. Nicholas in Mavrovo.

Having analyzed the architecture of these two churches, several analogies are evident: in both the trunks of the columns are comprised of rings of stone and are relatively low - just over $3 \mathrm{~m}$ including the capitals; however, at St. George the westernmost pair consists of superimposed columns, the lower of which support the gallery while the upper ones the dome, and instead of columns the eastern pair was replaced by masonry pillars. In both churches the blind domes, arches and vaults were massively built; in 
both appear the specific extended arches in the lateral naves, with the difference that in Kamensko all the side arches are solved in this way, and in Gorna Vlashka Maala only the western pair. Furthermore, at Kamensko the column capitals are simply profiled, while at the church of St. George they are based on the Corinthian type (see fig. III.100B), made of stone relief, with the exception of the western pair of superimposed columns that have simpler capitals.

At St. Nicholas Gerakomija, the third church of this typology built in Ohrid towards the middle of the century and fresco-painted in 1860, the upper parties were composed with particular complexity (fig. III.194C). Three unequally sized domes were formed in the central nave (fig. III.195B), of which the western one, which is located in the gallery, is significantly smaller. The domes in the naos reach a height in the apex of almost $8 \mathrm{~m}$, and a span of approximately $3 \mathrm{~m}$. The bays within the lateral naves, formed by the transverse arches connecting the columns with the north and south wall, were covered by shallow vaults in the longitudinal direction, while in the altar a vault appears in the longitudinal direction above the central bay, and in the transverse direction above the lateral ones. Another crucial difference of this church in comparison with the two older ones is the used material: the columns were made of wood, in the typical Revival manner, and were thus able to reach a height of just over $5 \mathrm{~m}$, with a diameter of only $40 \mathrm{~cm}$. These columns, of course, carry a lightweight wooden "false" vaulted structure.
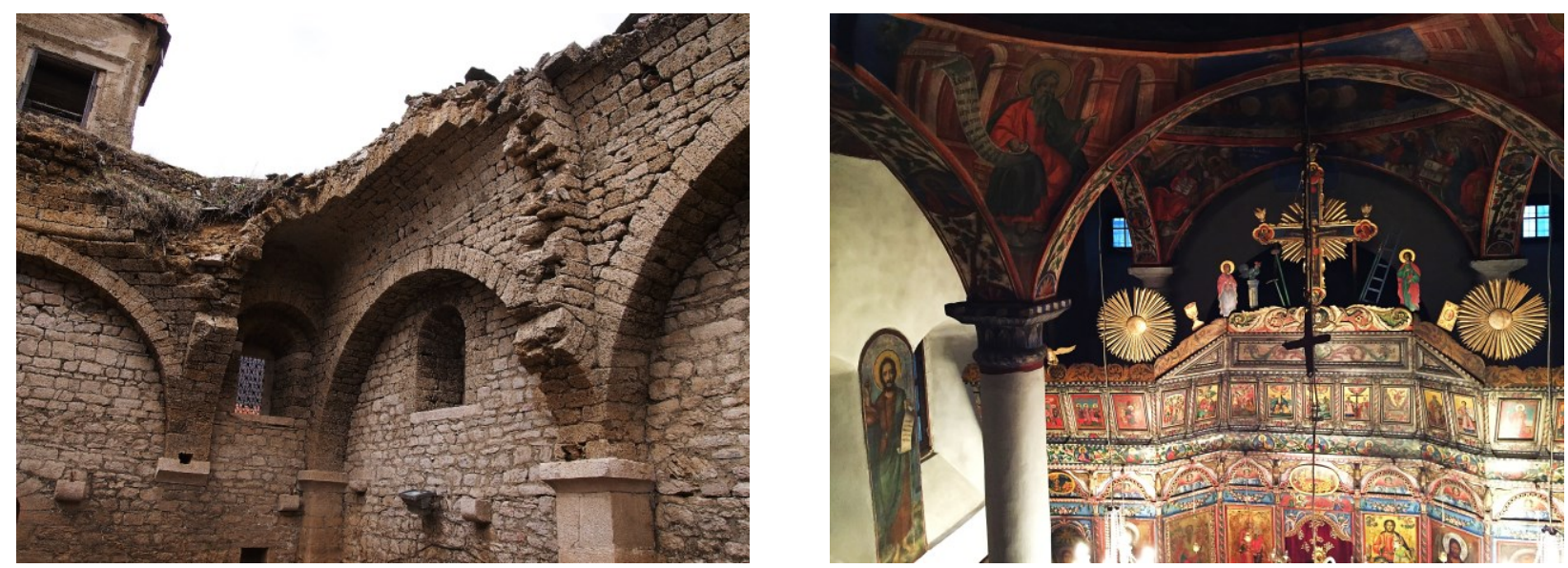

Figure III.195 Revival basilicas with blind domes: A. St. Nicholas in Mavrovo (Gostivar); B. St. Nicholas Gerakomija in Ohrid.

Furthermore, this typological sub-group includes the church of St. Nicholas in Mavrovo (fig. III.194D), built in 1850, and a hundred years later immersed in the Mavrovo accumulation (see fig. II.26B). The quality of the stone processing (fig. III.195A), the solid and precise construction and the rich ornamentation in shallow relief ${ }^{458}$ of this church have been discussed several times so far. The structure preserved to date: the perimeter walls with three pairs of massive pilasters (and a pair of semi-pilasters in the very western corners of the naos), the tall five-sided apse, the fragments of the arches and even of the blind domes (for example, more than half of the dome in the altar has been preserved to date), allow for a drawing reconstruction of its original architecture. ${ }^{459}$ According to this reconstruction, the naos of the three-nave basilica of St. Nicholas in Mavrovo was divided into a total of 12 bays with the help of longitudinal and transverse semicircular arches connecting the three pairs of stone columns (fragments

\footnotetext{
458 As one of very few such examples, at the church of St. Nicholas in Mavrovo, even the plinth of the iconostasis was made entirely of stone and is preserved in situ even today, while the upper parts that were made of wood, as well as the construction of the gallery, have completely disappeared.

459 Thanks to the favorable weather conditions (low water level in the Mavrovo accumulation), this church was documented in the winter of 2016/2017, within the subject "Conservation and restoration of architectural heritage" at the Institute for Protection of Construction Heritage, History of Architecture and Art, Faculty of Architecture - Skopje, with a group of students from the VIII semester of the integrated studies in architecture. Thereby, a complete drawing reconstruction was made under the mentorship of prof. d-r Elizabeta Kasapova.
} 
of which are preserved among the ruins of the upper parts of the church accumulated in its interior, while the north-west one is preserved in situ, including the monolithic stone capital). The arches were accepted by the pilasters which were interconnected by analog semicircular arches, so that arched niches were formed within the lateral walls. In the central nave, in approximately square bays, four approximately equal large blind domes were placed, of which the eastern one rests on the altar apse itself, as was the case with the slightly older church of the Most Holy Mother of God Kamensko in Ohrid. The elongated rectangular bays above the lateral naves were bridged with semi-cylindrical vaults, while small blind domes were inserted above the small lateral sections of the altar intended for prothesis and diaconicon. In this church, therefore, the typological solution is the most mature and most innovative, and at the same time it is the most precisely executed, with ideally straight walls, equal spans, thoughtful and elegant proportioning. The stratigraphic analysis of the walls points to a wooden structure for the gallery, and the preserved consoles along the south and west facades (on which the entrance portals, which are richly decorated in shallow relief, were actually placed) point to an open " $\mathrm{L}$ " - shaped porch made of wooden construction.

In continuation, a case-study of this particular typology will be elaborated in more detail.

\section{"St. Nicholas" in Vevchani (Struga), 1834-1864}

The church of St. Nicholas in the village of Vevchani, near Struga, is an outstanding representative of the Revival sacred architecture. It was built on an artificially flattened plateau, which dominates the landscape of the village, on the site of an older church whose inventory is partially preserved in the current temple (Грозданов, 2004: 107). It lies flat on the leveled terrain, without digging into the ground characteristic of the first decades of the XIX century, i.e. before the constitutional reforms in the country (see Chapter II.1), although its construction began in $1834 .{ }^{460}$ The construction of the church lasted a long time and was completed in 1864, followed by work on its internal decoration. Namely, the frescoensemble and iconostasis of the church in Vevchani are the work of the most prolific Revival painter Dicho Zograf and his eldest son, Avram Dichov. Dicho Zograf painted the throne icons in 1867, which is considered the year of consecration of the church; however in the church there is also an older icon by the same author (Mother of God with Christ), dated in 1849. The fresco painting of the church entrusted to Avram Dichov was completed in 1879 , confirmed by his partially preserved signature in the lunette above the southern entrance to the naos, as well as an inscription inside the temple (Ibid: 108).

St. Nicholas in Vevchani has quite impressive dimensions for a rural church: the naos measures 12.75 / $17 \mathrm{~m}$; its total length reaches $19.5 \mathrm{~m}$ including the altar apse. It is a compact building (the width to length ratio equals 3:4), without a narthex, open porches or other auxiliary rooms (fig. III.199). ${ }^{461}$ However, the partially preserved consoles, made of decorative profiled stone blocks, arranged in a horizontal line on the south façade imply that the church originally had a wooden porch, probably of an open type, along the entire south, and most likely along the west façade, which protected the entrances to the temple and provided a covered space for gathering of the faithful before and after liturgy and

\footnotetext{
460 The preparations for the construction of this temple took a long time, and in 1835 a permit was obtained from the Ottoman government, an event written in the Codex of the church of St. George in the nearby town of Struga (Грозданов, 2004: 107).

461 Like many other Revival churches, the church in Vevchani in the recent past has been subject to unprofessional, arbitrary and harmful interventions performed by the local population, the church board and the clergy. Namely, to the west of the church, an auxiliary building was erected connected to the church through a closed porch along its entire western façade, including a bell tower. With these additions, the authentic composition of the church was disturbed to a great extent, and its western façade, now almost imperceptible behind the newly built structures, was deprived of its authentic monumentality.
} 
during the great feasts and celebrations. The church was covered in the usual way for the Revival basilicas: without a clerestory, with a gabled roof featuring characteristic trapezoidal east and west facades.

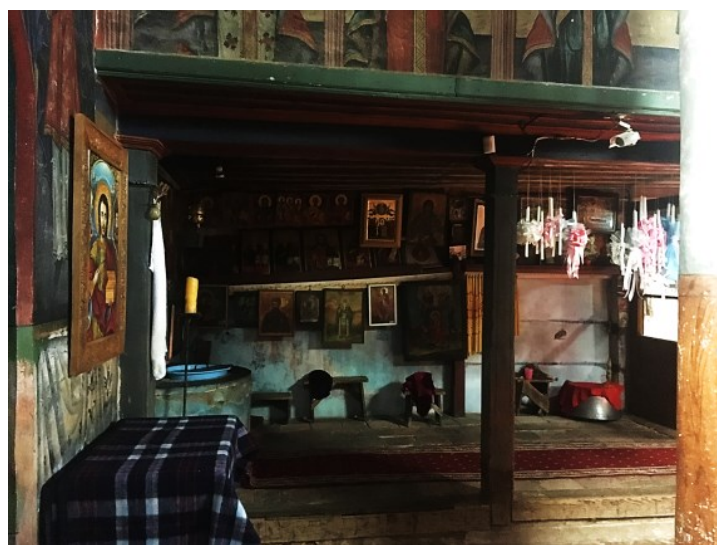

Figure III.196 St. Nicholas in Vevchani (Struga). View of the south-west corner of the "narthex" below the gallery.

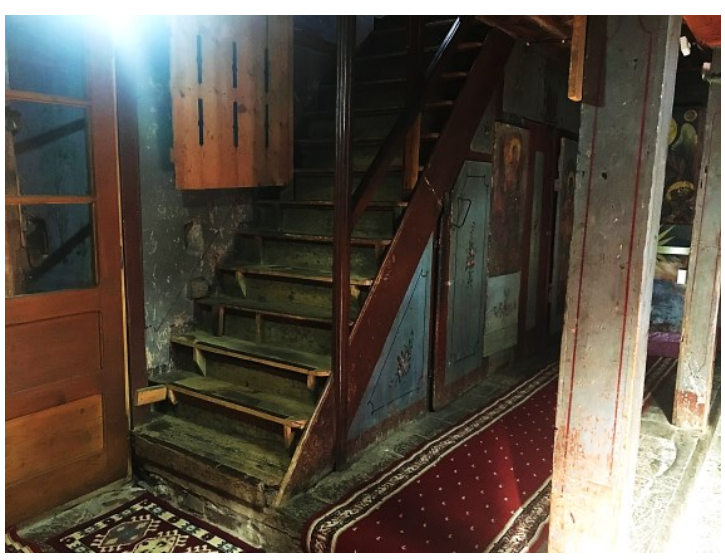

Figure III.197 St. Nicholas in Vevchani (Struga). View of the north-west corner of the "narthex" below the gallery.
According to the typological solution, St. Nicholas in Vevchani is a three-nave pseudo-basilica with a deep, semicircular altar apse (fig. III.199-200). The altar area incorporates a prothesis and diaconicon marked with semicircular niches in the east façade wall. The naos is divided into three naves via three pairs of massive columns, $60 \mathrm{~cm}$ in diameter and $5 \mathrm{~m}$ in height, including their bases and capitals, which consist of a rather complex profile: a torus at the bottom surrounding the trunk of the column; followed by an inverted tetrahedron, with cut corners; followed by several concave and convex segments; and finished with a truncated pyramid (fig. III.198). Above these complex profiled capitals stretch semi-circular arches which interconnect the columns with the perimeter walls, strengthened with wooden beams that connect and tie the whole system. With the help of the transverse arches (with a height at the apex of $\sim 7.5 \mathrm{~m}$ ) and the longitudinal ones $(80 \mathrm{~cm}$ lower), the threenave disposition of the church's plan transforms in the upper parts of the church into a grid of approximately square bays in the central nave, ${ }^{462}$ and rectangular (elongated) ones in the lateral naves (fig. III.200A). Despite the variable length, the bays are covered equally in all three naves, in a symmetrical

composition: with a blind dome in the six bays which correspond to the naos and half-domes (consisting of semi-cylindrical vaults towards the perimeter walls, and blind semi-domes supported on pendentives towards the arcades) in the three bays above the gallery (see fig. II.15, III.200A) as well as the three bays in the altar. The shape of the bays caused the domes in the central nave to have an approximately regular circular shape, while in the side naves they are extremely elongated - oval. Approximately at the elevation where the domes rest on the pendentives (at a height of $7.7 \mathrm{~m}$ in the central and $7.3 \mathrm{~m}$ in the lateral naves), flows a profiled partition cornice. The total height of the naos is proportional to the church's imposing dimensions in plan: the central nave reaches $9.8 \mathrm{~m}$ from the floor to the top of the blind domes; the lateral ones approximately $1.5 \mathrm{~m}$ less (fig. III.201A). The monumental space thus obtained enabled the installation of a very tall iconostasis, as well as a larger number of windows on all four facades ${ }^{463}$ (see fig. III.69A).

The gallery covers a relatively narrow rectangular space, with a central semicircular balcony. Its fence consists of a solid completely fresco-painted parapet (emporia) ${ }^{464}$ topped with a musharabia (fig.

\footnotetext{
${ }^{462}$ An exception is the eastern field above the iconostasis, which is much shorter.

${ }^{463}$ A total of 18 windows: 3 on the north façade, 4 on the south, 5 on the west (in the gallery space, in two levels) and 6 on the east façade ( 3 in the apse and 3 above it).

464 The fresco-ensemble of the gallery parapet consists of eight medallions with busts of medieval rulers and martyrs, in a symmetrical composition flanking the central scene of the Dormition of the Mother of God. Furthermore, under the influence of older local cults, Avram Dichov painted a representation of the Seven Vise Men on the north wall in the naos: the saints are arranged in a pyramidal composition around a table prepared for communion, with a scroll with the Cyrillic alphabet; in the center
} 
III.198, III199B, III.200B). As was common for the Revival churches, the space under the gallery was conceived as a replacement for a narthex, separated from the remaining naos with the wooden subconstruction of the gallery and, in this case, further differentiated since it was raised on a low platform 20 $\mathrm{cm}$ above the floor in the naos. This narthex also includes a baptistery (fig. III.196-197).
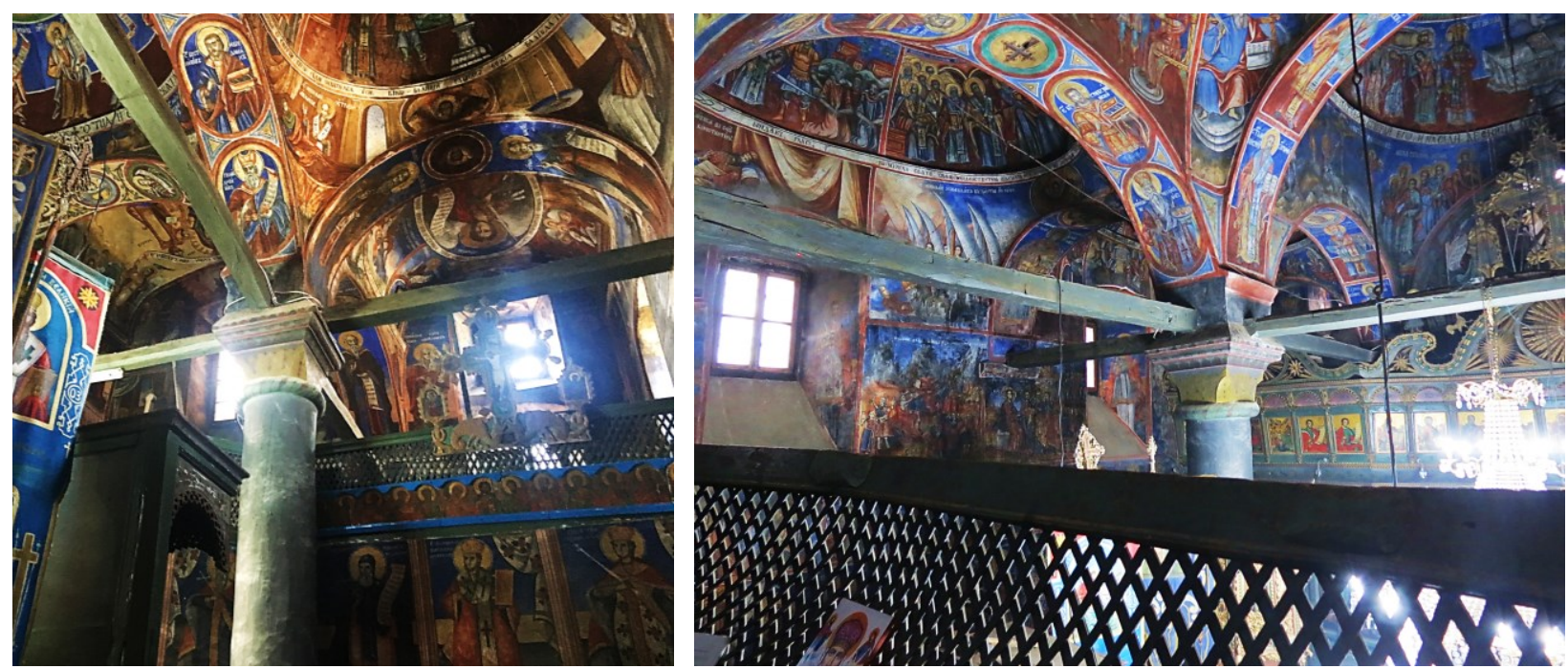

Figure III.198 St. Nicholas in Vevchani (Struga): A. View from the naos towards the gallery; B. View from the gallery towards the north-eastern part of the naos.

In addition to its architectural qualities, one of the key features of the church of St. Nicholas in Vevchani is its masonry of exceptionally high quality: its structure is solid and massive, with almost exclusive use of very high quality hewn and precisely arranged stone blocks in ideally horizontal rows, which resulted in a minimal need for mortar binder (fig. III.200B-C, III.201). The exceptional technique in the processing of the stone is evident both in the construction of the perimeter façade walls, whose thickness is $115 \mathrm{~cm}$, as in the internal structure. Namely, the three pairs of massive circular columns that divide the naos into three naves were built from the same impressively processed stone; as were the capitals, pilasters, dividing and crown cornices, lunettes, window transennas, oculi and rosettes, the floor throughout the church which was composed of stone slabs, etc. Some of the blocks, especially within the entrance portals, the monolithic architrave window lintels and the corner pilasters were further decorated in shallow relief with a variety of motifs: angels (see fig. III.83B), Maltese and procession crosses (see fig. III.67), hexagrams and solar symbols inscribed in circular medallions, etc. The dominant use of well hewn and carved stone is due to the top mastery and skill in stone-masonry, which was carried out on site where the stone was hand carved and processed, after being transported by oxen to the construction site from the quarry Majdan, located higher on the slopes of the mountain Jablanica above the village.

Furthermore, the exceptional mastery of the master-builders of the church in Vevchani is expressed in the complex internal spatial and structural concept, as well as in the composition of the facades as an expression of the internal structure of the church. Namely, the facades are divided into three zones: a low plinth; the façade canvas (drawn inwards by $10 \mathrm{~cm}$ ) and the third zone of the façade protruding outward again by $7 \mathrm{~cm}$, separated by a profiled horizontal semicircular cornice, topped by the profiled crown cornice. The façade canvases themselves are divided into bays ( 3 on the western and 4 on the northern and southern facades) with the help of shallow rectangular pilasters, sixty centimeters wide and approximately $7 \mathrm{~cm}$ in depth (fig. III.200C, III.201B). On the east façade, dominated by a spacious and high altar apse, such pilasters are placed only at the corners. Furthermore, the pilasters themselves have

of the composition is placed St. Clement, as a most prominent local saint; the usual representation of St. Angelarius is replaced by St. Erasmus who, as noted earlier, is a particularly revered saint in the wider Ohrid region (Грозданов, 2004: 108-116). 
capitals consisting of a complex profile with several precisely executed segments. The same decorative profile is present in the rectangular window jambs on the longer facades, as well as the consoles for the porch construction, which have been partially preserved. The south and west facades are pierced by the entrance portals, two on the south (one larger entrance portal leading to the naos and a smaller one leading directly to the altar) and one in the axis of the west façade of the church.
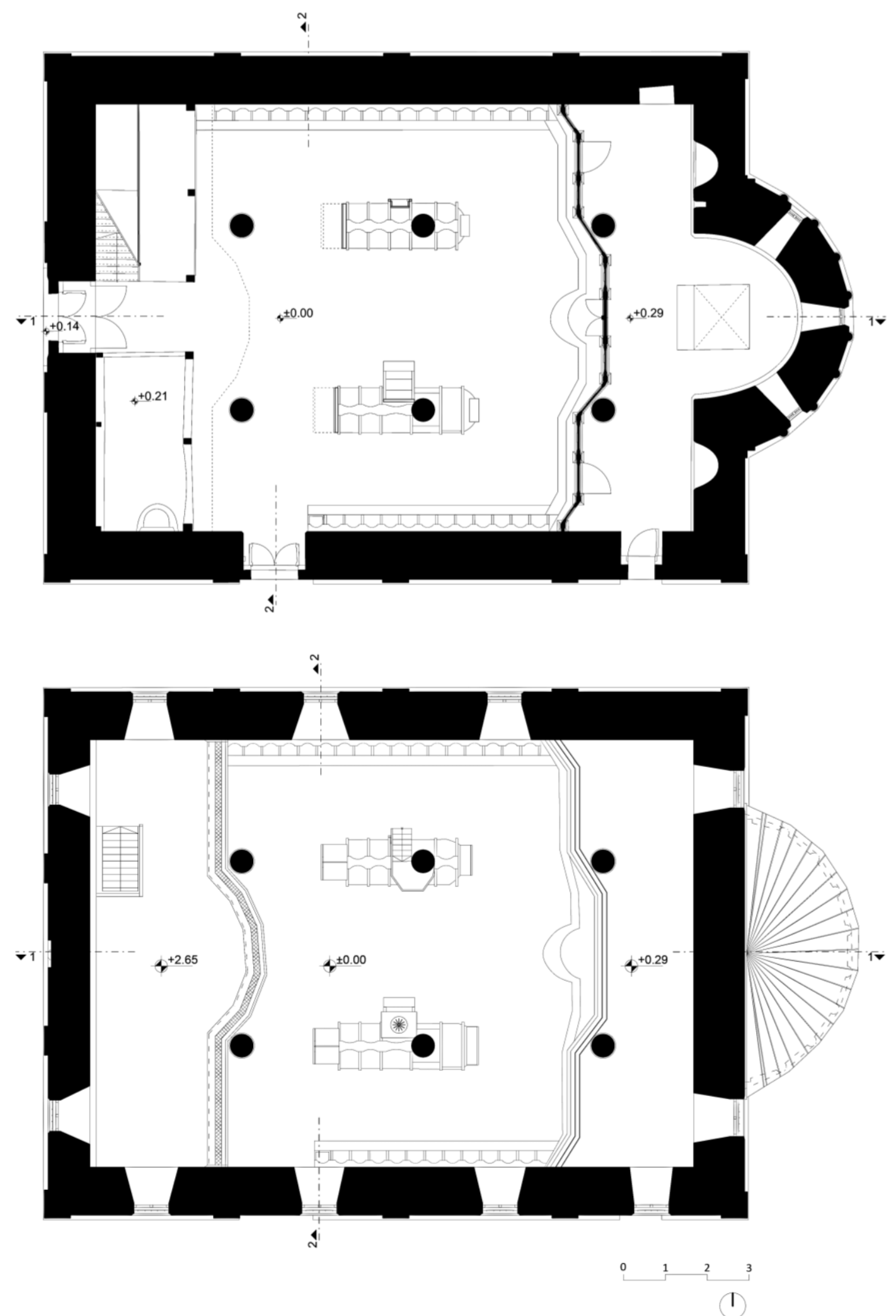

Figure III.199 St. Nicholas in Vevchani (Struga). Plans: A. Ground floor ( \pm 0.00$)$; B. Gallery $(+2.65)$. 

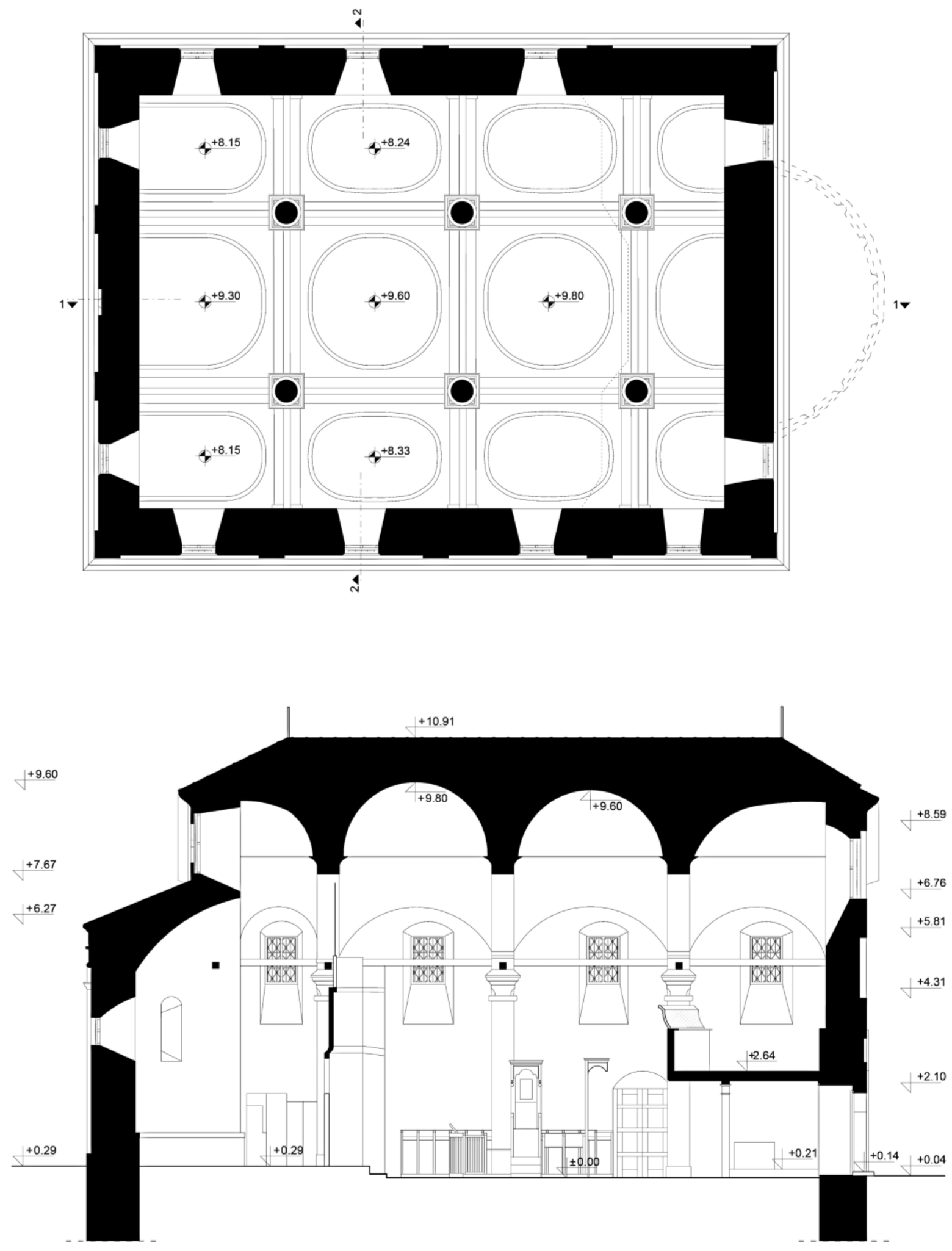

Figure III.200 (this page) St. Nicholas in Vevchani (Struga). A. Plan of the ceiling; B. Longitudinal section (1-1).

Figure III.201 (opposite page) St. Nicholas in Vevchani (Struga). A. Transversal section (2-2); B. Eastern façade; C. Southern façade. 

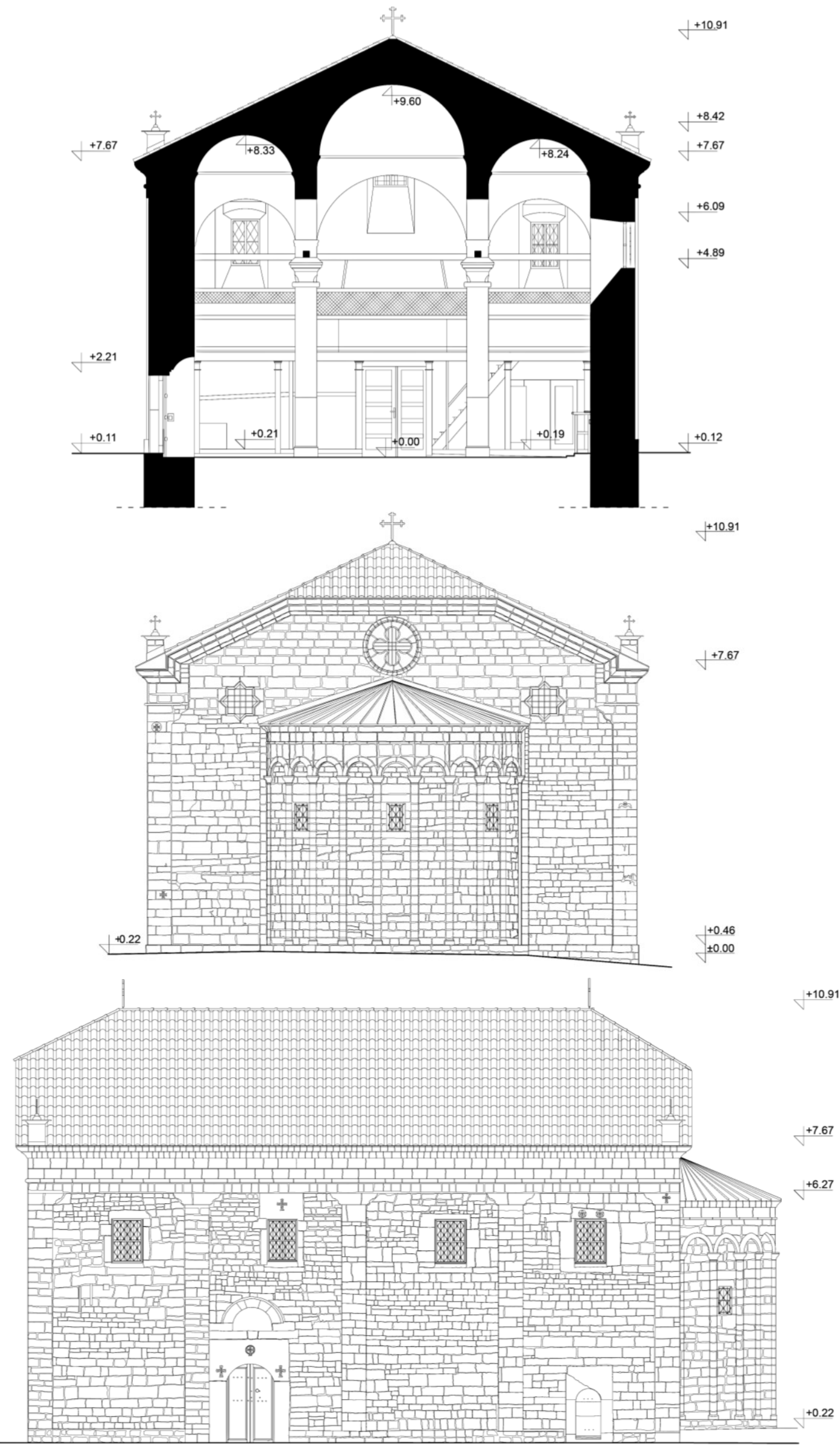
The eastern façade of St. Nicholas in Vevchani is dominated by a semicircular apse divided into nine segments via semicircular pilasters connected by arches (fig. III.201B, III.202A). Above the zone of the arches appears an identical semicircular division cornice as the ones on the other facades. The apse is illuminated through rectangular windows in the central and the penultimate lateral segments. In the case of the shorter facades, a change in the masonry is evident, exactly in the upper parts, i.e. above the level of the crown cornices of the longer facades, where one can witness, conditionally speaking, a second construction phase, certainly due to the decades-long construction of the temple and the likely inevitable changes in the master-builder team. Namely, the upper parts of the shorter facades were executed in stone and brick in alternating layers, with a vertical piece of brick between the stone blocks (fig. III.202A). However, despite the use of brick, the stone work remained exceptional. This section of the western and eastern facades is where the windows made of precisely carved stone were installed. On the east façade above the apse, there is a monumental central circular oculus which houses a stone window transenna in the shape of a four-leaf clover. This central window is flanked by smaller windows, the axis of which is set approximately at the level of the semicircular cornice, with a very rare and interesting shape of an eightpointed star. On the west façade, on the other hand, there is a high double window (see fig. III.66B), ${ }^{465}$ flanked by two oculi made of a profiled stone frame surrounded by a thin ring of a single row of bricks (see fig. III.67), under which, in their vertical axis, appear rectangular windows, identical to those on the longer facades and installed at the same height. Towards the middle of the west façade and a little higher, in a symmetrical composition, there are two significantly smaller circular oculi, carved into stone slabs.
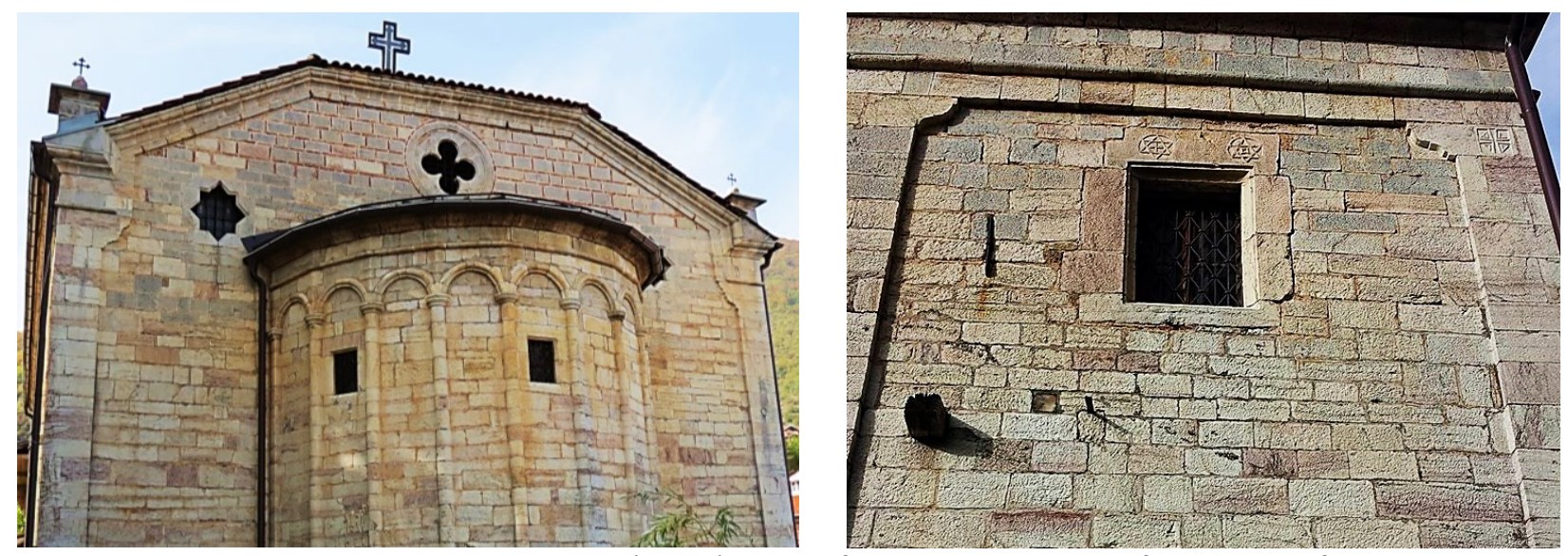

Figure III.202 St. Nicholas in Vevchani (Struga): A. View from the east; B. Detail of the southern façade.

The exceptionally well-designed and executed construction of the church is a result of the longstanding traditional occupation of the population of Vevchani with construction, as evidenced by the preserved residential and vernacular architecture in the village. It can be said that the stone masonry of the church of St. Nicholas in Vevchani even draws certain influences from the Romanesque and the Gothic. Namely, the specific details in the processing of the stone and the shaping of the façade canvases and their elements speak of possible connections of the Vevchani master-builder groups, widely famous for their skill, with the Adriatic coast, Dalmatia, Italy, and even further with Western Europe. It is possible that their experiences acquired through contact with the Western European historical influences were transferred to their native village. In that direction, a completely unique feature of the church in Vevchani, which again indicates evident direct Western European influences, is the existence of four decoratively processed pinnacles ${ }^{466}$ that exceed the roof, placed at the very corners of the building, as elements specific

\footnotetext{
${ }^{465}$ Almost identical double windows can be found at the churches in the villages of Drmeni and Carev Dvor in the region of Prespa. ${ }^{466}$ A pinnacle (from the Latin pinaculus), is a constructive and decorative element built of stone in the form of a pillar finished with a conical or pyramidal element, often used in Gothic architecture. In addition to the ornamental effect, the role of the
} 
to the Gothic architecture (fig. III.201B-C, III.202A). They are composed of low square masonry pillars with profiled capitals and conical ornaments which support crosses. ${ }^{467}$
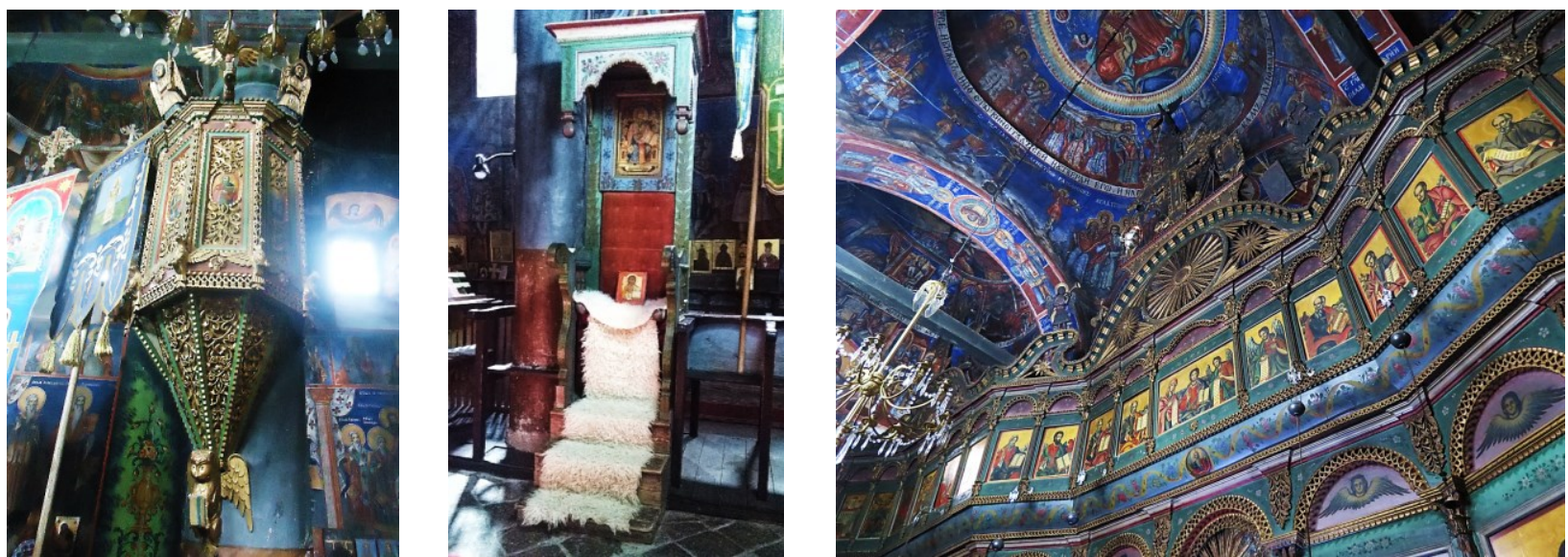

Figure III.203 St. Nicholas in Vevchani (Struga): A. The ambo; B. The bishop's throne; C. Detail of the iconostasis.

As expected, the interior of the church was treated with the same due care (see fig. II.10B). The emphasis is on the tall two-story iconostasis, placed on a low tribune made of reddish stone, as well as on the luxurious church furniture: a pulpit, a bishop's throne, icon pedestals, etc. All were made with abundant use of woodcarving in shallow and high relief, as well as abundant painting and gilding (fig. III.203). For example, the pedestal of the pulpit which, as usual, was shaped as an inverted cone, was entirely wood-carved, with a baroque abundance of interweaving and floral motifs, and ends at the bottom in a gilded sculpture of a griffin. On the sides of the pulpit balcony, within gilded wood-carved ornaments, oval mandorlas with icons were inserted. The stone columns and their capitals were also painted, with the exception of the eastern pair which are located behind the altar partition. The iconostasis was elegantly conceived and purified from abundant sculptural decoration, so that the woodcarved completely gilded royal doors stand out. A specific baroque playfulness was achieved in the area of the Crucifixion, where in the axis of each nave an oval mandorla was placed (of which the central one is the largest) with accompanying solar motifs, connected by a wavy crown cornice that flows along the entire iconostasis (fig. III.203C). The iconostasis is topped by three ornamental crosses, corresponding to each nave, of which the central one is a monumental Crucifixion.

\section{III.5.B.4 THREE-NAVE BASILICAS WITH CENTRAL NAVE CLERESTORY}

As has been mentioned many times before, the Revival three-nave basilicas are in fact pseudobasilicas, meaning that their three-nave disposition is visible only inside the temple, covered from the outside with a gabled or bonnet roof. However, there are a few exceptions among the three-nave, and several examples among the five-nave basilicas, where the central nave is taller than the lateral ones not only in the interior but also on the fifth façade. The three-nave basilicas with an central nave clerestory, according to the classification made so far, constitute an extremely small group comprised of only $2 \%$ of

pinnacles was basically structural, as counter-weight at key points of the building in order to overcome the lateral thrust of the arches. In the Gothic cathedrals, one pinacle was placed over each flying buttress, i.e. it corresponded to each span of an arch in the interior. At the church in Vevchani, only four such pinnacles are placed at the corners of the building.

${ }^{467}$ Besides the church in Vevchani, similarly conceived pinnacles are found at the corners of the low rectangular altar apse of the church of St. Demetrius in the village of Sedlarci (Strumica), which is also a very unusual and unique solution. 
the total number of Revival three-nave basilicas (see chart III-2). The churches of this typological subgroup registered so far are listed in the following table (table III-13):

\begin{tabular}{|l|l|l|l|c|l|}
\hline & CHURCH & VILLAGE & REGION (TOWN) & YEAR & $\begin{array}{c}\text { ADDITIONAL INFORMATION } \\
\text { fresco-painting / icons, renovations }\end{array}$ \\
\hline 1 & St. Nicholas & $/$ & Krushevo & 1832 & renovated in 1905/1906 \\
\hline 2 & St. Savior - Ascension of Christ & Drachevo & Skopje & 1849 & \\
\hline 3 & The Most Holy Mother of God & Sogle & Veles & 1855 & \\
\hline 4 & Dormition of the Most Holy Mother of God & $/$ & Delchevo & 1858 & \\
\hline 5 & St. Peter and Paul & Papradishte & Veles & 1875 & \\
\hline 6 & Dormition of the Most Holy Mother of God & Oreshe & Veles & $/$ & renovated in 1967 \\
\hline
\end{tabular}

Table III-13 Three-nave Revival basilicas with central nave clerestory.

They are located in various urban and rural areas throughout Macedonia (see map III-B). To some extent, it can be said that a certain concentration of basilicas with central nave clerestory is found in central Macedonia (the villages Sogle, Oreshe and Papradishte in the region of Veles, the village of Drachevo, which although located in the Skopje valley, gravitates towards Veles). To this group, of course, should be added the cathedral basilica St. Panteleimon in Veles, a five-nave building with a central nave clerestory, which is one of the most monumental and grandiose works of Andreja Damjanov and which had a huge impact on other master-builders from the Revival period (see Chapters III.5.B.1 and III.5.C). In addition to this is the origin of some of the master-builders of this type of three-nave churches. Namely, from the identified authors of the buildings with this specific typology, Andon Kitanov, author of the Most Holy Mother of God in Sogle (fig. III.204) and Gjorgji Novakov - Dzongar, author of St. Peter and Paul in Papradishte (see fig. III.25), were both born and educated in the village of Papradishte where, as was pointed out earlier, Andreja Damjanov himself was born and where his family master-builder group operated and was supplied with members.

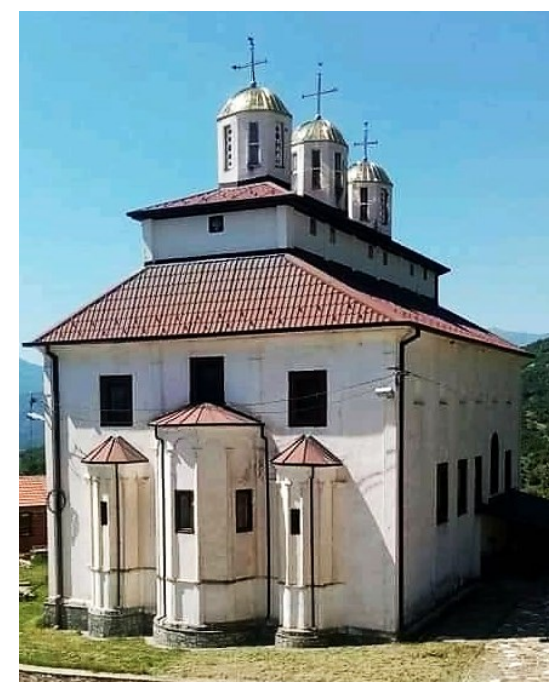

Figure III.204 The Most Holy Mother of God in Sogle (Veles). View from the northeast.

In their interiors, the three-nave basilicas with a central nave clerestory were not uniformly arranged, but rather with various combinations of vaults, domes supported on drums, blind domes and architrave construction. At the church of St. Nicholas in Krushevo, for example, the taller central nave is bridged with a semi-cylindrical vault, while the lateral naves were covered with a flat ceiling; St. Peter and Paul in Papradishte (Veles) has 3 blind domes in the central nave, while the lateral ones have 6 each; the Most Holy Mother of God in Sogle (Veles) has 3 domes set on high drums that rise from the central nave clerestory which, unlike the other churches of this group, is covered with a bonnet roof, etc. Yet, their unifying feature is the superiority in height of the middle nave in comparison with the lateral ones evident also on the church exterior, i.e. the fifth façade. Therefore, their typological solution clearly draws direct parallels with the early-Christian three-nave basilicas and their medieval Byzantine descendants.

\section{"St. Savior - Ascension of Christ" in Drachevo (Skopje), 1848/1849}

The church of St. Savior (Ascension of Christ) was built in the village of Drachevo, near the town of Skopje, towards the middle of the XIX century. Since Drachevo is an old settlement, there was undoubtedly an older church preceding the monumental Revival one, which served the local population in earlier centuries. This older village church was probably built on the location known as "Gorna Crkva" 
(Upper Church); it likely dated to the post-Byzantine period, as confirmed by the preserved royal doors with an inscribed year: 1661, which today are kept in the treasury of the church of St. Savior (Станоевски, 1999: 8-9). This post-Byzantine church does not exist today; its desolation can be linked to the abandonment of Drachevo in the late XVII century, caused by the Austro-Turkish War of 1683-1699, the Karposh Uprising, the plague epidemic and the subsequent arson of the town of Skopje by the Austrian armies in 1689. After these extremely unfavorable events, the re-establishment of Ottoman rule meant strong repressions on the autochthonous Macedonian population, which was the reason for the villagers of Drachevo to withdraw high in the nearby mountain Karadzica where they formed a temporary settlement (Малковски, 2007: 42). The original village location began to be repopulated and to develop with greater intensity at the end of the XVIII century and throughout the XIX century. Precisely from this phase of re-development of the village originates the present church of St. Savior. ${ }^{468}$

The new church was built a hundred meters to the southeast of the old abandoned church whose material, according to local oral testimony, was re-used to build the new one (Ibid: 21$).{ }^{469}$ The exact dating of its construction is based on two preserved inscriptions within the church itself. The first one is located under the gallery, on the north wall of the naos and reads: сєа цєрковъ съ зидаса въ 1849 бивши митрополитъ г. Иоаким служав василиі свА- созидаa. This inscription can be dated after 1868 , i.e. after the death of the "former metropolitan Joachim", as mentioned in the inscription (Станоевски, 1999: 18-19), which also serves to date the painting of the frescoes in the church. The second inscription is located on the north altar door, where the year 1848 was written in Old

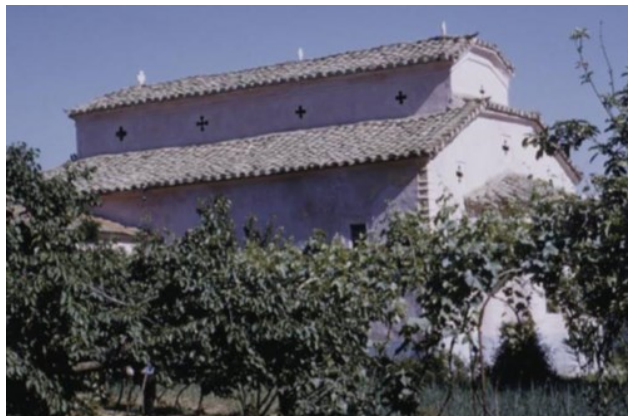

Figure III.205 St. Savior in Drachevo (Skopje) in 1954. View from the south-east.

Church Slavonic. This inscription dates from 1858, when the famous Revival master-painter Dicho Zograf and his collaborators worked on the iconostasis of the church (Ibid: 19).

According to its typology, St. Savior in Drachevo is a three-nave basilica. Its dimensions are 20.30 / $11.80 \mathrm{~m}$, with a height of over $11 \mathrm{~m}$, making this church one of the largest three-nave buildings, especially those built in rural areas (fig. III.205). The ratio of the width to the length of the church is $1: 1.72$, i.e. a golden ratio was used in the proportional design of the temple. As was usual for the monumental sacred architecture from the XIX century, the outer walls of the church were built of crushed stone and lime mortar, very massively, with a thickness of $110 \mathrm{~cm}$ (fig. III.208). While the wall canvases were built in a non-representative manner with a more modest material ${ }^{470}$ and then completely plastered, better hewn stone blocks were used at the corners of the building, as well as for the construction of the windows and

\footnotetext{
468 Namely, in the middle of the XIX century, the more prominent villagers of Drachevo, together with the priest Vasilij, initiated the construction of a new, larger church, because "the old one was small and did not meet the church needs" (Станоевски, 1999: 18) since the village significantly grew in the XIX century. Also, the older church was probably deterioreted as a result of the almost complete abandonment of Drachevo for an entire century. The request for construction of a new church was submitted to the Skopje Pasha, under the auspices of the Skopje Metropolitan Joachim, who also appears as the church's founder.

${ }^{469}$ According to the testimony of the informant Velika Bozhinovska from Drachevo, all the inhabitants of the village participated in this activity, especially the younger generation, arranged in two rows: on one side the boys, on the other the girls. The stone blocks were transferred from hand to hand from the old church to the construction site of the church of St. Savior (Станоевски, 1999: 21). It is interesting to compare this procedure with a local legend from the vicinity of the town of Ohrid written in the XIX century by Kuzman Shapkarev, according to which the walls of Ohrid's citadele were built with stone blocks from the nearby archeological site of Hermeleja which were "passed from hand to hand by the entire population, which was lined up in long lines as chains along the one-hour distance from the suburbs to the town; and that the people of both sexes were so busy that hardly an old woman was left with seven cradles with small children to care for them, while all the other men, women and children were busy transporting the stones" (Маленко и Кузман, 1988: 90). It can therefore be concluded that this was a standard practice when re-utilizing existing material for the construction of an important public building.

470 Especially knowing that in the case of the church in Drachevo, the remains of an older demolished church were used.
} 
doors. The interior and roof structure was made entirely of wood. According to the Ottoman legislation in the given period, the church was buried approximately one meter into the ground (fig. III.210).

The naos of the church is divided into three naves with the help of a total of 10 columns arranged in 5 pairs, placed on cubic stone pedestals (fig. III.208-210). Their total height is $5 \mathrm{~m}$, including the capital and the pedestal; the body of the columns is made of wood, with lightweight wooden capitals shaped using the kjulum paste (fig. III.206). The columns are interconnected with a series of semicircular arches in an east-west direction, separating the central significantly higher nave from the lateral lower naves. In the north-south direction, the columns are not connected by arches, so that the whole length of the central nave is a single volume, accentuated by its considerable height: $10.40 \mathrm{~m}$, as opposed to that of the lateral naves - $7.35 \mathrm{~m}$, i.e. lower by $3 \mathrm{~m}$ (fig. III.210).
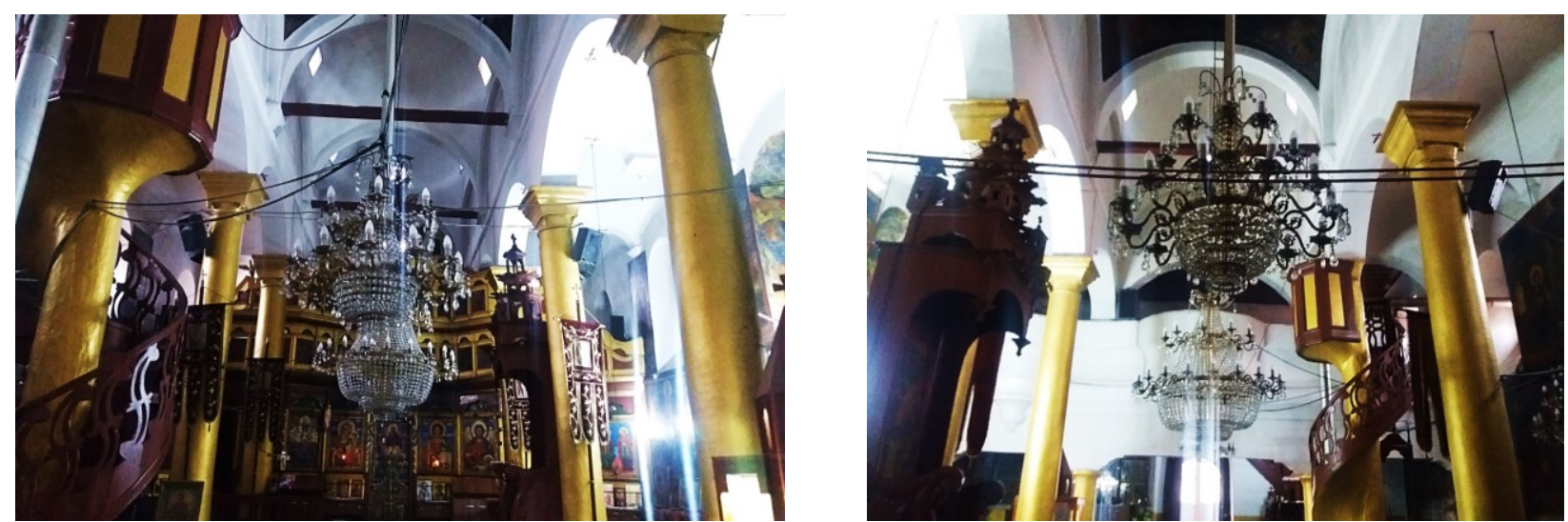

Figure III.206 St. Savior in Drachevo (Skopje): A. View from the narthex below the gallery towards the altar; B. View from the naos towards the gallery.

The three-nave disposition of the plan is transformed in the upper zone of the church into a more complex system of 12 approximately square bays, four along each nave, which do not correspond to the pairs of columns in the arcades, for the transverse arches were shifted to the east (fig. III.209). Namely, the square fields in the central nave are formed by semicircular arches in both directions, carried on decorative profiled consoles connected transversely with wooden ties that tighten the system. The lateral naves are also divided into four approximately square bays defined by the outer walls of the church and the arcades, while in the transverse direction they are separated by three double arches, very specifically shaped, with a central decoratively processed pendant (fig. III.207A). ${ }^{471}$ These arches, like those in the central nave, rest on profiled consoles.
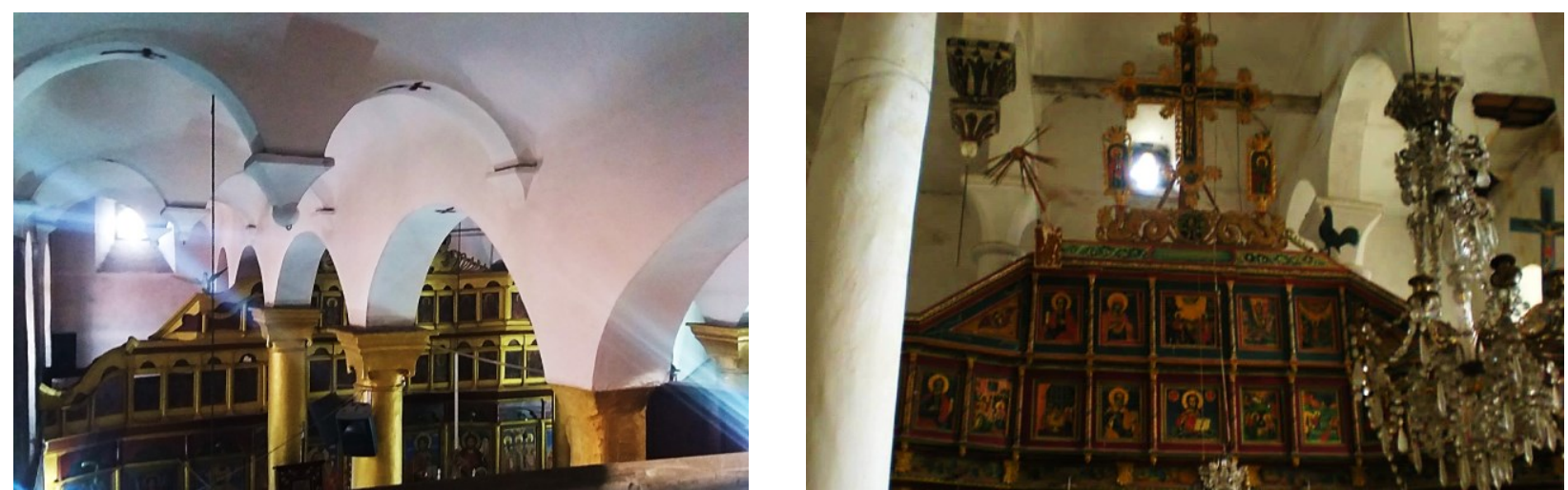

Figure III.207 Examples of double arches with decorative pendants: A. in the lateral naves of St. Savior in Drachevo (Skopje); B. in the central nave of St. Nicholas in Orlanci (Kichevo).

\footnotetext{
${ }^{471}$ Identically conceived pendants in the center of double arches can be found at the church of St. Panteleimon in Veles and the church of St. Nicholas in the village of Orlanci near Kichevo (fig. III.207B). Furthermore, the appearance of double arches as early as in the Roman monumental architecture in Macedonia must not be overlooked (see footnote 20).
} 
On the approximately square bases thus obtained rest blind domes, shallow in the lateral naves and higher in the central nave (fig. III.209). A special feature of the whole space is the abundance of light, because the domes in the central nave are illuminated with one window on the north and south side, as well as on the west and east at both ends of the central nave (fig. III.210). All these windows are externally decorated with stone-carved transennas in the form of four-leaf clovers (phytomorphic crosses). The whiteness of the upper parties also contributes to this effect. Namely, all the domes in the nave and their substructure of arches and consoles were completely whitewashed, with the exception of the third dome in the central nave viewed from the east, which plays the role of a central dome and was painted with the canonically defined composition Christ Pantocrator, encircled by medallions with busts of various saints.

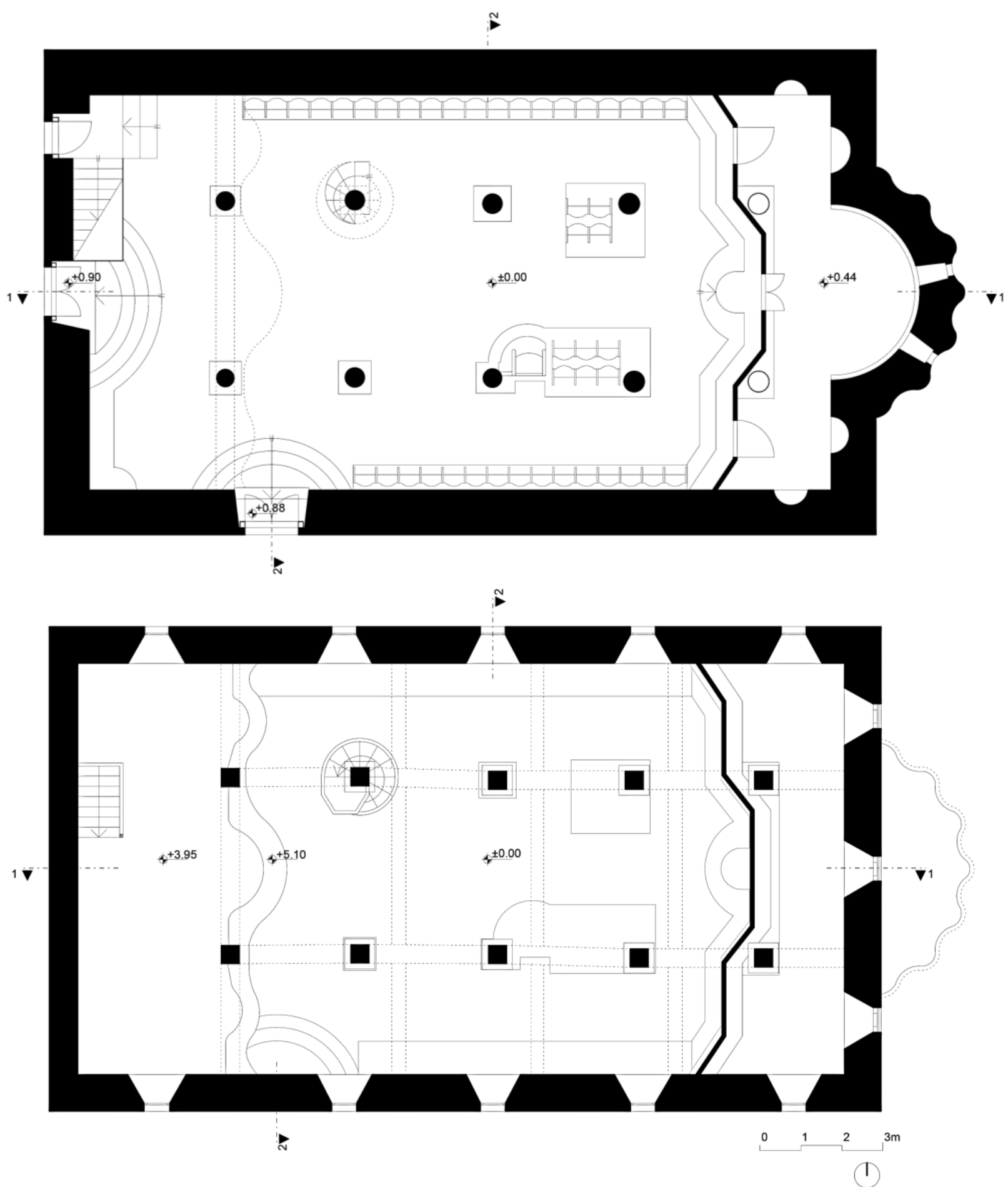

Figure III.208 St. Savior in Drachevo (Skopje). Plans: A. Ground floor ( \pm 0.00$)$; B. Gallery (+3.95). 


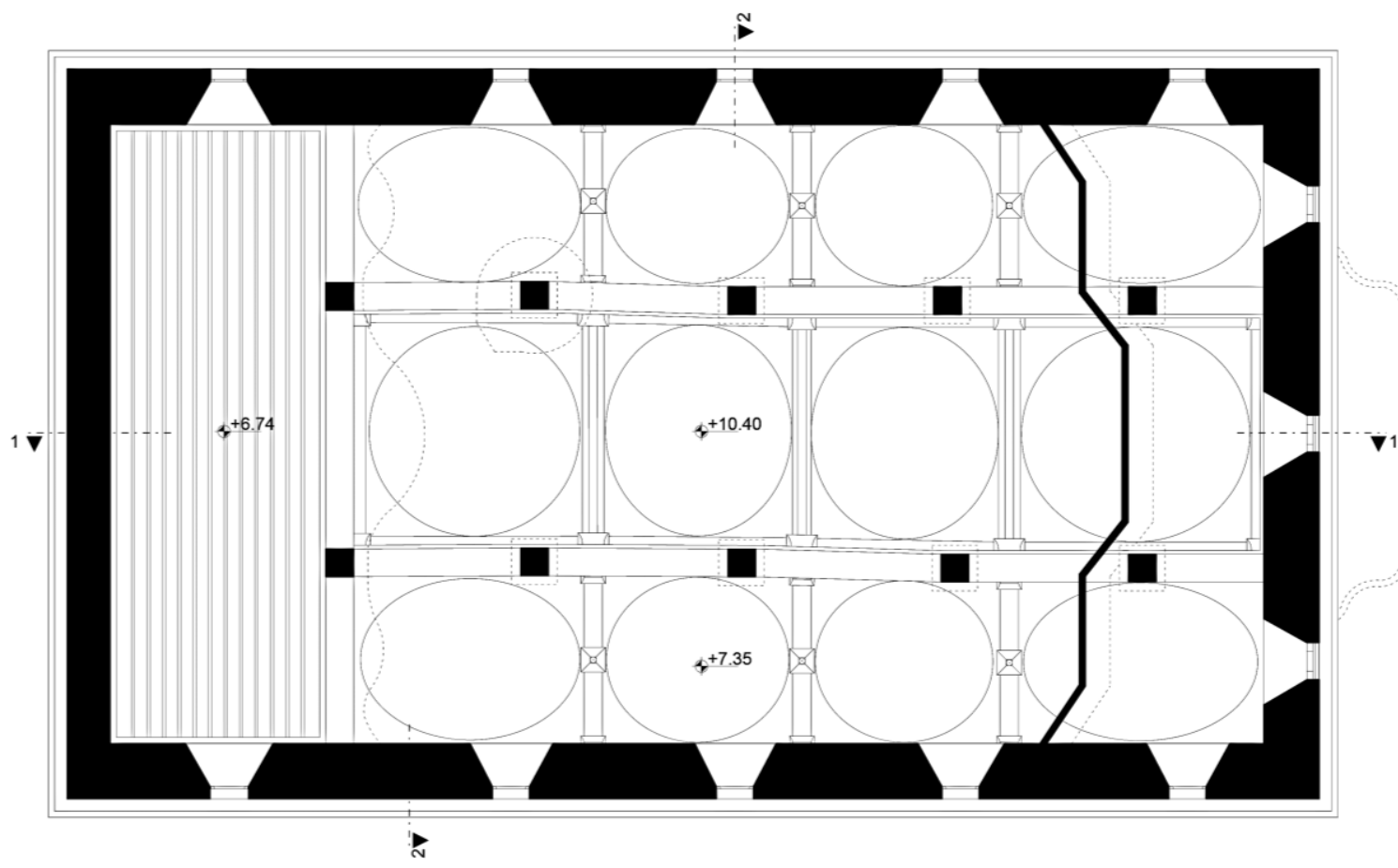

₹

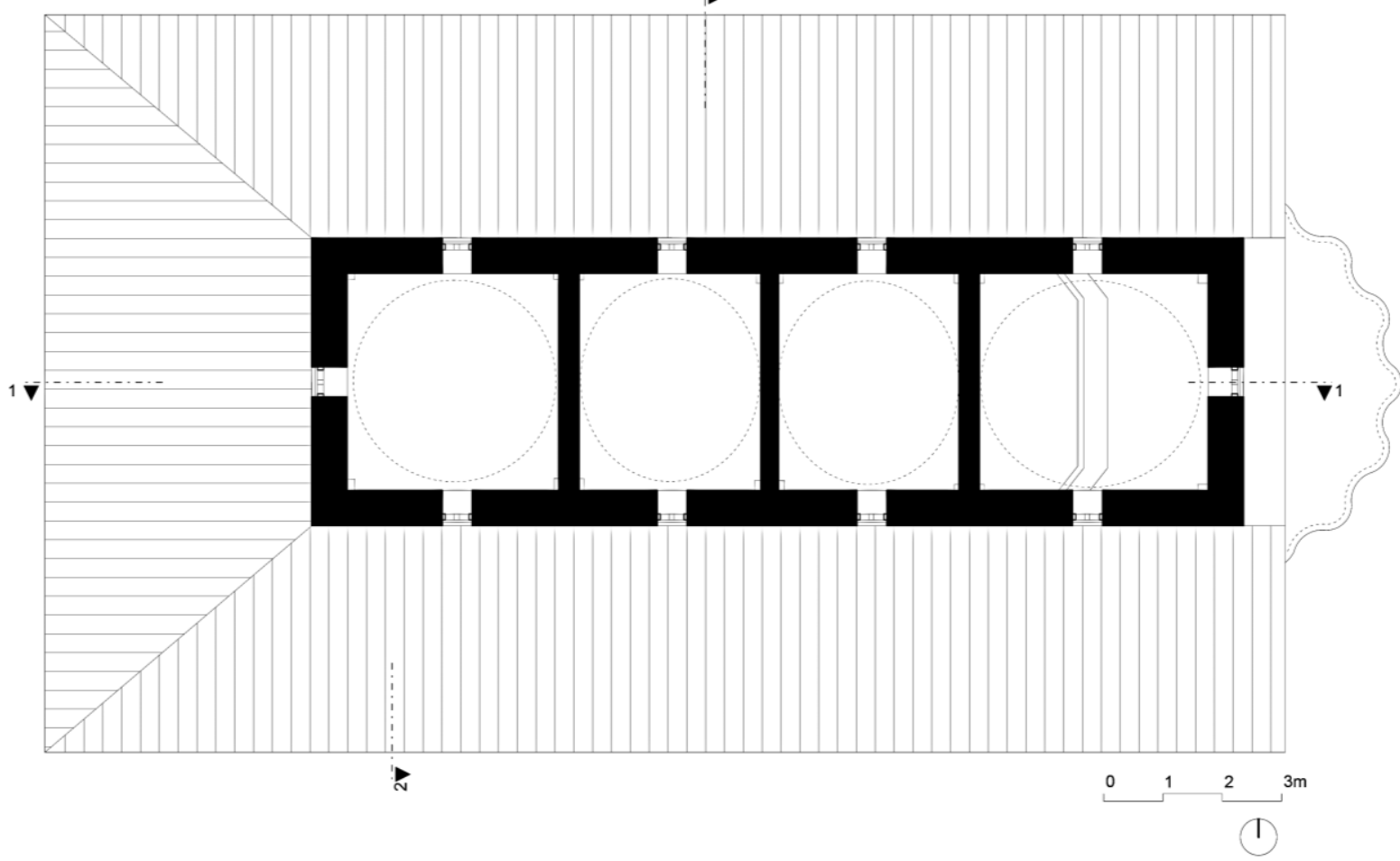

Figure III.209 (this page) St. Savior in Drachevo (Skopje). Plans: A. Ceiling (+6.74); B. Central nave clerestory (+10.40).

Figure III.210 (opposite page) St. Savior in Drachevo (Skopje). Sections: A. Longitudinal (1-1); B. Transversal (2-2). 

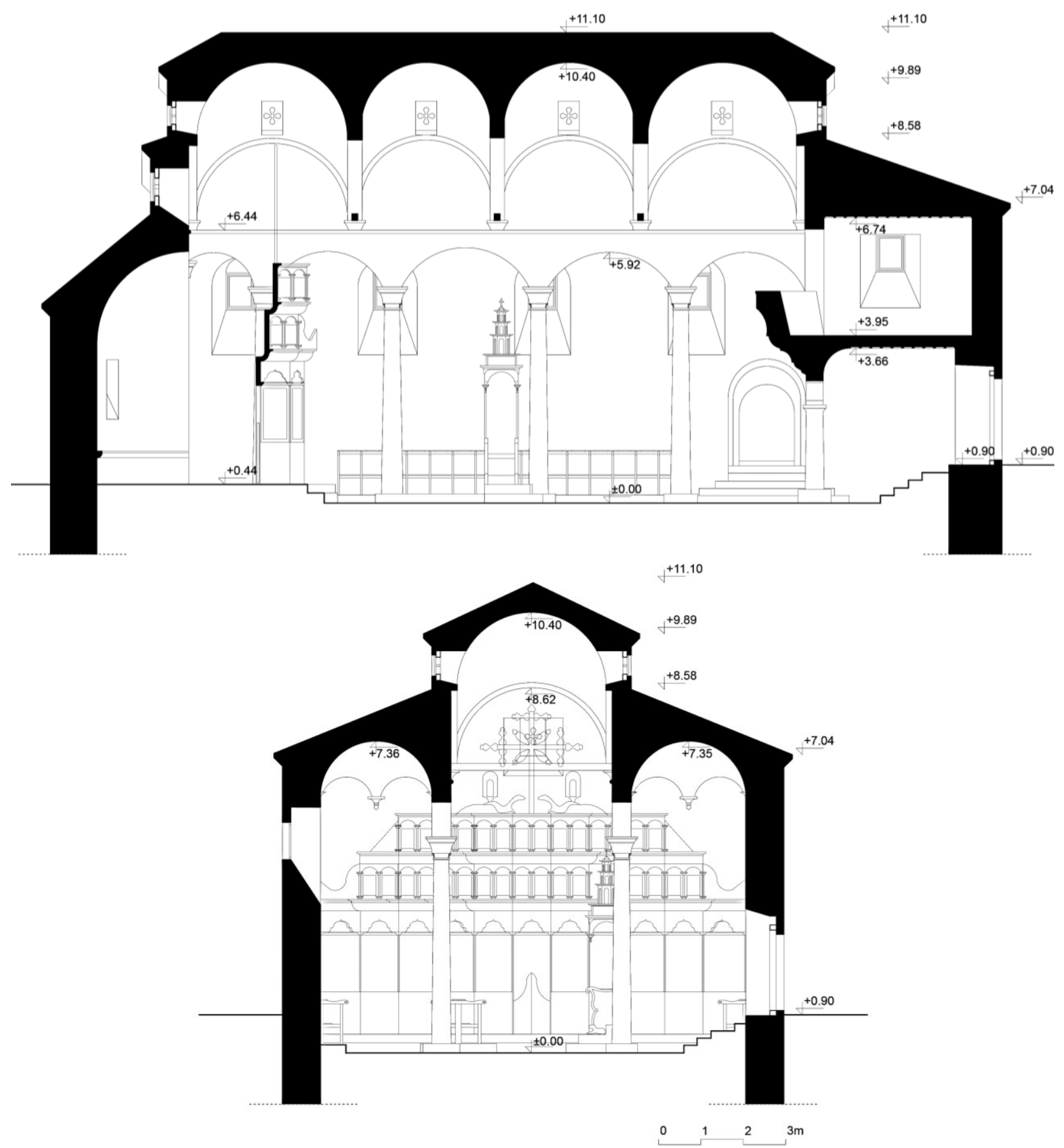

As was usual for the Revival basilicas, there is no classical narthex, which was replaced by its substitute below the gallery, in the southwest corner of which is a stone baptistery. The gallery is made of a wooden structure which rests on the western pair of columns. Its depth corresponds to the axial distance between the columns in the naos. Apart from the northwest corner of the naos, the gallery can be accessed directly from the outside through a door near the north corner of the west façade, which conditioned the installation of a stone staircase leading from the porch to the "narthex", on which rests a wooden staircase leading to the gallery (fig. III.208A). The gallery is defined by the perimeter walls of the church on the north, west and south sides, illuminated by one window in the south and north wall, placed higher than the windows of the naos. To the east it opens towards the nave cantilevered by $120 \mathrm{~cm}$, with a monumental, baroque curvature in the form of three semicircular balconies placed in the axes of the central and side naves (see fig. III.39A). The gallery parapet, with a height of $1.15 \mathrm{~m}$, is made of solid wood and covered with plaster. An important feature of the church in Drachevo is the complete absence of a 
musharabia, which speaks of the advanced understanding of its master-builders and users in an otherwise traditional and conservative society (fig. III.206B, III.210A).

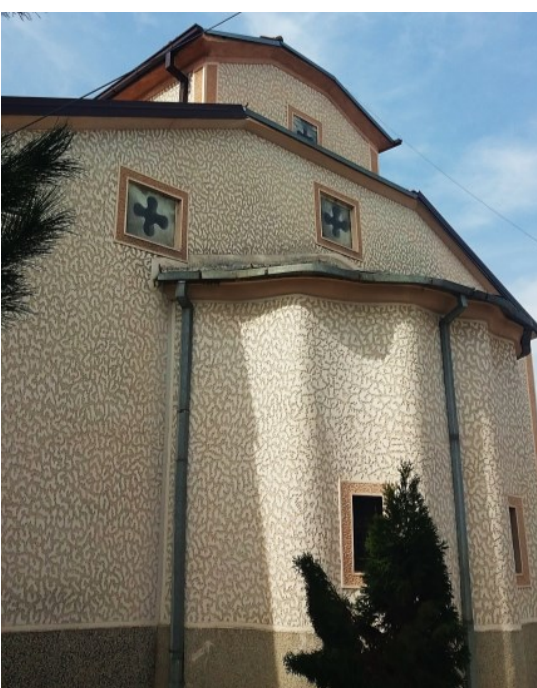

Figure III.211 St. Savior in Drachevo (Skopje). View of the eastern façade.

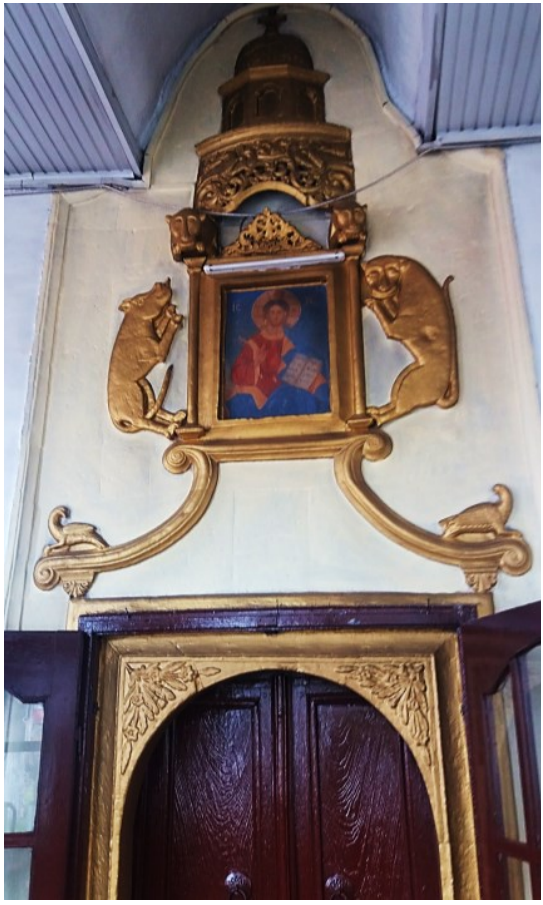

Figure III.212 St. Savior in Drachevo (Skopje). View of the western portal.

The altar apse of the church of St. Savior in Drachevo is semicircular on the inside, and wavy on the outside (fig. III.211), divided into seven segments, illuminated through two windows, asymmetrically placed in relation to the longitudinal axis of the church. The apse is flanked by the prothesis and diaconicon, marked with appropriate niches in the east, south and north walls of the church. If the apse façade had had a decorative finish (profiles, columns, cornices and similar processing), it was lost with the construction of a new façade in the 1990s by the local population. ${ }^{472}$ It is quite possible that such a decoration existed, considering the elaboration of the entrance portals. Namely, the main entrances to the naos are defined as two representatively executed portals on the west and south facades, ${ }^{473}$ of which the western portal is especially sculpturally and decoratively processed (fig. III.212). According to the established practice, almost the entire length of the side walls in the naos is lined with wooden seats on a low plinth (fig. III.208A). Similar wooden seats appear in the colonnades, between the third and fourth pairs of columns, which are used as choirs. The wood-carved bishop's throne was placed within the southern choir (fig. III.210A), with characteristic wooden pendants at the ends of the canopy, analogous to the pendants of the double arches in the side naves.

Unfortunately, we do not know who the master-builders of the church of St. Savior in Drachevo were. However, knowing that the master-builder groups that built the houses in Drachevo originated from the villages of Gorno Vranovci and Papradishte in the region of Veles and were "especially appreciated for their great expertise" (Малковски, 2007: 94), it is quite probable that the master-builders of the monumental village church also came from these villages. Stanoevski (1999), however, erroneously states: "the builders of the church are probably the people of Debar, Petre Garkata with his group, who also built the church of the Mother of God" (Станоевски, 1999: 21). ${ }^{474}$ Although completely arbitrary and essentially wrong, ${ }^{475}$ this statement in some way confirms the obvious stylistic connections of the church of St. Savior in Drachevo with the somewhat earlier works of master Andreja Damjanov and his team, including the cathedral of the Most Holy Mother of God in Skopje,

\footnotetext{
472 Namely, in the 1990s, unfortunately, the façades of the church were rebuilt, in a completely uncharacteristic way, using cement mortar. At that time, also, the authentic floor comprised of large stone slabs (Станоевски, 1999: 22) was replaced with the current marble floor which also lines the pedestals of the columns.

473 Unfortunately, today there is no sculptural processing at the southern portal, which certainly disappeared during the construction of the open porch on the west and south sides of the church in 1912, which was later glazed.

${ }^{474}$ He refers to the church of the Most Holy Mother of God in Skopje, whose construction begun under the master-builder Damjan from Papradishte and was completed by his son, Andreja Damjanov, in 1835.

475 As already discussed (see Chapter II.5), Petre Garkata was a famous Revival wood-carver, but not an architect.
} 
and especially with St. Panteleimon in Veles, as well as the church in Vranje (Serbia), whose author is his brother, Kosta Damjanov.

The first and most important indicator for the use of the brothers Damjanov's works as a prototype is the chosen architectural typology itself: a fully defined monumental three-nave basilica, with a central nave clerestory, with characteristic "saddle"-shaped shorter facades and multiple columns (five pairs) that define the three-nave disposition of the naos. Certainly, the exceptional mastery of Andreja Damjanov presented in the architecture of the church in Veles was adapted to the conditions of the church in Drachevo. Thus, the baroque curvature of the gallery, as well as its composition with three cantilevered balconies is analogous to that of Veles (see fig. III.37); as is the composition of the central nave which in Veles' cathedral is divided into three fields covered with blind domes by means of the same system of semicircular arches supported on profiled consoles; the side naves are divided into fields with identical double semicircular arches with decorative pendants in their center, which are also present in the series of shallow arcades in Veles, as well as at the iconostasis and the bishop's throne in Drachevo. In fact, it can be concluded that the church in Drachevo faithfully reflects the three-nave nucleus of the five-nave basilica in Veles. Furthermore, analogies between the church of St. Panteleimon in Veles as a "model" and St. Savior in Drachevo as its "replica" also exist in the sculptural decoration of the entrance portals, with the characteristic baroque curvature of the two " $\mathrm{S}$ "-volutes placed laterally above the lintel, topped with birds in profile (fig. III.212). Even the later (in 1912) built open porch on the west and south side of the church in Drachevo in its shape and disposition was directly inspired by the porches prevalent in the churches of the Damjanov brothers and their characteristic and recognizable architectural vocabulary. All these data undoubtedly indicate the village of Papradishte near Veles as the place of origin of the masterbuilders of the church of St. Savior in Drachevo. ${ }^{476}$
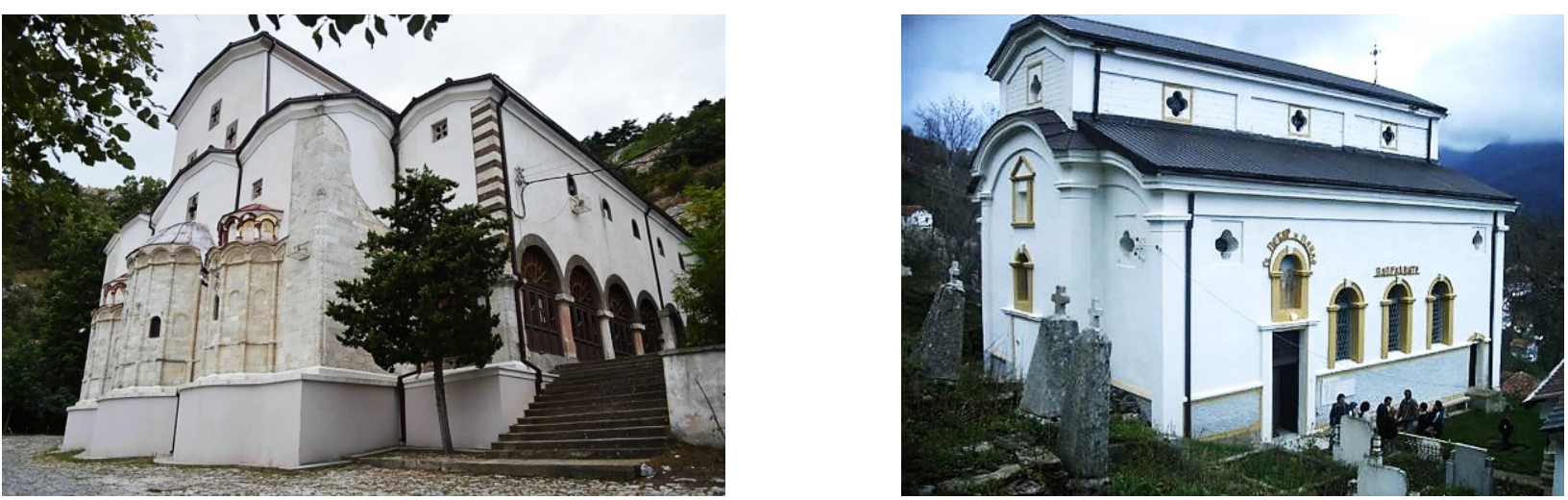

Figure III.213 A. St. Panteleimon in Veles; B. St. Peter and Paul in Papradishte (Veles).

The relations with Papradishte continued in the following period as well. Namely, in addition to the early works of Andreja Damjanov as its predecessors, parallels can be drawn between the church in Drachevo and the church of St. Peter and Paul built in Papradishte in 1875 (see fig. III.25, III.213B). This church, work of the master-builder Gjorgji Novakov-Dzongar who, as is known, originates from the same village, follows the same architectural patterns: a compact three-nave basilica, with a center nave clerestory, without a narthex, porches or extensions. There is a gallery on the west side, and a semicircular altar apse on the east. The dimensions of the nave, excluding the altar apse, are 12/16 m, i.e. the proportion of the church is 3:4. The naos is divided into three naves by means of five pairs of very tall, slender columns, connected to each other by arches, as well as to shallow pilasters on the side walls, thus

\footnotetext{
${ }^{476}$ An additional indicator in this direction is one of the throne icons from the iconostasis of the church in Drachevo, Christ Pantocrator, whose author is the painter Dimitria Dukovich from the village of Papradishte, as stated in the inscription on the icon itself: сие иконо правешь $\widetilde{\omega}$ кзза велешка $\widetilde{\omega}$ село папрадиши, азь грешен димитриа дукович и ако нешо кусурь имат Фци стьи да ми простит и гдь да ми прости (Станоевски, 1999: 37).
} 
forming ideally square fields covered with blind domes, six in the lateral naves and three large blind domes hidden within the prismatic volume of the central nave clerestory. Unlike the church in Drachevo, the arches in the lateral naves are single, lacking the specific profiled pendants. The reinforcement of the perimeter walls with shallow pilasters on the inside, and on the corners of the building on the outside, enabled it to be built with relatively thin perimeter walls, despite the large spans and the imposing height of the temple. As a unique feature of the church in Papradishte, the central nave is further emphasized by projecting it outwards to the east and west. Another similarity with the church in Drachevo is the illumination of the central nave clerestory with rectangular windows fitted with four-leaf clover / phytomorphic cross stone transennas. There are also similarities between the two churches in the simple profiling of the crown cornice, as well as in the purified, simplistic treatment of the completely plastered facades. Lastly, there are parallels in the fresco-ensembles of both churches, whose authors are Dimitar Andonov Papradishki and Gjorgji Zografski, both from the village of Papradishte.

It can therefore be concluded that at the church of St. Peter and Paul in Papradishte the architectural structure applied earlier at St. Savior in Drachevo was further developed and perfected, the solution of the projecting central nave is more innovative, and its spatial and proportional composition is far more precise, which is ultimately due to its experienced, talented and renowned architect.

\section{III.5.B.5 THREE-NAVE BASILICAS WITH ONE OR MORE DOMES SUPPORTED ON ELEVATED DRUMS}

The emergence of this category of Revival basilicas dates towards the middle and during the second half of the XIX century, when the provisions of the Gülhane Hatt-i Shariff and the Hatt-i Humayun were already well into force (see Chapter III.1). The newly acquired rights of the Orthodox church founders and guild associations, led by the church-school municipalities, enabled them to orient themselves towards the construction of monumental basilicas, without the need to disguise the buildings' height by digging into the ground. Of special importance is the freedom gained in the arrangement of the fifth façade, which will result in the design and construction of Revival churches with domes supported on elevated drums, which exceed the roof; in some cases a composition of 3 such "real" domes in the central nave, and even multi-dome solutions.

The three-nave basilicas with one or more domes supported on elevated drums are a relatively small group: they represent $6 \%$ of the total number of three-nave basilicas and only $2.6 \%$ of all hitherto typologically classified Revival churches. In terms of their distribution (see map III-B), they are predominantly found in urban areas (the towns of Krushevo, Bitola, Negotino), in monasteries (Osogovo Monastery, Zabel Monastery, Pantelej), as well as in some rural settlements. The churches which belong to this typological sub-group are listed in the table below (table III-14):

\begin{tabular}{|l|l|l|l|l|l|}
\hline & CHURCH & VILLAGE & REGION (TOWN) & YEAR & $\begin{array}{c}\text { ADDITIONAL INFORMATION } \\
\text { fresco-painting / icons, renovations }\end{array}$ \\
\hline 1 & St. Joachim - Osogovo monastery & Babin Dol & Kriva Palanka & $1847-51$ & \\
\hline 2 & $\begin{array}{l}\text { Dormition of the Most Holy Mother of } \\
\text { God - Zabel monastery }\end{array}$ & Zabel & Kumanovo & $1852-56$ & \\
\hline 3 & St. George & $/$ & Negotino & 1860 & \\
\hline 4 & St. John & Ljubojno & Prespa & 1861 & renovated in 1921 after the 1903 fire \\
\hline 5 & St. Sunday & $/$ & Bitola & 1862 & with newer frescoes and icons \\
\hline 6 & St. Nicholas & Cerovo & Gostivar & 1864 & \\
\hline 7 & St. Constantine and Helena & Omorani & Veles & 1871 & \\
\hline 8 & St. Nicholas & Galate & Gostivar & 1876 & \\
\hline 9 & The Most Holy Mother of God & Cera & Makedonska Kamenica & 1880 & \\
\hline 10 & Holy Trinity & $/$ & Krushevo & 1881 & \\
\hline 11 & St. Panteleimon & Pantelej & Kochani & 1885 & \\
\hline
\end{tabular}




\begin{tabular}{|l|l|l|l|c|c|}
\hline 12 & St. George & Beljakovce & Kumanovo & 1894 & \\
\hline 13 & St. John & $/$ & Krushevo & 1897 & \\
\hline 14 & St. Nicholas & Gorno Sonje & Skopje & 1897 & \\
\hline 15 & St. Sotir & Bukovo & Bitola & $/$ & \\
\hline
\end{tabular}

Table III-14 Three-nave Revival basilicas with one or more domes supported on elevated drums.

The oldest church of this type is the catholicon of the Osogovo Monastery - the church of St. Joachim, one of the most unique and freely composed Revival churches (fig. III.214). It was built between 1847-1851 by Andreja Damjanov and his master-builder group. In essence, it is a large three-nave basilica, with three altar apses, without a narthex or a gallery, which, as was elaborated earlier, was a common occurrence in monastic churches. Originally it was likely meant to be encircled with lower open porches on all three sides of the naos, of which only the south and west segments exist today (fig. III.214D). It was built with exceptional quality of the well-processed hewn and carved stone, precise profiles and high relief at the apses (see fig. III.85) and within the three entrance portals (see fig. III.60C), i.e. with the easily recognizable architectural lexicon characteristic of Andreja Damjanov. However, the church in the Osogovo monastery boasts substantial differences from his usual typological matrix.
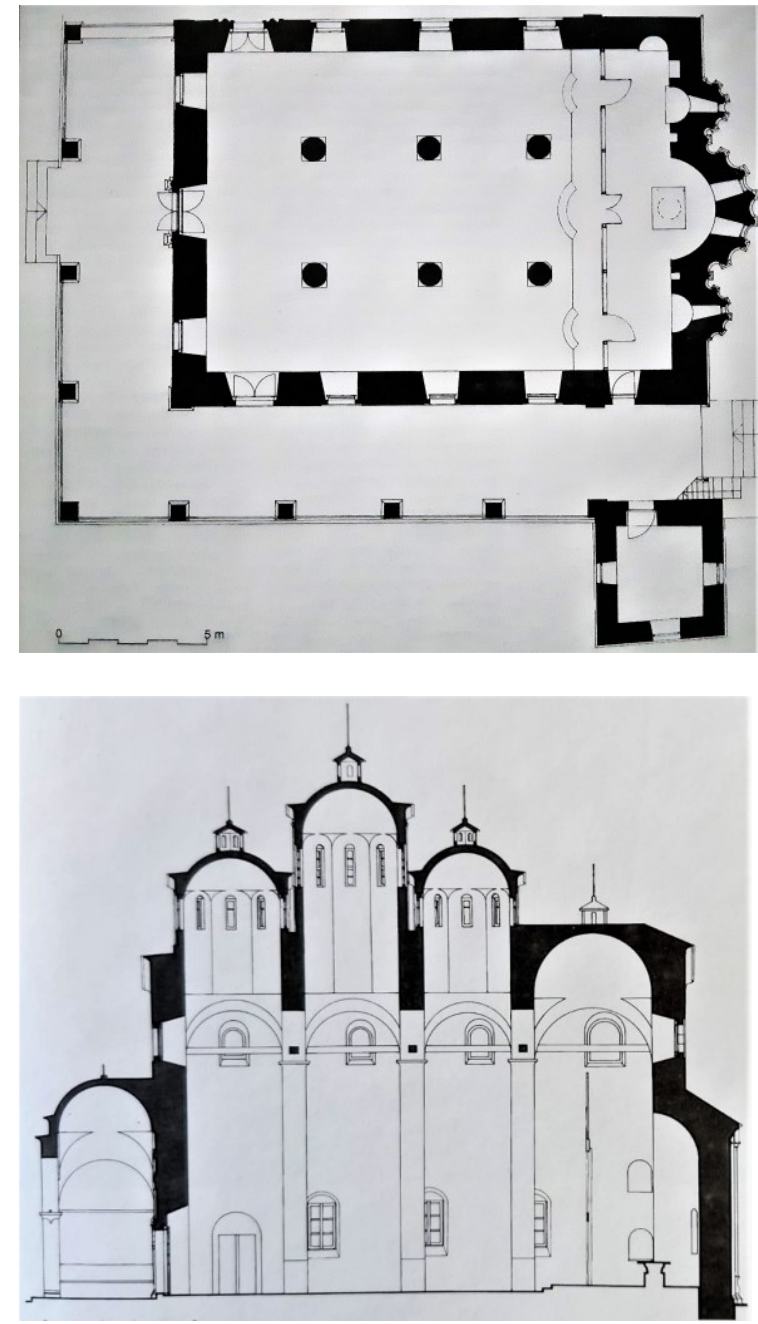

Figure III.214 St. Joachim - Osogovo monastery: A. Plan; B. Eastern façade; C. Longitudinal section; D. View from the west.

Namely, on the inside the church is divided into 3 naves with the help of two rows of 3 columns, connected by arches in both directions, so that 12 fields are formed in the upper parts of the naos (fig. III.214A). All of these fields are covered with domes in a complex arrangement: 5 are domes set on elevated drums, suspended high above the roof and arranged in the shape of a cross; 4 do not have a drum; the remaining 3 are blind domes. Another specific feature of St. Joachim Osogovski is the 
appearance of a "transept", i.e. a trapezoidal elevation which corresponds to the third and fourth bay on the north and south facades and to the middle nave on the west and east ones. Thus, in the upper part of the naos, the basilica is transformed into an elongated inscribed cross. Later, Andreja Damjanov will use a completely purified solution of the inscribed cross typology at the church of St. Archangel Michael in Chichevo, region of Veles, also a catholicon of an older monastery. The multi-domed arrangement of these two churches was made possible both by the skill and innovation of their architect, as well as by the fact that the social constraints were not so strongly expressed in the isolated monastic environments.

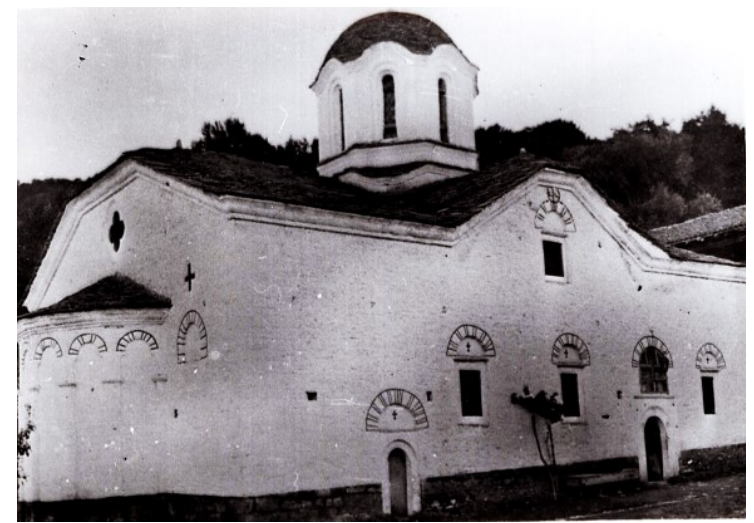

Figure III.215 St. Sotir in Bukovo (Bitola), photographed in 1899. View from the north-east.

The solution of the remaining churches of this group is more classical and more in line with the already established Revival construction practice. Three-nave basilicas with a single dome prevail, supported on an elevated drum which exceeds the classical gabled roof. Such are:

- Dormition of the Most Holy Mother of God in the Zabel Monastery, which has a dome set on a spacious, low octagonal drum (see fig. III.5A, III.80B);

St. John in Ljubojno (Prespa), which was burned in 1903 and rebuilt in 1921 (Томовски, 1970: 31);

St. Constantine and Helena in Omorani (Veles), which was built by Jakov, son of Gjorgji Damjanov and also partially rebuilt in 1913 after a fire, when over the original gabled roof of the three-nave pseudo-basilica a transept was inserted with a cubic pedestal which supports the dome on an octagonal drum, as well as a porch with a bell tower added on the west side of the naos;

- $\quad$ St. Nicholas in Galate (Gostivar), which besides the central dome on a high cylindrical drum has a massive square bell tower above the gallery (see fig. V.8);

- St. John in Krushevo, which in addition to the dome on an elevated drum has two towers on the west side, above the gallery;

- St. Nicholas in Gorno Sonje (Skopje), which is essentially a reconstruction of an older church, with a dome on an octagonal, plastered drum, also possibly a later addition; and

- $\quad$ St. Sotir - Bukovo monastery in Bukovo (Bitola), with a dome on a high drum and a specific transept elevation on the lateral facades (fig. III.215), which resembles the solution of the church in Magarevo (see fig. III.22) and the Osogovo Monastery (see fig. III.214), i.e. a combination of a three-nave pseudo-basilica and an inscribed cross on the fifth façade.
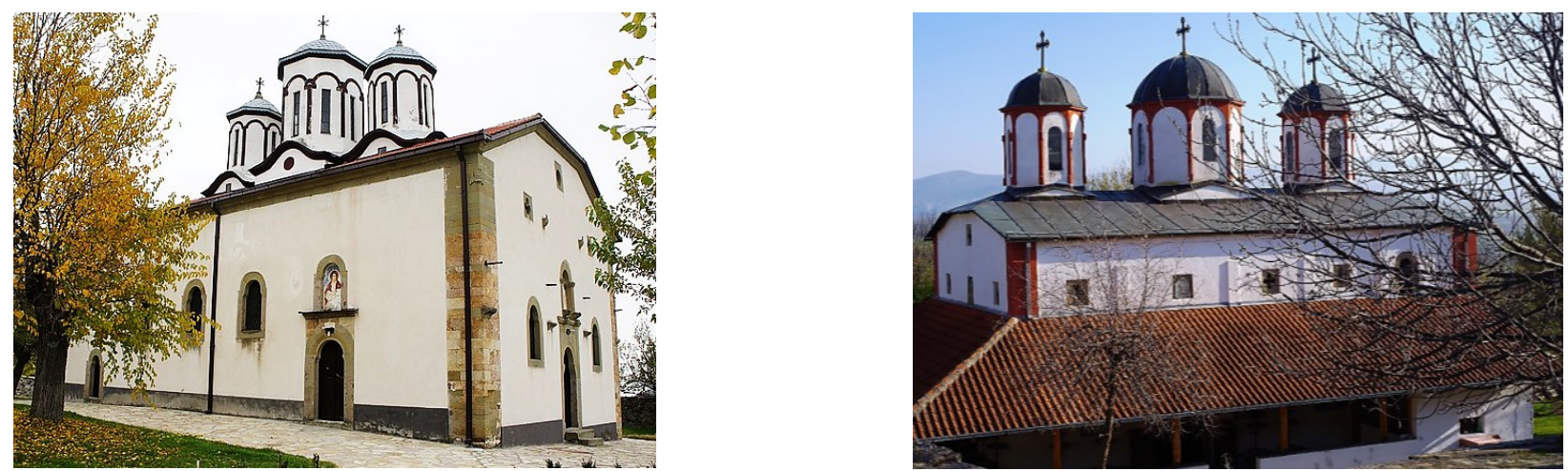

Figure III.216 Examples of three-dome three-nave basilicas: A. St. Panteleimon in Pantelej (Kochani); B. St. George in Negotino. 
Furthermore, there are several examples of basilicas with 3 domes on high, elevated drums placed along the central nave. Such are:

- $\quad$ The Most Holy Mother of God in Cera (Makedonska Kamenica), which was renovated in the 1990s;

- $\quad$ St. George in Negotino, work of the master-builder Andon Kitanov (fig. III.216B), which has 3 domes set on drums of which the central one is higher; and

St. Panteleimon in Pantelej (Kochani), also by Andon Kitanov (fig. III.216A), very similar to the church in Negotino by the same architect, with the difference that besides 3 domes supported on elevated drums it also has 2 blind domes in the central nave. The three nave disposition of the naos is achieved by two rows of massive columns, connected to each other and to the perimeter walls by semicircular arches (fig. III.217). However, the central nave formed in this way has a rather large span, which would complicate the construction of the domes and their very high, elongated drums. Thus, in order to reduce the span, consoles were introduced above the capitals of the columns which carry the sub-dome arches in both directions, as was the case, for example, at the church of St. Savior in Drachevo (see fig. III.209, III.210), with the difference that in Drachevo instead of on drums, the blind domes rested directly on the arches. The lateral naves of the church in Pantelej are covered with semi-cylindrical vaults, and the whole system is restrained with wooden ties.

In the context of these two closely related churches (St. George in Negotino and St. Panteleimon in Pantelej), the church of the Most Holy Mother of God in the village of Sogle, region of Veles (see fig. III.204) must be mentioned. Built by the same author in 1855, it is the first in his series of similar three-domed basilicas. However, in Sogle the three drums do not emerge directly from the gabled roof of a pseudobasilica, but the central nave above which the domes are placed is in fact a clerestory of a "real" basilica composition, and in addition it is covered in a specific way with a bonnet instead of a gabled roof.

The origin and influences under which the domes supported upon elevated drums appeared in the Revival sacred architecture are clear: they most consistently transfer and transform the medieval Byzantine patterns of a dome-covered space, manifested in the middle-Byzantine three-nave basilicas with a dome and the churches of transitional character (St. Sophia in Ohrid, St. George in Staro Nagorichane, the Most Holy Mother of God in Drenovo, the Most Holy Mother of God in Velushina), as well as in the late-Byzantine compact church buildings of the inscribed and compact inscribed cross types (see fig. I.33). In the previous decades of the Revival XIX century, although the construction of "real" domes set on protruding, elevated drums was legally 
prohibited, the efforts of the master-builders to replace the dome with the available permitted substitutes are clearly evident: semi-cylindrical vault, blind domes secluded within a plain gabled roof, blind calottes and rosettes in the flat ceilings, all the way to painted round and oval medallions (fig. III.218), as found in post-Byzantine churches throughout the centuries under Ottoman rule and in many of the Revival basilicas of the earlier decades. In other words, the appearance of three-nave basilicas with domes supported on drums is the result of a logical evolution of the Revival sacral construction and the culmination of the process of its gradual release from legal constraints and limitations that finally enabled a creative interpretation of the most representative older Byzantine domed models.

\section{"St. Sunday" in Bitola, 1862}

The church of St. Sunday was built in Bitola in 1862, as confirmed by the inscription placed high on the east façade. It is a rather large building, measuring 13.6 / $24 \mathrm{~m}$, not counting the altar apse. According to its typology, it is a three-nave basilica with a very interesting solution. Namely, St. Sunday in Bitola is one of those Revival churches mentioned earlier (see Chapter III.3, fig. III.51, III.52) where on the ground floor to the west of the naos there is an open masonry porch, while on the first floor a gallery expands over said porch (fig. III.220). ${ }^{477}$ The naos is accessed from the porch through the western entrance portal in the axis of the western façade, and the height difference of $60 \mathrm{~cm}$ is overcome via 4 stairs. There are two more lateral entrance portals placed in a symmetrical composition, placed in the third bay from the west. They are made of precisely joined high-quality hewn stone blocks, with an arched lintel and placed in a very shallow arched niche framed by a thin profiled frame. Of these, the southern portal was additionally fresco-painted (fig. III.219). ${ }^{478}$ The whole composition was created under very evident

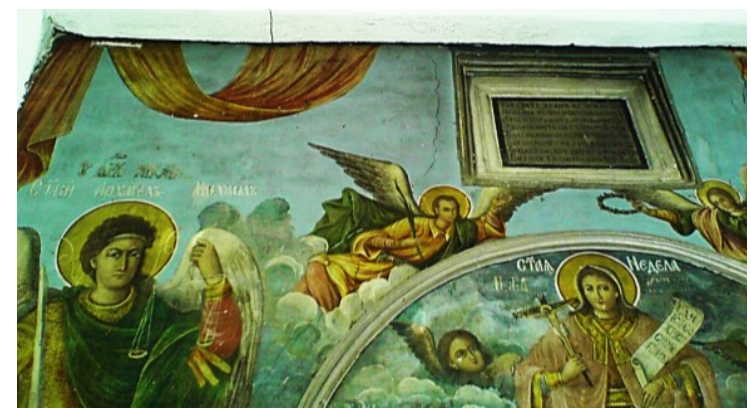

Figure III.219 St. Sunday in Bitola. Detail of the southern entrance portal. baroque Western European influences. Above the patron saint's niche is a rectangular field, framed with the same thin frame, containing the founding inscription, which informs us that the church was "built from the ground up" during the reign of bishop Venedict of Byzantium, who consecrated it in 1863 (Василиев, 1965: 244). This entrance is used as the main entrance today, and the western one has lost its primary function to a large extent. In addition to the three entrances intended for the believers, the altar can be entered directly from the south, through a smaller door, which today is part of a separate chapel at the eastern end of the southern narthex, itself a later addition to the church (see fig. III.225).

Thus defined, on the ground floor the naos has total dimensions of 13.6 / $18.6 \mathrm{~m}$ excluding the apse; that is, it has a ratio of 1:1.3 (fig. III.220). It is divided into three naves by means of three pairs of massive columns, $5.6 \mathrm{~m}$ in height including their thin hexagonal capitals. The spans of the naves formed in this way are $5.2 \mathrm{~m}$ in the central nave and approximately $3.3 \mathrm{~m}$ in the side naves. To the west of it there was originally an open porch (today unfortunately very modified, partially closed-off and unified with the new narthex along the south façade) with massively built square pillars with geometrically profiled

\footnotetext{
477 A very similar concept is found in the church Dormition of the Most Holy Mother of God, also known as the Vlah Church, built in Veles in 1882, where the gallery is also placed over an open porch composed of massive masonry pillars connected by large arches. The main difference is the lack of a dome supported on an elevated drum at the church in Veles, which also has a cubic bell-tower that rises above the western façade and over the gallery.

478 The patron saint composition (St. Sunday, flanked by angels against a background of clouds) is painted in the lunette formed by the arched frame, with an inscription in the lower zone. The patron saint composition continues on the sides of the portal, where the archangels Michael and Gabriel are depicted as "guardians of the entrance", while above the lunette appear two more angels, one of which crowns St. Sunday with a wreath.
} 
capitals, between which were formed 5 arched openings on the west façade and 2 on the side facades (north and south). Measuring from the west façade of the ground floor, the porch is projected outward to the west for a total of $5.5 \mathrm{~m}$. On the upper floor, the naos extends over this zone, thus reaching a full length of $24 \mathrm{~m}$. Over the west façade wall of the ground floor, in the upper zone, two short columns were placed, so that at this level there are a total of 4 pairs of columns in the naos (fig. III.220B). Between themselves and the perimeter walls (whose thickness is approximately $100 \mathrm{~cm}$ ) the columns are connected with wide semicircular arches, and the whole system is made rigid with wooden ties at the base of each arch. In this way, the upper zone of the church is sectioned into 15 bays of which those in the central nave are approximately square, in the side naves are rectangular, and twice as narrow in the eastern bays above the altar (fig. III.221A).

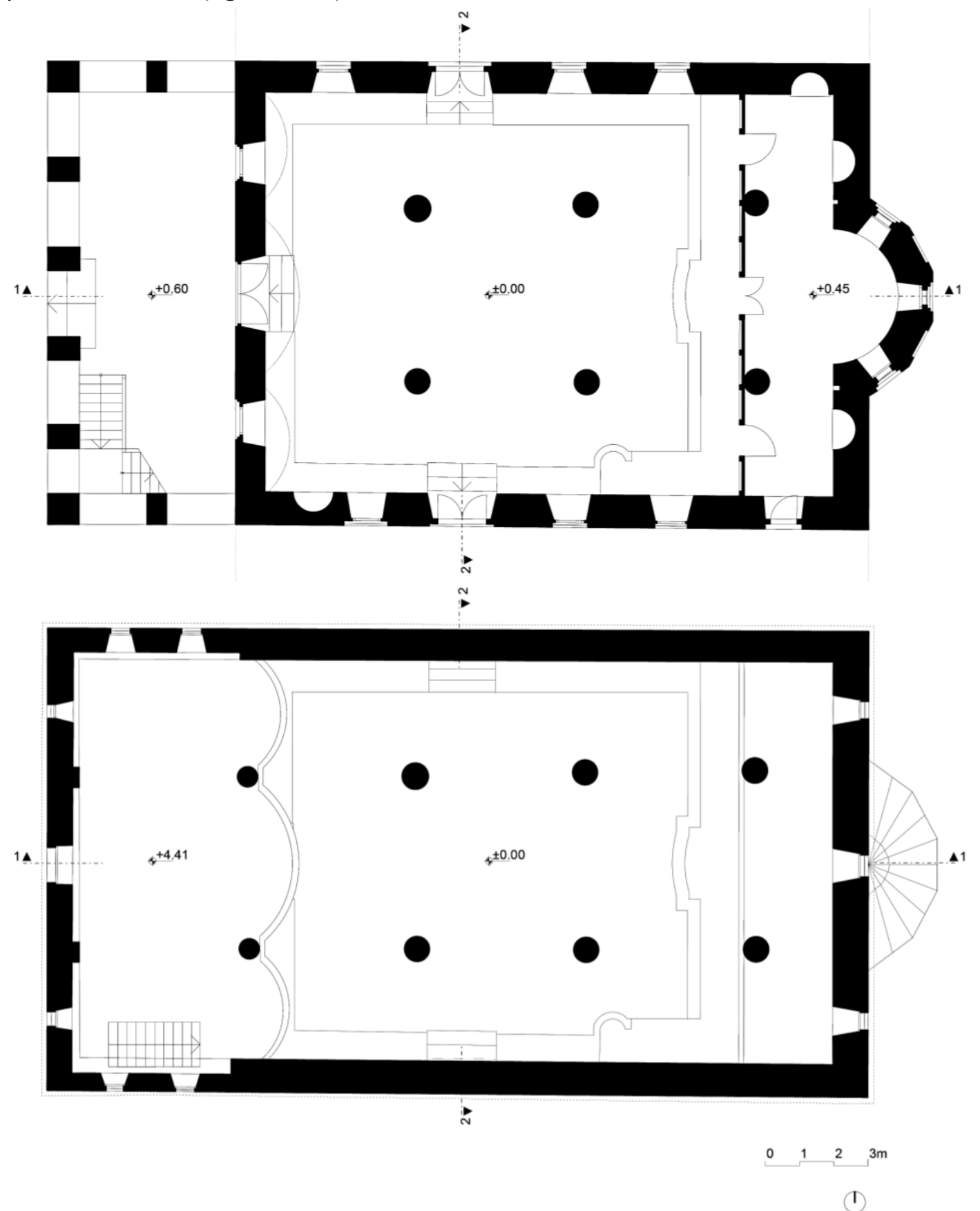

Figure III.220 (this page) St. Sunday in Bitola. Reconstruction of the original architectural composition prior to the later additions (southern porch and chapels). Plans: A. Ground floor $( \pm 0.00)$; B. Gallery $(+4.41)$.

Figure III.221 (next page) St. Sunday in Bitola. A. Plan of the ceiling; B. Fifth façade; C. Longitudinal section (1-1). 


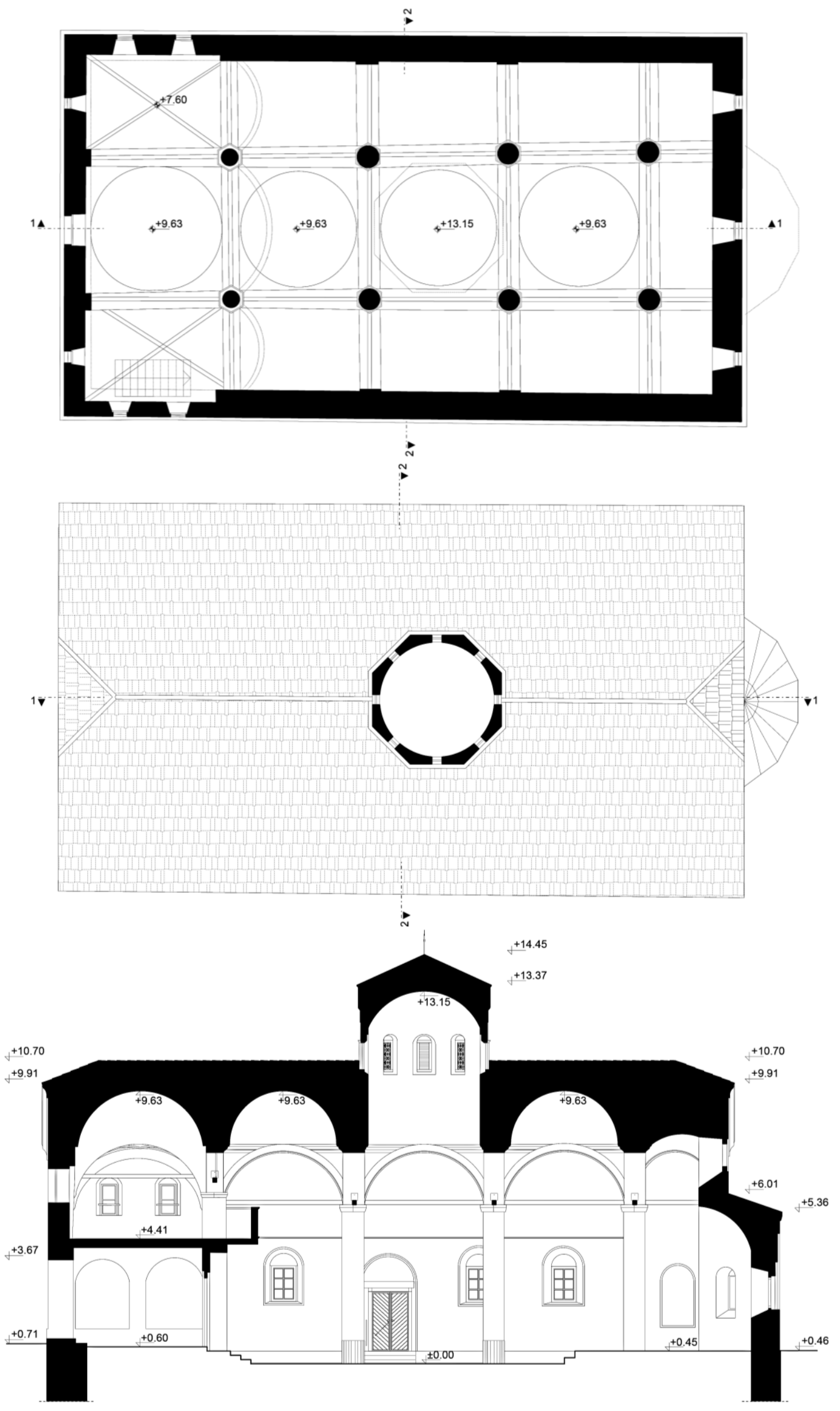




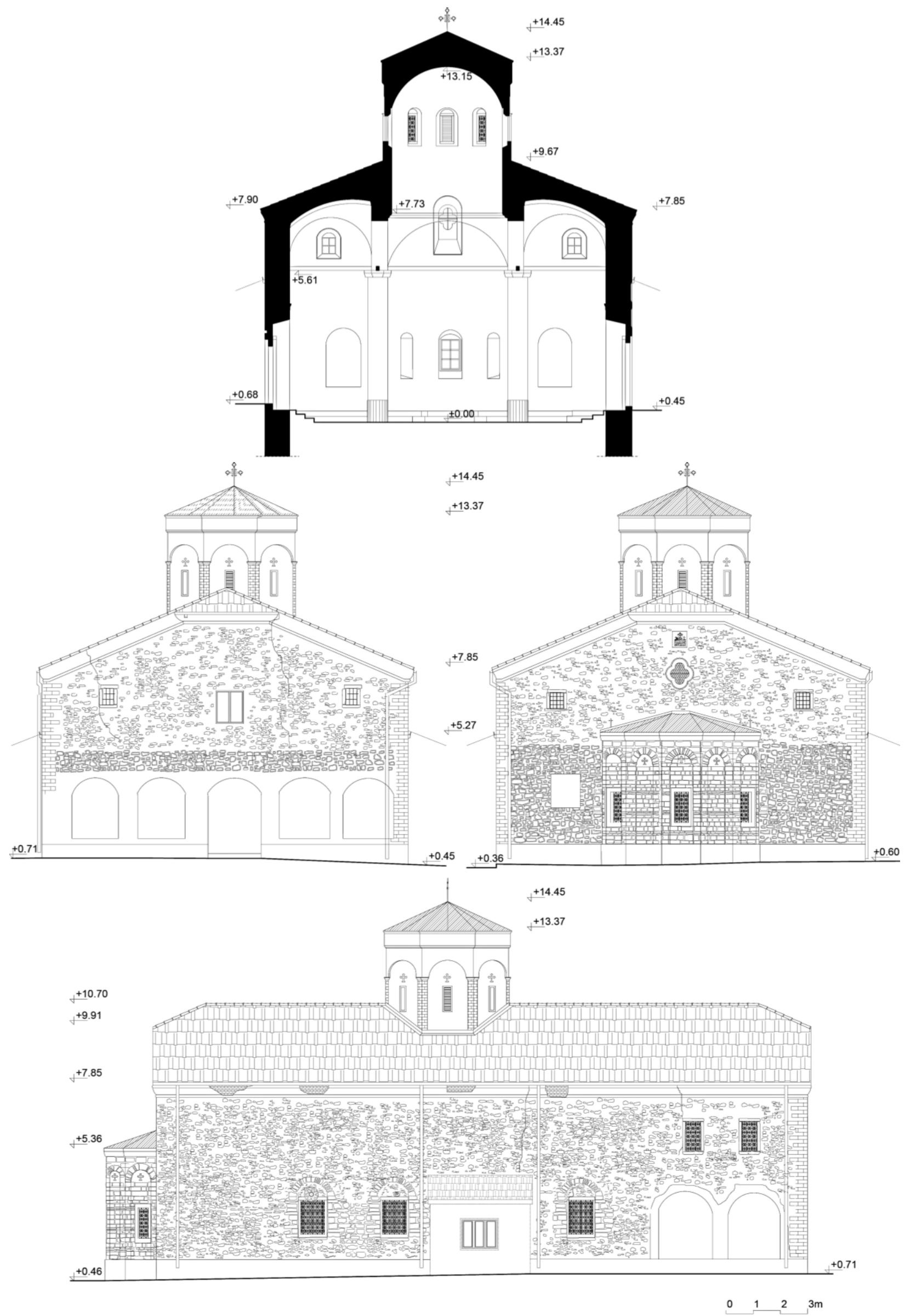

Figure III.222 St. Sunday in Bitola. A. Transversal section (2-2); B. Reconstructed western and eastern facades; C. Northern façade. 
The bays in the upper parts of the basilica are covered as follows: in the middle nave, viewed from the west, the first two and the fourth bay are covered with blind domes, and the third with the "real" dome supported on an elevated, internally cylindrical and externally octagonal drum; in the side naves the western bays are bridged with cruciform arches with massive ribs, and the rest with a $1 / 2$ barrel vault, with a slight curvature, as are the bays in the altar space (fig. III.223B). Unlike the rest of the nave, which was simply plastered (with a representation of a starry sky on the ceilings), the dome of the church was fresco-painted in 1864, by order of the fur-makers' guild of Bitola. It is illuminated through windows on each side of the drum, placed into shallow arched niches, formed by angular pilasters of hewn blocks of stone and capitals with simple profiling. The maximum height from the floor of the nave to the top of the dome is $13.15 \mathrm{~m}$, as opposed to $9.6 \mathrm{~m}$ in the case of the blind domes. The gallery that extends over the west porch is cantilevered towards the naos through three semicircular balconies (one in each nave), of which the central one is the largest (fig. III.223A) and here the gallery reaches a total depth of $6.5 \mathrm{~m}$. It is accessed from the south-west corner of the porch via "L"-shaped stairs. The pulpit is placed in its usual position, high on the north-west pillar of the sub-dome bay and consists of a polygonal balcony (with small icons placed on the sides) over a pedestal in the shape of an inverted cone (fig. III.223A). The bishop's throne, on the other hand, rests on the southeastern pillar of the sub-dome bay. Wooden seats for the faithful are placed along the perimeter walls, on a low plinth.
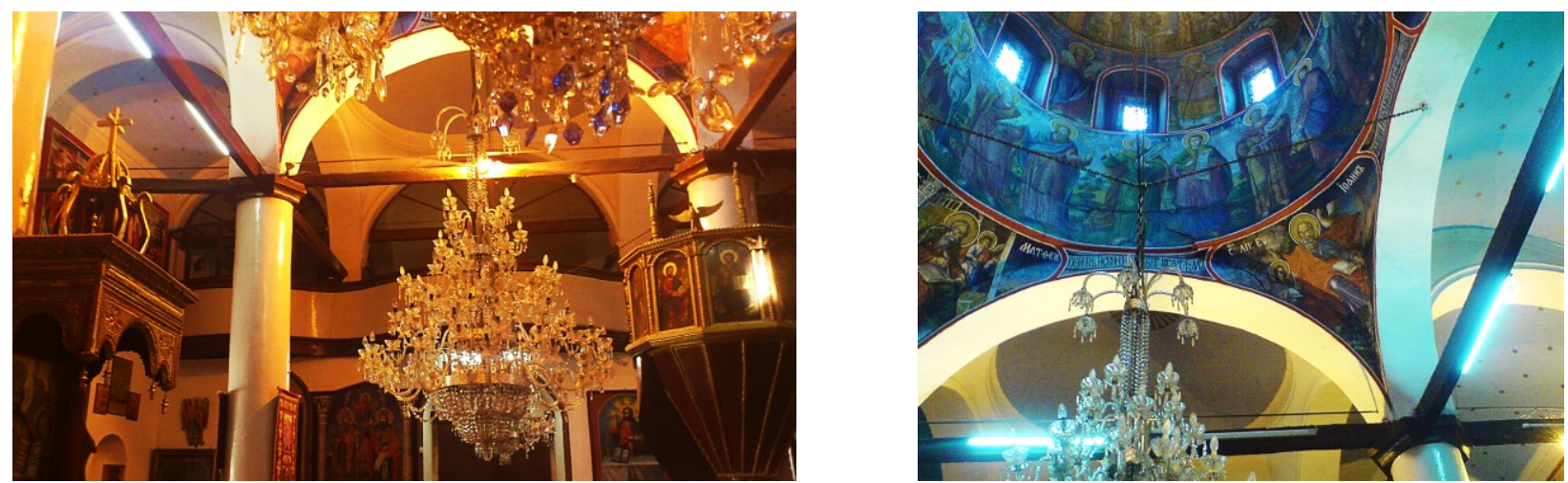

Figure III.223 St. Sunday in Bitola: A. View from the naos towards the gallery; B. View towards the dome.

As was pointed out, the church was quite massively built: its perimeter walls are $\sim 1 \mathrm{~m}$ thick. The facades are made of crushed and partially hewn stone (with the exception of the corners and the porch pillars which are made of properly carved blocks with minimal joints) with decorative protruding mortar joints (fig. III.224). On the eastern façade, such mortar joints were elaborated up to the height of the apse crown cornice, while in the upper zone the façade was simply plastered, as was the low plinth (fig.

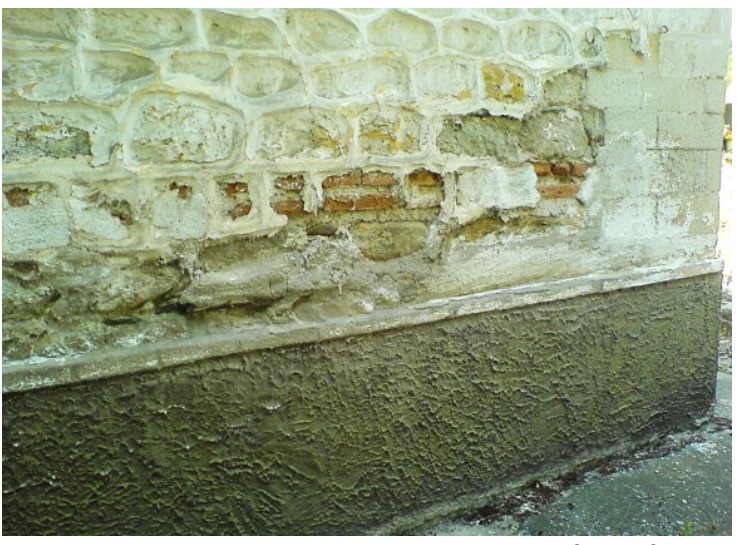

Figure III.224 St. Sunday in Bitola. Detail of the façade masonry of stone and brick layers, disguised with protruding mortar joints.
III.222B). It is illuminated through simple rectangular windows placed on the side, while high above the apse there is a window in the shape of a four-leaf clover, above which the year of construction has been preserved inscribed in a rectangular field. The apse is relatively low and five-sided; a shallow arched niche is made in each of the sides along the entire height; three simple rectangular window openings are arranged in a symmetrical composition (fig. III.222B, III.225A). The apse ends with a three-tiered crown cornice, as do the facades of the church, visible beneath the partially dilapidated mortar. The applied masonry is specific: for every three layers of hewn 
stone, a layer of 2 rows of bricks appears, which today is exposed in the lower zone where the mortar has peeled off (fig. III.224). The only decoration in shallow relief is a small elongated cross with phytomorphization of the arms, under the arch of the central niche.
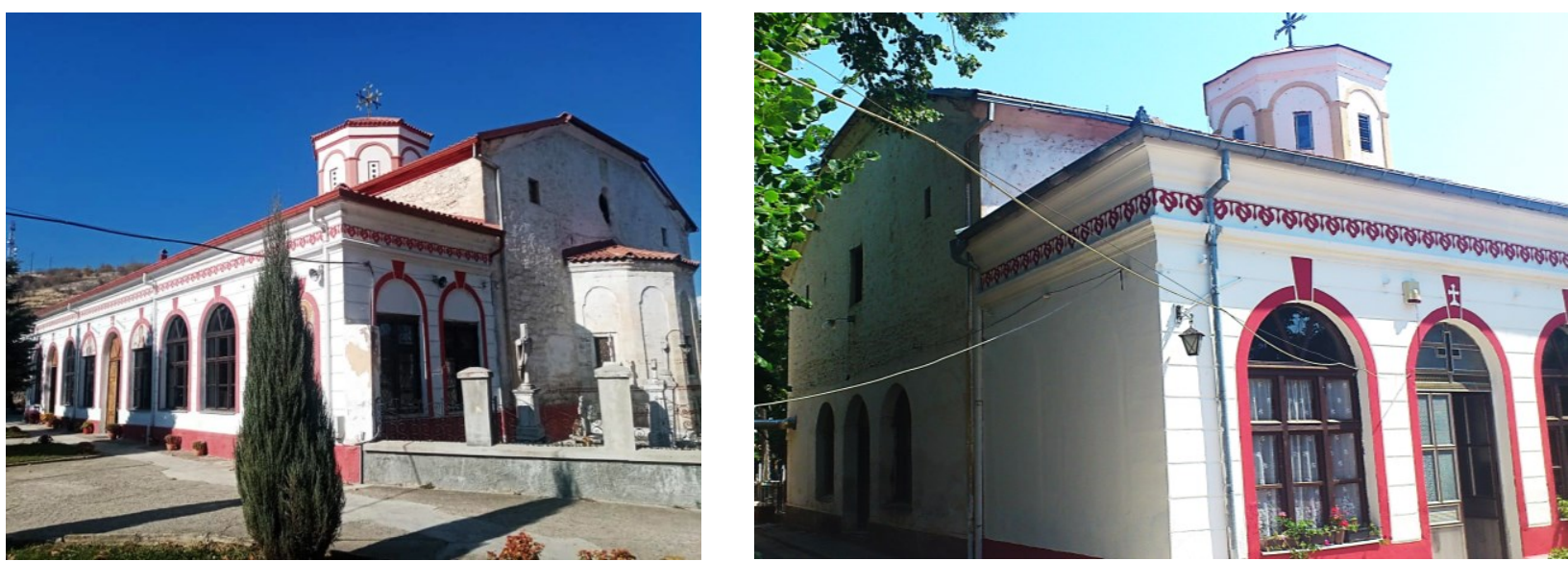

Figure III.225 St. Sunday in Bitola: A. Contemporary view from the south-east; B. Contemporary view from the south-west.

The western façade lacks stone relief decoration; the windows (three in number, in a symmetrical composition) are rectangular, identical to those on the apse and in the lower zone of the eastern façade. Their jambs and lintels are made of profiled carved stone blocks. Here, the grouting of the joints, which according to a stratigraphic analysis was originally analogously distributed in two zones as that of the east façade, is preserved today in only one segment approximately in the middle of the façade (fig. III.222B). That change in the lower zone of the façade certainly occurred when the original open porch was altered: the end arches were completely walled-in, a door was placed in the central one, and the two lateral arches that flank it were glazed (fig. III.225B). The arched openings on the north and south façade were also completely filled-in with masonry. Above them, in the zone of the gallery, there are simple rectangular, architrave windows, while in the lower zone of the façade in the naos, the windows have arched openings. Along the north façade are preserved stone consoles that indicate the existence of an open porch, which can be assumed to have existed on the south side as well, in a symmetrical composition, protecting the two side entrances to the naos from the external weather conditions.

The interior of the church was renovated in the XX century, when the iconostasis was made, the authentic floor (most likely made of stone slabs) was replaced with terrazzo, and glazing was added above the parapet of the gallery balconies.

\section{III.5.C “FIVE-NAVE” BASILICAS}

The five-nave basilicas are one of the Revival typological matrices specific exclusively for the most monumental cathedral churches ${ }^{479}$ built in the largest and most economically developed towns: Skopje, Bitola, Veles, Prilep, Krushevo, Shtip and Kumanovo; and several culturally and economically highly developed rural settlements: Novo Selo, Gopesh, Malovishte, Magarevo (map III-C). Therefore, unlike some of the other previously elaborated typological solutions, it is not a geographically limited group; however, greater concentration is present in the southern part of Macedonia, in the region Bitola-Prilep-

\footnotetext{
${ }^{479}$ Namely, the five-nave Revival basilicas have truly monumental dimensions. As an illustration, the church of St. Annunciation in Prilep is $32 \mathrm{~m}$ long, $26.5 \mathrm{~m}$ wide (including the porches, i.e. all 5 naves), and $9 \mathrm{~m}$ high (Василиев, 1965: 158); St. Panteleimon in Veles is $30 \mathrm{~m}$ long and $27 \mathrm{~m}$ wide in total, etc.
} 
Krushevo, and especially around the town of Bitola towards which the villages Gopesh, Magarevo and Malovishte gravitate. ${ }^{480}$

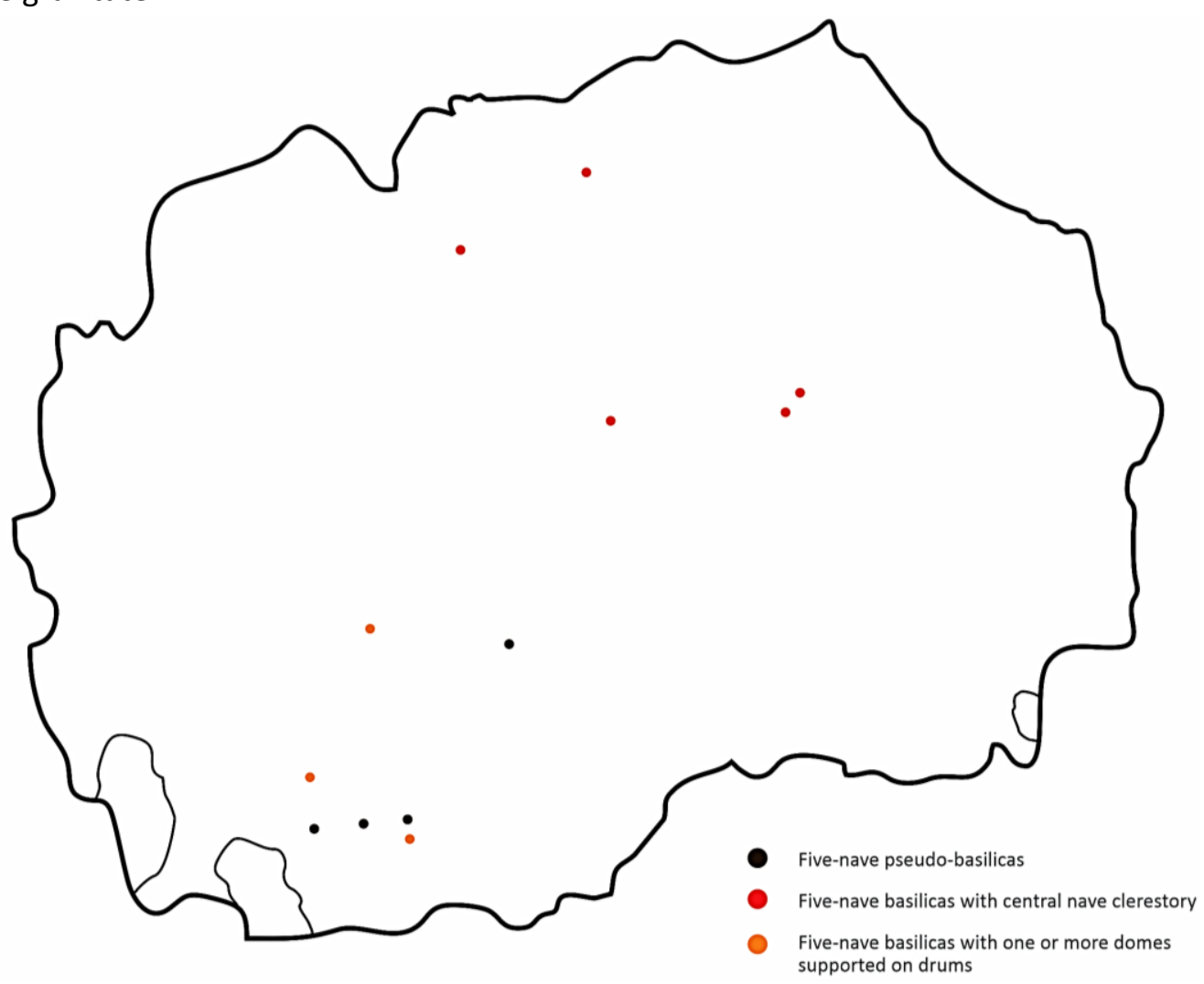

Map III-C Distribution of the Revival five-nave basilicas.

In terms of the representation of this typology within the total number of Revival churches, the five-nave basilicas represent a small part, only $2.3 \%$ of the total number of classified Revival basilicas, which is due to their exceptional monumentality for which it was necessary to provide significantly more funds, appropriate permission for construction and to hire the best and most renowned master-builders, wood carvers and icon and fresco painters. The five-nave Revival basilicas are listed in the following table (table III-15):

\begin{tabular}{|l|l|l|l|c|c|}
\hline & CHURCH & VILLAGE & REGION (TOWN) & YEAR & $\begin{array}{c}\text { ADDITIONAL INFORMATION } \\
\text { fresco-painting / icons, renovations }\end{array}$ \\
\hline 1 & St. Demetrius & $/$ & Bitola & 1830 & \\
\hline 2 & The Most Holy Mother of God & $/$ & Skopje & 1835 & \\
\hline 3 & St. Demetrius & Magarevo & Bitola & 1835 & \\
\hline 4 & St. Annunciation & $/$ & Prilep & 1838 & \\
\hline 5 & St. Panteleimon & $/$ & Veles & 1840 & \\
\hline 6 & The Most Holy Mother of God & Novo Selo & Shtip & 1850 & \\
\hline 7 & St. Nicholas & $/$ & Kumanovo & 1851 & \\
\hline 8 & St. Petka & Malovishte & Bitola & 1856 & \\
\hline 9 & St. Nicholas & $/$ & Shtip & 1867 & \\
\hline 10 & Dormition of the Most Holy Mother of God & $/$ & Krushevo & 1867 & \\
\hline 11 & The Most Holy Mother of God & $/$ & Bitola & $1870 / 1871$ & \\
\hline 12 & St. Transfiguration & Gopesh & Bitola & 1871 & \\
\hline
\end{tabular}

Table III-15 Five-nave Revival basilicas.

480 The Vlach (Aromanian) villages Magarevo, Gopesh and Malovishte in the vicinity of the town of Bitola experienced extraordinary economic and social prosperity during the Revival, developing to the extent of small towns: namely, in the XIX century the villages Trnovo and Magarevo together reached a total of 5.000 inhabitants. This enabled them to finance and erect monumental sacred buildings otherwise atypical of rural areas. 
The architectural composition of this group of churches is the following: on the ground floor, according to their architectural typology, they are actually three-nave basilicas, with a spacious naos, three apses on the east side, without a separate narthex, but with open arcade porches that surround the naos from the north, west and south in a " $U$ " shape. At the upper level, the naos expands above the open porches, acquiring a five-nave disposition. Here, the three-nave volume is surrounded on all three sides by a gallery. In some of the five-nave churches, the porches on the north and south side extend all the way to the east façade (Magarevo, Gopesh, Malovishte), while in others they are shorter and reach approximately up to the middle of the lateral façades (in Prilep, Krushevo, the Most Holy Mother of God in Bitola), or even less (at the Most Holy Mother of God in Skopje), but still the five-nave concept on the second level is clearly legible. For some of the five-nave basilicas built by Andreja Damjanov (in Veles, Novo Selo near Shtip and Kumanovo) and Gjorgji Novakov Dzongar (St. Nicholas in Shtip), it is characteristic that the additional two lateral naves to the east reach the line of the altar partition, i.e. they are one bay (the altar bay) shorter than the

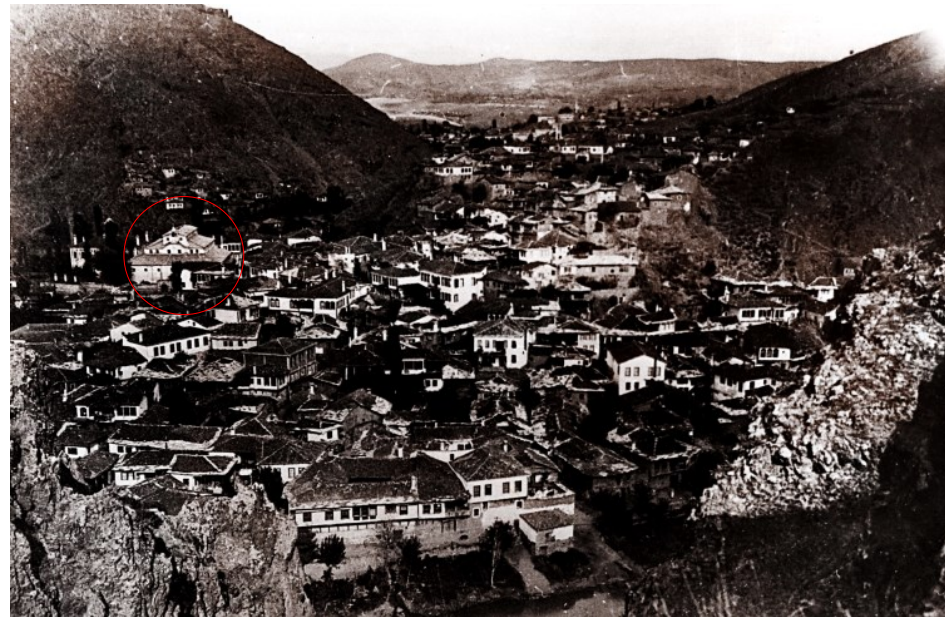

Figure III.226 The Most Holy Mother of God in Novo Selo (Shtip). Overview of the village of Novo Selo in 1899 and the dominant silhouette of Andreja Damjanov's church. central naos (fig. III.227).

Of course, within this typologically unique group, there are variations and different solutions, especially in the upper parts of the churches (see map III-C). Thus, in the older churches of this type there is no basilica clerestory on the fifth façade, which in fact classifies these churches as "pseudo-basilicas" covered with a gabled roof: St. Demetrius in Bitola, St. Annunciation in Prilep, and later the churches of St. Petka in Malovishte, St. Demetrius in Magarevo, St. Transfiguration in Gopesh and St. Nicholas in Shtip (fig. III.227). In others, the present concept of a central nave clerestory defines them as "true"

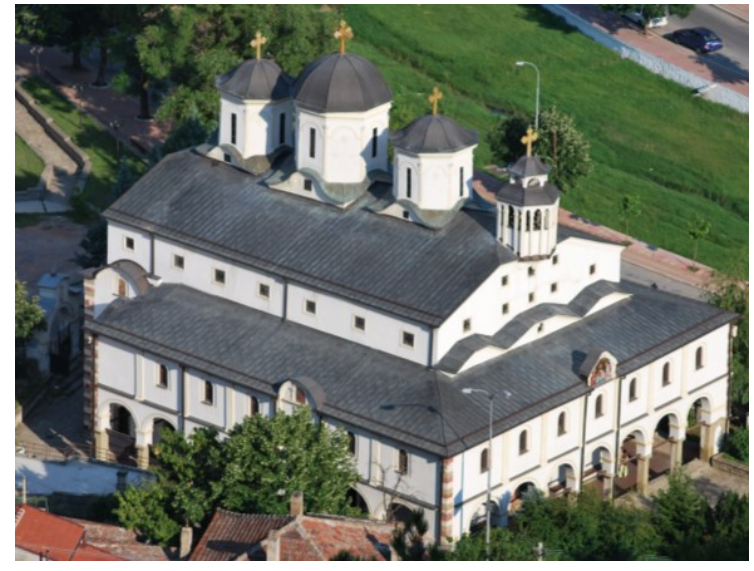

Figure III.227 St. Nicholas in Shtip. Aerial overview. basilicas: the Most Holy Mother of God in Skopje, St. Panteleimon in Veles, the Most Holy Mother of God in Novo Selo near Shtip (fig. III.226) and St. Nicholas in Kumanovo. Additionally, a transept clerestory is hinted at the church in Magarevo (see fig. III.22, III.26A); ${ }^{481}$ a bell tower appears within the church building itself at Shtip, Novo Selo, Kumanovo, Gopesh and Krushevo. At the churches with the most developed spatial plasticity appear domes supported on elevated protruding drums: at St. Nicholas in Shtip (fig. III.227), St. Transfiguration in Gopesh, Dormition of the Most Holy Mother of God in Krushevo, as well as the churches that Andreja Damjanov built outside the borders of Macedonia (in present-day Serbia and Bosnia and Herzegovina).

${ }^{481}$ The fifth façade is similarly conceived at the church of St. Sotir in the village of Bukovo near Bitola (see fig. III.215), which also has a central dome elevated on a drum, as well as the Osogovo monastery, which has an even more complex composition (see fig. III.214) 
Referring to the five-nave basilicas as a specific sub-type characteristic of the Revival sacral architecture, Aleksandar Kadijević claims that the new type of town basilica church, characterized by the multi-storied exterior porches of the same height as the temples themselves, with auxiliary compartments extending on all three sides of the building was conceived for the first time towards the middle of the XIX century, at the church of St. Mina built in Thessaloniki in 1852 (Кадијевић, 1997: 16), while previously "the porches which on three sides surround the basilica-divided cubic volume of the temple, by the middle of the nineteenth century were necessarily lower than its longitudinal central block" (Ibid: 15). As monuments closest to St. Mina in Thessaloniki, which he clearly designates as a prototype of the town basilicas, Kadijević lists St. George in Gumenisa (1863); Dormition of the Most Holy Mother of God in Janjica (1867) and St. Athanasius in Ber (Veria) from 1904, all today on the territory of the Republic of Greece. Regarding Andreja Damjanov, who is the author of a significant part of the Macedonian five-nave basilicas (in Skopje, Novo Selo near Shtip, Kumanovo, Veles), Kadijević states that "his involvement in the Western tradition, expressed mainly in the decoration and arrangement of the interiors, speaks of the modernity of his architecture, of his readiness to fit into the new course of basilica architecture, conceived in the middle of the century in Thessaloniki" (Ibid: 17).

Of course, a simple chronological enumeration of the monumental five-nave basilicas built in Macedonia absolutely refutes Kadijević's theory. Namely, in Macedonia, churches with the same or similar typology were built twenty years earlier, most of them precisely by Andreja Damjanov and his masterbuilder group. The oldest is St. Demetrius in Bitola, built as early as 1830 .

\section{“St. Demetrius" in Bitola (1830)}

The cathedral church of St. Demetrius in Bitola was built in the early decades of the Revival, in 1830, on the site of a smaller chapel dating from 1726, which burned down in a fire. Of course, the reasons why conditions for such a monumental construction venture were created precisely in Bitola lie in the importance and economic power that the town reached in the preceding period. Namely, Bitola gradually grew into one of the most developed administrative, ecclesiastical and economic centers in the European part of the Ottoman Empire, and in 1836 became the seat of the Rumelia Eyalet, where all major Western European countries held their consular offices. Also, Bitola was the seat of the Pelagonia Diocese, whose metropolitan Gregory (1826-1833) stood out as an exceptionally capable church administrator. In 1835, Gregory even became Patriarch of Constantinople, known as Gregory VI (Грозданов, 2004: 157), which speaks of his extremely influential personality. The following year he raised the authority of the Pelagonia diocese to the rank of archbishopric (Тричковска, 2008: 24). Under his leadership, in 1826 preparations began for the construction of a new, monumental church as the seat of the metropolis, thanks to the contributions by the prominent citizens and the most powerful guild associations of the town. ${ }^{482}$ That same year, for part of the cathedral's decoration, he hired the painter Mihail Zograf and his sons, who had settled in Krushevo from the village of Samarina in Epirus at that time (see Chapter II.4). ${ }^{483}$

The cathedral church of Bitola is an exceptionally monumental building: including the side chambers and the altar apses, its' total dimensions are 37/42 m (Василиев, 1965: 158). As the other churches of this typological group, St. Demetrius in Bitola is a three-nave basilica at ground floor level (fig. III.228), whose total dimensions are $23 / 30 \mathrm{~m}$, excluding the three altar apses. The proportional ratio of

\footnotetext{
482 The eminent Vlach citizens of Bitola, Naum Nakarushi and Dimitrije Nedu, together with "all the guilds" from Bitola, contributed the most to the construction of the town's cathedral.

${ }^{483}$ Among their works is a gift box painted by Mihail dating from 1826 (Тричковска, 2008: 74), a kissing icon of the patron saint from 1829 and the icon Christ on a shirt (mandilion). It is for this church that, in 1842, Mihail's son Nikola Mihailov will make his first independent (signed) work, the icon of Jesus Christ the Great Hierarch intended for the bishop's throne (Ibid: 87).
} 
the three-nave ground floor is therefore 1:1.3, i.e. it has a wide and proportionally relatively short naos. With the help of two rows of 7 slender columns, it is divided into three naves, of which the central one is $9.1 \mathrm{~m}$ wide and the lateral ones $5.7 \mathrm{~m}$. Their mutual ratio is, therefore, approximately 3:2. The columns are $6.5 \mathrm{~m}$ high in total and consist of three-tiered bases, a cylindrical trunk that slightly narrows towards the top and capitals in the shape of inverted truncated pyramids, decorated in shallow relief. They are made entirely of polished marble, with the exception of the easternmost pair, hidden behind the altar partition (fig. III.229) which, in fact, are the only ones that have been preserved authentically, made of wood with mortar coatings and finished with fine polished plaster. The remaining columns in the naos and their bases and capitals were replaced with marble ones in 1999, during the renovation of the church. The columns are architravely connected to each other. The difference in height between the top of the capitals and the level of the beam, placed at $7.5 \mathrm{~m}$ measured from the naos floor, is overcome by lateral arch extensions in the eastwest direction (fig. III.228-230). The space above the capitals, on the side of the central nave, is decorated with profiled oval medallions, painted with representations of the apostles, some of which are attributed to masters from the workshop of Mihail Zograf (Тричковска, 2008: 92-93). Approximately 50 $\mathrm{cm}$ above the architrave the central nave is encircled by a cornice on which rest wooden tiebeams, placed above every second column, which strengthen the system in the transverse direction (fig. III.230B) and which also correspond to the flat wooden ceiling above the lateral naves. In contrast, the large span of the central nave is overcome by a continuous false barrel vault with a slightly lowered arch section, reaching a total of $11.2 \mathrm{~m}$ in height.

Surrounding the naos on all three sides is an open porch, $4 \mathrm{~m}$ wide on the west and $5 \mathrm{~m}$

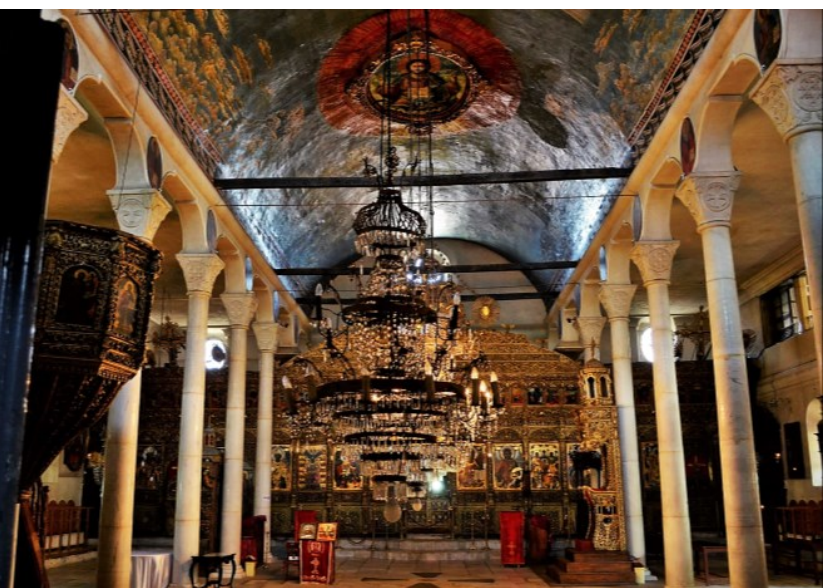

Figure III.228 St. Demetrius in Bitola. Naos, view towards the east.

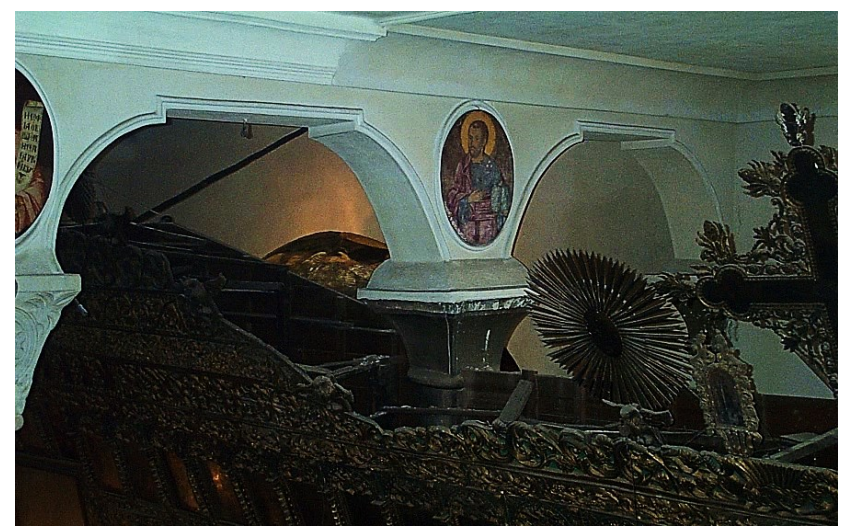

Figure III.229 St. Demetrius in Bitola. View of one of the remaining authentic columns and capitals behind the iconostasis. on the south and north side, quite irregular in plan, extending trapezoidally from west to east. At the eastern ends, the porches widen by $1.6 \mathrm{~m}$ and form side chapels. The north one is completely closed, with access from the south, while the south one is separated from the corridor using two stone columns with shallow relief capitals, in fact spoliae dating probably from the early-Christian period. At the western corners of the porch, staircase towers provide direct access to the upper floor gallery from the outside. As a very specific solution, there is no entrance at the west façade of the porch and a semicircular niche is placed in the axis on its inner side. The main entrances are from the side facades, on which there are two portals: one main entrance in the axis of the façade and one through the staircase towers. The naos is then accessed through the porches via several entrances placed in a symmetrical composition: the main entrances are three portals on the west façade of the naos and one on the north and south façade; while at the eastern ends of the porch there are smaller entrances leading directly to the altar, on both sides. The porches consist of a series of massive masonry pillars (with square and rectangular cross-section) interconnected by semicircular arches, which 
were glazed at a later date. Above the porches develops a gallery open to the naos, which is in fact the main feature of the five-nave basilicas, serving as a "women's church" as evidenced by the direct external access. On the inside, the total height of the additional naves from the north and south side is equal to the lateral naves in the naos (fig. III.230B). From the outside, however, their total height in relation to the facades of the side naves is lower by about $2 \mathrm{~m}$, since all five naves are covered with a continuous gabled roof, meaning St. Demetrius is essentially a pseudo-basilica. This seems to be the confusion of Kadijević, who has claimed that the additional naves are lower than the naos at all five-nave churches until the middle of the XIX century. The reasons why the church of St. Demetrius in Bitola lacks a clerestory on the fifth façade (lacks gradation of the masses), lie in its early dating, almost an entire decade before the Gülhane Hatt-i sheriff (1839). In the later churches of this typological group the solution of the upper parties will further evolve and become far more diverse, with blind domes and domes supported on elevated drums, bell towers and emphasized central nave clerestory.
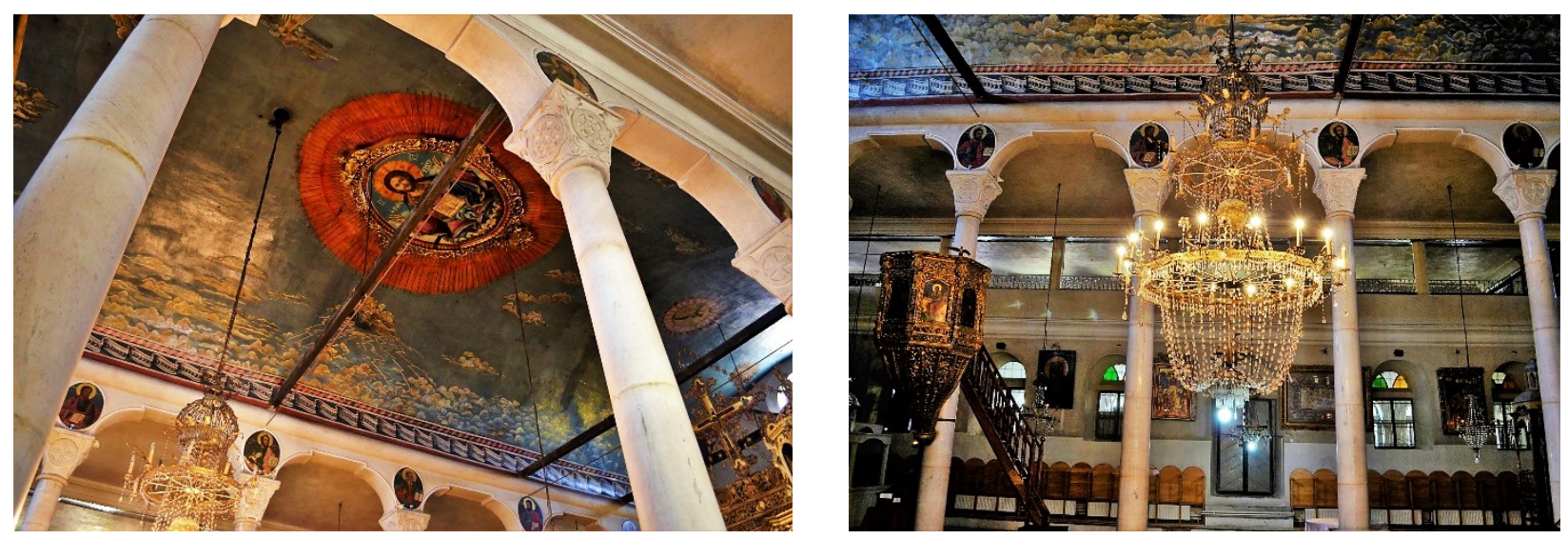

Figure III.230 St. Demetrius in Bitola: A. The central nave vault; B. View towards the northern gallery.

Inside, the "U"-shaped gallery of St. Demetrius comprises a series of octagonal columns with simple capitals, placed over the perimeter walls of the three-nave ground floor (fig. III.230B). Above the north and south walls of the naos, the gallery parapet is straight, and on the west side it has a " $\mathrm{S}$ " baroque curved line, with arched balconies facing the naos. Low decorative grills (musharabia) rest on the solid parapet. The eastern ends of the northern and southern nave of the gallery are closed off into chapels (the southern one is dedicated to the Transfiguration of Christ, and the northern one to St. Gregory) which house, divided into two parts, the iconostasis of the old demolished chapel, dating from 1738 (Ќорнаков, 1993: 129-130).
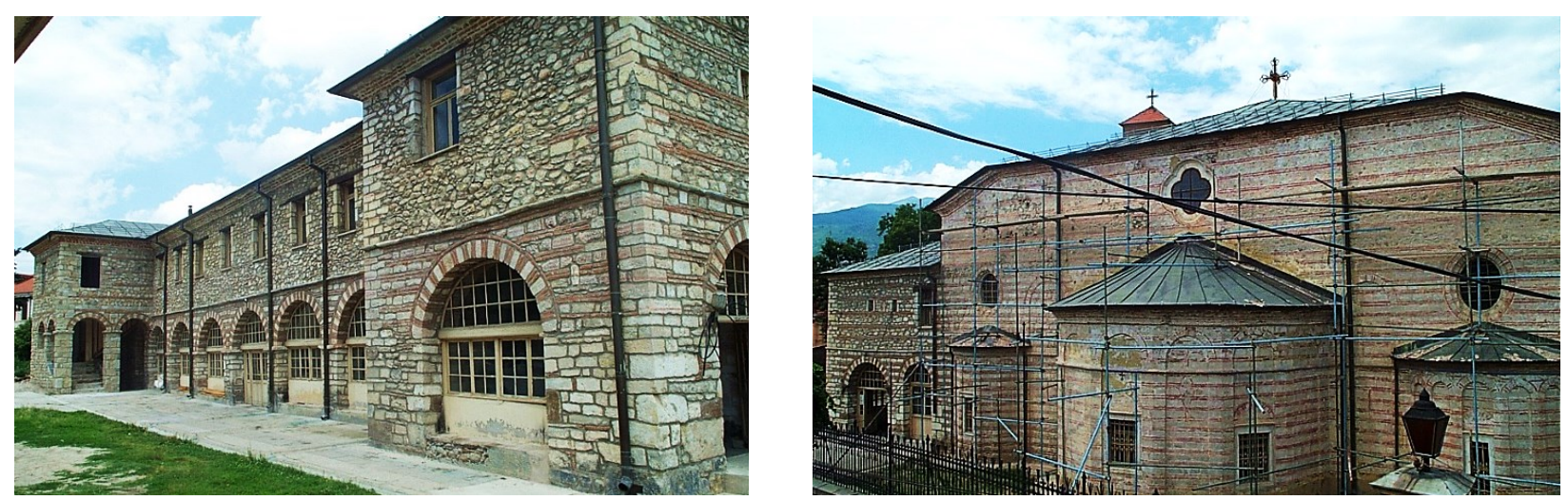

Figure III.231 St. Demetrius in Bitola: A. View from the south-east; B. View from the east.

During the renovation of the church in 1999-2002, the previously plastered facades were stripped of the multiple mortar coatings, revealing unexpected masonry techniques. The abundant use of brick in 
combination with hewn and crushed stone is surprising (fig. III.231). As expected, the eastern façade is of the highest quality. Up to a height of approximately $7 \mathrm{~m}$, which corresponds to the top of the oval windows above the side apses, the east façade was built of rows of hewn stone alternating with two rows of bricks. The syllable is precise, and the rows of bricks are completely flat and continuous along the entire façade, including the three altar apses. Namely, the church of St. Demetrius has three apses, of which the central one is bigger, seven-sided, with shallow masonry pilasters connected in the upper zone with arches made alternately of blocks of stone and two bricks. ${ }^{484}$

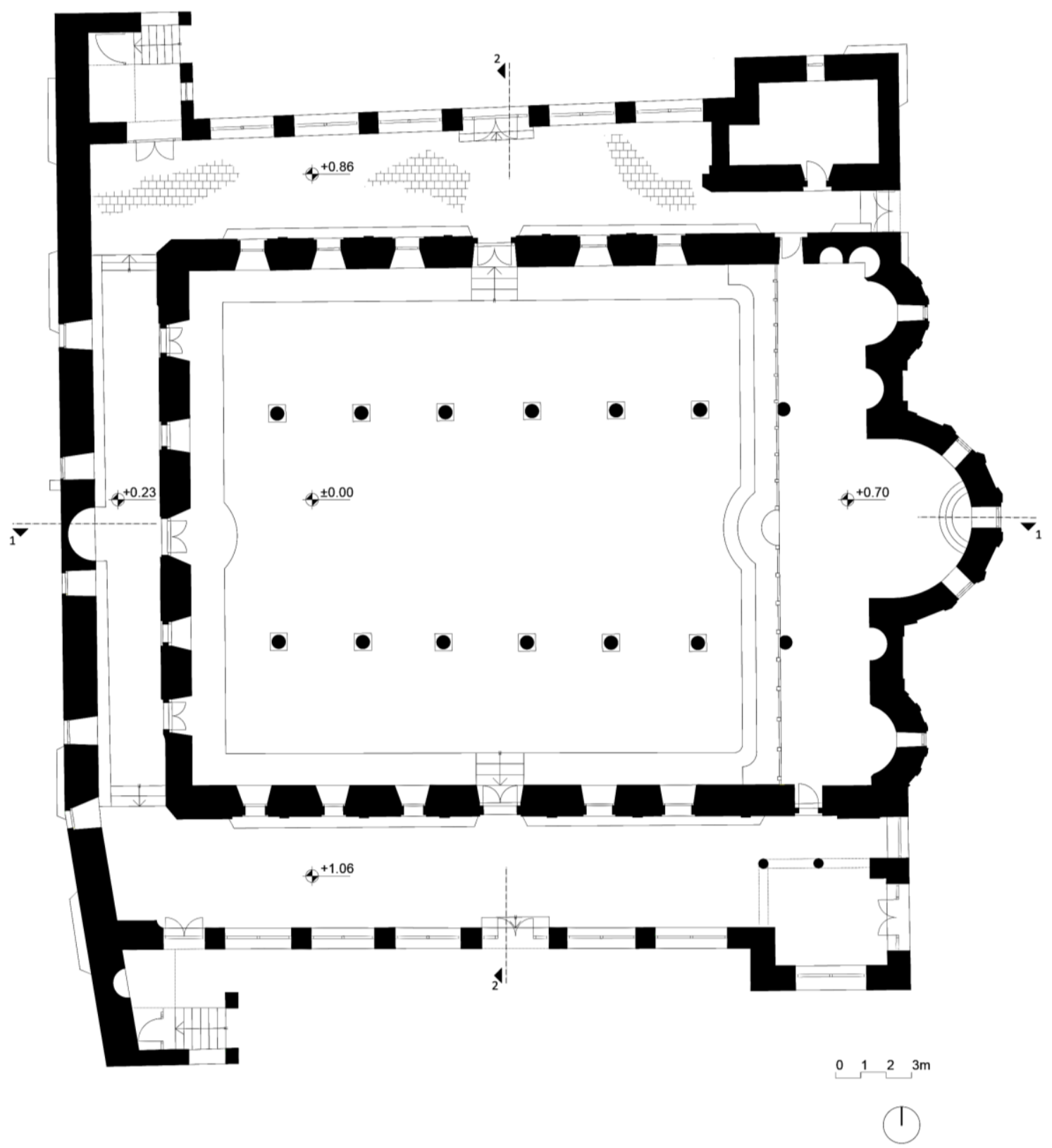

Figure III.232 St. Demetrius in Bitola. Ground floor plan ( \pm 0.00$)$.

\footnotetext{
${ }^{484}$ As a comparison, the large basilicas of the previous century built in the Vlach center of Moskopole, mentioned earlier (see Chapter II.2), were also made of alternating rows of stone and brick (see fig. II.5A, fig. III.89B), in a Byzantine manner. In that direction, knowing that the founders of the church in Bitola were the town leaders, among whom in this period there were many Vlach families who immigrated from the region of Moskopole, it seems logical to look for the influences on the masonry techniques used at the cathedral church of Bitola in this group of monuments. Then, only a few years later, the porches of the church in Magarevo, one of the richest Vlach villages in the region of Bitola, were built in the same way (see Chapter III.3, fig. III.22, III.26A, III.50A).
} 


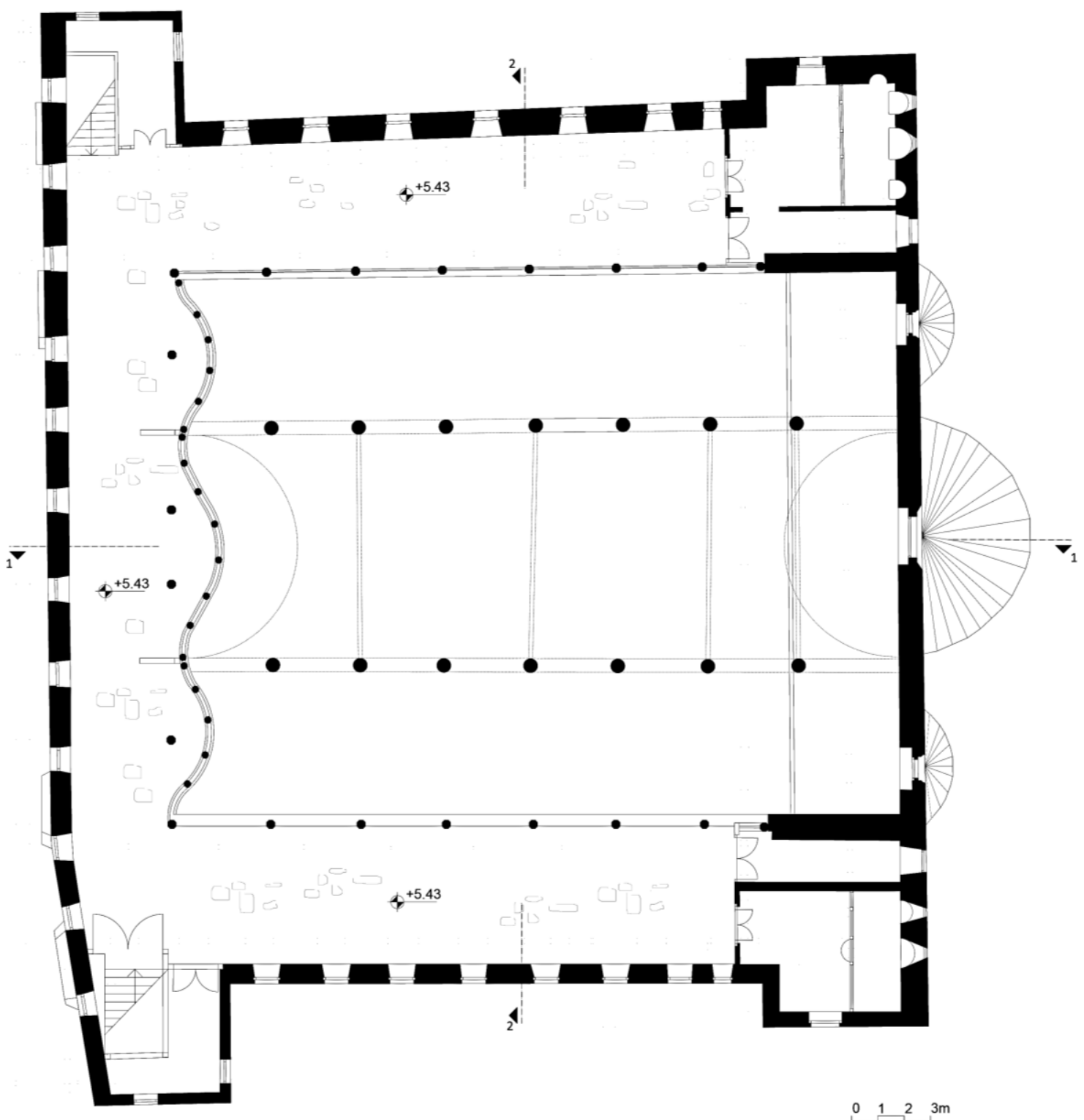

(1)

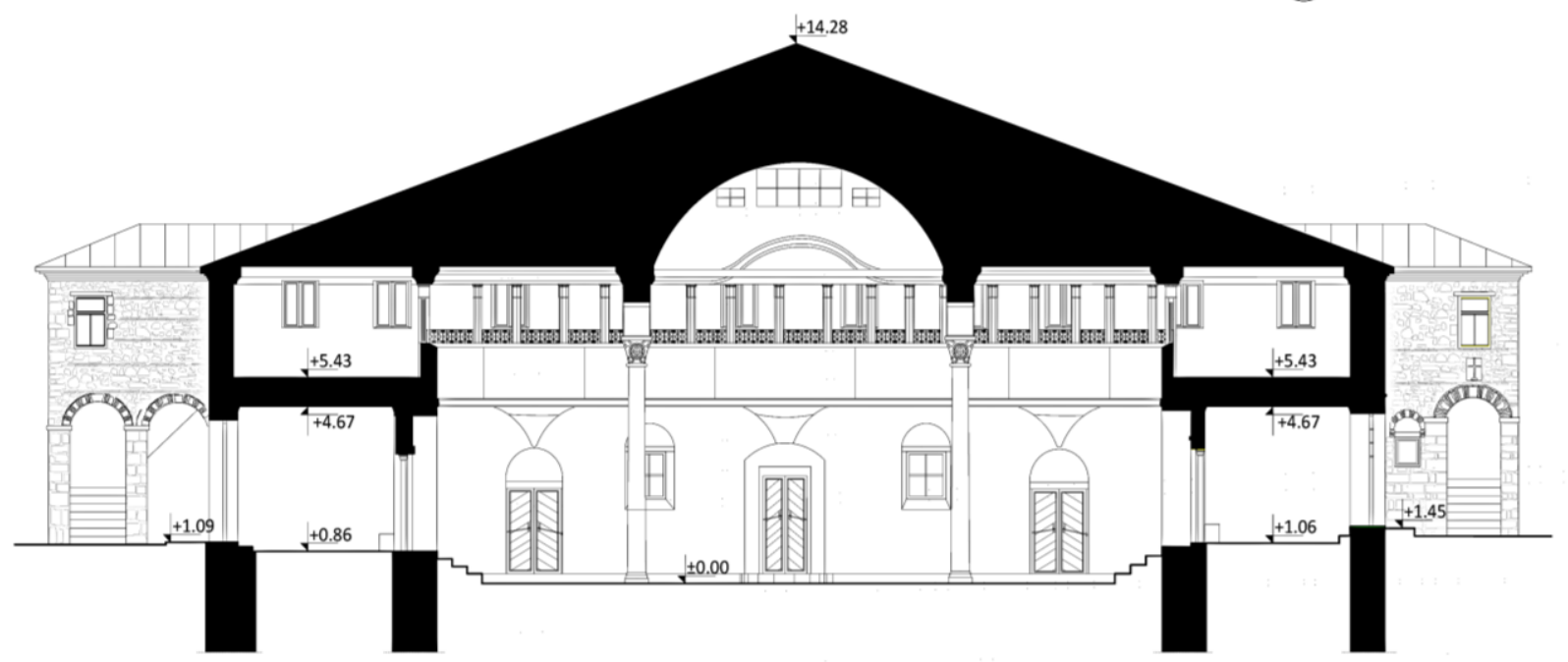

Figure III.233 St. Demetrius in Bitola. A. Gallery plan (+5.43); B. Transversal section (2-2). 

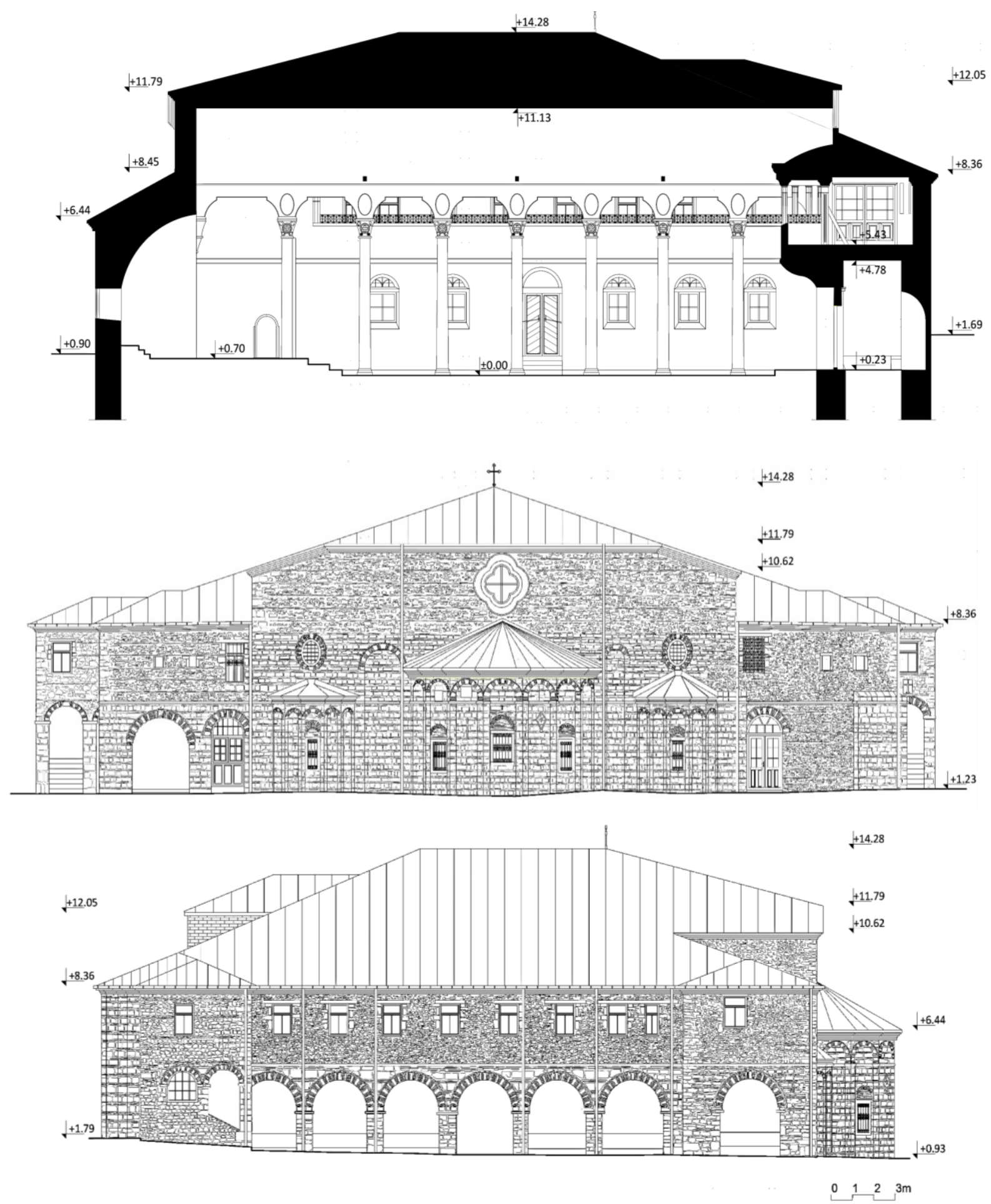

Figure III.234 St. Demetrius in Bitola. A. Longitudinal section (2-2); B. Eastern façade; C. Southern façade.

Seven shallow niches were formed on the altar apse, in which three single windows were inserted in a symmetrical composition, with stone frames, over which brick arches help distribute the loads (fig. III.234B). The side apses, which are smaller and five-sided with a single window placed in the axis, were conceived in a similar way. A separating cornice made of stone, with a semicircular profile, flows continuously along all four facades of the building, visually distinguishing the open porches from the upper floor. This cornice also separates the applied masonry: in the lower zone, the porches are built in the described way, with pillars of stone blocks and arches built by alternating blocks of stone and two bricks; over the cornice the masonry changes into a simple construction of crushed stone. On the east façade, however, simpler masonry appears in the upper zone (above the elevation of $\sim 7 \mathrm{~m}$, and at the side 
sections above the dividing cornice), consisting of $\sim 50 \mathrm{~cm}$ high belts of crushed stone, separated by 2 rows of brick. ${ }^{485}$ The corners of the building were executed with extremely massive stone blocks, and the crown cornices with cantilever brick. The low-quality masonry in the area above the dividing cornice, on the lateral and west facades, suggests that even during construction, it was planned for the upper half of these facades to be plastered.

As a very significant discovery, during the removal of the plaster coatings, traces of an original painted imitation of a façade opus with alternating layers of stone blocks and rows of bricks were found. ${ }^{486}$ It can therefore be assumed that after finishing the masonry of the east façade (up to $7 \mathrm{~m}$ in height) and of the lateral facades (up to the height of the separating cornice), probably due to reduction of available resources, the remaining structure was constructed with more modesty, using plain crushed stone and leveling layers of brick, and then plastered and painted. Indicatively, other examples of painted façade opus can be found in St. John the Forerunner - Slepche Monastery (Касапова, 2017) in the region of Demir Hisar; St. Demetrius in Bukovo, region of Bitola (see fig. III.6) and the churches of St. John in Ljubojno and St. Elijah in Ezerani, both in the region of Prespa (see Chapter III.2), all of which are geographically and culturally close and connected with Bitola. In addition, a painted façade opus is present in the medieval church of St. George in Kurbinovo (Prespa) which dates from the XII century (see Chapter I.4.3). The insistence on a decorative façade opus in stone and brick, achieved in any possible way, even if painted, is evidence that the Byzantine traditions were not abandoned, nor were the medieval decorative masonry techniques forgotten despite centuries of Ottoman occupation.

The illumination of the church of St. Demetrius is through proportionally large windows, densely arranged on the upper floor, since the church is significantly wide, and there is no central nave clerestory. The upper level windows are simple, with architrave lintels and window sills made of stone blocks (on the side facades) or brick (on the west façade). Arched window openings appear only on the ground floor of the staircase towers (fig. III.233). As usual, decorative windows adorn the east façade: large oval windows above the side apses; a large window shaped like a phytomorphic cross (a four-leaf clover) above the altar apse. The entrance portals were made of stone with shallow relief: for example, the northern portal to the altar, at the eastern end of the northern open porch, was shaped as a combination of concave and convex arched segments, above which a procession cross with trefoil arms was placed on a profiled pedestal, flanked on both sides by relief representations of angels. The south portal to the altar is simpler.
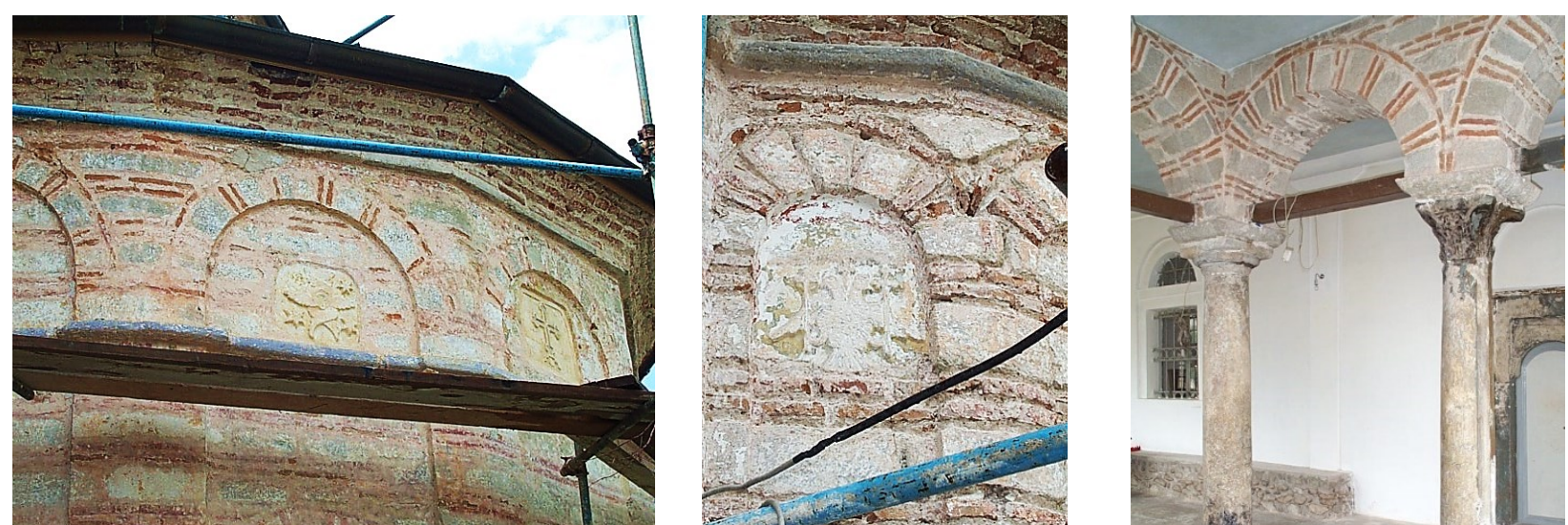

Figure III.235 St. Demetrius in Bitola. Details of shallow reliefs: A-B. Details of the altar apse; C. Spoliae in the southern porch.

Besides the decorative masonry, stone blocks with various motifs in shallow relief were embedded on the facades of the church of St. Demetrius in Bitola: procession crosses with trefoil arms, double-

485 The same type of masonry was used at the church of St. Elijah in Star Dojran (1848), whose author is Gjorgji Novakov - Dzongar. ${ }^{486}$ According to the testimony of Zoran Altiparmakov, architect-conservator at IPMCM - Bitola, interviewed in August 2020. 
headed eagles (fig. III.235A-B) ${ }^{487}$ cherubim accompanied by solar motifs, etc. Spoliae were also used in the construction of the church: in addition to the columns and capitals in the southern chapel (fig. III.235C), fragments of slabs, pedestals, a large stone slab with an inscription in ancient Greek and other fragments were re-utilized in the church's masonry.

The interior of the church is monumental despite the lack of frescoes. Namely, in addition to the mentioned oval medallions in the central nave, its vault was painted with a representation of the sky in the center of which appears a large oval mandorla depicting the image of Christ Pantocrator (see fig. II.9A, III.228, III.230A). It is framed with a lavish baroque gilded frame, adorned with painted radiating beams of light. A similar, smaller mandorla was painted to the west, along the axis of the vault. Rays of light penetrate the blue background covered with painted clouds, symbolizing the Holy Spirit. This composition was completely unknown prior to 2005, when it was discovered under layers of accumulated soot from decades of candle-burning. Another fresco composition is present at the south entrance portal. With the exception of these compositions, the entire interior was whitewashed. The emphasis therefore was placed on the magnificent monumental iconostasis, the pulpit, the bishop's throne and the multitude of icon and gospel pedestals and other luxurious church furnishings in deep wood carving, many of which were produced by the best-known woodcarving workshops of the XIX century Revival.

As soon as 1835, in the village of Magarevo, not far from Bitola, another church dedicated to St. Demetrius was built, according to many similarities, using the new cathedral of Bitola as a model (see fig. III.22, III.26A, III.50A). Namely, this village church is also a five-nave basilica, with additional lateral naves which on the ground floor consist of open porches with an even rhythm of massive pillars connected with semicircular arches made very decoratively by alternating hewn stone and 2 pieces of brick. Here too, to the east, the porches end with tower-like expansions, which on the ground floor house separate chapels with an entrance from the west, i.e. from the covered porch, as well as a direct communication with the prothesis / diaconicon in the altar. The main entrances to the naos are located at the side facades, via the open porches, and a western entrance is completely absent, which is a clear indicator that the church in Magarevo consistently followed the Bitola prototype. Furthermore, specific to this church is the transept which corresponds to the eastern half of the nave, illuminated with decorative oculi. The eastern façade is especially decorative, with three altar apses (a large central seven-sided and smaller lateral five-sided apses), with blind arched niches, again made according to the model of the Bitola temple. The rhythm of the lateral ground floor arcades, their processing and the merging of the roof of the central volume - the three-nave naos with the additional lateral naves in a single huge continuous gabled roof are irresistibly reminiscent of the monumental three-nave basilicas built less than a century earlier in Moskopole (see Chapters II.2, III.3), where the Vlach founders of the village of Magarevo actually came from. However, the key difference is that in the churches of Moskopole the porches are limited only to the south (or south and west) façade and only at ground floor level. The " $U$ "-shaped upper floor gallery is, therefore, definitely a Revival novelty, which they readily accepted and incorporated in their later work.

A few years later, in 1838, the cathedral church of St. Annunciation was built in the nearby town of Prilep, whose authors are the local master-builders Riste Taslamiche and Kosta Lauco. ${ }^{488}$ In this church the five-nave disposition is partial: the additional side naves (with an arcade open porch on the ground floor and a gallery open towards the naos on the first floor) end at approximately two thirds of the naos from

\footnotetext{
487 The double-headed eagle is an important Byzantine symbol and coat of arms of the Palaeologan dynasty.

488 As a result of the traditional occupation with architecture or the arts within the family, Kosta's son Pere Lauco was also a master-builder, author of the monastery of St. Elijah in Melnica (Mariovo) built in 1870-1872. The author of the monastery's fresco ensemble painted in 1881 was Avram Dichov, son of the painter Dicho Zograf.
} 
west to east (fig. III.236A). Also, the side naves are as high as the core three-nave naos of the church, which establishes the main feature of this typology which Kadijević recognized for the first time at the church of St. Mina in Thessaloniki, built 14 years later. From the outside it is simply conceived, without a dome or clerestory on the fifth façade, relatively low and dug a few steps into the ground, according to the legal restrictions still in force. On the east façade there is a large altar apse flanked by two smaller ones (prothesis and diaconicon). The three-nave naos at the ground level was partitioned with 6 pairs of tall, slender wooden columns. The central nave was covered with a "false" barrel vault while the lateral ones with a flat ceiling, as was the case at the older church of St. Demetrius in Bitola. The gallery was defined by a solid parapet fence above which was placed a musharabia of diagonally intertwined wooden slats; above the side entrances to the naos it extends convexly, in the form of baroque curved balconies. ${ }^{489}$
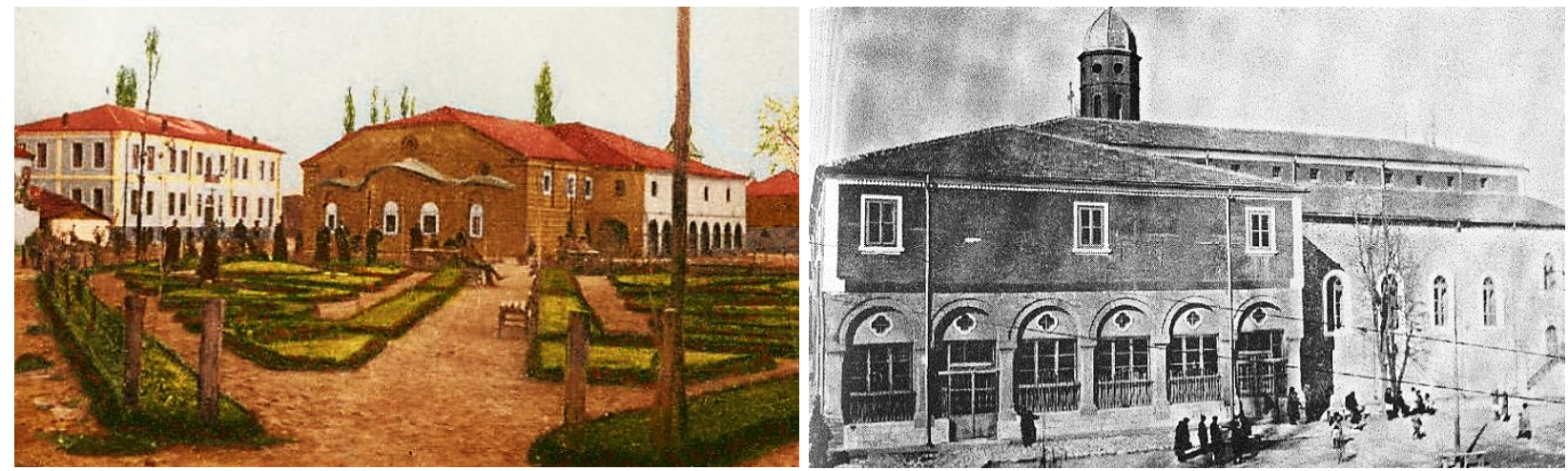

Figure III.236 A. St. Annunciation in Prilep; B. The Most Holy Mother of God in Skopje. Photographed at the beginning of the XX century.

As for Andreja Damjanov, the five-nave basilica solution will truly mark his opus, starting with The Most Holy Mother of God in Skopje, whose long-term construction started by his father, was completed in 1835 (fig. III.236B). Afterwards, he developed and perfected this particular typology, introducing defining elements such as a "true" basilica disposition of the fifth façade, pyramidal composition of the masses and blind domes in the central nave. He will go on to build the five-nave basilicas: St. Panteleimon in Veles (1840); the Most Holy Mother of God in Novo Selo near Shtip (1850) and St. Nicholas in Kumanovo (1851), all built before the church of St. Mina in Thessaloniki. ${ }^{490}$

Despite being the earliest independent project of Andreja Damjanov, the cathedral church of St. Panteleimon in Veles is a masterpiece of this specific Revival typology. It was founded on an artificial plateau on an otherwise very steep terrain high in the gorge of the river Vardar in the town of Veles. The specific topography prevented the formation of the usual western entrance; Andreja Damjanov therefore used the narrow western narthex to accommodate the stairs leading to the upper floor (fig. III.237), which would become one of the characteristic elements of this typology which he would later use in other churches (in Novo Selo, Kumanovo, Vranje) even though they had no such spatial restrictions. Although there are many similarities with the older five-nave buildings in Bitola, Prilep and, of course, in Skopje, at St. Panteleimon for the first time the central nave rose higher than the side ones, hiding 3 spacious blind domes in its elongated prismatic volume. The later churches of this type will follow this system. The height of the naos achieved with the central nave clerestory allowed the insertion of two superimposed galleries,

\footnotetext{
489 The interior of the church is almost entirely white, with limited fresco ensembles in the apse and in the vault of the central nave. The dominant role is played by the magnificent iconostasis, the pulpit, the wood-carved throne of the church founder Hadzi Riste Damjanović - Logothet, made by master Dimitar (Mitar) Stanishev, as well as the bishop's throne, one of the last works of Petre Filipovski Garkata, which is also considered a masterpiece of this type of wood-carved furniture (Ḱорнаков, 2016: 112). ${ }^{490}$ Most of the churches that the Damjanov family's master-builder group built outside of Macedonia (in Serbia and Bosnia and Herzegovina) follow the same typology. Such is the church of St. Trinity in Vranje (Serbia), built in 1859 by Andreja's brother Kosta (Томовски, 1967: 14).
} 
giving the church interior a playful charm, complemented by a wealth of arcades, pendants, bas-reliefs and evident Baroque and Islamic influences (see fig. III.37, III.174B). The eastern façade is especially decorative, which in this case is the "face" of the temple (see fig. III.213A), with "rich rhythm and variety of roof planes and cornices" (Василиев, 1965: 161). The five-nave disposition is especially pronounced on this façade, because the side naves from the core three-nave naos and the additional lateral naves have the same height and their eastern façades end with a trapezoidal shape - a saddle-shaped roof.
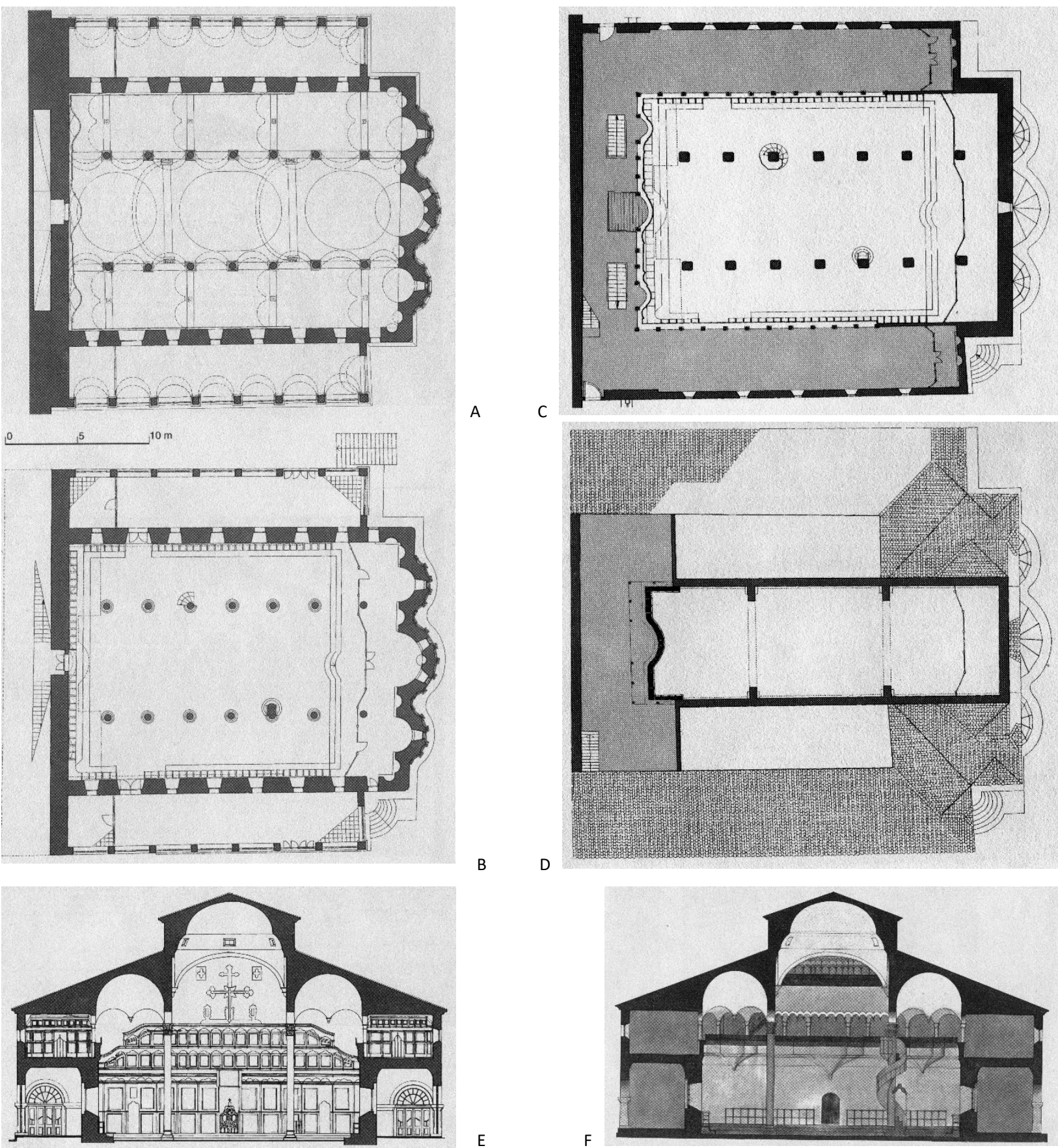

B
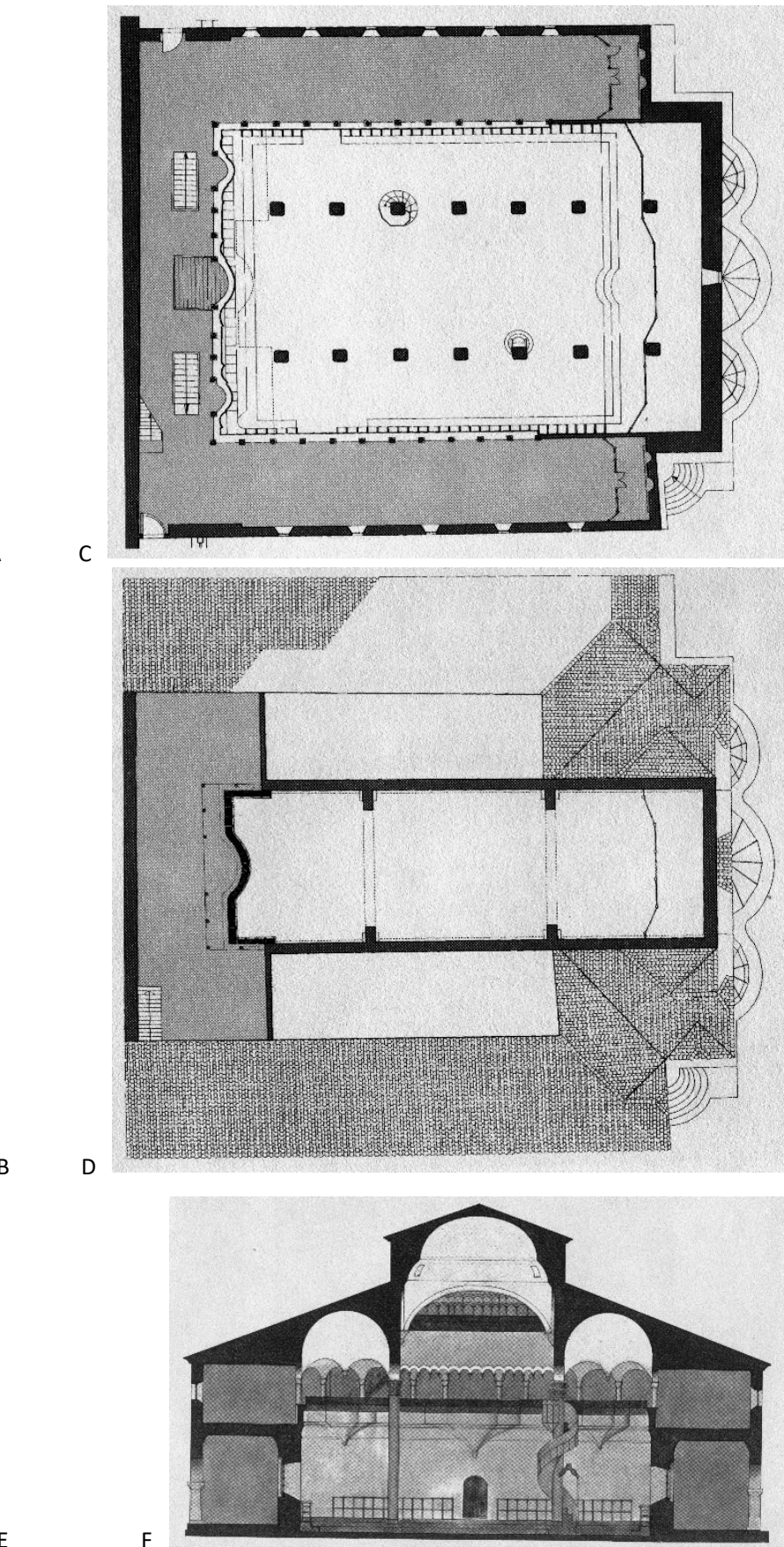

Figure III.237 St. Panteleimon in Veles: A. Ceiling; B. Ground floor; C. First gallery; D. Second gallery; E. - F. Transversal sections.

Although obviously strongly inspired by St. Panteleimon in Veles, at the Most Holy Mother of God in the village of Novo Selo near Shtip (1850) Andreja Damjanov introduced several novelties. The additional side naves became lower than the lateral ones within the three-nave core, so the scaling of the whole building is threefold, strongly expressed with the central nave clerestory, which hides four blind domes within. This allowed for a gradation in the east façade composition: in the first plane are the 
decoratively partitioned apses, in the second the roofs at the level of the additional lateral naves, in the third the roofs above the side naves of the three-nave core and in the fourth the central nave; all were shaped in the form of a saddle. Another novelty is a small bell tower placed high on top of the west façade. Andreja Damjanov will further develop these elements at the church of St. Nicholas in Kumanovo, built almost simultaneously (in 1851).
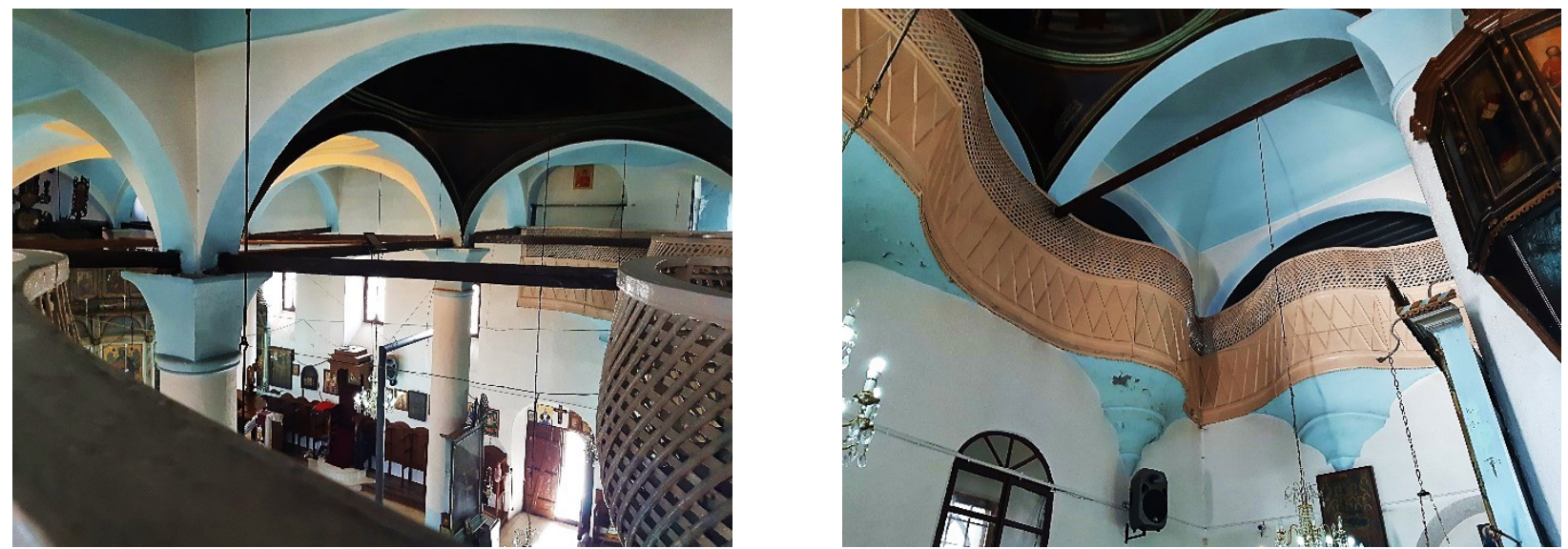

Figure III.238 Dormition of the Most Holy Mother of God in Krushevo: A. View from the northern gallery towards the south B. View from the naos towards the north-west corner of the gallery.

The five-nave basilica as a monumental typological solution continued to be built in Macedonia in the second half of the XIX century, both in urban and in several rural settlements. In 1867, the cathedral church of St. Nicholas was built in the town of Shtip (see fig. III.227) by the master-builder Gjorgji Novakov Dzongar; the same year the church of the Dormition of the Most Holy Mother of God was built in the town of Krushevo (fig. III.238). At these two churches, the five-nave typology introduced a novelty: domes supported on elevated, protruding drums. At St. Nicholas, three such domes pierce the gabled roof, complemented by a decorative bell-tower over the western façade. At the church in Krushevo, a central dome placed on an octagonal drum is flanked to the east and west by blind domes and a high octagonal bell-tower develops over the southeast corner of the gallery.
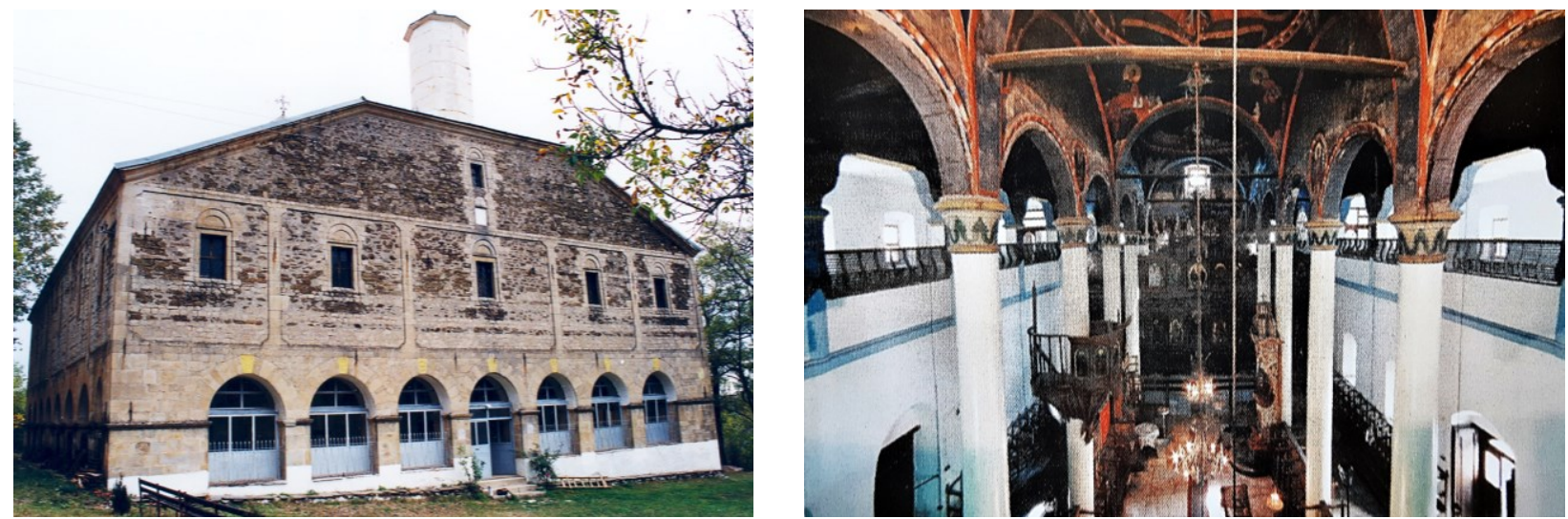

Figure III.239 A. St. Transfiguration in Gopesh (Bitola). View from the north-west; B. St. Petka in Malovishte (Bitola). View from the gallery towards the naos.

As for the abovementioned Vlach villages near the town of Bitola, in 1856 in the village of Malovishte the monumental five-nave pseudo-basilica dedicated to St. Petka was built; a little later, in 1871, the church of St. Transfiguration was erected in the nearby village of Gopesh, following the same typological pattern (fig. III.239A). In these churches the five-nave disposition is complete, i.e. the external two naves comprised of an open porch on the ground floor and a gallery on the first floor expand along the naos all the way to its eastern façade (fig. III.239B). 
According to everything stated before, it is clearly erroneous to consider the church of St. Mina in Thessaloniki as a prototype of this specific Revival basilical typology, and its conception should be sought much earlier in the past. Then, what is the origin of the "five-nave" basilicas?

As with the single-nave and three-nave basilicas, the model for this specific solution should be sought in the construction of past eras. The oldest prototype of a five-nave basilica in the region is the church of St. Demetrius in Thessaloniki, built during the reign of Theodosius II (408-450), over a IV century martyrium (Hoddinott, 1963: 127-128). It consists of a five-nave naos with galleries above the side naves, a narthex, a transept to the east in front of the apse, which gives the naos a clear " $T$ "-shape and a complex altar solution. Galleries above the side naves can be found in a group of early-Byzantine monuments, such as the church Acheiropoietos in Thessaloniki and St. John Stoudios in Constantinople, where access to the galleries is provided from the outside of the building; as well as the basilicas with a dome of the so-called "capital type" built throughout the Empire in the following centuries.

Furthermore, the five-nave basilicas built in Macedonia in the middle-Byzantine period must not be overlooked - the basilica at "Kale-Krupishte" and St. George - Yeni Mosque in Bitola (see Chapter II.4.2) where the five-nave disposition develops at the ground floor level. In fact, although preserved only as archeological remains, the five-nave basilicas in Bitola and Krupishte testify that the concept of a monumental five-nave temple was long known, present and widespread in the Macedonian traditional ecclesiastical architecture.

In other churches from the same period (X-XI century) appear galleries (tribunes) that extend over the narthex and side naves along the entire length of the naos in an otherwise three-nave basilica disposition. In these churches, the prototype for the " $U$ "-shaped upper floor galleries in the Revival five-nave churches can be easily recognized. This solution is specific to the cathedral of St. Achilles (see fig. I.18) and the basilica in Serres, which was similarly conceived (Томовски, 2000:

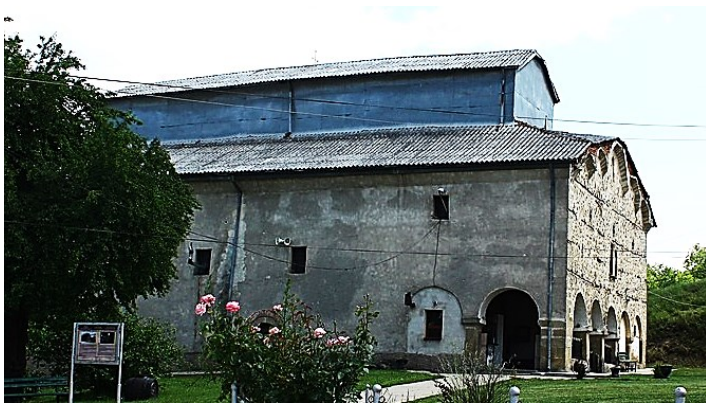

Figure III.240 Dormition of the Most Holy Mother of God in Delchevo (Carevo Selo). 156). Furthermore, a gallery set above the narthex opens towards the naos at the cathedral of St. Sophia in Ohrid (see fig. I.22, I.23A); later, at the beginning of the XIV century, the monumental exonarthex was added to the Ohrid cathedral, which, as mentioned, essentially consists of an open porch on the ground floor and a gallery on the first floor, flanked on both sides by massive square domed towers (see fig. I.24).

Far to the northeast, in Kyiv Russia, based on the early and middle-Byzantine tradition and using the same architectural vocabulary, several monumental five-nave domed churches were built in the XI century, with upper-floor galleries above the side naves and the western narthexes (St. Sophia in Kyiv, St. Savior in Chernigov, St. Sophia in Novgorod, St. Sophia in Polotsk, etc.), apparently inspired by the basilicas with a dome of the capital type.

The idea of placing galleries over the narthex and side naves originated, therefore, from the depths of Byzantine construction history, and is especially associated with important capital temples and episcopal seats from the early-Christian period, later repeated in the middle-Byzantine period, with modifications, precisely at the churches built as cathedrals of independent kingdoms and principalities, again in correlation with their predominantly ceremonial nature. Therefore, it is not surprising that in the Revival period basilicas following this concept were built as the most monumental urban cathedrals, as well as churches in several rich rural areas that in the given period almost had the status of towns.

However, in the context of the Revival basilicas, it must not be forgotten that the conceptual idea of placing a closed volume over an open arcade porch was also present in churches that do not belong to 
the monumental "five-nave" type. The externally closed upper-floor volume of these churches inside the building is actually a gallery open to the naos, i.e. it houses the "women's church". Although not particularly common, this solution was used in a group of three-nave churches (see Chapter III.3) which include St. Nicholas in Golemo Radobil (Prilep), St. Nicholas in Star Istevnik (Delchevo), St. Nicholas in Virche (Delchevo), Dormition of the Most Holy Mother of God in Leunovo (Mavrovo), St. Theodore Tyron in Piperovo (Shtip); as well as St. Elijah in Selce near Debar, St. Savior in Veles (see Chapter III.5.E) and St. Sunday in Bitola, which was addressed in detail within the category of three-nave basilicas with domes supported on drums (see Chapter III.5.B.5). In the context of the connection of these churches with the "five-nave" basilicas, the church Dormition of the Most Holy Mother of God built in Delchevo (Carevo Selo) in 1857 by the master-builder Vasil (Василиев, 1965: 305) is of special importance (fig. III.240). According

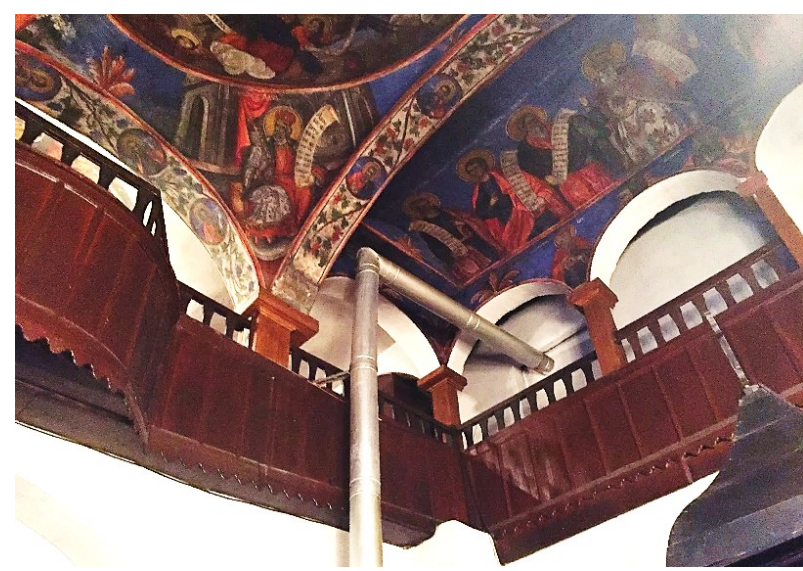

Figure III.241 St. Nicholas Gerakomija in Ohrid. View from the naos towards the north-west corner of the gallery. to its conception, this church is a three-nave basilica with a central nave clerestory, in whose prismatic volume three blind domes placed on eight-sided drums are hidden, while the side naves are covered with a decorated flat wooden ceiling. To the west, a gallery develops over an open porch consisting of an arcade of five arches on the west and two on the side facades, carried on massive pillars built of hewn granite blocks, with geometrically profiled capitals. Of interest is also the solution of the shorter facades that in the upper zone are composed of five blind cantilevered arches that descend steeply from the center towards the ends of the facades. ${ }^{491}$ In this way, and with the dominant clerestory of the central nave, the master-builder Vasil in an otherwise three-nave basilica evoked a "five-nave" solution characteristic of the most monumental cathedrals built a little earlier in Veles, Skopje, Novo Selo, etc.

Furthermore, the seed of the five-nave concept can also be recognized at two three-nave Revival churches with a "U"-shaped (St. Nicholas Gerakomija in Ohrid) or "L"-shaped upper floor gallery (St. Elijah in Stenche near Tetovo). At St. Nicholas Gerakomija in Ohrid (fig. III.241), the specific location conditions forced the installation of an open arcade porch with a gallery on the southern side, while the western façade is completely blind. In the thickness of the north wall there appears a very narrow gallery (less than $50 \mathrm{~cm}$, which means that in this section it is completely useless) whose sole purpose is to provide a symmetrical composition in relation to the gallery above the western part of the nave and above the south porch emphasized with the wooden construction and processing of the fence. At St. Eijah in Stenche, the gallery develops on the first floor of a closed porch that envelops the naos on the west and north sides (see fig. III.99).

From all the above, it can be concluded that the introduction of a closed upper floor over an open, arcade-style porch is a phenomenon characteristic of the Revival three-nave basilicas in general, which in the "five-nave" type was further developed as a result of the naturally imposed need to add additional side naves along the entire length of the naos (or partially - along its western half), which on the ground floor were solved as an open porch, and on the upper floor as an integral part of the inner temple.

\footnotetext{
491 The longer facades of the central nave clerestory are divided into 10 semicircularly arched niches, surrounded by a wide cornice (Василиев, 1965: 305) which creates a serrated effect on the otherwise long, uniform planes. The northern façade of the nave is shaped in a similar way, where a higher niche appears in the middle, flanked by rows of four lower niches, again with the same serrated effect. Additionally, ornaments were painted in the niches. Unfortunately, this composition has been largely destroyed by later alterations, and the central clerestory and the side facades of the nave were completely plastered (fig. III.240).
} 


\section{III.5.D DOMED SINGLE-NAVE BASILICAS}

Compared to the single-nave and three-nave basilicas, the Revival domed single-nave basilicas represent a very small group - only 3\% of the total number of so-far classified Revival churches. However, they can stylistically and typologically clearly be defined as a separate category. The domed single-nave basilicas are mainly concentrated in western Macedonia (the regions of Debar, Reka, Gostivar, Kichevo, Struga), with a single solitary specimen in the regions of Mariovo, Prilep and Bitola (map. III-D), whose authors are certainly again derived from the Debar master-builder school, where this specific solution undoubtedly originated.

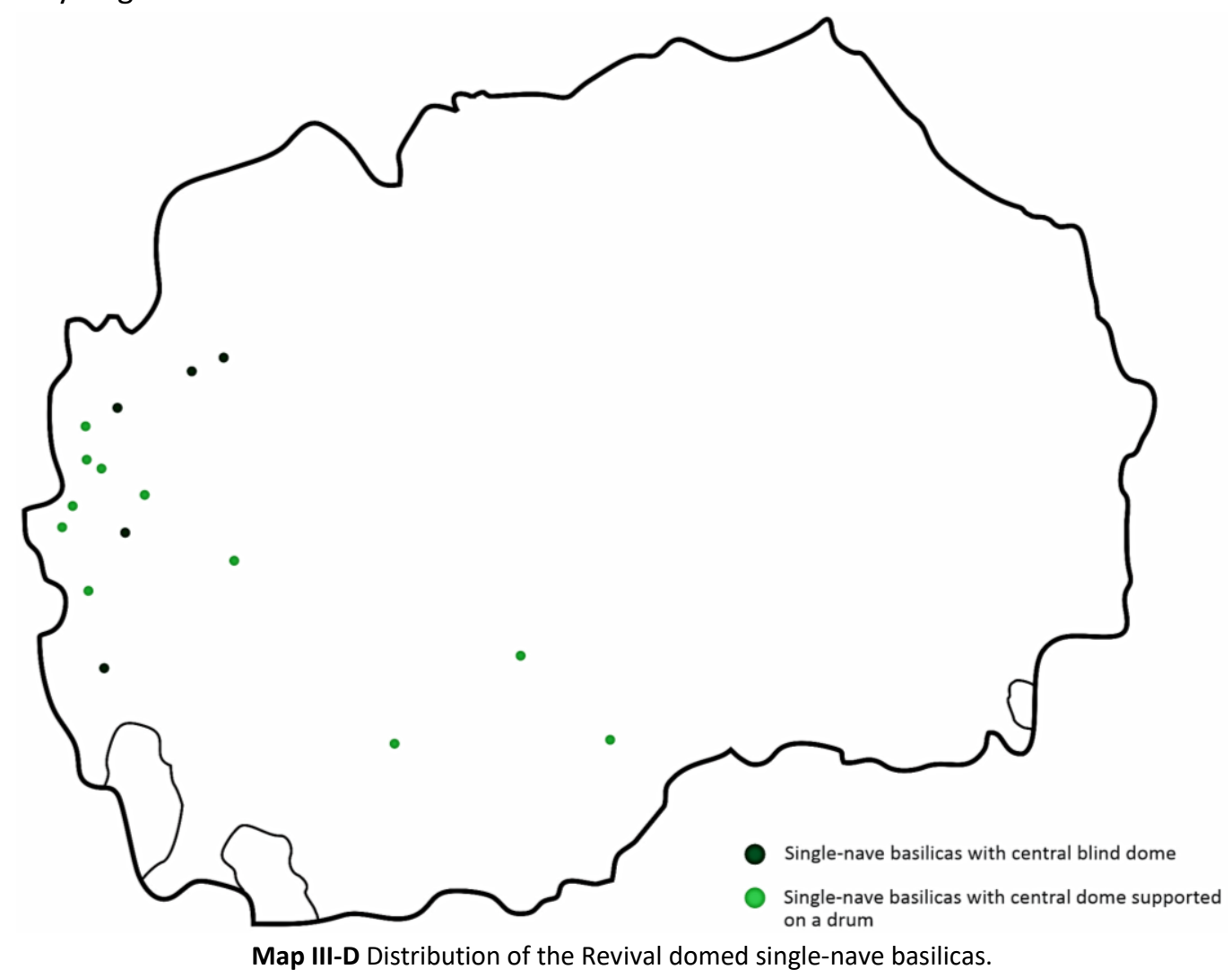

The so far identified Revival domed single-nave basilicas are listed chronologically in the following table (table III-16):

\begin{tabular}{|c|c|c|c|c|c|}
\hline & CHURCH & VILLAGE & REGION (TOWN) & YEAR & $\begin{array}{c}\text { ADDITIONAL INFORMATION } \\
\text { fresco-painting / icons, renovations }\end{array}$ \\
\hline 1 & St. John the Baptist - Bigorski monastery & Bitushe & Debar & 1800 & $\begin{array}{l}\text { renovation of an older church whose } \\
\text { fragments were integrated }\end{array}$ \\
\hline 2 & St. George & Lazaropole & Debar & $1832-1833$ & $\begin{array}{l}\text { icons and frescoes from several } \\
\text { phases until } 1841\end{array}$ \\
\hline 3 & St. George & Rajchica & Debar & 1835 & the dome was fresco-painted in 1840 \\
\hline 4 & St. Demetrius & / & Gostivar & 1840 & \\
\hline 5 & St. Achilles of Larissa & Trebishte & Debar & 1840 & \\
\hline 6 & $\begin{array}{l}\text { The Immaculate Mother of God - Krninski } \\
\text { monastery }\end{array}$ & Dolenci & Kichevo & 1848 & \\
\hline 7 & St. Demetrius & Volkovija & Gostivar & 1852 & \\
\hline 8 & Dormition of the Most Holy Mother of God & Gari & Debar & 1856 & \\
\hline 9 & St. Archangel Michael & Tashmarunishta & Struga & 1858 & \\
\hline 10 & St. Nicholas & Prilepec & Prilep & 1872 & \\
\hline 11 & St. Elijah - Melnichki monastery & $\begin{array}{l}\text { Melnica } \\
\text { (Vitolishte) }\end{array}$ & Mariovo & 1872 & \\
\hline 12 & St. Nicholas & Tresonche & Debar & 1873 & \\
\hline 13 & St. Nicholas & Pechkovo & Gostivar & 1874 & \\
\hline 14 & St. Demetrius & Bogdevo & Gostivar & & \\
\hline
\end{tabular}




\begin{tabular}{|l|l|l|l|l|l|}
\hline 15 & St. Archangel Michael & Lisolaj & Bitola & & \\
\hline 16 & St. Nicholas & Selci & Struga & & $\begin{array}{l}\text { the onion-shaped dome possibly dates } \\
\text { from the post-WWII renovation }\end{array}$ \\
\hline
\end{tabular}

Table III-16 Domed Revival single-nave basilicas.

In the Revival basilicas of this sub-type, the naos is divided into three distinctive bays of which the central one is the largest and is approximately square in plan, while the lateral ones (to the east and west) are shorter and thus rectangular in shape. The nave is dominated by a large, monumental dome placed above the central bay. This dome can be blind (in Gostivar, Pechkovo, Bogdevo, Gari, Volkovija, Tashmarunishta) or raised on an elevated drum (in Bigorski monastery, Krninski monastery, Trebishte, Lazaropole, Lisolaj, Melnichki monastery, Prilepec, Selci). It extends to the widest possible available span, as wide as the naos itself (fig. III.242, III.245). In the north-south direction, it is supported on the façade walls of the church directly (as in the church of St. Nicholas in Tresonche and St. Demetrius in Bogdevo) or via attached semicircular arches connecting lateral pilasters (as in the churches of St. George in

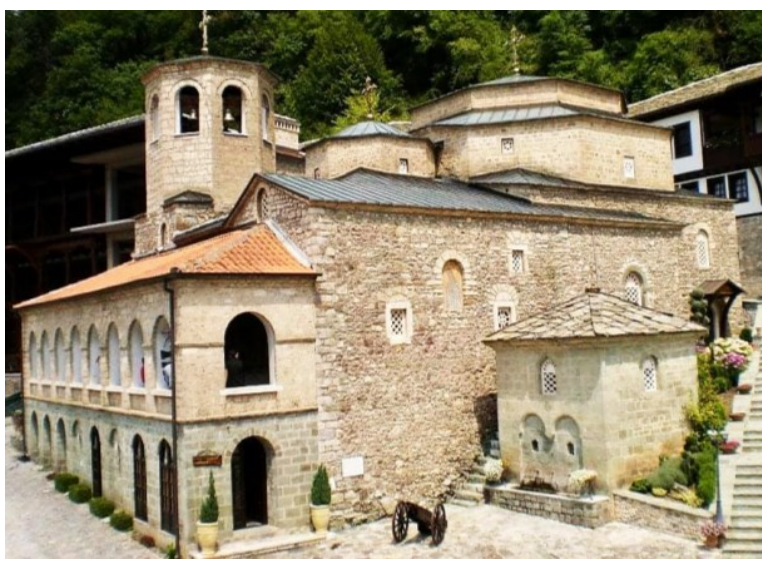

Figure III.242 St. John the Baptist-Bigorski monastery near the town of Debar. View from the south-west.
Rajchica, St. Archangel Michael in Lisolaj and St. Archangel Michael in Tashmarunishta). In the eastwest direction, the dome rests on an appropriate sub-dome structure - transverse arches supported on consoles (in Tresonche) or pilasters (in Rajchica, Lisolaj and Tashmarunishta). At the most developed type of domed basilicas, which also have the most monumental dimensions, on the east and west side the dome rests on masonry pillars (at St. George in Lazaropole, the Bigorski monastery, Dormition of the Most Holy Mother of God in Gari) connected with each other by arches. Thus, conditionally speaking, the naos in the east and the west bay

transforms from a single-nave into a three-nave arrangement (see fig. III.246).

The uniqueness of this church typology naturally raises the question: under what influences it originated and how it arrived in Macedonia, more precisely in the region of Reka (Debar)?

From the opinions expressed in science so far, it can be concluded that this solution is characteristic of the monastery churches and derives from their traditional centralized typologies: a compact inscribed cross or a trefoil with a central dome set upon a drum (Николовски, 2018: 17). In the context of attributing the origin of this specific Revival typology to patterns adapted from older monastic catholicons, the fact that a significant part of the churches in this sub-group are themselves, in fact, monastery churches ${ }^{492}$ must not be overlooked.

Going back to the Middle Ages under Byzantine rule, it is clear that the dome was the main and most significant element of the sacred architecture from the earliest beginnings to the late-Byzantine period. It comes as no surprise, then, that churches with domes that "covered the whole space built to carry them" (Kopaћ, 2007: 32) were also built in Byzantium. Such are the basilicas with a central dome built in Macedonia in the middle-Byzantine period, based on the old metropolitan cathedral of Thessaloniki (see fig. I.27A), especially the churches in Drenovo (see fig. I.29A) and, probably, Velushina (see fig. I.26), whose central domed space is surrounded by lower perimeter " $U$ "-shaped naves (see Chapter II.4). In their central core, covered with a dome spanning the entire free space, a prototype for

\footnotetext{
492 St. John the Baptist - Bigorski monastery near Debar, its metochion churches St. George in Rajchica and St. Achilles of Larissa in Trebishte, both near Debar; the Immaculate Mother of God - Krninski monastery near Kichevo; St. Elijah - Melnichki monastery in Mariovo; St. Archangel Michael in Lisolaj (Bitola) and St. Nicholas in Prilepec (Prilep).
} 
the central bay of the Revival domed single-nave basilicas can be recognized. In this context, parallels can also be drawn with the compact inscribed cross churches, such as St. George in Goren Kozjak (see Chapter I.3), as well as the late-Byzantine examples of single-nave churches with a central domed bay, such as the church in Poloshko, St. Archangel Michael in Varosh and the church of St. Nicholas in Chelopek.
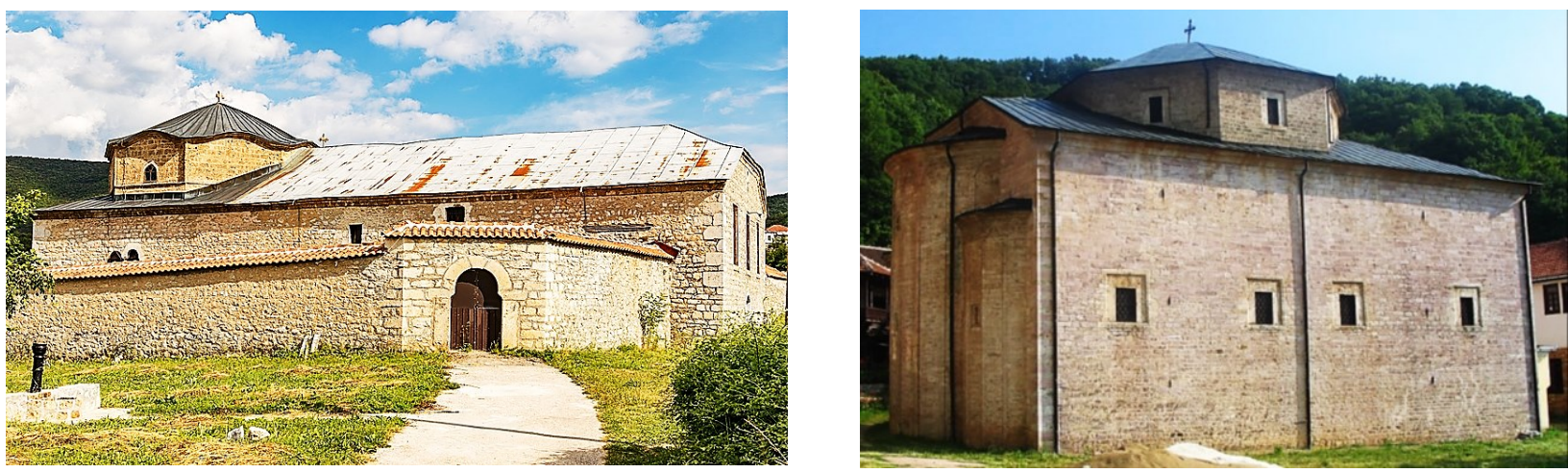

Figure III.243 A. St. George in Lazaropole (Debar); B. the Immaculate Mother of God - Krninski monastery near Kichevo.

In addition, another group of geographically relatively close monuments - the Rashka style group (built in the XII-XIII and the first half of the XIV century on the territory of present-day southwestern Serbia, Kosovo and part of Montenegro) is worth mentioning. It is comprised of essentially single-nave vaulted buildings with massive pilasters and leaning arches that support a dome whose span corresponds to the width of the nave, placed on a massive cubic pedestal that penetrates through the otherwise gabled roof. ${ }^{493}$ It is in this penetration in the gabled roof that analogies of the Revival domed basilicas with the older buildings of the Rashka style group are most clearly suggested. Later, in the late-Byzantine period, an example of a compact domed church with a square naos is the Royal Church in the Studenica Monastery, built under the auspices of the Serbian King Milutin.
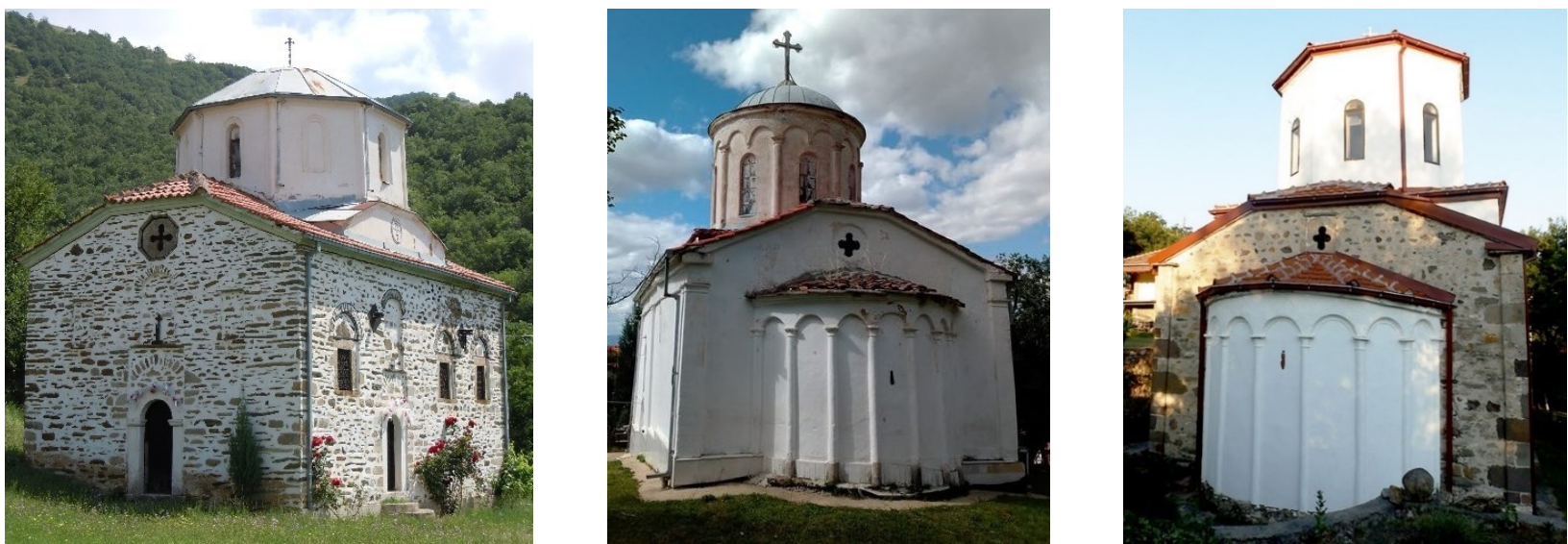

Figure III.244 A. St. Archangel Michael in Lisolaj (Bitola); B. St. Nicholas in Prilepec (Prilep); C. St. Elijah - Melnichki monastery (region of Mariovo).

Despite the geographical and temporal distance, it is necessary to turn our attention to a very significant group of monastery catholicons, built in present-day Greece and the Aegean islands in the XI century, under evident oriental (Middle Eastern) and influences from the Empire's capital Constantinople. These are large buildings in the center of which, over a square base, a monumental dome is formed carried on eight supports (pillars, columns or side pilasters), which under the dome itself develop into a system of squinches (at the southern church of the monastery of Hosios Loukas in Phocida, the monastery of

493 Their architecture is further complicated with low side vestibules which in some examples even turn into a high transept (Banjska Monastery, near Kosovska Mitrovica), separate chambers for prothesis and diaconicon, as well as a narthex and a bell tower to the west (Ненадовић, 1980: 30-67). 
Daphne in Athens), or conchs (at Nea Moni on the island of Chios). To the east of this central bay develops a three-partite altar, separated by the eastern pair of sub-dome pillars; in the same way to the west of the dome there are three bays, or naves conditionally speaking, which clearly implies that despite the dome that extends across the entire width of the nave, these churches are essentially based on a threenave basilica type. At the main church of this group, Hosios Loukas, which is considered to have inspired the rest, a system of chambers (so-called "pseudo-lateral naves") develop to the north and south, emphasizing the width of the central field in the form of a transept and enhancing the basilica impression. According to Vojislav Korać and Marica Shuput: "the two types of buildings with a dome on eight supports (or squinches) are the product of those conceptions in the architecture of the XI century, undoubtedly capital, according to which the temple should become a space whose central and largest part forms a whole under a single dome (...) It is understandable that such a space tends to get as large dimensions as possible, i.e. a dome with the largest possible diameter. In an ideological sense, it would be a return to early Byzantine patterns" (Кораћ и Шупут, 1998: 154). ${ }^{494}$ Furthermore, a nave completely covered with a monumental dome, carried on four corner pilasters in the form of a completely compact inscribed cross, can be found at the Christ Chora (Kahrie Mosque) in Constantinople, from the beginning of the XII century, with extensions from the XIV century, which is presumed to have originally had a perimeter nave as did St. Sophia in Thessaloniki (Бошковић, 1967: 101).

How did all these older churches built almost eight centuries earlier, some in regions relatively far from Macedonia, come to influence the appearance of the Revival domed single-nave churches? It seems logical that the Revival master-builders who cruised all over the Balkans and beyond with their construction groups got in touch with one of these specific buildings and conveyed the idea of a large dome on four or eight supports, transforming it into the Revival type. ${ }^{495}$ This theory seems all the more plausible given that most of the examples of this specific typology are concentrated primarily in the Reka region which, as has been said, is where most of the master-builder groups in fact originated from ${ }^{496}$ and where construction had been nurtured for centuries as a family profession. In that direction also points the fact that the oldest monument of this type is the church of the monastery St. John the Baptist Bigorski monastery built at the very beginning of the century, around 1800, on the remains of two older, single-nave post-Byzantine churches (Поповска-Коробар, 2015: 382). The Bigorski monastery and its catholicon church were and remain the spiritual center of the Reka region. ${ }^{497}$

\footnotetext{
${ }^{494}$ Regarding the appearance of a domes supported on squinches in the capital and then in the provinces of Byzantium, as an architectural element alien to Byzantine architecture, the same authors agree with the previously expressed views on Armenian influences, intensified by the reign of an emperor of Armenian descent in the period, and even the historically confirmed presence of Armenian architects in Constantinople (Ibid).

495 In that context, a very important and indicative data was published by T. Smiljanić-Bradina, according to which Gjurchin Kokalevski (1775-1863), the founder of the church of St. George in Lazaropole, one of the most powerful and influential people in the Reka region who was even addressed with the title "prince" (Поповска-Коробар, 2013: 234), in 1807 together with the hired master-stonemason Stojan from Lukovo "went to Mount Athos to see Abbot Anatolij, his countryman, from whom he received the plan of the church" (Смиљанић-Брадина, 1940: 142, quoted by Поповска-Коробар, 2013: 232). However, it should not be overlooked that the catholicon of the Bigorski Monastery was "renovated" earlier, at the very end of the previous century (see footnote 497), which means that this specific architectural typology had already been "brought" or restored in the Reka region well before Gjurchin Kokalevski's expedition to Mount Athos.

${ }^{496}$ As an illustration, it is known that master Stojan, builder of the church of St. George in Lazaropole, came from the village of Lukovo, region of Debarski Drimkol, as did master Ivan, who together with his master-builder group built the church of the Immaculate Mother of God - Krninski monastery near Kichevo in 1848.

497 The reconstruction of the Bigorski monastery that will turn it into the most important sanctuary and spiritual center of the whole Debar-Reka region began in the XVIII century, under its first abbot hieromonk Hilarion (1743-1781 / 1782), native of the village Tatar Elevci near Debar, who founded the convent of the monastery in the village of Rajchica and created conditions for economic and artistic revival of the monastery. Under the leadership of the monastery abbot, monk Mitrophan (1796-1807), born in the nearby village of Lazaropole, a new monumental monastery church was built around 1800, incorporating parts of the older one(s), as evidenced by a preserved fresco from the second half of the XVIII century on the south wall of the temple, and in the same year he ordered the dome (supported on squinches!) to be painted, probably by a group of painters from the Korcha region.
} 

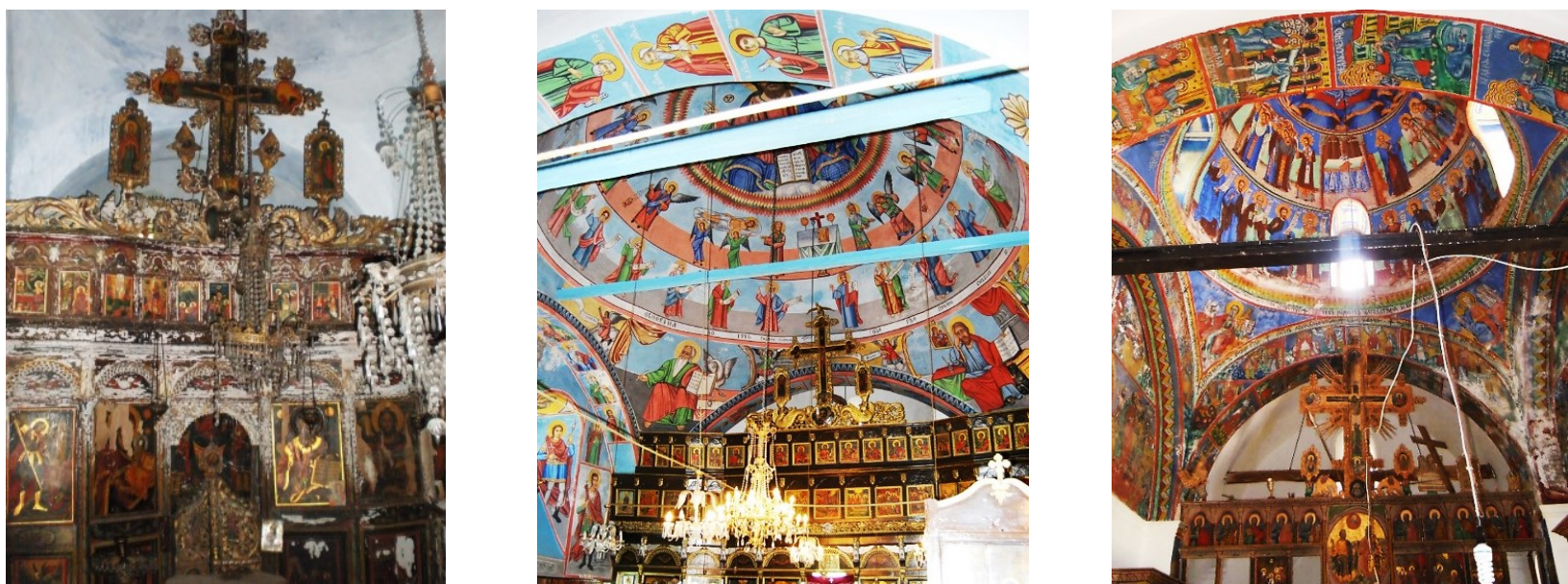

Figure III.245 St. Demetrius in Volkovija (Debar); B. St. Demetrius in Gostivar; C. St. Archangel Michael in Lisolaj (Bitola).

Finally, the centuries-old dominance of Islamic monumental architecture must not be overlooked, which itself took over the domed systems from the oldest Byzantine Constantinople monuments in order to cover as large a span as possible without any free-standing supports (which distort visibility and segment the space). Thus, the Ottoman mosques in Macedonia are predominantly cubic buildings covered by a large dome set on a usually low drum, and the transition from a square to a circular base is achieved through angular squinches, pendants - stalactites or cantilever elements. This solution helps overcome significant spans, often over $10 \mathrm{~m}$ even at the smaller mosques, ${ }^{498}$ while the largest domes of the Byzantine monuments in Macedonia covered a span of 6 to a maximum of $7 \mathrm{~m}$, reduced in the lateByzantine period to about $3 \mathrm{~m}$ (Ненадовић, 1980: 293-295). Adopting this specific architectural typology made it possible to place domes with imposing spans within the Revival domed single-nave basilicas: at the church of the Immaculate Mother of God - Krninski Monastery near Kichevo (see fig. III.243B), for example, the dome reaches a height of $16 \mathrm{~m}$ and a span of $11 \mathrm{~m}$ (Тричковска, 2008: 226). Another direct influence from the Islamic sacred architecture are its open porches divided into bays covered with blind domes, which in the Revival domed single-nave basilicas was adopted for the cases which include an integrated narthex instead of a gallery, such as at St. George in the village of Rajchica near Debar (Тричковска, 1993: 120) and at the Immaculate Mother of God - Krninski Monastery near Kichevo.
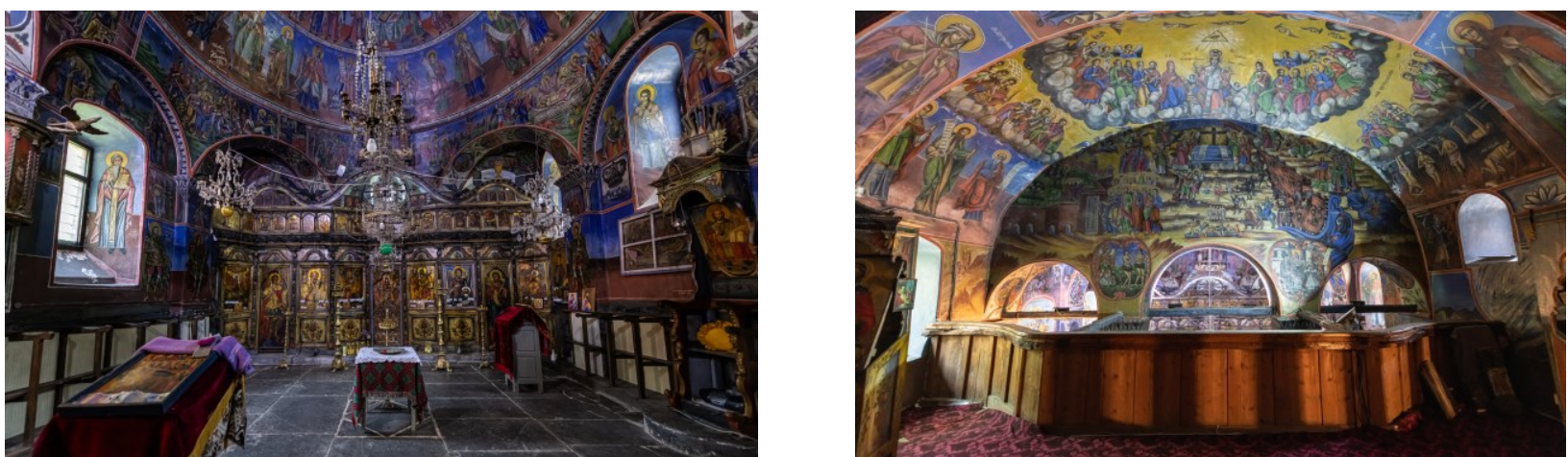

Figure III.246 Dormition of the Most Holy Mother of God in Gari (Debar): A. View of the naos towards the altar; B. View from the gallery towards the naos.

After his death, Arsenij (1807-1839), a native of the nearby village of Galichnik, was appointed abbot and continued the reconstruction of the monastery complex, building many auxiliary and economy buildings, as well as decorating the church and the dining room with icons and frescoes, for which purpose he invited the famous paintors Mihail Zograf and his son Danil (Николовски, 2018: 20-21). Later, the famous painter Dicho Zograf worked in the Bigorski Monastery, and the woodcarving group of Petre Garkata produced the wood-carved iconostasis masterpiece. In other words, in the construction and decoration of this monastery complex participated many of the most famous and well-established Revival artists.

498 As an illustration, the dome of the Mustafa Pasha Mosque in Skopje, dating from 1492, has a span of $16 \mathrm{~m}$ and rests on squinches in the corners of the square naos. The loads are accepted by the extremely massive, $2 \mathrm{~m}$ wide perimeter walls. 
Based on all these influences that arrived to Macedonia directly or indirectly, a specific type of domed single-nave basilica was created in the Revival. Of course, within the typological sub-group of domed basilicas, there are nuances in the shaping of the space, the transfer of loads, the appearance or absence of a gallery, etc. For example, in some churches of this group the dome is carried on pilasters on the side walls (at St. Achilles of Larissa in Trebishte, Dormition of the Most Holy Mother of God in Gari, St. Archangel Michael in Tashmarunishta, St. Archangel Michael in Lisolaj) which form arched niches similar to the churches of the category of single-nave vaulted basilicas with lateral pilasters connected with arches (see Chapter III.5.A.3). Furthermore, in some of these churches the western and eastern bay that flank the central dome field were treated as three-nave basilicas (in Lazaropole, Gari and the Bigorski monastery), divided into three naves by means of pillars on which the large dome is carried on the west and east sides (fig. III.246), very similar to the older Byzantine churches with domes on eight supports mentioned earlier. In addition, there are crucial differences in the treatment of the fifth façade: at the churches in Gostivar, Pechkovo, Gari, Volkovija and Tashmarunishta the large dome is blind, hidden under the gabled roof in a completely Revivalist way (see fig. III.245A-B). In the other churches it is a "real" dome that rises above the roof, regularly placed on an eight-sided drum, which varies from a very low drum that penetrates directly from the roof (at Bigorski Monastery, Lazaropole, Trebishte, Krninski Monastery, see fig. III.242-243), all the way to a high drum on a square pedestal (at Lisolaj, Melnichki Monastery, Tresonche, Rajchica, Prilepec, Selci, see fig. III.244).

All the churches from this group, of course largely because of their location in the very heart of the Debar-Reka master-builder school, are extremely monumental, of high quality and precisely designed, built and richly decorated. In many of them the signatures of the painter Dicho Zograf ${ }^{499}$ and his son Avram Dichov $^{500}$ have been preserved, as well as icons by Mihail Zograf and his son, monk Danil, ${ }^{501}$ iconostasis and church furnishings by Petre Garkata and other objects of the highest artistic value. In other words, this group includes some of the most important masterpieces of the Revival sacred architecture in Macedonia and its accompanying artistic manifestations - frescoes, icon painting and woodcarving.

"St. Nicholas" in Tresonche (Debar), 1873

The church of St. Nicholas was built in 1873 on a dominant hill (fig. III.247) in the center of the oldest Mijak village of Tresonche. It is a newer church in the village whose main temple is the older church of St. Peter and Paul, built in 1844 (see Chapter III.5.B.1). According to its typological solution, St. Nicholas is a domed single-nave basilica, one of the smallest and most compact within this particular stylistic group. It is a very elongated building with total external dimensions of $6.2 / 11.4 \mathrm{~m}$, not counting the altar apse.

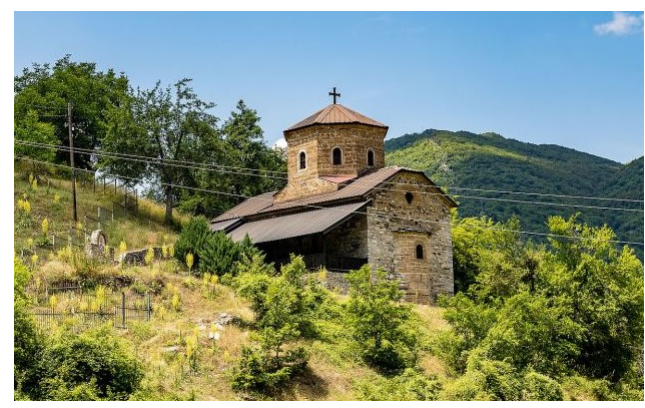

Figure III.247 St. Nicholas in Tresonche (Debar). View from the south-east.
The internal dimensions of the nave are 4.5 / $9.8 \mathrm{~m}$, which means that a proportional ratio that exceeds 1:2 was used for the design of the church (see fig. III.249). The single-nave arrangement is emphasized externally since the façade canvases are continuous, without fragmentation using pilasters or cornices (fig. III.248). It is even more legible inside the church, because there is no sub-dome supporting structure comprised of pillars and/or pilasters. The dome rather rests to the north and south on arches embedded

\footnotetext{
${ }^{499}$ At St. John the Baptist - Bigorski monastery; St. George in Rajchica (Debar); St. Achilles of Larissa in Trebishte; St. George in Lazaropole; the Immaculate Mother of God - Krninski monastery; St. Archangel Michael in Tashmarunishta.

${ }^{500}$ At the Immaculate Mother of God - Krninski monastery in 1880 (Василиев, 1965: 33), St. Elijah - Melnichki Monastery in 1881 and St. Nicholas in his native village of Tresonche.

501 In the Bigorski monastery, the church in Lazaropole and Rajchica, where they painted the dome.
} 
within the perimeter walls, and in the opposite direction, on the east and west side, on transverse semicircular arches. These arches, which are accepted by small consoles on the side walls, actually divide the single-nave space into three zones. ${ }^{502}$ Centrally, the transverse arches define the approximately square sub-dome bay, which is accessed directly from the south side of the church through the main entrance portal, originally protected by an open porch, the existence of which is evidenced by preserved stone consoles in the masonry of the façade (fig. III.248B). Namely, because from the west side the ground level of the church is completely dug into the sloping terrain, up to a height of almost $3 \mathrm{~m}$, the main entrance to the temple is exactly the southern entrance portal. To the east and the west, rectangular bays bridged with low barrel vaults flank the domed bay. The western bay was intended to house a gallery ("women's church") which, in addition to an internal access from the naos via wooden stairs placed along the northern perimeter wall, can also be accessed through a direct entrance, also from the south, skillfully using the local topography with a pronounced slope (fig. III.248B-251). The eastern bay houses the altar space, separated from the naos with a high altar partition. The dome is not ideally placed in the center of the prismatic volume of the building, but is rather displaced to the east, since the western gallery bay is twice as long as the altar bay (fig. III.247, III.248A). The overall spatial arrangement of the church, therefore, is dominated by a large dome with a span of $4.6 \mathrm{~m}$, equal to the entire width of the naos. The base of the dome (which corresponds to the apex of the arches upon which it rests) is placed at an elevation of $+5.8 \mathrm{~m}$ and its maximum height is $9.8 \mathrm{~m}$. It is placed on a tall octagonal drum that exceeds the ridge of the roof by $3 \mathrm{~m}$ (Филиповски и Бошковски, 1995: 23), which draws direct parallels with the octagonal drum of St. John - Bigorski Monastery (see fig. III.242). ${ }^{503}$
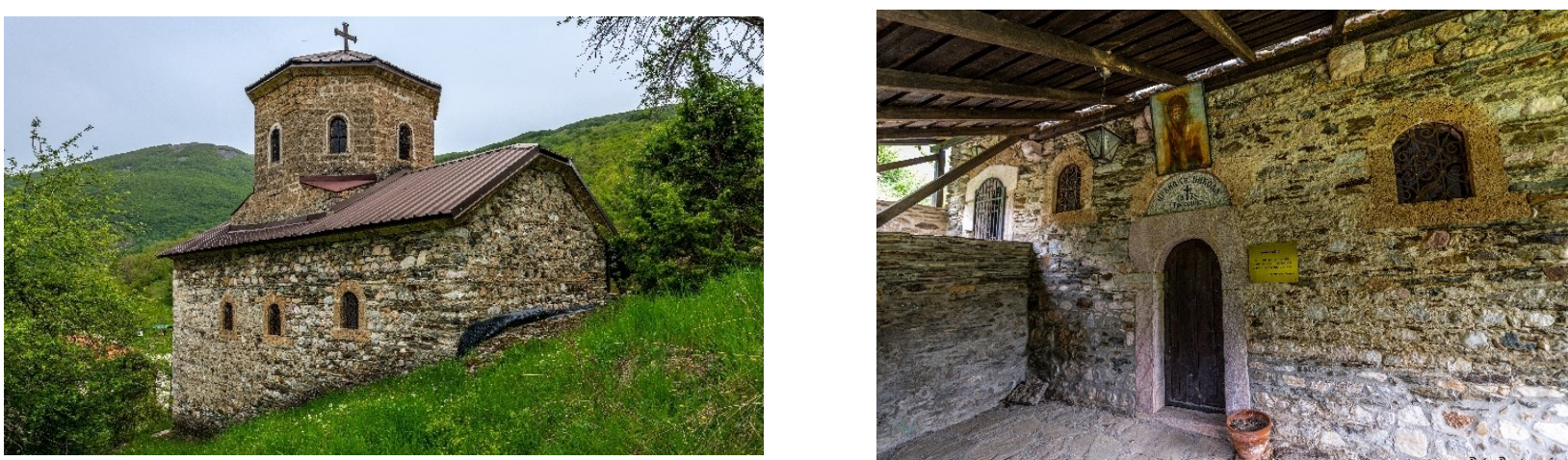

Figure III.248 St. Nicholas in Tresonche (Debar): A. View from the north-west; B. Detail of the southern facade.

Regarding the applied architectural elements, St. Nicholas in Tresonche follows the established Revival patterns. The altar apse is three-sided and quite small, with a maximum of $60 \mathrm{~cm}$ in depth (fig.

\footnotetext{
502 The sub-dome structure of St. Nicholas in Tresonche, therefore, in many ways is a direct parallel to the late-Byzantine church of St. Nicholas in the village of Chelopek near Tetovo, mentioned earlier, where the dome also rests on a substructure of arches and consoles, without internal pilasters on the south and north walls, flanked to the east and west with shorter bays bridged with barrel vaults. The facades of this late-Byzantine church, however, reflect the internal structure, i.e. the cruciform shape is emphasized, complemented by abundant late-Byzantine façade brickwork decoration. The church in Chelopek was renovated in the first half of the XIX century, according to the dating of the throne icons as early as 1830 , when the original dome supported on an elevated drum, previously demolished, was replaced by a blind "false" Revival dome hidden beneath the bonnet roof of the restored temple; the entire narthex was incorporated into the elongated naos, under the same roof; and a very deep gallery on a wooden sub-structure was introduced. The iconostasis, the church furniture, etc. were also replaced. The comparison of these two churches, as well as the fact that the older church in Chelopek was renovated at the beginning of the Revival, during which the master-builders had the opportunity to get acquainted with its original construction, confirms the thesis that the Revival domed basilicas emerged as a separate typology, following older locally and regionally represented patterns.

${ }^{503}$ A particularly similar dome on an octagonal, slightly lower drum, can be found at the church of St. Elijah in the nearby village of Selce, within the same region of Reka, i.e. a church built under the same influences and, perhaps, by the same master-builder group. In spite of its many characteristics, especially in terms of its upper parts and the fifth façade, which place the church in Selce within the domed basilicas category, its single-nave volume is complemented by lateral conchs (apses), which brings it closer to the trefoil solutions. Thus, in this typological classification it is placed in the category of combined typological solutions.
} 
III.247) and illuminated through a single window. On the inside, two semicircular niches in the east wall, intended for prothesis and diaconicon flank the altar apse; additionally, there is another very shallow semicircular niche in the north wall of the altar (fig. III.249A). The entire church was built using crushed and hewn stone and lime mortar, with better quality masonry at the corners of the building, as well as the windows and doors' lintels. The thickness of the perimeter walls is $\sim 80 \mathrm{~cm}$, with the exception of the apse wall and the drum, which are less massive for structural reasons. The apse and the drum are made of hewn limestone arranged in straight, horizontal rows, with thin mortar joints (fig. III.248A). The profiled crown cornices were executed in the same stone as the four-leaf clover window transenna carved out of a large block of stone, placed high on the east façade, above the apse (fig. III.251). The west façade lacks a window with a stone transenna, despite it being a common Revival motif (fig. III.250). It is interesting to note that the other (older) church in the village, St. Peter and Paul, also lacks windows on the west façade (see Chapter III.5.B.1), even though the topography of the terrain does not present an obstacle in its case. This implies that a blind western façade was a local feature of importance.

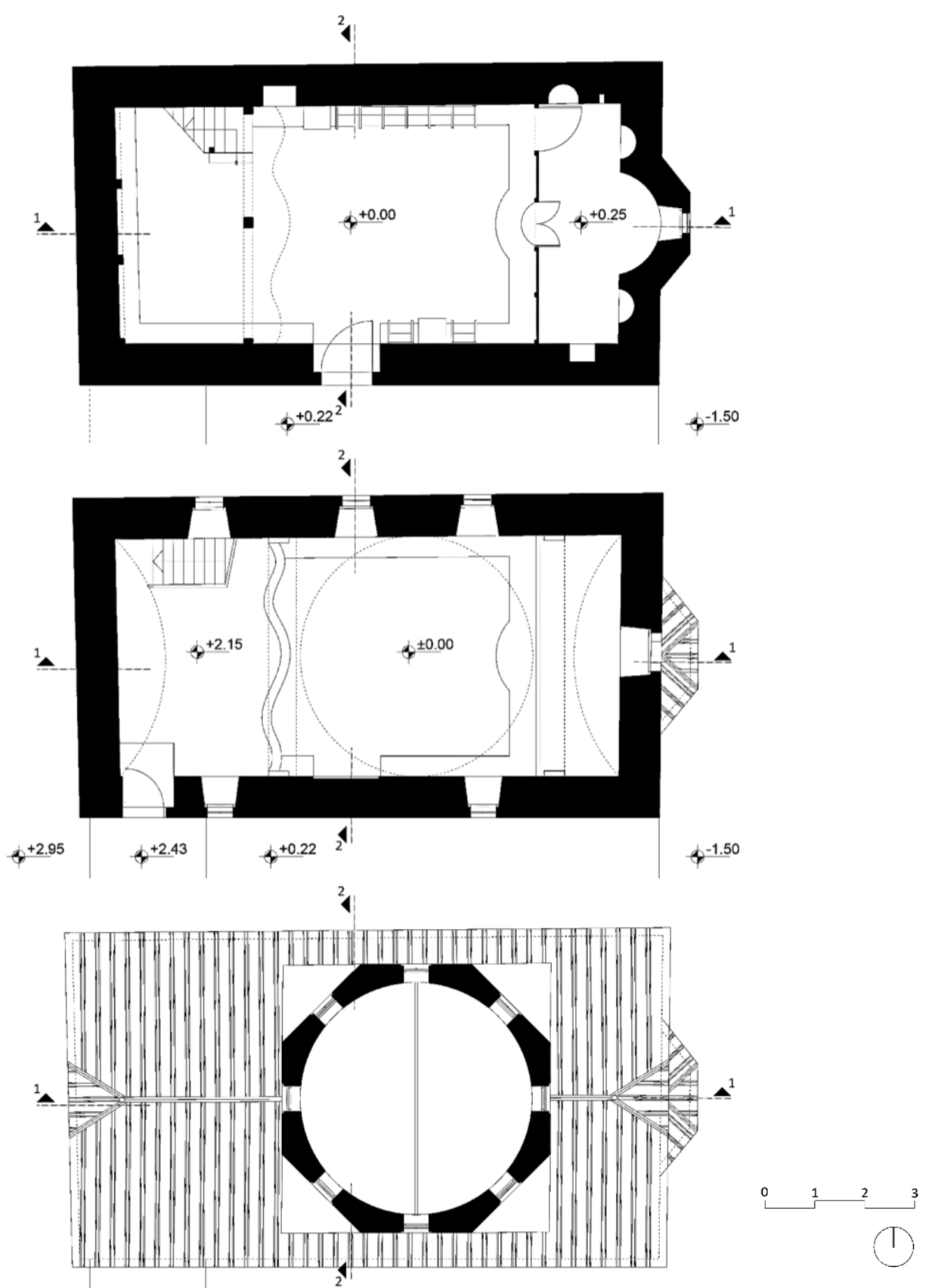

Figure III.249 St. Nicholas in Tresonche (Debar). Plans: A. Ground floor ( \pm 0.00$)$; B. Gallery (+2.15); C. Dome - fifth façade. 

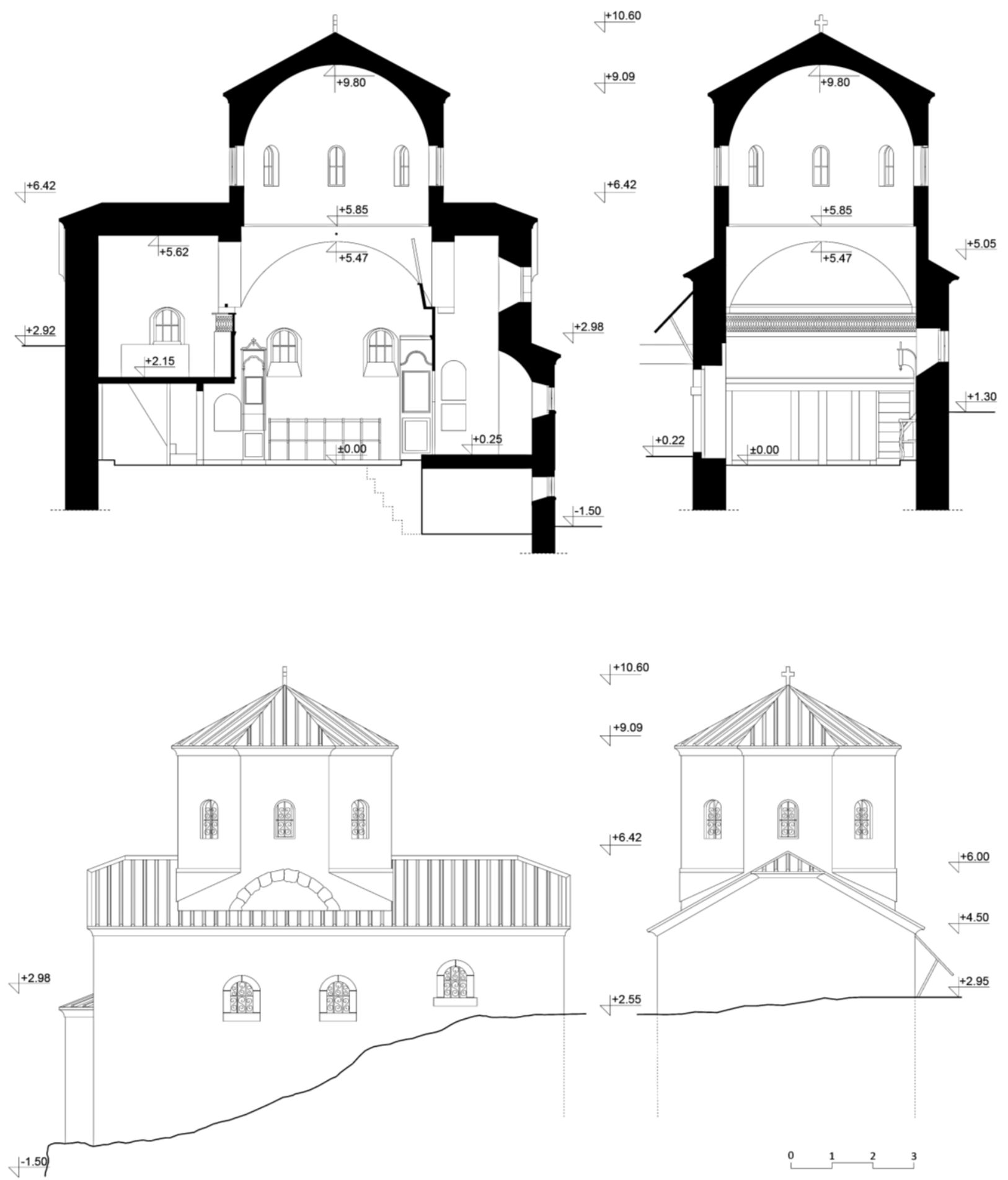

Figure III.250 (this page) St. Nicholas in Tresonche (Debar). A. Longitudinal section (1-1) and Transversal section (2-2); B. Northern and Western façade.

Figure III.251 (next page) St. Nicholas in Tresonche (Debar). Eastern and Southern façade. 

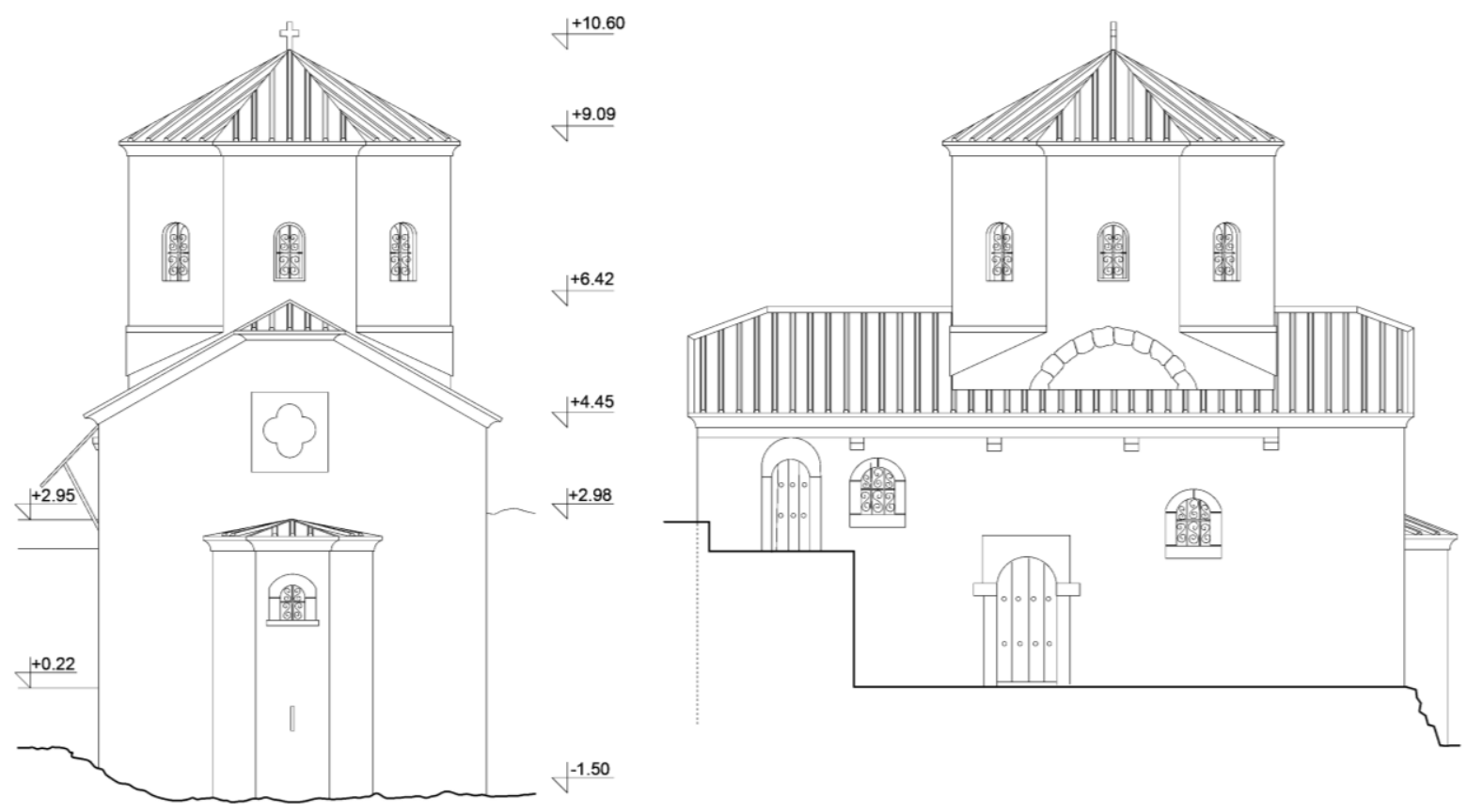

$v^{-1.5}$

With the exception of the sub-gallery space, which is completely dug into the sloping terrain, the building is well and abundantly lit (fig. III.252). The nave, in addition to the abundant zenithal light it receives from the windows placed on all eight sides of the drum (fig. III.248A), is illuminated through three windows on the north (the west of which corresponds to the gallery and is placed slightly higher) and two on the south façade of the church (fig. III.250-III.251). All these windows are arched, made of hewn blocks of stone. They were closed on the outside with decorative wrought iron bars, and on the inside they originally had wooden shutters, later replaced with glass. Initially, the church was covered with stone slabs, which have recently been replaced with sheet metal. Also, an open porch has been built on the south side, which replaces the original porch that certainly existed there in the first place.
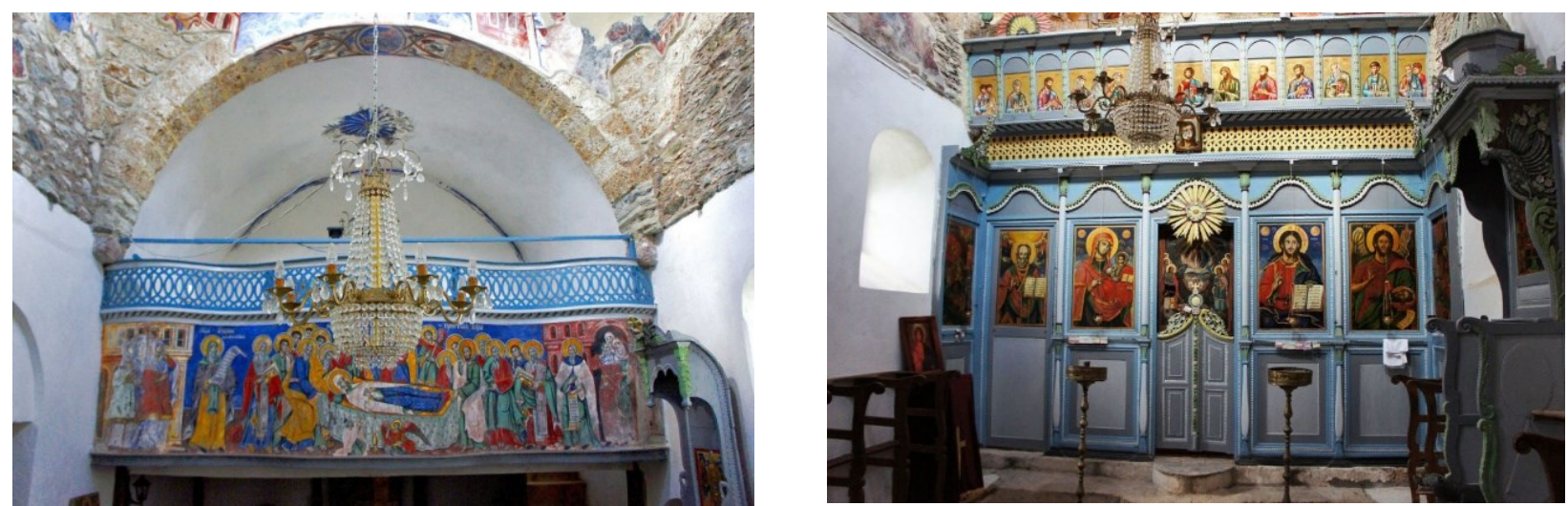

Figure III.252 St. Nicholas in Tresonche (Debar): A. View towards the gallery; B. View towards the iconostasis.

Inside, the dome bay and its cubic volume were emphasized and visually defined with the help of two delimiting backdrops placed just below the arches that support the dome: the altar partition to the east and the gallery fence to the west (fig. III.250A, III.252). Both are made of wood, with elegant proportions and use of decorative profiles and carved details. The iconostasis is flat, divided horizontally into two zones and vertically, conditioned by the width of the naos, into five segments, of which the central one is slightly wider and houses the royal doors (fig. III.252B). To enable the placement of multiple icons, two additional segments line the side walls to the west of the iconostasis. Instead of a cosmitis, a meander-shaped wooden lattice is placed between the two zones of the iconostasis. High above the 
second zone a complex symmetrical composition was installed, consisting of a central Crucifixion flanked by oval medallions framed with carved ornaments, and a plethora of symbolic representations: solar motifs, sculpturally processed roosters, ${ }^{504}$ pillars, kettles, etc.

To the west of the sub-dome bay extends the upper-floor gallery, carried on an independent wooden substructure (fig. III.252A). The fence has a specific baroque curved profile, shaped by fused concave and convex segments as was common in many Revival churches. Its lower zone is a completely fresco-painted solid parapet; above it appears a low wooden musharabia, very decoratively processed as an intertwining of circular medallions, unlike the usual simple model comprised of diagonally intertwined planks. Along the walls there are wooden seats placed on a low wooden platform; on the south side they incorporate a decoratively processed bishop's throne, and on the north one an icon "kissing pedestal". The use of color on the wooden elements is interesting, with dominant blue, gray and green tones. The iconostasis itself was painted ${ }^{505}$ by Avram Dichov, a native of Tresonche (Тричковска, 2008: 34), who is also the author of the frescoes and icons made for this church probably between $1870-1880 .{ }^{506}$ The frescoensemble of the church of St. Nicholas develops in the altar, the nave, the dome and the fence of the gallery (so-called emporia); the limited space imposed a shortening of the usual program. Today, unfortunately, while the architecture of the church is in a relatively good state of preservation, the fresco painting in the lower zone is severely damaged and in need of urgent conservation.

A very interesting and unique feature of the church of St. Nicholas in Tresonche is the existence of an underground crypt ossuary that extends under the altar bay (fig. III.250, III.253). The ossuary makes use of the particularly steep terrain: while the western part of the church is dug into the terrain, the eastern end rests on a leveled embankment, which created a sufficient height for the construction of an underground chamber. It is accessed from the inside of the temple, through an opening in the floor southeast of the main portal, i.e. adjacent to the bishop's throne, which hides the secret passage inserted into the wooden platform on which the seats for the congregation are placed. The crypt is illuminated through a very narrow slit-like window in the axis of the apse (fig. III.250-III.251). According to local oral tradition,, ${ }^{507}$ this ossuary houses the transferred remains from the neighborhood cemetery, ${ }^{508}$ including those of the famous village elder Sarzho Bradinoski (1778-1889), founder of the older village church of St. Peter and Paul, as well as those of important local revolutionaries

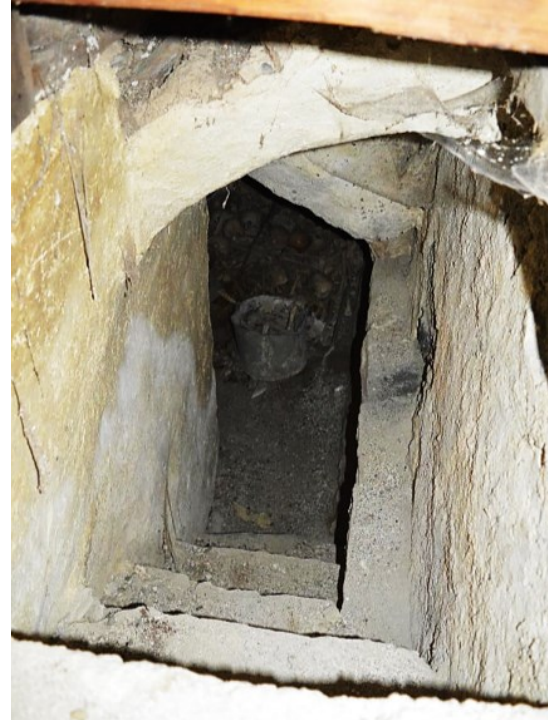

Figure III.253 St. Nicholas in Tresonche (Debar). Entrance to the ossuary / crypt below the altar platform. and participants in the liberation uprisings of the second half of the XIX - the beginning of the XX century.

\footnotetext{
504 Besides the dove regularly present in Eucharistic representations, the rooster is also one of the Christian symbols of birds good messengers (Ристовска-Пиличкова, 2012: 275). Sculptural representations of roosters are also present on the iconostasis of the church St. Nicholas in Orlanci, near Kichevo (see fig. III.207B).

505 The decorative painting of the iconostasis is a common Revival practice. For example, Avram Dichov's father Dicho Zograf, in his recognizable manner, painted the iconostasis of several churches in the Reka region: St. Peter and Paul in his native village Tresonche, St. George in Rajchica, St. Achilles of Larissa in Trebishte, St. Elijah in Selce, as well as in the wider region, for example the church St. Elijah in Stenche (Tetovo), where both father and son worked. In the spirit of the Levantine Baroque, "in an effort to "fill" these areas, vases with flowers, fountains with landscape surroundings, framed with spread curtains or painted geometric frames, friezes of vines and floral motifs were painted in parallel with the traditionally present Old Testament scenes" (Тричковска, 2008: 34).

506 So far, only the Crucifixion has been accurately dated in 1883.

507 Informant Avram Avramovski, born in Skopje in 1982, originally from the village of Tresonche, interviewed in December 2020.

508 In Tresonche there used to exist separate cemeteries for each of the 14 neighborhoods in the village.
} 


\section{III.5.E COMBINED TYPOLOGICAL SOLUTIONS}

The last defined typological category comprises the churches with combined typological solutions, in which the basilica typology is combined with other architectural concepts. It is the smallest group of monuments, present at only $2.1 \%$ of all Revival churches classified so far (map III-E). However, despite the limited number, the churches in this category are of great importance as representatives of a final stage in the evolutionary development of the Revival sacred architecture, i.e. the culmination of the eclectic compilation in reference to the sacred architecture of the past epochs.

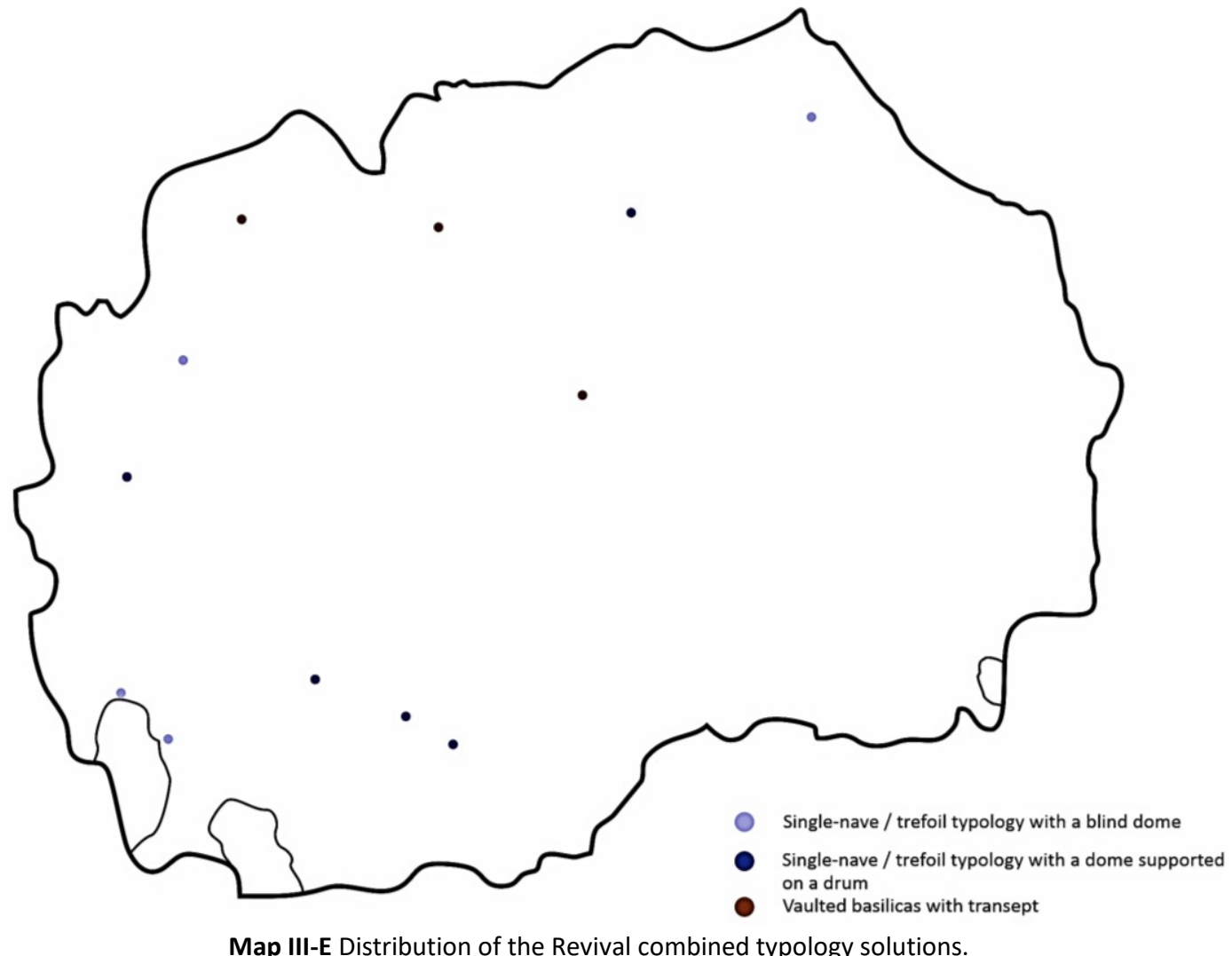

All churches of this group were built in the last third of the XIX century, after several decades of intensive construction of ecclesiastic architecture, meaning decades of development, upgrade and advancement of knowledge and skills of the master-builder groups. At the same time, they appear after the completion of the process of social reforms and liberalization of the sacred construction, which would enable the design of spatially more developed and constructively bolder solutions, such as the appearance of lateral conchs, "true" domes elevated upon protruding drums, transepts, clerestories on the fifth façade, etc. This process was announced, towards the middle of the century, in the opus of Andreja Damjanov, who in his mature creative years was increasingly moving away from the basilica inclining towards transitional types, such as the church of St. Joachim - Osogovski monastery (1847-1851), and even a clean inscribed cross - the monastery St. Archangel Michael in Gorno Chichevo near Veles (1861). The last one is especially significant: though being an inscribed cross with five domes, which is in itself a specific medieval pattern, yet "the church is not a medieval copy. The whole architecture is the fruit of a modern language of form. The modern transposition begins in the plan which is strongly elongated as opposed to the Byzantine solutions, which allows for the interior space to be experienced much more basilically than centrally, and which is in line with the architectural trends of the time" (ХаџиеваАлексиевска и Касапова, 2001: 150). This trend was continued by his son, Dame Andreev, in whose 
opus ${ }^{509}$ there is an evident free treatment of the Revival models, in a "logical development line of the architectural language and the treatment of decorative plastic, interior, composition and other elements of the buildings" (Грчев, 1998: 34).

Therefore, it is the combined typological solutions that would, in fact, announce the end of the Revival construction and its gradual transformation into modern architecture, both in terms of use of prefabricated materials as of the professional academic education of the architects and the various stylistic influences they incorporated in their work. Towards the end of the century, the evident greater typological diversity speaks vastly of the open doors for various influences in the church construction. Namely, "the transformation of the basilica domeless buildings, the gradual changes in the expression and stylistic specifics of the plastic ornament and decoration, as well as the development and transmission of construction experiences in several generations of builders, produces specific objects that are gaining importance as autochthonous authorial works that may represent a degree of mastery of the craft" (Грчев, 1998: 57). The distinct "combinations" of architectural typologies, which emerged at the dusk of the XIX century Revival, will be discussed in further detail on the following pages.

\section{III.5.E.1 Single-nave basilica / trefoil combined solutions}

The most common combined solution is a trefoil central solution incorporated into an elongated single-nave basilica, which can also be considered a single-nave basilica (or a compact inscribed cross) with lateral conch choirs. Of course, the typological solution used in this group of monumental Revival churches has significantly older roots. In the Demir Hisar region, for example, it can be traced to the catholicon of a local monastery, preserved to this day in ruins: St. Apostle Thomas, also known as Shuti Manastir (the "Abandoned monastery"), located between the villages of Graishte and Vardino, probably dating from the XV-XVI century (Дапчев, 1996: 222). Initially, the relatively large temple was designed as a combination of a vaulted single-nave church with lateral pilasters and arched niches (as discussed in detail earlier, this solution was very characteristic of the southwestern region of Macedonia in the postByzantine period - see Chapter I.5.1) and a trefoil (fig. III.254). Namely, in the central bay formed by the lateral pilasters, the niches in the side walls are substituted by semicircular conchs - choirs, five-sided on the outside and slightly shallower than the altar apse, which is shaped in the same way (Касапова, 2020). In addition to St. Apostle Thomas, two other monastery churches with combined solutions, or "single-nave churches with choirs" (Ibid), date from the postByzantine period (see map I-2), namely the Introduction of the Most Holy Mother of God - Karpino Monastery (dated in the XVI century) and the Most Holy Mother of God - Leshok monastery (originally from the XIV century, but rebuilt from the foundation up in the XVII century and then, like many other examples, expanded and renovated in the Revival). In addition to these post-Byzantine examples, of exceptional importance are the older monastic catholicons that would actually establish for the

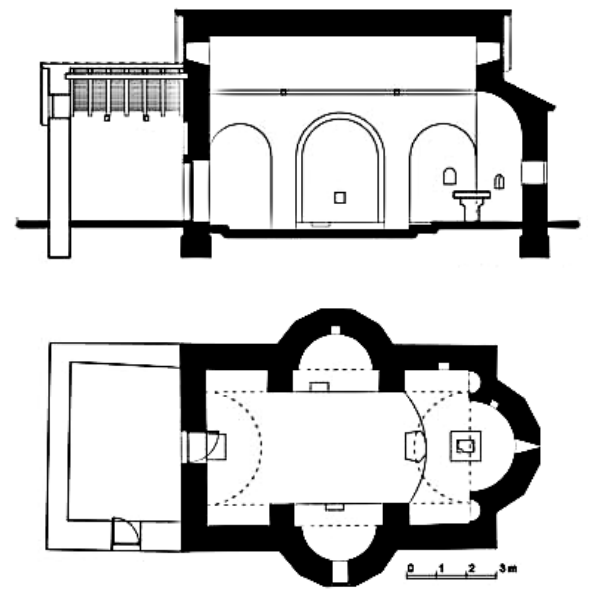

Figure III.254 St. Apostle Thomas - Shuti monastery, near Demir Hisar. Plan and longitudinal section.

\footnotetext{
509 Dame Andreev is the author of St. Demetrius in Skopje (1896), St. Cyril and Methodius in Tetovo (1903-1918), the Most Holy Mother of God in Veles (1905), St. Constantine and Helena in Skopje (1926, collapsed in the 1963 earthquake) and, perhaps, St. George in Skopje (1924-1927). With the exception of the churches of St. Demetrius in Skopje and the Most Holy Mother of God in Veles, all others were completed and consecrated after his death in 1921.
} 
first time the trefoil as a characteristic monastic ecclesiastical typology: as early as the IX century in Ohrid at the monasteries of St. Clement and Nahum (see fig. I.11, Chapter I.3); in the XI century in Strumica (the monastery of the Mother of God Eleusa in the village of Veljusa); in the XIV century in the region of Skopje (St. Andrea on the river Treska and the Holy Archangels in the village of Kuchevishte), as well as the monasteries on Mount Athos which are mainly a combination of a developed inscribed cross with a trefoil and the churches of the so-called "Moravian School" in Serbia from the XIV-XV century.

Based on all these older models, a typologically differentiated group of monuments would be established and developed in the Revival, that for the purpose of this dissertation have been named as

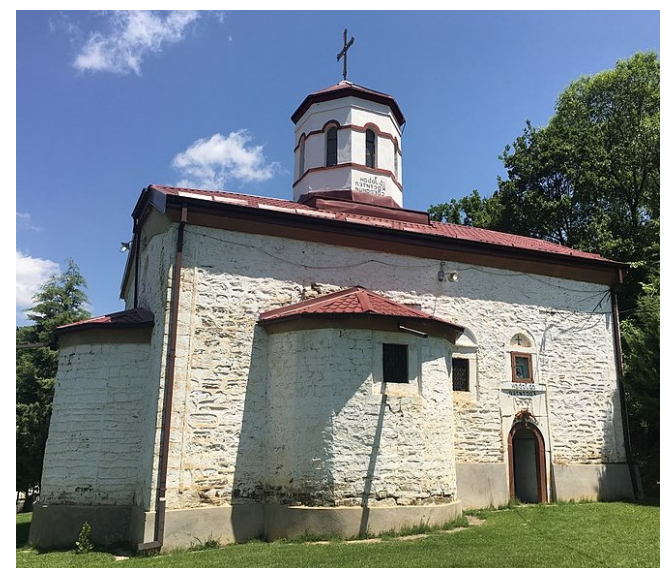

Figure III.255 St. John in Beranci (Bitola). View from the north-east.

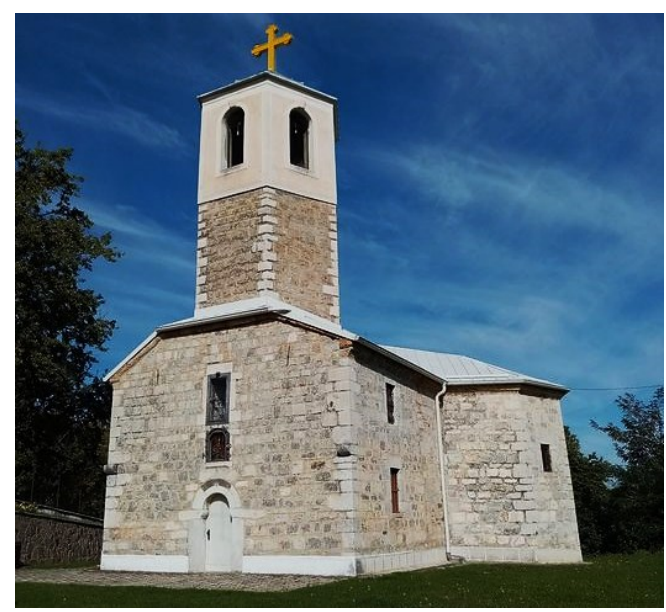
"single nave basilica / trefoil combined solutions". The nature of their architecture: a defined central space inserted into an elongated volume, in itself dictated the insertion of a dome, whose manifestation on the fifth façade or its lack allows for further division of this typological category into two subgroups: basilica / trefoil with a dome supported on an elevated drum or basilica / trefoil with a blind dome. Furthermore, at some churches of this group the lateral conchs are visible from the outside (fig. III.256A), while at others they are merged into rectangular lateral wings (fig. III.256B) so that from the outside these churches abandon the trefoil and achieve a cruciform appearance.

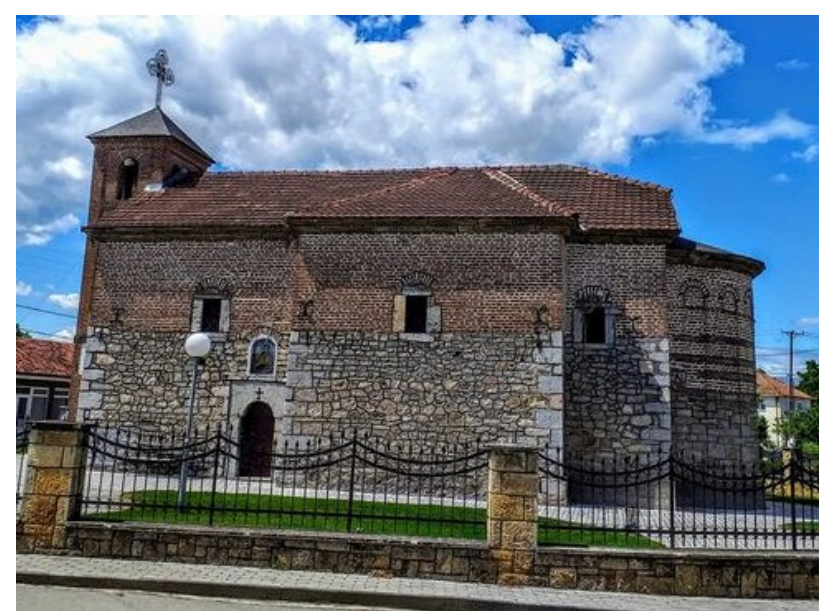

Figure III.256 Examples of single-nave basilica / trefoil combined solutions with blind domes: A. St. Archangel Michael in Vrutok (Gostivar); B. St. John the Baptist in Misleshevo (Struga).

The following table (table III-17) lists the Revival churches built with a single-nave basilica / trefoil combined typological solution:

\begin{tabular}{|c|c|c|c|c|c|}
\hline & CHURCH & VILLAGE & REGION (TOWN) & YEAR & $\begin{array}{c}\text { ADDITIONAL INFORMATION } \\
\text { fresco-painting / icons, renovations }\end{array}$ \\
\hline \multicolumn{6}{|c|}{ with a dome supported on an elevated drum } \\
\hline 1 & St. John the Forerunner & Slepche & Demir Hisar & 1862 & $\begin{array}{l}\text { frescoes from 1889, icons, wood-carved } \\
\text { baldachin and candlesticks from } 1895\end{array}$ \\
\hline 2 & St. Elijah & Selce & Debar (Reka) & 1864 & \\
\hline 3 & St. George & Gradishte & Kumanovo & 1864 & on the foundations of an older monastery \\
\hline 4 & Resurrection of Christ & Dalbegovci & Bitola & 1868 & renovated in the $X X$ century \\
\hline 5 & St. John & Beranci & Bitola & 1879 & renovated in 1979 \\
\hline \multicolumn{6}{|c|}{ with a blind dome } \\
\hline 6 & St. Nicholas, Dolna Vlashka Maala & / & Ohrid & 1863 & \\
\hline
\end{tabular}




\begin{tabular}{|l|l|l|l|c|l|}
\hline 7 & St. Archangel Michael & Vrutok & Gostivar & 1876 & \\
\hline 8 & St. Theodore Tyron & Konopnica & Kriva Palanka & $1881-1885$ & \\
\hline 9 & St. John the Baptist & Misleshevo & Struga & & $\begin{array}{l}\text { later renovated using brick in the upper parts } \\
\text { of the facades }\end{array}$ \\
\hline
\end{tabular}

Table III-17 Combined typological solutions. Single-nave basilica/trefoil with dome on an elevated drum.

In the XIX century Revival, this typology was applied at one of the most important and monumental temples, the church of St. John the Forerunner - Slepche Monastery ${ }^{510}$ near the village of Slepche, region of Demir Hisar (fig. III.257). It was built in 1862 by master Kosta from Cer and his master-builder group (Касапова, 2017), on the sight of an older, larger basilica, ${ }^{511}$ whose remains have yet to be fully discovered and explored. It consists of an elongated nave arranged in the form of a compact inscribed cross, divided into three bays by means of massive rectangular pilasters on the side walls, interconnected by semicircular arches. This system, let us recall, was regularly applied to the single-nave vaulted churches in the Demir Hisar region and beyond in western Macedonia (see Chapter III.5.A.3). In this way, low semicircular arched niches were formed laterally from the pilasters to the east and west; the lateral (eastern and western) equally long bays were covered with a barrel vault, and in the center of the nave a square bay was formed in which the whole span was overcome by a massive dome, very similar to the domed basilicas characteristic of the western parts of Macedonia (see Chapter III.5.D). The difference compared to the last type consists in the additional lateral conchs to the north and south of the central bay which attribute a trefoil concept to the otherwise elongated nave. On these conchs, slightly shallower than a half-circle, as well as on the transverse arches between the pilasters, rests the central dome on an octagonal drum, placed on a low cubic pedestal that penetrates the typical Revival gabled roof of the building. The transition from the square base to the drum cylinder is specifically solved: with a combination of angular pendentives and squinches (Грозданов, 2004: 245). The prototype for this solution should certainly be sought in the aforementioned postbyzantine church of St. Apostle Thomas - Shuti Monastery whose remains are located near Slepche. The two monastery churches have almost identical plans, and the essential difference is the appearance of a dome supported on a drum, which in the older church according to the restrictive Ottoman laws was replaced by a barrel vault. Both churches have a narthex, with the difference that in Slepche the narthex and the naos are fully integrated: they are not separated with a wall, but rather with very massive pilasters connected by a transverse arch. The narthex ${ }^{512}$ is transversally divided into three bays: deep lateral arched niches and a central domed bay, also carried on an octagonal equally high drum.

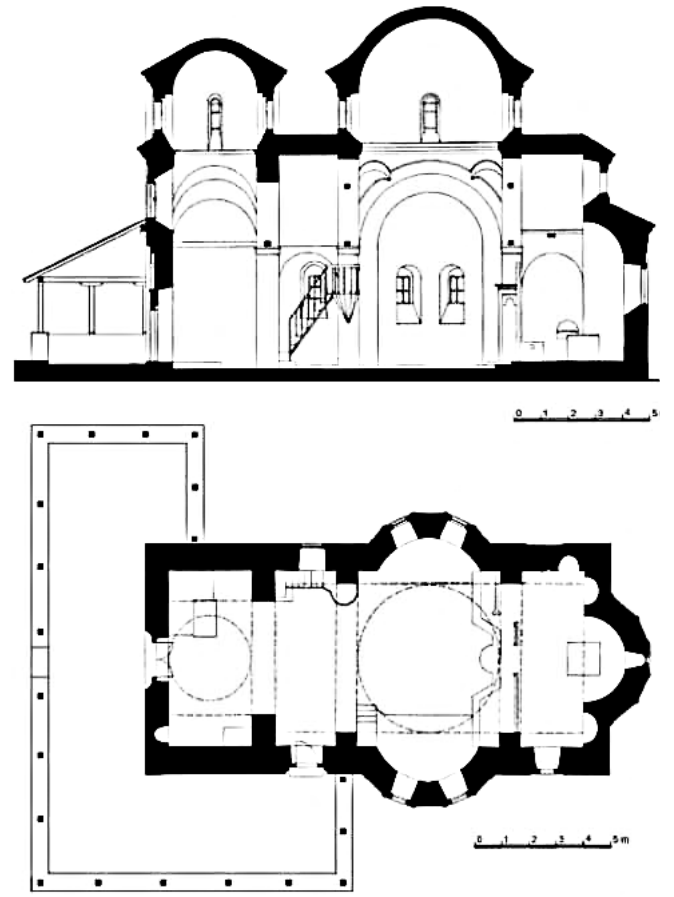

Figure III.257 St. John - Slepche monastery. Plan and longitudinal section.

\footnotetext{
${ }^{510}$ According to Asen Vasiliev, it was built by master Kitan Petrov from Tresonche (Василиев, 1965: 205), who is also the author of the wood-carved iconostasis. However, recent detailed research by Elizabeta Kasapova proved that the author is in fact master Kosta from the nearby village of Cer, whose name, along with his collaborators, is engraved on two stone slabs embedded on the west façade of the temple, flanking the western entrance portals (Касапова, 2017). Quite similarly conceived slabs with their names are installed on the south façade of the church of St. Nicholas in the village of Slepche, built only five years later, in 1867 (see fig. III.84C).

${ }^{511}$ According to the results of the partial archeological excavations undertaken in July 2019 within the III International Demir Hisar Summer School. Source: https://isk.edu.mk, accessed on 26.06.2020.

512 St. John is a catholicon of a large and important monastery. Its nature imposed the need for a vestibule - narthex, but not a gallery, since the monastic community had a strictly female population.
} 
The catholicon of the Slepche Monastery is the oldest and most influential Revival church with a combined typological solution and an example by which the remaining churches with this typology were formed (fig. III.255) not only during the Revival, but also deep into the next, XX century. ${ }^{513}$

\section{"St. Elijah" in Selce (Debar), 1864}

The church of St. Elijah in the village of Selce (region of Reka - Debar) was built on an older cult location, and consecrated in 1864. Since it is the main village church, a "women's church" was formed on the upper floor gallery which, in addition to the stairs in the north-west corner of the naos, has its own direct external access from the north, "skillfully using the terrain conditions" (Филиповски, 1996: 262). It essentially consists of an elongated single-nave naos (or a compact inscribed cross), divided into three symmetrically conceived bays by means of 2 wide pilasters with simple rectangular capitals, adjacent to the north and south walls and interconnected by transverse arches (fig. III.259-260). The central bay is larger and approximately square in shape $(5.8 / 5.5 \mathrm{~m})$ while the side bays are narrower and rectangular. A large spacious dome is placed over the central field, the span of which $(5.5 \mathrm{~m})$ corresponds to the width of the nave. The dome rests on the square base via angular pendentives; externally it is shaped into a relatively low, octagonal drum (fig. III.258).
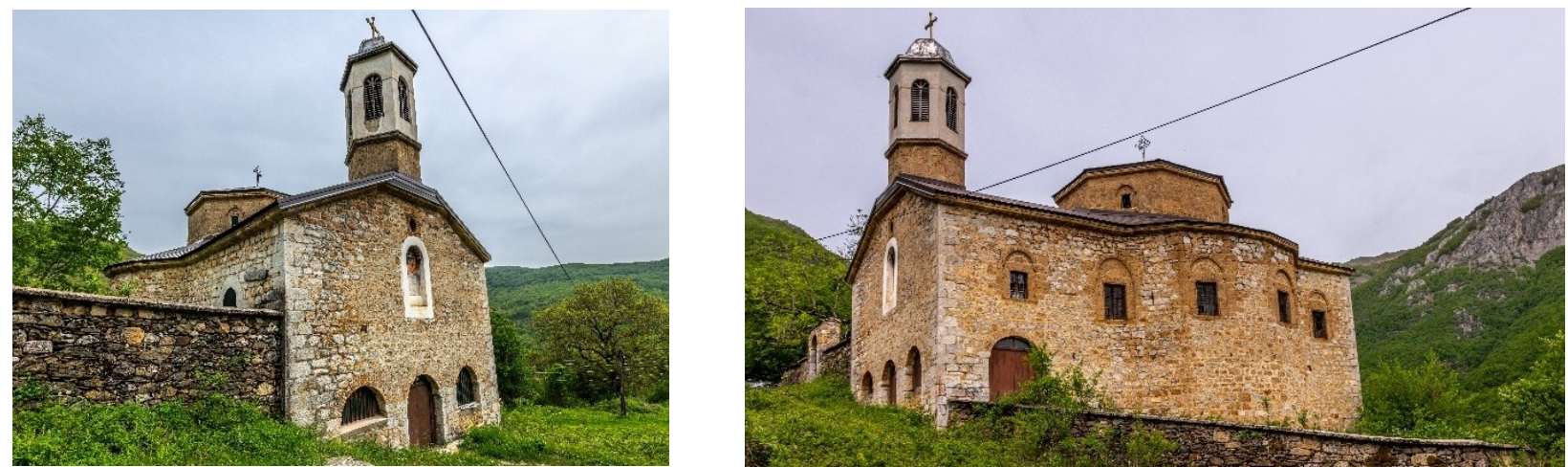

Figure III.258 St. Elijah in Selce (Debar): A. View from the north-west; B. View from the south.

So far, the typological solution is quite similar to the domed single-nave basilicas that are particularly characteristic of the Reka - Debar region (see Chapter III.5.D). However, at the church in Selce the central bay extends laterally with two externally pentagonal, semi-elliptical conchs, as high as the nave itself, combining the domed basilica typology with a trefoil solution (fig. III.258-261). The dome, thus, is carried on the arches between the pilasters in the transverse direction, and on the half-domes above the lateral conchs in the longitudinal direction, which is the only constructive difference in comparison to the domed single-nave basilicas.

Specific for this church is the existence of a vestibule - an open arcade porch (as discussed earlier, see Chapter III.5.C) with massive masonry pillars connected by three arches on the west and one on the south side (fig. III.258). The pillars are made of quality-hewn limestone, up to the height of the arches, which in turn are made of sandstone. This open porch (which was later partially closed) supports the gallery on the upper floor, cantilevered over the nave with a curved shape (fig. III.259B). The fence of the

\footnotetext{
513 As is the case with the other typological sub-groups of this systematization, the combined solutions can be traced in a longer period deep into the next, XX century. For example, in the village of Lavci near Bitola in 1939 the church of St. Nicholas was designed as an elongated three-nave pseudo-basilica with a central dome supported on a drum, supplemented by conch choirs to the north and south sides corresponding to the sub-dome span (Грчев, 1998: 124-129). On the west side of the naos, a baroque curved gallery is developed, which together with the completely Revival saddle-shaped facades and the stone-carved transennas in the form of a phytomorphic cross testify to the long duration and consistent application of the Revival shapes and patterns.
} 
gallery consists of a solid parapet topped with a latticework "S"-shaped musharabia (fig. III.262B). Above the gallery, in the axis of the west façade, stands a tall octagonal bell tower (fig. III.260, III.261). To the east, a five-sided altar apse significantly smaller than the lateral conchs is flanked by shallow semicircular prothesis and diaconicon niches, identical to those on the north and south walls, in a symmetrical composition (fig. III.259A).
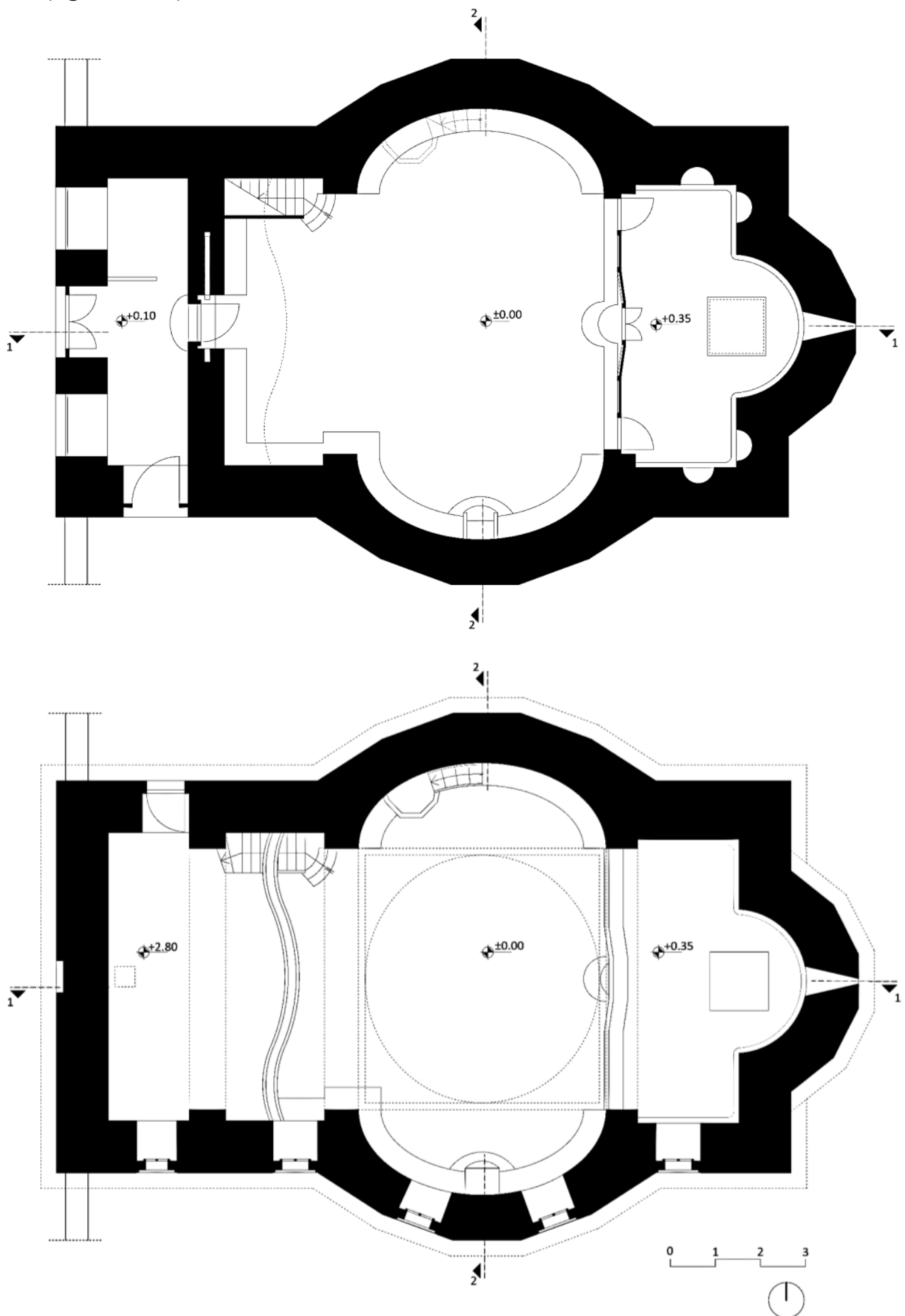

Figure III.259 St. Elijah in Selce (Debar). Plans: A. Ground floor ( \pm 0.00$) ;$ B. Gallery $(+2.80)$. 


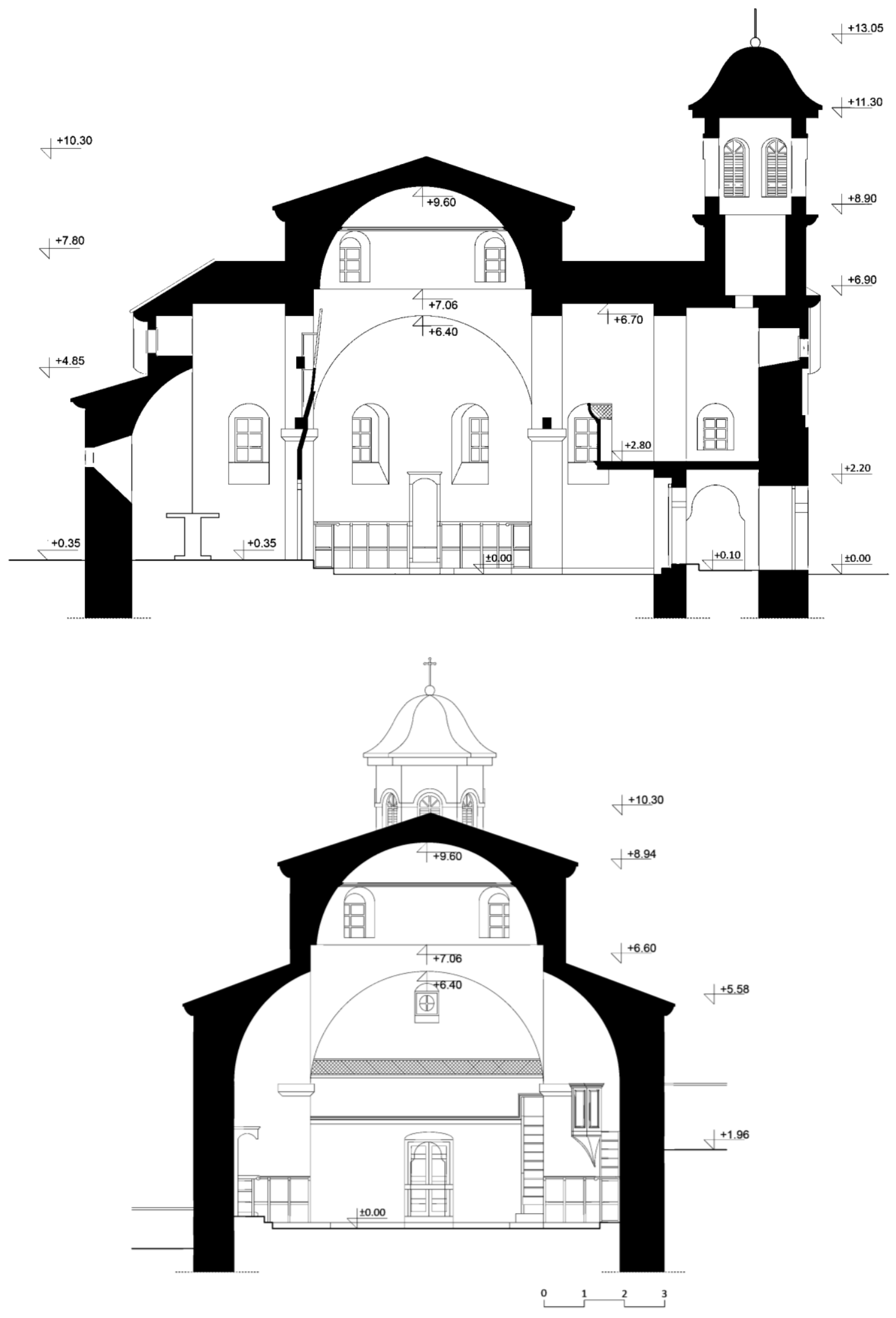

Figure III.260 (this page) St. Elijah in Selce (Debar). Longitudinal section (1-1); B. Transversal section (2-2).

Figure III.261 (opposite page) St. Elijah in Selce (Debar). A. North façade; B. East façade. 


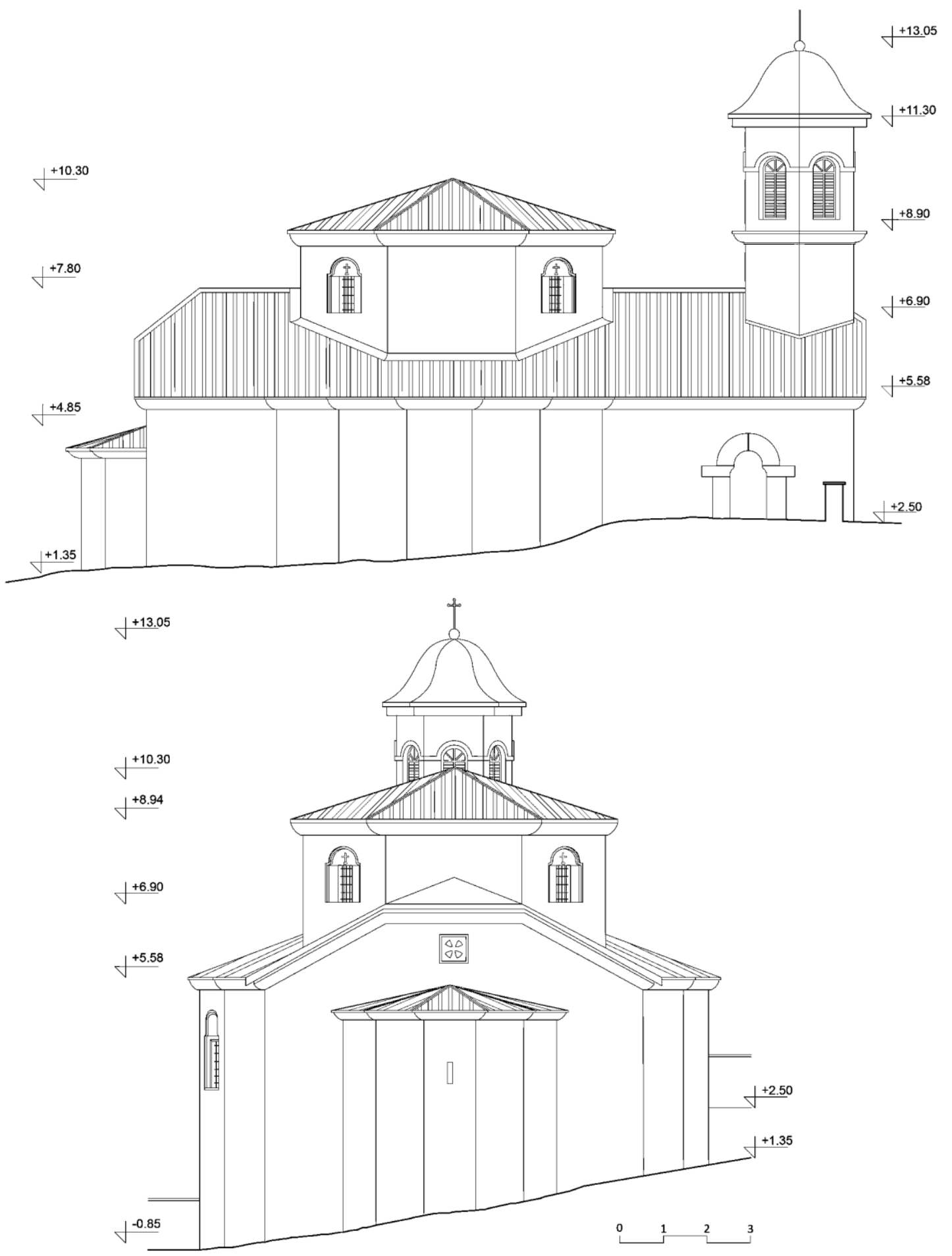

The church of St. Elijah is characterized by exceptionally high quality processing of the stone used to construct not only the perimeter walls, but also the dome, the pendentives and arches (fig. III.258, III.262). The façade canvases, made of hewn stone, are interspersed the corners with large limestone blocks, as were used for the porch pillars, the crown cornices, the octagonal pedestal of the bell tower, the entire drum of the dome and the decorative profiled arched window sills so that harmony is achieved in the façade texture and color. High above the western entrance portal there is a very high arched patron saint niche, in which the patron composition is partially preserved, depicting St. Elijah in the usual way, in his fiery heavenly chariot. The niche is topped with a decorative stone-carved transenna shaped into an oval oculus in an otherwise square window opening. In addition to this oculus, a stone transenna also appears on the opposite, eastern façade, above the apse. All the remaining illumination of the church's 
interior comes from the dome, which is lit by four windows and from the south façade, which is marked by a row of single windows in the lateral bays (in the altar and under the gallery) and two symmetrically positioned windows in the southern conch. The gallery is illuminated by a smaller window also on the south façade. In contrast, the northern façade, with the exception of the entrance portal leading directly to the second (gallery) level, is completely blind (fig. III.261A), conditioned by the harsh climatic conditions in this mountainous region. Originally, like all other Revival buildings in this area, the roof was covered with overlapping thin stone slabs, later replaced with corrugated metal cladding.
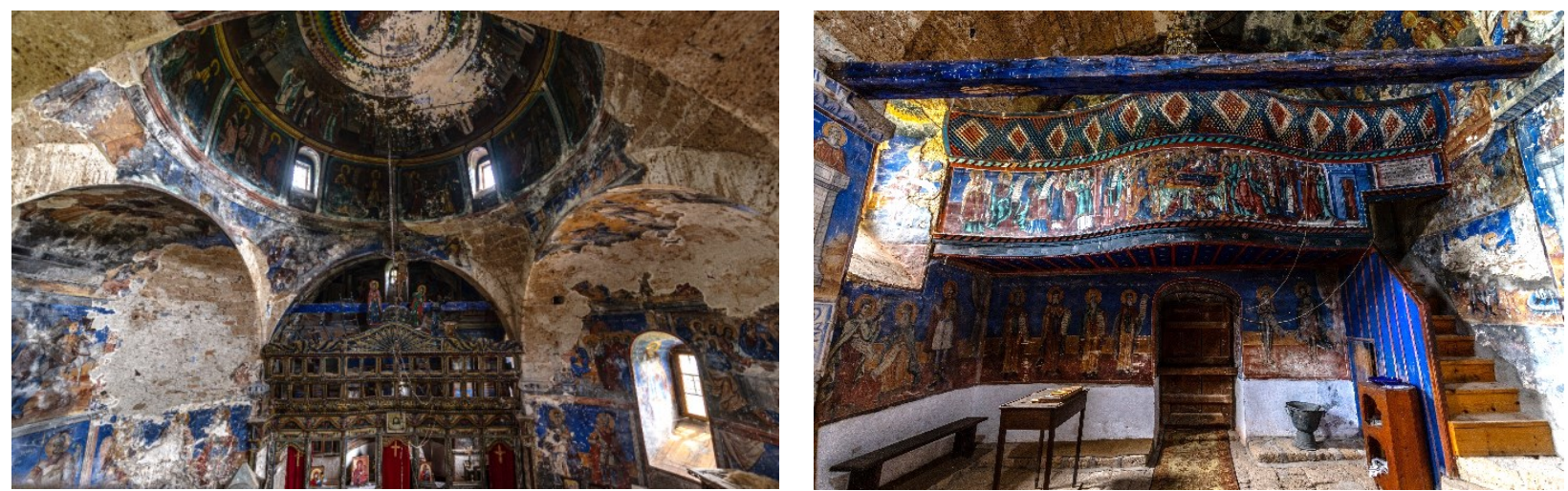

Figure III.262 St. Elijah in Selce (Debar): A. View from the gallery towards the altar; B. View from the naos towards the gallery.

The interior is dominated by the treatment of the floor covered by stone slabs, the magnificent iconostasis placed between the eastern pair of pilasters and the complete fresco painting of all surfaces in the nave (fig. III.262B). Namely, the group of the master-painter Dicho Zograf worked on the frescoes of this church in 1864, as confirmed by two inscriptions in the southern conch and the fresco-painted emporia of the gallery. Today, the fresco ensemble is partially preserved, as it suffered from severe atmospheric moisture prior to the repairs of the roof (fig. III.262). The iconostasis, whose icons were completed in 1866, is very monumental, with a symmetrical composition and outstanding decorative processing. It was divided into 7 equal fields (high doors to the altar are placed on the side, the royal doors adorn the center field), with two additional narrow fields on the north and south wall (fig. III.262A). All available surfaces were painted with rich floral ornaments, angels, wreaths, garlands. In the first zone, the large throne icons, by Dicho Zograf himself, were placed on a base made of panels on which, instead of floral motifs, scenes from the lives of Adam and Eve from the Old Testament were painted; the royal doors and the perde (curtain) above them were fully gilded. The two zones were divided by an arched cosmitis depicting circular medallions with saints' busts, wrapped in blooming grapevine shoots. It was topped by smaller holiday icons in two rows, above which, appears a baroque frieze of " $\mathrm{S}$ " volutes and a central radiant ornament, on which the Crucifix is placed.

Unfortunately, the village of Selce has long been completely abandoned because of intense migration in the XX century. The church of St. Elijah has therefore been an easy target for theft and vandalism on several occasions. Today, tragically, all icons of the iconostasis are missing (see fig. II.27, III.262A), including the royal doors, and an invaluable cultural heritage has been forever lost.

\section{III.5.E.2 Vaulted basilicas with a transept}

The churches of this typological sub-group are in fact a combination of a three-nave basilica and an inscribed cross. The solution is especially clearly legible on the fifth façade, where instead of the usual continuous gabled roof, a transverse transept appears, and at their intersection rises a low cubic pedestal covered with a bonnet roof, hiding a blind dome inside. The cruciform pattern is also emphasized inside 
the temple. It is important to note that this is not the first time that such a combined type was built in Macedonia: one of the most monumental post-Byzantine temples, St. George in Mlado Nagorichane was conceived in a similar way, the main difference being the external appearance of the cruciform solution, all the more explicit due to the central nave clerestory (see fig. I.50, I.51).

This small group of vaulted basilicas with a transept consists of the following churches (table III-18):

\begin{tabular}{|c|c|c|c|c|c|}
\hline & CHURCH & VILLAGE & REGION (TOWN) & YEAR & $\begin{array}{l}\text { ADDITIONAL INFORMATION } \\
\text { fresco-painting / icons, renovations }\end{array}$ \\
\hline 1 & St. Savior - Ascension of Christ & / & Veles & & \\
\hline 2 & St. Demetrius & / & Skopje & 1896 & \\
\hline \multicolumn{6}{|c|}{ Churches of this combined typology built at the beginning of the XX century: } \\
\hline 3 & St. Cyril and Methodius & / & Tetovo & $1903-18$ & built using a design project from 1885 \\
\hline
\end{tabular}

Table III-18 Combined typological solutions. Vaulted basilicas with a transept.

The vaulted three-nave basilicas with a transverse transept marked the opus of the master-builder Dame Andreev. Basically, these buildings are very similar to those built by his father Andreja Damjanov towards the middle of the XIX century. The similarities are especialy evident between St. Demetrius in Skopje (fig. III.263) and St. Cyril and Methodius in Tetovo (fig. III.264), which were obviously constructed according to the same design, with very small changes in the execution. Both churches are three-nave basilicas, with a "U"-shaped porch on the west side which supports a gallery on the upper floor, clearly indicating that their specific solution arose from the five-nave Revival churches built mostly by Andreja Damjanov himself. The key difference is the existence of a transept which manifests itself on the lateral facades only as a triangular tympanum, because there is no gradation of the core three-nave volume or, in other words, these churches are "pseudo-basilicas". As a reminder, the naos of the Ohrid Archbishopric's cathedral St. Sophia was solved in an identical way in the XI century. During the Revival, a hint of a transept is present in the church of St. Joachim - Osogovo monastery (see fig. III.214), as well as the churches in the villages of Bukovo and Magarevo near Bitola (see fig. III.215). At St. Demetrius in Skopje the transept rises above a continuous crown cornice that flows along the north and south façade, i.e. it is visually added above the lower volume where the basilical nature of the church is not disturbed. At St. Cyril and Methodius in Tetovo, on the other hand, the transept is subtly emphasized in all its height with the help of shallow pilasters comprised of blocks of river stone, also used at the corners of the building, with the help of which the elongated plastered facades were dissected, at the same time emphasizing the internal spatial concept of the temple (Грчев, 1998: 35). In this way the integration of the basic basilica typology with the concept of the inscribed cross reaches a mature manifestation. At the intersection of the transept and the central nave, bridged by barrel vaults, rises a cubic pedestal which hides the blind dome within. In contrast, the corner bays are covered with cruciform arches,

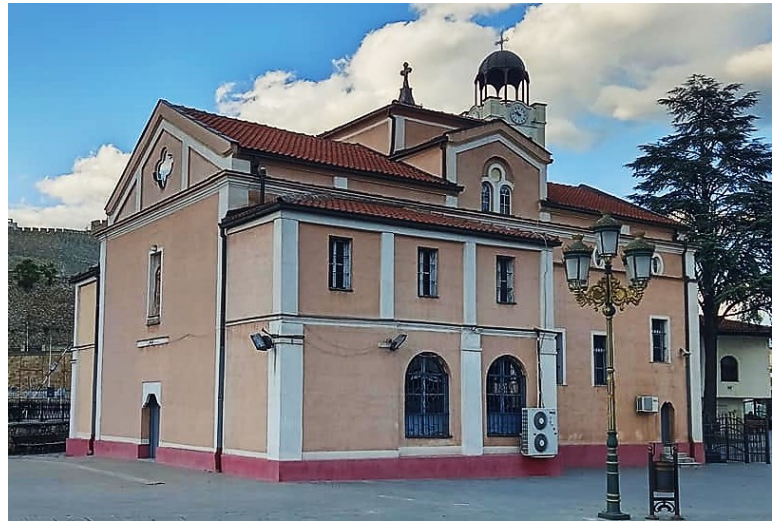

Figure III.263 St. Demetrius in Skopje. View from the southwest.

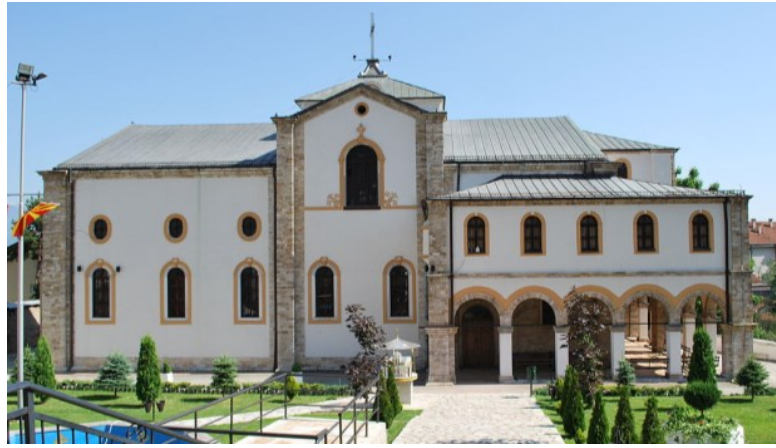

Figure III.264 St. Cyril and Methodius in Tetovo. View from the north. 
which further emphasizes the cruciform solution of the temple on the inside.

This model, with some modifications, persisted throughout the first half of the XX century, albeit in a somewhat reduced form. Such an example is the church of the Most Holy Mother of God in Trnovo (Bitola), built in 1926-1934 as a replacement for the original eponymous Revival basilica dating from 1837, demolished in 1916, during the First World War. The church in Trnovo was conceived as an elongated three-nave basilica with an outwardly exposed transept, a five-dome arrangement in the naos and a narthex with a bell tower on the west side (Грчев, 1998: 113-114). However, the lack of financial resources caused the construction to stop and the upper parts to be completed as a pseudo-basilica with a transept tympanum of the side facades, as the one present in some Revival churches (Bukovo, Magarevo, Osogovo Monastery). Furthermore, the churches of St. Constantine and Helena and St. George, both built in Skopje during the 1920s - 1930s, repeat the same solution consisting of a three-nave core with a two-story " $U$ "shaped system of open porches and a gallery enclosing the naos on the west side, a central dome supported on an elevated drum and a bell tower above the gallery. The lack of a defined transept in these very similarly conceived and shaped churches is alleviated by placing triangular tympanums on the north and south facades, which correspond to the domed bay.

\section{"St. Savior - Ascension of Christ" in Veles}

St. Savior is a cemetery church built in the town of Veles, on the left shore of the Vardar river, while the town itself, in the Revival, developed amphitheatrically on the opposite bank of the river. It was built on an older cult site, perhaps on older foundations, ${ }^{514}$ and the exact year of its construction is not known. However, judging by the influences exerted on it by the Veles cathedral church of St. Panteleimon, built in 1840 , this year can be considered as terminus post quem. The terminus ante quem can be pinned to 1884 , when the "L"-shaped open porch was built along the west and south facades, as confirmed by a preserved inscription. However, the porch and the courtyard were paved reusing existing tombstones, some dating, for example, to 1864 , which means that the church was already built and consecrated at that time. All of the above narrows its likely construction date towards the middle of the XIX century.

The church of St. Savior consists of a very elongated three-nave naos (whose ratio is almost 2:1) covered with a gabled roof without external central nave clerestory, in which the introduction of a transept created a cruciform solution (fig. III.265). It was built very monumentally: the naos measures 13.4/25.6 $\mathrm{m}$, not counting the low seven-sided altar apse (fig. III.266, III.267). The three-nave arrangement in the naos consists of two rows of 7 tall, slender columns of which the last pair to the east were left without decorative processing, since they are hidden behind the altar partition. The rest have composite, very decoratively processed capitals. They are interconnected via low, elliptical arches in the

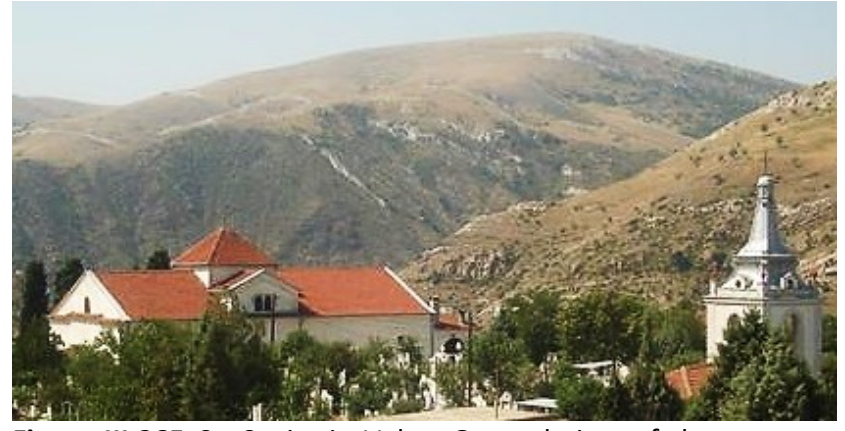

Figure III.265 St. Savior in Veles. General view of the cemetery complex from the south-west. longitudinal direction, while in the transverse direction arches appear only in the lateral naves, which form square fields covered with ribbed vaults in the naos and barrel vaults in the altar and gallery. The transverse arches in the lateral naves, supported by consoles on the perimeter walls, are solved in a characteristic way: as double arches, with decorative pendants in the center (fig. III.267). It must not be forgotten that identical double arches with

\footnotetext{
${ }^{514}$ Several icons dating to 1817 and 1819 testify to this older phase.
} 
pendants, also in the lateral naves, appear at St. Savior in Drachevo built in 1849 (see Chapter III.5.B.4) and at St. Panteleimon in Veles, from 1840 (see Chapter III.5.C). As St. Panteleimon is one of the most monumental and most representative Revival churches, it comes as no surprise that St. Savior in Veles copied certain architectural details and decorative patterns from the contemporary five-nave basilica built across the river.
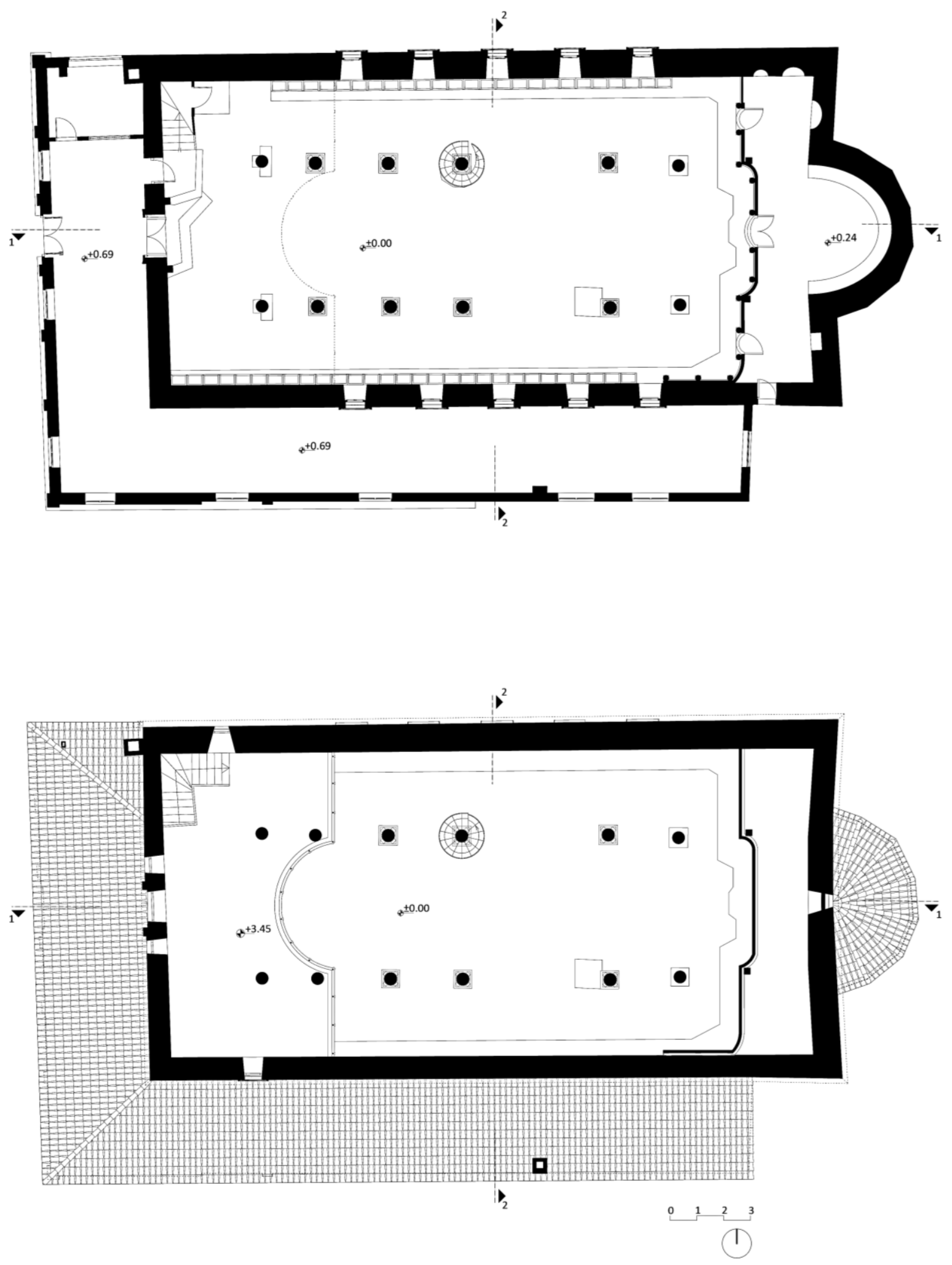

Figure III.266 St. Savior - Ascension of Christ in Veles. Plans: A. Ground floor ( \pm 0.00$)$; B. Gallery (+3.45). 


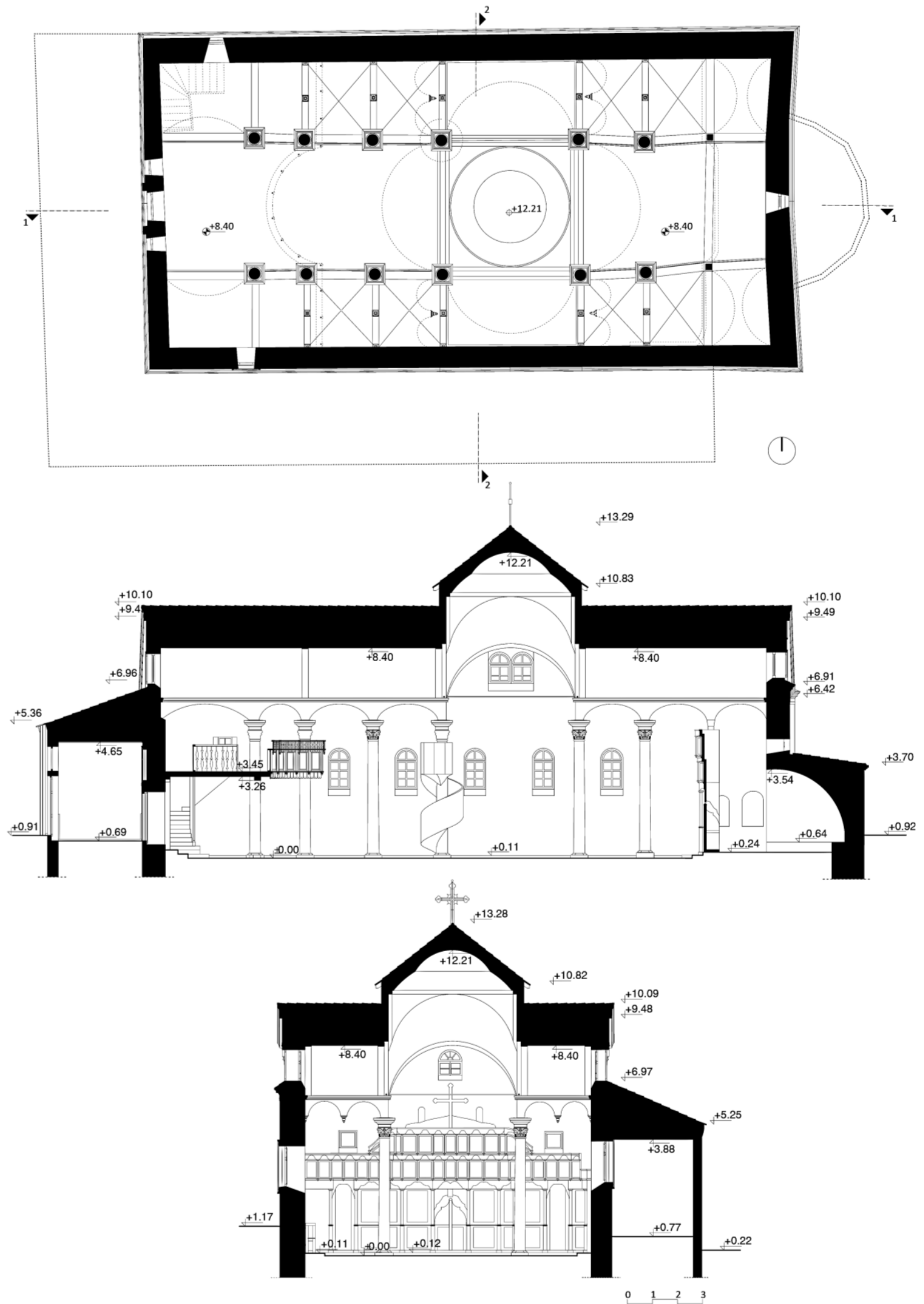

Figure III.267 St. Savior - Ascension of Christ in Veles. A. Plan of the ceiling (+8.40); B. Longitudinal section (1-1); C. Transversal section (2-2). 

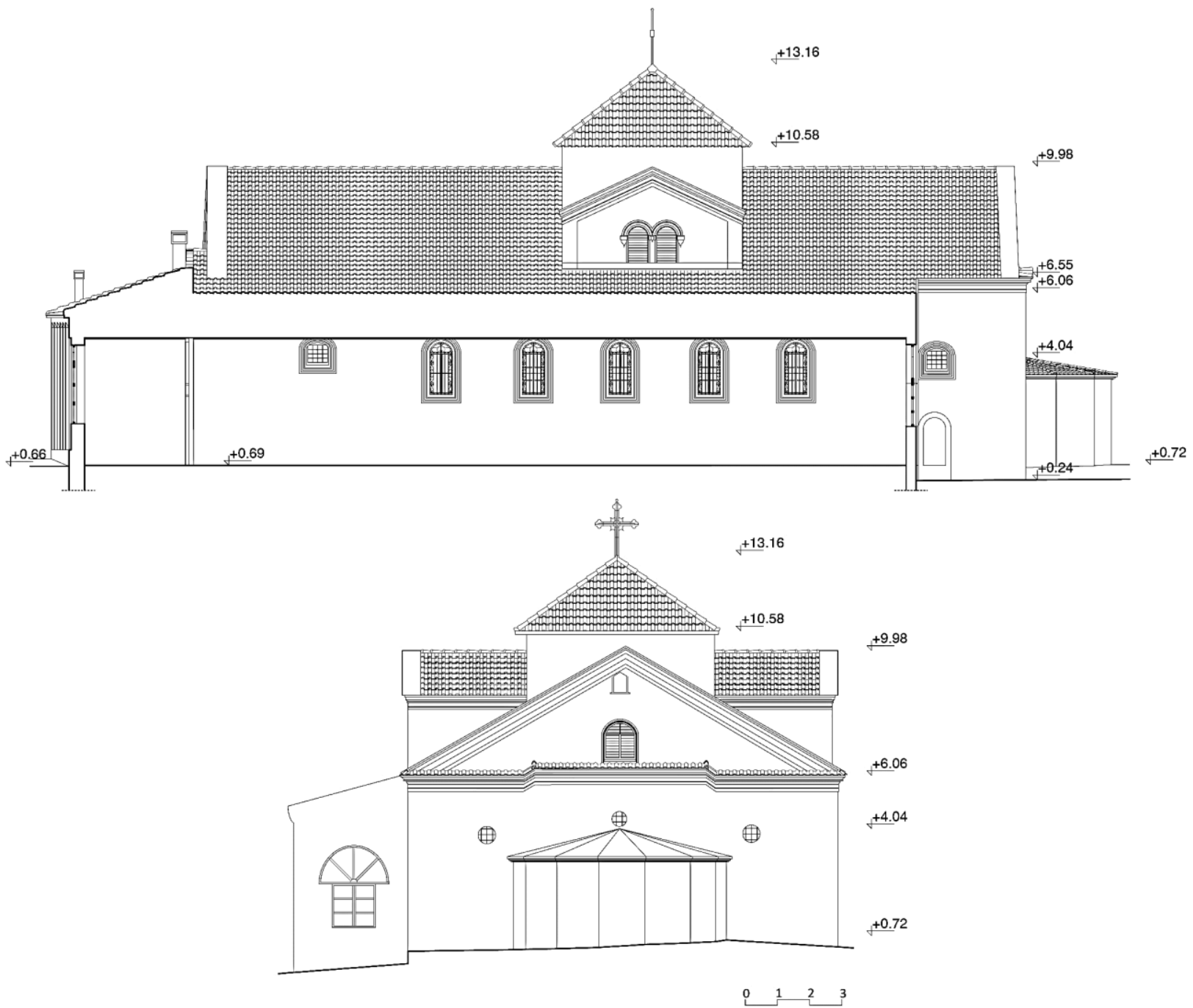

Figure III.268 St. Savior - Ascension of Christ in Veles. A. Southern façade; B. Eastern façade.

However, the essential difference between them is the completely divergent concept of the upper parties. Namely, as has been elaborated earlier, St. Panteleimon is a five-nave basilica with a central nave clerestory which hides three large blind domes. At St. Savior, on the other hand, an elevated transept was planned during the tracing of the building, as confirmed by the arrangement of the columns in the naos (fig. III.266). Their axial distance in the longitudinal direction is about $2.7 \mathrm{~m}$, with the exception of the fourth span from the east, which is twice as large, i.e. $5.5 \mathrm{~m}$. In this span, a transept extends across all three naves, covered, as well as the central nave, with a barrel vault whose height at the apex, measured from the floor, reaches $8.4 \mathrm{~m}$. The transept is not ideally placed in the middle of the naos, but is rather moved to the east, which is conditioned by the uneven rhythm of the columns in the western parts, i.e. in the gallery area. At its intersection with the central nave, an approximately square bay is formed, in which a domed solution is naturally imposed, very similar to the medieval Byzantine churches of the inscribed cross type and the basilicas with a dome. In these Byzantine typological solutions, as discussed earlier, at the intersection of the nave and the transept, on a cubic pedestal, a dome rises on a high, elevated drum supported on four angular pendentives. In the Revival basilicas combined with a cruciform solution, a cubic pedestal covered with a blind dome rises at their junction on a square base, and this is in fact the main difference between these two typologies (fig. III.267-268). Nevertheless, despite the absence of a mature, completely free, protruding dome, the analogy with these older Byzantine patterns is very clear. Furthermore, there are analogies with the Moskopole group of vaulted basilicas from the 
previous, XVIII century, that were also discussed in more detail earlier, and which also consist of bays with different spans of which the square ones in the central nave are covered with blind, massive masonry domes, and the narrower spans are solved as ribbed or barrel vaults.

At the church of St. Savior in Veles, therefore, at the junction of the central nave and the transept, instead of a cylindrical drum, a cubic tower rises $2 \mathrm{~m}$ above their apex, with shallow arches on all four sides, between which, in the corners, are placed the pendentives (fig. III.267). On the thus formed circular base, whose span is reduced to $4.9 \mathrm{~m}$ with the help of cantilevered elements and arches, a blind dome with a rather unusual cross-section is placed: in the lower zone it consists of a ring of a very slightly arched surface, so that the actual span of the blind dome is reduced to only $3.2 \mathrm{~m}$; in the upper zone finally appears the blind dome itself whose apex (and the total height of the temple) is $12.2 \mathrm{~m}$. This construction

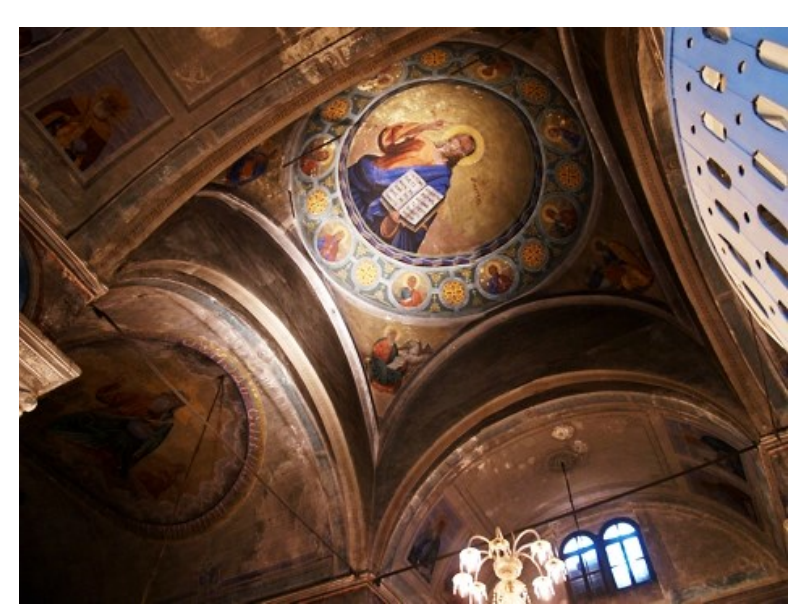

Figure III.269 St. Savior in Veles. View towards the dome.

is covered from the outside with a pyramidal bonnet roof, and the cubic pedestal itself is only slightly raised above the ridge of the gabled roof, i.e. only $70 \mathrm{~cm}$ (fig. III.268). As it is a blind dome, the church is illuminated only through windows on the perimeter walls of the naos, where a high arched window corresponds to each span; in the tympanum of the transept, where a double window is formed in a similar way; a triple window on the west wall in the gallery; as well as windows above the apse and in the altar. It is interesting that, despite the monumental dimensions, the church is entered through only one western entrance portal, from the north side of which a smaller portal leads directly to the staircase for the gallery, meaning this was an entrance intended exclusively for women. The access to the gallery at the church of St. Savior in Drachevo was solved in an identical manner, which is another common feature of these two contemporary temples.

The interior of St. Savior in Veles was lavishly decorated, with a tall multi-story iconostasis; an ambo placed high on the northwestern column under the dome, accessed via a spiral staircase; a bishop's throne; icon pedestals, etc. Also, the decorative finish of the gallery fence contributes to the general impression (the gallery is flat in the lateral naves and concave in the central one), with pendants, profiles and cornices. Later, the church was renovated / decorated on two ocasions: in 1908-1910 and 1921-1922, when it was fresco-painted by the famous painter Gjorgji from Veles, who worked under a strong influence of European Academism (fig. III.269). 


\section{THE REVIVAL TYPOLOGY IN THE FIRST HALF OF THE XX CENTURY}

The first decades of the XX century brought significant social changes, as the culmination of the process of awakening of the national consciousness in Macedonia. The crisis at the end of the XIX century, marked by several strong national liberation uprisings, culminated with the llinden Uprising of 1903 and the celebration of the first, albeit brief, free and independent Republic in Krushevo. Soon followed the Balkan Wars (1912/1913), when the Ottoman Empire, after five centuries of domination, lost its last Balkan dominions and the territory of Macedonia was divided between Greece, Bulgaria, Albania and the Kingdom of the Serbs, Croats and Slovenians, from which Yugoslavia would later emerge. ${ }^{515}$ Shortly afterwards, the First World War (1914-1918) took place, a turbulent period in which existential issues replaced the cultural impulse of the Revival, which slowly faded after a century of intense architectural and artistic creation, leading to "interruption of continuity, displacement of the last representatives of some construction groups, and to some extent cessation of the intensive construction activity" (Грчев, 1998: 23). After the wars, the territory of Macedonia constituted a formal part of four independent Balkan states and its architecture was further developed under their directive.

It is clear that the intense and frequent military actions of the first half of the XX century by themselves significantly affected the state of preservation of the already built religious architecture. During the llinden Uprising, and especially following its bloody suppression by the Ottomans, many churches were burned down and completely destroyed. ${ }^{516}$ The same fate fell upon the Revival churches during the First World War when the battle front line (the so-called "Thessaloniki", "Southern" or "Macedonian" front) transversed the southern parts of Macedonia. The regions of Bitola, Prilep, Mariovo, Tikvesh and Dojran suffered the most: many villages were forcibly displaced, properties confiscated, the locals were mobilized or suffered famine and disease. Unfortunately, many of the Revival churches were looted ${ }^{517}$ and partially or completely destroyed. ${ }^{518}$

\footnotetext{
515 Today's territory of the Republic of Macedonia remained within the Kingdom of the Serbs, Croats and Slovenians until the fascist occupation by Germany, Bulgaria and Albania during the Second World War. After the liberation, it constituted a Republic within the Socialist Federation of Yugoslavia until 1991, when it declared independence.

516 For instance, the church of St. Nicholas in Krushevo (built in 1832) was set on fire in 1903, including the iconostasis (work of Petre Garkata's wood-carving group), and then restored in 1905-1907; the church of St. Nicholas in the village of Orlanci (built in 1872), was also set on fire in 1903, then restored in 1908 including, fortunately, the preserved authentic iconostasis, made in 1882-1885, etc.

517 It is known that, during the War, the iconostasis of the church in the village of Trnovo (near Bitola) was burned, the one in Brusnik was dismantled and stolen by the French armies, whereas the one in Magarevo by the Germans (Василиев, 1965: 192). 518 As an illustration, the bombing of Dojran completely destroyed the old town, which would never be rebuilt on the same location. The cathedral basilica St. Elijah has been finally restored in recent years after an entire century of ruined state.
} 


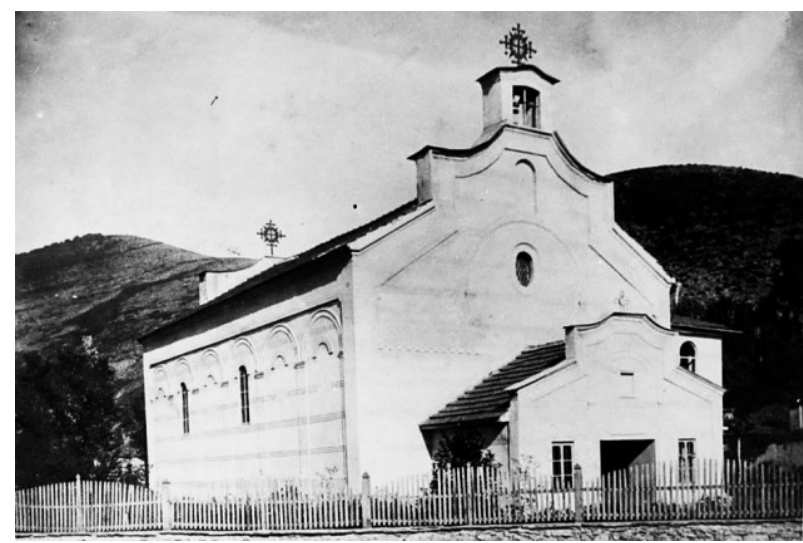

Figure IV.1 St. Peter and Paul in Kichevo (1907). View from the north-west.

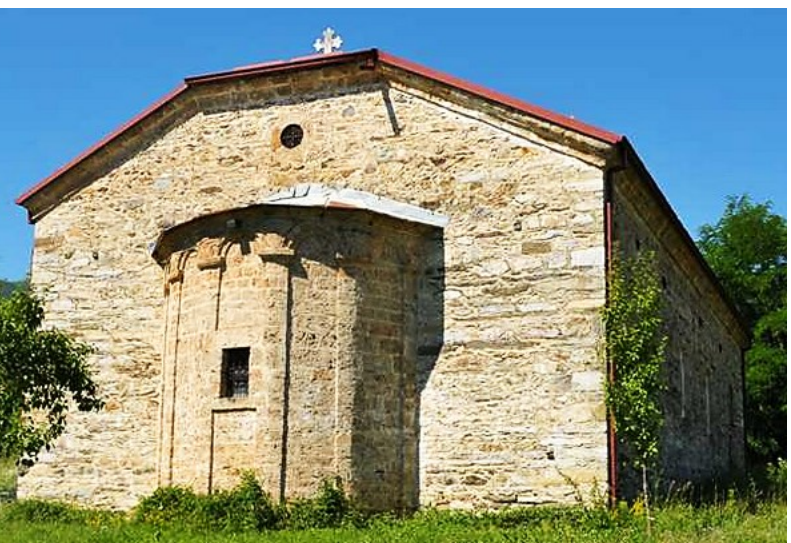

Figure IV.2 Dormition of the Mother of God in Sloeshtica, near Demir Hisar (1908). View from the north-east.
After the war, during a short period of relative stability in the 1920s, some of the churches were restored. In this period, inevitably, new styles were introduced in the religious architecture, such as the so-called "SerbianByzantine" style (Грчев, 1998: 25-26) (19 $^{519}$ as a modern interpretation of the Moravian postByzantine architectural school. ${ }^{520}$ In addition to many Byzantine elements and influences (arcades, bell-towers on the west façade, friezes of small blind arcades under the roof cornice, rosettes, and horizontal division of the facades into several distinctive zones), various classicist elements and influences from European Academism and even the Secession ${ }^{521}$ are also present. Sometimes, some of these novelties were used to "upgrade" the Revival buildings renovated in this period. Of course, the changes relate not only to the typology of the newly-built temples, but also to the construction process itself. Namely, as opposed to the traditional crafts used in construction during the XIX century Revival, in the next century (after the First, and with greater intensity after the Second World War) prefabricated building materials of industrial production were already available and in frequent use, including brick, cement, ceramic tiles, concrete and reinforced concrete and metal cladding (Покропек и Стрончек, 1992: 102). This would certainly change the principle of work in construction as well as the nature of the construction

\footnotetext{
${ }^{519}$ According to Kokan Grchev: "The flourishing of construction and artistic crafts that elevated the churches from the XIX century to the level of a complete work of art, defined the coordinates of the "national" style in Macedonia. The importance of this phenomenon is so great that in the new socio-political conditions after the end of the First World War, the tendencies to impose the values of a differently defined "national style" were clearly emphasized by the new state and placed in a different constellation that contributed to the redefinition of the morphology of the church construction" (Грчев, 1998: 7-8).

520 In accordance, several churches were built following different typological patterns, characteristic of past eras. Such example is the church of St. Trinity, built in Kumanovo by Debar craftsmen at the very beginning of the XX century, in 1901-1902 (frescopainted in 1904), whose project made by the Russian architect Vladimir Antonov was a donation of the Serbian government, which explains the evident influences from the Moravian school. St. Trinity comprises a square naos arranged in the form of an inscribed cross with a multi-domed elevation; additional bays as wide as the central nave expand to the east and west which emphasizes the length of the building ostensibly resembling a cross-shaped church. The church of St. Archangel Michael in Skopje (1930-1932) has a similar appearance, with the exception of groin vaults substituting the domes of the corner bays in the naos. The color treatment of the façades of St. Trinity in redish tones and the circular oculus on the west façade are undisputed parallels with the Moravian architecture. However, the multi-domed system is a local influence of several very important medieval monuments: the churches in Matejche and Staro Nagorichane (see Chapter I.4.3), whose influence is evident in later examples, such as the Osogovo Monastery by Andreja Damjanov. In addition to the multi-domed system, St. Trinity demonstrates other parallels with the Revival temples: a gallery - "women's church" with a convex balcony, a tall iconostasis etc. Similar "Moravian" influences as the ones evident at St. Trinity, including horizontal division cornices, twisted columns and a circular oculus, are also evident in other churches from the region of Kumanovo: St. Savior built in 1931 in Romanovce, which has omitted the multidome system at the expense of a central dome, as well as St. George in Deljadrovce (1930). The latter, as well as St. Theodore Tyron in Srpci (1929) near Bitola have a compact trefoil plan with a central dome (Грчев, 1998: 102, 134-135).

${ }^{521}$ For example, the church St. George built in the 1930s in the village of Petrovec, near Skopje, though shaped exactly according to the Revival models - a pseudo-basilica, with a subtly ejected transept and a central dome supported on an octagonal drum, also bears secessionist decorative motifs on the corners of the façades, below the cornice (Грчев, 1998: 153).
} 
groups, and the traditional crafts (stone masonry, carpentry, wood-carving, etc.) would gradually disappear.

Despite these turbulent developments and the inevitable modernization of construction, no sharp interruption occurred and the Revival basilical typologies, following the principle of already established traditions on which Orthodox Christianity still largely rests, persisted and continued to be built resisting external influences (fig. IV.2). Namely, in the first half of the XX century, almost 200 basilical churches were built (or renovated) all over Macedonia (see Annex). The characteristics of the Revival's construction are especially visible in the churches built in the first decades of the century, when the tradition and the crafts were still very much alive (fig. IV.4-5).$^{522}$ In some of them, the combination of a massive and wooden frame construction system was still in use. ${ }^{523}$ Therefore, it can be said that the churches built in these first decades of the XX century belong to a "transitional period" (Крстиќ, 2014: 174). Although significantly simplified, with mostly completely plastered, purified façades, the Revival architectural typology is still clearly legible: pseudo-basilicas, with a continuous gabled roof, entrance portals with arched patron saint niches and multilateral or semicircular altar apses. Vaulted, mostly single-nave, but also three-nave buildings prevail, sometimes with western galleries, or bell towers in front of the west façade (fig. IV.3B) or on top of it (fig. IV.1, IV.3A). Additionally, some churches (for example, St. Nicholas in Krusheani, Dormition of the Mother of God in Sloeshtica, near Demir Hisar, St. Nicholas in Gorno Dobrenoec near Kichevo) still incorporated stone-carved cross-shaped windows within the western and eastern façades (fig. IV.1-2), which also indicates a consistent reflection of the Revival features in the newly-built buildings.
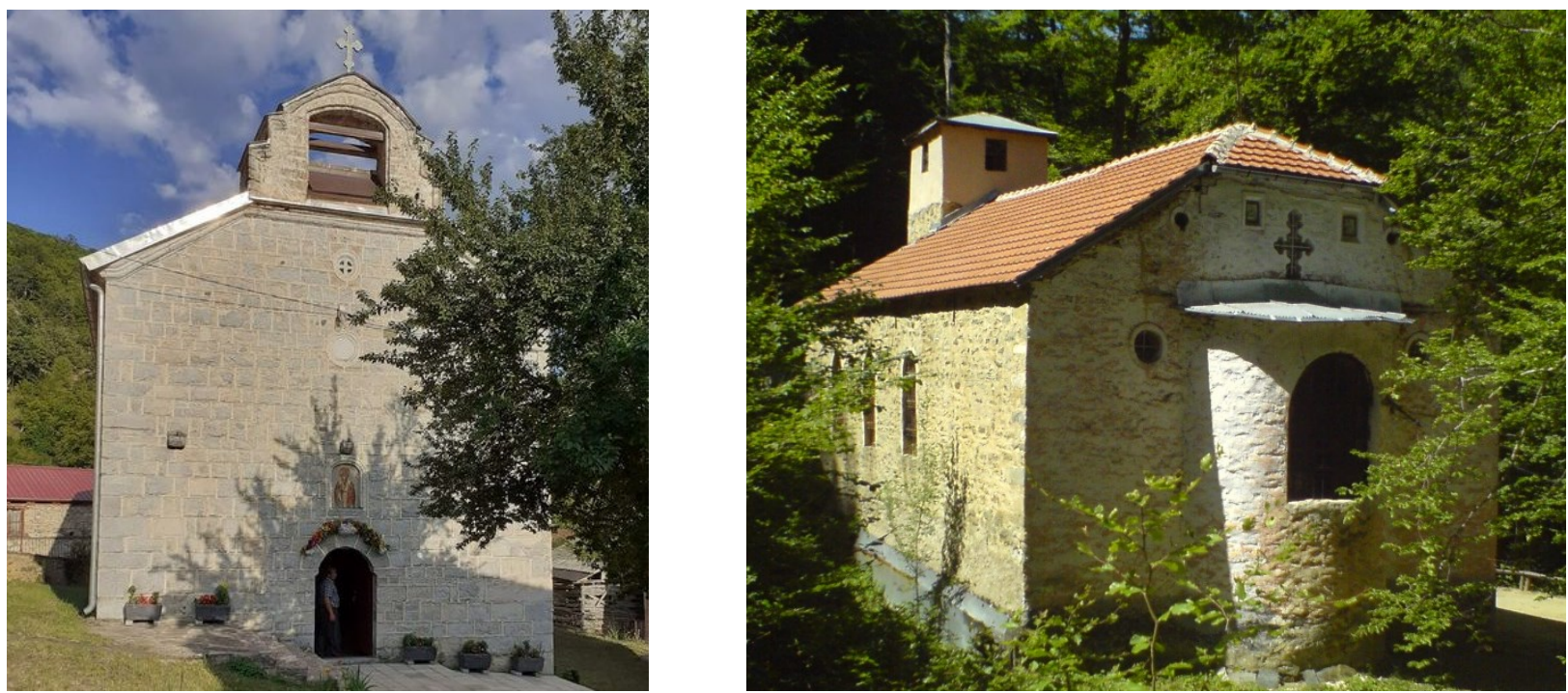

Figure IV.3 A. St. Nicholas in Gorno Dobrenoec (Kichevo). Western façade; B. St. Ana in Malovishte (Bitola). View from the east.

In addition to the basilical models, in the first decades of the XX century representatives of other Revival typological solutions, examples of a persistent regional architectural tradition, were also built: combinations of single-nave basilica and trefoil, such as the church of St. Nicholas built in 1939 in the

\footnotetext{
522 The last Revival fresco-painters, such as Dimitar Andonov Papradishki and Gjorgji Zografski, were still active in this period. Their work can be found in the church of St. George in Kratovo (dating from 1925), for example. In addition, Papradishki still worked at the Osogovo Monastery, at St. Demetrius in Skopje (where he painted frescoes in 1897, and icons in 1907-1909 and 1939), in 1917 he painted the blind dome of the church of St. Cyril and Methodius in Tetovo, in 1924 he worked on the frescoes and icons of the church of St. Petka in Skopje, the following year he painted the icons for the church of St. George in Petrovec, in 1927 he worked at St. Constantine and Helena in Skopje, and St. Mina, also in Skopje (Грчев, 1998: 36-37). One of the last remaining wood-carvers, Nestor Aleksiev, also worked on the iconostasis and bishop's thrones in some of the churches from the first half of the XX century (Михајловски и Грамосли, 1990: 43-53).

${ }^{523}$ Such examples are the churches of St. Leontius in Graishte (1927) and the Holy Mother of God in Barakovo (1942), both in the region of Demir Hisar (Дапчев, 1996: 219, 224), both depicting false wooden vaults.
} 
village of Lavci near Bitola (see footnote 513); combinations of a three-nave basilica with an inscribed cross, such as the previously mentioned church of St. Cyril and Methodius in Tetovo (fig. III.264) and the Most Holy Mother of God in Trnovo; and even domed single-nave basilicas, such as St. Savior in Lokov (region of Struga), built in 1932 and St. John the Baptist in Bitola, consecrated in 1938, and demolished in 1976 (Грчев, 1998: 130)..$^{524}$

The continuity of the Revival's construction traditions is partly due to the fact that some of the

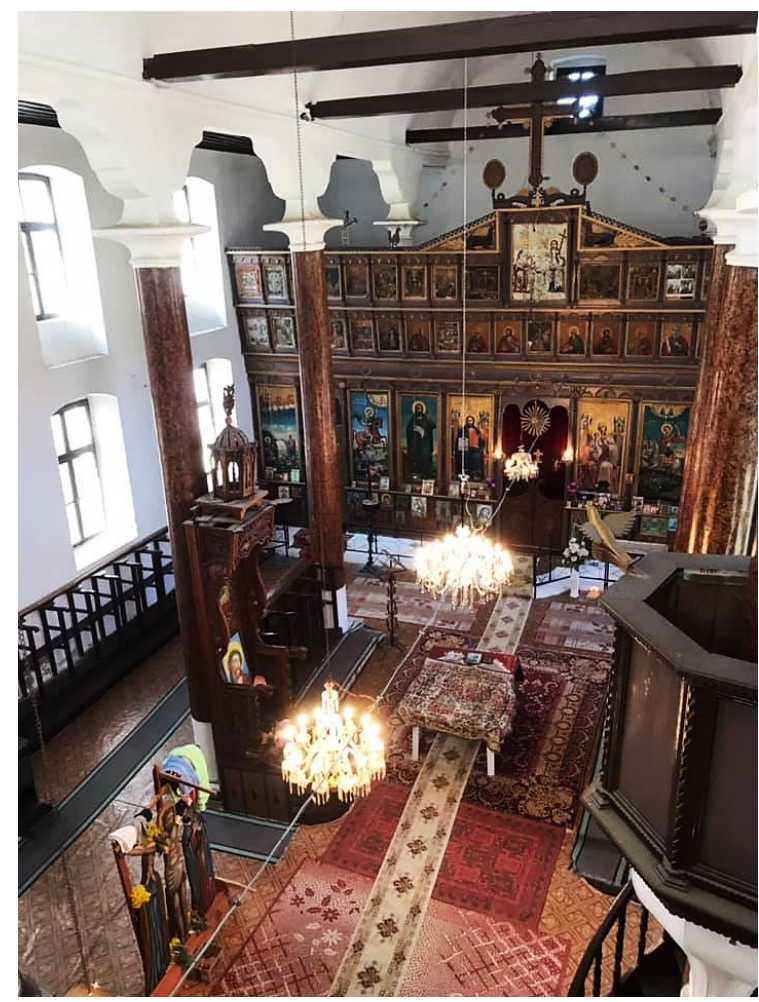

Figure IV.4 St. George in Smilevo, near Demir Hisar (1911) View from the gallery towards the altar.

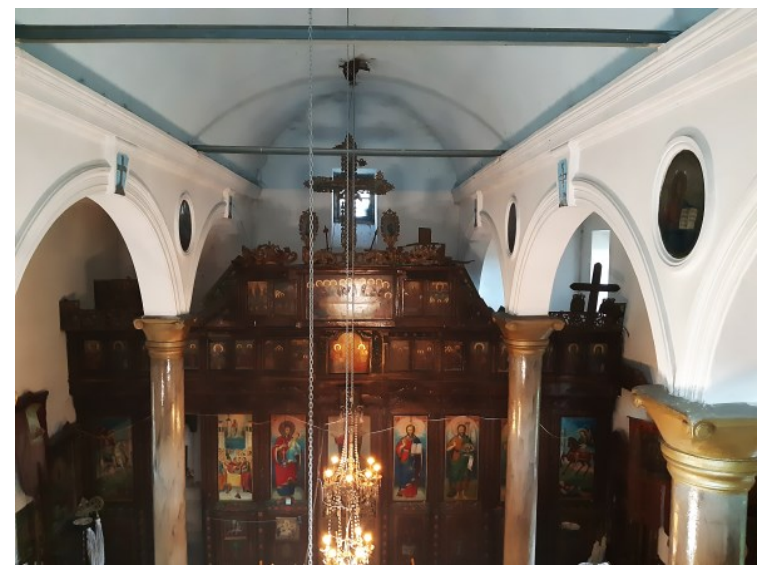

Figure IV.5 Dormition of the Most Holy Mother od God in Janche, near Debar (1924). View from the gallery towards the naos in the east. basilicas from the first decades of the XX century were built on older foundations or remains of older churches: St. Apostles Peter and Paul in Kichevo (1907), St. Athanasius and St. Demetrius in Shtrbovo (Prespa), from the 1930s, St. Athanasius in Nikodin (renovated in 1935), as well as St. Nicholas in Sveto Mitrani, near Krushevo, St. Ana in Malovishte (near Bitola) in 1936, etc. Also, many new churches were built following the same traditional patterns (fig. IV.4IV.5). The construction of these churches according to an older, existing model is evident both in the typology used as well as the specific local characteristics. For example, in the region of Prilep mostly single-nave, vaulted buildings with a semicircular altar apse were built and, as a local characteristic, they included a massive square belltower on the west side of the building, i.e. above the western entrance, whose ground floor thus formed a porch protecting the western entrance to the temple. This type of bell-tower, despite being atypical for the Revival architecture and a clearly imported architectural element, was also added to some of the Revival churches in the region and further throughout Macedonia ${ }^{525}$ during their reconstruction after the First World War and under the Kingdom of Yugoslavia. In that context, their design is often inspired by the neo-Byzantine style that would dominate the Serbian architecture in the early $X X$ century. Indicatively, they continued to be built as such in the following decades, which suggests that the entire architectural composition of some existing buildings, including their newer, posterior, unauthentic extensions, were adopted as models for the design and construction of new church buildings.

\footnotetext{
524 The church of St. John the Baptist in Bitola was conceived as a domed basilica, with a spacious dome supported on a low octagonal drum placed on a square pedestal whose width corresponds to the entire span of the naos. The compact volume of the building was surrounded on all three sides by open porticos, ending in closed chapels to the east.

525 Namely, at St. Nicholas in Krivogashtani (1847), St. Elijah in Veselchani (1857), St. Athanasius in Vitolishte (1862), the church of the same name in Godivje (1860), St. Marina in Borotino (1862), St. Nicholas in Korenica (1859), St. Nicholas in Mavrovo (1850), Nativity of Mother of God in Malo Konjari (1873) and Nativity of Mother of God in Kadino Selo (1862).
} 
Older local patterns can be tracked deep into the XX century in other regions as well. For example, in the region of Kriva Palanka, the churches in the villages of Otoshnica and German, built in the first decades of the century, are three-nave vaulted basilicas, with tall octagonal columns such as those found at the Revival churches in the nearby villages of Radibush and Stracin (see fig. III.98). The Revival influences are especially evident in the church in Otoshnica, built with precisely executed and meticulously arranged trachyte masonry, as a typical local landmark (see Chapter III.2); with a relatively small and rather low altar apse (as in the churches at Radibush, Petralica and Rankovce, where the remains of older post-Byzantine churches have been incorporated into the later, Revival reconstructions), as well as window transennas carved out of stone slabs. In the region of Demir Hisar, the churches of St. Panteleimon in Sveta from 1905 (see fig. III.135C) and Dormition of the Most Holy Mother of God in Sloeshtica from 1908 (fig. IV.2), although posterior, follow the local dominant Revival architectural typology of basilicas with lateral pilasters connected with semi-circular arches (see Chapter III.5.A.3). A complete continuity of the Revival traditions can be observed in the three-nave basilicas of St. George in Smilevo, from 1911 (fig. IV.4); St. Cyril and Methodius in Stenje, region of Prespa, from 1911-1927 (fig. IV.6); Dormition of the Most Holy Mother of God in the village of Janche, near Debar, from 1924 (fig. IV.5), ${ }^{526}$ etc. There are also, albeit rarely, very unusually conceived three-nave basilicas, where the traditional model was boldly transformed using a new stylistic language, such as the church of St. Peter and Paul at the Bukovo cemetery in Bitola (fig. IV.7), dating from the $1930 s^{527}$

In the second half of the century, after 1945, under the new socialist state order, the construction of new churches subsided, while the existing ones were appointed a new function as monuments of culture. The Byzantine churches were granted special interest and scientific recognition, and would therefore be subsequently restored and protected, while the Revival architecture, especially the rural

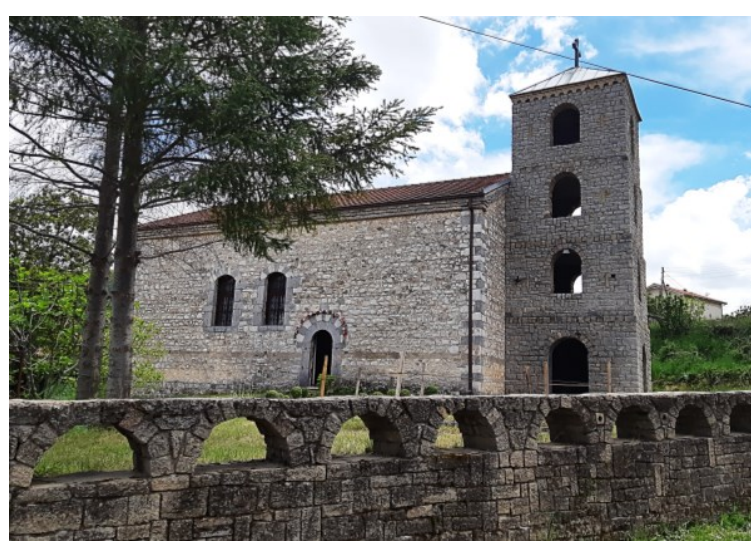

Figure IV.6 St. Cyril and Methodius in Stenje, Prespa (19111927). View from the north-west.

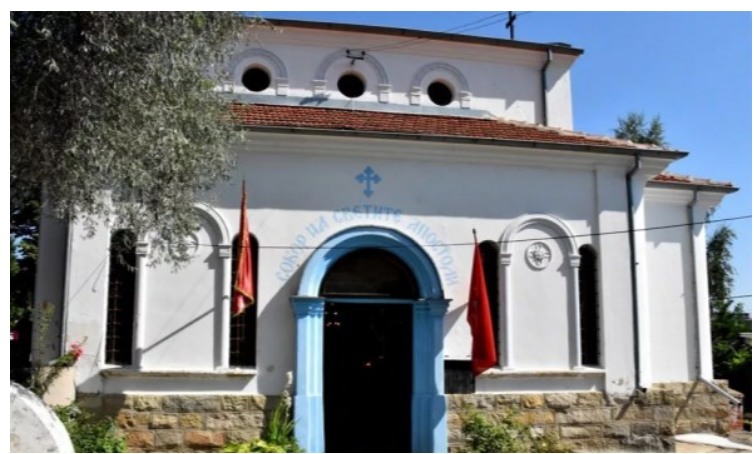

Figure IV.7 St. Peter and Paul - Bukovo cemetery in Bitola. View from the south. churches, faced gradual but continuous degradation as a result of the processes of intense migration (see Chapter II.6). Towards the end of the XX century, after the establishment of an independent state and the abolition of the socialist state order, the construction and renovation of churches intensified with increasing presence of central or conchal solutions, in the spirit of the medieval, late-Byzantine typological patterns. This change in architectural

\footnotetext{
526 The church Dormition of the Most Holy Mother of God in Janche is a three-nave basilica with a flat ceiling above the lateral naves and a semi-cylindrical vault in the central nave. It incorporates a gallery - a "women's church", a circular medallion frescopainted on the vault and oval mandorlas above the capitals of the columns in the central nave (fig. IV.5), as well as many other Revival features both in the interior and in the external façade's articulation (see fig. III.18A).

527 St. Peter and Paul is a small three-nave basilica with a central nave clerestory and a rather unusually conceived plan: the west façade is significantly submerged in the terrain, thus the nave is accessed through a south and north portal in the axis of the respective facades; to the east the central nave is projected outwards and ends flat, without a semicircular apse. The façades are absolutely symmetrically arranged, and the illumination of the church's interior is through a triple window to the east, elongated windows on the longer façades and circular oculi within the clerestory (fig. IV.7) (Грчев, 1998: 119).
} 
"fashion" is another example of a restoration of a historical architectural typology upon which the Christian cult is built (or restored), after decades of dormancy, although now largely reduced to a form, a decorative cladding applied to buildings constructed with modern materials, techniques and procedures. This process takes place at the expense of the basilicas which are increasingly abandoned ${ }^{528}$ or, in the cases where basilicas are in fact built, they are significantly simplified, more modest, stripped to their basic design elements, while the masterpieces of this architectural typology remain in the past.

\footnotetext{
528 However, basilical temples were also built in the second half of the XX century: the Holy Mother of God in Peshtalevo (Prilep) in 1965; the Holy Mother of God in Vrboec (Prilep) in 1966; St. Nicholas in Suvodol (Makedonski Brod) in 1967; St. Nicholas in Krusheani in 1970; St. Nicholas in Kalishta (Struga) in 1972; the Resurrection of Christ in Alinci (Prilep) in 1975; St. Elijah in Slavej (Prilep), in 1978; St. George in Belovodica in 1980; St. Nicholas in Lazhani (Prilep) in 1987, the Most Holy Mother of God in Krivogashtani near Prilep in 1990, etc.
} 


\section{DISCUSSION AND FINAL CONSIDERATIONS}

\section{(Dis)Continuity of basilical typologies}

The unique Revival sacral architecture was reviewed in detail on the previous pages, with an analysis of its origin, the influences under which it emerged and its extremely rich typological diversity as the main subject of interest of this doctoral dissertation. At the beginning of the research, i.e. in the introduction of this doctoral dissertation, the following hypothesis was set: The monumental Christian architecture of the XIX century and its basilical typology represent a case of a "resurrection" of an ancient and predominantly abandoned architectural typology inspired by the most important historic periods for Christianity in Macedonia, as a process characteristic for epochs of social Revival. One such epoch of social Revival is the XIX century. It is of exceptional importance that, despite the specific social constellation in Macedonia as the last European province within a formerly huge and powerful, but very cruel and extremely conservative feudal Empire still stuck in the Middle Ages, the XIX century was marked by identical developments as the processes that took place in a wider European context. As the official architectural academic schools throughout Europe and the world, the Macedonian master-builders, regardless of their lack of formal education, joined the contemporary eclectic movements, driven by romanticism, the nostalgic return to the stylistic achievements of past eras, but at the same time with a significant humanistic note and a remarkable dose of optimism, resulting from the processes of increasingly intensified national awakening and its revolutionary, liberating context.

In such an atmosphere, complex interactions and influences will contribute to the growth of the Revival architecture into a "phenomenon with multilayered meaning" (Грчев, 2003: 158). Researchers of the Revival ecclesiastical architecture have so far taken the position that, to a greater or lesser extent, the main influences for its emergence and formation were often predominantly recognized in the imported Western European contemporary and older, already established stylistic manifestations, with a solid base, of course, in the traditional materials, construction techniques and procedures. There is no doubt that these movements significantly modeled the construction practice in the XIX century, and are especially legible in the secondary plastic and relieves of the entrance portals, the shaping of the capitals, the various moldings, wreaths, cornices, mandorlas and medallions and the abundant ornaments of the altars partitions where baroque and rococo elements are clearly recognizable. In such a complex context, at first glance it seems that the "resurrection" of the basilica as the dominant typological determinant of the Revival sacral construction is caused by some sudden, perhaps even external impulse. It is especially easy to accept it as a plausible hypothesis if this specific period is observed as an isolated segment and if there is a lack of a thorough, rigorous chronological review of the overall architectural ecclesiastical opus in 
Macedonia in the context of a wider region with which it formed a unified political, religious and/or ideological entity at certain times. The following table (table V-1) gives a chronology of the Christian ecclesiastical architecture in Macedonia from its official establishment in the IV century until today, with an attempt to graphically represent the predominantly used typological solution in specific separate historical periods: the early-Christian period (IV-VI century); the transitional period of stabilization of Byzantium and assimilation of the Slavs (VII-IX century); tsar Samuel's independent kingdom (X-XI century); the middle and late-Byzantine period (XII-XIV century); the Ottoman occupation - post-Byzantine period (XV-XVIII century); the Revival (XIX century) and the Modern age (XX century).

\begin{tabular}{|c|c|c|c|c|c|c|c|c|c|c|c|c|c|c|c|c|c|}
\hline \multirow{3}{*}{ Church typology } & \multicolumn{17}{|c|}{ Timeframe (IV - XX century) } \\
\hline & IV & $\mathrm{v}$ & VI & VII & VIII & IX & $\mathrm{x}$ & $X I$ & XII & XIII & XIV & $x V$ & $\mathrm{XVI}$ & XVII & XVIIII & \multirow{2}{*}{$\begin{array}{c}\text { XIX } \\
\text { Revi } \\
\text { val }\end{array}$} & $x \mathrm{X}$ \\
\hline & \multicolumn{3}{|c|}{ Early-Christian } & \multicolumn{3}{|c|}{$\begin{array}{l}\text { Transitional } \\
\text { period }\end{array}$} & \multicolumn{2}{|c|}{$\begin{array}{l}\text { Samuel's } \\
\text { kingdom }\end{array}$} & \multicolumn{3}{|c|}{$\begin{array}{c}\text { Middle and } \\
\text { Late-Byzantine }\end{array}$} & \multicolumn{4}{|c|}{ Post-Byzantine period } & & $\begin{array}{c}\text { Mod } \\
\text { ern }\end{array}$ \\
\hline \multicolumn{18}{|l|}{ Single-nave basilicas } \\
\hline \multicolumn{18}{|l|}{ Three-nave basilicas } \\
\hline \multicolumn{18}{|l|}{ "Five-nave" basilicas } \\
\hline \multicolumn{18}{|c|}{ Single-nave domed basilicas } \\
\hline \multicolumn{18}{|l|}{ Combined solutions } \\
\hline \multicolumn{18}{|c|}{ Trefoil / quatrefoil buildings } \\
\hline Inscribed cross solutions & & & & & & & & & & & & & & & & & \\
\hline
\end{tabular}

Table V-1 Chronological distribution of Christian ecclesiastical typologies (IV-XX century).

From the chronological presentation in table $\mathbf{V - 1}$ it becomes clear that in all separate historical periods in which the social conditions in Macedonia and in the region drastically changed, different typological solutions prevailed in the sacral architecture. However, in addition to the dominant architectural form, regularly (although in smaller numbers) other related or divergent architectural types would appear that intertwine, complement and produce, through transitional and combined forms, new dominant architectural solutions that would come to replace the older ones.

Thus, in the early-Christian period (IV-VI century) monumental three-nave basilicas prevail, which in fact were formed on the basis of ancient and oriental matrices precisely in that period, were adapted to the Christian cult and established as the basic and most common typological solution in the Christian monumental architecture (fig. V.1A). Namely, they are basilicas covered with a flat wooden ceiling, with a naos separated into three naves by means of two arcades consisting of columns connected by arches. They regularly have an altar apse to the east and a narthex to the west, with lateral tribunes and auxiliary chambers. In addition, although to a lesser extent, single-nave basilicas, cross-shaped and trefoil or central buildings were built, especially as tomb churches, martyriums and baptisteries.

In the next several centuries (VII-IX century), marked by the Slavic expansion in the Balkans and the Christian missions aimed at their baptism, new churches were built in very limited numbers. Nevertheless, completely different, more compact typological solutions prevail: the trefoil churches characteristic of monastery catholicons (which, at the same time, are tomb churches) would become dominant, while churches of the inscribed cross type would also begin to be built, completely in line with the contemporary construction in Byzantium's capital Constantinople.

The dominance of the monumental three-nave basilicas would be re-established after a hiatus of several centuries (fig. V.1B). This type of church buildings would mark the sacred construction of the 
middle-Byzantine period (X-XI century), and would arise from the court architecture of the Kingdom of Samuel and its autocephalous church organization (Ohrid Patriarchate / Archbishopric). During that period, the three-nave basilicas would retain the same proportions of the central versus the lateral naves (usually 2:1) as the early-Christian basilicas, with the difference that the arcades are composed of massive masonry pillars or a combination of pillars and columns. A special variety would be achieved in the upper parts with a development from a flat wooden ceiling, through vaulting, to the appearance of a central dome, culminating with the complete differentiation of the solution known as the inscribed cross. Several five-nave basilicas also date from the same time, formed with the addition of side chapels and porches / naves on the north and south side of the three-nave nucleus. A completely sporadic construction of churches of the inscribed cross type is also witnessed.

The late-Byzantine period (XII-XIV century) would be marked by the absolute expansion of the churches of the inscribed cross type, with one or more (five) domes supported upon high drums and boasting compact, slender, tall volumes. To a lesser extent, three-nave typological solutions would appear (fig. V.1B), most often as reconstructions built on foundations of older middle-Byzantine basilicas, which in the upper parts accepted the modern dominant model and were solved as an adapted inscribed cross with one or more domes inserted in the basilica. The single-nave buildings, on the other hand, developed as single-nave domed solutions (especially characteristic of the mausoleum churches), churches of the compact inscribed cross type, as well as a specific group of single-nave churches with a transverse nave (transept) that would appear in the Ohrid region at the passage from the XIV to the XV century.

The sacral construction of the post-Byzantine period (XV-XVIII century) is almost without exception dominated by the single-nave vaulted buildings. Regarding the origin of the dominant sacral typology, the process of transformation of single-nave domed buildings from the late-Byzantine period, which would be forced to abandon the domed structure during the Ottoman rule replacing it with a semi-cylindrical vault, is clear (fig. V.1C). The sub-dome structure specific for the compact inscribed cross solution would be preserved in the post-Byzantine churches with lateral pilasters connected by arches, thus forming lateral arched niches. In contrast, trefoils and inscribed cross-type churches would appear quite sporadically - as a few solitary examples. Of particular interest, however, are several examples of postByzantine three-nave basilicas. Their monumental dimensions are preserved, but the buildings have a significantly lower height and naves covered with semi-cylindrical vaults without central nave clerestory. In this group of three-nave churches the proportional ratio changes in relation to the older models and almost equal spans prevail in the central and lateral naves; they have approximately equal height; and the arcades consist of massive masonry pillars connected by arches, placed at a shorter axial distance.

The circle will be closed in the XIX century. Namely, the sacral architecture of the XIX century Revival actually synthesized all previous typological solutions (fig. V.2), based primarily on the single-nave and three-nave basilica as its basic and almost equally represented typological matrices, including the most monumental sub-typological category of the multi-nave ("five-nave") basilica. The single-nave basilical typological solutions show their continuous evolution from the late-Byzantine to the post-Byzantine single-nave churches with which the Revival single-nave basilicas share many similarities. However, during the Revival, the single-nave churches would increase in size several times compared to the smaller postByzantine churches, would introduce a gallery, and would develop more complex solutions in the upper parts: a semi-cylindrical vault, flat ceiling, coffer ceilings, blind domes, or domes set on elevated drums. The same tendency of "complicating", transforming and upgrading the basic typological pattern is also characteristic of the three-nave solutions. It is clear that the Revival master-builders "revived" the threenave basilica as a typology characteristic primarily of the early-Christian and then of the middle-Byzantine period, after which it was at least seemingly abandoned and replaced by less monumental, but more practical, more innovative and constructively more diverse solutions. Nevertheless, as we have seen, the 
three-nave basilicas continued to be built in both the late-Byzantine and post-Byzantine periods. Their even sporadic appearance is of exceptional importance because it indicates the constant uninterrupted duration of the tradition of their construction, as well as their symbolic meaning that had not been lost even during the most turbulent, unfavorable and restrictive social circumstances. It is in the Revival that the three-nave basilicas would come to experience a real expansion and, especially, a wealth of spatial conceptual solutions. The heavy, massive masonry pillars were abandoned and replaced with slender, light wooden columns, which in the upper parts carry a variety of combinations of flat and coffer ceilings, blind domes, domes without or with a drum, semi-cylindrical and quarter-cylinder vaults, bell towers, etc. The proportional ratio would return to the original 2:1 in favor of the central nave, and the axial distance between the columns would expand, compared with the post-Byzantine three-nave basilicas.
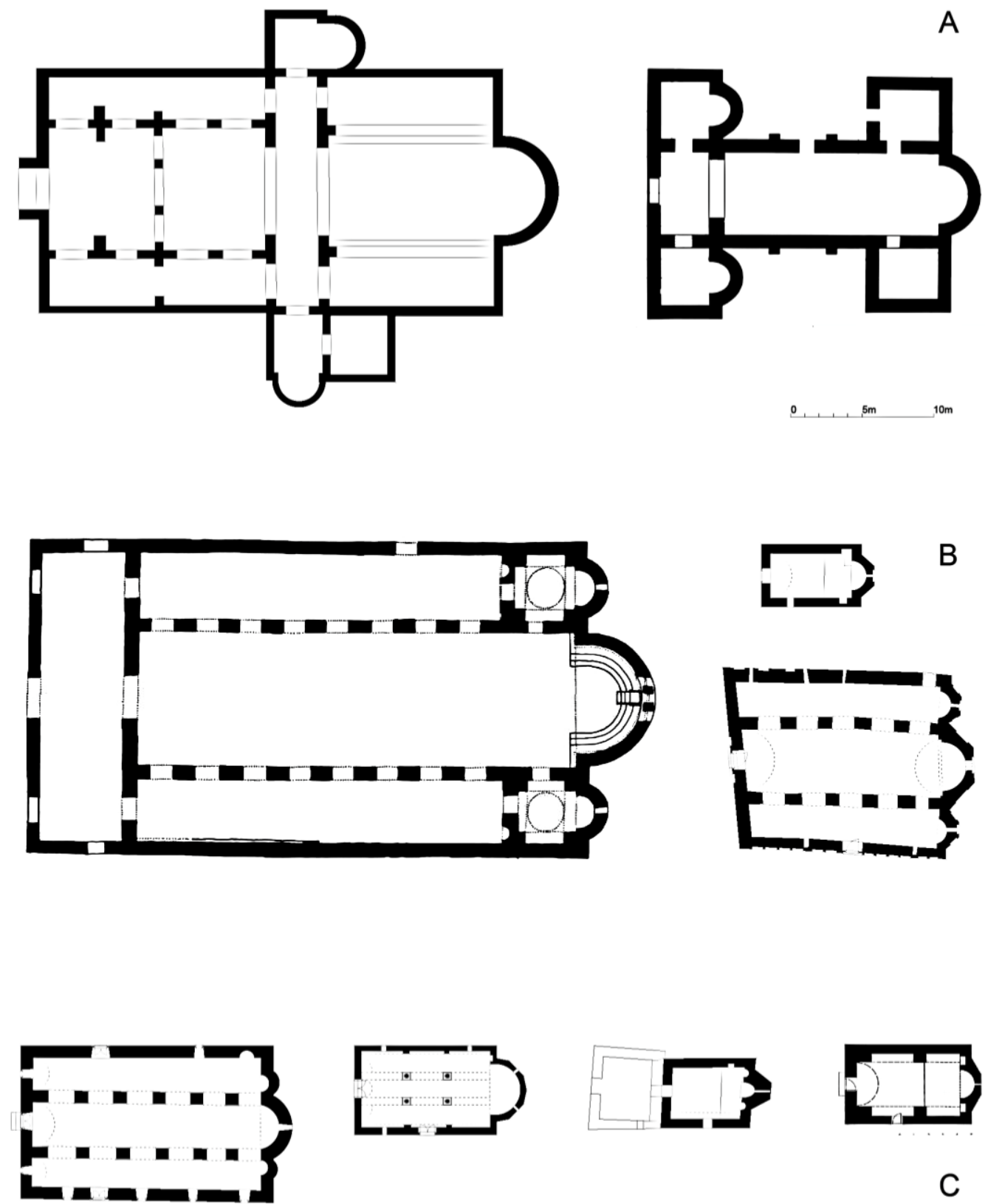

C

Figure V.1 (this page) Comparative overview of the basilical typologies in the previous centuries. A. Early-Christian basilicas (IVVI century); B. Byzantine basilicas (IX-XIV century) and C. Post-Byzantine basilicas (XV-XVIII century).

Figure V.2 (opposite page) Comparative overview of the Revival typological solutions. A. Single-nave basilicas; B. Three-nave basilicas; C. Five-nave basilicas; D. Domed single-nave basilicas and E. Combined typological solutions. 

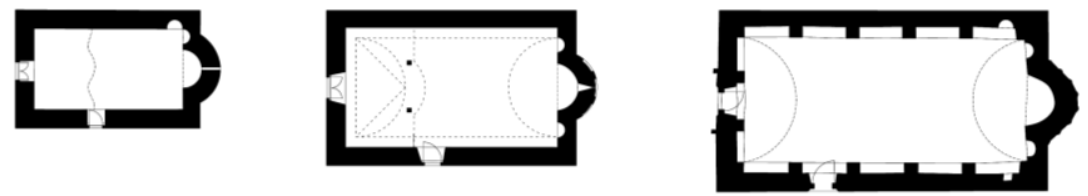

A
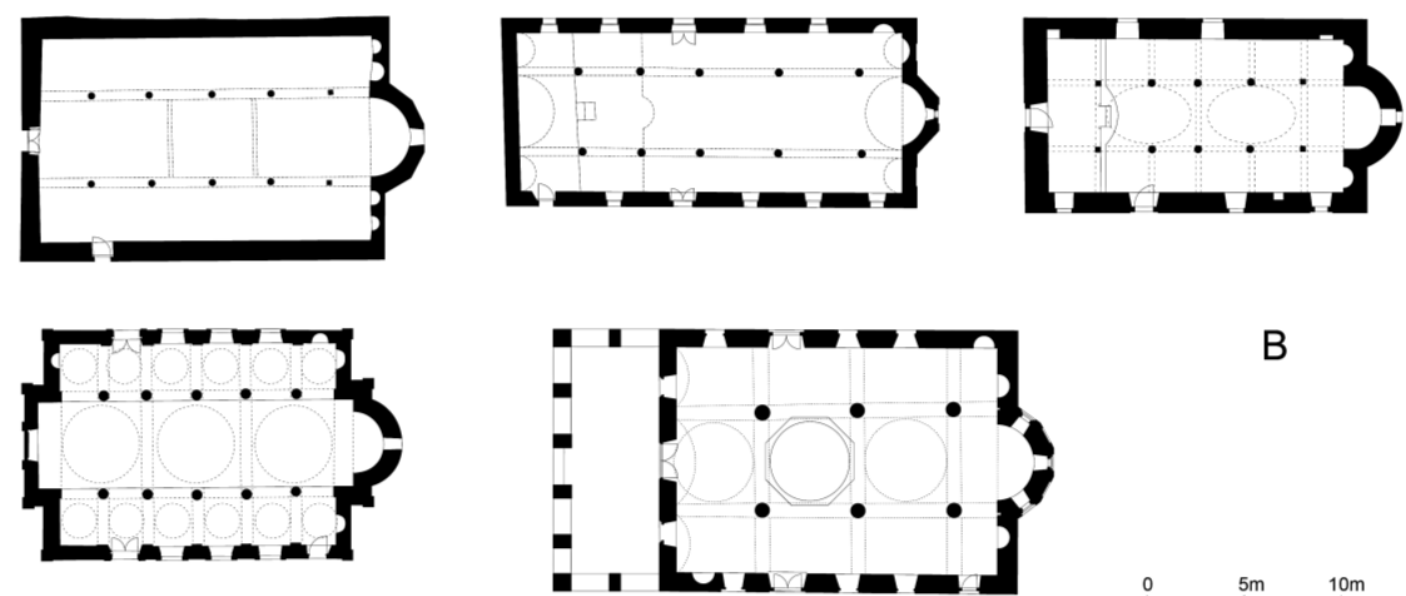

B

C
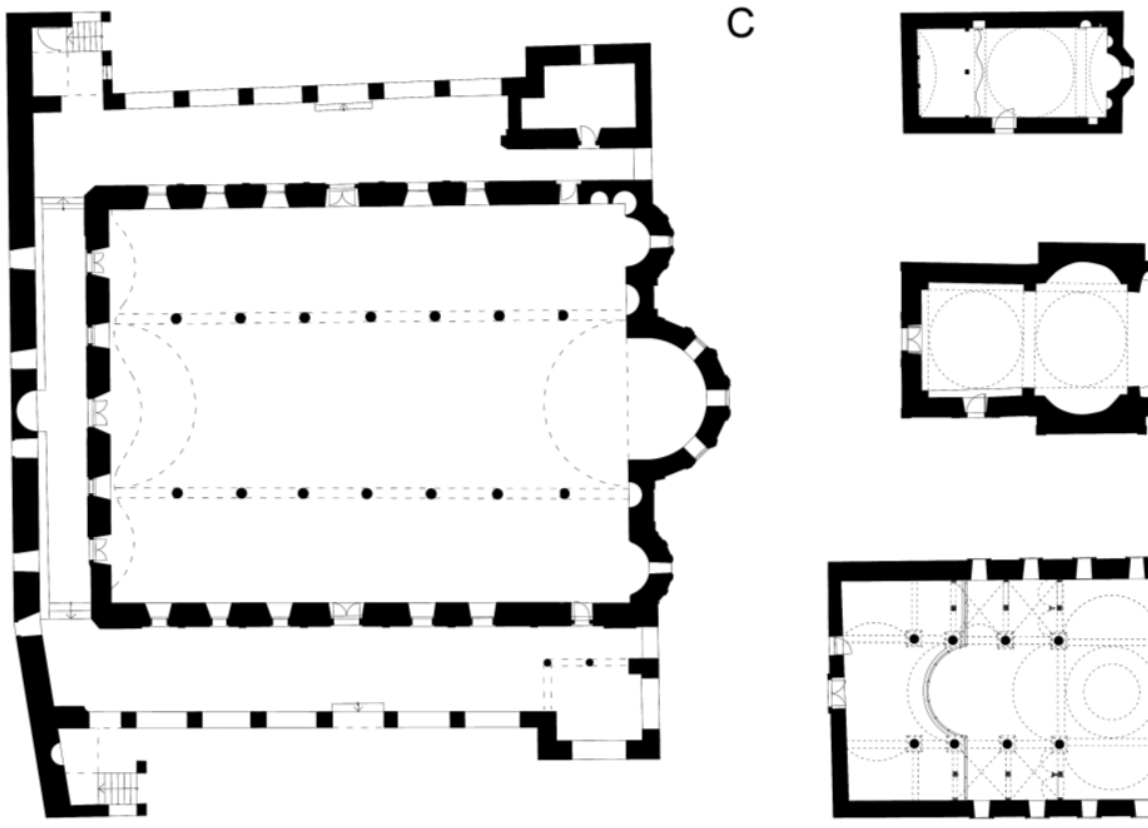

D

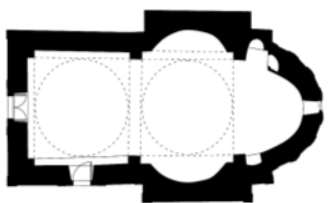

E

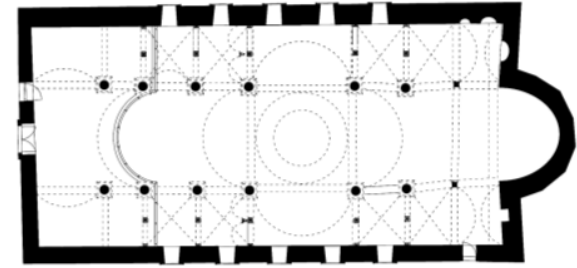

In conclusion, we can talk more about continuity than about discontinuity in the development of the ecclesiastical architecture in Macedonia, although with different intensity in different historical stages. Of course, this continuity refers to the basic typological concept while, as has been elaborated before, the architectural solutions constantly underwent changes, simplification or transformation, both of the structural system and of the elements that shaped the space. Even for those typological solutions for which there seems to be chronological discontinuity, a more detailed analysis of the Revival sacral architecture indicates that, through specific typological variations such as the domed single-nave basilicas 
and the combined typological solutions, it incorporated the inscribed cross with one or more domes, the compact inscribed cross, the trefoil buildings as well as the basilicas with a dome of the so-called "transitional type". In other words, the Revival monumental ecclesiastical architecture is in fact a recapitulation of all older typological solutions from which a new, unique and stylistically completely defined architecture emerges, "a dynamic model that has the ability to transform within a defined architectural language" (Грчев, 1998: 22).

It is this dynamic property of the Revival ecclesiastical architecture that would contribute, at the turn from the XIX to the XX century, towards a new cycle in sacred construction. As was the case with the transition from the middle-Byzantine to the late-Byzantine period, when in Macedonia the firmly rooted basilica typology began to transform via basilicas with a dome (of the transitional type), to the then modern solution of an inscribed cross, analogly the Revival basilicas via the combined solutions, which appeared in the last decades of the XIX century, would approach again the inscribed cross and the trefoil central solutions, creating an "original quality of the spatial organization of church buildings, which unfortunately due to turbulent historical events will not be developed in its logical consequences" (Ibid). ${ }^{529}$

\title{
Regional characteristics and representation of individual typological solutions
}

In the previous chapters (Chapter III.5), all the typological models that developed in the ecclesiastical architecture during the Revival were systematically analyzed. In terms of the prevalence of the different identified typological solutions, the largest percentage of Revival churches are single-nave and three-nave basilicas, in almost equal distribution: $47.1 \%$ ( 251 churches) and $45.6 \%$ ( 243 churches) respectively. The other typological solutions are present in much smaller numbers and also have an almost completely equal percentage share in the total number of typologically classified Revival churches (533 in total): the five-nave basilicas represent 2.3\% (12 buildings); the domed single-nave basilicas 3.0\% (16 buildings); and the combined models $2.1 \%$ (11 buildings). Their percentage ratios are presented in the following chart (chart V-1):

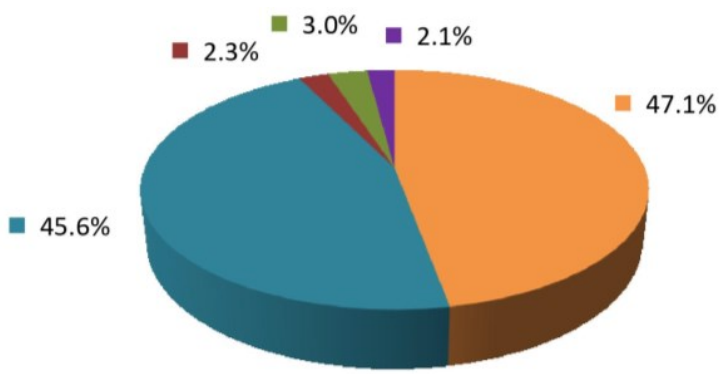

\section{Typology of Revival churches}

\author{
ningle-nave basilicas \\ three-nave basilicas \\ five-nave basilicas \\ domed single-nave basilicas \\ combined models
}

Chart V-1 Distribution of the Revival typological categories (in \%).

Of course, the different typological models were not built equally throughout the Revival, as can be concluded by the following chart (chart V-2). Their frequency varies from decade to decade as a result of various factors. On one hand, the social conditions played a significant role. Namely, at the beginning of the XIX century, Christian temples were built in a very limited number; a remarkable intensification of Christian religious construction occured in the fourth decade, i.e. after 1830 . This construction boom

\footnotetext{
529 In that context, at the end of the XIX and the transition to the XX century, other types of church buildings were already being built (despite the existence of the basilical typological solutions), such as the church of St. Cyril and Methodius in Resen (built in 1894), which is shaped as a free cross, and the church of the same name in Strumica (1905-1912) conceived and built in a similar way, which has a narrow narthex with a bell tower on the western façade. Seemingly in the form of a free cross is also the church of St. Trinity in Kumanovo (1901-1902) (see footnote 520).
} 
coincided with the end of the latest in the series of many Russian-Turkish wars, which took place in 18281829 , and the official start of the reformation process of the Ottoman state, culminating with the significant legal changes defined by the Gülhane's Hatt-i shariff of 1839 and the Hatt-i Humayun of 1856 (see Chapter III.1). Towards the middle of the century, i.e. in the sixth and seventh decades, the Revival church production would culminate, and then decline sharply, reaching at the end of the century approximately the same number of churches as those built in the 1830s. The sharp decline can again be explained by the change in socio-political conditions and the events that will lead to the so-called "Great Eastern Crisis" (1875-1878), beginning with the liberation uprisings in Bosnia and Herzegovina in 1875, in Bulgaria in 1876 and in Macedonia in 1876 and 1878, culminating with yet another RussianTurkish War (1877-1878).

of particular interest is the comparison of the intensity of construction of the separate typological models during the XIX century. At first glance, it seems that the one-nave and three-nave basilicas were built with approximately equal growth in accordance with the general trend. However, it is indicative that the threenave basilicas are more numerous than their one-nave contemporaries in the first half of the century; they will reach their culmination as a dominant typological solution in the sixth decade; and then afterwards they will be built in a significantly smaller number. The same phenomenon, although less obvious due to their smaller total share in the Revival churches, is evident for the five-nave monumental basilicas, which were built most intensively in 1830-1840 and towards the middle of the century. In contrast, the single-nave basilicas were most intensively built in an extended period from the sixth to the eighth decade of the XIX century, when they would

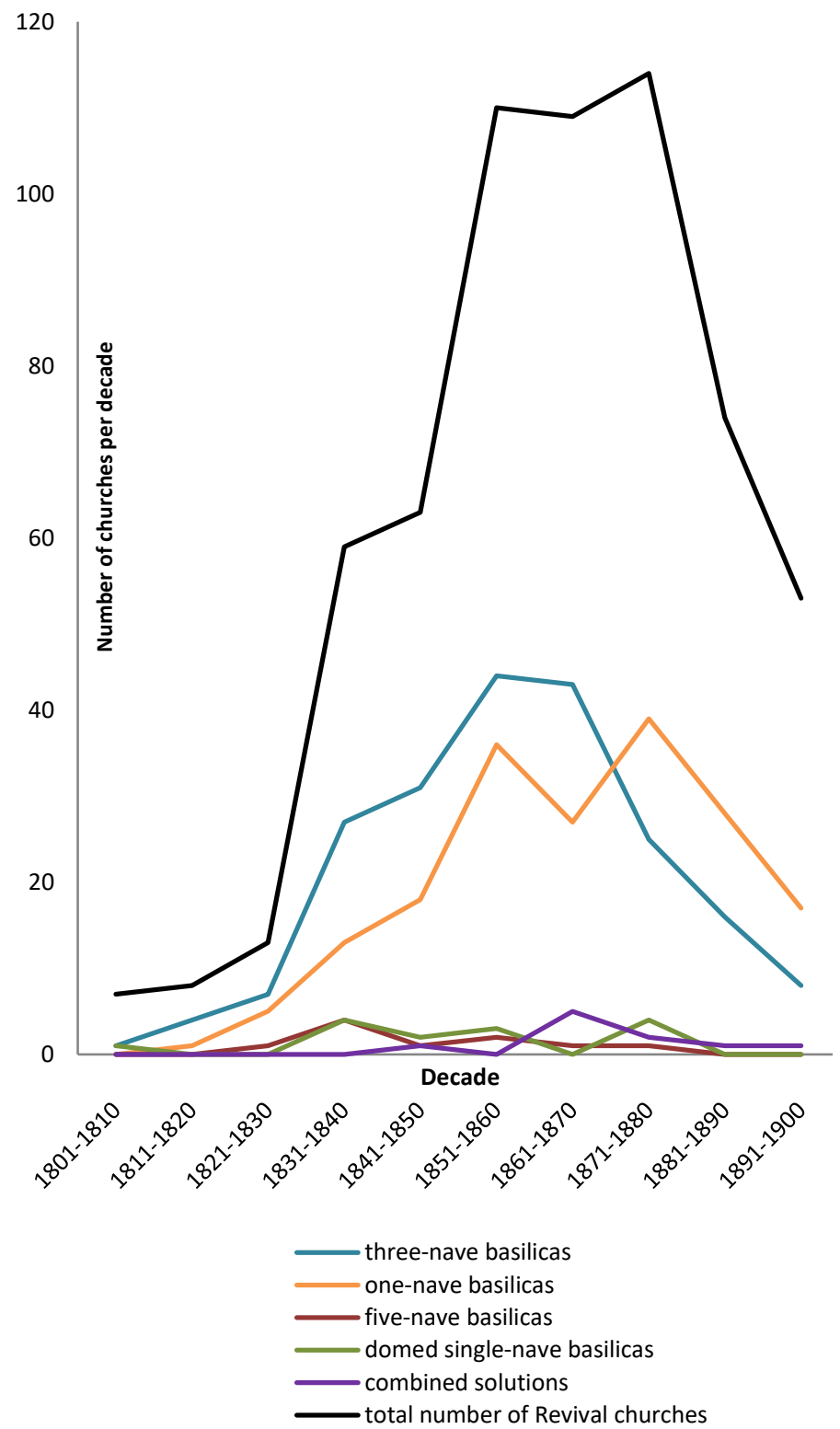

Chart V-2 Temporal distribution of the construction of the specific typological categories of Revival churches along the XIX century. actually reach their culmination, and only then would their numbers gradually decrease.

Certainly, the intensity of construction of the different typologies was again in line with the social atmosphere: the construction of the most monumental solutions, which required more material resources and greater expertise from the master-builders, coincided with the most favorable life conditions for the Christian inhabitants in the Ottoman society i.e. with those several decades of peace and a certain well-being officialized by the Tanzimat reforms. It comes as no surprise that these greater material resources and availability of the best master-builder groups were prevalent in the economically 
and socially fast-developing towns, which were also significantly more open to external influences and cultural and stylistical imports, as opposed to the rural settlements which were more traditionalist, and had much more limited resources at their disposal. It is precisely the bigger and richer towns throughout Macedonia where the largest three-nave and five-nave basilicas were built in the first decades of the XIX century as their cathedral churches: Berovo (in 1818), Bitola (in 1830), Valandovo (in 1830), Krushevo (in 1832), Kriva Palanka (in 1833), Kavadarci (in 1834), Skopje (in 1835), Struga (in 1835), Kratovo (in 1836), Negotino (in 1837), Ohrid (in 1838, in 1839, etc.), Prilep (in 1838), Veles (in 1840), Gostivar (in 1840), Gevgelija (in 1842), Resen (in 1843), etc. From these urban centers, the Revival construction boom soon spread to the surrounding rural areas. Later, in the second half of the century, especially in the years preceding or coinciding with the "Great Eastern Crisis", the monumental typologies were built to a lesser extent, and the single-nave churches dominated as constructively simpler to build, and thus cheaper and easier solutions and, as such, much more common in the rural environment.

In this context, it is interesting to follow the construction of the combined models, which appear later, towards the middle of the century, and culminate in the seventh decade. Their appearance and development were conditioned on one hand by the full legal liberalization completed only in 1856, and on the other by the natural process of development of knowledge and skills within the master-builder groups. Namely, after several decades of extremely intense practical work in a wide variety of ecclesiastical, residential, military or economy buildings, the Revival master-builders were able to produce and create bolder, more innovative models and solutions, which as demonstrated before would close the circle and herald completely different trends in the sacred architecture of the next century.

In addition to their different temporal representation by decades within the XIX century, the typological sub-groups of the Revival churches are also represented differently regarding their geographical distribution (map V-1), as was elaborated in detail before.

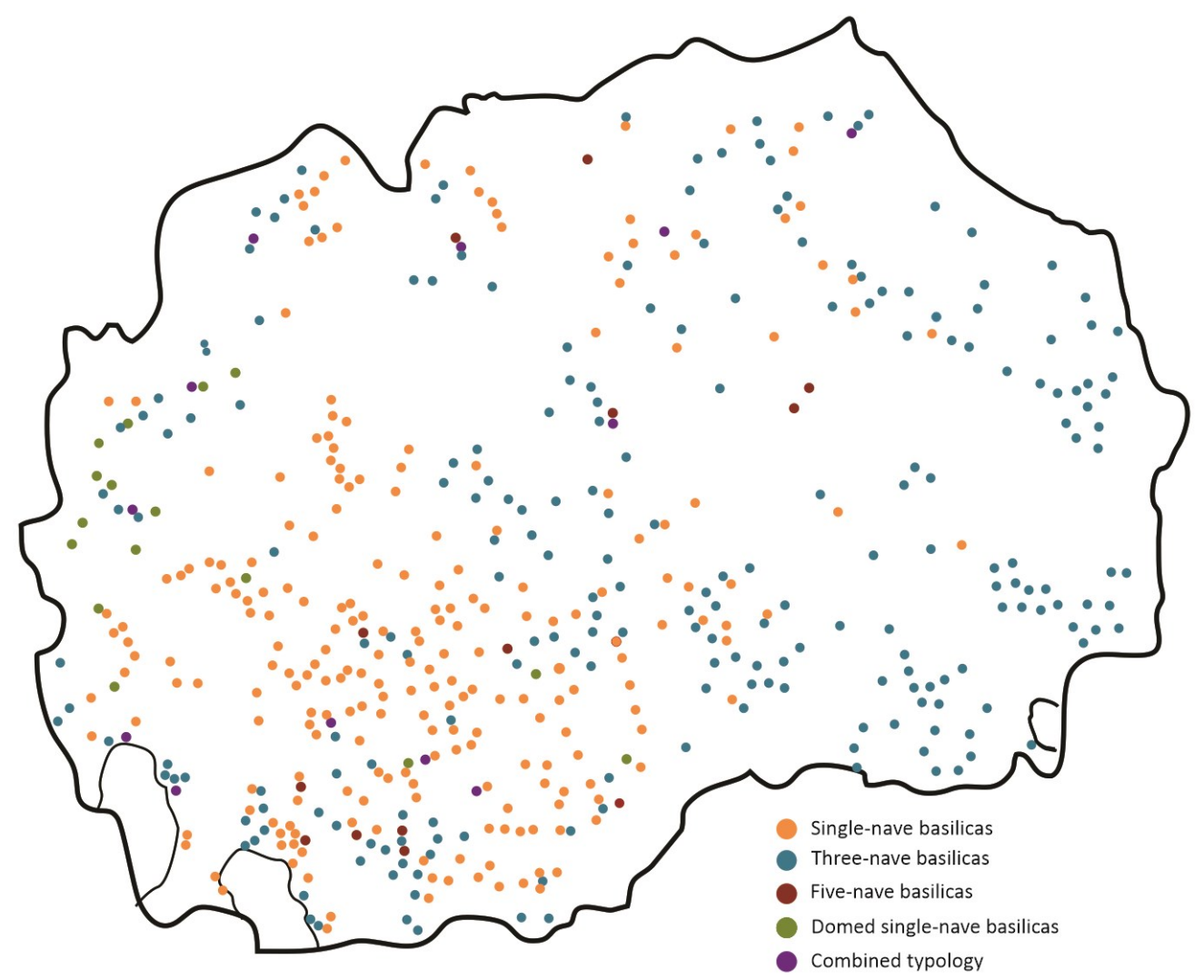

Map V-1. Geographical distribution of the XIX century Revival church typologies within Macedonia. 
In general, the division of eastern and western Macedonia facilitated with the Vardar river valley as a natural division, corresponds to the regions of domination of the three-nave and single-nave typological models, respectfully. In the eastern parts of Macedonia (the areas around the towns of Kochani, Vinica, Makedonska Kamenica, Berovo, Delchevo, Pehchevo) three-nave basilicas with flat wooden ceilings over all three naves predominate, often with an elevated central nave which received additional decorative processing - division into fields in which then rosettes were constructed over square, round or octagonal bases and radiant and cross-shaped motifs and coffer ceilings were regularly introduced. In some cases, a small blind dome was executed in the central nave: at the churches in the villages of Lipec, Blatec (fig. V.3), ${ }^{530}$ Pancharevo, Budinarci. As a specific local landmark, the gallery has a concave indentation correspondent to the central nave, ${ }^{531}$ instead of a balcony cantilevered above the naos as a more common and usual solution. The region of Sveti Nikole is also dominated by three-nave basilicas (in Sveti Nikole, Sopot, Mechkuevci and Bogoslovec), with open " $U$ "-shaped porches, lower than the naos itself. In addition to the typological solution, the churches from the region of the town of Sveti Nikole share similarities in their shaping and decorative processing: for example, at the church of St. Nicholas in Mechkuevci three windows with phytomorphic cross transennas are placed in a triangular composition on the western façade, identical to the church in Bogoslovec. Also, the wooden columns and capitals that support the porch are shaped in a similar way, with arches with a curved (convex) line and a profile obtained with the help of wooden planks and

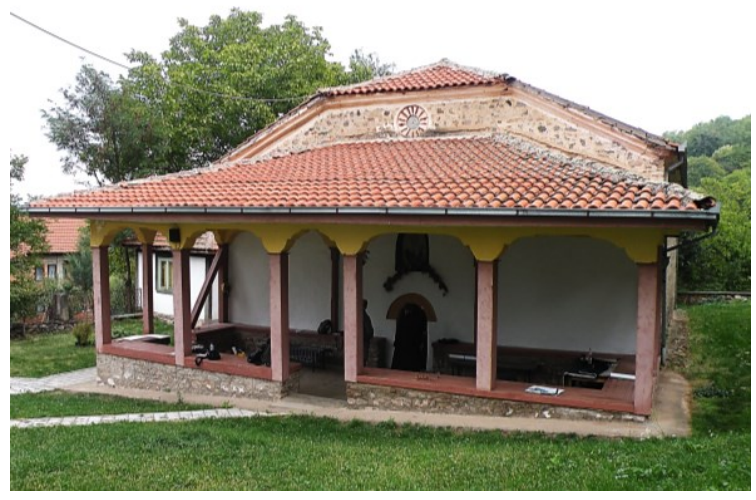

Figure V.3 St. Elijah in Blatec (Vinica). View from the west.

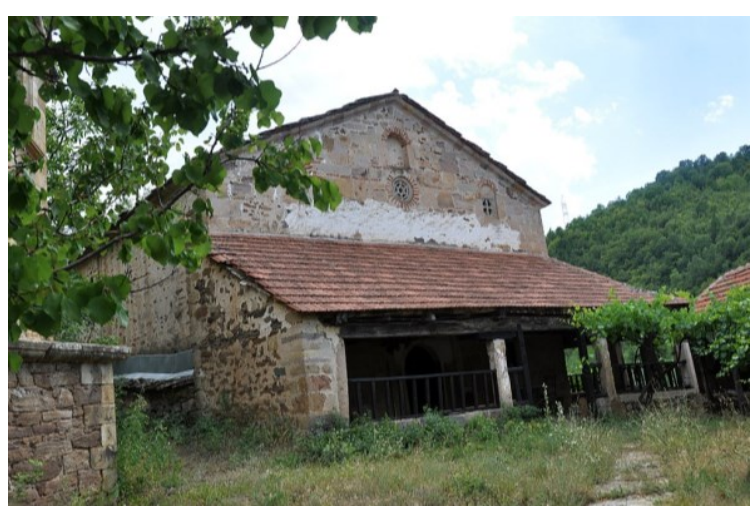

Figure V.4 St. Nicholas in Opila (Kriva Palanka). View from the north-west. plaster coatings. As in other regions, there is an evident strong local cult of a specific saint, to which several temples are dedicated, in this case St. Nicholas, after whom the regional town itself was named. Villages which today belong to other municipalities also gravitate towards it, such as the village of Orashac in the region of Kumanovo, where the church of St. Nicholas, though single-nave, can be connected with the Sveti Nikole Revival basilicas according to its characteristics - especially as far as the open arcade wooden porches are concerned.

In the north-eastern parts of Macedonia (the areas around the towns of Kumanovo, Kratovo, Kriva Palanka), the three-nave models also generally prevail. Such is the case with the churches from the region of Kriva Palanka (the church of St. Demetrius in the town itself, the churches in the villages Gradec, Rankovce, Radibush, Stracin, Rugjince, the Osogovo monastery), usually covered with a flat wooden ceiling decorated with coffer ceilings and, in some cases, with blind domes. An exception is the church in the village of Konopnica, which is a combined trefoil solution, as well as two one-nave churches in the villages of Ginovci and Petralica, which represent Revival renovations of churches from the post-Byzantine

\footnotetext{
530 The churches in the villages of Lipec and Blatec were both painted rather unusually, with representations of architectural complexes on the gallery fence and medallions with floral ornaments on the side walls which, together with the similarities in the architecture of these churches, indicate that probably they originate within the same master builder and painting workshop.

531 At the churches in Berovo, Budinarci, Vladimirovo, Negrevo, Pehchevo, Robovo, etc.
} 
period (i.e. from the XVII century). Another characteristic feature of this region's religious architecture is the quality masonry with well-hewn blocks of trachyte stone, and rarely with the use of brick. The processing of the window transennas is specific, in the form of complex filigree arabesques, for example

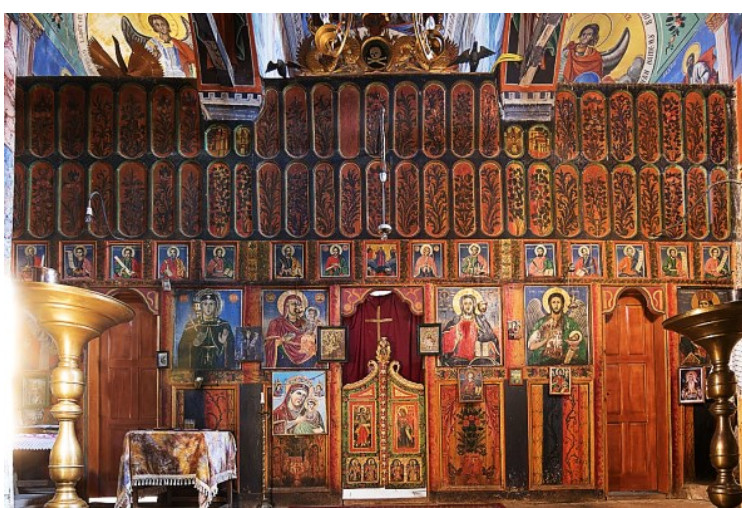

Figure V.5 St. Petka in Radibush (Kriva Palanka). View of the iconostasis. at the churches of St. John and St. Nicholas in Kratovo; the churches in the villages of Opila (fig. V.4), Zhegljane, the Zabel monastery, etc. As a local feature present in some of the churches of this group, ${ }^{532}$ although the height of the space allows a three-zone division of the iconostasis, still above the throne icons only one row of smaller icons (the Deisis and the prophets' icons) is placed, and above them flanking the Crucifixion develops a two-row array of very elongated and narrow oval panels painted with floral ornamentation - reminiscence of the tree of life motif (fig. V.5).

In the wider areas of south-eastern Macedonia (the areas around the towns of Strumica, Gevgelija, Demir Kapija, Dojran, Negotino and Kavadarci), the three-nave basilicas with a flat wooden ceiling again prevail as a typological solution (in some cases supplemented with blind domes, for example at the church in Novo Selo near Strumica), with a large semicircular altar apse without external dissection (an exception, for example, is the church in Monospitovo where the apse is composed of seven shallow, double niches separated by wide pilasters with capitals), nor decoration and, quite often, three windows on the eastern façade: a centrally placed window with a stone-carved transenna and two lateral windows, which are often shaped like a comma (at St. George in Novo Selo; St. Athanasius in Bosilovo). Even the single-nave churches in the region (in the villages of Bojanchishte, Gradishte, Glishikj) are covered with flat wooden ceilings. Most of Strumica's churches were later re-painted and supplemented with a bell tower placed on top of the western façade, or attached to it from the outer side, usually with a square or rectangular cross-section. The churches in the regions of Gevgelija and Tikvesh have largely preserved frescoes, and in some of them (in Garnikovo, Dragozhel, Resava) the narthex is separated from the naos by two additional columns (Ќорнаков, 1987: 168-169).

In the central areas of Macedonia, such as the region of Veles, the dominant typology consists of three-nave basilicas with monumental dimensions, built of crushed and carved stone, often with semicircular altar apses. Inside, prevail flat and coffer wooden ceilings or blind domes, while in some churches obviously built with mutual influences rarer features can be observed, such as an externally manifested central nave clerestory (for example, the churches in Papradishte and the neighboring village of Oreshe, as well as the church in Drachevo, a village which, although located outside of the region of Veles, still gravitates towards it).

In contrast, the single-nave typologies are more common in western Macedonia (areas around the towns of Makedonski Brod, Kichevo, Demir Hisar), with certain modifications and specific features for the individual regions that make it up. Thus, in the areas that gravitate around Makedonski Brod (fig. V.6), prevail single-nave basilicas with unusually pronounced height, compared to the width of the temple (for example, at the churches in Tomino Selo, Sushica, Topolnica, Gorno Krushje). The height of the buildings is additionally accentuated by an extremely pronounced, slender, polygonal (usually five-sided) altar apse, which occupies over $2 / 3$ of the height of the east façade and, in turn, is divided using slender columns

532 At the churches in the villages of Rankovce, Radibush, Opila and the church of St. Trinity in the village of German, built later, in the XX century. 
with a semicircular cross section, connected by arches. The, rectangular windows on the side facades are also elongated and, in the region of Makedonski Brod, characterized by exceptional processing, with precise carving and arrangement of the stone, as well as shaping of the arches and their profiling.
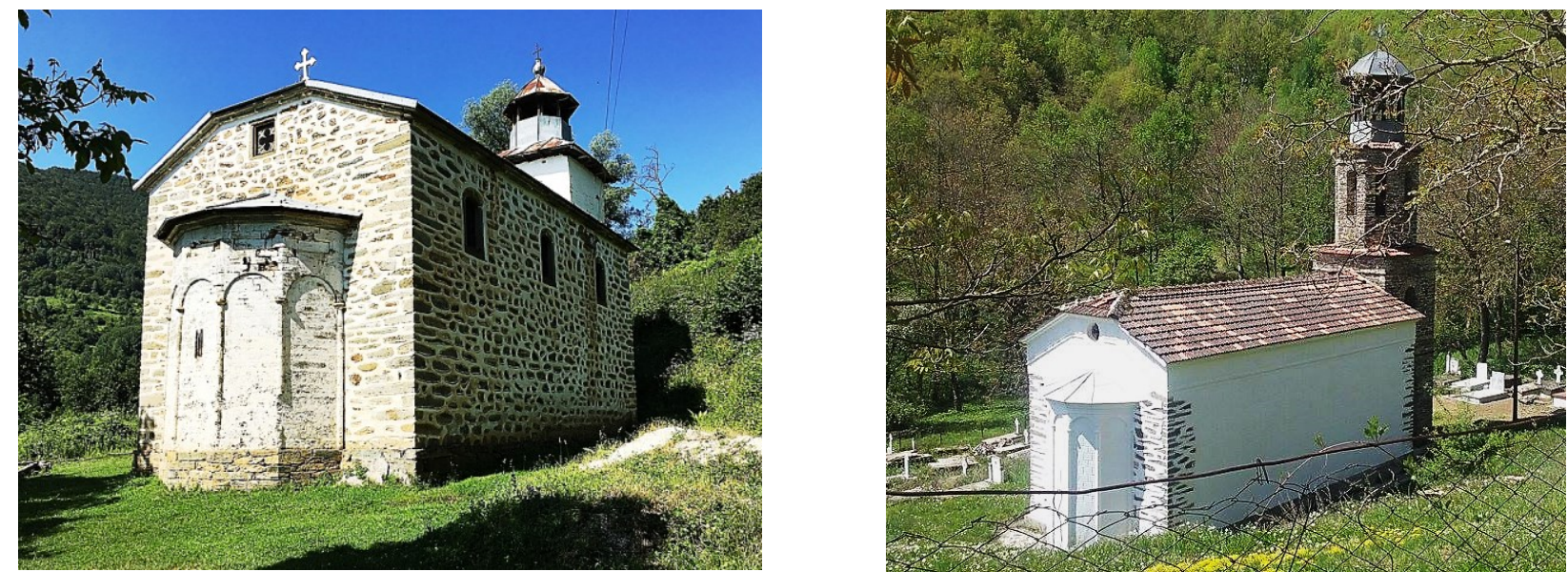

Figure V.6 A. St. Talalej in Gorno Krushje (Makedonski Brod); B. St. Athanasius in Topolnica (Makedonski Brod).

Another regional specific feature are the decorative protruding mortar joints (at Belica, Tomino Selo, Slansko, Greshnica, Gorno Krushje). At some of these churches where the masonry is preserved in its authentic condition, i.e. which have not been plastered later on, the type of masonry is also particularly interesting, specific for this region. Namely, thin stone slabs - slates were used, obviously easily accessible in the villages' surrounding environment, both for the construction of the arches of the portals or the windows, constructed with dense stacking of the slates, as well as on the façade canvases themselves, where fragments of such slates were inserted between the pieces of crushed stone in all directions in addition to horizontally, which contributes to a pictoresque effect of the masonry. In order to strengthen the facades, long stone blocks were placed in approximative layers, and especially at the corners of the building. Examples of this specific masonry procedure are found at the church of St. Nicholas in Dolno Krushje - where the arches of the patron saint niches within the portals are constructed in the described way, while the lintels themselves are carved from a single block of stone; at St. John in Kovach, etc.

Furthermore, as with the churches in Makedonski Brod, compact, very tall, slender buildings also dominate in the region of Kichevo, without additional vestibules, narthexes and, often, without open porches. The facades are sometimes decoratively processed with protruding mortar joints and mostly painted white later on (fig. V.7). Also, as in Makedonski Brod, they are characterized by very interestingly shaped portals and window openings, with evident baroque influences, " $S$ " volutes, floral reliefs, etc. The windows are also elaborate, placed into larger shallow niches, with architrave (at Belica, Prostranje, Kladnik) or arched (at Malo Crsko) lintels. In some cases, the niches are double (inscribed), and their height is especially emphasized.

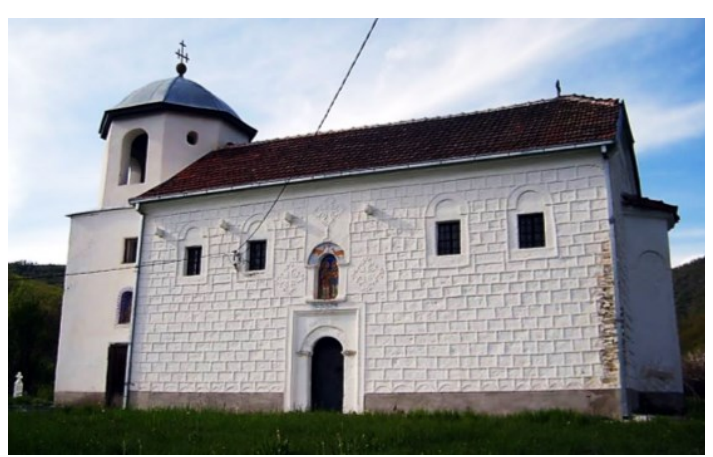

Figure V.7 St. Cosmas and Damian in Svetorache (Kichevo). View from the south-east.

In the region of Demir Hisar single-nave vaulted basilicas dominate, usually without a gallery and with a three-sided or five-sided altar apse. It is precisely from this region, based on local post-Byzantine monastery churches, that originate and here are most common the churches of the specific typology of single-nave vaulted basilicas with pilasters connected by arches in the side walls, in some examples with transverse ribs under the vault itself. Many of the Demir Hisar churches have stone facades with 
decorative protruding mortar joints and a completely gabled roof, without the trapezoidal shaping of the shorter facades. Often, closed narthexes were later added to the west side, and less often open porches, protecting the common appearance of fresco-painted western facades, which constitute another local feature characteristic for a number of churches in the region of Demir Hisar.

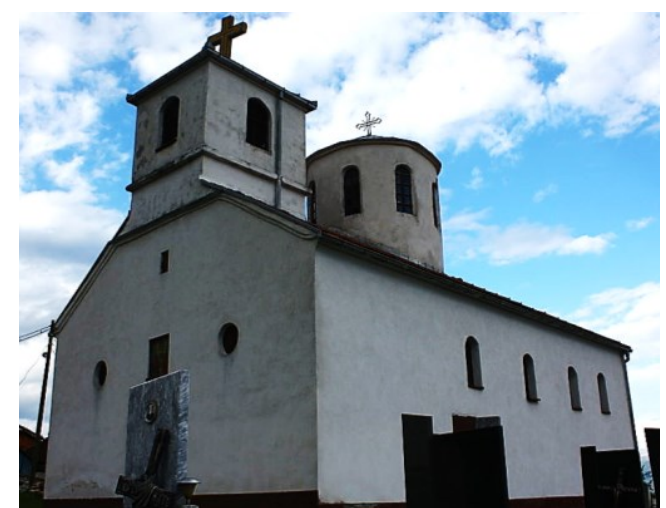

Figure V.8 St. Nicholas in Galate (Gostivar). View from the south-west.

In the north-western region (around the towns of Tetovo, Gostivar) the typological solution is not unified; however, a common specificity is the installation of a bell tower on top of the west façade (fig. V.8), following the example of some medieval churches built in the OhridCastoria cultural area. Such is the church St. Demetrius in Gostivar, which as the main town church was a prototype for the churches built later in the region: St. Petka in Gostivar, St. Nicholas in Zubovce; St. Elijah and St. Athanasius in Zhelezna Reka; St. John in Novo Selo; St. Nicholas in Belovishte; St. Archangel Michael in Krakornica; St. Nicholas in Galate.

In the south-western region of Macedonia (gravitating around the towns of Ohrid, Struga, Resen Prespa), the typological overview is also not completely unified. In the region of Struga (Malesija, Drimkol) single-nave churches with a semicircular, relatively high apse prevail, built of crushed stone, without external elaboration with pilasters or blind niches. Such examples are the Dormition of the Most Holy Mother of God in Modrich; St. Nicholas in Prisovjani; Introduction of the Most Holy Mother of God in Burinec; St. Sunday in R'zhanovo and St. Savior in Lokov (which were renovated in 1907 and 1930 respectfully, after their arson during the llinden Uprising); while St. Archangel Michael in Tashmarunishta, which also has a very high apse, was designed as a domed single-nave basilica. Unusually, over the apse and on the western façade predominate extremely small windows covered with stone-carved transennas, as cross-shaped openings or oval mandorlas. The solution of the vault in the nave is also characteristic: in the churches in Lokov and R'zhanovo the whole vault is bridged with a spacious blind dome, which is carried on the side walls reinforced with pilasters, and because both were restored after a fire during the Ilinden uprising, it can be deduced that the single-nave domed basilica model was restored on this occasion as an older local type, based on their original design. In some of the churches in this region, a closed narthex was added later on the west side, incorporated into the elongated church, using the same type of crushed stone masonry (such example is the Dormition of the Most Holy Mother of God in Zbazhdi).

In contrast to this predominant typology in the rural areas north of Struga, in the villages on the slopes of the mountain Jablanica, on the left side of the river Drim, large three-nave basilicas were most commonly built (in the villages Vevchani, Gorna and Dolna Belica, Jablanica). It is important to note that the villages of Gorna and Dolna Belica were inhabited in the XIX century by Vlach families, originaly from Moskopole. In addition to the three-nave disposition, these churches share other common features, such as façade pilasters (also present at the church in Oktisi), a high altar apse and stone masonry of the highest quality. Of course, the key to this architecture is the church in Vevchani, whose construction began half a century before that of the rest (see Chapter IV.5.B.3). The church in the village of Jablanica, built in 1886, has no façade arrangement using pilasters, but is characterized by a very tall apse, as well as exceptional quality masonry in carved and hewn stone.

In the urban areas in southwestern Macedonia (Ohrid, Struga, Resen) the dominant typology are three-nave basilicas with barrel vaults or blind domes. A completely unusual typology was applied at the churches of St. George in Soshani and the Most Holy Mother of God in Volino, both villages in the region of Ohrid. Namely, a transept appears in the upper zone of these single-nave churches, certainly under the 
influence of the older late-Byzantine churches built in Ohrid and its surroundings (see Chapter I.4.3) characterized by such a solution which was undoubtedly taken as a model, again in the spirit of romantic throwback to architecture of the past. At the church in Soshani, the transept is accentuated by a semicircular arched shallow niche, as well as an entrance portal placed in its axis on the south façade of the church.
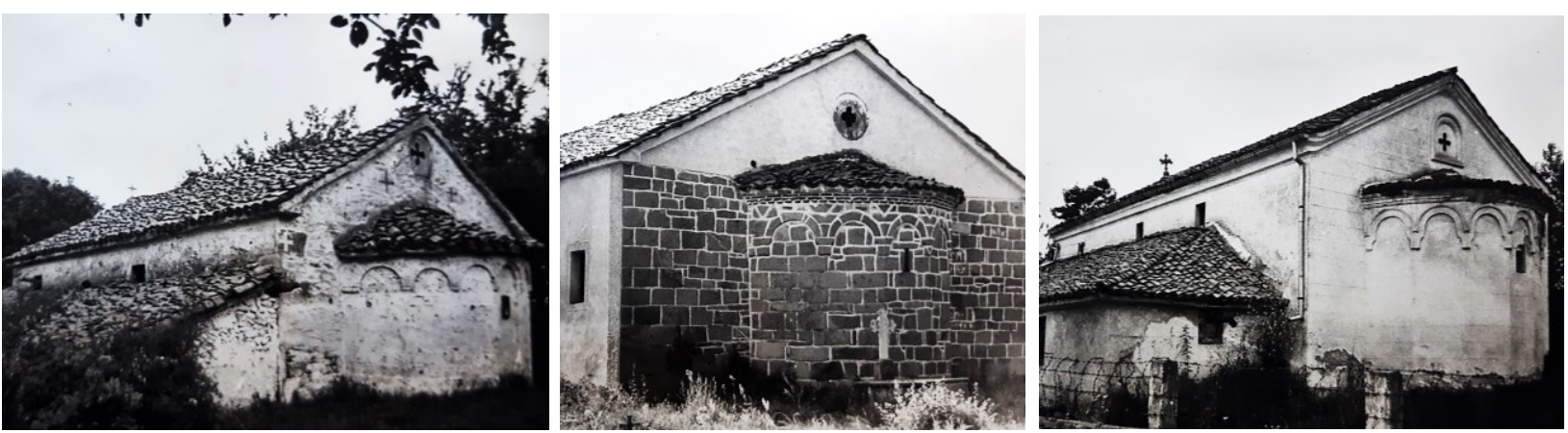

Figure V.9 Examples of altar apses with cantilevered blind arcades at churches in villages in the region of Prespa: A. St. George in Podmochani (Prespa); B. St. Nicholas in Nakolec (Prespa); C. St. Elijah in Ezerani (Prespa).

The Revival churches in the region of Prespa do not share a single typology. Three-nave basilicas (in Resen, Nakolec, Ljubojno, Dolno Perovo, Drmeni, Carev Dvor) and single-nave vaulted churches (in Ljubojno, Rajca, Dolna Bela Crkva, Grnchari) are equally represented; there are also two single-nave basilicas with side pillasters connected by arches (in Podmochani and Ezerani), whose solution is a remake of a local tradition based on an important post-Byzantine monastery church (the Slivnica Monastery). As a local characteristic, the churches in Prespa, regardless of their type, are covered by completely gabled roofs, without trapezoidal shaping of the east and west façade (fig. V.9). Furthermore, the churches in this region use brick, especially in the masonry of the apse and the eastern façade, even resembling the Byzantine opus cloisonné which consists of alternating rows of limestone and brick with vertical pieces of brick between the stone blocks (in Dolno Perovo and Drmeni). Lastly, as a local feature, in the upper zone of the apse (whether semicircular or polygonal) appears a frieze of blind arcades supported on small, decorative profiled consoles (in Resen, Podmochani, Nakolec, Ezerani, Drmeni, and Carev Dvor).

As for the other typological sub-groups, they also appear to be concentrated in certain regions. The domed single-nave basilicas originate from and prevail within the Debar-Reka region, in the extreme west of Macedonia, gravitating around the focal point - St. John - Bigorski Monastery (see Chapter III.5.D). Another common element found at many of the churches in the Reka region is the fencing of the church yard with a relatively high massive masonry wall and gate (in the villages Kichinica, Lazaropole, Tresonche, Janche, etc.) which was conditioned by the frequent raids and attacks of the Albanian gangs in this isolated mountain region close to the border (see Chapter III.1). The churches from the Debar-Reka region are characterized by exceptional quality of the masonry which enabled the vaulted parties to be built in a massive system (at the churches of St. Nicholas in Mavrovo, St. Nicholas in Tresonche, St. Elijah in Selce, the Bigorski monastery). As a local landmark, the gallery parapet fence, the so-called emporia, was completely fresco-painted (at both churches in Tresonche, in Selce, Trebishte and Rosoki). Lastly, the fivenave basilicas (see Chapter III.5.C) and the combined typological solutions (see Chapter III.5.E), in accordance with their nature, are built predominantly in the urban areas (Skopje, Veles, Prilep, Shtip, Bitola) as the town's cathedral churches; as monastic catholicons (the Slepche Monastery); and in several exceptionally developed villages, especially in the region of Bitola.

From all of the above, it can be concluded that the dominance of a specific typological solution was based on two principal phenomena. According to the first model, the chosen typology was based on pronounced local influences from important ecclesiastic buildings of the past, often important monastic 
churches that were historically revered as the holiest of places, centers of spiritual culture and literacy that united the Macedonian people during the long centuries of the Ottoman occupation. The most striking example are the vaulted single-nave churches with side pilasters connected by arches from the south-western parts of Macedonia, which had spread in a geographical area that coincides with the location of the post-Byzantine churches that served as a prototype for the development of this specific typology. The second model refers to the intensive construction of Revival churches by the same construction teams within a particular region, or by local construction "schools", which had already established their own recognizable style, were appriciated and sought after, and whose movement from village to village marks the spreading and transformation as well as the adaptation of the typological solution specific for them. A striking example of this phenomenon are the three-nave basilicas in southeastern Macedonia, especially in the region of Gevgelija-Dojran, which were built almost without exception by the master-builder group of Andon Kitanov; then, the three-nave basilicas in the region of Prespa (Resen, Drmeni, Carev Dvor) which were also obviously built according to the same pattern; the domed single-nave basilicas, which extend to the south and east from an epicenter in the Debar-Reka region, and other examples.

\section{Construction systems, materials and structure}

As was elaborated in detail before, the XIX century Revival ecclesiastical architecture truly embraced the combined structural system comprised of massively built perimeter walls, predominantly constructed with masonry in hewn, cut or crushed stone of various type and provenance and lime mortar as a binder, and an interior structure (galleries, columns, arches, architraves, vaults, blind domes and a wide array of interior furnishings, ornaments and decoration) constructed entirely out of wood. It is clear that this system was favored since it allowed for the construction of churches with less financial means and in a shorter amount of time, which resulted in a greater mobility of the master-builder groups that could therefore work with incredible intensity and cover vast territories. Also, this combined system allowed for the appearance and proliferation of a wide variety of structural and decorative elements executed in wood, kjulum paste, plaster and mortar coatings, resulting in an abundance of ornament and great picturesqueness of the churches' interiors.

However, as was said, there are examples of Revival churches executed entirely out of stone masonry. Which of these two construction systems was chosen for each individual church was a complex matter dependent on several conditions.

On one hand, the determining factor was the availability of different construction materials in the vicinity of the construction site and, directly linked to it, the financial repercussion of the provision of high quality hewn stone blocks and their transport to the location from distant quarries. Therefore, it comes as no surprise that the churches with upper parties constructed out of stone were built predominantly in the western part of Macedonia, where such stone was abundant and more available. Of course, it must not be forgotten that this was also the region of origin of the best and most sought after master-builder groups (the Debar - Reka master-builder "school") whose proven experience, know-how and mastery of masonry and the accompanying crafts were another important factor contributing to the chosen construction system. In other words, the construction of churches entirely out of stone blocks was reserved for the financially well off communities, whether urban, rural or monastic, who could afford the cost of such construction and accordingly the master-builder groups that could execute it.

Nevertheless, the availability of material resources appears not to have been the crucial determinant. This is made evident when enumerating the most monumental town cathedral churches, 
predominantly five-nave and three-nave basilicas, which were without exception erected using the combined structural system. The chosen structural system in their case was, of course, closely linked to the elected typology, as well as the persona of the contracted master-builder and his already established architectural expression. An illustration to this trend are the grandiose five-nave basilicas whose dimensions, spans and general nature of the building undoubtedly conditioned their construction as a combination of a massively built masonry shell and light-weight wooden internal structure. As for the extremely important role of the architect (master-builder), it is clear that the more famous master-builder groups had an already well established architectural vocabulary, a certain type of church which they were famous for and which they consistently applied, of course with many alterations, improvements, and embellishments dependent on the particular church in question, the demands of the founders and church councils, the available funds, materials and expertise, as well as their own professional evolution with the passage of time and the accumulated experience. For example, Andreja Damjanov's work is comprised basically of monumental five-nave basilicas built with combined construction systems, applied consistently even in the case when he chose a different architectural typology, such as the Osogovo monastery where even though the columns were executed in stone, they still support an upper lightweight wooden construction, despite its complex, elaborate multi-domed elevation. Another example is the opus of Andon Kitanov, who is the author of numerous three-nave basilicas covered with flat wooden ceilings concentrated in the south-eastern regions of Macedonia, as well as a group of three such basilicas which have three domes supported on elevated drums in the central nave (see Chapter III.5.B.5).

It can therefore be concluded that the most important factor when choosing the construction system was the previously chosen typology. Namely, all of the Revival churches which were constructed entirely of stone are either single-nave domed basilicas (St. John - Bigorski monastery, St. Nicholas in Tresonche, St. George in Lazaropole, the Immaculate Mother of God - Krninski monastery near Kichevo, St. Achilles in Trebishte, St. George in Rajchica, etc. see Chapter III.5.D), a combination of such domed basilicas with a trefoil solution (St. John - Slepche monastery, St. Elijah in Selce, etc. see Chapter III.5.E), or three-nave basilicas with blind domes (St. Nicholas in Mavrovo, etc.). In other words, once more, the crucial determinant was the need to copy, imitate or transform an existing church considered as a model - prototype, be the reasons of ideological, aesthetic or other nature, certainly in line with the very nature of the Revival movement itself and its interpretative, associative and eclectic essence. 
380 | THE XIX CENTURY BASILICAS IN MACEDONIA: ORIGIN, TYPOLOGY AND INFLUENCES 


\section{CONCLUSIÓN. FUTURAS LÍNEAS DE INVESTIGACIÓN}

En conclusión, se puede decir sin lugar a dudas que la arquitectura sacra del movimiento del s. XIX conocido como "Renacimiento" es el colofón del largo desarrollo de la construcción macedonia, tanto en términos de monumentalidad, la excepcional diversidad de modelos tipológicos, como en términos de logros máximos en las artesanías que la componen. A pesar de la obvia disponibilidad hacía, condicionalmente hablando, influencias "extranjeras", los maestros constructores, pintores y talladores de madera del Renacimiento no fueron imitadores ciegos de las matrices modernas entonces actuales, sino más bien creadores de una arquitectura nueva, específica y única, utilizando básicamente un método de compilación. Con una facilidad admirable derivada de la larga tradición, su proceso creativo fue el resultado de un método intuitivo, muchos años de formación práctica dentro de los grupos de construcción de sus familias y su capacidad innata. Además, no pertenecer a ninguna escuela académica formal o estilo "nacional" les permitió una libertad excepcional para combinar fórmulas, modelos y patrones arquitectónicos tradicionales con un compromiso creativo y ecléctico de un contexto histórico y cultural más amplio. De manera impresionante, todo esto fue logrado con herramientas y técnicas primitivas, con materiales disponibles localmente, exclusivamente a mano, sin el uso de materiales de construcción prefabricados industriales o aparatos y ayudas técnicas desarrolladas.

Como se muestra en las páginas anteriores, con respecto a sus excepcionales logros arquitectónicos y artísticos, las basílicas del Renacimiento más representativas no son inferiores a los principales logros del patrimonio arquitectónico bizantino medio y paleocristiano, que fueron imitados en el espíritu del romanticismo característico de la época. La diferencia esencial es que las iglesias monumentales más antiguas fueron construidas dentro de escuelas de arquitectura generalizadas, bajo el patrocinio de las más altas autoridades eclesiásticas y seculares dentro de poderosos reinos e imperios, mientras que las basílicas del Renacimiento fueron construidas para el hombre común, por un hombre común - el maestro de obras, y la actitud de la gente hacia la iglesia fue "más inmediata, más cercana" (Кораћ и Шупут, 1998: 392). Aunque sin educación formal y originario de una zona rural, el talento excepcional del maestro constructor le permitió superar la multiplicación mecánica de los modelos de iglesia más simples ya establecidos en el período posbizantino y comenzar a crear una nueva dirección arquitectónica específica. Sin embargo, son precisamente estos siglos de restricciones excepcionales sobre la arquitectura sagrada cristiana infligidas por el estado ocupante otomano los que son cruciales para dar forma a la puesta en escena en la que los maestros constructores del Renacimiento crearon el nuevo estilo arquitectónico. Es más, la brusca ruptura con la corte bizantina provocada por las conquistas otomanas en los Balcanes y la posterior desintegración del Imperio también provocó una parada en el desarrollo evolutivo de las líneas 
estilísticas lógicas de la arquitectura sagrada del período bizantino tardío. No importa cuán negativos fueran para la población cristiana macedonia estos fenómenos, para los maestros constructores permitieron una cierta distancia de las conexiones directas con lo medieval, es decir, facilitaron experiencias de construcción nuevas y diferentes.

En esos siglos de aparente estancamiento, los maestros constructores se vieron obligados, reduciendo el programa eclesiástico bizantino tradicional, a crear nuevas soluciones espaciales: además de la estructura de bóveda de una sola nave de amplia distribución, aparecieron iglesias de una nave con bóvedas transversales, iglesias de una nave abovedadas con pilastras laterales conectadas por arcos, e incluso (aunque esporádicamente) soluciones combinadas de una nave con conchas laterales, así como varias basílicas de tres naves. El papel de estas últimas como eslabones en el hilo continuo de las tipologías basilicales en suelo macedonio desde la época paleocristiana hasta la actualidad es de una importancia excepcional. Exactamente esas experiencias, así como la ocupación dominante con la arquitectura residencial y vernácula que serviría para su especialización en el trabajo con madera y sistemas de construcción de marcos de madera, prepararon a los maestros constructores macedonios para el amplio campo de la expresión creativa del Renacimiento del siglo XIX complementado por la afluencia de elementos e influencias externas estilísticas, culturales y de otro tipo.

Por supuesto, el proceso para recibir diversas influencias no es unidireccional: además de absorber de las distintas fases históricas de la arquitectura macedonia y, en un contexto más amplio, la arquitectura sacra bizantina, de la arquitectura residencial y vernácula, de otros entornos vecinos y distantes, y expresiones estilísticas más antiguas o contemporáneas, la arquitectura del Renacimiento transmitió igualmente su influencia, tanto espacialmente a través de la Península Balcánica como temporalmente. Esto es especialmente evidente en la larga existencia del tipo basilical a pesar de los cambios socioeconómicos esenciales, en lo profundo del siglo XX y hasta el día de hoy.

Por último, se puede concluir que se han cumplido los principales objetivos de esta tesis doctoral:

- Se identificó el origen y la influencia de la arquitectura sacra monumental del período conocido como Renacimiento del siglo XIX, cuya solución dominante es la tipología basilical;

- Se confirmó su posible conexión con la arquitectura basilical de la corte del reino de Samuel (siglos $\mathrm{X}$-XI) y su importancia;

- Se mostró la influencia del prototipo para dicha arquitectura: las basílicas del período paleocristiano.

Además, se lograron los resultados esperados:

- Como resultado primario, se confirmó la hipótesis inicial: el monumental edificio sagrado del siglo XIX y su tipología basilical es un caso de "resurrección" de una tipología arquitectónica antigua y mayoritariamente abandonada inspirada en los períodos históricos más importantes de Macedonia, como un proceso característico de las épocas de renacimiento social.

- Como resultados secundarios, se ha profundizado en el conocimiento de la arquitectura sacra monumental del siglo XIX; Se elaboró documentación fotográfica y planos técnicos de diversas iglesias que enriqueció la documentación existente de este tipo de patrimonio construido, que por sí mismo permitiría futuras investigaciones, análisis y estudios comparativos, contribuyendo al mismo tiempo a la valorización, protección y revitalización de este conjunto de monumentos.

¿Cuáles son las posibles líneas de investigación futuras en el contexto de la arquitectura sacra del Renacimiento?

El trabajo de investigación relacionado con la preparación de esta tesis doctoral, además de la investigación de fuentes primarias, las propias iglesias del Renacimiento (trabajo de campo), consistió en gran parte en la investigación de la documentación, los archivos y la bibliografía existentes. Además de la documentación preparada por el autor para las necesidades de esta tesis doctoral, fue consultada gran 
cantidad de documentación de dibujos y fotografías que fue compartida desinteresadamente por parte del Instituto de Protección del Patrimonio Arquitectónico, Historia del Arte y la Arquitectura de la Facultad de Arquitectura de Skopje, el Instituto de Folklore "Marko Cepenkov" de la Universidad "Santos Cirilo y Metodio"- Skopje, así como documentación de los archivos de los Institutos para la Protección de Monumentos Culturales y Museos en Ohrid y Bitola, y el Centro Nacional de Conservación de Macedonia. De ese modo, la necesidad y los beneficios de la cooperación interinstitucional para unir la documentación existente de las iglesias del Renacimiento y su futura actualización quedaron prácticamente demostradas, no solo dentro de Macedonia, sino también en cooperación con las instituciones profesionales competentes para la protección de monumentos culturales e instituciones científicas de países vecinos que comparten este importante patrimonio arquitectónico común.

La investigación llevada a cabo a lo largo de varios años completada permitió una revisión exhaustiva de la arquitectura sacra del Renacimiento en Macedonia, que ha sido inexistente e inédita hasta la fecha, en la que se registraron más de 800 basílicas del Renacimiento del s. XIX, de las cuales 605 fueron fechadas con precisión (según el año de construcción, consagración del templo o su pintura al fresco), utilizando inscripciones conservadas, referencias bibliográficas e históricas, etc. Por lo tanto, se puede decir que se estableció una base de datos inicial de la construcción sacra del Renacimiento, que permite su catalogación, clasificación y documentación continua, sistemática y completa. Esta significativa cifra estadística permite la conducción de varias líneas de investigación adicionales. Entre ellas en esta tesis doctoral se analizaron la intensidad de la construcción de las iglesias Renacimiento por años / décadas; su distribución geográfica dentro de las fronteras actuales de Macedonia y, por supuesto, su tipología arquitectónica. En ese sentido, la clasificación tipológica realizada en esta tesis doctoral no puede considerarse definitiva ni por el número de subcategorías tipológicas propuestas, ni por el número de iglesias pertenecientes a esas subcategorías, porque su número total no es exhaustivo. Por lo tanto, como una continuación lógica de esta investigación científica, se planea que la clasificación tipológica de las iglesias del Renacimiento en Macedonia sea mejorada, ampliada y actualizada con nuevas perspectivas y conocimientos científicos en el futuro. En este contexto, es posible profundizarla tanto horizontalmente, descubriendo nuevas subcategorías tipológicas adicionales, como verticalmente, mediante un estudio monográfico más detallado de los monumentos representativos individuales del "Renacimiento" del s. XIX. 


\section{CONCLUSION. FUTURE LINES OF INVESTIGATION}

In conclusion, it can without a doubt be said that the Revival sacred architecture is the crown of the long-term development of Macedonian construction, both in terms of monumentality, the achieved exceptional diversity of typological models, and in terms of top achievements in the crafts that comprise it. Despite the obvious availability to, conditionally speaking, "foreign" influences, the Revival masterbuilders, painters and wood-carvers were not blind imitators of the then current, modern matrices, but rather creators of a new, specific, unique architecture, using basically a compilation method. With admirable ease arising from the long-standing tradition, their creative process was the result of an intuitive method, many years of practical training within family-led construction groups and their innate capacity. Furthermore, not belonging to any formal academic school or "national" style allowed them exceptional freedom to combine traditional architectural formulas, models and patterns with creative, eclectic engagement from a broader historical and cultural context. In an impressive way, all this was achieved with primitive tools and techniques, with locally available materials, exclusively by hand, without the use of industrial prefabricated building materials or developed technical apparatus and aids.

As shown on the previous pages, regarding their exceptional architectural and artistic achievements, the most representative Revival basilicas are not inferior to the top achievements of the middle-Byzantine and early-Christian architectural heritage, which were imitated in the spirit of Romanticism characteristic of the epoch. The essential difference is that the older monumental churches were built within widespread architectural schools, under the patronage of the highest ecclesiastical and secular authorities within powerful kingdoms and empires, while the Revival basilicas were built for the common man, by a common man himself: the master-builder, thus the attitude of the people towards the church was "more immediate, closer" (Кораћ и Шупут, 1998: 392). Although without formal education and originating from a rural area, the exceptional talent of the master-builder allowed him to rise above the mechanical multiplication of the already established simpler church models in the post-Byzantine period and begin to create a new, specific architectural direction. Yet, in fact, it is precisely these centuries of strict regulations and restrictions on the Christian sacred architecture inflicted by the Ottoman occupant state that are crucial to shaping the mise-en-scène in which the Revival master-builders created the new architectural style. Namely, the sharp break with the Byzantine court caused by the Ottoman conquests in the Balkans and the subsequent disintegration of the Empire, also caused a stop to the evolutionary development of the logical stylistic lines of the sacred architecture of the late-Byzantine period. No matter how negative they were for the Macedonian Christian population, these phenomena for the master-builders enabled a certain distance from the direct connections with the medieval, i.e. new and different construction experiences. In those centuries of apparent stagnation, the master-builders 
were forced, reducing the traditional Byzantine ecclesiastical program, to create new spatial solutions, in addition to the widespread small single-nave vaulted structure: single-nave churches with transverse vaults, single-nave vaulted churches with lateral pilasters connected by arches, and even (although sporadically) combined trefoil solutions, as well as several three-nave basilicas whose role as links in the continuous thread of the basilical typologies on Macedonian soil from the early-Christian period to the present day is of exceptional importance. Exactly those experiences, as well as the dominant occupation with residential and vernacular architecture that would serve towards their specialization in the work with wood and wooden frame construction systems, prepared the Macedonian master-builders for the wide field of creative expression enabled by the XIX century Revival, complemented by the influx of foreign elements and external stylistic, cultural and other influences.

Of course, the process of receiving various influences was not one-way: as much as it absorbed from the historical layers of Macedonian and, in a broader context, Byzantine sacred architecture, from the residential and vernacular architecture, from other neighboring and distant environments and older or contemporary stylistic expressions, the Revival architecture equally transmitted its influence, both spatially across the Balkan Peninsula as well as temporarily. This is especially evident in the long existence of the basilica type despite the essential socio-economic changes, deep in the XX century and to this day.

Lastly, it can be concluded that the main goals of this doctoral dissertation have been met:

- the origin and the influence of the monumental sacred architecture from the period known as the XIX century Revival were identified, whose dominant solution is the basilica typology;

- its potential connection with the court basilica architecture of Samuel's kingdom (X-XI century) and its significance were confirmed;

- the influence of the prototype for such architecture: the basilicas of the early-Christian period, was shown.

Also, the expected results were achieved:

as a primary result, the initial hypothesis was confirmed: The monumental sacred building from the XIX century and its basilica typology is a case of "resurrection" of an old and mostly abandoned architectural typology inspired by the most important historical periods in Macedonia, as a process characteristic of the epochs of social revival.

as secondary results, the knowledge of the monumental sacred architecture from the XIX century has been deepened; drawing and photo documentation of various churches was prepared which enriched the existing documentation of this type of built heritage, that would itself enable future research, analysis and comparative studies, at the same time contributing to the valorization, protection and revitalization of this group of monuments.

What are the possible future lines of research in the context of the Revival sacred architecture?

Namely, the long-term research work related to the preparation of this doctoral dissertation, in addition to the research of primary sources - the Revival churches themselves (field work), consisted to a large extent of research of existing documentation, archives and bibliography. In addition to the documentation prepared by the author for the needs of this doctoral dissertation, existing drawing and photo documentation was selflessly shared by the Institute for Protection of Built Heritage, History of Architecture and Art at the Faculty of Architecture in Skopje, the Institute of Folklore "Marko Cepenkov" at "St. Cyril and Methodius" University - Skopje, as well as documentation from the archives of the Institutes for the Protection of Monuments of Culture and Museums in Ohrid and Bitola, and the National Conservation Center of Macedonia. Thereby, the need and benefits of inter-institutional cooperation in order to unite the existing documentation of Revival churches and its future upgrade were practically proved, not only within Macedonia, but also in cooperation with the professional competent institutions 
for protection of cultural monuments and appropriate scientific institutions in neighboring countries which share this important common architectural heritage.

The completed several-year research yielded a thorough review of the Revival ecclesiastical architecture in Macedonia, that has been non-existent and unpublished up to date, in which over 800 Revival basilicas were recorded, of which 605 were accurately dated (according to the year of construction, consecration of the temple or its fresco-painting), using preserved inscriptions, bibliographic and historical references, etc. Thus, it can be said that an initial database of the Revival sacral construction was established, which enables its further continuous systematic and thorough cataloging, classification and documentation. This significant statistical figure allows for the conduct of various further lines of research, among which are the analysis of the intensity of construction of the Revival churches by years / decades; analysis of their geographical distribution within the present borders of Macedonia and, of course, analysis of their architectural typology, which were completed in this doctoral dissertation. In that sense, the typological classification made in this doctoral thesis cannot be considered final either by the number of proposed typological sub-categories, or by the number of churches belonging to those subcategories, because their total number is not exhaustive. Thus, as a logical continuation of this scientific research, the typological classification of the Revival churches in Macedonia will be upgraded, expanded and updated with new scientific insight and knowledge in the future. In this context, it is possible to upgrade it both horizontally - by discovering new, additional typological sub-categories and identifuing the individual monuments which belong to these groups, and vertically - by a more detailed, monographic study of individual representative Revival monuments. 


\section{ANNEX}

\section{Chronological Overview of the XIX Century Churches in Macedonia}

1800

1. "St. John" - Bigorski monastery, DEBAR

2. "St. Savior", NOGAEVCI (Veles), 1800-1820

\section{1}

3. "St. Nicholas", PODMOCHANI (Prespa)

1802

4. "St. John", KOVACH (Makedonski Brod)

1804

5. "St. Nicholas", VRANISHTA (Struga)

1807

6. "St. Petka", GALICHNIK (Debar)

1812

7. "St. Elijah", DOBREJCI (Strumica)

8. "St. Elijah", MARCHINO (Probishtip)

1817

9. "Dormition of the Most Holy Mother of God", VATASHA (Kavadarci)

1818

10. "St. Archangel Michael", BEROVO

11. "The Most Holy Mother of God", LESHOK (Tetovo)

1820

12. "St. Nicholas", ULANCI (Veles), 1820-1830

13. "St. Savior", SKOPJE

1821

14. "St. Athanasius", VOJNICA (Veles)

1825

15. "St. John Theologan”, BOGOSLOVEC (Sveti Nikole)

1826

16. "St. Elijah", GRADESHNICA (Mariovo)

17. "St. Nicholas", BOLNO (Prespa)

18. "St. Savior - Ascension of Christ", KRUSHEVO
19. "Nativity of the Most Holy Mother of God", KANINO (Bitola)

20. "St. Archangel Michael", KRUSHEVICA (Mariovo)

21. "St. Archangel Michael", SREDNO EGRI (Bitola)

22. "St. Demetrius", BITOLA

23. "St. Demetrius", DIHOVO (Bitola)

24. "St. Demetrius", SMOKVICA (Gevgelija)

25. "St. Demetrius", VALANDOVO

26. "St. Nicholas", TRKANJE (Kochani)

1831

27. "St. Constantine and Helena", TOMINO SELO (Makedonski Brod)

28. "St. Elijah", RADOVISH, 1831-1859

29. "St. George", GORNO SRPCI (Bitola)

1832

30. "St. Nicholas", KRUSHEVO

31. "St. Petka”, DOLNO EGRI (Bitola)

1833

32. "St. Demetrius", KRIVA PALANKA

33. "St. George", LAZAROPOLE (Debar), 1832/1833

1834

34. "Dormition of the Most Holy Mother of God", GJAVATO (Bogdanci)

35. "St. Demetrius", KAVADARCI

36. "St. George", SERMENIN (Gevgelija)

1835

37. "Dormition of the Most Holy Mother of God", GJAVATO (Bitola)

38. "Introduction of the Most Holy Mother of God", ROSOKI (Debar)

39. "St. Demetrius", MAGAREVO (Bitola)

40. "St. George", BREZOVO (Demir Hisar)

41. "St. George", RAJCHICA (Debar)

42. "St. George", STRUGA

43. "St. Petka", NIZHEPOLE (Bitola)

44. "St. Petka", TRAP (Bitola)

45. "The Most Holy Mother of God", SKOPJE 
46. "St. Athanasius", LENISHTE (Prilep)

47. "St. John", KRATOVO

48. "St. Mercury", BARESHANI (Bitola)

49. "St. Nicholas", DOLNO VODNO (Skopje)

1837

50. "Holy Transfiguration - St. Sotir" (Bukovo monastery), BUKOVO (Bitola)

51. "St. Athanasius", BOGOMILA (Veles)

52. "St. Athanasius", NEGOTINO

53. "St. Athanasius", ZHABJANI (Bitola)

54. "St. George", NOVOSELANI (Prilep)

55. "St. Mina", GARNIKOVO (Kavadarci)

56. "St. Nicholas", LERA (Bitola)

57. "The Most Holy Mother of God", TRNOVO (Bitola)

\section{8}

58. "St. Annunciation", PRILEP

59. "St. Archangel Michael", OPTICHARI (Bitola)

60. "St. Constantine and Helena", MONOSPITOVO (Strumica)

61. "St. Demetrius", KAVADARCI

62. "St. Elijah", VELMEVCI (Demir Hisar)

63. "St. George", TROJACI (Prilep)

64. "St. George", Gorna Vlashka Maala, OHRID

65. "St. Nicholas", BASHINO SELO (Veles)

66. "St. Nicholas", ZRKLE (Makedonski Brod)

\section{9}

67. "St. Archangel Michael" - Boshava monastery, DOLNA BOSHAVA (Kavadarci)

68. "St. George", OLEVENI (Bitola)

69. "St. George", VELUSHINA (Bitola)

70. "St. Savior - Ascension of Christ", ORAOVEC (Veles)

71. "The Most Holy Mother of God Kamensko", OHRID

1840

72. "Dormition of the Most Holy Mother of God", LEUNOVO (Mavrovo)

73. "Holy Trinity", PODLES (Veles), 1840-1850

74. "Nativity of the Most Holy Mother of God", VASILEVO (Strumica)

75. "St. Achilles of Larisa", TREBISHTE (Debar)

76. "St. Archangel Michael", RESAVA (Kavadarci)

77. "St. Constantine and Helena", LUBNICA (Radovish)

78. "St. Demetrius", GOSTIVAR

79. "St. Nicholas", BROD (Mariovo)

80. "St. Nicholas", VELMEJ (Ohrid)

81. "St. Nicholas", VLADILOVCI (Veles)

82. "St. Panteleimon", VELES

83. "St. Savior", GORNO CHICHEVO (Veles), 1840-1850

84. "St. Savior", KOLESHINO (Strumica)

\section{1}

85. "The Most Holy Mother of God", SENCE (Mavrovo)

\section{2}

86. "St. Athanasius", BOSILOVO (Strumica)

87. "St. Athanasius", KOKOSHINJE (Kumanovo)

88. "St. Cosma and Damian - The Holy Healers", OHRID

89. "St. George", NOVO SELO (Strumica)

90. "St. Petka", DUF (Mavrovo)

91. "St. Savior - Ascension of Christ", GEVGELIJA

92. "St. Savior", VLADIMIROVO (Berovo)
1843

93. "St. George", RESEN

1844

94. "St. Cosma and Damian", PESHTANI (Ohrid)

95. "St. Peter and Paul", TRESONCHE (Debar)

1845

96. "St. Athanasius", JUDOVO (Kichevo)

97. "St. Athanasius", NOVACHANI (Veles)

98. "St. Marina", ZUBOVCE (Gostivar)

99. "St. Nicholas", PODGORCl (Struga)

100. "St. Peter and Paul", RATEVO (Berovo), 1845-1876

1846

101. "Nativity of the Most Holy Mother of God", BRAZDA (Skopje)

102. "Nativity of the Most Holy Mother of God", GORNI MANASTIREC (Makedonski Brod)

103. "St. Athanasius", BOLNO (Prespa)

104. "St. Nicholas", MECHKUEVCI (Sveti Nikole)

105. "St. Nicholas", MRAMOREC (Ohrid)

106. "St. Nicholas", VINCE (Kumanovo)

1847

107. "Dormition of the Most Holy Mother of God", ROBOVO (Pehchevo)

108. "St. Archangel Michael", MOGILA (Bitola)

109. "St. Demetrius", STRACIN (Kratovo)

110. "St. George", IVANJEVCI (Bitola)

111. "St. Joachim" - Osogovo monastery, KRIVA PALANKA (1847-1851)

112. "St. Nicholas", KRIVOGASHTANI (Prilep)

113. "St. Nicholas", LUUBANCI (Skopje)

114. "St. Nicholas", SVETI NIKOLE

115. "St. Nicholas", TETOVO (1842-47)

116. "St. Savior - Ascension of Christ", KOZHLE (Skopje)

\section{8}

117. "Dormition of the Most Holy Mother of God", EVLA (Prespa)

118. "Dormition of the Most Holy Mother of God", NEMANJICI (Sveti Nikole)

119. "St. Archangel Michael", BEROVO

120. "St. Archangel Michael", BITUSHE (Debar)

121. "St. Athanasius", ORIZARI (Kochani)

122. "St. Demetrius", GRUNISHTA (Mariovo)

123. "St. Elijah", STAR DOJRAN

124. "St. George", MALO CRSKO (Kichevo)

125. "St. George", PODMOCHANI (Prespa)

126. "St. John the Baptist", LESKI (Vinica)

127. "St. Nicholas", JAGOL (Kichevo)

128. "St. Nicholas", KRATOVO

129. "St. Nicholas", TRN (Bitola)

130. "St. Theodore", GORNO DUPENI (Prespa)

131. "The Immaculate Mother of God" - Krninski monastery, KICHEVO

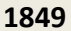

132. "St. Archangel Michael", GRCHISHTE (Valandovo)

133. "St. Athanasius", BERANCl (Bitola)

134. "St. Demetrius", ZRNOVCI (Kochani)

135. "St. Nicholas", KICHINICA (Mavrovo)

136. "St. Nicholas", VRBEN (Mavrovo)

137. "St. Petka", CAPARI (Bitola) 
138. "St. Petka", RAMNE (Makedonski Brod)

139. "St. Savior", DRACHEVO (Skopje)

140. "St. Savior - Ascension of Christ", LIPEC (Vinica)

\section{0}

141. "St. Annunciation", GORNI ZABEL (Kumanovo)

142. "St. Constantine and Helena", RAZLOVCl (Delchevo)

143. "St. Elijah", BLATEC (Vinica)

144. "St. George", BOISHTE (Demir Hisar)

145. "St. Nicholas", MAVROVO

146. "St. Panteleimon", EHLOVEC (Kichevo)

147. "St. Theodore Stratylate", DOLNO OREHOVO (Bitola)

148. "The Most Holy Mother of God", NOVO SELO (Shtip), (1836-1850)

1851

149. "Dormition of the Most Holy Mother of God", DOLENCI (Demir Hisar)

150. "St. Athanasius", GABROVO (Gevgelija)

151. "St. Nicholas", KUKURECHANI (Bitola)

152. "St. Nicholas", KUMANOVO

\section{2}

153. "Dormition of the Most Holy Mother of God", ZABEL (Kumanovo), 1852-1856

154. "Dormition of the Most Holy Mother of God", ZBAZHDI (Struga)

155. "St. Demetrius", VOLKOVIJA (Mavrovo)

156. "St. Demetrius", ZLATARI (Prespa)

157. "St. Elijah", RAOTINCI (Tetovo)

158. "St. Elijah", S'LP (Veles)

159. "St. George", ZUBOVO (Strumica)

160. "St. Nicholas", MOKRENI (Veles)

161. "St. Nicholas", PRISOVJANI (Struga)

162. "The Most Holy Mother of God", DUF (Gostivar)

163. "The Most Holy Mother of God", ZHELEZNEC (Demir Hisar)

164. „The Immaculate Mother of God", LJUBOJNO (Prespa)

\section{3}

165. "Dormition of the Most Holy Mother of God", BISTRICA (Veles)

166. "St. George", KRIVENI (Prespa)

167. "St. Nicholas", OPILA (Kriva Palanka)

168. "The Most Holy Mother of God", ZLETOVO (Probishtip)

\section{4}

169. "St. Constantine and Helena", RAKLISH (Radovish)

170. "St. George", BUDINARCI (Berovo)

171. "St. Nicholas", NAKOLEC (Prespa)

172. "St. Savior", CRESHEVO (Skopje)

\section{5}

173. "St. Nicholas", GLUVO (Skopje)

174. "The Most Holy Mother of God", SOGLE (Veles)

\section{6}

175. "Ascension of Christ - St. Marina", SVETOMITRANI (Krushevo)

176. "Dormition of the Most Holy Mother of God", GARI (Debar)

177. "Holy Trinity", CHUCHER SANDEVO (Skopje)

178. "St. Archangel Michael", RADOVO (Demir Hisar)
179. "St. Athanasius", SEKIRCI (Prilep)

180. "St. Nicholas", BILJANIK (Bitola)

181. "St. Nicholas", NOSHPAL (Bitola)

182. "St. Nicholas", VRBJANI (Prilep)

183. "St. Petka", MALOVISHTE (Bitola)

1857

184. "Nativity of the Most Holy Mother of God", LOPATICA (Bitola)

185. "St. Athanasius", CHIFLIK (Demir Kapija)

186. "St. Elijah", KADINO (Skopje)

187. "St. Elijah", VESELCHANI, (Prilep)

188. "St. George", OSTRILCI (Krushevo)

189. "St. Nicholas", GRADEC (Kriva Palanka)

190. "St. Nicholas", RAJCA (Prespa)

191. "St. Nicholas", VIRCHE (Delchevo)

192. "St. Savior - Ascension of Christ", DOLNENI (Prilep)

193. "St. Theodore Tyron", DRENOVCI (Prilep)

\section{8}

194. "Dormition of the Most Holy Mother of God", DELCHEVO

195. "St. Archangel Michael", TASHMARUNISHTA (Struga)

196. "St. Archangel Michael", VINICA

197. "St. Athanasius", PRZHDEVO (Demir Kapija)

198. "St. Constantine and Helena", NEGREVO (Pehchevo)

199. "St. Cosma and Damian", SVETORACHE (Kichevo)

200. "St. Demetrius", DRACHEVICA (Demir Kapija)

201. "St. Demetrius", KONSKO (Gevgelija)

202. "St. Elijah", EZERANI (Prespa)

203. "St. George", GRAD (Delchevo)

204. "St. Nicholas", BABINO (Demir Hisar)

205. "St. Nicholas", PROSTRANJE (Kichevo)

206. "St. Nicholas", VRANESHTICA (Kichevo)

207. "St. Peter and Paul", PEHCHEVO

208. "St. Peter and Paul", STAJOVCE (Kriva Palanka)

209. "St. Petka", BIGOR DOLENCI (Kichevo)

210. "St. Sunday", SLATINO (Ohrid)

211. "St. Theodore", PODMOL (Bitola)

\section{9}

212. "Holy Trinity", ROPOTOVO (Prilep)

213. "Nativity of the Most Holy Mother of God", MARUL (Bitola)

214. "St. Elijah", ELSHANI (Ohrid)

215. "St. George", LOGOVARDI (Bitola)

216. "St. Nicholas", DRAGOSH (Bitola)

217. "St. Nicholas", LEVA REKA (Prespa)

218. "St. Nicholas", KORENICA (Prilep)

219. "St. Petka", RADIBUSH (Kriva Palanka)

220. "The Most Holy Mother of God", BOTUN (Ohrid)

1860

221. "Dormition of the Most Holy Mother of God", PARALOVO (Bitola)

222. "Dormition of the Most Holy Mother of God", STARAVINA (Mariovo)

223. "Nativity of the Most Holy Mother of God", SUVODOL (Bitola)

224. "St. Archangel Michael", KLINOVO (Mariovo)

225. "St. Archangel Michael", MAKOVO (Mariovo)

226. "St. Athanasius", GODIVJE (Prilep)

227. "St. Athanasius" / "St. Savior", IVENI (Mariovo)

228. "St. Athanasius", KRUSHEANI (Prilep)

229. "St. Athanasius", PETALINO (Bitola) 
230. "St. Athanasius", SOVIKJ (Bitola)

231. "St. Athanasius", STARAVINA (Mariovo)

232. "St. Constantine and Helena", MIRAVCI (Gevgelija)

233. "St. Demetrius", BALINCI (Valandovo)

234. "St. Demetrius", GRADEC (Valandovo)

235. "St. Demetrius", KOVANEC (Gevgelija)

236. "St. Demetrius", TRNOVO (Bitola)

237. "St. Demetrius - St. Paraskeva", RAPESH (Mariovo)

238. "St. George", GERMIJAN (Bitola)

239. "St. George", NEGOTINO

240. "St. George", NOVOSELANI (Bitola)

241. "St. George", OTUNJE (Tetovo)

242. "St. Nicholas Gerakomija", OHRID

243. "St. Nicholas", GODIVJE (Ohrid)

244. "St. Nicholas", POPOEC (Kichevo)

245. "St. Nicholas", SOPOTSKO (Prespa)

246. "St. Nicholas", TOPLICA (Prilep)

247. "St. Petka", DOLNO ORIZARI (Veles)

248. "St. Petka", KANINO (Bitola)

249. "St. Petka", LISOLAJ (Bitola)

250. "St. Petka", MILETKOVO (Gevgelija)

251. "St. Petka", SKOCHIVIR (Mariovo)

252. "St. Savior", CHEMERSKO (Kavadarci)

253. "St. Savior", DOBRUSHEVO (Bitola)

254. "St. Savior", GRAESHNICA (Bitola)

255. "St. Savior - Ascension of Christ", STINIK (Strumica)

256. "St. Savior - Ascension of Christ", ZHIVOJNO (Bitola)

257. "St. Sunday", ORLE (Mariovo)

258. "St. Sunday", STOJAKOVO (Bogdanci)

1861

259. "Introduction of the Most Holy Mother of God", SHLEGOVO (Kratovo)

260. "St. Athanasius", LOZNANI (Bitola)

261. "St. Athanasius", MOJNO (Bitola)

262. "St. Demetrius", LAZHEC (Bitola)

263. "St. Elijah", CHELOPECI (Kichevo)

264. "St. George", RAMNA (Bitola)

265. "St. John the Baptist", BULACHANI (Skopje)

266. "St. John the Theologan", LUUBJNO (Prespa)

267. "St. Peter and Paul", TAJMISHTE (Kichevo)

268. "St. Petka", GORNO OREHOVO (Bitola)

269. "St. Petka", PRDEJCI (Gevgelija)

270. "St. Savior - Ascension of Christ", RASHTAK (Skopje)

\section{2}

271. "Nativity of the Most Holy Mother of God", KADINO SELO (Prilep)

272. "Nativity of the Most Holy Mother of God", SETOLE (Tetovo)

273. "St. Athanasius", KUKLISH (Strumica)

274. "St. Athanasius", VITOLISHTE (Mariovo)

275. "St. Cosma and Damian", PLETVAR (Prilep)

276. "St. George", RIBARCI (Mariovo)

277. "St. George", VASHAREJCA (Bitola)

278. "St. John the Forerunner", SLEPCHE (Demir Hisar)

279. "St. Marina", BOROTINO (Prilep)

280. "St. Nicholas", GRADESHNICA (Mariovo)

281. "St. Nicholas", KARBUNICA (Kichevo)

282. "St. Nicholas", ZOVIKJ (Mariovo)

283. "St. Panteleimon", UMA (Gevgelija)

284. "St. Sunday", BITOLA

285. "St. Talalej - St. Nicholas", GNEOTINO (Bitola)
286. "St. Athanasius", CER (Demir Hisar)

287. "St. Athanasius", GLOGJI (Tetovo)

288. "St. Athanasius", IZVOR (Veles)

289. "St. Nicholas", Dolna Vlashka Maala, OHRID

290. "St. Theodore Tyron", PIPEROVO (Shtip)

1864

291. "Holy Trinity", NIVICHANI (Kochani)

292. "Nativity of the Most Holy Mother of God", CRNICHANI (Bitola)

293. "St. Athanasius", DOLNO DUPENI, (Prespa)

294. "St. Athanasius", RAKLE (Prilep)

295. "St. Demetrius", DUNJE (Mariovo)

296. "St. Elijah", SELCE (Debar)

297. "St. George", GRADISHTE (Kumanovo)

298. "St. Nicholas", CEROVO (Gostivar)

299. "St. Nicholas", VEVCHANI (Struga)

300. "St. Savior", GRUMAZI (Mariovo)

301. "St. Savior", ROBOVO (Strumica)

302. "St. Savior", TOPOLCHANI (Prilep)

1865

303. "Dormition of the Most Holy Mother of God", KRANI (Prespa)

304. "St. Anthonius", BIGOR DOLENCI (Kichevo)

305. "St. Elijah", GABROVO (Strumica)

306. "The Most Holy Mother of God", BOJANCHISHTE (Tikvesh)

\section{6}

307. "St. Archangel Michael", KOKRE (Mariovo)

308. "St. Demetrius", CRNOBUKI (Bitola)

309. "St. Elijah", MAKEDONSKA KAMENICA

310. "St. Elijah", POPCHEVO (Strumica)

311. "St. George", GORNO VODNO (Skopje)

312. "St. John the Forerunner", JANKOVEC (Prespa)

313. "St. Nicholas", BELOVISHTE (Gostivar)

314. "St. Nicholas", CER (Demir Hisar)

315. "St. Nicholas", DREN (Prilep)

316. "St. Nicholas", KLISURA (Demir Kapija)

317. "St. Nicholas", TEARCE (Tetovo)

318. "St. Savior", BRATIN DOL (Bitola)

1867

319. "Dormition of the Most Holy Mother of God", KRUSHEVO

320. "Dormition of the Most Holy Mother of God", NOVO ZMIRNEVO (Bitola)

321. "St. Athanasius", DOLNO PEROVO (Prespa)

322. "St. Elijah", ALDANCI (Krushevo)

323. "St. Elijah", KAPINOVO (Veles)

324. "St. Elijah", STENCHE (Tetovo)

325. "St. George", BELICA (Kichevo)

326. "St. George", LESKOVICA (Shtip)

327. "St. George", SLATINA (Makedonski Brod)

328. "St. George", ZHEGLJANE (Kumanovo)

329. "St. Nicholas", SHTIP

330. "St. Nicholas", SLEPCHE (Demir Hisar)

331. "St. Panteleimon", NIKIFOROVO (Mavrovo)

332. "St. Savior", PETROVO (Gevgelija)

333. "Holy Trinity", DABILE (Strumica)

334. "Nativity of the Most Holy Mother of God", BAROVO (Demir Kapija) 
335. "Resurrection of Christ", DALBEGOVCI (Bitola)

336. "St. Archangel Michael", VRPSKO (Mariovo)

337. "St. Athanasius", CAPARI (Bitola)

338. "St. Athanasius", NOVACI (Bitola)

339. "St. Athanasius", RAJCHICA (Debar)

340. "St. Demetrius", BROSHTNICA (Debar)

341. "St. Nicholas", DREN (Demir Kapija)

342. "St. Nicholas", NEBREGOVO (Prilep)

343. "St. Nicholas", STAR ISTEVNIK (Delchevo)

344. "St. Nicholas", SVINJISHTE (Kichevo)

\section{9}

345. "Dormition of the Most Holy Mother of God", MARENA (Kavadarci)

346. "St. Athanasius", BALDOVENCI (Bitola)

347. "St. Demetrius", GLISHIKJ (Tikvesh)

348. "St. Demetrius", KOSTURINO (Strumica)

349. "St. Demetrius", VRANJEVCI (Bitola)

350. "St. Nicholas", NOVO SELO (Skopje)

351. "St. Savior - Ascension of Christ", DRENOVO (Veles)

352. "The Most Holy Mother of God", PCHINJA (Kumanovo)

\section{0}

353. "Holy Trinity", SKACHINCI (Veles)

354. "Holy Trinity", SMOLARI (Strumica)

355. "St. Athanasius", BARBAREVO (Strumica)

356. "St. Barbara", ZHUZHNJE (Gostivar)

357. "St. Elijah", KONJSKO (Prespa)

358. "St. Elijah", RICH (Strumica)

359. "St. Elijah", SACHEVO (Strumica)

360. "St. George", BRAJKOVCI (Valandovo)

361. "St. George", MURTINO (Strumica)

362. "St. George", PIPEROVO (Strumica)

363. "St. Nicholas", GOLEMO RADOBIL (Prilep)

364. "St. Nicholas", ROTINO (Bitola)

365. "St. Petka", CHANISHTE (Mariovo)

366. "St. Petka", KOZICA (Kichevo)

367. "St. Petka", PLESHINCI (Probishtip)

368. "St. Savior - Ascension of Christ", BELI (Kochani)

369. "The Most Holy Mother of God", BITOLA

1871

370. "Dormition of the Most Holy Mother of God", SELCE (Prilep)

371. "Dormition of the Most Holy Mother of God", SMOJMIROVO (Berovo)

372. "Holy Transfiguration", GOPESH (Bitola)

373. "Holy Transfiguration", PRILEP

374. "Holy Trinity", BREZICA (Skopje)

375. "Nativity of the Most Holy Mother of God", BACH (Mariovo)

376. "St. Athanasius", KOSHANI (Kavadarci)

377. "St. Athanasius", PODVIS (Kichevo)

378. "St. Athanasius", PREMKA (Kichevo)

379. "St. Constantine and Helena", OMORANI (Veles)

380. "St. Elijah", DRAGOSH (Bitola)

381. "St. Elijah", PLAKJE (Ohrid)

382. "St. George", DRMENI (Prespa)

383. "St. George", MAGAREVO (Bitola)

384. "St. George", STARO VOLKODERI (Prespa)

385. "St. Nicholas", BRAJCHINO (Prespa)

386. "St. Nicholas", IVANCHISHTA (Kichevo)

387. "St. Nicholas", PREOD (Sveti Nikole)

388. "St. Nicholas", SUSHICA (Gostivar)
389. "St. Theodore Tyron", KRKLINO (Bitola)

390. "The Most Holy Mother of God", PANTELEJ (Kochani)

1872

391. "Dormition of the Most Holy Mother of God", DEBAR

392. "St. Athanasius", TOPOLNICA (Makedonski Brod)

393. "St. Athanasius", ZAPOLZHANI (Prilep)

394. "St. Demetrius", LOKVICA (Makedonski Brod)

395. "St. Elijah" - Melnica monastery, VITOLISHTE (Mariovo)

396. "St. George", DUPJANI (Kichevo)

397. "St. George", OSOJ (Debar)

398. "St. Nicholas", BRZHDANI (Kichevo)

399. "St. Nicholas", ORLANCI (Kichevo)

400. "St. Nicholas", PRILEPEC (Prilep)

401. "St. Panteleimon - St. Clement", VELGOSHTI (Ohrid)

402. "St. Savior - Ascension of Christ", INJEVO (Radovish)

403. "St. Savior", ROZHDEN (Mariovo)

404. "The Most Holy Mother of God", JELOSHNIK (Tetovo)

405. "The Most Holy Mother of God", MAKEDONSKI BROD

406. "The Most Holy Mother of God", SHESHKOVO (Kavadarci)

1873

407. "Introduction of the Most Holy Mother of God", RUSJACI (Makedonski Brod)

408. "Nativity of the Most Holy Mother of God", MALO KONJARI (Prilep)

409. "St. Demetrius", TATAR ELEVCI (Debar)

410. "St. George", ZASHLE (Demir Hisar)

411. "St. John", DEBRISHTE (Kavadarci)

412. "St. Nicholas", BUKOVO (Negotino)

413. "St. Nicholas", DVORCI (Makedonski Brod)

414. "St. Nicholas", MIRKOVCI (Skopje)

415. "St. Nicholas", TRESONCHE (Debar)

416. "St. Panteleimon", BELICA (Makedonski Brod)

417. "The Most Holy Mother of God", FARISH (Kavadarci)

1874

418. "Dormition of the Most Holy Mother of God", KLADNIK (Kichevo)

419. "Dormition of the Most Holy Mother of God", RASTOJCA (Demir Hisar)

420. "St. Archangel Michael", SPANCHEVO (Kochani)

421. "St. Athanasius", SENOKOS (Prilep)

422. "St. Demetrius", OREOVEC (Prilep)

423. "St. Elijah", BRAJCHINO (Prespa)

424. "St. Elijah", MELNICA (Veles)

425. "St. Nicholas", BELO POLE (Prilep)

426. "St. Nicholas", GOLEMO ILINO (Demir Hisar)

427. "St. Nicholas", LESKOEC (Prespa)

428. "St. Nicholas", PAVLESHENCI (Sveti Nikole)

429. "St. Nicholas", PECHKOVO (Gostivar)

430. "St. Nicholas", SOPOTNICA (Demir Hisar)

431. "St. Nicholas", VRANCHE (Prilep)

432. "St. Panteleimon", MAKRIEVO (Strumica)

433. "St. Petka", DOLNO BARBAREVO (Probishtip)

434. "St. Petka", MIRKOVCI (Skopje)

1875

435. "Dormition of the Most Holy Mother of God", DRAGOZHANI (Bitola)

436. "Dormition of the Most Holy Mother of God", DRASLAJCA (Struga) 
437. "St. Archangel Michael", BENCHE (Makedonski Brod)

438. "St. Athanasius", KUCHEVISHTE (Skopje)

439. "St. George", BLACE (Skopje)

440. "St. George", MILETINO (Tetovo)

441. "St. Elijah", CEROVO (Demir Hisar)

442. "St. Nicholas", BUDIMIRCI (Mariovo)

443. "St. Nicholas", CAREV DVOR (Prespa)

444. "St. Nicholas", KRAJNICI (Veles)

445. "St. Peter and Paul", PAPRADISHTE (Veles)

446. "St. Petka", TREBICHINO (Strumica)

447. "St. Theodore", SVETOTODORI (Bitola)

1876

448. "Nativity of the Most Holy Mother of God", BUCHIN (Krushevo)

449. "St. Archangel Michael", VRUTOK (Gostivar)

450. "St. Constantine and Helena", MOKRINO (Strumica)

451. "St. George", KUNOVO (Gostivar)

452. "St. George" - Paralovo monastery, PARALOVO (Bitola)

453. "St. George", ZASHLE (Krushevo)

454. "St. Nicholas", GALATE (Gostivar)

455. "St. Savior - Ascension of Christ", KARBINCI (Shtip)

1877

456. "St. Archistrateg Michael", KLEPACH (Bitola)

457. "St. Demetrius", DOLNA CHARLIJA (Bitola)

458. "St. George", GORNI LIPOVIKJ (Radovish)

\section{8}

459. "Holy Trinity", BRUSHANI (Tikvesh)

460. "Resurrection of Christ", DRAGARINO (Bitola)

461. "St. Demetrius", KUMANICHEVO (Kavadarci)

462. "St. Elijah", VESHJE (Negotino)

463. "St. John the Baptist", GORNI BALVAN (Shtip)

464. "St. Nicholas", SOPOT (Sveti Nikole)

465. "St. Nicholas", VIROVO (Demir Hisar)

466. "St. Petka", SELCE (Krushevo)

467. "The Most Holy Mother of God", BITOLA

\section{9}

468. "St. Athanasius", BOHULA (Kavadarci)

469. "St. Elijah", MIRKOVCI (Skopje)

470. "St. John", BERANCI (Bitola)

471. "St. Peter and Paul", LUPSHTE (Makedonski Brod)

472. "St. Stephen", KONOPISHTE (Kavadarci)

\section{0}

473. "Nativity of the Most Holy Mother of God", BEGNISHTE (Kavadarci)

474. "Nativity of the Most Holy Mother of God" Gjurishte monastery, GJURISHTE (Sveti Nikole)

475. "St. Athanasius", DOLNO CHICHEVO (Veles)

476. "St. Demetrius", PETALINO (Bitola)

477. "St. Demetrius", PUTURUS (Bitola)

478. "St. Elijah", FURKA (Dojran)

479. "St. Elijah", RAKOTINCI (Skopje)

480. "St. Nicholas", KRUPISHTE (Shtip)

481. "St. Nicholas", MEGLENCI (Bitola)

482. "The Most Holy Mother of God", CERA (Makedonska Kamenica)

483. "The Immaculate Mother of God", KICHEVO

484. "Holy Trinity", KRUSHEVO
485. "Nativity of the Most Holy Mother of God", SHTAVICA (Mariovo)

486. "St. Nicholas", KRSTEC (Prilep)

487. "St. Nicholas", LJUBANCI (Skopje)

488. "The Most Holy Mother of God", LATOVO (Makedonski Brod)

1882

489. "Dormition of the Most Holy Mother of God", VELES

490. "Nativity of the Most Holy Mother of God", DAVIDOVO (Gevgelija)

491. "St. Demetrius", POLCHISHTE (Mariovo)

492. "St. Elijah", STENCHE (Tetovo)

493. "St. Nicholas", BUKOJCHANI (Kichevo)

494. "St. Stephen", SHIVEC (Kavadarci)

\section{3}

495. "Dormition of the Most Holy Mother of God", DRAGOBRASHTE (Vinica)

496. "Holy Trinity", RASHTANI (Veles)

497. "Nativity of the Most Holy Mother of God", TRNOVCI (Bitola)

498. "St. Athanasius", KOZICHINO (Kichevo)

499. "St. Athanasius", LUKOVO (Debar)

500. "St. George", VOISLAVCI (Radovish)

501. "St. Nicholas", ODRI (Tetovo)

502. "St. Petka", PLESHENCI (Probishtip)

\section{4}

503. "Introduction of the Most Holy Mother of God", DOLNO MELNICHANI (Debar)

504. "St. Archangel Michael", KRKLE (Mariovo)

505. "St. Demetrius", GORNO DIVJACI (Krushevo)

506. "St. Elijah", BUSILCI (Veles)

507. "St. Nicholas", EDINAKOVCI (Demir Hisar)

508. "St. Nicholas", RAKOVEC (Veles)

509. "St. Petka", BESHISHTE (Mariovo)

510. "St. Petka", SIRICHINO (Tetovo)

\section{5}

511. "Dormition of the Most Holy Mother of God", ZHURCHE (Demir Hisar)

512. "St. Elijah", BUNESH (Probishtip)

513. "St. Elijah", LISICHE (Veles)

514. "St. Elijah", ZHIVENJE (Kumanovo)

515. "St. Nicholas", BELICHICA (Mavrovo)

516. "St. Nicholas", BELOVODICA (Prilep)

517. "St. Nicholas", METIMIR (Demir Hisar)

518. "St. Nicholas", RUDNIK (Veles)

519. "St. Nicholas", STRMASHEVO (Demir Kapija)

520. "St. Nicholas", ZAGORICHE (Demir Hisar)

521. "St. Panteleimon", PANTELEJ (Kochani)

522. "St. Theodore Tyron", KONOPNICA (Kriva Palanka)

523. "The Most Holy Mother of God", RANKOVCE (Kriva Palanka)

\section{6}

524. "St. Athanasius", SUVO GRLO (Demir Hisar)

525. "St. Demetrius", DOBROVENI (Bitola)

526. "St. Demetrius", PANCHAREVO (Delchevo)

527. "St. Elijah", JABLANICA (Struga)

528. "St. George", PETRALICA (Kriva Palanka)

529. "St. Talalej - St. Nicholas", DOBROMIRI (Bitola) 
530. "Dormition of the Most Holy Mother of God", MARGARI (Prilep)

531. "St. Demetrius", BRNIK (Mariovo)

532. "St. George", NOVO SELO (Veles)

533. "St. Nicholas", ARILEVO (Krushevo)

534. "St. Nicholas", BELCHE (Demir Hisar)

535. "St. Nicholas", DOLNO DIVJACI (Krushevo)

536. "St. Nicholas", PUSTA REKA (Krushevo)

537. "St. Nicholas", SLIVICA (Bitola)

538. "St. Petka", RUSINOVO (Berovo)

539. "St. Stephen", NEZHILOVO (Veles)

\section{8}

540. "St. Constantine and Helena", DOLNA BELA CRKVA (Prespa)

541. "St. Elijah", ZASHLE (Demir Hisar)

542. "St. George", CAPARI (Bitola)

\section{9}

543. "St. John the Baptist", KRUSHJE (Prespa)

544. "St. Petka", GORNA BELICA (Struga)

\section{0}

545. "St. Athanasius", GABALAVCI (Bitola)

546. "St. Athanasius", VOJNICA (Veles)

547. "St. Constantine and Helena", SOKOLARCI (Kochani)

548. "St. Constantine and Helena", ZAGORANI (Prilep)

549. "St. Nicholas", SLANSKO (Makedonski Brod)

550. "St. Nicholas", SUSHICA (Makedonski Brod)

551. "St. Peter and Paul", KRSTOAR (Bitola)

552. "St. Petka", VELGOSHTI (Ohrid)

553. "St. Savior", GOLOZINCI (Veles)

554. "St. Savior - Ascension of Christ", KALEN (Mariovo)

555. "The Most Holy Mother of God", GORNO SELO (Prilep)

\section{1}

556. "St. Athanasius", BAZERNIK (Demir Hisar)

557. "St. George", PESHTANI (Mariovo)

558. "St. Nicholas", SEKIRANI (Bitola)

559. "St. Nicholas", VIR (Makedonski Brod)

560. "St. Peter and Paul", RADOBOR (Bitola)

561. "St. Peter and Paul", ZVECHAN (Makedonski Brod)

562. "St. Talalej", BREST (Makedonski Brod)

\section{2}

563. "Dormition of the Most Holy Mother of God", DOLNA BELICA (Struga)

564. "St. George", ZLESTI (Ohrid)

565. "St. Savior", MALO RUVCI (Prilep)

566. "St. Savior", TREBOVLE (Makedonski Brod)

567. "The Most Holy Mother of God", KRIVA KRUSHA (Veles)

568. "The Most Holy Mother of God", POPADIJA (Veles)

\section{3}

569. "St. Archangel Michael", DOLNO DUPENI (Prespa)

570. "St. Nicholas", OMORANI (Veles)

571. "St. Petka", ZHIVOVO (Mariovo)

572. "St. Sunday", DVORCI (Makedonski Brod)

573. "St. Vlasius", LOZHANI (Struga)

\section{4}

574. "Dormition of the Most Holy Mother of God", KRAVARI (Bitola)
575. "Dormition of the Most Holy Mother of God", MODRICH (Struga)

576. "St. Elijah", MITRASHINCI (Berovo)

577. "St. George", BELJAKOVCE (Kumanovo)

578. "St. Petka", RUGJINCE (Kumanovo)

1895

579. "St. Athanasius", TEOVO (Veles)

580. "St. Demetrius", BUKOVO (Bitola)

581. "St. George", KOSOVO (Makedonski Brod)

\section{6}

582. "St. Cyril and Methodius", GEVGELIJA

583. "St. Demetrius", KESENDRE (Kavadarci)

584. "St. Demetrius", SKOPJE

585. "St. Talea - St. Nicholas", NOVO SELO (Skopje)

586. "The Most Holy Mother of God", POBOZHJE (Skopje)

1897

587. "St. Elijah", BRODEC (Skopje)

588. "St. John", KRUSHEVO

589. "St. Nicholas", DREN'K (Kumanovo)

590. "St. Nicholas", GORNO SONJE (Skopje)

\section{8}

591. "St. Christopher" - Krstoar monastery, KRSTOAR (Bitola)

592. "St. Elijah", MALO ILINO (Demir Hisar)

593. "St. John the Baptist", DOBROSHTE (Tetovo)

594. "St. Peter and Paul", MESHEISHTA (Ohrid)

595. "St. Savior", CRESHNEVO (Makedonski Brod)

596. "St. Savior", UMLENA (Delchevo)

597. "St. Talalej", GORNO KRUSHJE (Makedonski Brod)

\section{9}

598. "St. Constantine and Helena", BELIMBEGOVO (Skopje)

599. "St. Demetrius", CAREVIKJ (Prilep)

600. "St. George", RADISHANI (Skopje)

\section{0}

601. "St. Elijah", NIKULJANE (Kumanovo)

602. "St. Elijah", VINICHE (Skopje)

603. "St. Nicholas", BALIN DOL (Gostivar)

604. "St. Nicholas", JANKOVEC (Prespa)

605. "The Most Holy Mother of God", VOLINO (Ohrid)

\section{Revival Churches with Unknown Dates of Construction (XIX} Century)

606. Church in DUPJACHANI (Prilep)

607. "Dormition of the Most Holy Mother of God", ORESHE (Veles)

608. "Dormition of the Most Holy Mother of God", KLENOEC (Kichevo)

609. "Holy Archangels", BUKOVO (Bitola)

610. "Holy Trinity", DOLNO GJUGJANCI (Sveti Nikole)

611. "Holy Trinity", GORNO TROGERCI (Shtip)

612. "Holy Trinity", KOSTOMAR (Probishtip)

613. "Holy Trinity", NIKODIN (Prilep) 
614. "Introduction of the Most Holy Mother of God", BURINEC (Struga)

615. "Introduction of the Most Holy Mother of God", SREDOREK (Prilep)

616. "Nativity of the Most Holy Mother of God", DRAZHEVO (Strumica)

617. "Nativity of the Most Holy Mother of God", MALO RADOBIL (Prilep)

618. "Nativity of the Most Holy Mother of God", PODINO (Bitola)

619. "Resurrection of Christ", DEDEBALCI (Bitola)

620. "St. Annunciation", BANJANI (Skopje)

621. "St. Archangel Michael", BRCHEVO (Struga)

622. "St. Archangel Michael", DOLNO SRPCI (Bitola)

623. "St. Archangel Michael", DZEPISHTE (Debar)

624. "St. Archangel Michael", KRAKORNICA (Mavrovo)

625. "St. Archangel Michael", LAVCHANI (Kichevo)

626. "St. Archangel Michael", LISOLAJ (Bitola)

627. "St. Archangel Michael", NOVO SELO (Demir Hisar)

628. "St. Archangel Michael", OSOJ (Debar)

629. "St. Archangel Michael", ROSTUSHE (Debar)

630. "St. Archangel Michael", TEPAVCI (Bitola)

631. "St. Athanasius", ASAMATI (Prespa)

632. "St. Athanasius", BOGDANCI

633. "St. Athanasius", BOROVEC (Struga)

634. "St. Athanasius", BREZHANI (Ohrid)

635. "St. Athanasius", BUKOVO (Bitola)

636. "St. Athanasius", CHAJLE (Gostivar)

637. "St. Athanasius", CRVENA VODA (Ohrid)

638. "St. Athanasius", DIHOVO (Bitola)

639. "St. Athanasius", GOLEMO CRSKO (Demir Hisar)

640. "St. Athanasius", GORNO JELOVCE (Gostivar)

641. "St. Athanasius", GORNO KONJARI (Skopje)

642. "St. Athanasius", GOSTIRAZHNI (Prilep)

643. "St. Athanasius", GRADEC (Valandovo)

644. "St. Athanasius", GRADESHNICA (Mariovo)

645. "St. Athanasius", GRNCHARI (Prespa)

646. "St. Athanasius", NAKOLEC (Prespa)

647. "St. Athanasius", NEGORCI (Gevgelija)

648. "St. Athanasius", NICHPUR (Mavrovo), 1792?

649. "St. Athanasius", NIKODIN (Prilep)

650. "St. Athanasius", NIZHEPOLE (Bitola)

651. "St. Athanasius", OKTISI (Struga)

652. "St. Athanasius", SELCI (Struga)

653. "St. Athanasius", SLIVNICA (Prespa)

654. "St. Athanasius", SMOLEVO (Bitola)

655. "St. Athanasius", STAR PRISAD (Prilep)

656. "St. Athanasius", STENCHE - GORNO FALISHE (Tetovo)

657. "St. Athanasius", STENJE (Prespa)

658. "St. Athanasius", STRAGOVO (Kavadarci)

659. "St. Athanasius", STRUGOVO (Demir Hisar)

660. "St. Athanasius", SVEKJANI (Veles)

661. "St. Athanasius", TREBOSH (Tetovo)

662. "St. Athanasius", VISHNI (Struga)

663. "St. Athanasius", ZHELEZNA REKA (Gostivar)

664. "St. Barbara", LUKOVO (Debar)

665. "St. Clement", KLIMESHTANI (Ohrid)

666. "St. Constantine and Helena", MRZENCI (Gevgelija)

667. "St. Cosma and Damian", GORNO MELNICHANI (Debar)

668. "St. Demetrius", BANJISHTE (Debar)

669. "St. Demetrius", BOGDEVO (Gostivar)

670. "St. Demetrius", BRUSNIK (Bitola)

671. "St. Demetrius", BUNARCHE (Kavadarci)
672. "St. Demetrius", VEPRCHANI (Mariovo)

673. "St. Demetrius", GRLJANI (Vinica)

674. "St. Demetrius", GUGJAKOVO (Mariovo)

675. "St. Demetrius", MELNICA (Mariovo)

676. "St. Demetrius", MITROJ KRSTI (Gostivar)

677. "St. Demetrius", PARESHI (Debar)

678. "St. Demetrius", POMENOVO (Veles)

679. "St. Demetrius", RABETINO (Kichevo)

680. "St. Demetrius", RADNJA (Kavadarci)

681. "St. Demetrius", RAKITNICA (Demir Hisar)

682. "St. Demetrius", SLIVNICA (Prespa)

683. "St. Demetrius", STARI GRAD (Veles)

684. "St. Demetrius", STRAGOVO (Kavadarci)

685. "St. Elijah", BELEKOVCI (Kumanovo)

686. "St. Elijah", BIRINO (Krushevo)

687. "St. Elijah", DOBREVO (Probishtip)

688. "St. Elijah", DOLANI (Shtip)

689. "St. Elijah", DOLNO VRANOVCI (Veles)

690. "St. Elijah", KRANI (Prespa)

691. "St. Elijah", LAKTINJE (Ohrid)

692. "St. Elijah", LESKOVO (Demir Hisar)

693. "St. Elijah", LJUBOJNO (Prespa)

694. "St. Elijah", LUKE (Kriva Palanka)

695. "St. Elijah", MALO CRSKO (Kichevo)

696. "St. Elijah", NEPROSHTENO (Tetovo)

697. "St. Elijah", ORASHAC (Kumanovo)

698. "St. Elijah", RABETINO (Kichevo)

699. "St. Elijah", SKOCHIVIR (Mariovo)

700. "St. Elijah", STARO SELO (Prespa)

701. "St. Elijah", STROVIJA (Mariovo)

702. "St. Elijah", SURDULCI (Radovish)

703. "St. Elijah", ZHELEZNA REKA (Gostivar)

704. "St. Erasmus", GABAVCI (Ohrid)

705. "St. Eremiah", GORNI DISAN (Negotino)

706. "St. George", GODIVJE (Ohrid)

707. "St. George", DOLNI BALVAN (Shtip)

708. "St. George", DOLNO JELOVCE (Gostivar)

709. "St. George", JASENOVO (Veles)

710. "St. George", KAMEN DOL (Negotino)

711. "St. George", OREL (Sveti Nikole)

712. "St. George", ORESHE (Veles)

713. "St. George", PIRAVA (Valandovo)

714. "St. George", POESHEVO (Bitola)

715. "St. George", PRIKOVCI (Kratovo)

716. "St. George", RANCHENCI (Sveti Nikole)

717. "St. George", SLEPCHE (Prilep)

718. "St. George", SOSHANI (Ohrid)

719. "St. George", SUSHICA (Skopje)

720. "St. George", SHEMSHEVO (Tetovo)

721. "St. John", MISLESHEVO (Struga)

722. "St. John", STREZHEVO (Bitola)

723. "St. John the Baptist", BONCHE (Mariovo)

724. "St. John the Baptist", DREVENO (Probishtip)

725. "St. John the Theologan", LAKI (Vinica)

726. "St. John the Theologan", PRELUUBISHTE (Tetovo)

727. "St. Mino", VRUTOK (Gostivar)

728. "St. Nicholas", BRODEC (Mavrovo)

729. "St. Nicholas", BUKOVO (Bitola)

730. "St. Nicholas" (cemetery church), CAREV DVOR (Prespa)

731. "St. Nicholas", CHEPIGOVO (Prilep)

732. "St. Nicholas", CRESHNEVO (Veles)

733. "St. Nicholas", DABNICA (Prilep)

734. "St. Nicholas", DOLNO KOSOVRASTI (Debar)

735. "St. Nicholas", DRAGOZHEL (Kavadarci) 
736. "St. Nicholas", GINOVCE (Kriva Palanka)

737. "St. Nicholas", GORNI DISAN (Negotino)

738. "St. Nicholas", IZBISHTE (Prespa)

739. "St. Nicholas", KARAMANI (Bitola)

740. "St. Nicholas", KNEZHJE (Sveti Nikole)

741. "St. Nicholas", KOPANCE (Tetovo)

742. "St. Nicholas", KRAPA (Makedonski Brod)

743. "St. Nicholas", KRNINO (Veles)

744. "St. Nicholas", LABUNISHTA (Struga)

745. "St. Nicholas", LESHNICA (Gostivar)

746. "St. Nicholas", MALI VLAJ (Struga)

747. "St. Nicholas", OBLAVCE (Kumanovo)

748. "St. Nicholas", OBRSHANI (Prilep)

749. "St. Nicholas", ODRI (Tetovo)

750. "St. Nicholas", ORAOV DOL (Veles)

751. "St. Nicholas", ORASHAC (Kumanovo)

752. "St. Nicholas", POKRVENIK (Prespa)

753. "St. Nicholas", RADOZHDA (Struga)

754. "St. Nicholas", SELCI (Struga)

755. "St. Nicholas", STEPANCI (Veles)

756. "St. Nicholas", STREZHEVO (Bitola)

757. "St. Nicholas", SVETORACHE (Kichevo)

758. "St. Nicholas - St. Archangel", VARDINO (Demir Hisar)

759. "St. Nicholas", VOGJANI (Prilep)

760. "St. Nicholas", ZUBOVCE (Gostivar)

761. "St. Peter and Paul", GORNO AGLARCI (Bitola)

762. "St. Peter and Paul", GOVRLEVO (Skopje)

763. "St. Peter and Paul", SMILOVCI (Veles)

764. "St. Peter and Paul", SRBJANI (Kichevo)

765. "St. Petka", CER (Demir Hisar)

766. "St. Petka", GABROVNIK (Veles)

767. "St. Petka", GORNO ORIZARI (Skopje)

768. "St. Petka", GOSTIVAR

769. "St. Petka", GRBAVEC (Kavadarci)

770. "St. Petka", MARVINCI (Valandovo)

771. "St. Petka", PORODIN (Bitola)

772. "St. Petka", SUDIKJ (Shtip)
773. “St. Petka”, TUDENCE (Tetovo)

774. "St. Petka", ZHVAN (Demir Hisar)

775. "St. Savior", BIDZEVO (Struga)

776. "St. Savior", CRNEEC (Bitola)

777. "St. Savior", DOLNO TROGERCI (Shtip)

778. "St. Savior", LOKOV (Struga)

779. "St. Savior", NEREZI (Struga)

780. "St. Savior", VELES

781. "St. Savior", VEVCHANI (Struga)

782. "St. Savior", BANJICA (Veles)

783. "St. Savior", EVLA (Prespa)

784. "St. Savior", NISTROVO (Mavrovo)

785. "St. Savior", R'LEVCI (Veles)

786. "St. Savior", ROGACHEVO (Tetovo)

787. "St. Savior", ULANCI (Veles)

788. "St. Stephen", PALIKURA (Kavadarci)

789. "St. Sunday", ARVATI (Prespa)

790. "St. Sunday", BRAILOVO (Prilep)

791. "St. Sunday", KRCHIN (Debar)

792. "St. Sunday", R'ZHANOVO (Struga)

793. "St. Triphun", KUCHKOVO (Skopje)

794. "St. Vasilius", GRNCHISHTE (Kavadarci)

795. "The Most Holy Mother of God", BELOVISHTE (Tetovo)

796. "The Most Holy Mother of God", BOROVEC (Struga)

797. "The Most Holy Mother of God", GNILESH (Mariovo)

798. "The Most Holy Mother of God", GRADISHTE (Kavadarci)

799. "The Most Holy Mother of God", KRKLINO (Bitola)

800. "The Most Holy Mother of God", KRUSHICA (Kichevo)

801. "The Most Holy Mother of God", SLATINO (Ohrid)

802. "The Most Holy Mother of God", SRETKOVO (Gostivar)

803. "The Immaculate Mother of God", JANKOVEC (Prespa)

804. "The Immaculate Mother of God", POPOLZHANI (Kichevo) 
396 | THE XIX CENTURY BASILICAS IN MACEDONIA: ORIGIN, TYPOLOGY AND INFLUENCES 


\section{Churches from the First Half of the XX Century with Revival Typology}

1. "Holy Trinity", KUMANOVO, 1901

2. "St. Nicholas", BREZNICA (Makedonski Brod), 1901

"Holy Trinity", TROOLO (Probishtip), 1901

4. "St. Nicholas", DOLNO KRUSHJE (Makedonski Brod), 1902

5. "St. Elijah", POZHARANE(Gostivar), 1902

6. "St. Cyril and Methodius", TETOVO, 1903-1918,

7. "St. Elijah", TAZHEVO (Makedonski Brod), 1903

8. "St. George", BIGLA (Delchevo), 1903

9. "St. Elijah", ROGACHEVO (Tetovo), 1903

10. "St. Nicholas", BLIZANSKO (Makedonski Brod), 1904

11. "St. Nicholas", GORNO BOTUSHE (Makedonski Brod), 1905

12. "St. Panteleimon", SVETA (Demir Hisar), 1905

13. "The Most Holy Mother of God", VELES, 1905

14. "St. Demetrius", TETOVO, 1906-1912

15. "St. Peter and Paul", KICHEVO, 1907

16. "St. Elijah", RAMNE (Ohrid), 1907

17. "St. Sunday", R'ZHANOVO (Struga), 1907

18. "St. Savior", ELOVEC (Veles), 1908

19. "Dormition of the Most Holy Mother of God", SLOESHTICA (Demir Hisar), 1908

20. "St. Nicholas", GORNA GJONOVICA (Gostivar), 19081910

21. "St. Nicholas", LESHANI (Ohrid), 1909

22. "Holy Presentation", DUPENI (Prespa), 1909

23. "St. Elijah", RADOVNICA (Kriva Palanka)

24. "St. Nicholas", DEDINO (Radovish), 1910

25. "St. Petka", BADILEN (Strumica), 1910

26. "St. George", SMILEVO (Demir Hisar), 1911

27. "St. Demetrius", KNEZHINO (Kichevo), 1911

28. "Nativity of the Most Holy Mother of God", BOGORODICA (Gevgelija), 1911

29. "St. Elijah", DREN (Negotino), 1911

30. "St. Demetrius", KRIVOGASHTANI (Prilep), 1912

31. "St. Nicholas", POZHARANE (Gostivar), 1912

32. "Holy Trinity", GOLEMO KONJARI (Prilep), 1912

33. "Nativity of the Most Holy Mother of God", BEROVO, 1912

34. "St. Nicholas", BITOVO (Makedonski Brod), 1912

35. "St. Nicholas", ZHILCHE (Tetovo), 1913

36. "St. Demetrius", VRAPCHISHTE (Gostivar), 1912-1916

37. "St. Petka", VRAPCHISHTE (Gostivar), 1912-1916

38. "Nativity of the Most Holy Mother of God", MALO RADOBIL (Prilep), 1913

39. “St. Annunciation", JELOSHNIK (Tetovo), 1913

40. "The Most Holy Mother of God", TETOVO, 1913-1918

41. "St. George", STARO SELO (Tetovo), 1914

42. "St. Nicholas", DOLNO BOTUSHE (Makedonski Brod), 1915

43. "St. Demetrius", ILOVICA (Strumica), 1915

44. "St. Savior", DOLNO PALCHISHTE (Tetovo), 1915-1916

45. "St. George", KOCHANI, 1917

46. "St. Athanasius", RADIOVCE (Tetovo), 1917

47. "St. Talalej", INCHE (Makedonski Brod), 1918

48. "St. Athanasius", VRAPCHISHTE (Gostivar), 1918
49. "St. George", KLECHOVCE (Kumanovo), 1918

50. "St. Peter and Paul", DOLNA BANJICA (Gostivar), 1918

51. "St. Archangel Michael", DOLNI DISAN (Negotino), 1918/1919

52. "St. Archangel Michael", MOGILEC (Makedonski Brod), 1919

53. "The Most Holy Mother of God", MILETINO (Tetovo), 1919

54. "St. George", SUSHICA (Strumica), 1918-1920

55. "St. Nicholas", TENOVO (Tetovo), 1920

56. "St. John", RASTESH (Makedonski Brod), 1920

57. "St. Petka", PROSTRANJE (Kichevo), 1920

58. "St. George", DOLNI MANASTIREC (Makedonski Brod), 1920

59. "St. Nicholas", KALUGJEREC (Makedonski Brod), 1920

60. "St. John", OTOSHNICA (Kriva Palanka), 1920

61. "The Most Holy Mother of God", LJUBANCI (Skopje), 1920

62. "St. George", BELOTINO (Strumica), 1920-1930

63. "St. George", PETRALINCI (Strumica), 1920-1930

64. "St. Nicholas", DLABOCHICA (Kriva Palanka), 1921

65. "The Most Holy Mother of God", OSLOMEJ (Kichevo), 1921

66. "St. Athanasius", BALTEPE - TETOVO, 1922

67. "St. John the Baptist", KURBINOVO (Prespa), 1922

68. "Dormition of the Most Holy Mother of God", SKREBATNO (Ohrid), 1922

69. "St. George", RASHTANI (Kichevo), 1922

70. "St. Nicholas", TUIN (Kichevo), 1922

71. "St. John", EZERANI (Prespa), 1922

72. "St. Athanasius", BRVENICA (Tetovo), 1922

73. "St. Cosma and Damian", JEDOARCE (Tetovo), 1922

74. "Holy Trinity", GORENCl (Ohrid), 1923

75. "The Most Holy Mother of God", SARAKJINO (Tetovo), 1923

76. "Holy Trinity", PODVIS (Prilep), 1924

77. "St. Nicholas", OPENICA (Ohrid), 1924

78. "St. George", DEBRESHE (Gostivar), 1924

79. "Holy Trinity", BRZAK (Kumanovo), 1920-те

80. "Dormition of the Most Holy Mother of God", JANCHE (Debar), 1924

81. "Holy Trinity", BOLNO (Prespa), 1924

82. "St. John Vladimir", PODGORCI (Struga), 1924

83. "The Most Holy Mother of God", DVORISHTE (Berovo), 1924

84. "St. Petka", VRATNICA (Tetovo), 1924/25

85. "St. Nicholas", RASTESH (Makedonski Brod), 1925

86. "St. Petka", BOISHTE (Demir Hisar), 1925

87. "St. John", NOVO SELO (Gostivar), 1925

88. "St. Nicholas", OKTISI (Struga), 1925

89. "St. Nicholas", CHUMOVO (Prilep), 1925

90. "St. George of Kratovo", KRATOVO, 1925

91. "St. Petka", BEDINJE (Kumanovo), 1925

92. "St. Mino", GORNO KONJSKO (Ohrid), 1927

93. "St. Cyril and Methodius", STENJE (Prespa), 1911 1927 
94. "The Most Holy Mother of God", GORNO KONJARI (Kumanovo), 1927

95. "St. George" CHAIR - SKOPJE, 1924-1927

96. "St. Elijah", OROVNIK (Ohrid), 1927

97. "St. George", KOPRISHNICA (Demir Kapija), 1928

98. “St. Archangel Michael”, ARVATI (Prespa), 1929

99. "St. Demetrius", SHTRBOVO (Prespa), 1929

100. "St. Athanasius", SHTRBOVO (Prespa), 1930s

101. "Holy Trinity", GERMAN (Kriva Palanka), 1930s

102. "St. George", PETROVEC (Skopje), 1930s

103. "St. Peter and Paul" - Bukovo cemetery, BITOLA, $1930 \mathrm{~s}$

104. "St. Demetrius", DOBROVNICA (Kriva Palanka), 1930

105. "The Most Holy Mother of God", DUSHOGUBICA (Kichevo), 1930-1936

106. "Dormition of the Most Holy Mother of God", VLADEVCI (Strumica), 1930

107. "St. George", VELMEJ (Ohrid), 1931

108. "St. George", VELEBRDO (Mavrovo), 1931

109. "St. George", MALA RECHICA (Tetovo), 1931

110. "St. Nicholas", DEBRESHTE (Prilep), 1932

111. "St. Savior - Ascension of Christ", LOKOV (Struga), 1932

112. "Dormition of the Most Holy Mother of God", SEKIRNIK (Strumica), 1932

113. "St. Athanasius", MACHEVO (Berovo), 1932

114. "St. Demetrius", SELCE (Prilep), 1933

115. "St. Petka", GRESHNICA (Makedonski Brod), 1933

116. "The Most Holy Mother of God", RECHANI (Kichevo), 1933

117. "St. Petka", TABANOVCE (Kumanovo), 1933

118. "St. Constantine and Helena", PODMOLE (Ohrid), 1934

119. "Nativity of the Most Holy Mother of God", ZAVOJ (Ohrid), 1934

120. "St. Theodore Tyron", KOVACH (Makedonski Brod), 1934

121. "St. Elijah", SLANSKO (Makedonski Brod), 1934

122. "St. Elijah", DVORCI (Makedonski Brod), 1934

123. "St. Nicholas", SVINISHTA (Ohrid), 1934

124. "The Most Holy Mother of God", TRNOVO (Bitola), 1926-1934

125. "St. George", PIRAVA (Valandovo), 1932-1934

126. "St. Elijah", DOLNO KRUSHJE (Makedonski Brod), 1935

127. "The Most Holy Mother of God", JAGOL DOLENCI (Kichevo), 1935

128. "St. Sunday", TENOVO (Tetovo), 1935

129. "St. Sunday", OSOJ (Kichevo), 1935

130. "St. George", GRKO POLE (Ohrid), 1935

131. "St. Elijah", RICH (Strumica), 1935

132. "The Most Holy Mother of God", GORNO / DOLNO SREDORECHIE (Ohrid), 1936

133. "St. Constantine and Helena", MRZENCI (Gevgelija), 1925-1936

134. "Holy Trinity", MOZHDIVNJAK (Kriva Palanka), 1936

135. "St. George", LUKOVICA (Tetovo), 1936

136. "St. Theodore Tyron", KRIVOGASHTANI (Prilep), 1936

137. "St. Demetrius", ATISHTA (Kichevo), 1936

138. "Holy Trinity", LOKVENI (Prilep), 1936

139. "St. Ana", MALOVISHTE (Bitola), 1936

140. "St. Elijah", LUKE (Kriva Palanka), 1936
141. "St. Demetrius", SUSHEVO (Strumica), 1936

142. "St. Elijah", GRADSKO BALDOVCI (Strumica), 1936

143. "St. George", PELINCE (Kumanovo), 1936

144. "St. Athanasius", KONJSKO (Prespa), 1937

145. "St. Elijah", DAVIDOVO (Gevgelija), 1937

146. "St. George", BLACE (Tetovo), 1937

147. "St. Nicholas", KURATICA (Ohrid), 1937

148. "St. Elijah", PREMKA (Kichevo), 1937

149. "St. Elijah", VELGOSHTI (Ohrid), 1937

150. "The Most Holy Mother of God", DEMIR KAPIJA, 1937

151. "St. George", SIRKOVO (Tikvesh), 1938

152. "St. Elijah", DOBREVO (Probishtip), 1938

153. "St. George", POKRAJCHEVO (Radovish), 1935-1938

154. "St. Peter and Paul", VRBJANI (Ohrid), 1938

155. "Ascension of Christ", ARBANASHKO (Kumanovo), 1938

156. "St. Peter and Paul", LATOVO (Makedonski Brod), 1938

157. "St. Nicholas", GORNO DOBRENOEC (Kichevo), 1938

158. "St. John the Theologan", BITOLA, 1938, demolished in 1976

159. "Nativity of the Most Holy Mother of God", RAKITEC (Radovish), 1939

160. "St. Nicholas", LAVCI (Bitola), 1939

161. "St. George", CHETIRCE (Kumanovo), 1939

162. "St. John the Theologan", CHIFLIK (Pehchevo), 19391941

163. "St. John Chrysostom", ANGELCI (Strumica), 1940

164. "St. John", REZHANOVCE (Kumanovo), 1941

165. "St. Nicholas", TREBENISHTA (Ohrid), 1942

166. "St. Savior - Ascension of Christ", GABREVCI (Radovish), 1944

167. "St. Sunday", VAPILA (Ohrid), 1945

168. "St. Peter and Paul", ZHIVOVO (Mariovo), 1945

169. "St. Savior - Ascension of Christ", ZVECHAN (Makedonski Brod), 1946

170. "Dormition of the Most Holy Mother of God", DOLNI LIPOVIKJ (Radovish), 1947

171. "St. Archangel Michael", BLIZANSKO (Makedonski Brod), 1947

172. "St. George", DEVICH (Makedonski Brod), 1948

173. "St. John", LUUBANCI (Skopje), 1940s

174. "Dormition of the Most Holy Mother of God", VELESEתO (Bitola)

175. "The Most Holy Mother of God", KALUGJERICA (Radovish)

176. "The Most Holy Mother of God", ZLEOVO (Radovish)

177. "St. Archangel Michael", MOIN (Gevgelija)

178. "St. George", SKORUSHA (Radovish)

179. "Holy Trinity", DESOVO (Prilep)

180. "St. Nicholas", JAOREC (Kichevo)

181. "St. Sunday", MALO CRSKO (Kichevo)

182. "The Most Holy Mother of God", NOVO SELO (Kichevo)

183. "St. Petka", LOKOV (Struga)

184. "The Most Holy Mother of God", NOVO SELO (Ohrid)

185. "St. Demetrius", TUMCHEVISHTE (Gostivar)

186. "Holy Trinity", LOPATE (Kumanovo)

187. "Holy Trinity", RECHICA (Kumanovo)

188. "St. Demetrius", SEDLARCI (Strumica) 


\section{Older Churches Reconstructed in the XIX Century}

1. "St. John" - Bigorski monastery, DEBAR, 1800

2. "St. Savior - Ascension of Christ", NOGAEVCI (Veles), 1800-1820

3. "St. Savior", SKOPJE, 1820 - renovation of a church from XVI-XVII century (Тричковска, 2008: 56)

4. "St. George", STRUGA, 1835 - renovation of a XIII century church

5. "St. Savior - Ascension of Christ", VELES, 1837 - built over the remains of a XIV century church

6. "Holy Transfiguration", BUKOVO (Bitola), 1837 - renovation of an older monastery

7. "St. Demetrius", KAVADARCI, 1838

8. "Holy Trinity", CHUCHER SANDEVO (Skopje), 1838/1856 - renovation of a XIII century church, demolished in 1938

9. "St. Nicholas", VELMEJ (Ohrid), 1840 - annex to a XIII century church

10. "St. Nicholas", VLADILOVCI (Veles), 1840 - renovation of a XVII century church

11. "St. Marina", ZUBOVCE (Gostivar), 1845

12. "Nativity of the Most Holy Mother of God", BRAZDA (Skopje), 1846 - addition of a narthex to the single nave post-Byzantine church (Велев, 1990: 35)

13. "Nativity of the Most Holy Mother of God", GORNI MANASTIREC (Makedonski Brod), 1846 - renovation of a medieval temple (Велев, 1990: 45)

14. "St. Athanasius", BOLNO (Prespa), 1846 - renovation of an older church, renovated and consecrated again in 1989

15. "St. Nicholas", KRATOVO, 1848

16. “St. Petka", CAPARI (Bitola), 1849 - renovated first in 1724 (Велев, 1990: 155)

17. "St. Demetrius", ZRNOVCI (Kochani), 1849 - over old foundations

18. "Dormition of the Most Holy Mother of God", ZABEL (Kumanovo), 1852-1856, foundations of a church from 1330

19. "St. Elijah", RAOTINCE (Tetovo), 1852 narthex to a XV century single-nave vaulted church

20. "Dormition of the Most Holy Mother of God", ZBAZHDI (Struga), 1852 - renovation of a 1752 chapel

21. "The Most Holy Mother of God", ZLETOVO (Probishtip), 1853, renovation of a post-Byzantine church

22. "St. Nicholas", GLUVO (Skopje), 1855

23. "St. Petka", РОBOZHJE (Skopje) 1855 - single-nave XV century church was turned into a three-nave basilica

24. "The Most Holy Mother of God", KOZHLE (Skopje), 1856 - renovation of the church "St. Nicholas" (XIII-XIV century)

25. "St. Elijah", ELSHANI (Ohrid), 1859 - renovation of a XV century church

26. "St. George", NEGOTINO, 1860

27. "St. John the Forerunner", SLEPCHE (Demir Hisar), 1862

28. "St. Petka", CRESHNEVO (Veles), 1862 - renovation of a church from 1601

29. "Holy Trinity", NIVICHANI (Kochani), 1864

30. "St. George", GRADISHTE (Kumanovo), 1864, older foundations, from a demolished monastery

31. "St. George", GORNO VODNO (Skopje), 1866 - older foundations

32. "St. Archangel Michael", VRPSKO (Mariovo), 1868 - over an older post-Byzantine church

33. "St. Savior - Ascension of Christ", DRENOVO (Veles), 1862, renovation of a XVII century church (Николовски, 2017: 276)

34. "St. Petka", MURGASH (Kumanovo), renovation of a XVI-XVII century church (Машниќ, 2015: 251-252).

35. "St. Elijah", BOGOMILA (Veles), a XVII century church serves as the altar of a larger cemetery temple

36. "St. George", MARTOLCI (Veles), 1872 - renovation of a XVII century church

37. "St. Nicholas", PRILEPEC (Prilep), 1872

38. "St. Nicholas", BUKOVO (Negotino), 1873 - renovation of a medieval (XIV century) church, demolished in 1813

39. "St. Nicholas", MIRKOVCI (Skopje), 1873

40. "St. Athanasius", SENOKOS (Prilep), 1874

41. "St. Archangel Michael", SPANCHEVO (Kochani), 1874 - renovation of a single-nave post-Byzantine church

42. "St. Athanasius", KUCHEVISHTE (Skopje), 1875, over older foundations (Велев, 1990: 26)

43. "St. George", MILETINO (Tetovo), 1875, over older foundations

44. "St. George", ZASHLE (Krushevo), 1876 - renovation of an older sanctuary (Велев, 1990: 78)

45. "St. Nicholas", VATASHA - Moklishki monastery (Kavadarci), 1879, renovation of a church from 1595

46. "St. Petka", SIRICHINO (Tetovo), 1884, a western annex to a XVI - XVII century church

47. "St. Nicholas", RAKOVEC (Veles), 1884, renovation of a XVII century church

48. "St. George", PETRALICA (Kriva Palanka), 1886, renovation of a XVII century church

49. "St. George", RADISHANI (Skopje), 1899 - renovation of an older church

50. "St. Athanasius", VOJNICA (Veles), 1890 - renovation of an older monastery (Велев, 1990: 23)

51. "St. Athanasius", KOVACH (Makedonski Brod), 1891 - renovation of a XVII century church

52. "St. George", BELJAKOVCE (Kumanovo), 1892-1894 - renovation of an older church

53. "St. Nicholas", OMORANI (Veles), 1893 - renovation of an older monastery

54. "St. Nicholas", CHELOPEK (Tetovo), renovation of a XIV century church

55. "The Most Holy Mother of God", DABNISHTE (Kavadarci) - renovation of a XIII century church 
56. "The Most Holy Mother of God", LESHOK (Tetovo), a western annex to a XIV century church

57. "St. Nicholas", GINOVCE (Kriva Palanka), renovation of a XVII century church

58. "St. Elijah", LISICHE (Veles) - renovation of an older church

59. "Dormition of the Most Holy Mother of God", DABNISHTE (Kavadarci) - renovation of a XIII century church, fresco-painting and royal doors from the XIX century

60. "St. Cosma and Damian", SVETORACHE (Kichevo) - older foundations

61. "The Most Holy Mother of God", DRENOVO (Kavadarci)

62. "St. Athanasius", ASAMATI (Prespa)

63. "St. Nicholas", GABROVNIK (Veles), eastern wall from the XVII century

64. "St. Peter and Paul", MESHEISHTA (Ohrid)

65. "St. Nicholas", ULANCI (Veles) - renovation of a XVII century church

66. "St. Demetrius", POMENOVO (Veles) - renovation of a XVII century church

67. "St. Athanasius", GORNO KONJARI (Skopje)

68. "Dormition of the Most Holy Mother of God", DIVLJE (Skopje) - older church from 1603/4

69. "St. George", SUSHICA (Skopje) - renovation of an older church (Велев, 1990: 86)

70. "Dormition of the Most Holy Mother of God", DOLENCl (Demir Hisar), 1851 - annex to an older church

71. "St. Petka", ZHVAN (Demir Hisar) - annex to a post-Byzantine church

72. "St. Demetrius", RAKITNICA (Demir Hisar) - renovation of a post-Byzantine church (XVI-XVII century) - a Revival gallery and architrave instead of a vaulted ceiling

73. "St. Athanasius", SUVO GRLO (Demir Hisar) - renovation of an older church

74. "The Most Holy Mother of God", RANKOVCE (Kriva Palanka) - renovation of a XVII century church

75. "St. Athanasius", RILEVO (Prilep) - renovation of a XVII century church

76. "St. George", BLACE (Skopje) - renovation of a XVI-XVII century church

77. "St. Nicholas", KOSHINO (Prilep) - renovation of a XVII century church

78. "The Most Holy Mother of God", MAZHUCHISHTE (Prilep) - renovation of a XVIII century church 


\section{List of illustrations}

Figure I.1 Source: Hoddinott (1963).

Figure I.2 Source: www.edessanews.gr.

Figure I.3 Source: А. Микулчиќ (1999); В. Чипан (1996).

Figure I.4 Source: Микулчиќ (1999).

Figure I.5 Source: A. Hodinott (1963); В. Ѓорѓnевска (2003).

Figure I.6 Source: Каранаков (2014).

Figure I.7 Source: Белдедовски (2003).

Figure I.8 Documentation: IPBHHAA, FA, UCaM - Skopje.

Figure I.9 Source: Микулчиќ (1999).

Figure I.10 Source: Алексова (1995).

Figure I.11 Source: Димитрова, Коруновски и Грандаковска (2013).

Figure 1.12 Source: А. Алексова (1995); В. Milojević, published bу Алексова (1989).

Figure I.13 Source: Skyllitzes Matritensis, fol. 185r, Biblioteca Nacional de España.

Figure I.14 Source: Macedonia Catena Mundi (1994).

Figure I.15 Source: Кораќ и Шупут (1998).

Figure I.16 Documentation: IPBHHAA, FA, UCaM - Skopje, adapted from Milojević, reproduced by Алексова (1995).

Figure I.17 Documentation: IPBHHAA, FA, UCaM - Skopje, adapted from the archive of IPMCM - Bitola.

Figure I.18 Source: Кораћ и Шупут (1998).

Figure I.19 Photography no. Q269-49, Mission of the Russian Science Academy to Macedonia, Archive of IFMC Skopje.

Figure I.20 Source: A. https://en.wikipedia.org/; B. https://lakes.mk/.

Figure I.21 Source: A. IPBHHAA, FA, UCaM - Skopje, adapted from https://classic.europeana.eu/; B. https://publicitet.mk.

Figure I.22 Documentation: the author, adapted from the archive of IPMCM - Ohrid.

Figure I.23 Photography: A. Daniel C. Waugh; В. Чипан (1996).

Figure I.24 Source: Коруновски и Димитрова (2006).

Figure I.25 Documentation: the author, adapted from the archive of IPMCM - Ohrid.

Figure I.26 Documentation: the author, adapted from the archive of IPMCM - Bitola.

Figure I.27 Source: Кораћ и Шупут (1998).

Figure I.28 Source: А. Кораћ и Шупут (1998); В. Коруновски и Димитрова (2006).

Figure I.29 Source: A. the author; B. Кораћ и Шупут (1998). Figure I.30 Photography: A. and B. P. Stojanovski; C. M. Stojchevska.

Figure I.31 Photography no. Q266-23, Mission of the Russian Science Academy to Macedonia, Archive of IFMC Skopje.

Figure I.32 Source: A. the author, adapted from Микулчиќ (1999); B. https://en.wikipedia.org/.

Figure I.33 Source: Documentation by NCC, published by Коруновски и Димитрова (2006).

Figure I.34 Source: Documentation by NCC, published by Коруновски и Димитрова (2006).

Figure I.35 Photography no. Q266-41, Mission of the Russian Science Academy to Macedonia, Archive of IFMC Skopje.
Figure I.36 Source: G. Subotic, published by Коруновски и Димитрова (2006).

Figure 1.37 Documentation: the author, adapted from $\mathrm{S}$. Korunovski.

Figure I.38 Source: https://en.wikipedia.org/.

Figure I.39 Documentation: the author, adapted from NCC.

Figure I.40 Documentation: the author.

Figure I.41 Source: https://cfcd.finance.gov.mk/.

Figure I.42 Source: Николовски (2019).

Figure I.43 Source: А. Крстиќ (2012); В. Касапова (2020).

Figure I.44 Documentation: the author.

Figure 1.45 Source: the author.

Figure I.46 Documentation: the author.

Figure 1.47 Source: the author.

Figure 1.48 Documentation: the author, adapted from Крстиќ (2009).

Figure 1.49 Source: A. the author, adapted from Крстиќ (2012); B. https://mia.mk/.

Figure 1.50 Documentation: the author, adapted from Крстиќ (2012).

Figure I.51 Photography no. Q265-52, Mission of the Russian Science Academy to Macedonia, Archive of IFMC Skopje.

Figure 1.52 Documentation: the author, adapted from the archive of IPMCM - Bitola.

Figure 1.53 Source: IPMCM - Bitola.

Figure I.54 Source: IPMCM - Bitola.

Figure 1.55 Source: IPMCM - Bitola.

Figure II.1 Source: https://upload.wikimedia.org/.

Figure II.2. Source: https://www.alamy.com/.

Figure II.3 Source: https://en.wikipedia.org/.

Figure II.4 Source: https://www.pelagon.mk/.

Figure II.5 Source: the author.

Figure II.6 Photography: the author.

Figure II.7 Photography: the author.

Figure II.8 Source: Николовски (2013).

Figure II.9 Photography: L. Doneva and T. Dodeva.

Figure II.10 Source: Хаџиева-Алексиевска и Касапова (2001)

Figure II.11 Photography: A. T. Madzunarov; B. J. M. Fernández Cuadros.

Figure II.12 Photography: Z. Karapanchev.

Figure II.13 Source: Хаџиева-Алексиевска и Касапова (2001).

Figure II.14 Photography: the author.

Figure II.15 Photography: the author.

Figure II.16 Photography: the author.

Figure II.17 Photography: IPBHHAA, FA, UCaM - Skopje.

Figure II.18 Source: https://www.dke.org.mk/.

Figure II.19 Source: А. Лилчиќ и Илјоска (1997); В. Филипова (1997).

Figure II.20 Source: Коруновски и Димитрова (2006).

Figure II.21 Source: Грозданов (2015).

Figure II.22 Source: Ќорнаков (2016).

Figure II.23 Source: https://mk.wikipedia.org/.

Figure II.24 Photography: A. https://mk.wikipedia.org/; B.

A. Nikolov. 
Figure II.25 Photography: http://www.muzejnegotino.mk/. Figure II.26 Photography: A. https://www.facebook.com/; B. M. Skrizhevski.

Figure II.27 Photography: D. Damjanovski.

Figure II.28 Source: www.whereismacedonia.org.

Figure III.1 Source: https://mk.wikipedia.org/. Figure III.2 Photography: NCC - Skopje.

Figure III.3 Photography: the author. Figure III.4 Photography: the author.

Figure III.5 Source: A. https://mk.wikipedia.org/; B. the author.

Figure III.6 Photography: IPMCM - Bitola.

Figure III.7 Source: https://mk.wikipedia.org/.

Figure III.8 Photography: A. https://mk.wikipedia.org/; B. FA - Skopje.

Figure III.9 Photography: L. Todoroska.

Figure III.10 Photography: the author.

Figure III.11 Source: www.wikipedia.org.

Figure III.12 Photography: IPBHHAA, FA, UCaM - Skopje.

Figure III.13 Source: https://mk.wikipedia.org/.

Figure III.14 Photography: the author.

Figure III.15 Source: A. Photography by B. Jovanovska; B. https://mk.wikipedia.org/.

Figure III.16 Source: A. the author; B. and C. Archive of IFMC - Skopje.

Figure III.17 Source: A. and B. http://tirekovmirece.com/; C. archive of IFMC - Skopje.

Figure III.18 Photography: the author.

Figure III.19 Photography: the author.

Figure III.20 Source: Fernández Cuadros (2014).

Figure III.21 Photography: private collection of G. Angelichin - Zhura.

Figure III.22 Photography: https://bitola.info/mk/.

Figure III.23 Photography: the author.

Figure III.24 Source: https://mk.wikipedia.org/.

Figure III.25 Photography: N. Veljanova.

Figure III.26 Source: A. https://bitola.info/mk/; B. Photography by D. Damjanovski.

Figure III.27 Photography: A. L. Mitkovska; B. B. Grujovski. Figure III.28 Photography: the author.

Figure III.29 Photography: IPMCM - Bitola.

Figure III.30 Source: A. www.pelagon.mk; B. IPMCM Bitola; C. Photography by D. Serafimovska.

Figure III.31 Source: A. https://mk.wikipedia.org/i B. IPMCM - Bitola.

Figure III.32 Photography: A. S. Vasileva; B. and C. https://mk.wikipedia.org/.

Figure III.33 Photography: the author.

Figure III.34 Source: IPMCM - Bitola.

Figure III.35 Photography: the author.

Figure III.36 Source: A. Photography by T. Dodeva; B. https://mk.wikipedia.org/.

Figure III.37 Source: https://marh.mk/.

Figure III.38 Photography: A. IPBHHAA, FA, UCaM - Skopje;

B. the author.

Figure III.39 Photography: A. the author; B. Z. Karapanchev.

Figure III.40 Photography: the author.

Figure III.41 Photography: the author.

Figure III.42 Photography: https://mk.wikipedia.org/.

Figure III.43 Photography: NCC - Skopje.

Figure III.44 Source: A. and B. IPBHHAA, FA, UCaM - Skopje;

C. https://snappygoat.com/.

Figure III.45 Photography: IPMCM - Bitola.

Figure III.46 Photography: A. the author; B. IPMCM - Bitola.
Figure III.47 Photography: IPMCM - Bitola.

Figure III.48 Source:

A. https://visitkumanovo.wordpress.com/; B.

https://ovcepole33.wordpress.com/.

Figure III.49 Photography: the author.

Figure III.50 Photography: A. https://bitola.info/.com; B. the author.

Figure III.51 Photography: https://mk.wikipedia.org/.

Figure III.52 Photography: A. the author; B. http://www.oldprilep.com/.

Figure III.53 Photography: the author.

Figure III.54 Photography: D. Mitevska.

Figure III.55 Photography: https://mk.wikipedia.org/.

Figure III.56 Photography: https://mk.wikipedia.org/.

Figure III.57 Photography: A. IPBHHAA, FA, UCaM - Skopje; B. IPMCM - Bitola.

Figure III.58 Photography: A. the author; B. A. Aleksovska. Figure III.59 Photography: A. https://mk.wikipedia.org/; B. the author.

Figure III.60 Photography: A. K. Simeonovski; B. www.WherelsMacedonia.org; C. the author.

Figure III.61 Source: https://mk.wikipedia.org/.

Figure III.62 Source: https://mk.wikipedia.org/.

Figure III.63 Source: https://mk.wikipedia.org/.

Figure III.64 Photography: the author.

Figure III.65 Source: https://mk.wikipedia.org/.

Figure III.66 Photography: the author.

Figure III.67 Photography: the author.

Figure III.68 Photography: K. Simeonovski.

Figure III.69 Photography: the author.

Figure III.70 Photography: IPMCM - Bitola.

Figure III.71 Photography: P. Jankulovski.

Figure III.72 Photography: A. https://mk.wikipedia.org/; B. IPMCM - Bitola.

Figure III.73 Source: https://mk.wikipedia.org/.

Figure III.74 Photography: A. https://mk.wikipedia.org/; B. D. Balinski.

Figure III.75 Photography: IPMCM - Bitola.

Figure III.76 Photography: A. www.mojrodenkraj.mk; B. and $\mathbf{C}$. the author.

Figure III.77 Photography: the author.

Figure III.78 Photography: V. Lazarovska.

Figure III.79 Photography: the author.

Figure III.80 Photography: A. IPMCM - Bitola; B. https://mk.wikipedia.org/.

Figure III.81 Photography: https://mk.wikipedia.org/.

Figure III.82 Photography: A. https://mk.wikipedia.org/; B. FA - Skopje.

Figure III.83 Photography: the author.

Figure III.84 Photography: A. and B. IPMCM - Bitola; C. www. WherelsMacedonia.org.

Figure III.85 Photography: the author.

Figure III.86 Photography: A. the author; B. https://ovcepole33.wordpress.com/; C. S. Vasileva.

Figure III.87 Photography: https://mk.wikipedia.org/.

Figure III.88 Photography: A. https://mk.wikipedia.org/; B. the author.

Figure III.89 Photography: A. J. Pargovski; B. the author; C. IPMCM - Bitola

Figure III.90 Photography: the author.

Figure III.91 Photography: www.pelagon.mk.

Figure III.92 Photography: A. IPMCM - Bitola; B. the author.

Figure III.93 Photography: J. Pargovski.

Figure III.94 Photography: www.pelagon.mk. 
Figure III.95 Photography: A. www.mojrodenkraj.mk; B. IPMCM - Bitola.

Figure III.96 Photography: the author.

Figure III.97 Photography: A. the author; B. IPMCM - Bitola. Figure III.98 Photography: A. https://mk.wikipedia.org/; B. the author.

Figure III.99 Photography: NCC -Skopje.

Figure III.100 Photography: the author.

Figure III.101 Photography: the author.

Figure III.102 Photography: IPMCM - Bitola.

Figure III.103 Photography: IPMCM - Bitola.

Figure III.104 Photography: the author.

Figure III.105 Photography: IPBHHAA, FA, UCaM - Skopje.

Figure III.106 Photography: A. the author; B. www.pelagon.mk.

Figure III.107 Photography: the author.

Figure III.108 Photography: A. the author; B. https://mk.wikipedia.org/.

Figure III.109 Photography: IPBHHAA, FA, UCaM - Skopje.

Figure III.110 Photography: IPMCM - Bitola.

Figure III.111 Photography: IPMCM - Bitola.

Figure III.112 Source: A. St. www.pelagon.mk; B. https://mk.wikipedia.org/.

Figure III.113 Source: Historic-cultural Monuments in the Cross-border Region Kriva Palanka - Kystendil (2013).

Figure III.114 Photography: IPMCM - Bitola.

Figure III.115 Photography: the author.

Figure III.116 Photography: the author.

Figure III.117 Photography: the author.

Figure III.118 Documentation: IPBHHAA, FA - Skopje, adapted by the author.

Figure III.119 Photography: the author.

Figure III.120 Photography: the author.

Figure III.121 Photography: the author.

Figure III.122 Documentation: the author.

Figure III.123 Documentation: the author.

Figure III.124 Photography: the author.

Figure III.125 Photography: the author.

Figure III.126 Photography: the author.

Figure III.127 Photography: the author.

Figure III.128 Photography: the author.

Figure III.129 Documentation: IPBHHAA, FA, UCaM Skopje, adapted by the author.

Figure III.130 Documentation: IPBHHAA, FA, UCaM Skopje, adapted by the author.

Figure III.131 Documentation: IPBHHAA, FA, UCaM Skopje, adapted by the author.

Figure III.132 Photography: the author.

Figure III.133 Source: Mariovo (2009).

Figure III.134 Source: Поповска-Коробар (2015).

Figure III.135 Source: Дапчев (1996).

Figure III.136 Source: A. IPMCM - Bitola; B. https://mk.wikipedia.org/.

Figure III.137 Source: Дапчев (1996).

Figure III.138 Photography: E. Kasapova.

Figure III.139 Photography: E. Kasapova.

Figure III.140 Photography: E. Kasapova.

Figure III.141 Photography: E. Kasapova.

Figure III.142 Documentation: IPBHHAA, FA, UCaM Skopje, adapted by the author.

Figure III.143 Documentation: IPBHHAA, FA, UCaM Skopje, adapted by the author.

Figure III.144 Photography: E. Kasapova.

Figure III.145 Photography: www.pelagon.mk.

Figure III.146 Photography: P. Stojanovski.
Figure III.147 Photography: A. D. Damjanovski; B. IPMCM Bitola.

Figure III.148 Photography: IPMCM - Bitola.

Figure III.149 Documentation: the author, adapted from IPMCM - Bitola.

Figure III.150 Documentation: the author, adapted from IPMCM - Bitola.

Figure III.151 Photography: the author.

Figure III.152 Photography: the author.

Figure III.153 Photography: https://en.wikipedia.org/.

Figure III.154 Photography: https://en.wikipedia.org/.

Figure III.155 Photography: the author.

Figure III.156 Source: Historic-cultural Monuments in the Crossborder Region Kriva Palanka - Kystendil (2013).

Figure III.157 Source: http://tresonce.mk/.

Figure III.158 Photography: NCC - Skopje.

Figure III.159 Documentation: NCC - Skopje, digitized by IPBHHAA, FA, UCaM - Skopje, adapted by the author.

Figure III.160 Documentation: NCC - Skopje, digitized by IPBHHAA, FA, UCaM - Skopje, adapted by the author.

Figure III.161 Documentation: NCC - Skopje, digitized by IPBHHAA, FA, UCaM - Skopje, adapted by the author.

Figure III.162 Photography: NCC - Skopje.

Figure III.163 Source: http://tresonce.mk/.

Figure III.164 Photography: https://en.wikipedia.org/.

Figure III.165 Documentation: NCC - Skopje, adapted by the author.

Figure III.166 Photography: the author.

Figure III.167 Photography: the author.

Figure III.168 Photography: the author.

Figure III.169 Photography: the author.

Figure III.170 Documentation: IPBHHAA, FA, UCaM - Skopje, adapted by the author.

Figure III.171 Documentation: IPBHHAA, FA, UCaM - Skopje, adapted by the author.

Figure III.172 Documentation: IPBHHAA, FA, UCaM - Skopje, adapted by the author.

Figure III.173 Photography: the author.

Figure III.174 Photography: A. the author; B. https://marh.mk/.

Figure III.175 Photography: the author.

Figure III.176 Photography: I. Zografina.

Figure III.177 Photography: the author.

Figure III.178 Documentation: IPBHHAA, FA, UCaM - Skopje, adapted by the author.

Figure III.179 Documentation: IPBHHAA, FA, UCaM - Skopje, adapted by the author.

Figure III.180 Documentation: IPBHHAA, FA, UCaM - Skopje, adapted by the author.

Figure III.181 Photography: the author.

Figure III.182 Photography: the author.

Figure III.183 Photography: the author.

Figure III.184 Photography: the author.

Figure III.185 Photography: the author.

Figure III.186 Photography: the author.

Figure III.187 Documentation: the author.

Figure III.188 Documentation: the author.

Figure III.189 Photography: the author.

Figure III.190 Photography: the author.

Figure III.191 Photography: the author.

Figure III.192 Photography: the author.

Figure III.193 Photography: the author.

Figure III.194 Documentation: IPBHHAA, FA, UCaM - Skopje, adapted by the author.

Figure III.195 Photography: the author. 
Figure III.196 Photography: the author Figure III.197 Photography: the author. Figure III.198 Photography: the author. Figure III.199 Documentation: IPBHHAA, FA, UCaM - Skopje, adapted by the author.

Figure III.200 Documentation: IPBHHAA, FA, UCaM - Skopje, adapted by the author.

Figure III.201 Documentation: IPBHHAA, FA, UCaM - Skopje, adapted by the author.

Figure III.202 Photography: the author.

Figure III.203 Photography: the author.

Figure III.204 Photography: O. Nestorov.

Figure III.205 Photography: https://www. facebook.com/.

Figure III.206 Photography: the author.

Figure III.207 Photography: A. the author; B. https://en.wikipedia.org/.

Figure III.208 Documentation: the author.

Figure III.209 Documentation: the author.

Figure III.210 Documentation: the author.

Figure III.211 Photography: the author.

Figure III.212 Photography: the author.

Figure III.213 Photography: A. https://marh.mk/; B. https://tirekovmirece.com/

Figure III.214 Source: A, В, С. Хаџиева-Алексиевска и Касапова, 2001; D. photography by D. Velichkovski.

Figure III.215 Photography no. Q267-34, Mission of the Russian Science Academy to Macedonia, Archive of IFMC Skopje.

Figure III.216 Photography: https://mk.wikipedia.org/. Figure III.217 Photography: https://mk.wikipedia.org/. Figure III.218 Photography: https://mk.itarpejo.org/.

Figure III.219 Photography: IPMCM - Bitola.

Figure III.220 Documentation: the author, based on archival documentation of IPMCM - Bitola.

Figure III.221 Documentation: the author, based on archival documentation of IPMCM - Bitola.

Figure III.222 Documentation: the author, based on archival documentation of IPMCM - Bitola.

Figure III.223 Photography: IPMCM - Bitola.

Figure III.224 Photography: IPMCM - Bitola.

Figure III.225 Photography: A. S. Pulevska; B. IPMCM Bitola.

Figure III.226 Photography no. Q266-33, Mission of the Russian Science Academy to Macedonia, Archive of IFMC Skopje.

Figure III.227 Source: https://www.wikidata.org/.

Figure III.228 Photography: J. Nikolovski.

Figure III.229 Photography: IPMCM-Bitola.

Figure III.230 Photography: J. Nikolovski.

Figure III.231 Photography: IPMCM-Bitola.

Figure III.232 Documentation: the author, adapted from the archives of IPMCM - Bitola.

Figure III.233 Documentation: the author, adapted from the archives of IPMCM - Bitola.

Figure III.234 Documentation: the author, adapted from the archives of IPMCM - Bitola.

Figure III.235 Photography: IPMCM-Bitola.

Figure III.236 Source: A. http://www.oldprilep.com/; B. Хаџиева-Алексиевска и Касапова (2001).

Figure III.237 Source: Хаџиева-Алексиевска и Касапова (2001).

Figure III.238 Photography: the author.

Figure III.239 Photography: A. IPMCM - Bitola; В. Палигора (1998).

Figure III.240 Source: https://www.wikipedia.org/.
Figure III.241 Photography: IPBHHAA, FA, UCaM - Skopje. Figure III.242 Photography: N. Spirovski.

Figure III.243 Photography: A. https://mk.wikipedia.org/; B. O. Veljanoska.

Figure III.244 Photography: A. IPMCM - Bitola; B. D. Damjanovski; C. www.pelagon.mk.

Figure III.245 Photography: A. https://mk.wikipedia.org/; B. https://gostivarpress.mk/; C. IPMCM - Bitola.

Figure III.246 Photography: D. Damjanovski.

Figure III.247 Photography: http://tresonce.mk/.

Figure III.248 Photography: A. D. Damjanovski; B. http://tresonce.mk/.

Figure III.249 Documentation: the author, based on archival documentation from NCC - Skopje, digitized by IPBHHAA, FA, UCaM - Skopje.

Figure III.250 Documentation: the author, based on archival documentation from NCC - Skopje, digitized by IPBHHAA, FA, UCaM - Skopje.

Figure III.251 Documentation: the author, based on archival documentation from NCC - Skopje, digitized by IPBHHAA, FA, UCaM - Skopje.

Figure III.252 Photography: http://tresonce.mk/.

Figure III.253 Photography: E. Kasapova.

Figure III.254 Source: Касапова, 2020.

Figure III.255 Photography: K. Simeonovski.

Figure III.256 Photography: A. S. Petrovska; B. I. Zografina.

Figure III.257 Source: Касапова, 2020.

Figure III.258 Photography: D. Damjanovski.

Figure III.259 Documentation: the author, based on archival documentation from NCC - Skopje.

Figure III.260 Documentation: the author, based on archival documentation from NCC - Skopje.

Figure III.261 Documentation: the author, based on archival documentation from NCC - Skopje.

Figure III.262 Photography: D. Damjanovski.

Figure III.263 Photography: V. Jovanoski.

Figure III.264 Source: https://commons.wikimedia.org/. Figure III.265 Source: http://tirekovmirece.com//.

Figure III.266 Documentation: IPBHHAA, FA, UCaM Skopje, adapted by the author.

Figure III.267 Documentation: IPBHHAA, FA, UCaM Skopje, adapted by the author.

Figure III.268 Documentation: IPBHHAA, FA, UCaM Skopje, adapted by the author.

Figure III.269 Photography: http://www.povardarskaeparhija.org.mk/.

Figure IV.1 Photography: https://en.wikipedia.org/. Figure IV.2 Photography: https://en.wikipedia.org/. Figure IV.3 Photography: A. R. Vasileski; B. IPMCM - Bitola. Figure IV.4 Photography: https://en.wikipedia.org/.

Figure IV.5 Photography: the author.

Figure IV.6 Photography: the author.

Figure IV.7 Photography: https://bitolanews.mk/.

Figure V.1 Source: the author.

Figure V.2 Source: the author.

Figure V.3 Photography: IPBHHAA, FA, UCaM - Skopje.

Figure V.4 Photography: https://en.wikipedia.org.

Figure V.5 Photography: https://en.wikipedia.org/.

Figure V.6 Photography: https://en.wikipedia.org/.

Figure V.7 Photography: https://en.wikipedia.org/.

Figure V.8 Photography: https://en.wikipedia.org/.

Figure V.9 Source: Томовски (1970). 


\section{BIBLIOGRAPHY}

\section{Cyrillic alphabet}

АЛЕКСИЕВ, Е. „Православен храм Св. Апостоли Петар и Павле“, Православен храм Свети Апостоли Петар и Павле село Тресонче, Музеј на град Скопје, 1995.

„XIX век: време на промени“, Македонија. Милениумски културно-историски факти, том 4, МПМ, Скопје, 2013, 2183-2216 (A).

„XX век: ликовната уметност во Македонија“, Македонија. Милениумски културно-историски факти, том 4, МПМ, Скопје, 2013, 2323-2438 (Б).

АлекСОВА, Б. (1995) Loca Sanctorum Macedoniae. Kулm на мартирите во Македонија од IV до IX век. Скопје: Матица Македонска.

„Старохристијански црковни центри во Македонија”, Старохристијанската археологија во Македонија, МАНУ, Скопје, 2003: 7-40.

АЛЕКСОСКА, С. „Животниот пат на уметникот“, Димитар Андонов Папрадишки (1859-1954). Ретроспектива, Национална Галерија на Македонија, 2005.

АНГЕЛИЧИН-ЖУРА, Г. (2010) Прилози од историјата на уметноста во Охридската диецеза. Охрид: НУ Завод за заштита на спомениците на културата и Музеј - Охрид.

„Црквата Св. Четириесет маченици во Охрид“, Црквата Св. Четириесет маченици во Охрид. Археолошки локалитет, НУ Завод за заштита на спомениците на културата и Музеј - Охрид, Охрид, 2010: 75-87.

„Црквата Св. Ѓорѓи во село Врбјани, Охридско“, Страници од историјата на уметноста на Охрид и Охридско (XV-ХІХ век), Охрид, 1997: 99-126.

„Црквата Св. Ѓорѓи во село Врбјани - Охридско“, Лихнид бр. 6, Охрид, 1988: 241-259.

АПОСтолОВА ЧАЛОВСКА, Е. „Континуитетот на типолошките обрасци во преродбенската сакрална архитектура низ примерот на еднокорабните базилики со пиластри од југозападна Македонија“, Етнолог бр. 19, Скопје, 2020: 192-210.

„Црквата „Рождество на Пресвета Богородица“ во Тепавци како пост-византиски антецедент на преродбенските тробродни базилики“, Македонски фолклор бр. 76, Скопје, 2020

„Црквите од преродбенскиот период од регионот на Скопска Црна Гора: типологија и стилски особености“, Македонски фолклор бр. 74, Скопје, 2018: 217-235.

„Кон проучувањето на црквата Св. Спас во с. Драчево, Скопско - потекло, типологија, влијанија“, Етнолог бр. 18, Скопје, 2017: 197-213.

„Црквата Св. Спас (Вознесение Христово) во село Кожле, Скопско“, Македонски фолклор бр. 72, Скопје, 2017: 95-116.

„Црквата Св. Софија во Охрид и оформувањето на првите стручно-научни институции за заштита на културното наследство во Македонија“, Македонски фолклор бр. 71, Скопје, 2016: 161-172.

БАЛАБАНОВ, К. „Иконостасот во нашите средновековни цркви”, Современост бр. 3, Скопје, 1954 „Културно-историски споменици во Кочани и кочанско“ во Кочани. Скопје, 1970. (1974) Спомениците на културата во регионот на злетово. Скопје.

БАЛАБАНОВ, НИКОЛОВСКИ и ЌОРНАКОВ (1980) Споменици на културата на Македонија. Скопје: Мисла.

БАРИШИћ, Ф. „Два грчка натписа из Манастира и Струге“, Зборник Радова Византолошког Института бр. VIII 2 , (Mélanges Georges Ostrogorsky II), Београд, 1964: 12-38.

БЕЛДЕДОВСКИ, 3. „Комплексот на епископската базилика во Баргала,” Старохристијанската археологија во Македонија, МАНУ, Скопје, 2003: 207-223.

БИТРАКОВА-ГРОЗДАНОВА, В. „Базиликата во Октиси”, Лихнид бр.7, Охрид, 1989.

„Старохристијански споменици во Охридско. Поликонхална црква”, Архитектурата на почвата на Македонија. Прилози за истражувањето на историјата на културата на почвата на Македонија, Макропроект „Историја на културата на Македонија”, книга 9, МАНУ, Скопје, 2000. 
„Голем Град“ во Македонско културно наследство. Археолошки локалитети, Министерство за култура на Република Македонија, Скопје, 2008.

БИТРАКОВА-ГРОЗДАНОВА, В. и ПУПАЛЕСКИ, Б. „Ранохристијанската сакрална архитектура во Преспа”, Лихнид бр.7, Охрид, 1989.

Бошковић, Ђ. и томовСКИ, К. „Средновековната архитектура во Охрид“, Зборник на трудови, Охрид, 1961. "Средновековната архитектура во Охрид", Архитектурата на почвата на Македонија. Прилози за истражувањето на историјата на културата на почвата на Македонија, Макропроект „Историја на културата на Македонија", книга 9, МАНУ, Скопје, 2000.

Бошковић, Ћ. (1967) Архитектура средњег века. Београд: Научна књига.

„Средновековната архитектура во Македонија”, Архитектурата на почвата на Македонија. Прилози за истражувањето на историјата на културата на почвата на Македонија, Макропроект “Историја на културата на Македонија", книга 9, МАНУ, Скопје, 2000.

БОшкоСкИ, М. „Комитопулот Давид, Цар Давид, Св. Давид Цар (историско-уметнички преглед)”, Патримониум.мк бр. 10, Скопје, 2012.

ВАСИлИЕВ, А. (1965) Български възрожденски майстори. София: Наука и изкуство.

ВЕЛЕВ, И. (1990) Преглед на средновековни иркви и манастири во Македонија. Скопје: Наша книга.

ВЕЛИЧковСКИ, В. „Вовед кон животот и ликовното дело на Димитар Андонов Папрадишки“, Димитар Андонов Папрадишки (1859-1954). Ретроспектива, Национална Галерија на Македонија, 2005.

ВОЛИЊЕЦ, Р. и АЛЕКСИЕВСКА, Ј. „Експресија на ентериерот“, Културно наследство бр. Х-ХІ (1983-84), Скопје, 1987: 5974.

ГАБЕЛИЋ, С. (2017) Челопек. Црква Св. Николе (XIV и XIX век). Београд: Филозофски факултет.

ГЕОРГИЕВА ПЕТКОВСКА, В. (2001) Византиска фрилозофија. Скопје: Табернакул.

ГЕОРГИЕВСКИ, М. „Христофор Жефарович како бакрорезец, зограф и печатар од XVIII век“, Културно наследство бр. XIIXIII (1985-86), Скопје, 1988: 39-43.

ГРАБРИЈАН, Д. „Организација на станбената површина“, Архитектурата на почвата на Македонија. Прилози за истражувањето на историјата на културата на почвата на Македонија, Макропроект „Историја на културата на Македонија", книга 10, МАНУ, Скопје, 2000: 19-23.

ГРОзДАНОВ, Ц. „За македонската ликовна уметност од XIX век и мијачката школа“, Цивилизации на почвата на Македонија. Прилози за истражувањето на историјата на културата на почвата на Македонија, Макропроект „Историја на културата на Македонија”, книга 2, МАНУ, Скопје, 1995: 191-208. (2004) Уметноста и културата на 19 век во Западна Македонија. Скопје: МАНУ.

гРОЗДАНОСКИ, Р. „Библиската физиономија на Македонија во времето на апостолскиот период” , Старохристијанската археологија во Македонија, МАНУ, Скопје, 2003: 75-110.

ГРЧЕВ, К. (1998) Црковното градителство во Македонија 1918-1940. Скопје: Институт за фолклор „Марко Цепенков“. (2003) Архитектонските стилови во македонската архитектура од крајот на XIX век и периодот меѓу двете светски војни. Скопје: Институт за фолклор „Марко Цепенков“.

ДАПЧЕВ, Ѓ. „Демир Хисар - Евиденција на архитектонското наследство“, Културно наследство бр. 19-20-21 (1992-93-94), Скопје, 1996: 217-240.

ДЕРОКО, А. (1951) Средњевековни градови у Србији, Црној Гори и Македонији. Београд: Просвета.

(1953) Монументална и декоративна архитектура у средњевековној Србији. Београд: Научна књига.

димитровА, Е. „Ремек-дела на ранохристијанската уметност во Македонија“, Македонија. Милениумски културноисториски факти, том 3, МПМ, Скопје, 2013: 1405-1462.

"Изведбата на евхаристичните сцени во ранохристијанската декоративна пластика“, Старохристијанската археологија во Македонија, МАНУ, Скопје, 2003: 133-150.

ДИМИТРОВА, Е., КОРУНОВСКИ, С. и ГРАНДАКОВСКА, С. „Средновековна Македонија. Култура и уметност“, Македонија. Милениумски културно-историски факти, том 3, МПМ, Скопје, 2013: 1525-1802.

ДОНЕВ, Ј. „Македонија 1850-1913“, Македонија. Милениумски културно-историски факти, том 4, МПМ, Скопје, 2013. 2095-2181.

ѓОРர́ИЕВ, В. „Македонија во османлискиот период“, Македонија. Милениумски културно-историски факти, том 4, МПМ, Скопје, 2013: 1869-1956.

ЃОРГИЕВСКА, А. „Нови сознанија за старохристијанските базилики во Битолско,” Старохристијанската археологија во Македонија, МАНУ, Скопје, 2003: 225-237.

„ИСТОРИЈА НА МАКЕДОНСКИОТ НАРОД”, Том І, Македонија од праисториското време до потпаѓањето под турска власт (1317 година), редактор проф. д-р Бранко Панов, Институт за Национална Историја, Скопје, 2000.

JAНАКИЕВСКИ, Т. „Неraclea Lyncestis”, 30 години заштита на спомениците на културата во Социјалистичка Република Македонија, Републички Завод за заштита на спомениците на културата, Скопје, 1983.

јОВАНОВА, Л. „Македонија во римскиот период (археологија)“, Македонија. Милениумски културно-историски фракти, том 2, МПМ, Скопје, 2013: 789-930.

јОВАНОВИћ, М. (1987) Српско ирквено градитељство новијег доба. Београд-Крагујевац.

јОВАНОвСКИ, В. (2005) Населбите во Преспа. Местоположба, историски развој и минато. Скопје: Ѓурѓа.

КАДИЈЕВИЋ, А. (1997) Један век тражења националног стила у српској архитектури (средина ХІХ - средина XX века). Београд: Грађевинска књига.

(2016) Византијско градитељство као инспирација српских неимара новијег доба. Београд: Српска Академија Наука и Уметности. 
КАРАНАКОВ, Б. (2013) Геометриските и перспективните системи - средства за суперпонирана визуелизација на сакралната слика и внатрешната архитектура во средновековна Македонија (докторска дисертација). Скопје: Архитектонски факултет.

КАСАПОВА, Е. „Прилог кон реконструкцијата на манастирската црква Св. Апостол Тома кај с. Граиште, Демир Хисар“, Зборник на трудови од II Меѓународна научна конференција „Манастирот Слепче и поствизантиската уметност на Балканот од XVI и XVII век“, Журче - Демир Хисар, 2020 (in print).

„Преродбенските дострели во сакралната архитектура на Охрид“, Монумента бр. 4, 2019: 311-349.

„Архитектонските особености на манастирската црква „Св. Јован Претеча“, Слепче“, Зборник на трудови од Меѓународниот научен симпозиум Манастир Свети Јован Крстител, Слепче, духовен, книжевен и уметнички чентар, Журче - Демир Хисар, 2017.

(2012) Архитектурата на ирквата Св. Димитрија - Марков Манастир. Скопје: Каламус.

(2010) Архитектурата на комплексот Марков Манастир (докторска дисертација). Скопје: Филозофски факултет.

КИРОВСКА, И. (1999) Смислата на декорацијата во македонското градителство од ХІХ век. Скопје: Републички завод за заштита на спомениците на културата.

кондАКОв, Н. П. (1909) Македония. Археологическое путешествие. Санктпетербургь: Типография Императорскои Академии Наукь.

КОНСТАНТИнОВСКИ, Г. (2001) Градителите во Македонија XVII-XX век. Скопје: Табернакул.

КОРАЌЕВИЌ, Д. (2002) Скупи. Градска територија. Скопје: Музеј на град Скопје.

КОРАћ, В. „О природи обнове и правцима развитка архитектуре у раном средњем веку у источним и западним областима Југославије", Зборник радова Византолошког института бр. VIII 2 , (Mélanges Georges Ostrogorsky II), Београд, 1964: 209-226

„Смисао грађења по узору. Примери у српској архитектури XIV века“, Зборник радова Византолошког института бр. 41, Београд, 2004: 205-212.

„Монументална архитектура у Византији и Србији у последњем веку Византије. Особена обрада фасадних површина", Зборник радова Византолошког института, бр. 43, Београд, 2006.

„Свети Ђорђе у Горњем Козјаку. Опажања о архитектури”, Зограф бр. 31, Београд, 2006/7: 29-34.

„Света Софија у Охриду, простор, структура, облици. Извори”, Зограф бр. 32, Београд, 2008: 29-35.

КОРАћ, В. и ШУПУТ, М. (1998) Архитектура византијског света. Београд: Народна књига.

КОРУнОВСКИ, С. и ДИМИтРОВА, Е. (2006) Византиска Македонија. Скопје: Детска радост.

коцо, Д. „Црквата Св. Софија во Охрид”, Годишен Зборник на Филозофскиот факултет, книга 2, Скопје, 1949.

„Св. Богородица Челница“, Старинар XX, 1969: 171-180.

„Културните споменици во Струга и Струшко“ во Струга и Струшко (ред. В. Малески). Струга: Собрание на општина Струга, 1970: 325-333.

„Ранохристијански базилики во областа на Охридското Езеро”, Архитектурата на почвата на Македонија. Прилози за истражувањето на историјата на културата на почвата на Македонија, Макропроект “Историја на културата на Македонија”, книга 9, МАНУ, Скопје, 2000 (А): 27-33.

„Наколните живеалишта во Охридското Езеро крај Струга и средновековните споменици во Струга и Струшко", Архитектурата на почвата на Македонија. Прилози за истражувањето на историјата на културата на почвата на Македонија, Макропроект “Историја на културата на Македонија", книга 9, МАНУ, Скопје, 2000 (Б): 65-73.

„Црквата Св. Софија во Охрид”, Архитектурата на почвата на Македонија. Прилози за истражувањето на историјата на културата на почвата на Македонија, Макропроект "Историја на културата на Македонија", книга 9, МАНУ, Скопје, 2000 (В): 121-124.

КРСтИќ, С. „Црквата Св. Ѓорѓи Кратовски во Кратово“, Музејски гласник бр. 7, Кратово, 2014: 174-199.

(2012) Црковни споменици во кумановско. Куманово: Н.У. Музеј - Куманово.

„Црквата Св. Никола во Стрезовце“, Македонско наследство бр. 34-35, Скопје: 203-212.

КУМБАРАџИ-БОГОЕВИЌ, Л. „НатПисната Плоча од Фаик-Пашината џамија во Скопје“, Културно наследство 16 / 1989, Скопје, 1993: 137-143.

ЛАЗАРЕВ, В.Н. „Живопис XI-XII веков в Македонии“, XII Congrès international des études byzantines, Ochride, 1961, Rapports V, Belgrade - Ochride, 1961: 105-134

лилчиќ, В. „Ранохристијански засводени гробници во Македонија”, Жива антика год. 33, том 1, Скопје, 1983: 95-108. „Нови ранохристијански наоди околу Прилеп”, Годишен зборник на Филозофскиот фракултет на универзитетот во Скопје, Скопје, 1984: 87-109.

„Траги на ранохристијански базилики во средното повардарие”, Лихнид бр.7, Охрид, 1989: 69-87.

лилчиќ, В. и ИлјоскА, В. „Каталог на ранохристијанските цркви во република Македонија“, Македонско наследство, година II / 1997, број 5, Скопје: 21-25.

МАВРОДИНОВ, Н. (1957) Искуството на българското възраждане. София: Наука и изкуство.

МАКСимОВић, Љ. „О хронологији словенских упада на византијску територија крајем седамдесетих и почетком осамдесетих година VI века", Зборник радова Византолошког института бр. VIII 2 (Mélanges Georges Ostrogorsky II), Београд, 1964: 263-271.

МАЛЕНКО, В. „Црквата Св. Четириесет маченици во Охрид“, Црквата Св. Четириесет маченици во Охрид. Археолошки локалитет, НУ Завод за заштита на спомениците на културата и Музеј - Охрид, Охрид, 2010: 7-34. „Ранохристијански објекти во Охрид и Охридско”, Лихнид бр.7, Охрид, 1989: 3-22.

МАЛЕНКО, В. И КУЗМАН, П. „Хермелеја”, Лихнид бр.6, Охрид, 1988: 89-116. 
МАлковски, ѓ. (2007) Драчево од античко време до денес. Скопје: Месна заедница „Драчево“ - Драчево.

MAHEBA, Е. „Базиликата Де од Хераклеја Линкестис", Лихнид бр. 7, Охрид, 1989.

„Хераклеја во раното христијанство”, Културно наследство бр. 16 (1989), Скопје, 1993.

(А) „Раносредновековна материјална култура во Македонија“, Македонија. Милениумски културноисториски факти, том 3, МПМ, Скопје, 2013: 1263-1328.

(Б) „Археологијата на Македонија во Турското средновековие (XV-XVIII век)“, Македонија. Милениумски културно-историски факти, том 4, МПМ, Скопје, 2013: 1957-2050.

МАшниќ, М. „Белешки за малку познатата црква Св. Петка во с. Мургаш“, Патримониум.мк година 8, бр. 13, Скопје, 2015: 249-256.

„Зидно сликарство цркве Св. Ђорђа Победоносца у Младом Нагоричину“. Зборник Матице срспке за ликовне уметности 40, Нови Сад, 2012: 19-40.

(А) „Свети Никола, с. Стрезовце крај Куманово”. Во Македонско културно наследство. Христијански споменици, Скопје, 2008: 78-81.

(Б) „Свети Ѓорѓи Победоносец, с. Младо Нагоричане крај Куманово”. Во Македонско културно наследство. Христијански споменици, Скопје, 2008: 70-73.

„Манастирот Св. Никола Ореоечки“, Културно наследство XIV-XV (1987-88), Скопје, 1990: 5-19.

микулчиќ, и. „Траги од ранохристијански базилики околу Скопје“, Годишен зборник на Филозофскиот фракултет на универзитетот во Скопје, книга 7 (33), 1981: 97-124.

(1982) Старо Скопје со околните тврдини. Скопје: Македонска книга.

„Девол-град во Раец“, Годишен зборник на Филозофскиот факултет на универзитетот во Скопје, книга 10 (36), 1983: 211-218.

(1996) Средновековни градови и тврдини во Македонија. Скопје: МАНУ.

„Антички градови во Македонија“, Макропроект Историја на културата на Македонија, книга 8, Скопје, MAHУ, 1999.

МИЛАНОВА, С. „Прилог кон проучуваето на делото на зографот Дамјан Андреев“, Културно наследство XIV - XV (19871988), Скопје, 1990: 125-132.

МИЉКОВИЌ-ПЕПЕК, П. И НИКОЛОВСКИ, А. „Состојбата и валоризацијата на црковните споменици на културата од XIV век до денес на територијата на собранието на општина Тетово“ во Студии за доцновизантискиот и периодот на преродбата (XIX век) во уметноста на Македонија, Скопје: Каламус, 2010.

МИљКовиќ-ПЕПЕК, П. „Црквата Мали Свети Врачи во Охрид“, Културно наследство 19-20-21 (1992-93-94), Скопје, 1996: 81-137.

МИРонскИ, М. „1467 - Тресонче - 1994“, Православен храм Свети Апостоли Петар и Павле село Тресонче, Музеј на град Скопје, 1995.

МИТЕВСКИ, Љ. и ВЕСЕЛИНОВСКИ, Б. (2005) 500 години ирква „Св. Никола“, с. Трново - Крива Паланка. Крива Паланка: Одбор за одбележување на прославата 500 години Црква Свети Никола, с. Трново.

МИТРЕВСКИ, Н. „Претставите на сесловенските првоучители св. Кирил и св. Методиј во живописот од XIX век во Пелагонија, Мариово и Демирхисарско“, Патримониум.мк, Скопје: 291-302.

МИХАЈЛОВСКИ, Ј. (2005) Десет века Свети Јоаким Осоговски. Куманово: Македонска ризница.

МИХАЈЛОВСКИ, Р. „Прилози кон студијата за катедралната црква Св. Димитриј во Битола“, Пелагонитиса 7- 8 (1999): 112124.

„Битолската Јени џамија во светлината на најновите археолошки откритија“, Патримониум.мк година 2, бр. 3-4, 5-6, Скопје, 2009: 183-188.

„Од духовното наследство на Via Egnatia: црквите Успение на Пресвета Богородица од Велушина и Богородица Пречиста од Граешница“, Патримониум.мк година 4, бр. 9, Скопје, 2011: 141-156.

МИХАЈЛОВСКИ, Р. и ГРАМОСЛИ, ґ́. „Дејноста на копаничарот Нестор Алексиев во Битола и Битолско“, Културно наследство XIV - XV (1987-1988), Скопје, 1990: 43-53.

Мошин, В. (1975) Споменици за средновековната и поновата историја на Македонија, т. І. Скопје: Архив на Македонија.

НАМИЧЕВ, П. и НАМИЧЕВА, Е. „Урбаниот концепт на градот од 19 и почетокот на 20 век во Македонија“, Природни ресурси и технологии №. 7, Штип, 2013: 77-84.

НЕНАДОВИЋ, С. (1980) Архитектура у Југославији од IX-XVIII века. Београд: Научна књига.

НЕСТОРОВА-ТОМИЌ, М. „Придонес за лоцирање на ранохристијански објекти во Скопје“, Старохристијанската археологија во Македонија, МАНУ, Скопје, 2003: 165-190.

НЕСтОРОВИћ, Б. (1974) Архитектура старог века. Београд: Научна књига.

НИколовСКА, М. „Потекло и развој на архитектонските форми во периодот од IX до XIII век во Македонија“, Зборник на трудови: Самуиловата држава во историската, воено-политичката, духовната и културната традиција на Македонија, Завод за заштита на спомениците на културата и музеј, Струмица, 2015: 271286.

николовски, А. (А) „Сакрална архитектура, живопис, иконопис и декоративна пластика во 19 век во Преспа“, Културно наследство Х-ХІ (1983-84), Скопје, 1987: 35-57.

(Б) „Евиденција на спомениците на културата во Берово, Делчево и Виница“, Културно наследство X-XI (1983-84), Скопје, 1987: 175-193.

(А) „Никола Михаилов - Последниот потомок од зографската фамилија на Михаил Зиси“, Културно наследство 14/15 (1987/1988), Скопје, 1990: 21-41. 
(Б) „Евиденција и стручна документација на верските објекти во крушевскиот крај“, Културно наследство 14/15 (1987/1988), Скопје, 1990: 133-142.

„Резултатите од евиденцијата и стручната документација во Битолскиот крај“, Културно наследство 16 (1989), Скопје, 1993: 157-174.

николовски, Д. „Прилог кон делото на зографот Никола Михаилов“, Ниш и Византија ХІ, Ниш, 2013: 355-366.

„Резултати од валоризацијата на црквите во селата Богомила и Бистрица во областа Азот, Велешко“. ПАТРИМОНИУМ.МК бр. 11, Скопје, 2013: 185-208.

„Прелиминарни конзерваторски истражувања на црквата Св. Ѓорѓn во с. Црквино, Велешко“, Ниш и Византија XIV, Ниш, 2016: 465-482.

„Новооткриени творби на зографот Никола Михаилов во црквата Св. Димитрија во с. Зрновци, Кочанско. Прилог кон делото на зографот Никола Михаилов“. ПАТРИМОНИУМ.МК бр. 14, Скопје, 2016: 239-263.

„Прилог кон проучувањата на поствизантиската уметност во општина Чашка, Велешко“. ПАТРИМОНИУМ.МК бр. 15, Скопје, 2017: 259-286.

„Христијански сакрални споменици во општините Дебар и Маврово и Ростуша“ во Културното наследство во Дебарско - Реканскиот регион, Скопје: Министерство за култура на Република Македонија, Управа за заштита на културното наследство, 2018: 15-28.

нИколовски, 3. „Локалитетот „Стара црква“, с. Довезенце / Кастел и културен простор“, Музејски гласник бр. 11, Куманово, 2012: 44-53.

ОСТРОГОРСКИ, Г. (1959) Историја Византије. Београд: Српска књижевна задруга.

ПАВЛОВСКА, Ј., НИЌИФОРОВИЌ, Н. и КОЦЕВСКИ, О. (2011). Карта на верски објекти во Република Македонија. Комисија за односи со верските заедници и религиозни групи Скопје: Менора.

ПАЛИГОРА, Р. „Студија за поврзување и промоција на манастирскиот туризам на Баба Планина“, Центар за развој на пелагонискиот плански регион, Битола, 2011.

(1998) Св. Петка. Маловишта. Битола: Црковен одбор, с. Маловишта.

ПАНОВ, Б. (1985) Средновековна Македонија, том 3. Скопје: Мисла.

„Струмичката епархија во доцноантичкиот и раносредновековниот период", Старохристијанската археологија во Македонија, МАНУ, Скопје, 2003: 111-126.

ПЕТРОВ, К. „Нови резултати од истражувањата на црквата Св. Пантелејмон во Нерези (II)“, Годишен зборник на Филозофскиот факултет на универзитетот во Скопје, книга 8 (34), 1982: 145-197.

ПЕTPOВА, Е. (2008) Стоби. Водич. Скопје: Музеј на Македонија.

ПЕТРОВИЌ, Р. „Прилог кон проучувањето на творештвото од македонските зографи на Косово - Хочански паберци“, Културно наследство, бр. Х-ХІ (1983-84), Скопје, 1987: 115-122.

ПОКРОПЕК, М. и СТРОНЧЕК, Т. (1992) Споредбена монографија на македонското село Јабланица и полските села Пјентки и Твароги. Скопје: Институт за фолклор „Марко Цепенков“.

поПОВСКА-КоРОБАР, В. (А) „Свети Спас“ во Македонско културно наследство. Христијански споменици, Министерство за култура на Република Македонија, Скопје, 2008.

(Б) „Манастир Слепче - Прилепско“ во Македонско културно наследство. Христијански споменици, Министерство за култура на Република Македонија, Скопје, 2008.

„За иконостасот на црквата Свети Ѓорѓи во Лазарополе“, Патримониум.мк VI, no.11, 2013: 223-250). "Иконостасот во црквата на Бигорскиот манастир во XVIII век“, во Бигорски манастир - 20 години возобновено монаштво, 2015: 382-401.

РАДОЈЧИЋ, С. „Прилози за историју најстаријег Охридског сликарства”, Зборник радова Византолошког института бр. VIII 2 , (Mélanges Georges Ostrogorsky II), Београд, 1964: 355-382.

РАДОВАНОВИќ, В. „Култ простонародних црквених ктитора у Јужној Србији“, Гласник Скопског научног друштва III, Скопје, 1927: 99-104.

РАСОЛКОСКА-НИКОЛОВСКА, 3. „Топличкиот манастир во светлината на новите истражувања“, Климент Охридски и улогата на Охридската книжевна школа во развитокот на словенската просвета, МАНУ, Скопје, 1989: 323-333.

РИстовскА-ПИлИчкоВА, J. (2012) Македонската традиционална текстилна орнаментика - класификација, типологија и семиотика на ликовните елементи (докторска дисертација). Скопје: Институт за фолклор „Марко Цепенков".

СВетИеВА, А. (1992) Резбарени тавани, долапи и врати во Македонија. Скопје: Институт за фолклор „Марко Цепенков“.

СНАЈВЛИ, К. „Ранохристијанскиот период во Р. Македонија - црквите“, Македонија. Милениумски културно-историски факти, том 3, МПМ, Скопје, 2013: 1329-1404.

СНБГАРОВъ, И. (1932) История на Охридската архиепископия-патријашия. Оть падането и под Турцить до нейното унищожение (1394-1767). София: Македонски научень институть.

СТАНОЕВСКИ, К. (1999) Православниот храм Свети Спас Драчево. Скопје: Македонска Православна Црква.

СТАРДЕЛОВ, Г. „Проникнувањето на цивилизациите на почвата на Македонија (воведни напомнувања)“, Цивилизации на почвата на Македонија, Прилози за истражувањето на историјата на културата на почвата на Македонија, Макропроект „Историја на културата на Македонија”, книга 2, МАНУ, Скопје, 1995: 5-9.

томовски, К. „Велешките мајстори и зографи во XIX и XX век“, Културно наследство V, Скопје, 1959. „Дејноста на велешките мајстори и зографи во XIX и XX век“, Сто години велешка гимназија, Велес, 1961 : 157-168.

(1966) Мајстор Андреа Дамјанов (1813-1878). Скопје: Архитектонско- градежен факултет. „Саборна црква Св. Тројице у Врању“, Врањски гласник књ. III, Врање, 1967: 13-26. 
„Дејноста на мајсторите-градители, копаничари и зографи од с. Лазарополе во XIX и XX век“, Историја 1, година V, Скопје, 1969: 221-227.

(1970) Монументална христијанска архитектура во Преспа. Скопје: Универзитет „Кирил и Методиј“, Архитектонско - градежен факултет.

„Хаџи Никола Живковиќ - Хаџи Неимар (1792-1870). Прв архитект на Белград и обновена Србија“, Историја 1, година VIII, Скопје, 1972: 155-158.

„Дејноста на мајсторите - градители од „Дебарската школа“ во XIX век“, Бигорски научно - културни собири - Гостивар, Скопје, 1973.

„Архитектонското творештво во Македонија за време на турско-османлиското владеење“, Цивилизации на почвата на Македонија. Прилози за истражувањето на историјата на културата на почвата на Македонија, Макропроект „Историја на културата на Македонија“, книга 2, МАНУ, Скопје, 1995: 239-244. "Христијанска архитектура во Преспа“, Архитектурата на почвата на Македонија. Прилози за истражувањето на историјата на културата на почвата на Македонија, Макропроект „Историја на културата на Македонија“, книга 9, МАНУ, Скопје, 2000: 147-164 (А).

„Дебарските куќи од XIX век“, Архитектурата на почвата на Македонија. Прилози за истражувањето на историјата на културата на почвата на Македонија, Макропроект „Историја на културата на Македонија", книга 10, МАНУ, Скопје, 2000: 71-85 (Б).

томовСКИ, К. и БОЖинОСКИ, В. (2008) Протомајсторот Ѓор́́ Новаков Џонгар, живот и дело. Скопје: МАНУ.

тоМОСКИ, Т. „Морозвиждска епископија“, Културно наследство VII, Скопје, 1978: 93-96.

„Средновековни градови во Македонија", 30 години заштита на спомениците на културата во Социјалистичка Република Македонија, Републички Завод за заштита на спомениците на културата, Скопје, 1983.

„Како топонимот Манастир се наложил за втор назив на градот Битола“, Годищен зборник на Филозофскиот факултет, книга 19 (45), Скопје, 1992: 93-105.

ТРАЈКОВСКИ, К. „Истражувања во Мородвис, 1980“, Зборник на Археолошки музеј на Македонија 1979-1982, X-XI, Скопје, 1983: 133-142.

„Morobisdon. Crkveni kompleks sa nekropolom“, Arheološki pregled 1985, Ljubljana, 1986: 176.

„Ранохристијанска гробница во Мородвис“, Лихнид 7, Охрид, 1989: 89-94.

„Поглед врз средновековната археологија на Брегалница“, Macedoniae Acta Archaeologica 13, Скопје, 1992: 273-280.

„Мородвис“ во Македонско културно наследство. Археолошки локалитети, 80-81. Скопје: Министерство за култура на Р. Македонија, Управа за заштита на културното наследство, 2008: 80-81.

„Најкуса историска и археолошка слика на Македонија од IX до XIV век“, Македонија. Милениумски културно-историски факти, том 3, МПМ, Скопје, 2013: 1463-1524.

тричковскА, J. (2008) Делата во Македонија на сликарското семејство на Михаил од Самарина (докторска дисертација). Скопје: Универзитет „Св. Кирил и Методиј“, Филозофски факултет.

„Композицијата Оплакување Христово од проскомидијата во црквата Св. Ахилие Лариски во Требиште“, Културно наследство 16 (1989), Скопје, 1993: 119-128.

ТУРСКИ ДОКУМЕНТИ ЗА МАКЕДОНСКАТА ИСТОРИЈА 1800-1803 (1951) том I, СКопје: Научен ИнстИтут за национална историја на македонскиот народ.

ЌОРНАКОВ, Д. (А) „Развојниот пат на резбарството во Македонија“, Културно наследство X-ХІ (1983-84), Скопје, 1987: 533.

(Б) „Резултати од евиденцијата и стручната документација на спомениците на културата - цркви и манастири во Мариовскиот, Тиквешкиот и Гевгелискиот крај“, Културно наследство X-XI (1983-84), Скопје, 1987: $149-174$.

„Резултати од евиденцијата на спомениците на културата - цркви и манастири во битолскиот крај“, Културно наследство 14/15 (1987/1988), Скопје, 1990: 143-147.

„Битолскиот иконостас од 18 век во резба“, Културно наследство 16 (1989), Скопје, 1993: 129-135.

(1998) Резбарски центри во Македонија. Скопје - Мелбурн: Матица македонска.

(2016) По трагите на нашите предци. Нови сознанија за македонското културно наследство. Скопје: Матица Македонска.

ФИлиповА, С. (1997) Архитектонска декоративна скулптура во Македонија во 5-6 и 11-12 век. Скопје - Мелбурн: Матица Македонска.

„Нови наоди пластика од црквата Св. Богородица во Дреново“, Годишен Зборник на Филозофскиот Факултет бр. 48, Скопје, 1995: 277-283.

Филиповић, М. С. „Андреја Дамјанов из Велеса, зограф и неимар“, Музеји 2, Београд, 1949: 33-50.

ФилиповСКИ, Љ. и Бошковски, В. „Станбени и црквени објекти во село Тресонче“, Православен храм Свети Апостоли Петар и Павле село Тресонче, Музеј на град Скопје, 1995.

„Архитектонските валери на малореканските села Росоки и Селце“, Културно наследство 22-23 (1995-96), Скопје, 1996.

ХАРМУТ, М. „Отоманската архитектура во Македонија: критички осврт кон најважните споменици од периодот меѓу XV и XIX век“, Македонија. Милениумски културно-историски факти, том 4, МПМ, Скопје, 2013: 2051-2092.

ХАЏИЕВА-АЛЕКСИЕВСКА, Ј. „Македонските градители, градителските школи и нивната улога во создавањето на новата архитектонска естетика во преродбенската сакрална архитектура“. Макропроект Историја на културата на Македонија, книга 1, МАНУ, Скопје, 1995. 
ХАЏИЕВА-АЛЕКСИЕВСКА, Ј. и КАСАПОВА, Е. (2001) Архитект Андреа Дамјанов. Скопје: авторите.

ХАЏИЕВА-АЛЕКСИЕВСКА, Ј. и ХАЏИЕВА-МРГУД, В. „Улогата на македонските архитекти и уметници во создавањето на дворската архитектонска и сакрална уметничка естетика во новосоздадените држави Србија и Црна Гора во XIX век" Македонски фолклор бр. 68, Скопје, 2009: 98-105.

ЦВетковСКИ, С. (2010) Живописот на Дичо Зограф и Аврам Дичов. Студии и прилози. Струга: НУ Музеј „Д-р Никола Незлобински".

ЧАУСИДИС, Н. „Контактот меѓу културата на јужните Словени и Византија“, Цивилизации на почвата на Македонија, Прилози за истражувањето на историјата на културата на почвата на Македонија, Макропроект „Историја на културата на Македонија”, книга 2, МАНУ, Скопје, 1995: 91-101.

чИПАН, Б. (1978) Македонските градови во ХІХ век и нивната урбана перспектива. Скопје: МАНУ. „Старата чаршија во Охрид”, 30 години заштита на спомениците на културата во Социјалистичка Република Македонија, Републички Завод за заштита на спомениците на културата, Скопје, 1983.

(1996) Св. Софија: катедрален храм на Охридската архиепископија. Скопје: Сигмапрес, Универзитет “Св. Кирил и Методиј", Архитектонски Факултет.

„Св. Софија во Охрид од XI век, Самоил и архиепископот Лав”, Архитектурата на почвата на Македонија. Прилози за истражувањето на историјата на културата на почвата на Македонија, Макропроект „Историја на културата на Македонија”, книга 9, МАНУ, Скопје, 2000: 125-134 (А).

„Старата градска архитектура во Охрид”, Архитектурата на почвата на Македонија. Прилози за истражувањето на историјата на културата на почвата на Македонија, Макропроект „Историја на културата на Македонија", книга 10, МАНУ, Скопје, 2000: 25-35 (Б)

ШЕВО, Љ. „Исламски утицај на српску уметност у доба отоманске власти“, Византијско наслеђе и српска уметност II, Сакрална уметност српских земаља у средњем веку, Београд, 2016: 575-581.

ШИВАЧЕВъ, А. (1929) Християнството на Балканския полуостровъ. София: Печатница на Армейски я военноиздателски фондъ.

ШУКАРОВА, А. „Духовната археологија на Јустинијана Прима“, Старохристијанската археологија во Македонија, МАНУ, Скопје, 2003: 127-132.

„Македонија во стариот свет“, Македонија. Милениумски културно-историски факти, том 1, МПМ, Скопје, 2013

шупут, М. (1984) Српска архитектура у доба турске власти 1459-1690. Београд: Филозофски факултет, Институт за историју уметности.

\section{Latin alphabet}

ALEKSOVA, B. "Stobi", Macedonian National Treasures, Makedonska kniga, Skopje, 1989 (A).

"The Early Christian Period", Macedonian National Treasures, Makedonska kniga, Skopje, 1989 (B).

ANDROUDIS, P. "Muslim and Latin Presence in the Treasures of Mount Athos (13th-15th Centuries)", Arte Medievale, serie IV, anno 10, 2020: 337-352.

APOSTOLOVA CHALOVSKA, E. "The XIX Century Basilicas in Macedonia: a Conservation Challenge", Proceedings of the International Conference Contemporary Challenges on Protection and Managing of the Natural and Cultural Heritage, Ohrid, 2020: 123-140.

"The Exonarthex of the Church of St. Sophia, Ohrid - Origin, Typology, Influences", Proceedings of the International Conference Rethinking the Framework of Interdisciplinary Cooperation between Cultural Heritage, Local Economic Development, Tourism and Media, Ohrid, 2015: 28-42.

APOSTOLOVA CHALOVSKA E. \& JUAN VIDAL, F. (2019) "The Cathedral of St. Sophia in Ohrid, Macedonia. An Example of an Innovative Restoration from the 1950s." In (Alfonso Ippolito \& Carlo Inglese eds.) Conservation, Restoration, and Analysis of Architectural and Archaeological Heritage. Hershey PA: IGI Global, 81-107.

APOSTOLOVA CHALOVSKA, E. \& RISTOVSKA PILICHKOVA, J. "The Stone Relief Decoration of the Church of St. Nicholas in Vevchani. Analysis and Semiotic Interpretation", Proceedings of the International Scientific Symposium Rethinking the Framework of Interdisciplinary Cooperation between Cultural Heritage, Local Economic Development, Tourism and Media, Ohrid, 2017.

"The Elements of the Brickwork Decoration, Stone Relief and Fresco Decoration from the Church of St. Sophia in Ohrid and the Macedonian Traditional Textile: Iconographic Characteristics and Parallels", Proceedings of the International Scientific Symposium Rethinking the Framework of Interdisciplinary Cooperation between Cultural Heritage, Local Economic Development, Tourism and Media, Ohrid, 2016: 19-33.

ARNHEIM, R. (2001) La Forma Visual de la Arquitectura. Barcelona: Editorial Gustavo Gili S.A

ASSMANN, J. "Communicative and Cultural Memory" in Cultural Memory Studies. An International and Interdisciplinary Handbook, Berlin - New York, 2008: 109-118.

BABIĆ, B. "Material Culture of Macedonian Slavs", Macedonian National Treasures, Makedonska kniga, Skopje, 1989.

BALABANOV, K. "The Art of the Late Middle Ages", Macedonian National Treasures, Makedonska kniga, Skopje, 1989.

BARRERAS, D. \& DURÁN, C. (2010) Breve historia del Imperio bizantino. Madrid: Ediciones Nowtilus S.L.

BLUESTONE, D. "Challenges for Heritage Conservation and the Role of Research on Values" in Values and Heritage Conservation (eds. E. Avrami, R. Mason \& M. de la Torre), The Getty Conservation Institute, Los Angeles, 2000: 65-67.

BOGDANOVIĆ, J. “On the Architecture of the Konaks in Serbia (1804-1830s)”, Serbian Studies 21/2 (2007), 2010: $161-180$. 
BoŠKoviĆ, Dj. "L'eéglise de Sainte-Sophie á Salonique et son reflet dans deux monuments postérieurs en Macédonie et en Serbie", Archaeologia Jugos/avica I, Beograd, 1954.

BREJE, L. (1976) Vizantijska civilizacija. Beograd: Nolit.

BROWN, P. (1971) The World of Late Antiquity. AD 150-750. London: Thames and Hudson.

CHATFORD CLARK, D. L. "Viewing the liturgy: a space syntax study of changing visibility and accessibility in the development of the Byzantine church in Jordan", World Archaeology Vol. 39 (1), Taylor \& Francis, 2007: 84-104.

CHOISY, A. (1997) El arte de construir en Bizancio. Madrid: Instituto Juan de Herrera.

CONTI, A. "La continuidad en un mundo en cambio permanente" in Los Nuevos paradigmas de la conservación del patrimonio cultural. 50 años de la Carta de Venecia (eds. Francisco Javier López Morales \& Francisco Vidargas), Instituto Nacional de Antropología e Historia, Córdoba, 2014: 101-119.

FERNÁNDEZ CUADROS, J. M. (2014) La bóveda de madera de la basílica de Santa Croce in Gerusalemme (Roma) (trabajo final de máster). Valencia: Universidad Politécnica de Valencia.

FINE jr, J. Van Antwerp (1991) The Early Medieval Balkans. A Critical Survey from the Sixth to the Late Twelfth Century. The University of Michigen Press.

(1994) The Late Medieval Balkans. A Critical Survey from the Late Twelfth Century to the Ottoman Conquest. The University of Michigen Press.

FIGES, O. (2010) Crimea. The Last Crusade. London: Penguin Books.

GELZER, H. (1902) Der Patriarchate von Achrida. Geschichte u Urkunden. Lepzig: Teubner.

GÓMEZ ROBLES, L. "A Methodological Approach Towards Conservation", Conservation and Management of Archaeological Sites Vol. 12, No. 2, May, 2010, 146-169.

HADZIEVA-ALEKSIEVSKA, J. "Proportional and Modular Models in Early-Christian Basilicas in the Lihnida Region - West Illyrian Prefecture", Proceedings of the International Conference Studies in Ancient Structures, YTU Faculty of Architecture Publication, Istanbul, 1997: 59-68.

"Persistenza e transformazione del modello basilicale nell'architettura ortodossa in Macedonia, dal IX a XIII secolo. Transmissioni occidental e oriental", III Incontro Internazionalle sull'architettura, Parabita, 2011.

HODDINOTT, R. F. (1963) Early Byzantine Churches in Macedonia and Southern Serbia. A Study of the Origins and the Initial Development of East Christian Art. London: MacMillan \& Co LTD.

JENSEN, U. J. "Cultural Heritage, Liberal Education and Human Flourishing”, in Values and Heritage Conservation (eds. E. Avrami, R. Mason \& M. de la Torre), The Getty Conservation Institute, Los Angeles, 2000: 38-43.

JIVÉN, G. \& LARKHAM, P. J. "Sence of Place, Authenticity and Character: a Comentary", Journal of Urban Design Vol. 8, No. 1, 2003: 67-81.

JOKILEHTO, J. "Authenticity: A General Framework for the Concept" in Nara Conference on Authenticity in Relation to the World Heritage Convention (ed. K. E. Larsen), Nara, Japan, 1-6 November 1994. Paris: UNESCO World Heritage Centre, 1995: 17-34.

KADIJEVIĆ, A. "Mixture of Styles and Civilizations in the Ecclesiastical Architecture of Andreja Damjanov in Balkanic Regions under Turkish Rule", XV Turk Tarih Kongresi, Ankara, 2010: 2125-2135.

KIEL, M. "Armenian and Ottoman Influences on a group of village churches in North-East Macedonia. A contribution to the history of art of the Armenian daispora", Revue des etudes armeniennes VIII, Paris, 1971: 267-282. (1985) Art and Society of Bulgaria in the Turkish Period. Assen/Maastricht: Vim Gorcum.

KRAUTHEIMER, R. (1979) Early Christian and Byzantine Architecture, New York: Penguin Books.

LICHENOSKA, Z. "The Macedonian Wood-craft from the $18^{\text {th }}$ and the $19^{\text {th }}$ Century", Macedonian National Treasures (Ed. Grozdanov et al.), Skopje, 1989: 287-307.

LOWENTHAL, D. "Stewarding the Past in a Perplexing Present", Values and Heritage Conservation, Getty Conservation Institute, Los Angeles, 2000: 18-25.

(1985) The Past is a Foreign Country. Cambridge: Cambridge University Press.

MacDONALD, W. (1965) Early Christian and Byzantine Architecture. New York: George Braziller.

MANGO, C. (1974) Architettura bizantina. Milano: Mondadori Electa.

MATHEWS, T. F. "Private" Liturgy in Byzantine Architecture: Towards a Re-Appraisal", Cahiers archéologiques. Fin de l'antiquité et Moyen Âge, vol. 30 (1982): 125-138.

MELVANI, N. "The middle Byzantine sanctuary barriers of Mount Athos: Templon and iconostasis", $\triangle \mathrm{A} \Sigma \mathrm{K} \wedge \mathrm{A} A \Pi \mathrm{AO} \mathrm{O \Sigma H}$

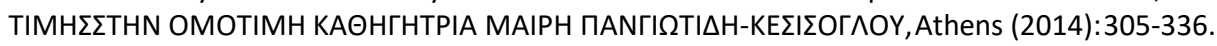

MIHAJLOVSKI, R. "The Basilica of the Dormition of the Holy Virgin in Velushina", Journal of the Australian Early Medieval Association, volume 3, (2007): 225-241.

MILJKOVIĆ-PEPEK, P. "L'eglise de Saint-Elie pres du village de Grnčari”, Byzantion XXXVIII, 1968.

NIKOLOVSKI, A. "The 19th Century Art", Macedonian National Treasures (Ed. Grozdanov et al.), Skopje, 1989: 269-283.

OBOLENSKY, D. "The Byzantine Impact on Eastern Europe", The Byzantine Inheritance of Eastern Europe, Variorum Reprints, London, 1982.

PEARCE, S. "The Making of Cultural Heritage" in Values and Heritage Conservation (eds. E. Avrami, R. Mason \& M. de la Torre), The Getty Conservation Institute, Los Angeles, 2000: 59-64.

PETROVSKA, E. T. "The Triconch at Tudence: a Short Analysis of the Type in the History of Architecture", Macedonioan Historical Review vol. 1, 2010: 81-88.

PIPER, D. (2004) The llustrated History of Art. London: Bounty Books.

POULIOS, I. (2014) The Past in the Present. A Living Heritage Approach - Meteora, Greece. London: Ubiquity Press.

PRATS, L. (1997) Antropología y patrimonio. Barcelona: Ariel.

PROEVA, N. "Review. 100 years of Trebenishte, 2018, Sofia (Skopje, Belgrade)", VADH 112, 2019: 189-201. 
RISTESKI, I.; KOCHANKOVSKA, V.; HADZI-PECOVA, C.; DIMITROVSKI, K. \& PETKANOVSKA, I. (2009) Discovering the Architectural Heritage of Mariovo. Skopje: CeProSARD.

ROTH, L. M. (1999) Entender la arquitectura. Sus elementos, historia y significado. Barcelona: Gustavo Gili.

SARADI, H. "The use of ancient spolia in Byzantine monuments: the archaeological and literary evidence", International Journal of the Classical Tradition Vol. 3, Issue 4, 1997: 395-424.

SCHELLEWALD, B. M. (1986) Die Architektur der Sophienkirche in Ohrid. Bonn: PhD Thesis.

SCHMIDT-ANNABERG, H. "Die basilica Aja Sofia in Ochrida", Deutsche Bauzaitung 44-48, Berlin, 1921.

SNIVELY, C. S. "Churches and Cemeteries: Religion and Death in Early Christian Macedonia" in Cтарохристијанската археологија во Македонија, Македонска Академија на Науките и Уметностите, Скопје, 2003: 59-74.

TAMM, M. "History as Cultural Memory: Mnemohistory and the Construction of the Estonian Nation". Journal of Baltic Studies Vol. 39, No. 4, 2008: 499-516.

TCHIPAN, B. "The Old City Architecture", Macedonian National Treasures (Ed. Grozdanov et al.), Makedonska kniga, Skopje, 1989. TOMOVSKI, K. (A) "Medieval Architecture in Macedonia”, Macedonian National Treasures (Ed. Grozdanov et al.), Makedonska kniga, Skopje, 1989.

(B) "Islamic Architecture", Macedonian National Treasures (Ed. Grozdanov et al.), Makedonska kniga, Skopje, 1989.

VITRUVIUS (1960) The Ten Books on Architecture. Transl. M. H. Morgan. New York: Dover Publications.

WALTER, C. (1982) Art and Ritual of the Byzantine Church. London: Variorum Publications.

WESTON, R. (2011) 100 Ideas that Changed Architecture. London: Laurence King Publishing. 